Das Papsttum und das vielgestaltige Italien

$$
\begin{array}{|c|}
W \\
\text { DE } \\
\hline
\end{array}
$$




\section{Abhandlungen der Akademie der Wissenschaften zu Göttingen}

Neue Folge, Band 5

Studien zu Papstgeschichte und Papsturkunden

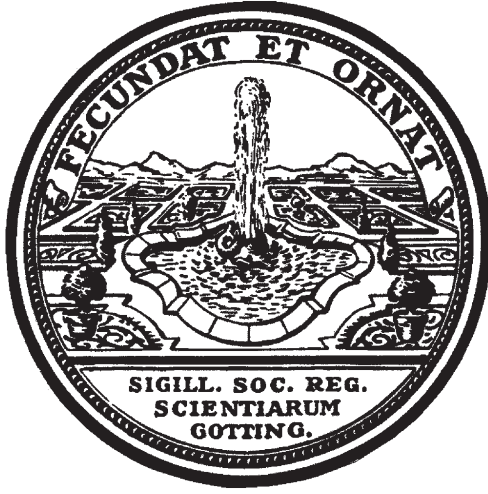

Walter de Gruyter · Berlin · New York 


\section{Das Papsttum und das vielgestaltige Italien}

Hundert Jahre Italia Pontificia

Herausgegeben von

Klaus Herbers und Jochen Johrendt

Walter de Gruyter · Berlin · New York 


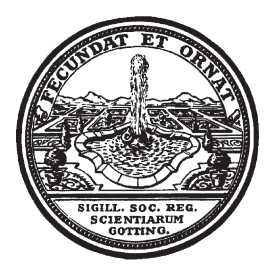

Vorgelegt von Herrn Prof. Dr. Klaus Herbers und eingeführt von Herrn Prof. Dr. Frank Rexroth in der Sitzung vom 11. Januar 2008

(0) Gedruckt auf säurefreiem Papier, das die US-ANSI-Norm über Haltbarkeit erfüllt.

ISBN 978-3-11-021467-3

\section{Bibliografische Information der Deutschen Nationalbibliothek}

Die Deutsche Nationalbibliothek verzeichnet diese Publikation in der Deutschen Nationalbibliografie; detaillierte bibliografische Daten sind im Internet über http://dnb.d-nb.de abrufbar.

(C) Copyright 2009 by Walter de Gruyter GmbH \& Co. KG, 10785 Berlin

Dieses Werk einschließlich aller seiner Teile ist urheberrechtlich geschützt. Jede Verwertung außerhalb der engen Grenzen des Urheberrechtsgesetzes ist ohne Zustimmung des Verlages unzulässig und strafbar. Das gilt insbesondere für Vervielfältigungen, Übersetzungen, Mikroverfilmungen und die Einspeicherung und Verarbeitung in elektronischen Systemen.

Printed in Germany

Einbandgestaltung: Meta Systems, Wustermark

Druck und buchbinderische Verarbeitung: Hubert \& Co. GmbH und Co. KG, Göttingen 


\section{Vorwort}

„Des Privilegs der Göttinger Professoren (obwohl ich leider nur noch einer in partibus infidelium bin), in diesen Anzeigen ihre eigenen Werke zu loben, bediene ich mich, nicht um auf diesem Wege wenigstens zu e i n e r literarischen Anerkennung zu gelangen, sondern weil ich die willkommene Gelegenheit wahrnehmen möchte, gewisse mir notwendig erscheinende Erörterungen über den I. Band der im Juli d. J. erschienen Italia Pontificia vorzubringen. Sie würden die Einleitung des Bandes selbst zu sehr belastet haben, abgesehen davon, daß mein Latein nicht zu längeren und schwierigeren Auseinandersetzungen ausgereicht haben würde. Haben doch die kurzen Einleitungen schon Schweiß genug gekostet“. Mit diesen Worten zeigte Paul Fridolin Kehr 1906 in den Göttingischen Gelehrten Anzeigen 168 den ersten Band der Italia Pontificia an ${ }^{1}$.

Wo steht die Forschung 100 Jahre später? Jubiläen und kein Ende? 1988: 100 Jahre Deutsches Historisches Institut in Rom: Festakt und Band mit einem Beitrag zur Italia Pontificia - 1996: 100 Jahre Papsturkundenwerk: Jubiläumstagung in der Akademie in Göttingen und Tagungsband mit einem Beitrag zur Italia Pontificia. Ist nicht schon alles gesagt, was bei Jubiläen in der Regel gesagt zu werden pflegt? Die hier als Band vorliegenden Beiträge einer Tagung vom Oktober 2006, die gemeinsam von der Göttinger Akademie, der PiusStiftung für Papsturkundenforschung und dem Deutschen Historischen Institut in Rom organisiert wurde, ziehen in mehrfacher Hinsicht Bilanz. Es ging darum zu fragen, inwieweit sich dieser Teil des Göttinger Papsturkundenwerkes, der am weitesten vorangeschritten ist, bewährt hat, wo er der Nachträge bedarf und was er für moderne Fragestellungen der Geschichtswissenschaft und weiterer Nachbardisziplinen leistet.

Die Worte Kehrs von 1906 zeigen aber deutlich - vergleicht man sie mit denen von 1896 -, daß nun Farbe bekannt werden mußte, daß die alten Pläne in der Praxis verändert worden waren und sich deshalb auch das Unternehmen neu ausrichtete. Als der frühere Sekretär der Pius-Stiftung, Rudolf Hiestand, 1988 zum 100-jährigen Jubiläum des Deutschen Historischen Instituts auf die Italia Pontificia zu sprechen kam, konnte er herausstellen, wie sehr das Werk mit

1 Jetzt bequem nachzuschlagen im Nachdruck seiner Schriften: Paul Fridolin KeHR: Ausgewählte Schriften, 2 Bde., hg. v. Rudolf Hiestand, Göttingen 2005 (AAG, phil.hist. Kl., 3. Folge 250), Bd. 1 S. 18-35, hier S. 18 (= Selbstanzeige von Italia Pontificia, in: GGA 168. 1906). 
dem auch 2006 gastgebenden Institut verbunden war, ohne daß es je (wir fügen hinzu: „leider") zu einer institutionellen, formalen Verbindung kam². Jedoch gilt die Italia Pontificia, wie Hiestand acht Jahre später zum Jubiläum des Gesamtprojektes „Göttinger Papsturkundenwerk“ 1996 formulierte, als „Paradestück des Unternehmens" ${ }^{3}$, obwohl sie, wie er ebenfalls aussprach, bis heute unvollendet blieb.

Worin liegt dann aber die Bedeutung der Italia Pontificia für das Gesamtunternehmen? Drei Aspekte seien hervorgehoben:

- Zunächst in der Vorbildfunktion, denn die Grundstruktur der Regestenbände, die Kehr schon bald, nachdem er das ursprüngliche Ziel einer kritischen Edition aller Papsturkunden bis 1198 aufgegeben hatte, als die eigentliche Aufgabe ansah, blieb in den Folgebänden grundsätzlich gleich.

- Zum zweiten waren bei dem revolutionären Ziel, Papsturkunden von unten nach oben zu erschließen, also von den Empfängern und nicht wie Jaffé vom Aussteller her, lokale und regionale Abgrenzungen schwierig, denkt man nur an sich ändernde Bistumsgrenzen, Filialklöster und weiteres. Kehr war hier ein unverbesserlicher Pragmatiker, der beispielsweise bei der Italia oft die Verhältnisse des 12. Jahrhunderts einfach zur Richtschnur für die Anordnung erklärte.

- Zum dritten zeigte aber die fortschreitende Arbeit die notwendigen Änderungen: inwieweit Historiographie, kanonistische Quellen, Delegationsmandate und anderes in die jeweiligen Bände gehört, änderte sich schon bei den weiteren Bänden der Italia Pontificia, mehr aber noch bei den Bänden der Germania und Gallia Pontificia.

Viel wichtiger war aber vielleicht, daß die Italia nur durch den gleichzeitigen Fortgang der anderen Arbeiten dem Ende zugetrieben werden konnte. Ein Beispiel kann dies gut erläutern: In den Jahren, als die Bände der Italia Pontificia 8-10 bearbeitet wurden, die Süditalien betrafen und große Schwierigkeiten bereiteten, gebot es die Kenntnis der früheren politischen Verhältnisse, auch die Iberische Halbinsel und insonderheit die Krone Aragón zu bereisen. $\mathrm{Daß}$ gerade in diesen Jahren und für Spanien die Unterstützung des Heiligen Stuhles durch Papst Pius XI. wichtig wurde, sei in großer Dankbarkeit erwähnt,

2 Rudolf Hiestand: Die Italia Pontifica, in: Das Deutsche Historische Institut in Rom 1888-1988, hg. v. Reinhard Elze/Arnold Esch, Tübingen 1990, S. 167-189. Siehe zum Verhältnis von Italia Pontificia und Deutschem Historischem Institut in Rom auch den Beitrag von Michael Matheus im vorliegenden Band.

3 Rudolf Hiestand: Die unvollendete Italia Pontificia, in: Hundert Jahre Papsturkundenforschung. Bilanz - Methoden - Perspektiven. Akten eines Kolloquiums zum hundertjährigen Bestehen der Regesta Pontificum Romanorum vom 9.-11. Oktober 1996 in Göttingen, hg. v. DEMs., Göttingen 2003 (AAG, phil-hist. Kl. 3. Folge 261), S. 47-57, hier S. 47. 
denn auf diese Zeit geht auch die diesem Papst verdankte Stiftung zurück, von der das Papsturkundenwerk bis heute profitiert.

Dazu kommt, daß die Papsturkundenforschung von Anfang an - ganz modern - als eine europäische und internationale Aufgabe angesehen wurde: Anderen Unternehmungen sei die „Beschränkung auf die Denkmäler der eigenen Nation eigentümlich“, hingegen, so Kehr, hätten ,alle Nationen des Abendlandes [...] Theil an der gemeinsamen Überlieferung" des Mittelalters. Und dann der vielzitierte Satz: „Wenn irgend ein wissenschaftliches Unternehmen geeignet ist, diese Liga der an derselben Aufgabe arbeitenden italienischen, französischen und deutschen Gelehrten zu fördern, so ist es unser Plan “ ${ }^{4}$. Diese Internationalität, die sich seit den 1960er Jahren auch verstärkt in der Einbindung ausländischer Mitarbeiter und Mitarbeiterinnen niederschlug, ist heute fester Bestandteil und sicher das große Plus des Papsturkundenwerkes insgesamt.

Schon deshalb werden die Nachträge - auch für die Italia Pontificia - nicht abreißen, aber wir hoffen immer noch darauf, bald einen Nachtragsband mit den inzwischen angefallenen Neufunden und Ergänzungen vorlegen zu können und schließlich zwei weitere Bände voranzutreiben zu den schon von Paul Fridolin Kehr geforderten Regesten „Decreta generalia“, die dem Romband nicht beigegeben wurden, sowie zu den weltlichen Herrschern Italiens, von den römischen Kaisern der Spätantike bis hin zu den Gegenkönigen des ausgehenden 11. und 12. Jahrhunderts.

Das Unternehmen fand seit den Anfängen Kritiker, denn der Plan, die Regesten nach Empfängern, nicht nach Ausstellern zu ordnen, blieb das besonders Revolutionäre. Kehr verteidigte dies, indem er davon sprach, daß sich die Masse der Mandate von Alexander III. an kaum chronologisch einordnen ließe. In seinen Worten: „der Eilige, der solche Stücke in den Jafféschen Regesten aufsuchen und finden soll, kann zuweilen darüber in Verzweiflung geraten" ".

Natürlich ließ Kritik an dem neuen Prinzip - nach Empfängern und nicht nach Ausstellern zu ordnen - insbesondere der Wiener Schule, schon nach dem ersten Band nicht auf sich warten. Aber die Meinungsverschiedenheiten darüber, ob die chronologische Anordnung der Papstregesten oder diejenige nach Ausstellern oder Empfängern sinnvoller sei, sind bis heute nicht ausgeräumt worden, wenn auch der Streit inzwischen dank der verschiedenen Hilfsmittel, wie Gesamtverzeichnisse oder Register, weniger akut ist. Allerdings scheint die Fülle des Materials mit über 25.000 Urkunden einen Umfang erreicht zu haben, der

4 Paul Fridolin KenR: Über den Plan einer kritischen Ausgabe der Papsturkunden bis Innozenz III (1896), jetzt ebenso bequem zugänglich in: KEHR: Ausgewählte Schriften (wie Anm. 1) S. 3-17, hier S. 4f., vgl. Hiestand: Italia Pontificia (wie Anm. 2) S. 171.

5 KeHr: Selbstanzeige (wie Anm. 1) S. 599 (24). 
neue Schritte gebietet. Damit auch Nichtfachleute ohne die Kenntnis der unterschiedlichen Hilfsmittel übersichtlicher die Ergebnisse einer mehr als 100jährigen Grundlagenforschung nutzen können wurde Anfang 2007 ein nur mit Kurzregesten erstelltes Gesamtverzeichnis als „neuer Jaffé “ begonnen, das sowohl in gedruckter als auch elektronischer Form zur Verfügung stehen soll ${ }^{6}$.

Von der Gesamtzahl, die dieses Verzeichnis umfassen wird, sind allein 11024 Urkunden zur Italia Pontificia gehörig, deren Ergebnisse bei der Tagung in Rom gewürdigt wurden. Das Gesamtunternehmen hat inzwischen durch verschiedene Initiativen neue Impulse erhalten, obwohl der Grundlagenforschung nach wie vor der Wind ins Gesicht bläst. Aber freuen wir uns: er bläst wenigstens noch, denn ein scharfer Wind ist für den Segler immer noch besser als eine zum Stillstand verdammende Flaute.

Anliegen der Tagung war es aber auch, die Möglichkeiten des Grundlagenwerkes an neuen Fragestellungen zu erproben, denn auch die an der Materialerschließung und -aufbereitung Beteiligten sollten die Auswertung der erarbeiteten Ergebnisse nicht ausschließlich anderen überlassen. Der für den Druck etwas handlicher gefaßte Titel des Kongresses ${ }^{7}$ unterstrich dies Anliegen, stellt doch gerade die jüngere Forschung zunehmend Fragen danach, wie Integrationsprozesse im mittelalterlichen Europa auch durch Desintegration begleitet waren. Das vielgestaltige Italien erschien für vergleichbare Untersuchungen ein denkbar günstiges, weil eingeschränktes Exerzierfeld, denn die uneinheitlich gestaltete Landkarte wurde im Laufe des frühen und hohen Mittelalters auch durch die Aktivitäten der Päpste maßgeblich beeinflußt. Hieraus ergab sich folgerichtig die Anordnung der Redebeiträge bei der Tagung sowie die inhaltliche Struktur des vorliegenden Bandes. Nach einer Betrachtung der wechselnden politischen Kraftzentren (II) wurden die verschiedenen teilweise sehr eigenständigen kirchlichen Traditionen Italiens vorgestellt (III) bevor mit Blick auf das Papsturkundenwerk der Italia Pontificia nach möglichen Nachträgen und Ergänzungen aus verschiedenen Überlieferungen gefahndet wurde (IV). Die Stellung der universal agierenden Orden und die daraus resultierenden Konsequenzen für Papsturkunden und Integrationsprozesse wurden in einem letzten Abschnitt behandelt (V). Da die einführenden Begrü-

6 Dies geschieht im Rahmen des Akademienprogramms, vgl. die Informationen auf der Homepage http:/www.papsturkunden.gwdg.de/Akademieprojekt/Jaffe_3_/jaffe_3_.html (6. Dezember 2008) - In Zusammenarbeit mit den Informatikern in Erlangen wurde ein neues Programm zur Erfassung und Erschließung der Papsturkunden und Papstkontakte bis 1198 erarbeitet, bei dem die Suche und Gruppierung nach Empfängern ebenso wie eine zeitliche Strukturierung möglich sein wird.

7 Er lautete: Das Papsttum und das vielgestaltige Italien - Integration und Desintegration im frühen und hohen Mittelalter. Hundert Jahre Italia Pontificia; Il Papato e l'Italia multiforme - integrazione e disintegrazione nell'alto e pieno medioevo. Cent'anni di Italia Pontificia. 
ßungsworte und der Eröffnungsvortrag eigens aufgenommen wurden (I) und ein zusammenfassendes Schlusskapitel angefügt wurde (VI), erübrigen sich weitere inhaltliche Bemerkungen an dieser Stelle.

Jedoch haben die Herausgeber vielfältig zu danken. Der Kongreß wurde finanziell nicht nur von der Deutschen Forschungsgemeinschaft unterstützt, sondern ebenso durch die großzügige Gastfreundschaft des Direktors des Deutschen Historischen Instituts in Rom, Herrn Prof. Dr. Michael Matheus. Die reibungslose Durchführung der Tagung in einer angenehmen und anregenden Atmosphäre wurde durch den Einsatz seiner Mitarbeiter möglich. In gemeinsamer Diskussion der Herausgeber, an der auch Herr Dr. Matthias Maser in Erlangen großen Anteil hatte, ist die Konzeption und Vorbereitung der Tagung Zug um Zug vorangebracht worden. Dazu kamen weitere Helfer und Helferinnen, in Göttingen Frau Vera Schwarz, in organisatorischen Fragen die entsprechenden Sekretariate in Erlangen und Rom sowie ideelle Unterstützung von vielen anderen Seiten.

Hinsichtlich der Drucklegung der Tagungsakten sind wir den Autorinnen und Autoren verpflichtet, die ihre Manuskripte (meist) zügig ablieferten; für die formale Bearbeitung der Beiträge sagen wir Herrn Dr. Gordon Blennemann, Frau stud. phil. Judith Werner und Herrn stud. phil. Philipp Winkler, sowie Frau stud. phil. Larissa Düchting, besonders aber Frau stud. phil. Katharina Götz für die Erstellung des Registers Dank, ebenso der Akademie der Wissenschaften zu Göttingen, die nicht nur das Projekt seit langem begleitet, sondern die Beiträge nun auch in ihre "Neuen Abhandlungen“ aufgenommen hat. Allen genannten und vielen weiteren gilt unser herzlicher Dank.

Erlangen - München

Klaus Herbers, Jochen Johrendt 
Bereitgestellt von | De Gruyter / TCS

Angemeldet | 217.89.40.26

Heruntergeladen am | 21.12.12 10:45 


\section{Inhalt}

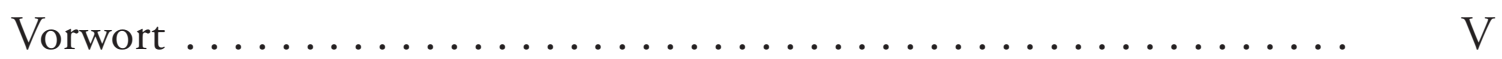

\section{Einführungen}

Michael Matheus

Das Deutsche Historische Institut (DHI) in Rom und Paul Fridolin

Kehrs Papsturkundenwerk ...................... 3

Don Raffaele Farina

La Biblioteca Apostolica Vaticana e il Papsturkundenwerk ......... 13

Klaus Herbers

Das Papsttum und die „vielen“ Italien als Orbis Christianus? . . . . . 17

II. Rom und die wechselnden politischen Kraftzentren Italiens im frühen und hohen Mittelalter

Matthias Maser

Die Päpste und das oströmische Kaisertum im sechsten Jahrhundert . .

Guglielmo Cavallo

Le influenze bizantine nei secoli IX e X tra Campania e Lazio. Qualche

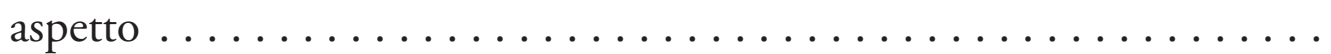

III. Rom und die Kirchen Italiens - zwischen Autonomie, Konkurrenz und Anpassung

Wolfgang Huschner

Benevent, Magdeburg, Salerno. Das Papsttum und die neuen

Erzbistümer in ottonischer Zeit $\ldots \ldots \ldots \ldots \ldots \ldots \ldots \ldots$

Jean-Marie Martin

L'Italie méridionale . . . . . . . . . . . . . . . . . . . . . . . . . . 109 
Maria Pia Alberzoni

Gli interventi della Chiesa di Roma nella provincia ecclesiastica

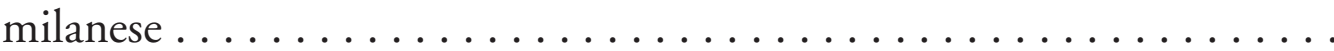

JOCHEN JOHRENDT

Italien als Empfängerlandschaft (1046-1198): ein Vergleich aus der Perspektive des Urkundenalltags in Ligurien, Umbrien und Kalabrien .

Dieter Girgensohn

Kehrs Regesta Pontificum Romanorum: Entstehung wissenschaftlicher Ertrag - organisatorische Schwächen

IV. Nichturkundliche Überlieferung - eine undankbare Nachlese? (Register, Briefsammlungen, Kanonessammlungen, Historiographie, Kardinalsschreiben, Inschriften)

Rudolf SchiefFeR

Die päpstlichen Register vor 1198 .................. 261

LotTe KÉRY

Kanonessammlungen als Fundorte für päpstliche Schreiben . . . . . . . . 275

Giulia Barone

Tradizioni storiografiche e agiografiche: alcuni esempi .........

DieTrich LOHRMANN

Berichte von der Kurie über den Erwerb umstrittener Prozeßmandate und Privilegien $(12 .-13$. Jahrhundert) $\ldots \ldots \ldots \ldots \ldots \ldots \ldots$

Werner Maleczek

Die Brüder des Papstes Kardinäle und Schriftgut der Kardinäle .....

Sebastian Scholz

Epigraphische Zeugnisse der Päpste in Rom. Ein Desiderat der Italia

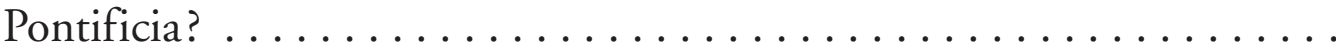

Tommaso di Carpegna Falconieri

Osservazioni sulle edizioni dei documenti romani dei secoli IX-XII, con particolare riferimento alla storia ecclesiastica $\ldots \ldots \ldots \ldots \ldots \ldots$

Hubert Houben

Auf den Spuren mittelalterlicher Urkunden in neuzeitlicher

Überlieferung: Beispiele aus Süditalien 
Rudolf Hiestand

„Verborgene Schätze“. Nichtitalienische Stücke in den „Papsturkunden

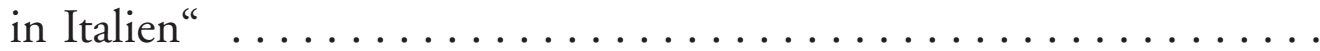

\section{Die universal agierenden Orden in Italien}

Rinaldo Comba

I monaci bianchi e il papato in Italia: caratteri e metamorfosi delle identità e idealità cistercensi nella prima metà del XII secolo ......

Mario Sensi

Movimenti riformatori nell'Italia centrale

Kristjan Toomaspoeg

L'„Italia Pontificia“ e le vicende degli ordini religioso-militari nella

Penisola .....................................

Rudolf Hiestand

Die „Italia Pontificia“ und das Kreuzzugsgeschehen ............. 615

\section{Resümee}

KLaus Herbers und Jochen Johrendt

Ergebnisse und Perspektiven

Orts- und Personenregister ....................... 693 
Bereitgestellt von | De Gruyter / TCS

Angemeldet | 217.89.40.26

Heruntergeladen am | 21.12.12 10:45 


\section{Abkürzungen}

Die Abkürzungen des Bandes orientieren sich am Abkürzungsverzeichnis des Lexikons des Mittelalters, Bd. 1 S. XXIII-LXIII. Davon abweichende Abkürzungen sind (N.B. Abkürzungen, die nur in einzelnen Beiträgen verwendet wurden, sind dort erläutert):

Auvray

Berger

De la Roncière

Desimoni

Digard

FR

FW

Gay

GN

GP

Horoy

IP

$\mathrm{JK} / \mathrm{JE} / \mathrm{JL}$
Les Registres de Grégoire IX, ed. Lucien Auvray, 4 Bde., Paris 1896-1955 (Bibliothèque des Écoles françaises d'Athènes et de Rome, Sér. 2/9).

Les Registres d'Innocent IV, ed. Élie Berger, 4 Bde., Paris 1884-1921 (Bibliothèque des Écoles françaises d'Athènes et de Rome, Sér. 2/1).

Les Registres d'Alexandre IV, ed. Charles Bourel DE LA Roncière/Joseph de Loye/Auguste Coulon, 3 Bde., Paris 1902 - 1953 (Bibliothèque des Écoles françaises d'Athènes et de Rome, Sér. 2).

Camillo Desimoni: Regesti delle lettere pontificie riguardanti la Liguria, in: Atti della Società Ligurie di Storia patria 19 (1887) S. 5-131.

Les Registres de Boniface VIII, ed. Georges Digard/ Maurice Faucon/Antoine Thomas/Robert Fawtier, 4 Bde., Paris 1907-1939 (Bibliothèque des Écoles françaises d'Athènes et de Rome, Sér. 2).

Johannes Ramackers, Papsturkunden in Frankreich. Neue Folge.

Wilhelm Wiederhold, Papsturkunden in Frankreich.

Les Registres de Nicolas III (1277-1280), ed. Jules GAY, Paris 1898 (Bibliothèque des Écoles françaises d'Athènes et de Rome, Sér. 2).

Göttinger Nachrichten

Germania Pontificia

Honorii III Romani pontificis opera omnia, ed. CésarAuguste Horoy, 5 Bde., Paris 1879-1882 (Bibliotheca patristica medii aevi).

Italia Pontificia, Italia pontificia

JAFFé-KaltenbrunNer/JAFFÉ-EwALD/JAFFÉ-LÖWENFELD, Regesta Pontificum Romanorum 
Jordan

Langlois

LexMA

$\mathrm{MC}$

Migne PL

Mittarelli

$\mathrm{O} 1-3$

Potthast

Pressutti

Prou

Les Registres de Clément IV (1265-1268), ed. Édouard Jordan, 2 Bde., Paris 1893-1945 (Bibliothèque des Écoles françaises d'Athènes et de Rome, Sér. 2).

Les Registres de Nicolas IV, ed. Ernest Langlois, Paris 1886-1893 (Bibliothèque des Écoles françaises d'Athènes et de Rome, Sér. 2).

Lexikon des Mittelalters

Paul Fridolin KeHR: Le bolle pontificie anteriori al 1198

che si conservano nell'archivio di Monte-Cassino, in: Miscellanea Cassinense 2 (1899) S. 1-90.

Patrologiae cursus completus accurante Jacques-Paul Migne, Series Latina.

Giovanni Benedetto Mittarelli: Annales Camaldulenses Ordinis Sancti Benedicti quibus plura interseruntur tum ceteras Italico-monasticas res, tum historiam ecclesiasticam remque diplomaticam illustrantia, 9 Bde., Venedig 17551773 (ND Farnborough 1970).

Rudolf Hiestand: Papsturkunden für Templer und Johanniter. Archivberichte und Texte, Göttingen 1972 (Vorarbeiten zum Oriens Pontificius 1). Papsturkunden für Templer und Johanniter. Neue Folge, Göttingen 1984 (Vorarbeiten zum Oriens Pontificius 2). Papsturkunden für Kirchen im Heiligen Land, Göttingen 1985 (Vorarbeiten zum Oriens Pontificus 3).

Regesta pontificum Romanorum, 1198-1304.

Regesta Honorii papae III. ex Vaticanis archetypis aliisque fontibus, ed. Petrus Pressutti, 2 Bde., Roma 1888/1895 (ND Hildesheim/New York 1978).

Les Registres d'Honorius IV, ed. Maurice Prou, Paris 1888 (Bibliothèque des Écoles françaises d'Athènes et de Rome, Sér. 2/7).

PUU in Frankreich Papsturkunden in Frankreich

PUU in Italien Paul Fridolin KeHr: Papsturkunden in Italien. Reiseberichte zur Italia Pontificia, 6 Bde., Città del Vaticano 1977 (Acta Romanorum Pontificum 1-6).

$\mathrm{RRH}$

Reinhold Röнricht: Regesta Regni Hierosolymitani 1097-1291, Innsbruck 1893. Additamentum, Berlin 1904. 


\section{Einführungen}


Bereitgestellt von | De Gruyter / TCS

Angemeldet | 217.89.40.26

Heruntergeladen am | 21.12.12 10:47 


\title{
Das Deutsche Historische Institut (DHI) in Rom und Paul Fridolin Kehrs Papsturkundenwerk
}

\author{
Michael Matheus
}

Am 7. November 1896, vor über 110 Jahren, schlug Paul Fridolin Kehr (18601944) im Rahmen der öffentlichen jährlichen Jahresfeier der königlichen Gesellschaft der Wissenschaften in Göttingen, der späteren Akademie, den Plan einer kritischen Ausgabe der Papsturkunden bis Innozenz' III. vor. Die Edition sollte das Material bis 1198, mithin die gesamte in zahlreichen Bibliotheken und Archiven Europas verstreute Ausstellerüberlieferung der lateinischen Kirche bis zu jenem Datum erfassen, ab dem die päpstliche Register- und damit die Ausstellerüberlieferung in nennenswertem Umfang einsetzt. Dieser Plan wurde im darauf folgenden Jahr beschlossen, das Vorhaben einer kritischen Edition pries der Initiator als ruhmvolles Vorhaben ${ }^{1}$.

Die Aufgabe dieses Beitrags besteht nicht darin, die Genese dieses „ungeheuren Unternehmens "2 mit seinen zahlreichen Untergliederungen wie der Italia Pontificia, der Germania, der Gallia, der Hispania, der Polonia Pontificia und anderen mehr zu untersuchen. Das Unternehmen firmierte - wohl nicht zufällig - unter verschiedenen Bezeichnungen: Regesta Pontificum Romanorum, Göttinger Papsturkundenwerk, Papsturkundenwerk der Pius-Stiftung. Keine dieser Bezeichnungen läßt eine Verbindung zum Deutschen Historischen Institut erkennen. Gerade dieses Verhältnis soll an dieser Stelle in erster Linie untersucht werden.

Im folgenden interessieren vor allem drei Aspekte. Es geht um Beginn und Dauer des Vorhabens und insbesondere um die Italia Pontificia; gefragt werden soll nach der nationalen bzw. internationalen Ausrichtung des Projektes und schließlich nach dem Verhältnis zwischen Papsturkundenwerk und Deutschem Historischem Institut in Rom.

1 Rudolf Hiestand: 100 Jahre Papsturkundenwerk, in: Hundert Jahre Papsturkundenforschung. Bilanz - Methoden - Perspektiven, hg.v. DEMs., Göttingen 2003 (AAG, phil.-hist. Kl., 3. Folge 261), S. 11-44, hier S. 12. Zur Situation der Göttinger Akademie im ausgehenden 19. Jahrhundert vgl. Martin GierL: Geschichte und Organisation. Institutionalisierung als Kommunikationsprozess am Beispiel der Wissenschaftsakademien um 1900, Göttingen 2004 (AAG, phil.-hist. Kl., 3. Folge 233).

2 Harry Bresslau, in: Jahresberichte der Geschichtswissenschaft 19 (1896) IV S. 133. 
1) Zehn Jahre veranschlagte Kehr 1896 bis zur Vollendung der geplanten Edition. Auch wenn er die Dimensionen der Arbeit zweifellos unterschätzte, daß zehn Jahre nicht ausreichen würden, konnten er und andere, ja mußten sie wohl wissen. Nicht erst heute ist jeder Wissenschaftler gut beraten, Geldgeber nicht mit unrealistisch dimensionierten Unternehmungen zu verschrecken. Aber fürs erste hatte Kehr Erfolg, und dabei profitierte er wohl davon, daß der altehrwürdige Wissenschaftsstandort Göttingen, konkret die Göttinger Gesellschaft, sich mit einem Vorzeigeprojekt profilieren wollte, nicht zuletzt gegenüber der Berliner Konkurrenz. Als Kehr bereits nach nur zwei Jahren Archivrecherche 1898 dem Ministerium zu verstehen gab, er benötige mehr Mittel, das Projekt könne zudem nicht in zehn, sondern erst in fünfzehn Jahren abgeschlossen sein, stieß er trotz glänzender Beziehungen zu Schlüsselfiguren der Ministerialbürokratie auf Skepsis und Zurückhaltung. Statt der beantragten Summe von jährlich 8000 Mark wurden 2000 Mark bewilligt, freilich unter der Bedingung, daß ganz gegenwartsnah „der Plan hinreichend begrenzt sei“. Es waren nicht zuletzt großzügige Spenden, die einen zügigen Fortgang des Unternehmens bis zum Ersten Weltkrieg entscheidend förderten, und zudem der Rückhalt durch das römische Institut.

Manches dürfte zu dieser gewollten oder jedenfalls in Kauf genommenen Fehleinschätzung beigetragen haben: eine Mischung aus Leidenschaft für eine bedeutende wissenschaftliche Zielsetzung, zudem Eitelkeit und Ambitionen gegenüber Konkurrenten. Mit dem Papsturkundenwerk plante Kehr - so wurde treffend beobachtet - anfangs in gewisser Weise eine "Gegenmonumenta" ${ }^{\text {"3. }}$ Nicht mehr nur um „deutsche“ Kaiserurkunden sollte es gehen, nach Vorarbeiten wie jenen von Philipp Jaffé und Julius von Pflugk-Harttung lag die Beschäftigung mit Papsturkunden gleichsam „in der Luft “4. Kehrs Verhältnis zu wichtigen Monumentisten war jedenfalls gespannt, bis er im Jahre 1919 selbst die Leitung dieser Einrichtung übernahm. Damals stand er längst schon im Ruf des „beste(n) Urkundenkenner(s) in Deutschland“5. In Rechnung sollte man aber auch das stellen, was man als Zeitgeist bezeichnen könnte, der uns ebenso am Wickel hat wie damals einen Paul Fridolin Kehr. Um die Katastrophe des Ersten Weltkrieges wußte 1896 noch niemand. Die Jahre waren von ungeheurem Optimismus geprägt. Nicht nur wirtschaftlich ging es aufwärts in dem nach Weltgeltung strebenden neuen Kaiserreich, auch in der Wissenschaft, nicht zuletzt in der Geschichtswissenschaft, gaben Optimismus und Stolz, bisweilen

3 Stefan Weiss: Paul Kehr - Delegierte Großforschung: Die „Papsturkunden in Frankreich" und die Vorgeschichte des Deutschen Historischen Instituts in Paris, in: Das Deutsche Historische Institut Paris und seine Gründerväter. Ein personengeschichtlicher Ansatz, hg.v. Ulrich Pfeil, München 2007 (Pariser Historische Studien 86), S. 35-58.

4 Hiestand: Papsturkundenwerk (wie Anm. 1) S. 19.

5 Johannes Haller: Lebenserinnerungen. Geschehenes - Gehörtes - Gedachtes, Stuttgart 1960, S. 134. 
auch imperiale Stimmen den Ton an, die schon deshalb blühen konnten, weil die Leistungen der deutschen Geschichtswissenschaft auch im Ausland anerkannt und bewundert wurden.

Kehr pflegte eine enge Verbindung zu Friedrich Althoff, der faktisch das preußische Kultusministerium leitete, welches „Funktionen eines Reichswissenschaftsministeriums wahrnahm“". Die Gründung schlagkräftiger, international konkurrenzfähiger Forschungseinrichtungen stand auf der Tagesordnung. Wissenschaft sollte über die Tätigkeit des Einzelforschers hinaus zunehmend als "Großbetrieb" (Adolf Harnack) organisiert werden. Solche Konzepte entsprachen Kehrs Ambitionen, und er zählte zu jenen, welche die Chancen erkannten, die vor diesem Hintergrund das preußische Kultusministerium und die dort maßgeblichen Beamten eröffneten ${ }^{7}$.

Freilich, der Respekt vor Kehrs großer Leistung gründete und gründet damals wie heute ja nicht auf einer mißratenen zeitlichen und das heißt eben auch inhaltlichen Dimensionierung seines Vorhabens. Erwies sich die geplante Edition sehr bald als nicht realisierbar, so legte Kehr nach zehn Jahren (1906) gewichtige Ergebnisse vor, den ersten Band der Regesta Pontificum Romanorum und damit zugleich den ersten Band der Italia Pontificia. Von der Genese und der Konzeption handeln mehrere Beiträge des vorliegenden Bandes, nicht zuletzt jener von Dieter Girgensohn, der mit der Vorlage des zehnten Bandes im Jahre 1975 diese Reihe vorläufig abschloß ${ }^{8}$. Hier nur soviel. Mit Blick auf die ursprünglich angestrebte Edition werden die Regesta bis in jüngste Publikationen hinein wohl kaum zutreffend als „Zwischenstufe“ bezeichnet. Tatsächlich hatten Kehr und seine Mitstreiter zwischen 1896 und 1906 ein völlig neues Konzept entwickelt. Für Kehr selbst handelte es sich um eine „urkundliche Quellenkunde (der Papsturkunden) auf breitester Grundlage", die nach einzelnen europäischen Ländern gegliedert werden sollte und mit der Italia ihren Anfang nahm. Als „Zwischenstufe " können da eher die wertvollen Reiseberichte gelten, in denen über jene Archive und Bibliotheken berichtet wurde, welche Kehr und seine Mitstreiter durchforsteten und die größtenteils 1977 in fünf

6 Bernhard vom Brocke: Die Kaiser-Wilhelm Gesellschaft im Kaiserreich. Vorgeschichte, Gründung und Entwicklung bis zum Ausbruch des Ersten Weltkriegs, in: Forschung im Spannungsfeld von Politik und Gesellschaft. Geschichte und Struktur der Kaiser-Wilhelm-/Max-Planck-Gesellschaft, hg. v. Rudolf Vierhaus/Bernhard vom Brocke, Stuttgart 1990, S. 17-162, hier S. 74, 77. Vgl. auch DERs.: Hochschul- und Wissenschaftspolitik in Preußen und im Deutschen Kaiserreich 1882-1907: das „System Althoff“, in: Bildungspolitik in Preußen zur Zeit des Kaiserreichs, hg.v. Peter BAumGART, Stuttgart 1980, S. 9-118.

7 Ulrich PfeIL: Vorgeschichte und Gründung des Deutschen Historischen Instituts Paris. Darstellung und Dokumentation, Ostfildern 2007 (Instrumenta 17), S. 30 ff.

8 Siehe Dieter Girgensohn in diesem Bande S. 215-257. 
Bänden zusammen mit einem Registerband publiziert wurden ${ }^{9}$. Bis heute gilt die Italia Pontificia, gewissermaßen der Auftakt des Papsturkundenwerks, als dessen „Herz“ und „Paradestück“10.

2) Wiederholt wurde darauf hingewiesen, Kehr habe bei der Erforschung des Papsttums bewußt über nationalstaatliche Unternehmungen hinausgreifen wollen, und in diesem Sinne beschrieb er auch die Aufgabe des Preußischen Historischen Instituts in Rom ${ }^{11}$. Tatsächlich warb er schon 1896 vor der Göttinger Gesellschaft explizit für eine „Liga“ von Forschern mehrerer Länder (und das meinte vor allem Forscher aus Deutschland, Italien und Frankreich) ${ }^{12}$ und sprach sich unmißverständlich gegen Versuche aus, geschichtswissenschaftliche Arbeit in diesem Felde nach „Nationalitäten und nach nationaler Überlieferung scheiden zu wollen“, ,jedenfalls für die älteren Jahrhunderte, deren Grundgedanke die Einheit und die Universalität des christlichen Abendlandes war "13. Man sollte die in solchen Formulierungen erkennbar werdenden internationalen Perspektiven würdigen, sie nicht gering schätzen, gerade vor dem Hintergrund mancher anderer nationaler Verengung des Blicks unter den Zeitgenossen. Freilich sollte man sich auch über die Grenzen und Ambivalenzen der Kehrschen Intentionen im Klaren sein. Für ihn bestand kein Zweifel daran, daß gerade Deutsche zu einem solchen Unternehmen berufen seien. Als er im Jahre 1902 versuchte, Johannes Haller als Mitstreiter für die Gallia Pontificia zu gewinnen, ließ Kehr den Kollegen wissen: „Ich hoffe sicher auf Ihre Mitwirkung, nicht nur um meiner eigenen Unternehmung halber, sondern auch im Interesse unserer Geschichtswissenschaft: wir müssen Frankreich erobern, wie wir Italien erobern. ${ }^{\text {“14 }} \mathrm{Ihm}$ war bewußt, daß das Papsturkundenwerk „die Kräfte eines Einzelnen“ überstieg und eine Organisation vonnöten war, um die „all-

9 Paul Fridolin Kenr: Papsturkunden in Italien. Reiseberichte zur Italia Pontificia 1-5, Città del Vaticano 1977 (Acta Romanorum Pontificum 1-5), mit Register zusammengestellt von Raffaello Volpini (ebd. 6). Vgl. Walther Holtzmann: Nachträge zu den Papsturkunden Italiens X, in: NAG, phil.-hist. Kl. 8 (1962 [1963]) S. 206-247.

10 Rudolf Hiestand: Die unvollendete Italia Pontificia, in: Papsturkundenforschung (wie Anm. 1), S. 47-57, hier S. 47.

11 Vgl. die „Denkschrift über die Zukunft des Historischen Instituts in Rom“, verfaßt von Paul F. Kehr (April 2007), in: Hubert Houben: Hundert Jahre deutsche Kastellforschung in Süditalien, in: QFIAB 84 (2004) S. 103-136, hier S. $131 \mathrm{ff}$.

12 Rudolf Hiestand: Das Göttinger Papsturkundenwerk, in: Jahrbuch der historischen Forschung in der Bundesrepublik Deutschland 1988 (1989) S. 13-17.

13 Paul Fridolin Kenr: Über den Plan einer kritischen Ausgabe der Papsturkunden bis Innocenz III. (Göttingen 1896), in: DERs.: Ausgewählte Schriften, 2 Bde., hg. v. Rudolf Hiestand, Göttingen 2005 (AAG, phil.-hist. Kl., 3. Folge 250/1-2), Bd. 1 S. 3-17, hier S. 5.

14 Pfeil (wie Anm. 7) S. 39. 
mähliche Eroberung aller dieser Länder vorzubereiten und durchzuführen“15. Solche kulturhegemoniale Ausdrucksweise entspricht wohl einer durchaus zeittypischen imperialen Semantik, wobei es Kehr um die Ziele des auf Quellenerschließung zielenden Organisators ging ${ }^{16}$. Mit Blick auf die international ausgerichtete "Gelehrtenrepublik" vor dem Ersten Weltkrieg wurde denn auch zutreffend festgestellt: „Internationalismus verband im Zeitalter des Imperialismus, der zugleich nationale Konkurrenzen förderte. ${ }^{17}$ Der von Kehr schon vor 1914 gepflegte Sprachduktus von der Archiveroberung in benachbarten Staaten entsprach jedenfalls der mentalen Disposition zahlreicher Intellektueller, die wie große Teile der deutschen Bevölkerung bei Kriegsausbruch von einer Welle der nationalistischen Begeisterung erfaßt wurden ${ }^{18}$.

Der erste Weltkrieg unterbrach das Unternehmen der Papsturkundenforschung nicht dauerhaft. An seinen Zielen, an seiner kulturimperialistischen Sprache hielt Kehr fest, als er auch im Zweiten Weltkrieg alles daran setzte, das wissenschaftsorganisatorische Großvorhaben der Papsturkundenforschung unter veränderten Bedingungen weiter voran zu treiben. In einem Rückblick aus dem

15 Paul Fridolin KeHR: Italienische Erinnerungen (Wien 1940), in: Ders.: Ausgewählte Schriften (wie Anm. 13) Bd. 2 S. 1303-1332, hier S. 1312.

16 Josef Fleckenstein: Paul Kehr. Lehrer, Forscher und Wissenschaftsorganisator in Göttingen, Rom und Berlin, in: Geschichtswissenschaft in Göttingen. Eine Vorlesungsreihe, hg.v. Hartmut Boockmann/Hermann Wellenreuther, Göttingen 1987 (Göttinger Universitätsschriften Serie A: Schriften 2), S. 239-260.

17 Rüdiger vom Bruch: Geistige Kriegspropaganda. Der Aufruf von Wissenschaftlern und Künstlern an die Kulturwelt, in: Europa und die Europäer. Quellen und Essays zur modernen europäischen Geschichte, hg.v. Rüdiger Hohls u. a., Stuttgart 2005, S. 392 396, hier S. 392. Vgl. auch: Jürgen von UNGERN-STERnBERG/Wolfgang von UnGERNSternberg: Der Aufruf „An die Kulturwelt!“ Das Manifest der 93 und die Anfänge der Kriegspropaganda im Ersten Weltkrieg. Mit einer Dokumentation, Stuttgart 1996 (Historische Mitteilungen, Beiheft 18). Rüdiger vom BRUCH: Weltpolitik als Kulturmission. Auswärtige Kulturpolitik und Bildungsbürgertum in Deutschland am Vorabend des Ersten Weltkrieges, Paderborn u. a. 1982 (Quellen und Forschungen aus dem Gebiet der Geschichte, N.F. 4). Zu Kehr vgl.: Michèle Schuвert: Zum Wirken Paul Fridolin Kehrs für ein deutsches historisches Zentralinstitut oder: der lange Weg zum KaiserWilhelm-Institut für Deutsche Geschichte, in: Die Kaiser-Wilhelm-/Max-Planck-Gesellschaft und ihre Institute. Studien zu ihrer Geschichte: Das Harnack-Prinzip, hg.v. Bernhard vom Brocke/Hubert Laitko, Berlin u.a. 1996, S. 423-444; Dies.: MeisterSchüler. Theodor von Sickel und Paul Fridolin Kehr (nach ihrem Briefwechsel), in: MIÖG 106 (1998) S. 149-166; DIEs.: Paul Fridolin Kehr als Professor und als Akademiemitglied in Göttingen (1895-1903). Ein Historiker im Konflikt zwischen Lehre und Forschung. Zugleich ein Beitrag zur Geschichte der Papsturkundenedition, in: AZ 82 (1999) S. $81-125$.

18 Kultur und Krieg: Die Rolle der Intellektuellen, Künstler und Schriftsteller im Ersten Weltkrieg, hg.v. Wolfgang J. Mommsen, München 1996 (Schriften des Historischen Kollegs, Kolloquien 34); Kurt Flasch: Die geistige Mobilmachung. Die deutschen Intellektuellen und der Erste Weltkrieg. Ein Versuch, Berlin 2000. 
Jahre 1940 heißt es: „So begann ich die archivalische Eroberung Italiens im Herbst 1896. "19 Der Reisende ,in archivalibus ${ }^{\text {“20 }}$ hielt sich - wie er nicht ohne Stolz bekundete - persönlich „die Eroberung der italienischen und spanischen Archive vor ${ }^{\text {"21 }}$, wobei in einem Zusatz immerhin ausdrücklich vom friedlichen Charakter dieser Eroberung die Rede ist ${ }^{22}$.

Bezeichnend ist wohl auch, daß zur Zeit Kehrs keiner der Reiseberichte und Regestenbände einen italienischen oder französischen Verfasser hatte ${ }^{23}$. Gelehrte

19 KeHR: Italienische Erinnerungen (wie Anm.15) S. 1313.

20 Ebd. S. 1315.

21 Ebd. S. 1312.

22 Ebd. S. 1314. Eine Biographie zu Paul Fridolin Kehr ist ein Forschungsdesiderat. Auch seine Rolle in der NS-Zeit ist bisher allenfalls ansatzweise untersucht. Zur Orientierung vgl. Stefan Weiss: Paul Kehr-Bibliographie, in: QFIAB 72 (1992) S. 374-437. Siehe auch die bibliographischen Angaben von Stefan Weiß, in: KeHr: Ausgewählte Schriften (wie Anm. 13) Bd. 2 S. 1331-1397. Vgl. insbesondere: Michael F. Feldkamp: Pius XI. und Paul Fridolin Kehr. Begegnungen zweier Gelehrter, in: AHP 32 (1994) S. 293-328. Paul F. Kehr. Zugänge und Beiträge zu seinem Wirken und zu seiner Biographie. Veranstaltung zum 60. Geburtstag von Arnold Esch am 20. Mai 1996, Tübingen 1997; Hartmut Lehmann: Geschichts- und kulturwissenschaftliche Spezialforschung im Spannungsfeld von nationalsozialistischer Ideologie und nationalsozialistischer Eroberungspolitik, in: Geschichte der Kaiser-Wilhelm-Gesellschaft im Nationalsozialismus, 2 Teilbde., hg.v. Doris Kaufmann, Göttingen 2000, S. 545-553; Horst Fuhrmann: Paul Fridolin Kehr - „Urkundione“ und Weltmann, in: DERs.: Menschen und Meriten. Eine persönliche Portraitgalerie, München 2001, S. 174-212; Leo Just. Briefe an Hermann Cardauns, Paul Fridolin Kehr, Aloys Schulte, Heinrich Finke, Albert Brackmann und Martin Spahn 1923-1944, hg., eingeleitet und kommentiert v. Michael F. Feldkamp, Frankfurt am Main u. a. 2002; Stephan Selzer: Zwischen Rom und Merseburg. Paul Fridolin Kehr und das Urkundenbuch des Hochstiftes Merseburg, in: Sachsen und Anhalt 25 (2002/2003) S. 83-102; Folker Reichert: Paul Kehr und Karl Hampe über die Zukunft der Monumenta Germaniae Historica nach dem Ersten Weltkrieg, in: DA 60 (2004) S. 549-569. In einem Brief Kehrs vom 6.8.1940 an Friedrich Bock, der faktisch die Leitung des DHI in Rom wahrnahm, heißt es u. a.: „... unsere persönlichen Beziehungen sind mindestens so fest wie die Achse und unsere Übereinstimmung in allen wesentlichen Dingen ist so groß, daß sich eigentlich eine Aussprache erübrigt.“ Er informiert anschließend Bock über (bisher nicht näher untersuchte) Pläne, die römische Institutslandschaft neu zu ordnen, und fährt fort: „Es wird notwendiger Weise zu einer immer größeren Intimität zwischen Italia und Germania kommen - das kann und muß eins der großen Ergebnisse des großen Krieges und Sieges sein. Und als alter Praktiker bin ich immer geneigt und bereit, das Mögliche aus den Ereignissen auch für unser wissenschaftlich-kulturelles Programm zu ziehen. Ich bin, wie Sie wissen, da ganz ohne Vorurteile und historische Hemmungen und habe deshalb auch das Kulturinstitut von Hoppenstädt akzeptiert; freilich als Institut der K. WilhelmGesellschaft wirkt es ein bischen komisch“. Archiv des DHI-Rom, Bestand S1, Nr. 94. Den Hinweis verdanke ich Herrn Karsten Jeduitschka, der 2006 eine neue Tektonik des Institutsarchivs erstellt hat, vgl. Karsten Jeduitschka: Das Archiv des Deutschen Historischen Instituts in Rom. Geschichte und Bestände, in: QFIAB 86 (2006) S. 1-40.

23 Hiestand: Papsturkundenwerk (wie Anm. 1) S. 34. 
im Gastland werden genannt, unter ihnen der von Kehr wiederholt gerühmte langjährige Mitarbeiter Luigi Schiaparelli $(1871-1934)^{24}$. Aber aufs Ganze gesehen blieb die Italia Pontificia ein „deutsches Unternehmen mit italienischer $\mathrm{Hilfe}^{\text {"25 }}$. Zu einer Internationalisierung des Papsturkundenwerks kam es nicht. Erst 1996, hundert Jahre nach Kehrs Initiative, trafen sich die aktuellen Mitarbeiter des Projektes zu einer ersten persönlichen, wissenschaftlichen Zusammenkunft ${ }^{26}$.

3) Offiziell bzw. formal waren weder das Papsturkundenwerk noch die Italia Pontificia ein Projekt des Deutschen Historischen Instituts und seiner Vorgängereinrichtungen. Beide existieren in den Tätigkeitsberichten des römischen Instituts nicht ${ }^{27}$. Freilich erscheint jene Formulierung nicht hinreichend zu sein, die Italia Pontificia sei insbesondere in den ersten Jahren und Jahrzehnten dem römischen Institut „verbunden“ gewesen. Ohne das römische Institut gäbe es das „Herz“, das Paradepferd - so Rudolf Hiestand - des Papsturkundenwerks nicht, und zwar auch dank des Engagements zweier Direktoren des Instituts, wobei über Kehr hinaus auch an seinen eigentlichen wissenschaftlichen Erben zu erinnern ist, an Walther Holtzmann, den ersten Direktor in der Nachkriegszeit $^{28}$. Doch zurück zu Kehr. Er wollte Göttingen den Rücken kehren, die Langeweile an der dortigen Universität, einer - wie er sagte - „alten Bude“29, beklagte er. Ihn trieb es nach Rom, wo er endlich 1903 die Leitung des dortigen 1888 gegründeten Preußischen Historischen Instituts übernahm. Und möglicherweise hat sich ja Kehr auch mit Blick auf die spätere Italia Pontificia so leidenschaftlich in jenem „Kampf um Rom“ engagiert, bei dem es um die Leitung und die Aufgaben des römischen Instituts ging ${ }^{30}$. Mit der Übernahme

24 Rudolf Hiestand: Die Italia Pontificia, in: Das Deutsche Historische Institut in Rom 1888-1988, hg.v. Reinhard Elze/Arnold Esch, Tübingen 1990 (Bibliothek des Deutschen Historischen Instituts in Rom 70), S. 167-189, hier S. 185 f.

25 Hiestand: Papsturkundenwerk (wie Anm. 1) S. 35; Pfeil (wie Anm. 7) S. $31 \mathrm{ff}$.

26 Rudolf Hiestand: Vorwort, in: Papsturkundenforschung (wie Anm. 1) S. 8 f.

27 Hiestand: Italia Pontificia (wie Anm. 24) S. 167.

28 Walther Holtzmann war 1921 auf Vermittlung Harry Bresslaus zu Kehr gekommen. Zu Holtzmann als Direktor des DHI vgl. Michael Matheus: Gestione Autonoma. Zur Wiedereröffnung und Konsolidierung des Deutschen Historischen Instituts in Rom (1953 bis 1961), in: Deutsche Forschungs- und Kulturinstitute in Rom in der Nachkriegszeit, hg.v. DEMs., Tübingen 2007 (Bibliothek des Deutschen Historischen Instituts in Rom 112), S. 99-126.

29 Fleckenstein (wie Anm. 16) S. 250.

30 Lothar Burchardt: Gründung und Aufbau des preußischen Historischen Instituts in Rom, in: QFIAB 59 (1979) S. 334-391; Arnold Esch: Die Lage der deutschen wissenschaftlichen Institute in Italien nach dem Ersten Weltkrieg und die Kontroverse über ihre Organisation. Paul Kehrs „römische Mission“ 1919/1920, in: QFIAB 72 (1992) S. 314-373; Michèle Schubert: Auseinandersetzungen über Aufgaben und Gestalt des 
des römischen Direktorats hatte der zum wissenschaftlichen Großorganisator in Sachen Geschichtswissenschaft werdende Kehr eine wichtige Etappe erreicht. Diesem Amt sollten viele weitere folgen. Wenngleich nur indirekt, so wurde und darauf hat schon Rudolf Hiestand wiederholt hingewiesen - das römische Institut zu einer zentralen und unverzichtbaren Ressource für das Papsturkundenprojekt, und dies ließe sich (was hier unterbleiben muß), gerade für die so fruchtbaren Jahre bis zum Ausbruch des Ersten Weltkrieges, die Kehr im Rückblick als die „schönste und erfolgreichste Zeit meines gelehrten Lebens“ ${ }^{\text {«31 }}$ galt, auf eindrucksvolle Weise demonstrieren.

Von Anfang an war sich Kehr bewußt: das Papsturkundenwerk überstieg die Kräfte eines Einzelnen, organisatorischer Rückhalt war vonnöten. Unter sich wandelnden Verhältnissen gelang es ihm immer wieder in einer eindrucksvollen Mischung von persönlichen und institutionellen Faktoren, die Absicherung und den Fortgang des Unternehmens zu betreiben. Was die persönlichen Netzwerke betrifft, so sei lediglich an die wohl prominenteste Verbindung erinnert, die kollegiale und freundschaftliche Zusammenarbeit mit Achille Ratti, Bibliothekar der Biblioteca Ambrosiana, Präfekt der Biblioteca Vaticana, dann Papst Pius XI., dem die nach ihm genannte, 1931 in der Schweiz gegründete Stiftung ihre Existenz verdankt ${ }^{32}$. Vielleicht war es ja gerade dieses flexible, virtuose Spiel mit verschiedenen, persönlichen und institutionellen Faktoren wie der Göttinger Gesellschaft bzw. Akademie, dem römischen Institut und schließlich der Stiftung, das entscheidend dazu beitrug, daß einem Projekt historischer Grundlagenforschung wie dem Papsturkundenwerk über zwei Weltkriege, über Inflation und Wirtschaftskrise hinweg der Atem niemals ausging.

Jahrzehntelang war die entscheidende Triebfeder des Unternehmens Paul Fridolin Kehr, darüber sollten aber die Mitstreiter und insbesondere jene am römischen Institut nicht aus dem Blick geraten. Gerade sie wurden wiederholt neben einer ganzen Reihe junger Wissenschaftler für die Arbeit an der Italia Pontificia engagiert, die Institutsbibliothek zudem ganz im Sinne der Arbeit an Papsturkunden bestückt. Verglichen mit dem Meister, den Kardinal Rambolla „un altro Mommsen“33, und den Fleckenstein einen „zweiten Mabillon“ nannte ${ }^{34}$, war bisher von den zahlreichen Mitstreitern Kehrs, den „Hilfsarbeitern" wie sie damals genannt wurden, nur vereinzelt und eher nebenbei die

Preußischen Historischen Instituts in den Jahren von 1900 bis 1903, in: QFIAB 76 (1996) S. 383-454.

31 KeHr: Italienische Erinnerungen (wie Anm. 15) S. $1324 \mathrm{f}$.

32 Hiestand: Papsturkundenwerk (wie Anm. 1) S. $15 \mathrm{f}$.

33 Hiestand: Italia Pontificia (wie Anm. 24) S. 173. Vgl. Kehr: Italienische Erinnerungen (wie Anm. 15) S. 1317.

34 Fleckenstein (wie Anm. 16) S. 260. 
Rede. Die Regestenbände der Italia Pontificia tragen alle den Namen Kehrs, immerhin werden in den Reiseberichten die Hilfsarbeiter namentlich genannt ${ }^{35}$.

Noch ist niemand jener Mannschaft systematisch nachgegangen, ohne deren Arbeit die Italia Pontificia nicht vorstellbar wäre, darunter manch klangvoller Name der deutschen Wissenschaft und insbesondere der Mediävistik. Hier sei stellvertretend für andere auf Aloys Ruppel verwiesen, der von 1908 bis 1910 auf Anweisung Kehrs in den Marken und in der Romagna Archivreisen unternahm, einige mit Kehr gemeinsam. Als langjähriger Direktor des Mainzer Gutenbergmuseums und Professor der Buchwissenschaft an der Johannes Gutenberg-Universität Mainz hat sich Ruppel später auf anderen Feldern einen Namen gemacht ${ }^{36}$. Seine bisher nicht edierten Erinnerungen ${ }^{37}$ beleuchten die Arbeit an der Italia Pontificia (und so manch anderes kulturgeschichtlich Interessante) einmal nicht aus der Perspektive des Meisters, für Ruppel ein „wenig angenehmer Tyrann ${ }^{\text {“38 }}$, den er als solchen fürchten, zugleich aber auch schätzen lernte.

Hier nur eine Kostprobe aus der Erinnerung an eine mit Kehr durchgeführte Reise, die in Modena begann, und wo nicht nur Ruppels philologischpaläographische Fähigkeiten, sondern auch seine kulinarischen Kenntnisse einer strengen Prüfung unterzogen wurden. Im Anschluß an ein Abendessen läßt Ruppel in folgender Weise Kehr zu Wort kommen: „Sie werden sich gewundert haben, daß ich Sie nach den Speisen und Getränken fragte. Auch ich wurde einst in Wien [und hier wird wohl auf Theodor von Sickel angespielt - Kehrs Lehrer in Wien] so geprüft. Er ließ mich verschiedene Weine trinken und ich mußte jedes Mal Herkunft und Jahrgang nennen. Und als die Weinprobe zu Ende war, sagte er mir: Wer einen guten Wein nicht von einem schlechten, wer einen Rheinwein nicht von einem Mosel unterscheiden kann, der kann auch eine gefälschte Urkunde nicht von einer echten unterscheiden. ${ }^{\text {“39 }}$

Jenes Geflecht von Mitarbeitern und Kontaktpersonen im Gastland, die in Archivberichten und Erinnerungen genannt werden, stellt ein interessantes, bisher kaum beachtetes Stück Gelehrten- und Wissenschaftsgeschichte dar ${ }^{40}$. Von diesem Netzwerk profitiert das Institut noch heute. Denn manche Namen derer, die an der Italia Pontificia mitwirkten, wirken bisweilen immer noch wie Türöffner bei aktuellen Besuchen von Bibliotheken und Archiven in Italien.

35 Hiestand: Papsturkundenwerk (wie Anm. 1) S. 22 f., 34 f.; Ders.: Italia Pontificia (wie Anm. 24) S. 171 Anm. 17, S. 172, 174.

36 Zur ersten Orientierung vgl. Friedrich Sснӥтz: Aloys Ruppel: Leben und Werk, Mainz 1982.

37 Stadtarchiv Mainz, Nachlaß Ruppel, 12. Im folgenden zitiert nach der maschinenschriftlichen Fassung. Eine Edition dieser Erinnerungen ist geplant.

38 Ebd. S. 75, 80.

39 Ebd. S. 104.

40 Hiestand: Italia Pontificia (wie Anm. 24) S. 186. 
Was das Verhältnis zwischen römischem Institut und Italia Pontificia betrifft, so kann es mit folgender Formel umschrieben werden: mit Bedacht gehütete Distanz, aber zugleich eine beide Seiten befruchtende Symbiose. ${ }^{41}$

Auch wenn es in Rom anders als beim Pariser Institut nicht zu einer institutionellen Verklammerung mit der Papsturkundenarbeit kam ${ }^{42}$, am Interesse und an der Unterstützung des römischen Instituts für diese Arbeit besteht kein Zweifel ${ }^{43}$. Institutionell verankert sollte und wird das Papsturkundenwerk über die Piusstiftung hinaus bei der Göttinger Akademie sein. Nachträge zur Italia Pontificia sind zweifellos wünschenswert ${ }^{44}$; dabei sollte man sich freilich bewußt sein, daß die Erforschung der Papsturkunden einen Prozeß darstellt, der nie als abgeschlossen gelten kann. Schon deshalb erscheint der Einsatz neuer elektronischer Mittel und Verfahren sinnvoll, die (auch virtuelle) Möglichkeiten einer internationalen Zusammenarbeit eröffnen, wie sie sich Paul Fridolin Kehr nicht vorstellen konnte.

\section{Riassunto}

Il contributo si occupa degli inizi e della prosecuzione del progetto avviato da Kehr, tenendo particolarmente conto dell'Italia Pontificia. In un secondo momento mette in discussione la presunta internazionalizzazione di quest'opera, che, di fatto, fu raggiunta solo verso la fine del XX secolo. In ultima analisi l'Italia Pontificia è rimasta un 'impresa tedesca. Infine il contributo mette in luce il ruolo svolto dall'Istituto Storico Germanico di Roma, che - nonostante l'Italia Pontificia non sia mai stata un progetto ufficiale dell'Istituto - ha messo a disposizione dell'impresa notevoli risorse. Questo importante sostegno „informale" esiste tuttora.

41 Ebd. S. 189.

42 Für die Gallia Pontificia ist am DHI Paris derzeit Rolf Grosse zuständig.

43 Hier sind insbesondere Publikationen von Jochen Johrendt aus seiner Zeit als Mitarbeiter des römischen DHI zu nennen: Jochen JohrendT: Papsttum und Landeskirchen im Spiegel der päpstlichen Urkunden (896-1046), Hannover 2004 (MGH Studien und Texte 33); DERs.: Cum universo clero ac populo eis subiecto, id ipsum eodem modo fecerunt. Die Anerkennung Alexanders III. in Italien aus der Perspektive der Papsturkundenempfänger, in: QFIAB 84 (2004) S. 38-68; DERs.: La protezione apostolica alla luce dei documenti pontifici (896-1046), in: BISI 107 (2005) S. 135-168; DERS.: Ein bisher unbekannter Kardinal in einem neu entdeckten feierlichen Privileg Innocenz' III.? Gregorius/Rogerius tituli sancte Anastasie presbiter cardinalis, in: RHMitt 48 (2006) S. $157-170$.

44 Hiestand: Unvollendete Italia Pontificia (wie Anm. 10) und mehrere Beiträge in diesem Bande. 


\title{
La Biblioteca Apostolica Vaticana e il Papsturkundenwerk*
}

\author{
Don Raffaele Farina
}

Signor Presidente, cari colleghi e amici,

La mia presenza e la mia parola in questo importante Convegno Internazionale vogliono esprimere prima di tutto la cordiale adesione della Biblioteca Apostolica Vaticana, in particolare del Cardinale Bibliotecario, del Prefetto e degli Scriptores della Biblioteca, al centenario di Italia Pontificia e alla presente manifestazione scientifica; ma anche la solidarietà e la riconoscenza, in qualche modo anche a nome delle istituzioni scientifiche e culturali del Vaticano e della Santa Sede, alle istituzioni che hanno promosso e gestito nel secolo che ricordiamo una ricca attività scientifica e culturale universalmente apprezzata: mi riferisco ovviamente al Papsturkundenwerk e, in particolare, all'Accademia delle Scienze e all'Università di Göttingen, alla Pius-Stiftung e alle personalità che qui rappresentano tali benemerite istituzioni.

Presente, accanto all'Archivio Segreto Vaticano, pur se in maniera marginale e occasionale, sin dagli inizi, nel 1896, dell'attività del Papsturkundenwerk, la Biblioteca Apostolica Vaticana è entrata in maniera formale nel 1931, a norma dello Statuto $(\$ 10)$, tra i membri della Commissione Scientifica della PiusStiftung für Papsturkunden- und mittelalterlichen Geschichtsforschung. I rapporti e l'amicizia del fondatore Paul Fridolin Kehr con Achille Ratti, all'Ambrosiana prima e poi alla Vaticana, consolidatisi dopo l'elezione a Papa nel 1922, furono fondamentali per l'espansione e stabilizzazione del grande progetto scientifico del Papsturkundenwerk.

I contatti di Kehr erano soprattutto con il Cardinali Bibliotecario, il Card. Giovanni Mercati. In una lettera del 16 dicembre del 1936, Kehr esprime la sua preoccupazione per la salute del Papa: „la perdita di un padrone come Pio XI sarà per il piccolo ceto degli eruditi una vera catastrofe, perché la vecchia scienza non vale nel mondo civile di oggi più nulla". La descrizione del clima politico nella Berlino di quegli anni, la sua destituzione dalla direzione dei Monumenta Germaniae Historica e dell'Istituto Storico Prussiano, le difficoltà economiche non lo scoraggiano dal lavoro (a Merano trova un oasi di pace dover riesce a lavorare); e fa cenno, tra le altre pubblicazioni in preparazione, al IX volume dell'Italia Pontificia. Conclude esprimendo „la soddisfazione di una vita laboriosa, di cui il

\footnotetext{
* La corrispondenza citata in questo contributo è conservata nell'Archivio della Prefettura
} della Biblioteca Apostolica Vaticana tra i materiali e le carte non ancora inventariati. 
merito in gran parte ha il Santo Padre, il Card. Ehrle e Vostra Eminenza Rev.ma [il Card. Mercati]“. E il 17 ottobre dell'anno seguente, nel 1937, annuncia il suo viaggio a Roma: „ho ottenuto finalmente il permesso di partire per Roma coi materiali delle bolle pontificie (per qualche tempo sequestrati!!!), per finire i lavori da fare per l'edizione del IX volume dell'Italia pontificia“.

Alla fine della II guerra mondiale e nell'immediato periodo postbellico, la Santa Sede (in particolare il Sostituto alla Segreteria di Stato Mons. Giovanni Battista Montini), con la collaborazione del Cardinale Bibliotecario Card. Giovanni Mercati e del Prefetto P. Anselmo Albareda, è riuscita a rintracciare l'eredità di Paul Kehr, le sue carte, la fondazione in Svizzera. Ma queste sono vicende note, sulle quali è stato scritto. Il Card. Mercati, scrivendone il 15 gennaio 1947, al Presidente dell'Accademia delle Scienze, il Prof. Carl Friedrich Ruldolf Smend, ricorda che, per ordine di Pio XII, „fin dal gennaio del 1945, quando s'intese la morte del Kehr, la Segreteria di Stato ed io quale Cardinale Bibliotecario di S.R.C., non abbiamo cessato di ricercare, per tutte le vie che ci aprivano, tanto il fondo Pio XI per salvarlo dalla confisca e dalle distrazioni che ne potevano temere, e per assicurarne l'impiego totale e col maggior frutto nell'opera per cui era stato elargito, quanto per conoscere le disposizioni finali del Kehr, il quale negli ultimi colloqui con me si era mostrato non tranquillo sull'avvenire a causa delle mutate condizioni pubbliche e poi del sequestro per oltre mezzo anno dei materiali raccolti e delle sue carte, ed era dubbioso sul modo di provvedere efficacemente alla conservazione e all'uso di quelli e all'incolumità della fondazione".

L'anno precedente, nel 1946, il P. Anselmo Albareda, Prefetto della Biblioteca Vaticana, scrivendo al medesimo Presidente Smend, con quella diligenza e accuratezza che ne hanno fatto il migliore dei gestori della Biblioteca Vaticana nell'ultimo secolo, nota che „ora, dopo le pratiche più diligenti non è comparsa alcuna diversa disposizione del medesimo Kehr e quindi si può ritenere con pieno vigore lo Statuto del 23 novembre del 1931, sono stato avvertito di significarle la mia accettazione a membro della sopranominata Commissione e di compiere i doveri che ne discendono".

Cari colleghi e amici, nel concludere queste brevi annotazioni e citazioni, voglio esprimere qui pubblicamente la mia disponibilità e quella della Biblioteca Vaticana ad andare oltre gli obblighi che derivano dall'essere il Prefetto membro della Commissione Scientifica e a contribuire fattivamente allo sviluppo dell'attività della nostra Fondazione, della Pius-Stiftung, sull'esempio dei due grandi amici e fondatori, il Papa Achille Ratti Pio XI e il Prof. Paul Fridolin Kehr.

Vi ringrazio per la Vostra attenzione

Don Raffaele Farina 


\section{Zusammenfassung}

Der Autor überbringt den Tagungsteilnehmern den Gruß der Biblioteca Apostolica vaticana als deren Präfekt sowie ihr Repräsentant in der wissenschaftlichen Kommission der Pius-Stiftung für Papsturkunden- und mittelalterlichen Geschichtsforschung. Aus der unedierten Korrespondenz ergeben sich nicht nur die guten Beziehungen zwischen den beiden Institutionen, sondern vor allem die ausschlaggebende Hilfe, die der Pius-Stiftung vom Kardinalbibliothekar und vom Präfekt der Biblioteca vaticana sofort nach dem Krieg von 1945 an angeboten wurde, um den Geldbestand einzuholen und zu bewahren, der von Pius XI. in der Schweiz und vom Archiv der Pius-Stiftung gestiftet worden war, ebenso wie dokumentierende Güter und Urkunden, die Paul Fridolin Kehr hinterlassen hat. 
Bereitgestellt von | De Gruyter / TCS

Angemeldet | 217.89.40.26

Heruntergeladen am | 21.12.12 10:47 


\title{
Das Papsttum und die „vielen“ Italien als Orbis Christianus?
}

\author{
Klaus Herbers
}

\section{Problemstellung}

„Eine unglaubliche Geschichte ist uns zu Ohren gekommen“, so die bewegte Klage eines Papstes im 9. Jahrhundert. In seinem Brief an einen Abt Honorat tadelte er, daß in dessen Kloster der gregorianische Gesang nicht nur abweichend von den Gepflogenheiten des römischen Sitzes, sondern auch von der fast ganzen okzidentalen Kirche, gepflegt werde. Desposco, ich fordere, so fährt der Papst in der ersten Person Singular fort, daß die Gemeinschaft dort nicht länger vom caput, vom Haupt der Kirche abweiche, er droht gegebenenfalls mit Exkommunikation und Anathem, beschwört die Einheit und nennt die römische Kirche mater omnium et magistra vestra ${ }^{1}$.

Das Schreiben ist in zwei Fragmenten der bekannten „Collectio Britannica“ enthalten, die nach den neuesten, noch nicht veröffentlichten Forschungen von Christof Rolker nach 1108 zusammengestellt worden sein soll, und es wird dort einem Papst Leo zugeschrieben, den wir mit Leo IV. (847-855) identifizieren müssen. Ziemlich sicher ist aber der angesprochene Abt nicht, wie früher behauptet, derjenige von Farfa, sondern von S. Salvatore sub monte Lentenano ${ }^{2}$, bei Rieti, an den Grenzen des damaligen Patrimonium Petri, also vor den Toren Roms. Aber warum Ermahnungen in liturgicis; was war mit dem gregorianischen Gesang gemeint? Die musikhistorische Forschung ist uneinig, ob im Kloster beim Monte Lentenano mailändische, süditalische, byzantinisch-griechische oder gar fränkisch bestimmte liturgische Gebräuche vorherrschten, und

1 Vgl. JE 2651, RI 1/4/2/1 Nr. 212; Der Text in Epistolae selectae Sergii II., Leonis IV., Benedicti III., pontificum Romanorum, ed. Adolf von Hirsch-Gereuth, in: MGH Epp. Karol. 3, Berlin 1899, S. 581-614, hier S. 603 f. Nr. 33. Zur Interpretation Klaus Herbers: Leo IV. und das Papsttum in der Mitte des 9. Jahrhunderts. Möglichkeiten und Grenzen päpstlicher Herrschaft in der späten Karolingerzeit, Stuttgart 1996 (Päpste und Papsttum 27), S. 289-295. - Der folgende Text orientiert sich am bei der Tagung gehaltenen Vortrag und bietet nur die wichtigsten Anmerkungen.

2 JE 2651, RI 1/4/2/1 Nr. 212; vgl. auch RI 1/3/1 Nr. 350. 
bleibt entsprechend unsicher, was in diesem Fall unter gregorianisch verstanden wurde ${ }^{3}$.

Die Diskussion um das Fragment, die ich in diesem Einleitungsbeitrag nicht weiter vertiefen möchte, macht für das Anliegen der Tagung und des hier vorgelegten Bandes mehrerlei deutlich:

- ein Papst des 9. Jahrhunderts greift mit römischer Autorität an den Grenzen des Patrimonium Petri zugunsten einheitlicher liturgischer Gebräuche ein,

- $\quad$ die fehlende Einheit wird - so jedenfalls die Vermutungen der Forschung auf sehr verschiedene, in Italien konkurrierende Traditionen zurückgeführt,

- das Schreiben postuliert eine Einheitlichkeit der okzidentalen Kirche, von der man am Monte Lentenano abweiche ${ }^{4}$,

- und schließlich: Das Fragment ist zwar seit der Entdeckung der „Collectio Britannica" 1877/78 bekannt, aber wegen der zweifelhaften Zuordnung nicht in die Italia Pontificia eingegangen, wo es in Band 4 auf Seite 25 eingeschoben werden müßte.

Wir wissen nicht, ob Leo IV. langfristig bezüglich Liturgie und Gesang am Monte Lentenano Erfolg hatte. Wie auch immer: Der Text erschien offensichtlich an der Wende zum 12. Jahrhundert wichtig genug, um ihn in eine kanonistische Zwischensammlung aufzunehmen. Dazu tritt ein weiterer Aspekt: Leo IV. wollte offensichtlich - und der Kompilator unterstrich dies durch seine Auswahl - vereinheitlichend und integrierend wirken. War dies eine Ausnahme oder die Regel?

Mein Beitrag, der einige Perspektiven des Bandes eröffnend ansprechen soll, kann sich nicht darauf beschränken, die den meisten bekannte Vielfalt Italiens im frühen und hohen Mittelalter nur einfach in Erinnerung zu rufen. Vielmehr will ich ausgehend von dem skizzierten Beispiel danach fragen, inwieweit Aktionen und Reaktionen der Päpste in einem Prozeß des Mit- und Nebeneinanders dieser Vielfalt integrierend und/oder desintegrierend beabsichtigt waren oder wirkten. Dies könnte neue Interpretationsmöglichkeiten bieten, weil herkömmliche Thesen zur Geschichte des Papsttums im frühen und hohen Mittelalter davon ausgehen, daß die Päpste vor allem seit dem 11. Jahrhundert zu einer lateinischen Einheit des westlichen Europa maßgeblich beigeträgen hätten. Diesen Überlegungen stehen neuere Interpretationen entgegen, die eher umgekehrt die Vielfalt als das Kennzeichen auch des mittelalterlichen Europa

3 Vgl. hierzu Herbers: Leo (wie Anm. 1) S. 292, mit Referat der teilweise kontroversen Forschungen.

4 Epistolae selectae (wie Anm. 1) S. 604 Nr. 33: ... ab omni pene occidentali aecclesia, et prorsus ab omnibus, qui Latinis vocibus laudem aeterno regi conferunt et sonos canoros persolvunt, dissentiatis. 
postulieren ${ }^{5}$ und damit indirekt auch die Integrationsleistungen des hochmittelalterlichen Papsttums relativieren. Daraus ergibt sich die Frage, ob und inwieweit die Integrationskraft des Papsttums vor den Toren Roms, in Italien, besonders gut wirksam werden konnte. War Italien so etwas wie ein Orbis christianus, en miniature" oder hatten die Päpste vielleicht gerade hier besondere Schwierigkeiten zu gewärtigen, weil die Vielfalt dem entgegenstand? Wie weit reicht die These, daß der Papst in dieser Zeit in Italien - anders als bei anderen Empfängergruppen - weniger als "Stellvertreter des Apostelfürsten gesehen wurde, sondern als Mitbischof in Italien“, die Jochen Johrendt für das 10. und beginnende 11. Jahrhundert vertreten hat ${ }^{6}$, über diesen Zeitraum hinaus?

Der vorgelegte Band berücksichtigt damit, zweitens, die Voraussetzungen der Arbeiten von Paul-Fridolin Kehr und seiner Mitarbeiter, der Italien pragmatisch vor dem Hintergrund einer sich stets verändernden Karte der ApenninHalbinsel in eine Italia Media (später Band 1-4), eine Italia superior (Band $5-7$ ) und eine Italia inferior (Band 8-10) unterschied ${ }^{7}$. Die Tagung war aber zugleich - angesichts des weitgehenden Abschlusses der Italia Pontificia ${ }^{8}-$ dem $^{2}$ Grundsatz verpflichtet, die Sammlung der Papsturkunden als die Voraussetzung für tiefergehende Interpretationen zu nutzen ${ }^{9}$ und die deutende Untersuchung des Materials nicht nur anderen zu überlassen. Dies entspricht im übrigen Kehrs eigener Meinung, der immer wieder bedauerte, daß die Fülle der Arbeit die Zeit zur Interpretation des Materials kaum zulasse, aber trotzdem vielfältig Stellung nahm, wie der 2005 von Rudolf Hiestand besorgte Nachdruck der Ausgewählten Schriften Kehrs eindrücklich belegt ${ }^{10}$.

5 Michael Borgolte: Europa entdeckt seine Vielfalt 1050-1250, Stuttgart 2002 (Handbuch der Geschichte Europas 3), zu verschiedenen Europakonzeptionen vgl. jetzt auch Klaus Herbers: Europa und seine Grenzen im Mittelalter, in: Grenzräume und Grenzüberschreitungen im Vergleich. Der Osten und der Westen des mittelalterlichen Lateineuropa, hg.v. Klaus Herbers/Nikolas Jaspert, Berlin 2007 (Europa im Mittelalter. Abhandlungen und Beiträge zur historischen Komparatistik 7), S. 21-41.

6 Jochen Johrendt: Papsttum und Landeskirchen im Spiegel der päpstlichen Urkunden (896-1046), Hannover 2004 (MGH Studien und Texte 33), zusammenfassend S. 261.

7 Vgl. Rudolf Hiestand: Die Italia Pontifica, in: Das Deutsche Historische Institut in Rom 1888-1988, hg.v. Reinhard Elze/Arnold Esch, Tübingen 1990 (Bibliothek des Deutschen Historischen Instituts 70), S. 167-189, hier S. 177.

8 Rudolf Hiestand: Die unvollendete Italia Pontificia, in: Hundert Jahre Papsturkundenforschung. Bilanz - Methoden - Perspektiven. Akten eines Kolloquiums zum hundertjährigen Bestehen der Regesta Pontificum Romanorum vom 9.-11. Oktober 1996 in Göttingen, hg.v. DEMs., Göttingen 2003 (AAG, phil.-hist. Kl., 3. Folge 261), S. 47-57.

9 Vgl. zum Beispiel Paul Fridolin KeHR: Zur Geschichte Wiberts von Ravenna (Clemens III), in: SPA. PH, Berlin 1921, H. 19, S. 355-368 (Nachdr. in: DERs.: Ausgewählte Schriften, 2 Bde, hg.v. Rudolf Hiestand, Göttingen 2005 [AAG, phil.-hist. Kl., 3. Folge 261], Bd. 1 S. 209-222, hier S. 209).

10 KeHr: Schriften (wie Anm. 9). 
Die Italia ist aber unvollendet ${ }^{11}$. Deshalb weise ich schließlich auch auf einige Quellengruppen hin, die der Diplomatiker Kehr, „der auf Urkunden pürschte", weniger im Blick hatte, denn die zitierte These von Jochen Johrendt hat dieser vor allem durch eine Untersuchung der von Harald Zimmermann vorgelegten Urkunden für das 10. und beginnende 11. Jahrhundert (8961046) gewonnen ${ }^{12}$.

Diese drei Perspektiven verdeutliche ich mit fünf kurzen Aperçus, die zeitlich und räumlich zumindest eine gewisse Varianz aufweisen sollen, aber von eigenen Arbeitsschwerpunkten mitbestimmt sind. Dies dürfte deshalb kein grundsätzlicher Nachteil werden, weil die Beiträge des Bandes dies erweitern und weil es zunächst vor allem auf die Fragestellungen ankommt.

\section{Italien und Rom - Objekte der Begierde oder Hinterland?}

Die Bezeichnung Italien - die auch von Kehr benutzt wurde - leitet fehl, denn die Geschichte Italiens ist nicht einfach eine Fortsetzung der altrömischen, obwohl dies Vertreter der Renaissance wiederholt behaupteten, und die Publizistik des Risorgimento dies weiter unterstrich. Natürlich gab es die Bezeichnung Italia schon seit der Spätantike, vor allem als geographische Bezeichnung für die Apenninen-Halbinsel. Als diese Halbinsel durch den römischen Stadtstaat in der Antike politisch geeint wurde, verstand man unter Italien das Gebiet südlich von Magra und Rubikon, die Po-Ebene galt jedoch als Gallia Cisalpina, die erst Caesar Italien angliederte.

Ganz anders war der Sprachgebrauch einige Jahrhunderte später. Zwar verwendete man weiterhin den geographischen Begriff, aber nach dem Untergang des Langobardenreiches (568-774), das seine Schwerpunkte im wesentlichen in der Po-Ebene und der Toskana besaß, kam für dieses Areal die Bezeichnung Regnum Italiae auf, viele hochmittelalterliche Quellen meinen mit Italia entsprechend oft eher den nördlichen Teil der Halbinsel. Die Mitte und der Süden standen nach den oströmischen Eroberungen und den Gotenkriegen des 6. Jahrhunderts teilweise wieder unter oströmischer bzw. byzantinischer Herrschaft, so daß die Namen Rom und Neu-Rom zeitweise wichtiger als die Bezeichnung Italien wurde. Da aber neben den verschiedenen teilweise unabhängigen Herrschaften sowohl mit dem Regnum Italiae als auch mit den byzantinisch dominierten Gebieten eigentlich Territorien mit Leuten existierten, die Herrschern in fernen Zentren unterstanden, wurde das Schicksal Italiens

11 Vgl. den Titel der in Anm. 8 genannten Abhandlung von Rudolf Hiestand.

12 Harald Zimmermann: Papsturkunden 896-1046, 3 Bde., Wien 1988-1989 (Österreichische Akademie der Wissenschaften, phil.-hist. Kl. Denkschriften 174, 177, 198) (Bd. 1 und 2 in 2. Aufl.). 
vielfach nicht auf der Apenninen-Halbinsel, sondern anderswo entschieden. Italien oder Teile davon waren eventuell das ferne Hinterland, wurden aber in bestimmten Situationen zum Zankapfel und Objekt der Begierde und des Streites, der durch kirchliche Gliederung der Einflußbereiche der Patriarchen von Konstantinopel und Rom weiter verschärft werden konnte.

Verfolgt man die Entwicklung der Karte im Laufe des Mittelalters weiter, so blieb neben und innerhalb des Regnum Italiae eine Vielzahl kleiner und fast eigenständiger Herrschaften besonders an den Küsten bestehen. Weiterhin gab es vor allem im ravennatischen Raum und in Süditalien einen starken byzantinischen Einfluß, der nur teilweise die fast unabhängigen kleinen Herrschaften wie Neapel, Gaeta oder Amalfi integrieren konnte. Hinzu traten ab dem 9. Jahrhundert muslimische Territorien in Süditalien, besonders in Sizilien sowie schließlich die entstehenden Normannenreiche im 11. und 12. Jahrhundert. Im Zentrum lagen aber Rom und das Patrimonium Petri, wo die Päpste zunächst mit starker Rückbindung an den oströmischen Kaiser Einfluß besaßen, seit dem 8. Jahrhundert aber mit Legitimation der Karolinger und der neuen westlichen Kaiser weitgehend selbständig agierten; deshalb sei dieser Bereich hier ausgespart.

Wo also beginnen, und wo enden Rom und Italien? Gehören die Kontakte mit den oströmischen Kaisern, soweit sie Rom betreffen, zur Italia Pontificia? Wie ist zu verfahren, wenn oströmischer Kaiser und Patriarch von Konstantinopel die Kontrahenten Roms sind? Werden dann Kaiser und Patriarch getrennt, einmal in IP 11 („Reges et Imperatores“) und einmal in einen Oriens graecus pontificius? Die Beiträge von Matthias Maser und Guglielmo Cavallo setzen sich mit diesem komplizierten Geflecht näher auseinander ${ }^{13}$; einige Problempunkte thematisiert mein zweites Aperçu:

\section{Süditalien - ein kleines, vielfältiges Europa?}

Byzanz trat nicht nur immer wieder in direkten Kontakt mit Rom und anderen Zentren Italiens. Besonders die Position Siziliens änderte sich im 8. und 9. Jahrhundert. Verweist die Abschrift des Registers von Papst Gregor I. noch häufig auf Sizilien und die dortigen päpstlichen Patrimonien, wie die chronologische Übersicht in IP 10 gut verdeutlicht ${ }^{14}$, so änderte sich dies unter dem

13 Siehe unten, S. 39-68 und 69-83.

14 Gregor der Große: Registrum epistularum, ed. Dag Norberg, Turnhout 1982 (CCL 140, 140A), vgl. auch (vor allem des Kommentars wegen immer noch) Gregor der Große: Registrum epistularum, ed. Paul Ewald/Ludo Moritz Hartmann, Berlin 1891 1899 (MGH Epp. 1-2); vgl. auch den Elenchus vor allem in IP 10, S. XIX-XXVIII. 
Einfluß byzantinischer Interessen und noch mehr nach der weitgehenden Inbesitznahme der Insel durch die Muslime im 9. Jahrhundert.

Seitdem die kirchlichen Institutionen Siziliens und Kalabriens während des Bilderstreites von Kaiser Konstantin V. (741-775) gezwungen worden waren, sich dem Patriarchat von Konstantinopel zu unterstellen ${ }^{15}$, war nach den vielen frühmittelalterlichen ein weiterer Konflikt mit den römischen Päpsten, die dies nicht anerkannten, vorprogrammiert. Sizilien aber wurde für den Patriarchat von Konstantinopel kurzzeitig zur Kaderschmiede: Patriarch Methodios (843847) stammte von dort, und Erzbischof Gregor Asbestas von Syrakus (845863) wäre auch fast zum Patriarchen in Konstantinopel aufgestiegen, unterlag aber Ignatios. Der Eklat folgte: Bei der Weihe des Ignatios zum Patriarchen soll der hitzige Gregor von Syrakus die Kerzen, die er in Händen hielt, zu Boden geworfen haben ${ }^{16}$, wurde von Ignatios der Kirche verwiesen und soll den neuen Patriarchen sodann verwünscht haben. Gegen seine darauf folgende Absetzung (847/48) appellierte er aber an den römischen Stuhl und bot damit dem Papst eine Steilvorlage, jurisdiktionelle Ansprüche gegenüber dem Patriarchen von Konstantinopel zu formulieren ${ }^{17}$. Sizilien wurde so teilweise zum Schauplatz für einen Ost-West-Konflikt, war mit dem übrigen Süditalien immer wieder das Mittelglied einer Dreiecksgeschichte, die kaum aus der Perspektive der Italia Pontificia allein zu erfassen ist. Beachtenswert ist auch hier wiederum die Überlieferung: Nicht Urkunden, sondern Registerfragmente, Konzilsakten sowie Parteischriften und historiographische Quellen bieten die wichtigsten Informationen ${ }^{18}$.

Süditalien erscheint in diesem Falle somit eher als Austragungsort oder als Schlachtfeld für andere Beziehungen oder Konflikte. Was sich aber an Mög-

15 Die Datierung ist umstritten, vgl. Herbers: Leo (wie Anm. 1) S. 302, zu verschiedenen Vorschlägen der Forschung.

16 Vgl. z. B. Anastasius Bibliothecarius in seiner Praefatio zur lateinischen Fassung des 8. ökumenischen Konzils, ed. Anastasii bibliothecarii epistolae sive praefationes, ed. Ernst Perels/Gerhard Laehr, in: MGH Epp. Karol. 5, Berlin 1928, S. 395-442, hier S. 404 Nr. 5; vgl. die Vita Ignatii, ed. Mansi 16 Sp. 232; MPG CV Sp. 512. Demnach warf Gregor die Kerzen, die er in der Hand hielt, zu Boden. Dies könnte bewußt auf einen Exkommunikationsritus anspielen. Vgl. die weiteren Nachweise bei Venance Grumes/ Jean Darrouzìs: Les regestes des actes du Patriarcat de Constantinople 1/2: Regestes de 715 à 1043; 1/3: Regestes de 1043 à 1206. 2. Aufl. von Jean Darrouzès, Paris 1989 (Le partriarcat Byzantin, Série 1) Nr. 445. Zum Hintergrund Patricia Karlin-Hayter: Gregory of Syracuse, Ignatios and Photios, in: Iconoclasm. Papers Given at the Ninth Spring Symposium of Byzantine Studies, University of Birmingham March 1975, hg.v. Anthony Bryer/Judith Herrin, Birmingham 1977, S. 141-145 und Herbers: Leo (wie Anm. 1) S. 303.

17 Ebd. S. $304 \mathrm{f}$.

18 Vgl. zum Beispiel die einschlägigen Nummern der Regesten von Grumel/Darrouzès (wie Anm. 16), sowie bei RI 1/4/2/1. 
lichkeiten anbot, um in diesem Raum auch päpstlichen Einfluß stärker zur Geltung zu bringen und vereinheitlichend $\mathrm{zu}$ wirken, sollte schon deshalb wieder problematisch werden, weil gleichzeitig arabisch-berberisch-muslimische Bedrohungen neue Machtkonstellationen erzwangen. Die sarazenischen Schiffe, teilweise Freibeuter, teilweise aus dem aghlabidischen Nordafrika kommend, suchten sogar 846 Rom heim ${ }^{19}$ und verunsicherten noch das ganze 9. Jahrhundert hindurch die Küsten des Patrimonium Petri. Die Päpste reagierten und mußten nun mit den süditalischen civitates, mit Byzanz und den karolingischfränkischen Herrschern den Schulterschluß suchen ${ }^{20}$.

Papst Johannes VIII. (872-882) bemühte sich z. B. um ein byzantinisches Schutzkontingent von zehn Kriegsschiffen (Chelandien) ${ }^{21}$. Der Papst ermahnte die süditalischen civitates immer wieder, ihre Bündnisse mit den Sarazenen aufzugeben, jedoch ohne langfristigen Erfolg. In Traetto, im Süden des Patrimonium Petri, handelte er mit einigen süditalischen Stadtstaaten 877 nur die Grundzüge einer Abmachung aus. Ohne ,Schutzgelder' war kaum Ruhe herzustellen. Amalfi sollte die Küsten des Patrimonium Petri gegen eine Summe von 10.000 Mankusen schützen ${ }^{22}$. Die Amalfitaner versuchten jedoch ${ }^{23}, 12.000$ Mankusen herauszupressen. In dieser unsicheren Situation brach Johannes 878 mit dem Schiff ins Frankenreich auf ${ }^{24}$. Zuvor schloß er ein Abkommen mit den Sarazenen ${ }^{25}$ : Für 25.000 Mankusen wollte er Sicherheit erkaufen. „Der Stuhl Petri zinste den Anhängern des Lügenpropheten, damit sie sein Gebiet nicht völlig zu Grunde richteten und zur Einöde machten. Dahin führte der Mangel

19 IP 10 S. 467 Nr. 13, RI 1/4/2/1 Nr. 59 und 60.

20 Vgl. allgemein hierzu Nicola Cilento: I Saraceni nell'Italia meridionale nei secoli IX e X, in: Archivio storico per le province Napoletane, N. S. 38 (1959) S. 109-122, sowie die folgenden Anm.

21 JE 3092, ed. Registrum Johannis VIII. papae, ed. Erich CAspar, in: MGH Epp. Karol. 5, Berlin 1928, S. 1-272, hier S. 45 Nr. 47. Vgl. später JE 3303, ed. Registrum Johannis VIII., S. 214 Nr. 245.

22 Schutzvertrag: JE 3126, ed. Registrum Johannis VIII. (wie Anm. 21) S. 75 Nr. 79. Die Mankusen scheinen hier offensichtlich als Rechnungseinheit zu dienen.

23 Dies geschah unter falscher Aussage gegenüber früheren Abmachungen, wie Johannes in einem Brief an Salerno kommentiert: JE 3127, ed. Registrum Johannis VIII. (wie Anm. 21) S. 81 Nr. 86.

24 Johannes FrIED: Boso von Vienne oder Ludwig der Stammler. Der Kaiserkandidat Johannes VIII. in: DA 32 (1976) S. 193-208; vgl. weiterhin Hubert Mordek/Gerhard Schmitz: Papst Johannes VIII. und das Konzil von Troyes (878), in: Geschichtsschreibung und geistiges Leben im Mittelalter. Festschrift für Heinz Löwe zum 65. Geburtstag, hg.v. Karl Hauck/Hubert Mordek, Köln 1978, S. 179-225, bes. S. $179 \mathrm{f}$.

25 JE 3139, ed. Registrum Johannis VIII. (wie Anm. 21) S. 85 Nr. 89, RI 1/3/1 Nr. 551; Fred Engreen: Pope John the Eighth and the Arabs, in: Speculum 20 (1945) S. $318-$ 330, hier S. 321 Anm. 4. 
eines mächtigen Kaisers und Schirmherrn der Kirche", so kommentierte noch Ernst Dümmler dieses Ereignis ${ }^{26}$.

Dies war ein Tribut, kein Vertrag wie ihn hingegen einige süditalische $c i$ vitates mit den Sarazenen geschlossen hatten: Gegen diese pacta oder foedera impia der Süditaler, zog Johannes VIII. in mehr als zwanzig meist in seinem Register erhaltenen Briefen zu Felde ${ }^{27}$. Er selbst schloß 878 mit den Sarazenen keinen Vertrag, sondern leistete Tribut. Vielleicht war sogar das Geld in dieser direkten Zahlung besser als bei den Amalfitanern oder anderen Küstenstädten angelegt, denn auch nachdem Johannes nach Rom zurückgekehrt war, blieben weitere Verhandlungen mit den süditalischen civitates schwierig. So versprach der Papst beispielsweise Bischof Athanasius von Neapel eine Geldsumme, damit dieser seine sarazenischen Freibeuter entlasse. Dieser schickte jedoch nur die bisherigen Helfer heim, ließ sich das Geld auszahlen, um anschließend neue, in Sizilien rekrutierte Sarazenen einzustellen ${ }^{28}$.

Ein Versuch, im Dezember 879 den Schutz für die Küsten Roms von den Amalfitanern zu erkaufen ${ }^{29}$, verdeutlicht die komplizierte Situation. Johannes VIII. versprach ihnen über die schon 877 vereinbarten 10.000 Mankusen hinaus weitere 1.000 sowie Zollfreiheit im römischen Hafen. Sollten sie aber das Bündnis mit den Sarazenen nicht lösen, drohte der Papst mit einer Handelssperre $^{30} .886$ dachte Papst Stephan V. daran, den Handel mit Neapel gegebenenfalls ernstlich zu behindern ${ }^{31}$. Die Versuche zur Errichtung einer gemeinsamen Front und die faktisch desintegrativen Kräfte dieser Konstellation sind offensichtlich. In der Überlieferung ist es aber wieder weniger urkundliches als briefliches und kanonistisches Material, das dank der Registerabschrift zu Jo-

26 Ernst Dümmler: Geschichte des Ostfränkischen Reiches, 3 Bde., Leipzig, 2. Aufl. $1887-1888$ (Nachdr. 1960), Bd. 3 S. 73.

27 Vgl. Giorgio Balladore/ Giulio Vismara: Acta Pontificia Juris Gentium usque ad annum MCCCIV, Mailand 1946, S. 270-274, Nr. 37-63.

28 JE 3343, ed. Registrum Johannis VIII. (wie Anm. 21) S. 241 Nr. 273, und JE 3346, ed. Registrum Johannis VIII., S. 246 Nr. 279; vgl. Ekkehard EıскноғF: Seekrieg und Seepolitik zwischen Islam und Abendland. Das Mittelmeer unter byzantinischer und arabischer Hegemonie (650-1040), Berlin 1966, S. 230. Vgl. auch Erchembert, Historia Langobardorum Beneventanorum, ed. Georg WaITz, in: MGH SRL 1, Hannover 1878, S. $231-264$, hier S. 255.

29 JE 3308, ed. Registrum Johannis VIII. (wie Anm. 21) S. 218 f. Nr. 250; vgl. zu früheren Anstrengungen im September z. B. JE 3278, ed. Registrum Johannis VIII., 192 Nr. 214.

30 Ebd.

31 JL 3414, ed. Fragmenta registri Stephani V. papae, ed. Erich CAspar, in: MGH Epp. Karol. 5, Berlin 1928, S. 334-353, hier S. 337 Nr. 7: Et non dicas, quia, si domnus apostolicus veniens messes nostras deleverit, habemus alias provincias, unde labores habere possimus. Nam nos et Romam Sardiniam Corsicam et totam christianitatem contra te claudemus, ut nullo modo recuperare valeatis. 
hannes VIII. umfassend befragt werden kann, über Empfängerarchive jedoch wenig aussagt.

Gab es aber wirklich keine direkten Kontakte mit den neuen muslimischen Machthabern auf der Insel Sizilien, teilweise auch an anderen Orten Süditaliens? Die Suche in der IP 10 bietet zumindest ein Stück zu Papst Marinus I., der den Emir von Sizilien gebeten habe, daß er den Erzbischof (von Syrakus) und den Bischof von Mileto freilasse und die von den Sarazenen gefangenen Sklaven ausliefere. Indes, das Stück ist erst im 18. Jahrhundert in sizilianischer Sprache überliefert, und Dieter Girgensohn hat mit Recht ein Fälschungskreuz vor das entsprechende Regest gestellt ${ }^{32}$.

Vor dem Hintergrund dieses Beleges habe ich vor einigen Jahren noch weitere Bemerkungen zu päpstlichen Aktivitäten gesucht und gefunden, die bisher in die gängigen Verzeichnisse zur Papstgeschichte von Jaffé und in die Italia Pontificia nicht eingegangen sind. Aber hier ist die Überlieferung problematisch: Sie sind angeblich in arabischer Sprache aufgezeichnet, wurden spätestens im 17. Jahrhundert ins Sizilianische übersetzt und in die Jahre 883 bis 887 datiert, damit den Päpsten Marinus I., Hadrian III. und Stephan V. bzw. Al-Hasan ben al Abbas, dem Emir von Syrakus, zugeordnet. Es geht um den Freikauf von Sklaven. Die Muslime, so heißt es in dem letzten dieser einschlägigen Briefe, seien besser als die Christen, denn sie würden Sklaven für Geld freilassen. Dem päpstlichen Wunsch, künftig von Versklavungen ganz abzusehen, könne jedoch nicht entsprochen werden; die Griechen seien ja ebenso gefürchtete Sklavenjäger. Nach verschiedenen Prüfungen steht inzwischen soviel fest: In diesen Schreiben wurden wohl erst von sehr späten Autoren angebliche Nachrichten über die sarazenische Gefangenschaft des Bischofs von Syrakus und anderer Sizilianer zu einem fiktiven Briefwechsel verarbeitet ${ }^{33}$. Dabei haben diese sogar angeblich arabische „Urfassungen“ aufgezeichnet, deren Schriftbild zwar fremde Zeichen suggeriert, die mit dem Arabischen aber nichts zu tun haben. Diese literarischen Abenteuer des 18. Jahrhunderts möchte ich noch weiter verfolgen ${ }^{34}$, für die Italia Pontificia werden auch diese Schreiben im

32 IP 10 S. 186 Nr. $† 72$.

33 In diesen Zusammenhang könnte auch das von Girgensohn in Anm. 32 erwähnte Stück, das Marinus I. zugeschrieben wird, gehören.

34 Vgl. die (phantasiehaften) Abb. und Übertragungen bei Alfonso Arroldi (ed.): Codice diplomatico Arabo-Siciliano, Palermo 1789, für die hier interessierende Zeit S. 244263. Diese Aufzeichnungen wurden vor einigen Jahren noch als echt angesehen von Raffaele Tucciarone: I saraceni nel ducato di Gaeta e nell'Italia centromeridionale (secoli IX e X), Gaeta 1991, bes. S. 87-99; vgl. jedoch schon den Eintrag von Guiseppe Gabrieli: Airoldi, Alfonso in der Enciclopedia Italiana di scienze, lettere ed arti 2, Mailand 1929, S. 36, der unterstreicht, daß Airoldi zunächst den Fälschungen von Giuseppe Vella Glauben schenkte. Zu Giuseppa Vellas Wirken vgl. die Monographie von Thomas Freller: The Rise and Fall of Abate Giuseppe Vella. A story of forgery and 
Nachtragsband - ähnlich wie Kehr bei den gelehrten Pisaner Erfindungen ${ }^{35}$ mit einem Fälschungskreuz zu versehen sein. Dennoch läßt sich nicht leugnen, daß die Texte die Situation des 9. Jahrhunderts, als sich Muslime, Griechen sowie Venezianer rege am Sklavenhandel beteiligten, teilweise treffen könnten. Dafür gibt es weiterhin zumindest einen Anknüpfungspunkt, in der zeitgleichen Vita Stephans V. (885-891): Bei Beginn seines Pontifikates sei alles in Rom geplündert und leer gewesen, der neue Papst habe über nichts verfügt, um Klerus und Scholen zu beschenken oder um Gefangene zurückzukaufen ${ }^{36}$. Weniger die Kontakte mit den Arabern als vielmehr das Schicksal der Gefangenen scheint zentral gewesen zu sein. Gefangene auszulösen war in Rom nichts Außergewöhnliches, kein Novum. Mehrere Briefe Gregors I. von 592 bis 598 berichten davon ${ }^{37}$, auch Johannes IV. griff um 640 in den dalmatinischen Gefangenenhandel ein ${ }^{38}$. Johannes VIII. ermahnte sardische Fürsten, die von Griechen gekauften heidnischen Sklaven freizulassen ${ }^{39}$, obwohl die päpstliche Sorge meist nur christlichen Sklaven galt. Für die Päpste war aber das Problem des Gefangenenfreikaufes vor allem im früheren Mittelalter in Italien nicht erst seit den Sarazenenzügen auch in praktischer Hinsicht akut. Damit bot aber die italische Perspektive dieser Epoche auch Orientierungen für juristische Festlegungen und weiteres Verhalten in der Kreuzzugszeit.

\section{Konkurrenz oder Einheit?}

Obwohl die neuen Konstellationen im Süden ausreichend Konfliktstoff boten, versuchten die Päpste ebenso im Norden, beispielsweise in Ravenna, eigenständige Tendenzen einzudämmen oder bei Streitigkeiten zwischen Aquileja und Grado, die auch in der unterschiedlichen Orientierung hinsichtlich Byzanz mit

deceit, Malta 2001 (ich danke Herrn Kollegen Titus Heydenreich in Erlangen und Herrn Dr. Thomas Freller für ihre Informationen).

35 Vgl. hierzu IP 3 S. 355 ff. sowie Paul Fridolin KeHR: Der angebliche Brief Paschals II. an die Consuln von Pisa und andere Pisaner Fälschungen, in: QFIAB 6 (1904) S. 316342.

36 ... vel unde captivos redimeret..., „Liber pontificalis“, ed. Louis Duchesne: Le Liber pontificalis. Texte, introduction et commentaire, 2 Bde., Bd. 3 hg.v. Cyrille Vogel, Paris 1886-1892, 1957, hier Bd. 2 S.192.

37 Gregor: Register (wie Anm. 14); JE 1210, 1361, 1412, 1459, 1469, 1510, vgl. Acta Pontificia juris gent. (wie Anm. 27) S. 446 Nr. 36-41.

38 JL Bd. 1 S. 228.

39 JE 2983, ed. Fragmenta registri Johannis VIII. papae, ed. Erich CAspar, in : MGH Epp. Karol. 5, Berlin 1928, S. 273-312, hier S. 288 f. Nr. 27; IP 10 S. 379 Nr. 26. - Vgl. auch den Bericht über den Freikauf des Erzbischof Rotland von Arles, für den die Sarazenen Lösegeld kassiert haben sollen, obwohl er bereits gestorben war, vgl. den bewegenden Bericht in den Annales Bertiniani, ed. Felix Grat/Jeanne Vielliard/Suzanne Clémencet: Les Annales de Saint-Bertin, Paris 1964, ad a. 869, S. 165 f. 
begründet waren und bis nach Venedig hin ihre Auswirkungen hatten, zu vermitteln ${ }^{40}$. Die Beiträge von Antonio Carile und Maria Pia Alberzoni behandelten auf der römischen Tagung die wichtigen eigenständigen Zentren Ravenna und Mailand ${ }^{41}$.

Manche dieser Zentren stellten auch Rom mit Traditionen und Heiligenkulten einen Ausweis ihrer Eigenständigkeit entgegen. Apostelkulte waren besonders wirksam. Dies ließe sich am Beispiel Venedigs und des Markuskultes sehr gut zeigen ${ }^{42}$. Noch deutlicher wird am Beispiel Benevents, worüber JeanMarie Martin handelt, wie die skizzierten neuen Konstellationen Süditaliens veränderte politische und kirchenpolitische Schwerpunkte begünstigten. Das Vordringen und die Eroberungen der Aglabiden und weiterer muslimischer Gruppen in Süd- und Mittelitalien ${ }^{43}$ förderte - glaubt man den Berichten - eine verstärkte Übertragung von Reliquien. Besonders interessant ist der Fall des Apostels Bartholomäus. Seine Gebeine wurden 838 von Lipari (wohin sie 580 gekommen sein sollen) nach Benevent übertragen ${ }^{44}$. Was wird im zugehörigen

40 Dies hat Paul Fridolin Kehr unter anderem in der grundlegenden Studie zu Rom und Venedig deutlich gemacht, vgl. Paul Fridolin KeHR: Rom und Venedig bis ins 12. Jahrhundert, in: QFIAB 19 (1927) S. 1-180.

41 Zum Beitrag von Maria Pia Alberzoni siehe unten S. 135-181. Der Beitrag von Antonio Carile fehlt in diesem Band.

42 Alfons ZetTler: Die politischen Dimensionen des Markuskults im hochmittelalterlichen Venedig, in: Politik und Heiligenverehrung im Hochmittelalter, hg.v. Jürgen Petersohn, Sigmaringen 1994 (VuF 42), S. 541-571.

43 Grundlegend zum muslimischen Italien: Michele Amari: Storia dei musulmani di Sicilia, 3 Bde., Florenz 2002-2003 (= Neuausgabe mit Angabe der Originalpaginierung der Ausgabe von 1837-1839) (zur fraglichen Zeit bes. Bd. 1 und 2); Rudolf Hiestand: Byzanz und das Regnum Italicum im 10. Jahrhundert, Zürich 1964 (Geist und Werk der Zeiten 9), bes. S. 19-32; Eickhoff: Seekrieg (wie Anm. 28); Horst Enzensberger: Unteritalien seit 774, in: Handbuch der Europäischen Geschichte, Bd. 1, hg. v. Theodor Schieffer, Stuttgart 1976, S. 784-804. Zum Beitrag Jean-Marie Martin siehe unten S. $109-133$.

44 Vgl. hierzu Anastasius Bibliothecarius, Sermo Theodori Studitae de sancto Bartholomeo apostolo, hg.v. Ulla Westerbergh, Stockholm 1963 (Acta Universitatis Stockholmiensis. Studia Latina Stockholmiensia 9), vor allem S. 10-17, und allgemein Antonio Vuolo: „Agiografia Beneventana“, in: Longobardia e longobardi nell'Italia meridionale. Le istitutizioni ecclesiastiche, hg.v. Giancarlo Andenna/Giorgio Picasso. Atti del $2^{\circ}$ convegno internazionale di studi promosso dal Centro di Cultura dell'Università cattolica del Sacro Cuore. Benevento 29-31 maggio 1992, Mailand 1996, S. 199-237. Einige Aspekte des Bartholomäuskultes hat Kerstin STEINIGER: Bartholomäusverehrung in Benevent vor dem Hintergrund der politischen Situation in Süditalien im 9. und 10. Jahrhundert (unveröff. Zulassungsarbeit Erlangen 2000) erarbeitet. Zusammenfassend und zu weiteren Forschungsdesideraten Klaus Herbers: Heilige an den Grenzen „Lateineuropas“, in: Sakralität zwischen Antike und Neuzeit, hg. v. DEms./Berndt Hamm/ Heidrun Stein-Kecks, Stuttgart 2007 (Beiträge zur Hagiographie 6), S. 101-111, hier S. $103-105$. 
Translationsbericht erzählt? Die Muslime hätten demnach die Liparischen Inseln geplündert und dabei auch das Apostelgrab nicht geschont. Darauf hatte ein griechischer Mönch eine Vision ${ }^{45}$, in der ihm aufgetragen wurde, er solle die durch den Angriff zerstreuten Gebeine sammeln. Der Mönch lehnte dies zunächst mit sehr handfesten Argumenten ab: Schließlich habe Bartholomäus vor den Muslimen keinen Schutz gewährt. Der Heilige machte demgegenüber geltend, er habe durchaus für das Inselvolk gebetet, das jedoch durch eigene Schwächen selbst an der Entwicklung schuld sei, und ermahnte den griechischen Mönch erneut, die Gebeine zu sammeln. Als der Mönch erwiderte, er könne kaum alle zerstreuten Knochen finden, antwortete der Heilige, bei Anbruch der Dunkelheit würden diese in der Dunkelheit leuchten. Der griechische Mönch gehorchte, jedoch führt die Erzählung nun die Langobarden ein, die den Leichnam des Apostels abholten. Auf dem Meer wurden sie von Sarazenen angegriffen, aber der Apostel rettete und beschützte sie. Dann wurde Bartolomäus cum magno honore recte ${ }^{46}$ nach Benevent gebracht.

Die Sarazenen stören die Ordnung, aber die Griechen haben dem nichts entgegenzusetzen, so daß die Langobarden im Translationsbericht folgerichtig als die eigentlichen Befrieder der Gegend erscheinen. Selbstredend ist die translatio aus langobardisch-beneventanischer Perspektive geschrieben. Mit Bartholomäus wurde Benevent durch einen Sakralisierungsschub - immerhin besaß man nun einen Apostelleichnam - zunächst zu einem Bollwerk gegen die Muslime, weil die Griechen versagt hatten.

Erst über ein Jahrhundert später entfaltete der Kult weitere Wirkkräfte. Wolfgang Huschner erläutert in diesem Band seine Thesen weiter, inwieweit die Gründung des Erzbistums Benevent $969^{47}$ in den Zusammenhang einer Auseinandersetzung zwischen östlichem und westlichem Kaiserreich gehört, die an dieser Stelle kirchenpolitisch ausgetragen wurde ${ }^{48}$. Weitere Erzbistumsgründungen wie Salerno oder Capua erfolgten fast zeitgleich oder wenig später. Dabei erwuchs aber in Benevent mit einer Aposteltradition auch für Rom bis ins hohe Mittelalter eine Konkurrenz, wie bischöfliche Kopfbedeckung, Ehrenvorrechte $^{49}$, Urkundenwesen ${ }^{50}$ und weiteres belegen. Die Apostelreliquien und

45 ... cuidam Graeco monacho ..., Anastasius Bibliothecarius, ed. Westerbergh (wie Anm. 44) S. 11.

46 Ebd. S. 12.

47 JL 3738; IP 9 S. 54 Nr. 15. RI 2/5 Nr. 459.

48 Siehe unten S. 87-108; vgl. bereits Wolfgang Huschner: Benevent - Capua - Magdeburg - Salerno. Neue Erzbistümer an der Peripherie des lateinischen Europa im 10. Jahrhundert, in: Der Hoftag in Quedlinburg 973. Von den historischen Wurzeln zum Neuen Europa, hg. v. Andreas Ranft, Berlin 2006, S. 37-49, hier S. 43.

49 Bernhard Schimmelpfennig: Die Tiara des Erzbischofs von Benevent, in: Ex ipsis rerum documentis. Beiträge zur Mediävistik. Festschrift für Harald Zimmermann zum 65. Geburtstag, hg.v. Klaus Herbers/Hans Henning Kortüm/Carlo Servatius, Sig- 
die Grabestradition wurden in späterer Zeit zunehmend weniger gegen Byzanz oder die Muslime als vielmehr gegenüber Rom wirksam ${ }^{51}$. Die Möglichkeiten der Päpste, hier zu integrieren, waren gering und verlangten einen langen Atem. Es fällt jedoch auf, daß die Dokumentation zur Erhebung und päpstlichen Bestätigung der verschiedenen Erzbistümer - und das ist vor dem Hintergrund unserer quellenmäßigen Auswahl wichtig - nur zu einem Teil in Form von Papsturkunden überliefert ist: im Falle Capuas durch die historiographische Überlieferung ${ }^{52}$, im Falle Salernos sind es spätere Urkunden, welche die Erhebung 983 erkennen lassen ${ }^{53}$.

\section{1054 oder 1059? Die normannische Entscheidung}

Nicht 1054 in Konstantinopel, sondern viel eher 1059 auf der Synode von Melfi mit den sich daraus ergebenden Folgen sei das Schisma zwischen Ost- und Westkirche begründet worden, dies hat jüngst Axel Bayer noch einmal unterstrichen $^{54}$. Wurde die Glaubensspaltung in Süditalien durch Papsttum und Normannen besiegelt? Das Entstehen der normannischen Herrschaft in Süditalien mischte die Karten noch einmal grundlegend neu, schon Leopold Ranke bemerkte in seiner Weltgeschichte, daß dies mehr als vieles andere die Dekomposition verschiedener Großreiche der damaligen Zeit zur Folge gehabt habe ${ }^{55}$. Dabei blieb die Position der Päpste zunächst ausgrenzend. Die Nor-

maringen 1991, S. 363-371, besonders S. 368 f., zur Grenzsituation Benevents und entsprechenden symbolischen Akten (mit weiterer wichtiger Literatur S. 369 Anm. 40). Vgl. weiterhin DERs.: Ein Bischof dem Papste gleich? Zu den Insignien und Vorrechten des Erzbischofs von Benevent, in: Aus Archiven und Bibliotheken. Festschrift für Raymund Kottje zum 65. Geburtstag, hg. v. Hubert Mordek, Frankfurt am Main 1992 (Freiburger Beiträge zur mittelalterlichen Geschichte 3), S. 391-411; Hans Belting: Studien zum beneventanischen Hof, in: Dumbarton Oaks Papers 16 (1962) S. 141 193, und DERs.: Studien zur beneventanischen Malerei, Wiesbaden 1968 (Forschungen zur Kunstgeschichte und zur christlichen Archäologie 7).

50 Herbert Zielinski: Fra ,charta' e documento pubblico: gli atti dei vescovi della Longobardia meridionale, in: Andenna/Picasso (wie Anm. 44) S. 149-176.

51 Vgl. Herbers: Heilige (wie Anm. 44) S. $104 \mathrm{f}$.

52 JL Bd. 1 S. 471; IP 8 S. 223 Nr. *34; RI 2/5 Nr. 393.

53 IP 8 S. 345 Nr. *10; RI 2/5 Nr. 618.

54 Axel BAyer: Spaltung der Christenheit. Das sogenannte Morgenländische Schisma von 1054 (Beih. AKu 53) 2. unveränderte Auflage, Köln/Weimar 2004, bes. S. 122-124 und zusammenfassend S. 206-208. - Zu Melfi vgl. auch Georg Gresser: Die Synoden und Konzilien in der Zeit des Reformpapsttums in Deutschland und Italien von Leo IX. bis Calixt II. 1049-1123, Paderborn 2006 (Konziliengeschichte, Reihe A), S. 48-51 (beide mit der älteren Literatur).

55 Hierzu wiederum Paul Fridolin KeHR: Die Belehnungen der süditalienischen Normannenfürsten durch die Päpste (1059-1192), Berlin 1934 (AAB, phil.-hist. Kl.), 
mannen waren für die Päpste zunächst nur ein neuer Gegner in einer alten Grundkonstellation, denn es fällt zumindest auf, daß die Berichte über die Kämpfe Leos IX. gegen die Normannen diffuse Begrifflichkeiten verwenden. Meinten Saraceni oder Agareni eigentlich nur Muslime, so wurden dies bald Begriffe für den Gegner schlechthin, jedenfalls heißen die Normannen in manchen päpstlich bestimmten Quellen Agareni ${ }^{56}$.

Mit Nikolaus II. begann jedoch eine neue päpstliche Politik. Jedenfalls begründete dieser Papst im August 1059 ein Lehnsverhältnis mit Robert Guiscard $^{57}$. Hinter dieser neuen Orientierung nach den verschiedenen Auseinandersetzungen mit den in Süditalien expansiv agierenden Normannen standen unter anderem Subdiakon Hildebrand und Abt Desiderius von Montecassino. Der Papst legitimierte in Melfi aber die Herrschaft Robert Guiscards auf Kosten von Byzanz ${ }^{58}$. Zu den langfristigen Konsequenzen weiterer Belehnungen bis hin in staufische Zeit hat wiederum Paul Fridolin Kehr bei der Vorbereitung der IP 8 und 9 mit seinem Beitrag zu den Belehnungen der süditalienischen Normannenfürsten durch die Päpste (1059-1192) den Grund für weitere Interpretationen gelegt ${ }^{59}$. Es ist auffällig, wie sehr er dieses Ereignis als Einschnitt ansah, vieles zuvor - die byzantinische oder die sarazenische Herrschaft sowie die verschiedenen Prinzipate - eher als Vorgeschichte dem unterordnete ${ }^{60}$. Allerdings ist zu unterstreichen, daß das Normannenreich Rogers und der beiden Wilhelme aus verschiedenen ,Staaten' und nicht nur aus den Lehnsgebieten des römischen Stuhls erwachsen ist. Insofern war die Integrationskraft der Päpste durch Lehnsbeziehungen - wie dies ja vielleicht trotz einiger jüngster Zweifel zu

S. 355-368, (Nachdr. in: DERs.: Schriften [wie Anm. 9] Bd. 1 S. 591-641, zu Rankes Urteil S. 592).

56 Vgl. hierzu bereits allgemein Carl Erdmann: Die Entstehung des Kreuzzugsgedankens, Stuttgart 1935 (Forschungen zur Kirchen- und Geistesgeschichte 6), S. 110 . - Die Verwendung unter Leo IX. war sicher kein Einzelfall, denn schon im 10. Jahrhundert kritisierte Ekkehard IV. von St. Gallen den diffusen Gebrauch. Er wandte sich dagegen, die Ungarn als Agarener zu bezeichnen: Qui autem Ungros Agarenos putant, longa via errant, Ekkehardus, Casus Sancti Galli, hg. und übersetzt von Hans F. Haefele, Darmstadt 1980 (AusgQ 10), S. 170 (ich benutze die von Hans F. Haefele verbesserte Ausgabe, vgl. zur Sache dort auch S. 171 Anm. 51).

57 Grundlegend hierzu (mit weiteren Belegen und Literatur): Josef DeÉr: Papsttum und Normannen. Untersuchungen zu ihren lehnsrechtlichen und kirchenpolitischen Beziehungen, Köln/Wien 1972 (Studien und Quellen zur Welt Kaiser Friedrichs 2/1), S. 96 f. und 101-103, Vincenzo D'Alessandro: Fidelitas Normannorum. Note sulla fondazione dello Stato normanno e sui rapporti col papato, in: DERs.: Storiografia e politica nell'Italia normanna, Neapel 1978 (Nuovo Medioevo 3), S. 99-220, bes. S. 134-138.

58 Vgl. die verschieden Regesten IP 8 S. 12 Nr. 15 und 16 mit Hinweis auf die Überlieferungen bei Deusdedit III 285 und im Liber Censuum cap. 163 sowie die in der vorigen Anm. zitierte Literatur.

59 KeHr: Belehnungen (wie Anm. 55).

60 Ebd. S. 593. 
anderen Reichen im Orbis christianus angestrebt wurde - zwar gegeben, konnte aber nur teilweise wirken. Hinsichtlich der Überlieferung fällt wiederum auf, daß Registerfragmente, Sammlungen und Notizen von Deusdedit sowie Albinus und Cencius entscheidend für unsere Kenntnisse der Abläufe von Melfi sind ${ }^{61}$. Die Archive der Herzöge von Apulien und der Fürsten von Capua sind vollständig zugrunde gegangen, zum Archiv der Normannenkönige wird von Hugo Falcandus berichtet, daß es im Jahre 1161 beim Aufstand gegen König Wilhelm I. zum größten Teil vernichtet worden sei ${ }^{62}$. So bleibt auch hier für die Beziehungen zur weltlichen Gewalt kaum urkundliche Überlieferung, nur für die geistlichen Institutionen lassen sich die Empfängerarchive rekonstruieren.

Abgesehen von der politischen Tragweite waren die kirchenpolitischen Konsequenzen zentral, denn nach der sukzessiven Errichtung einer einheitlich römisch-lateinischen Hierarchie - auf der Synode von Melfi (eventuell auch erst etwas später) - wurden die Bischöfe Johannes von Trani und Siponto, die mit Byzanz im Einvernehmen standen, abgesetzt ${ }^{63}$. Damit begann ein Prozeß der Latinisierung der Kirche in Süditalien. Die Verdrängung der Sarazenen in Sizilien, der diejenige in Sardinien und Korsika durch Pisa und Genua hinzuzufügen ist, führte dazu, daß die neue kirchliche Landkarte im Süden Italiens besonders verworren erscheint, weil nur teilweise alte Strukturen wiedererrichtet wurden. In der Folge bildete sich dennoch als Grundtendenz heraus, daß nach dem Vertrag von Benevent $1156^{64}$ die Herrscher weitgehend auch den Klerus kontrollierten und indirekt bestimmten, wie weit der Arm des Papstes überhaupt reichen konnte. Wie gering der Einfluß im Vergleich zu manchen Gebieten sein konnte, ist dem Beitrag von Jochen Johrendt zu entnehmen ${ }^{65}$. Daß allerdings die Gestaltung der Papsturkunden die normannische Kanzlei nach 1156 besonders beeinflußte, ist erwiesen, auch wenn Theo Kölzer den von Kehr postulierten „mächtigen Einfluß der Papsturkunde“ inzwischen auf ein realistisches Maß zurückgestutzt hat ${ }^{66}$.

61 Siehe oben Anm. 57.

62 Vgl. KeHr: Belehnungen (wie Anm. 55) S. 594. Zur Nachricht vgl. auch die Einleitung von Horst EnZENsberger: Einleitung, in: Guillelmi I regis diplomata, Köln/Weimar/ Wien 1996 (Codex diplomaticus regni Siciliae 1/3), S. IX-XVI, hier S. X (mit weiteren Hintergrundsinformationen).

63 IP 9 S. 290 Nr. 2 und S. 235 Nr. 11, vgl. Bayer (wie Anm. 54) S. 123 f. mit Anm. 47 zur Forschungsdiskussion.

64 KeHr: Belehnungen (wie Anm. 55) S. $636 \mathrm{f}$.

65 Unten, S. 183-213, dies freilich auch wegen der Konsequenzen der Stellungnahmen im Schisma von 1130.

66 Theo Kölzer: Der Einfluß der Papsturkunde auf die Urkunden der normannischen Könige Siziliens, in: Papsturkunde und europäisches Urkundenwesen. Studien zu ihrer formalen und rechtlichen Kohärenz vom 11. bis 15. Jahrhundert, hg. v. Peter Herde/ Hermann Jаковs, Köln 1999 (Beih. ADipl. 7), S. 307-317, hier S. 315. 


\section{Ubi est papa, ibi est Roma: Papst Lucius III. 1184 im Großeinsatz}

„Ubi est papa, ibi est Roma“, dieser Satz des 13. Jahrhunderts deutet die Schwierigkeiten an, die zuweilen entstanden, wenn man den Hauptort der Christenheit theoretisch festlegen wollte ${ }^{67}$. Er besitzt auch seinen Hintergrund in langen Abwesenheiten der Päpste des 11. und 12. Jahrhunderts von Rom und in den verschiedenen oft lange amtierenden Gegenpäpsten dieser Zeit. Mein letztes Aperçu geht auf diese Aspekte ein und greift einen weiteren Punkt auf, der indirekt alle regional gegliederten Pontificien betrifft. Die Päpste des ausgehenden 11. und 12. Jahrhundert waren wesentlich weniger in Rom, aber auch nicht nur in dem vielgestaltigen Italien unterwegs. Dabei hatten sich neue Institutionen ausgebildet von den Kardinälen bis zur päpstlichen Kanzlei. Legaten wurden zunehmend entsandt, Delegationsmandate ausgestell $t^{68}$.

Vielfältige Fragen standen an, als Lucius III. im Oktober 1184 mit Friedrich I. in Verona zusammentraf. Es waren dies nicht nur Verhandlungen über die Mathildischen Güter, sondern auch Fragen des Kreuzzugs und weitere Punkte. Der neue Band der Regesten Lucius' III., der im Rahmen der Regesta Imperii erschienen ist ${ }^{69}$, läßt nicht nur gut erkennen, wie sehr Lucius III. die Ergebnisse des Dritten Laterankonzils umgesetzt hat, sondern auch, wie leistungsfähig die päpstliche Kanzlei mit ihrem täglichen Ausstoß an Urkunden geworden war ${ }^{70}$. Seit dem 22. Juni 1184 bis zu seinem Tod am 25. November 1185 amtierte Lucius III. in Verona. Mehr als 800 Urkunden und Deperdita verzeichnen die Regesten sicher für diese $\mathrm{Zeit}^{71}$. Als der Kaiser kam, scheint die Kanzlei auf

67 Michele Maccarrone: Ubi est papa, ibi est Roma, in: Aus Kirche und Reich. Studien zu Theologie, Politik und Recht im Mittelalter. Festschrift für Friedrich Kempf zu seinem 75. Geburtstag und fünfzigjährigen Doktorjubiläum, hg.v. Hubert Mordek, Sigmaringen 1983, S. 371-382; Johannes Laudage: Rom und das Papsttum im frühen 12. Jahrhundert, in: Europa an der Wende vom 11. zum 12. Jahrhundert. Beiträge zu Ehren von Werner Goez, hg. v. Klaus Herbers, Stuttgart 2001, S. 23-53, bes. S. 23 und 53.

68 Ich verzichte auf Einzelnachweise, die bequem den verschiedenen Beiträgen des Sammelbandes Das Papsttum in der Welt des 12. Jahrhunderts, hg.v. Ernst-Dieter HeHL/ Ingrid Heike Ringel/Hubertus Seibert, Stuttgart 2002 (Mittelalterforschungen 6) entnommen werden können, vgl. auch zusammenfassend den Einleitungsbeitrag von Ernst-Dieter Hehl: Das Papsttum in der Welt des 12. Jahrhunderts. Einleitende Bemerkungen zu Anforderungen und Leistungen, in: ebd. S. 9-23, sowie die Schlußbemerkungen von Alfons BeCKer: Das 12. Jahrhundert als Epoche der Papstgeschichte, in: ebd. S. 293-323.

69 RI 4/4/4/1-2; hier geht es vor allem um die zweite Lieferung zu den Jahren $1184-$ 1185 .

70 Vgl. bereits die Tabelle bei Rudolf Hiestand: Die Leistungsfähigkeit der päpstlichen Kanzlei im 12. Jahrhundert mit einem Blick auf den lateinischen Osten, in: Herde/ Jаковs (wie Anm. 66) S. 23.

71 Ohne die undatierten und unsicheren Stücke 1181-1185. 
Hochtouren gearbeitet zu haben, mit statistischen Vergleichen hat Rudolf Hiestand dies vor einigen Jahren deutlich hervorgehoben ${ }^{72}$. Der Aufenthalt in Verona läßt aber einen weiteren Aspekt erkennen: Von den Urkunden für italische Personen und Institutionen gibt es aus dieser Zeit nur ganz wenige, die an Empfänger in Mittel- und Süditalien gerichtet waren ${ }^{73}$. Aus der Perspektive der Urkunden dominierte Norditalien. Der Satz Ubi est papa, ibi est Roma heißt also auch, daß der päpstliche Aufenthaltsort die Gänge der Bittsteller an die Kurie durchaus beeinflussen konnte.

Ein weiteres Problem lassen aber diese Urkunden Lucius' III. in Verona darüber hinaus erkennen: Viele galten Ritterorden und Orden. Die teilweise standardisierten Privilegien und Gnadenbriefe wurden aber zuweilen an den Orden allgemein, bald an ein eigenes Haus oder auch an eine Ordensprovinz oder ,Ordenszunge' gerichtet. Die Archivgeschichte zeigt, daß allgemein adressierte Schriftstücke durchaus im Archiv eines bestimmten Hauses aufbewahrt werden konnten. Auch wenn ein bestimmter Adressat genannt wird und wenn es zum Beispiel in der Adresse heißt in Anglia constitutis bedeutete dies nicht automatisch, daß die Vergünstigungen nur für Templer oder Johanniter in England gedacht waren, sondern vielmehr, daß der englische Ordenszweig dieses Privileg erbeten hatte und dann eine Ausfertigung mit dem üblichen Formular erhielt. Wohin gehören diese Briefe aber dann: zur Italia Pontificia, zum Oriens Pontificius oder wozu sonst? Die Beiträge von Rinaldo Comba, Mario Sensi und Kristjan Toomaspoeg berücksichtigen diese Probleme ${ }^{74}$.

\section{Schlußfolgerungen und Fragen}

Was bieten die Aperçus für unsere Fragestellungen? „Unglaubliches ist uns zu Ohren gekommen", so formulierten nicht nur Päpste des 9., sondern auch des 12. Jahrhunderts, obwohl ich diese Aspekte nicht mehr im einzelnen präsentieren konnte. Die Vielfalt Italiens, so dürfte aber hoffentlich deutlich geworden sein, führte dazu, daß die Bemühungen der Päpste um Anerkennung Roms, um Integration und Einfluß, die wir im ganzen Orbis christianus in Ansätzen seit dem 8./9., entscheidend aber seit dem 11./12. Jahrhundert beobachten können, auch auf Italien im kleinen zutreffen konnten. Waren sie manchmal vielleicht sogar besonders schwierig, wie das normannische Reich nahe legen könnte? Meine Beispiele betrafen stärker den Süden und das frühere Mittelalter, sie

72 Hiestand: Leistungsfähigkeit (wie Anm. 70).

73 Abzulesen an der Konkordanztabelle der neuen Nummern mit denen der Italia pontificia bei RI 4/4/4/2 S. 590-595.

74 Unten, S. 515-555, und 557-591. Der Tagungsbeitrag von Mario Sensi konnte nicht in diesen Band aufgenommen werden. 
haben auch versucht, zur Thematik ,Papsttum und Muslime', die mich schon seit langer Zeit beschäftigt, einen fehlenden Beitrag in unserem Band etwas zu kompensieren ${ }^{75}$. Italien war in der fraglichen Zeit sicher ein kleines vielfältiges Europa mit römisch-lateinischen, griechisch-orthodoxen und muslimischen Traditionen, es war - jedenfalls über lange Zeit - kein geographisch geschlossener, Orbis christianus latinus' im kleinen. Insofern erscheinen gerade hier Aspekte der aktuellen Europa-Debatte in der mediävistischen, aber auch in der aktuellen Diskussion wie in einem Brennglas eingefangen ${ }^{76}$. Inwieweit die Päpste aber aufgrund wechselnder Verhältnisse zu einer einheitlichen Kultur beitrugen, integrierend wirken konnten, steht auf einem anderen Blatt. Außerhalb des Patrimonium Petri versuchten sie dies immer wieder, wie Beispiele zu griechischen Traditionen, muslimischen Bedrohungen und das Normannenbündnis verdeutlichen. In den politischen Zuordnungen, die bei meinen Aperçus stärker im Vordergrund standen, waren Schwankungen deutlich; viel eher könnte vielleicht eine kontinuierlich steigende Einflußnahme für die hier weniger beachtete kirchliche Organisation in Liturgie, Verfahrensweisen und anderem gelten. Vielleicht könnte als eine Arbeitshypothese jedoch die Frage formuliert werden, ob der Anteil Italiens an den zahlreichen verschiedenen Kulturen die Vereinheitlichung nach päpstlichem Vorbild gegenüber anderen Ländern des Orbis christianus in unserem Zeitraum eher erschwert hat. Oder anders: Ab welchem Zeitpunkt und in welchen Konstellationen ergaben sich Möglichkeiten, päpstlichen Einfluß geltend zu machen, aber auch Normen und Vorbilder mit Erfolgschancen zu implementieren? Welche Rolle spielten die empfangenden und fordernden Institutionen und Personen in diesem, push and pull'-Prozeß, wie es die Soziologen ausdrücken würden ${ }^{77}$ ?

Wenn die Versuche zu langfristig erfolgreichen Integrationsprozessen auch in den Urkunden bis zum Investiturstreit kaum deutlich werden, vielmehr der Papst im Sinne Jochen Johrendts in den Urkunden in Italien eher als Mitbischof erscheint $^{78}$, so ergeben sich am Ende dieses Beitrags zwei zentrale Aufgaben für die künftige Arbeit: Wie ist dieses Verhältnis zwischen Papst und italischen

75 Ursprünglich war ein solcher Vortrag vorgesehen; hierzu plane ich eine separate Abhandlung.

76 Siehe hierzu oben Anm. 5.

77 Vgl. dazu Klaus Herbers: Im Dienste der Universalität oder der Zentralisierung? Das Papsttum und die „Peripherien“ im hohen Mittelalter - Schlussbemerkungen und Perspektiven, in: Römisches Zentrum und kirchliche Peripherie. Das universale Papsttum als Bezugspunkt der Kirchen von den Reformpäpsten bis zu Innozenz III., hg. v. Jochen Johrendt/Harald Müller, Berlin/New York 2008 (Neue Abhandlungen der Göttinger Akademie der Wissenschaften 2), S. 323-343. Sowie das von den Herausgebern dieses Bandes initiierte internationale DFG-Netzwerk mit dem Titel „Zentrum und Peripherie? Das universale Papsttum und die europäischen Regionen im Hochmittelalter“.

78 Siehe oben Anm. 6. 
Bischöfen sowie geistlichen Institutionen vor 896 und besonders nach $1046 \mathrm{zu}$ bestimmen, sowie, zweitens, wie kann die nichturkundliche Überlieferung, die ja mehrfach zu Wort kam, das Bild verändern? Hier liegt, so glaube ich, eines der Felder für Nachträge zur Italia, aus meinem Arbeitsbereich hatte ich einige Beispiele genannt. Nicht von ungefähr ist die dritte Sektion unserer Tagung am stärksten besetzt. Basierte das Unternehmen, insbesondere der Italia Pontificia anfangs vor allem auf Dokumentation der urkundlichen Überlieferung, die noch durch Nachträge weiter ergänzt werden kann, wie Tommaso di Carpegna Falconieri und Dieter Girgensohn in ihren Tagungsbeiträgen aussprachen ${ }^{79}$, so hat Kehr nur zögernd - auf Drängen Rudolf Smends - auch die Briefe und zuweilen - aber nicht immer - epigraphische Zeugnisse hinzugefügt, worauf Sebastian Scholz eingeht ${ }^{80}$. Erst bei der Arbeit weitete sich die Berücksichtigung der nichturkundlichen Überlieferung kontinuierlich aus. War es im Falle des von mir genannten Schreibens an Abt Honoratus die kanonistische Überlieferung, wohl unter Nutzung päpstlicher Register, über deren Aussagekraft und quellenkritische Schwierigkeiten Lotte Kéry und Rudolf Schieffer Auskunft geben $^{81}$, so zeigten die Fälle Benevents, wie wichtig hagiographische Berichte, die Giulia Barone vorstellt ${ }^{82}$, oder verschriftlichte Erzählungen über den Erwerb von Urkunden werden können, wie Dietrich Lohrmann verdeutlicht ${ }^{83}$. Insgesamt bedingte der vergleichsweise frühe Abschluß der Italia Pontificia auch restriktive Aufnahmekriterien. Welche Bedeutung dennoch Kardinals- und Legatenurkunden haben können, unterstreicht Werner Maleczek ${ }^{84}$. Ob dann die Suche bis zu den literarischen Produktionen der Neuzeit über die Gefangenenfreikäufe bei den Sarazenen führen muß, und wie weit sie überhaupt führen kann, muß zunächst offen bleiben.

Das Papsttum und die, vielen' Italien: Die Tagung und der hier vorgelegte Band führen uns in diese verschiedenen Welten, ihr Anlaß bietet zahlreiche Möglichkeiten, stolz auf das ,Paradestück' des Unternehmens zu blicken. Die Vielfalt des Werkes und Italiens erlauben aber zugleich Anfragen und Anregungen für die Zukunft. Gerade vor dem Hintergrund der Vor- und Nachteile räumlicher Gliederungsprinzipien sei die Frage gestellt, wie sehr es an der Zeit sein könnte, chronologische und regionale Verzeichnisse zu kombinieren, um

79 Unten, S 389-401 und 215-257.

80 Unten, S 373-388.

81 Unten, S 275-297 und 261-273.

82 Unten, S 299-309.

83 Unten, S 311-329.

84 Unten, S 331-372. 
die angedeuteten Probleme einer manchmal künstlichen räumlichen Zuordnung zumindest abzumildern und damit Perspektiven für neue Fragen zu eröffnen ${ }^{85}$.

\section{Riassunto}

Prendendo spunto dall'esempio del secolo IX, l'autore mette in luce la complessità dell'Italia nell'alto e pieno medioevo e si ricollega in questo contesto alle discussioni sulla formazione dell'Europa (latina). In particolar modo esamina l'opera di integrazione e l'azione di disintegrazione del papato. Complessivamente si valutano anche la suddivisione dell'Italia, operata da Fridolin Kehr, in Italia media, Italia superior e Italia inferior, nonché le categorie documentarie poco considerate nel processo di ultimazione dell'Italia Pontificia.

Seguono poi cinque breve riflessioni su questioni che riguardano: 1) Italia e Roma come "unità" concettuale e geografica, 2) l'immagine dell'Italia meridionale come una forma di "Europa variegata" e un "campo di battaglia" per ulteriori conflitti (Bisanzio, il mondo musulmano), 3) rapporti concorrenziali con Roma (ad esempio a Ravenna o a Benevento), 4) la questione normanna del secolo XI, 5) le dimore dei Papi fuori Roma e le consequenze che ne risultano. In questo modo è stato presentato un catalogo di punti che rimandano agli altri contributi del volume.

85 Hierzu sind Initiativen in Erlangen/Göttingen im Gange, die versuchen, Regestentraditionen, die von chronologischen oder von geographisch-institutionellen Gesichtspunkten ausgingen, durch elektronische Aufbereitung zusammenzuführen. 


\section{Rom und die wechselnden politischen Kraftzentren Italiens im frühen und hohen Mittelalter}


Bereitgestellt von | De Gruyter / TCS

Angemeldet | 217.89.40.26

Heruntergeladen am | 21.12.12 10:48 


\title{
Die Päpste und das oströmische Kaisertum im sechsten Jahrhundert
}

\author{
MatThias Maser
}

Seit dem Untergang des weströmischen Kaisertums im Jahr 476 hatten sich die Päpste in Italien in einem herrschaftlichen Umfeld zu behaupten, das vom heterogenen Nebeneinander verschiedener Mächte geprägt war. Zwar war die okzidentale Hälfte des Imperiums 476 der staatsrechtlichen Theorie zu Folge unter die Alleinherrschaft des östlichen Kaisertums zurückgefallen. In der Realität jedoch eröffnete der Untergang der weströmischen Kaiserherrschaft in Italien den Raum für zahlreiche neue Herrschaftsbildungen. Noch im 5. Jahrhundert waren dies zunächst der Prinzipat des Skiren Odoaker, der bald vom ostgotischen regnum abgelöst wurde; in der zweiten Hälfte des 6. Jahrhunderts folgten das langobardische Königreich von Pavia sowie die weitgehend eigenständigen Herzogtümer von Benevent und Spoleto. Seit dem Anbruch des Mittelalters mußte die römische Kirche damit in einem höchst „vielgestaltigen“ Italien agieren.

Unter den Mächten jedoch, die die heterogenen politischen Verhältnisse der Apenninhalbinsel im frühen Mittelalter gestalteten, kam - aus päpstlicher Perspektive betrachtet - dem Kaisertum eine besondere Bedeutung zu. Die Beziehungen, die die römische Kirche im 6. Jahrhundert zu Konstantinopel pflegte, unterschieden sich grundsätzlich von den Kontakten zu anderen italischen Mächten der Zeit. Das römische Verhältnis zu Ostgoten oder Langobarden war bei allem Bemühen um Ausgleich und Akkulturation ${ }^{1}$ geprägt von Differenzerfahrungen und dem Bewußtsein um eine "gefühlte" religiös-ethnisch-kulturelle Alterität ${ }^{2}$. Ganz anders im Fall des byzantinischen Reichs: Trotz aller Konflikte, die das Verhältnis zwischen den Kaisern und den Päpsten im anbrechenden Frühmittelalter belasteten, begriffen sich die römische Kirche und ihre Bischöfe während dieser Zeit doch stets als dem Imperium zugehörig. Das

1 Christoph Schӓғеr: Probleme einer multikulturellen Gesellschaft. Zur Integrationspolitik im Ostgotenreich, in: Klio 83 (2001) S. 182-197, hier v.a. S. 187-192.

2 Jörg Spielvogel: Die historischen Hintergründe der gescheiterten Akkulturation im italischen Ostgotenreich (493-553 n. Chr.), in: HZ 274 (2002) S. 1-24, hier S. 1618; Schäfer: Probleme (wie Anm. 1) S. 192 f.; Stefano Gasparri: Roma e i Longobardi, in: Roma nell'Alto Medioevo, Spoleto 2001 (Settimane di Studio del Centro Italiano di studi sull'Alto Medioevo 48), S. 219-247, hier S. 219 f., 225 f. Allgemein: Ottorino Bertolini: Roma e i Longobardi, Rom 1972, S. 13-21. 
aktive Bemühen um eine Lösung der westlichen Kirche aus den Bezügen des oströmischen Reichs, wie es schließlich im 8. Jahrhundert zum Bündnis der Päpste mit den Franken führen sollte, kann nicht ohne weiteres auf die vorausgehenden Jahrhunderte zurückprojiziert werden ${ }^{3}$. Auch wenn politisch-militärische Realitäten die Päpste in dieser Zeit in eine zunehmende Eigenständigkeit zwangen, blieb doch der römische Reichsverband der primäre Bezugsrahmen päpstlicher Politik.

Bei allem grundsätzlichen Bekenntnis zum Imperium wurden jedoch im 6. Jahrhundert wichtige Grundlagen für die spätere Emanzipation des Papsttums von Byzanz gelegt. Vor allem in der ersten Hälfte des Jahrhunderts waren es heftige Konflikte mit Konstantinopel, die den Päpsten den Rahmen für die Entwicklung weitreichender Ansprüche und Positionen boten, die auf lange Sicht das programmatische Fundament des päpstlichen Aufstiegs zu universaler Geltung legten. In der Auseinandersetzung mit dem Kaisertum formulierten römische Bischöfe zukunftsweisende Grundsätze ihrer Selbstwahrnehmung sowie des Verhältnisses zwischen päpstlicher und kaiserlicher Macht. Dabei war es über weite Strecken dieser Epoche eben die politische, Vielgestaltigkeit' Italiens, die Radikalität und Reichweite der päpstlichen Primatsansprüche überhaupt erst gestattete. In der zweiten Hälfte des Jahrhunderts verboten zwar gewandelte politische Rahmenbedingungen den Päpsten die lautstarke und programmatische Verfechtung ihrer Primatsansprüche. Wieder aber waren es auch in dieser Zeit gerade die heterogenen herrschaftlichen Realitäten der Apenninhalbinsel, die das Papsttum nun faktisch in Führungsfunktionen hineinwachsen ließen, aus denen heraus sich Rom, Italien und die päpstliche Kirche auf lange Sicht aus dem Imperium lösen sollten.

Den so skizzierten Phänomenen soll im Folgenden nachgegangen werden: Welche Problemstellungen verlangten im anbrechenden Frühmittelalter die programmatische Selbstpositionierung des Papsttums gegenüber Byzanz? Welche Themen und Streitfragen bestimmten in dieser Zeit die Auseinandersetzungen zwischen Papst- und Kaisertum? Welche politischen Rahmenbedingungen prägten im 6. Jahrhundert Formen und Inhalte der Kommunikation? Und welche Interessenlagen, Konzeptionen und Vorstellungen förderten oder verhinderten auf beiden Seiten jeweils eine Einigung?

3 Claudio Azzara: L'ideologia del potere regio nel papato altomedievale: secoli VI-VIII, Spoleto 1997 (Centro Italiano di Studi sull'Alto Medioevo, Spoleto. Testi, studi, strumenti 12), S. 1-3; Gert Haendler: Die Trennung der abendländischen Kirchen vom römischen Staat im Zeitalter der Völkerwanderung, in: Die Rolle des Papsttums in der Kirchengeschichte bis 1200. Ein Überblick und achtzehn Untersuchungen, hg. v. DEMS., Göttingen 1993, S. 149-161, hier S. 155-158. 


\section{Das Imperium als Bezugsrahmen der päpstlichen Politik}

Die herausragende Bedeutung des Imperiums für die Politik der Päpste im anbrechenden Frühmittelalter spiegelt sich bereits im Umfang der erhaltenen Quellen wieder. Ein bedeutender Teil sowohl der Papstbriefe ${ }^{4}$ als auch der an römische Bischöfe dieser Zeit gerichteten Schreiben ist der päpstlichen Korrespondenz mit Kaisern, Patriarchen sowie hochgestellten Persönlichkeiten am Hof in Konstantinopel zuzuordnen. Für zahlreiche Pontifikate ${ }^{5}$ des frühen 6. Jahrhunderts dominiert dieser Verfasser- bzw. Adressatenkreis die Überlieferung und läßt somit bereits rein quantitativ die Beziehungen zu Byzanz als primäres Thema der päpstlichen Politik jener Zeit erscheinen. Dieser Eindruck ist zwar

4 Die systematische Erschließung der päpstlichen Korrespondenz mit den Kaisern in Konstantinopel in Regestenform bleibt ein drängendes Desiderat der „unvollendeten Italia Pontificia" (vgl. Rudolf Hiestand: Die unvollendete Italia Pontificia, in: Hundert Jahre Papsturkundenforschung. Bilanz - Methoden - Perspektiven. Akten eines Kolloquiums zum hundertjährigen Bestehen der Regesta Pontificum Romanorum vom 9.-11. Oktober 1996 in Göttingen, hg.v. DEMs., Göttingen 2003, S. 47-57, hier S. 55 f.), das bislang nur unzureichend durch die Briefsammlung Thiels (Andreas THIEL: Epistolae Romanorum pontificum genuinae et quae ad eos scriptae sunt, 2 Bde., Braunsberg 1867) sowie die Kaiserregesten Dölgers (Franz Dölger: Die Regesten der Kaiserurkunden des oströmischen Reichs von 565-1453, München 1924 [Corpus der griechischen Urkunden des Mittelalters und der neueren Zeit/A.I.]) kompensiert wird. Auch ein künftiger Band IP 11 „Imperatores et Reges“ wird jedoch nicht die Gesamtheit der „Byzanzpolitik“ des Papsttums abbilden können, als deren Akteure und Ansprechpartner neben den Herrschern selbst komplementär unbedingt Patriarchen, endemische Synoden oder auch päpstliche Bevollmächtigte in der Reichshauptstadt zu berücksichtigen sind. Die Regestierung dieser Kontakte wird im Rahmen der Reihe „Oriens Pontificus" des Papstregestenunternehmens zu erfolgen haben.

5 Von den insgesamt 135 in der "Collectio Avellana» überlieferten Briefen von und an Papst Hormisdas (514-523) sind z. B. 54 unmittelbar der päpstlichen Korrespondenz mit dem Kaiser und hochgestellten Persönlichkeiten des Hofes zuzurechnen. Nimmt man die Schreiben von und an Konstantinopolitaner Patriarchen sowie einschlägige römischen Legaten in der Hauptstadt hinzu, erhöht sich diese Zahl auf 101 Dokumente; zum Briefcorpus des Hormisdas vgl. allgemein Sara Ranalli: L'epistolario di Papa Ormisda, nel quadro della letteratura latina cristiana del VI secolo, in: Studi e materiali di storia delle religioni 61 (1995) S. 19-54, hier v.a. S. 20-41 sowie Celestino Noce: Papa Ormisda: momenti significativi della sua vida, in: Atti del convegno su Papa Ormisda (514-523): magistero, cura pastorale ed impegno ecumenico, hg.v. DEMs., Frosinone 1993, S. 19-41, hier S. 38-41 mit Anm. 1. Ähnliches gilt z. B. für den kurzen Pontifikat Agapets I. (535-536): Von insgesamt neun erhaltenen Briefen von bzw. an diesen Papst (vgl. Epistulae Imperatorum, Pontificum, aliorum inde ab anno 367 usque ad annum 553 datae Avellana quae dicitur collectio, ed. Otto GüNther, Wien/ Prag/Leipzig 1895-1898 [Corpus Scriptorum Ecclesiasticorum Latinorum 25], S. 8591 Nr. 82, sowie Epistulae Merovingici et Karolini aevi I, ed. Wilhelm GundLAch/Ernst DüMmLER, Berlin 1892 [MGH Epp. 3/1], Nr. 36, 37) behandeln fünf direkt Aspekte der römisch-konstantinopolitanischen Beziehungen. 
sicherlich auch der spezifischen Form der Überlieferung vieler einschlägiger Dokumente in Briefsammlungen mit engem thematischem Fokus wie der "Collectio Avellana»", in Synodalakten oder diplomatischen Dossiers wie im Fall der so genannten Vigiliusbriefe ${ }^{7}$ geschuldet; jedoch zeigt gerade diese inhaltliche Schwerpunktsetzung bereits der frühen Überlieferung die Bedeutung, die schon Zeitgenossen dem Themenfeld der päpstlich-kaiserlichen Beziehungen jener Epoche beimaßen. Auch die historiographische Überlieferung, nicht zuletzt gerade die um 530 einsetzende ,offizielle' Geschichtsschreibung des Papsttums im «Liber Pontificalis» ${ }^{8}$, bestätigt diesen Eindruck: Die Papstviten aus der ersten Hälfte des 6. Jahrhunderts fokussieren sehr stark das päpstliche Agieren gegenüber Byzanz und seiner Kirche ${ }^{9}$, während andere zeitgenössische Geschehnisse von vermeintlich einschneidender Konsequenz für die römische Kirche, wie z. B. die langobardische Invasion in Italien 568 und ihre Folgen ${ }^{10}$, kaum Erwähnung finden.

Das Imperium wurde in Rom im 6. Jahrhundert als der vornehmliche politische Bezugsrahmen wahrgenommen. Es präsentierte sich den Päpsten dabei in zwei Dimensionen von unterschiedlicher Wichtigkeit. Der militärischadministrative Apparat der Kaiserherrschaft, also der byzantinische „Staat“, war für die Päpste lange von eher zweitrangiger Bedeutung. In der Praxis war Staatlichkeit nicht an das Imperium gebunden: Ein halbes Jahrhundert, von 476 bis 535, waren Rom und seine Kirche dem direkten Zugriff des Kaisertums

6 Coll. Avell. (wie Anm. 5). Als weitere Beispiele sind die von Eduard Schwartz unter dem Titel „Publizistische Sammlungen zum Acacianischen Schisma“ gemeinsam edierten «Collectio Veronensis» und «Collectio Berolinensis» zu nennen, vgl. Eduard Schwartz: Publizistische Sammlungen zum Acacianischen Schisma, in: AAM phil.-hist. Abt. N.F. 10 (1934) S. 10-304.

7 Ders.: Vigiliusbriefe. Zur Kirchenpolitik Justinians, in: SBA phil.-hist. Kl. Heft 2 (1940).

8 Le Liber pontificalis, ed. Louis Duchesne, Paris 1886-1892 (Bibliothèque des Écoles françaises d'Athènes et de Rome, sér. 2/3). Weitere ergiebige historiographische Quellen zu den päpstlich-kaiserlichen Beziehungen des 6. Jahrhunderts sind: Liberatus von Karthago: Breviarium causae Nestorianorum et Eutychianorum, in: Acta Conciliorum Oecumenicorum 2: Concilium Universale Chalcedonense, 5: Collectio Sangermanensis, hg. v. Eduard Schwartz, Berlin 1962, S. 98-141; Victoris Tunnunensis Chronicon cum reliquiis ex Consularibus Caesaraugustanis et Iohannis Biclarensis Chronicon, ed. Carmen Cardelle de Hartmann, Turnhout 2001 (CCh SL 173A), sowie Evagrios Scholasticus, Historia ecclesiastica, ed. Adelheid HüBner, Turnhout 2007 (Fontes Christiani 57/1-2).

9 Sehr deutlich z. B. die Vita des Hormisdas im Lib. Pont. (wie Anm. 8) vol. 1, S. $269-$ 274, vgl. zur «Vita Hormisdae» auch Sara Ranalli: L'opera del pontefice Ormisda nel panorama del monachesimo occidentale del VI secolo, in: Rivista Cistercense 12 (1995) S. 3-20, hier v.a. S. 3-13 sowie Noce: Ormisda (wie Anm. 5) S. 22-25, 32-37.

10 Bertolini: Roma e i Longobardi (wie Anm. 2) S. 14-17; Gasparri: Roma (wie Anm. 2) S. 232-234. 
entzogen, die Herrschaft lag faktisch in den Händen Odoakers bzw. seit 482 der ostgotischen Könige. Zwar bemühten sich Teile des römischen Senatorenadels und damit auch einflußreiche Kreise innerhalb der römischen Kirche seit dem ausgehenden 5. Jahrhundert immer wieder darum, die Herrschaft der Germanenkönige durch die staatsrechtliche Anerkennung als delegierte kaiserliche Amtsgewalt zu legitimieren ${ }^{11}$ und damit die Anbindung Italiens an das Imperium wieder zu intensivieren. Einer solchen stärker reichsverbundenen Partei standen in Rom aber stets auch Kräfte gegenüber, die eine allenfalls lockere herrschaftliche Bindung des Reichswestens an Konstantinopel und ein auskömmliches Arrangement mit den Ostgoten wünschten ${ }^{12}$. Die diesbezüglichen Interessenkonflikte unter den senatorial-kirchlichen Eliten, gepaart mit unterschiedlichen religionspolitischen Vorstellungen, steigerten sich bis zum Ausbruch eines Schismas 498, aus dem schließlich die eher reichskritische Partei unter Papst Symmachus als Sieger hervorging. ${ }^{13}$ Analoge Frontstellungen zwischen pro-gotischen und pro-byzantinischen Kräften bestimmten die Papstwahlen bis zur Mitte der 530er Jahre, ohne damit jedoch jemals die prinzipielle Zugehörigkeit Roms und Italiens zum Imperium in Frage zu stellen.

Eine zweite, für das Papsttum ungleich wichtigere Dimension des Imperiums stellte die byzantinische Reichskirche ${ }^{14}$ dar. Seit Mitte des 5. Jahrhunderts ist diese als Gemeinschaft der fünf Metropolkirchen von Rom, Alexandria, Antiochia, Jerusalem und schließlich Konstantinopel sowie ihrer Suffragane zu fassen. Die Gemeinschaft dieser Kirchen fand ihren Ausdruck in der communio, derer sich die Metropoliten regelmäßig gegenseitig versicherten und die durch die Nennung der Bischofsnamen im Rahmen der Meßliturgie ritualisiert wurde, im Austausch von Wahl- und Weiheanzeigen sowie vor allem in der gemein-

11 Filippo Burgarella: Il Senato, in: Roma nell'Alto Medioevo (wie Anm. 2) S. 121 175, hier S. 121-124; Christoph SCHÄFER: Der weströmische Senat als Träger antiker Kontinuität unter den Ostgotenkönigen (490-540 n. Ch.), Sankt Katharinen 1992, S. 212-239; John Moorhead: The Laurentian Schism: East and West in the Roman Church, in: Church History 47 (1978) S. 125-136, hier v.a. S. 126-129; Johannes Haller: Das Papsttum. Idee und Wirklichkeit, Bd. 1: Die Grundlagen, Esslingen 1950, S. $215 \mathrm{f}$.

12 Dies schlägt sich u. a. in der bereitwilligen Übernahme von Ämtern in der Hierarchie des ostgotischen regnums nieder: SCHÄFER: Senat (wie Anm. 11) S. 143-145, 149-211; Ders.: Probleme (wie Anm. 1) v.a. S. 188 f.

13 Eckhard Wirbelauer: Zwei Päpste in Rom. Der Konflikt zwischen Laurentius und Symmachus (498-514). Studien und Texte, München 1993 (Quellen und Forschungen zur antiken Welt 16), v.a. S. 9-44; Jeffrey Richards: The Popes and the Papacy in the Early Middle Ages 476-752, London/Boston 1979, S. 69-99; Moorhead: Laurentian Schism (wie Anm. 11) v.a. S. 129-136; Schwartz: Publizistische Sammlungen (wie Anm. 6) S. 226 f., 230-237.

14 Basil Studer: Theology in the Imperial Church (300-450), in: History of Theology, Bd. 1: The Patristic Period, hg.v. Angelo Di Berardino, Collegeville 1997, S. 251 408, hier S. $256 \mathrm{f}$. 
samen Bemühung um Orthodoxie und die Einheit des Dogmas im Rahmen ökumenischer Konzilien. Seit Mitte des 5. Jahrhunderts trat als Leiter dieser Konzilien der Kaiser in Erscheinung; nach dem vorherrschenden byzantinischen Kirchenmodell war er der von Gott bestellte Garant kirchlicher Einheit und Rechtgläubigkeit. Bereits Eusebius hatte im 4. Jahrhundert mit seinem Panegyrikus auf Kaiser Konstantin die ideologische Basis dieser späterhin unter dem Schlagwort des "Caesaropapismus" diskutierten Herrschaftskonzeption gelegt ${ }^{15}$, die in der Person des christlichen Kaisers die weltliche wie die kirchliche Lenkung der Christenheit zusammenführte. Zwar hatte diese auf das disziplinärorganisatorische bezogene kirchliche Leitungsfunktion des Imperators nie dogmatische Kompetenzen umfaßt. In der kirchenpolitischen Praxis jedoch verschwammen diese Zuständigkeitsgrenzen leicht, wenn der Kaiser Konzilsbeschlüssen bezüglich des rechten Glaubens durch die Promulgation als Reichsgesetz allgemeine Gültigkeit verschaffte und für deren Durchsetzung mit staatlichen Mitteln sorgte.

\section{Leitlinien der Auseinandersetzungen: Das Erbe von Chalkedon}

Gerade diese unscharfen Kompetenzen des Kaisertums als herrschaftliches Haupt der Reichskirche mußten zwangsläufig zu Konflikten mit den Päpsten führen. Das Verhältnis zwischen ihnen und dem byzantinischen Kaiserhof war vor allem in der ersten Hälfte des 6. Jahrhunderts daher alles andere als unbelastet ${ }^{16}$. Zu einem großen Teil resultierten die immer wieder ausbrechenden Konflikte aus widerstreitenden Ansichten beider Seiten über die Führungsrolle innerhalb der Reichskirche. Rom beanspruchte für sich eine auf petrinische Apostolizität gegründete ${ }^{17}$ Primatstellung in Lehr- und daraus abgeleitet auch in

15 Der Begriff und das mit ihm bezeichnete Herrschaftssystem ist seit langem Gegenstand kritischer Diskussion: Deno John Geanakoplos: Church and State in the Byzantine Empire: A Reconsideration of the Problem of Caesaropapism, in: Church History 34 (1965) S. 381-403; Jean-Marie Sansterre: Eusèbe de Césarée et la naissance de la théorie „cesaropapiste“, in: Byzantion 42 (1973) S. 131-195, 532-594, hier zur Berechtigung des Begriffs v.a. S. 589-593; Gilbert Dagron: Emperor and Priest. The Imperial Office in Byzantium, Cambridge 2003 (Past and Present Publications), S. 131 135.

16 Als Überblick vgl. Claire Sotinel: Emperors and Popes in the Sixth Century: The Western View, in: The Cambridge Companion to the Age of Justinian, hg.v. Michael Maas, Cambridge 2004, S. 267-290 sowie Haller: Papsttum (wie Anm. 11) S. $203-$ 308.

17 Zur von Leo dem Großen entworfenen „Petrinologie“ des Papsttums vgl. Walter ULLmann: Gelasius I. (492-496). Das Papsttum an der Wende der Spätantike zum Mittelalter, Stuttgart 1981 (Päpste und Papsttum 18), S. 61-87; Michele Maccarrone: „Sedes apostolica - vicarius Petri“, in: Ders.: Romana Ecclesia Cathedra Petri, hg.v. 
Disziplinfragen. Die Kaiser wiederum sahen sich mit der aus ihrem Amt erwachsenden Aufgabe konfrontiert, durch religions- und kirchenpolitische Maßnahmen die Einheit der Christenheit in einer Kirche und unter einem gemeinsamen Glaubensbekenntnis zu wahren. Akut wurde diese kaiserliche Aufgabe angesichts der drohenden Spaltung der Reichskirche über christologische Streitfragen, deren Ursprünge weit ins 5. Jahrhundert zurückreichten: Im Jahr 451 hatte das Konzil von Chalkedon die Lehrformel von den zwei „unvermischten und ungetrennten " Naturen Christi kanonisiert. Der Konzilsbeschluß sollte der Christenheit nach jahrzehntelangen Kontroversen ${ }^{18}$ wieder ein gemeinsames christologisches Bekenntnis geben und so die Einheit der Kirche retten. Schon bald aber wurde klar, daß das Chalcedonense an dieser Aufgabe gescheitert war: Die unterlegene Partei der sogenannten Monophysiten lehnte die Zwei-Naturen-Lehre als häretisch ab. Vor allem in Ägypten eskalierten die religiösen Konflikte und bedrohten die Einheit von Reich und Kirche. Da selbst staatliche Zwangsmaßnahmen den inneren Frieden nicht gewährleisten konnten, wurden schließlich inhaltliche Lösungsversuche unumgänglich: Das chalkedonensische Bekenntnis sollte soweit konkretisiert bzw. modifiziert werden, daß es für alle Glaubensparteien des Reichs akzeptabel wurde und als dogmatische Grundlage einer einigen Reichskirche taugte. Einen ersten Anlauf in diese Richtung unternahm Kaiser Zenon: 482 dekretierte er mit dem „Henotikon“19 ein vom Konstantinopolitaner Patriarchen Akakios erarbeitetes KompromißGlaubensbekenntnis und machte damit den Auftakt einer über fast zwei Jahrhunderte von seinen Nachfolgern verfolgten Politik, über die Promulgation dogmatischer Kompromißformeln ${ }^{20}$ den Kirchenfrieden herbeizuführen.

Die römische Kirche reagierte auf das Henotikon mit Ablehnung. Das Glaubensedikt versuchte die Streitfragen zwischen den Religionsparteien im Reich dadurch zu umgehen, daß man das Konzil von Chalkedon zwar nicht ausdrücklich widerrief, als Definitionsgrundlage der Orthodoxie neben den ökumenischen Versammlungen von Nikäa, Konstantinopel und Ephesus aber stillschweigend überging. Den Monophysiten sollte ein demütigendes Bekenntnis zu der verhaßten Synode erspart und so die Rückkehr in die orthodoxe

Pietro Zerbi/Raffaello Volpini/Alessandro Galuzzi, Rom 1991 (Italia Sacra. Studi e documenti di storia ecclesiastica 47-48), S. 1-101, hier S. 49-61.

18 Patrick T. R. Gray: The Legacy of Chalcedon: Christological Problems and their Significance, in: The Cambridge Companion to the Age of Justinian (wie Anm. 16) S. 215-238, hier S. 215-221 et passim.

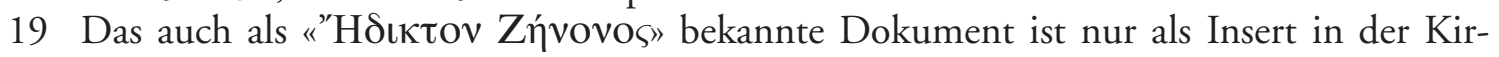
chengeschichte des Evagrios überliefert: Evagrios Scholasticus: Hist. eccl. (wie Anm. 8) Bd. 2 S. 358-364, lib. III, cap. 14.

20 Weitere entsprechende Versuche erfolgten unter Justinian I. in Form der sog. ,Theopaschitischen Formel', des ,Drei-Kapitel-Edikts' von 553 und des wenig erfolgreichen ,Aphtartodoketismus'; im 7. Jahrhundert scheiterten entsprechende Kompromissversuche auf Basis des ,Monenergetismus' sowie des ,Monotheletismus'. 
Kirchengemeinschaft erleichtert werden. Gerade dies war für Rom jedoch nicht akzeptabel: Das in Chalkedon kanonisierte Credo wurde als das Werk Papst Leos I. gesehen. Die Konzilsväter hatten sich 451 mit ihrer christologischen Lehrentscheidung in Inhalt und Wortlaut beinahe vollständig ${ }^{21}$ einem Lehrbrief $\operatorname{Leos}^{22}$ angeschlossen. Das Konzil von Chalkedon war damit für die Päpste zum Symbol der apostolischen Lehrautorität des Römischen Stuhls geworden. Jede Veränderung der chalkedonensischen Kanones mußte diese Lehrautorität und damit auch die hegemonialen Ansprüche Roms in Frage stellen.

Obwohl also mit dem Henotikon die Lehrgewalt Roms auf dem Spiel stand, behandelten Papst Felix III. und seine Nachfolger den Fall ab 483 nicht als Glaubensfrage, sondern als disziplinäre Angelegenheit. Nicht die theologischen Implikationen des Henotikons, sondern flankierende Aspekte der kirchlichen Rechtsordnung boten die Ansatzpunkte für den päpstlichen Widerstand: Als Versöhnungsgeste gegenüber den Monophysiten hatte Akakios 482 den noch in Chalkedon wegen Häresie verurteilten Petrus Mongos in die Kirchengemeinschaft mit Konstantinopel aufgenommen und ihn nach seiner Verpflichtung auf das Henotikon zum Patriarchen von Alexandria geweiht. 483 lud Felix deshalb Akakios vor ein römisches Synodalgericht, um sich hier für die von ihm zu vertretenden scandala - namentlich die communio mit einem verurteilten Ketzer - zu rechtfertigen ${ }^{23}$. Als Akakios die Vorladung zurückwies und gar eine päpstliche Gesandtschaft durch Übertölpelung dazu brachte, ihrerseits die eucharistische Gemeinschaft mit Vertretern der alexandrinischen Kirche zu zelebrieren $^{24}$, kündigte eine römische Synode 584 mit der Exkommunikation und

21 Die Konzilsväter übernahmen die päpstlichen Vorgaben zwar nicht unbesehen, schlossen sich aber einer Auslegung seiner Schriften im Sinne Kyrills von Alexandrien an, vgl. KarlHeinz Uthemann: Zur Rezeption des Tomus Leonis in und nach Chalkedon. Wider den dogmenhistorischen Begriff „strenger Chalkedonismus“, in: Studia Patristica 34 (2001) S. 572-604, hier S. 577-593, 602 f.; Stephan Otto Horn: Die Stellung des Bischofs von Rom auf dem Konzil von Chalcedon, in: Il primato del vescovo di Roma nel primo millennio. Ricerche e testimonianze. Atti del Symposium Storico-Teologico, Roma, 9-13 ottobre 1989, hg.v. Michele Maccarrone, Vatikanstadt 1991 (Pontificio Comitato di Scienze Storiche. Atti e documenti 4), S. 261-274, hier v. a. S. 270-272.

22 Der sog. «Tomus Leonis» in: Acta Conciliorum Oecumenicorum, ed. Eduard Schwartz, Bd. 2/2/1, Berlin 1932, S. 24-33.

23 Vgl. Collectio Berolinensis Nr. 23, ed. Eduard Schwartz, in: Ders.: Publizistische Sammlungen (wie Anm. 6) S. 59-117, hier S. 75.

24 Zur gescheiterten Gesandtschaft der Bischöfe Vitalis und Misenus von Cumae von 483 sowie zu ihrem Nachspiel vgl. Evagrios Scholasticus: Hist. eccl. (wie Anm. 8) Bd. 2 S. 372-378, lib. III, cap. 18-21. Dazu Philippe Blaudeau: Condamnation et absolution synodales d'un légat: le cas de Misène de Cumes (483-495), in: I Concili della cristianità occidentale. Secoli III-V. XXX incontro di studiosi dell'antichità cristiana, Roma 3-5 maggio 2001, Rom 2002 (Studia ephemeridis Augustinianum 78), S. 503 528, hier v.a. S. 505-513 und Schwartz: Publizistische Sammlungen (wie Anm. 6) S. 203-207. 
Absetzung des Kontrahenten der Konstantinopolitaner Kirche die Gemeinschaft auf und löste so das bis 519 dauernde Akakianische Schisma aus ${ }^{25}$.

Über 35 Jahre und fünf Pontifikate hinweg folgten Felix' Nachfolger im Großen und Ganzen der von ihm eingeschlagenen Marschrichtung, die mit keinem Wort auf inhaltliche Aussagen des Henotikon einging, sondern dieses über Verfahrensfragen zu Fall zu bringen suchte. Diese Verweigerung theologischer Auseinandersetzung ist in der Literatur oft mit Befremden bemerkt worden $^{26}$, tatsächlich machte aber das Henotikon eine dogmatische Diskussion gar nicht erforderlich, da es trotz zahlreicher provokanter Formulierungen keinerlei wirklich häretische Aussagen traf. ${ }^{27}$ Nicht so sehr der Inhalt des Henotikons als mehr seine Form bot daher den Päpsten Angriffsfläche: Der Kaiser versuchte mit herrscherlicher Amtsgewalt der Reichskirche den rechten Glauben per Gesetz zu verordnen. Scharf wies Felix Kaiser Zenon daher in einem Brief zurecht: In den sacrosancta habe er die Kirche nicht zu belehren, sondern sein Haupt den Priestern Christi zu unterwerfen und von ihnen Belehrung entgegenzunehmen ${ }^{28}$ ! Für Felix und seine Nachfolger stellte sich der Fall des Henotikon weniger als dogmatisches denn als ekklesiologisches Problem $\operatorname{dar}^{29}$ : Nicht die Frage nach Glaubensinhalten war durch das Henotikon aufgeworfen worden, sondern vielmehr die Frage, wem in der Reichskirche die

25 Zum Akakianischen Schismas siehe ebd. S. 161-262 sowie die Darstellung in einschlägigen Überblickswerken: Hans-Georg BЕск: Die frühbyzantinische Kirche, in: Handbuch der Kirchengeschichte, Bd. 2: Die Reichskirche nach Konstantin dem Großen. 2. Halbbd.: Die Kirche in Ost und West von Chalkedon bis zum Frühmittelalter (451-700), hg.v. Hubert Jedin, Freiburg/Basel/Wien 1975, S. 3-92, hier S. 3-17; Haller: Papsttum (wie Anm. 11) S. 219-252.

26 Beck: Kirche (wie Anm. 25) S. 8-10; Haller: Papsttum (wie Anm. 11) S. 225; Schwartz: Publizistische Sammlungen (wie Anm. 6) S. 203. Möglicherweise ist das Beharren der Päpste auf juristischen Kategorien - wohlwollend betrachtet - bereits Ausdruck eines zukunftsweisenden Verrechtlichungsprozesses, der die römische Kirche als kulturgeschichtliche Leistung im Mittelalter insgesamt auszeichnete. Gleichzeitig jedoch stellt sich die Frage, ob diese Verweigerung inhaltlicher Auseinandersetzung nicht letztlich Ausdruck eines Unvermögens des Westens war, mit der elaborierten Theologie des Ostens mitzuhalten. Eine solche Interpretation neigt allerdings wohl zu sehr dazu, den offenkundigen Niedergang theologischer Kompetenz in der Westkirche des 7. Jahrhunderts vorschnell auf frühere Epochen zurückzuprojizieren.

27 Ausdrücklich konstatiert das Edikt, keinen neuen Glauben zu definieren, sondern nur die nikäanische Orthodoxie samt ihrer Bestätigung durch nachfolgende Konzilien zu bekräftigen, vgl. Evagrios Scholasticus: Hist. eccl. (wie Anm. 8) Bd. 2, S. 364, lib. III,

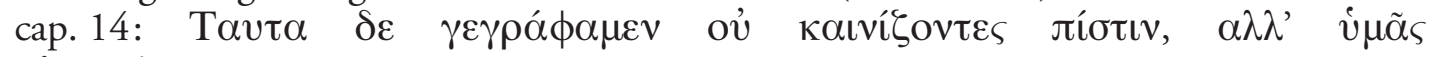
$\pi \lambda \eta \rho о \phi о \rho о \tilde{v} v \varepsilon \varsigma$.

28 Brief Felix' an Zenon: Certum est enim hoc rebus vestris esse salutare, ut cum de causis agitur dei, iuxta ipsius constitutum regiam voluntatem sacerdotibus Christi stuedatis subdere, non praeferre, et sacrosancta per eorum praesules discere potius quam docere... (Coll. Berol. n. 33, ed. Schwartz in: Schwartz: Publizistische Sammlungen [wie Anm. 6] S. 81 f.).

29 Ebd. S. $214 \mathrm{f}$. 
Autorität zukommen sollte, solche Glaubensinhalte zu definieren. Angesichts der Mitwirkung des Konstantinopolitaner Patriarchen Akakios an der henotischen Religionspolitik verwies auch diese Frage auf Chalkedon: In einem später als Kanon 28 überlieferten, für das Papsttum höchst ärgerlichen Beschluß hatte das Konzil Konstantinopel als Patriarchensitz bestätigt und diesen der Kirche des „Alten Rom“ gleichgestellt ${ }^{30}$. Zwar war dem petrinischen Stuhl ein Ehrenvorrang gegenüber dem „Neuen Rom“ zuerkannt worden, für Leo I. und seine Nachfolger war es aber nicht akzeptabel, daß dem neuen Patriarchensitz aufgrund seiner Sonderrolle als Kirche der kaiserlichen Reichshauptstadt Weiheund Jurisdiktionskompetenzen gegenüber den orientalischen Kirchen zukommen sollten ${ }^{31}$. So war es nicht allein die scheinbare Mißachtung der chalkedonensischen Orthodoxie und ihres Vaters, Papst Leos, die das päpstliche Rom gegen die henotische Politik Zenons und Akakios' aufbrachte. Als mindestens ebenso skandalös empfand es die römische Kirche, daß der Konstantinopolitaner Patriarch mit dem Henotikon die religionspolitische Initiative an sich gezogen hatte und eigenmächtig in Zusammenarbeit mit dem Kaiser eine Einung der Reichskirche versuchte, ohne deren römisches Haupt zu konsultie$\operatorname{ren}^{32}$.

War die Haltung der römischen Kirche seit Felix III. gegenüber der henotischen Religionspolitik somit aus reinem Statusdenken zu erklären? Riskierten die Päpste bewußt um der Wahrung eigener Suprematie-Ansprüche willen eine Spaltung der Kirche? Auch wenn einem modernen Beobachter Roms kompromißlose Ablehnung des Henotikons und aller begleitenden Maßnahmen sowie die sture Verweigerung inhaltlich-theologischer Auseinandersetzung angesichts der drängenden Notwendigkeit eines Ausgleichs mit den anderen religiösen Parteien des Reichs wie eine obstruktive Blockadepolitik ${ }^{33}$ erscheinen mag, lassen sich doch weniger negative Erklärungen für das päpstliche Agieren finden: So sehr eine Wahrung des chalkedonensischen Glaubens auch den politischen Interessen der römischen Kirche dienlich gewesen sein mag, so ist

30 Ullmann: Gelasius (wie Anm. 17) S. 88-95; siehe auch Evangelos K. Chrysos: Der sogenannte 28. Kanon von Chalkedon in der Collectio Prisca, in: AHC 7 (1975) S. $109-117$.

31 Stefan Otto Horn: Die Auseinandersetzungen um die Autorität der Kirche von Konstantinopel am Vorabend des acacianischen Schismas, in: Weisheit Gottes - Weisheit der Welt. Festschrift für Joseph Ratzinger zum 60. Geburtstag, Bd. 1, hg. v. Walter BAIER, St. Ottilien 1987, S. 697-711, hier v.a. S. 698-701 und passim; Ullmann: Gelasius (wie Anm. 17) S. 98-103. Zu einem Beispiel der manipulativen westlichen Rezeption des „Kanons“ vgl. Chrysos: Kanon (wie Anm. 30).

32 Schwartz: Publizistische Sammlungen (wie Anm. 6) S. 203. Siehe auch: Horn: Auseinandersetzungen (wie Anm. 31) S. 709-711.

33 Haller: Papsttum (wie Anm. 11) S. 222 f., sieht in der Ladung des Akakios' vor ein römisches Synodalgericht im Jahre 482 eine bewusste Provokation des Bruchs zwischen den Kirchen. 
dem Papsttum doch grundsätzlich auch eine ernsthafte Sorge um die Wahrung der Orthodoxie zu unterstellen ${ }^{34}$. Chalkedon hatte mit der Autorität eines ökumenischen Konzils gültige Inhalte des rechten Glaubens formuliert, die nicht ohne weiteres aus kirchenpolitischer Opportunität einfach aufgegeben werden konnten. Nicht nur in Rom war man dieser Ansicht: Zahlreiche chalkedonensisch gesinnte Gemeinschaften aus dem Orient appellierten an den Papst, den wahren Glauben gegen die monophysitenfreundliche Religionspolitik des Kaisers zu verteidigen, und erzeugten so in Rom beträchtlichen Handlungsdruck $^{35}$. Auch zeigt der Briefverkehr verschiedener Päpste der Schismenzeit deutlich, wie sehr das Papsttum von den Anhängern der chalkedonensischen Orthodoxie im Reichsosten als Schutzinstanz gegen Repressalien und Verfolgung im Zuge der kaiserlichen Religionspolitik betrachtet wurde ${ }^{36}$. Die päpstliche Haltung im Akakianischen Schisma entsprach somit durchaus auch Erwartungen Dritter, deren Motive für ihr Beharren auf Chalkedon sicher nicht im Verdacht des rein egoistischen Strebens nach Statuserhalt stehen. Zudem verweigerten die Päpste mittelfristig keineswegs jede theologische Auseinandersetzung im Interesse einer Integration der Reichskirche. Mehrfach fanden sich die Päpste im 6. Jahrhundert bereit, im Zuge eines ,neochalkedonensischen' Kurses notwendige Konkretisierungen des Glaubensfundaments von 451 auf ihre Rechtgläubigkeit hin zu prüfen und im positiven Fall zu

34 Darauf weist z.B. hin: Luciano Orabona: Ormisda e la risoluzione dello scisma di Acacio, in: Atti del convegno su Papa Ormisda (514-523): magistero, cura pastorale ed impegno ecumenico, hg. v. Celestino Noce, Frosinone 1993, S. 43-56, hier S. 54 f.

35 Besonderen Druck übten die Mönche des Akoimetenklosters bei Konstantinopel auf Felix aus, vgl. Evagrios Scholasticus: Hist. eccl. (wie Anm. 8) Bd. 2, S. 374-378, lib. III, cap. 19-21. Zweimal traten Vertreter der Akoimeten auf einem römischen Synodalgericht als Ankläger gegen päpstliche Legaten auf, die sich in Konstantinopel der Kollaboration mit der henotischen Partei schuldig gemacht haben sollen, vgl. Blaudeau: Condamnation (wie Anm. 24) S. 513-515, sowie Schwartz: Publizistische Sammlungen (wie Anm. 6) S. 204-207. Zu den Akoimeten vgl. auch Heinrich BАснт: Die Rolle des orientalischen Mönchtums in den kirchenpolitischen Auseinandersetzungen um Chalkedon 431-519, in: Das Konzil von Chalkedon, Bd. 2: Entscheidung um Chalkedon, hg.v. Alois Grillmeier/Dems., Würzburg 1973, S. 193-314, hier v.a. S. 269-291.

36 Besonders deutlich zeigen dies die Briefwechsel des Hormisdas mit verschiedenen Empfängern im Osten, wie z.B. den Mönchen der Syria Secunda (Coll. Avell. [wie Anm. 5] Nr. 139 f., vgl. dazu Cornelia B. Horn: The Correspondence Between the Monks of Syria Secunda and Pope Hormisdas in 517/518 A.D, in: Journal of Maronite Studies [www.mari.org/JMS/october97] 1/4 [1997]) oder dem orthodoxen Bischof Johannes von Nikopolis (Coll. Avell. [wie Anm. 5] Nr. 123 und 124 sowie ferner Nr. 127, $133-135,137,173$ und 175) 
approbieren ${ }^{37}$. Nicht akzeptabel aber war für sie die im Henotikon versuchte gänzliche Aufgabe dieses Fundaments.

Die Verteidigung des Chalkedonense als definitorische Basis der Orthodoxie und gleichzeitiges Symbol päpstlicher Suprematie sowie die Behauptung der römischen Führungsrolle in der Reichskirche gegen Herausforderungen von Seiten des Kaisertums, vor allem aber des Konstantinopolitaner Patriarchats, wurden somit die Leitlinien der päpstlichen Politik einer ganzen Epoche. Die Auseinandersetzungen zwischen Rom und Byzanz, die aus dieser Politik zwangsläufig erwuchsen, belasteten die Kräfte der römischen Kirche im 6. Jahrhundert mehrfach bis aufs Äußerste. Zugleich jedoch bildeten die Konflikte um das Erbe von Chalkedon den Hintergrund, vor dem die Päpste zukunftsweisende Positionen hinsichtlich der Stellung Roms im Gefüge der Kirchen sowie hinsichtlich der päpstlich-kaiserlichen Beziehungen entwickeln und behaupten konnten. Die Epoche nach Chalkedon war damit eine formative Phase für die theoretische Konzeption eines institutionellen Papsttums und seines Anspruchs auf universale Suprematie in Glaubens- und Disziplinfragen ${ }^{38}$. Dabei waren es jedoch gerade die politischen Umstände der Zeit, die den römischen Bischöfen an der Wende vom 5. zum 6. Jahrhundert die Entwicklung und Erprobung solcher Positionen überhaupt erst ermöglichten: Seit 476 waren Rom und seine Kirche dem Zugriff des Kaisertums entzogen. Zwangsmaßnahmen, wie sie von staatlicher Seite gegen chalkedonensische Gegner der kaiserlichen Religionspolitik im Osten des Reiches ergriffen wurden, waren im Westen somit nicht durchführbar; und auch die Kontrolle der römischen Kirche durch die italischen Könige hielt sich in Grenzen, beließ doch beispielsweise der Arianer Theoderich der katholischen Kirche Italiens weitgehende Autonomie ${ }^{39}$. Die Päpste profitierten somit direkt von der „Vielgestaltigkeit“ Italiens: Bis zum Ende des Akakianischen Schismas, ja faktisch bis zur Wiedererrichtung byzantinischer Herrschaft in Italien Mitte der 530er Jahre, konnten sie zwischen

37 So im Falle der von Justinian favorisierten ,theopaschitischen Formel', die bereits 519 von Papst Hormisdas geprüft, letztlich aber erst von Johannes II. und Agapet I. approbiert wurde, siehe unten S 54-57.

38 Als das wohl bekannteste und wirkmächtigste Beispiel ist hier sicher die sog. „ZweiGewalten-Lehre" zu nennen, die Gelasius I. 494 in einem Brief (JK 632, ed. Schwartz: Publizistische Sammlungen [wie Anm. 6] S. 19-24) gegenüber Kaiser Anastasios vertrat, vgl. dazu: Ullmann: Gelasius (wie Anm. 17) S. 198-212; Ders.: Der Grundsatz der Arbeitsteilung bei Gelasius I, in: HJb 97/98 (1978) S. 41-70; Wilhelm EnssLin: Auctoritas und potestas. Zur Zweigewaltenlehre des Papstes Gelasius I, in: HJb 74 (1955) S. 661-668. Gegen eine ,programmatische' Interpretation: Alan CotTrell: Auctoritas and Potestas. A Reevaluation of the Correspondence of Gelasius I on papalimperial relations, in: MSt 55 (1993) S. 95-109.

39 Frank Ausbüttel: Theoderich der Große. Der Germane auf dem Kaiserthron, Darmstadt 2003 (Gestalten der Antike), S. 92-107, hier v.a. S. 92-99; SCḦ̈FER: Probleme (wie Anm. 1) S. 192-194. 
den Mächten in einem relativ geschützten Raum agieren und hier zukunftsweisende Positionen und Leitsätze in der Auseinandersetzung mit dem Imperium in einer Radikalität formulieren, die unter anderen Umständen wohl kaum denkbar gewesen wären ${ }^{40}$.

\section{Das Justinian'sche Zeitalter}

So sehr die Unmöglichkeit kaiserlicher Einflußnahme in Rom dem Papsttum an der Wende zum 6. Jahrhundert erweiterte Handlungsmöglichkeiten eröffnete, so sehr fällt auf, daß die Päpste der Zeit dennoch keine dauerhafte und endgültige Lösung aus eben diesem Einflußbereich des Kaisertums suchten. Imperium und Reichskirche bildeten weiterhin den selbstverständlichen Rahmen, innerhalb dessen Rom seine Suprematieansprüche verfocht. Ziel der päpstlichen Bemühungen war nicht die Lösung Roms aus der kaiserlichen Herrschaft, sondern die Umsetzung der genuin römischen Vorstellung von der hierarchischen Gestaltung von Reichskirche und Christenheit unter päpstlicher Führung $^{41}$. Die Möglichkeiten, diese Vorstellungen zur Geltung zu bringen, änderten sich grundlegend - zunächst zum Guten -, als es 518 in Konstantinopel zu einem Dynastiewechsel kam und der nachmalige Kaiser Justinian an der Seite seines Onkels Justin I. die Zügel einer neuen Religionspolitik in die Hand nahm. Das henotische Programm hatte nach über drei Jahrzehnten der Kirchenspaltung abgewirtschaftet; insbesondere in Konstantinopel drängte die Mehrheit der Bevölkerung auf eine Rückkehr zum chalkedonensischen Glauben $^{42}$. In der Karwoche des Jahres 519 unterzeichneten daher der Kaiser und sein Neffe, Patriarch Johannes sowie alle Teilnehmer einer endemischen Synode in der Hauptstadt ein von päpstlicher Seite diktiertes Glaubensbekenntnis ${ }^{43}$, das

40 Sotinel: Emperors and Popes (wie Anm. 16) S. 269 f.; Haller: Papsttum (wie Anm. 11) S. 226 f.; Schwartz: Publizistische Sammlungen (wie Anm. 6) S. 204.

41 Deutlich zeigt dies z. B. die gelasianische Zwei-Gewalten-Lehre: Gelasius' Scheidung einer weltlichen und einer geistlichen Führungskompetenz bezogen sich auf dasselbe Gemeinwesen; kaiserliche potestas und päpstliche auctoritas werden als Ordnungsmächte innerhalb derselben (universalen) Gemeinschaft begriffen, woraus überhaupt erst der Bedarf zur theoretischen Klärung ihres (Konkurrenz)-Verhältnisses erwuchs.

42 Milton V. Anastos: The Emperor Justin I's Role in the Restoration of the Chalcedonian Doctrine, 518-519, in: DERs.: Aspects of the Mind of Byzantium. Political Theory, Theology, and Ecclesiastical Relations with the See of Rome, hg. v. Speros VRYONIS JR./ Nicholas Goodhue, Aldershot 2001 (Variorum Collected Studies Series 717), Nr. IV, S. 125-139, hier v.a. S. 129-133; Jakob Speigl: Synoden im Gefolge der Wende der Religions-Politik unter Kaiser Justinos (518), in: OKS 45 (1996) S. 3-20, hier S. 3-8; BECK: Kirche (wie Anm. 25) S. 16 f.

43 Den sog. «Libellus Hormisdae»: Coll. Avell. (wie Anm. 5) S. 520-522 Nr. 116b. Vgl. dazu: Jesús SAn Martín: La „Prima salus“ del papa Hormisdas (514-523), in: Revista 
das Chalcedonense als Basis der Orthodoxie anerkannte, ausdrücklich Roms überragende Autorität in Glaubensfragen feststellte und den Forderungen der Päpste nach Streichung des Patriarchen Akakios und aller seiner henotischen Nachfolger während der Schismenzeit aus den Bischofslisten Konstantinopels in vollem Umfang entsprach. Die Bereitschaft, mit der man sich in Byzanz von Rom die Modalitäten der Kircheneinheit diktieren ließ, muten auf den ersten Blick wie eine bedingungslose Kapitulation an. Justin und Justinian waren zwar persönlich Anhänger des Chalkedonismus, angesichts der unvermeidlichen Verschärfung der Konflikte mit den Monophysiten, die eine Rückkehr zum chalkedonensischen Bekenntnis bedeuten mußte, traten allerdings neben diese persönlichen Orientierungen wohl handfestere Motive für die religionspolitische Wende von 518: Eventuell begannen bereits zu diesem Zeitpunkt in Konstantinopel die ersten Planungen für die Restauration der italischen Reichsprovinz $^{44}$, die ab $535 \mathrm{im}$ Rahmen der Gotenkriege in Angriff genommen wurde. Bei allem ernsthaften Bestreben zur Orthodoxie sollte die Wiederherstellung der Kircheneinheit zwischen Rom und Byzanz möglicherweise auch die romanische Bevölkerung Italiens dem arianischen ,Regime' der Ostgoten entfremden und sie wieder enger an das Imperium binden ${ }^{45}$.

Nach über dreieinhalb Jahrzehnten war das Schisma 519 endlich überwunden. Zunächst allerdings änderte sich durch den Zusammenschluß der Kirchen wenig an den politischen Realitäten. Weiterhin hatte das Kaisertum faktisch keine Möglichkeiten, seine Herrschaft auf der Apenninhalbinsel direkt auszuüben. Im Gegenteil: Auch wenn die Wiederannäherung von Rom und Konstantinopel mittelfristig nicht ohne Auswirkungen auf die Beziehungen zwischen Papsttum und König Theoderich blieb ${ }^{46}$, konnte sich doch über mehrere Pontifikate hinweg gerade eine pro-gotische Partei den Papstthron si-

Española de Teología 1 (1940/1941) S. 767 -812; Walter HAACKE: Die Glaubensformel des Papstes Hormisdas im Acacianischen Schisma, Rom 1939 (Analecta Gregoriana 20); sowie allgemein Orabona: Risoluzione (wie Anm. 34).

44 Anastos: Justin I’s Role (wie Anm. 42) S. 136 f. Zu einer gegenläufigen Einschätzung gelangt hingegen Sotinel: Emperors and Popes (wie Anm. 16) S. 273.

45 AusbütTel: Theoderich (wie Anm. 39) S. 107, sieht in den Ereignissen des Jahres 519 eine deutliche Zäsur im Verhältnis zwischen Theoderich und dem Papsttum. Anders hingegen Sotinel: Emperors and Popes (wie Anm. 16) S. 273, die darauf hinweist, daß Hormisdas 518 die formale Zustimmung Theoderichs zur Wiedervereinung der römischen und der konstantinopolitanischen Kirche erbat und erhielt.

46 Vgl. z. B. die Behandlung Papst Johannes' I. durch Theoderich bzw. die diesbezüglich von päpstlicher Seite gestreute Propaganda: Wilhelm Ensslin: Papst Johannes I. als Gesandter Theoderichs des Großen bei Kaiser Justinos I, in: BZ 44 (1951) S. 127-134; Heinz Löwe: Theoderich der Große und Papst Johannes I., in: HJb 72 (1953) S. 83100. Theoderich sah seine Herrschaft offensichtlich zudem durch „hochverräterische“ Machenschaften bedroht, wie Prozeß und Hinrichtung des Boethius zeigen. Vgl. dazu SchäFER: Senat (wie Anm. 11) S. 240-262, der das Geschehen freilich stark unter der Perspektive sozialer Gegensätze innerhalb des Senats beleuchtet. 
chern. Weiterhin erlaubte die fortbestehende, Vielgestaltigkeit' Italiens den Päpsten, ihre Führungsansprüche gegenüber Byzanz mit Nachdruck zur Geltung zu bringen, ohne irgendwelche Zwangsmaßnahmen befürchten zu müssen. Trotz der Beilegung des Akakianischen Schismas war das Konfliktpotential zwischen Rom und Konstantinopel keineswegs beseitigt: Auch wenn sich beide Seiten 519 in einem reichen Briefwechsel ${ }^{47}$ gegenseitig ihre Freude über den endlich erreichten Kirchenfrieden zusicherten, zeigte sich rasch in aller Deutlichkeit, wie unterschiedlich die jeweiligen Positionen und Vorstellungen eigentlich waren: Der Kaiserhof begriff die Union als Rückführung der italischen Kirche in das Gefüge der vom Kaiser gelenkten Reichskirche ${ }^{48}$. In Konstantinopel ging man offensichtlich von einer weitgehend gleichberechtigten Partnerschaft der beiden Metropolkirchen aus. In mehreren Briefen Justins I. sowie hochgestellter Persönlichkeiten des Kaiserhofes wird die erreichte Einheit der Kirchen so als concordia ecclesiarum catholicae fidei ${ }^{-49}$ charakterisiert, als das einmütige Miteinander mehrerer orthodoxer Kirchen. Patriarch Johannes II. wiederum beschrieb die wiederhergestellte Einheit als Vereinigung der beiden „allerheiligsten Kirchen Gottes, jener des alten und jener des neuen Rom“, ,jener des apostolischen Stuhls Petri und jener der Kaiserstadt ${ }^{\text {‘50 }}$ und betonte damit ausdrücklich die Gleichrangigkeit beider Kirchen. Zwar erkannte Johannes an, daß diese Wiedervereinigung auf Basis der in Rom gehüteten Orthodoxie erfolgt war, daraus leitete sich für ihn jedoch keine rechtliche Suprematie der römischen Kirche $\mathrm{ab}^{51}$. Nach Johannes' Vorstellung war es die gegenseitige spiritalis caritas unter Gleichberechtigten, die ein vinculum insolubile zwischen beiden Kirchen knüpfte ${ }^{52}$. Das im Osten gepflegte Reichskirchenbild glich damit also einem föderalen Bund autonomer Kirchen unter kaiserlicher

47 Erhalten v. a. in der Collectio Avellana, vgl. dazu Ranalli: Epistolario (wie Anm. 5) v. a. S. $20-33$.

48 Sotinel: Emperors and Popes (wie Anm. 16) S. 270 f.; Luigi Magi: La Sede Romana nella corrispondenza degli imperatore e patriarchi bizantini (VI-VII sec.), Löwen/Rom 1972 (Bibliothèque de la Revue d'Histoire Ecclésiastique 57), S. 300-303.

49 Coll. Avell. (wie Anm. 5) S. 612 Nr. 160 Z. 1; ebd. S. 636 Nr. 181 Z. 6 f. dasselbe Bild im Schreiben des Anastasius, ebd. S. 616 Nr. 165 Z. 12.

50 Coll. Avell. (wie Anm. 5) S. 608 Nr. 159 Z. 5-7: ... sanctissimas enim dei ecclesias, id est superioris et novellae istius Romae, unam esse accipio; illam sedem apostoli Petri et istius augustae civitatis unam esse definio. Siehe auch ebd. S. 613 Nr. 161 Z. 8-10: ...utrasque ecclesias tam senioris quam novae Romae unam esse evidenter intelligens [...] cognosco....

$51 \mathrm{Daß}$ dies in Rom anders gesehen wurde, war Johannes indessen wohl bewusst: So versuchte er durch ein erklärendes Proömion dem «Libellus Hormisdae» den Charakter eines freiwillig verfassten Briefes und nicht einer pflichtschuldigen Unterwerfung unter die dogmatische Autorität Roms zu geben, vgl. den Bericht der Gesandten an Hormisdas in Coll. Avell. (wie Anm. 5) S. 620 Nr. 167 Z. 10-15; dazu auch MAgr: Sede Romana (wie Anm. 48) S. 45-48.

52 Coll. Avell. (wie Anm. 5) S. 637 Nr. 182 Z. 14 f. 
Leitung, geeint durch gegenseitige caritas und dasselbe rechtgläubige Bekenntnis.

Diese Vorstellungen deckten sich keineswegs mit der römischen Perspektive: Papst Hormisdas begriff die Wiederherstellung der Kircheneinheit vielmehr als Anerkennung des dogmatischen wie disziplinären Primats Roms ${ }^{53}$. Dies stellte er in einem Brief an Patriarch Johannes klar: Endlich seien nun dank göttlicher Barmherzigkeit die zerstreuten membra Christi wieder in einem "corpus" vereint, endlich das gefledderte Vermächtnis des Herrn wieder zusammengefügt ${ }^{54}$. Gegen die Vielzahl der Kirchen der orientalischen Ekklesiologie stellte Hormisdas die Einheit des einen corpus Christi. Nicht die Föderation verschiedener Kirchen, sondern die eine kirchliche Gemeinschaft aller Christen war das projektierte Ziel des römischen Reichskirchenmodells. Vor diesem Hintergrund konnte auch nicht von einem glücklichen Zusammenschluß der beiden ,römischen' Kirchen die Rede sein, wie dies in Konstantinopel beschworen wurde. Aus päpstlicher Sicht hatte sich vielmehr das lange der Häresie verfallene Konstantinopel demütig der Lehrautorität Roms unterworfen und so waren nun in Anspielung auf Matt. 16,18 die fundamenta auch der östlichen Kirche auf den Fels der firmitas des Apostelfürsten gegründet ${ }^{55}$. Für einen wahren Kirchenfrieden aber, so Hormisdas in einem Instruktionsschreiben an seinen Legaten, müsse der Kaiser jetzt die Kirchen in aller Welt, namentlich jene von Alexandria und Antiochia, zur communio sedis apostolicae zurückrufen ${ }^{56}$. Die dogmatische Grundlage dieser communio sah der Papst dabei offensichtlich in seinem libellus Hormisdae.

Am Kaiserhof in Byzanz war man seit dem Dynastiewechsel von 518 durchaus bereit, den solcherart beanspruchten apostolischen Primat Roms in gewissen Formen anzuerkennen. Justinian, der schon lange vor seiner eigenen Kaisererhebung für die Religionspolitik seines Onkels verantwortlich zeichnete, suchte für die nun anstehenden Aufgaben den Schulterschluß mit dem Papsttum: Der Wiedervereinigung von Rom und Konstantinopel mußte die Reintegration auch der heterodoxen Kirchen des Orients folgen. Als Basis einer solchen Reintegration empfahl sich in Justinians Augen die Aufnahme eines konkretisierenden Zusatzes zum chalkedonensischen Bekenntnis, der die Zweifel der Monophysiten an dessen Orthodoxie zerstreuen sollte. Bereits 519

53 Sotinel: Autorité (wie Anm. 48) S. 270 f.; Magi: Sede Romana (wie Anm. 48) S. $302 \mathrm{f}$.

54 Coll. Avell. (wie Anm. 5) S. 624 Nr. 169 Z. 22-26: Nunc enim misericordia procurante divina in unius corporis vultum dissipata olim Christi membra convenient et ab iniquissimis direpta latronibus annuntiata propheticis vocibus domini nostri redintegratur hereditas ...; siehe auch Magr: Sede Romana (wie Anm. 48) S. 53.

55 Coll. Avell. (wie Anm. 5) S. 624 f. Nr. 169 Z. 26-28: ... et vere in huius petrae fide, id est apostolorum principis firmitate, Orientalis ecclesiae fundamenta solidantur.

56 Coll. Avell. (wie Anm. 5) S. 627 Nr. 170 Z. 13. 
ersuchte Justinian Papst Hormisdas daher um eine Stellungnahme zur sogenannten „Theopaschitischen Formel ${ }^{\text {“ } 57}$. Ausdrücklich huldigte Justinian in dem betreffenden Schreiben der Lehrautorität Roms und erklärte, er wolle für katholisch erachten, was der Papst ihm antworte ${ }^{58}$. Verfolgt man aber die weitere Korrespondenz in dieser Sache, so wird rasch deutlich, was Justinian eigentlich meinte: Der künftige Kaiser erwartete offensichtlich kein Urteil des Papstes über die Rechtgläubigkeit der vorgeschlagenen Formel, sondern eine Bestätigung derselben. Justinian hatte den Theopaschismus zum Weg aus der Kirchenspaltung erkoren und drängte nun den Papst, diesen Weg durch die Approbation kraft apostolischer Autorität zu unterstützen ${ }^{59}$. Als Hormisdas diesem Ansinnen jedoch nicht entsprach, sondern die Theopaschitische Formel nach der Einholung theologischer Gutachten aus der nordafrikanischen Kirche ${ }^{60} 521$ ablehnte, beendete dies für lange Zeit alle engeren Kontakte zwischen Rom und Byzanz. Unterbrochen nur von einem triumphalen Besuch Johannes' I. in Konstantinopel $^{61}$, für den jedoch die Initiative nicht vom Papst, sondern von König Theoderich ausging, der den Pontifex 526 zur Übernahme einer Gesandtschaft an den Kaiserhof in religionspolitischen Angelegenheiten zwang, brach 521 eine über ein Jahrzehnt währende Funkstille zwischen Rom und Konstantinopel $\mathrm{an}^{62}$.

$57 \mathrm{Zu}$ Justinians Bemühen um die Formel Unus ex trinitate passus est vgl. allgemein: Jakob Speigl: Formula Iustiniani, in: Ostkirchliche Studien 44 (1995) S. 105-134, hier S. 107-111, 114-118; Gray: Legacy (wie Anm. 18) S. 228 f.

58 Coll. Avell. (wie Anm. 5) S. 646 Nr. 188 Z. 11 f.: Hoc enim credimus esse catholicum, quod vestro religioso responso nobis fuerit intimatum.

59 Coll. Avell. (wie Anm. 5) Nr. 189. Vgl. Sotinel: Emperors and Popes (wie Anm. 16) S. $272 \mathrm{f}$.

60 Theresia Hainthaler: Entwicklungsstufen in der Haltung der nordafrikanischen Kirche zur theopaschitischen Frage, in: Cristianesimo e specificità regionali nel mediterraneo latino. XII incontro di studiosi dell'antichità cristiana, Roma 6-8 maggio 1993, Rom 1994 (Studia Ephemeridis „Augustinianum“ 46), S. 215-228, hier S. 222-225; siehe auch Filippo CARCiONE: La controversia tra Ormisda e i monaci sciti sula formula „Unus de Trinintate passus est carne“: Calcedonismo integralista e calcedonismo integrato a confronto, in: Atti del convegno su Papa Ormisda (wie Anm. 34) S. 57-73.

61 Zur Reise Johannes’ nach Byzanz vgl. Massimiliano Vitiello: „Cui Iustinus imperator veniente ita occurrit ac si Beato Petro“, in: Byzantinische Zeitschrift 98 (2005) S. 81 96; Achim Thomas HACK: Das Empfangszeremoniell bei mittelalterlichen Papst-KaiserTreffen, Köln 1999 (Beih. RI 18), S. 385-406; Paul Goubert: Autour du voyage à Byzance du Pape saint Jean I ${ }^{\text {er }}(523-526)$, in: Orientalia Christiana Periodica 24 (1958) S. 339-352; Löwe: Theoderich (wie Anm. 46); Ensslin: Papst Johannes I. (wie Anm. 46).

62 Sotinel: Emperors and Popes (wie Anm. 16) S. 273 konstatiert pointiert: „The only way to avoid admitting the antagonism between Rome and Constantinople was by avoiding any actual dealings between them". 
Als Justinian - 527 selbst Kaiser geworden - schließlich das gegenseitige Schweigen brach und 533 erneut in Rom um eine dogmatische Stellungnahme ersuchte, geschah dies wohl vor dem Hintergrund strategischer Überlegungen. Die Planungen für die Restauration der Reichsprovinz Italien dürften zu diesem Zeitpunkt in vollem Gange gewesen sein und ließen in Konstantinopel ein gutes Einvernehmen mit dem Papst angeraten erscheinen ${ }^{63}$ : Trotz Hormisdas' Ablehnung hatte Justinian am Theopaschismus festgehalten und 533 den Zusatz zum Symbolum unus ex tritintate passus est eigenmächtig kraft kaiserlicher Autorität als gültiges Reichsrecht promulgiert ${ }^{64}$, ohne Rom überhaupt zu kontaktieren. Erst mit gehöriger Verspätung, dafür umso ehrerbietiger wandte sich der Kaiser nun an Papst Johannes II. mit der Bitte um Bestätigung seiner religionspolitischen Maßnahme ${ }^{65}$ : Erstmals sprach er in seinem Schreiben die römische Kirche direkt als caput omnium sanctarum ecclesiarum an; eine noch ausdrücklichere Anerkennung hatte der päpstliche Primatsanspruch bislang in den kaiserlichen Verlautbarungen nicht gefunden ${ }^{66}$. Abermals hegten Kaiser und Papst jedoch unterschiedliche Vorstellungen von den Kompetenzen, die aus einer solchen herausgehobenen Position erwachsen sollten: In der Adresse des genannten Schreibens sprach Justinian seinen Korrespondenzpartner als sanctissimus archiepiscopus almae urbis Romae ac patriarcha an. Eben dieser Patriarchentitel aber verortete den römischen Bischof im Rahmen eines Kirchenmodells $^{67}$, das Justinian wenig später als geltendes Reichsrecht festschreiben sollte: Justinian ging von einer hierarchisch gegliederten Kirche aus, die unterhalb der kaiserlichen Spitze in fünf gleichberechtigte Patriarchate verfaßt war. Diese galten ihm dabei als Verfassungsorgane, die die Umsetzung der kaiserlichen Reichskirchenpolitik in den unteren Hierarchieebenen zu gewährleisten hatten. Seine eigene Stellung an der Spitze dieses hierarchischen Kirchenmodells, sah Justinian durch göttliche Einsetzung legitimiert: Von Gott war er, der Kaiser, an die Spitze der Christenheit gestellt und diesem für die Einheit von Reich und

63 Ebd. S. 276.

64 Corpus Iuris Civilis, Codex Iustinianus, ed. Theodor Mommsen/Paul Krueger, Hildesheim 1997, I,6; vgl. Speigl: Formula Iustiniani (wie Anm. 57) S. 114-118.

65 Coll. Avell. (wie Anm. 5) S. 84. Ders. Brief in CICiv Cod. Iust. (wie Anm. 64) I,1,8; vgl. Speigl: Formula Iustiniani (wie Anm. 57) S. 122-126.

66 MAgr: Sede Romana (wie Anm. 48) S. $111 \mathrm{f}$.

67 Enrico Morini: Roma nella pentarchia, in: Roma fra oriente e occidente, Spoleto 2002 (Settimane di studio del Centro Italiano di Studi sull'Alto Medioevo 49), S. 833-939, hier v.a. S. 845-853 und passim; Rudolf Schieffer: Der Papst als Patriarch von Rom, in: Il primato del vescovo di Roma (wie Anm. 21) S. 433-451, hier S. 439 f.; Vittorio Peri: La pentarchia: istituzione ecclesiale (IV-VII sec.) e teoria canonico-teologica, in: Bisanzio, Roma e l'Italia nell'alto medioevo, Spoleto 1988 (Settimani di studio del Centro Italiano di Studi sull'Alto Medioevo 34), S. 209-311, hier v.a. S. 228-230. 
Kirche verantwortlich ${ }^{68}$. Ein römischer Primat konnte in diesem Modell allenfalls den Anspruch auf eine Ehrenstellung ${ }^{69}$ als Hort apostolischer Orthodoxie, nicht jedoch auf jurisdiktionelle Vorrechte gegenüber anderen Kirchen des Reichs oder gar die alleinige dogmatische Definitionsgewalt begründen ${ }^{70}$. Justinian war bereit, in seinen religionspolitischen Zielen die Autorität Roms in Lehrfragen zu konsultieren, erwartete aber selbstverständlich die Kooperation der Päpste. In Rom sah man dies natürlich anders: Zwar entsprach Papst Johannes II. dieses Mal dem Ersuchen um eine Approbation der Theopaschitischen Formel $^{71}$. Anstatt jedoch einfach - wie von Justinian gefordert - die kaiserliche Rechtssetzung mit päpstlicher Autorität zu bekräftigen, ließ Johannes das vorgelegte Glaubensbekenntnis zunächst einer intensiven theologischen Prüfung unterziehen bevor er es 534 für orthodox erklärte ${ }^{72}$. Und als Justinian 536 erneut um die formale Bestätigung dieser Approbation durch Johannes' Nachfolger Agapet I. ersuchte, gewährte dieser die Bitte nur unter dem ausdrücklichen Hinweis, er bestätige die kaiserliche epistola fidei „nicht etwa, weil wir Laien die Vollmacht zur Verkündung [der Lehre] zugestehen, sondern weil wir bestätigen [können], daß der Eifer Eures Glaubens mit den Vorschriften unserer Kirchenväter übereinstimmt $[\ldots]^{\text {“73 }}$. Agapet bescheinigte damit dem Kaiser, das von ihm vorgelegte Credo sei orthodox, sprach dem Kaiser aber im selben Satz kategorisch das Recht zur Lehrverkündung im Reich ab.

Agapets kurzer Pontifikat von Mai 535 bis April 536 stellte einen letzten Moment des Triumphes für die römische Kirche gegenüber dem Kaisertum dar. Justinian war angesichts der absehbaren Schwierigkeiten des gerade ausgebrochenen Gotenkrieges in Italien auf ein gutes Verhältnis zum Papsttum ange-

68 CICiv Cod. Iust. (wie Anm. 64) I,17,1: Deo auctore nostrum gubernantes imperium, quod nobis a caelesti maiestate traditum est..., oder ebd. I,29,5: Quum propitia divinitate Romanum nobis sit delatum imperium sollicita cura, cauta diligentia pertractantes perspeximus. Zum herrscherlichen Selbstbild Justinians vgl. zusammenfassend Mischa MeIer: Justinian. Herrschaft, Reich, Religion, München 2004 (Beck'sche Reihe Wissen 2332), S. 7-13; Otto Mazal: Justinian I. und seine Zeit. Geschichte und Kultur des Byzantinischen Reiches im 6. Jahrhundert, Köln/Weimar/Wien 2001, S. 86-92.

69 Corpus Iuris Civilis, Novellae, ed. Rudolf SchöLl/Wilhelm Kroll, Hildesheim 2005, Nov. 131, cap. 2.

70 Magi: Sede Romana (wie Anm. 48) S. 110 f.

71 Richards: Popes (wie Anm. 13) S. 142 f. vermutet, die römische Kirche sei zu diesem Zeitpunkt zu sehr mit internen Parteikämpfen beschäftigt gewesen, um gegen die kaiserliche Anmaßung dogmatischer Gewalt zu protestieren.

72 Sotinel: Emperors and Popes (wie Anm. 16) S. 275 f.; Hainthaler: Entwicklungsstufen (wie Anm. 60) S. $223 \mathrm{f}$.

73 Coll. Avell. (wie Anm. 5) S. 343 Nr. 91 Z. 13-15: ... non quia laicis auctoritatem praedicationis admittimus sed quia stadium fidei vestrae partum nostrorum regulis congruens confirmamus.... 
wiesen $^{74}$. Als Agapet daher nach Byzanz reiste ${ }^{75}$, konnte er hier die Abdankung des offen der monophysitischen Partei zuneigenden Patriarchen Anthimus erzwingen und selbst den Kandidaten seiner Wahl, Menas, als Nachfolger auf dem Konstantinopolitaner Patriarchenstuhl weihen ${ }^{76}$. Seine Reise war ein großer Erfolg für die päpstlichen Führungsansprüche innerhalb der Reichskirche: „Der allerfrömmste Kaiser Justinian erniedrigte sich voller Freude vor dem apostolischen Stuhl“", resümiert der «Liber pontificalis» triumphierend ${ }^{77}$. Nach Agapet jedoch, der noch 536 in Konstantinopel verstarb, veränderten sich die politischen Bedingungen, unter denen die Päpste ihre Byzanzpolitik gestalten konnten, drastisch: Noch im Dezember desselben Jahres hielten byzantinische Truppen unter Belisar Einzug in Rom. Nach einem halben Jahrhundert waren die Bischöfe der Stadt damit für den langen Arm der byzantinischen Staatsmacht wieder erreichbar. Als erster mußte dies Papst Silverius erfahren, der nach dem Ableben seines Vorgängers wohl im Juni 536 als letzter Papst mit ostgotischer Protektion ${ }^{78}$ erhoben worden war. Bereits im Frühjahr 537 wurde Silverius der hochverräterischen Kollaboration mit König Witigis angeklagt und auf kaiserlichen Befehl hin abgesetzt. Verschiedene Quellen ${ }^{79}$ deuten einen Zusammenhang dieser Papstabsetzung mit religionspolitischen Plänen Justinians bzw. seiner monophysitenfreundlichen Gattin Theodora an und feiern Silverius für seine Standhaftigkeit angesichts der kaiserlichen Forderung nach päpstlicher Rehabilitation des häretischen Ex-Patriarchen Anthimus von Konstantinopel. Tatsächlich dürfte dieser Brückenschlag zu religionspolitischen Themen jedoch lediglich ein Echo der aggressiven Polemik ${ }^{80}$ sein, die die spätere

74 Sotinel: Emperors and Popes (wie Anm. 16) S. 277; zu einer anders lautenden Einschätzung kommt Schwartz: Vigiliusbriefe (wie Anm. 7) S. 46.

75 Zu Agapets Reise vgl. НАск: Empfangszeremoniell (wie Anm. 61) S. 385-406; Wilhelm Ensslin: Papst Agapet I. und Kaiser Justinian I, in: HJb 77 (1957) S. 459-466; Venance Grumel: La papauté à Byzance: saint Agapet (535-536), in: Estudis Franciscans 41 (1927) S. 11-27.

76 Jakob Speigl: Die Synode von 536 in Konstantinopel, in: Ostkirchliche Studien 43 (1994) S. 105-153, hier S. 121-130.

77 Lib. Pont. (wie Anm. 8) S. 288: ... se humilavit sedi apostolicae .... Schwartz: Vigiliusbriefe (wie Anm. 7) S. $44 \mathrm{f}$. bezeichnet den Bericht des Lib. Pont. allerdings als eine „zur Fratze verzerrte Legende“ und weist daraufhin, daß Agapet mit seinen Maßnahmen bei Justinian offene Türen einrannte.

78 Vgl. den Bericht über die gekaufte Unterstützung König Theodahats: Lib. Pont. (wie Anm. 8) S. 290. Siehe auch Sotinel: Emperors and Popes (wie Anm. 16) S. 279; Dies.: Autorité (wie Anm. 48) S. 447 Anm. 34; Paul Hildebrand: Die Absetzung des Papstes Silverius (537), in: HJb 42 (1922) S. 213-249, hier S. $244 \mathrm{f}$.

79 Zur Auswertung der entsprechenden Textstellen im Lib. Pont., bei Liberatus von Karthago, Victor von Tunnuna sowie Prokop vgl. Hildebrand: Absetzung (wie Anm. 78) v. a. S. $214-235$.

80 Zur Polemik gegen Vigilius vgl. Jakob Speigl: Leo quem Vigilius condemnavit, in: Papsttum und Kirchenreform: Historische Beiträge. Festschrift für Georg Schwaiger zum 
Überlieferung über Silverius' Nachfolger Vigilius ergoß. Auch dieser mußte das Scheitern seiner päpstlichen Führungsansprüche an Justinians selbstherrlicher Kirchenherrschaft erleben: Nachdem die Festschreibung der theopaschitischen Formel keine Aussöhnung mit den Monophysiten gebracht hatte, unternahm Justinian einen erneuten Versuch, die Einheit der Reichskirche wiederherzustellen. 543 oder 544 promulgierte er ein Edikt, das die Schriften - die sogenannten „Drei Kapitel“81 - der noch in Chalkedon für rechtgläubig befundenen Theologen Theodor von Mopsuestia, Theodoret von Kyrrhos und Ibas von Edessa verurteilte. Eben diese drei Autoren galten in monophysitischen Kreisen als Vordenker des Nestorianismus; ihre ausdrückliche Verurteilung sollte daher das chalkedonensische Bekenntnis vom Vorwurf nestorianischer Tendenzen befreien ${ }^{82}$. Gegen Justinians Edikt formierte sich vor allem im Reichswesten breiter Widerstand ${ }^{83}$. Von zahlreichen Gesandtschaften bestürmt, sah sich Papst Vigilius bald an die Spitze der Opposition gedrängt und verweigerte der kaiserlichen Rechtssetzung in Glaubensdingen die Zustimmung: Die Verurteilung der Drei Kapitel widerspreche den Kanones von Chalkedon und sei damit inakzeptabel. Als daraufhin im November 545 kaiserliche Polizeitruppen Vigilius aus Rom nach Sizilien und nach einem längeren Zwischenaufenthalt weiter nach Konstantinopel eskortierten, sprechen die stark tendenziösen Quellen ${ }^{84}$ von einer gewaltsamen Entführung des Papstes. Zwar könnte es sich bei der Abreise des Vigilius angesichts der drohenden ostgotischen Belagerung Roms auch um eine Evakuierung aus Sicherheitsgründen gehandelt haben ${ }^{85}$, immerhin wäre diese aber so plötzlich erfolgt, daß der mitten aus einer Meßfeier

65. Geburtstag, hg. v. Manfred Weitlauff/Karl Hausberger, St. Ottilien 1990, S. $1-$ 15; Rudolf Schieffer: Eine übersehene Fiktion aus dem Dreikapitelstreit, in: ZKG 101 (1990) S. 80-87; siehe auch DERs.: Zur Beurteilung des norditalienischen DreikapitelSchismas, in: ZKG 87 (1976) S. 167-201.

81 Zum sog. ,Dreikapitelsstreit' vgl. Antonio Placanica: Teologia polemica e storiografia ecclesiastica nella controversia dei Tre Capitoli, in: Res Christiana. Temi interdisciplinari di patrologia, hg. v. Antonio Quacquarelli, Rom 1999, S. 129-254, hier v. a. S. 129169; Geevarghese Chediath: La controverse des Trois Chapitres, in: Istina 43 (1998) S. 75-90 sowie künftig den Sammelband Celia Chazelle/Katy Cubitt: The Crisis of the Oikumene, Turnhout 2007 (Studies in the Early Middle Ages 14).

82 Placanica: Teologia polemica (wie Anm. 81) S. 131 f.; Vincenzo Poggi: La controverse des Trois Chapitres, in: Istina 43 (1998) S. 99-110, hier S. 100 f.; Chediath: Controverse (wie Anm. 81) S. $83 \mathrm{f}$.

83 Peter BRuns: Zwischen Rom und Byzanz. Die Haltung des Facundus von Hermiane und der nordafrikanischen Kirche während des Drei-Kapitel-Streits (553), in: ZKG 106 (1995) S. 151-178, hier v.a. S. 155-158; SChiefFer: Beurteilung (wie Anm. 80) S. 168-170, sowie die entsprechenden Beiträge in Chazelle/Cubitt: Crisis (wie Anm. 81).

84 So v.a. Victor Tunnunensis Chron. (wie Anm. 8) S. 44 cap. 132.; aber auch Lib. Pont. (wie Anm. 8) S. 297.

85 So Sotinel: Emperors and Popes (wie Anm. 16) S. 281; anders dagegen Richards: Popes (wie Anm. 13) S. 143 f. 
gerissene Papst keinerlei organisatorische Vorbereitungen mehr für die Zeit seiner Abwesenheit treffen konnte ${ }^{86}$. Ob nun freiwillig oder gezwungenermaßen nach Konstantinopel gelangt, wurde Vigilius hier im Frühjahr 547 zunächst mit allen Ehren empfangen. Bei aller Ehrbezeugung ließ Justinian aber von Anfang an keinen Zweifel daran, daß er von Vigilius nichts anderes als eine Approbation der Drei-Kapitel-Verurteilung akzeptieren würde. Der Papst saß zwischen allen Stühlen: Die Westkirche sah in ihm ihren Repräsentanten gegen Justinians ketzerische Religionspolitik, während der Kaiser mit allen Mitteln die päpstliche Zustimmung zu seinem Drei-Kapitel-Edikt erreichen wollte. Zunächst versuchte Vigilius offensichtlich den Triumph seines Amtsvorgängers Agapet zu wiederholen ${ }^{87}$ und in Konstantinopel als Bewahrer einer apostolischen Orthodoxie aufzutreten. Hatte aber Justinian gegenüber Agapet 536 aus strategischen Erwägungen bezüglich seiner italischen Restaurationspläne noch einlenken müssen, so war es dieses Mal der Papst, der den schlechteren Stand hatte: Vigilius war der Rückweg ins umkämpfte Rom abgeschnitten und so befand er sich ganz in der Hand eines kaiserlichen ,Gastgebers', der im Zweifelsfall auch vor dem Einsatz von Gewalt gegenüber dem widerspenstigen Papst nicht zurückschreckte. Fast acht Jahre blieb Vigilius in Byzanz und agierte hier unter dem Druck von beiden Seiten äußerst unglücklich ${ }^{88}$. Mit seinem ständigen Hin und Her zwischen Zustimmung und Ablehnung des Drei-Kapitel-Edikts, mit geheimen Verpflichtungserklärungen gegenüber dem Kaiser und spektakulären Widerrufen seiner eigenen Verlautbarungen verspielte er seine theologischdogmatische Autorität in der Westkirche. Und als sich nach Jahren des Konflikts 553 endlich eine Konzilsentscheidung für Justinians religionspolitische Maßnahme abzeichnete, erklärte auch der Kaiser dem protestierenden Papst zynisch, er lege keinen Wert mehr auf seine Mitwirkung: Päpstliche Schriftstücke, die die Drei Kapitel verurteilten, habe er bereits zur Genüge, ein weiteres brauche er nicht; falls sich Vigilius aber gegen die Verurteilung auszusprechen gedenke, so verfalle er ohnehin seinem eigenen Anathem ${ }^{89}$. Noch am selben Tag suspendierte das V. ökumenische Konzil in Konstantinopel Vigilius auf kaiserliches Ersuchen hin von seinem Amt und kanonisierte eine Woche später die Verur-

86 So die Vita Vigilii in Lib. Pont. (wie Anm. 8) S. 297; Richards: Popes (wie Anm. 13) S. 144.

87 Sotinel: Autorité (wie Anm. 48) S. 457; Dies.: Emperors and Popes (wie Anm. 13) S. 281.

88 Die wechselvolle Geschichte von Vigilius' Aufenthalt in Konstantinopel soll hier nicht im Einzelnen nachgezeichnet werden. Vgl. dazu Sotinel: Autorité (wie Anm. 48) S. 457-463; Richards: Popes (wie Anm. 13) S. 145-153; Haller: Papsttum (wie Anm. 11) S. 268-279; Schwartz: Vigiliusbriefe (wie Anm. 7) S. 60-72.

89 Vgl. den Bericht der Konstantinopolitaner Synode in der Sitzung vom 26. Mai 553, in: Concilium universale Constantinopolitanum sub Iustiniano habitum, ed. Johannes Straub, Berlin 1971 (ACO 4/1), S. 185 Z. 34-40. 
teilung der Drei Kapitel ${ }^{90}$. Vom Kaiser in Arrest genommen, konnte Vigilius seinen Protest nicht lange aufrechterhalten: Im Februar 554 publizierte er seine offizielle Anerkennung der Drei-Kapitel-Verurteilung ${ }^{91}$ und zog sich damit in der Westkirche endgültig den Vorwurf zu, ein Verräter an der Leonischen Orthodoxie von Chalkedon zu $\operatorname{sein}^{92}$.

\section{Das spätere 6. Jahrhundert}

Zwischenzeitlich hatte sich die Lage in Italien grundlegend gewandelt. Justinians General Narses hatte seit 552 sukzessive das Ostgotenreich zerschlagen und die Apenninhalbinsel endgültig wieder dem Kaisertum unterstellt. 554 restaurierte Justinian mit seiner Pragmatica Sanctio ${ }^{93}$ formell die Herrschaft des Imperiums über Italien - angeblich auf Bitten des Vigilius, wie das Dokument bezeugt. Mit diesem Verfassungsdokument trug Justinian in Ansätzen der Tatsache Rechung, daß der römische Bischof in Italien über religiös-kirchliche Belange hinaus zu einer Instanz der öffentlichen Ordnung geworden war und betraute den Papst offiziell mit der Kontrolle einzelner Bereiche der Zivilverwaltung. Vigilius selbst konnte diese Funktionen jedoch nicht mehr wahrnehmen; er starb bereits 555 auf der Rückreise in Syrakus und sollte Rom nicht wiedersehen. Angesichts der Bedeutung, die dem Papsttum bei der Durchsetzung der kaiserlichen Religionspolitik in Italien zukommen mußte, griff Justinian nun direkt in die Nachfolgeregelung ein und befahl die Wahl und Weihe Pelagius' I. ${ }^{94}$ In vielen Überblicksdarstellungen zur Papstgeschichte markiert der Sturz des Vigilius und die Erhebung seines Nachfolgers von Kaisers Gnaden den Auftakt und zugleich den ersten Höhepunkt einer Phase, die verschiedentlich als Epoche der „byzantinischen Gefangenschaft ${ }^{\text {“95 }}$ der römischen Kirche apostrophiert wird. In der Tat geriet das Papsttum in der zweiten Hälfte des 6. Jahrhunderts in formale

90 ACO 4/1 (wie Anm. 89) S. 200 f. bzw. ebd. can. 12-14, S. 218 f.

91 Engelbert Zetтl: Die Bestätigung des V. Ökumenischen Konzils durch Papst Vigilius, Bonn 1974 (Antiquitas 1/20), gegen ältere Zweifel an der Echtheit der entsprechenden Papstbriefe.

92 Vgl. Speigl: Leo (wie Anm. 80).

93 CICiv Nov. (wie Anm. 69) Nov. vom 13. August 554. Vgl. dazu G. G. Archi: Pragmatica sanctio pro petitione Vigilii, in: Festschrift für Franz Wieacker zum 70. Geburtstag, hg.v. Okko Behrends, Göttingen 1979, S. 11-36; Gottfried Härtel: Zur Problematik der pragmatischen Sanktion, speziell zur Sanctio pragmatica pro petitione Vigilii, in: Iura 27 (1976) S. 33-49.

94 Richards: Popes (wie Anm. 13) S. 157 f.; Rudolf M. Mainka: Papst Pelagius I. (556561) und die Einheit der Kirche, in: Claretianum 4 (1964) S. 81-145, hier S. $84 \mathrm{f}$.

95 Haller: Papsttum (wie Anm. 11) S. 285 f. Harald Zimmermann: Das Papsttum im Mittelalter, Stuttgart 1981 (UTB 1151), S. 42, spricht gar von einer Epoche „Unter byzantinischer Tyrannei“. 
Abhängigkeit vom Kaiserhof: Seit 555 mußte vor der Weihe eines gewählten Papstes die kaiserliche Bestätigung des Elekten eingeholt werden. Im Einzelfall konnte sich diese Prozedur über viele Monate hinziehen ${ }^{96}$. Kaum in das durch den Kampfbegriff einer ,Gefangenschaft' suggerierte Bild paßt jedoch der Befund, daß nach der Abreise des Pelagius aus Byzanz die direkten römischkonstantinopolitanischen Beziehungen für Jahrzehnte praktisch zum Erliegen kamen $^{97}$. Zwar konsultierten die Päpste weiterhin die byzantinische Staatsmacht in den unterschiedlichsten Angelegenheiten. Derartige Kontakte spielten sich nun aber weitgehend auf der provinziellen Ebene ab: Bis 567 vertrat der Feldherr Narses in Ravenna die Kaiserherrschaft in Italien; nach seiner Abberufung übernahm der praefectus praetorio Longinus die Funktionen eines kaiserlichen Statthalters, die bis Mitte der 580er Jahre in die institutionalisierten Formen des Exarchats überführt werden sollten ${ }^{98}$. Das Kaisertum verfügte damit nun in Italien über einen dauerhaften Repräsentanten mit weitreichenden Kompetenzen, der - zusammen mit untergeordneten und teilweise in Rom selbst ansässigen Funktionsträgern der byzantinischen Zivil- und Militärverwaltung $^{99}$ - den römischen Bischöfen als Ansprechpartner in allen administrativ-politischen Angelegenheiten diente. Selbst in Fragen der kirchlichen Disziplin erkannten die Päpste die Zuständigkeiten und Befugnisse dieser Statthalter an, ja ersuchten gar um deren Eingreifen: So verlangte Pelagius I. 559 von Narses sowie vom magister militum Johannes die gerichtliche Verfolgung Bischof Paulinus' von Fossombrone bzw. sogar dessen Inhaftierung, nachdem dieser angesichts der römischen Approbation des Drei-Kapitel-Edikts öffentlich die Orthodoxie des apostolischen Stuhls bestritten und die Exkommunikation gegen den Papst ausgesprochen hatte ${ }^{100}$; und auch Pelagius II. sowie Gregor I.

96 Richards: Popes (wie Anm. 13) S. 168.

97 Sotinel: Emperors and Popes (wie Anm. 16) S. 285-287; Magr: Sede Romana (wie Anm. 48) S. 156, $158 \mathrm{f}$.

98 Vera von Falkenhausen: L'Esarcato d'Italia (VI-VIII secolo), in: I Bizantini in Italia, hg.v. Guglielmo Cavallo, Mailand 1982 (Antica madre 5), S. 3-45, hier 12-14, sowie noch immer grundlegend Charles DieHL: Études sur l'administration Byzantine dans l'exarchat de Ravenne (568-751), Paris 1888 (Bibliothèque des Écoles françaises d'Athènes et de Rome 53), S. 6-23.

99 Bernard Bavant: Le duché byzantin de Rome. Origine, durée et extension géographique, in: Mélanges d'archéologie et d'histoire 91 (1979) S. 41-88, für das sechste Jahrhundert v.a. S. 41-66, sowie Dienl: Administration (wie Anm. 98) S. 124-133.

100 Pelagii I pape epistulae quae supersunt (556-561), ed. Pius M. Gassò/Columba M. Battle, Montserrat 1956, S. 159-161, Nr. 60. (an Narses) bzw. S. 178 f. Nr. 69 (an Johannes). Weitere Schreiben Pelagius' I. an byzantinische Funktionsträger in Italien in Angelegenheiten der kirchlichen Disziplin: Nr. 52, 53, 65, 70 und 70, vgl. dazu: MainKa: Pelagius I. (wie Anm. 94) S. 106-111, 140-144. 
traten mehrfach mit den Exarchen von Ravenna bezüglich des schismatischen norditalienischen Klerus in Briefkontakt ${ }^{101}$.

In hierarchisch-disziplinären Angelegenheiten war die kaiserliche Kirchenherrschaft für die Päpste in der zweiten Hälfte des 6. Jahrhunderts somit offensichtlich eine unstrittige Selbstverständlichkeit. Auseinandersetzungen über theologisch-dogmatische Definitionskompetenzen des weltlichen Reichsoberhaupts, wie sie die Jahrzehnte seit Ausbruch des Akakianischen Schismas geprägt hatten, blieben der römischen Kirche hingegen nach dem Drei-Kapitel-Streit über lange Zeit erspart. Zwar unternahm Justinian gegen Ende seines Lebens nochmals einen Versuch, die Reichskirche auf Basis eines autokratisch diktierten Glaubensbekenntnisses zu einen. Allerdings starb der Kaiser 565, bevor der Streit über den von ihm favorisierten Aphtartodoketismus ${ }^{102}$ abermals die Religionsparteien im Reich entzweien konnte. Sein Nachfolger Justin II. ließ die neue Glaubensformel seines Onkels wieder fallen und dekretierte zur Beschwichtigung ein eher traditionelles, die Provokation weiterer Auseinandersetzungen vermeidendes Bekenntnis ${ }^{103}$. In der religionspolitischen Praxis wandte sich Justin zudem von Justinians Kurs einer Versöhnung mit den Anti-Chalkedonensiern auf Basis christologischer Kompromißformeln ab und begann eine Repressionspolitik gegen die Monophysiten. Als schließlich im Zuge des 572 wieder ausgebrochenen Perserkrieges vorübergehend beinahe die gesamte monophysitische Bevölkerung im Osten des Reichs unter sassanidische Herrschaft geriet, entfiel für das Kaisertum zudem auf Jahrzehnte die Notwendigkeit zum religionspolitischen Spagat zwischen der chalkedonensischen Westkirche und den Monophysiten.

Die christologischen Streitfragen, die in der Vergangenheit so oft zum Konflikt zwischen Päpsten und dem Kaisertum über die Führung der Reichskirche geführt hatten, ruhten somit seit dem V. Ökumenischen Konzil von 553 und sollten erst in den 630er Jahren nach der erfolgreichen Rückgewinnung der persischen Eroberungen wieder aufkommen. Rom und seine Kirche hatten diese Ruhephase dringend nötig: Papst Pelagius I., der sich 555 angesichts der ihm in Aussicht gestellten Papstwürde opportunistisch vom vehementen Kritiker zum treuen Verfechter der umstrittenen Religionspolitik Justinians gewandelt hatte, stieß in weiten Teilen Italiens und darüber hinaus auf offene Ablehnung. In Rom selbst mußte der Statthalter Narses Pelagius' Weihe gegen Widerstände im Klerus absichern ${ }^{104}$. Große Teile des norditalienischen Klerus - so die Kirchen

101 IP 5 S. 2 Nr. 1 bzw. S. 3 Nr. 3, 5, 6 und 9.

102 Beck: Kirche (wie Anm. 25) S. 36 f.

103 Überliefert bei Evagrios Scholasticus: Hist. eccl. (wie Anm. 8) Bd. 2 S. 556-564 lib. V cap. 4.

104 Richards: Popes (wie Anm. 13) S. 158 f.; Mainka: Pelagius I. (wie Anm. 94) S. 9092. 
von Mailand und Aquileia - kündigten Rom die Gemeinschaft auf; das „DreiKapitel-Schisma" sollte, seit 568 politisch verfestigt durch den Langobardeneinfall, die italienische Kirche bis Ende des 7. Jahrhunderts spalten ${ }^{105}$. Und auch außerhalb Italiens, in Spanien, Afrika und Gallien, hatten die Vigilius-Katastrophe und die zweifelhaft gewordene Reputation des Pelagius die Autorität des Papsttums schwer erschüttert. Wichtigste Aufgabe Pelagius' I. war es daher, das verlorene Ansehen des apostolischen Stuhls im Westen Stück um Stück zurück zu gewinnen ${ }^{106}$. Nur langsam konnte er dabei gewisse Erfolge verzeichnen, die ein erneutes Aufbrechen religionspolitischer Konflikte ${ }^{107}$ wohl kaum überdauert hätten.

Trotz der über lange Phasen nur noch sporadischen direkten Kontaktaufnahmen Roms mit dem Kaiserhof in Byzanz ist die zweite Hälfte des 6. Jahrhunderts keineswegs als eine Phase der bewußten Abkehr des Papsttums vom Imperium und der Reichskirche zu bezeichnen. Das Bewußtsein einer Zugehörigkeit zum Römischen Reich, einer Identität von Romanitas und Christianitas, bestimmte die päpstliche Politik dieser Jahrzehnte ${ }^{108}$. Deutlich spricht dies z. B. aus Briefen Pelagius' I. und Pelagius' II. an fränkische Empfänger: Beide Päpste entwarfen in ihren Schreiben ${ }^{109}$ herrschaftstheoretische Modelle zur Integration des merowingischen Königtums in den universalen Rahmen des christlichen Imperiums ${ }^{110}$. Und auch Gregor der Große definierte sich und sein päpstliches Amt letztlich unbeirrbar über sein Römertum, das ihn fest mit dem christlichen Imperium und seiner Reichskirche verband ${ }^{111}$. Der Bezugsrahmen

105 Claire Sotinel: The Three Chapters and the Transformation of Italy, in: The Crisis of the Oikoumene (wie Anm. 81) S. 85-120; Claudio Azzara: Il regno longobardo in Italia e i Tre Capitoli, in: ebd. S. 209-222; siehe auch Schieffer: Beurteilung (wie Anm. 80).

106 Michele Maccarrone: „Fundamentum Apostolicarum Sedium“, in: Ders.: Romana Ecclesia Cathedra Petri (wie Anm. 17) S. 357-431, hier v.a. S. 362-371; Mainka: Pelagius I. (wie Anm. 94) S. 90-112.

107 Sotinel: Emperors and Popes (wie Anm. 16) S. 285, erklärt so das Fehlen jeglicher direkter Kontaktaufnahme Pelagius' mit den Kaiserhof in Konstantinopel: Eine zu enge Anbindung an den Kaiser, dessen Religionspolitik Stein des Anstoßes war, verbot sich aus taktischen Gründen. Zu dieser Argumentation paßt jedoch schlecht die enge Kooperation, die Pelagius auf inneritalienischer Ebene mit Justinians Bevollmächtigtem Narses sowie dem dezidiert der Drei-Kapitel-Politik des Kaisers anhängenden Prälaten von Ravenna pflegte, vgl. Richards: Popes (wie Anm. 13) S. 154-161.

108 Ebd. S. 165 f.

109 Pelagii I epist. (wie Anm. 100) Nr. 3, und 6-8 (an König Childebert I.) sowie MGH Epp. 3/1 (wie Anm. 5) Nr. 9 (an Bischof Aunacharius von Auxerre).

110 Vgl. dazu ausführlich Claudio Azzara: „Pater vester, clementissimus imperator“, in: Studi Medievali, Ser. 336 (1995) S. 303-320, hier v. a. S. 311-313, 316-319.

111 Claude Dagens: San Gregorio Magno tra Oriente e Occidente, in: Communio (Milano) 144 (1995) S. 42-49, hier v.a. S. 45-47; Charles Pietri/Luce Pietri: Église universelle et „Respublica christiana“ selon Grégoire le Grand, in: Memoriam sanctorum 
von Reich und Reichskirche bestimmte so auch in der zweiten Hälfte des 6. Jahrhunderts das politische Handeln der Päpste. Vor diesem Hintergrund sind die vereinzelten Fälle direkter Kontaktaufnahmen mit byzantinischen Korrespondenzpartnern zu sehen: Unverrückbare Leitlinie der päpstlichen Politik blieb weiterhin die Bekämpfung aller Herausforderungen der apostolischen Suprematie innerhalb der einen Reichskirche. Auch wenn die römischen Primatsansprüche unter den krisenhaften Zeitumständen nicht mehr in programmatisch-theoretischer Form propagiert wurden, ergab sich doch aus päpstlicher Sicht mehrfach die Notwendigkeit statussichernder Intervention in Konstantinopel: Bereits 588 protestierte so Pelagius II. gegen den dem Konstantinopolitaner Metropoliten beigelegten Titel eines „Ökumenischen Patriarchen"; vor allem aber sein Nachfolger Gregor I. kämpfte vehement gegen diese scheinbare Statuserhöhung des byzantinischen Amtsbruders, aus der leicht - so die römischen Befürchtungen - jurisdiktionelle Vorrechte gegenüber anderen Kirchen abgeleitet werden konnten ${ }^{112}$. Seinen Apokrisiar in Konstantinopel wies Gregor an, dem Patriarchen die eucharistische Gemeinschaft zu verweigern, bis dieser auf den provokanten Titel verzichte ${ }^{113}$. Und als seit 594 die römische Jurisdiktionsgewalt über das dalmatinische Bistum Salona nicht zuletzt angesichts kaiserlicher Einmischung auf dem Spiele stand, erklärte Gregor pathetisch, er sei eher bereit zu sterben, als eine Minderung der Rechte des Heiligen Petrus hinzunehmen ${ }^{114}$.

Die kirchliche Politik verwies die Päpste also weiterhin auf den Rahmen des Imperiums. Die politische und militärische Wirklichkeit freilich sah anders aus: Angesichts der Bedrohungen an den Nord- und Ostgrenzen des Reichs, die seit 572 beinahe alle Ressourcen des Imperiums banden, rückten Italien und damit auch das Papsttum zwischenzeitlich faktisch aus dem Blickfeld der Kaiser - sehr zum Nachteil der römischen Kirche, die sich ihrerseits seit 568 mit der langobardischen Bedrohung konfrontiert sah. 577/78 und 580 suchten päpstlich-

venerantes. Miscellanea in onore di Monsignore Victor Saxer, Vatikanstadt 1992 (Studi di Antichità 48), S. 647-665, hier S. 653 f.; Eugen Heinrich Fischer: Gregor der Große und Byzanz, in: ZRGKanAbt 36 (1950) S. 15-144, hier v.a. S. 129-131, 134137. Selbst in theologisch-liturgischen Streitfragen nahm Gregor keine grundsätzlich anti-byzantinische Haltung ein, wohl aber eine anti-konstantinopolitanische, vgl. Lellia Cracco Ruggini: Grégoire le Grande et le monde byzantin, in: Grégoire Le Grand. Colloques internationaux du C.R.N.S. 612, Chantilly 15-19 septembre 1982, hg.v. Jacques Fontaine/Robert Gillet/Stan Pellistrandi, Paris 1986, S. 83-94, hier v.a. S. $86-88$.

112 André Tuilien: Grégoire le Grande et le titre de Patriarche Ecuménique, in: Grégoire Le Grand (wie Anm. 111) S. 69-82; Magr: Sede Romana (wie Anm. 48) S. 164, $173-$ 179.

113 Gregorii I papae Registrum epistularum, ed. Paul Ewald/Ludwig Hartmann, Berlin 1891 (MGH Epp. 1), epp. V, 44 und V, 45

114 Ebd. S. 286, ep. V/6: ... ego ..., qui ante paratior sum mori, quam beati Petri ecclesiam meis diebus degenerari. 
stadtrömische Gesandtschaften in Konstantinopel um Militärhilfe gegen die Invasoren, die 579 erstmals Rom belagerten, nach - vergeblich: Obwohl die Delegation beträchtliche Summen zur Finanzierung eines Truppenkontingents mitführte, konnte Kaiser Tiberius mangels eigener Soldaten den Römern nur raten, das Geld entweder zur Bestechung der langobardischen Feinde oder zur Anwerbung z. B. fränkischer Hilfstruppen zu benützen ${ }^{115}$. Angesichts solcher Unfähigkeit des Imperiums, in Italien seine Aufgabe als militärische Schutzmacht aber auch verschiedene Funktionen in der Zivilverwaltung effektiv zu erfüllen, wuchsen nun die Päpste zunehmend in öffentliche Funktionen hinein, die ursprünglich zum Aufgaben- und Kompetenzbereich der Kaiserherrschaft zählten. Bereits unter Pelagius II. waren dies sozialkaritative Funktionen z. B. in der Lebensmittelversorgung der römischen Bevölkerung gewesen, vor allem unter Gregor dem Großen übernahm das Papsttum aber zunehmend auch administrative, außenpolitisch-diplomatische, ja sogar militärische Aufgaben. Gregors Pontifikat von 590 bis 604, der durch das erhaltene Briefregister so reich dokumentiert ist wie kaum ein zweiter im Frühmittelalter, markiert damit einen wichtigen Meilenstein in der langsamen Lösung Roms aus seinem byzantinischen Bezugsrahmen: Von Gregor wohl so nicht angestrebt, wurde der römische Bischof angesichts pragmatischer Notwendigkeiten immer deutlicher zum eigentlichen Repräsentanten Roms und weiter Teile der Provinz Italien.

Die Beziehungen der Päpste zum byzantinischen Kaiserhof im 6. Jahrhundert weisen zwei Phasen auf: Während die erste Hälfte des Jahrhunderts vor allem geprägt war von einer programmatischen Artikulation päpstlicher Primatsansprüche und daraus resultierender Auseinandersetzungen, erlebte die zweite Hälfte den Auftakt einer eher notgedrungen denn aktiv verfolgten Verselbständigung der päpstlichen Kirche Roms als italische Führungsinstanz.

Vor allem die erste Hälfte des 6. Jahrhunderts stand dabei im Zeichen des Erbes von Chalkedon: Die Notwendigkeit zur Konkretisierung und Erläuterung der noch undeutlich gebliebenen chalkedonensischen Christologie zwang die byzantinischen Kaiser zu immer neuen religionspolitischen Initiativen, die mit tragischer Regelmäßigkeit auf den Widerstand der römischen Kirche stoßen mußten. Rom konnte Modifikationen des chalkedonensischen Symbolon schwerlich tolerieren, da mit Chalkedon die auf unverbrüchliche Orthodoxie gegründeten Primatsansprüche der Papstkirche standen und fielen. Zudem war Rom nicht bereit, sich dem Konstantinischen Kirchenbild einer von einem priesterlichen Kaiser geführten hierarchischen Kirche zu fügen. Einem solchen Anspruch hielten die römischen Bischöfe - nicht zuletzt auch in Abgrenzung zu Ansprüchen des konstantinopolitanischen Patriarchats - den Petrinischen Pri-

115 Falkenhausen: Esarcato (wie Anm. 98) S. 12; Bavant: Duché byzantin (wie Anm. 99) S. $47 \mathrm{f}$. 
mat entgegen. Die Möglichkeiten beider Seiten, ihre Positionen zur Geltung zu bringen, variierten stark mit den sich wandelnden politischen Rahmenbedingungen. Die langen Jahrzehnte des Akakianischen Schismas bis 519 erlaubten Rom in einer formativen Phase, das Selbstbewußtsein als Hort der Orthodoxie sogar - und gerade! - gegen einen häretischen Kaiser auszubilden. Die Kompromißlosigkeit, mit der Rom das Chalkedonensische Symbolon und seine damit verknüpften Primatsansprüche verteidigte, wäre aber im direkten $\mathrm{Zu}$ griffsbereich des Kaisertums nicht durchzuhalten gewesen. Erst der politische Freiraum zwischen Ostgotenreich und Imperium eröffnete dem Papsttum für ein gutes halbes Jahrhundert diese Möglichkeiten. Die Inkompatibilität päpstlicher und kaiserlicher Vorstellungen von Ekklesiologie und Kirchenunion zeigten sich bereits nach der Überwindung des Akakianischen Schismas deutlich und als Rom schließlich im Zuge der justinian'schen Restaurationen 535 wieder ins Reichsgefüge integriert wurde, mußte es zwangsläufig zur Konfrontation beider Reichskirchenmodelle und ihrer Repräsentanten kommen. Blickt man auf das Schicksal des Vigilius scheint auf den ersten Blick in dieser Auseinandersetzung der ,Caesaropapismus' eines Justinian den Sieg davon getragen zu haben. In der Tat sehen wir die Päpste seit der zweiten Hälfte des 6. Jahrhunderts in fester formeller Abhängigkeit vom byzantinischen Kaisertum. Freilich, die notgedrungene Übernahme immer weiter gefaßter Aufgabenbereiche des von Kriegen und Krisen überforderten byzantinischen Staatsapparates durch die Päpste leitete bald einen langsamen Wandlungsprozeß der römischen Kirche ein, der das Papsttum immer mehr aus dieser Abhängigkeit von orientalisch-byzantinischen Bezügen lösen und langfristig in neue, europäische Konstellationen hineinführen sollte.

\section{Riassunto}

I rapporti tra i papi e la corte imperiale bizantina durante il VI secolo si suddividono in due fasi: mentre la prima metà del secolo era caratterizzata soprattutto dall'articolazione programmatica delle rivendicazioni circa il primato pontificio, e dai conflitti che ne risultavano, iniziava nella seconda metà un processo, più subìto che alimentato attivamente, nel cui corso la Chiesa romana si sarebbe configurata come istanza di guida sulla Penisola.

Soprattutto la prima fase era segnata dall'eredità di Calcedonia: la necessità di concretizzare e spiegare la cristologia, rimasta ancora sfumata durante quel concilio, costringeva gli imperatori bizantini a sviluppare sempre nuove iniziative di politica religiosa che con tragica regolarità incontravano la resistenza della Chiesa romana. Difficilmente Roma avrebbe potuto tollerare delle modificazioni al simbolo di Calcedonia, dal quale derivavano le rivendicazioni del primato della chiesa papale, basate sull'ortodossia assoluta. Roma inoltre non era 
disposto ad accettare la concezione costantiniana di una chiesa gerarchica guidata da un imperatore sacerdotale. A una tale concezione i vescovi romani contrapponevano - non ultimo per respingere le richieste del patriarchato di Constantinopoli - il primato petriniano. Le possibilità di tutt'e due le parti per far valere la loro rispettiva posizione variavano fortemente secondo le condizioni politiche di fondo in continuo cambiamento. I lunghi decenni dello scisma acaciano, durato fino al 519, permisero a Roma nel corso di una fase formativa di sviluppare la consapevolezza di essere la fortezza dell'ortodossia anche - e addirittura! - contro un imperatore eretico. La risolutezza, con la quale Roma difendeva il simbolo di Calcedonia e la rivendicazione del primato ad esso collegata, non sarebbe però stata sostenibile all'interno dell'area direttamente controllata dall'Impero. Solo lo spazio politico creatosi tra il Regno degli Ostrogoti e l'Impero aprì al Papato per un buon mezzo secolo questa strada. L'incompatibilità tra le concezioni imperiali e quelle papali circa l'ecclesiologia e l'unione della chiesa si manifestò chiaramente già dopo la fine dello scisma acaciano; quando poi Roma con le restaurazioni giustiniane del 535 venne reintegrata nell'assetto dell'Impero, si arrivò inevitabilmente allo scontro tra $\mathrm{i}$ due modelli di chiesa imperiale e dei loro rappresentanti. Considerando il destino di Vigilio, sembra a prima vista che sia stato il 'cesaropapismo' di un Giustiniano ad avere la meglio in questo conflitto. Effettivamente vediamo i papi in uno stretto rapporto di dipendenza formale dall'Impero bizantino a partire dalla seconda metà del VI secolo. Certo, con l'inevitabile assunzione, da parte dei papi, di funzioni sempre più vaste dell'apparato statale bizantino, oberato da guerre e crisi, iniziò ben presto un lento processo di cambiamento della chiesa romana che avrebbe liberato il papato sempre di più da questi legami orientali-bizantini e inserito, a lungo termine, in nuove costellazioni, cioè quelle europee. 


\title{
Le influenze bizantine nei secoli IX e X tra Campania e Lazio Qualche aspetto
}

\author{
Guglielmo Cavallo
}

Individuare e stabilire quali furono nei secoli IX e X le influenze della civiltà bizantina nell'Italia centro-meridionale in generale, e soprattutto di quale intensità esse furono e in quali modi esse si manifestarono è tema arduo e complesso. Da una parte, infatti, si tratta di un'area nella quale l'eredità grecoromana dell'ultima antichità giocò un peso notevole, e dove perciò non sempre è possibile distinguere tra persistenze locali di antica tradizione e più recenti apporti dall'Oriente bizantino, e d'altra parte, nell'Italia centrale e meridionale territorio peraltro dal variegato quadro geostorico, politico-istituzionale e religioso - la stessa civiltà di Bisanzio non si irradiò da un solo polo, Costantinopoli, ma anche da aree provinciali con le loro specificità, e le influenze furono altresì di indole diversa nel tempo e nei vari ambiti, giungendo per vie e veicoli vari ${ }^{1}$. Va chiarito, altresì, che il concetto di influenza qui non sarà trattato sotto l'aspetto generale dell'Histoire et culture dans l'Italie byzantine $^{2}$, ma sarà inteso nel senso della ricezione della civiltà di Bisanzio, latamente considerata, in contesti fondamentalmente latini e limitatamente alla Campania e al Lazio nei secoli IX e X. Di questa ricezione, peraltro, nei limiti di tempo qui consentiti, non potranno che essere discussi solo alcuni aspetti.

L'impressione più immediata che emerge e che si vuole qui verificare è quella dell'affievolirsi - lungo una linea di demarcazione segnata dal tardo secolo VIII almeno per Roma - di influenze bizantine rispetto al periodo precedente. Nonostante l'elemento greco-orientale fosse rimasto piuttosto numeroso in centri come Napoli e la stessa Roma e si fosse insediato nell'Italia meridionale non solo bizantina, ma anche longobarda, e nonostante vi fosse una continuità di compresenze e incontri etnici tra Greci e Latini e di relazioni con Bisanzio a vari livelli, non sembra tuttavia che nei secoli IX e X la ,grecità abbia

1 Mi limito a rinviare alla lezione spoletina, ormai classica, di Agostino Pertusi: Bisanzio e l'irradiazione della sua civiltà in Occidente nell'alto medioevo, in Centri e vie di irradiazione della civiltà nell'alto medioevo, Spoleto 1964 (Sett. cent. it. 11), pp. 75-133.

2 Il riferimento è al volume: Histoire et culture dans l'Italie byzantine, a cura di André Jacob/Jean-Marie Martin/Ghislaine Noyé, Roma 2006 (Collection de L'École Française de Rome 363), cui si rimanda per le molteplici proiezioni di Bisanzio nell'Italia centrale e meridionale greca. 
giocato un ruolo significativo nella compagine latina in termini di ricezione da parte di quest'ultima.

Si possono prendere le mosse dalla conoscenza della lingua greca e dalle traduzioni dal greco. Ove si eccettuino etnie e individui di stirpe greco-orientale o italo-greca, nei secoli IX e X la conoscenza della lingua greca negli ambienti latini risulta inesistente o assai limitata. $\mathrm{E}$ anche in quest'ultimo caso è da chiedersi: quale conoscenza? A quali livelli? Non è lecito, infatti, parlare per quest'epoca genericamente e semplicemente di ,lingua greca'. Già da lungo tempo - conseguenza della diglossia, vale a dire dell'antica separazione linguistica tra stile attico e koinè - esistevano diverse varietà di greco come mezzo di comunicazione scritta e orale. In tutta l'Italia di cultura latina la conoscenza della lingua greca alta rimase ovviamente del tutto ignorata; né sono testimoniati, del resto, strumenti linguistici adeguati per apprendere la stessa lingua greca. Una ricerca su grammatiche e dizionari greci nell'Europa carolingia ne ritrova l'uso, peraltro modesto, al di là delle $\mathrm{Alpi}^{3}$. Al Lazio, e forse a Roma, sembra potersi attribuire solo il codice di Londra, British Library, Harley 5792, riferibile all'inizio del secolo IX e contenente un glossario greco-latino, quello impropriamente detto "glossario dello pseudo-Cirillo» ${ }^{4}$, ed è di speciale interesse osservare che tracce sicure di questo glossario si trovano comunque tra quel secolo e il successivo nella traduzione in latino, fatta a Roma, del dossier agiografico dei santi edesseni Gurias, Samonas e Abibos 5 . In questa prospettiva di carenza di grammatiche e lessici adeguati sono da valutare perciò certe conoscenze della lingua greca che si dimostrano attestate tra Campania e Lazio.

Si prenda Napoli e la sua cerchia ducale tra la seconda metà del secolo IX e i primi due terzi del X. Dal duca Sergio I ai suoi figli Gregorio III, Atanasio e Stefano, fino a suo nipote Atanasio II e più tardi al lociservator Gregorio e al duca Giovanni III, tutti si possono ritenere - e alcuni sono esplicitamente detti - istruiti nella lingua greca non meno che nella latina ${ }^{6}$. I più commissionano

3 Carlotta Dionisottr: Greek Grammars and Dictionaries in Carolingian Europe, in: The Sacred Nectar of the Greeks: The Study of Greek in the West in the Early Middle Ages, a cura di Michael W. Herren/Shirley Ann Brown, London 1988 (King's College London Mediaeval Studies), pp. 1-56.

4 Si vedano Emma Condello: Una scrittura e un territorio. L'onciale dei secoli V-VIII nell'Italia meridionale, Spoleto 1994 (Biblioteca di Medioevo Latino 12), pp. 100 sg., e Paolo Radiciottri: Manoscritti digrafici grecolatini e latinogreci nell'alto medioevo, in: RHMitt 40 (1998) pp. 91-94.

5 Paolo Chiesa: Il dossier agiografico latino dei santi Gurias, Samonas e Abibos, in: Aevum 65 (1991) pp. 229-232.

6 Mi limito a rimandare a Vera von Falkenhausen: La Campania tra Goti e Bizantini, in: Storia e civiltà della Campania, Il Medioevo, a cura di Giovanni Pugliese Carratelli, Napoli 1992, p. 26, e a Jean-Marie Martin: Hellénisme politique, hellénisme religieux

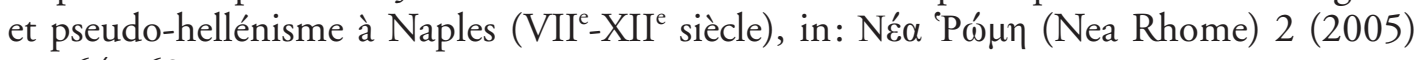
pp. 64-69. 
traduzioni di testi agiografici al circolo di interpreti della cosiddetta „scuola napoletana", e Atanasio II traduce egli stesso la Passio Arethae ${ }^{7}$; ma la lingua greca in cui si dimostrano scritte vite di santi o raccolte di miracoli è solitamente una lingua medio-bassa, talora magari vicina a quella del parlato quotidiano. Queste traduzioni, certo, costituiscono una forma di ricezione della letteratura agiografica bizantina, ma rivelano solo una conoscenza della lingua ad un livello tutt'altro che alto, e in ogni caso si risolvono in una destrutturazione della cultura greca, una sua assimilazione nella cultura dominante, la latina. Né del resto in quest'epoca si trattava sempre di traduzioni vere e proprie, giacché talvolta, in realtà, venivano rielaborate e migliorate traduzioni precedenti, forse del VII e dell'VIII secolo, che risultavano manchevoli o addirittura suscitavano nei lettori o ascoltatori ridiculum potius quam imitationem ${ }^{8}$. Queste riscritture non richiedevano alcuna conoscenza del greco, giacché di sicuro non veniva fatto alcun controllo sui testi greci; ed anzi la vicenda narrata nel greco costituiva più volte „un semplice punto di partenza“ che offriva „il destro al traduttore per una rielaborazione del racconto in direzioni originali“" ( $\mathrm{Si}$ può osservare per inciso, senza peraltro volerne trarre alcuna conseguenza sul piano delle influenze tra Bisanzio e Napoli, che all'incirca nella stessa epoca Simeone Metafrasta a Costantinopoli rielaborava stilisticamente le antiche vite di santi perché scritte in maniera rozza, tanto che, per dirla con Michele Psello, la lettura

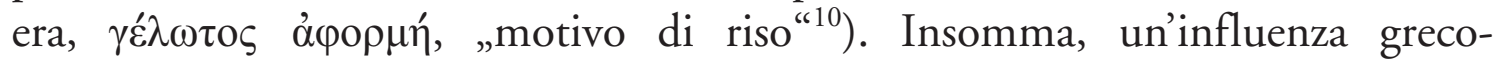
orientale sul santorale napoletano va senz'altro ammessa, come mostra anche il calendario liturgico marmoreo di San Giovanni Maggiore del secolo IX, il quale reca un numero assai alto di santi greci rispetto ai latini ${ }^{11}$, ma questa influenza non implica alcuna autentica conoscenza della lingua greca.

Nell'ambito delle traduzioni dal greco a Napoli va ricordata una testimonianza scarsamente nota anche se ad essa è dedicato un bel contributo di Arsenio Frugoni. La testimonianza conferma ed esplicita il quadro qui tracciato. Si tratta del Prologus della traduzione - eseguita nel secolo X da un arciprete Leone non meglio identificato - del famoso "Romanzo di Alessandro» attribuito allo

7 Si veda soprattutto Paolo Chiesa: Le traduzioni dal greco: l'evoluzione della scuola napoletana nel X secolo, in: Lateinische Kultur im X. Jahrhundert. Akten des I. Internationalen Mittellateinerkongresses (Heidelberg, 12-15.IX.1988), a cura di Walter Berschin, Stuttgart 1991 (=MJb 24/25 [1989-1990]), pp. 67-86; ma riescono utili anche Guglielmo Cavallo: La cultura greca. Itinerari e segni, in: Storia e civiltà della Campania (cit. nota 6), pp. 278-282, e Martin: Hellénisme (cit. nota 6) pp. 64-69.

8 Bonito: «Vita Theodori», in: AASS Febr. 2, Antwerpen 1658, pp. 30sg.

9 Chiesa: Le traduzioni (cit. nota 7) p. 73.

10 Michele Psello: «Encomio per Simeone Metafrasta», in: Michaelis Pselli Orationes hagiographicae, a cura di Elizabeth A. Fischer, Stuttgart/Leipzig 1994, p. 278.

11 Hippolyte Delehaye: Hagiographie napolitaine, in: AnalBoll 57 (1939) pp. 5-64; Domenico Mallardo: Il calendario marmoreo di Napoli, Roma 1947. 
Pseudo-Callistene ${ }^{12}$. In tal Prologus Leone racconta, in terza persona, che egli, dai duchi Giovanni (Giovanni III) e Marino (il giovane figlio di Giovanni) fu inviato con un incarico agli imperatori di Bisanzio Costantino (Costantino VII Porfirogenito) e Romano (Romano II). E qui Leone cepit inquirere libros ad legendum, e tra questi uno ne trovò historiam continentem certamina et victorias Alexandri regis Macedoniae, lo trascrisse e ne portò con se la copia a Napoli rendendone consapevoli i suoi signori. Un giorno il sagacissimus duca Giovanni, ricordando che l'arciprete Leone possedeva il «Romanzo di Alessandro», lo chiamò a sé invitandolo a farne una traduzione de Greco in Latinum. Questo invito ducale si inquadrava in una più vasta attività letteraria e di recupero librario di Giovanni III, il quale, primum, fece raccogliere i libri quos in sua dominatione invenit, nel suo ducato totius Campaniae, e questi renovavit atque meliores effectus (= effecit): il duca dunque volle che tali libri fossero trascritti in nuova veste, ma non prima che vi fossero stati apportati miglioramenti testuali. L'arciprete Leone ci informa anche che si trattava soprattutto di libri sacri. La testimonianza chiarisce molte cose sul modo di procedere dei duchi di Napoli riguardo alle traduzioni: essi verosimilmente recuperavano nel loro ducato totius Campaniae sia modelli greci ivi scritti o giunti in qualche modo, sia libri latini contenenti traduzioni precedenti commissionando, secondo i casi, o traduzioni o rielaborazioni per migliorarne la lingua. Quanto al «Romanzo di Alessandro», testo profano, si trattava in ogni caso di letteratura di consumo, giacché scritto, si sa, in uno stile semplice e colloquiale. La traduzione latina peraltro - più tardi diffusa ampiamente con il titolo «Historia de proeliis» - tradisce la scarsa conoscenza del greco da parte del traduttore ${ }^{13}$, a ulteriore conferma delle competenze linguistiche non più che medio-basse nella Napoli dell'epoca.

Quel che va sottolineato tuttavia è che a Napoli si devono ammettere in quest'epoca pratiche di apprendimento del greco spinte talora - come nel caso dell'entourage ducale e della scuola di traduttori - fino a forme di bilinguismo, magari non perfetto, che peraltro il più delle volte erano limitate alla conoscenza del semplice alfabeto. Si tocca qui un altro fenomeno, spesso ricorrente nelle carte napoletane proprio del IX e del X secolo: la consuetudine da parte di un buon numero di testimoni - un terzo circa del totale attestato - di sottoscrivere gli atti privati in lingua latina ma in caratteri greci ${ }^{14}$. In un caso come quello di

12 L'edizione qui utilizzata è quella di Friedrich Pfister: Der Alexanderroman des Archipresbyter Leo, Heidelberg 1913, pp. 45sg. Sul Prologus si veda Arsenio Frugoni: La biblioteca di Giovanni III duca di Napoli (dal Prologus dell'arciprete Leone al «Romanzo di Alessandro»), in: Annali della Scuola speciale per archivisti e bibliotecari della Università di Roma 9 (1969) pp. 161-171.

13 Chiesa: Le traduzioni (cit. nota 7) p. 82.

14 Sul fenomeno si vedano Francesca Luzzati Laganà: Le firme greche nei documenti del Ducato di Napoli, in: StM, $3^{a}$ ser. 23 (1982) pp. 729-752; Vera von Falkenhausen: A Mediaeval Neapolitan Document, in: The Princeton University Library Chronicle 30 
Napoli, ove il gioco di acculturazioni tra Greci e Latini doveva essere complesso, è difficile risalire dalle firme in caratteri greci alle etnie diverse delle mani agenti. Ma la più parte di quanti sottoscrivevano, a quel che hanno osservato Vera von Falkenhausen e Jean-Marie Martin erano latini, tra cui molti membri della locale gerarchia militare-amministrativa, e non greci; e al di là delle motivazioni sottese al fenomeno - vezzo, emulazione, propensione filo-bizantina, rivendicazione di identità culturale - importa osservare che queste firme indicano solo un'alfabetizzazione greca di base, tanto più ove si trovino adoperate, come sovente, forme maiuscole, le quali mostrano un'istruzione elementare ferma al primo stadio di apprendimento dei segni alfabetici greci, giacché la scrittura minuscola si imparava in una fase successiva. Questi latini, insomma, si

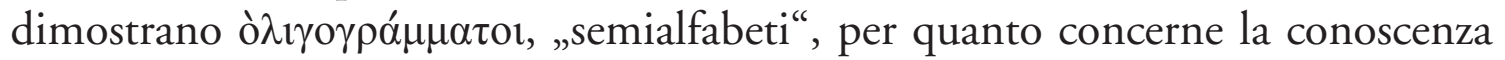
del greco. Può essere di qualche interesse osservare che a Napoli sono testimoniate anche iscrizioni, forse del tardo secolo X, parzialmente in lettere greche ma di lingua latina, quali si conservano su due sarcofagi parietali, posti l'uno sull'altro ed una volta adattati ad altare, nella chiesa di S. Maria a Pugliano ${ }^{15}$.

Da Napoli a Roma. Quanto qui per i secoli IX e X si conoscesse di greco e a quale livello fuori di etnie e insediamenti greci, peraltro perenti a quell'epoca, è difficile dire, ma il vuoto di documentazione - a parte anche qui un certo numero di traduzioni agiografiche dal greco in latino - va interpretato verosimilmente come sostanziale assenza. Si conosce una lettera in greco inviata da papa Pasquale I (817-824) all'imperatore di Bisanzio Leone V (813-820) sul culto delle immagini, ma questa lettera - costruita quasi interamente intessendo citazioni bibliche e qualche ripresa da Giovanni Damasceno dimostra quanto scarsa e pedestre fosse la conoscenza del greco nella cancelleria pontificia $^{16}$. Di lì a poco se ne perderà ogni traccia. Unica luminosa eccezione Anastasio Bibliotecario nella Roma della seconda metà del secolo IX, attivo soprattutto all'epoca dei papi Nicola I, Adriano II e Giovanni VIII ${ }^{17}$. Anastasio traduce testi agiografici, almeno una dozzina di vite di santi, ma anche gli atti

(1968/1969) pp. 171-182, e EAD.: La Campania (cit. nota 6) p. 26; Martin: Hellénisme (cit. nota 6) pp. 73-76.

15 Bartolomeo Capasso: Monumenta ad Neapolitani Ducatus Historiam pertinentia, 2/2, Napoli 1892, pp. 229-232.

16 Thomas F. X. Noble: The Declining Knowledge of Greek in Eight- and Ninth-Century Papal Rome, in: BZ 78 (1985) pp. 56-62.

17 Su Anastasio Bibliotecario e le sue traduzioni dal greco mi limito a rimandare a Girolamo Arnaldi: Anastasio Bibliotecario, in: DBI 3 (1961) pp. 25-37, e a Claudio Leonardi: Anastasio Bibliotecario e l'ottavo concilio ecumenico, in: StM 8 (1967) pp. 59-192, ID.: L'agiografia romana nel secolo IX, in: Hagiographie cultures et sociétés, IV ${ }^{\mathrm{e}}-\mathrm{XII}^{\mathrm{e}}$ siècle. Actes du Colloque organisé à Nanterre et à Paris (2-5 mai 1979), Paris 1981, pp. 471-489, e ID.: Anastasio Bibliotecario e le traduzioni dal greco nella Roma altomedievale, in: The Sacred Nectar (cit. nota 3) pp. 277-296. 
dei concilii ecumenici di Nicea (II, 787) e di Costantinopoli (IV, 869-870), la "Chronographia tripartita di Niceforo», Giorgio Sincello e Teofane Confessore, i cosiddetti «Collectanea», silloge di scritti attinenti al monotelismo quasi tutti dei secoli VII e VIII, e infine alcuni testi teologici. Ma queste traduzioni mostrano solo che a Roma „non si era più in grado, salvo qualche eccezione, di intendere il greco $^{\text {" } 18}$. Le stesse traduzioni di vite di santi, del resto, presentano impianto narrativo, situazioni, quadri mentali e psicologici tante volte lontani da quelli greco-orientali, segno di adattamenti funzionali a esigenze e gusti di chiese locali e di un pubblico diverso ed estraneo rispetto ai destinatari d'origine. Si trattava talora addirittura di retroversioni, come nel caso della passio di s. Dionigi, il cui testo, tradotto da Anastasio e da lui attribuito al patriarca Metodio, altro non era che una versione greca della passio latina composta da Ilduino. È significativa, altresì, l'attenzione dedicata da Anastasio a vite di santi romani quali Acacio e i papi Clemente I e Martino I. In particolare la vita di Martino I è paradigmatica nel mostrare in queste agiografie - ha scritto Claudio Leonardi - „una linea che tende a mettere in rilievo, basandosi sugli stessi testi bizantini, le eresie dei cristiani d'Oriente e i soprusi del potere politico di Costantinopoli, per affermare in ultima istanza, e in opposizione a Bisanzio, l'ortodossia di Roma e la sua autonomia politica “19. È da chiedersi insomma in che limiti si possa parlare di autentiche influenze bizantine, pur ammettendo che attraverso la traduzione di vite di santi l'Italia centro-meridionale fece da intermediaria tra Bisanzio e l'Occidente nel diffondere certe narrazioni di miracoli di immagini. Anastasio Bibliotecario deve essere menzionato anche per la revisione della traduzione fatta da Giovanni Scoto del corpus dello Pseudo-Dionigi l'Areopagita e per la traduzione, che egli stesso fece, degli scholia di Cirillo di Scitopoli e di Massimo il Confessore a tal testo ritrovati in un manoscritto venutogli ad manus nella stessa Roma. Certo, come è stato scritto, dopo la sua scoperta, l',oeuvre du Pseudo-Denys ordonne le monde ${ }^{\text {“20 }}$, ma la sua influenza risulta marcata nella cultura carolingia, mentre meno sembra essersi esercitata nella Roma dei secoli IX e X, nonostante la presenza ne fosse da tempo e saldamente attestata ${ }^{21}$.

18 LeOnARd: Anastasio Bibliotecario e le traduzioni (cit. nota 17) p. 278.

19 ID.: Le traduzioni dal greco nella Roma altomedievale, in: Fatti, patrimoni e uomini intorno all'Abbazia di s. Nilo nel medioevo. Atti del I colloquio internazionale (Grottaferrata, 26-28 Aprile 1985), Grottaferrata 1988, p. 109.

20 Evelyne Patlagean: Les stoudites, l'empereur et Rome: figure byzantine d'un monachisme riformateur, in: Bisanzio, Roma e l'Italia nell'alto medioevo, 1, Spoleto 1988 (Sett. cent. it. 34), p. 434. Si veda anche Jean-Marie SANSTERre: Les moines d'Occident et le monachisme d'Orient du $\mathrm{VI}^{\mathrm{e}}$ au XI $\mathrm{XI}^{\mathrm{e}}$ siècle: entre textes anciens et réalités contemporaines, in: Cristianità d'Occidente e cristianità d'Oriente (secoli VI-XI), 1, Spoleto 2004 (Sett. cent. it. 51), pp. 297sg.

21 Si veda ultimamente Salvatore Lilla: Brief Notes on the Greek Corpus Areopagiticum in Rome during the early middle ages, in: Dionysius 19 (2001) pp. 201-214. 
Si entra, così, in un'altra questione, quella del culto delle immagini, la quale, per quanto qui si dirà, è largamente debitrice ai lavori di Jean-Marie Sansterre ${ }^{22}$. La situazione si presenta fluida e complessa, tanto che lo stesso Sansterre concludeva il suo più ampio intervento sul gioco di influenze ed evoluzioni parallele tra l'Italia e Bisanzio con l'ammissione „ma contribution n'a pas pu répondre à la question “23. Innanzitutto va fatta una distinzione ancora una volta tra VIII e IX secolo: a Roma e più in generale in Italia si fecero sentire i riflessi del primo iconoclasmo, mentre del secondo non si ebbe in sostanza quasi alcuna traccia. Nell'860 Anastasio Bibliotecario, in una lettera all'imperatore Michele III, scritta a nome di papa Nicola I - nel ribattere alle insinuazioni dell'imperatore e del patriarca Fozio circa lo scarso sostegno della Chiesa di Roma al culto delle immagini - costruisce una difesa dottrinale servendosi di materiali del secolo precedente ${ }^{24}$. Ma in ogni caso, ha scritto Sansterre, „les situations romaine et byzantine ne sont pas identiques" ${ }^{\text { } 25}$.

A Roma vi sono, certo, manifestazioni di culto e forme di rappresentazione che richiamano da vicino il funzionamento dell'immagine a Bisanzio: si pensi alla processione dell'Achiropita del Salvatore conservata al Laterano - attestata almeno fino alla metà del secolo IX - la notte precedente la festa dell'Assunta, quando tra un tripudio di lumi, l'immagine, posta accanto ad un'icona della Vergine, veniva esposta alla venerazione di fedeli imploranti ${ }^{26}$, o si pensi ancora, secondo quanto narra Giovanni Immonide verso l'875, all'immagine di Gregorio Magno che era a Sant'Andrea in Clivo Scauri, davanti alla quale la fiammella di un cero talora si accendeva miracolosamente ${ }^{27}$, o si pensi infine all'episodio, sentito a religiosissimis viris e quindi riferito da Liutprando, a detta del quale sanctorum quaedam imagines si inchinarono in San Pietro davanti alle spoglie di papa Formoso - condannato nel processo in presenza del cadavere

22 Jean-Marie SAnsterre: Entre 'koinè méditerranéenne', influences byzantines et particularités locales: le culte des images et ses limites à Rome dans le haut Moyen Âge, in: Europa medievale e mondo bizantino. Contatti effettivi e possibilità di studi comparati. Tavola rotonda del XVIII Congresso del CISH (Montréal, 29 agosto 1995), a cura di Girolamo Arnaldi/Guglielmo Cavallo, Roma 1997 (Nuovi studi storici 40), pp. 109-124, ID.: Attitudes occidentales à l'égad des miracles d'images dans le haut Moyen Âge, in: Annales HSS 53/6 (1998) pp. 1219-1241, e iD.: Entre deux mondes? La vénération des images à Rome et en Italie d'après les textes des $\mathrm{VI}^{\mathrm{e}}-\mathrm{XI}^{\mathrm{e}}$ siècles, in: Roma fra Oriente e Occidente, 2, Spoleto 2002 (Sett. cent. it. 49), pp. 993-1050.

23 SANSTERre: Entre deux mondes? (cit. nota 22) p. 1049.

24 Nicolai I. papae epistolae, ed. Ernst Perels, in: MGH Epp. Karol. 4, Berlin 1925, pp. $436-438$ n. 82.

25 SAnsterre: Entre deux mondes? (cit. nota 22) p. 1006.

26 Michel Andrieu: Les Ordines Romani du Haut Moyen Âge, vol. 5: Les textes (Ordo L), Louvain 1961 (SSL 29), pp. 358-362.

27 Giovanni Diacono: S. Gregori Magni Vita, IV, 85, in: Migne PL 75 col. 231 B. 
dell'897 - per testimoniarne la santità ${ }^{28}$. Né mancano immagini che sanguinano o che cambiano posto nella chiesa cui appartengono. In tutti questi casi di manifestazioni reali o di fatti leggendari è lecito parlare almeno di „une allure byzantine ${ }^{\text {2 } 29}$.

Ma d'altra parte a Roma il culto delle immagini rimase nel complesso un fenomeno più limitato che a Bisanzio, né fu incoraggiato dalla Chiesa, forse perché questa ne temeva una diffusione tale da sfuggire al suo controllo. Vi furono anche altre differenze: la venerazione tributata al crocefisso, che talora opera miracoli - se ne incontra un esempio a Roma nel 921 - non trova riscontro a Bisanzio. E ancora, nonostante nella citata lettera di Nicola I a Michele III si affermi il principio che si debbono venerare le immagini dei santi non meno delle reliquie, in realtà questa equivalenza rimase teorica, giacché a Roma, e più in generale nell'Italia centro-meridionale, le immagini furono relegate in secondo piano rispetto al culto delle reliquie. A Miseno, per esempio, quando nel secolo X si scopre un'immagine musiva di san Sossio, non si esita - a detta del racconto agiografico - a distruggerla sfondando la parete per raggiungere il corpo del santo annunciato dal dipinto ${ }^{30}$. Del resto a Napoli e nell'Italia meridionale un interesse per il culto delle immagini compare non prima del X-XI secolo, forse provocato da immigrazioni di Greci dalla Calabria, mentre prima di quell'epoca manca qualsiasi testimonianza significativa ${ }^{31}$. Ma tra Bisanzio e l'Italia c'è soprattutto una differenza di fondo. A Bisanzio l'immagine ha una giustificazione teologica nel rapporto che lega la figura al prototipo, mentre in Italia, e più in generale in Occidente, questa giustificazione manca, e l'immagine è sostanzialmente ridotta, nel solco del pensiero di Gregorio Magno, a funzione didascalica. In ultima analisi, per quanto concerne il culto delle immagini, la questione delle influenze bizantine tra Campania e Lazio si dimostra, va ribadito, fluida e complessa, e in ogni caso non ne va enfatizzata la portata.

Quando si passi a considerare il monachesimo, non sono da mettere in dubbio né la presenza di monasteri e monaci greci nell'Italia del IX e X secolo né le relazioni che intercorsero, talora anche intense, tra monachesimo greco e monachesimo benedettino, ma che l'orientale lumen avrebbe permeato la

28 Liutprandi Cremonensis Antapodosis, ed. Paolo Chiesa, Turnhout 1998 (CChrCM 156), I, 31, pp. $23 \mathrm{sg}$.

29 SAnsterre: Entre 'koinè méditerranéenne' (cit. n. 22) p. 116.

30 Giovanni Diacono Napoletano: Translatio sancti Sosii, 28, in: AASS Sept. 6, Paris 1867, p. 880 (testo ristampato da Translatio S. Sosii auctore Iohanne Diacono, ed. Georg WAITZ in: MGH SRL, Hannover 1878, pp. 461-462).

31 Jean-Marie Martin: Quelques remarques sur le culte des images en Italie méridionale pendant le haut Moyen Âge, in: Cristianità ed Europa. Miscellanea di studi in onore di Luigi Prosdocimi, a cura di Cesare Alzati, vol. 1/1, Roma/Freiburg/Wien 1994, pp. 223-236. 
magistra latinitas - non solo in Italia ma in tutta l'Europa medievale - fino a penetrare profondamente nella coscienza stessa della cristianità occidentale è tesi di Patricia M. McNulty e Bernard Hamilton che va fortemente ridimensiona$\mathrm{ta}^{32}$. Si prendano proprio i territori longobardo-cassinesi qui considerati, dove nei secoli IX e X coesistevano già da tempo etnie di lingua, tradizioni e rito greco con quelle di lingua e di rito latino, e dove perciò incontro e confronto tra i due monachesimi erano continui e serrati, con presenze di monaci (e monache) greci in monasteri latini e viceversa ${ }^{33}$. Questi contatti culminarono nella visita, storicamente accertata, di san Nilo a Montecassino all'epoca dell'abate Aligerno: narra l'agiografo che „gli venne incontro tutta la comunità dei monaci, anche i sacerdoti e i diaconi, rivestiti degli abiti sacri, come nel giorno festivo, recando in mano ceri e incensieri; e con questa pompa introdussero il beato nel monastero. Sembrava loro di ascoltare e di vedere o il grande Antonio venuto da Alessandria, o meglio, il grande Benedetto, il divino loro legislatore e maestro, resuscitato dai morti “34. Il riferimento ad Antonio, il grande asceta del deserto, indica certo quanto la comunità cassinese rimase colpita e ammirata dalla figura altrettanto ascetica, di san Nilo, dal modello scabro ed eroico di monachesimo antico che egli rappresentava e che era stato a fondamento della istituzione stessa di san Benedetto. Questa ammirazione, infatti, affondava le sue radici in una certa nostalgia dell'antica perfezione, stimolata dalla lettura di traduzioni di vite di santi che si maceravano nel deserto come quella largamente diffusa di santa Maria Egiziaca. Ma l'ammirazione restò soltanto tale, e quel modello di spiritualità non esercitò alcuna influenza sui monaci cassinesi, dediti a

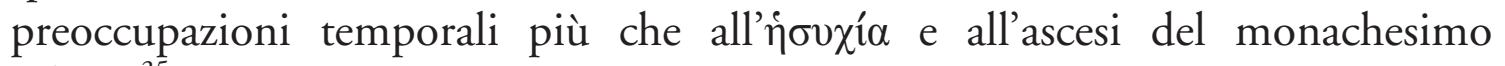
niliano ${ }^{35}$.

32 Patricia M. Mc Nulty/Bernard Hamilton: Orientale lumen et magistra latinitas: Greek Influences on Western Monasticism (900-1100), in: Le Millénaire du Mont Athos. Études et Mélanges, vol. 1, Chevetogne 1963, pp. 181-216, rist. in: Bernard Hamilton: Monastic Reform, Catharism and the Crusades (900-1300), London 1979 (Variorum Reprints. Collected Studies Series 97).

33 Jean-Marie Sansterre: Le monachisme bénédictin et le monachisme italo-grec au $\mathrm{X}^{\mathrm{e}}$ et dans la première moitié du $\mathrm{XI}^{\mathrm{e}}$ siècle: relations et distinctions, in: Il monachesimo italiano dall'età longobarda all'età ottoniana (secc. VIII-X). Atti del Convegno di studi storici sull'Italia benedettina (Nonantola, 10-13 settembre 2003), Cesena 2006, pp. $102-104$.

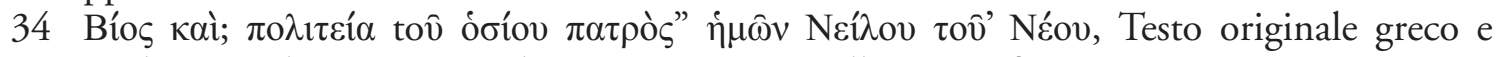
studio introduttivo a cura di Germano Giovanelli, Grottaferrata 1972, p. 112 (cap. 73).

35 Si vedano i lavori di Jean-Marie Sansterre: Saint Nil de Rossano et le monachisme latin, in: Miscellanea di studi in onore di P. Marco Petta, a cura di Augusta Acconcia Longo/Santo Lucì/Lidia Perria, vol. 2, Grottaferrata 1992 (Bollettino della Badia Greca di Grottaferrata n. s. 45 [1991]), pp. 339-386, e iD.: Le monachisme bénédictin (cit. n. 33) pp. 97-118. 
Ma mancarono influenze anche per altri aspetti. L'ubbidienza alla Regola di san Benedetto non ammetteva deroghe ma solo qualche libertà interpretativa ${ }^{36}$ ed era assai lontana dai diversi tipika che monastero per monastero in qualche modo guidavano la vita monastica greca, almeno quando la guidavano, giacché non vanno dimenticate le diffuse forme di idiorritmia. Da un monachesimo greco altalenante tra diversi modelli di vita nella più assoluta libertà e che non conosceva regole di valore generale, nulla potevano recepire le pratiche benedettine. E ancora, la sostanziale stabilità del monachesimo latino ${ }^{37}$ - „il monastero deve essere costruito, se possibile, in modo che ci sia tutto il necessario, ... perché i monaci non siano costretti a girovagare, il che non giova assolutamente alle loro anime“, recita la regola di san Benedetto ${ }^{38}$ - non poteva in alcun modo recepire la tendenza alla forte mobilità o comunque a certe maniere di vita itineranti del monachesimo italo-greco che si dislocava tra Calabria, Lucania, Campania e Lazio. Nessuna influenza, inoltre, si può documentare sotto il profilo culturale: a Montecassino, almeno fino all'inizio del secolo XI, non sono testimoniati monaci di lingua latina che conoscessero il greco, neanche tra i più colti quale un Lorenzo d'Amalfi; né si può provare che vi si trascrissero codici greci; né, ancora, si può documentare alcuna influenza del tipo di codice italo-greco (tecniche librarie, scritture, ordini decorativi) sul tipo di codice cassinese. Manoscritti di opere greche e di scuola niliana, quali l'Ottob. gr. 251 e il Casin. 431, scritti sul tornante tra i secoli X e XI e contenenti letteratura monastica, non furono trascritti nell'abbazia, pur se, a quanto ha dimostrato Enrica Follieri, vi entrarono fin dall'inizio del secolo XI e uno dei due vi si conserva ancora ${ }^{39}$. Ma furono letti da chi? Sembra trattarsi di doni all'abbazia o di acquisizioni al fine di arricchire la biblioteca, ma senza una precisa destinazione a pratiche di lettura. Del resto che solo due codici greci si dimostrino entrati a Montecassino in età antica di fronte alla notevolissima produzione libraria di scuola niliana ${ }^{40}$ è circostanza già di per sé eloquente nel

36 SAnsterre: Le monachisme bénédictin (cit. nota 33) pp. 99sg.

37 Si veda quanto scrive Jean-Marie SANSTERre: Attitudes à l'égard de l'errance monastique en Occident du VI ${ }^{\mathrm{e}}$ au XI siècle, in: Voyages et voyagerurs à Byzance et en Occident du $\mathrm{VI}^{\mathrm{e}}$ au XI $\mathrm{XI}^{\mathrm{e}}$ siècle. Actes du Colloque international organisé par la Section d'Histoire de l'Université libre de Bruxelles en collaboration avec le Departement des Sciences Historiques de l'Université de Liège (5-7 mai 1994), a cura di Alain Dekkers/JeanMarie Sansterre/Jean-Louis Kupper, Genève 2000, pp. 215-234.

38 La règle de saint Benoît, ed. Adalbert de VogüÉ/Jean Neufville, Paris 1972 (SC 182), 66, 6-7, p. 660.

39 Enrica Follieri: Due codici greci già cassinesi oggi alla Biblioteca Vaticana: gli Ottob. gr. 250 e 251, in: Palaeographica, diplomatica et archivistica. Studi in onore di Giulio Battelli, vol. 1, Roma 1979 (Storia e letteratura 139), pp. 159-221.

40 Si vedano almeno i lavori di Santo Lucà: Attività scrittoria e culturale a Rossano: da s. Nilo a s. Bartolomeo da Simeri (secoli X-XII), in: Atti del Congresso internazionale su s. Nilo di Rossano (28 settembre-1 ottobre 1986), Rossano/Grottaferrata 1989, 
testimoniare un sostanziale disinteresse per la cultura greca. Il monachesimo benedettino ignorò del tutto o quasi persino testi greci fondamentali per la formazione del monaco, quali il «Prato spirituale» di Giovanni Mosco, la «Scala del Paradiso» di Giovanni Climaco, le «Catechesi» di Teodoro Studita. Insomma il soggiorno di san Nilo a Montecassino e la sua successiva permanenza insieme al suo seguito nel monastero di San Michele a Vallelucio, una dipendenza cassinese, e più in generale i molti contatti tra i due monachesimi in tutta l'area longobardo-cassinese, nella compagine del monachesimo latino non ebbero che una portata assai limitata su qualsiasi piano: della spiritualità, delle pratiche devozionali, della cultura, degli schemi mentali e dei comportamenti concreti inerenti alla professione monastica. Vi furono solo alcuni individui di quella compagine (il futuro abate di Montecassino Giovanni III, il monaco Liutius) che si sentirono spinti a vivere esperienze della spiritualità greco-orientale soggiornando in luoghi come la Terra Santa, il Sinai, l'Athos ${ }^{41}$.

Qualche cenno sul monachesimo anche a Napoli e a Roma. A Napoli non sembra che nei secoli IX e X monaci e monasteri greci abbiano esercitato una qualche influenza spirituale e culturale sui monaci latini, limitandosi questi a sottoscrivere talora in caratteri greci, più volte peraltro in lingua latina e rozzamente, o a imparare, magari attraverso il solo ascolto, rudimenti del canto liturgico greco. Anzi, molti monasteri non conservavano di greco che solo il nome ${ }^{42}$. Quanto a Roma, si suole invocare il monastero dei Santi Bonifacio e Alessio sull'Aventino - fondato nel 977 da Sergio, metropolita di Damasco fattosi monaco - come „crocevia dell'incontro fra Oriente greco e Occidente latino, fra cristianità mediterranea e cristianità europea" che assolveva "la funzione di ponte fra le diverse culture e anime della chiesa e di centro donde si irradiavano esperienze e modelli culturali e spirituali da un limite all'altro dell'orbe cristiano “43. Ma se è vero che il monastero dei Santi Bonifacio e Alessio godette di visite di Graeci optimi ${ }^{44}$ e di relazioni privilegiate con l'Oriente ${ }^{45}$,

pp. 25-73, e ID.: Scritture e libri della scuola niliana, in: Scritture, libri e testi nelle aree provinciali di Bisanzio. Atti del Seminario di Erice (18-25 settembre 1988), a cura di Guglielmo Cavallo/Giuseppe De Gregorio/Marilena Maniaci, vol. 1, Spoleto 1991 (Biblioteca del Centro per il collegamento degli studi medievali e umanistici nell'Università di Perugia 5), pp. 319-387.

41 Vera von Falkenhausen: Il monachesimo italo-greco e i suoi rapporti con il monachesimo benedettino, in: L'esperienza monastica benedettina e la Puglia. Atti del Convegno di studio organizzato in occasione del XV centenario della nascita di san Benedetto (Bari/Noci/Lecce/Picciano, 6-10 ottobre 1980), a cura di Cosimo Damiano Fonseca, Galatina 1983, pp. 128sg.; Sansterre, Le monachisme bénédictin (cit. nota 33) p. 111.

42 Su tutta la questione si veda Martin: Hellénisme (cit. nota 6) pp. 69-73.

43 Filippo Burgarella: Presenze greche a Roma: aspetti culturali e religiosi, in: Roma fra Oriente e Occidente (cit. nota 22) p. 986. 
giacché ad esso si rivolse Oreste patriarca di Gerusalemme per chiedere disposizioni ecclesiali, sembra comunque doversi escludere che all'interno del monastero convivesse una comunità greca accanto alla latina, ciascuna con la sua osservanza; e d'altra parte è argomento di discussione se il monastero dei Santi Bonifacio e Alessio abbia veramente esercitato una vasta influenza sul monachesimo occidentale trasmettendo modi e pratiche della spiritualità greco-orientale ${ }^{46}$. Anche in questo caso si trattò piuttosto di scelte individuali: si pensi ad Adalberto di Praga, che in quel monastero si umiliò fino a svolgere $\mathrm{i}$ lavori più servili come gli antichi asceti ${ }^{47}$.

E vengo alle conclusioni. Nei secoli IX e X mancano significative influenze di Bisanzio nell'Italia centro-meridionale latina. La stessa Roma si stacca man mano dall'Oriente, con cui non ha più relazioni politiche o religiose di qualche peso. Nonostante presenze greche a diversi livelli e nei diversi quadri della società - presenze talora forti ed estese dalla Sicilia a Roma - e nonostante una produzione di testi, di libri, di documenti, di iscrizioni, di monete, di prodotti artistici greci, non vi fu da parte dei Latini una ricezione della lingua, della cultura, della spiritualità greca più che superficiale o individuale. Alle influenze non certo marcate, che si sono man mano rilevate non è molto quel che si può aggiungere: istituzioni caritatevoli come le diaconie, ispirate a Napoli e a Roma da modelli greco-orientali ${ }^{48}$, o certi usi documentari come la continuità nell'uso del papiro come supporto sempre a Roma, a Napoli e in qualche altro ambito italo-meridionale ${ }^{49}$, o stilemi cancellereschi di ascendenza bizantino-imperiale che si son voluti vedere nella scrittura curiale romana antica della cancelleria pontificia $^{50}$, o a Roma sintomi greci nella scrittura e nella decorazione dei fogli di restauro 55-70 del Vat. lat. 3836, il cosiddetto omiliario di Agimondo, o il tracciato secondo maniere greche della minuscola carolina del codice Düsseldorf

44 Jean-Marie SAnsterre: Le monastère des Saints-Boniface et Alexis sur l'Aventin et l'expansion du christianisme dans le cadre de la "Renovatio Imperii Romanorum» d'Otton III, in: RevBén 100 (1990) pp. 502sg., e ID.: Saint Nil de Rossano (cit. nota 35) pp. 373-380.

45 Burgarella (cit. nota 43) p. 987.

46 Su questi argomenti si veda sempre Sansterre: Saint Nil de Rossano (cit. nota 35) pp. 379sg. e 385sg., e ID.: Le monachisme bénédictin (cit. nota 33) pp. 107-111.

47 Mc Nulty/Hamilton (cit. nota 32) p. 211.

48 Per Roma si veda il classico lavoro di Henry-Irénée Marrou: L'origine orientale des diaconies romaines, in: MAH 57 (1940) pp.95-142, e per Napoli Martin: Hellénisme (cit. nota 6) pp. 60-62.

49 ID: Chartula in tumbo scripta, bolumen chartacium. Le papyrus dans les duchés tyrrhéniens pendant le haut Moyen Âge, in: MEFRM 112 (2000) pp. 183-189.

50 Si veda almeno Jan-Olof T JäDER: Le origini della scrittura curiale romana, in: Bullettino dell'Archivio Paleografico Italiano, $3^{a}$ ser. $2-3$ (1963/1964) pp. 7-54. 
E 1 dell'epoca di Giovanni VIII, o altro del genere ${ }^{51}$. Resta, certo, sullo sfondo, il problema delle influenze bizantine su arte e programmi iconografici di quell'epoca: problema assai indagato e dibattuto. Ultimamente, a questo proposito, i mosaici per la chiesa di San Marco a Roma, commissionati da Gregorio IV (827-844) sono stati considerati, tra l'altro, come difesa della validità delle immagini contro l'iconoclasmo ${ }^{52}$. Ma in fatto di influenze storicoartistiche è da chiedersi più in generale con Hagen Keller: „ist die Rezeption

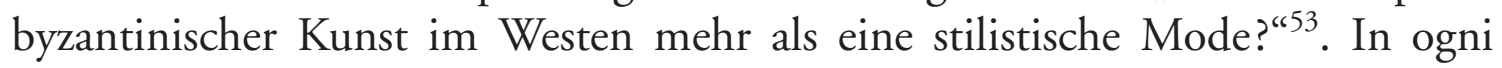
caso argomenti relativi alle arti figurative o agli assetti urbanistici, così come temi di carattere politico, economico, militare, non rientrano nel mio discorso, limitato come questo è ad alcuni aspetti delle influenze bizantine.

Lingua, maniere del sociale, usi, testi e pratiche devozionali, sottigliezze teologiche, ideali monastici, arti, forme grafiche della grecità esercitarono un loro fascino o acquisirono un qualche prestigio nella compagine latina; e sono questo fascino, questo prestigio che spiegano certi fenomeni di cosiddetta ,ellenizzazione', i quali tuttavia non servirono a promuovere né una più esperta conoscenza della lingua greca né una coscienza e un'assunzione dei valori della grecità nell'Italia centro-meridionale. Bisanzio è destrutturata nelle traduzioni in latino, è ridotta a modesto segno grafico nelle sottoscrizioni, è ripresa come civiltà delle immagini svuotata di significati, è proposta come modello spirituale senza alcuna convinta adesione.

Senza nascondersi la complessità e le distinzioni inerenti al problema dell',alterità' tra Greci e Latini, fascino della grecità e vocazioni ,ellenizzanti' si dimostrano per lo più di facciata. La realtà sono invece una diffidenza e un'avversione profonde verso Bisanzio. Anastasio Bibliotecario taccia i Greci di difetti connaturali come la furberia e l'inaffidabilità ${ }^{54}$. In un contesto di contatti continui e intensi come quello tra Campania e Lazio, la cronachistica latinocassinese non è aliena da termini come „superbia“ e "tracotanza“ rivolti ai Greci $^{55}$. Su questa diffidenza, su questa avversione dei Latini nei confronti dei Greci (che trovano del resto riscontro in atteggiamenti analoghi di Bisanzio

51 Guglielmo Cavallo: Interazione tra scrittura greca e scrittura latina a Roma tra VIII e IX secolo, in: Miscellanea codicologica François Masai dicata, a cura di Pierre Cockshaw/Monique-Cécile Garand/Pierre Jodogne, Gand 1979, pp. 23-29; John Osborne: The Use of Painted Initials by Greek and Latin Scriptoria in Carolingian Rome, in: Gesta 29 (1990) pp. 76-85.

52 Claudia Bolgia: The Mosaics of Gregory IV at S. Marco, Rome: Papal Response to Venice, Byzantium and the Carolingians, in: Speculum 81 (2006) pp. 1-34.

53 Hagen Keller: Das ottonische Kirchenreich und Byzanz, in: Cristianità d'Occidente (cit. nota 20) p. 254.

54 Arnaldi (cit. nota 17) p. 26.

55 Chronica Monasterii Casinensis, ed. Hartmut Hoffmann, Hannover 1980 (MGH SS 34), II, 37, p. 237. 
verso il mondo latino) ${ }^{56}$ il discorso si potrebbe allargare, oltre i confini dei territori qui considerati, all'Italia in generale e magari all'Europa, ma sarebbe discorso lungo ${ }^{57}$. Mi sia consentito ricordare solo due testimonianze del secolo $\mathrm{X}^{58}$. Mendax Graecia esclama Raterio di Verona citando Giovenale (Sat. X 174), l'autore antico che si scagliava contro qualsiasi alterità etnica ${ }^{59}$. Ma è soprattutto la lettura di Liutprando di Cremona che si rivela assai istruttiva: Liutprando nella sua prosa $\mathrm{fa}$ dotto sfoggio di termini greci che egli ha imparato a padroneggiare nel corso delle sue ambascerie e dei suoi soggiorni in Oriente e di cui sente il fascino ${ }^{60}$; ma nella sua considerazione i Greci sono „gente ignobile“, „uomini molli, effeminati, menzogneri, di nessun sesso, poltroni“, da loro "promanano tutte le eresie" o tutte le "ciance vuote", il loro basileus veste e mangia in modi indecenti ed è mendace, superbo, avido ${ }^{61}$. E dunque, al di là dell'ammirazione, della superficiale imitazione o delle occasionali incidenze, nella compagine latina emerge un sostanziale rigetto antropologico di Bisanzio.

\section{Zusammenfassung}

Obwohl im 9. und 10. Jahrhundert Einzelne und Gruppen griechisch-orientalischer Herkunft sich sowohl im byzantinischen und auch langobardischen Süditalien als auch in Zentralitalien niederließen, und obwohl sie relativ zahlreich in Zentren wie Neapel und Rom waren, scheint es dennoch nicht so, als ob die byzantinischen Einflüsse auf die lateinische Basis signifikant und ausgeprägt gewesen wären. Die Kenntnis der griechischen Sprache in den lateinischen Milieus erweisen sich als nicht bestehend oder sehr gering: die Übersetzung der Heiligenviten und einiger anderer Texte vom Griechischen ins

56 SAnStERre: Le monachisme bénédictin (cit. n. 33) p. 107.

57 Si vedano almeno il classico Herbert Hunger: Graeculus perfidus - 'I $\tau \alpha \lambda$ òs i $\tau \alpha \mu$ ós. Il senso dell'alterità nei raporti greco-romani ed italo-bizantini, con una introduzione di Otto Kresten, Roma 1987, e ultimamente Chris Wickнam: Ninth Century Byzantium through Western Eyes, in Byzantium in the Ninth Century: Dead or Alive? Papers from the Thirtieth Spring Symposium of Byzantine Studies, Birmingham, March 1996, a cura di Leslie Brubaker, Aldershot/Brookfield/Singapore/Sidney 1998 (Society for the Promotion of Byzantine Studies. Publications, 5), pp. 245-256.

58 Una raccolta di testimonianze di quest'epoca con discussione critica si deve a Michael Rentschler: Griechische Kultur und Byzanz im Urteil westlicher Autoren des 10. Jahrhunderts, in: Saeculum 29 (1978) pp. 324-355.

59 Die Briefe des Bischofs Rather von Verona, ed. Fritz Weigle, Weimar 1949 (MGH Epp. DK 1), p. 30 n. 5.

60 Johannes KODER: Liutprand von Cremona und die griechische Sprache, in: ID./Thomas Weber: Liutprand von Cremona in Konstantinopel, Wien 1980, pp. 17-61.

61 Liutprandi Cremonensis Relatio de legatione Constantinopolitana, 9, 22, 28, 40, 54, ed. Chiesa (cit. nota 28) pp. 191, 196 sg., 199, 204 sg, 211. 
Lateinische in Neapel offenbaren eine spärliche Kenntnis der Originalsprache oder aber Bearbeitungen von lateinischen Übersetzungen, die in der vorhergehenden Epoche gemacht worden sind. In Rom kann richtige Kenntnis der griechischen Sprache allein Anasthasius Bibliothecarius zuerkannt werden; er war als Übersetzer vieler griechischer Texte zur Zeit der Päpste Nikolaus I., Hadrian II. und Johannes VIII. tätig. In Rom blieb auch der Bilderkult - ein Phänomen von großer Bedeutung in den byzantinischen Kultpraktiken beschränkt und wurde vom Papsttum nicht gefördert, vielleicht weil befürchtet wurde, dass eine große Verbreitung stattfinden und die Kirche die Kontrolle darüber verlieren könne. Das Mönchtum betreffend, gibt es sichere Beweise sowohl für die Präsenz von griechischen Klöstern und Mönchen als auch für Beziehungen zwischen dem griechischen und benediktinischen Mönchtum, jedoch fehlen bedeutsame Einflüsse der griechisch-orientalischen Spiritualität auf lateinische Mönche, mit einigen, einzelnen Ausnahmen. Byzanz und seine Kultur übten einen gewissen Einfluss auf das lateinische Element aus, aber diese Faszination war nur eine Äußerliche, während in Wirklichkeit Teile der Lateiner den Griechen Misstrauen und Abneigung entgegenbrachten. Diese verhinderten ein wirkliches Eindringen der byzantinischen Einflüsse zwischen Kampanien und Latium in dieser Epoche. 
Bereitgestellt von | De Gruyter / TCS

Angemeldet | 217.89.40.26

Heruntergeladen am | 21.12.12 10:48 


\section{Rom und die Kirchen Italiens - zwischen Autonomie, Konkurrenz und Anpassung}


Bereitgestellt von | De Gruyter / TCS

Angemeldet | 217.89.40.26

Heruntergeladen am | 21.12.12 10:48 


\title{
Benevent, Magdeburg, Salerno. Das Papsttum und die neuen Erzbistümer in ottonischer Zeit
}

\author{
Wolfgang Huschner
}

Nach der zu Beginn des 12. Jahrhunderts entstandenen altrussischen Chronik, die man dem Mönch Nestor aus dem Kiever Höhlenkloster zuschrieb, hat Großfürst Vladimir von Kiev (980-1015) vier Optionen eingehend prüfen lassen, bevor er sich 988 für den Übertritt von der Gentilreligion zum Christentum nach orthodoxem Ritus entschied. Er soll Gesandte von den griechischen und lateinischen Christen, den Juden und Muslimen empfangen und seinerseits Gesandte zu ihnen geschickt haben, um die Vorzüge und Nachteile der jeweiligen Religion zu ergründen. Byzanz mit seiner Hauptstadt Konstantinopel repräsentierte dabei die griechische Christenheit, das ottonische Reich mit seinem bedeutendsten Erzbistum Mainz die lateinische; der Islam wurde durch die Wolgabulgaren ${ }^{1}$ und das Judentum durch die Chazaren ${ }^{2}$ vertreten. Nachdem die erwünschten Informationen über die vier Glaubensrichtungen eingeholt worden waren, seien die beiden christlichen Varianten in die engere Wahl gekommen. Letztlich habe dann die Schönheit des Gottesdienstes in Konstantinopel den Ausschlag für die Annahme des griechischen Christentums in Kiev gegeben ${ }^{3}$. Das ist natürlich eine literarisch gestaltete Erzählung, welche die Entscheidung Vladimirs für das orthodoxe Christentum aus der Retrospektive auf originelle Weise illustrierte. In der Forschung betrachtet man die Version in der "Nestor-Chronik“ aber nicht als reine Erfindung, sondern als Reflex auf die diplomatischen Beziehungen der Rus' im 10. Jahrhundert ${ }^{4}$. Für

1 István Zimonyi: Wolgabulgaren, in: LexMA 9 (1998) Sp. 315-317.

2 Swetlana Alexandrowna Pletnjowa: Die Chasaren. Mittelalterliches Reich an Don und Wolga, Leipzig 1978, S. 126-130.

3 Povest' vremennych let [Erzählung von den vergangenen Jahren], Teil 1: Text und Übersetzung, hg.v. Dimitrij S. Lichačev/Boris A. Romanov, Moskau/Leningrad 1950, S. 74 f. (im folgenden PVL 1); Die altrussische Nestorchronik Povest' vremennych let, übers. v. Reinhold Trautmann, Leipzig 1931 (Slavisch-baltische Quellen und Forschungen, Heft 6), S. 75-77; Die Nestorchronik, übers. v. Ludolf Müller, München 2001 (Handbuch zur Nestorchronik 4, Forum Slavicum 56), S. 131-134.

4 Simon FrankLin/Jonathan Shepard: The Emergence of Rus 750-1200, London/New York 1996, S. 160; Aleksandr V. Nazarenko: Drevnaja Rus' na meždunarodnych putjach. Meždisciplinarnye očerki kul'turnych, torgovych, političeskich svjazej IX-XII vekov [Die Alte Rus' auf internationalen Wegen. Interdisziplinäre Beiträge zu kulturel- 
das hier zu behandelnde Thema ist relevant, daß man sich beim Übertritt zum Christentum zwischen zwei Richtungen entscheiden mußte. Für die Kiever Rus' schien die Hinwendung zum griechischen Christentum in gewisser Weise vorgezeichnet gewesen zu sein. Seit dem 9. Jahrhundert bestanden politische, kulturelle und wirtschaftliche Beziehungen oder Kontakte zwischen Byzanz und der Rus". Besonders der „Weg von den Warägern zu den Griechen“ führte zur Aufnahme von Handelsbeziehungen, die relativ kontinuierlich existierten, in der Intensität aber schwankten ${ }^{6}$. In der ersten Amtszeit des Patriarchen Photios von Konstantinopel (858-867, 877-886) erfolgten erste Versuche, das griechische Christentum in der Rus' zu verankern, die aber keinen dauerhaften Erfolg hatten ${ }^{7}$. Dennoch existierte in der ersten Hälfte des 10. Jahrhundert eine christliche Gemeinde in Kiev, und im Umkreis des Kiever Fürsten Igor agierten 944 nicht nur Heiden, sondern auch Christen ${ }^{8}$. Nach dem Tode Igors 945 übernahm seine Frau Olga die Regentschaft (945-960/61) für ihren noch unmündigen Sohn Svjatoslav'. Olga wurde zwischen 945 und 957 in Kiev oder in Konstantinopel auf den christlichen Namen Helena getauft ${ }^{10}$. Sie repräsentierte offenbar jenen Teil der Führungsgruppen in der Kiever Rus', welcher die Hinwendung zum Christentum befürwortete. Ihr heranwachsender Sohn Svjatoslav stand hingegen an der Spitze jener Kreise, die das Christentum ablehnten und für die Beibehaltung der Gentilreligion eintraten. Olga und Svjatoslav verfolgten nicht nur in der Kirchen-, sondern auch in der Außen- und Innenpolitik grundsätzlich verschiedene Ziele. Bei diesem Richtungsstreit innerhalb der Führungsgruppen könnte der Status einer künftigen christlichen Kirche in der Kiever Rus' durchaus eine eminente Bedeutung besessen haben ${ }^{11}$.

len, Handels- und politischen Beziehungen 9.-12. Jahrhundert], Moskau 2001, S. $391-$ 434 .

5 Josef Bujnoch: Geschichte und Vorgeschichte der Missionierung Rußlands, in: Millennium Russiae Christianiae. Tausend Jahre Christliches Rußland 988-1988, hg.v. Gerhard Birkfellner, Köln/Weimar/Wien 1993 (Schriften der Bundesrepublik Deutschland zur Förderung der Slawischen Studien 16), S. 25-41, hier S. 27-32.

6 Manfred Hellmann: Die Handelsverträge des 10. Jahrhunderts zwischen Kiev und Byzanz, in: Untersuchungen zu Handel und Verkehr der vor- und frühgeschichtlichen Zeit in Mittel- und Nordeuropa, Teil 4: Der Handel der Karolinger- und Wikingerzeit, hg.v. Klaus Düwel/Herbert Jankunn/Harald Siems/Dieter Timpe, Göttingen 1987, S. 643-666.

7 Hans-Georg Beck: Geschichte der orthodoxen Kirche im byzantinischen Reich, Göttingen 1980 (Die Kirche in ihrer Geschichte 1, Lieferung D 1), S. 129; Bujnoch (wie Anm. 5) S. $32 \mathrm{f}$.

8 PVL 1 (wie Anm. 3) S. 38; Bujnoch (wie Anm. 5) S. 34.

9 Carsten Goenrke: Männer- und Frauenherrschaft im Kiever Fürstenhaus: Olga von Kiev als Regentin (945-960/61), in: FOG 50 (1995) S. 139-154.

10 Der Ort und der Zeitpunkt der Taufe Olgas sind in der Forschung umstritten. Vgl. Goehrke (wie Anm. 9) S. $147 \mathrm{f}$.

11 Ebd. S. 146-149. 
Die Fürstin von Kiev reiste 957 mit einer Gesandtschaft nach Konstantinopel. Dort verhandelte man über Probleme des Handels sowie über die Frage einer eigenständigen Kirchenorganisation für die Kiever Rus' ${ }^{12}$. Das Vorbild für eine solche Forderung Olgas dürfte das bulgarische Reich gewesen sein, das bisher die größte kirchliche Unabhängigkeit erlangt hatte. 870 erstritt sich Bulgarien von Konstantinopel eine eigene erzbischöfliche Kirche. Zar Symeon von Bulgarien (893-927) ging später noch einen Schritt weiter: 926 erklärte er die bulgarische Kirche für unabhängig und erhob den Erzbischof zum Patriarchen ${ }^{13}$.

Fürstin Olga von Kiev bekam 957 in Konstantinopel bezüglich einer eigenen Kirchenorganisation offenbar keine verbindlichen Zusagen ${ }^{14}$. Sie schickte deshalb 959 eine Gesandtschaft an König Otto I. (936-973) und ließ um die Entsendung eines Bischofs und von Priestern nachsuchen ${ }^{15}$. Die Fürstin von Kiev verhielt sich damit ähnlich wie der bulgarische Herrscher Boris (852-889, gest. 907), der ein möglichst hohes Maß an kirchenorganisatorischer Unabhängigkeit für sein Land anstrebte und dafür Konstantinopel und Rom gegeneinander ausspielte. Olga wandte sich allerdings nicht an Rom, sondern an Otto I., den König des Ostfränkischen Reiches ${ }^{16}$. In Byzanz entschied letztlich nicht der Patriarch von Konstantinopel, sondern der Kaiser über neue kirchenorganisatorische Strukturen ${ }^{17}$. Vielleicht wählte Olga (Helena) deshalb den hegemonialen Herrscher im Westen für ihr Anliegen und nicht den Papst in Rom. Möglicherweise spielte auch das allmählich sichtbar werdende Modell der ottonischen Reichskirche eine Rolle ${ }^{18}$. Zudem standen mit Brun von Köln $(953-965)^{19}$ und Wilhelm von Mainz $(954-968)^{20}$ ein Bruder und ein Sohn Ottos I. an der Spitze von zwei bedeutenden Erzbistümern, was als sehr enge personale Verbindung zwischen dem König und den führenden kirchlichen Repräsentanten seines Reiches erscheinen mochte.

12 Ludwig Steindorff: Das Kiever Reich in Europa um das Jahr 1000, in: Der Hoftag in Quedlinburg 973. Von den historischen Wurzeln zum Neuen Europa, hg.v. Andreas RANFT, Berlin 2006, S. 73-83, hier S. $76 \mathrm{f}$.

13 John Julius Norwich: Byzanz. Auf dem Höhepunkt der Macht 800-1071, Düsseldorf u. a. 1994, S. 96-101, 112-114, 119 f., 139 f., 164 f., $184-187$.

14 BECK (wie Anm. 7) S. 130.

15 Reginonis abbatis Prumiensis Chronicon cum continuatione Treverensi, ed. Friedrich Kurze, Hannover 1890 (MGH SS rer. Germ. 50), Continuatio Reginonis ad a. 959 S. 170.

16 BeCK (wie Anm. 7) S. 103-105, 109 f., 113.

17 Ebd. S. 115.

18 Andrzej Poppe: Once Again Concerning the Baptist of Olga, Archontissa of Rus', in: Dumbarton Oaks Papers 46 (1992) S. 271-277, hier S. 276.

19 Josef Fleckenstein: Brun I., Erzbischof von Köln, in: LexMA 2 (1983) Sp. 753-755.

20 Alois Gerlich: Wilhelm, Erzbischof von Mainz (17. Dez. 954-2. März 968), in: LexMA 9 (1998) Sp. 156 f. 
Im ottonischen Reich bestimmte man zuerst einen Mönch des Klosters St. Alban zu Mainz namens Libutius zum Missionsbischof für die Kiever Rus', der aber vor der Abreise verstarb. Auf Empfehlung Erzbischof Wilhelms von Mainz wurde danach der Mönch Adalbert von St. Maximin vor Trier als Missionsbischof ausgewählt. Beide Missionare für die Kiever Rus' kamen demnach aus dem Umkreis des Erzbischofs von Mainz, der an der Spitze der wichtigsten und größten Kirchenprovinz im ostfränkischen Reich stand. Libutius und wohl auch Adalbert wurden aber nicht durch den Mainzer, sondern durch den Erzbischof von Hamburg-Bremen geweiht ${ }^{21}$, der für die Mission und den Aufbau einer Kirchenorganisation in Skandinavien zuständig war. Adalbert von Trier brach im Frühjahr oder Sommer 961 nach Kiev auf und kehrte Ende 962 von dort zurück $^{22}$. Die Missionsreise war nicht erfolgreich verlaufen und deshalb nur von kurzer Dauer.

Adalbert, der die Fortsetzung der Chronik Reginos von Prüm verfaßte, gab als Grund für die gescheiterte Missionsreise an, daß die Bitte der Kiever Gesandten um die Entsendung von Missionaren nicht aufrichtig gewesen $\operatorname{si}^{23}$. In der Forschung favorisierte man deshalb die Auffassung, daß Olga mit ihrem Wunsch nach einem lateinischen Bischof Konstantinopel nur unter Druck setzen wollte. In der jüngeren Forschung wird dagegen ernsthaft in Erwägung gezogen, daß Olga eine Mission von lateinischer Seite als Alternative zur griechischen Kirche anstrebte. Aus der Sicht der Fürstin wären von dem weiter entfernt von Kiev gelegenen ottonischen Reich weniger politische Einflußnahme und größere Zugeständnisse in kirchenorganisatorischer Hinsicht zu erwarten gewesen. Der Mißerfolg Adalberts von Trier sei vor allem damit zu erklären, daß vor dessen Ankunft ein Regierungswechsel in Kiev erfolgt war. Olgas Sohn Svjatoslav hatte inzwischen die Herrschaft übernommen. Sowohl er als auch seine Gefolgschaft lehnten das Christentum ab und traten für die traditionelle Gentilreligion in der Kiever Rus' ein. Letztlich müsse jedoch offen bleiben, ob Olga und die mit ihr verbundenen Führungsgruppen tatsächlich die Anbindung an die lateinische Kirche im Westen anstrebten oder ob die bei Otto I. angeforderten lateinischen Missionare nur als Druckmittel gegenüber Konstantinopel gedacht waren ${ }^{24}$.

21 Continuatio Reginonis (wie Anm. 15) ad a. 960, S. 170: ... Libutius ex coenobitis sancti Albani a venerabili archiepiscopo Adaldago genti Rugorum episcopus ordinatur.

22 Ebd. ad a. 961, 962 S. 170 und 172.

23 Ebd. ad a. 959 S. 170: Legati Helenae reginae Rugorum (...) ficte, ut post claruit, ad regem venientes episcopum et presbyteros eidem genti ordinari petebant; Wilhelm WATTENBACH/ Robert Holtzmann: Deutschlands Geschichtsquellen im Mittelalter. Die Zeit der Sachsen und Salier. Neuausgabe, besorgt v. Franz-Josef Schmale, Teil 1: Das Zeitalter des Ottonischen Staates (900-1050), Weimar 1967, S. 169 f.

24 Mechthild Keller: Konturen: Die Darstellung der Ostslawen in Chroniken und Annalen des 9.-13. Jahrhunderts, in: Russen und Rußland aus deutscher Sicht 
Nach dem Tode seiner Mutter 969 begann Svjatoslav eine aggressive Außenpolitik. 970 eroberte er Bulgarien, wo die Zarenfamilie in seine Gefangenschaft geriet ${ }^{25}$. Der oströmische Kaiser Johannes Tsimiskes (969-976) erkannte die Gefährlichkeit des Kiever Herrschers und handelte sofort. Er besiegte Svjatoslav in Bulgarien. Dieser wurde bei seinem Rückzug in die Kiever Rus' 972 überfallen und getötet ${ }^{26}$. Der byzantinische Kaiser nutzte seinen Sieg über den Kiever Herrscher zu einem harten Vorgehen gegen Bulgarien aus. Er schaffte die eigenständige Kirchenorganisation ab, löste das bulgarische Erzbistum Ochrid auf und ließ alle Bistümer wieder dem Patriarchen von Konstantinopel unterstellen. Außerdem zwang er den amtierenden Zaren zur Abdankung und ließ das Land durch byzantinische Verwaltungsbeamte und Militärs regieren. Bulgarien wurde damit zu einer byzantinischen Provinz ${ }^{27}$. Es wäre deshalb nur zu verständlich, wenn bulgarische Große anschließend das Bündnis mit dem westlichen Kaiser Otto gesucht hätten ${ }^{28}$.

Die Herrscherinnen und Herrscher des 9. und 10. Jahrhunderts in Ostmittel- und Osteuropa interessierten sich in Verbindung mit der Christianisierung vor allem für die Frage, welchen hierarchischen Status die Kirche in ihren Ländern künftig erhalten würde. In dieser Hinsicht hatten sich Konstantinopel und Rom bisher kaum voneinander unterschieden. Beide waren bestrebt, den neuen christlichen Ländern relativ eigenständige Kirchenprovinzen vorzuenthalten und sie möglichst direkt der Jurisdiktion des Patriarchen von Konstantinopel oder jener des Papstes in Rom zu unterstellen. Im ostfränkischen Reich versuchte man, die neuen Christen in Skandinavien und bei den Slaven mit Hilfe von solchen Erzbistümern kirchenorganisatorisch zu erfassen, die an den Grenzen des eigenen Reiches eingerichtet worden waren (HamburgBremen, Salzburg ${ }^{29}$. Diese Varianten kollidierten in der Regel aber mit den Vorstellungen der Führungsgruppen in den ostmittel- und osteuropäischen Ländern.

Bei der folgenden Betrachtung der lateinischen Erzbistumsgründungen in Benevent, Magdeburg und Salerno soll deshalb die Frage im Vordergrund ste-

9.-17. Jahrhundert, hg.v. DEMS., München 1985 (West-östliche Spiegelungen, Reihe A/ 1), S. 57-83, hier S. 63 f.; Goenrke (wie Anm. 9) S. 144, 149 f.; Steindorff (wie Anm. 12) S. 78.

25 Erich Donnert: Das Kiewer Rußland. Kultur und Geistesleben vom 9. bis zum beginnenden 13. Jahrhundert, Leipzig/Jena/Berlin 1983, S. 45-47.

26 Franklin/Shepard (wie Anm. 4) S. 145-150.

27 Ralph-Johannes Lilie: Byzanz. Das zweite Rom, Berlin 2003, S. 244.

28 Nach einer Angabe bei Thietmar von Merseburg, die er aus den „Quedlinburger Annalen“ übernahm, seien zu Ostern 973 auch Legaten der Bulgaren zum Hoftag in Quedlinburg erschienen. Thietmar von Merseburg: Chronicon, ed. Robert HoltzMANN, Berlin 1935 (MGH SS rer. Germ. N.S. 9), lib. II cap. 31 S. 76.

29 Arnold Angenendt: Mission zwischen Ost und West, in: Birkfellner (wie Anm. 5) S. 3-23, hier S. 16. 
hen, welche kirchenorganisatorischen Möglichkeiten der lateinische Westen im letzten Drittel des 10. Jahrhundert aus der Sicht der ostmittel- und osteuropäischen Herrscher zu bieten hatte. In Mähren ${ }^{30}$ und in Ungarn ${ }^{31}$ hatte es in der Vergangenheit wechselnde Hinwendungen zur griechischen oder lateinischen Kirche gegeben. In Böhmen setzten sich zu Beginn des 10. Jahrhunderts die Führungsgruppen, welche Anhänger des lateinischen Christentums waren, gegen jene durch, die das orthodoxe Christentum bevorzugten ${ }^{32}$. Seit etwa 967 könnte zwischen Kaiser, Papst und böhmischem Herzog über die Gründung des Bistums Prag und die eventuelle Einbeziehung Mährens in die Prager Diözese verhandelt worden $\operatorname{sein}^{33}$. Im Herrschaftsbereich der Piasten favorisierte man das lateinische Christentum, das sich dort von Böhmen aus - in Verbindung mit der Eheschließung zwischen Mieszko I. (963-992) und der böhmischen Prinzessin Dobrava - zu verbreiten begann ${ }^{34}$. In der Kiever Rus' war die Frage nach Annahme des Christentums infolge der verstärkten Hinwendung des Fürsten Svjatoslav zur Gentilreligion zunächst wieder offen.

In Italien, wo sich Kaiser Otto I. (936-973) von Ende 966 bis Anfang 972 aufhielt $^{35}$, war es ihm endlich gelungen, den etwa seit 955 verfolgten Plan zur Errichtung einer erzbischöflichen Kirche in Magdeburg zu realisieren. Die Gründung der neuen erzbischöflichen Kirche im Nordosten seines Reiches wäre ohne das langjährige kaiserliche Engagement in Italien sowie ohne die Unterstützung des Papstes und von Geistlichen südalpiner Provenienz nicht möglich gewesen $^{36}$. Da im nordalpinen Reich maßgebliche geistliche und weltliche Große gegen die Gründung einer Magdeburger Metropolitankirche auftraten, sollte sie mit Hilfe des Papstes realisiert werden. Ein dokumentierter Versuch dieser Art erfolgte nach der Kaiserkrönung von 962 in Rom. Otto I. ließ sich von Papst Johannes XII. (955-964) eine Urkunde ausstellen, in der man die Umwandlung des Klosters St. Mauritius zu Magdeburg in eine erzbischöfliche

30 Vladimír VavríneK: Mission in Mähren: Zwischen dem lateinischen Westen und Byzanz, in: Europas Mitte um 1000. Beiträge zur Geschichte, Kunst und Archäologie, 2 Bde., hg. v. Alfried Wieczorek/Hans-Martin Hinz, Darmstadt 2000, 1, S. 304-310.

31 Angenendt (wie Anm. 29) S. 11 f.; Géza Érszegr: Die Christianisierung Ungarns anhand der Quellen, in: Wieczorek/Hinz (wie Anm. 30) 2, S. 600-607, hier S. 606 f.

32 Friedrich Prinz: Böhmen im mittelalterlichen Europa. Frühzeit, Hochmittelalter, Kolonisationsepoche, München 1984, S. 67.

33 RI 2/5 Nr. 426, 512.

34 Roman Micha£owski: Polen und Europa um das Jahr 1000. Mit einem Anhang: Zur Glaubwürdigkeit des Berichts von Gallus Anonymus über das Treffen in Gnesen, in: Ranft (wie Anm. 12) S. 51-72, hier S. $56 \mathrm{f}$.

35 RI 2/1 Nr. 437a-c, 549a.

36 Wolfgang Huschner: Transalpine Kommunikation im Mittelalter. Diplomatische, kulturelle und politische Wechselwirkungen zwischen Italien und dem nordalpinen Reich (9. bis 11. Jahrhundert), Hannover 2003 (MGH Schr. 52/1-3), hier 2, S. 624657. 
Kirche und die des Klosters Merseburg in ein Suffraganbistum anordnete ${ }^{37}$. Die Errichtung einer erzbischöflichen Kirche in Magdeburg wurde in der Papsturkunde von 962 jedoch an den Konsens der fünf anderen Erzbischöfe im nordalpinen Reich gebunden. Darüber hinaus sollte auch für die Weihe der künftigen Suffraganbischöfe Magdeburgs die Zustimmung der fünf Erzbischöfe erforderlich sein. Das lief letztlich auf eine Einschränkung der Magdeburger Metropolitanrechte und einen reduzierten Status des geplanten Magdeburger Erzbistums hinaus ${ }^{38}$.

Als Otto I. im Sommer 966 wieder nach Italien zog, hatte er während des zwanzig Monate währenden Aufenthaltes im nordalpinen Reich ${ }^{39}$ alles in seinen Kräften stehende getan, um die erforderlichen Voraussetzungen für die Gründung eines unabhängigen Erzbistums in Magdeburg zu schaffen. Vor allem war es ihm gelungen, Erzbischof Wilhelm von Mainz, den bisherigen Hauptgegner des Projekts, durch entsprechende Gegenleistungen für die Unterstützung des Magdeburger Vorhabens zu gewinnen ${ }^{40}$. Dennoch dürfte es nach wie vor viele Magdeburg-Gegner gegeben haben ${ }^{41}$. Auf einer Kirchenversammlung im nordalpinen Reich hätte man deshalb auch 966 keinen Konsens über die Gründung eines Magdeburger Erzbistums erzielen können. Deshalb suchte der Kaiser nicht nur die Unterstützung von Papst Johannes XIII. (965-972), sondern auch jene von geistlichen Großen aus Italien. So wurde der Beschluß über die Errichtung einer erzbischöflichen Kirche in Magdeburg auf der Synode von San Severo in Classe im April 967 fast ausschließlich von südalpinen Bischöfen gefaßt $\mathrm{t}^{42}$. Sie betrachteten sich offenbar als zuständig und kompetent für solche Entscheidungen über Metropolitankirchen im nordalpinen Reich. Zudem stand neben der Autorität des Papstes auch jene der Metropoliten von

37 Papsturkunden 896-1046, Bd. 1: 896-996, hg.v. Harald Zimmermann, Wien ${ }^{2} 1988$ (DÖAW, phil.-hist. Kl., Denkschriften 174; Veröffentlichungen der Historischen Kommission 3), Nr. 154.

38 Helmut Beumann: Theutonum nova metropolis. Studien zur Geschichte des Erzbistums Magdeburg in ottonischer Zeit, hg. v. Jutta Krimm-Beumann, Köln/Weimar/Wien 2000 (Quellen und Forschungen zur Geschichte Sachsen-Anhalts 1), S. 170-197, hier S. 183.

39 RI 2/1 Nr. 369a-434.

40 Helmut Beumann: Entschädigungen von Halberstadt und Mainz bei der Gründung des Erzbistums Magdeburg, in: Ex Ipsis Rerum Documentis. Beiträge zur Mediävistik. Festschrift für Harald Zimmermann, hg. v. Klaus Herbers/Hans Henning Kortüм/ Carlo Servatius, Sigmaringen 1991, S. 383-398, hier S. 383 f., 390-398; Ders.: Die Ottonen, Stuttgart/Berlin/Köln ${ }^{3} 1994$ (Urban-Taschenbücher 384), S. 99 f., 103.

41 Gerd Althoff: Die Gründung des Erzbistums Magdeburg, in: Otto der Große, Magdeburg und Europa, 2 Bde., hg.v. Matthias Puhle, Mainz 2001, Bd. 1, S. $344-$ 352, hier S. 348 f.; Johannes Laudage: Otto der Große. (912-973). Eine Biographie, Regensburg 2001, S. 212-214, 222.

42 RI 2/5 Nr. 413 Anm. Als Teilnehmer aus dem nordalpinen Reich sind nur Landward von Minden und Otger von Speyer bekannt. 
Aquileja, Ravenna und Mailand, die an der Spitze vieler ihrer Suffragane an dieser für Italien repräsentativen Kirchenversammlung teilnahmen, hinter den Beschlüssen von Classe. Die Bischöfe aus Italien dokumentierten ihre Zustimmung zur Magdeburger Gründung, indem sie auf der entsprechenden Papsturkunde nach der Subskription von Johannes XIII. und nach dem Signum Kaiser Ottos I. eigenhändig unterschrieben ${ }^{43}$.

Papst Johannes XIII. erwies sich in der Magdeburger Frage nicht nur als kompetenter, sondern auch aktiver Kooperationspartner des Kaisers. Er hatte seine kirchliche Laufbahn bis zur Erhebung zum Bischof von Narni in Rom absolviert und galt als sehr gebildet. Johannes war 965 auf kanonisch korrekte Weise und mit kaiserlicher Zustimmung in sein Amt gelangt. Er wurde von Otto I. unterstützt, agierte aber keineswegs nur als ein Papst von Kaisers Gnaden. So orientierte er sich in der Magdeburger Frage konsequent an kirchenrechtlichen Normen ${ }^{44}$ und vertrat auch spezifisch päpstliche Interessen. Er begrenzte den potentiellen kirchlichen Organisationsraum des neuen Magdeburger Erzbistums - vermutlich mit Rücksicht auf die begonnene Christianisierung im Herrschaftsbereich der Piasten - auf die slawischen Gebiete bis zur $\mathrm{Oder}^{45}$. Außerdem ist die Verbindung zwischen Adalbert, dem ersten Erzbischof von Magdeburg (968-981), und Papst Johannes XIII. sehr aufschlußreich. Adalbert versuchte wohl schon im Herbst 968, die Unterstellung des Klosters Weißenburg im Elsaß, dessen Abt er seit 966 war, unter die neue erzbischöfliche Kirche von Magdeburg zu erreichen. Otto I. stand diesem Anliegen zunächst ablehnend gegenüber, während der Papst es sehr unterstützte. Durch Briefe und Boten soll Johannes XIII. den Kaiser wiederholt ersucht haben, der Übertragung Weißenburgs an Magdeburg zuzustimmen ${ }^{46}$. Sie erfolgte schließlich auch, aber erst nach dem Tode des Papstes 972. Das betreffende kaiserliche Diplom, in dem man die Fürsprache des verstorbenen Papstes eigens erwähnte, enthält eine interessante Begründung für die Schenkung des Klosters Weißenburg an Magdeburg: Das neue Erzbistum befinde sich in einer Region, in der überwiegend noch unvollkommene Christen lebten, während das Kloster Weißenburg in einem Gebiet liege, wo schon wahre und vollkommene Christen an-

43 Zimmermann (wie Anm. 37) S. 348 Nr. 177.

44 In der betreffenden Papsturkunde, die über den Beschluß der Synode von Classe zur Gründung der erzbischöflichen Kirche von Magdeburg informiert, wurde die (noch nicht erfolgte) Zustimmung des Erzbischofs von Mainz und des Bischofs von Halberstadt, die kirchenrechtlich für Magdeburg zuständig waren, zur Bedingung gemacht. Vgl. ebd. Nr. 413.

45 Ebd. S. 375 Nr. 190; Dietrich Claude: Geschichte des Erzbistums Magdeburg bis in das 12. Jahrhundert, 2 Teile, Köln/Wien 1972-1975 (Mitteldeutsche Forschungen 67/ $1-2)$, Teil 1, S. 86-90.

46 RI 2/5 Nr. 453. 
sässig seien ${ }^{47}$. Die Übertragung Weißenburgs sollte also der geistlichen Unterstützung des neuen Magdeburger Erzbistums dienen.

Adalbert war nicht der ursprüngliche kaiserliche Kandidat für die erzbischöfliche Würde, sondern Abt Richar von St. Mauritius zu Magdeburg. Erst nach dem Empfang eines heimlich überbrachten Briefes soll Otto I. seinen Kandidaten fallen gelassen und den Missionsbischof zum ersten Metropoliten von Magdeburg bestimmt haben ${ }^{48}$. Falls es einen solchen Brief gegeben hat, wird sich dessen Absender wohl nie konkret ermitteln lassen. Er müßte allerdings ein großes politisches Gewicht besessen haben, wenn er den Kaiser in einer so wichtigen Angelegenheit umstimmen konnte. Deshalb käme Papst Johannes XIII. durchaus in Betracht. Aus seiner Sicht dürfte kaum jemand besser als Magdeburger Erzbischof geeignet gewesen sein als jener Adalbert, der aus einem Gebiet stammte, in dem schon lange Christen lebten, und der die Landstriche zwischen Magdeburg und der Kiever Rus' bereits aus eigener Anschauung kannte. In der Papsturkunde vom 18. Oktober 968, in der die Verleihung des Palliums an Adalbert dokumentiert wurde, ging man dann auch konkret auf dessen Person ein. So wie einst Papst Zacharias den Bonifatius, der erst zu den Heiden entsandt worden war, später in der Mainzer Kirche inthronisieren ließ, habe nun Johannes XIII. den Missionar Adalbert zum Erzbischof von Magdeburg erhoben ${ }^{49}$. Nicht nur aus päpstlicher, sondern auch aus kaiserlicher Perspektive war Adalbert durch sein früheres Wirken als Missionsbischof in der Kiever Rus' besonders für die Würde eines Magdeburger Erzbischofs geeignet. Seine Berufung konnte den Druck auf den östlichen Kaiser durchaus erhöhen, der gerade mit dem ottonischen Gesandten Liudprand von Cremona über strittige Fragen verhandelte. Der durch die Erhebung Adalberts reaktivierte ottonische Anspruch auf die Kiever Rus' als potentielles Missionsgebiet könnte durchaus die beabsichtigte Wirkung erzielt haben ${ }^{50}$. Otto I. und Johannes XIII. handelten in der Magdeburger Angelegenheit demzufolge auch nach universalen Gesichtspunkten. Aus ihrer Sicht gehörte die Errichtung der Magdeburger Kirchenprovinz wohl in den großen Rahmen der Konkurrenz

47 Die Urkunden Konrad I., Heinrich I. und Otto I., ed. Theodor Sickel, Hannover 1879-1884 (MGH DD regum et imperatorum Germaniae 1), D O. I. 365, S. $501 \mathrm{f}$.

48 Thietmar von Merseburg (wie Anm. 28) lib. II cap. 22 S. 64.

49 Zimmermann (wie Anm. 37) S. 375 Nr. 190. Im Mandat Ottos I. an die Großen Sachsens wird Adalbert ebenfalls ausdrücklich als Missionar der Russen vorgestellt; Urkunden Konrad I., Heinrich I. und Otto I. (wie Anm. 47) D O. I. 366, S. 502 f.: ... virum venerabilem Adalbertum episcopum Rugis olim prędicatorem destinatum et missum archiepiscopum et metropolitanum totius ultra Albiam et Salam Sclavorum gentis modo ad deum converse vel convertende fieri decrevimus...

50 Aleksandr V. Nazarenko: Die Rus' und Deutschland vor 988, in: Le origini e lo sviluppo della christianità slavo-bizantina, a cura di Stanislaw W. Swierkosz-Lenart, Rom 1992 (Nuovi studi storici, 17), S. 19-42, hier S. 32-37. 
zwischen Rom und Konstantinopel bei der Errichtung von Kirchenorganisationen in Ostmittel-, Ost- und Südeuropa. Magdeburg war zudem nur eine von vier neuen Kirchenprovinzen, die innerhalb von vier Jahren an der Peripherie des griechischen und des lateinischen Europa errichtet wurden: 966 gründete man das Erzbistum Capua, 967/968 jenes von Magdeburg, 968 die griechische Kirchenprovinz von Otranto und 969 das Erzbistum von Benevent ${ }^{51}$.

Die Gründung des lateinischen Erzbistums Benevent erfolgte zu jener Zeit, als die Spannungen zwischen dem östlichen und dem neuen westlichen Kaiser ihren Höhepunkt erreicht hatten. Otto I. wünschte sich für seinen 967 zum Mitkaiser gekrönten Sohn Otto II. ${ }^{52}$ eine purpurgeborene byzantinische Prinzessin zur Frau, um die Akzeptanz der westlichen Kaiserwürde durch Ostrom allseits demonstrieren zu können. Als man sich in Konstantinopel gegenüber dem Ansinnen Ottos I. reserviert verhielt, versuchte der westliche Kaiser, sein Ziel durch militärischen Druck zu erreichen und rückte in Apulien ein ${ }^{53}$. Apulien und Lukanien bildeten die Kerngebiete des byzantinischen Themas ,Langobardia'. Dieses Thema war gegen Ende des 9. Jahrhunderts nach mehreren byzantinischen Siegen gegen die Araber in Süditalien errichtet worden. Aus byzantinischer Sicht gehörten dazu auch die Fürstentümer Benevent, Capua und Salerno sowie die Seestädte Amalfi, Neapel und Gaeta ${ }^{54}$. Bei einer vollständigen Realisierung dieses byzantinischen Anspruchs wäre Rom beinahe zu einer Grenzstadt zwischen den Einflußsphären des östlichen und des westlichen Kaiserreiches geworden. Nicht zuletzt deshalb unterstützte die päpstliche Seite den neuen westlichen Kaiser bei dessen Süditalienpolitik. Zudem war die alte Konkurrenz zwischen Rom und Konstantinopel um den Vorrang unter den Patriarchensitzen nach wie vor mitbestimmend für die Gestaltung der päpstlichen Politik ${ }^{55}$. Zu einer Vereinbarung zwischen den beiden Kaisern, die aller Voraussicht nach auf Kosten der päpstlichen Interessen in Süditalien zustande kommen würde, sollte es möglichst nicht kommen. So torpedierte Johannes XIII. mittels eines Briefes, den päpstliche Boten 968 nach Konstantinopel brachten, die laufenden und schwierigen Verhandlungen zwischen dem ottonischen Gesandten Liudprand von Cremona und dem östlichen Kaiser. In dem päpstlichen Schreiben wurde der Basileus gezielt als „Kaiser der Griechen“ und nicht als „Kaiser der Römer" angesprochen, wie man es in Konstantinopel selbstverständlich erwartete. Vielmehr bezeichnete man darin Otto I. als „Kaiser

51 RI 2/5 Nr. 393, 413, 418, 449, 450, 452, 458, 459.

52 RI 2/1 Nr. 463b; RI 2/5 Nr. 433.

53 RI 2/1 Nr. 467, 468a, b.

54 Vera von Falkenhausen: Untersuchungen über die byzantinische Herrschaft in Süditalien vom 9. bis ins 11. Jahrhundert, Wiesbaden 1967 (Schriften zur Geistesgeschichte des östlichen Europa 1), S. 29 f.

55 Axel Bayer: Spaltung der Christenheit. Das sogenannte Morgenländische Schisma von 1054, Köln/Weimar/Wien 2002 (Beih. zum AK 53), S. 9-14, 18-20. 
der Römer“. Nach Darstellung Liudprands habe der päpstliche Brief seine ohnehin wenig aussichtsreiche Verhandlungsposition nochmals erheblich verschlechtert ${ }^{56}$.

Der oströmische Kaiser Nikephoros Phokas (963-969) engagierte sich jedoch nicht persönlich in Süditalien. Unter seinem Kommando hatte man 961 Kreta nach fast 150 Jahren arabischer Besetzung zurückerobert. Einige Jahre später verdrängte Nikephoros die Muslime von der Insel Zypern. Unter seiner Führung gelangte 969 auch die alte Patriarchenhauptstadt Antiochia nach mehr als 330 Jahren wieder in christliche Hand ${ }^{57}$. Deshalb kritisierte Nikephoros gegenüber dem ottonischen Gesandten Liudprand den Angriff Ottos I. auf Apulien als ein Verhalten, das eines christlichen Herrschers, der sich zudem noch den Kaisertitel anmaßte, unwürdig sei. Während er sich um die Befreiung alter christlicher Länder von arabischer Herrschaft bemühe, sei Otto I. in christliche Gebiete eingefallen ${ }^{58}$. Allerdings hatte Otto I. aus der Sicht des östlichen Kaisers den Bogen überspannt, als er sich militärisch in Apulien engagierte. Im Unterschied zu Kalabrien, wo durchgängig eine griechische Kirchenorganisation bestand, existierte in Apulien eine lateinische Kirche, welche die Byzantiner bisher kaum angetastet hatten. Die Bischöfe Apuliens unterstanden in kirchlicher Hinsicht Rom, in weltlichen Belangen Konstantinopel ${ }^{59}$. Trotzdem verschob Nikephoros die persönliche militärische Auseinandersetzung mit Otto I. in Italien ${ }^{60}$ zugunsten eines bereits geplanten Feldzuges nach Syri$\mathrm{en}^{61}$. Zugleich ergriff er aber mehrere Maßnahmen, die seinen Anspruch auf die byzantinische Herrschaft in Süditalien unterstrichen. So sagte er König Adalbert von Italien, der durch Otto I. vertrieben worden war, materielle und militärische Unterstützung gegen den westlichen Kaiser zu. Nikephoros initiierte die Einrichtung einer neuen byzantinischen Verwaltungsorganisation in Italien ${ }^{62}$. Außerdem sorgte der Basileus für eine kirchenorganisatorische Veränderung: er veranlaßte die Erhebung von Otranto im äußersten Südosten des Themas ,Langobardia' zum Haupt einer griechischen Kirchenprovinz. Nach Darstellung Liudprands soll Nikephoros den Patriarchen von Konstantinopel sogar ange-

56 Liudprand von Cremona: Relatio de legatione Constantinopolitana, ed. Paolo CHiEsA, Turnhout 1998 (CC CM 156), cap. 47, 49-51, S. 207-210.

57 Norwich (wie Anm. 13) S. 221-225, $245 \mathrm{f}$.

58 Liudprand von Cremona (wie Anm. 56) cap. 11, 19, 21, 25, 31.

59 Falkenhausen (wie Anm. 54) S. 148-156.

60 Liudprand von Cremona (wie Anm. 56) cap. 27.

61 Georg Ostrogorsky: Geschichte des byzantinischen Staates, München ${ }^{3} 1963$ (Handbuch der Altertumswissenschaft 12/1/2) S. 241.

62 Falkenhausen (wie Anm. 54) S. $48 \mathrm{f}$. 
wiesen haben, den lateinischen Gottesdienst in ganz Apulien und Kalabrien zu untersagen $^{63}$.

Zum Glück für Otto I. kam es nicht mehr zu einer direkten militärischen Konfrontation zwischen ihm und dem byzantinischen Herrscher, denn Nikephoros Phokas wurde Ende 969 ermordet. Der neue oströmische Kaiser Johannes Tzimiskes, ein ebenso guter Heerführer wie Nikephoros, mußte bald andere Prioritäten setzen, weil sich um 969/970 die internationale Lage schlagartig verändert hatte. So stand eine militärische Konfrontation zwischen Byzanz und der Kiever Rus' in Bulgarien unmittelbar bevor. Außerdem mußte Johannes Tzimiskes, der seinen Vorgänger Nikephoros Phokas ermordet hatte, seine Herrschaft auch innenpolitisch stabilisieren. Der Ostkaiser lenkte deshalb gegenüber Otto I. ein und sandte ihm eine kaiserliche Prinzessin für seinen Sohn ${ }^{64}$. Die kirchenpolitische Konkurrenz in Süditalien dürfte indes weiter bestanden haben. So bezeichnete Liudprand von Cremona die fünf Bistümer Acerenza, Tursi, Gravina, Matera und Tricarico, die der Patriarch von Konstantinopel 968 Otranto als Suffragane zugeordnet hatte, als Bistümer unter päpstlicher Oberhoheit ${ }^{65}$. In dieser Frage dürfte der neue Basileus die gleiche Position wie sein Vorgänger eingenommen haben ${ }^{66}$. Wie das kompromißlose Vorgehen von Johannes Tzimiskes gegen die bisher eigenständige bulgarische Kirche zeigt, engagierte er sich militärisch und politisch für die Wahrung der Einflußsphäre des Patriarchats von Konstantinopel.

Die Gründung des lateinischen Erzbistums Benevent 969 könnte eine Reaktion auf die 968 erfolgte Einrichtung der griechischen Kirchenprovinz Ot-

63 Liudprand von Cremona (wie Anm. 56) cap. 62, S. 215: Nicephorus cum omnibus ecclesiis homo sit impius, livore, quo in vos abundat, Constantinopolitano patriarchae praecepit ut Hydrontinam ecclesiam in archiepiscopatus honorem dilatet, nec permittat in omni Apulia seu Calabria Latine amplius, sed Grece divine mysteria celebrare.

64 RI 2/5 Nr. 492; RI 2/2 Nr. 597e; Nikolaus Gussone: Trauung und Krönung. Zur Hochzeit der byzantinischen Prinzessin Theophanu mit Kaiser Otto II., in: Kaiserin Theophanu. Begegnung des Ostens und des Westens um die Wende des ersten Jahrtausends, 2 Bde., hg.v. Anton von Euw/Peter Schreiner, Köln 1991, 2, S. 161-173.

65 Liudprand von Cremona (wie Anm. 56) cap. 62 S. 215: Scripsit itaque Polyeuctos Constantinopolitanus patriarcha privilegium Hydrontino episcopo, quatinus sua auctoritate habeat licentiam episcopos consecrandi in Acirentila, Turcio, Gravina, Maceria, Tricario, qui ad consecrationem domini apostolici pertinere videntur.

66 Wie viele der fünf Bistümer im 10. Jahrhundert aktiv als Suffragane der neuen griechischen Kirchenprovinz Otranto fungierten, ist schwer zu beurteilen. Falls das nur auf das Bistum Tursi zutreffen sollte, wäre die griechische Kirchenprovinz Otranto nur wenig über das Stadium eines Vorhabens hinausgelangt. Die Reduzierung auf nur ein Bistum ist jedoch fraglich. André JaCOB/Jean-Marie Martin: Die griechische Kirche in Italien (650-1050), in: Bischöfe, Mönche und Kaiser (642-1054), hg.v. Gilbert Dagron/ Pierre Riché/André Vauchez. Deutsche Ausgabe bearb. und hg.v. Egon Boshof, Freiburg/Basel/Wien 1994 (Die Geschichte des Christentums 4), S. 366-387, hier S. $375,377$. 
ranto gewesen $\operatorname{sein}^{67}$. Vielleicht war sie aber auch schon längerfristig geplant. Fürst Pandulf Eisenkopf von Capua (961-981) hatte sich dafür entschieden, das traditionelle Lavieren zwischen dem Osten und dem Westen aufzugeben und sich längerfristig mit Otto I. zu verbünden. Dafür belohnte man ihn mit dem Herzogtum Spoleto. Zudem wurde Capua das erste Erzbistum Kampaniens. Außer Capua lenkte Pandulf Eisenkopf indirekt auch das Fürstentum Benevent, in dem sein Sohn als Fürst regierte ${ }^{68}$. Insofern könnte mit der Errichtung eines eigenen Erzbistums Benevent von vornherein eine stärkere Bindung dieses Fürstentums an den lateinischen Westen intendiert gewesen sein. Gleichwohl erfolgte die Gründung des Beneventaner Erzbistums in einer sehr spannungsreichen Phase zwischen dem östlichen und dem westlichen Kaiser. Nikephoros Phokas forderte gegenüber dem ottonischen Gesandten Liudprand die Fürstentümer Benevent und Capua für Byzanz ${ }^{69}$.

Nach Apulien wirkten seit 968/969 von Norden aus eine lateinische und von Süden her über Lukanien eine griechische Metropolitankirche hinein. Um die Wirkung des neuen lateinischen Erzbistums Benevent in Apulien zu begrenzen, erhoben die Byzantiner im 10. und 11. Jahrhundert sukzessive mehrere apulische Bistümer, darunter Tarent, Trani und Brindisi, in den Status von (autokephalen) Erzbistümern. Die meisten Reibungsflächen existierten natürlich in jenen Gebieten, in denen sich das byzantinische Thema ,Langobardia' mit der neuen lateinischen Kirchenprovinz Benevent überschnitt. Das betraf vor allem die Städte Ascoli Satriano, Bovino und Siponto. Um die byzantinische Herrschaft in Apulien auch im kirchlichen Bereich zu gewährleisten, nahm man auf die Personalauswahl bei der Besetzung von Bistümern entsprechend Einfluß. Nur Geistliche, die sich gegenüber dem oströmischen Kaiser loyal verhielten, ließ man in kirchliche Führungspositionen aufsteigen. Außerdem ließen die Byzantiner in Apulien mehrfach zwei Bistümer oder Erzbistümer von loyalen Kirchenfürsten in Personalunion leiten. Die weltlichen Kompetenzen und Rechte von lateinischen Bischöfen in Apulien waren im Vergleich zu jenen in Oberitalien und im nordalpinen Reich sehr gering, sie oblagen meist der byzantinischen Verwaltung ${ }^{70}$.

Konflikte zwischen der griechischen und der lateinischen Kirche blieben in Süditalien nicht auf Apulien beschränkt. Auf lateinischer Seite gründete man im Sommer 983 das Erzbistum Salerno ${ }^{71}$, das vor allem in die Basilicata und nach

67 Falkenhausen (wie Anm. 54) S. 151-153.

68 Rudolf Köpke/Ernst Dümmler: Kaiser Otto der Große, Leipzig 1876, S. 411, 414, 462-464; Paolo Delogu: Pandulf I., Fürst von Capua und Benevent, gen. ,Eisenkopf in: LexMA 6 (1993) Sp. 1652.

69 Liudprand von Cremona (wie Anm. 56) cap. 27.

70 Falkenhausen (wie Anm. 54) S. 151-157.

71 RI 2/5 Nr. 618. 
Kalabrien ausstrahlen sollte ${ }^{72}$. In Kalabrien bestanden die beiden griechischen Kirchenprovinzen Reggio Calabria und Santa Severina. Die Metropolitankirche von Reggio besaß anfangs elf und dann zwölf Suffraganbistümer ${ }^{73}$, die von Santa Severina verfügte über zunächst vier und später fünf Suffraganbistümer ${ }^{74}$. Ebenso wie bei der Errichtung der neuen lateinischen Erzbistümer Capua und Benevent bezog sich die Gründung der Kirchenprovinz Salerno auf ein langobardisches Fürstentum. Sie erfolgte nach der Niederlage Kaiser Ottos II. gegen die Araber im Süden Kalabriens 982 und während seines erneuten Engagements in Süditalien $983^{75}$. Innerhalb des Fürstentums Salerno währte in dieser Zeit eine politisch instabile Übergangsphase zwischen dem Ende der ersten und dem Beginn der zweiten fürstlichen Dynastie ${ }^{76}$. Aus einer Urkunde von Papst Johannes XV. (985-996) für den Erzbischof von Salerno aus dem Jahre 989 geht hervor, daß man der neuen lateinischen Kirchenprovinz die Bistümer Acerenza, Bisignano, Cosenza, Conza, Nola, Malvito und Pesto zugewiesen hatte ${ }^{77}$. Die Unterstellung der Bistümer Acerenza, Bisignano, Cosenza und Malvito unter die lateinische Metropole Salerno barg längerfristig Konfliktstoff zwischen Konstantinopel und Rom. Diese Bistümer gehörten aus byzantinischer Sicht aber weiter zur entsprechenden griechischen Kirchenprovinz. Um den Ansprüchen des Erzbischofs von Salerno zu begegnen, griffen die Byzantiner auch in Kalabrien zu Maßnahmen, die sich bereits in Apulien bewährt hatten ${ }^{78}$. Eine weitere Kontroverse betraf die Zuordnung des Bistums Acerenza. Die Griechen betrachteten es als Suffragan der Metropolitankirche von Otranto, die Lateiner wiesen es der neuen Kirchenprovinz von Salerno $\mathrm{zu}^{79}$. Insgesamt blieben die Ansprüche des Erzbischofs von Salerno auf die Bistümer im byzantinisch beherrschten Gebiet bis zur Mitte des 11. Jahrhunderts wohl weitgehend theo-

72 Dieter Girgensohn: Dall'episcopato greco all'episcopato latino nell'Italia meridionale, in: La Chiesa greca in Italia dall'VIII al XVI secolo, Padua 1973 (Italia Sacra 20), S. 2543, hier S. 30 f.; Vera von Falkenhausen: The Display of Byzantium in Italy. Wie stellte sich Byzanz, seinen Untertanen in Italien, deren Nachbarn und den Eroberern dar?, in: Proceedings of the 21st International Congress of Byzantine Studies, London, 21-26 August 2006, I, London 2006, S. 58-78, hier S. 74 f.

73 Amantea, Bisignano, Cosenza, Crotone, Locri (Gerace), Nicastro, Rossano, Squillace, Tauriano, Tropea, Vibona; Cassano.

74 Cerenzia, Gallipoli, Isola Capo Rizzuto, Umbriatico; Strongoli.

75 Dirk AlvermanN: Königsherrschaft und Reichsintegration. Eine Untersuchung zur politischen Struktur von regna und imperium zur Zeit Kaiser Ottos II. (967) 973-983, Berlin 1998 (Berliner Historische Studien 28), S. 197 f., $422-424$.

76 Huguette Taviani-Carozzi: La principauté lombarde de Salerne (IX $-X^{e}$ siècle). Pouvoir et société en Italie lombarde méridionale, 2 Bde., Rom 1991 (Collection de l'École française de Rome 152), Bd. 1, S. 327-336, $672 \mathrm{f}$.

77 Zimmermann (wie Anm. 37) Nr. 673.

78 Falkenhausen (wie Anm. 54) S. $148 \mathrm{f}$.

79 Taviani-Carozzi (wie Anm. 76) S. 673. 
retischer Natur ${ }^{80}$. Konkurrenz zwischen der griechischen und der lateinischen Kirche gab es jedoch nicht nur in Süditalien, sondern auch in Mittel- und Osteuropa.

Mehrere historiographische Quellen des 10. und 11. Jahrhunderts informieren darüber, daß zu Ostern 973 Gesandtschaften aus verschiedenen Ländern am kaiserlichen Hof in Quedlinburg eingetroffen seien. So sollen Gesandte der Beneventer, Bulgaren, Dänen, Griechen, Ungarn, Slaven bzw. aus Böhmen und Polen nach Quedlinburg gekommen sein ${ }^{81}$. Im Hinblick auf die Zahl der auswärtigen Gäste in Quedlinburg läßt sich ein Trend in der Überlieferung konstatieren: Je später die Quelle entstand, desto mehr Gesandtschaften wurden es. Die meisten Abordnungen führte der Geschichtsschreiber Lampert von Hersfeld auf, der sein Werk mehr als hundert Jahre später verfaßte ${ }^{82}$. Außer den schon genannten seien auch Römer, Italiener und Russen in Quedlinburg erschienen $^{83}$. Obwohl sich Zahl und Herkunftsländer nicht genau bestimmen lassen, sprechen verschiedene Anhaltspunkte dafür, daß zumindest mehrere Gesandtschaften zu Ostern 973 an den Hof des westlichen Kaisers kamen ${ }^{84}$.

So war es im 10. Jahrhundert mehrfach noch offen, wo sich jeweils die griechische oder die lateinische Kirche in den mittel- und osteuropäischen Ländern letztlich durchsetzen würde. In Mähren ${ }^{85}$ und in Ungarn hatte es in der Vergangenheit engere Kontakte sowohl zur griechischen als auch zur lateini-

80 Hans-Walter Klewitz: Zur Geschichte der Bistumsorganisation Campaniens und Apuliens im 10. und 11. Jahrhundert, in: QFIAB 24 (1932/33) S. 1-61, hier S. 17 f.

81 RI 2/1 Nr. 562d.

82 Wattenbach/Holtzmann (wie Anm. 23) Teil 2: Das Zeitalter des Investiturstreits (1050-1125), S. 462 f.

83 Lampert von Hersfeld: Annales, ed. Oswald Holder-Egger, Hannover/Leipzig 1894 (MGH SS. rer. Germ. 38), S. 1-304, ad a. 973 S. 42: Illucque venerunt legati plurimarum gentium, id est Romanorum, Grecorum, Beneventorum, Italorum, Ungariorum, Danorum, Sclavorum, Bulgariorum atque Ruscorum, cum magnis muneribus.

84 Der zeitgenössische Historiograph Widukind von Corvey erwähnt nur allgemein die Anwesenheit von Repräsentanten vieler Völker in Quedlinburg. Widukind von Corvey: Rerum gestarum Saxonicarum libri tres, hg. v. Paul Hirsch/Hans-Eberhard Lohmann, Hannover ${ }^{5} 1935$ (MGH SS rer. Germ. 60), lib. III cap. 75 S. 152: ... ubi diversarum gentium multitudo conveniens ... Durch die zeitgenössische urkundliche Überlieferung ist nur Bischof Odalrich von Cremona (973-1004) während der Osterwoche in Quedlinburg nachweisbar; Urkunden Konrad I., Heinrich I. und Otto I. (wie Anm. 47), D O. I. 429. Der etwa vierzig Jahre nach dem Quedlinburger Hoftag schreibende Bischof Thietmar von Merseburg nannte in seiner Chronik zunächst die Herzöge von Polen und Böhmen. Anschließend übernahm er die Gesandtenliste (Griechen, Beneventaner, Ungarn, Bulgaren, Dänen, Slawen) aus den einige Jahre früher entstandenen Quedlinburger Annalen in sein Werk. Thietmar von Merseburg (wie Anm. 28) lib. II cap. 31 S. 76: Huc confluebant inperatoris edictu Miseco atque Bolizlavo duces et legati Grecorum, Beneventorum, Ungariorum, Bulgariorum, Danorum et Sclavorum ...

85 VavríneK (wie Anm. 30). 
schen Kirche gegeben. In einigen Gebieten Ungarns dominierte noch zur Zeit König Stephans I. die griechische Kirche ${ }^{86}$. Durch die gewaltsame Beseitigung des bulgarischen Patriarchats 972 dürfte die Kirche von Konstantinopel jedoch - zumindest kurzzeitig - an Anziehungskraft verloren haben. Zugleich rückte die lateinische Kirche wieder stärker als Alternative in das Blickfeld. Welche Perspektiven eröffnete sie im letzten Drittel des 10. Jahrhunderts für die Länder in Mittel- und Osteuropa?

Die Gründungen der Erzbistümer Benevent, Capua, Magdeburg und Salerno demonstrierten zunächst, daß Rom im Unterschied zum 9. Jahrhundert durchaus bereit war, neue Metropolitankirchen zu errichten. Überdies verkörperten sie in bestimmter Hinsicht verschiedene Varianten von neuen erzbischöflichen Kirchen, was künftig auch für ostmittel- und osteuropäische Länder von Interesse sein konnte. Aus deren Sicht erhielt Pandulf Eisenkopf von Capua wohl ein eigenes Erzbistum, weil er sich eindeutig auf die Seite des westlichen Kaisers und des Papstes gestellt hatte. Interessant dürfte für mittel- und osteuropäische Herrscher des weiteren gewesen sein, daß sich die neue Kirchenprovinz Capua mit dem weltlichen Herrschaftsbereich des Fürstentums deck$\mathrm{te}^{87}$. Überdies war der erste Erzbischof von Capua ein Bruder des amtierenden Fürsten $^{88}$, was man sicher auch anderswo als wünschenswerte Konstellation betrachtete. In bezug auf die kirchenrechtlichen Absicherungen und die konkreten Maßnahmen bei der Errichtung von neuen Kirchenprovinzen ließen sich ebenfalls entsprechende Schlüsse ziehen. So erfolgte die kirchenrechtlich maßgebende Entscheidung über die Erhebung Benevents - wie zuvor die über Magdeburg $^{89}$ - auf einer Synode, an der außer dem Papst und dem Kaiser viele geistliche Große aus Italien teilnahmen. Zudem waren natürlich die Fürsten von Capua und Benevent bei den Beratungen zugegen ${ }^{90}$. Dies ließ sich so interpretieren, daß eine vorrangig von italienischen Bischöfen besuchte Synode unter Leitung des Papstes sowie in Anwesenheit des westlichen Kaisers und des jeweils zuständigen weltlichen Herrschers auch künftig die Einrichtung von neuen Erzbistümern beschließen könnte.

Ein Vergleich der Erzbistumsgründungen im 10. Jahrhundert läßt Gemeinsamkeiten und Unterschiede zwischen ihnen hervortreten. So wiesen etwa die kirchenrechtlichen Absicherungen der neuen Metropolitankirchen von Magdeburg und Benevent sowie der Aufbau der beiden Kirchenorganisationen einige Parallelen auf. Der Kreis der Bischöfe, der für die Errichtung der Erzbistümer Magdeburg und Benevent votierte, war partiell identisch. Mittel- und

86 Érszzegi (wie Anm. 31) Bd. 2, S. $606 \mathrm{f}$.

87 Klewitz (wie Anm. 80) S. 4.

88 RI 2/5 Nr. 393.

89 Ebd. Nr. 413.

90 Ebd. Nr. 458. 
längerfristig hatte man Magdeburg und Benevent allerdings unterschiedliche Aufgaben zugedacht. In bezug auf Magdeburg standen die weitere Christianisierung und die Mission in den Gebieten östlich von Elbe und Saale im Vordergrund. In bezug auf Benevent spielte die politische Konkurrenz zwischen Ost- und Westrom sowie zwischen der lateinischen und der griechischen Kirche in Süditalien eine Hauptrolle. Um ihre Aufgaben erfüllen zu können, benötigten aber sowohl Magdeburg als auch Benevent eine funktionsfähige kirchenorganisatorische Basis ${ }^{91}$. Ebenso wie in der Magdeburger Kirchenprovinz sollten in der von Benevent an geeigneten Orten künftig Suffraganbistümer entstehen. Im Verlauf des 10. und 11. Jahrhunderts wurden in der Beneventaner Kirchenprovinz einige der 969 dafür vorgesehenen Orte Bischofssitze, andere hingegen nicht. Manche dienten auch nur zeitweilig als Bischofssitz ${ }^{92}$. Ähnliche Vorgänge lassen sich in der Magdeburger Kirchenprovinz konstatieren ${ }^{93}$. Veränderungen bei den Suffraganbistümern waren innerhalb der neuen Kirchenprovinzen also mittel- und längerfristig möglich. Bezüglich ihrer Bindung an Rom unterschieden sich die Metropoliten von Benevent und Magdeburg. Während der Erzbischof von Benevent künftig stets vom Papst in Rom geweiht werden sollte, war das nur für den ersten Metropoliten von Magdeburg vorgesehen. Später sollten die Erzbischöfe von Magdeburg immer durch ihre Suffragane geweiht werden ${ }^{94}$. Bei der Anzahl und Bedeutung der Tage, an denen Erzbischof Adalbert von Magdeburg das Pallium tragen durfte ${ }^{95}$, orientierte

91 Deshalb sah Adalbert, der erste Erzbischof von Magdeburg (968-981), seine vordringlichste Aufgabe nicht in der Mission der Slawen, sondern im Aufbau einer funktionsfähigen und von anderen nordalpinen Metropolen unabhängigen Magdeburger Kirchenprovinz. Wolfgang Georgi: Zur Präsenz und Tätigkeit der Bischöfe der Magdeburger Kirchenprovinz im slawischen Siedlungsgebiet (10. bis 12. Jh.), in: Struktur und Wandel im Früh- und Hochmittelalter. Eine Bestandsaufnahme aktueller Forschungen zur Germania Slavica, hg. v. Christian LüBke, Stuttgart 1998 (Forschungen zur Geschichte und Kultur des östlichen Mitteleuropa 5), S. 257-271, hier S. 260-266; DERs.: Die Bischöfe der Kirchenprovinz Magdeburg zwischen Königtum und Adel im 10. und 11. Jahrhundert, in: Die früh- und hochmittelalterliche Bischofserhebung im europäischen Vergleich, hg.v. Franz-Reiner Erkens (Beih. zum AK 48), S. 83-137, hier S. 99-101.

92 KLewitz (wie Anm. 80) S. 9-15.

93 Das Bistum Merseburg wurde 981 aufgehoben und 1004 wieder eingerichtet. Das Bistum Zeitz wurde 1028 nach Naumburg verlegt. RI 2/5 Nr. 598, 599, 990; Christian LüBKE: Regesten zur Geschichte der Slaven an Elbe und Oder (vom Jahr 900 an), Teil 4: Regesten 1013-1057, Berlin 1987, Nr. 584.

94 RI 2/5 Nr. 418, 449, 450, 452, 459.

95 Zimmermann (wie Anm. 37) S. 175 Nr. 190; Weihnachten, Epiphanie, Ostern, Christi Himmelfahrt, Peter und Paul, Laurentius, Mariae Himmelfahrt, Mauritius, Weihetage von St. Mauritius zu Magdeburg und deren Suffragankirchen, Ordinationstage des Metropoliten und der Suffraganbischöfe. 
man sich 968 an den entsprechenden Privilegien für Mainz und Trier ${ }^{96}$. Im Vergleich zu den Metropoliten von Magdeburg, Mainz und Trier verlieh der Papst an den ersten Erzbischof von Benevent eine größere Zahl von Pallientagen $^{97}$. Das umfangreichste Pallium-Privileg hatte der Papst aber an Erzbischof Brun von Köln vergeben, der das Pallium nach eigenem Ermessen anlegen konnte ${ }^{98}$.

Während die Stadt Benevent die kirchenrechtlichen Anforderungen an einen erzbischöflichen Sitz von vornherein in allen Punkten erfüllte, hatten die vielen geistlichen Großen aus Italien, die 967 in Classe über die Erhebung Magdeburgs zur erzbischöflichen Metropole berieten, offenbar Zweifel am civitas-Status von Magdeburg. Die Bindung des Bischofssitzes an eine civitas war ein alter kirchenrechtlicher Grundsatz, der schon auf den Konzilien bzw. Synoden im 4. und 5. Jahrhundert (Nicäa 325, Sardica 343 und Chalcedon 451) festgelegt worden war. Die kirchenrechtlich verankerte Beziehung zwischen $c i$ vitas und sedes episcopalis, die im Rahmen von entsprechenden Strukturen im antiken Römischen Reich entstanden war, galt in mittelalterlicher Zeit weiter ${ }^{99}$. Im Hinblick auf die als Bischofssitze vorgeschlagenen Orte Meißen, Merseburg und Zeitz zeigten sich die Synodalen von Classe kompromißbereit. In bezug auf den Ort Magdeburg, der als erzbischöfliche Metropole vorgesehen war, bestanden die Bischöfe aus Italien aber auf dem civitas-Status. Im Unterschied zu den Magdeburg betreffenden Dokumenten, in denen man den civitas-Status des Ortes mehrfach besonders betonte, wurde ein solcher Status für Benevent in der Papsturkunde für den ersten Erzbischof überhaupt nicht erwähnt. Bei Benevent, Capua und Salerno fielen die Entscheidungen in dieser Frage verhältnismäßig leicht. Die bereits bestehenden Bischofssitze wurden erzbischöfliche Zentren. Überdies bestanden an dem civitas-Status der fürstlichen Metropolen von Benevent, Capua und Salerno sicher keinerlei Zweifel ${ }^{100}$.

96 Thomas Zотz: Pallium et alia quaedam archiepiscopatus insignia. Zum Beziehungsgefüge und zu Rangfragen der Reichskirchen im Spiegel der päpstlichen Privilegierung des 10. und 11. Jahrhunderts, in: Festschrift für Berent Schwineköper, hg. v. Helmut Maurer/ Hans Patze, Sigmaringen 1982, S. 155-175, hier S. 158-163.

97 Zimmermann (wie Anm. 37) S. 391 Nr. 197: Weihnachten, Epiphanie, Ostern, Christi Himmelfahrt, Pfingsten; Mariae Reinigung, Mariae Verkündigung, Mariae Himmelfahrt, Mariae Geburt; Johannes der Täufer, Natales aller Apostel, Michaelis; Weihetag der Beneventaner Kirche, Ordinationstage des Erzbischofs und der Suffranbischöfe.

98 Ruotger: Vita Brunonis archiepiscopi Coloniensis, ed. Irene Oтт, Weimar 1951 (MGH SS rer. Germ. N. S. 10), cap. 27 S. 27.

99 Gerhard Dilcher: Die Bischofsstadt. Zur Kulturbedeutung eines Rechts- und Verfassungstypus, in: Das Mittelalter 7 (2002) Bd. 1 S. 14.

100 Wolfgang Huschner: Civitas und sedes archiepiscopalis von Magdeburg im 10. Jahrhundert, in: Sachsen und Anhalt 24 (2002/2003) S. 123-151, hier S. 131-133, 136138. 
Außer Kaiser Otto I. dürften sich 973 auch die auswärtigen Gesandten, die zum Quedlinburger Hoftag anreisten, besonders für die neue erzbischöfliche Metropole Magdeburg interessiert haben. Die Beneventaner waren vermutlich erstaunt darüber, daß man so einen kleinen Ort zum Zentrum einer Kirchenprovinz erhoben hatte. Gesandte aus den slavischen Ländern oder aus Ungarn sahen das wohl anders. Wenn das, was sie in Magdeburg zu sehen bekamen, vielleicht auch nur den Mindestanforderungen entsprach, welche die römischlateinische Kirche an eine neue erzbischöfliche Metropole stellte, dann war deren Errichtung zweifellos auch in ihren Ländern möglich. An politischen Zentren wie Gnesen, Kiev oder Prag, deren ursprüngliche Siedlungsstrukturen denen von Magdeburg glichen, hätte man demnach ohne weiteres den Sitz eines lateinischen Erzbischofs einrichten können. Insofern war Magdeburg ein Präzedenzfall für die Errichtung von lateinischen Kirchenorganisationen in Mittelbzw. in Ostmitteleuropa.

In konzeptioneller Hinsicht unterschieden sich die neuen lateinischen Erzbistümer Magdeburg sowie Benevent, Capua und Salerno voneinander. Magdeburg entsprach der fränkisch-imperialen Tradition, wonach die Mission und die anschließende kirchenorganisatorische Erfassung der neuen Christen jenseits der Reichsgrenzen von Erzbistümern ausgingen, die an den (inneren) Rändern des Imperiums errichtet worden waren (Hamburg-Bremen, Salzburg). Im Unterschied dazu traten die Päpste seit Gregor dem Großen (590-604) für den Grundsatz ein, wonach jede Provinz oder jede Gens ein eigenes Erzbistum erhalten sollte. Nikolaus I. (858-867) definierte in seinen Antworten auf die Fragen des bulgarischen Herrschers Boris die rechtliche Stellung eines lateinischen Metropoliten. Danach sollte ein Erzbischof vom Papst eingesetzt, jeweils für ein Volk bestimmt und erst nach dem Empfang des Palliums amtsfähig $\operatorname{sein}^{101}$. Die neuen Erzbistümer in den langobardischen Fürstentümern Benevent, Capua und Salerno wurden demzufolge nach päpstlichen Prinzipien errichtet. Gleichwohl dürften die Gründungen der Erzbistümer Benevent und Salerno auch mit westlich-imperialen Tendenzen gegenüber dem griechischen Süditalien verbunden gewesen sein. Im Hinblick auf die Errichtung von eigenständigen Kirchenorganisationen im lateinischen Europa galten die Erzbistümer von Benevent, Capua und Salerno aber wohl als Präzedenzfälle. Sie offerierten die Möglichkeit, sich dem Christentum zu öffnen, ohne in die kirchliche und damit auch politische Abhängigkeit des östlichen oder des westlichen Imperiums zu geraten. Die Unterstellung unter das politisch noch recht unbedeutende Papsttum des 10. Jahrhunderts erlaubte de facto die Herstellung einer relativ eigenständigen Landeskirche ${ }^{102}$. Im Hinblick auf Nordund Ostmitteleuropa stellten Benevent, Capua und Salerno eine konkrete la-

101 Angenendt (wie Anm. 29) S. 13-16.

102 Ebd. S. 17. 
teinische Alternative dar zu der drohenden kirchenorganisatorischen Abhängigkeit von den im ottonischen Reich gelegenen Erzbistümern HamburgBremen, Magdeburg, Mainz und Salzburg. Möglicherweise wurde diese Alternative nach der Gründung der Bistümer Prag und Mähren, die der Kirchenprovinz Mainz zugeordnet wurden ${ }^{103}$, noch deutlicher wahrgenommen.

Die auf Konstantinopel fixierte Kirche schuf im 10. Jahrhundert ebenfalls einen solchen Präzedenzfall. Seit 980 agierte Vladimir, ein Sohn Svjatoslavs, als Alleinherrscher in der Kiever Rus'. Er verstärkte zunächst die Bindungen an die Gentilreligion und versuchte sogar, sie zur Herrschaftslegitimation zu nutzen ${ }^{104}$. Vielleicht gedachte er auf diese Weise, einer kirchenorganisatorischen Abhängigkeit entweder aus dem Süden oder aus dem Westen Europas zu begegnen. Die Entscheidung für die Annahme des griechischen Christentums fiel, als die Herrschaft von Kaiser Basileios II. (976-1025) durch einen Aufstand seines Vetters Bardas Phokas ernsthaft gefährdet war. Der byzantinische Kaiser wandte sich mit der Bitte um militärische Unterstützung an Vladimir von Kiev. Für die Hand von Anna, der purpurgeborenen Schwester des Kaisers, sagte Vladimir seine Hilfe zu und erklärte sich bereit, zum Christentum überzutreten. Offenbar wurde dem Reich Vladimirs sogleich ein eigener Metropolitansitz in Kiev und damit eine eigene Kirchenorganisation zugestanden ${ }^{105}$. Für das Herrschaftsgebiet der Piasten ergab sich daraus eine neue Situation. Jenseits der östlichen Grenzen ihres Landes begann sich eine russisch-orthodoxe Kirche zu formieren, die auf Konstantinopel ausgerichtet war. Nach dem Tod Ottos II. 983 bzw. spätestens nach dem der Kaiserin Theophanu 991 dürften die von Magdeburg ausgehenden kirchenorganisatorischen Expansionsbestrebungen wieder verstärkt worden sein. Mieszko I. suchte wohl deshalb die direkte Anbindung an die Römische Kirche. Er übertrug seinen Herrschaftsbereich in kirchlicher Hinsicht an St. Peter in Rom. Der Empfänger der Schenkung war Papst Johannes XV. ${ }^{106}$. Damit wurde einerseits den Magdeburger Bestrebungen ein Riegel vorgeschoben und andererseits eine Abgrenzung zur byzantinisch orientierten Kirche in der Kiever Rus' erreicht ${ }^{107}$. Es war ein wichtiger Schritt auf dem Wege zur

103 RI 2/5 Nr. 512.

104 STEIndorfF (wie Anm. 12) S. 79.

105 Andrzej Poppe: The Political Background to the Baptism of Rus'. Byzantine-Russian Relations 986-989, in: Dumbarton Oaks Papers 30 (1976) S. 197-224; Gerhard Podskalsky: Christentum und theologische Literatur in der Kiever Rus' (988-1237), München 1982, S. 24-28; Lilie (wie Anm. 27) S. 247-249; Steindorff (wie Anm. 12) S. $79 \mathrm{f}$.

106 RI 2/5 Nr. 703; Wolfgang Huschner: Giovanni XV (985-996), in: Enciclopedia dei Papi, Bd. 2, Rom 2000, S. 104.

107 Aus der Perspektive Vladimirs von Kiev war mit dem Übertritt der Führungsgruppen seines Landes zum orthodoxen Christentum offenbar keine Abschließung gegenüber dem lateinischen Westen verbunden. Vladimir empfing und unterstützte den lateinischen Missionsbischof Brun von Querfurt, der bei den Petschenegen missionieren wollte. 
Gründung des polnischen Erzbistums Gnesen im Jahre $1000^{108}$. Mieszko I. und sein Nachfolger Bolesław Chrobry (992-1025) wollten keine Anbindung der polnischen Kirche an einen Metropolitansitz im ottonischen Imperium, sondern strebten nach den Vorbildern der Erzbistümer in den Fürstentümern Benevent, Capua und Salerno eine eigenständige Kirchenprovinz für ihr Land an. Sie favorisierten damit ebenso wie Stephan von Ungarn im Hinblick auf Gran das päpstliche Konzept bei der Errichtung von Erzbistümern.

Im 10. Jahrhundert war für Herrscher in Ostmittel- und Osteuropa in Verbindung mit der Christianisierung ihrer Länder die Frage relevant, welchen hierarchischen Status die künftige Kirchenorganisation erhalten würde. Sowohl Konstantinopel als auch Rom hatten im 9. Jahrhundert den neu christianisierten Ländern in der Regel keine eigenen Erzbistümer zugestanden. Kurz vor der ersten Jahrtausendwende änderte sich das. In diesem Zusammenhang stellt sich die Frage, in welcher Hinsicht die neuen lateinischen Erzbistümer Benevent (969), Capua (966), Magdeburg (967/68) und Salerno (983) für ostmittel- und osteuropäische Länder als Vorbilder gewirkt haben könnten. Benevent, Capua, Magdeburg und Salerno signalisierten insgesamt, daß man in Rom - anders als im 9. Jahrhundert - zur Errichtung von Erzbistümern bereit war. Überdies zeigte sich bei den Gründungsvorgängen, welche kirchenrechtlichen Schritte erforderlich waren, um ein neues Erzbistum möglichst dauerhaft abzusichern. Benevent, Magdeburg, Salerno sowie die orthodoxe Metropolitankirche von Kiev (988) gehörten zudem in den großen Rahmen der Konkurrenz zwischen der griechischen und der lateinischen Kirche um Missionsgebiete und Kirchenorganisationen in Ostmittel-, Ost- und Südeuropa. Magdeburg einerseits sowie Benevent, Capua und Salerno andererseits stellten in konzeptioneller Hinsicht unterschiedliche lateinische Erzbistümer dar. Magdeburg entsprach der fränkisch-imperialen Tradition, welche die Mission und die anschließende kirchliche Organisation von Metropolitansitzen ausgehen ließ, die nahe an den

Vgl. Keller (wie Anm. 24) S. 66. Im 11. Jahrhundert gab es relativ viele Heiratsverbindungen zwischen dem Kiever Fürstenhaus einerseits und Königs- und Adelsfamilien im lateinischen Europa andererseits. Erst gegen Ende des 11. Jahrhunderts wurden solche Eheschließungen seitens der orthodoxen Kirche kritisiert. Vgl. dazu Manfred HellMANN: Die Heiratspolitik Jaroslavs des Weisen, in: FOG 8 (1962) S. 7-25; DERs.: Westeuropäische Kontakte der Alten Rus', in: Birkfellner (wie Anm. 5) S. 81-94, hier S. 92 f.; Hedwig Röckelein: Heiraten - ein Instrument hochmittelalterlicher Politik, in: RANFT (wie Anm. 12) S. 99-135, hier S. 107-110.

108 Charlotte Warnke: Ursachen und Voraussetzungen der Schenkung Polens an den heiligen Petrus, in: Europa Slavica - Europa Orientalis. Festschrift für Herbert Ludat zum 70. Geburtstag, hg.v. Klaus-Detlev Grothusen/Klaus Zernack, Berlin 1980 (Osteuropastudien der Hochschulen des Landes Hessen, Reihe 1: Giessener Abhandlungen zur Agrar- und Wirtschaftsforschung des europäischen Ostens 100), S. 127-177; MICHAzowski (wie Anm. 34) S. 57. 
Grenzen des Imperiums (Hamburg-Bremen, Salzburg) gelegen waren. Benevent, Capua und Salerno stimmten hingegen mit alten päpstlichen Grundsätzen überein, wonach jedes Volk oder jede Provinz eigene Erzbistümer erhalten sollte. Vor allem Benevent, Capua und Salerno dürften deshalb Vorbilder für die im Jahre 1000 gegründeten lateinischen Erzbistümer Gnesen und Gran in Polen und Ungarn gewesen sein.

\section{Riassunto}

Nel X secolo, e nel contesto della cristianizzazione dei loro paesi, premeva ai sovrani dell'Europa centrorientale e orientale la questione dello status gerarchico che avrebbe trovato la futura organizzazione ecclesiale. Durante il IX secolo né Costantinopoli né Roma avevano di norma concesso, ai paesi appena cristianizzati, l'istituzione di proprie arcidiocesi. La situazione cambiò nell'ultimo scorcio del primo millennio. In questo contesto si pone la questione sotto quale aspetto le nuove arcidiocesi latine di Benevento (969), Capua (966), Magdeburg (967/68) e Salerno (983) avrebbero potuto fungere da modello ai paesi dell'Europa centrorientale e orientale. Queste quattro città segnalavano nel complesso che Roma, diversamente dall'atteggiamento tenuto durante il IX secolo, era disponibile a far erigere delle arcidiocesi. Si potevano inoltre dedurre da questi processi fondativi quali misure fossero necessarie, dal punto di vista giuridico ecclesiale, per consolidare quanto più durevolmente possibile una nuova arcidiocesi. Benevento, Magdeburg, Salerno e la chiesa metropolitana ortodossa di Kiev (988) rientravano infine nel grande contesto della concorrenza tra la chiesa latina e quella greca relativa ai territori missionari e alle organizzazioni ecclesiali nell'Europa centrorientale, orientale e meridionale. Magdeburg da una parte, e Benevento, Capua e Salerno dall'altra, rappresentavano tipi concettuali diversi di una arcidiocesi latina. Mentre Magdeburg corrispondeva alla tradizione franco-imperiale, dove la missione e la successiva organizzazione ecclesiale partiva da sedi metropolitane collocate vicine ai confini dell'Impero (Amburgo-Brema, Salisburgo), i casi di Benevento, Capua e Salerno si basavano invece sugli antichi princìpi papali, secondo cui ogni popolo od ogni provincia avrebbe dovuto ottenere una propria arcidiocesi. Perciò sarà stato soprattutto l'assetto di Benevento, Capua e Salerno a servire da modello per le arcidiocesi latine di Gniezno in Polonia e Gran in Ungheria, istituite nell'anno 1000. 


\title{
L'Italie méridionale
}

\author{
Jean-Marie Martin
}

Nous entendons par 'Italie méridionale' l'ensemble des territoires qui, à partir $\mathrm{du} \mathrm{XII}^{\mathrm{e}}$ siècle, ont constitué le royaume de Sicile, soit les actuelles régions des Abruzzes, du Molise, de la Campanie (avec l'extrémité des provinces latiales de Frosinone et de Latina), Pouille, Basilicate, Calabre et Sicile (avec Malte). Or, avant l'unification monarchique, ces régions ont connu des sorts bien différents et une histoire complexe depuis la basse Antiquité: les Abruzzes ont fait partie du duché lombard de Spolète, la Campanie (à l'exception des enclaves de Naples-Amalfi et Gaète, restées byzantines avant de devenir indépendantes) et le Molise du duché, puis de la principauté de Bénévent (ensuite partagée avec Salerne, puis Capoue); il en allait de même pour la Pouille et la Basilicate avant la conquête byzantine de la fin du IX ${ }^{\mathrm{e}}$ siècle; Byzance n'avait alors conservé que la Calabre; la Sicile, enfin, a été dominée par les musulmans du IX au $\mathrm{XI}^{\mathrm{e}}$ siècle. La conquête normande du $\mathrm{XI}^{\mathrm{e}}$ siècle n'a pas unifié ces régions, partagées entre la principauté normande de Capoue, le duché de Pouille - constitué de seigneuries pratiquement indépendantes - et le comté de Sicile et Calabre ${ }^{1}$, sans parler de la zone de non-droit constituée par les Abruzzes ${ }^{2}$, du duché de Naples toujours indépendant ${ }^{3}$, et de la ville de Bénévent qui s'est donnée au pape au milieu du $\mathrm{XI}^{\mathrm{e}}$ siècle et constitue désormais une enclave $e^{4}$.

Certes, le Mezzogiorno n'est pas la seule région italienne à avoir connu des transformations et recompositions politiques. Toutefois le royaume de Sicile, même partagé en 1282, devait, jusqu'en 1860, constituer une zone nettement séparée du reste de l'Italie. En outre, les institutions ecclésiastiques ont subi,

1 Ferdinand Chalandon: Histoire de la domination normande en Italie et en Sicile, Paris 1907, réimpr. anast. New York 1960 et 1969, 2 vol.

2 Laurent Feller: Les Abruzzes médiévales. Territoire, économie et société en Italie centrale du IX au XII siècle, Rome 1998 (Bibliothèque des Écoles françaises d'Athènes et de Rome 300).

3 Jean-Marie Martin: Guerre, accords et frontières en Italie méridionale pendant le haut Moyen Âge. Pacta de Liburia, Divisio principatus Beneventani et autres actes, Rome 2005 (Sources et documents d'histoire du Moyen Âge publiés par l'École française de Rome 7).

4 Otto Vehse: Benevent als Territorium des Kirchenstaats bis zum Beginn der avignonesischen Epoche, dans: QFIAB $22(1930-1931)$ pp. 87-160; 23 (1931-1932) pp. $80-119$. 
dans les diverses régions qui le composent, des bouleversements très supérieurs à ceux qui ont affecté le reste de l'Italie et même de l'Occident romain.

\section{L',Italia Pontificia“ et le Midi}

On comprend que la classification des documents pontificaux émis du $V^{e}$ à la fin du XII ${ }^{e}$ siècle et adressés aux diverses institutions de l'Italie méridionale n'ait pas été facile. Les terres du royaume de Sicile occupent, dans l'Italia Pontificia, une partie du volume 4, l'ensemble des volumes 8 et 9, enfin la plus grande partie du volume 10, dont la fin est consacrée à la Sardaigne et à la Corse; ces volumes ont été publiés respectivement en 1909, 1935, 1962 et $1975^{5}$.

À juste titre, on a commencé par les Abruzzes, dont les six évêchés ont traversé pratiquement toute la période (les quelques évêchés paléochrétiens disparus ne sont pas bien importants ${ }^{6}$ ) et ont continué d'être soumis à l'autorité métropolitaine de Rome; en outre, les actes pontificaux adressés à des laïques y sont rares. On pouvait donc sans mal présenter les Abruzzes dans leur cadre ecclésiastique (la province romaine) sans se préoccuper des vicissitudes politiques qui les ont finalement liées à la Sicile.

Pour le reste de la partie continentale du Royaume, c'est la géographie politique créée par les Normands qui a déterminé le choix des limites territoriales. Le volume 8 commence en effet par trois évêchés appartenant également à la province romaine, Fondi, Gaète et Sora, mais politiquement rattachés au Midi depuis le VIII ${ }^{\mathrm{e}}$ ou le IX ${ }^{\mathrm{e}}$ siècle. C'est pourquoi ils viennent après le regnum Normannorum lui-même, réalité du $\mathrm{XII}^{\mathrm{e}}$ siècle ${ }^{7}$, mais aussi après le patrimonium Campaniae de l'Église romaine, réalité du $\mathrm{VI}^{\mathrm{e}}$ siècle, et avant les diverses entités politiques du haut Moyen Age. Mise à part cette exception, la géographie religieuse retenue est généralement celle des évêchés du XII ${ }^{\mathrm{e}}$ siècle, regroupés sous les métropoles créées à la fin du $\mathrm{X}^{\mathrm{e} 8}$. Les très nombreux évêchés paléochrétiens, disparus au $\mathrm{VI}^{\mathrm{e}}$ ou au $\mathrm{VII}^{\mathrm{e}}$ siècle en général, sont insérés dans ce cadre géographique général ${ }^{9}$; ont d'ailleurs été traités de la même façon quelques

5 IP 4 pp. 8-10. Kehr reconnaît lui-même les difficultés spécifiques de l'Italie méridionale (IP 8 p. 6: Arduum sane est res Italiae inferioris plane et accurate exponere).

6 Amiterno, Ofena, Ortona, Vasto.

7 IP 8 pp. $1-61$.

8 Quelques rares évêchés paléochrétiens, comme Nocera ou Herdonia, ont droit à un chapitre.

9 Formiae, Minturnae, Forum Popilii, Cubulteria, Atella, Patria, Agropoli, Grumentum, Misène (IP 8); Caudium, Aufidena, Aeca, Carmeianum, Canosa, Marcellianum (IP 9); Tempsa, Myria, Cirella, Thurii, Vibo Valentia, Taureana (IP 10). 
évêchés morts-nés (Biccari, Cisterna ${ }^{10}$ ) ou très mal documentés (Vico Equense, Massa Lubrense, Morcone) de la dernière période.

La Sicile a une histoire plus simple, sinon plus calme. Roger I ${ }^{\text {er }}$ et Roger II se sont en général bornés à restaurer des évêchés paléochrétiens ou byzantins, abandonnés à l'époque musulmane; ceux qui n’ont pas été recréés sont traités comme ceux des régions continentales; mais on doit souligner qu'ici ce ne sont généralement pas les abandons de sites qui ont détruit ces évêchés ${ }^{11}$.

Le schéma ainsi suivi a permis de rendre compte de l'évolution, ici passablement chaotique, de la géographie civile et ecclésiastique $\mathrm{du} \mathrm{V}^{\mathrm{e}}$ au $\mathrm{XII}^{\mathrm{e}}$ siècle, particulièrement complexe dans la partie médiane du Royaume (Abruzzes et Sicile exceptées).

Avant de voir comment peuvent s'expliquer ces changements et d'analyser les particularismes, réels et nombreux, de l'Italie méridionale concernant aussi bien l'organisation interne de l'Église que ses rapports avec les pouvoirs laïques et avec Rome, je voudrais dire quelques mots sur le travail accompli par Paul Kehr et son équipe - M. Klinkenborg et Luigi Schiaparelli qui ont effectué la plupart des recherches sur le terrain dans le Midi, Walther Holtzmann et Dieter Girgensohn qui ont achevé son œuvre -, qui déborde largement la seule recherche de documents pontificaux. Dans les comptes rendus de mission („Reiseberichte“) publiés dans les „Nachrichten“ de l'Académie de Göttingen et réimprimés dans les volumes des „Papsturkunden in Italien“, ils ont laissé de précieuses indications sur de très nombreux fonds d'archives ${ }^{12}$.

Une image globale - et négative - de l'état des archives méridionales est fourni dans le tout premier article ${ }^{13}$ : „Die Überlieferung des Südens, über die so mancher Sturm hinweggegangen ist, ist sehr trümmerhaft. Die wenigen wohl-

$10 \quad$ IP 9 pp. 227 et 343.

11 Termini Imerese, Lilybée (Marsala), Carini, Triocala, Lentini, Milazzo, Tindari, Alesa.

12 Paul Fridolin Kenr: Papsturkunden in Italien. Reiseberichte zur Italia Pontificia, 6 vol., Cité du Vatican 1977 (Acta Romanorum pontificum 1-6). Concernent le Midi les articles suivants: Papsturkunden in Benevent und der Capitanata, dans: ibid. vol. 1 S. 219-272 (1898); Papsturkunden in Apulien, dans: ibid. S. 273-326; Papsturkunden in den Abruzzen und am Monte Gargano, dans: ibid. S. 327-372; Papsturkunden im Principato, in der Basilicata und in Calabrien, dans: ibid. S. 373-386; Papsturkunden in Sizilien, dans: ibid. vol. 2 S. 33-87 (1899); Papsturkunden in Malta, dans: ibid. S. 89-130; Papsturkunden in Salerno, La Cava und Neapel, dans: ibid. S. $381-$ 452; Papsturkunden in Campanien, dans: ibid. S. 453-511. Il faut y ajouter le volume de la Miscellanea Cassinese (également réimprimé dans les Papsturkunden) consacré à l'édition de documents pontificaux du Mont-Cassin: Paul Fridolin KeHR, Le bolle pontificie anteriori al 1198 che si conservano nell'Archivio di Montecassino, MontCassin 1899. En outre, des documents pontificaux concernant le Midi sont publiés dans plusieurs des articles intitulés Papsturkunden in Rom et dans les Nachträge zu den Papsturkunden Italiens, notamment dans le dixième article, dû à Walther HoltzmanN (1962).

13 KeHR: Papsturkunden in Benevent (cit. n. 12) p. 46. 
erhaltenen Archive ragen wie Inseln aus der allgemeinen Verwüstung hervor. Der Besuch der meisten Orte brachte nur die traurige Gewissheit, dass nichts mehr vorhanden." Si des appréciations positives sont portées sur quelques fonds - archives capitulaires de Bari, de Troia (toutefois non classées), de Giovinazzo, de Tarente, archives d'une paroisse de Campobasso, de San Severo („,klein, aber wichtig"), de Palerme, de Catane, sans parler de Naples, du Mont-Cassin ou de Cava, on déplore l'état des archives de Syracuse, où „die ganze ältere Überlieferung zerstört ist“. On détaille parfois les causes et la date des pertes: l'archivio capitolare d'Ascoli Satriano a brûlé en 1656, les archives de Celano ont été emportées par un chanoine en 1867, l'archivio vescovile d'Isernia a brûlé en 1860, l'archivio capitolare de Bojano a disparu dans un tremblement de terre en 1805, l'archivio comunale de Monte Sant'Angelo a été détruit par des brigands en 1814, les archives de Vieste ont été brûlées par les Turcs en 1554, celles de Vico del Gargano ont été détruites par un tremblement de terre en 1646, celles du couvent de S. Matteo, à San Giovanni in Lamis, ont brûlé en 1799, l'évêché de Cassano allo Jonio a brûlé au XIX siècle, les archives de S. Giovanni Terista ont brûlé en 1806; à Messine, tout a été détruit à la fois par „Erdbeben [avant 1908], Brand und Bombardement". On voit que ces destructions ont parfois des causes physiques, ou étrangères, mais sont souvent dues à l'incurie et que l'époque de la vice-royauté, et surtout celle du royaume des Bourbons - qui avaient rassemblé à Naples une bonne partie des archives du Royaume - ont été désastreuses pour bien des fonds locaux. Il est vrai qu'à l'époque des missions envoyées par Kehr la situation commençait à se redresser: le premier volume du «Codice diplomatico Barese» est publié en 1897, pratiquement au moment de la visite de Schiaparelli, qui salue explicitement l'effort accompli. Les envoyés de Kehr soulignent d'ailleurs qu'ils ont été le plus souvent bien, voire cordialement reçus par les autorités et les notables locaux.

En dépit d'inévitables changements, les indications fournies dans ces „Reiseberichte" restent aujourd'hui précieuses. Peu de choses ont échappé aux chercheurs. Signalons-en quelques-unes. Dans le Molise, les parchemins conservés à l'église paroissiale de S. Cristina de Sepino (dont une centaine d'actes médiévaux, du XII ${ }^{e}$ su $\mathrm{XV}^{\mathrm{e}}$ siècle) n'ont pas été répertoriés: ils constituent l'un des principaux fonds de cette région; nous les avons publiés avec Errico $\mathrm{Cu}$ ozzo $^{14}$. Il ne semble pas que les parchemins grecs et latins du monastère grec de Carbone, en Basilicate, conservés à Rome au palais Doria Pamphili, aient été indiqués ${ }^{15}$. Enfin, la seule copie intégrale du cartulaire-chronique de S. Barto-

14 Errico Cuozzo/Jean-Marie Martin: Le pergamene di S. Cristina di Sepino (11431463), Rome 1998 (Sources et documents d'Histoire du Moyen Âge publiés par l'École française de Rome 1).

15 Voir en revanche Walther Holtzmann: Papst-, Kaiser- und Normannenurkunden aus Unteritalien, dans: QFIAB 36 (1956) pp. 34-85. 
lomeo di Carpineto, dans les Abruzzes, a été découverte en 1949 à la Bibliothèque Ambrosienne, où elle avait été emportée par un abbé commendataire ${ }^{16}$. Permettons-nous encore de signaler une erreur dont l'érudition de Kehr et de son équipe n'est pas coutumière: l'acte du pape Paul I ${ }^{\text {er }}$ (762) pour le clergé et le peuple de Nardò, enregistré dans l'Italia Pontificia ${ }^{17}$, est un faux moderne, qui vise à donner une antiquité indue à un monastère sans doute fondé par le comte de Conversano à la fin du XI ${ }^{e}$ siècle ${ }^{18}$. D'autre part, la création de l'archevêché de Siponto, dont Holtzmann créditait Benoît $\mathrm{IX}^{19}$, est maintenant attribuée à Benoît VIII (peut-être en 1022) ${ }^{20}$. On sait encore que Pardus était évêque de Salpi, non d'Arpi ${ }^{21}$. La date de déposition de deux évêques apuliens du $\mathrm{XI}^{\mathrm{e}}$ siècle a été corrigée ${ }^{22}$. La consécration par le pape d'évêques méridionaux, souvent mentionnée, par exemple, dans les biographies épiscopales (Naples, Amalfi), ne paraît pas avoir donné lieu à la rédaction d'un acte, et ne devrait donc pas être mentionnée comme telle ${ }^{23}$. Enfin, nous indiquons en appendice un certain nombre d'éditions récentes de textes et de documents cités dans les volumes considérés.

Terminons cette revue en rappelant que Kehr et son équipe ont édité, en appendice à leurs „Reiseberichte", le texte ou le résumé de 276 actes méridionaux trouvés dans les archives méridionales, et de 74 actes trouvés pour la plupart à Rome, mais concernant le Midi: la récolte et le bilan ne sont pas minces; d'autres actes ont été publiés ensuite, notamment par Holtzmann.

Compte tenu de l'état des archives, le nombre d'actes pontificaux par destinataire est rarement considérable. Ajoutons - mais c'est une évidence - que, ici comme ailleurs, on n'a conservé de documents pontificaux en nombre qu'à partir du milieu du $\mathrm{XI}^{\mathrm{e}}$ siècle, époque où les débuts de la réforme ont amélioré

16 Gratianus a S. Teresia O.C.D.: Castigationes Kehrianae, dans: Ephemerides Carmeliticae 3 (1949) pp. 351-404. L'auteur en profite pour apporter un certain nombre de corrections de détail.

17 IP 9 p. $415 \mathrm{n}^{\circ} 1$.

18 Voir Louis Duval-Arnould/André Jacob: La description du diocèse de Nardò en 1412 par Jean de Epiphaniis est-elle authentique?, dans: BISI 90 (1982-83) pp. 331-53. On ne sait en outre pourquoi l'Italia Pontificia a placé Nardò dans l'évêché d'Otrante, alors que la ville faisait partie de celui de Gallipoli, même si elle cherchait (avec un certain succès) à ne pas en dépendre.

19 IP 9 p. $235 \mathrm{n}^{\circ} 10$.

20 Armando Petrucci: Codice diplomatico del monastero benedettino di S. Maria di Tremiti (1005-1237), 3 vol., Rome 1960 (Fonti 98), ici vol. 2 p. 25.

21 IP 9 p. 218; voir Giorgio Otranto: Pardo vescovo di Salpi, non di Arpi, dans: Vetera Christianorum 19 (1982) pp. 159-169.

22 IP 9 p. $146 \mathrm{n}^{\circ} 1$ (un évêque d'Ascoli Satriano) et p. $290 \mathrm{n}^{\circ} 2$ (Jean de Trani); voir Tilmann Sснмідт: Alexander II. (1061-1073) und die römische Reformgruppe seiner Zeit, Stuttgart 1977 (Päpste und Papsttum 11), p. 187-195.

23 Telle était l'opinion de Charles Piétri. 
l'organisation des services pontificaux, et où le pape a définitivement abandonné le papyrus pour le parchemin; de la période antérieure, on a surtout conservé des registres factices - registres de Grégoire le Grand ou de Jean VIII, «Codex Carolinus»- ou des actes passés dans les collections canoniques ${ }^{24}$. L'ensemble le plus important est sans conteste celui du Mont-Cassin (où le «Registrum Petri Diaconi» a conservé la copie de nombreux actes pontificaux du $\mathrm{X}^{\mathrm{e}}$ siècle): 318 numéros ${ }^{25}$; S. Vincenzo al Volturno n'en a que $29^{26}$, comme Casauria ${ }^{27}$, Cava $36^{28}$.

Les évêchés les plus importants atteignent rarement de tels chiffres; les plus anciens sont parfois mieux servis au VI $\mathrm{e}^{\mathrm{e}}$ siècle par Grégoire le Grand qu'en plein Moyen Age. Le plus riche est celui de Naples ${ }^{29}: 86$ actes pontificaux, dont 48 (plus de la moitié) paléochrétiens (jusqu’à Grégoire le Grand inclus); vient ensuite Bénévent ${ }^{30}$, avec 73 actes, dont 4 paléochrétiens, ce qui met ce siège en première position pour la période médiévale; il est vrai que la ville était métropole depuis 969, et constituait une enclave pontificale depuis le milieu du $\mathrm{XI}^{\mathrm{e}}$ siècle. Capoue ${ }^{31}$ (les deux cités successives, l'antique et la médiévale) en a 59 (dont 11 paléochrétiens), Salerne ${ }^{32} 54$ (dont 4 paléochrétiens).

Quand on quitte la Campanie, les métropoles, même les plus importantes, sont généralement moins riches. On a conservé 77 actes pontificaux concernant le siège de Syracuse ${ }^{33}$, mais 59 sont paléochrétiens et remontent à l'époque où la ville était l'une des deux plus importantes de Sicile. On tombe ensuite à 45 actes (dont 3 paléochrétiens) à Brindisi ${ }^{34}, 42$ à Trani ${ }^{35}, 37$ (dont 18 paléochrétiens) à Palerme $^{36}, 27$ à Bari ${ }^{37}$. La petite métropole de Conza della Campania ${ }^{38}$ doit se contenter de 8 documents. De très nombreux petits évêchés, enfin, ne bénéficient d'aucun document pontifical conservé: Calvi, Sarno, Policastro,

24 Voir, pour la période antérieure au Xe siècle, Jean-Marie Martin/Errico Cuozzo/Stefano Gasparri/Matteo Villani: Regesti dei documenti dell'Italia meridionale (570-899), Rome 2002 (Sources et documents d'Histoire du Moyen Âge publiés par l'École française de Rome 5).

25 IP 8 pp. $115-193$.

26 IP 8 pp. $247-254$.

27 IP 4 pp. $300-306$.

28 IP 8 pp. $315-330$.

29 IP 8 pp. $432-450$.

30 IP 9 pp. $50-71$.

31 IP 8 pp. $215-226$.

32 IP 8 pp. $344-361$.

33 IP 10 pp. 301-320.

34 IP 9 pp. 386-396.

35 IP 8 pp. $290-299$.

36 IP 10 pp. 224-235.

37 IP 9 pp. 317-324.

38 IP 9 pp. 507-509. 
Nusco, Massa Lubrense, Vico Equense, Morcone, Trevico, Volturara, Montecorvino, Lesina, Fiorentino, Guardialfiera, Bojano, Minervino, Molfetta, Bitonto, Bitetto, Ugento, Castro, Leuca, Lacedonia, Bisaccia, Satriano, Oppido, Bova, Crotone, Martirano, Umbriatico, Cerenzia, Belcastro, Strongoli; ils sont tous situés dans ce que nous avons appelé la partie médiane du Royaume.

\section{Les évêchés méridionaux}

La longueur de cette énumération de sites peu connus et peu importants explique la rareté des actes pontificaux adressés à chaque évêché. Elle révèle la première originalité de l'organisation ecclésiastique du Midi continental (les Abruzzes et la Sicile constituent deux cas différents). En effet, le réseau épiscopal de ces régions a connu une histoire particulièrement tourmentée $\mathrm{du} \mathrm{VI}^{\mathrm{e}}$ au XII ${ }^{e}$ siècle.

Le Midi continental abritait, dans l'Antiquité, de très nombreuses petites cités, mais peu de grandes (Capoue, Canosa, Tarente). C'est dans ce cadre que le réseau épiscopal a commencé à se développer aux $I V^{e}$ et $V^{e}$ siècles. Il a continué à progresser au $\mathrm{VI}^{\mathrm{e}}$ siècle, utilisant même des établissements non citadins (Amalfi, Carmeianum dans le nord de la Pouille ${ }^{39}$, Trani, Tropea). La crise des $\mathrm{VI}^{\mathrm{e}}$ et VII ${ }^{\mathrm{e}}$ siècles - liée à la fois sans doute à la peste et à l'invasion lombarde - a provoqué l'abandon d'un grand nombre de sites, surtout dans les grandes plaines de la Campanie centrale (Formiae, Minturnae, Cales, Forum Popilii, Vulturnum) et du Tavoliere de Pouille (Aecae, Carmeianum, Herdonia), qui redeviennent en partie marécageuses ${ }^{40}$; les disparitions d'évêchés sont plus nombreuses encore que celles de sites. Dans l'ancienne province d'Apulia-Calabria, sur les 17 sièges attestés à l'époque paleochrétienne, seuls 8 - moins de la moitié - survivent encore au milieu du $\mathrm{IX}^{\mathrm{e}}$ siècle $^{41}$. Même si le taux de pertes est un peu moins fort en Campanie et en Calabre (où quelques sièges se déplacent),

39 Voir Jean-Marie Martin/Ghislaine Noyé: La Capitanata nella storia del Mezzogiorno medievale, Bari 1991, pp. 231-261. Le site de l'évêché était peut-être celui de San Giusto, situé plus à l'ouest: voir San Giusto. La villa, le ecclesiae. Primi risultati dagli scavi nel sito rurale di San Giusto (Lucera) 1995-1997, sous la dir. de Giuliano Volpe, Bari 1998.

40 Voir Martin/Noyé: La Capitanata (cit. n. 39) pp. 7-46; Jean-Marie Martin: La Pouille du VI ${ }^{\mathrm{e}}$ au XII ${ }^{\mathrm{e}}$ siècle, Rome 1993 (Collection de l'École française de Rome 179), pp. 148 -154; Jean-Marie Martin/Ghislaine Noyé: Les façades maritimes de l'Italie du Sud: défense et mise en valeur (IV -XIII siècle), dans: Castrum 7. Zones côtières littorales dans le monde méditerranéen au Moyen Âge: défense, peuplement, mise en valeur, sous la dir. de Jean-Marie Martin, Rome/Madrid 2001 (Collection de l'École française de Rome 105/7, Collection de la Casa de Velázquez 76), pp.467-512, ici pp. $487-488$.

41 Martin: La Pouille (cit. n. 40) p. 247. 
il n'en est pas moins remarquable ${ }^{42}$. On ne connait pas d'autre région de l'ancien empire d'Occident (sauf peut-être l'Angleterre conquise par les Anglo-Saxons païens) qui ait connu une telle instabilité dans ce domaine. Dans les principautés lombardes du Sud, on y reviendra, la principale autorité en matière ecclésiastique est le prince ${ }^{43}$, non les évêques.

Après le creux des $\mathrm{VII}^{\mathrm{e}}$-IX ${ }^{\mathrm{e}}$ siècles, la reprise aboutit à une impressionnante prolifération d'évêchés: sur le territoire apulien, il passe de 8 à $46^{44}$. Dans l'ensemble du Royaume à l'époque souabe (et donc déjà à la fin du XII' siècle), Norbert Kamp a compté 145 diocèses $^{45}$, pour un territoire mesurant environ $100000 \mathrm{~km}^{2}$. Si on en enlève les 10 diocèses siciliens et les 6 des Abruzzes, qui constituent deux petits réseaux normaux, on voit que c'est dans la région médiane que la prolifération atteint son maximum (un évêché couvre en moyenne $2500 \mathrm{~km}^{2}$ en Sicile, moins de $700 \mathrm{~km}^{2}$ dans l'ensemble du Royaume).

Cette reprise commence dans la seconde moitié du $\mathrm{X}^{\mathrm{e}}$ siècle ${ }^{46}$, sous l'égide de Rome, avec la création dans le Midi de nouvelles métropoles, chargées de se créer des suffragants; toute l'Italie méridionale dépendait jusqu'alors de la métropole romaine (toutefois, après la soustraction d'obédience de la Calabre au VIII siècle, les autorités byzantines avaient déjà créé les deux métropoles grecques de Reggio et de Santa Severina, après celles de Catane et Syracuse en Sicile ${ }^{47}$ ). Dans les principautés lombardes et les duchés tyrrhéniens, le pape crée une métropole par entité politique; naissent ainsi celles de Capoue en 966, Bénévent en 969, Amalfi en 987, Salerne avant 989, Naples avant 990, Sorrente

42 Voir les articles, toujours utiles, de Mgr Duchesne, dans le cadre de sa polémique avec Amedeo Crivellucci: Louis Duchesne: Les évêchés d'Italie et l'invasion lombarde, dans: MAH 23 (1903) pp. 83-116 et 25 (1905) pp. 365-399.

43 Martin: La Pouille (cit. n. 40) pp. 237-241.

44 Ibid. p. 563.

45 Norbert Kамр: Kirche und Monarchie im staufischen Königreich Sizilien. I. Prosopographische Grundlegung: Bistümer und Bischöfe des Königreichs 1194-1266, 4 vol., Munich 1973-1982.

46 Voir Louis Duchesne: Les évêchés de Calabre, dans: Mélanges Paul Fabre. Études d'histoire du Moyen Âge, Paris 1902, pp. 1-16, réimpr. dans: ID.: Scripta minora. Études de topographie romaine et de géographie ecclésiastique, Rome 1973 (Collection de l'École française de Rome 13) pp. 439-454. Voir surtout Hans-Walter Klewitz: Zur Geschichte der Bistumsorganisation Campaniens und Apuliens im 10. und 11. Jahrhundert, dans: QFIAB 24 (1932-33) pp. 1-61; ID.: Studien über die Wiederherstellung der römischen Kirche in Süditalien durch das Reformpapsttum, dans: QFIAB 25 (1933-34) pp. 105-157 (réimpr. dans: ID., Reformpapsttum und Kardinalkolleg, Darmstadt 1957).

47 Voir Jean-Marie Martin: Léon, archevêque de Calabre, l'Église de Reggio et la lettre de

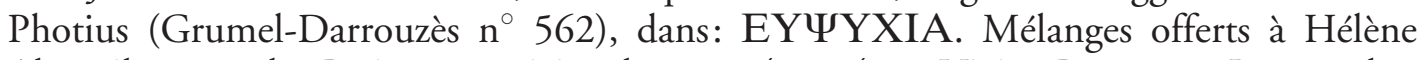
Ahrweiler, 2 vol., Paris 1998, ici vol. 2 pp. 481-491; Vivien Prigent: Les évêchés byzantins de la Calabre septentrionale au VIII siècle, dans: MEFRM 114-2 (2002) pp. 931-953. 
au début du XI $\mathrm{XI}^{\mathrm{e}}$ siècle (sans doute après que la ville est devenue capitale d'un duché indépendant de Naples). Les métropoles lombardes dominent des territoires assez vastes; ceux des métropoles tyrrhéniennes au contraire sont d'une taille ridicule; or il semble qu'elles se donnent tout de suite des suffragants: Minori, Scala, Lettere, Capri pour Amalfi, Massa Lubrense et Vico Equense pour Sorrente; chacun de ces diocèses atteint à peine la taille d'une plebs de l'Italie centrale.

Dans la Pouille, politiquement byzantine depuis la fin du IX ${ }^{\mathrm{e}}$ siècle, mais de rite latin, le palais pontifical semble tout ignorer des réalités géographiques et politiques locales ${ }^{48}$. Dans le centre de la région, les métropoles sont en fait créées par les autorités locales, et sans doute les prélats eux-mêmes, et ensuite reconnues par Rome. L'évêque qui siège à Bari, capitale du catépan, mais qui en général prend le titre de Canosa (siège paléochrétien relativement prestigieux définitivement disparu au $\mathrm{IX}^{\mathrm{e}}$ siècle) porte le titre d'archevêque dès 953 , avant donc le début de l'érection des autres métropoles méridionales par le pape. Par une reproduction de type amibien, la théorique métropole de Canosa, après s'être fixée à Bari, s'installe aussi à Trani et à Brindisi (siège replié à Oria depuis le IX siècle), créant ainsi trois métropoles. L'évêque de Tarente devient archevêque en 978, celui de Lucera en 1005 (mais ce siège, rattaché par le pape à la métropole de Bénévent, doit abandonner ses prétentions). Il semble en fait que les autorités impériales donnent à certains évêques latins le titre honorifique d'archevêque qui, dans l'esprit de celui qui le porte (et sans doute aussi aux yeux du palais pontifical) implique le pouvoir métropolitain.

La confusion est telle qu'en 1063, Alexandre II, énumérant d'une part dans un privilège à l'archevêque de Trani, de l'autre dans un privilège à l'archevêque de Bari les villes dans lesquelles l'un et l'autre peuvent installer des suffragants, nomme sept mêmes villes dans l'un et l'autre texte ${ }^{49}$. Autre problème aux confins du territoire byzantin ${ }^{50}$ : en 989 , Jean XV a donné à l'archevêque de Salerne, comme suffragant, le siège d'Acerenza (que les autorités byzantines avaient voulu, vingt ans plus tôt, soumettre à la nouvelle métropole grecque d'Otrante). Quand Alexandre II fait d'Acerenza une métropole, il est conduit à donner à l'archevêque de Salerne le titre (dépourvu de toute valeur pratique) de primat pour ne pas nier sa théorique autorité sur Acerenza, comme sur Conza della Campania, également promue au rang métropolitain au milieu du $\mathrm{XI}^{\mathrm{e}}$ siècle. On voit à quelles improvisations est réduit le pape dans ces régions.

La seule réussite pontificale est l'extension aux nouvelles cités de Capitanate (fondées au premier quart du $\mathrm{XI}^{\mathrm{e}}$ siècle et de population entièrement latine),

48 Martin: La Pouille (cit. n. 40) pp. 566-582.

49 IP 9 p. $291 \mathrm{n}^{\circ} 3$ et p. $318 \mathrm{n}^{\circ} 4$.

50 IP 9 pp. 453 et 505. 
avec l'accord des autorités impériales, de l'autorité métropolitaine de Bénévent ${ }^{51}$. Le pape détache alors de Bénévent le siège de Siponto, qui lui était lié depuis le VII ${ }^{\mathrm{e}}$ siècle, et qui aurait été enclavé dans les nouveaux évêchés, pour en faire une nouvelle métropole qu'il contrôle de près ${ }^{52}$.

Ajoutons, du côté grec, la transformation en métropole, en 968, de l'archevêché autocéphale d'Otrante, chargé d'organiser des évêchés grecs dans les régions depuis peu hellénisées de la Basilicate, alors que le reste du Salento grec dépend de la métropole calabraise de S. Severina. Mais les Normands feront du siège d'Otrante, latinisé, la métropole du Salento.

C'est dans ce cadre complexe que les évêchés se sont multipliés. Leurs promoteurs sont sans doute variés, surtout après la conquête normande, d'autant que les premières listes de suffragants fournies par le pape ne sont que virtuelles: en 1025, Jean XIX indique à l'archevêque de Bari une liste de 17 ou 18 localités, parmi lesquelles le métropolitain devra choisir 12 sièges épiscopaux pour ses suffragants. En outre, certains sièges non pourvus continuent longtemps de figurer sur les listes pontificales (Corato, Barletta dans la métropole de Trani, Modugno, Acquatetta, Montemilone, Vitalba dans celle de Bari). Les derniers sièges n'apparaissent qu'à l'époque normande, parfois sans doute sur initiative seigneuriale: ainsi les deux suffragants de Tarente (Mottola et Castellaneta), Bitonto, Bitetto, Andria, ou encore Ugento et Leuca ${ }^{53}$ en Pouille; en Campanie, l'évêché de Sarno est fondé par l'archevêque de Salerne en $1066^{54}$, celui de Nusco apparaît à la même époque. En Calabre, les Normands déplacent le siège de Malvito à San Marco Argentano, celui de Vibo Valentia à Mileto; les minuscules évêchés de Belcastro et Strongoli, dans la Sila, n’apparaissent pas avant le $\mathrm{XII}^{\mathrm{e}}$ siècle $^{55}$. Toutefois, le réseau est pratiquement complet à cette époque, où le pape refuse la création de nouveaux diocèses, par exemple à

51 Walther Holtzmann: Der Katepan Boioannes und die kirchliche Organisation der Capitanata, dans: NAG (1960) pp. 19-39.

52 Jean-Marie Martin: La città di Siponto nei secoli XI-XIII, dans: San Leonardo di Siponto. Cella monastica, canonica, domus Theutonicorum. Atti del convegno internazionale (Manfredonia, 18-19 marzo 2005), sous la dir. de Hubert Houben, Galatina 2006, pp. 15-32. C'est sans doute à cette occasion qu'a été composée la Vie de saint Laurent de Siponto.

53 André JАСОв: Ecclesia Alexanensis alias Leucadensis. À la recherche du siège primitif d'un diocèse salentin, dans: RSCI 33 (1979) pp. 490-499; iD.: Le culte de saint Vincent de Saragosse dans la Terre d'Otrante byzantine et le sermon inédit du Vaticanus Barberinianus Gr. 456 (BHG 1867e), dans: Philomathestatos. Studies in Greek and Byzantine Texts presented to Jacques Noret for his Sixty-Fifth Birthday, sous la dir. de Bart Janssens/Bram Roosen/Peter Van Deun, Leuven/Paris/Dudley/MA 2004 (Orientalia Lovaniensia. Analecta 137), pp. 285-296.

54 IP 8 p. 303.

55 IP 10 pp. 130 et 135. 
Monte Sant'Angelo et à Foggia ${ }^{56}$; on ne note plus guère, ensuite, que la naissance du diocèse d'Atri dans les Abruzzes en $1252^{57}$ et de rares nouveautés plus tardives.

La répartition de ces évêchés entre les métropoles est très inégalement logique. On a déjà signalé les cas extrêmes d'Amalfi et de Sorrente. Si le modèle théorique qui attribue symboliquement douze évêchés à une province est prévu - et à peu près réalisé - dans les cas de Bénévent ou de Bari, il ne l'est pas dans les autres provinces apuliennes: la métropole de Siponto n'a qu'un suffragant, que lui donne Pascal II (Vieste) ${ }^{58}$, celles de Trani et de Tarente chacune deux (ceux de Tarente n'apparaissent qu'un siècle après la métropole).

La singularité est encore aggravée du fait qu'un assez grand nombre d'évêchés sont 'exempts' (c'est - à - dire immediate subiecti) $)^{59}$, pour des raisons variables, mais surtout à cause de l'inconsistance des métropoles. C'est sans doute pour des raisons politiques qu'Aversa s'est émancipée de Naples et Ravello d'Amalfi. En Calabre (où ont longtemps coexisté évêchés grecs et latins), cinq diocèses du nord (Bisignano, San Marco Argentano, Cassano, Taverna, Nicastro) et deux du sud (Squillace, nouvel évêché latin fondé par les Normands, et Mileto, capitale comtale) dépendent de Rome; mais Alexandre III ne conserve que Bisignano, San Marco et Mileto, soumettant les autres à la métropole (latinisée par les Normands) de Reggio. En Pouille, les quatre cas connus sont spécifiques. Troia, ville la plus importante de la Capitanate, est pratiquement tout de suite rattachée directement à Rome. Melfi, d'abord soumise à Bari, est rattachée à Rome au plus tard sous Pascal $\mathrm{II}^{60}$, sans doute parce que cette première capitale normande a abrité plusieurs conciles; le siège jumeau de Rapolla (à 3 ou $4 \mathrm{~km}$ de Melfi) suit le même destin. Quant à celui de Monopoli, il est soustrait au métropolitain d'Oria, qui l'a lui-même occupé; après son rattachement à Rome, la province d'Oria-Brindisi prend un visage particulièrement original, avec ses deux sièges métropolitains plus ou moins concurrents (et vivant sous des dominations politiques différentes) et leur unique suffragant d'Ostuni.

On voit que plusieurs régions du Midi ont acquis une géographie ecclésiastique peu rationnelle, qui se fige au XII ${ }^{\mathrm{e}}$ siècle.

La principale conséquence de la prolifération des diocèses est que la majorité ont des territoires réduits, voire très réduits, et ne sont ni riches ni puissants.

56 Sur le cas de Foggia, ville qui a connu une croissance exceptionnelle au XII ${ }^{\mathrm{e}}$ siècle, mais n'a pu avoir d'évêché propre, voir Jean-Marie Martin: Foggia nel Medioevo, Galatina 1998 , pp. 38-47.

57 IP 4 p. 307.

58 IP 9 p. 231.

59 Voir Otto Vehse: Bistumsexemtionen bis zum Ausgang des 12. Jahrhunderts, dans: ZRGKanAbt 57 (1937) pp. 86-160, ici pp. 112-127.

60 Martin: La Pouille (cit. n. 40) p. 575. 
Quelques Églises avaient été bien dotées à l'époque byzantine: ainsi la métropole de Reggio, qui contrôlait en outre de nombreux monastères grecs de la province $^{61}$, ou, à un niveau plus modeste, la cathédrale grecque d'Oppido ${ }^{62}$ et la cathédrale latine d'Oria, qui possèdait des vaxalli, c'est-à-dire des parèques, en $1011^{63}$. Mais le rythme même des créations de diocèses fait que c'est surtout à l'époque normande que se constitue le temporel des cathédrales ${ }^{64}$. Il consiste en terres, parfois en hommes (plus rarement en habitats); en outre, la plupart des cathédrales touchent la dîme des revenus publics de la cité (parfois d'autres lieux $\mathrm{du}$ diocèse), ce qui les lie économiquement au pouvoir politique; certaines reçoivent les taxes spécifiques pesant sur les juifs et leurs activités (teinture et apprêt).

Mais, en général, elles ne disposent pas de véritables pouvoirs seigneuriaux. Il faut toutefois, dans ce domaine encore, faire deux exceptions en faveur des Abruzzes de tradition carolingienne et de la Sicile comtale. Dans les Abruzzes, les évêques de Chieti, Forcone, Penne et Teramo sont seigneurs de leurs cités respectives (peu importantes, à vrai dire ${ }^{65}$. En Sicile, il en va de même pour ceux de Cefalù (depuis 1145), Patti, Monreale et Catane ${ }^{66}$. Rien de tel dans la zone médiane: certes, l'archevêque de Reggio est seigneur de Bova, petite cité qui abrite un de ses suffragants ${ }^{67}$; celui de Salerne a trois ou quatre castra; mais la plupart doivent se contenter de casalia, ou de rien du tout. Un document récemment publié ${ }^{68}$ montre toutefois qu'au XIII ${ }^{\mathrm{e}}$ siècle la cathédrale de Cosenza était riche en villani rassemblés dans des baiulationes rurales.

On mesure la distance qui sépare la richesse et la puissance de l'archevêque de Milan ou de Ravenne de celles de leurs collègues du Midi, même les mieux dotés.

À cela s'ajoute une autre cause structurelle de faiblesse pour l'épiscopat méridional: l'absence prolongée d'églises publiques, c'est-à-dire la domination absolue, jusqu'au XII ${ }^{e}$ siècle, de l'église privée ${ }^{69}$. D'une part, en effet, le mot

61 André Guillou: Le brébion de la métropole byzantine de Règion (vers 1050), Cité du Vatican 1974 (Corpus des actes grecs d'Italie et de Sicile 4).

62 ID.: La Théotokos de Hagia-Agathè (Oppido) (1050-1064/1065), Cité du Vatican 1972 (Corpus des actes grecs d'Italie et de Sicile 3).

63 Annibale De Leo: Codice diplomatico Brindisino, vol. 1, éd. Gennaro Maria Monti, Trani 1940, n 2; voir Martin: La Pouille (cit. note 40) p. 707.

64 Voir ibid. pp. 599-618.

65 Kaмp: Kirche und Monarchie (cit. n. 45) pp. 4, 16, 36, 49.

66 Ibid. pp. 1043, 1078, 1184, 1203.

67 Ibid. p. 916.

68 Errico Cuozzo: La Platea di Luca arcivescovo di Cosenza (1203-1227), Avellino 2007.

69 Voir l'article classique de Hans Erich FeIne: Studien zum langobardisch-italischen Eigenkirchenrecht, Teil 2, dans: ZRGKanAbt 31 (1942) pp. 1-105; Martin: La Pouille (cit. n. 40) pp. 237-241. Sur l'organisation ecclésiastique du Midi lombard, voir aussi Bruno Ruggiero: Principi, nobiltà e Chiesa nel Mezzogiorno longobardo, Naples 1973; 
plebs n'apparaît qu'avec une extrême rareté dans le Midi; il est utilisé dans un acte copié dans le "Chronicon Vulturnense», qu'on datait de 839 et que son dernier éditeur a ramené en $764^{70}$, mais sert seulement à un évêque pour revendiquer (en vain) une église finalement jugée privée. À Bari, deux actes de la fin $\mathrm{du} \mathrm{X}^{\mathrm{e}}$ et du début du $\mathrm{XI}^{\mathrm{e}}$ siècle l'utilisent apparemment pour désigner des „Eigenkirchen“ épiscopales. D’autre part, les évêques continuent jusqu'au $\mathrm{XII}^{\mathrm{e}}$ siècle à faire des cartae libertationis, renonçant formellement à leur pouvoir canonique sur certaines „Eigenkirchen“; mais, à l'inverse de Feine, nous pensons que ces documents visent, paradoxalement, à affirmer leurs droits théoriques, auxquels ils ne renoncent jamais complètement. Il est remarquable que les papes réformateurs eux-mêmes (Nicolas II et Grégoire VII) reconnaissent parfois l'indépendance d'une „Eigenkirche“ dans ces régions ${ }^{71}$.

La découverte par l'archéologie d'églises munies d'un baptistère ${ }^{72}$ ne contredit pas ces données: il va de soi que les chrétiens étaient baptisés, même en l'absence d'églises publiques. Seule la ville de Naples, qui a conservé des institutions paléochrétiennes et imite le modèle romain, dispose de catholicae maiores, l'équivalent des tituli romains, et aussi de diaconies; mais les églises privées y sont nombreuses, et le mot plebs n'y est utilisé que très rarement ${ }^{73}$. Dans les zones grecques, l'église publique n'apparaît qu'après la conquête normande, avec le très relatif alignement disciplinaire qui s'ensuit ${ }^{74}$. Partout, il faut attendre le XII ${ }^{\mathrm{e}}$ siècle pour voir un début de normalisation, qui ne touche qu'indirectement les pouvoirs épiscopaux ${ }^{75}$, et qui consiste souvent à faire passer les églises privées sous la coupe de monastères et à remplacer la propriété des églises par le ius patronatus. Les premières paroisses publiques commencent toutefois à apparaître à l'époque normande (mais «public" signifie d'abord «seigneurial $\left.{ }^{76}\right)$.

ID.: Potere, istituzioni, chiese locali: aspetti e motivi del Mezzogiorno medioevale, dai Longobardi agli Angioini, Bologne 1977, rééd. Spolète 1991.

70 Herbert Zielinski: CDL IV-2. I diplomi dei duchi di Benevento, Rome 2003 (Fonti $65), n^{\circ} 47$.

71 IP 9 p. $368 \mathrm{n}^{\circ} 1$ (Nicolas II pour l'église des SS. Pietro e Paolo de Rutigliano, 1059), p. $355 \mathrm{n}^{\circ} 1$ (Grégoire VII pour le monastère de S. Giovanni Battista de Giovinazzo, 1078).

72 Villaggi fluviali nella Pianura Pestana del seccolo VII. La chiesa e la necropoli di S. Lorenzo di Altavilla Silentina, sous la dir. de Paolo Peduto, Salerne 1984.

73 Martin/Cuozzo/Gasparri/Villani: Regesti (cit. n. 24) nº 709 (première moitié du $\mathrm{IX}^{\mathrm{e}}$ siècle).

74 Sur l'Église grecque, renvoyons une fois pour toutes à André JACOB/Jean-Marie Martin: L'Église grecque en Italie (v. 650-v. 1050), dans: Évêques, moines et empereurs (6101054), sous la dir. de Gilbert Dagron/Pierre Riché/André VAuchez, Paris 1993 (Histoire du christianisme 4), pp. 349-371.

75 Martin: La Pouille (cit. n. 40) pp. 638-641.

76 Ibid. pp. 639-640. 
On comprend que, dans ce cadre étriqué, l'épiscopat méridional brille surtout par sa médiocrité; on en connaît d'ailleurs mal les représentants, nombreux et généralement obscurs ${ }^{77}$. Il n'attire pas l'élite sociale: en Pouille, le seul évêque que nous connaissions issu d'une famille comtale est, à l'extrême fin du XII ${ }^{\mathrm{e}}$ siècle, Gauthier de Palearia, évêque de Troia, puis archevêque de Palerme, chancelier d'Henri VI et de Frédéric II $^{78}$ (qui ne passe pour un modèle ni comme évêque, ni comme homme d'État). Quelques autres membres de l'aristocratie peuvent être cités: le siège de Salerne est occupé, pendant la seconde moitié du XII siècle, par Romuald Guarna, membre d'une famille de barons d'origine lombarde (par ailleurs médecin, chroniqueur et membre de l'entourage royal), puis par Nicolas, fils du vice-chancelier Matthieu d'Ajello; mais Salerne est la capitale politique des provinces continentales du Royaume, et de tels exemples sont rares ailleurs. En outre le Royaume ne dispose que de très rares centres sérieux de formation intellectuelle et pastorale: du Mont-Cassin sont venus Alfan de Salerne, plusieurs archevêques de Siponto, accessoirement des évêques d'Ugento ${ }^{79}$. Mais la plupart des sièges, surtout dans les petits évêchés de population lombarde, sont occupés par des notables locaux qui ne semblent pas toujours à la hauteur.

On fait aussi appel à des étrangers - surtout français ou anglais - dans les régions où l'élément local n'est pas de tradition occidentale: ainsi dans le Salento, à l'intérieur de la zone hellénophone et autour ${ }^{80}$. Saluons le rôle joué, dans la nouvelle métropole d'Acerenza, par l'archevêque Arnaud (un Français d'après son nom), chargé par Alexandre II d'établir cinq évêchés à choisir sur une liste de douze sites, et qui s'est acquitté avec fermeté et ponctualité de cette mission ${ }^{81}$. En Sicile, Geoffroy Malaterra ${ }^{82}$ expose qu'on a choisi comme premiers évêques l'„Allobroge“ Gerland (originaire de la Franche-Comté) à Agrigente, le Provençal Roger à Syracuse, le Breton Ansger à Catane; au XII siècle, le recrutement

77 Norbert Kамp: Soziale Herkunft und geistlicher Bildungsweg der unteritalienischen Bischöfe in normannisch-staufischer Zeit, dans: Le istituzioni ecclesiastiche della societas Christiana dei secoli XI-XII. Diocesi, pievi e parrocchie. Atti della sesta settimana internazionale di studio Milano 1974, Milan 1977, pp. 89-116.

78 ID.: Kirche und Monarchie (cit. n. 45) pp. 509-514 et 1122-1125.

79 Martin: La città di Siponto (cit. n. 52); id.: Le Mont-Cassin et l'évêché d'Ugento, dans: Medievalia et Vaticana. Études offertes à Louis Duval-Arnould, réunies par ID./ Bernadette Martin-Hisard/Agostino Paravicini Bagliani, Florence 2008, pp. 311 322.

80 Citons les prélats, probablement français par leur nom, Hugues et Bérard d'Otrante, Drogon et Albert de Tarente, Baudry de Gallipoli; Martin: La Pouille (cit. n. 40) p. 525.

81 Ibid. p. 569.

82 Ernesto Pontieri: De rebus gestis Rogerii Calabriae et Siciliae comitis et Roberti Guiscardi ducis fratris eius auctore Gaufredo Malaterra monacho benedictino, Bologne 1927 (Rerum Italicarum Scriptores 5/1), IV, 7. 
des évêques siciliens (dont certains jouent un rôle politique de premier plan, comme familiares regis) est encore largement international (même si Gauthier Ophamil, archevêque de Palerme de 1169 à 1190, n'était pas anglais ${ }^{83}$ ). Enfin, surtout avant 1130, le pape a parfois son mot à dire dans le choix des évêques: c'est lui qui installe des Cassinésiens sur le siège de Siponto; il envoie aussi quelques cardinaux (tel Baialardus, que Calixte II charge de la métropole de Brindisi-Oria $^{84}$ ).

Les saints évêques de l'époque de la réforme sont particulièrement rares et peu typés, à l'exception de Bérard des Marses, dont le diocèse n'était pas encore séparé du territoire pontifical ${ }^{85}$ : citons Jean de Montemarano, Bernard de Carinola, Albert de Montecorvino ${ }^{86}$, Richard d'Andria, Roger de Cannes ${ }^{87}$ et, du côté grec, Luc d'Isola Capo Rizzuto. Ajoutons que le respect par le clergé (prêtres, diacres, sous-diacres) du célibat semble dans le Midi en retard sur l'évolution générale ${ }^{88}$.

\section{Les Églises, Rome et le pouvoir politique}

Les rapports entre les autorités politiques et religieuses constituent une autre originalité du Midi. Il y a peu de choses à dire avant les Normands, c'est-à-dire aussi avant le début de la réforme romaine: les autorités politiques interviennent normalement dans le choix des prélats, qu'il s'agisse des agents de l'Empereur byzantin ou des princes lombards (l'évêque de Bénévent se recrute souvent dans la famille princière). Entre les premiers Normands et la papauté réformatrice, une alliance objective finit par se nouer ${ }^{89}$. Mais les principes réformateurs ne

83 Voir Kamp: Kirche und Monarchie (cit. n. 45) pp. 1112-1119.

84 Martin: La Pouille (cit. n. 40) p. 577.

85 Voir Jacques Dalarun: Bérard des Marses. Un modèle épiscopal grégorien, dans: Liber Largitorius. Études d'histoire médiévale offertes à Pierre Toubert par ses élèves, réunies par Dominique Barthélemy/Jean-Marie Martin, Genève 2003, pp. 59-85.

86 Voir Jean-Marie Martin/Ghislaine Noyé: La cité de Montecorvino en Capitanate et sa cathédrale, dans: MEFRM 94 (1982) pp. 513-549. Sur les saints évêques: Amalia Galdi: Santi territori poteri e uomini nella Campania medievale, Salerne 2004.

87 Voir Jean-Marie Martin: Les modèles paléochrétiens dans l'hagiographie apulienne, dans: Bulletin de la Société nationale des Antiquaires de France (1990) pp. 67-86.

88 Voir la décrétale d'Alexandre III à l'évêque de Salpi (dans le nord de la Pouille) demandant que les prêtres et diacres mariés abandonnent leurs épouses, que les sous-diacres pourront les garder avec eux; il n'est pas question de sanctions: Walther Holtzmann: Kanonistische Ergänzungen zur Italia Pontificia V-X, dans: QFIAB 38 (1958) pp. 67 $175 \mathrm{n}^{\circ} 190$.

89 Voir Josef Dé́r: Papsttum und Normannen. Untersuchungen zu ihren lehnsrechtlichen und kirchenpolitischen Beziehungen, Cologne/Vienne 1972 (Studien und Quellen zur Welt Kaiser Friedrichs II. 1). 
sont pas faciles, on l'a vu, à appliquer dans le Midi. En outre, dans cette alliance, le pape est le plus souvent en position d'assisté: il se réfugie parfois dans le Midi pour échapper à l'empereur germanique, fait même intervenir les Normands à Rome en 1084. On a vu que son rôle dans la constitution du réseau épiscopal n'était pas dominant dans le Midi continental. En Sicile, il est nul, puisque le comte, puis roi - seul fondateur d'évêchés - prétend depuis 1098 à la fonction permanente d'unique légat pontifical dans l'île ${ }^{90}$, qui est de ce fait pratiquement coupée de Rome (jusqu'à l'unité italienne); le pape n'envoie de légats qu'auprès du souverain, à Palerme ${ }^{91}$.

Roger II étend, en fait, cette pratique à l'ensemble du Royaume. Selon Jean de Salisbury, rex enim aliorum more tirannorum ecclesiam terre sue redegerat in servitutem, nec alicubi patiebatur electionem libere celebrari, sed prenominabat quem eligi oporteret, et ita de officiis ecclesiasticis sicut de palacii sui muneribus disponebat ${ }^{22}$. Pendant un temps, le pape refuse de consacrer les évêques 'élus' par Roger II (comme plus tard par Frédéric II). Les pouvoirs du roi sont officialisés par le 'concordat' de Bénévent, conclu en 1156 au lendemain de la victoire militaire de Guillaume ${ }^{\text {er }}$ sur Hadrien IV $^{93}$. Le roi admet, dans la seule partie continentale du Royaume, les appels à Rome, les transferts d'évêques par le pape, qui peut faire des consécrations et des visites; mais il ne peut tenir de concile dans la ville où le roi réside (en fait, il n'en tient plus dans le Royaume, où il n'envoie même plus de légat, si ce n'est à la cour); le roi a un droit de veto absolu sur les élections épiscopales, puisqu'il peut refuser l'élection d'un proditor, d'une [persona] inimica ou simplement magnificentie nostre hodiosa. Le 'concordat' de Gravina, en $1192^{94}$, supprime la clause hodiosa et réaffirme le droit pour le pape d'envoyer des légats et de réunir des conciles (dans la seule partie continentale du Royaume: la Sicile reste fermée), mais il n’est pas appliqué, non

90 IP 10 p. 188 n 86 . Voir Salvatore Fodale: Comes et legatus Siciliae, Palerme 1970.

91 Voir Jean-Marie Martin: Quelques réflexions sur les relations d'Alexandre III avec l'Italie méridionale, dans: Papauté, Monachisme et Théories politiques. Études d'histoire médiévales offertes à Marcel Pacaut, 1: Le pouvoir et l'institution ecclésiale, sous la dir. de Pierre Guichard/ Marie-Thérèse Lorcin/Jean-Michel Poisson/Michel Rubellin, Lyon 1994, pp. 111-121.

92 Ioannis Saresberiensis: Historia pontificalis, ed. Marjorie M. Chibnall, Londres e. a. 1956, XXXIII, p. 65. Voir Norbert Kamp: Der unteritalienische Episkopat im Spannungsfeld zwischen monarchischer Kontrolle und römischer libertas von der Reichsgründung Rogers II. bis zum Konkordat von Benevent, dans: Società, potere e popolo nell'età di Ruggero II. Atti delle terze Giornate normanno-sveve (Bari 1977), Bari 1979, pp. 99-132.

93 Horst Enzensberger: Guillelmi I. regis diplomata, Cologne/Weimar/Vienne 1996 (Codex diplomaticus regni Siciliae 1/3), $\mathrm{n}^{\circ} 12$.

94 Herbert Zielinski: Tancredi et Willelmi III regum diplomata, Cologne/Vienne 1982 (Codex diplomaticus regni Siciliae 1/5), $\mathrm{n}^{\circ} 25$. 
plus que le projet d'accord avec Constance ${ }^{95}$. Ainsi le royaume de Sicile, dont le souverain est vassal du Saint-Siège et dont le territoire jouxte celui de l'État pontifical en formation, est-il l'un des États les plus fermés, sinon au principe de la réforme de l'Église, du moins aux interventions pontificales que celle-ci soustend et même à bien des aspects de la libertas Ecclesiae. Cette situation sera poussée à l'extrême par Frédéric II au siècle suivant.

De semblables contraintes touchent les monastères, du moins les plus importants ${ }^{96}$. Un acte de 1174, dont la copie a été ajoutée au «Registrum Petri Diaconi», déjà remarqué et publié par Chalandon ${ }^{97}$, montre comment se faisait l'élection de l'abbé du Mont-Cassin (monastère directement rattaché à Rome et jouissant officiellement du privilège de libre élection) à l'époque de Guillaume II: le roi demande aux moines d'élire secrètement (et unanimement) l'un d'entre eux, dont trois ou quatre représentants de la communauté viendront soumettre le nom à l'approbation royale; mais si le souverain fait un autre choix, ces représentants devront l'entériner.

Le monachisme revêt des formes assez différentes selon les traditions régionales. Naples abrite de nombreux et importants monastères urbains, masculins et féminins, latins et 'grecs' (ces derniers suivent le 'règle de saint Basile' $)^{98}$. Dans les principautés lombardes et les Abruzzes se trouvent quelques très grandes abbayes (le Mont-Cassin, S. Vincenzo al Volturno, S. Clemente a Casauria) qui, après une crise profonde à la fin du $\mathrm{IX}^{\mathrm{e}}$ siècle, ont repris vie au $\mathrm{X}^{\mathrm{e}}$ en construisant des seigneuries pratiquement indépendantes avec l'appui des souverains. La Pouille ne possède que de petits monastères latins, la Calabre des monastères grecs, qui semblent également peu importants. Dans la Sicile musulmane ne survivent que de très rares monastères grecs.

Les seigneurs normands en Pouille, le duc en Pouille et en Calabre, le comte en Sicile fondent de nouveaux établissements; en Pouille, certains disposent de droits seigneuriaux, mais rarement de l'ensemble des droits seigneuriaux sur une localité. Pratiquement aucun établisssement méridional n'est affilié à une congrégation extérieure: si les pratiques et la spiritualité clunisiennes ont touché

95 Gerhard BAAKEN: Ius Imperii ad Regnum. Königreich Sizilien, Imperium Romanum und Römisches Papsttum vom Tode Kaiser Heinrichs VI. bis zu den Verzichterklärungen Rudolfs von Habsburg, Cologne/Weimar/Vienne 1993 (Beih. RI 11), pp. 41sq.

96 Permettons-nous de renvoyer à Jean-Marie Martin: Les seigneuries monastiques, dans: Nascita di un regno. Poteri signorili, istituzioni feudali e strutture sociali nel Mezzogiorno normanno (1130-1194). Atti delle $17^{\mathrm{e}}$ Giornate normanno-sveve (Bari 2006) sous la dir. de Raffaele Licinio/Francesco Violante, Bari 2008, pp. 177-205.

97 Registrum Petri Diaconi, $\mathrm{n}^{\circ} 171 \mathrm{E}$, éd. Chalandon: Histoire de la domination normande (cit. n. 1) vol. 2 p. 591 n. 2.

98 Voir Jean-Marie Martin: Hellénisme politique, hellénisme religieux et pseudo-hellénisme à Naples (VII $-\mathrm{XII}{ }^{\mathrm{e}}$ siècle), dans: Nea Rhōmē 2 (2005) (Miscellanea Vera von Falkenhausen), pp. 59-77. 
le Mont-Cassin au milieu du $\mathrm{X}^{\mathrm{e}}$ siècle et Cava dès sa fondation (au début du $\mathrm{XI}^{\mathrm{e}}$ ) et se répandent dans leurs dépendances respectives, presque aucun monastère méridional, même les fondations de Robert Guiscard peuplées de Normands, n'a de lien institutionnel avec les abbayes françaises ${ }^{99}$. À l'époque monarchique, la coupure entre l'Italie méridionale et le reste de l'Occident est encore plus nette: le mouvement cistercien touche à peine le Royaume au XII ${ }^{e}$ siècle - sans doute en partie à cause de l'hostilité qui a opposé saint Bernard à Roger II à l'occasion du schisme pontifical de 1130. Le monachisme réformé du XII siècle apparaît ici sous la forme de petites congrégations locales: fondations de Guillaume de Verceil (le Goleto et Montevergine), de Jean de Matera (Pulsano), de Jean de Tufara (S. Maria del Gualdo) ${ }^{100}$. Le roi regroupe des monastères grecs sous un archimandrite (celui de Messine, puis celui de Carbone), mais ces congrégations (sauf celle de Pulsano) restent internes au Royaume.

La monarchie favorise les monastères (qu'on pense à la fondation de Monreale); en Sicile, d'ailleurs, plusieurs cathédrales sont confiées à des Bénédictins ou à des chanoines réguliers (Patti-Lipari, Catane, Cefalù, Monreale); sur le continent, les monastères participent, on l'a dit, à la réforme de l'Église en recevant des „Eigenkirchen“. La monarchie réduit la puissance politique et militaire des grandes abbayes lombardes, mais ne les empêche pas de s'enrichir: le contrôle des élections abbatiales les rend d'ailleurs généralement dociles.

\section{Églises latines et Églises grecques}

Le Midi possède encore un autre caractère original par rapport au reste de l'Italie, et même de l'Occident: il abrite des Églises latines, mais aussi grecques. Ce point mérite d'être présenté et expliqué; mais, à mon avis, il n'est en rien

99 Une exception fugitive, en Sicile, où S. Maria Iummaris de Sciacca a sans doute été rattachée à Cluny; voir Glauco Cantarella: Osservazioni a proposito di un monastero cluniacense in Sicilia, dans: Benedictina 25 (1978) pp. 109-126.

100 Voir Martin: La Pouille (cit. note 40) pp. 683-689) Francesco Panarelli: Dal Gargano alla Toscana: il monachesimo riformato latino dei Pulsanesi (secoli XII-XIV), Rome 1997 (Nuovi studi storici 38); Jean-Marie MarTin: L'érémitisme grec et latin en Italie méridionale ( $\mathrm{X}^{\mathrm{e}}-\mathrm{XIII}{ }^{\mathrm{e}}$ siècle), dans: Ermites de France et d'Italie (XI $-\mathrm{XV}^{\mathrm{e}}$ siècle), sous la dir. d'André VAuchez, Rome 2003 (Collection de l'École française de Rome 313), pp. 175-198; Charles Hilken: Memory and Comunity in Medieval Southern Italy. The History, Chapter Book and Necrology of Santa Maria del Gualdo Mazzocca, Toronto 2008 (Studies and Texts 157). C'est grâce à IP 9 p. 108, que j'ai connu l'existence du cartulaire de S. Maria del Gualdo, que j'ai publié: Jean-Marie Martin: Le cartulaire de S. Matteo di Sculgola en Capitanate (Registro d'istrumenti di S. Maria del Gualdo) (1177-1239), 2 vol., Bari 1987 (Codice diplomatico Pugliese 30). 
responsable des antagonismes ou de la confusion que j'ai tenté de décrire, comme on le croit souvent.

Je pense que c'est de Sicile (et non de Grèce) qu'est arrivée, sans doute surtout à l'époque de la conquête de l'île par les Arabes, une population grecque dans le Midi continental ${ }^{101}$. La Sicile, en effet, dont la partie orientale n'avait jamais complètement abandonné la langue grecque depuis la plus haute Antiquité, semble s'être largement réhellénisée à l'époque de la domination byzantine ${ }^{102}$.

La décision impériale de faire passer, au début du VIII ${ }^{\mathrm{e}}$ siècle, la Sicile (et la Calabre qui en dépendait administrativement) du patriarcat romain à celui de Constantinople est, certes, une mesure agressive vis-à-vis du pape qui commençait à se tourner vers les Francs (et qui l'a ressentie comme telle); elle ne signifie pas que toutes les églises siciliennes (et encore moins calabraises) soient déjà grecques; notons qu'au VII siècle le pape lui-même a placé un certain nombre de Grecs de Rome à des postes importants dans tout l'Occident (Augustin de Canterbury). À partir du IX siècle, la Calabre méridionale et orientale est grecque; elle abrite les deux métropoles de Reggio et de Santa Severina; c'est, semble-t-il, à partir de ces régions que l'hellénisme a gagné la partie occidentale du Salento: l'évêché de Gallipoli et même, plus tard, celui de Castro (Palaiokastron $)^{103}$ dépendent de la métropole de Santa Severina, tandis qu'Otrante, archevêché autocéphale, est au contraire en relations directes avec les Balkans. Otrante, comme Syracuse, était assez profondément hellénisée pour connaître l'iconoclasme (qui, à notre avis, n’a pas touché Naples, du moins sous sa forme proprement religieuse $\left.{ }^{104}\right)$. Au total, l'appartenance à l'une ou l'autre Église dépend de la culture dominante de la population: les zones grecques du sud abritent des Églises grecques, les zones latines du nord, des Églises latines.

Entre les deux zones, les frictions semblent avoir été assez rares. En 887/88, au lendemain de la conquête byzantine, le patrice Georges a tenté d'installer de force un évêque grec à Tarente, mais les protestations du pape Étienne V (sans doute appuyé par la majorité de la population) ont fait échouer cette manœuvre ${ }^{105}$; désormais Tarente n'aura plus que des prélats latins, alors que la ville, proche du Salento hellénophone, abrite une forte minorité grecque. Au $\mathrm{XI}^{\mathrm{e}}$ siècle, celle-ci est prise en charge par une sorte de chorévêque grec, qui ne

101 Jean-Marie MARTin: Une origine calabraise pour la Grecìa salentine?, dans: RSBN 32 33 (1985-1986) pp. 51-63.

102 La Sicile byzantine est le sujet de la thèse, encore inédite, de Vivien Prigent (Université de Paris-IV).

103 André Jасов: Le Vat. Gr. 1238 et le diocèse de Paléocastro, dans: RSCI 25 (1971) pp. 516-523.

104 Martin: Hellénisme politique (cit. n. 98).

105 IP 9 p. $437 \mathrm{n}^{\text {os }} 5-6$. 
fait pas vraiment concurrence à l'archevêque latin ${ }^{106}$; à l'époque normande, il semble que le monastère de S. Pietro Imperiale, soumis au Mont-Cassin depuis 1080, serve de lieu de culte pour la population grecque de la ville ${ }^{107}$.

Autres territoires disputés au $\mathrm{X}^{\mathrm{e}}$ siècle, du moins en théorie: ceux dans lesquels l'élément hellénophone progresse, dans le nord de la Calabre et en Basilicate. Certains évêchés jusqu'alors latins sont considérés comme grecs; parmi les nouveaux suffragants lucaniens de la métropole d'Otrante prévus en 968, on trouve par exemple Acerenza; mais rien ne dit que ce siège ait été réellement hellénisé, ni même qu’il ait alors existé: celui de Gravina, qui devait aussi dépendre de la métropole d'Otrante, ne sera créé qu'à la fin du $\mathrm{XI}^{\mathrm{e}}$ siècle par le nouvel archevêque latin d'Acerenza; le seul evêché grec effectivement créé dans cette région semble être celui de Tursi; sa latinisation, apparemment difficile, à l'époque normande, s'accompagnera de son déplacement à Anglona ${ }^{108}$.

On voit que les zones et les moments de friction sont peu nombreux. Dans la région salernitaine, comme à Tarente, l'Église grecque est représentée par quelques chorévêques dont la présence n'altère pas le réseau épiscopal. En revanche, les autorités byzantines n’ont jamais cherché à helléniser les évêchés des régions latines qu'elles dominaient, même celui de Bari, capitale du catépanat. Le caractère grec - ou pro-grec - de la metropole de Trani, qui aurait fait contrepoids à Bari, est une légende: Jean, archevêque de Trani (et aussi de Siponto), destinataire de la fameuse lettre polémique de Léon d'Ohrid au moment du schisme, est un Latin, partisan des azymes et sa déposition n’a rien à voir avec le schisme, passé ici, comme ailleurs, pratiquement inaperçu ${ }^{109}$. On a vu que le catépan avait collaboré avec Rome pour faire naître les nouveaux évêchés latins de Capitanate. Il n'y a donc pas de concurrence entre les deux Églises, et leur coexistence n'est pas cause des originalités structurelles précédemment signalées.

À l'époque normande, le paysage change un peu, mais pas énormément. En Sicile, où la population grecque (et arabe chrétienne de rite byzantin ${ }^{110}$ ) est nombreuse, les fondations de monastères grecs (dont le S. Salvatore de Messine)

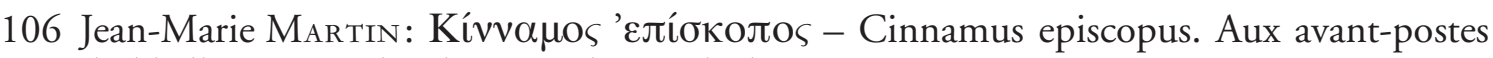
de l'hellénisme sud-italien vers l'an mil, dans: RSBN 27 (1990) [Rome 1991] pp. 89_ 99.

107 Martin: Le Mont-Cassin et l'évêché d’Ugento (cit. n. 79).

108 Santa Maria di Anglona. Atti del Convegno internazionale di studio (Potenza-Anglona, 13-15 giugno 1991), sous la dir. de Cosimo Damiano Fonseca/Valentino Pace, Galatina 1996.

109 Jean-Marie Martin: Jean, archevêque de Trani et de Siponto, syncelle impérial, dans: Byzance et ses périphéries (Mondes grec, balkanique et musulman). Hommage à Alain Ducellier, Toulouse 2004, pp. 123-130.

110 Henri Bresc/Annliese Nef: Les Mozarabes de Sicile (1100-1300), dans: Cavalieri alla conquista del Sud. Studi sull'Italia normanna in memoria di Léon-Robert Ménager, sous la dir. d'Errico Cuozzo/Jean-Marie Martin, Ariano Irpino 1998, pp. 134-156. 
sont plus nombreuses que celles d'abbayes latines ${ }^{111}$. Elles ne sont pas négligeables non plus dans les zones hellénophones du continent: la Théotokos du Patir près de Rossano en Calabre, S. Nicola de Casole près d'Otrante, S. Vito del Pizzo près de Tarente. D'autre part la discipline grecque, qui admet le mariage des prêtres, est maintenue: dans les diocèses possédant un clergé grec, les privilèges pontificaux étendent le privilège du for non seulement aux prêtres grecs, mais aussi à leurs enfants nés après leur ordination ${ }^{112}$. En revanche, on cherche à latiniser l'épiscopat, même dans les régions purement grecques (Reggio, Otrante), d'autant que la Sicile et la Calabre sont réintégrées au patriarcat romain. Tous les diocèses créés en Sicile sont latins. On laisse toutefois des prélats grecs dans de petits diocèses du sud de la Calabre (et même dans la métropole de Santa Severina, qui a perdu tout droit sur le Salento). Deux cas sont plus difficiles: à Rossano, en 1093, la population empêche la latinisation du siège; à Gallipoli, on ne connaît qu'un évêque latin au début du XII siècle; ses successeurs sont grecs jusqu'à l'époque angevine (l'un écrit au patriarche de Constantinople pour résoudre un point de liturgie ${ }^{113}$; au dernier quart du $\mathrm{XII}^{\mathrm{e}}$ siècle, les Latins commencent à rogner les droits de l'évêque en faveur du monastère bénédictin de $S$. Maria de Nardò (probablement fondé à la fin du $\mathrm{XI}^{\mathrm{e}}$ siècle) ${ }^{114}$ qui finit par devenir le siège d'un nouveau diocèse latin aux $\mathrm{XIV}^{\mathrm{e}}$ et $\mathrm{XV}^{\mathrm{e}}$ siècles ${ }^{115}$; mais Gallipoli est le dernier diocèse à évêque grec du Salento. En dépit de l'acculturation progressive des populations grecques ${ }^{116}$, le rite grec est utilisé en Calabre et dans la Terre d'Otrante jusqu'à l'époque moderne ${ }^{117}$ (il ne l'est plus aujourd'hui que par des Albanais arrivés plus tard en Calabre et en Sicile), et le vocabulaire grec n'a pas encore fini de disparaitre des dialectes du sud de la Calabre et du Salento. La domination latine n'a donc pas plus détruit

111 Lynn Townsend White, Jr.: Latin Monasticism in Norman Sicily, Cambridge (Mass.) 1938, pp. 41-43.

112 Martin: La Pouille (cit. n. 40) p. 616.

113 André Јасов: Gallipoli bizantina, dans: Paesi e figure del vecchio Salento III, sous la dir. d'Aldo De Bernart, Galatina 1989, pp. 281-312.

114 Walther Holtzmann: Aus der Geschichte von Nardò in normannischer und staufischer Zeit, dans: NAG (1961) pp. 35-82.

115 IP 9 p. 414.

116 Récemment étudiée dans une thèse, sous presse á l’École française de Rome, de l'Université de Paris-I par Annick Peters-Custot.

117 Jules GaY: Notes sur la conservation du rite grec dans la Calabre et dans la Terre d'Otrante au XIV ${ }^{\mathrm{e}}$ siècle. Listes de monastères basiliens (d'après les archives du Vatican), dans: BZ 4 (1895) pp. 59-66; iD.: Étude sur la décadence du rite grec dans l'Italie méridionale à la fin du XVI ${ }^{\mathrm{e}}$ siècle, dans: Revue d'histoire et de littérature religieuses 2 (1897) pp. 481-495; Zacharias N. Tsirpantis: Memorie storiche sulle comunità e chiese greche in Terra d'Otranto (XVI secolo), dans: La Chiesa greca in Italia dall'VIII al XVI secolo. Atti del Convegno storico interecclesiale (Bari 1969), 3 vol., Padoue 1972 1973 (Italia sacra 21), pp. 845-877. 
(du moins à court et moyen terme) le rite grec que la domination byzantine n'avait détruit le rite latin, et la coexistence d'Églises grecques et latines ne nous semble donc pas avoir été un facteur important dans l'évolution décrite.

\section{Conclusion}

Le fait fondamental, dans cette histoire, est à nos yeux la double coupure du haut Moyen Âge: crise profonde des $\mathrm{VI}^{\mathrm{e}}-\mathrm{VIII}{ }^{\mathrm{e}}$ siècles et isolement vis-à-vis des deux empires aux VIII ${ }^{\mathrm{e}}$-IX ${ }^{\mathrm{e}}$ siècles pour la plupart des régions continentales; en Sicile, qui n'a pas été affectée par ces phénomènes, c'est l'occupation musulmane qui a donné à l'île une histoire originale.

La crise des $\mathrm{VI}^{\mathrm{e}}$-VIII ${ }^{\mathrm{e}}$ siècles a touché inégalement le Midi, épargnant (relativement) les Abruzzes et les duchés tyrrhéniens; dans les autres régions, elle entraîne une diminution considérable du nombre des évêchés et, partant, une décadence de l'institution épiscopale et même de la notion d'église publique; l'église privée jouit d'un quasi-monopole pastoral, renforçant le pouvoir des laïques (notamment des princes lombards) sur l'institution ecclésiale.

Aux $\mathrm{X}^{\mathrm{e}}-\mathrm{XII} \mathrm{e}^{\mathrm{e}}$ siècles, un réseau épiscopal se reconstitue dans des conditions anarchiques: ni avant, ni après la réforme du $\mathrm{XI}^{\mathrm{e}}$ siècle, Rome n'a les moyens d'imposer ses vues à des autorités politiques locales au demeurant très différentes les unes des autres; c'est au moment de la réforme romaine que la désagrégation des pouvoirs publics atteint son maximum dans le Sud; de ce point de vue, l'Église grecque jouissait de conditions plus favorables dans le cadre de l'Empire byzantin. En outre, le pape se place sous la protection des Normands durant les luttes contre les empereurs germaniques. Aussi, paradoxalement, le fait pour l'Italie normande d'avoir une frontière commune avec le territoire administré par le pape favorise le non-respect de la libertas Ecclesiae: c'est au lendemain d'une guerre victorieuse contre le pape (qui soutenait ses ennemis intérieurs et extérieurs) que Guillaume ${ }^{\mathrm{er}}$ a pu imposer le ,concordat ' de Bénévent, qui fermait le Royaume aux interventions pontificales.

Ainsi s'est confirmée l'originalité du Midi, au moment où, dans le reste de l'Occident, la réforme de l'Église mettait un peu d'ordre dans l'institution ecclésiale et dans ses rapports avec les puissances temporelles. Cette auto-exclusion relative a des conséquences dans tous les domaines de la vie religieuse, et notamment dans le développement du monachisme.

Mais l'originalité globale du Midi ne signifie pas homogénéité interne: on a déjà évoqué les particularismes des Abruzzes et de la Sicile. De même, Naples conserve des caractères originaux. Ces spécificités ne sont d'ailleurs pas limitées au domaine ecclésiastique.

Sans la grande entreprise de Paul Kehr, bien des points aujourd'hui acquis seraient longtemps restés dans l'ombre. Le travail accompli par son équipe 
déborde en outre largement, comme on l'a dit, le but de la recherche. Il a ensuite suscité des recherches nouvelles. Parmi les savants qui ont œuvré dans le sillage de Kehr, signalons en particulier Walther Holtzmann, responsable de deux des volumes méridionaux de l'Italia Pontificia, qui a apporté de nouveaux et importants documents, dont nous avons signalé certains au passage. Saluons aussi la mémoire de Norbert Kamp, dont $j$ 'avais fait la connaissance il y a près de quarante ans, à l'Archivio capitolare de Troia. Chronologiquement, sa grande œuvre porte sur la période immédiatement postérieure à celle dont s'est occupé Kehr. Mais il remonte, en fait, assez loin dans le XII siècle; en outre, le tableau qu'il donne de chaque évêché, de son territoire, de ses biens, de ses revenus, de ses droits ${ }^{118}$ complète parfaitement les données de l'Italia Pontificia.

Le travail n'est pas terminé. Même si nous n'avons pas repéré de lacune dans la présentation des documents pontificaux dans l'œuvre de Kehr, et en dépit des nombreuses pertes déjà signalées, les autres documents inédits sont encore nombreux dans le Midi ${ }^{119}$. L'édition de tels documents n'apportera sans doute pas de nouveautés dans le domaine des actes pontificaux; mais elle aidera à mieux les comprendre.

\section{Éditions récentes de textes et d'actes méridionaux cités dans l'Italia Pontificia}

Herbert Bloch: Monte Cassino in the Middle Ages, 3 vol., Rome 1986.

Chronica monasterii Casinensis, ed. Hartmut Hoffmann, Hannover 1980 (MGH SS 34).

Giuseppe Coniglio: Le pergamene di Conversano, 1 (901-1265), Bari 1975 (Codice diplomatico Pugliese 20).

Pasquale Cordasco/Maria Cannataro Cordasco/Antonio D'Itollo: Pergamene angioine di Terra di Bari, Bari 1981 (Codice diplomatico Pugliese 24).

Pasquale Corsi: Le pergamene dell'archivio capitolare di San Severo (secoli XII-XV), Bari 1974.

Edoardo D'Angelo: Falcone di Benevento, Chronicum Beneventanum. Città e feudi nell'Italia dei Normanni, Tavarnuzze (Impruneta, Firenze) 1998.

Pietro De Leo: Le carte del monastero dei Santi Niccolò e Cataldo in Lecce (secc. XIXVII), Lecce 1978 (Centro di studi salentini. Monumenti 2).

118 Voir en outre les deux importants articles, comprenant des éditions de textes, de Dieter Girgensohn/Norbert Kamp: Urkunden und Inquisitionen des 12. und 13. Jahrhunderts aus Patti, dans: QFIAB 45 (1965) pp. 1-240; EID.: Urkunden und Inquisitionen der Stauferzeit aus Tarent, dans: QFIAB 41 (1961) pp. 137-234.

119 On connaît ainsi l'importance de l'Archivo ducal de Medinaceli, à Tolède, qui contient de nombreux actes de monastères siciliens et calabrais. Voir Cristina RognONi: Les actes privés grecs de l'Archivo ducal de Medinaceli (Tolède), I. Les monastères de SaintPancrace de Briatico, de Saint-Philippe-de-Boiôannès et de Saint-Nicolas-des-Drosi (Calabre, $\mathrm{XI}^{\mathrm{e}}-\mathrm{XII}^{\mathrm{e}}$ siècles), Paris 2004. 
Ludovica De Nava/Dione Clementi: Alexandri Telesini abbatis Ystoria Rogerii regis Sicilie Calabrie atque Apulie, Rome 1991 (Fonti 112).

Horst Enzenberger: Guillelmi I. regis diplomata, Cologne/Weimar/Vienne 1996 (Codex diplomaticus regni Siciliae 1/3).

Enrico Fuselli: Il Chronicon di S. Bartolomeo di Carpineto, L'Aquila 1996 (Documenti per la storia d'Abruzzo) (v. Pio).

Oronzo Giordano: Documenti papali dei secc. XI e XII relativi alle diocesi di Brindisi e di Oria, dans: Studi di storia pugliese in onore di Giuseppe Chiarelli, vol. 1, Galatina 1972 , p. $423-438$.

Dieter Girgensohn/Norbert Kamp: Urkunden und Inquisitionen der Stauferzeit aus Tarent, dans: QFIAB 41 (1961) p. 137-234.

Herbert Houben: Die Abtei Venosa und das Mönchtum im normannisch-staufischen Süditalien, Tübingen 1995 (Bibliothek des Deutschen Historischen Instituts in Rom 80).

Ioannis Saresberiensis: Historia pontificalis, ed. Marjorie M. Chibnall, Londres/ Édimbourg/Paris/Melbourne/Toronto/New York 1956.

Jean-Marie Martin: Les chartes de Troia., vol. 1 (1024-1266), Bari 1976 (Codice diplomatico Pugliese 30).

Jean-Marie Martin: Le cartulaire de S. Matteo di Sculgola en Capitanate (Registro d'istrumenti di S. Maria del Gualdo) (1177-1239), 2 vol., Bari 1987 (Codice diplomatico Puglisese 21).

Jean-Marie Martin (con uno studio di Giulia Orofino): Chronicon Sanctae Sophiae (cod. Vat. Lat. 4939), 2 vol., Rome 2000 (Fonti per la storia dell'Italia medievale. Rerum Italicarum Scriptores 3).

Marguerite Mathieu: Guillaume de Pouille, La geste de Robert Guiscard, Palerme 1976 (Istituto siciliano di Studi bizantini e neoellenici. Testi e monumenti. Testi 4).

Léon-Robert Ménager: Recueil des actes des ducs normands d'Italie (1046-1127), vol. 1: Les premiers ducs (1046-1087), Bari 1981.

Dag Norberg: S. Gregorii Magni Registrum epistularum, libri I-XIV, 2 vol., Turnhout 1982 (CChr SL 140-140A).

Michela PAstore: Le pergamene di San Giovanni Evangelista in Lecce, Lecce 1970 (Centro di studi salentini. Monumenti 1).

Armando Petrucci: Codice diplomatico del monasterio benedettino di S. Maria di Tremiti (1005-1237), 3 vol., Rome 1960 (Fonti 98).

Alexandri monachi Chronicorum liber Sancti Bartholomei de Carpineto, ed. Berardo PIo, Rome 2001 (Fonti per la Storia dell'Italia medievale. Rerum Italicarum Scriptores 5) (v. FusELLI).

Ulla Westerbergh: Chronicon Salernitanum. A critical edition with studies on literary and historical sources and on langage, Stockholm/Lund 1956 (Studia Latina Stockholmiensia 3).

Herbert Zielinski: Tancredi et Willelmi III regum diplomata, Cologne/Vienne 1982 (Codex diplomaticus regni Siciliae 1/5). 


\section{Zusammenfassung}

Das südliche Italien (Königreich Sizilien im 12. und 13. Jahrhundert) nimmt einen Teil von Band 4, die gesamten Bände 8 und 9 sowie den Großteil des Bandes 10 der IP ein. Darin sind alle verfügbaren Unterlagen aufgenommen (mit kleinen Fehlern).

Viele frühchristliche Bistümer verschwanden während der Krise des 6. und 7. Jahrhunderts; die Wiederherstellung des bischöflichen Netzes im 10.-12. Jahrhundert hingegen multiplizierte die kleinen und kleinsten Diözeses. Sie wurden in ungleichen Provinzen zusammengeführt. Die Überzahl der privaten Kirchen bis zum 12. Jahrhundert zeigt deutlich die Schwäche der einzelnen Bischöfe. Die Fremdeinflüsse im Mönchtum sind schwach.

Zur Zeit der Kirchenreform wurden die Kirchen des Königreichs durch die politische Macht der Normannen dem Herrscher unterworfen. Allerdings löste die Koexistenz von lateinischen und griechischen Kirchen keine spezifischen Probleme aus. 
Bereitgestellt von | De Gruyter / TCS

Angemeldet | 217.89.40.26

Heruntergeladen am | 21.12.12 10:48 


\title{
Gli interventi della Chiesa di Roma nella provincia ecclesiastica milanese
}

\author{
Maria Pia Alberzoni
}

\section{Gli studi di Paul Kehr}

Nei „Nachträge zu den Papsturkunden Italiens“ apparsi nel 1912 Paul Kehr, oramai prossimo alla pubblicazione del VI volume dell'„Italia Pontificia“, stese un bilancio complessivo delle ricerche svolte negli archivi milanesi e lombardi, per le quali tanto era debitore a Hermann Kalbfuss. E in tale circostanza il Kehr formulò alcune preziose riflessioni, dalle quali intendo prendere le mosse nel presente contributo.

Egli, esaminando i principali risultati conseguiti sulla scorta della copiosa documentazione raccolta, non esitava ad affermare che, grazie ad essa, „Die Geschichte der Beziehungen des Erzbistums Mailand zu Rom wird in einigen Punkten nicht unwesentlich aufgeklärt "1. In particolare il suo interesse si appuntava sulle vicende del XII secolo, giacché a suo parere la completa sottomissione della Chiesa di Milano, tradizionalmente orgogliosa del proprio prestigio e della sostanziale autonomia nei confronti della Chiesa di Roma, poteva dirsi raggiunta nel corso del pontificato di Innocenzo II, allorché, nel 1135 l'arcivescovo Robaldo rinunciò alla consolidata prerogativa di accogliere il pallio a Milano, dalle mani di un legato, e si recò alla sede apostolica, dove ricevette dal pontefice l'ambito simbolo del potere arcivescovile. „In der Tat ist es seitdem mit der Autonomie des Mailänder Metropoliten ein für alle Mal zu Ende; von nun an häufen sich die Eingriffe Roms in die inneren Angelegenheiten der Mailänder Kirche“ (p. 365).

Il Kehr metteva quindi in luce l'assoluta fedeltà alla sede romana manifestata dagli arcivescovi di Milano a partire dagli anni quaranta del XII secolo, con particolare attenzione alla personalità di Galdino, cardinale, arcivescovo e,

1 Paul Fridolin Kenr: Nachträge zu den Papsturkunden Italiens, in: NGG Phil.-hist. Kl. 4 (1912), pp. 328-334, ora in: PUU in Italien, vol. 5 p. 364: „Für den Historiker und den Kirchenhistoriker bietet der neue Band nicht nur neues Material die Fülle, sondern auch reichen Stoff zu historischen Betrachtungen. Als ich die Regesten ordnete und den Band redigierte, drängten sich mir einige Beobachtungen auf, auf die ich hier kurz eingehen möchte, in dem Wunsche, daß sie gelegentlich von berufener Seite ausführlicher behandelt werden möchten“" 
durante tutto il suo episcopato, legato papale: „Welche außerordentliche Tätigkeit dieser Mann in dem großen Streit zwischen Friedrich I. und Alexander III. entfaltet hat, das finde ich in unsern Darstellungen dieser Zeit keineswegs genügend hervorgehoben (...). Es wäre wohl eines monographischen Versuches wert" (p. 365) $)^{2}$.

Così pure a suo giudizio gli strumenti decisivi per l'affermazione del primato papale nella provincia ecclesiastica facente capo a Milano, oltre al moltiplicarsi delle richieste di protezione apostolica per i numerosi monasteri presenti nella regione - che si accompagnò al diffondersi delle dedicazioni a s. Pietro -, a partire da Urbano II, furono i frequenti soggiorni dei papi nella regione e la partecipazione a sinodi nel corso dei loro viaggi oltralpe, la fitta presenza di legati papali, segnatamente nella seconda metà del XII secolo, nonché il fatto che alcuni membri del collegio cardinalizio provenivano dalla

2 La suggestione qui espressa dal Kehr sta alla base del lavoro di Gerhard Dunken: Die politische Wirksamkeit der päpstlichen Legaten in der Zeit des Kampfes zwischen Kaisertum und Papsttum in Oberitalien unter Friedrich I., Berlin 1931 (Historische Studien 209), pp. 9sg.: „In Oberitalien zeugte von dem Aufblühen der Hierarchie eine gesteigerte Religiosität, die auf die verschiedensten Momente zurückzuführen ist, darauf hatte schon Kehr aufmerksam gemacht. ... Mit dem Pontifikat Eugens III. beginnt so auch für Oberitalien durch das Auftreten der Legaten eine neue Aera, die auf kirchlichem Gebiete zur ,moralische Eroberung der Lombardei' und ganz Oberitaliens führen sollte“; alle osservazioni del Dunken si potrebbe aggiungere che fin dall'XI secolo l'azione dei legati nell'Italia settentrionale non era stata certo marginale. Per quanto riguarda l'arcivescovo Galdino manca ancora la monografia auspicata dal Kehr; studi utili, anche se parziali, sul personaggio sono quello di taglio agiografico di Enrico Cattaneo: Galdino della Sala cardinale e arcivescovo di Milano, in: Contributi dell'Istituto di Storia Medioevale, vol. 1: Raccolta di Studi in memoria di Giovanni Soranzo, Milano 1968 (Scienze storiche 10), pp. 129-165, quelli di Annamaria Ambrosioni: Le città italiane fra papato e impero dalla pace di Venezia alla pace di Costanza, in: La pace di Costanza 1183. Un difficile equilibrio di poteri fra società italiana e impero, Bologna 1984 (Studi e testi di storia medioevale 8), pp. 35-57, e Annamaria Ambrosioni: Alessandro III e la Chiesa ambrosiana, in: Miscellanea Rolando Bandinelli, papa Alessandro III. Studi raccolti da Filippo LiotTa, Siena 1986, pp. 3-41 (ora entrambe in Annamaria Ambrosioni: Milano, papato e impero in età medievale. Raccolta di studi, a cura di Maria Pia Alberzoni/Alfredo Lucioni, Milano 2003 [Bibliotheca erudita. Studi e documenti di storia e filologia 21], pp. 373-443, da dove saranno tratte le successive indicazioni), di Marco Pogliani: Il dissidio fra nobili e popolari a Milano. La controversia del 1203 fra l'arcidiacono e il primicerio maggiore, in: Ricerche storiche sulla Chiesa ambrosiana 10, Milano 1981 (Archivio ambrosiano 42), pp. 5-111 (con l'edizione di importanti fonti); un breve profilo in Klaus Ganzer: Die Entwicklung des auswärtigen Kardinalats im hohen Mittelalter. Ein Beitrag zur Geschichte des Kardinalkollegiums vom 11. bis 13. Jahrhundert, Tübingen 1963 (Bibliothek des Deutschen Historischen Instituts in Rom 26), pp. 114-118; i risultati di questi studi sono ripresi in Maria Pia Alberzoni: Nel conflitto tra papato e impero: da Galdino della Sala a Guglielmo da Rizolio (1166-1241), in: Diocesi di Milano, vol. 1, Brescia 1990 (Storia religiosa della Lombardia 9), pp. 227-231. 
regione padana e in essa risiedettero a lungo ${ }^{3}$. Anche a questo proposito il Kehr sottolineava l'assenza di approfondimenti storiografici su tali fenomeni („Daneben aber traten andere Faktoren in Wirksamkeit, an denen man bisher beinah achtlos vorbeigegangen ist, obwohl sie ganz offenbar von nicht geringerer Bedeutung gewesen sind“, p. 367) ${ }^{4}$, per giungere a formulare un importante suggerimento: „Eine genauere Zusammenstellung dieser Legaten, ihrer Sprengel, ihrer Funktionen und ihrer Akte wäre sehr erwünscht und gäbe uns ein sehr viel deutlicheres Bild von der ständigen Einwirkung, die die Päpste im 12. Jahrhundert auf die Verhältnisse der Lombardei ausgeübt haben, als wir es bisher besitzen" (p. 368). Accanto ai cardinali legati in Lombardia, il Kehr non tralasciava di richiamare l'attenzione sull'importante ruolo svolto dai suddiaconi papali pure incaricati dai pontefici di importanti compiti, per giungere alla conclusione: „Täuscht mich nicht alles, so ist im 12. Jahrhundert kein Land von päpstlichen Agenten hohen und niedern Ranges so sehr durchsetzt gewesen als gerade die Lombardei“ (p. 368).

L'ampio lavoro sulle fonti aveva dunque reso evidente al Kehr la necessità di considerare in modo correlato due strumenti di fondamentale importanza per comprendere gli interventi della Chiesa romana in Lombardia: i legati, soprattutto i cardinali, e i suddiaconi papali. Le ricerche in proposito sono altamente debitrici all'Italia Pontificia, anche se proprio in tale direzione sarebbe auspicabile una nuova valorizzazione del materiale documentario edito e inedito 5 .

3 Sui rapporti tra la Chiesa ambrosiana e quella romana nel XII secolo basti qui rinviare a Piero Zerbi: La Chiesa ambrosiana di fronte alla Chiesa romana dal 1120 al 1135, in: StM ser. $3^{a} 4$ (1963) pp. 136-216, ora in ID.: Tra Milano e Cluny. Momenti di vita e cultura ecclesiastica nel secolo XII, II edizione ampliata, Roma 1991 (Italia sacra. Studi e documenti di storia ecclesiastica 28), pp. 125-230, e ad Ambrosioni (cit. nota 2) in particolare agli studi della Parte seconda, pp. 297-572.

4 Il Kehr aggiungeva anche questa iportante notazione: „... ich meine die Tätigkeit des päpstlichen Legaten und der in der lombardischen Städten residierenden Kardinäle. Ich wage nicht von ständigen Legaten zu reden; aber viel fehlt nicht daran, daß man schon im 12. Jahrhundert von einer solchen Institution in der Lombardei sprechen könnte"; sulle caratteristiche dei legati residenti è di recente tornato Ludwig FalKenstein: Wilhelm von Champagne, Elekt von Chartres (1164-1168), Erzbischof von Sens (1168/69-1176), Erzbischof von Reims (1176-1202), Legat des apostolischen Stuhles, im Spiegel päpstlicher Schreiben und Privilegien, in: ZRGKanAbt 89 (2003) pp. $107-$ 284; una parte dello studio è stata pubblicata anche in francese: ID.: Guillaume aux Blanches Mains: archevêque de Reims et légat du Siège Apostolique (1176-1202), in: RHEF 91 (2005) pp. 5-25.

5 Esemplare in proposito la documentazione relativa al suddiacono papale Alexius in Papsturkunden in Frankreich N. F. 8: Paris I, ed. Dietrich Lohrmann, Göttingen 1989, pp. $62-64$ e i nn. 57-76, 85, 97, 98, 100-103, 148. L'ottima ricerca di Stefan Weiss: Die Urkunden der päpstlichen Legaten von Leo IX. bis Coelestin III. (1049-1198), Köln/Weimar/Wien 1995 (Beihefte zu den RI 13), consente di ricostruire l'attività di 


\section{La storiografia}

Nei cento anni che oramai ci separano dalle ricerche del Kehr, mentre importanti studi hanno indagato le relazioni del papato riformatore con le diverse regioni della christianitas, permane relativamente scarso il numero di contributi attenti alle modalità secondo le quali tali relazioni si attuarono: in tal senso è esemplare per il periodo altomedievale il volume di Jochen Johrendt ${ }^{6}$. È stato inoltre chiarito in modo sostanziale il ruolo svolto da movimenti e personalità di rilievo nell'orientare i rapporti tra la Chiesa romana e quella ambrosiana - basti per tutti ricordare gli studi sulla Pataria o sui viaggi di s. Bernardo ${ }^{7}$. Così pure non mancano ricerche relative agli interventi del papa nel quadro dello scontro tra regnum e sacerdotium, per orientare dal punto di vista ecclesiale e, quindi, politico, le scelte di una o più città, per le quali rinvio alla recente panoramica tratteggiata da Claudia Zey ${ }^{8}$.

alcuni suddiaconi papali, ma solo in quanto incaricati della legazione; ID.: Legatenurkunde und Papsturkunde, in: Hundert Jahre Papsturkundenforschung. Bilanz Methoden - Perspektiven. Akten eines Kolloquiums zum hundertjährigen Bestehen der Regesta Pontificum Romanorum vom 9.-11. Oktober 1996 in Göttingen, hg. v. DEms., Göttingen 2003 (AAG, phil-hist. Kl. 3. Folge 261), pp. 335-350 (p. 336-337).

6 Jochen Johrendt: Papsttum und Landeskirchen im Spiegel der päpstlichen Urkunden (896-1046), Hannover 2004 (MGH Studien und Texte 33), dove, sulla scorta della documentazione edita dallo Zimmermann, sono messi; in luce i diversi rapporti instauratisi tra il centro e la periferia, vale a dire i regni derivati dal dissolvimento dell'impero carolingio, Francia, Germania, Italia e ,Catalogna'; si veda, inoltre, Jochen Johrendt: La protezione apostolica alla luce dei documenti pontifici (896-1046), in: BISI 107 (2005) pp. 135-168.

7 Sull'azione di s. Bernardo in favore della ricomposizione dello scisma papale: Piero Zerbi: I rapporti di s. Bernardo di Chiaravalle con i vescovi e le diocesi d'Italia, in: Vescovi e diocesi in Italia nel Medioevo (sec. IX-XIII). Atti del II convegno di Storia della Chiesa in Italia (Roma, 5-9 settembre 1961), Padova 1964 (Italia sacra. Studi e documenti di storia ecclesiastica 5), pp. 219-313, ora in: Pietro Zerbi: Tra Milano e Cluny (cit. nota 3) pp. 3-109, nonché i contributi negli atti di convegni: Bernardo cistercense, Spoleto 1990 (Atti dei Convegni dell'Accademia Tudertina e del Centro di studi sulla spiritualità medievale 26) e San Bernardo e l'Italia, a cura di Pietro Zerbi, Milano 1993 (Bibliotheca erudita. Studi e documenti di storia e filologia 8).

8 Nell'impossibilità di richiamare la ricchissima bibliografia sull'argomento, mi limito a rinviare al recente e aggiornato saggio di Claudia ZEY: Im Zentrum des Streits. Mailand und die oberitalienischen Kommunen zwischen regnum und sacerdotium, in: Vom Umbruch zur Erneuerung? Das 11. und beginnende 12. Jahrhundert - Positionen der Forschung, a cura di Jörg Jarnut/Matthias Wemhoff, München 2006, pp. 595-611. Si veda ora anche il puntuale inquadramento proposto da Jochen JohrendT/Harald Müller: Zentrum und Peripherie. Prozesse des Austausches, der Durchdringung und der Zentralisierung der lateinischen Kirche im Hochmittelalter, in: Römisches Zentrum und kirchliche Peripherie. Das universale Papsttum als Bezugspunkt der Kirchen von den Reformpäpsten bis zur Innozenz III, a cura di Jochen JohrendT/Harald MüLLER, Berlin/ New York 2008 (Neue AAG 2), pp. 1-16. 
È solo il caso, poi, di accennare agli studi di Cinzio Violante sulla Pataria, a quelli di Pietro Zerbi e di Annamaria Ambrosioni, volti a indagare specificamente le relazioni tra Milano e il papato nel XII secolo, ai quali è possibile aggiungere le più recenti ricerche di Alfredo Lucioni e le considerazioni di Nicolangelo D'Acunto (per limitarmi all'ambito strettamente milanese) ${ }^{9}$. Fondamentali rimangono i contributi di Hagen Keller e della sua Scuola, che hanno consentito di meglio inquadrare il contesto sociale entro il quale si definirono scelte rilevanti nelle relazioni tra il papato e la Lombardia ${ }^{10}$.

Sull'altro versante disponiamo di studi volti a indagare importanti settori del governo della Chiesa, basti pensare ai volumi di Ina Friedländer e di Gerhard Dunken sulle legazioni papali in Lombardia nella seconda metà del XII secolo ${ }^{11}$, fino al più recente volume di Stefan Weiß, dove grazie all'esame della documentazione dei legati papali tra 1049 e 1198 si apportano anche importanti precisazioni in merito alla natura delle loro missioni, molte delle quali svolte nell'Italia padana ${ }^{12}$. Sono inoltre da ricordare diversi lavori dedicati alla ricostruzione delle carriere e dei compiti di governo svolti dai cardinali, nonché al funzionamento della curia papale, come è possibile evincere dalla ricca bibliografia ricordata da Werner Maleczek nella sua ampia e dettagliata ricerca sulla composizione e sui compiti del collegio cardinalizio tra XI e XIII secolo ${ }^{13}$.

9 Cinzio Violante: La Pataria milanese e la riforma ecclesiastica, vol. 1: Le premesse (1045-1057), Roma 1955 (Studi storici 11-13); si veda anche la valida messa a punto di Alfredo Lucioni: L'età della Pataria, in: Diocesi di Milano (cit. nota 2) pp. 167-226. Oltre agli studi ricordati sopra, alla nota 3, si veda anche ID.: L'arcivescovo Anselmo IV da Bovisio e la società milanese alla fine dell'XI secolo, in: Deus non voluit. I Lombardi alla prima crociata $(1100-1101)$. Dal mito alla ricostruzione della realtà, a cura di Giancarlo Andenna/Renata Salvarani, Milano 2003, pp. 31-217; Nicolangelo D'Acunto: Chiesa romana e chiese della Lombardia: prove ed esperimenti di centralizzazione nei secoli XI e XII, in: Johrendt/Müller: Zentrum (cit. nota 8) pp. $207-233$.

10 Hagen KeLLER: Adelsherrschaft und städtische Gesellschaft in Oberitalien (9.-12. Jahrhundert), Tübingen 1979 (Bibliothek des Deutschen Historischen Instituts in Rom 52); si veda anche la traduzione italiana: iD.: Signori e vassalli dell'Italia delle città (secoli IX-XII), Torino 1995, soprattutto per l'ampia introduzione storiografica, con importanti aggiornamenti sullo sviluppo degli studi.

11 Ina Friedlaender: Die päpstlichen Legaten in Deutschland und Italien am Ende des XII. Jahrhunderts (1181-1198), Berlin 1928 (Historische Studien 117); Dunken (cit. nota 2).

12 WeIss (cit. nota 5) pp. 339sg.

13 Werner Maleczek: Papst und Kardinalskolleg von 1191 bis 1216. Die Kardinäle unter Coelestin III. und Innocenz III., Wien 1984 (Publikationen des Historisches Instituts beim Österreichischen Kulturinstitut in Rom 1/6), pp. 207-240 e 297-350; Maleczek ha inoltre specificamente considerato il ruolo svolto dai legati papali soprattutto nel tardo medioevo: ID.: Die päpstlichen Legaten im 14. und 15. Jahrhundert, in: 
Tale quadro storiografico consente ancor più di sottolineare l'importanza dell'impresa legata al nome di Paul Kehr: l'Italia Pontificia costituisce infatti il punto di riferimento imprescindibile per tutti i lavori qui ricordati, giacché, con la segnalazione non solo dei documenti papali, ma anche di quelli dei legati, ha offerto agli studiosi uno strumento prezioso e uno stimolo alle ricerche.

D'altra parte, l'esame degli interventi messi in atto dalla sede apostolica per raggiungere quella che sempre il Kehr definì „die moralische Eroberung der

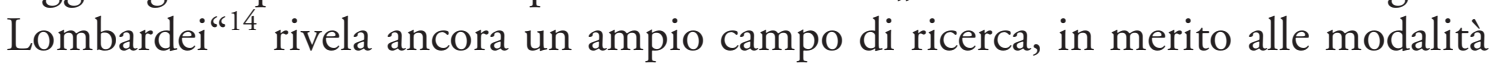
di intervento e, soprattutto, agli strumenti dei quali il papato si servì. Se infatti nell'XI secolo furono soprattutto i legati papali - la maggior parte dei quali era costituita dai vescovi legati residenti, o stabili - a rappresentare e a introdurre in sede locale le direttive della sede apostolica, nel corso del XII secolo si assistette a un affinarsi della strumentazione disponibile, da Alessandro III individuata soprattutto nei cardinali legati, nonché all'emergere di alcune interessanti sperimentazioni ${ }^{15}$.

Precisamente su questi strumenti „nuovi“, ai quali già accennava il Kehr, intendo rivolgere l'attenzione, soprattutto a partire dal pontificato di Eugenio $\mathrm{III}^{16}$. Preciso fin d'ora che non è certo possibile in questa sede procedere a un esame completo delle carriere e dell'attività degli ecclesiastici a diverso titolo coinvolti nella realizzazione delle direttive romane entro la vasta provincia ecclesiastica facente capo a Milano, che nel XII secolo comprendeva gran parte dell'Italia settentrionale e che, anche dopo la sottrazione della sede genovese (1133), si estendeva pur sempre all'attuale Piemonte e alla Lombardia, ad

Gesandtschafts- und Botenwesen im spätmittelalterlichen Europa, hg. von Rainer C. Schwinges/Klaus Wriedt, Ostfildern 2003 (VuF 60), pp. 33-86; si veda, inoltre, dello stesso autore, l'intervento nel corso del presente Convegno.

14 KeHr (cit. nota 1) p. 367.

15 Per l'azione dei cardinali sullo scorcio dell'XI secolo mi limito a rinviare ad Arimanno da Gavardo, sul quale Ganzer (cit. nota 2) pp. 40-43 e Lucioni (cit. nota 2) pp. 134139; mi valgo, inoltre, delle osservazioni di Marcel PACAUt: I legati di Alessandro III (1159-1181), in: RHE 50 (1955) pp. 821-838 e di Claudia ZeY: Die Augen des Papstes. Zu Eigenschaften und Vollmachten päpstlicher Ligaten, in: JoHrendT/ MüLLER: Zentrum (cit. nota 8) pp. 77-108; EAD.: Handlungsspielräume - Handlungsinitiativen. Aspekte der päpstlichen Legatenpolitik im 12. Jahrhundert, in: Zentrum und Netzwerk, Kirchliche Kommunikationen und Raumstrukturen im Mittelalter, a cura di Gisela Drossвach/Hans-Joachim Sснмidt, Berlin 2008 (Scrinium Friburgense 22), pp. 63-92.

16 KeHR (cit. nota 1) pp. 368sg.: „Dabei ist zugleich zu beachten, daß viele dieser Kardinäle selbst Lombarden waren und Pfründe in den dortigen Kirchen besaßen, z.T. sogar dauernd dort residierten. ... Auch den mit lombardischen Kirchenpfründen bedachten Subdiakonen des apostolischen Stuhles wäre in diesem Zusammenhange nachzugehen“. 
esclusione delle diocesi di Pavia, direttamente soggetta alla Chiesa romana, di Como, legata ad Aquileia, e di Mantova, dipendente da Grado ${ }^{17}$.

\section{Le tappe della sperimentazione}

\subsection{La presenza dei pontefici nella regione}

Come già segnalava il Kehr, i viaggi dei pontefici attraverso la regione padana diedero un contributo rilevante nel processo che condusse all'ampliamento delle prerogative papali in sede locale ${ }^{18}$. Se certo una svolta significativa si ebbe con i viaggi di Leone IX, che nel 1050 transitò nella regione e nel settembre presiedette un sinodo a Vercelli ${ }^{19}$, un importante snodo nelle relazioni tra le Chiese dell'Italia padana e il papato è da individuarsi nel viaggio e nella lunga permanenza di Urbano II nel 1095, allorché prese parte al cosiddetto concilio di Piacenza ${ }^{20}$. Nel secolo successivo, poi, soggiornarono in Lombardia Pasquale II nel 1106 e ancora nel gennaio del 1107, di ritorno rispettivamente dai regni di Francia e di Borgogna ${ }^{21}$. Callisto II attraversò la regione padana nella primavera

17 Valido punto di riferimento per uno sguardo d'insieme sono i volumi della Storia religiosa della Lombardia e del Veneto, accanto ai quali si possono segnalare, per l'attuale Piemonte, Storia della Chiesa di Ivrea dalle origini al XV secolo, a cura di Giorgio Cracco, con la collaborazione di Andrea Piazza, Roma 1998 (Chiese d'Italia 1), il recente volume Diocesi di Novara (Brescia 2007) e, per Genova, Valeria Polonio: Tra universalismo e localismo: costruzione di un sistema (569-1321), in: Il cammino della Chiesa genovese dalle origini ai nostri giorni, a cura di Dino Puncuh, Genova 1999, pp. $77-210$.

18 KeHR (cit. nota 1) p. 367.

19 Julius von Pflugk-Harttung: Acta pontificum Romanorum inedita, vol. 2, Stuttgart 1884 (Graz 1958), p. 75 n. 109: cum consilio coepiscoporum nostrorum in synodo, quod habuimus Vercellis, decrevimus; IP 6/2 p. 122 n. 2 (Torino, S. Michele alla Chiusa). Il percorso del papa è ricostruibile sulla base di JL vol. 1 p. 538-540; una attenta analisi dei motivi che ispirarono i viaggi papali, con una puntuale messa a punto sulla permanenza dei pontifici nell'Italia meridionale in Jochen Johrendt: Die Reise der frühen Reformpäpste - Ihre Ursachen und Funktionen, in: RQ 96 (2001) pp. 57-94.

20 IP 6/2 pp. 124sg. n. 11 (datum Placentiae); il percorso seguito da Urbano II durante la sua permanenza nell'Italia settentrionale tra il febbraio e il luglio del 1095, quindi di ritorno dal regno di Francia nel settembre-ottobre 1096, si può ricostruire sulla base di JL vol. 1 pp. 676-680 e 690; Giorgio PICAsso: Il Concilio di Piacenza nella tradizione canonistica, in: Il Concilio di Piacenza e le Crociate, Piacenza 1996, pp. 109-119.

21 La sosta di Pasquale II a Casale Monferrato è attestata in «Fragmentum martyrologii ecclesiae Beati Evasii Casalensis», in: Monumenta historiae patriae, Scriptores 3, Augustae Taurinorum 1848, col. 446; si vedano le indicazioni in IP 6/2 p. 42 n. * ${ }^{*}$ : il Kehr segnala però la notizia offerta dal Chronicon di Ekkehardus, secondo la quale Pasquale II avrebbe trascorso il Natale 1106 a Cluny. L'itinerario del viaggio del papa è ricostruibile sulla base di JL vol. 1 pp.726-728; si veda inoltre Glauco Maria 
del 1120 diretto dalla Borgogna verso Roma ${ }^{22}$; Innocenzo II, anch'egli sulla via che dal regno di Francia lo conduceva a Roma tra l'aprile e l'agosto del $1132 \mathrm{fu}$ ad Asti, Novara, Mortara, Pavia, Piacenza, Cremona e Brescia ${ }^{23}$; Eugenio III transitò in Lombardia nel marzo del 1147 e, di ritorno dal concilio di Reims, nel mese di giugno del 1148 fu a Vercelli, dove, alla presenza di quattordici cardinali, di numerosi prelati e dell'abate Bernardo di Clairvaux, consacrò la cattedrale di S. Maria; quindi si diresse a Cremona per tenervi un sinodo con i vescovi lombardi ${ }^{24}$, attraversando diverse città della regione ${ }^{25}$.

A questi soggiorni in itinere sono da aggiungere la permanenza di Alessandro III a Venezia, dal 9 maggio fino alla metà di ottobre $1177^{26}$, i circa tre anni trascorsi dalla curia papale a Verona sullo scorcio del pontificato di Lucio III, precisamente dall'estate del 1184 fino alla sua morte avvenuta il 25 novembre $1185^{27}$, e per tutto quello di Urbano III $(1185-1187)^{28}$ : si trattò di un periodo contraddistinto da relazioni assai strette tra il papato e le Chiese dell'Italia padana, un motivo ancor più evidente allorché si consideri l'origine milanese di

Cantarella: Pasquale II, in: Enciclopedia dei papi, vol. 2, Roma 2000, pp. 228-236, soprattutto $229-230$.

22 Giovanni Miccoli: Callisto II, in: Enciclopedia dei papi (cit. nota 21) pp. 248-254, alle pp. 251-252 un breve cenno dell'incontro avvenuto a Tortona tra il papa e il cronista milanese Landolfo di S. Paolo; IP 6/2 p. 43 n. 4, l'edizione in: Ferdinando Gaвотто/Umberto Fisso: Le carte dello Archivio capitolare di Casale Monferrato fino al 1313, vol. 1, Pinerolo 1907 (Biblioteca della Società Storica Subalpina 40), pp. 14sg. n. X (Piacenza, 1120 aprile 23: si tratta della conferma da parte di Callisto II dei beni e dei privilegi della chiesa di Casale Sant'Evasio); l'itinerario del papa si può ricostruire grazie a JL vol. 1 pp. 794sg.

23 IP 6/2 p. 23 nn. 8-10: per l'itinerario del papa si veda JL vol. 1 pp. 856-858; qualche cenno alla sosta piacentina in Tommaso Di CARpegna Falconieri: Innocenzo II, in: Enciclopedia dei papi (cit. nota 21) pp. 261-268, soprattutto pp. 264-265.

24 Litinerario del pontefice verso il regno di Francia come pure le tappe del suo ritorno sono evincibili rispettivamente da JL vol. 2 p. 39 e pp. 58-59; si veda anche Harald ZimmermanN: Eugenio III, in: Enciclopedia dei papi (cit. nota 21) pp. 279-285 (per il viaggio pp. 280 -282). Sulla consacrazione della basilica di S. Maria (1148 giugno 17) vedi IP 6/2 p. 23 n. 9; su tale circostanza Laura Minghettr Rondoni: San Bernardo alla consacrazione della cattedrale di S. Maria di Vercelli, in: San Bernardo e l'Italia (cit. nota 7) pp. $141-147$.

25 Si veda, ad esempio, PUU in Italien, vol. 3 pp. $120-122$ n. 6 (1148 luglio 7): Eugenio III, da Cremona, conferma i possessi dei canonici di Novara; per l'itinerario vedi JL vol. 2 p. 58 sg.

26 Paolo Brezzi/Andrea Piazza: Alessandro III, in: Enciclopedia dei papi (cit. nota 21) pp. 291-302.

27 Grado Giovanni Merlo: Lucio III, in: Enciclopedia dei papi (cit. nota 21) pp. $308-$ 311; gli spostamenti verso Verona sono ricostruibili sulla base di JL vol. 2 pp. 465sg.: Lucio III lasciò Sora diretto ad Ancona alla fine di maggio 1184; il 22 luglio era a Verona, dove rimase fino alla morte.

28 Ganzer (cit. nota 2) pp. 134-136; Paolo Grillo: Urbano III, in: Enciclopedia dei papi (cit. nota 21) pp. 311-314. 
Urbano III. Durante questo triennio l'esercizio di una giurisdizione diretta del vescovo di Roma sulle Chiese della regione padana assunse tratti meglio definiti: basti qui ancora accennare al pur breve pontificato di Urbano III (25 novembre 1185-20 ottobre 1187), che anche come pontefice continuò a intrattenere strette relazioni (soprattutto tramite la concessione di privilegi e la soluzione di cause giudiziarie) con numerose istituzioni ecclesiastiche dell'Italia settentrionale, dalle quali sperava di ricevere il necessario appoggio per sottrarsi all'isolamento in cui Federico I lo costringeva ${ }^{29}$.

\subsection{I cardinali originari della regione padana}

Accanto alla personale presenza dei pontefici e della curia papale è opportuno considerare quella dei cardinali provenienti dalle Chiese lombarde, che, grazie alle accurate ricerche condotte nel corso dello scorso secolo e messe a frutto nell'opera di Werner Maleczek, siamo in grado di individuare agilmente. Costoro, infatti, non furono solo attivi al fianco del papa, ma a loro fu spesso affidato il compito della legazione nelle rispettive terre d'origine, dove talora si trattennero per soggiorni prolungati ${ }^{30}$. Va inoltre accennato che sovente la presenza di cardinali legati nell'Italia settentrionale è da porre in relazione al transito verso le terre d'oltralpe meta della legazione, una evenienza spesso sfruttata per visitare $\mathrm{i}$ centri a loro più noti, per risiedervi anche solo temporaneamente e per svolgervi importanti uffici.

Fin dall'XI secolo la scelta dei pontefici fu certo suggerita dalla sempre più sentita necessità di garantire un raccordo organico tra la regione e la sede apostolica, sia al fine di affermare l'autorità del vescovo di Roma nei confronti dell'episcopato dell'Italia settentrionale, sia - e questo soprattutto a partire dal pontificato di Alessandro III - per garantire il necessario raccordo politico con i più forti alleati del pontefice nello scontro con Federico I e gli antipapi a lui fedeli ${ }^{31}$.

29 Annamaria Ambrosioni: Monasteri e canoniche nella politica di Urbano III. Prime ricerche per la ,Lombardia', in: Istituzioni monastiche e istituzioni canonicali in Occidente (1123-1215). Atti della settima Settimana internazionale di studio (Mendola 28 agosto-3 settembre 1977), Milano 1980, pp. 601-631, ora in Ambrosioni (cit. nota 2) pp. 337-372.

30 Maleczzek Papst (cit. nota 13) pp. 251sg.

31 Pacaut (cit. nota 15) pp. 824-828; Ovidio Capitani: Alessandro III, lo scisma e le diocesi dell'Italia settentrionale, in: Popolo e Stato nell'età di Federico I Barbarossa. Alessandria e la Lega lombarda. Relazioni e comunicazioni al XXXIII Congresso storico subalpino per la celebrazione dell'VIII centenario della fondazione di Alessandria (Alessandria, 6-9 ottobre 1968), Torino 1970, pp. 221-238; Ambrosioni (cit. nota 2) pp. $376-390$ e $428-434$. 
Consideriamo brevemente le nomine: nel 1133 fu creato cardinale il piacentino Azzo (1133-1139) ${ }^{32}$, seguito nel decennio successivo ancora dal concittadino Ribaldo $(1143-1156)^{33}$, dai milanesi Goizone $(1140-1144)^{34}$ e Guido da Somma $(1143-1151)^{35}$, dal novarese Ugo $(1144-1150)^{36}$, dal bolognese Guarino (1144-post 1154) ${ }^{37}$ e da Guido da Crema (1145), passato tra i più decisi sostenitori di Federico I, quindi dal 1164 antipapa con il nome di Pasquale III $(1164-1168)^{38}$. Nel 1151 fu la volta di Ildebrando Crassus, forse appartenente alla canonica regolare di S. Maria de Reno di Bologna (1152$1178)^{39}$, di Oddo da Brescia $(1152-1174)^{40}$, poi di Ardizzone da Rivoltella

32 Maleczex Papst (cit. nota 13) p. 242, fissa le date del cardinalato di Azzo tra 1134 e 1139, anno della morte; in realtà Azzo è definito già nel 1133 cardinale diacono della Chiesa romana, nonché preposito della canonica di S. Antonino (vedi anche PUU in Italien, vol. 3 pp. $245-247 \mathrm{nn} .6$ e 7), mentre la promozione al titolo presbiterale di S. Anastasia, ad opera di Innocenzo II, risale al 1134; anche WeIss (cit. nota 5) p. 132, ignora la precedente carriera; oltre a Gian Paolo Bulla: Amministrazione, patrimonio e potere della basilica di S. Antonino nella Piacenza del XII secolo, in: Bollettino storico piacentino 92 (1997) p. 42, si veda ora Ivo Musajo Somma: Il capitolo della cattedrale di Piacenza nel XII secolo (1155-1199), tesi di Dottorato di ricerca in Storia medievale (ciclo XV), Università Cattolica di Milano a. a. 2002/2003, pp. 61-67.

33 Maleczer Papst (cit. nota 13) p. 242: Ribaldo, canonico della cattedrale piacentina, fu creato cardinale prete di S. Anastasia (1146-1156); Musajo Somma (cit. nota 32) pp. 66 e 139.

34 Maleczer Papst (cit. nota 13) p. 242: cardinale prete di S. Cecilia; su di lui Weiss (cit. nota 5) p. 147.

35 Maleczek Papst (cit. nota 13) p. 242: cardinale prete di S. Lorenzo in Damaso nel 1143, nel 1149 promosso alla sede episcopale di Ostia († 1151); si veda anche WeIss (cit. nota 5) p. 163.

36 Maleczer Papst (cit. nota 13) p. 242: cardinale prete di S. Lorenzo in Lucina; Weiss (cit. nota 5) p. 159.

37 Maleczer Papst (cit. nota 13) p. 242: cardinale vescovo di Preneste; Roger Aubert: Guarinus, in: DHGE 22, Paris 1988, coll. 559-560.

38 Maleczer Papst (cit. nota 13) p. 242: nel 1145 creato cardinale diacono di S. Maria in Portico e nel 1158 promosso al titolo presbiterale di S. Maria in Trastevere; WeIss (cit. nota 5) p. 161.

39 Johannes Matthias Brixius: Die Mitglieder des Kardinalkollegiums von 1130-1181, Diss. Berlin 1912, p. 55 n. 12 e p. 109 nota 128; Barbara Zenker: Die Mitglieder des Kardinalkollegiums von 1130-1159, Diss. Würzburg 1964, pp. 107-109; DunkeN (cit. nota 2) pp. 19-20 (Ildebrando dal 1148 fu rettore o amministratore vescovile della chiesa di S. Giminiano di Modena), 83-87, 103-107, 117-120; GANZER (cit. nota 2) pp. 100-102; Roger Auber t: Hildebrand, in: DHGE 24 (1993) coll. 485-488; Weiss (cit. nota 5) pp. 207-212: nel 1152 sottoscrive come sancte Romane ecclesie diaconus cardinalis; dal 30 gennaio 1153 cardinale diacono di S. Eustachio, dal 1154 Mutinensis ecclesie rector et procurator, alla fine del 1156 creato cardinale prete dei SS. XII Apostoli ( $\dagger$ $1178)$.

40 Maleczer Papst (cit. nota 13) p. 242: cardinale diacono di S. Nicola in Carcere Tulliano; WeIss (cit. nota 5) pp. 212-217. 
$(1157-1186)^{41}$ e di Guglielmo da Pavia (o de Marengo) $(1158-1178)^{42}$. Alessandro III creò cardinali Manfredo di Lavagna $(1162-1178)^{43}$, Ugo da Bologna $(1166-1177)^{44}$, Galdino della Sala $(1165-1167)$, poi arcivescovo di Milano $^{45}$, Lombardo da Piacenza (1171), poi arcivescovo di Benevento ${ }^{46}$, Petro

41 Paolo Lamma: Ardizzone da Rivoltella, in: DBI 4 (1962) pp. 41-42; Ganzer (cit. nota 2) pp. 133sg.; Maleczen Papst (cit. nota 13) p. 242: creato nel 1157 cardinale diacono di S. Teodoro. La controversa provenienza di questo ecclesiastico (da Ottone Morena indicato come de Rivoltella) dal territorio bergamasco, bresciano o cremonese, sembra essere definitivamente risolta in favore della sua origine cremonese/bergamasca da un documento del 1176 dicembre 7, edito da Cesare Vignati: Codice diplomatico laudense, vol. 2, Milano 1885, n. 75 e, ora, da Ada Grossi: Il Liber iurium del Comune di Lodi, Roma 2004 (Pubblicazioni degli Archivi di Stato 42), nn. 94 e 96, consultabile anche in: Codice diplomatico della Lombardia medievale (www.cdlm.unipv.it/edizione/ lo/cerreto-spietro).

42 Weiss (cit. nota 5) pp. 232-239; Guglielmo da Pavia, viene definito de Marengo (forse perché originario di Bosco Marengo, località in diocesi di Tortona, destinata in seguito a essere uno dei centri su cui si articolerà la nascita di Alessandria) in un testimoniale redatto il 3 dicembre 1177, relativo a una causa circa la dipendenza dal vescovo di Novara dell'ospedale e della chiesa di S. Maria di Barzi (1177 dicembre 3), in: Oreste Scarzello/Giovanni Battista Morandi/Andrea Leone: Le carte dell'Archivio capitolare di S. Maria di Novara, Torino 1924 (Biblioteca della Società Storica Subalpina 80), pp. 38sg. n. CDXCIV: Et eo tempore (oltre 4 anni prima, presumibilmente nel 1172), pro illa discordia fuimus ante Guilielmum cardinalem, qui tunc uenerat in partes illas et nuntiauimus ei discordiam illam (...). Predictus Otto, reuersus, dixit (...); et post hoc uidi similiter discordiam inter conuersos ipsius domus et posuerunt eam sub dompno Guilielmo de Marengo, et fuit ab annis tribus infra de illa discordia que fuit sub ipso Guilielmo; questa testimonianza è finora sfuggita alla storiografia. Guglielmo era stato arcidiacono della cattedrale pavese ed era insignito del titolo di magister; nel maggio del 1158 fu creato da Adriano IV cardinale prete di S. Pietro in Vincoli e alla fine di dicembre del $1176 \mathrm{fu}$ promosso da Alessandro III cardinale vescovo di Porto ( $\dagger 18$ gennaio 1178); oltre a Fedele SAvio: Gli antichi vescovi d'Italia dalle origini al 1300 descritti per regioni. La Lombardia, 2/2: Cremona - Lodi - Mantova - Pavia, Bergamo 1932, p. 434, e a Roger Aubert: Guillaume de Pavie, in: DHGE 22 (1988) coll. 982sg., si veda ora Stephan Freund: Guglielmo da Pavia, in: DBI 61 (2003) pp. 22-25 e Maria Pia Alberzoni: Vercelli e il papato, in: Vercelli nel secolo XII. Atti del quarto Congresso storico vercellese, Vercelli 2005, pp. 101-103; EAD.: Norditalienische Pilgerhospize im 12. und 13. Jahrhundert, in: Wege zum Heil. Pilger und heilige Orte an Mosel und Rhein, a cura di Thomas Frank, Stuttgart 2009, pp. 271-290 (p. 282).

43 Maleczer Papst (cit. nota 13) p. 243: nel dicembre 1162 creato cardinale diacono di S. Giorgio in Velabro, nel 1163 cardinale prete di S. Cecilia, quindi dal 1176 al 1178 cardinale vescovo di Preneste; Weiss (cit. nota 5) p. 243; Alberzoni Vercelli (cit. nota 42) p. $103-104$.

44 Maleczer Papst (cit. nota 13) p. 242: cardinale diacono di S. Eustachio.

45 Maleczer Papst (cit. nota 13) p. 242: cardinale prete di S. Sabina (1165-1167, il Maleczek indica 1166 perché, essendo avvenuta in dicembre la sua creazione, le sottoscrizioni iniziano con l'anno successivo), quindi arcivescovo di Milano fino alla morte (1176); si vedano gli studi ricordati sopra, alla nota 2. 
da Pavia $(1173-1182)^{47}$, Raniero Parvo da Pavia $(1175-1183)^{48}$. Da Lucio III furono accolti nel collegio cardinalizio il milanese Uberto Crivelli (11821185), poi papa Urbano $\mathrm{III}^{49}$, che, a sua volta, nel 1185 creò cardinale il veronese Adelardo, dal 1188 fino alla sua morte, presumibilmente avvenuta nel 1214, vescovo della sua città ${ }^{50}$, e il piacentino Pietro Diani $(1185-1206)^{51}$; Clemente III, infine, creò cardinale il lombardo Giovanni, già vescovo di Tuscania, dal 1189 cardinale prete di S. Clemente e dal 1199 al 1210 cardinale vescovo di Albano ${ }^{52}$.

46 Maleczer Papst (cit. nota 13) p. 243: cardinale prete di S. Ciriaco (1171), poco dopo trasferito alla sede beneventana Ganzer (cit. nota 2) pp. 121-123.

47 Cardinale prete di S. Grisogono (1173-1179), quindi cardinale vescovo di Tuscolo (1179-1182): la sua biografia è ricostruita da Dietrich Lohrmann: Petrus von St. Viktor in Paris. Zur Vorgeschichte eines Legaten Alexanders III. in Frankreich, in: Deus qui mutat tempora. Menschen und Institutionen im Wandel des Mittelalters. Festschrift für Alfons Becker zu seinem 65. Geburtstag, hg. von Ernst-Dieter HeHL, Sigmaringen 1987, pp. 259-267 (che chiarisce la sua precedente carriera come arcidiacono di Pavia, quindi come abate di Saint-André di Chartres); su di lui anche Wilhelm Janssen: Die päpstlichen Legaten in Frankreich vom Schisma Anaklets II. bis zum Tode Coelestins III. (1130-1198), Köln/Graz 1961, pp. 92-108; indubbiamente, come ben chiarisce il Lohrmann, il fatto che fosse arcidiacono di Pavia non garantisce circa la sua origine lombarda, ma diversi indizi sembrano piuttosto accreditarla e a tal fine sono interessanti le osservazioni di Weiss (cit. nota 5) pp. 254-265; Maleczzex Papst (cit. nota 13) p. 244 indica invece Pietro come di origine francese; ritengo di poterlo considerare ,lombardo', sia per la provenienza a lui attribuita nelle cronache, sia per l'indubbio stretto legame con un altro esponenste del collegio cardinalizio, Guglielmo da Pavia: una chiara testinionianza in tal senso è offerta da una lettera indirizzata a Pietro da Alessandro III il 27 marzo 1178, con la quale il cardinale era incaricato di recuperare e di portare alla curia alcuni oggetti preziosi, già appartenuti a Guglielmo da Pavia e che questi aveva lasciato a Limoges (Migne PL 200 coll. 1163sg.).

48 Maleczer Papst (cit. nota 13) p. 242: Raniero nel 1175 fu creato cardinale diacono di S. Giorgio in Velabro, nel 1182-1183 fu promosso cardinale prete dei SS. Giovanni e Paolo; Weiss (cit. nota 5) p. 268.

49 Maleczek Papst (cit. nota 13) p. 243; Ganzer (cit. nota 2) pp. 134-136: creato nel 1182 cardinale prete di S. Lorenzo in Damaso, dal 1185 arcivescovo di Milano; per la sua legazione, vedi Weiss (cit. nota 5) pp. 285sg.

50 Maleczek Papst (cit. nota 13) pp. 68 e 243: creato nel 1185 cardinale prete di S. Marcello, dal 1188 al 1212 vescovo di Verona, vedi Ganzer (cit. nota 2) pp. 137-140.

51 Maleczek Papst (cit. nota 13) pp. 85sg.; id.: Diani, Pietro, in: DBI 39 (1991) pp. 648-650; ID.: Zwischen lokaler Verankerung und universalem Horizont. Das Kardinalskollegium unter Innocenz III., in: Innocenzo III. Urbs et orbis. Atti del Congresso Internazionale (Roma, 9-15 settembre 1998), a cura di Andrea SommerLECHNER, vol. 1, Roma 2003 (Nuovi Studi storici 55), pp. 102-154, qui pp. 133-134; GanZer (cit. nota 2) pp. 136sg.; Weiss (cit. nota 5) pp. 290-294.

52 MaleczeK Papst (cit. nota 13) pp. 94sg. e 243: dal 1188 vescovo di Tuscania (dal 1192 di Viterbo-Tuscania), creato cardinale prete di S. Clemente nel 1189 e nel 1199 promosso alla sede episcopale di Albano († 1210-1211). 
Si tratta dunque di una presenza ininterrotta, particolarmente nutrita a partire dalla metà del secolo, la cui importanza non va sottovalutata nell'esame delle relazioni tra la provincia ecclesiastica di Milano e la sede romana.

\subsection{I legati papali}

I più significativi interventi della sede apostolica nella regione, soprattutto negli anni dello scontro tra Federico I e Alessandro III, furono affidati ai legati papali, che nella maggioranza dei casi erano anche cardinali.

Non intendo qui proporre una panoramica completa in merito alla loro azione, giacché a tale proposito è possibile rinviare agli studi sopra ricordati, in particolare a quello di Gerhard Dunken. Mi limiterò piuttosto a formulare alcune considerazioni sull'attività dei legati a partire dall'esame della carriera di alcuni dei più attivi nella regione padana, in primo luogo di quella di Galdino della Sala, al fine di individuare sia la linea d'azione perseguita dalla sede apostolica, sia gli strumenti di cui fece uso nelle diverse circostanze.

\subsubsection{Arcivescovo e legato papale: il cardinale Galdino della Sala.}

L'ammirazione del Kehr e del Dunken per l'intensa azione svolta da Galdino si comprende facilmente anche solo grazie a un rapido sguardo ai suoi interventi più significativi, promossi per rafforzare il fronte alessandrino, anche dal punto di vista politico, quindi nell'opposizione a Federico I nell'Italia settentrionale: di fatto fu grazie all'attività dei legati che il papa ottenne l'auspicato successo non solo all'interno della Chiesa, ma anche nei confronti del sovrano ${ }^{53}$.

Il 5 settembre 1167, dopo oltre cinque anni di lontananza, Galdino, che quando nel 1162 all'avvicinarsi degli eserciti imperiali e delle città nemiche aveva abbandonato la città era arcidiacono della cattedrale, rientrava a Milano come cardinale - nel dicembre del 1165 Alessandro III lo aveva creato cardinale prete di S. Sabina -, arcivescovo e legato papale, o come „Papstvikar für Oberitalien", come il Dunken lo definì ${ }^{54}$. Non solo: con il suo rientro nella città anche la diocesi e la provincia ecclesiastica tornavano in qualche modo a esistere

53 Si tratta di un motivo giustamente enfatizzato dal Dunken (cit. nota 2) p. 94: „so ist damit unzweifelhaft der Beweis geliefert, daß in diesen Jahren dem deutschen Kaiser in den päpstlichen Legaten die bedeutendsten Politiker der Kurie entgegengetreten sind und ihm die Basis seiner oberitalienischen Machtpolitik entrissen haben", ampiamente accolto dalla successiva storiografia.

54 Ibid. pp. 80sg.: „Mailand wurde durch Galdin der Mittelpunkt der alexandrinischen Propaganda im zweiten Abschnitt des Schismas. Galdins Stellung selbst wurde nochmals erhöht durch seine Ernennung zum ,Legatus contra Imperium Aenobarbi'. Es war das eine kluge Politik Alexanders III., dem Mailänder Metropoliten durch seine Ernennung zum Legaten, d.h. zum Papstvikar für Oberitalien mit dem ständigen Sitz in Mailand.“ 
e a essere attive al fianco di Alessandro III. Notiamo in primo luogo che Galdino dopo la consacrazione episcopale non si intitolò più cardinale, ma arcivescovo e legato papale, un motivo peraltro consueto in un momento in cui la carica episcopale era considerata eminente rispetto a quella cardinalizia ${ }^{55}$. D'altra parte giustamente è stato fatto notare che il fenomeno dell',,auswärtiges Kardinalat" piuttosto che „una istituzione vera e propria“ sia „il sintomo di un nuovo stile di governo della Chiesa universale ${ }^{\text {" } 56}$, che si sviluppa a partire dal pontificato alessandrino: in tal senso l'esame delle singole carriere consente di mettere a fuoco gli snodi più significatici di tale evoluzione, di fondamentale importanza per l'affermazione sempre più netta del primato papale.

Nell'accostare con una rapida carrellata i principali interventi attuati dal legato non bisogna però dimenticare che nel periodo della sua attività anche altri legati o cardinali legati furono attivi nella regione: delle loro coeve iniziative si darà conto, ma sempre in relazione all'attività dell'arcivescovo di Milano.

Il primo campo entro cui si sviluppò l'azione di Galdino fu teso a riportare il clero della città e della diocesi all'obbedienza alessandrina: si tratta di un ambito geografico entro il quale egli avrebbe potuto far valere la sua autorità anche solo in quanto metropolita, ma certo la qualità degli interventi richiesti aveva suggerito l'opportunità di rafforzare la sua posizione con il compito di legato. Probabilmente già nel 1168, l'arcivescovo pose a capo della canonica di S. Giovanni Battista di Monza il milanese e suddiacono della Chiesa romana Oberto da Terzago ${ }^{57}$. Fin dal mese di marzo del 1168 inviò a Lodi gli abati dei monasteri cittadini di S. Ambrogio e di S. Vincenzo, che indussero il clero locale, allora fedele a Federico I e all'antipapa Pasquale III (il lombardo Guido da Crema), al completo riconoscimento di Alessandro III, alla deposizione del vescovo scismatico e all'elezione di un presule obbediente alle direttive di Galdino $^{58}$. Così pure, in questo caso grazie esclusivamente all'autorità di legato apostolico, Galdino fin dal 1167 aveva provveduto a sostituire il vescovo filoimperiale di Como con un altro favorevole ad Alessandro III; analoghi provvedimenti furono presi per altre diocesi suffraganee, quali Novara e

55 Ganzer (cit. nota 2) pp. 187-204; id.: Das roemische Kardinalkollegium, in: Le istituzioni ecclesiastiche della „societas christiana“ dei secoli XI-XII. Papato, cardinalato ed episcopato. Atti della quinta Settimana internazionale di studio (Mendola, 26-31 agosto 1971), Milano 1974, pp. 153-181, qui soprattutto pp. 179sg.: nell'uso di abbandonare o mantenere il titolo cardinalizio anche dopo la nomina a una sede vescovile il pontificato di Alessandro III costituì una sorta di spartiacque, poiché a partire dal suo pontificato prevalse l'uso di mantenere in ogni caso il titolo di sancte Romane ecclesie cardinalis, accanto a quello della sede episcopale ricoperta.

56 Carl Gerold Fürst: Intervento nella discussione della lezione di Klaus Ganzer ricordata alla nota 55, in: Le istituzioni ecclesiastiche (cit. nota 55) p. 184, e MaLeczeK Papst (cit. nota 13) pp. 251sg.

57 Ambrosioni (cit. nota 2) pp. 429sg.

58 Dunken (cit. nota 2) pp. 81sg.; Ambrosioni (cit. nota 2) pp. 431-433. 
Cremona $^{59}$. Ancora nel 1168 ebbe inizio la costruzione di Alessandria, con la costituzione della relativa diocesi, ovviamente suffraganea di Milano, eretta sottraendo alcune pievi alle vicine Pavia, Asti e Acqui, che fino ad allora si erano mostrate favorevoli a Federico I ${ }^{60}$. Proprio contro Pavia, dove il vescovo fedele ad Alessandro III era stato costretto all'esilio, Galdino rinnovò l'interdetto, decretato nel 1160 dal cardinale Giovanni di S. Maria in Portico ${ }^{61}$. Anche gli abitanti del Seprio, che nel 1158 avevano aderito a Federico I, nel marzo del 1168 giurarono di stare praeceptis Galdini archiepiscopi et conscilii Mediolani e, per rendere ancora più evidente la volontà di controllare quel territorio a nord di Milano, l'arcivescovo, contro le consuetudini locali, nominò arciprete di S. Maria del Monte a Varese il diacono della Chiesa ambrosiana Pietro da Bussero $^{62}$. Nel 1169 Galdino allontanò il vescovo scismatico di Alba e provvide alla nomina di un successore di fiducia e nell'anno successivo un'analoga sorte toccò ai vescovi di Bergamo e Vercelli; nel 1170 fu la volta della sostituzione del vescovo di Asti ${ }^{63}$. Sempre nel 1170 Galdino riuscì a insediare a Torino il milanese Milone da Cardano e a sostituire il vescovo filoimperiale di Tortona ${ }^{64}$.

59 Dunken (cit. nota 2) p. 82; Ambrosioni (cit. nota 2) p. 430.

60 Sulla fondazione di Alessandria un esauriente quadro è offerto da Geo Pistarino: Alessandria nel mondo dei Comuni, in: StM ser. $3^{\text {a }} 11$ (1970) pp. 1-101; la documentazione pontificia agli inizi della diocesi di Alessandria è in IP 6/2 pp. $201-$ 202; di grande utilità la ricostruzione di Giulio Fiaschini: La fondazione della diocesi di Alessandria ed i contrasti con i vescovi acquesi, in: Popolo e stato (cit. nota 31) pp. 496512; si veda anche ID.: Chiesa e Comune in Acqui medievale, Acqui 1969.

61 Dunken (cit. nota 2) pp. 82 sg.; SAvio (cit. nota 42) pp. 430-437; Weiss (cit. nota 5) pp. $242 \mathrm{sg}$.

62 Ambrosioni (cit. nota 2) p. 431; su Pietro da Bussero e la sua intensa opera dal punto di vista amministrativo: Juliane TREDE: Untersuchungen zum Verschriftlichungsprozeß im ländlichen Raum Oberitaliens. Die Urkunden der Pilgerkirche S. Maria di Monte Velate bei Varese aus dem 12. und 13. Jahrhundert, Frankfurt am Main 2000 (Gesellschaft, Kultur und Schrift. Mediävistische Beiträge 9), pp. 202-208; importanti precisazioni circa la data della nomina e dell'ingresso di Pietro nella nuova carica sono in Alfredo Lucioni: Cronologia degli arcipreti di S. Maria di Monte Velate per i secoli X-XVI, in: Rivista della Società storica varesina 24 (2006-2007) pp. 11-33 (soprattutto 21-22).

63 Dunken (cit. nota 2) p. 93; il Dunken aggiunge a quesi casi anche la sostituzione del vescovo di Cremona, ma secondo SAvio (cit. nota 42) pp. 86-87, il presule filofedericiano Presbitero da Medolago era stato allontanato dalla sua sede prima del 23 aprile 1167, quando risulta già presente Offredo (consacrato entro il 29 maggio 1168).

64 Dunken (cit. nota 2) p. 93; Ambrosioni (cit. nota 2) p. 432; su Milone da Cardano si veda ora anche Renato Bordone: Il movimento comunale: le istituzioni cittadine e la composizione sociale durante il XII secolo, in: Storia di Torino, vol. 1: Dalla preistoria al comune medievale, a cura di Giuseppe SERGI, Torino 1997, pp. 639-646. 
Infine, nel 1175, l'arcivescovo ottenne che venisse nominato vescovo di Alessandria il suddiacono papale Arduino ${ }^{65}$.

Gli interventi di Galdino si concentrarono dunque con singolare intensità nella zona che corrisponde a grandi linee alla parte centro-occidentale della vasta provincia ecclesiastica, della quale peraltro non facevano parte Como e Pavia, da sempre antagoniste di Milano e che per questo motivo si erano schierate dalla parte dell'imperatore. È dunque plausibile ipotizzare il pieno sostegno del Comune ambrosiano alle iniziative dell'arcivescovo, che in qualche modo spianavano la strada all'ampliarsi della rete di alleanze facenti capo a Milano, vale a dire della Lega lombarda: non è forse un caso che le Chiese entro le quali più decisa fu l'azione di Galdino corrispondono alle località che - ancora a eccezione di Pavia e di Como - più a lungo costituirono l'ambito entro cui si esercitò sensibilmente l'influsso politico del comune di Milano, come rivela anche solo un rapido sguardo alle liste dei podestà comunali e, soprattutto, alla loro provenienza ${ }^{66}$. Galdino, dunque, anche grazie all'autorità legatizia di cui era investito, poté agire autorevolmente soprattutto nei territori situati entro l'area di influenza politica del comune ambrosiano, o in quelli in cui il comune stesso sperava di rafforzare la propria posizione.

\subsubsection{Gli altri cardinali legati}

A conferma di una divisione degli ambiti d'azione dei legati in relazione ai punti d'appoggio politici sui quali potevano fare affidamento è utile ricordare che negli anni cruciali tra 1167 e 1170 Galdino non era l'unico legato papale presente nella regione, giacché in essa nei medesimi anni agivano altri cardinali lombardi. Si tratta del bolognese Ildebrando Crassus, nel 1157, nel 1159-1169, nel $1171-1176$ e nel 1178 legato papale nelle regioni del nord-est dell'Italia settentrionale (Venezie e Romagna) ${ }^{67}$, del bresciano Oddo di S. Nicola in Carcere Tulliano, incaricato della legazione probabilmente nel gennaio del

65 Dunken (cit. nota 2) pp. 93sg. e 120sg.; Ambrosioni (cit. nota 2) p. 434; Maria Pia Alberzoni: Città, vescovi e papato nella Lombardia dei Comuni, Novara 2001, pp. $174-176$.

66 Si veda Elisa Occhipintr: Il podestariato in età comunale: flussi di esportazione e di reclutamento, in: Archivio storico lombardo 120 (1994) pp. 13-37; Enrico Artifoni: I podestà itineranti e l'area comunale piemontese. Nota su uno scambio ineguale in: I podestà dell'Italia comunale, vol. 1/1: Reclutamento e circolazione degli ufficiali forestieri (fine XII sec.-metà XIV sec.), a cura di Jean-Claude Maire Vigueur, Roma 2000 (Nuovi Studi Storici 51/Collection de l'École française de Rome 268), pp. 23-45.

67 Dunken (cit. nota 2) pp. 63, 70-78, 83-87, 103-107, 117, 128, 143; Weiss (cit. nota 5) pp. 207-212; РACAUT (cit. nota 15) pp. 833sg., sottolinea gli ampi poteri affidati al cardinale Ildebrando (legatus in tota Lombardia), un esperto giurista, che seppe dispiegare le sue capacità diplomatiche anche a sostegno e, per così dire, a integrazione della coeva azione del pragmatico Galdino. 
1170, ma che risulta attivo nell'Italia settentrionale a partire dall'autunno di quell'anno $^{68}$. Nel corso di questa legazione egli certo collaborò a consolidare le istituzioni ecclesiastiche bresciane nella fedeltà da poco riaffermata ad Alessandro III ${ }^{69}$, così pure fu in diverse occasioni al fianco di Galdino, sia a Milano, sia a Brescia, dove nel 1172 Oddo, oltre a giudicare gli ecclesiastici scismatici di quella città, intervenne per la soluzione di alcune cause ecclesiastiche relative alla diocesi e alla provincia mentre, forse sulla via del ritorno alla curia, nel novembre del 1172 fu attivo a Piacenza, assieme a un altro cardinale legato, Manfredo di S. Giorgio in Velabro ${ }^{70}$. Anche in questo caso dovette essere fondamentale l'appoggio del Comune bresciano all'azione del legato, un fatto che ne rafforzò la possibilità di intervento, resa ancor più organica dalla stretta alleanza politica che univa i due Comuni, entrambi appartenenti alla Lega lombarda.

Oddo, peraltro, aveva già svolto una legazione in Lombardia prima del 1156 con il cardinale Guido da Crema ${ }^{71}$, poi nel 1158 fu ancora presente assieme a un altro cardinale lombardo, Ardizzone da Rivoltella cardinale diacono di S. Teodoro, come inviato di Adriano IV nella regione padana per compiere una visita di carattere generale, contrassegnata da una decisa impronta politica di segno antiimperiale ${ }^{72}$.

Sempre nel decennio 1167-1176 altri cardinali lombardi svolsero almeno parte della loro attività legatizia nella regione padana. In primo luogo Guglielmo da Pavia o de Marengo, già arcidiacono della cattedrale pavese e insignito del titolo di magister, nel maggio del 1158 creato da Adriano IV cardinale prete di S. Pietro in Vincoli e alla fine di dicembre del 1176 promosso da Alessandro III cardinale vescovo di Porto $(\dagger 18 \text { gennaio } 1178)^{73}$. Questi era già stato incaricato di una legazione in Lombardia da Adriano IV nell'agosto del 1159, quindi tornò nella regione per partecipare al concilio indetto da Federico I a Pavia nel febbraio del 1160, giacché egli era stato uno degli elettori del filofedericiano

68 Dunken (cit. nota 2) pp. 87-89; Weiss (cit. nota 5) pp. 212-221, consente di apportare importanti correzioni alla cronologia proposta dal Dunken: la lettera di incarico da parte di Alessandro III risalirebbe infatti al gennaio del 1170 e i suoi interventi a Brescia sarebbero ad essa successivi.

69 PUU in Italien, vol. 5 n. 11 pp. 439sg. (1167 maggio 1); Dunken (cit. nota 2) p. 88.

70 Ibid. pp. 97 e 99-102 e Pacaut (cit. nota 15) p. 834.

71 Dunken (cit. nota 8) p. 17; IP 6/1 pp. 340-342 nn. 1 e 3.

72 Ibid. pp. 35-40 („Da die Legaten noch später in der Erzdiözese Mailand visitiert haben, kann ihre Legation schlechthin nicht eine besondere nur nach Mailand gerichtete gewesen sein, sondern hatte durchaus den Charakter einer Visitationsreise."); WeIss (cit. nota 5) p. 212.

73 Oltre alla bibliografia citata sopra, alla nota 42, si vedano i cenni in BRIXIUs (cit. nota 39) p. 60 n. 13 e pp. 118-119 nota 147 (che segnala la notizia, fornita però esclusivamente da Rahewino, circa la sua provenienza dall'Ordine cisterciense), e in ZENKer (cit. nota 39) pp. 118-123 n. 93. 
Vittore $\mathrm{IV}^{74}$. Ma già nell'ottobre del 1160 Guglielmo era passato tra i sostenitori di Alessandro III e, in stretto raccordo con questo papa, svolse le successive legazioni in Lombardia, precisamente nel 1169, nell'ottobre-novembre del 1172 , tra la metà di maggio e il mese di settembre del $1175^{75}$. Il suo soggiorno del 1169 fu decisivo per il rientro del legittimo vescovo pavese nella sua sede e la sua attività durante la sua permanenza nella regione è perlopiù documentata nella soluzione di alcune cause ecclesiastiche, soprattutto nel 1172 e nel $1175^{76}$.

Un altro cardinale collaborò attivamente con Galdino nella regione padana: il genovese Manfredo di Lavagna, cardinale diacono di S. Giorgio in Velabro, promosso nel 1173 al titolo presbiterale di S. Cecilia e nel novembre del 1176 alla sede episcopale di Preneste ${ }^{77}$. Di passaggio dall'Italia settentrionale al ritorno dalla legazione svolta tra 1168 e 1169 in Ungheria, Manfredo fu forse attivo a Modena $^{78}$, ma il suo più lungo soggiorno nella regione si colloca tra $1170 \mathrm{e}$ 1172, quando il cardinale fu impegnato a sostenere l'opera dei colleghi di legazione Oddo di S. Nicola in Carcere Tulliano e Ildebrando dei XII Apostoli ${ }^{79}$. Nella tarda primavera-estate 1170 era a Piacenza; nella primavera del 1171 nuovamente alla curia, quindi nell'autunno dello stesso anno in Liguria, dove rimase per circa un anno; nell'ottobre del 1172 era di nuovo a Piacenza, per partecipare a un incontro dei rettori della Lega e lì si trattenne per un certo periodo, come attesta la soluzione di alcune cause tra ecclesiastici ${ }^{80}$.

74 Dunken (cit. nota 2) pp. 52, 57, 90sg. e 125-127.

75 Pacaut (cit. nota 15) pp. 632-822, insiste sulle doti eminentemente diplomatiche del cardinale; Janssen (cit. nota 47) p. 65, definisce così Guglielmo: „Sicherlich der politisch begabteste und gewandteste Kardinal, über den Alexander III. derzeit verfügen konnte“, aggiungendo che proprio negli anni dello scisma la sua attività a sostegno del pontefice fu infaticabile; si veda, inoltre, WeIss (cit. nota 5) pp. 232-239, dove però non si fa cenno alle legazioni del 1169 e del 1172, poiché per queste non si sono conservati documenti originali dei legati; le notizie su queste missioni sono però desumibili da altri atti.

76 Savio (cit. nota 42) pp. 430-437; Dunken (cit. nota 2) pp. 90-92.

77 Ibid. p. 122; Brixius (cit. nota 39) p. 64 n. 17 e pp. 122sg. nota 163; Manfredo di Lavagna, cardinale diacono di S. Giorgio in Velabro (dicembre 1162), cardinale prete di S. Cecilia (settembre 1173), infine cardinale vescovo di Preneste (novembre $1176-\dagger 17$ gennaio 1178). È assai probabile che alla lunga permanenza del cardinale nella regione e all'importanza dei compiti svolti si possa far risalire l'influsso dei Fieschi, che piazzarono diversi esponenti nei capitoli cattedrali della regione, per i quali rinvio a Mauro RonZANi: Vescovi, capitoli e strategie famigliari nell'Italia comunale, in: La Chiesa e il potere politico dal Medioevo all'età contemporanea, a cura di Giorgio ChitTolini/ Giovanni Miccoli, Torino 1986 (Storia d'Italia. Annali 9), pp. 120-138, che però non accenna a tale possibilità.

78 Dunken (cit. nota 2) pp. 89-90.

79 Ibid. pp. 105-107, e WeIss (cit. nota 5) pp. 243sg.

80 Dunken (cit. nota 2) pp. 110-114 e 122. 
Ancora un cardinale lombardo, Ardizzone da Rivoltella, già suddiacono della Chiesa romana, creato da Adriano IV cardinale diacono di S. Teodoro ${ }^{81}$, che nel corso del pontificato di Adriano IV aveva svolto una legazione in Lombardia $^{82}$, nell'aprile del $1175 \mathrm{fu}$ nuovamente inviato nella regione e qui rimase a lungo, almeno fino al 1182, garantendo così la presenza di un esponente della curia romana nel delicato periodo successivo alla morte di Galdino († 18 aprile 1176) e alla sconfitta di Federico I a Legnano ${ }^{83}$. Ardizzone, però, a differenza di Galdino, non svolse il ruolo di legato permanente e nemmeno di legato in Lombardia, ma fu piuttosto impegnato come „residierender Kardinal", forse per garantire un collegamento tra Alessandro III e la Lega lombarda nel corso delle trattative che, attraverso la pace di Venezia, avrebbero portato alla pace di Costanza ${ }^{84}$.

Mi sono soffermata sull'attività di Galdino e sulle coeve presenze di cardinali, limitandomi a quelli originari dell'Italia settentrionale per evidenziare come gli interventi dell'arcivescovo abbiano riguardato perlopiù diocesi suffraganee della sede ambrosiana, mentre, nei casi di Como e Pavia, il sostegno politico di Milano che in quegli anni mirava a un rafforzamento della Lega dovette essere decisivo per garantire non solo l'efficacia, ma la stessa possibilità di azione del legato: nonostante il titolo cardinalizio unitamente a quello di arcivescovo e di legato, Galdino non avrebbe potuto svolgere una così vasta attività - così vasta da suscitare l'ammirazione del Kehr - se non avesse potuto contare sul sostegno del Comune di Milano e di quelli collegati.

Inoltre, risulta impossibile considerare adeguatamente l'azione dell'arcivescovo Galdino in quanto legato papale, senza avere presente la contemporanea e spesso congiunta attività degli altri cardinali lombardi insigniti del medesimo compito e pure presenti nella regione. Si trattò di un imponente sforzo diplomatico intrapreso da Alessandro III per contrastare la fortuna del fronte filoimperiale nell'Italia settentrionale, entro il quale svolsero un ruolo rilevante sia i legati 'stabili' - oltre a Galdino, come si è detto perlopiù attivo nella parte

81 Brixius (cit. nota 39) p. 58 n. 2 e p. 113 nota 138; ZENKER (cit. nota 39) pp. 157-159.

82 Dunken (cit. nota 2) pp. 35sg.; Ganzer (cit. nota 2) pp. 133sg.; Weiss (cit. nota 5) p. 212.

83 Oltre alla bibliografia citata sora, alla nota 41, va appena accennato che il Dunken è convinto dell'origine milanese di Ardizzone, mentre il Maleczer Papst (cit. nota 13) p. 242, lo indica come proveniente „aus der Gegend von Cremona“: Ambrosioni (cit. nota 2) p. 414, sulla scorta di Paolo Guerrini: Cronotassi biobibliografica dei cardinali, arcivescovi, vescovi e abbati regolari di origine bresciana dal secolo IX al tempo presente, in: Memorie storiche della diocesi di Brescia 25 (1958) pp. 14sg., lo ritiene bresciano; la documentazione ricordata sopra, alla nota 41 , sembra confermare il radicamento della sua famiglia tra Lodi, Bergamo e Cremona.

84 Dunken (cit. nota 2) p. 153; il Dunken aggiunge che per Lucio III il cardinale Ardizzone avrebbe nella sostanza svolto il medesimo servizio di un cardinale permanente (,ständiger Legat"). 
occidentale della regione (e della provincia metropolitica), il cardinale Ildebrando dei XII Apostoli, dal 1154 pressoché ininterrottamente presente nel settore orientale dell'Italia settentrionale ${ }^{85}$, , con gli altri cardinali originari della regione, quali Ardizzone di S. Teodoro, il pavese Guglielmo di S. Pietro in Vincoli, il bresciano Oddo di S. Nicola in carcere Tulliano, e il genovese Manfredo di S. Giorgio in Velabro. Così nel giro di appena tre-quattro anni l'intera Lombardia passò sotto il controllo di Alessandro III, fino a configurarsi come la più sicura alleata del pontefice nel conflitto ancora aperto con Federico I. Si può allora comprendere l'enfasi con la quale il Dunken in diversi passaggi del suo lavoro sottolinè̀ la valenza politica delle legazioni alessandrine, giungendo ad asserire che, grazie ad esse, „Die staufische Politik war in Oberitalien an sich schon 1170 an der Kirche und ihren Organen, den päpstlichen Legaten, gescheitert ${ }^{\star 86}$.

\subsubsection{Perché non fu rinnovata la legazione al successore di Galdino}

Il Dunken individuava ancora nel 1170 un'importante svolta nella tormentata vicenda dei rapporti tra Chiesa romana e Chiesa ambrosiana, poiché a suo parere proprio allora si sarebbe verificata la completa sottomissione di Milano alla sede apostolica, secondo modalità ancor più forti e definitive di quelle verificatesi nel 1135, a seguito dell'intervento di s. Bernardo per porre fine allo scisma e orientare Milano verso l'obbedienza a Innocenzo II $^{87}$ : nel 1170, infatti, nonostante Galdino fosse arcivescovo e legato papale, furono tre giudici delegati, precisamente l'abate del monastero di Cerreto, il preposito della canonica di Crescenzago e il suddiacono papale Giovanni Buono, a pronunciare una sentenza nella causa tra il presule e l'arciprete dei decumani (il clero milanese in cura d'anime) a motivo dell'elezione del primicerio dei decumani stessi, elezione che Galdino avrebbe voluto controllare completamente, come aveva fatto con

85 Su Ildebrando, cardinale diacono di S. Eustachio, nel 1156 promosso cardinale prete dei SS. XII Apostoli, oltre alla bibliografia indicata sopra, alla nota 39, vedi Dunken (cit. nota 2) pp. 83-87, 103-107, 117-120 (Ildebrando dal 1148 fu rettore o amministratore vescovile della chiesa di S. Giminiano di Modena); a p. 166 si precisa che Ildebrando non può propriamente essere considerato un legato permanente, giacché fino al 1178 è indicato come legato in Lombardia, e come vicarius del papa; Paul Fridolin KeHR: Kaiser Friedrich I. und Venedig während des Schismas, in: QFIAB 17 (1914) p. 233, definisce la posizione di Ildebrando nei confronti del governo di Venezia come „ständiger Nuntius bei der Republik“; Ambrosioni (cit. nota 2) pp. 338sg. e 394-396.

86 Dunken (cit. nota 2) p. 94.

87 Ibid. pp. 94sg.: „Das Jahr 1170 war auch nach anderer Richtung hin bedeutsam, denn die früher widerstrebende Erzdiözese Mailand, die stets mit Rom konkurriert hatte, wurde endgültig von der ambrosianischen Tradition getrennt." 
quelle dei vertici delle istituzioni ecclesiastiche della diocesi e della provincia ${ }^{88}$. L'affermazione del Dunken può forse essere ridimensionata sulla base di due diverse considerazioni. La prima riguarda la particolare posizione dell'arcivescovo in una causa che lo vedeva opporsi al suo clero: le controversie tra il clero - soprattutto il capitolo della cattedrale - e il vescovo della medesima diocesi richiedevano solitamente l'intervento di giudici esterni alla diocesi - altrimenti il vescovo sarebbe stato al tempo stesso giudice e parte in causa nel processo -, in primis del metropolita, in questo caso coincidente con una delle parti in causa ${ }^{89}$. L'intervento di giudici delegati papali esterni alla diocesi ambrosiana, pertanto, non può costituire un indice sicuro della diminuzione delle prerogative arcivescovili.

In secondo luogo sembra di cogliere, soprattutto in un documento vescovile del 1173, con cui Galdino, in quanto arcivescovo e legato papale, prendeva sotto la protezione della Chiesa di Milano la canonica bresciana di S. Giovanni Evangelista de foris, addirittura una smaccata imitatio delle formule presenti nella documentazione papale, indubbiamente favorita dal fatto che il documento si rifaceva esplicitamente a un privilegio di Alessandro $\mathrm{III}^{90}$. Fu forse proprio un'eccessiva imitatio dello stile di governo papale perseguita da Galdino

88 Giorgio Giulini: Memorie spettanti alla storia, al governo ed alla descrizione della città e campagna di Milano ne' secoli bassi, vol. 3, Milano $2^{\mathrm{a}}$ edizione 1855, pp. 696sg.; l'annosa causa tra l'arcivescovo e il primicerio dei decumani è stata riesaminata nelle sue fasi essenziali, fino alla conclusione avvenuta solo nel 1203, da Pogliani (cit. nota 2) pp. $5-14$.

89 Una sistematizzazione del diritto canonico in tal senso è posteriore di qualche decennio, basti qui solo ricordare il commento alla costituzione 7 del IV concilio lateranense di Joannis Tevtonici Apparatus, in: Constitutiones Concilii quarti Lateranensis una cum commentariis Glossatorum, ed. Antonio García y García, Città del Vaticano 1981 (MIC A Corpus Glossatorum 2), p. 194: Set quomodo deuoluitur hic potestas iudicandi de capitulo ad episcopum, cum episcopus sit de ipso capitulo? Est enim caput capituli, ut extra iii. de uerbor. signif. Cum clerici, extra iii. de conces. prebend. non uacant. Post electionem. Si enim episcopus non esset de capitulo sequeretur quod capitulum esset monstrum non habens caput, ergo episcopus est de capitulo, sicut ille qui preest exercitui est de ipso exercitu, ff. de hiis qui notant. infam. l. ii. (...) Ego credo quod ubicumque est episcopus de capitulo, si episcopus est negligens cum aliis, deuoluitur ius corrigendi uel eligendi ad metropolitanum.

90 PUU in Italien, vol. 5 p. 448 n. 16; l'atto è ora disponibile in una nuova edizione a cura di Michele Ansani: Le carte della canonica di S. Giovanni ,de foris' di Brescia (10871200), in: Codice diplomatico della Lombardia medievale (cit. nota 41); sul processo imitativo della diplomatica papale da parte delle cancellerie vescovili è ora punto di riferimento Othmar Hageneder: Papsturkunde und Bischofsurkunde (11.-13. Jh.), in: Die Diplomatik der Bischofsurkunde vor 1250. Referate zum VIII. Internationalen Kongreß für Diplomatik (Innsbruck, 27. September - 3. Oktober 1993), hg. von Christoph Haidacher/Werner KöFler, Innsbruck 1995, pp. 39-55; nel medesimo volume si vedano pure i contributi di Giovanna Nicolaj: Note di diplomatica vescovile italiana (secc. VIII-XIII), pp. 377-392, e di Maria Franca BArOni: La documentazione arcivescovile milanese in forma cancelleresca (secc. XI-metà XIII), pp. 305-317. 
- un motivo che peraltro lo stesso Dunken mette in luce - a suscitare la diffidenza del papa, che poteva vedere in tale atteggiamento un riemergere dell'orgoglio della sede ambrosiana, un motivo che tanto aveva ostacolato il processo di riconoscimento dell'eminente ruolo della sede apostolica anche nei confronti della Chiesa di Milano" ${ }^{91}$ Nel 1173, però, non era opportuno ridimensionare o prendere le distanze dall'azione di Galdino, pena la perdita di un importante alleato nello scontro che si profilava oramai imminente contro Federico I. Si potrebbe così comprendere perché, dopo la morte di Galdino e con la mutata situazione politica seguente alla sconfitta del Barbarossa a Legnano, la „ständige Legation“ non venne più rinnovata ad Algisio da Pirovano, il successore di Galdino, ma tale compito fu nella sostanza svolto da Ardizzone da Rivoltella ${ }^{92}$.

\section{Dai cardinali legati ai cardinali residenti: Uberto Crivelli e Pietro Diani}

Dal maggio del 1185 un altro cardinale, che già aveva svolto almeno una legazione in Lombardia, sedeva sulla cattedra di Ambrogio, il milanese Uberto Crivelli. Egli poteva vantare una carriera di tutto rispetto, sviluppatasi soprattutto nel periodo dell'esilio francese di Alessandro III, al seguito del quale egli, con gli altri ecclesiastici ambrosiani era rimasto per oltre tre anni ${ }^{93}$. Grazie alla sua formazione giuridica - Uberto aveva studiato a Bologna - egli fece una rapida e brillante carriera a Bourges, dove divenne arcidiacono e

91 Oltre al quadro generale tratteggiato da Zerbi (cit. nota 3), si veda Dunken (cit. nota 2) p. 153: „Vielleicht hatte die Ständige Legatur in Mailand trotz ihres günstigen Einflusses während des Schismas auch Nachteile gebracht, die Lucius III. als früherer Legat (Hubald von Ostia) in den verflossenen Jahren hatte kennen lernen können. Während Galdin stets als ,Legatus Apostolicae Sedis' erschien, hatte Alghisius diese Würde nicht mehr"; il Dunken, inoltre, adduce proprio l'esempio del privilegio concesso da Galdino alla chiesa di S. Giovanni Evangelista di Brescia come sintomo di un'usurpazione di prerogative della sede romana - la protezione alle chiese -, che lo stesso Galdino fino agli anni sessanta del secolo aveva costantemente richiesto ai papi, piuttosto che concedere sullo stile di quella papale.

92 Ibid. p. 153: „Für Lucius III. leistete der residierende Kardinallegat Arditio demnach die gleichen Dienste eines ständigen Legaten“; sul problema si vedano anche le osservazioni di Ambrosioni (cit. nota 2) pp. 435-442.

93 FriedlaEnder (cit. nota 11) p. 15; la carriera del cardinale è tratteggiata da Elfriede Kartusch: Das Kardinalskollegium in der Zeit von 1181-1227. Ein Beitrag zur Geschichte des Kardinalates im Mittelalter, Diss. Wien 1948, pp. 196-199; DunkeN (cit. nota 2) pp. 154sg.; Ganzer (cit. nota 2) pp. 134-136; Weiss (cit. nota 5) pp. $285 \mathrm{sg}$. (con la rettifica di un'ipotesi avanzata dal Dunken); si veda, inoltre, la bibliografia citata sopra, alle note $28-29$. 
addirittura nel 1182 fu anche eletto arcivescovo, carica che però non volle accettare $^{94}$. Dal 1168 egli era anche arcidiacono della Chiesa milanese e proprio nel 1182 fu creato cardinale prete di S. Lorenzo in Damaso da Lucio III, che nel 1183 lo incaricò della legazione nell'Italia settentrionale, dove rimase fino al luglio del 1184. Il cardinale, che nel frattempo era stato eletto vescovo di Vercelli, ma non risulta avere mai assunto anche quella carica, da Milano dove perlopiù risiedette sentenziò in diverse cause ${ }^{95}$; d'altra parte in considerazione del fatto che da quell'anno la curia papale fu a Verona è lecito ritenere che Uberto sia rimasto nell'Italia settentrionale.

Nel maggio del 1185 fu eletto arcivescovo di Milano e nel novembre del medesimo anno divenne papa con il nome di Urbano III: ciò non significò l'allontanamento dall'Italia settentrionale, giacché la curia era a Verona e lì il pontefice rimase - senza peraltro rinunciare alla carica di arcivescovo - fino al termine del suo pontificato $(\dagger 20 \text { ottobre } 1187)^{96}$.

La brillante carriera, qui appena accennata, di Uberto Crivelli consente di cogliere le linee di una tendenza affermatasi fin dallo scorcio degli anni settanta del secolo: i cardinali lombardi da allora (forse il primo caso fu quello segnalato dal Dunken di Ardizzone di S. Teodoro) effettuarono soggiorni prolungati nella città d'origine e nel territorio ad essa prossimo, quindi nelle regioni di cui avevano diretta conoscenza, talora come legati papali, ma soprattutto perché esperti di quella specifica situazione e autorevoli in essa, al di sopra dei poteri locali proprio per la dignità cardinalizia: si tratta di un eloquente indice dell'accresciuta importanza del collegio cardinalizio nel governo della Chiesa intera ${ }^{97}$. Tale orientamento della sede apostolica troverebbe conferma nel fatto che sullo scorcio del XII secolo all'interno della curia romana è possibile notare il progressivo definirsi di ambiti di interesse relativi alle diverse regioni della cristianità, per i quali era riconosciuta la competenza dei cardinali provenienti da quelle regioni, o che vi avevano effettuato lunghi soggiorni.

Le numerose missioni svolte dal piacentino Pietro Diani nella regione padana, dove risiedette perlopiù a Piacenza, sua città natale, esemplificano bene queste nuove tendenze: dapprima suddiacono papale e insignito del titolo di

94 Le informazioni sulla carriera ,francese' di Uberto Crivelli sono fornite dal suo condiscepolo Stefano di Tournai (Stephani Tornacensis Epistolae, in: Migne PL 211 col. 409 n. 121): Annamaria Ambrosioni: Due chierici milanesi del XII secolo e gli studi di diritto, in: Annals of the Archive of „Ferran Valls i Taberner's Library“ 9/10 (1991) pp. 103-118, ora in EAD. (cit. nota 2) pp. 213-228.

95 Dunken (cit. nota 2) p. 155; Ganzer (cit. nota 2) p. 135 nota 10, evidenzia che in un documento del Crivelli pubblicato da Giovanni Pietro Puricelli (sec. XVII) il luogo di emissione era: in civitate Mediolani, in palatio domini cardinalis; Alberzoni Vercelli (cit. nota 42) pp. $108-112$.

96 Grillo (cit. nota 28) pp. 313sg.; Ambrosioni (cit. nota 2) pp. 337-372.

97 Ganzer (cit. nota 54) pp. 171sg.; Maleczer Papst (cit. nota 13) pp. 336-347. 
magister, quindi dallo scorcio del 1176 preposito del capitolo della chiesa di S. Antonino di Piacenza, Pietro, nel marzo del 1185 fu creato da Lucio III cardinale diacono di S. Nicola in Carcere Tulliano e nel 1188 fu promosso da Clemente III al titolo presbiterale di S. Cecilia ${ }^{98}$.

Assieme al cardinale Soffredo di S. Maria in Via Lata - anch'egli contraddistinto dal titolo di magister - il Diani svolse una legazione per pacificare Pisa e Genova, al fine di favorire la realizzazione della crociata. Quindi dalla città ligure i due legati si spostarono in Lombardia, dove tra la fine del 1188 e la primavera del 1189, si adoperarono per mettere pace tra i comuni - un'altra condizione indispensabile per l'organizzazione della spedizione in Terra Santa. Fin dalla primavera del 1189 Soffredo tornò alla curia papale, mentre Pietro Diani continuò da solo la legazione nell'Italia settentrionale fino al termine del $1190^{99}$. Dopo aver trascorso alla curia qualche mese il Diani già nella tarda estate del 1191 era di nuovo legato papale in Lombardia ${ }^{100}$, dove soggiornò a Milano, Piacenza, Padova, Parma, Verona e Mantova, e nella regione rimase fino al maggio del 1193, per favorire la pacificazione tra $\mathrm{i}$ comuni e l'imperatore; in questa occasione egli incontrò il pieno favore di Enrico VI, col quale nel 1195 per incarico papale, dapprima assieme al cardinale Graziano dei SS. Cosma e Damiano (un altro magister) nelle Marche, quindi dall'autunno del 1195 fino all'inizio del 1196 in Germania (con il cardinale Giovanni di S. Stefano in Celiomonte) trattò per la preparazione della crociata e la predicò in accordo con l'imperatore con grande successo, così che, quando il suo collega di legazione Giovanni tornò alla curia, egli rimase alla corte imperiale e accompagnò il sovrano nel suo ritorno nel regno d'Italia; solo nell'autunno inoltrato del 1196 Pietro fu di nuovo alla curia ${ }^{101}$.

Egli, dunque, soggiornò nella regione tra 1188 e 1190 e tra 1191 e 1193. Anche in seguito il Diani fu sovente in Lombardia per svolgere un'intensa azione pacificatrice in accordo questa volta con Enrico VI. Fu infine il cardinale, fino alla sua morte, avvenuta nel 1206, a garantire e a mediare personalmente le

98 Si veda la bibliografia citata sopra, alla nota 51.

99 Maleczer Papst (cit. nota 13) p. 85; Friedlaender (cit. nota 11) pp. 48 - 50 e 58-68.

100 Egli sottoscrisse privilegi papali tra il 2 maggio e il 30 agosto 1191: MALECzex Papst (cit. nota 13) pp. 364sg. nn. 2-26; quindi fu nuovamente alla curia dal 28 maggio 1193 : ibid. p. 369 n. 109.

101 Ibid. p. 96, che, oltre a giovarsi del lavoro della FrIEDLAENDER (cit. nota 11) pp. 88-93, considera le precisazioni cronologiche suggerite da Gerhard BaAken: Die Verhandlungen zwischen Kaiser Heinrich VI. und Papst Coelestin III. in den Jahren 1195-1197, in: DA 27 (1971) pp. 457 -513. La prima sottoscrizione del Diani di ritorno dalla legazione alla curia papale è del 7 dicembre 1196. 
relazioni tra la sua città natale, Piacenza, dove risiedette a lungo anche durante il pontificato di Innocenzo III, e la sede romana ${ }^{102}$.

\section{I suddiaconi della Chiesa romana}

Il caso appena accennato del cardinale Pietro Diani si presta a introdurre un ultimo aspetto che intendo considerare: l'importante ruolo svolto dai suddiaconi della Chiesa romana in quanto esecutori delle direttive apostoliche nell'Italia settentrionale.

Il suddiaconato subì proprio a partire dal periodo della riforma dell'XI secolo un'importante evoluzione, che, non senza perduranti ambiguità, lo portò a essere talora considerato tra gli ordini maggiori - diaconato e presbiterato fino a prevedere che, nel caso di evidente utilità, un suddiacono potesse assurgere alla dignità vescovile $\mathrm{e}^{103}$. A tale ascesa contribuì certo il prestigio di alcuni suddiaconi - segnatamente dei suddiaconi della Chiesa romana -, nonché il fatto che costoro fossero talora incaricati di importanti missioni per conto del papa $^{104}$. Come ha messo in luce Reinhard Elze, in molti casi furono loro affidati delicati compiti, soprattutto legazioni, poiché essi facevano parte del clero direttamente impegnato nel servizio dei pontefici ${ }^{105}$. Più di recente Tommaso di

102 Maleczek Papst (cit. nota 13) p. 86; id.: Diani, Pietro (cit. nota 51) p. 650: l'ultima sottoscrizione del cardinale a un privilegio papale risale al 2 novembre 1206; la circostanza è considerata con il dovuto risalto da Pietro Maria CAmpi: Dell'historia ecclesiastica di Piacenza, vol.2, Piacenza 1651, pp. 94sg. Pietro, probabilmente in previsione delle lunghe e pericolose legazioni che si prospettavano, aveva chiesto fin dal 1191 o 1192 a Celestino III la licentia testandi, il più antico di questo genere di atti che si sia conservato: Agostino Paravicini Bagliani: I testamenti dei cardinali del Duecento, Roma 1980 (Miscellanea della Società Romana di storia patria 25), pp. XLIII-XLIV e 3; sugli interventi di Pietro Diani soprattutto in relazione a istituzioni ecclesiastiche vercellesi Alberzoni Vercelli (cit. nota 42) pp. 113-119.

103 Robert L. Benson: The Bishop-elect. A Study in Medieval Ecclesiastical Office, Princeton (N.Y.) 1968, pp. 64sg., e, soprattutto Roger E. Reynolds: The Subdiaconat as a Sacred and Superior Order, in: ID.: Clerics in the Early Middle Ages, Hierarchy and Image, Aldershot 1999 (Collected Studies Series 669), pp. 1-39 n. IV (First Publication).

104 Basti qui per tutti accennare alla legazione svolta nel 1056 da Ildebrando (il futuro Gregorio VII), allora suddiacono di Vittore II: WeIss (cit. nota 5) pp. 18sg. In quell'occasione il suddiacono Ildebrando presiedette come legato papale un sinodo a Chalon-sur-Saône, durante il quale vennero deposti ben sei vescovi; si tratta di un'esperienza che ben consente di cogliere l'importanza della proposizione n. 4 del «Dictatus papae».

105 Reinhard ElZE: Die päpstliche Kapelle im 12. und 13. Jahrhundert, in: ZRGKanAbt 36 (1950) pp. 145-204, qui pp. 153-157 (rist. in: ID., Päpste - Kaiser - Könige und die mittelalterliche Herrschaftssymbolik. Ausgewählte Aufsätze, a cura di Bernhard Schimmelpfennig, London 1982, pp. 145-204): „Im übrigen erscheinen sie während des 12. 
Carpegna ha sottolineato come fino alla 'serrata del collegio cardinalizio' dell'XI secolo, „i suddiaconi erano tra i maggiori dignitari della città “106. A partire dal XII secolo, forse in relazione alla notevole mobilità dei clerici per motivi di studio, si nota un certo numero di suddiaconi della Chiesa romana non romani e, tanto meno, impegnati nel servizio liturgico nelle chiese dell'Urbe, quanto piuttosto insigniti di importanti benefici nelle città di provenienza, oppure in località prossime al luogo dei loro studi, soprattutto se si trattava delle scuole di teologia del regno di Francia ${ }^{107}$. Ben presto, certo in considerazione dell'alto livello della loro cultura e dei meriti acquisiti nel servizio alla Chiesa di Roma, alcuni suddiaconi ascesero alla dignità cardinalizia, come appunto, tra quelli qui ricordati, Ardizzone da Rivoltella, Lombardo e Pietro Diani da Piacenza ${ }^{108}$.

Si trattava di chierici che avevano ricevuto l'ordinazione suddiaconale dal pontefice, pur provenendo da diverse diocesi - quello di poter ordinare chierici da qualsiasi diocesi era un diritto decisamente rivendicato fin dal "Dictatus papae» (n. 14) -, e che pertanto avrebbero potuto ricevere le successive

Jhs. an der Kurie und außerhalb, bei Legationen und in Gerichtswesen in einer den Kardinälen ähnlichen, wenn auch nachgeordneten Stellung“" (p. 154).

106 Tommaso Di Carpegna Falconieri: Il clero di Roma nel medioevo. Istituzioni e politica cittadina (secoli VIII-XIII), Roma 2002, p. 137.

107 Elze (cit. nota 105) pp. 155sg.: „Infolgedessen finden sich viele päpstliche Subdiakone seit dem Auftreten dieser Bezeichnung - als Kanoniker italienischer und französischer Kirchen".

108 Si veda, inoltre, il caso, ben documentato grazie al ricco epistolario che si è conservato, del suddiacono papale Alexius che, dal soggiorno parigino e dagli studi condotti presso $S$. Vittore a partire dalla primavera del 1159 , nonché da importanti servigi resi al papa, soprattutto da una legazione in Scozia, si attendeva una promozione cardinalizia, che sopraggiunse solo nel 1188, quando fu creato cardinale prete di S. Susanna: Papsturkunden in Frankreich N.F. 8 (cit. nota 5) pp. 62sg.; PACAUT (cit. nota 15) pp. 828sg. („Une légation est donc une étape dans le cursus qui mène des offices pontificaux au cardinalat."), e Maleczen Papst (cit. nota 13) pp. 248sg., che evidenzia i suoi legami con la famiglia romana Capocci, la medesima cui sarebbe stato legato anche il cardinale Pietro de Mizo, o Cataxius (notiamo che si sono conservate tre lettere di questo cardinale al suddiacono Alexius: Papsturkunden Frankreich N.F. 8 [cit. nota 5] nn. 58-60); l'appartenenza alla famiglia Capocci è segnalata da MaLeczek Papst (cit. nota 13) p. 248sg. Pietro fu cardinale diacono di S. Eustachio, dal 1166 cardinale prete di S. Lorenzo in Damaso; in due documenti pavesi del 1174 è denominato Cataxius (1174 luglio 9, Pavia: Le carte del monastero di San Pietro in Ciel d'Oro di Pavia, 2 [1165-1190], a cura di Ezio Barbieri/Maria Antonietta Casagrande Mazzoli/Ettore CAu, Pavia/Milano 1984, nn. 74 e 75). Lidentificazione tra Pietro de Mizo (sul quale vedi Helene Tillmann: Ricerche sull'origine dei membri del collegio cardinalizio nel secolo XII, 2/2, in: RSCI 29 [1975] pp. 365-366, che però non ricorda il nome Cataxius e ritiene il cardinale membro di una famiglia romana) e Pietro Cataxius è in WeIss (cit. nota 5) pp. 240-242, che alle pp. 262sg., mette anche in luce i motivi della vicinanza o, quanto meno, della comune formazione di Pietro de Mizo con il cardinale pavese Guglielmo di Pavia; si veda ID.: Legatenurkunde und Papsturkunde (cit. nota 5) pp. $342-344$. 
ordinazioni solo dal vescovo di Roma, al quale rimanevano direttamente soggetti; al tempo stesso acquisivano importanti privilegi e una dignità che, proprio per la loro vicinanza al papa, li collocava in una condizione particolare rispetto agli ecclesiastici locali. D'altra parte l'esenzione dalla giurisdizione diocesana loro accordata era finalizzata a garantire la più ampia disponibilità al servizio del pontefice, un motivo che attesta la sempre maggior incisività del primato papale in tutte le Chiese ${ }^{109}$. Già il Kehr aveva opportunamente richiamato l'attenzione sui suddiaconi della Chiesa romana come agenti privilegiati di Alessandro III in Lombardia e alla loro attività dedicò una certa attenzione anche Annamaria Ambrosioni, nel suo studio su Alessandro III e la Chiesa ambrosiana ${ }^{110}$.

Oltre ai già ricordati suddiaconi ascesi alla dignità cardinalizia nel corso del XII secolo, meritano di essere ricordati altri esponenti di questo gruppo attivamente impegnati all'interno dei capitoli di importanti chiese, soprattutto di cattedrali, e a noi noti perché impegnati in compiti di carattere giudiziario, sovente affidati loro dal papa ${ }^{111}$.

\subsection{Suddiaconi impegnati nelle cause giudiziarie}

Oberto da Terzago dal 1168 arciprete di Monza, nominato a questa carica dall'arcivescovo Galdino per garantirsi il controllo su una Chiesa, in precedenza segnata da forti tendenze filoimperiali ${ }^{112}$, si distinse per le competenze di carattere giuridico, come suggerisce il fatto che a lui sia stata affidata la soluzione di diverse cause giudiziarie tra ecclesiastici: oltre a una controversia da lui risolta

109 Elze (cit. nota 105) p. 156.

110 Oltre alla osservazione del KeHr (cit. nota 1) pp. 368sg.: „Dabei ist zugleich zu beachten, daß viele dieser Kardinäle selbst Lombarden waren und Pfründen in den dortigen Kirchen besaßen, z. T. sogar dauernd dort residierten. ... Auch mit lombardischen Kirchenpfründen bedachten Subdiakonen des apostolischen Stuhles wäre in diesem Zusammenhange nachzugehen. Täuscht mich nicht alles, so ist im 12. Jahrhundert kein Land von päpstlichen Agenten hohen und niedern Ranges so sehr durchsetzt gewesen als gerade die Lombardei“". Sull'importanza dei suddiaconi della Chiesa romana nelle funzioni di raccordo tra la sede apostolica e le diverse regioni, oltre a MALECZEK Papst (cit. nota 13) pp. 250sg., si veda Ambrosioni (cit. nota 2) pp. 395-398 e 435442.

111 Ardizzone da Rivoltella, quando ancora era semplicemente suddiacono della Chiesa romana fu incaricato da Eugenio III, insieme al magister Omnibonus, di risovere una lite tra il vescovo Gerardo di Bologna e l'abate Alderico di Padova (1153): Dunken (cit. nota 2) p. 16; la sentenza è stata recepita nelle decretali gregoriane (X. 2.7.2 = Aemilius Friedberg: Corpus iuris canonici, vol. 2, Leipzig 1879, col. 266).

112 Ambrosioni (cit. nota 2) p. 437. 
nel 1170 per incarico dell'arcivescovo Galdino ${ }^{113}$, ancora nel 1181 sentenziò in una lite tra i canonici della cattedrale di Piacenza e il vescovo di quella città Tedaldo, circa i diritti su una chiesa piacentina ${ }^{114}$.

Il magister Giovanni Buono da Fornovo, canonico di S. Vincenzo a Bergamo, fu anch'egli un esperto giurista, come si evince dagli incarichi che ricevette: nel $1170 \mathrm{fu}$ uno dei tre giudici delegati papali impegnati nella soluzione della già ricordata causa tra Galdino e il clero decumano per l'elezione del primicerio ${ }^{115}$, quindi, nel 1174, svolse un importante ruolo in una controversia tra il vescovo di Lodi e il preposito della basilica di S. Nazaro di Milano $^{116}$. Lo stesso suddiacono, inoltre, tra 1170 e 1172 era stato incaricato di procedere materialmente alla restituzione di una notevole somma di denaro, a suo tempo mutuata ad Alessandro III dal piacentino Giovanni Grasso: il cardinale Manfredo di S. Giorgio in Velabro avrebbe dovuto consegnare il denaro al vescovo di Piacenza, che, a sua volta, per il tramite di Giovanni Buono, lo avrebbe destinato al creditore ${ }^{117}$.

Ancora grazie alla documentazione dell'Italia Pontificia emergono indicazioni circa il suddiacono lodigiano Ugo, incaricato da Celestino III nel 1193 di emanare gravi sanzioni disciplinari nei confronti del vescovo di Pavia, Lanfranco, nel caso in cui questi non avesse osservato la sentenza a lui sfavorevole circa il godimento delle decime di Port'Albera, una località contesa con la vicina diocesi di Piacenza ${ }^{118}$.

\subsection{I suddiaconi incaricati dal papa di svolgere legazioni}

Tra i suddiaconi papali presenti nelle Chiese lombarde è possibile individuare almeno due casi di incarichi legatizi. Alberto da Somma, suddiacono papale nonché nipote del cardinale vescovo di Ostia Guido da Somma, nella tarda estate e nell'autunno del 1177 svolse una legazione in Lombardia ${ }^{119}$. Nel 1178 fu inviato in Inghilterra per invitare i vescovi inglesi al Concilio lateranense ${ }^{120}$. Ancora per incarico di Alessandro III egli nel 1179-1180 fu nuovamente

113 Vedi sotto, nota 129.

114 PUU in Italien, vol. 2 p. 274 n. 38: la sentenza, pronunciata da Oberto assieme all'arcidiacono della Chiesa milanese Uberto Crivelli, fu approvata da Lucio III il 3 ottobre 1182.

115 Vedi sopra, nota 88; Giulini (cit. nota 88) III, p. 696 (edizione in ibid. 7, p. 131).

116 Dunken (cit. nota 2) p. 95; Ambrosioni (cit. nota 2) p. 437.

117 PUU in Italien, vol. 2 p. 264 n. 26; DUNKEN (cit. nota 2) p. 110.

118 PUU in Italien, vol. 2 pp. $284-285$ n. 48.

119 Dunken (cit. nota 2) pp. 140sg.; Pacaut (cit. nota 15) p. 828; Weiss (cit. nota 5) p. 269.

120 Ambrosioni (cit. nota 2) p. 438; Weiss (cit. nota 5) p. 269. 
inviato nell'Italia settentrionale, precisamente a Venezia, ma durante il suo viaggio toccò anche la Lombardia orientale, segnatamente Brescia, nonché alcune città della Lombardia occidentale, come fa suppore il suo intervento (13 luglio 1180) presso i vescovi di Tortona, Piacenza, Cremona e Parma in favore del monastero pavese di S. Maria Teodote ${ }^{121}$. Il 10 ottobre, a Venezia, egli ricevette istruzioni per recapitare ai rettori della Lega lombarda le lettere di Federico I in merito alle trattative di pace con Alessandro III e i cardinali; il 22 dello stesso mese era a Parma, dove espose le richieste dell'imperatore ai consoli di Milano, Piacenza e Alessandria. In seguito fu anche a Novara, dove si occupò di alcune questioni relative all'amministrazione della diocesi e al pagamento del censo alla Chiesa romana ${ }^{122}$.

Un altro suddiacono papale, Sicardo, pure lui esperto di diritto e teologia, che aveva studiato forse a Colonia alla scuola del suo concittadino Prepositino, quindi a Bologna, svolse almeno una legazione per conto di Lucio III in Germania ${ }^{123}$, il medesimo pontefice che, secondo la personale testimonianza di Sicardo, nel 1183 lo aveva ordinato suddiacono ${ }^{124}$. La carriera di Sicardo ebbe importanti sviluppi in sede locale, giacché egli nel 1185 fu eletto vescovo di Cremona e fu poi incaricato da Urbano III nel dicembre del 1185 di svolgere una legazione in Lombardia - legazione che si protrasse fino al giugno dell'anno successivo $^{125}$-, un incarico che gli fu rinnovato nel 1212 da Innocenzo III, questa volta per contrastare, unitamente ad Ariprando Visconti, un altro vescovo proveniente dalle file dei suddiaconi papali e insignito della legazione, la politica di Ottone di Braunschweig in Lombardia ${ }^{126}$.

121 Dunken (cit. nota 2) p. 148.

122 IP 6/2 p. 60 n. 7; Ambrosioni (cit. nota 2) p. 397; EAd.: Un documento sulla vita comune dei canonici di S. Ambrogio, in: Contributi dell'Istituto di Storia Medioevale, vol. 3, a cura di Pietro Zerbi, Milano 1975 (Scienze storiche 12), pp. 3-28, ora in Ambrosioni (cit. nota 2) pp. 156-159, nello stesso volume si vedano anche le pp. 378, 381, 438sg.

123 Dunken (cit. nota 2) pp. 158-160; Oswald Holder-Egger: De vita Sicardi, in: MGH SS 31, Hannover/Leipzig 1902, pp. 22-59; su di lui Ch. LefEBvre in: DDC 7 (1965) coll. 1008-1011; Giorgio PicAsso in: Dictionnaire de spiritualité 14 (1988) coll. 810-814; André VAuchez: Innocent III, Sicard de Crémone et la canonisation de saint Homebon ( $\dagger$ 1197), in: Innocenzo III (cit. nota 51) pp. 435-453; Edward Coleman: Sicard of Cremone as Legate of Innocent III in Lombardy, in: Innocenzo III (cit. nota 51) pp. 929-953.

124 Non sono frequenti notizie sulle ordinazioni suddiaconali da parte dei pontefici, come nota Elze (cit. nota 105) pp. 155sg. nota 63.

125 Dunken (cit. nota 2) pp. 159sg.; sul lungo episcopato di Sicardo, mi limito a rinviare a Savio (cit. nota 42) pp. 94-121.

126 Alberzoni Città (cit. nota 65) pp. 71-73. 


\subsection{I suddiaconi nei capitoli delle cattedrali}

Sarebbe indubbiamente utile avviare un censimento dei suddiaconi della Chiesa romana che nel XII secolo ottennero cariche di rilievo all'interno dei capitoli di cattedrali o di importanti chiese ${ }^{127}$, ma il compito è reso oltremodo arduo dal fatto che spesso le menzioni nei documenti o le sottoscrizioni non riportano tutte le dignità ricoperte: si tratta di un problema analogo a quello che si pone qualora si voglia indagare sul titolo di magister ${ }^{128}$. Basti qui esemplificare con due significativi casi. Il primo è offerto da un documento contenente la già ricordata sentenza pronunciata nel luglio del 1170, per incarico dell'arcivescovo Galdino, dal suddiacono della Chiesa romana Oberto, che nel testo della sentenza dichiara di essere Sancte Romane Ecclesie subdiaconus et Modoeciensis archipresbiter, mentre nella sottoscrizione si trova solo: Ego Obertus subdiaconus et Modoetiensis ecclesie minister subscripsi ${ }^{129}$. Un secondo esempio si colloca verso la fine del secolo: ancora a Milano, tra i sottoscrittori a un diploma

127 Accanto ai tre casi ricordati da Elze (cit. nota 105) p. 156 nota 67 (Oberto da Terzago a Monza, Paolo Scolari a S. Maria Maggiore a Roma e a un non ricordato arciprete di S. Angelo), si aggiungano quelli menzionati da Ambrosioni (cit. nota 2) 397sg. Mi limito qui a segnalare almeno altri quattro casi: 1) il magister Giovanni Buono da Fornovo, che in una sentenza emessa dal vescovo di Bergamo Guala nell'agosto del 1174 è indicato come domini pape subdiaconus e canonico della chiesa di Bergamo; 2) un non meglio identificato prepositus Sancti Prosperi (Reggio Emilia), indicato da Celestino III come subdiaconus noster (1192 aprile 23: Julius von Pflugk-Harttung: Acta pontificum Romanorum inedita, vol. 3, Stuttgart 1886, p. 383 n. 447); 3) il magister Aicardo di Burolo, preposito del capitolo di Ivrea almeno dal 16 luglio 1196, quando Celestino III confermò una sentenza del vescovo di Tortona: Le carte dell'Archivio capitolare (cit. nota 42) pp. 183-184 n. DCXXXIII (il documento è edito anche in PUU in Italien 3 pp. $138-139$ n. 24); nel corso di questa controversia Aicardo era procuratore dei chierici di S. Nazaro e fu forse proprio lui a recarsi presso la corte papale per ottenere la conferma della sentenza. Un'altra importante attestazione su Aicardo è in una lettera del primo anno di pontificato di Innocenzo III (Die Register Innocenz' III., 1: 1. Pontifikatsjahr, 1198/1199. Texte, bearbeitet von Othmar Hageneder/Anton Haidacher, Graz/Köln 1964 [Publikationen der Abteilung für historische Studien des Österreichischen Kulturinstituts in Rom 2/1], p. 62 n. 40), che consente di cogliere un incarico affidato ad Aicardo da Celestino III: Preterea dilectis filiis Aicardo Yporiensi et magistro Marescoto canonice Gualteri prepositis, Romane ecclesie subdiaconis, dedit ipse predecessor noster firmiter in mandatis; il relativo documento di Celestino III è indicato in IP 6/2 p. 67 n. *29 (sulla base del Registro di Innocenzo III; infine 4) magister Marescotus, preposito della canonica pavese di S. Maria Gualtieri; si vedano, inoltre, sotto (note 133sg. e 141 e testo corrispondente) i casi di Oldeberto Tornielli, Giovanni Tornielli e Obizo de Castello, canonici di Novara; di Guglielmo Balbo e di Alberto Amicone (vedi sotto, note $139-145)$.

128 Rainer Maria Herkenrath: Studien zum Magistertitel in der frühen Stauferzeit, in: MIÖG 88 (1980) pp. 3-35.

129 Edizione a cura di Michele Ansani: Codice diplomatico della Lombardia medievale (cit. nota 41), Milano, S. Vittore al Corpo, n. 3. 
dell'arcivescovo Filippo da Lampugnano del 22 ottobre 1197 compaiono i domini Ariprando Visconti ed Enrico da Settala, designati in quella occasione come subdiaconi iamdicte ecclesie, vale a dire della Chiesa di Milano ${ }^{130}$. In realtà, grazie alla documentazione di provenienza papale, sappiamo che entrambi i chierici erano suddiaconi della Chiesa romana ${ }^{131}$.

Un suddiacono papale poteva accedere a una dignità capitolare qualora avesse ottenuto validi appoggi in sede locale, ma soprattutto presso la curia papale, come è possibile cogliere grazie a una lettera di Innocenzo III, che riferisce in modo dettagliato una causa giudiziaria vertente sul conseguimento di un beneficio nella cattedrale di Novara. Il 5 marzo del 1198, due settimane dopo la consacrazione papale, Innocenzo III incaricava il vescovo di Lodi di risolvere una questione dibattuta tra il capitolo della Chiesa di Novara e il chierico Alberto Siccus ${ }^{132}$. Quest'ultimo, grazie alla mediazione di suo fratello Giacomo, nel 1196 aveva ottenuto da Celestino III una lettera di raccomandazione presso il vescovo di Novara Oberto, che, in accordo con il capitolo, aveva assegnato un beneficio ad Alberto; e questi da allora in eadem ecclesia stetit, cantavit et legit et cum aliis divina officia celebravit. Il capitolo aveva addirittura inviato alla curia il dilectus filius Obizo de Castello, suddiacono papale e canonico di Novara, che aveva ottenuto sempre da Celestino III la conferma della nomina. Ma nel medesimo anno un canonico di Novara, il magister Ugo de Racaneto, fu eletto vescovo di Squillace in Calabria, un fatto di cui Giacomo e Alberto Sicco dichiararono di essere rimasti all'oscuro, e la prebenda di Ugo fu assegnata da Celestino III, dietro richiesta di alcuni cardinali e dell'imperatore, al suddiacono papale Giovanni Tornielli ${ }^{133}$.

130 Giulini (cit. nota 88) vol. 4 p. 94.

131 Per Ariprando: Die Register Innocenz' III., 5: 5. Pontifikatsjahr, 1202/1203. Texte, bearbeitet von Othmar Hageneder unter Mitarbeit von Christoph EgGer/Karl Rudolf/Andrea Sommerlechner, Wien 1993 (Publikationen des Historischen Instituts beim Österreichischen Kulturinstitut in Rom 2/5), p. 283 n. 143 (144): 1203 gennaio 19, Innocenzo III ordina al capitolo di Novara di assegnare una prebenda vacante dilecto filio Alibrando Vicecomiti, subdiacono nostro, Mediolanensi ordinario, quem virum esse novimus providum et discretum et tam scientia quam moribus adornatum; per Enrico da Settala: Register I (cit. nota 109) p. 183 n. 120: dilectus filius Henricus, subdiaconus noster, pro te (l'arcivescovo Filippo da Lampugnano) tam apud sedem apostolicam quam alias fideliter laboraverit: 1198 aprile, Innocenzo III ordina all'arcivescovo di Milano di assegnare a Enrico da Settala la carica vacante di cancelliere della Chiesa di Milano.

132 Hageneder (cit. nota 127) pp. 61-64 n. 40.

133 Ibid. p. 62: Cumque magister Hugo de Racaneto, eiusdem ecclesie tunc canonicus, in Calabria factus fuisset episcopus tempore procedente, ipso Jacobo et fratre suo promotionem suam penitus ignorantibus, dilectus filius Johannes Torniellus, subdiaconus noster, fuit de prebenda prefati Hugonis per predictum predecessorem nostrum ad preces imperiales et quorundam cardinalium investitus. 
Intanto il vescovo di Novara morì e gli successe il magister Pietro, già canonico della cattedrale, così che si liberò una prebenda che fu subito rivendicata sia da Giacomo, che riteneva fosse di diritto di suo fratello Alberto, sia da Giovanni; la complessa causa fu infine portata al cospetto di Celestino III, che, dopo aver sentito il parere dei cardinali, aveva infine assegnato la prebenda ad Alberto, lo aveva investito per anulum, e aveva rilasciato delle lettere per rafforzare la decisione presa e smorzare le resistenze di alcuni membri del capitolo, che continuavano a sostenere la candidatura del Tornielli. Celestino III aveva quindi incaricato due suddiaconi papali di sua fiducia, Aicardo di Ivrea e Marescotto, rispettivamente prepositi della cattedrale di Ivrea e della canonica Gualtieri di Pavia, di far rispettare la decisione papale dal capitolo di Novara, eventualmente servendosi di censure ecclesiastiche.

Senza voler qui esaminare ulteriormente l'andamento della causa, mi limito a notare quanto la lettera innocenziana consenta di cogliere, certo in via approssimativa, circa la consistente presenza dei suddiaconi papali all'interno dei capitoli cattedrali: lo stesso Giovanni Tornielli, che dal 1190 era già canonico nella concattedrale novarese di S. Gaudenzio, e che prima del 1206 ottenne anche l'ambito canonicato in S. Maria, fu poi eletto vescovo di Bergamo nell'autuno del $1211^{134}$.

In secondo luogo la missiva innocenziana risulta particolarmente istruttiva circa le modalità che consentivano ai suddiaconi di ottenere posti nei capitoli delle cattedrali: Celestino III era stato sollecitato a intervenire in favore del Tornielli dalle preghiere rivoltegli dall'imperatore Enrico VI e da alcuni cardinali, di cui non sono indicati i nomi. Ritengo, però che in questo caso sia possibile avanzare qualche fondata ipotesi: proprio nel 1196 il cardinale Pietro Diani tornava dalla legazione svolta nel regno di Germania e, infatti, raggiunse la curia solo nell'ottobre di quell'anno. Con lui era venuto nella penisola anche l'imperatore Enrico VI, che nel novembre, mentre ancora era a Tivoli fu raggiunto dal Diani, oramai divenuto un uomo di fiducia della corte imperiale, dal camerario Cencio e dal cardinale Ottaviano d'Ostia, inviati dal papa per proseguire le trattative con l'imperatore ${ }^{135}$. Ebbene: prima di giungere alla curia, Pietro Diani aveva soggiornato a Torino, Milano e Piacenza ${ }^{136}$, quindi doveva essere transitato da Novara, dove è probabile che i potenti congiunti del Tornielli, tra i quali era anche il vescovo di Acqui Ugo Tornielli - vescovo e al

134 Thomas Behrmann: Domkapitel und Schriftlichkeit in Novara (11.-13. Jahrhundert). Sozial- und Wirtschaftsgeschichte von S. Maria und S. Gaudenzio im Spiegel der urkundlichen Überlieferung, Tübingen 1994 (Bibliothek des Deutschen Historischen Instituts in Rom 77), pp. 57 e 297.

135 Maleczer Papst (cit. nota 13) p. 86.

136 Friedlaender (cit. nota 11) p. 97. 
tempo stesso arcidiacono della cattedrale di S. Maria di Novara -, gli abbiano avanzato la richiesta e abbiano ottenuto che fosse appoggiata presso il papa ${ }^{137}$.

Oltre ai meriti di studio erano dunque indispensabili consistenti appoggi da parte di prelati o di personaggi di alto rango, che consentivano di affermare per così dire anche in loco la posizione privilegiata dei suddiaconi della Chiesa romana.

\subsection{Filippo da Lampugnano e l'ordinazione dei suddiaconi}

Negli ultimi decenni del XII secolo il numero dei suddiaconi della Chiesa romana sembra decisamente lievitare, sia in relazione agli incarichi da loro svolti per conto del papa, sia per le brillanti carriere ad essi riservate in sede locale come pure alla curia romana ${ }^{138}$; non si può peraltro escludere che l'emergere più frequente di notizie a loro proposito sia dovuto alla più abbondante tradizione documentaria. Oltre al già ricordato Sicardo di Cremona una nutrita schiera di futuri vescovi lombardi proveniva dal gruppo dei suddiaconi papali: i milanesi Uberto da Pirovano, canonico di Monza e magister, dal 1206 cardinale diacono di S. Angelo, quindi arcivescovo di Milano ${ }^{139}$; il già ricordato Ariprando Visconti, ordinario della Chiesa di Milano, nonché canonico della cattedrale di Novara, poi vescovo di Vercelli e legato papale di Innocenzo III assieme a Sicardo di Cremona ${ }^{140}$; Enrico da Settala, cimiliarca della Chiesa ambrosiana e

137 La famiglia Tornielli è indicata da Behrmann (cit. nota 134) passim, come la meglio rappresentata nei capitoli novaresi a partire dal XII secolo; era sicuramente una famiglia con buone disponibilità finanziarie, così che in alcune occasioni concesse mutui in denaro ai canonici novaresi. Ugo era presente fin dal 1172 nel capitolo di S. Maria, del quale mantenne la dignità di arcidiacono anche durante il suo episcopato, e come arcidiacono della cattedrale concluse i suoi giorni, dopo che nel 1213 fu costretto a dimettersi da vescovo di Acqui-Alessandria: Alberzoni Città (cit. nota 65) pp. 173211; EAD.: I „mercatores Romani“ nel Registro di Innocenzo III, in: La storia e la memoria. In onore di Arnold Esch, a cura di Roberto Delle Donne/Andrea Zorzi, Firenze 2002, pp. 91-108.

138 Assai istruttiva è la corrispondenza relativa al suddiacono papale Alexius, al quale fin dal 1168 fu fatta balenare un'importante promozione presso la curia, probabilmente il suo ingresso nel collegio cardinalizio, per il quale avevano lavorato a lungo, oltre ai suoi parenti già presenti nel collegio cardinalizio, il cardinale Giacinto e il cardinale Guglielmo da Pavia, il quale pure aveva trascorso un lungo periodo a S. Vittore: Papsturkunden Frankreich N. F. 8 (cit. nota 5) nn. 67 e 99-102.

139 Ganzer (cit. nota 2) pp. 152sg.; Maleczek Papst (cit. nota 13) pp. 153sg.; Maria Pia Alberzoni: Hubert de Pirovano, in: DHGE 25 (1995) coll. 14-17.

140 Vedi sopra, note 126 e 130sg.; Ariprando Visconti, ordinario della Chiesa milanese, nel settembre del $1203 \mathrm{fu}$ attivo come procuratore degli ordinari della Chiesa milanese nella causa che li vedeva opposti al clero decumano della medesima città: Pogliani (cit. nota 2) pp. 84sg.; almeno dal 1203 era anche canonico di S. Maria di Novara: BeHrmann (cit. nota 134) pp. 60 e 270, dal 1208 al 1213 vescovo di Vercelli (Fedele SAvio: Gli 
nel 1213 nominato arcivescovo dal pontefice ${ }^{141}$; i novaresi Oldeberto Tornielli, dal 1185 presente nel capitolo della cattedrale di S. Maria di Novara e dal 1215 vescovo di quella città, e suo nipote Giovanni, dal 1190 nel capitolo novarese di S. Gaudenzio e dal 1211 vescovo di Bergamo ${ }^{142}$. Ad essi se ne possono aggiungere numerosi altri, che solo un'attenta indagine, soprattutto del clero cattedrale, potrà rivelare a pieno. Mi limito qui a ricordare ancora Guglielmo Balbo, suddiacono papale e ordinario della Chiesa milanese, anch'egli distintosi per indubbie capacità e conoscenze in campo giuridico, sovente impegnato come giudice delegato papale, e, soprattutto procuratore dell'arcivescovo Filippo da Lampugnano nell'annosa causa che fu dibattuta alla curia per il riconoscimento di importanti diritti della cattedra ambrosiana sul monastero di Scozola presso Sesto Calende ${ }^{143}$, dal 1201 arciprete della Chiesa milanese ${ }^{144}$. Alberto Amicone, nel capitolo della Chiesa ambrosiana almeno dal 1197 e nel 1213 successore di Guglielmo Balbo nella dignità di arciprete ${ }^{145}$.

Il loro numero e la loro fortuna aumentarono almeno fino al pontificato di Innocenzo III, il quale, a sua volta, probabilmente a Bologna, o comunque in quella regione, nel 1187 aveva ricevuto l'ordinazione suddiaconale da Gregorio VIII $^{146}$. Innocenzo III, infatti, ancor prima della sua consacrazione a vescovo di Roma, nel febbraio del 1198 dovette affrontare una richiesta dell'arcivescovo di Milano Filippo da Lampugnano, che riteneva necessario poter procedere alla consacrazione agli ordini sacri dei numerosi suddiaconi papali presenti tra il

antichi vescovi d'Italia dalle origini al 1300 descritti per regioni. Il Piemonte, Torino 1898, p. 488) e dal 1212 legato papale assieme a Sicardo di Cremona: Alberzoni Città (cit. nota 65) pp. 181sg. e 186-190.

141 Maria Pia Alberzoni: Henri de Settala, in: DHGE 23 (1990) coll. 1227-1230.

142 Behrmann (cit. nota 134) pp. 34, 57, 297, 308 (albero genealogico della famiglia); SAvio (cit. nota 138) pp. 275sg. (Oldeberto) e id.: Gli antichi vescovi d'Italia dalle origini al 1300 descritti per regioni. La Lombardia, 2/1: Bergamo - Brescia - Como, Bergamo 1929, pp. 88-99 (per Giovanni); le difficoltà incontrate da Giovanni per vedersi riconoscere la prebenda nel capitolo di S. Maria sono accennate sopra, note 132 133.

143 Die Register Innocenz' III., 2: 2. Pontifikatsjahr, 1199/1200. Texte, bearbeitet von Othmar Hageneder/Werner Maleczek/Alfred A. Strnad, Rom/Wien 1979 (Publikationen des Österreichischen Kulturinstituts in Rom 2/2), pp. 60-66 n. 37 (1199 aprile 16); Gesta Innocentii PP III, in: Migne PL 214 coll. LXXXIVsg.; sull'attività di Guglielmo Balbo, soprattutto come giudice delegato papale: Alberzoni Città (cit. nota 65) pp. 108sg., 181, 186-189, 232, 237.

144 Pogliani (cit. nota 2) passim. Si vedano, inoltre, i casi ricordati sopra, alla nota 127. 145 Fedele SAvio: Gli antichi vescovi d'Italia dalle origini al 1300 descritti per regioni. La Lombardia, 1: Milano, Firenze 1913, p. 567.

146 La notizia è nei Gesta Innocentii (cit. nota 143) col. XVIII: Hunc (Lotharium) sanctae memoriae Gregorius octavus papa in subdiaconum ordinavit; Wilhelm Iмкамр: Das Kirchenbild Innocenz III. (1198-1216), Stuttgart 1983 (Päpste und Papsttum 22), p. 23; Werner Maleczek: Innocenzo III, in: Enciclopedia dei papi (cit. nota 21) pp. 326350 . 
clero della sua diocesi ${ }^{147}$. Il presule doveva aver prospettato una situazione drammatica, nella quale egli si sarebbe trovato addirittura in difficoltà a trovare chierici degni della promozione che non avessero già ricevuto un'ordinazione dal papa - presumibilmente quella suddiaconale - e che, quindi, in quanto incardinati nel clero romano, pur essendo residenti nella diocesi ambrosiana, sarebbero potuti divenire diaconi o presbiteri solo grazie all'imposizione delle mani del vescovo di Roma ${ }^{148}$. Con buona probabilità tale forte concentrazione di chierici legati alla sede apostolica doveva verificarsi tra il clero della cattedrale, anche se la loro precisa entità è difficilmente valutabile sulla base delle sottoscrizioni ai documenti arcivescovili.

Innocenzo III rispondeva positivamente alla petizione dell'arcivescovo e gli concedeva di procedere auctoritate nostra alle ordinazioni di coloro che fossero risultati idonei e che avessero manifestato la loro volontà di ascendere al diaconato o al presbiterato ${ }^{149}$, altrimenti - evidentemente nel caso i suddiaconi avessero manifestato qualche resistenza ad accedere al diaconato - il presule avrebbe dovuto segnalare in una lettera al papa quali altri chierici 'romani' a suo parere potevano essere ritenuti idonei e necessari; in questo caso il pontefice si riservava di deliberare in merito e di far quindi giungere all'arcivescovo le indicazioni sul da farsi ${ }^{150}$.

A prescindere da considerazioni che suggerirebbero la volontà dell'arcivescovo di riprendere l'iniziativa in vista di un maggior controllo sul clero della sua diocesi, la situazione della Chiesa di Milano ministrorum solacio destituta, come descritta nella lettera innocenziana, può essere considerata non molto lontana dalla realtà: nel capitolo della cattedrale i suddiaconi dovevano essere realmente numerosi e così diveniva difficile promuovere agli ordini sacri coloro che ne

147 Hageneder (cit. nota 127) pp. 33sg. n. 22; Elze (cit. nota 105) pp. 168-171; Maria Pia Alberzoni: Lampugnano, Filippo da, in: DBI 63 (2004) pp. 285-288.

148 Hageneder (cit. nota 127) pp. 33sg. n. 22: Inde est, quod - sicut ex tuarum tenore litterarum accepimus - Mediolanensis ecclesia tam in capite quam in membris occasione clericorum illorum, qui ab ipso Romano pontifice ordinem receperunt, adeo est ministrorum solacio destituta, ut paucos clericos in eadem ecclesia valeas invenire, quos ad diaconatus et presbyteratus possis officium promovere.

149 Ibid. p. 34: Verum quia fraternitas tua suppliciter a nobis expetiit, ut ipsius ecclesie necessitatem sollicitudine paterna pensantes tibi deberemus licentiam indulgere manus posse illis ordinatione imponere.

150 Ibid.: Super hoc tue fraternitati taliter duximus respondendum, quod ipsius ecclesie necessitate pensata, si aliqui fuerint de supradictis clericis, qui ad hoc videntur idonei et spontanea voluntate per tuum ministerium voluerint ad sacros ordines promoveri, eos auctoritate nostra tibi liceat ordinare. Alioquin illos, quos ad officium illud magis idoneos ac necessarios fore noveris, nobis per tuas litteras significare curabis. Nos enim deliberato consilio respondebimus, quid tibi super hoc fuerit faciendum. Desidero qui esprimere la mia gratitudine al dottor Martin Bertram (Deutsches Historisches Institut in Rom) per i validi consigli offertimi nell'interpretazione di questo testo. 
avrebbero abbisognato per ricoprire le dignità capitolari ${ }^{151}$. A puro titolo esemplificativo ricordo i numerosi casi di arcipreti o prepositi che si intitolano suddiaconi della Chiea romana, un chiaro indizio che non avevano ancora ricevuto gli ordini maggiori, proprio perché il loro conferimento dipendeva dal vescovo di Roma. Tra questi casi si segnala quello di Oberto da Terzago, presente nel capitolo di Milano fin dal 1168, designato dall'arcivescovo Galdino arciprete di Monza, quindi dal 1194 anche arcidiacono della cattedrale di Milano, tra settembre 1195 e giugno 1196 arcivescovo di Milano: si ha l'impressione che la ragguardevole carriera di questo chierico dovette essere coronata dall'ordinazione presbiterale solo in un periodo di tempo prossimo all'elezione episcopale, un caso che certo non poteva passare inosservato e non suscitare perplessità nel suo successore sulla cattedra di Ambrogio, il magister Filippo da Lampugnano ${ }^{152}$.

Il fatto che i suddiaconi papali godessero di consistenti benefici nei capitoli di importanti chiese e poi non fossero in grado di adempiere ai compiti richiesti dalla dignità ricoperta fu motivo di attriti, sia all'interno dei collegi canonicali, sia tra capitoli e vescovi. Reinhard Elze ha inoltre indicato proprio nell'alto numero dei suddiaconi papali non residenti presso la curia romana e nei problemi derivanti dal loro approvvigionamento con benefici nelle Chiese locali uno dei motivi di scontento dei vescovi. L'esenzione dei suddiaconi papali dalla

151 Accenno qui a qualche esempio delle difficoltà nell'individuare con sicurezza i suddiaconi papali presenti nei capitoli delle cattedrali: 1) in un privilegio dell'arcivescovo Robaldo (1143-1144), al primo posto dopo l'arcivescovo compare Galdinus, cancellarius, il futuro arcivescovo; nel giugno del medesimo anno, lo stesso Galdino sottoscriveva un privilegio arcivescovile come Galdinus subdiaconus et cancellarius (in: Codice diplomatico della Lombardia medievale [cit. nota 41], ed. a cura di Ada Grossi/ Maria Franca BARONI); notiamo che negli stessi documenti emerge anche che un'altra importante carica - quella di tesoriere - era ricoperta da un suddiacono: Obitius subdiaconus et cimiliarca. 2) In un diploma dell'arcivescovo Filippo da Lampugnano (1197), pubblicato in GiULINI (cit. nota 88) 7, pp. 146-147, tra i sottoscrittori figurano tre suddiaconi, Lanterio da Lampugnano (un parente dell'arcivescovo), Ugo da Settala (appartenente alla stessa famiglia di un altro suddiacono papale, Enrico, nel 1213 nominato da Innocenzo III arcivescovo di Milano) e Alberto. L'appartenenza di quest' ultimo al gruppo dei suddiaconi papali è chiarita da una lettera di Innocenzo III del 6 febbraio 1201, indirizzata all'abate del monastero di S. Ambrogio e ad Alberto Amicono, subdiacono nostro canonico Mediolanensi (l'edizione in Werner MALECzen: La pieve di Casorate nella controversia con il monastero cisterciense di Morimondo. Un contributo sulla giurisdizione papale delegata al tempo di Innocenzo III, in: Archivio storico lombardo 123 [1997] p. 318); è dunque dalla documentazione papale che possiamo evincere notizie più sicure.

152 Renato Mambretti: Oberto da Terzago arcivescovo di Milano, in: Ricerche storiche sulla Chiesa ambrosiana (cit. nota 2) pp. 112-143 (in particolare 132); Liber Ordinarius Modoetiensis cum Kalendario-Obituario, Tomus B, ed. Renatus MambretTI, Roma 2001 (Bibliotheca „Ephemerides liturgicae. Subsidia“ 117), pp. 226-228. 
giurisdizione episcopale creava sovente attriti, come è ancora possibile evincere da una lettera di Innocenzo III al vescovo di Firenze, che nel 1206 ottenne di riportare all'obbedienza nei suoi confronti i suddiaconi papali che detenevano benefici di quella Chiesa, ma solo per quanto riguardava i doveri inerenti ai benefici stessi. È infatti assai incisiva la precisazione del papa, che, nel concedere al vescovo di pretendere obbedienza dai suddiaconi per quanto riguardava gli obblighi liturgici, non tralasciava di ricordare la particolare posizione dei suddiaconi: ut illis specialiter quantum convenit a te inter alios tibi subditos deferatur, quos benignitas apostolica collatione ispsius ordinis honoravit ${ }^{153}$. Il suddiacono della Chiesa romana, anche se non residente alla curia papale, era dunque da ritenersi in una condizione privilegiata, proprio in considerazione del suo legame istituzionale con il vescovo di Roma.

La presenza di suddiaconi della Chiesa romana nelle diverse Chiese locali si configura dunque come un fenomeno degno di attenzione per comprendere i modi e i tempi degli interventi papali all'interno delle diocesi. Se infatti a partire dalla fine dell'XI secolo il loro servizio ai pontefici si espresse soprattutto nell'adempimento di importanti funzioni diplomatiche, talora di carattere dichiaratamente politico, nel corso del XII secolo si nota un incremento della loro presenza stabile all'interno delle istituzioni ecclesiastiche diocesane, con importanti compiti di raccordo tra la sede romana e le Chiese particolari: da una parte, infatti, essi potevano controllare da vicino le decisioni dei vescovi e dei capitoli delle cattedrali e denunciare prontamente alla sede romana le eventuali inosservanze della normativa canonica; dall'altra essi erano utili agli stessi vescovi e ai capitoli per avere un canale preferenziale di accesso alla sede apostolica, presso la quale i suddiaconi papali erano sovente inviati come procuratori o messi per dirimere le cause più complesse ${ }^{154}$.

153 Elze (cit. nota 105) pp. 169sg. Il testo della lettera in: Die Register Innocenz' III. 9. Pontifikatsjahr, 1206-1207, bearbeitet von Andrea Sommerlechner/Othmar Hageneder/Christoph Egger/Rainer Murauer/Herwig Weigl, Wien 2004 (Publikationen des historischen Instituts beim Österreichischen Kulturforum in Rom 1/9), p. 79 n. 43 : Per tuas nobis litteras intimasti, quod, cum aliqui Romane ecclesie subdiaconi prelationes in tua diocesi assecuntur, pro quibus tibi tenentur obedientiam exhibere (...) illi subdiaconatus privilegium allegantes ea se asserunt non teneri, ac si per huiusmodi subdiaconatus officium ab obedientia, qua tibi tenentur ratione obtenti beneficii sunt exempti. (...) Ad quod tibi breviter respondemus, quod, etsi decens sit, ut illis specialiter quantum convenit a te inter alios tibi subditos deferatur, quos benignitas apostolica collatione ipsius ordinis honoravit, per eum tamen et obedientia, quam alias tibi debent, minime absolventur.

154 Mi limito qui a richiamare i casi di Guglielmo Balbo, nel 1199 inviato alla curia papale come procuratore dell'arcivescovo Filippo da Lampugnano per difendere gli interessi della Chiesa ambrosiana nel corso dell'annosa questione relativa al monastero di Scozola (vedi sopra, nota 143 e testo corrispondente), e di Obizo de Castello, canonico di Novara, inviato alla curia papale per ottenere la conferma del conferimento di un beneficio nel capitolo della cattedrale (vedi sopra nota 133 e testo corrispondente). 
Ritengo, inoltre, che tra i motivi che rendevano ambita l'ordinazione suddiaconale ad opera del papa fosse la possibilità di ottenere ragguardevoli benefici, al fine di potersi dedicare con maggior agio agli studi: una più attenta analisi delle carriere dei chierici insigniti di questa carica, infatti, mi sembra suggerisca l'alto livello della loro preparazione culturale, un motivo che li rendeva esponenti ancor più qualificati della politica papale nelle diverse Chiese ${ }^{155}$. Essere ordinati suddiaconi dal pontefice, pur senza rimanere a servizio del vescovo di Roma, costituiva una notevole opportunità, giacché, con l'appoggio del papa o di importanti esponenti della curia romana diveniva possibile aspirare a ricche prebende in uno o più collegi di chierici, dove poi era in ogni caso garantita una certa libertà di azione, giacché i suddiaconi papali continuavano a dipendere dal vescovo di Roma. In tal modo i chierici desiderosi di intraprendere carriere di studio, un motivo che spesso coincideva con l'aspirazione a una brillante carriera ecclesiastica, potevano in forza della loro ordinazione papale ottenere benefici che consentissero loro di dedicarsi per un certo numero di anni allo studio a Parigi o a Bologna ${ }^{156}$.

È dunque auspicabile un censimento dei suddiaconi presenti nei diversi capitoli - di cattedrali o di chiese importanti, non solo nella regione padana per poter verificare, laddove la documentazione lo consenta, se essi erano anche suddiaconi della Chiesa romana ${ }^{157}$.

\section{Dai suddiaconi ai cappellani}

D'altra parte ai vantaggi loro concessi si accompagnava, come si è visto, l'obbligo di assumere delicati e spesso difficili incarichi per conto del pontefice, come potevano essere le legazioni, il recapito di importanti missive o l'esecuzione di ordini papali contrastati in sede locale ${ }^{158}$.

155 Indico appena i suddiaconi papali lombardi per i quali è stato possibile accertare il titolo di magister: Marescotto, Aicardo di Ivrea, Giovanni Buono da Fornovo, Pietro Diani, Sicardo di Cremona, Uberto da Pirovano.

156 Peter Classen: La curia romana e le scuole di Francia, in: Le istituzioni ecclesiastiche (cit. nota 55) pp. 432-436; ID.: Rom und Paris: Kurie und Universität im 12. und 13. Jahrhundert, in: ID.: Studium und Gesellschaft im Mittelalter, hg. von Johannes Fried, Stuttgart 1983 (MGH Schriften 29), pp. 127-169; Maleczek Verankerung (cit. nota 51) pp. 102-174.

157 ELZE (cit. nota 105) p. 157 nota 70: „Sichere Anhaltspunkte für die Identifizierung von Subd. und Kap. gibt es nicht. Die auswärtigen päpstl. Subd. haben wohl meistens nicht zur Kapelle gehört. Die Auswahl der nachstehend angeführten Subdiakone ist daher willkürlich, doch schien es im Rahmen dieser Arbeit unmöglich, sie alle (es sind über 100) zu berücksichtigen".

158 In tale prospettiva è illuminante il caso del suddiacono papale Alexius, i cui incarichi sono facilmente ricostruibili grazie all'epistolario da lui raccolto e conservato presso la 
Non solo. A partire dagli ultimi decenni del XII secolo, quando la presenza dei suddiaconi papali nei capitoli cominciò a essere consistente, essi divennero uno strumento importante nell'esercizio di quello che potremmo definire un controllo quotidiano dell'operato dei vescovi, soprattutto quando i presuli, spesso troppo coinvolti nelle vicende politiche delle città da cui provenivano $\mathrm{e}$ della cui Chiesa sovente erano anche a capo, faticavano a rispondere adeguatamente alle direttive papali ${ }^{159}$. Basti pensare ai numerosi casi in cui $\mathrm{i}$ vescovi della regione padana, già dallo scorcio del XII secolo, se da una parte dovettero far ricorso alla sede apostolica per ottenere il necessario appoggio nei confronti dei rispettivi comuni, dall'altro faticarono a rispondere alle pressanti direttive romane, già abbozzate nel canone 19 del III concilio lateranense ${ }^{160}$.

I suddiaconi papali si presentavano così come uno strumento assai duttile e al tempo stesso efficace per interventi di diversa natura, anche politica, ma soprattutto, quando si allentò la forte tensione che aveva segnato il periodo dello scontro tra Alessandro III e il Barbarossa, essi furono largamente impegnati in compiti di carattere disciplinare, volti a favorire l'introduzione in sede locale delle direttive romane - fossero queste di carattere politico, oppure semplicemente per garantire l'attuazione delle nomine di ecclesiastici graditi alla sede apostolica. La risposta di Innocenzo III, che già nel 1198 autorizzava l'arcivescovo Filippo da Lampugnano a ordinare ai gradi maggiori anche i suddiaconi della Chiesa romana, consente di collocare a quella data una svolta per la storia dei suddiaconi papali, alla quale sembra seguire un certo ridimensionamento, almeno per quanto riguarda la loro rappresentatività nei capitoli.

Una svolta succesiva di non facile decifrazione si ebbe con il pontificato di Innocenzo IV e con la decisa affermazione dei cappellani papali, il cui numero cominciò allora a lievitare ${ }^{161}$. In considerazione dei lunghi soggiorni dei cardinali

canonica parigina di S. Vittore: Papsturkunden in Frankreich N.F. 8 (cit. nota 5) pp. 62-64 con l'indicazione dei relativi documenti; vedi anche i casi ricordati sopra note $115-126$.

$159 \mathrm{Mi}$ è parso di poter mettere in luce questo motivo a proposito dei vescovo di Ivrea Giovanni, accusato presso la sede papale di aver dissipato i beni della sua Chiesa probabilmente dal potente preposito della cattedrale eporediese, il suddiacono papale Aicardo: vedi Alberzoni Città (cit. nota 65) pp. 232-239.

160 Ibid. pp. $27-37$.

161 Elze (cit. nota 105) pp. 170sg.: „Und wenn auch die Subdiakone in den Registern von Innozenz III., Honorius III. und Gregor IX. eine ähnliche Rolle spielen wie in den Urkunden des 12. Jhs., seit Innozenz IV. verschwinden sie fast ganz ... . Zu der gleichen Zeit erhöhte sich die Zahl der päpstlichen Kapelläne um ein Vielfaches dadurch, daß nun auch in weitem Umfange auswärtige Geistliche diesen Rang erhielten, die sicher niemals dem Papst als Kapellan gedient hatten. So ging die Funktion der auswärtigen Subdiakone auf die auswärtigen Kapelläne über ... . Warum aber die Subdiakone schließlich durch die Kapelläne ersetzt wurden von denen sie sich in die Stellung nach außen hin kaum unterschieden haben, ist schwer zu sagen". 
e della massiccia presenza di suddiaconi della Chiesa romana - con la totale affermazione dell'autorità giurisdizionale del papa sulla Chiesa intera saranno semplicemente definiti suddiaconi papali ${ }^{162}$ - nelle Chiese dell'Italia settentrionale il papato poteva dunque procedere a una drastica riduzione dell'invio di legati, ottenendo inoltre un più fattivo controllo sulle Chiese locali stesse ${ }^{163}$.

Si trattava di sperimentazioni, messe in atto dalla sede apostolica nel tentativo di rendere più organici e incisivi i suoi interventi nella regione padana, che indubbiamente diedero frutti non trascurabili. È possibile ipotizzare che, in considerazione dell'accresciuto numero dei suddiaconi e della loro provenienza dalle diverse regioni, non sempre il papa potesse avere di loro una conoscenza approfondita, al punto da poterli considerare strumenti del tutto affidabili; inoltre taluni suddiaconi papali, che pure erano stati accolti entro un capitolo, nel quale erano anche giunti a ricoprire importanti dignità, non si erano rivelati all'altezza della situazione e avevano fatto prevalere interessi personali o familiari, proprio quelli che la sede apostolica pensava di debellare ${ }^{164}$. Furono forse motivi come questi a favorire la progressiva affermazione dei cappellani papali. Quella dei suddiaconi della Chiesa romana può dunque essere considerata come una sperimentazione entro il vivace 'laboratorio' politico e diplomatico quale fu la curia papale per tutto il XII secolo, il secolo cruciale per l'affermazione del primato romano in Occidente.

\section{Considerazioni conclusive}

L'osservazione dei rapporti tra la sede apostolica e le Chiese padane soprattutto nel XII secolo consente di apprezzare l'importanza dell'opera del Kehr, che certo ha nell'Italia Pontificia la sua espressione più compiuta. Si tratta, infatti, di uno strumento fondamentale per le ricerche non solo sulle relazioni tra centro e periferia, ma anche per conoscere le modalità del governo delle singole Chiese. A questo proposito è doveroso rimarcare l'utilità dello spazio dedicato alla documentazione relativa ai legati papali, sia cardinali, sia di rango inferiore. Grazie alle ricerche di Stefan Weiß, ad esempio, disponiamo ora di un attendibile repertorio della documentazione prodotta dai legati, fossero essi

162 Ibid. p. 157: „Ferner mußte ein ,subdiaconus S.R.E.' als Vertreter der Römischen Kirche, ein ,capellanus domini pape' als Diener des Papstes erscheinen, und der Wechsel von ,subdiaconus S.R.E.' über ,subdiaconus domini pape' und ,capellanus domini pape' zu ,subdiaconus et capellanus domini pape' gehört in die Entwicklung, die von der Autorität der Römischen Kirche zur Herrschaft des Papstes im Abendland führt“.

163 Ambrosioni (cit. nota 2) pp. 435-442.

164 Anche a questo proposito rimando all'esemplare caso del suddiacono papale Aicardo di Ivrea, coinvolto in una complessa vicenda patrimoniale e politica, rivelatasi fallimentare per la Chiesa e il comune di Ivrea: Alberzoni Città (cit. nota 65) pp. 236-241 e 247. 
cardinali, o no. Sarebbe egualmente utile e auspicabile un aggiornato repertorio della documentazione cardinalizia, almeno fino a tutto il XII secolo, con particolare attenzione ai sigilli e alle caratteristiche formali degli atti.

Sarebbe parimenti auspicabile l'adeguata valorizzazione anche della documentazione relativa ad altre importanti figure al servizio del pontefici nei delicati compiti di governo, mi riferisco ai giudici delegati papali e, soprattutto, ai suddiaconi della Chiesa romana, come ho cercato di mettere in evidenza nel presente lavoro. Per queste categorie, ad esempio, le fonti pubblicate nei „Papsturkunden“ relativi ai regni di Francia e di Inghilterra, grazie anche alla più sofisticata metodologia adottata e alla valorizzazione delle raccolte epistolari conservatesi, consentono di valutare in modo più esauriente il significato delle missioni svolte anche da chierici di rango minore in risposta a direttive apostoliche, sia in questioni politiche di vasto respiro, sia nell'adempimento di incarichi più 'quotidiani', ma non meno significativi, quali il conferimento di benefici nei capitoli delle cattedrali o di importanti chiese, sia nel garantire l'esecuzione di disposizioni papali. A questo proposito indubbiamente la documentazione degli ultimi decenni del XII e dell'inizio del XIII secolo offre maggiori indicazioni, ma spesso si riferisce con estremo dettaglio a fatti avvenuti prima del $1198^{165}$.

Uno strumento di fondamentale importanza sarebbe in primo luogo la compilazione di un censimento il più possibile completo degli ecclesiastici attivi in sede locale - legati, cardinali, suddiaconi e giudici delegati - per incarico della sede apostolica: si tratta di un lavoro che potrà costituire la base per individuare e per valorizzare adeguatamente la documentazione utile, sia di provenienza papale, sia prodotta nelle diverse regioni. A questo proposito $\mathrm{mi}$ sembra di una certa utilità fornire un elenco degli ecclesiastici di origine lombarda, o che nella regione avevano ricoperto una importante dignità, creati cardinali prima del 1198. Si tratta di un primo contributo, sicuramente bisognoso di verifiche e precisazioni, su un problema che ancora non si può dire totalmente risolto ${ }^{166}$.

D'altra parte non bisogna dimenticare che nei cento anni che oramai ci separano dal primo volume dell'Italia Pontificia la documentazione nuovamente

165 A puro titolo esemplificativo, si veda la ricostruzione delle vicende che portarono alla fondazione della diocesi di Alessandria e alla nomina del primo vescovo nella persona del suddiacono papale Arduino, ben descritta nella documentazione di Innocenzo III (vedi sopra, nota 65) e l'assegnazione di un beneficio nel capitolo di S. Maria di Novara da Parte di Celestino III (vedi sopra, note 132sg.); l'importante ruolo svolto dai delegati nell' adempimento degli ordini papali è ben delineato da Harald MüLler: Entscheidung und Nachfrage. Die delegierten Richter als Verbindungsglieder zwischen Kurie und Region sowie als Gradmesser päpstlicher Autorität, in: JoHrendt/MüLler: Zentrum (cit. note 8) pp. 109-131.

166 Vedi la tabella in Appendice. 
edita, o edita in modo più accurato ${ }^{167}$, è cresciuta con un ritmo costante e, soprattutto negli ultimi decenni, ha assunto caratteri di apprezzabile scientifi$\operatorname{cità~}^{168}$. Non dimentichiamo poi anche i numerosi sussidi elettronici e le edizioni „in rete“, come il già ricordato Codice diplomatico della Lombardia ${ }^{169}$.

Inoltre la storiografia ha tratto molto vantaggio anche da una nuova valorizzazione del materiale già edito, che ovviamente può sempre fornire nuove risposte a domande „nuove“, vale a dire sostenute da nuovi orizzonti di ricerca. In alcuni casi, come si è visto, mi è stato possibile integrare notizie sugli interventi di papi, di cardinali e di suddiaconi proprio a partire dalla documentazione cosiddetta privata, in primo luogo i testimoniali, dove spesso sono riprese le diverse fasi di questioni agitate in tempi precedent $\mathrm{i}^{170}$. Le stesse osservazioni valgono anche per il materiale cronachistico, o diplomatistico, di cui pure sono apparse nuove importanti edizioni nelle classiche collane promosse dai MGH e dall'Istituto Storico italiano per il Medio Evo ${ }^{171}$.

Per tutte questi motivi rimane in ogni caso fondamentale, come già era ben presente nel metodo di lavoro del Kehr, il riferimento alla documentazione papale che risulta decisamente più precisa nella terminologia, soprattutto per quanto riguarda le istituzioni ecclesiastiche e l'indicazione delle qualifiche dei chierici. Senza peraltro dimenticare che talora anche la documentazione papale successiva (anche di molti anni) consente di conoscere nei dettagli lo

167 Basti qui solo un cenno alla meritoria opera dell'edizione viennese dei Registri di Innocenzo III, avviata dal prof. Othmar Hageneder, che è giunta alla pubblicazione del volume relativo al decimo anno di pontificato: Die Register Innocenz III. 10. Pontifikatsjahr, 1207/1208. Texte und Indices, a cura di Rainer Murauer/Andrea Sommerlechner/Othmar Hageneder/Christoph Egger/Reinhard Selinger/Herwig WeIgL, Wien 2007 (Publikationen des Historischen Instituts beim Österreichischen Kulturforum in Rom, II/110): grazie agli accurati indici e alle preziose note storiche, infatti, è ora possibile individuare agevolmente il richiamo a persone e documenti del periodo precedente; così pure merita di essere segnalato il Codice diplomatico della Chiesa bolognese. Documenti autentici e spuri (secoli IV-XII), a cura di Mario Fanti/ Lorenzo Paolini, Bologna 2004.

168 In proposito sono punto di riferimento i contributi raccolti in: Vom Nutzen des Edierens. Akten des internationalen Kongresses zum 150-jährigen Bestehen des Instituts für Österreichische Geschichtsforschung (Wien, 3.-5. Juni 2004), hg. von Brigitte Merta/Andrea Sommerlechner/Herwig Weigl, Wien/München 2005 (MIÖG Ergänzungsband 47).

169 Vedi sopra nota 41.

170 Valga per tutti la possibilità di individuare il nome della famiglia del cardinale Guglielmo da Pavia, vedi sopra, nota 42.

171 Maria Pia Alberzoni: Considerazioni su nuove proposte metodologiche nell'edizione delle fonti in ambito italiano, in: Vom Nutzen des Edierens (cit. nota 168) pp. 313328; lo stato della ricerca e delle edizioni di fonti e delineato in: Stato della ricerca e prospettive della medievistica tedesca, a cura di Michael Matheus/Massimo Miglio, Roma 2007 (Nuovi Studi storici 71). 
svolgimento di fatti relativi ai precedenti pontificati. Ma si tratta, ovviamente, di una casistica piuttosto circoscritta. 


\section{Appendice 1}

Cardinali lombardi creati tra 1110 e $1198^{*}$

1) Giovanni da Crema, CP di S. Crisogono 1116-1137

2) Gerardo da Bologna, CP di S. Croce in Gerusalemme 1123-1144, poi Lucio II $(1144 / 1145)$

3) Azzo, preposito della canonica di S. Antonino di Piacenza, CP di S. Anastasia $1134-1139$

4) Ribaldo, canonico di Piacenza, CD di S. Maria in Portico 1139, CP di S. Anastasia $1140-1156$

5) Goizone, CP di S. Cecilia 1140-1144

6) Guido da Somma, CP di S. Lorenzo in Damaso 1143; CV di Ostia $1149-1151$

7) Guarino da Bolona 1144

8) Ugo da Novara, CP di S. Lorenzo in Lucina 1144-1150

9) Guido da Crema, CD di S. Maria in Portico 1145, CP di S. Maria in Trastevere 1158-1164, dal 1164 antipapa con il nome di Pasquale III (1164-1168)

10) Oddo da Brescia, CD di S. Nicola in Carcere Tulliano 1152-1174

11) Ilebrando Crassus da Bologna, cardinale S.R.E. 1152; CD di S. Eustachio 1153, CP dei SS. XII Apostoli 1156-1178

12) Ardizzone da Rivoltella, CD di S. Teodoro 1157-1186

13) Guglielmo da Pavia (o de Marengo), CP di S. Pietro in Vincoli 1158-1176, CV di Porto $1176-1178$

14) Manfredo di Lavagna, CD di S. Giorgio in Velabro 1162, CP di S. Cecilia 1173, CV di Preneste 1176-1178

15) Galdino della Sala, CP di S. Sabina 1165-1167 poi arcivescovo di Milano

16) Ugo di Bologna, CD di S. Eustachio 1166-1177

17) Lombardo da Piacenza, CP di S. Ciriaco 1171, poi arcivescovo di Benevento

18) Pietro da Pavia, CP di S. Crisogono 1173, CV di Tuscolo 1179-1182

19) Raniero parvus da Pavia, CD di S. Giorgio in Velabro 1175, CP dei SS. Giovanni e Paolo 1182/1183

20) Uberto Crivelli, CP di S. Lorenzo in Damaso 1182-1185, poi arcivescovo di Milano (1185 maggio-novembre), quindi papa Urbano III 1185-1187

21) Adelardo, CP di S. Marcello 1185, dal 1188 vescovo di Verona

22) Pietro Diani, CD di S. Nicola in Carcere Tulliano 1185, CP di S. Cecilia $1188-1206$

23) Giovanni, già vescovo di Tuscania, CP di S. Clemente 1189, CV di Albano $1199-1210$

* Legenda: $\mathrm{CD}=$ cardinale diacono $\mathrm{CP}=$ cardinale prete; $\mathrm{CV}=$ cardinale vescovo 


\section{Appendice 2}

I cardinali lombardi sono qui collocati secondo scansioni cronologiche, per mettere in luce l'entità della loro presenza all'interno del collegio cardinalizio nel corso del XII secolo.

\begin{tabular}{|c|c|}
\hline $\begin{array}{l}1111- \\
1120\end{array}$ & Giovanni da Crema, 1116 CP di S. Crisogono \\
\hline \multirow{2}{*}{$\begin{array}{l}1121- \\
1130\end{array}$} & Giovanni da Crema, CP di S. Crisogono \\
\hline & Gerardo da Bologna, $1123 \mathrm{CP}$ di S. Croce in Gerusalemme \\
\hline \multirow{4}{*}{$\begin{array}{l}1131- \\
1140\end{array}$} & Giovanni da Crema, CP di S. Crisogono $(\dagger 1137)$ \\
\hline & Gerardo da Bologna, CP di S. Croce in Gerusalemme \\
\hline & Azzo, 1134 CP di S. Anastasia († 1139) \\
\hline & Ribaldo, 1139 CD di S. Maria in Portico \\
\hline \multirow{7}{*}{$\begin{array}{l}1141- \\
1150\end{array}$} & Gerardo da Bologna, CP di S. Croce in Gerusalemme $(\dagger 1144-1145)$ \\
\hline & Ribaldo, 1140 CP di S. Anastasia \\
\hline & Goizone, 1140 CP di S. Cecilia $(† 1144)$ \\
\hline & $\begin{array}{l}\text { Guido da Somma, 1143-1149 CP di S. Lorenzo in Damaso, } 1149 \text { CV di } \\
\text { Ostia }\end{array}$ \\
\hline & Guarino da Bologna (1144) \\
\hline & Ugo da Novara, 1144 CP di S. Lorenzo in Lucina († 1150) \\
\hline & Guido da Crema, 1145 CD di S. Maria in Portico \\
\hline \multirow{7}{*}{$\begin{array}{l}1151- \\
1160\end{array}$} & Ribaldo, CP di S. Anastasia $(\dagger 1156)$ \\
\hline & Guido da Somma, CV di Ostia († 1151) \\
\hline & Oddo da Brescia, 1152 CD di S. Nicola in Carcere Tulliano \\
\hline & $\begin{array}{l}\text { Ilebrando Crassus da Bologna, } 1153 \text { CD di S. Eustachio, } 1156 \text { CP dei SS. } \\
\text { XII Apostoli }\end{array}$ \\
\hline & Ardizzone da Rivoltella, 1157 CD di S. Teodoro \\
\hline & Guido da Crema, 1158 CP di S. Maria in Trastevere \\
\hline & Guglielmo da Pavia, 1158 CP di S. Pietro in Vincoli \\
\hline
\end{tabular}




\begin{tabular}{|c|c|}
\hline \multirow{7}{*}{$\begin{array}{l}1161- \\
1170\end{array}$} & Guido da Crema, CP di S. Maria in Trastevere \\
\hline & Oddo da Brescia, CD di S. Nicola in Carcere Tulliano \\
\hline & Ilebrando Crassus da Bologna, CP dei SS. XII Apostoli \\
\hline & Ardizzone da Rivoltella, CD di S. Teodoro \\
\hline & Guglielmo da Pavia, CP di S. Pietro in Vincoli \\
\hline & Manfredo di Lavagna, 1162 CD di S. Giorgio in Velabro \\
\hline & $\begin{array}{l}\text { Galdino della Sala, } 1165-1167 \text { CP di S. Sabina, poi arcivescovo di } \\
\text { Milano }\end{array}$ \\
\hline & Ugo di Bologna, 1166 CD di S. Eustachio \\
\hline \multirow{9}{*}{$\begin{array}{l}1171- \\
1180\end{array}$} & Oddo da Brescia, CD di S. Nicola in Carcere Tulliano $(\dagger 1174)$ \\
\hline & Ilebrando Crassus da Bologna, CP dei SS. XII Apostoli († 1178) \\
\hline & Ardizzone da Rivoltella, CD di S. Teodoro \\
\hline & $\begin{array}{l}\text { Guglielmo da Pavia, CP di S. Pietro in Vincoli, } 1176 \text { CV di Porto }(\dagger \\
\text { 1178) }\end{array}$ \\
\hline & Ugo di Bologna, CD di S. Eustachio $(\dagger 1177)$ \\
\hline & $\begin{array}{l}\text { Lombardo da Piacenza, } 1171 \text { CP di S. Ciriaco, poi arcivescovo di } \\
\text { Benevento }\end{array}$ \\
\hline & $\begin{array}{l}\text { Manfredo di Lavagna, } 1173 \text { CP di S. Cecilia, } 1176 \text { CV di Preneste }(\dagger \\
1178)\end{array}$ \\
\hline & Pietro da Pavia, 1173 CP di S. Crisogono, 1179 CV di Tuscolo \\
\hline & Raniero parvus da Pavia, 1175 CD di S. Giorgio in Velabro \\
\hline \multirow{7}{*}{$\begin{array}{l}1181- \\
1190\end{array}$} & Ardizzone da Rivoltella, CD di S. Teodoro $(\dagger 1186)$ \\
\hline & Pietro da Pavia, CV di Tuscolo $(† 1182)$ \\
\hline & Raniero parvus da Pavia, 1182 CP dei SS. Giovanni e Paolo ( $† 1183)$ \\
\hline & Uberto Crivelli, $1182-1185$ CP di S. Lorenzo in Damaso \\
\hline & Adelardo, 1185-1188 CP di S. Marcello, poi vescovo di Verona \\
\hline & $\begin{array}{l}\text { Pietro Diani, } 1185 \text { CD di S. Nicola in Carcere Tulliano, } 1188 \text { CP di S. } \\
\text { Cecilia }\end{array}$ \\
\hline & $\mathrm{i}, \mathrm{g}$ \\
\hline
\end{tabular}




\begin{tabular}{|l|l|}
\hline $\begin{array}{l}1191- \\
1200\end{array}$ & Pietro Diani, CP di S. Cecilia \\
\hline & Giovanni, CP di S. Clemente, 1199 CV di Albano \\
\hline
\end{tabular}

\section{Zusammenfassung}

Paul Kehr betont zuerst das starke Engagement des apostolischen Stuhls in der Lombardei: dieser bedient sich verschiedener Instrumente, um enge Verbindungen zwischen den Kirchen der Kirchenprovinz Mailand zu stiften: die Papstreisen in die Region, die zahlreichen lombardischen Kardinäle - viele davon waren im nördlichen Italien als päpstliche Legaten zugegen und hielten sich dort lange auf - sowie die päpstlichen Subdiakone. Die Aufgaben, die den Subdiakonen lombardischer Herkunft - deren Zahl in der zweiten Hälfte des 12. Jahrhunderts beachtlich zunahm - übertragen wurden, waren vielfältig. Darüber hinaus konnten sie mit päpstlicher Unterstützung einen Platz in den Kathedralkapiteln einnehmen; dort erhielten sie Pfründe, meist um für ihren Unterhalt während der Studien zu sorgen, und dort bildeten sie ein nützliches Kommunikationsmittel zwischen Zentrum und Peripherie, sowohl zur Abwicklung wichtiger Aufträge, als auch zur Erfüllung rechtlicher Aufgaben den Papst betreffend, dem gegenüber sie nur Rechenschaft ihrer Handlungen ablegen mussten. Am Anfang seines Pontifikats gewährte Innozenz III. dem Erzbischof von Mailand das Recht, die Subdiakone der römischen Kirche, die im Mailänder Klerus zugegen waren, in die großen Orden zu versetzten. Damit leitete er eine erste "Ablösung" zwischen ihnen und apostolischem Stuhl ein. Unter Innozenz IV. wurde die Regel, die erstmals von päpstlichen Subdiakonen ausgeführt worden war, von den päpstlichen Kaplänen angenommen. 
Bereitgestellt von | De Gruyter / TCS

Angemeldet | 217.89.40.26

Heruntergeladen am | 21.12.12 10:48 


\title{
Italien als Empfängerlandschaft (1046-1198): ein Vergleich aus der Perspektive des Urkundenalltags in Ligurien, Umbrien und Kalabrien
}

\author{
JOCHEN JOHRENDT
}

Eine Empfängerlandschaft zu skizzieren fällt mit Hilfe der Italia Pontificia nicht allzu schwer. Denn das Regestenwerk, das Kehr als „urkundliche Quellenkunde“ bezeichnete und in dem er lediglich "einen Notbehelf" $\operatorname{sah}^{1}$, nachdem er sein ursprüngliches Editionswerk aufgegeben hatte, bietet die Nachrichten über Kontakte zwischen Rom und den einzelnen Gliedern der Christenheit nach Empfängern geordnet, mit anderen Worten aus der Perspektive derer, die die Urkunden erhielten, und nicht aus der Perspektive der Zentrale. Nach diesem Anordnungsschema bietet die Italia Pontificia nicht weniger als 11024 Regesten, die Nachträge nicht mitgerechnet ${ }^{2}$. Und damit wird das "nicht allzu schwer“ des einleitenden Satzes wieder relativiert, denn die Fülle des Materials kann hier nicht behandelt werden. Die Darstellung Italiens als Empfängerlandschaft erfolgt daher am Beispiel von drei ausgewählten Regionen, die ich als eigenständige Empfängerlandschaften skizzieren möchte und die damit als Versatzstücke für ganz Italien dienen sollen. Die weiteren Ausführungen gliedern sich in drei Abschnitte, zunächst einige einleitende Bemerkungen zu den Stichworten Urkundenalltag bzw. Urkundungspraxis und Untersuchungszeitraum, dann eine grobe Skizze der drei ausgewählten Regionen und schließlich ein beispielhafter Vergleich der Rechtsinhalte in den drei Empfängerlandschaften.

1 So Paul Fridolin Kenr: [Selbstanzeige der Italia Pontificia 1], in: Göttingische gelehrte Anzeige 168 (1906) S. 593-610 (Wiederabdr. in: DERs.: Ausgewählte Schriften, hg.v. Rudolf Hiestand, 2 Bde., Göttingen 2005 [AAG, phil.-hist. Kl., 3. Folge 261], S. 18 36), hier S. 597 (22); vgl. dazu Rudolf Hiestand: 100 Jahre Papsturkundenwerk, in: Hundert Jahre Papsturkundenforschung, Bilanz - Methoden - Perspektiven, Akten eines Kolloquiums zum hundertjährigen Bestehen der Regesta Pontificum Romanorum vom 9.-11. Oktober 1996 in Göttingen, hg. v. DEMs., Göttingen 2003 (AAG, phil.-hist. Kl., 3. Folge 261), S. 11-44, hier S. 29.

2 Zur nicht abgeschlossenen Italia Pontificia vgl. jüngst Ders.: Die unvollendete Italia Pontificia, in: DERs.: Papsturkundenforschung (wie Anm. 1) S. 47-57, die Zahl der Regesten auf S. 49. Im Vergleich zum Regestenwerk Jaffés bietet die IP damit eine Verdopplung der Regesten. 
Urkunden sind in der Regel das Ergebnis einer Kommunikation zwischen mindestens zwei Parteien, dem Empfänger und dem Aussteller. Diese allgemeine Aussage trifft ohne Frage auch auf die hochmittelalterlichen Papsturkunden zu. Deutlich läßt sich dies auch sprachlich in den 150 Jahren vor Sutri nachweisen, als das Papsttum durch seine Passivität ${ }^{3}$ eine starke Prägung der Urkundenproduktion in ihrer Quantität, inhaltlichen Ausprägung und sogar der Formulierung durch die Empfängerseite ermöglichte ${ }^{4}$. Die Initiative zur Ausstellung der Urkunde ging vor der papstgeschichtlichen Wende des 11. Jahrhunderts vom Empfänger aus. Die Petenten traten an die Päpste heran und formulierten ihnen gegenüber ihre Wünsche, vermutlich meist bereits in Form eines Konzeptes, das die Grundlage für die später ausgestellte Urkunde darstellte. Der Einfluß der Empfänger konnte bis in die Gestaltung der Arenga und Sanctio hineinreichen ${ }^{5}$. Mit anderen Worten: Oft formulierten die zukünftigen

3 Vgl. dazu die Überblicksdarstellungen von Harald Zimmermann: Der Bischof von Rom im saeculum obscurum, in: Il primato del vescovo di Roma nel primo millennio. Ricerche e testimonianze, hg.v. Michele Maccarrone, Città del Vaticano 1991, S. 643-660; DERs.: Die Päpste des „dunklen Jahrhunderts“, in: Gestalten der Kirchengeschichte 11, hg.v. Martin Greschat (Das Papsttum 1), Stuttgart/Berlin/Köln 1985, S. 129-139; Heinrich Fichtenau: Vom Ansehen des Papsttums im zehnten Jahrhundert, in: Aus Kirche und Reich. Studien zu Theologie, Politik und Recht im Mittelalter. Festschrift für Friedrich Kempf zu seinem fünfundsiebzigsten Geburtstag und fünfzigjährigen Doktorjubiläum, hg.v. Hubert Mordek, Sigmaringen 1983, S. 117-124; Gerd Tellenbach: Zur Geschichte der Päpste im 10. und frühen 11. Jahrhundert, in: Institutionen, Kultur und Gesellschaft im Mittelalter. Festschrift für Josef Fleckenstein zu seinem 65. Geburtstag, hg.v. Lutz Fenske/Werner Rösener/ Thomas Zотz, Sigmaringen 1984, S. 165-177; sowie jüngst die passive Haltung der Päpste hinsichtlich der Artikulation und Umsetzung des Primatsanspruchs in der zweiten Hälfte des 10. Jahrhunderts abschwächend Sebastian ScHoLz: Politik - Selbstverständnis - Selbstdarstellung. Die Päpste in karolingischer und ottonischer Zeit, Stuttgart 2006 (Historische Forschungen 26), zusammenfassend S. 447 f. sowie S. 450; sowie Walther Brandmüller: Silvester II. Römischer Primat an der Schwelle zum 2. Jahrtausend, in: BISI 104 (2002) S. 1-29.

4 Vgl. dazu grundlegend die Arbeit von Hans-Henning Ковтüм: Zur päpstlichen Urkundensprache im frühen Mittelalter. Die päpstlichen Privilegien 896-1046, Sigmaringen 1995 (Beiträge zur Geschichte und Quellenkunde des Mittelalters 17); auf dessen Ergebnissen aufbauend auch Jochen Johrendt: Papsttum und Landeskirchen im Spiegel der päpstlichen Urkunden (896-1046), Hannover 2004 (MGH Studien und Texte 33).

5 Vgl. DERS.: Der Empfängereinfluß auf die Gestaltung der Arenga und Sanctio in den päpstlichen Privilegien (896-1046), in: ADipl 50 (2004) S. 1-11; einer der wenigen Fälle, in denen Konzept und ausgestellte Urkunde vorhanden sind, dürfte das Magdeburger Primatsprivileg von 968 sein. In den «Liber privilegiorum sancti Mauricii» wurden beide Versionen eingetragen, vgl. dazu Ders.: Das Magdeburger Primatsprivileg 
Empfänger die Inhalte bereits als Petenten vor und bestimmten damit maßgeblich, was zur päpstlichen Urkunde wurde. Rom reagierte und spiegelte Empfängerwünsche in Form von ausgestellten Urkunden in die Kirchen zurück. Zur Veranschaulichung möchte ich auf die im Jahre 1006 auf Bitten des Bischof Rainald von Paris für das Kloster St-Maur-des-Fossés ausgestellte Urkunde als extremes Beispiel des Empfängereinflusses verweisen ${ }^{6}$. Der Bittsteller kam nicht allein mit seinen Vorstellungen und Wünschen nach Rom, sondern hatte bereits die fast fertige Urkunde mitgebracht. Die von ihm dort vorgelegte Empfängerausfertigung hatte lediglich für den Papstnamen ein Spatium freigelassen und ebenso am unteren Ende den Platz für die Datierung. Beides wurde hinzugefügt und das von Rainald eingereichte Stück auf diese Weise in eine Papsturkunde umgewandelt. Die so gestaltete Urkunde illustriert in ihrer äußeren Form, von wem die Initiative ausging, wer das Stück formulierte und so ihren Inhalt bestimmte: der Empfänger.

Doch meine weiteren Ausführungen gelten nicht den 150 Jahren vor, sondern den 150 Jahren nach Sutri, der Epoche vom Beginn des Reformpapsttums bis zu Innozenz III. ${ }^{7}$ Das Übergewicht der Empfänger bei der Ausstellung und Gestaltung der Urkunden wurde durch die papstgeschichtliche Wende des 11. Jahrhunderts zurückgedrängt. Die Veränderung in der Urkundungspraxis ist nicht nur an der neuen äußeren Gestaltung der Papsturkunden

aus dem Jahr 968. Zur Echtheitsfrage von JL †3729 und †3730, in: ADipl 47/48 (2001/ 2002) S. $1-7$.

6 Die Papsturkunden 896-1046, bearb. v. Harald Zimmermann, 3 Bde., Wien ${ }^{2} 1988-$ 1989 (DÖAW, phil.-hist. Klasse 174, 177 u. 198), S. 815-819 Nr. 426, Vorbemerkung S. 816. Zu dieser Urkunde vgl. jüngst Rolf Grosse: Die beiden ältesten Papsturkunden für das Domkapitel von Paris (JL 3949 und 3951), in: L'acte pontifical et sa critique. Études réunies par Rolf Grosse, Bonn 2007 (Studien und Dokumente zur Gallia Pontificia 5), S. 15-30, hier S. $18 \mathrm{f}$.

7 Zur Frage, ob es sich dabei um eine Epoche der Kirchengeschichte handelt vgl. bejahend Alfons Becker: Das 12. Jahrhundert als Epoche der Papstgeschichte, in: Das Papsttum in der Welt des 12. Jahrhunderts, hg.v. Ernst-Dieter Hehl/Ingrid Heike Ringel/Hubertus Seibert, Stuttgart 2002 (Mittelalter-Forschungen 6), S. 293-323, bes. S. 293 f.; sowie Jochen Johrendt/Harald Müller: Zentrum und Peripherie. Prozesse des Austausches, der Durchdringung und der Zentralisierung der lateinischen Kirche im Hochmittelalter, in: Römisches Zentrum und kirchliche Peripherie. Das universale Papsttum als Bezugspunkt der Kirchen von den Reformpäpsten bis zu Innozenz III., hg. v. Dens., Berlin/New York 2008 (Neue AAG 2) S. 1-16. Eine andere Periodisierung hinsichtlich des jurisdiktionellen Primatsanspruchs bei Agostino Paravicini Bagliani: Il trono di Pietro. L'universalità del papato da Alessandro III a Bonifacio VIII, Rom 1996, S. 91-118; speziell für den italienischen Bereich vgl. die einleitenden Bemerkungen von Maria Pia Alberzoni: Vercelli e il papato, in: Vercelli nel secolo XII. Atti del quarto congresso storico Vercellese, Vercelli, Salone S. Eusebio - Seminario, 18-1920 ottobre 2002, Vercelli 2005, S. 79-136, bes. S. 79-81. 
unter Leo IX. zu erkennen ${ }^{8}$, sondern auch an dem starken Anstieg der Urkundenausfertigung. Und nicht nur die Anzahl der Urkunden erhöhte sich, sondern auch der geographische Rahmen der Empfänger vergrößerte sich. Die christliche Welt wurde aus römischer Perspektive gleichsam ,größer und dichter" ${ }^{(9)}$. Aus der Zeit von 896 bis 1046 sind 630 Urkunden überliefert - darunter noch etliche Fälschungen aus späterer Zeit ${ }^{10}$. Dieser Urkundenproduktion innerhalb eines Zeitraums von 150 Jahren steht bereits in den 1070er Jahren die Zahl von 686 Urkunden gegenüber. Der Wert von eineinhalb Jahrhunderten wird also bereits in dem Jahrzehnt von 1071 bis 1080 übertroffen und erreicht 100 Jahre später in den 1180er Jahren mit 4138 Urkunden den sechsfachen Wert dieses Jahrzehnts ${ }^{11}$.

8 Vgl. allgemein Thomas Frenz: Papsturkunden des Mittelalters und der Neuzeit, Stuttgart ${ }^{2} 2000$ (Historische Grundwissenschaften in Einzeldarstellungen 2), bes. S. $19-$ 23, dort auch die weitere Literatur, der noch hinzuzufügen ist: Joachim DahlHaus: Aufkommen und Bedeutung der Rota in den Urkunden des Papstes, in: AHP 27 (1989) S. $7-84$.

9 So Ernst-Dieter Hehl: Das Papsttum in der Welt des 12. Jahrhunderts. Einleitende Bemerkungen zu Anforderungen und Leistungen, in: Hehl/Ringel/Seibert (wie Anm. 7) S. 9-23, hier S. 9.

10 Vgl. dazu Johrendt: Papsttum (wie Anm. 4) S. 283-285. Nach Abzug aller Fälschungen bleibt ein Korpus von 477 Urkunden bestehen, das heißt, daß pro Jahr im Durchschnitt 3,17 Stücke überliefert sind, vgl. ebd. S. 14 f.; vgl. auch den ähnlichen Wert für die Zeit von 855 bis 882 bei Klaus Herbers: Päpstliche Autorität und päpstliche Entscheidungen an der Wende vom 9. zum 10. Jahrhundert, in: Recht und Gericht in der Kirche um 900, hg. v. Wilfried Hartmann unter Mitarbeit v. Annette Grabowsky, München 2007 (Schriften des Historischen Kollegs 69), S. 7-30, hier S. 10. Nachzutragen ist zur Auflistung der Spuria bei Johrendt RI 2/5 Nr. †936, ed. Zimmermann: Papsturkunden (wie Anm. 6) Nr. †397. Auch wenn die Urkunde im Laufe der Untersuchung nicht berücksichtigt wurde, fehlt sie in der Auflistung der nach 1046 entstandenen Spuria, vgl. dazu jüngst Söhnke Thalmann: Henning Rose und der gefälschte Ablaßbrief Papst Silvesters II. (1001) für St. Michael in Hildesheim. Anmerkungen zur Rezeption der älteren Hildesheimer Geschichtsschreibung im frühen 16. Jahrhundert, in: Vielfalt und Aktualität des Mittelalters. Festschrift für Wolfgang Petke zum 65. Geburtstag, hg.v. Sabine Arend/Daniel Berger/Carola Brückner/Axel Ehlers/Sabine Graf/Gaby Kuper/Söhnke Thalmann, Bielefeld 2006 (Veröffentlichungen des Instituts für Historische Landesforschung der Universität Göttingen 48), S. 653-677, hier S. 654 mit dem Hinweis in Anm. 6.

11 Die genauen Zahlen sind: bis 1060511 Urkunden, bis 1070453 Urkunden, bis 1080 686 Urkunden, bis 1090326 Urkunden, bis 1100606 Urkunden, bis 1110671 Urkunden, bis 1120836 Urkunden, bis 1130939 Urkunden, bis 11401131 Urkunden, bis 11501990 Urkunden, bis 11602158 Urkunden, bis 11702471 Urkunden, bis 1180 3476 Urkunden, bis 11904138 Urkunden, bis 12003468 Urkunden. Den Zahlen liegen die Auswertungen bei Frank Martin Bischoff: Urkundenformate im Mittelalter. Größe, Format und Proportionen von Papsturkunden in Zeiten expandierender Schriftlichkeit (11.-13. Jahrhundert), Marburg 1996 (Elementa diplomatica 5), S. 186 f. zugrunde. Zur Entwicklung der Leistungsfähigkeit der päpstlichen Kanzlei in dieser Zeit 


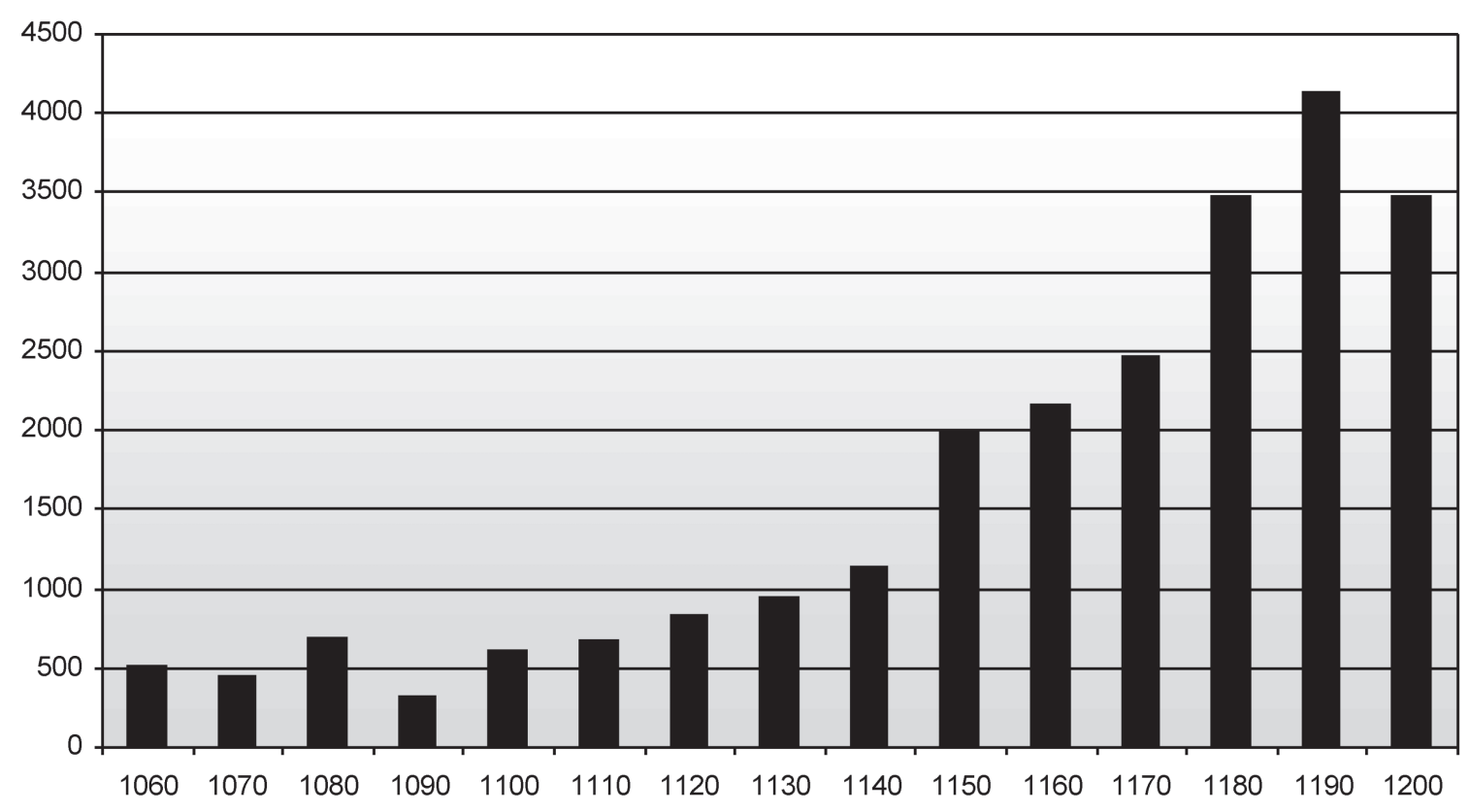

Auch wenn der Anteil der Empfänger sowohl an der Formulierung der Urkunden als auch an der Initiative zur Ausstellung der Urkunde in dieser Zeit geringer wurde, so ist er doch nie verschwunden und darf nicht unterschätzt werden. Noch im ausgehenden 12. Jahrhundert kamen die Päpste vermutlich in den meisten Fällen nicht von sich aus auf den Gedanken, Urkunden auszustellen. So bestätigte Clemens III. 1191 der Abtei Santo Stefano in Genua eine Besitzübertragung sicherlich nicht aus eigenem Antrieb, sondern war vermutlich von den Mönchen darum gebeten worden ${ }^{12}$.

Da der Einfluß der Empfänger aus dem Urkundenwesen der Päpste auch nach Sutri nicht verschwand, gewähren die Urkunden auch nach der papstgeschichtlichen Wende, während der von Rom mit starker Intensität vorangetriebenen Zentralisation der lateinischen Kirche auf das Papsttum, einen guten

vgl. Rudolf Hiestand: Die Leistungsfähigkeit der päpstlichen Kanzlei im 12. Jahrhundert mit einem Blick auf den lateinischen Osten, in: Papsturkunde und europäisches Urkundenwesen. Studien zu ihrer formalen und rechtlichen Kohärenz vom 11. bis 15. Jahrhundert, hg.v. Peter Herde/Hermann Jakobs, Köln/Weimar 1999 (Beih. zum ADipl 7), S. 1-26, mit einer tabellarischen Auflistung der ausgestellten Urkunden für das 12. Jahrhundert auf S. 23, der jedoch zu anderen Zahlen kommt, da er die Deperdita nicht berücksichtigte. Zumal die Zahlen des ausgehenden 12. Jahrhunderts dürften nochmals nach oben zu korrigieren sein, vgl. Przemysław Nowak: Die Urkundenproduktion der päpstlichen Kanzlei 1181-1187, in: ADipl 49 (2003) S. 91-122, hier S. $91-93$.

12 Vgl. IP 6/2 S. 312 Nr. 14 vom 13. Februar 1191: Clemens III. bestätigt dem Abt Guido die Übertragung der Kirche S. Iulianii im Gebiet von Noli durch den Bischof von Savona, ed. Acta Pontificum Romanorum inedita, ed. Julius von Pflugk-Harttung, 3 Bde., Tübingen 1881-1886, hier Bd. 3 S. 380 Nr. 440. 
Einblick in das, was die Empfänger in den einzelnen Regionen beschäftigte, was sie von Rom haben wollten und was nicht, in welchen Bereichen sie eine Bestätigung von päpstlicher Seite für nützlich erachteten und in welchen sie sich nicht um eine Unterstützung aus Rom bemühten.

Angesichts der enormen Steigerung der Produktivität der päpstlichen Kanzlei liegt es auf der anderen Seite nahe, den Urkunden auch innerhalb der kirchlichen Entwicklung, der Zentralisierung der Kirche auf Rom, und der päpstlichen Instrumente, mit deren Hilfe diese Zentralisierung vorangetrieben wurde, einen entscheidenden Platz zuzuweisen. So formulierte Rudolf Hiestand treffend über die Papsturkunden und ihre Funktion bei der Ausrichtung der Kirchen auf Rom: Es waren „das gleiche Schreibmaterial, die gleiche Tinte, die gleiche Schrift, die gleiche Sprache, die gleichen äußeren Formen, die gleichen formelhaften Elemente", die in den jeweiligen Urkunden eingesetzt wurden. „Zusammen mit den Kirchenrechtssammlungen, den großen Kirchenversammlungen und den von Rom ausgeschickten Legaten schufen sie die Einheit der Kirche, über die das Papsttum den Jurisdiktionsprimat in Anspruch nahm. ${ }^{13}$ Beide Entwicklungen scheinen parallel zu verlaufen: Die Kirche wurde in immer stärkerem Maße auf Rom ausgerichtet und gleichzeitig nahm die Anzahl der Urkunden zu, die man in Rom erbat und welche die Päpste ausstellten. Man möchte retrospektiv geradezu von einer teleologischen Entwicklung sprechen, an deren Ende mit Innozenz III. ein - wie Kehr es formulierte „die Welt regierendes Papsttum“ stand ${ }^{14}$. Wie sich diese Entwicklung vor Ort vollzog, was diese Zentralisation für die Bischöfe Südfrankreichs, Englands, des Reichs nördlich der Alpen, Reichsitaliens oder Unteritaliens konkret bedeutete, ob diese Entwicklung einheitlich, in Schüben, parallel oder sehr unterschiedlich verlief, ist nicht klar. Die Beantwortung der Fragen verweist nicht allein auf das Gehorsam fordernde Papsttum, sondern rückt die Kirchen vor Ort in das Zentrum des Interesses, läßt nach der Bereitschaft der Aufgeforderten fragen, dem päpstlichen Gebot Folge zu leisten ${ }^{15}$.

Bezogen auf die Urkunden der Päpste, bedeutet dies, daß die Empfänger bzw. deren Urkunden in den Blick genommen werden müssen. Denn ihnen ist $\mathrm{zu}$ entnehmen, was man in den jeweiligen Regionen von den Päpsten zu erhalten wünschte und welches Bild vom Papsttum hinter diesen Wünschen

13 Hiestand: Papsturkundenwerk (wie Anm. 1) S. 7 f.

14 Paul Fridolin KenR: Über die Sammlung und Herausgabe der ältesten Papsturkunden bis Innocenz III (1198), in: NGG 1896 S. $72-86$ (Wiederabdr. in: DERs.: Ausgewählte Schriften [wie Anm. 1] 2 S. 3-17), hier S. 79 (10).

15 Vgl. zu dieser Fragestellung Johrendt/MülLer: Römisches Zentrum (wie Anm. 7). Auf der Grundlage dieses Bandes hat im Mai 2007 ein DFG-Netzwerk mit dem Titel „Zentrum und Peripherie? Das universale Papsttum und die europäischen Regionen im Hochmittelalter" seine Arbeit aufgenommen, das sich mit diesem Problem intensiv beschäftigen wird. 
stand. Viele Papstschutzverleihungen weisen auf eine starke Rolle des Papstes als Schutzherrn in einer Region hin ${ }^{16}$, Delegationsmandate auf seine Rolle als oberstrichterliche Spitze der Kirche, um nur zwei Beispiele zu nennen ${ }^{17}$. Die Fülle des Materials ab 1046 erlaubt es, sich auf einzelne Regionen innerhalb Italiens zu konzentrieren und auf diese Weise zu einem differenzierteren Bild von Italien als Empfängerlandschaft zu gelangen. Regionen bieten sich als Vergleichseinheiten nicht nur deshalb an, weil hier der Überlieferungszufall weniger ins Gewicht fallen dürfte als bei zwei einzelnen Empfängern, sondern auch, weil der einzelne Empfänger nicht als Solitär in einer Empfängerlandschaft stand. Je nachdem, ob fast alle Klöster in der unmittelbaren Umgebung eines untersuchten Empfängers den Papstschutz erhalten hatten oder ob dieser der einzige auf weiter Flur war, ist der Befund der Inschutznahme durch die Päpste anders zu interpretieren ${ }^{18}$. Regionen als Einheiten machen auch deswegen Sinn, weil die Empfänger neben dem Papst auch mit ihrem direkten Umfeld in Verbindung standen - in der Regel sogar intensiver als mit Rom. Dieses Umfeld prägte ihren Kontakt mit Rom, und hier sollte sich auch die Wirkung der römischen Unterstützung in Form einer Urkunde für den Empfänger entfalten. Welche Privilegien aus Rom für die Durchsetzung und Wahrung eigener Interessen nützlich waren, erwies sich nicht allein an der kanonistischen Ausgestaltung von Rechtsinstituten, sondern für den Empfänger ganz konkret vor Ort im Zusammenspiel mit den Positionen anderer Personen und

16 Dabei ist klar, daß der Papstschutz zumindest in der Zeit vor 1046 in den Regionen nördlich der Alpen, etwa im französischen und deutschen Bereich, eine ganz andere Bedeutung haben konnte, vgl. dazu auch Jochen JohrendT: La protezione apostolica alla luce dei documenti pontifici (896-1046), in: BISI 107 (2005) S. 135-168. Für den Zeitraum nach 1046 vgl. immer noch grundlegend Georg Schreiber: Kurie und Kloster im 12. Jahrhundert. Studien zur Privilegierung, Verfassung und besonders zum Eigenkirchenwesen der vorfranziskanischen Orden vornehmlich auf Grund der Papsturkunden von Paschalis II. bis auf Lucius III. (1099-1181), 2 Bde., Stuttgart 1910 (Kirchenrechtliche Abhandlungen 65-66). Eine moderne Untersuchung des Papstschutzes für den Untersuchungszeitraum fehlt. Auch die Exemtion bedarf dringend einer modernen Bearbeitung. Innerhalb des internationalen DFG-Netzwerks mit dem Titel „Zentrum und Peripherie? Das universale Papsttum und die europäischen Regionen im Hochmittelalter" hat sich Lotte Kéry dieses Themas angenommen. Als jüngste Frucht vgl. Lotte Kéry: Klosterexemtion in der Einöde? Bonifatius und das Privileg des Papstes Zacharias für Fulda (751), in: Archiv für mittelrheinische Kirchengeschichte 60 (2008) S. $75-110$.

17 Zu diesem Ansatz vgl. generell Johrendt: Papsttum (wie Anm. 4) S. 5-20.

18 Der Papstschutz wurde vor 1046 keineswegs häufig an italienische Empfänger erteilt. Für ganz Italien sind in der Zeit zwischen 896 und 1046 lediglich 13 Urkunden und zwei Spuria zu fassen, vgl. Johrendt: Papsttum (wie Anm. 4) S. 159-163, auffällig ist abgesehen von S. Vincenzo al Voturno das Fehlen derartiger Privilegien im Raum südlich der direkten Einflußsphäre der Päpste, ebd. S. 253 f. Vgl. auch Johrendt: Protezione (wie Anm. 16) S. 162-164. 
Institutionen, mit denen er in Konkurrenz stand. In der Rechtswirklichkeit vor Ort - die nicht allein durch das eigene päpstliche Privileg bestimmt wurde - lag die Bewährungsprobe für die Tauglichkeit der Inhalte und die Durchsetzungsfähigkeit Roms in dieser Rechtsgemeinschaft ${ }^{19}$.

Die drei Regionen, auf die ich mich im Folgenden konzentriere, sind Ligurien, Umbrien und Kalabrien. Sie hatten von 1046 bis 1198 nie durchgehend dieselbe Gestalt als Territorium ${ }^{20}$, in ihrer herrschaftlichen Organisation - für alle

19 Aus der Perspektive der Päpste stellt sich damit die Frage nach den Grenzen des „Herrschens aus der Ferne“, so der Ausdruck von Werner Goez: Möglichkeiten und Grenzen des Herrschen aus der Ferne in Deutschland und Reichsitalien (1152-1220), in: Die Staufer im Süden. Sizilien und das Reich, hg.v. Theo Kölzer, Sigmaringen 1996, S. 93-111, bes. S. 93-95, in Bezug auf die weltliche Gewalt. Vgl. dazu auch die Ausführungen von Thomas Wetzstein: Wie die urbs zum orbis wurde. Der Beitrag des Papsttums zur Entstehung neuer Kommunikationsräume im europäischen Hochmittelalter, in: Johrendt/MülLer: Römisches Zentrum (wie Anm. 7) S. 47-75, hier S. 73 f. Ohne expliziten Bezug auf Goez auch Detlev KraAcK: Regelung aus der Ferne und Klärung vor Ort. Moderne und traditionelle Instrumentarien herrscherlicher Einflußnahme auf das hochmittelalterliche Rechtsleben, in: Rechtsveränderung im politischen und sozialen Kontext mittelalterlicher Rechtsvielfalt, hg.v. Stefan Esders/Christine Reinle, Münster 2005 (Neue Aspekte der europäischen Mittelalterforschung 5), S. 101-121, am Beispiel der Herrschaft Friedrich Barbarossas. Zur Frage der Geltung von Recht vor Ort vgl. jüngst die Beiträge von Jürgen Weitzel: „Relatives Recht“ und „unvollkommene Rechtsgeltung“ im westlichen Mittelalter. Versuche einer vergleichenden Synthese zum „mittelalterlichen Rechtsbegriff“, in: Rechtsbegriffe im Mittelalter, hg. v. Albrecht Cordes/Bernd Kannowski, Frankfurt a. M. u. a. 2002 (Rechtshistorische Reihe 262), S. 43-62; sowie Gerhard Dilcher: Die Zwangsgewalt und der Rechtsbegriff vorstaatlicher Ordnungen im Mittelalter, in: ebd. S. 111-153.

20 Ligurien bildete erst ab 1162 eine rechtliche und formale Einheit unter der Führung Genuas. Damit wurde die als Folge der langobardischen Invasion Italiens entstandene Unterteilung in eine Maritima Langobardorum und eine Maritima Italorum wieder aufgehoben. Zur Metropole wurde Genua erst 1133 durch Innozenz II. erhoben. Diese Erhöhung Genuas ist als eine Art Nebenfrucht im Innozentianischen Schisma zu verstehen, da Mailand, zu dessen Kirchenprovinz Genua zuvor gehörte, Anaklet II. unterstützte, vgl. dazu Pier Fausto Palumbo: I precedenti, la vicenda Romana e le ripercussioni Europee dello scisma di Anacleto II., Rom ${ }^{2} 1995$ (Biblioteca storica 14), S. 462-464. Zur Erhebung und den dazugehörigen Suffraganen vgl. jüngst Valeria PolOnio: Istituzioni ecclesiastiche della Liguria medievale, Rom 2002 (Italia Sacra 67), S. 33-72, zur Vorgeschichte vgl. Beate ScHilling: Guido von Vienne - Papst Calixt II., Hannover 1998 (MGH Schr. 45), S. 480-482. Zu Ligurien vgl. zusammenfassender Geo Pistarino: Ligurien, in: LexMA 5 (1991) Sp. 1979-1982; zur Entwicklung Genuas vorrangig im 10. und 11. Jahrhundert vgl. jüngst: Paolo Guglielmottr: Definizioni di territorio e protagonisi poltici e sociali a Genova nei secoli X-XI, in: Comuni 
drei Regionen gelten andere politische Rahmenbedingungen was die Einflußmöglichkeiten der öffentlichen Gewalt und den Zustand der öffentlichen Gerichtsbarkeit anbelangt. Sie sind in gewisser Weise heuristische Einheiten, beispielhafte Einzelfacetten, durch deren komparatistische Untersuchung die vielgestaltige Italia näher beleuchtet werden soll. Gerade durch ihre Unterschiedlichkeit eignen sie sich, um die Vielfältigkeit Italiens nicht nur in politischer oder kirchlicher Hinsicht zu dokumentieren, sondern auch um die Unterschiede dessen vor Augen zu führen, was man sich in Rom an Urkunden ausstellen ließ. Wenn ich im folgenden die Urkunden für kirchliche Empfänger in Ligurien, Umbrien und Kalabrien untersuche, so geht es mir dabei nicht um die Rekonstruktion der Entwicklung einzelner Rechtsinstitute anhand der Beispiele dreier Regionen, sondern um die Entwicklung der Petenten, mögliche Veränderungen ihrer Begehrlichkeiten, die sie an Rom richteten. Es geht um eine knappe und beispielhafte Charakterisierung von drei Empfängerlandschaften, aus Perspektive der Italia Pontificia je eine innerhalb der Italia superior, media und inferior.

e memoria storica. Alle origini del comune di Genova, atti del convegno di studi Genova, 24-26 settembre 2001, Genua 2002 (Atti della società Ligure di storia di patria NS 42/1 [116/1]), S. 299-328, dort auch die neuere Literatur, sowie im Betrachtungshorizont zeitlich daran anschließend Alfred Haverkamp: Die Städte im Herrschafts- und Sozialgefüge Reichsitaliens, in: Stadt und Herrschaft. Römische Kaiserzeit und Hohes Mittelalter, hg.v. Friedrich Vittinghoff, München 1982 (HZ Beih. N.F. 7), S. 149-245, hier S. 217 f., 220 u. 229. Einen raschen Überblick über die Geschichte Genuas in der hier zu behandelnden Zeit bietet auch Valeria Polonio: Da provincia a signora del mare. Secoli VI-XIII, in: Storia di Genova. Mediterraneo, Europa, Atlantico, hg.v. Dino Puncuh, Genua 2003, S. 111-231, hier S. 136-179, mit weiterführender Literatur auf den Seiten 224-231.

Ähnlich wie in Ligurien kam es auch in Umbrien in Folge des Langobardeneinfalls zu einer Zweiteilung der Region in eine Tuscia romana und eine Tuscia Langobardorum. Die Teilung wurde erst am Ende des Untersuchungszeitraums unter Innozenz III. aufgehoben, der beide Teile wiedervereinigte und der päpstlichen Herrschaft unterwarf, vgl. den Überblick bei Silvestro Nessi: Umbrien, in: LexMA 8 (1997) Sp. 1208-1210.

Wie die beiden anderen Landschaften, so war auch Kalabrien eine zweigeteilte Region. Politisch wurden der nördliche und südliche Teil erst nach 1122 zusammengeführt, als der zunächst nur über den südlichen Teil herrschende Großgraf und spätere König Roger II. sich auch den nördlichen Teil dieser Region einverleibte, vgl. Josef DeÉR: Papsttum und Normannen. Untersuchungen zu ihren lehnsrechtlichen und kirchenpolitischen Beziehungen, Köln/Wien 1972 (Studien und Quellen zur Welt Kaiser Friedrichs 2/1), S. 176 f.; Hubert Houben: Roger II. von Sizilien. Herrscher zwischen Orient und Okzident, Darmstadt 1997 (Gestalten des Mittelalters und der Renaissance), S. 39-41. Zum Echo auf Rogers Vorgehen in der zeitgenössischen Historiographie vgl. Theo Broekmann: ,Rigor iustitiae'. Herrschaft, Recht und Terror im normannisch-staufischen Süden (1050-1250), Darmstadt 2005 (Symbolische Kommunikation in der Vormoderne), S. $120 \mathrm{f}$. 
Wenn es im folgenden immer wieder um die Anzahl von Urkunden geht, so sei deutlich bemerkt, daß es für eine quantitative Auswertung nicht um einzelne Urkunden gehen kann. Abweichungen von zwei oder drei Stücken können nicht als bedeutsam eingestuft werden. Sie können auf dem Überlieferungszufall beruhen, auf der unterschiedlichen Überlieferungschance von Urkundentypen die in den einzelnen Regionen durchaus abweichen $k^{21}{ }^{21}$. Die Überlieferungsproblematik stets im Hinterkopf, ist hinsichtlich der Quantität der erhaltenen und als Deperditum rekonstruierten Stücke festzustellen: Für Ligurien sind 179 Urkunden zu nennen, für Umbrien 202 und für Kalabrien 169. Dabei handelt es sich keineswegs um eine homogen geformte Überlieferung, sondern durch Überlieferungschance und Überlieferungszufall bedingte und bisweilen stark durch einzelne Empfänger geprägte bzw. verzerrte Befunde, die berücksichtigt werden müssen. Als Beispiele einer starken Prägung von Regionen durch einzelne Empfänger sei für Umbrien das Kloster S. Pietro in Perugia genannt, für das die Italia Pontificia zwischen 1046 und dem Pontifikat Alexanders III. 17 Nummern bietet ${ }^{22}$, oder noch verzerrender im Fall von Ligurien die 67 Nummern für die Kathedrale von Genua ${ }^{23}$. In Kalabrien gibt es hingegen keine derart oft von Rom bedachten Empfänger. Die chronologische Verteilung der Urkunden läßt bereits erste Unterschiede zwischen den Regionen deutlich werden ${ }^{24}$.

In Ligurien entspricht die Situation in sehr groben Zügen in etwa der gesamtkirchlichen Entwicklung. Zwar sind in einer Phase bis 1120 auffallend wenige Urkunden für diese Region überliefert, doch folgt danach wie in der Gesamtkirche ein rasanter Anstieg mit einem Höhepunkt in den 1180er Jahren.

21 Vgl. dazu grundlegend Arnold Esch: Überlieferungs-Chance und Überlieferungs-Zufall als methodisches Problem des Historikers, in: HZ 240 (1985) S. 529-570. In Hinblick auf den Überlieferungszufall werden im Fall von Kalabrien immer wieder diverse Erdbeben angeführt, mit der Vermutung, daß hier große Teile des Materials verloren gingen. Ohne Frage führten die Erdbeben zu Verlusten der Überlieferung. Für eine Betrachtung der Verteilung von Urkunden scheint dieses Argument jedoch ins Leere zu laufen, denn gerade in diesen Fällen wurden die Bestände in ihrer Gesamtheit getroffen. Ein Fehlen von Urkunden beispielsweise in den 1130er Jahren ist nicht auf derartige Naturereignisse zurückzuführen, die jedoch ohne Frage die Überlieferung formten - aber eben weniger selektierten.

22 Vgl. IP 4 S. 68 Nr. * $14-$ S. 71 Nr. *30.

23 Vgl. IP 6/2 S. 179 Nr. *1 - S. 293 Nr. 67, darunter jedoch 14 Nebenregesten.

24 Die genauen Zahlen der Verteilung sind: bis 1060 eine Urkunde, bis 1070 eine Urkunde, bis 1080 eine Urkunde, bis 1090 zwei Urkunden, bis 1100 keine Urkunde, bis 1110 eine Urkunde, bis 1120 drei Urkunden, bis 1130 fünf Urkunden, bis $1140 \mathrm{zehn}$ Urkunden, bis 115015 Urkunden, bis 116015 Urkunden, bis 117023 Urkunden, bis 118032 Urkunden, bis 119046 Urkunden, bis 119825 Urkunden. 


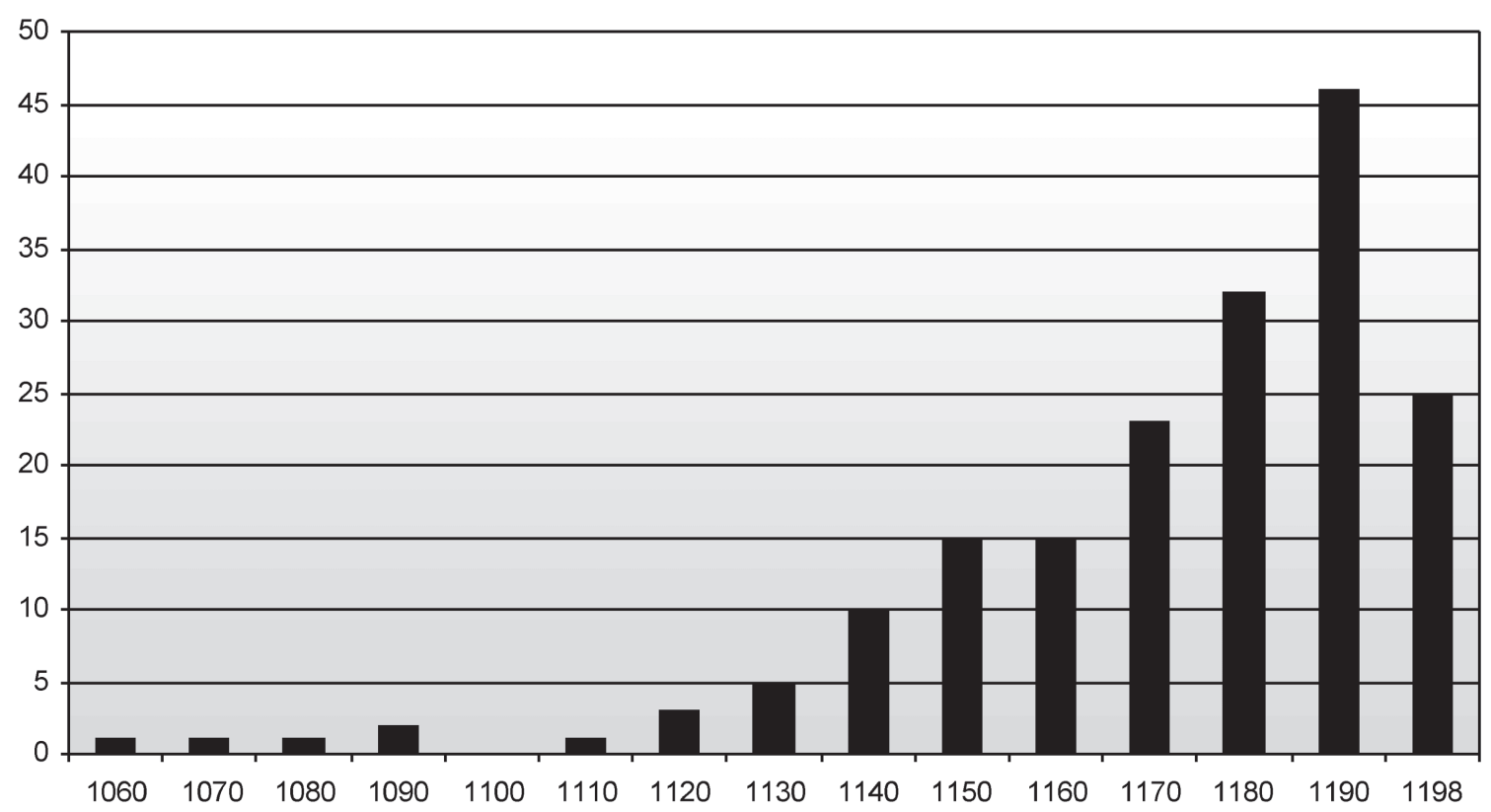

Chronologische Verteilung der Urkunden für Ligurien

Etwas anders stellt sich die Situation hingegen in Umbrien dar. Zwar bilden auch hier die 1180er Jahre den Höhepunkt, doch erweist sich die Urkundenverteilung anders als in Ligurien nicht als linear und auf diesen Punkt ausgerichtet. Vielmehr ist bereits in den ersten Jahrzehnten ein Rückgang der Urkundenproduktion für diese Region festzustellen, wobei sie in den 1080ern und 1090ern praktisch völlig zum Erliegen kommt, bevor sie sich bis in die $1140 \mathrm{er}$ Jahre erneut aufschwingt, um dann in den 1150ern bis 1170ern nochmals zurückzugehen. Im Gegensatz zu Ligurien ergeben sich damit zwei rückläufige Phasen für Umbrien, aus der Perspektive Roms gesprochen zum einen während des Pontifikats Gregors VII., und zwar ab dem Ausbruch des Wibertinischen Schismas ${ }^{25}$, zum anderen bereits ein Jahrzehnt vor dem Ausbruch des Alexandrinischen Schismas, wobei die chronologische Übereinstimmung zwischen dem erhöhten Wert der 1180er Jahre und dem Ende des Schismas mit dem 3. Laterankonzil von 1179 kein Zufall sein dürften ${ }^{26}$.

25 Auf den auffälligen Einschnitt in der Überlieferung für S. Pietro in Perugia zwischen 1065 und 1115 und für das Kathedralkapitel in Perugia zwischen 1060 und 1110 hat bereits Nicolangelo D'Acunto: Le fonti per la storia della chiesa di Perugia nell'alto medioevo, in: La chiesa di Perugia nel primo millennio. Atti del convegno di studi, Perugia, 1-3 aprile 2004, hg.v. Attilio Bartoli Langeli/Enrico Menestò, Spoleto 2005, S. 19-39, hier S. 35 f. hingewiesen.

26 Die Verteilung in Zahlen lautet: bis 106014 Urkunden, bis 1070 zehn Urkunden, bis 1080 acht Urkunden, bis 1090 keine Urkunde, bis 1100 eine Urkunde, bis 1110 sieben Urkunden, bis 1120 vier Urkunden, bis 1130 zehn Urkunden, bis 1140 elf Urkunden, bis 115021 Urkunden, bis 116015 Urkunden, bis 1170 neun Urkunden, bis 118017 Urkunden, bis 118017 Urkunden, bis 119037 Urkunden, bis 119836 Urkunden. 


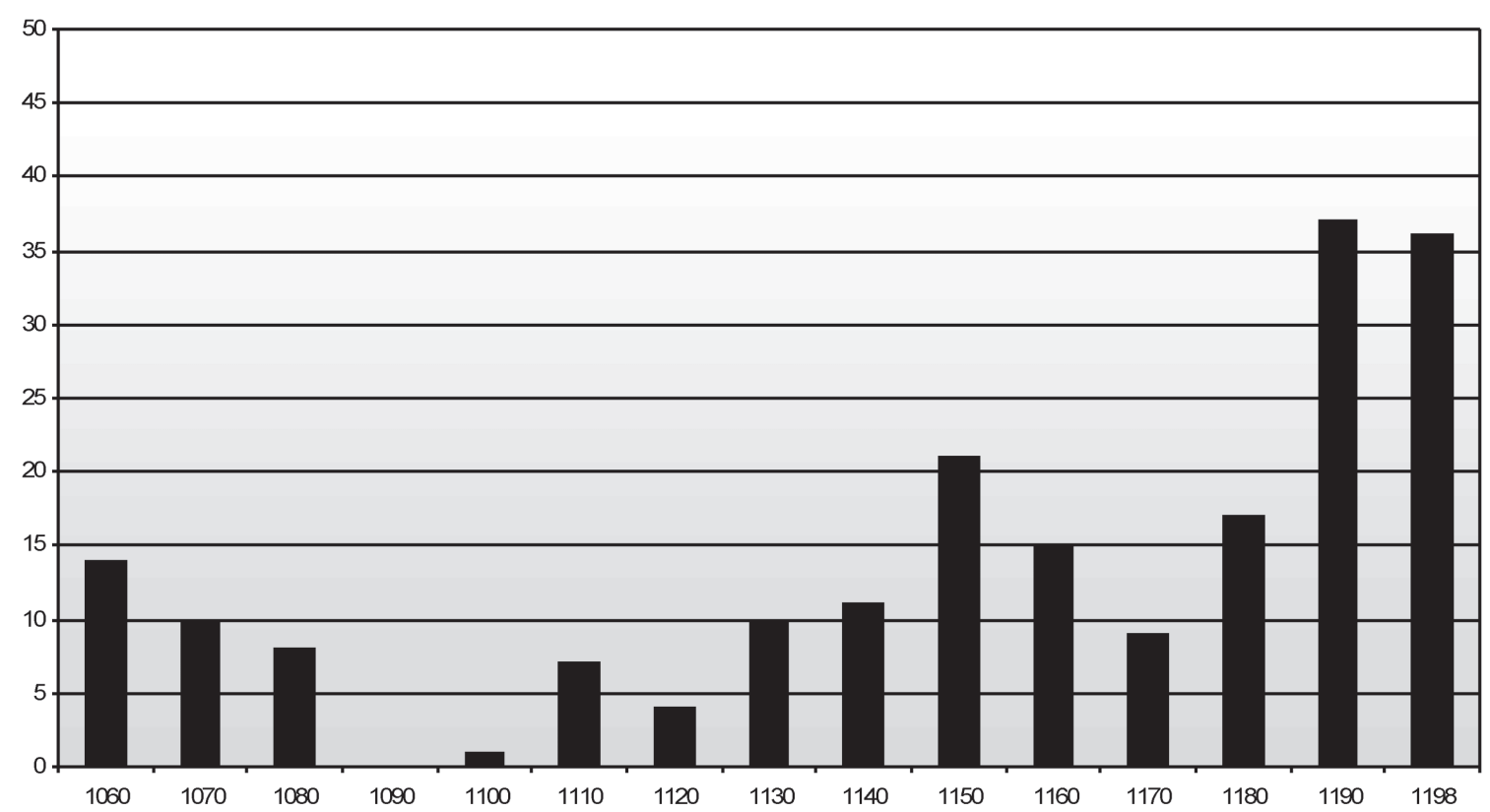

Chronologische Verteilung der Urkunden für Umbrien

Wiederum anders gestaltet sich die Urkundenverteilung in Kalabrien von den ersten Kontakten der Päpste mit der als lateinische Kirche zu weiten Teilen erst neu errichteten Kirche Kalabriens. Nach einem kontinuierlichen Anwachsen bis in das erste Jahrzehnt des 12. Jahrhunderts stagniert die Produktion im folgenden Jahrzehnt, bevor sie 1122 jäh abbricht. Das Niveau des ersten Jahrzehnts des 12. Jahrhunderts erreicht die Urkundenproduktion hier bis zum Ende des Untersuchungszeitraums nicht mehr. Die Auseinandersetzungen zwischen Roger II. und Calixt II. führten zu einem schlagartigen Ende der urkundlichen Tätigkeit der Stellvertreter Petri für kalabrische Empfänger. Daß man im Machtbereich des ersten Normannenkönigs mit Anaklet II. den aus der Retrospektive unterlegenen Kandidaten im Innozentianischen Schisma unterstützt hatte, förderte auch in der Folgezeit die Nachfrage nach Urkunden offenbar nicht sonderlich ${ }^{27}$. Man kann vermuten, daß die Erfahrung, auf das falsche Pferd gesetzt zu haben - und diese Erfahrung hatten im Innozentianischen Schisma in Italien außer Mailänder allein unteritalienische Empfänger

27 Zum Schisma in Hinblick auf die unteritalienische Situation vgl. Franz-Josef Schmale: Studien zum Schisma des Jahres 1130, Köln/Graz 1961 (Forschungen zur kirchlichen Rechtsgeschichte und zum Kirchenrecht 3), bes. S. 199-203; ferner Werner MaleczeK: Das Kardinalskollegium unter Innocenz II. und Anaklet II., in: AHP 19 (1981) S. 27 78; Mary Stroll: The Jewish Pope. Ideology and Politics in the Papal Schism of 1130, Leiden/New York 1987 (Brills Studies in Intellectual History), S. 65 f. u. 78-81. Zu den Folgen für die Urkundenausstellung bzw. -überlieferung vgl. Jochen JOHRENDT: Der Sonderfall vor der Haustüre - Kalabrien und das Papsttum, in: Johrendt/MüLler: Römisches Zentrum (wie Anm. 7) S. 243 f. 


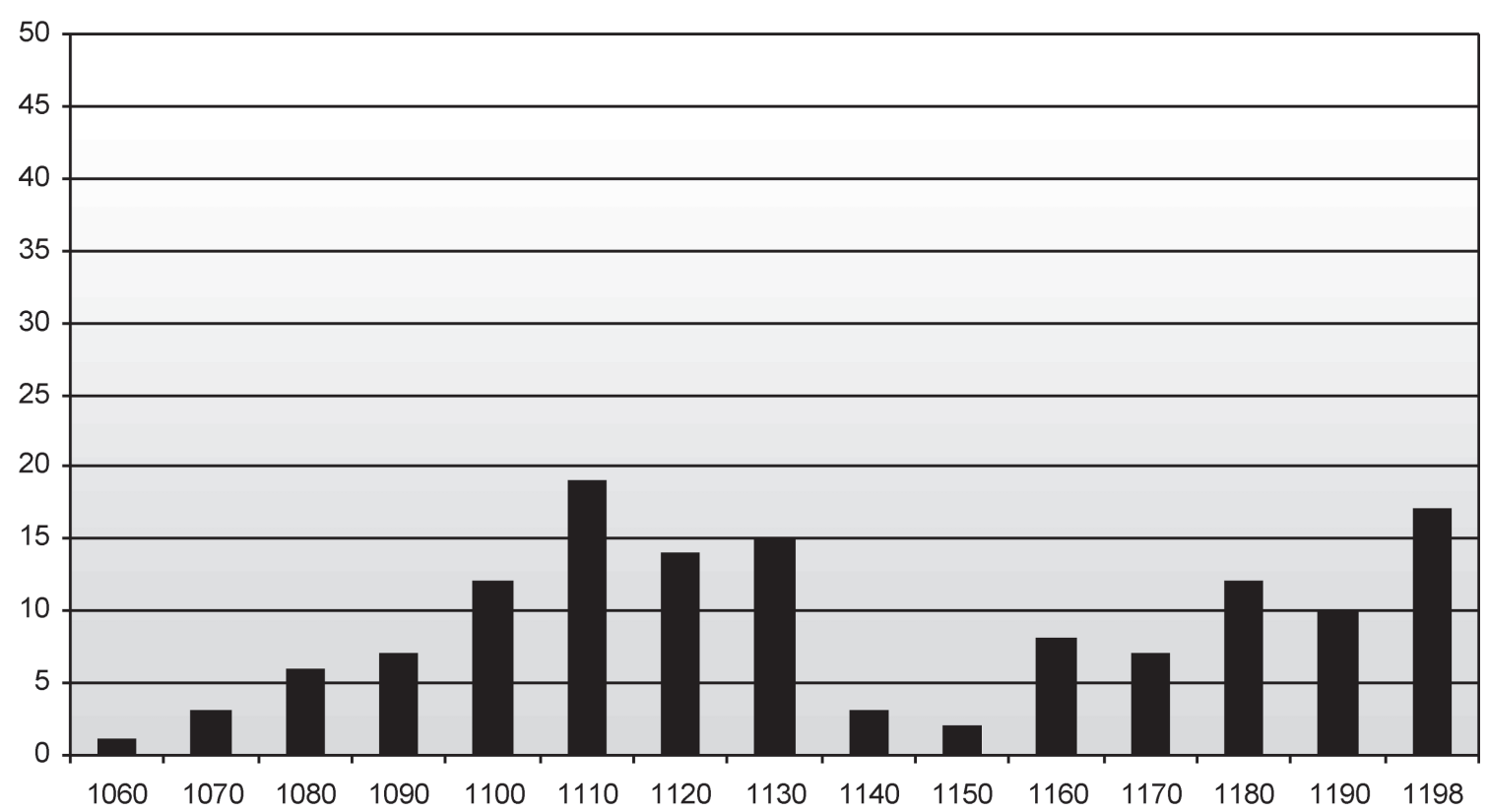

Chronologische Verteilung der Urkunden in Kalabrien

gemacht - im Verhältnis potentieller Empfänger dieser Region zu Rom Spuren hinterlassen hatte ${ }^{28}$.

Bisher sind nur quantitative Befunde vorgestellt und die Inhalte der Urkunden noch nicht berücksichtigt worden. Doch bereits diese regen zu Fragen nach papstnahen oder papstfernen Regionen Italiens während der Epoche der Zentralisation der Kirche auf Rom an, die ich hier allerdings nur andeuten $k a_{n}{ }^{29}$. Versteht man die Anzahl der für eine Region ausgestellten Urkunden als Indikator für die Nähe der jeweiligen Region zu Rom, so erweist sich Kalabrien innerhalb der vorgestellten Trias nach einer aus römischer Perspektive hoffnungsvollen Annäherung bis 1122 am Ende des Jahrhunderts als eine Rom gegenüber eher reservierte Empfängerlandschaft, Ligurien hingegen nach einer bis zu den 1120er Jahren reichenden Phase mangelnden Interesses an päpstlichen Urkunden als eine am Ende des Jahrhunderts eng an Rom gebundene

28 Die Zahlen sind: bis 1060 eine Urkunde, bis 1070 drei Urkunden, bis 1080 sechs Urkunden, bis 1090 sieben Urkunden, bis 1100 zwölf Urkunden, bis 111019 Urkunden, bis 112014 Urkunden, bis 113015 Urkunden, bis 1140 drei Urkunden, bis 1150 zwei Urkunden, bis 1160 acht Urkunden, bis 1170 sieben Urkunden, bis 1180 zwölf Urkunden, bis 1190 zehn Urkunden, bis 119817 Urkunden.

29 Zur Gesamtthematik der Zentralisation der Kirche von den Reformpäpsten bis zu Innozenz III. und den damit verbundenen Fragestellungen vgl. JoHrEndT/Müller: Zentrum (wie Anm. 7). Die Forschung befindet sich bei der Analyse der Zentralisation, der Ausrichtung der Kirchen auf Rom erst am Anfang. Zentrale und regionale Perspektive müssen zielorientiert miteinander verbunden werden. 
Region $^{30}$. Umbrien entspricht in etwa der gesamtkirchlichen Entwicklung einer kontinuierlichen Zunahme der Urkundenausfertigung, wenn man die beiden Phasen der Stagnation bzw. des Rückgangs von 1080 bis zur Jahrhundertwende und von 1150 bis 1180 außer Acht läßt.

Nicht nur in der Intensität der Kontakte zu Rom treten Abweichungen bzw. Phasenverschiebungen zutage, sondern auch bei den Inhalten der ausgefertigten Urkunden: So findet sich in Ligurien lediglich in einer und in Umbrien in zwei Papsturkunden die Regelung, daß der Abt vom Papst persönlich oder von dessen Beauftragtem geweiht werden soll. In Ligurien ist es ein Privileg Alexanders III. für das Kloster auf der Insel Gallinaria ${ }^{31}$ und in Umbrien ein Privileg für das Kloster des hl. Leucius in Todi und eines für das Kloster S. Pietro in Perugia, beide von Leo IX. ${ }^{32}$ Für derartige Bindungen der Klöster an die Päpste

$30 \mathrm{Ob}$ man hier in Analogie zu den in der Forschung üblichen Terminus „könignah“ von „papstnah“, „kuriennah“ oder „,romnah“ sprechen sollte, ist letztlich fraglich. Ähnlich wie bei der Begriffsbestimmung im weltlichen Bereich scheint die Bezeichnung „königsnah“ noch relativ einfach definierbar zu sein, da vordergründig an die Person des Königs gebunden. Schwieriger wird es jedoch bereits mit dem Begriff „,reichsnah“, der wohl eher zu dem hier gesuchten Begriff in Analogie steht. Die Begrifflichkeiten bleiben jedoch Chiffren, so lange der Zentralisierungsprozeß in seiner Eigenart nicht hinlänglich untersucht ist. Klar ist, daß es sich in keinem Fall um eine Ausrichtung an der Person des Papstes handelt, sondern um eine Akzeptanz von römischen Handlungsmustern, die Einbeziehung in ein durch das Papsttum mitgeprägtes „Ordnungs- und Bezugsraster“, vgl. dazu die grundlegenden Überlegungen von Gert Melville: Institutionen als geschichtswissenschaftliches Thema, in: Institutionen und Geschichte. Theoretische Aspekte und mittelalterliche Befunde, hg.v. DEMs., Köln/Weimar/Wien 1992 (Norm und Struktur 1), S. 1-24, das Zitat auf S. 2; sowie Reinhard BL̈̈Nker/Bernhard Jussen: Institutionen und Ereignis. Anfragen an zwei alt gewordene geschichtswissenschaftliche Kategorien, in: Institution und Ereignis. Über historische Praktiken und Vorstellungen gesellschaftlichen Ordnens, hg.v. DENS., Göttingen 1998 (Veröffentlichungen des MaxPlanck-Instituts für Geschichte 138), S. 9-16.

31 IP 6/2 S. 361 Nr. 1 vom 2. April 1169 für das Kloster S. Maria e S. Martino dell'Isola Gallinaria, ed. Pflugk-Harttung (wie Anm. 12) Bd. 3 S. 218 f. Nr. 212. Darin heißt es, S. 218: Electus [i.e. der gewählte Abt] vero ad Romanum pontificem vel, cui ipse mandaverit, benedicendus accedat. Dabei scheint es sich um eine Erstverleihung gehandelt zu haben, zur ähnlichen Ehrenrechten in Italien vor 1046 vgl. Joнrendt: Papsttum (wie Anm. 4) S. $178-180$.

32 Für das Kloster S. Leucii in Todi IP 4 S. 40 Nr. 1 vom 11. Oktober 1051, ed. PUU in Italien, Bd. 2 S. 324 f. Nr. 3, hier S. 325: liceat fratribus ex congregatione meliorem fratrem eligere et ad Romanum pontificem ducere, si in tempore fuerit, gratias et absque precio consecrandum; für S. Pietro in Perugia IP 4 S. 68 Nr. 15, ed. Migne PL 143 Sp. $681-$ 683 Nr. 64, hier Sp. 682D: Romani autem pontificis donum abbatiae et abbas ipse et 
war in diesen beiden Regionen offenbar kein Interesse vorhanden. Zwar sind Weihen von Bischöfen, Äbten und Kirchen durch den Papst oder päpstliche Legaten in beiden Regionen durchaus zu fassen ${ }^{33}$, doch für die schriftliche Fixierung und damit die dauerhafte Bindung der Weihe eines Bischofs oder Abtes an den Papst muß man Fehlanzeige erstatten - abgesehen von den drei genannten Urkunden, die damit eine gewisse Sonderstellung in Ligurien und Umbrien einnehmen. Das erstaunt um so mehr, als zumal in Umbrien am Beginn des Untersuchungszeitraums die Dichte der Urkunden auf eine sehr enge Bindung dieser Region zu den Päpsten schließen läßt, vor allem bis $1080^{34}$. Auch aus päpstlicher Perspektive wären hier mehr Weiheregelungen zu erwarten, da bereits Gregor VII. in den Weihen durch den Papst nicht nur eine Auszeichnung sah, sondern auch die Möglichkeit einer Kontrolle des Elekten auf seine Eignung hin. Für den hohen Stellenwert der Weihen bei Gregor VII. spricht auch, daß zwei der 27 Sätze seines berühmten «Dictatus papae» Weihen durch den Papst behandeln ${ }^{35}$. Daß die Päpste das Instrument der Weihen zur

consecratio abbatis sit in perpetuum. Auch bei diesen beiden Fällen scheint es sich um eine Erstverleihung gehandelt zu haben.

33 Für den ligurischen Bereich wären hier zu nennen: die Weihe der genuesischen Kathedrale oder der Kirche S. Gervasii am 10. und 11. Oktober 1118 durch Gelasius II., vgl. IP 6/2 S. 279 Nr. 2 und S. 348 Nr. *1, ed. Liber privilegiorum ecclesiae Ianuensis, hg. v. Dino Puncuh, Genua 1962 (Fonti e studi di storia ecclesiastica 1), S. 3 f. Nr. 1; die Weihe der Kirche von Portovetere durch Innozenz II., vgl. IP 6/2 S. 388 Nr. *3; die Weihe des Abtes von S. Maria e S. Martino auf der Insel Gallinaria durch Alexander III., vgl. IP 6/2 S. 361 Nr. 1 und die Weihe des Abtes von S. Capriagio dell'Aula durch denselben Papst, vgl. IP 6/2 S. 387 Nr. *8. Als Beispiel für eine Weihe durch einen Kardinallegaten in Ligurien wäre die Weihe des Hauptaltares der Kathedrale von Genua durch Petrus von S. Cecilia im Jahre 1188 zu nennen, vgl. IP 6/2 S. 290 Nr. *56. Für den umbrischen Bereich sind zu nennen: die Weihe der Kathedrale von Narni durch Eugen III. im März 1145, vgl. IP 4 S. 32 Nr. *4; die Weihe des Klosters Fonte Avellana in Anwesenheit des päpstlichen Legaten Gentilis am 31. August 1197, vgl. IP 4 S. 97 Nr. 17; 1105 wurde Johannes von Paschalis II. zum Bischof von Gubbio geweiht, vgl. IP 4 S. 82 Nr. *4.

34 Zur Verbindung des mittelitalienischen Mönchtums mit dem Papsttum vgl. Werner Goez: Kirchenreform und Investiturstreit, 910-1122, Stuttgart/Berlin/Köln 2000, S. 48-56. Zur Zeit Gregors VII., jedoch allein auf die Bistümer konzentriert vgl. Herbert Eduard John Cowdrey: Pope Gregory VII (1073-1085), Oxford 1998, S. 275-279; für den toskanischen Bereich (IP 3) vergleiche die schöne Arbeit von Werner Goez: Reformpapsttum, Adel und monastische Erneuerung in der Toskana, in: Investiturstreit und Reichsverfassung, hg.v. Josef Fleckenstein, Sigmaringen 1977 (VuF 17), S. 205-239.

35 Vgl. Das Register Gregors VII., 2 Bde., hg. v. Erich Caspar, Berlin 1920-1923 (MGH Epp. sel. 2/1-2), II/55a, S. 205 Z. 1-5: XIIII. Quod de omni ecclesia quocunque voluerit clericum valeat ordinare. $X V$. Quod ab illo ordinatus alii ecclesie preesse potest, sed non militare; et quod ab aliquo episcopo non debet superiorem gradum accipere. Daß Gregor von einem letzten Kontrollrecht der Wahl von Bischöfen durchaus auch gegen die Wahl durch Volk und Klerus Gebrauch machte und seine Wahl durch eine persönliche Weihe 
Bindung von kirchlichen Amtsträgern an Rom auch tatsächlich anwendeten, belegt die Klage des Mailänder Erzbischofs Philipp an Innozenz III., er könne nur wenig Kleriker finden, die er zu Diakonen und Presbytern weihen dürfe, da so viele von ihnen die Weihe zum Subdiakon durch den Papst erhalten hätten ${ }^{36}$.

Erstaunt der urkundliche Befund für Ligurien und Umbrien bereits vor diesem Hintergrund, so wird er im Vergleich mit Kalabrien noch auffälliger. Denn hier lassen sich nicht nur Quellenbelege für tatsächlich vollzogene Weihen von Äbten oder Bischöfen durch den Papst im Zeitraum von 1080 bis 1122 zusammentragen. Die entsprechenden Regelungen lassen sich auch in den Privilegien bis zu Clemens III. fassen. Vier Empfänger erhielten 17 echte Urkunden, und in einem Fall nahm man diese Regelung sogar in eine Fälschung auf ${ }^{37}$. Die schriftliche Festlegung, daß ein Abt oder Bischof allein durch den

bekräftigte, belegt der Fall des Elekten von Dol, den Gregor als ungeeignet verwarf und einen seiner Begleiter zum Bischof weihte. Vgl. dazu Reg. IV/4 f., IV/17 sowie V/22, V/ 23. Zur Bedeutung der Weihen in Rom für Gregor VII vgl. Uta-Renate BlumenthaL: Gregor VII. Papst zwischen Canossa und Kirchenreform, Darmstadt 2001 (Gestalten des Mittelalters und der Renaissance), S. 244-248; sowie Jochen Johrendt: „Ich habe die Gerechtigkeit geliebt und die Ungerechtigkeit gehasst“. Gregor VII. in Konflikt und Krise, in: Eigenbild im Konflikt. Krisensituationen des Papsttums zwischen Gregor VII. und Benedikt XV., hg.v. Michael Matheus/Lutz Klinkhammer, Darmstadt 2009, S. $20-44$, hier S. 30.

36 Überliefert ist nur die Antwort Innozenz' III. an Philipp von Lampugana in der er auf die Beschwerde des Erzbischofs eingeht, vgl. Die Register Innocenz' III., 1: 1. Pontifikatsjahr 1198/1199, bearb. von Othmar Hageneder/Anton Haidacher, Wien 1964 (Publikationen des Historischen Instituts beim Österreichischen Kulturinstitut in Rom 2/1), I/ 22 (= Роттнаsт 12). Zur Sache vgl. Reinhard Elze: Die päpstliche Kapelle im 12. und 13. Jahrhundert, in: ZRGKanAbt 36 (1950) S. 145-204; Wiederabdr. in: DERs.: Päpste - Kaiser - Könige und die mittelalterliche Herrschaftssymbolik. Ausgewählte Aufsätze, hg.v. Bernhard Schimmelpfennig/Ludwig Schmugge, London 1982 (CS 152), II, S. 145-204, hier S. 156 f. u. 169, der bereits darauf hinwies, daß das Echo der Quellen auf tatsächlich vom Papst vollzogene Weihen sehr schwach ist.

37 Die vier Empfänger sind: Der Bischof von Squillace, der Bischof von Mileto, der Abt der Zisterze S. Maria de Sambucina in der Diözese Bisignano, der Abt des Kloster SS. Trinità in Mileto. Hinzu kommt der Abt des Klosters S. Maria Mattina in einer Fälschung, vgl. Johrendt: Sonderfall (wie Anm. 27) S. 255. Daneben sind wesentlich mehr Nachrichten über vollzogene Weihen überliefert, in chronologischer Reihenfolge wären dies Anfang 1081 die Weihe Arnufs zum Bischof von Mileto durch Gregor VII., vgl. IP 10 S. 138 Nr. *2, zwischen 1091 und 1093 die Weihe Geralds zum Bischof von Mileto durch Urban II., vgl. IP 10 S. 138 Nr. *4, die Weihe des Abtes Roger von SS. Trinità in Mileto durch Paschalis II. zwischen 1099 und Anfang 1100, vgl IP 10 S. 145 Nr. *2, die Weihe des Hauptaltars des Klosters SS. Trinità durch Paschalis II. im Juli 1100, vgl. IP 10 S. 145 Nr. ${ }^{*} 4$, die Weihe des Bischofs Petrus von Squillace durch Paschalis II. zwischen Februar und April 1110, vgl. IP 10 S. 60 Nr. *10, die Weihe des Bischofs Johannes von Trium Tabernarum durch Calixt II. zwischen 1119 und Anfang 1121, vgl. IP 10 S. 79 Nr. ${ }^{*}$, die Weihe des Abtes Nikolaus von SS. Trinità in Mileto durch Calixt II. zwischen 1119 und Anfang 1122, vgl. IP 10 S. 146 Nr. ${ }^{*}$; ; Weiheaufträge an andere 
Papst geweiht werden durfte, scheint in dieser Empfängerlandschaft eine ganz andere Rolle gespielt zu haben, als dies in Ligurien oder Umbrien der Fall war, obwohl Kalabrien ab den 1120er Jahren sicherlich keine der intensiv auf Rom ausgerichteten Landschaften war, anders als in der Zeit zuvor. Sollte es sich um ein ,veraltetes Instrument' der Rombindung handeln, das in Kalabrien in einer urkundlichen - und damit an den Text der Vorgängerurkunde gebundenen Tradition nicht nur fortgeführt, sondern auch noch am Ende des 12. Jahrhunderts bewußt in Urkunden aufgenommen wurde ${ }^{38}$ ? Hatten sich die Instrumente, die man in dieser Region, in der die lateinische Kirche seit den Reformpäpsten erst im Aufbau begriffen war, bewährt und wurden daher nicht nur von den Päpsten bewußt eingesetzt, sondern auch von den Empfängern begehrt? In den anderen Regionen kann die Festschreibung der Weihe des Abtes oder Bischofs durch den Papst in jedem Fall keineswegs als „normal“ bezeichnet werden.

Doch neben der Weihe sind auch in etlichen anderen Bereichen deutliche Unterschiede in der chronologischen Entwicklung der Beziehungen zu Rom festzustellen sowie in der Akzeptanz der sich entwickelnden papalen Instrumente. $\mathrm{Zu}$ welchem Zeitpunkt und wie häufig wandten sich Konfliktparteien an Rom mit der Bitte um eine Lösung der Streitigkeiten durch den iudex ordinarius omnium? Mit dem Streitfall betraut, konnte dieser die Sache direkt an sich ziehen und die Streitparteien nach Rom zitieren bzw. einen Legaten entsenden, um die Angelegenheit zu untersuchen und schließlich eine entsprechende Sentenz zu fällen, oder er konnte einen Richter delegieren ${ }^{39}$.

durch den Papst lassen sich in vier Fällen nachweisen, vgl. IP 10 S. 91 Nr. 1, S. 112 Nr. 5, S. 21 Nr. ${ }^{*} 16$ und S. 22 Nr. ${ }^{*} 17$.

38 So die Regelung für die Zisterze S. Maria de Sambucina, die 1188 ein entsprechendes Privileg erhielt. Die Vorurkunde, unter Eugen III. 1150 ausgestellt, enthielt eine derartige Regelung nicht, vgl. Johrendt: Sonderfall (wie Anm. 27) S. 255 f.; zu den Anfängen vgl. auch die Bemerkungen bei Theo KöLzER: La monarchia normanno-svevo e l'Ordine Cistercense, in: I cistercensi nel mezzogiorno medioevale, Atti del Convegno internazionale di studio in occasione del IX centenario della nascita di Bernardo di Clairvaux (Martano - Latino - Lecce, 25-27 febbraio 1991), hg. v. Hubert Houben/ Benedetto Vetere, Lecce 1994, S. 91-116; sowie Hubert Houben: Die Abtei Venosa und das Mönchtum im normannisch-staufischen Süditalien, Tübingen 1995 (Bibliothek des Deutschen Historischen Instituts in Rom 80), S. 76 f. mit dem Verweis auf weitere Literatur.

39 Zur Delegationsgerichtsbarkeit vgl. Harald Müllen: Päpstliche Delegationsgerichtsbarkeit in der Normandie (12. und frühes 13. Jahrhundert), 2 Bde., Bonn 1997 (Studien und Dokumente zur Gallia Pontificia 4), hier Bd. 1 S. 9-21 mit einem allgemeinen Überblick; jüngst DERs.: Gesandte mit beschränkter Handlungsvollmacht. Zu Struktur und Praxis päpstlich delegierter Gerichtsbarkeit, in: Aus der Frühzeit der europäischen Diplomatie. Zum geistlichen und weltlichen Gesandtschaftswesen vom 12. bis zum 15. Jahrhundert, hg.v. Claudia Zey/Claudia MärtL, Zürich 2008, S. 41-65; sowie Jane E. SAYers: Papal Judges Delegate in the Province of Canterbury. A Study in Ecclesi- 
Für Ligurien sind in den 1130er Jahren die ersten Bitten um die Lösung eines Rechtsstreites an den Papst überliefert. Innozenz II. schlichtete Streitigkeiten zwischen Genua und Pisa, lud andere Streitparteien nach Rom vor. Ab der Mitte des 12. Jahrhunderts nahmen die Anfragen quantitativ deutlich zu und erreichten unter Lucius III. einen Höhepunkt. Aus seinem etwas mehr als vierjährigen Pontifikat sind nicht weniger als 14 Papsturkunden überliefert, die entweder Rechtsentscheidungen delegierten oder die auf diese Weise gefundenen Sentenzen bestätigten ${ }^{40}$. Insgesamt sind für Ligurien 72 derartige Urkunden zu fassen.

Damit unterscheidet sich Ligurien ganz klar von Umbrien. Der erste Beleg für die Klärung einer Kontroverse umbrischer Streitparteien stammt aus dem Jahr $1150^{41}$. Die nächsten Nachweise fallen wieder in den Pontifikat Lucius' III. ${ }^{42}$, und danach in die Pontifikate Clemens' III. und Cölestins III. Insgesamt sind für Umbrien lediglich 15 Urkunden aus diesem Themenbereich überliefert.

Für Kalabrien lassen sich schließlich so gut wie keine Nachweise für die Aktivität von delegierten Richtern oder Sentenzen durch den Papst selbst finden. Der einzige klare Fall einer Delegation ist unter Paschalis II. zu fassen, der den Erzbischof Roger von Reggio Calabria zusammen mit drei weiteren Richtern mit der Untersuchung der Simonievorwürfe gegen den Erzbischof Gualterius von Palermo beauftragte. Die Untersuchung endete - vermutlich im Rahmen einer Synode - mit dem Freispruch des palermitanischen Erzbischofs ${ }^{43}$.

astical Jurisdiction and Administration, Oxford 1971 (ND 1997); für den lombardischen Bereich vgl. jüngst Alberzoni: Vercelli (wie Anm. 7).

40 Allgemein sind ab Alexander III. mehr delegierte Richter nachweisbar, vgl. dazu Harald Müller: Entscheidung auf Nachfrage. Die delegierten Richter als Verbindungsglieder zwischen Kurie und Region und Gradmesser päpstlicher Autorität, in: JoHRENDT/ MüLler: Römisches Zentrum (wie Anm. 7) S. 109-131, hier S. 110 u. 119-121; DERs.: Delegationsgerichtsbarkeit (wie Anm. 39) S. 11, 20, 26 f. u. 267-270. Der Befund trifft auf Ligurien jedoch nicht zu. Hier scheint der Pontifikat Lucius' III. die entscheidende Wendemarke gewesen zu sein.

41 IP 4 S. 71 Nr. 29

42 IP 4 S. 19 Nr. 1 (= RI 4/4/4/1 Nr. 315), S. 96 Nr. *12, S. 97 Nr. 13 (= RI 4/4/4/1 Nr. 165 mit einer abweichenden Datierung zu IP 4), S. 27 Nr. *4 und S. 27 Nr. *6 (= RI 4/4/4/1 Nr. 949).

43 Die an der Untersuchung beteiligten Personen sind Erzbischof Rangerius von Reggio Clabria, Abt Hubert von S. Eufemia, Lanuinus von S. Maria de Turri und Bischof Ansger von Catania sowie 12 namentlich nicht genannte Bischöfe; IP 10 S. 22 Nr. 18 bzw. S. 229 Nr. 22, Edition des Auftrags Paschalis' II. bei Paul Hinschius: Über Pseudo-Isodor-Handschriften und Kanonessammlungen in spanischen Bibliotheken, in: ZKR 3 (1863) S. 122-146, hier S. 142 f.: quoniam quidem in ea vobis vices nostras commisimus. Ebd. S. 143 die Sentenz der Delegaten, in der die Zustimmung von 12 Bischöfen erwähnt wird. Zur Sache vgl. auch Carlo Servatius: Paschalis II. (10991118), Stuttgart 1979 (Päpste und Papsttum 14), S. 96 f.; Houben: Roger II. (wie Anm. 20) S. 33. Zum Verhältnis der kalabrischen Bischöfe zu Roger I. vgl. jüngst Julia BEK- 
Doch weitere Spuren delegierter Richter sind nicht überliefert. Die Häufigkeit der Delegationen und damit nicht zuletzt die Wirksamkeit dieses Instrumentes zur Durchsetzung papaler Ansprüche unterscheidet sich in den drei Regionen erheblich $^{44}$. Die über ein halbes Jahrhundert gängige Praxis der Delegation in Ligurien führte keineswegs dazu, daß man sich auch in Kalabrien um die Delegation eines Richters bemühte. Während man den hohen Wert für Ligurien auf die entwickelte Rechtskultur Genuas zurückführen könnte ${ }^{45}$ und den niedrigen Wert Kalabriens auf eine generelle Reserviertheit der kalabrischen Kirchen gegenüber päpstlichen Eingriffen, so ist der geringe Wert in Umbrien nicht ohne weiteres zu erklären. Das will ich hier auch gar nicht, sondern ich will mit diesen Beispielen verdeutlichen, wie sehr die sich in den Urkunden widerspiegelnde Kommunikation der Päpste mit einer Region auch am Ende des 12. Jahrhunderts inhaltlich durch die Region geprägt war - durch die Rahmenbedingungen der Empfänger vor $\mathrm{Ort}^{46}$.

Anhand eines anderen Beispiels, der Besitzbestätigung und damit teilweise verbunden dem Papstschutz, möchte ich noch etwas in die Tiefe gehen und dabei im weiteren nicht allein die in Ihrer Aussagekraft auf dem mehr oder weniger unsicheren Boden des Überlieferungszufalls beruhenden Pfade der numerischen Auswertung der Urkundenverteilung ${ }^{47}$ weiterbeschreiten, sondern daneben einen Blick auf die Formulierung der Rechtsinhalte werfen.

KER: Graf Roger I. von Sizilien. Wegbereiter des normannischen Königreichs, Tübingen 2008 (Bibliothek des Deutschen Historischen Instituts in Rom 117), S. 162-168; sowie DIEs.: La politica Calabrese dei primi conti Normanni dopo la conquista della Sicilia (1080-1130), in: Archivio storico per la Calabria e la Lucania 73 (2006), S. 47-70, hier S. 49-54.

44 Die Delegationsgerichtsbarkeit ist damit einer der Indikatoren für die Ausrichtung einer Region auf Rom, vgl. dazu Müller: Entscheidung (wie Anm. 40) S. 129-131.

45 Die delegierten Richter waren vorrangig mit Besitzstreitigkeiten zwischen kirchlichen Parteien beschäftigt, zum Beispiel des Kathedralkapitels, das wie bereits bemerkt die Überlieferungssituation in Ligurien maßgeblich prägt vgl. Polonio: Istituzioni (wie Anm. 20) S. 131-133.

46 Bereits Dietrich Lohrmann: Papstprivileg und päpstliche Delegationsgerichtsbarkeit im nördlichen Frankreich zur Zeit der Kirchenreform, in: Proceedings 6. IntKongrMK, Berkeley (California) 28 July-2 August 1980, hg.v. Stephan Kuttner/Kenneth PenNINGTON, Vatikanstadt 1985 (MIC C 7), S. 535-550, hier S. 541 Anm. 32 bemerkt, daß für eine angemessene Erfassung der Delegationsgerichtsbarkeit in Italien bis 1198 zunächst „eine gründliche Durchsicht der zehn Bände Italia pontificia notwendig“ wäre. Vgl. dazu jüngst die vorbildliche den lombardischen Bereich aufarbeitende Studie von Alberzoni: Vercelli (wie Anm. 7), zu den Delegaten bes. S. 86-97, zu Delegationen im genuesischen Bereich vgl. ebd. S. 124-126. Außerhalb des in IP 6/2 gebotenen Materials ist durchaus noch mit Zuwachs zu rechnen, vgl. etwa beispielsweise Puncun: Liber Privilegiorum (wie Anm. 33) S. 76 f. Nr. 60.

47 Von einer Statistik im eigentlichen Sinne kann aufgrund des geringen Materials keine Rede sein. 
Neben die bisher behandelte Frage, ob sich ein Rechtsinhalt in den Privilegien einer Region häuft, tritt somit auch die Frage, ob diese Rechtsinhalte unterschiedlich formuliert wurden, und wenn ja, ob es innerhalb des Untersuchungszeitraums eine Annäherung in der Formulierung zwischen den drei Regionen gab ${ }^{48}$. Besitzbestätigungen bieten sich hierfür an, da sie häufig genug vorkommen, um einen Vergleich zwischen den drei Regionen vornehmen zu können. Sie gehörten zum alltäglichen Geschäft der päpstlichen Kanzlei, und wurden, wie Dietrich Lohrmann es formulierte, „zu einem der erfolgreichsten Produkte der Papstkanzlei. “49 Sie konnten unterschiedlich lang ausfallen und ebenso nach divergierenden inneren Kriterien geordnet sein. Unter Besitzbestätigung sei dabei im folgenden nicht die Übertragung von Besitzungen durch den Papst an eine kirchliche Institution verstanden, sondern ausschließlich eine Bestätigung von Besitzungen. Besitzung kann dabei nicht nur eine konkrete Liegenschaft oder die mehr oder weniger ausführliche Auflistung von derartigen Liegenschaften und Immobilien bedeuten, sondern kann ebenso eine einzelne Schenkung oder Oblationen meinen.

In den Papsturkunden für Empfänger in Ligurien sind derartige Bestimmungen 35mal vorhanden, bei kalabrischen Empfängern 36mal. Deutlich weicht von diesem Bild die Anzahl der Besitzbestätigungen für den umbrischen Raum ab: Dort sind in 85 Urkunden derartige Regelungen zu fassen. Etwas mehr als $40 \%$ aller Urkunden für diese Region enthalten Besitzbestätigungen,

48 Zur Bandbreite der Formulierung in den Jahren 896-1046 vgl. Johrendt: Papsttum (wie Anm. 4) S. 76-115, mit einer tabellarischen Übersicht der häufiger verwendeten Formeln auf S. 114. In den italienischen Urkunden findet sich in jedem zweiten Fall eine Verwendung von «Liber Diurnus» Formularen V 86 bzw. 95, ed. Liber Diurnus Romanorum Pontificum, hg.v. Hans Foerster, Bern 1958, hier V 95, S. 175: ut nulli umquam nostrorum successorum pontificum vel aliae cuilibet magne parveque persone liceat ipsum prenominatum fundum quoquo modo auferre vel alienare; sowie ebd. V 89, S. 170: ut nulli umquam nostrorum successorum pontificum vel aliae cuiuslibet magne parveque persone ipsa prenominata loca a potestate et dicione iam fati monasterii auferre vel alienare potius in proprio suo. Vgl. zu Italien Johrendt: Papsttum (wie Anm. 4) S. 100-109. Zum «Liber Diurnus» und den drei überlieferten Handschriften vgl. zusammenfassend Leo Santifaller: Liber Diurnus. Studien und Forschungen von Leo Santifaller, hg.v. Harald Zimmermann, Stuttgart 1976 (Päpste und Papsttum 10), S. 228 f.; Foerster (wie in dieser Anm.) S. 36-68; sowie aus letzter Zeit Kолтüм: Urkundensprache (wie Anm. 4) S. 312-318, die Benutzung des «Liber Diurnus» durch die „päpstlichen Kanzlei“ zusammenfassend beschreibend S. 385-387.

49 Die unterschiedlichen Formeln der Enumeratio bonorum lassen sich besonders seit der Zeit Urbans II. nachweisen, vgl. Dietrich Lohrmann: Formen der Enumeratio bonorum in Bischofs-, Papst- und Herrscherurkunden (9.-12. Jahrhundert), in: ADipl 26 (1980) S. 281-311, hier S. 288, dort auch das Zitat. Vgl. ebenso Ders.: Kirchengut im nördlichen Frankreich. Besitz, Verfassung und Wirtschaft im Spiegel der Papstprivilegien des 11.-12. Jahrhunderts, Bonn 1983 (Pariser Historische Studien 20), S. 72-74, sowie $74-107$ u. $111 \mathrm{f}$. 
während es in Ligurien etwas weniger und in Kalabrien etwas mehr als 20\% sind. Die chronologische Verteilung der Urkunden gestaltet sich in den drei Regionen wie folgt:

Abgesehen von einem Deperditum unter Gregor VII. und einer überlieferten Urkunde Calixts II. von $1121^{50}$ setzten die Besitzbestätigungen für Ligurien Mitte der 1130er Jahre ein. Ihre chronologische Verteilung entspricht im Folgenden bis auf eine auffällige Lücke in den 1170er Jahren der Verteilung aller anderen Urkunden für Ligurien. Sollte diese Unterbrechung allein dem Überlieferungszufall geschuldet sein, oder verbirgt sich dahinter die Einschätzung der Empfänger, daß ihnen eine Besitzbestätigung durch den bis zum Frieden von Venedig im Jahre 1179 zumindest umstrittenen Papst wenig hilfreich erschien? Dieser Interpretation widerspricht, daß sich gerade Empfänger aus Ligurien in Vergleich zu anderen Regionen Italiens relativ früh von sich aus an Alexander III. gewandt und auf diese Weise auch vor 1167, dem entscheidenden Wendepunkt in der Anerkennung Alexanders III. aus Perspektive der Urkundenempfänger, ihre Oboedienz unter Beweis gestellt hatten ${ }^{51}$.

Die Verteilung in Umbrien ist demgegenüber absolut unauffällig und läßt keine unterschiedliche oder sich wandelnde Bewertung der Besitzbestätigung durch die Päpste vermuten. Sie scheint in dieser Region stets ein fester Bestandteil der Urkundeninhalte gewesen zu sein und zum Alltag gehört zu haben. Ähnliches gilt für Kalabrien. Auch nach der Konfrontation Rogers II. mit den Päpsten nach 1122, die zu einem harten Einschnitt in der Kommunikation zwischen den kalabrischen Kirchen und den Päpsten geführt hatte, blieben die Besitzbestätigungen ein unverändertes Begehren der Empfänger. Im Vergleich zu den beiden Empfängerregionen Umbrien und Kalabrien wird der Einschnitt in Ligurien bei den Besitzbestätigungen damit noch auffälliger.

Im folgenden möchte ich mich den konkreten Formulierungen der Besitzbestätigungen zuwenden. Wie wurden derartige Bestätigungen in den Urkunden formuliert, gibt es Unterschiede in den Regionen, bleiben diese erhalten oder ist eine vereinheitlichende Tendenz bis 1198 festzustellen? Ich beginne zunächst mit Ligurien: ${ }^{52}$ Die erste Besitzbestätigungsurkunde aus diesem Raum ist - wie bereits erwähnt - aus dem Pontifikat Calixts II. überliefert. Der einzige Inhalt dieser Urkunde ist die Bestätigung von namentlich genannten Besitzungen für das Kathedralkapitel von Genua. Derartige Privilegien, die dem

50 IP 6/2 S. 279 Nr. 3, zum Umfeld der Urkunde vgl. auch Schilling: Guido (wie Anm. 20) S. 480-482.

51 Vgl. Jochen Johrendt: Cum universo clero ac populo eis subiecto, id ipsum eodem modo fecerunt. Die Anerkennung Alexanders III. in Italien aus der Perspektive der Papsturkundenempfänger, in: QFIAB 84 (2004) S. 38-68, hier S. 64.

52 Von den 35 Besitzbestätigungen für diese Region sind zwei Deperdita, IP 6/2 S. 355 Nr. *1 von Gregor VII. für das Kathedralkapitel von Savona und IP 6/2 S. 309 Nr. *1 von Innozenz II. für das Kloster S. Stefano in Genua. 
Empfänger ausschließlich Besitzungen bestätigen, kommen in Ligurien sehr selten vor - im Gegensatz zu den beiden anderen Vergleichslandschaften ${ }^{53}$. Die Bestätigungsformel in der Calixturkunde lautet auctoritate sedis apostolice confirmamus, et ratam in perpetuum manere sancimus. Danach führt die Urkunde konkrete Besitzungen an und schließt mit einem Perturbationsverbot ${ }^{54}$. Unter Innozenz II. bieten die Urkunden für ligurische Empfänger bereits die ab Eugen III. fast ausschließlich gültige Formel der Besitzbestätigung ${ }^{55}$ in Kombina-

53 Für Ligurien wären eine Urkunde IP 6/2 S. 279 Nr. 3 vom 5. Januar 1121 durch Calixt II. zugunsten des Kathedralkapitels von Genua, ed. Puncun: Liber Privilegiorum (wie Anm. 33) S. 147-149 Nr. 110, und in gewisser Weise auch die drei Urkunden IP 6/2 S. 355 Nr. *1, S. 316 Nr. 1, S. 316 Nr. 2, zu nennen, die jeweils eine Besitzübertragung bestätigen. Für Umbrien lassen sich hingegen wesentlich mehr Urkunden nachweisen, die einzig und allein Besitzungen bestätigen und keinen weiteren Rechtsinhalt haben: IP 4 S. 75 Nr. 2 von 1059 durch Nikolaus II. zugunsten des Klosters S. Salvatore di Monte Acuto, IP 4 S. 69 Nr. *19 von (1059-61) zugunsten des Klosters S. Pietro in Perugia, IP 4 S. 31 Nr. 1 vom 17. Januar 1069 durch Alexander II. zugunsten des Kathedralkapitels von Narni, IP 4 S. 75 Nr. *4 von 1075 durch Gregor VII. zugunsten des Klosters S. Salvatore di Monte Acuto, IP 4 S. 62 Nr. 8 vom 13. Dezember 1136 durch Innozenz II. zugunsten des Bistums Perugia, IP 4 S. 44 Nr. 2 vom 11. Juni 1138 durch Innozenz II. zugunsten des Bistums Foligno, IP 4 S. 84 Nr. 1 vom 23. März 1138 durch Innozenz II. zugunsten des Kathedralkapitels von Gubbio, IP 4 S. 45 Nr. 1 von 1139 durch Innozenz II. zugunsten des Bistums Foligno, IP 4 S. 96 Nr. 8 vom 24. Mai 1139 durch Innozenz II. zugunsten des Klosters Fonte Avellana, IP 4 S. 34 Nr. *1 vom 18. Februar 1149 durch Eugen III. zugunsten der Kollegiatskirche S. Maria in Orticoli, IP 4 S. 44 Nr. 3 vom 17. März 1154 durch Anastasius IV. zugunsten des Bistums von Foligno, IP 4 S. 16 Nr. *3 von 1178 durch Alexander III. zugunsten des Klosters S. Silvestro (de monte Suavi). Für den kalabrischen Raum sind zu nennen: IP 10 S. 68 Nr. 3 vom September 1089 durch Urban II. zugunsten des Klosters S. Maria de Turri, IP 10 S. 81 Nr. *9 von (Anfang Januar 1122) durch Calixt II. für das Bistum Taverna (später nach Catanzaro verlegt), IP 10 S. 82 Nr. ${ }^{*} 11$ von $(1124-30)$ durch Honorius II. für das Bistum Taverna, IP 10 S. 82 Nr. *12 von (1130-43) durch Innozenz II. für das Bistum Taverna, IP 10 S. 148 Nr. *13 vom 1. Januar 1167 durch Alexander III. für das Kloster SS. Trinità in Mileto, IP 10 S. 97 Nr. 4 vom 23. Oktober (1171-80) durch Alexander III. zugunsten der Zisterze S. Maria de Sambucina und IP 10 S. 82 Nr. 14 vom 27. November 1178 durch Alexander III. zugunsten des Bistums Taverna. Zumal die Beispiele für das Bistum Taverna sind jedoch mit Vorsicht zu behandeln, da sie lediglich aus dem Privileg Alexanders III. rekonstruierte Deperdita sind. Ob sie allein eine Besitzbestätigung enthielten muß daher letztlich fraglich bleiben. Dennoch dürfte deutlich geworden sein, daß die ligurische Situation sich bei den reinen Besitzbestätigungen deutlich von den beiden anderen Bereichen unterscheidet. Für Ligurien ist lediglich eine Urkunde dieser Art zu nennen und unter Berücksichtigung der Bestätigungen von Übertragungen vier Urkunden, während es in Umbrien elf Urkunden dieses Typs sind und in Kalabrien acht.

54 IP 6/2 S. 279 Nr. 3, ed. Puncuh: Liber Privilegiorum (wie Anm. 33) S. 147-149 Nr. 110, hier S. 148.

55 So in IP 6/2 S. 356 Nr. 1 für das Kloster Sant' Eugenio, ed. Pflugk-Harttung (wie Anm. 12) Bd. 2 S. 315-317 Nr. 352, hier S. 316; sowie IP 6/2 S. 280 Nr. 9 für das 
tion mit der Papstschutzverleihung bzw. -bestätigung ${ }^{56}$. Sie wird mit eapropter, dilecti in Domino filii und damit einer direkten Ansprache der privilegierten Institution eingeleitet. Die Verleihung des Papstschutzes selbst lautet dann: sub beati Petri nostraque protectione suscipimus, et presentis scripti privilegio communimus. Mit den Worten statuentes, ut quascunque possessiones schließt sich daran eine allgemein formulierte Besitzbestätigung an: Die jetzigen und zukünftigen Besitzungen durch Schenkungen, Oblationen oder andere Formen der Übertragung sollen im festen Besitz des Urkundenempfängers und seiner Nachfolger bleiben. Die Aufzählung von konkreten Besitzungen wird schließlich eingeleitet mit den Worten: in quibus hęc propriis duximus exprimenda vocabulis. Die gesamte Besitzbestätigung wird oftmals mit einem Perturbationsverbot abgeschlossen ${ }^{57}$. Die so beschriebene Formel wird zwar auch noch unter Eugen III. variiert $^{58}$, doch ist sie trotz individueller Einschübe ${ }^{59}$ oder Varianten $^{60}$ für die

Kathedralkapitel von Genua, ed. Puncun: Liber Privilegiorum (wie Anm. 33) S. 155 f. Nr. 113.

56 Unter Eugen III. ist eine enorme Zunahme der Papstschutzprivilegien zu verzeichnen, vgl. Harald Zimmermann: Eugenio III, beato, in: Enciclopedia dei papi, Bd. 2, Rom 2000, S. 279-285, hier S. 283 f. Zur päpstlichen Verwaltung unter Eugen III. vgl. Michael Horn: Studien zur Geschichte Papst Eugens III., Frankfurt a. M. u.a. 1992 (Europäische Hochschulschriften 3/508), S. 193-201, jedoch ohne intensivere Auseinandersetzung mit der päpstlichen Kanzlei. Ebenfalls wenig Augenmerk auf die inneren Verhältnisse der Kurie hat die Studie von Helmut Gleber: Papst Eugen III. (1145-1153) unter besonderer Berücksichtigung seiner politischen Tätigkeit, Jena 1936 (Beiträge zur mittelalterlichen und neueren Geschichte 6), gelegt.

57 So etwa in IP 6/2 S. 281 Nr. 11, ed. Puncuh: Liber Privilegiorum (wie Anm. 33) S. 157-159 Nr. 114, hier S. 157, einer Urkunde Eugens III. für das Kathedralkapitel von Genua: Eapropter, dilecti in Domino filii, vestris iustis postulationibus clementer annuimus et Beati Laurentii ecclesiam, in qua divino mancipati estis obsequio, sub beati Petri et nostra protectione suscipimus, et presentis scripti privilegio communimus, statuentes ut quascunque possessiones, quecumque bona eadem ecclesia in presentium [Puncuh liest presentiarum] iuste et canonice possidet aut in futurum, concessione pontificum, largitione regum vel principum, oblatione fidelium seu aliis iustis modis, Deo propitio, poterit adipisci, firma vobis vestrisque successoribus et illibata permaneant. In quibus hec propriis duximus exprimenda vocabulis: Ecclesiam Sancte Marie Magdalene ...

58 So etwa in IP 6/2 S. 309 Nr. 4, ed. Pflugk-Harttung (wie Anm. 12) Bd. 3 S. 70 f. Nr. 68, hier S. 70, wo der Papstschutz so formuliert wird: Tuis ergo, dilecte in Christo fili, Iohannes abbas, petitionibus annuentes, beati Stephani monasterium, cui deo auctore presides, cum omnibus ad ipsum pertinentibus, in beati Petri tutelam protectionemque suscipimus, et ad exemplar predecessoris nostri felicis memorie pape Innocentii, sedis apostolice privilegio communimus. Die sich anschließende Besitzbestätigung folgt jedoch exakt der oben beschriebenen Formel. Im Privileg für das Bistum Luni, IP 6/2 S. 378 Nr. 21, ed. Migne PL Sp. 1371 f. Nr. 325 lautet die Einleitung der namentlichen Besitzauflistung hingegen: in quibus hęc propriis hominibus [wohl Druckfehler statt nominibus] duximus exprimenda, so daß vocabulum durch nomen ersetzt wurde.

59 So etwa in dem Privileg Anastasius' IV. für die Kollegiatskirche Sant'Andrea di Carrara, IP 6/2 S. 391 Nr. 3, ed. Pflugk-Harttung (wie Anm. 12) Bd. 3 S. 149 f. Nr. 141, hier 
weiteren Privilegien in dieser Region der Maßstab, wie Papstschutz und Besitzbestätigungen für ligurische Empfänger formuliert wurden ${ }^{61}$.

Abweichende Formulierungen der Besitzbestätigung finden sich im ligurischen Raum allein in fünf Urkunden für drei unterschiedliche Empfänger. Das ist zum einen die Bestätigung des Klosters Gallinaria im Besitz des Kathedralkapitels von Genua unter Alexander III. und Clemens III. Die Clemensurkunde wiederholt wörtlich den Text der Alexanderurkunde, die das auf der Insel Gallinaria gelegene Kloster 1169 an den Genueser Erzbischof übertrug. Die Übertragung und Bestätigung wird mit den unspektakulären und wenig formelhaften Worten in perpetuum apostolica auctoritate concedimus et pręsenti

S. 149, wo in der allgemeinen Formulierung des Besitzschutzes nach dem Papstschutz namentlich nicht genannte Zuwendungen des Bischof von Luni genannt werden. Im Privileg Alexanders III. für das Kloster Gallinara, IP 6/2 S. 361 Nr. 1, ed. PflugkHarttung (wie Anm. 12) Bd. 3 S. 218 f. Nr. 212, wurde zwischen die exakt nach den genannten Formeln für Papstschutz und Besitzbestätigungen gestalteten Teilen die Bestätigung der Regula Benedictini für dieses Kloster eingeschoben, ebenso in dem Privileg Urbans III. für das Kloster S. Stefano in Genua, IP 6/2 S. 311 Nr. 11, ed. Cornelio Desimoni: Regesti delle Lettere Pontificie riguardanti la Liguria, dai più antichi tempi fino all'avvenimento d'Innocenzo III, raccolti ed illustrati con documenti, in: Atti della Società Ligure di storia patria 19 (1888) S. 5-143, hier S. 112-114 Nr. 17, hier S. 112; ebenso in der Nachurkunde Cölestins III., IP 6/2 S. 312 Nr. 16, ed. PUU in Italien, Bd. 3 S. $364-366$ Nr. 5 (Teiledition).

60 Dabei kann es sich um Marginalien handeln, wie in dem Privileg Alexanders III. für das Kloster San Fruttuoso, IP 6/2, S. 347 Nr. 2, ed. Pflugk-Harttung (wie Anm. 12) Bd. 3 S. 209-211 Nr. 201, hier S. 210, in dem die Formel für den Papstschutz nicht mit eapropter, sondern mit proinde eingeleitet wird, oder mit quapropter in dem Privileg Lucius' III. für das Kathedralkapitel von Ventimiglia, IP 6/2 S. 366 Nr. 7 (= RI 4/4/4/1 Nr. 262), ed. Desimoni: Regesti (wie Anm. 59) S. 480-482 Nr. 30, hier S. 480, hier fehlt auch das Perturbationsverbot am Ende der Besitzauflistung.

61 So in den Privilegien folgender Päpste: Anastasius IV.: IP 6/2 S. 379 Nr. 26, ed. Migne PL 188 Sp. 1046 Nr. 56 (Teiledition) - Hadrian IV.: IP 6/2 S. 305 Nr. 7, ed. PflugkHarttung (wie Anm. 12) Bd. 3 S. 183 f. Nr. 172, hier S. 183 - Alexander III.: IP 6/2 S. 286 Nr. 36, ed. Pflugk-Harttung (wie Anm. 12) Bd. 3 S. 286 f. Nr. 315, hier S. 286 - Urban III.: IP 6/2 S. 289 Nr. 52, ed. Desimoni: Regesti (wie Anm. 59) S. 117-119 Nr. 20, hier S. 117 f. - Gregor VIII.: IP 6/2 S. 383 Nr. 10, ed. Desimoni: Regesti S. 482-485 Nr. 31, hier S. 482 f.; vermutlich auch IP 6/2 S. 290 Nr. 54, ed. PUU in Italien, Bd. 3 S. 363 f. Nr. 4 (Teiledition) - Cölestin III.: IP 6/2 S. 355 Nr. 2, ed. Migne PL 206 Sp. 953 f. Nr. 88, hier Sp. 953; IP 6/2 S. 292 Nr. 64, ed. Puncuh: Liber Privilegiorum (wie Anm. 33) S. 177-181 Nr. 122, hier S. 178; IP 6/2 S. 349 Nr. 2, ed. Desimoni: Regesti S. 129-131 Nr. 26, hier S. 129, ohne die einleitende Formel in quibus hec ... vocabulis vor der Nennung einer konkreten Besitzung. - Nicht klar einzuordnen sind aufgrund ihres fragmentarischen Überlieferungszustandes oder der schlechten Editionslage die Urkunden Anastasius' IV. IP 6/2 S. 390 Nr. 3, ed. PUU in Italien, Bd. 3 S. 71 Nr. 14 (Teiledition); Alexanders III. IP 6/2 S. 306 Nr. 10, ed. Desimoni: Regesti S. 101 Nr. 8 (Fragment). Vgl. dazu auch die Ergebnisse Lohrmanns am Beispiel der Normandie in Lohrmann: Kirchengut (wie Anm. 49) S. $111 \mathrm{f}$. 
privilegio confirmamus ausgedrückt ${ }^{62}$. Am Ende des Untersuchungszeitraums ist auch eine andere Form der Besitzbestätigung zu fassen, welche die eapropterFormel des Papstschutzes aufnimmt und in eine Besitzbestätigung umwandelt, wobei maximal ein Objekt namentlich genannt wird ${ }^{63}$.

Eine ganz andere Ausgangslage bei der Analyse der Besitzbestätigungen besteht für den umbrischen Raum, denn hier sind mit 85 Urkunden nicht nur wesentlich mehr Stücke dieses Typus' vorhanden, sondern die Überlieferung und man darf wohl vermuten, daß dies nicht allein dem Zufall zuzuschreiben ist - setzt hier bereits wesentlich früher ein. Bereits von Leo IX. sind drei Urkunden mit Besitzbestätigungen für umbrische Empfänger überliefert, fünf von Alexander II. Während in Ligurien die erste Urkunde unter Calixt II. zu fassen ist, liegen für Umbrien bis zu diesem Zeitpunkt bereits 14 Urkunden vor. Aus der Perspektive der Empfänger bedeutet dies, daß sie in Umbrien am Beginn des 12. Jahrhunderts bereits auf eine eigene Tradition zurückgreifen konnten. Besitzbestätigungen hatte man nicht erst seit Innozenz II. bzw. Eugen III. erbeten. So läßt sich für diesen Raum - anders als aufgrund des Materialmangels für Ligurien - ein Wandel feststellen.

Die Privilegien unter Leo IX. sind wenig formelhaft gehalten und führen nach Ausdrücken wie ut teneat, quod habet oder confirmamus et corroboramus teilweise namentlich Objekte auf ${ }^{64}$. Nur in einem Fall könnte dabei eine Verbindung mit einer Papstschutzverleihung vorliegen ${ }^{65}$. Die beiden sich anschließenden Urkunden Stephans IX. kennen keine Zusammensetzung von Papstschutz und Besitzbestätigung ${ }^{66}$. Dieses Verhältnis kehrt sich unter Nikolaus II. und Alexander II. um, denn von den fünf erhaltenen Urkunden kombinieren vier den Papstschutz mit einer Besitzbestätigung ${ }^{67}$, eine einzige bietet

62 Das Privileg Alexanders III. ist IP 6/2 S. 268 Nr. 13, ed. Migne PL 200 Sp. 115-118 Nr. 43, hier Sp. 116 f.; das Clemens' III. IP 6/2 S. 276 Nr. 46, ed. Desimoni: Regesti (wie Anm. 59) S. 119-122 Nr. 21, hier S. 121.

63 So in der Urkunde IP 6/2 S. 312 Nr. 14, ed. Pflugk-Harttung (wie Anm. 12) Bd. 3 S. 380 Nr. 440 (Clemens III.) für das Kloster San Stefano di Genova, die der Urkunde Cölestins III. IP 6/2 S. 312 Nr. 15, ed. Pfluggk-Harttung (wie Anm. 12) Bd. 3 S. $391 \mathrm{f}$. Nr. 462 als Vorlage diente und in der davon unabhängigen aber nach ähnlichem Muster formulierten Urkunde Cölestins III. IP 6/2 S. 308 Nr. 18, ed. Pflugk-HartTUNG (wie Anm. 12) Bd. 3 S. 387 Nr. 455.

64 So in IP 4 S. 40 Nr. 1, ed. PUU in Italien, Bd. 2 S. 324 f. Nr. 3, und IP 4 S. 68 Nr. 15, ed. Migne PL 143 Sp. 681-683 Nr. 64, hier Sp. 682; ohne konkrete Nennungen wird der Besitz hingegen bestätigt in IP 4 S. 77 Nr. 3, ed. Migne PL 143 Sp. 583 f. Nr. 2, hier Sp. 593C.

65 IP 4 S. 68 Nr. 15.

66 IP 4 S. 68 Nr. 16, ed. Migne PL 143 Sp. $872-874$ Nr. 3, hier Sp. 872 f. und IP 4 S. 110 Nr. 4, ed. PUU in Italien, Bd. 1 S. 412 f. Nr. 2.

67 So die Urkunde Nikolaus' II. IP 4 S. 69 Nr. 1, ed. Migne PL 143 Sp. 1301-1304 Nr. 1, hier Sp. 1302 f.; Alexander II.: IP 4 S. 90 Nr. 2, ed. PUU in Italien, Bd. 5 S. 146-149 Nr. 1, hier S. 147 f.; IP 4 S. 70 Nr. 21, ed. Migne PL 146 Sp. 1304-1306 
allein eine Besitzbestätigung $^{68}$. Doch auch hier ist noch keine klare Formelhaftigkeit zu erkennen. Die Formel für den Papstschutz wurde zwar bereits mit quapropter oder ideoque eingeleitet, doch der Schutz selbst konnte mit tutela, munimen oder defensio apostolica umschrieben werden.

Unter Paschalis II. ist dann erstmals eine Formulierung zu fassen, die bereits sehr nahe an die später gültige Formel heranreicht: Die Einleitung mit eapropter $^{69}$, in einem anderen Privileg dieses Papstes die Anrede der privilegierten Institution bzw. des Abtes als dilecte in domino fili und vor der namentlichen Auflistung von Besitzungen die Worte: in quibus hec propriis duximus vocabulis exprimend $a^{70}$. Demgegenüber erscheint die Urkunde Calixts II. für das Kathedralkapitel von Spoleto wie ein Rückschritt in der Präzisierung der Sprache päpstlicher Urkunden ${ }^{71}$. Die Urkunde Honorius' II. für das Kathedralkapitel von Narni von 1129 greift hingegen den Sprachgebrauch der Urkunden Paschalis' II. wieder auf - besonders beim Papstschutz - und bietet die Besitzbestätigung in der später gültigen Form mit der Einleitung statuentes, ut quascumque possessiones und dem entsprechenden Versatzstück vor der namentlichen Auflistung von Besitzungen ${ }^{72}$. Mit Innozenz II. ist die sprachliche Ausgestaltung der beiden Formeln und ihre Kombination dann endgültig ausgereift ${ }^{73}$, wobei auch in der Folgezeit bei monastischen Empfängern oftmals zwischen den Papstschutz und die Besitzbestätigung die Bestätigung der entsprechenden Regel eingeschoben wird. Zwar gibt es unter Innozenz II. in zwei Fällen noch Abweichungen von diesem Formular ${ }^{74}$, doch wurde für die umbrischen Empfänger ab Lucius II. praktisch nur noch eine Kombination von Papstschutz und Be-

Nr. 26, hier Sp. 1304 f.; IP 4 S. 9 Nr. 1, ed. Migne PL 146 Sp. 1351 f. Nr. 67, hier Sp. 1351.

68 IP 4 S. 31 Nr. 1, ed. Migne PL 146 Sp. 1352 Nr. 68.

69 IP 4 S. 70 Nr. 22, ed. Migne PL 163 Sp. $374-376$ Nr. 421, hier Sp. 374

70 IP 4 S. 110 Nr. 5, ed. PUU in Italien, Bd. 1 S. 415 f. Nr. 4, hier S. 415; ohne die formelhafte Anrede, aber mit den einleitenden Worten vor der namentlichen Besitzauflistung IP 4 S. 78 N. 1, ed. Pflugk-Harttung (wie Anm. 12) Bd. 2 S. 220 f. Nr. 240, hier S. 200.

71 IP 4 S. 2 Nr. 3, ed. Pflugk-Harttung (wie Anm. 12) Bd. 2 S. 231 f. Nr. 275. Der Besitzschutz wird hier in wenig formelhafter und eher an das 11. Jahrhundert erinnernder Weise formuliert mit den einfachen Worten: Confirmamus equidem vobis vestrisque successoribus. Es folgt die namentliche Nennung von Besitzungen, die mit einem Perturbationsverbot abgeschlossen wird.

72 IP 4 S. 31 Nr. 2, ed. Pflugk-Harttung (wie Anm. 12) Bd. 3 S. 30 Nr. 36.

73 IP 4 S. 107 Nr. 6, ed. PUU in Italien, Bd. 2 S. 558-564 Nr. 3, hier S. 559-563; IP 4 S. 70 Nr. 24, ed. Migne PL 179 Sp. $314-316$ Nr. 265, hier Sp. 314 f.; IP 4 S. 49 Nr. 1, ed. PUU in Italien, Bd. 1 S. 412 f. Nr. 7.

74 IP 4 S. 31 Nr. 3, ed. Pflugk-Harttung (wie Anm. 12) Bd. 3 S. 36 f. Nr. 42 ; IP 4 S. 45 Nr. 1, ed. PUU in Italien, Bd. 1 S. 419 f. Nr. 6. 
sitzbestätigung mit der eapropter- und der statutentes-Formel verwendet ${ }^{75}$. Reine Besitzbestätigungen sind zuvor allein unter Paschalis II. und Innozenz II. zu fassen $^{76}$.

Besitzbestätigungen für die umbrischen Empfänger gehörten somit zum alltäglichen Geschäft der päpstlichen Kanzlei - ab Paschalis II. erstmals in der dann immer häufiger verwendeten Form, wobei eine echte Standardisierung der Ausdrucksweise erst ab Lucius II. nachzuweisen ist. Anders als in Ligurien lassen sich hier kaum mehr Abweichungen feststellen.

Wie die umbrischen, so bieten auch die kalabrischen Urkunden zunächst keine feste Formulierung von Papstschutz und Besitzbestätigungen. So heißt es im Privileg Alexanders II. für das Kloster S. Maria della Matina von 1067: sub dominio apstolice sedis retinuimus und sub speciali tutela et defensione sancte sedis apostolice recipemus ${ }^{77}$, die sich anschließende Besitzbestätigung lautet: apostolica itaque auctoritate [...] confirmavimus, quicquid ad presens tenet [...] vel postmodum tenebunt ${ }^{78}$. Gegen Ende des dispositiven Teils der Urkunde findet sich noch ein Perturbationsverbot. Die Urkunde Urbans II. für die Kirche S. Salvatore in Oppido formuliert den Papstschutz mit den Worten: sub tutelam et protectionem apostolicae sedis accepimus et decreti presentis auctoritate munimus, woran sich die Besitzbestätigung mit Statuimus enim ohne weitere Formelhaftigkeit anschließt und mit einem Perturbationsverbot beendet wird ${ }^{79}$. Die wenig formelhafte Ausdrucksweise des Papstschutzes und der Besitzbestätigungen

75 Reine Besitzbestätigungen, die in der Formulierung allerdings auch an die Kombination von Papstschutz und Besitzbestätigung angelehnt sind, sind folgende Urkunden: Cölestin II.: IP 4 S. 84 Nr. 2, ed. Migne PL 179 Sp. 765 f. Nr. 1 - Lucius II.: IP 4 S. 70 Nr. 25, ed. Migne PL 179 Sp. $828-830$ Nr. 3, hier Sp. 828 f. - Anastasius IV.: IP 4 S. 44 Nr. 3, ed. PUU in Italien, Bd. 5 S. $162-165$ Nr. 7, hier S. 163 f. - Urban III.: IP 4 S. 64 Nr. 3, ed. Pflugk-Harttung (wie Anm. 12) Bd. 3 S. 336 f. Nr. 380 - Cölestin III.: IP 4 S. 83 Nr. 8, ed. Migne PL 206 Sp. 917 f. Nr. 60, hier Sp. 917. Die restlichen 40 Urkunden, die sich alle an der eapropter- und statutentes-Formel orientieren, zähle ich hier nicht auf.

76 Paschalis II.: IP 4 S. 4 Nr. 9, ed. Pflugk-Harttung (wie Anm. 12) Bd. 2 S. 192 Nr. 230 - Innozenz II.: IP 4 S. 62 Nr. 8, ed. Pflugk-Harttung (wie Anm. 12) Bd. 2 S. 288 f. Nr. 327; IP 4 S. 44 Nr. 2, ed. Migne PL 179 Sp. 367 f. Nr. 318; IP 4 S. 84 Nr. 1, ed. Migne PL 179 Sp. 351 f. Nr. 306, hier Sp. 361; IP 4 S. 96 Nr. 8, ed. Migne PL 179 Sp. $473-476$ Nr. 410, hier Sp. 473-475.

77 IP 10 S. 91 Nr. 2, ed. Franco Bartoloni: Additiones Kehrianae, in: QFIAB 34 (1954) S. 31-64, hier S. 41-43 Nr. 3, hier S. 41.

78 Ebd. S. 42; vgl. auch Walter Holtzmann: Das Privileg Alexanders II. für S. Maria Mattina, in: QFIAB 34 (1954) S. 65-87, zum Papstschutz ebd. S. 70-72; zum Kloster auch Houben: Venosa (wie Anm. 38) S. 39.

79 IP 10 S. 48 Nr. 1, ed. Camillo Minieri Riccio: Saggio di codice diplomatico formato sulle antiche scritture dell'Archivio di Stato di Napoli, Supplemento, Neapel 1882, S. 3 f. Nr. 3, hier S. 4. 
bleibt auch bei den weiteren Privilegien erhalten ${ }^{80}$. Das erste Mal läßt sich die später prägende und in den anderen Regionen bereits ausführlich dargestellte Formel Eapropter ... sub beati Petri et nostra protectione suscipimus etc. in einem Privileg Eugens III. für die Zisterze Sambucina ${ }^{81}$ und das Kloster SS. Trinità in Mileto $^{82}$ fassen. Ab diesem Zeitpunkt bleibt sie die beherrschende Formel, wenn in Privilegien für kalabrische Empfänger der Papstschutz ausgesprochen und Besitz bestätigt wird ${ }^{83}$. Daß der Pontifikat Eugens III. für die Formulierung der Besitzbestätigungen für kalabrische Empfänger jedoch keinen völligen Bruch bedeutete, belegen je eine Urkunde Alexanders III. und Lucius' III. In beiden Privilegien, das eine für Sambucina und das andere für die Kirche S. Pietro in Cariati, werden Besitzungen bestätigt, ohne daß die Empfänger in derselben Urkunde explizit in den Papstschutz genommen würden. Die Besitzbestätigung setzt mit der eigentlich für den Papstschutz typischen eapropter-Formel ein und bietet im einen Fall die Bestätigung einer Kirche im Besitz des Klosters Sambucina, im anderen Fall werden die Besitzungen nicht konkret genannt. Beide Male werden die Besitzungen in die eapropter-Formel eingesetzt, da der Abschluß der Besitzbestätigung wieder ganz dem Duktus der Papstschutzverleihung entspricht und beide Male auctoritate apostolica confirmamus et presentis

80 Die Bestätigung einer Schenkung an den Kartäuser Bruno und seinen Gefährten Lanuinus durch Urban II. ist ebenso wenig formelhaft gehalten, vgl. IP 10 S. 68 Nr. 3, ed. Migne PL Sp. 509B-509D Nr. 241, hier Sp. 509C; was auch für die Urkunde Urbans II. zugunsten von SS. Trinità in Mileto gelten kann, in welcher der Papstschutz mit in ius perpetuum ac tutelam apostolice sedis excipimus ausgedrückt wird. Die namentliche Auflistung von Gütern wird hier eingeleitet mit den Worten: hęc nominatim duximus annotanda und wird wieder mit einem Perturbationsverbot abgeschlossen, vgl. IP 10 S. 145 Nr. 1, ed. PUU in Italien, Bd. 2 S. 331-334 Nr. 8, hier S. 332 f.; dieselben Formulierungen finden sich in dem 1100 von Paschalis II. in seiner für das Kloster ausgestellten Urkunde, vgl. IP 10 S. 145 Nr. 3, ed. PUU in Italien, Bd. 2 S. 334-336 Nr. 9, hier S. $334 \mathrm{f}$.

81 IP 10 S. 96 Nr. 2, ed. Bartoloni (wie Anm. 77) S. 49-51 Nr. 6, hier S. 49 f.

82 IP 10 S. 147 Nr. 11, ed. Migne PL 180 Sp. 1452-1454, hier Sp. 1452 f.

83 So in den Urkunden folgender Päpste: Alexander III.: IP 10 S. 148 Nr. 14, ed. PUU in Italien, Bd. 2 S. 359 f. Nr. 25, fast wörtliche Wiederholung von IP 10 S. 147 Nr. 11; IP 10 S. 73 Nr. 19, ed. Benedetto Tromby: Storia critico-cronologica diplomatica del patriarca S. Brunone e del suo ordine cartusiano, 10 Bde., Neapel 1773-1779 (ND Salzburg 1981-1983) (Analecta Cartusiana 84), hier Bd. 4, App. S. 132 f. Nr. 4, hier S. 132; IP 10 S. 82 Nr. 14, ed. PUU in Italien, Bd. 5 S. 578-580 Nr. 9, hier S. 579 f.; IP 10 S. 39 Nr. 2, ed. Migne PL 200 Sp. 1213 Nr. 1401 - Lucius III.: IP 10 S. 127 Nr. 2 (= RI 4/4/4/1 Nr. 1009), ed. PUU in Italien, Bd. 5 S. $589-592$ Nr. 16, hier S. 590 f. - Clemens III.: IP 10 S. 97 Nr. 6, ed. Bartoloni (wie Anm. 77) S. 56-59 Nr. 11, hier S. 56 f. - Cölestin III.: IP 10 S. 94 Nr. 1, ed. PUU in Italien, Bd. 5 S. $598-$ $600 \mathrm{Nr}$. 22, hier S. $241 \mathrm{f}$. - vermutlich auch in den beiden wörtlich übereinstimmenden Privilegien Clemens' III. (IP 10 S. 158 Nr. 1, Teiledition bei PUU in Italien, Bd. 4 S. 240 f. Nr. 24) und Cölestins III. (IP 10 S. 159 Nr. 3, Teiledition PUU in Italien, Bd. 4 S. $243-246$ Nr. 27). 
scripti patrocinio communimus lautet ${ }^{84}$. Die scheinbar seit Eugen III. feststehende Formulierung war damit im kalabrischen Raum abgewandelt worden.

Als Ergebnis dieser inhaltlichen Untersuchung läßt sich festhalten, daß in allen drei Regionen die Formulierungen der Besitzbestätigungen im Laufe des Untersuchungszeitraums verändert wurden und sich einander angeglichen haben. Sie entsprachen etwa ab der Mitte des 12. Jahrhunderts einem einheitlichen Formular. Die äußere Ausdrucksform war damit vereinheitlicht worden und, um Rudolf Hiestand nochmals aufzugreifen: Nun war es in Ligurien, Umbrien und Kalabrien tatsächlich dieselbe Tinte, dasselbe Pergament und dieselbe Formelhaftigkeit, mit der Besitz bestätigt wurde. Der Weg dorthin gestaltete sich jedoch unterschiedlich, denn die ersten Ansätze zu dieser Neugestaltung sind in den drei Regionen zu unterschiedlichen Zeitpunkten festzustellen. Zu Ligurien lassen sich aufgrund der Überlieferungslage letztlich keine Aussagen treffen. In Umbrien ist der erste Gebrauch in den Urkunden bereits unter Paschalis II. zu fassen, und die endgültige Formulierung tritt unter Lucius II. auf, während die Urkunden für kalabrische Empfänger unter Paschalis II., Calixt II. und Innozenz II. bereits bekannte Formulierungen verwendeten und damit in traditionellen Bahnen blieben. Hier änderte sich die Ausdrucksweise erst unter Eugen III., wobei sich in allen drei Regionen vereinzelt auch noch nach dessen Pontifikat andere Formulierungen nachweisen lassen, vor allem gegen Ende des 12. Jahrhunderts. Die Anpassung der Ausdrucksweise in den Urkunden fand in Kalabrien also wesentlich später statt als in Umbrien.

Die drei beispielhaft gewählten Empfängerregionen Ligurien, Umbrien und Kalabrien haben deutliche Unterschiede zutage treten lassen. Nicht nur in der Intensität der Kontakte wurden Differenzen und Phasenverschiebungen deutlich. In dieser Perspektive entwickelte sich Ligurien von einer romfernen zu einer romnahen Landschaft, während Kalabrien eine umgekehrte Entwicklung vollzog. Die Untersuchung der Formulierung der Besitzbestätigungen demonstrierte, daß es in den Privilegien zu einer weitgehenden sprachlichen Normierung kam, zu einer Standardisierung von Rechtsinhalten, was eine sprachliche Angleichung der Privilegien in den drei Regionen bewirkte, jedoch in unterschiedlicher Geschwindigkeit. Davon unberührt blieben inhaltliche Un-

84 Die Urkunde Alexanders III. für Sambucina ist: IP 10 S. 97 Nr. 4, ed. Alessandro Pratesi: Carte latine di abbazie Calabresi provenienti dall'archivio Aldobrandini, Vatikanstadt 1958 (StT 197), S. 78 f. Nr. 31; Die Urkunde Lucius' III. für die Kirche S. Pietro in Cariati, IP 10 S. 108 Nr. 1 (= RI 4/4/4/1 Nr. 790), findet sich bei PUU in Italien, Bd. 4 S. 112 f. Nr. 7, die Besitzbestätigung auf S. 113. 
terschiede jedoch bestehen, wie die Beispiele der Delegationsgerichtsbarkeit und Weihe von Äbten oder Bischöfen illustrierten. Die sprachliche Normierung der Privilegien, die natürlich auch für die Kirchen außerhalb Italiens galt ${ }^{85}$, führte somit nicht zu einer inhaltlichen Normierung. Die Sprache, in welche man die gewünschten Sachverhalte verpackte, wurde in Kalabrien wie in Ligurien dieselbe. Doch eine Angleichung der Privilegien in inhaltlicher Weise - in dem Sinne, daß sich prototypisch entwickeln ließe, was ein Benediktinerabt des ausgehenden 12. Jahrhunderts sich aus Rom erbat - fand nicht statt. Die Inhalte waren nach wie vor stark durch die Empfängerregionen geprägt. Zugespitzt könnte man formulieren: Die Vereinheitlichung der Kirche und ihrer Zentralisation, die sich sprachlich in den Privilegien spätestens ab Eugen III. feststellen läßt, erweist sich anhand des hier untersuchten Gegenstandes als vordergründig, da sie zunächst nur die Ausdrucksformen veränderte, den Einzelkirchen jedoch Handlungsspielraum belie ${ }^{86}$. Dieses Ergebnis läßt sich sicherlich ohne weiteres auch auf andere Regionen Italiens und außerhalb der Apenninhalbinsel übertragen. Die Zentralisierungsbemühungen des Papsttums schlugen sich in der sprachlichen Erscheinungsform der Urkunden nieder, doch blieb die Heterogenität der Inhalte erhalten. Denn für sie blieb der Einfluß der Empfänger auch am Ende des 12. Jahrhunderts bestimmend.

\section{Riassunto}

Sono state rilevate delle differenze molto marcate tra le tre regioni di Liguria, Umbria e Calabria dal punto di vista dei documenti papali ricevuti - differenze e sfasamenti che riguardavano non solo l'intensità dei contatti: mentre la Liguria, in un primo momento lontana da Roma, vi si avvicinò nel corso del tempo, per la Calabria avvenne proprio il contrario. L'analisi delle formule relative alla conferma dei possedimenti dimostra che nei privilegi, destinati alle

85 Vgl. dazu Ludwig Schmitz-Kallenberg: Papsturkunden. Urkundenlehre I. und II. Teil. Grundbegriffe, Leipzig ${ }^{2} 1913$ (Grundriß der Geschichtswissenschaft 1/2), S. 99 „Der Pontifikat Innozenz' III. bezeichnet in der päpstlichen Diplomatik einen wichtigen Einschnitt: Jedes Schwanken der Kanzleigebräuche hört jetzt auf.“

86 Das wirft ein interessantes Licht auf den vielleicht bereits 1147 begonnenen und 1153 abgeschlossenen Papstspiegel Bernhards von Clairvaux «De consideratione», in dem er im dritten Buch die Zentralisation der Kirche im Rechtswesen, zu zahlreiche Exemtionen u. a. kritisierte, so in «De consideratione ad Eugenium papam», III/3/14, ed. Bernhard von Clairvaux, Sämtliche Werke lateinisch/deutsch, Bd. 1, hg.v. Gerhard B. WinkLER, Innsbruck 1990, S. 611-841, hier S. 724. Zur Sache vgl. Franz-Josef Schmale: Das Papsttum im Zeitalter Bernhards von Clairvaux und der frühen Staufer, in: Greschat (wie Anm. 3) S. 176-195, hier S. 182-184; Peter Dinzelbacher: Bernhard von Clairvaux. Leben und Werk des berühmten Zisterziensers, Darmstadt 1998 (Gestalten des Mittelalters und der Renaissance), S. 339-356, bes. S. 347 f. 
tre regioni, si arrivò a una larga standardizzazione linguistica e dei contenuti giuridici, perciò a una uniformazione linguistica, anche se a ritmi diversi. A parte ciò, continuavano a rimanere delle differenze di contenuto. Il linguaggio, in cui si trattavano gli affari desiderati, diventava lo stesso in Calabria e in Liguria, mentre i contenuti dei privilegi si mostravano ancora fortemente condizionati dai territori destinatari. Per dirlo in breve: l'unificazione della chiesa e la sua centralizzazione, constatabili a livello linguistico nei privilegi al più tardi a partire di Eugenio III, risultano solo apparenti sulla base dei materiali qui studiati, perché in un primo momento cambiavano solo le forme espressive, mentre rimaneva alle singole chiese ancora un proprio spazio 
Bereitgestellt von | De Gruyter / TCS

Angemeldet | 217.89.40.26

Heruntergeladen am | 21.12.12 10:48 


\title{
Kehrs Regesta Pontificum Romanorum: Entstehung - wissenschaftlicher Ertrag - organisatorische Schwächen
}

\author{
Dieter Girgensohn*
}

\section{Einführung}

Die Regesta pontificum Romanorum der Akademie der Wissenschaften zu Göttingen sind allem Anschein nach ein solides, gesundes Unternehmen: Gerade vor 14 Tagen ist ein neuer Band ausgeliefert worden ${ }^{1}$, der zweite der Abteilung Gallia pontificia, er macht insgesamt das zweite Dutzend voll ${ }^{2}$. Aber dagegen steht die Tatsache, daß das prominenteste Teilstück des Gesamtwerkes, die Italia pontificia, immer noch unvollendet ist, hat doch ihr ungemein rascher Anfang vor einem Jahrhundert ${ }^{3}$ längst eine holprige Fortsetzung gefunden: Seit dem Erscheinen des vorläufig letzten Bandes ${ }^{4}$ sind nun schon 31 Jahre ver-

${ }^{*}$ Der Charakter dieses Beitrags legt es nahe, in der schriftlichen Fassung die Vortragsform beizubehalten, doch sind - abgesehen von den hinzugefügten Belegen - einige Passagen ausgeweitet oder präzisiert worden. Die angehängten Thesen zur Fortführung des Unternehmens waren für die Schlußdiskussion gedacht, konnten aus Zeitgründen aber nicht ausgeführt werden. - Soweit die Arbeiten Kehrs in anastatischen Neudrucken vorliegen, werden sie danach zitiert: PUU in Italien und Paul Fridolin KeHr: Ausgewählte Schriften, hg.v. Rudolf Hiestand, Göttingen 2005 (AAG, phil.-hist. Kl., 3. Folge 250).

1 Gallia pontificia. Répertoire des documents concernants les relations entre la papauté et les églises et monastères en France avant 1198, 3: Province écclésiastique de Vienne, 1: Diocèse de Vienne, appendix Regnum Burgundiae, bearb. v. Beate Schilling, Göttingen 2006.

2 Vorher waren erschienen: 12 Bände Italia pontificia (1906-1975), 10 Bände Germania pontificia (1911-2005) und ein erster Band der Gallia pontificia (1998-2006).

3 Zwischen 1906 und 1914 sind die ersten sechs Bände von Kehr herausgegeben worden, der letzte in zwei Teilen. Sie umfassen Rom, Latium, die Toskana sowie Umbrien, die Marken und die Abruzzen, dann folgen die Emilia Romagna, die Lombardei, weiter Piemont und Ligurien. In dieser Anordnung spiegelt sich die ursprüngliche Absicht, das Material in drei Bänden vorzulegen: für Mittel-, Ober- und Unteritalien (s. Anm. 107). Soweit die Bistümer nicht romunmittelbar, sondern - nach dem Stand am Ende des 12. Jahrhunderts - zu Kirchenprovinzen zusammengefaßt waren, steht die Metropole immer am Anfang, die Suffragane schließen sich im Uhrzeigersinn geordnet an, beginnend jeweils im Norden.

4 Hier der genaue Titel, wie er dem Blatt mit der Nennung der Gesamtreihe Regesta pontificum Romanorum gegenübersteht: Italia pontificia sive repertorium privilegiorum et litterarum a Romanis pontificibus ante annum MCLXXXXVIII Italiae ecclesiis, 
gangen, also sogar mehr als die Pause von 27, die als Folge des Zweiten Weltkrieges zwischen dem achten und dem neunten verstrichen sind ${ }^{5}$, während der erste mondiale Konflikt eine Unterbrechung von lediglich neun Jahren bewirkt hatte ${ }^{6}$. Mir scheint es im übrigen angemessener, von den Regesta pontificum Romanorum Paul Kehrs zu reden, so wie er auch auf den Titelblättern der ersten 15 Bände bis 1975 als Urheber vermerkt war ${ }^{7}$, denn die typische Gestaltung dieses Regestenwerks ist sein ureigenstes Produkt. Genauso sollte man bewußter, als das im allgemeinen Sprachgebrauch begegnet, das Papsturkundenwerk, projektiert als monumentale Edition, unterscheiden vom Papsturkundenunternehmen der Göttinger Akademie, also den organisierten Anstrengungen auf dem Wege zur Realisierung jener Sammlung.

Die eingangs genannte Diskrepanz ist einer Reflexion wert. Begonnen werden mag mit einem Blick auf die Entstehung der Italia pontificia. Ihre Erfindung ist in meinen Augen ein Geniestreich, der aus einer Not hat eine Tugend werden lassen, als nämlich der Initiator des Papsturkundenunternehmens sich der Einsicht nicht mehr verschließen konnte, daß sein hochgemutes Vorhaben auf weit größere Schwierigkeiten stieß, als er sich und aller Welt vorgestellt hatte. Was Kehr ursprünglich beabsichtigte, soll hier in Erinnerung gerufen werden, dann skizziert, wie er auf die unerwarteten Schwierigkeiten reagierte. Hervorzuheben ist weiter der wissenschaftliche Nutzen, den dieses Zwischenprodukt für Papsturkunden- und Kirchengeschichtsforschung tatsächlich bietet. Endlich sei der Blick auf die Hindernisse bei der Fortsetzung der Regesta gelenkt - sie sind nach meiner Einschätzung nicht wissenschaftsimmanent, sondern eher im Bereich der Forschungsorganisation auszumachen,

monasteriis, civitatibus singulisque personis concessorum, iubente academia Gottingensi congessit Paulus Fridolinus Kenr 10: Calabria - Insulae, ed. Dieter Girgensohn usus Waltheri Holtzmann schedis, Turici 1975.

5 Das Material für das normannische Königreich Sizilien und für Kampanien (außer der Kirchenprovinz Benevent) erschien 1935, dasjenige für den Rest des festländischen Unteritaliens (bis auf Kalabrien) 1962, nun herausgegeben von Walther Holtzmann.

6 Die beiden Teile des Bandes 7 mit den Kirchenprovinzen Aquileia (doch ohne Trient, dazu vgl. Anm. 143, auch ohne Como, das schon in 6/1 bei der Lombardei behandelt worden war) und Grado sowie der Republik Venedig tragen die Daten 1923 und 1925.

7 Das gilt auch für Germania pontificia 1-3, Berlin 1911-1935. Erst mit Band 4 dieser Abteilung, Göttingen 1978, hat Theodor Schieffer den Brauch eingeführt, an die Stelle Kehrs den Sekretär der Pius-Stiftung zu setzen.

8 Rudolf Hiestand: 100 Jahre Papsturkunden, in: Hundert Jahre Papsturkundenforschung. Bilanz - Methoden - Perspektiven. Akten eines Kolloquiums zum hundertjährigen Bestehen der Regesta pontificum Romanorum vom 9.-11. Oktober 1996 in Göttingen, hg.v. DEms., Göttingen 2003 (AAG, phil.-hist. Kl., 3. Folge 261), S. 11-44, stellte unlängst fest, daß „die Regestenbände heute meist als das eigentliche Ziel des Papsturkundenwerkes angesehen werden, kaum jemand an die Edition denkt“ (S. 29). 
also gerade auf dem Felde, auf dem Kehr einmal als Akteur seine überragende Meisterschaft unter Beweis zu stellen verstanden hat?

Diese Ausführungen gründen auf persönlichen Erfahrungen, die meiner Mitarbeit an der Italia pontificia entstammen. Nun gibt es inzwischen eine ansehnliche Literatur über das Göttinger Papsturkundenunternehmen, insbesondere den kürzlich erschienenen Band mit den Referaten während des Colloquiums zum hundertjährigen Bestehen und darin vor allem den Beitrag von Rudolf Hiestand mit dem Titel Die unvollendete Italia Pontificia ${ }^{10}$, dem bereits Ausführungen aus Anlaß des römischen Institutsjubiläums im Jahre 1988 geschuldet waren ${ }^{11}$. Ich denke aber, daß darüber hinaus die Besinnung auf eigene Erlebnisse und Beobachtungen den einen oder anderen zusätzlichen Gesichtspunkt beizusteuern vermag. Sie sind freilich nicht mehr ganz frisch: Der Anfang meines Engagements für das Papsturkundenunternehmen reicht nun 46 Jahre und zwei Monate zurück; damals, im September 1960, begann meine Zeit als Amanuensis von Walther Holtzmann ${ }^{12}$; der Endpunkt fällt in das Jahr 1975, nach einjähriger Unterbrechung 1963-1964.

\section{Absichten und Konfrontation mit der Überlieferung}

Als der 35jährige Paul Kehr ${ }^{13}$ 1896, im Jahre nach seiner Berufung zum Ordinarius an der Georgia Augusta, die Königliche Gesellschaft der Wissenschaften zu Göttingen für sein Projekt einer Edition der Papsturkunden bis auf

$9 \mathrm{Zu}$ diesem Aspekt s. jetzt die Hinweise auf Äußerungen über Kehrs Befähigungen in Dieter Girgensohn: Schriften Paul Fridolin Kehrs in einer neuen Sammlung, in: QFIAB 86 (2006) S. 597-626, dort S. 599-602.

10 In: Hundert Jahre Papsturkundenforschung (wie Anm. 8) S. 47-57; s. noch seine einleitenden Ausführungen: 100 Jahre Papsturkundenwerk, ebd. S. 11-44, sowie das dort im Anhang gegebene Verzeichnis der in diesem Rahmen veröffentlichten Arbeiten auf S. 391-400 (unter Einschluß der noch geplanten Regestenbände). Weitere wichtige Beiträge werden in Anm. 14 genannt.

11 Ders.: Die Italia Pontificia, in: Das Deutsche historische Institut in Rom 1888-1988, hg.v. Reinhard Elze/Arnold Esch, Tübingen 1990 (Bibliothek des Deutschen historischen Instituts in Rom 70), S. 167-189. Neueren Datums ist DERs.: Die Göttinger Akademie als Trägerin eines internationalen Forschungsunternehmens: das Papsturkundenwerk, in: Die Wissenschaften in der Akademie. Vorträge beim Jubiläumskolloquium der Akademie der Wissenschaften zu Göttingen im Juni 2000, hg. v. Rudolf Smend/Hans-Heinrich Voigt, Göttingen 2002 (AAG, phil.-hist. Kl., 3. Folge $247=$ math.-phys. Kl., 3. Folge 51), S. 321-341.

12 Siehe Anm. 176.

13 Die reiche biographische Literatur findet sich - sorgfältig verzeichnet bis zum Erscheinungsjahr 2002 - in Stefan Weiss: Paul-Kehr-Bibliographie, in: KeHr: Schriften (wie Anm. *) Bd. 2 S. 1331-1397, dort S. 1390-1397. Zum Verhältnis von Leben und Werk s. noch Girgensohn: Schriften Kehrs (wie Anm. 9). 
Innozenz III. gewann ${ }^{14}$, hat er den Aufwand, der für die Vollendung dieses Vorhabens erforderlich sein würde, auch nicht annähernd abschätzen können. Allerdings war er sich sehr wohl bewußt, daß es sich um eine wirklich große Aufgabe handelte. Genau eine solche erwartete man, war doch die Gesellschaft damals gerade auf der Suche nach einer bedeutenden Unternehmung auf geisteswissenschaftlichem Gebiet, mit dem sie ihre internationale Reputation zu mehren hoffte. Daß es sich um ein mächtiges Unterfangen handeln würde, war Kehr schon bei den ersten Überlegungen zu seinem Projekt bewußt: Als er am 27. Januar jenes Jahres seinen früheren Lehrmeister Theodor von Sickel vorab in den Plan einweihte, hob er sogleich hervor, die Ausführung würde einem Einzelnen nicht gelingen können, so daß die Realisierung nur durch eine Akademie oder eine ähnliche wissenschaftliche Institution zu geschehen vermöchte ${ }^{15}$.

Das wird ausgeführt in dem förmlichen Antrag ${ }^{16}$, den Kehr und Max Lehmann mit dem Datum des 4. Mai der Göttinger Gesellschaft unterbreiteten mit dem Ziel, „eine kritische Ausgabe der päpstlichen Privilegien bis auf Innocenz III. zu veranstalten und die hierzu nöthigen Mittel, zunächst einen Beitrag von 1200 Mk für das Etatsjahr 1896/97, zu bewilligen“"17. Als Köder

14 Für Entstehung und Entwicklung des Papsturkundenunternehmens hervorzuheben sind - neben den unten zu referierenden programmatischen Äußerungen und Selbstzeugnissen Kehrs - die Lebensskizzen von Karl Brandi: Paul Kehr (von 1944), in: Jahrbuch der Akademie der Wissenschaften in Göttingen. Übergangsband für die Jahre 19441960, Göttingen 1962, S. 134-152; Walther Holtzmann: Paul Fridolin Kehr, in: DA 8 (1951) S. 26-58; Josef Fleckenstein: Paul Kehr. Lehrer, Forscher und Wissenschaftsorganisator in Göttingen, Rom und Berlin (zuerst 1987), in: DERs.: Ordnungen und formende Kräfte des Mittelalters. Ausgewählte Beiträge, Göttingen 1989, S. 469489; ferner Hiestand: Italia Pontificia (wie Anm. 11) und Ders.: 100 Jahre Papsturkundenwerk (wie Anm. 8). Zur Anfangsphase ist besonders hinzuweisen auf DENs.: Göttinger Akademie (wie Anm. 11) S. 322-327, und auf die detaillierte, in entscheidender Einzelheit korrektere Darstellung von Michèle Schubert: Paul Fridolin Kehr als Professor und als Akademiemitglied in Göttingen (1895-1903), in: AZ 82 (1999) S. $81-125$, dort S. 90-98.

15 Hinweis auf den Brief ebd. S. 92.

16 Göttingen, Archiv der Akademie der Wissenschaften, Scient. 165,2 Bl. 1 - ein herzlicher Dank gebührt Frau Christiane Wegener für das Entgegenkommen, mit dem sie mir die Benutzung dieses und anderer Aktenstücke erleichtert hat. Bei den Unterschriften unter der Eingabe steht Kehrs Name über dem Lehmanns, doch sah der Text zunächst die umgekehrte Reihenfolge vor, gewiß aus Gründen der Anciennität; das ist korrigiert worden. Schon der Wortlaut läßt ein stärkeres Gewicht des Erstgenannten erkennen, denn von ihm heißt es, er glaube, „durch seine bisherigen Arbeiten zur Leitung der Aufgabe hinreichend vorbereitet zu sein“. Daß Kehr der eigentliche Autor war, erwähnt Lehmann selbst in einem Schreiben an den Kultusminister aus dem Februar 1900: „Ich habe ... seinen Antrag auf Herausgabe der Papsturkunden unterschrieben“; zitiert von Schubert: Kehr in Göttingen (wie Anm. 14) S. 106.

17 Diese Passage und einige weitere bietet Brandi (wie Anm. 14) S. 137. 
benutzten die Antragsteller den Hinweis, es handele sich um ein Unternehmen, „von dem sie zu hoffen wagen, daß es der Gesellschaft zu dauerndem Ruhme gereichen werde “18. Die vorgeschlagene Aufgabe sei bisher von keiner Institution in Angriff genommen worden, „obwohl ihre Lösung eines der dringendsten Bedürfnisse der historischen Wissenschaft ist ... Es gibt kein Gebiet der älteren Geschichte des Mittelalters, welches so unsicher wäre wie die päpstliche Diplomatik.“ Bei der Auswahl maßgebend sei die Erwägung gewesen, „daß einer Akademie würdig nur eine Aufgabe sei, die ihrer Natur nach von einzelnen Gelehrten nicht gelöst werden könne und zugleich eine allgemeine Bedeutung für die Wissenschaft habe“. Denselben Gesichtspunkt betonte Kehr, als er sein Vorhaben am 7. November 1896 in der feierlichen Jahressitzung der Gesellschaft der Öffentlichkeit vorstellte: Ueber den Plan einer kritischen Ausgabe der Papsturkunden bis Innocenz III. ${ }^{19}$ Nun aber fügte er die Spezifizierung hinzu, für Kenner stehe außer Zweifel, „daß eine kritische Bearbeitung der gesamten päpstlichen Urkunden von den ältesten Zeiten bis zur Wende des 12. Jahrhunderts in ihrem weitesten Sinne nicht nur die Kräfte eines Einzelnen, sondern selbst die Kräfte einer gelehrten Gesellschaft übersteigen würde“.

Daher nahm Kehr in der Erkenntnis, daß er mit Bedacht vorgehen müsse, von Anfang an als Vorsichtsmaßnahme einige Einschränkungen vor. Das wird am deutlichsten bei der zeitlichen Begrenzung mit dem Tode Coelestins III. Anfang 1198. Wir wissen längst, daß dieser Einschnitt einer ernsthaften sachlichen Begründung entbehrt: Zwar beginnt mit jenem Jahr die Serie der recht lückenlos erhaltenen päpstlichen Register. Diese aber bieten ja nur einen Bruchteil der von der Kurie ausgegangenen Schriftstücke, vielleicht zehn bis zwanzig Prozent, während der Rest des Auslaufs eben nicht festgehalten worden ist $^{20}$. Nun ging es Kehr aber um mehr als nur um die Sammlung und die Publikation der Papsturkunden, vielmehr hatte er schon bei der Konzeption des Unternehmens dessen Ertrag nicht nur für die Papstdiplomatik und die Kanzleigeschichte, sondern mehr noch für ein vollständigeres Bild der Kirchenverwaltung sowie der innerkirchlichen und der politischen Aktivitäten der

18 Daß dieses Kalkül aufging, zeigt eine späte Laudatio Kehrs in den Akten der Göttinger Akademie der Wissenschaften: „Wir verdanken ihm die größte der wissenschaftlichen Unternehmungen unserer philologisch-historischen Klasse und damit einen Teil unserer wissenschaftlichen Weltgeltung"; wiedergegeben von SchuberT: Kehr in Göttingen (wie Anm. 14) S. 125.

19 Jetzt in: KeHr: Schriften (wie Anm. *) Bd. 1 S. 3-17, dort S. 7.

20 Siehe den Überblick von Othmar Hageneder: Die päpstlichen Register des 13. und 14. Jahrhunderts, in: Annali della Scuola speciale per archivisti e bibliotecari dell'Università di Roma 12 (1972) S. 45-76, zur Frage der Vollständigkeit S. 68-76. Die reiche Literatur zu den päpstlichen Registern ist verzeichnet im einschlägigen Kapitel von Thomas Frenz: Papsturkunden des Mittelalters und der Neuzeit, Stuttgart ${ }^{2} 2000$ (Historische Grundwissenschaften in Einzeldarstellungen 2), S. 59-71. 
Päpste als wichtiges Ziel im Auge ${ }^{21}$. Nimmt man diese Ausrichtung ernst, gilt somit auch für die Zeit ab 1198, daß der Weg zur Empfängerüberlieferung in Archiven und Bibliotheken unverzichtbar bleibt.

Der zweite Eingrenzungsversuch Kehrs ist thematischer Natur - und verrät ebenso seine Vorlieben wie unzureichende Spezialkenntnisse: Nicht aufnehmen wollte er in die Ausgabe die päpstlichen Schreiben in patristischer und in kanonistischer Überlieferung. Da er ja einsah, daß die Bearbeitung der Papsturkunden bis 1198 ,in ihrem weitesten Sinne“ die Möglichkeiten sogar einer wissenschaftlichen Institution überfordern würde, sollte die geplante Edition von vornherein auf die eigentlichen Produkte „des päpstlichen Urkundenwesens" beschränkt bleiben, nämlich auf die Schreiben, ,in denen ... irgend

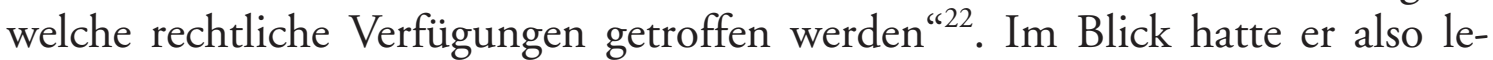
diglich diejenigen Stücke, die einmal zu den Empfängern gelangt waren und die sich in deren Archiven erhalten haben, wohin auch immer diese inzwischen gewandert sein mochten, oder die daraus in allgemeinere Abschriftensammlungen eingegangen sind. Kehr nannte sie „die Papsturkunden in strengem

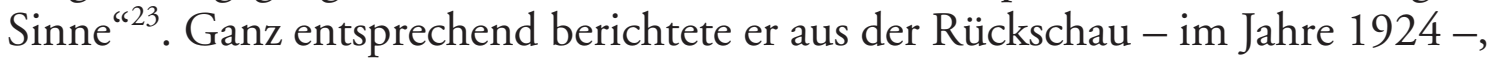
er habe für die Ausgabe ursprünglich überhaupt nur Texte seit dem 8. Jahrhundert vorgesehen gehabt ${ }^{24}$.

21 So verwies er gleich 1896 auf „die Geschichte der päpstlichen Verwaltung“, die aus der Gesamtübersicht über die erhaltenen Urkunden Gewinn ziehen werde; „die diplomatische Forschung" sei „schließlich selbst ein Stück Verfassungs- und Verwaltungsgeschichte geworden“; „die Geschichte der päpstlichen Kanzlei begleitet ... die Geschichte des Papstthums selbst“; er sprach gar von einem „Stück der allgemeinen Geschichte des Occidents im Mittelalter, für das die Ausgabe der Papsturkunden die kritisch gesicherte Grundlage schaffen soll“: KeHR: Schriften (wie Anm. *) Bd. 1 S. 15, 13. Später hob er hervor, es werde unverzichtbares Material für „die Feststellung der geschichtlichen und rechtlichen Beziehungen der einzelnen Kircheninstitute zu Rom und zur Kurie" gesammelt: Paul Fridolin Kehr: Rezension von Albertus Brackmann: Regesta pontificum Romanorum, Germania pontificia 2/1, Berlin 1923, in: Deutsche Literaturzeitung $45=$ N.F. 1 (1924) Sp. 1128-1143, dort Sp. 1132. In zusammenfassender Rückschau - aus dem Jahre 1940 - bezeichnete er es als „eines der Hauptergebnisse“ seiner Forschungsarbeiten in Rom während der 1880er Jahre, „daß zur richtigen Erkenntnis der Geschichte des Mittelalters und des damit untrennbar verbundenen Papsttums eine möglichst vollständige Sammlung und Bearbeitung der Urkunden der Päpste ... erforderlich sei“: KeHR: Schriften (wie Anm. ${ }^{*}$ ) Bd. 2 S. 1312.

22 Ebd. Bd. 1 S. 7, 10.

23 So in der Selbstanzeige des ersten Bandes der Italia pontificia (1906): ebd. S. 31, mit der Erläuterung: „unter Ausschluß sowohl der älteren Papstbriefe wie der in den Registern und in den kanonistischen Sammlungen aufgenommenen Stücke“. Den Begriff verwandte er schon 1896: ebd. S. 10-11.

24 KeHR: Rezension (wie Anm. 21) Sp. 1133: „Einst hatte ich eine Vision. Ich sah im Geiste eine Serie von dreißig Bänden, in denen das gesamte Papsturkundenmaterial des ganzen Abendlandes für vier bis fünf Jahrhunderte gesammelt und gesichtet war." Das erlaubt den Schluß auf den oben genannten Zeitraum. In der Vorstellung seines Planes 
Das bedeutete unter anderem den Verzicht auf eine Neubearbeitung der wenigen aus älterer Zeit erhaltenen Register und Registerfragmente oder der Ableitungen von solchen, wie sie etwa die Collectio Britannica ${ }^{25}$ darstellt. So stieß diese Einschränkung denn auch sofort auf Kritik ${ }^{26}$. Die äußerte neben anderen Achille Ratti ${ }^{27}$, damals noch einfacher Bibliothekar an der Ambrosiana, und wäre nicht schon Kehr gegenüber solchen Mahnungen einsichtig gewesen, hätte derselbe Gelehrte als Pius XI. gewiß nicht dem Papsturkundenunternehmen derart viel Förderung zugewendet. Längst ist wissenschaftliches Allgemeingut, daß eine solche Unterscheidung zwischen Papsturkunden „in strengem Sinne" oder aber in weniger strengem nicht weiterführt ${ }^{28}$. Dementsprechend sind in späteren Phasen des Unternehmens sämtliche päpstlichen Schreiben ohne Ausnahme berücksichtigt worden, so wie sie sich bei der Durchsicht von Archiven und Handschriftensammlungen haben aufspüren lassen. In die Regesta pontificum Romanorum - wenngleich in den frühen Bänden der Italia

hatte Kehr noch Erlasse aus dem 4. Jahrhundert als „die ersten päpstlichen Urkunden im strengen Sinn" genannt (KeHR: Schriften [wie Anm. *] Bd. 1 S. 11, wohl in Anspielung auf JK 259, 285, 328), nach dem Verlagsvertrag von 1900 (s. Anm. 100) sollten die Acta pontificum Romanorum mit Gregor I., also dem Ende des 6. Jahrhunderts, einsetzen.

25 Nicht ersetzt ist bisher die Beschreibung von P(aul) Ewald: Die Papstbriefe der Brittischen Sammlung, in: NA 5 (1880) S. 275-414, 503-596, mit der Wiedergabe der bis dahin ungedruckten Texte. Eine Gruppe davon ist kürzlich in kritischer Edition vorgelegt worden: Robert Somerville/Stephan Kuttrer: Pope Urban II, the Collectio Britannica, and the Council of Melfi (1089), Oxford 1996. Siehe dort S. 3-21 auch zum Inhalt sowie zu den Vermutungen über die Herkunft des Materials und den Entstehungsort der Sammlung, dazu noch Antonia FiORI: La "Collectio Britannica“ e la riemersione del Digesto, in: Rivista internazionale di diritto comune 9 (1998) S. 81 121. Weitere Literatur in Lotte Kéry: Canonical collections of the early Middle Ages (ca. 400-1140), Washington 1999 (History of medieval canon law), S. $237 \mathrm{f}$.

26 Der „Unterschied zwischen den älteren Papstbriefen und den späteren Urkunden rechtlicher Natur“ dürfte „zu begründen schwer sein“, schrieb - in einer ansonsten lobenden Besprechung - J(oseph) SAUER: Eine neue geplante Herausgabe der Papsturkunden, in: AKKR $77=3$. Folge 1 (1897) S. 401-405. Kehr selbst (KeHR: Schriften [wie Anm. *] Bd. 1 S. 31 Anm. 1) verwies auf die ähnliche Kritik von H(artmann) Grisar: Analecta Romana. Dissertazioni, testi, monumenti dell'arte riguardanti principalmente la storia di Roma e dei papi nel Medio Evo 1, Rom 1899, S. 663-666. Vgl. im übrigen die Aufzählung der Rezensionen zu den Publikationen des Papsturkundenunternehmens aus den ersten Jahren: Weiss (wie Anm. 13) S. 1343-1358.

27 In einer ausführlichen Inhaltswiedergabe des Planes von 1896 und der frühen Reiseberichte in: ASL Jg. $29=$ Ser. 3,18 (1902) S. 401-412, dort S. 402-406.

28 Auf Kritiken an seiner anfänglichen Einteilung der päpstlichen Schreiben reagierend, bemerkte Kehr 1906 ironisch (KeHr: Schriften [wie Anm. *] Bd. 1 S. 31 Anm. 2): „Das hat mir von seitens der Hüter der reinen Diplomatik bereits verschiedene Rüffel eingebracht." Zur Sache vgl. jetzt die Übersicht über die Texte des 4.-9. Jahrhunderts von Detlev Jasper/Horst Fuhrmann: Papal letters in the early Middle Ages, Washington 2001 (History of medieval canon law). 
pontificia noch nicht mit der wünschenswerten Vollständigkeit ${ }^{29}-$ sind zusätzlich sämtliche auffindbaren Nachrichten über verlorene Stücke eingeordnet worden und über sonstige Akte der Päpste, ob sie nun zu einer Urkunde geführt haben mögen oder nicht, wie etwa die Weihe einer Kirche, bezeugt durch Inschrift oder chronikalische Notiz. Doch sollte diese Ausweitung nach Kehrs Auffassung $^{30}$ keine präjudizierende Wirkung auf die eigentliche Ausgabe der Papsturkunden entfalten, dafür vielmehr das ursprüngliche, eingeschränkte Programm weiterhin gelten.

Aus den ersten Äußerungen der gelehrten Kritik geht außerdem hervor, daß einerseits die Größe des vorgenommenen Projekts Bewunderung weckte ${ }^{31}$. Das war die erklärte Absicht sowohl des Initiators als auch der verantwortlichen Institution gewesen ${ }^{32}$. Andererseits stieß die spezielle Vorbereitung für die Ausführung auf Skepsis. Kehr hatte in Wien gelernt bei Theodor von Sickel ${ }^{33}$, den er als seinen eigentlichen Lehrmeister angesehen hat ${ }^{34}$, aber nicht etwa den

29 Die forderte etwa $\mathrm{R}$ (obert) von Nostitz-Riemeck in seiner Besprechung des ersten Bandes in: HJb 28 (1907) S. 119-125, dort S. 121; er empfahl ausdrücklich die Aufnahme ausnahmslos aller Papstbriefe und -dekrete, abweichend vom ursprünglichen Plan. Auch der Initiator selbst empfand schon bald Unbehagen an solchen Einschränkungen und gab in der Selbstanzeige von 1906 „große und kleine Inkonsequenzen“ bei der von ihm zunächst getroffenen Auswahl zu, offenbar weil diese sich nicht immer ungezwungen begründen ließ. Dennoch hielt er noch daran fest, die durch bloße Erwähnungen bekannten Schenkungen der Päpste nur dann als Regesten aufzunehmen, wenn es sich um Immobilien handelte, dagegen die von einzelnen Gegenständen zu übergehen. Außerdem räumte er ein, daß „die die Papstwahl regelnden Akte“ gut in dem den Kardinälen gewidmeten Abschnitt hätten behandelt werden können. Dazu gesteht er freimütig: „Konsequenz ist leider meiner Tugenden letzte." Vgl. KeHR: Schriften (wie Anm. *) Bd. 1 S. 32 f., 28, 34; siehe auch unten bei Anm. 121.

30 Ebd. S. 31: Das in den Regesta darzubietende Material sei keineswegs auf die vollständig überlieferten Papsturkunden zu beschränken, es seien also auch „Deperdita, Auszüge, Notizen“ zu berücksichtigen, kurz: „die Akte der Päpste überhaupt“, doch zunächst nur, „soweit sie irgendwie auf einer durch Urkunden (im weitesten Sinne) beglaubigten Handlungen beruhen".

31 „Die Aufgabe ... ist gewaltig“, so daß sie „ein zaghaftes Gemüt erschrecken könnte“, empfand etwa Otto Krauske: Über den Plan einer kritischen Ausgabe der Papsturkunden bis Innocenz III., in: HZ 78 (1897) S. 456-461. Achille Ratti sprach vom „piano di una grandiosa impresa“ (s. Anm. 27). Lodovico ZDeKauer in: ASI, Ser. 5,20 (1897) S. 126-130 bezeichnete das Vorhaben als „un vero capolavoro“ und „il grandioso progetto“, meldete aber zugleich Zweifel an der Realisierbarkeit an. „Ein wissenschaftlich ebenso bedeutendes, als schwieriges ... Unternehmen ..., das ... ein monumentales Werk sein wird“, urteilte E(ngelbert) M(ÜHLBACHER) in: MIÖG 18 (1897) S. 205.

32 Siehe die Literatur in Anm. 14.

33 Ausführlich über dieses Verhältnis: Michèle Schubert: Meister - Schüler. Theodor von Sickel und Paul Fridolin Kehr (nach ihrem Briefwechsel), in: MIÖG 106 (1998) S. $149-166$.

34 Dazu s. die Selbstzeugnisse Kehrs bei Girgensohn: Schriften Kehrs (wie Anm. 9) S. 603, 609 . 
zweijährigen Ausbildungskurs ${ }^{35}$ in den historischen Hilfswissenschaften am Institut für österreichische Geschichtsforschung absolviert, sondern seine Erfahrungen lediglich bei den Diplomen von Kaisern und Königen gesammelt ${ }^{36}$. So warf man ihm gleich zu Beginn mangelnde Vertrautheit mit der Materie und außerdem überstürzte Hast vor, zumal da Kenner genüßlich darauf hinwiesen, er habe nicht einmal Jaffés Einleitung zu dessen Regesta pontificum Romanorum ordentlich gelesen ${ }^{37}$, obwohl diese doch in der damals neuen zweiten Auflage die erklärte Grundlage für Kehrs Sammeltätigkeit bildeten. Tatsächlich hatte er im ersten seiner Reiseberichte in den Nachrichten von der Königl. Gesellschaft der Wissenschaften zu Göttingen, Philologisch-historische Klasse denen noch so viele gefolgt sind - ein Mandat Alexanders IV. aus dem in Venedig erhaltenen Original als ein Stück Alexanders III. abgedruckt ${ }^{38}$. Das ist ein Anfängerfehler, denn schon Jaffé hatte unter den Zuordnungskriterien hervorgehoben, daß das Pontifikatsjahr in der Datierung dieses Urkundentyps erst unter Clemens III. eingeführt worden ist ${ }^{39}$.

Bereits die frühesten ernsthaften Arbeiten von Kehr und seinen Helfern in den Archiven und Bibliotheken Italiens erwiesen jedoch, daß einige grundlegende Annahmen für das Unternehmen verfehlt waren. Vergegenwärtigen wir uns die Ausgangslage. Kehr glaubte damals, die Gesamtmenge der erhaltenen Papsturkunden - immer bis Anfang 1198 - liege in der zweiten Auflage von Jaffés Regesta ziemlich vollständig erfasst vor. Er sprach 1896 von „über 17900

35 Aufbau und Anforderungen in jener Zeit schildert Alphons Lнотsкy: Geschichte des Instituts für österreichische Geschichtsforschung 1854-1954, Graz/Köln 1954 (MIÖG, Erg.bd. 17), S. 129-134, 150-152. Dort S. 186 f. wird Kehr als außerordentliches Mitglied des Kurses 1883-1885 geführt, er war damals jedoch nur wenige Monate in Wien, s. Schubert: Sickel und Kehr (wie Anm. 33) S. 152-154.

36 1886-1888 arbeitete er knapp zwei Jahre unter Sickel in der Wiener Diplomata-Abteilung, s. ebd. S. $159-161$.

37 Scharf ist die ungezeichnete Anzeige der Aufsätze des Jahres 1897 in: NA 23 (1898) S. 275-277, in der "die schnelle Veröffentlichung dieser einzelnen Reiseberichte“ als „eilfertig" und deshalb als zu fehleranfällig kritisiert wird. Sie stammt von Harry Breßlau, dem damaligen Herausgeber der Zeitschrift, an den sich Kehr denn auch in einer spöttischen Erwiderung direkt gewendet hat: PUU in Italien, Bd. 1 S. 160 Anm. 1.

38 Ebd. S. 25 f. Nr. 5. Kehr hat sich freilich beeilt, den Fehler öffentlich zu korrigieren: als kurze „Berichtigung“ in NGG, phil.-hist. Kl. 1896 am Schluß des Jahrgangs auf einem eigenen Blatt nach S. 356. Auch scheint er das Kollegen mitgeteilt zu haben, s. R(iccardo) Predelli: Notizia intorno a due recenti pubblicazioni, in: NAV 14 (1897) S. 186-194, dort S. 192 mit Anm. 1; diese Besprechung enthält übrigens auch Hinweise auf weitere Stücke, die dem Initiator bei seinem Archivbesuch entgangen waren.

39 Das Vorwort zur ersten Ausgabe der Regesta pontificum Romanorum hat Wilhelm Wattenbach auch der von ihm organisierten zweiten vorangestellt. Dort wird ausdrücklich gewarnt: Wenn in päpstlichen „epistolae“ zwischen 1124 und 1187 eine Jahresangabe auftaucht, „necesse sit, eas aut esse plane simulatas, aut ad alios pertinere papas“; Regesta pontificum Romanorum, 1, Leipzig 1885, S. X. 
Urkunden“, und nach seiner Schätzung mochte sich im Verlaufe der vorgenommenen systematischen Erforschung diese Zahl „gut und gern um ein weiteres Tausend vergrößern “ 40 . So meinte er, das Material sei - abgesehen von Ergänzungen - im Wesentlichen bekannt ${ }^{41}$, so daß seine Aufgabe weitgehend auf das Aufspüren besserer Textüberlieferung beschränkt bleiben könne.

Selbst aus heutiger Sicht scheint das allerdings ein verzeihlicher Irrtum. Immerhin hatte den Papsturkunden - wie ja auch den Königs- und Kaiserurkunden - seit Jahrhunderten ein bevorzugtes Forschungsinteresse gegolten, und um die möglichst vollständige Erfassung der älteren, eben bis 1198, hatte sich schon Jaffé in der 1851 erschienenen ersten Auflage der Regesta bemüht, jedenfalls soweit sie gedruckt waren. Viel zusätzliches Material beigebracht hatte dann die rege Sammeltätigkeit Julius von Pflugk-Harttungs, deren Früchte in den dreibändigen Acta pontificum Romanorum ${ }^{42}$ mit zusammen 1407 Nummern veröffentlicht sind, und eine direkte vorbereitende Leistung für den neuen Jaffé bilden die weiteren Ergänzungen durch Samuel Loewenfeld ${ }^{43}$ mit weiteren 424 Stücken. So dürfte 1896, nur acht Jahre nach dem Datum des zweiten Bandes der überarbeiteten Regesta pontificum Romanorum, wirklich der Eindruck gerechtfertigt gewesen sein, die Zahl der erhaltenen Papsturkunden werde sich nur noch geringfügig vermehren lassen.

Aus der Rückschau hat dieser Irrtum reiche Früchte gebracht, wäre doch ohne Kehrs Fehleinschätzung das Papsturkundenunternehmen wohl nie begründet worden. Nachdem es aber einmal in Gang gekommen war, hat sich während seiner nun hundertzehnjährigen Laufzeit die Menge der bekannten Papsturkunden überraschend ausgeweitet. Kehr selbst hatte anfangs auf einen Zuwachs von vielleicht einem Tausend gesetzt ${ }^{44}$, im Laufe der Zeit seine Erwartungen aber ständig höher schrauben können: auf ,3000 Nummern (nicht eingerechnet die Deperdita) " schätzte er 1906 die Vermehrung, insgesamt 25000 sah er am Ende seines Lebens zusammengekommen ${ }^{45}$.

Seither hat sich die Situation nur noch wenig verändert. Einige Zahlen können immerhin eine ungefähre Vorstellung vermitteln: Jaffé war 1851 in der erste Ausgabe seiner Regesta pontificum Romanorum bis Nummer 10749 gekommen und hatte 422 Fälschungen extra gezählt, also insgesamt 11171 Stücke gesammelt. In der zweibändigen Neuausgabe von 1885-1888 reicht die Numerierung bis 17679, ein Supplementum regestorum bietet zudem 326 mit Buchstaben gekennzeichnete Zusätze, das sind zusammen 18005 Urkunden

40 KeHR: Schriften (wie Anm. *) Bd. 1 S. 7.

41 Vgl. den Rückblick von 1934, zitiert bei Anm. 63.

42 Acta pontificum Romanorum inedita, ed. Julius von Pflugk-Harttung, 3 Bde., Tübingen/Stuttgart 1881-1886.

43 Epistolae pontificum Romanorum ineditae, Leipzig 1885.

44 Siehe Anm. 40.

45 KeHr: Schriften (wie Anm. *) Bd. 1 S. 19 Anm. 1 und Bd. 2 S. 1312. 
oder Erwähnungen von solchen bis Anfang 1198. Wenn man diese Zahl mit den bisherigen Ergebnissen des Papsturkundenunternehmens vergleichen will, sollte man besser auf sein eigentliches Ziel schauen, also die erstrebte Edition, nicht dagegen die bisher insgesamt aufgefundenen und zu Regesten verarbeiteten Urkunden und sonstigen päpstlichen Akte ${ }^{46}$ zugrunde legen; das macht sofort zwei Korrekturen erforderlich. Solche sind allerdings nicht nötig für bei Jaffé vorkommende Dubletten, denn diese sind nur in geringer Menge aufgetaucht ${ }^{47}$, so daß sie vernachlässigt werden dürfen. Aber einmal sind selbstverständlich die erschließbaren Deperdita außer acht zu lassen; man wird wohl nicht allzu sehr fehlgehen, wenn man in grober Schätzung ihren Anteil mit $10 \%$ ansetzt, also die 18000 Nummern um rund 2000 vermindert. Und abgezogen werden müssen zweitens die älteren Papstbriefe in patristischer und kanonistischer Überlieferung, die ja ausgeschlossen bleiben sollten; hierfür läßt sich jedoch nicht ohne weiteres ermitteln, um wieviel die Ausgangszahl bei Jaffé zu vermindern ist. Auf der anderen Seite nimmt Rudolf Hiestand jetzt an, daß sich der Zuwachs neuer Stücke vielleicht auf 9000 belaufen mag ${ }^{48}$. Die Grundlage für diese Schätzung wird nicht dargelegt, doch dürften hierbei die bloßen Erwähnungen nicht berücksichtigt worden sein, wohl dagegen auch Briefe an die Päpste sowie die bei Jaffé prinzipiell fehlenden Urkunden von päpstlichen Legaten und eventuell sogar von delegierten Richtern, deren Aufnahme in die Regesta pontificum Romanorum inzwischen ja zum Standard gehört oder doch gehören sollte ${ }^{49}$. Insgesamt kann man also nur die Größenordnung angeben: Die Vermehrung gegenüber dem Ausgangsbestand liegt für die Papsturkunden bei rund $50 \%$ und sogar erheblich darüber, wenn man die

46 In den Einleitungen der einzelnen Bände von Kehrs Regesta pontificum Romanorum wird das vorgelegte Material regelmäßig zu dem in der zweiten Auflage des Jaffé bereits Vorhandenen in Beziehung gesetzt, doch darf man dabei nicht übersehen, daß die Zahlen nicht ganz kompatibel sind. So wurden 1885-1888 päpstliche Handlungen auf Synoden (s. etwa IP 8 S. 41 Nr. *154, IP 9 S. 31 Nr. *58) berücksichtigt, haben aber keine eigenen Nummern erhalten, wie auch manche andere, nur chronikalisch überlieferte Anweisungen.

47 KeHr: Schriften (wie Anm. *) Bd. 1 S. 25 Anm. 2, nennt 36. Hinzu treten die Dekretalen, die auf ihrem Wege in die späteren Sammlungen in Teile zerlegt worden sind, somit auch in Jaffés Regesta unverbunden nebeneinander stehen können.

48 Hiestand: Göttinger Akademie (wie Anm. 11) S. 333, rechnete in einer 2000 vorgetragenen, 2002 veröffentlichten Skizze insgesamt „mit etwa 25-27000 Urkunden“, erläutert aber nicht, wie genau deren Abgrenzung zu verstehen ist. Ders.: 100 Jahre Papsturkundenwerk (wie Anm. 8) S. 40, gab 24500 bis 25000 als Gesamtzahl an. Damit waren nun die „erfassten Papsturkunden“ sowie die durch Nachlesen noch zu erwartenden Stücke gemeint. Unklar bleibt, ob dadurch der Stand zum Zeitpunkt des Referats (1996) oder bei dessen Publikation (2003) angesprochen war. 1988 oder 1990 hatte er die voraussehbare Menge mit über 27000 beziffert: DERs.: Italia Pontificia (wie Anm. 11) S. 170.

49 Vgl. jedoch Anm. 29. 
ursprünglich beabsichtigte Beschränkung allein - abkürzend gesagt - auf die durch Empfängerüberlieferung erhaltenen Papsturkunden zugrunde legt.

Die zweite irrige Annahme Kehrs betrifft die Menge der Archive und der Handschriftensammlungen, die einschlägiges Material enthalten. Für große Teile Italiens ließ sich eine Art Reiseführer benutzen: die von Kehr mehrfach erwähnten Notizen von Ludwig Bethmann ${ }^{50}$, die teilweise 1847, teilweise erst 1874 - postum - im Archiv der Gesellschaft für ältere deutsche Geschichtskunde erschienen sind. Er war im Land für die verschiedenen Editionsvorhaben der Monumenta Germaniae historica auf Reisen gewesen. Das hatten vor ihm schon in den allerersten Jahren dieser Institution deren Mitarbeiter getan und darüber berichtet ${ }^{51}$, unermüdlich auf der Suche nach brauchbarem Material, und viele andere Gelehrte folgten ihnen nach ${ }^{52}$ - wie ja auch Kehr selbst bereits 1885-1886 neben dem Diplomata-Herausgeber Sickel in Rom arbeitete ${ }^{53}$. Italien übte augenscheinlich schon damals für Historiker mit ihren wissenschaftlichen Interessen denselben unwiderstehlichen Reiz aus wie für die zahllosen deutschen Bildungsbeflissenen auf dem Wege in den Süden ${ }^{54}$. In Erin-

50 Reise durch Deutschland und Italien in den Jahren 1844, 1845, 1846, in: ArchGG 9 (1847) S. 513-658; Dr. Ludwig Bethmann's Nachrichten über die von ihm für die Monumenta Germaniae historica benutzten Sammlungen von Handschriften und Urkunden Italiens, aus dem Jahre 1854, ebd. 12 (1874) S. 201-426, 474-758.

51 Georg Heinrich Pertz: Italiänische Reise vom November 1821 bis August 1823, in: ArchGG 5 Tl. 1 (1824) S. 1-514, auch separat: Hannover 1824; (Friedrich) Bluhme: Vermischte Nachrichten von italiänischen Bibliotheken und Archiven im Sommer 1822 und Bericht über die im Sommer 1823 in Oberitalien ausgeführten Arbeiten, in ArchGG 5 Tl. 2 (1825) S. 575-592, 593-630. Siehe auch DENS. (nun in der Schreibweise Blume): Iter Italicum, 4 Bde., Berlin/Stettin 1824 und Halle 1827-1836, dazu ein Supplementum: DERs.: Bibliotheca librorum manuscriptorum Italica, Göttingen 1834.

52 Im Neuen Archiv der Gesellschaft für ältere deutsche Geschichtskunde begegnen - bis zum Beginn der Reisen des Papsturkundenunternehmens - bedeutende Namen zuhauf als Berichterstatter: Wilhelm Schum: Beiträge zur deutschen Kaiser-Diplomatik in italienischen Archiven im März und April 1874, in: NA 1 (1876) S. 121-157; Dr. H(ermann) Pabst's Reise nach Italien 1869/70, in: NA 2 (1877) S. 29-45; G(eorg) Waitz: Reise nach Italien im Frühjahr 1876, ebd. S. 325-381; Harry Bresslau: Reise nach Italien im Herbst 1876, in: NA 3 (1878) S. 77-138; Paul EwALD: Reise nach Italien im Winter von 1876 auf 1877, ebd. S. 139-181, 319-383; Ed(uard) WINKELMANN: Reisebericht, ebd. S. 627-654, und Bericht über eine Reise nach Italien 1878, in: NA 5 (1880) S. 9-30; O(swald) Holder-Egger: Bericht über eine Reise nach Italien 1885, in: NA 11 (1886) S. 253-288, und Bericht über eine Reise nach Italien im Jahre 1891, in: NA 17 (1892) S. 461-524; H(enry) Simonsfeld: Bericht über einige Reisen nach Italien, in: NA 15 (1890) S. 475-495.

53 Siehe Schubert: Sickel und Kehr (wie Anm. 33) S. 155-158.

54 Dazu s. jetzt Arnold Esch: Auf Archivreise. Die deutschen Mediävisten und Italien in der ersten Hälfte des 19. Jahrhunderts: aus Italien-Briefen von Mitarbeitern der Monumenta Germaniae Historica vor der Gründung des historischen Instituts in Rom, in: Deutsches Ottocento. Die deutsche Wahrnehmung Italiens im Risorgimento, hg.v. 
nerung an seine frühen Jahre hielt Kehr fest, es war „der Traum wohl aller jüngeren deutschen Historiker, die berühmten Bibliotheken und Archive Italiens ... kennenzulernen " 55 . Unter den veröffentlichten Informationen, die für solche Exkursionen Nutzen versprachen, nahm nun Bethmann mit seinem „bis dahin unübertroffenen Reiseführer durch die Archive und Bibliotheken Italiens ${ }^{\text {"56 }}$ bei den damaligen Historikern wohl dadurch eine Sonderstellung ein, daß er auf seinen jeweils mehrjährigen Reisen gewiß die meisten Stationen angesteuert hatte. Nun konnten Kehr und dessen Mitarbeiter seinen Spuren folgen ${ }^{57}$. Direkt einschlägig war ebenfalls Julius von Pflugk-Harttung mit den Angaben in seinem Iter Italicum ${ }^{58}$, hatte der doch bereits gezielt nach Papsturkunden gefahndet und auf der Apenninen-Halbinsel tatsächlich einen guten Teil des Materials für die Acta pontificum Romanorum sammeln können.

So wird gegen Ende des 19. Jahrhunderts der durchaus naheliegende Eindruck geherrscht haben, die interessanten Bestände in Italien seien bereits aufgespürt. Daß dies eine verfehlte Annahme war, daß es in Wirklichkeit noch viel zu entdecken gab, hat Kehr selbst nur wenig später genüßlich hervorgehoben, als er 1901 die Aufgabenstellung des Preußischen historischen Instituts in Rom als ungenügend kritisierte ${ }^{59}$, und 1906 schilderte er beredt seine Erfahrungen: „Es tauchten, sobald ich energisch in die Archive selbst eindrang, mit einem Male ganz neue Fonds auf, von denen ich bis dahin nichts wußte, Archive, deren Existenz bis dahin unbekannt war. ${ }^{660}$ Doch noch weit lückenhafter waren in Deutschland die Kenntnisse über die Urkunden- und Handschriftensammlungen in Frankreich, England, gar in Spanien ${ }^{61}$. Gerade im Rahmen des

Dems./Jens Petersen, Tübingen 2000 (Bibliothek des Deutschen historischen Instituts in Rom 94), S. 187-234, und DENS.: Für die Monumenta in Italien. Briefe Ludwig Bethmanns von einer Archiv- und Bibliotheksreise 1845/46, in: FMASt 36 (2002) S. 517-532.

55 KeHr: Schriften (wie Anm. *) Bd. 1 S. $41 \mathrm{f}$.

56 Ebd. S. 19: eine Bemerkung von 1906, der jedoch auf S. 21 eine ironische Distanzierung folgt mitsamt der Forderung, ,eine völlige Revision des ,Bethmann“" sei notwendig.

57 Gleich im ersten Reisebericht über Papsturkunden in Venedig werden die Informationen von Schum, Breßlau und Winkelmann als hilfreich genannt - nach dem „orientirenden Überblick" Bethmanns: PUU in Italien, Bd. 1 S. 1. Die Ausbeute seines Vorgängers Ferdinand Kaltenbrunner, der 1878 im Venezianer Archiv speziell nach Papsturkunden gesucht hatte, beurteilte Kehr dagegen als „nicht erheblich“.

58 Stuttgart 1883.

59 Das Preußische Historische Institut in Rom, in: Beilage zur Allgemeinen Zeitung (München) 1901 Nr. 9 (11. Jan.) S. 1-4. Der Artikel ist lediglich mit $\pi$ gezeichnet, zur Verfasserschaft s. zuletzt Girgensohn: Schriften Kehrs (wie Anm. 9) S. 611 f. Einen Überblick über die damalige Situation bietet die nachfolgende, nun unter P. Kehr gestellte Artikelserie Das Archivwesen Italiens, ebd. Nr. 172 (30. Juli) S. 1-4, 173 (31. Juli) S. 5-7, 181 (9. Aug.) S. 3-6, 185 (14. Aug.) S. 5-7, 194 (26. Aug.) S. 4-7.

60 KeHr: Schriften (wie Anm. *) Bd. 1 S. 19.

61 Siehe dazu die Bemerkungen aus der Rückschau: ebd. S. 45-47, 49. 
Papsturkundenunternehmens ist auf diesem Felde wahre Pionierarbeit geleistet worden, dagegen war am Anfang die Zerstreuung der Sammelobjekte, die enorme Menge ihrer Aufbewahrungsorte überhaupt nicht abzusehen.

Kehr stellte sich vielmehr ursprünglich vor, die in Angriff genommene Aufgabe würde sich in einem überschaubaren Zeitrahmen erledigen lassen und am Ende könnten 30 Bände mit der Gesamtheit der archivalisch überlieferten Papsturkunden des 8. bis 12. Jahrhunderts vorzuweisen $\operatorname{sein}^{62}$. Er mag selbst zu Wort kommen; 1934, als er der Preußischen Akademie der Wissenschaften „eine Art von Schlußbericht" über das Papsturkundenunternehmen erstattete er hatte ihn im Jahr zuvor bereits dem internationalen Historikerkongreß in Warschau vorgelegt -, gab er zu verstehen: „Ich war von der irrigen Annahme ausgegangen, daß das urkundliche Material im großen und ganzen bereits gesammelt sei und es sich da nur noch um Ergänzungen handeln würde." Vergeblich war die ursprüngliche Erwartung einer schnellen Bewältigung des Vorhabens gewesen: „ein Jahrzehnt und einige Mitarbeiter mochten dazu genügen “63.

Unter diesen Voraussetzungen begab sich Kehr im Jahre 1896 mit tollkühnem Mute - Kolumbus nicht unähnlich - auf ein großes Meer, vor seinen Augen ein hochgespanntes Ziel, doch ohne zureichende Seekarte, nur ausgerüstet mit einem Kompaß, nämlich der Forschungsmethode, die für die Sammlung der Urkunden der deutschen Könige und Kaiser entwickelt worden war, vornehmlich durch Theodor von Sickel, und die er als dessen „Assistent bei den Diplomata" ${ }^{" 64}$ erlernt hatte. Und auch er erreichte schließlich nicht das angestrebte Objekt, die Edition der Papsturkunden, wohl aber ein anderes, indem er die Regesta pontificum Romanorum schuf und in ihrem Rahmen die Italia pontificia.

62 Siehe Anm. 24.

63 KeHR: Schriften 1 (wie Anm. *) S. 41. Eine am Anfang vorausgesehene Zeitspanne von längerer Dauer - „in ein bis zwei Jahrzehnten“ - räumte er 1910 ein (s. Anm. 67). 1898 war er jedoch weit präziser gewesen; im Bericht der Göttinger Gesellschaft vom 3.-5. August (s. Anm. 92) werden - nach den zwei bislang verstrichenen Jahren weitere 15 vorausgesagt, genau spezifiziert: noch zwei für Italien, dann je drei für Deutschland und Frankreich, eins für Spanien, zwei für England, endlich eins für „Belgien, Holland und den Norden, im ganzen also 12-13 Jahre fortgesetzter archivalischer Arbeit", der anschließend die Publikation der Papsturkunden folgen sollte.

64 KeHR: Schriften (wie Anm. *) Bd. 1 S. 19. 


\section{Komplikationen und Auswege}

„Papsturkunden ohne Ende - könnte ich ausrufen.“65 Diesen Stoßseufzer stellte Paul Kehr im Jahre 1905 an den Anfang eines ersten Beitrags mit dem Titel Nachträge zu den Papsturkunden Italiens, der - an der Spitze einer Reihe von insgesamt neun, bis 1925 - unerläßlich wurde dank dem von ihm wiederholt unterstrichenen Erfordernis der wirklich vollständigen Erfassung des Materials. Aber es steht außer Zweifel, daß er schon viel früher so gedacht hat. Die insgesamt 1000 neuen Stücke, die er aufzuspüren erwartet hatte, sie fanden sich bereits beim ersten Durchgang, den Kehr und Mitarbeiter im Sturmlauf durch Italien vollführten. 1896 begann die Arbeit erst gegen Ende der Sommerferien, so daß die Ausbeute dieses Jahres nur 14 publizierte Stücke betrug, den erwähnten Alexander IV. abgezogen, aber es ging rasant weiter: 1897 waren es 33, 1898 bereits 139, 1899 gar 208, und im Jahre 1900 mit 196 Papsturkunden wurde die Marke des halben Tausends übersprungen, allein aus den italienischen Beständen.

Kehr räumte viel später ein, er habe die Hindernisse, auf die sein Vorhaben bei der praktischen Verwirklichung stieß, bei weitem unterschätzt, ,in vielleicht zu starkem Selbstvertrauen" habe er sich an die Aufgabe gemacht - so formulierte er $1924^{66}$. Selbstkritisch hatte er schon 1910 zugegeben: „Auch in unserem Arbeitsprogramm war noch manches unklar und unsicher. ... Wir gingen damals geradeweg auf die Ausgabe selbst los, glaubten mit der von den Vätern ererbten Methode den archivalischen Rohstoff in schnellem Durcheilen Italiens und der andern Länder Europas in ein bis zwei Jahrzehnten zusammenbringen zu können. ${ }^{\text {“67 }}$ Und 1918 bekannte er: „Als ich daran ging, übersah ich zwar die Größe dieses Unternehmens, nicht aber die ihm entgegenstehenden Schwierigkeiten. “68 Schon viel früher, 1903, hatte er geklagt: „Aber auf eine so mühsame und langwierige Arbeit bin ich doch nicht gefaßt gewesen. ${ }^{\text {“69 }}$

In der Tat wurde ihm bereits nach wenigen Jahren die Erkenntnis unabweisbar, daß auch nur für den Beginn der geplanten Textedition ein weitaus längerer Zeitraum des vorbereitenden Sammelns erforderlich sein würde, als je in Rechnung gestellt. Auf der anderen Seite empfand er, „da möglichste Vollständigkeit die erste Forderung ist“, stets die „Notwendigkeit, zuerst die materielle und die kritische Grundlage des ganzen Corpus zu schaffen "“70. Daß die enorme Zerstreuung des massenhaften Stoffes stets nur eine Annäherung an das

65 PUU in Italien, Bd. 5 S. 1. Die folgenden Ausführungen beruhen auf den Reiseberichten, die in den fünf Bänden erneut vorgelegt worden sind.

66 KeHR: Rezension (wie Anm. 21) Sp. 1128.

67 PUU in Italien, Bd. 5 S. 228.

68 KeHR: Antrittsrede, in: SPA 1918 S. 687-692, dort S. 689.

69 PUU in Italien, Bd. 4 S. 163.

70 Äußerungen von 1905 und 1909: ebd. Bd. 5 S. 3, 144 Anm. 1. 
Ideal erlaubt, muß ihm von Jahr zu Jahr deutlicher geworden sein, doch er ließ sich dadurch nicht abschrecken, vielmehr bekannte er unverdrossen 1908, lange nach dem Abschluß der ersten Phase systematischer Erforschung der italienischen Bestände: „schwerlich wird das Material jemals vollständig erschöpft werden, und vereinzelte Findlinge werden immer wieder an den Tag kommen "71. Kehr wurde nicht müde, an die methodischen Voraussetzungen seines Unternehmens zu erinnern, so 1912: „Immer wieder möchte ich betonen, daß das nächste Ziel unsrer Arbeit die möglichste Vollständigkeit in der Sammlung des Materiales ist." Aber in der Wirklichkeit der Archivforschungen hatte sich mehr und mehr eine Gewichtung, die Trennung zwischen Vordringlichem und Nachrangigem als unausweichlich erwiesen, und so fuhr er fort: „Alles andre, Kritik der Dokumente, Rezension der Texte, historische Verwertung ergibt sich dann von selbst." Von dem als richtig erkannten Wege wollte er nicht abweichen, obwohl „ich mit diesem Prinzip die Aussicht gefährde, selbst das geplante Unternehmen zu vollenden "72.

Es mußte dem ehrgeizigen Göttinger Professor darum gehen, in nicht allzu ferner Zukunft eine Art von Leistungsnachweis zu liefern: gegenüber der Gesellschaft der Wissenschaften als verantwortlicher Institution, gegenüber dem preußischen Kultusministerium und privaten Geldgebern, auf deren Förderung er angewiesen war, ja ganz allgemein vor der fachkundigen Öffentlichkeit, die an seinen Plänen regen Anteil nahm. Das bedeutete zweifellos auch Druck. Solchen - und die daraus resultierenden Entlastungsversuche - meint man zwischen den Zeilen zu spüren, wenn in dem Bericht über die Arbeit für die Ausgabe der älteren Papsturkunden, der seit 1897 Jahr für Jahr in den Nachrichten von der Königl. Gesellschaft der Wissenschaften zu Göttingen, Geschäftliche Mit$\mathrm{t}(\mathrm{h})$ eilungen, veröffentlicht wurde ${ }^{73}$, immer wieder die bevorstehende Vollendung wenigstens einer ersten Arbeitsetappe angekündigt wird. So schon 1899: „in nicht zu ferner Zeit die Forschungen in Italien zu allseitigem Abschluß zu bringen“; 1900: „Abschluß im nächsten Jahr“; 1901: „nun fast an das glückliche Ende unserer Arbeiten in Italien gelangt“; 1902: „materiell betrachtet ist in Italien die eigentliche Sammelarbeit in der Hauptsache unserem Programm entsprechend abgeschlossen", doch stehe noch die Durchsicht der päpstlichen Register aus. Deren Ertrag füllte dann in demselben Jahr drei starke Artikel, aber das nächste sah ebenso viele über die Funde in römischen Bibliotheken, und

71 Ebd. S. 61.

72 Ebd. S. 357.

73 Nur der erste ist von Kehr unterzeichnet, die folgenden sind anonym von der Kommission für die Herausgabe der älteren Papsturkunden erstattet, doch wird der eine oder andere im Inhaltsverzeichnis mit dem Namen des Initiators geführt. Die folgenden Zitate: 1899 S. 18, 1900 S. 15, 1901 S. 10, 1902 S. 20. 
darauf folgten noch Nachträge zu den Römischen Berichten, alles zusammen 440 Druckseiten ${ }^{74}$.

$\mathrm{Zu}$ bieten war also dringend Inhaltsreiches und nicht nur Vorläufiges wie die zahllosen Berichte über „Papsturkunden in ...". So erfand Kehr zur Abhilfe ein Zwischenprodukt, ein eigenes Regestenwerk. Das ist nun keine außergewöhnliche Vorstufe für die Edition von Urkunden in größerer Menge: Dieser Weg rationaler Vorbereitung war von Johann Friedrich Böhmer mit den Regesta imperii gewiesen worden. Kehr jedoch hatte von Anfang an aus seiner Geringschätzung gegenüber einem Regestenwerk kein Hehl gemacht. Dieses sei „doch nur ein Notbehelf“, formulierte er programmatisch schon $1896^{75}$.

Trotzdem veranlaßte die Not - „die bittere Not“, wie er zuspitzend formulierte $^{76}$ - nun doch die Einführung eines solchen Vorprodukts, ihn „zwang dieser Gang unserer Arbeiten wie die Fülle unserer Funde, vor die beabsichtigte Gesamtedition ein Zwischenwerk einzuschieben“, so erläuterte er später ${ }^{77}$. „Mit einer gewissen vergnügten Herzlosigkeit ${ }^{\text {"78 }}$ wich Kehr also von seinem Programm ab und ging auf ein näherliegendes Ziel zu. Das war eine Folge der Arbeitsweise, die er während der Sammeltätigkeit schnell entwickelt hatte. Die Änderung bestand darin, daß er sich, wie er 1906 ausführte, „anstatt ausschließlich nach Papsturkunden zu fahnden, zu einer systematischen Durchforschung aller Archive und Bibliotheken ${ }^{79}$ entschloß und die Rekonstruktion der alten zerrissenen Urkundenfonds als unsere nächste Aufgabe auffaßte“. Dadurch habe er "doch auch unsere ursprüngliche Aufgabe, die Sammlung der älteren Papsturkunden, über Erwarten fördern können. Denn eben auf diesem Wege haben wir die große Zahl von neuen Urkunden gefunden, die in solcher Masse gewiß Niemand erwartet hat. Mit dieser Forschungsmethode trat die Bearbeitung des Materials nach den Empfängergruppen durchaus in den Vordergrund." ${ }^{80}$

Er ließ es sich angelegen sein, den Gewinn durch diesen Methodenwechsel herauszustreichen. Damit „wuchs das Unternehmen gleichsam über sich selbst hinaus ..., damit erhob sich die bloße virtuose Sammeltätigkeit zu einer höheren archivalischen Wissenschaft", stellte er rückblickend fest ${ }^{81}$. Die Neuerung kommentierte Kehr 1924, er habe damals „das Unternehmen durch eine Än-

74 PUU in Italien, Bd. 3 S. $367-558$ und Bd. 4 S. 1-161, 163-249.

75 KeHr: Schriften (wie Anm. *) Bd. 1 S. 5 f.

76 Ebd. S. 24.

77 KeHR: Antrittsrede (wie Anm. 68) S. 690.

78 KeHr: Schriften (wie Anm. *) Bd. 1 S. 20.

79 Er fügte bei einer späteren Wiederaufnahme dieser Formulierung hinzu: „und privaten Sammlungen"; ebd. S. 44.

80 Ebd. S. 22 f.

81 KeHR: Antrittsrede (wie Anm. 68) S. 690. 
derung des ursprünglichen Planes sozusagen aus seiner Bahn geworfen " ${ }^{\text {"82. }}$. Dieses harsche Urteil verrät, daß er seine abschätzige Meinung über ein Regestenwerk keineswegs revidiert hatte. In der Selbstanzeige des ersten Bandes der Italia pontificia wiederholte er im Jahre 1906: „Aber Regesten sind und bleiben nun einmal Notbehelfe“; trotzdem konnte er sich der Einsicht von „der dringend notwendigen Neubearbeitung der Papstregesten“ nicht verschließen ${ }^{83}$. Dafür nun ermöglichte die neue Vorgehensweise den Anfang. Eine Briefstelle aus etwa derselben Zeit läßt auf Kehrs innere Einstellung schließen: „Die Kunst des Lebens ist, das Wünschenswerte auf das Mass des Möglichen zurückzuführen, und innerhalb der gegebenen Verhältnisse das Beste zu leisten" - so am 27. November 1905 an Arthur Haseloff, als der Direktor übertriebene Forderungen des Institutsmitarbeiters abwehren zu müssen meinte ${ }^{84}$.

Kehrs Sinneswandel hat spätestens zwei Jahre nach der Vorlage seines ursprünglichen Planes stattgefunden. Als frühestes Zeugnis dafür ist auf einen Brief vom 13. Juni 1898 hingewiesen worden, in dem der Titel Regesta pontificum Romanorum Italica auftaucht ${ }^{85}$. Er steht in einer der Mitteilungen über den Fortgang des Unternehmens, die Kehr - neben den offiziellen Eingaben an den preußischen Minister der geistlichen, Unterrichts- und Medizinalangelegenheiten - häufig persönlich an Ministerialdirektor Friedrich Althoff richtete, den Abteilungsleiter für die wissenschaftlichen Institutionen und seinen wichtigsten Ansprechpartner im Ministerium; noch Jahrzehnte später gedachte er

82 KeHR: Rezension (wie Anm. 21) Sp. 1130.

83 KeHr: Schriften (wie Anm. *) Bd. 1 S. 24, 32, 35. Ganz konsistent sind seine Äußerungen in diesem Punkte nicht, denn ebd. S. 26 machte er geltend, „neben der definitiven Ausgabe der Urkunden selbst“, vorzulegen „natürlich“ in chronologischer Reihung, werde „ein Regestenwerk in der Anlage des alten oder neuen Jaffé schwerlich noch notwendig sein". Nach seiner Vorstellung sollte also bei der Neubearbeitung der Regesten die topographische Anordnung genügen. Den Nutzen einer zeitlich geordneten Gesamtliste, in der auch die erschließbaren Deperdita und die sonstigen Notizen über päpstliche Akte einzureihen wären, hat er offensichtlich gering geachtet, obwohl er doch ebd. S. $32 \mathrm{f}$. tadelnd hervorhob, daß viele dieser Erwähnungen in der Neubearbeitung des Jaffé übergangen worden waren. Für die Kaiser dagegen hielt er chronologische Regestenverzeichnisse für empfehlenswert und sogar für diejenigen Päpste, die „oft ihre Residenz gewechselt" haben (ebd. S. 24). Solchen Äußerungen zum Trotz scheint Kehr zeitweise eine Neubearbeitung selbst vorbereitet zu haben, denn sonst wäre nicht erklärbar, daß er zwischen 1900 und 1902 in Aufsätzen einzelne der erst von ihm veröffentlichten Papsturkunden zitierte, indem er ihnen Jaffé-Nummern, vermehrt um einen Buchstaben, gab, wie sie ihrem Platz in den alten Regesta entsprechen würden; das wird hervorgehoben von Hiestand: 100 Jahre Papsturkundenwerk (wie Anm. 8) S. 27 f.

84 Zitiert von Hubert Houben: Hundert Jahre deutsche Kastellforschung in Süditalien, in: QFIAB 84 (2004) S. 103-136, dort S. 109.

85 Schubert: Kehr in Göttingen (wie Anm. 14) S. 102. 
seiner als „meines unvergeßlichen Gönners“86. 1898 nun ergänzte er aus Göttingen „den beifolgenden Bericht der Commission für die Herausgabe der älteren Papsturkunden ${ }^{\text {} 87}$ durch lange Ausführungen in seiner zierlichen Schrift, deren Zweck es war, „Ihre mächtige Fürsprache im Vornhinein zu erbitten“, denn es ging um eine außerordentliche Bewilligung für das Unternehmen der Gesellschaft der Wissenschaften, diese selbst sei im Begriff, „ein solches Gesuch einzureichen und zu begründen“. Bemüht um Althoffs „Protection“, führte Kehr aus, „daß wir keine Anstrengung gescheut haben, die Arbeiten mit allen Kräften zu beschleunigen. Das überreiche neue Material und die Sicherheit der gewonnenen Ergebnisse gehen weit über unsre kühnsten Hoffnungen hinaus.

Im Interesse der Sache liegt es im höchsten Maasse, auch in diesem und im nächsten Jahre mit dem gleichen Aufgebot von Kräften und Mitteln zu arbeiten. Dann würde es auch möglich sein, nach Ablauf dieser Frist einen ersten Band mit den Regesta pontificum Romanorum Italica zu publiziren, dem dann später ebensolche für Deutschland, Frankreich und Spanien, England folgen sollen." Dafür seien noch mehrere Reisen erforderlich, aber: „So gross diese Aufgaben auch sind, ihre Erfüllung würde dennoch mit den uns zur Verfügung stehenden Kräften möglich sein. Ich selbst opfere jede freie Stunde meiner freien Zeit und alle Ferien dem Unternehmen." Für den in den Archivdienst übertretenden Mitarbeiter Melle Klinkenborg stehe Wilhelm Wiederhold als „ein glücklicher Ersatz“ zur Verfügung, auch sei Luigi Schiaparelli, „eine Arbeitskraft ersten Ranges", zu weiterer Mitarbeit bereit; dieser hatte ja Kehrs Archivarbeit seit der ersten Reise unterstützt ${ }^{88}$.

„Die Kräfte sind also da, aber leider nicht im gleichen Masse die Mittel. Ew. Hochwohlgeboren wollen nicht glauben, daß ich mich eines besondern Verdienstes berühmen möchte, wenn ich zur Erläuterung der Lage bemerke, daß ich nicht allein alle Arbeiten unentgeltlich thue, sondern auch den größten Theil meiner archivalischen Reisen nach Italien aus eigenen Mitteln bestritten habe. Ich thue damit nur, was ich der Wissenschaft schuldig zu sein glaube. Aber leider werde ich allzuoft an die Grenzen meiner persönlichen Mittel erinnert.“ Da die Gesellschaft nicht noch mehr Geld aufbringen könne, „stehen wir jetzt vor der Zwangslage, entweder unsre Unternehmung einzuschränken und die Vollendung um Jahre hinauszuschieben, trotz der Arbeitslust der vorhandenen Mitarbeiter, - oder neue Unterstützung von dem hohen Ministerium zu erbitten." Angestrichen hat der Empfänger den Appell an die nationale Ehre:

86 KeHR: Schriften (wie Anm. *) Bd. 2 S. 1312. Siehe noch Dens.: Friedrich Althoff, in: Internationale Monatsschrift für Wissenschaft, Kunst und Technik 13 (1919) Sp. 1-16.

87 Dabei handelte es sich zweifellos um den Text, der veröffentlicht worden ist in: NGG, Geschäftl. Mitth. 1898 S. 23-26. Zu diesen Jahresberichten s. Anm. 73. Nach Ausweis der in ihnen enthaltenen Zeitangaben sind sie stets etwa im April entstanden.

88 Siehe Anm. 159-161. 
„Und ich darf zum Schlusse wohl sagen, daß es sich um ein Unternehmen handelt, daß, wenn es vollendet sein wird, ein neuer Ruhmestitel des Primats der deutschen Wissenschaft sein wird. ${ }^{\text {" }} 9$

Der avisierte Antrag der Gesellschaft - mit der Bitte um eine „Beihilfe“ von je 2000 Mark für 1898 und 1899 - ist am 9. Juli datiert und vier Tage später mit einer Begleitnotiz des vorsitzenden Sekretärs, des Altphilologen Friedrich Leo, dem Kurator der Göttinger Universität zur Weiterleitung an den Kultusminister zugestellt worden. Nach einem summarischen Hinweis auf die bisher erzielten Erfolge wird betont, es „wäre bei der Masse des Materials ein baldiger Abschluss des ersten Theiles unsrer Aufgabe aus wissenschaftlichem Interesse erwünscht: wir beabsichtigen nach Vollendung der Forschungen in Italien als erste Frucht unsrer Arbeiten zunächst die Papstregesten für Italien zu veröffentlichen und damit die Ergebnisse unsrer italienischen Forschungen der Wissenschaft zugänglich zu machen, ehe wir uns zu den Archiven der übrigen europäischen Länder wenden. Diese erste Aufgabe glauben wir in den nächsten zwei Jahren bewältigen zu können. " Das sei jedoch nur dann möglich, wenn der Fortgang nicht durch Mittelknappheit gehemmt werde. Bedauerlich wäre insbesondere, wenn aus diesem Grunde auf Schiaparelli verzichtet werden müßte, dessen Tüchtigkeit in den höchsten Tönen gerühmt wird: Gewonnen habe man in ihm „einen für die sachlich wie persönlich oft sehr schwierigen archivalischen Forschungen in Italien ganz besonders geeigneten und geschickten Mitarbeiter ..., dessen Herkunft und genaue Kenntniss seiner heimatlichen Verhältnisse uns Archive (zunächst: „Thüren") geöffnet hat, die bislang allen deutschen Forschern verschlossen waren "90.

Darauf antwortete am 30. Juli der Ministerialbeamte (Friedrich) Schmidt, später Schmidt-Ott. Er empfahl einen Antrag mit detaillierter Begründung, so daß dieser auch gegenüber dem Finanzministerium verwendet werden könne ${ }^{91}$. Die Göttinger Gesellschaft reagierte sofort: Am 3. August lag ein dreizehnseitiger Bericht über den bisherigen Verlauf des Papsturkundenunternehmens und die aktuellen Planungen vor ${ }^{92}$; diesen Entwurf leitete der Vorsitzende Leo wegen der Eilbedürftigkeit den Kommissionsmitgliedern ${ }^{93}$ im Umlaufverfahren zu -

89 Berlin, Geheimes Staatsarchiv Preußischer Kulturbesitz, Rep. 92 Nl Althoff B Kehr Nr. 87. Für die Vermittlung des Textes gilt Michèle Schubert mein herzlicher Dank.

90 Göttingen, Archiv der Akademie der Wissenschaften, Scient. 165,2 Bl. 25a-b.

91 Ebd. Bl. 27.

92 Ebd. Bl. 28b; das Vorblatt Leos für den Umlauf ist als Bl. 26 eingeordnet, seine zwei Tage später datierte Begleitnotiz als Bl.28a. Auszüge bietet Brandi (wie Anm. 14) S. 138.

93 Das waren - wie schon von Anfang an, s. NGG, Geschäftl. Mitth. 1898 S. 23 - die Sekretäre der beiden Klassen sowie Ferdinand Frensdorff, Max Lehmann und Kehr als Jüngster. 
einige letzte Korrekturen von der Hand Kehrs ${ }^{94}$ erweisen diesen als Autor; dann ging die Eingabe am 5. des Monats an den Universitätskurator und weiter „an den Herrn Minister der geistlichen pp. Angelegenheiten “. Der Bericht gipfelt in der Bitte um jährlich 8000 Mark, davon die Hälfte für Reisekosten ${ }^{95}$, um die Arbeiten mit möglichster Beschleunigung voranzutreiben. Dieser Betrag sollte für die gesamte Dauer des Unternehmens zugesagt werden, und dafür veranschlagte man „etwa 15 Jahre ununterbrochener Arbeit "96, doch „vorausgesetzt, daß uns die ganze Zeit hindurch hinreichende Kräfte und Mittel zu Gebote stehen". Die hochgespannten Erwartungen wurden allerdings bitter enttäuscht, denn nur 2000 Mark flossen als außerordentliche Mittel ${ }^{97}$, wohl entsprechend dem vorangegangenen Antrag aus dem Juli.

In diesem Zusammenhang interessiert am meisten die Beschreibung des Zwischenprodukts in der August-Eingabe ${ }^{98}$. „Wir beabsichtigen ferner, da die Edition selbst erst nach dem vollkommenen Abschluß der archivalischen Forschungen überhaupt in Angriff genommen werden kann, das nach und nach gesammelte Material zunächst nach den verschiedensten Ländern in kurzen Auszügen chronologisch geordnet mit Angabe der Fundstellen und der Literatur als Regesten ${ }^{98 a}$ zu publizieren. Es würde mithin nach Abschluß der italienischen Arbeiten, also voraussichtlich im Jahre 1901, ein erster Band Regesta pontificum Romanorum Italica publiziert werden, dem einige Jahre später ein zweiter Band: Regesta pontificum Romanorum Germanica mit den Regesten aller für deutsche Kirchen und Empfänger ausgestellten Papsturkunden folgen soll, und so fort für Frankreich, Spanien, England und den Norden." Das wirkt keineswegs so, als habe damals bereits die spätere Ordnung nach den einzelnen Institutionen im Rahmen der kirchlichen Hierarchie festgestanden. Im Bericht wird anschließend eine weitere Bedeutung der Regestenpublikation hervorgehoben, daß nämlich der Deutschland gewidmete Band „eine der notwendigen Voraussetzungen sein wird für die ersehnte Ger-

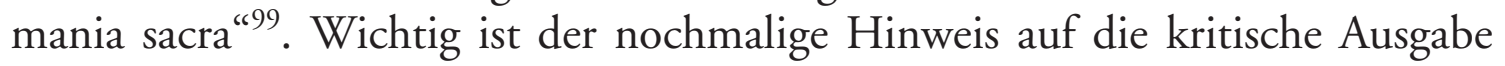
der Papsturkunden als den krönenden Abschluß des Unternehmens.

94 Sie tragen meist den auf die Ränder geschriebenen sprachlichen Einwänden Lehmanns Rechnung. Als letztes Kommissionsmitglied notierte Kehr sein Votum unten auf das Vorblatt des Umlaufs und bemerkte mit der ihm eigenen Ironie: „Ich verkleinere meine Übertreibungen mit Vergnügen und ersetze ... das ,ungeheuer' und ,gewaltig' mit den zutreffenderen Adjectiven."

95 Siehe Anm. 160.

96 Siehe Anm. 63.

97 Nach Brandi (wie Anm. 14) S. 139.

98 Wie Anm. 92.

98a Im Original unterstrichen.

99 Kehr hatte 1896 geschwankt, ob er der Gesellschaft der Wissenschaften zu Göttingen nicht eher eine Germania sacra als großes Unternehmen vorschlagen sollte. Über seine 
Zwei Jahre später, im August 1900, waren die Pläne zu konkreteren Vorstellungen über die Art der Publikation gediehen. Ein Vertrag zwischen der Göttinger Gesellschaft und dem Verlag Weidmann in Berlin hatte die Herausgabe der „Acta pontificum Romanorum von Gregor I. bis Coelestin III.“ zum Gegenstand, davor aber eines „Repertorium bullarum et epistolarum pontificum Romanorum " ${ }^{\text {"100 }}$. Hierbei hat es sich augenscheinlich um das Werk gehandelt, das bald darauf den - sichtlich von Jaffé entlehnten - Titel Regesta pontificum Romanorum erhielt; das zeigt schon die Ähnlichkeit mit einer Formulierung für den Inhalt der „Germania pontificia“ aus dem Jahre $1902^{101}$ und mit dem Untertitel, den die Bände dieser wie schon der Italia pontificia schließlich erhalten haben und bis heute tragen ${ }^{102}$. Auch die Kurzbezeichnungen für die Abteilungen werden etwa gleichzeitig in Gebrauch gekommen sein. Jedenfalls tauchen sie nur wenig später in den veröffentlichten Jahresberichten auf: die Germania pontificia 1901, bereits ausgewiesen als Arbeitsfeld Albert Brackmanns $^{103}$, die Italia pontificia folgte 1902; für sie gab Kehr damals sogar seiner Hoffnung Ausdruck, „daß noch in diesem Jahr mit dem Druck wird begonnen werden können " ${ }^{\text {"104 }}$. Auf ihre Vorbereitung scheint er schon in jener Zeit seine Energie konzentriert zu haben, doch erschienen parallel dazu die Reiseberichte immer noch in rastloser Folge. 1902 im Mai und im November

Vorstellung von deren Verhältnis zur Bearbeitung der Papsturkunden, besonders zur Germania pontificia, s. P. KeHR: Zur Einführung, in: Das Bistum Brandenburg 1, hg.v. Gustav Авв/Gottfried Wentz, Berlin 1929 (Germania sacra, Abt. 1/1/1), S. VII-XVI, dort S. VIIf., gleichzeitig veröffentlicht in den Berliner Sitzungsberichten unter dem Titel Zum ersten Band der neuen Germania sacra, jetzt in: KeHr: Schriften (wie Anm. *) Bd. 1 S. 62 f.

100 Hiestand: 100 Jahre Papsturkundenwerk (wie Anm. 8) S. 27.

101 Bericht für die Wedekindsche Preisstiftung für deutsche Geschichte (gewiß erstattet von Ferdinand Frensdorff), in: NGG, Geschäftl. Mitth. 1902 S. 127; genannt wird „die auf Antrag des Herrn Kehr ins Leben gerufene Germania pontificia: die Herstellung eines geographisch-historischen Repertoriums der Papsturkunden bis 1198, die an deutsche Empfänger gerichtet sind“.

102 Siehe Anm. 4. Erst für die Gallia pontificia ist von dieser Gepflogenheit abgewichen worden, vgl. Anm. 1.

103 NGG, Geschäftl. Mitth. 1901 S. 10. Er wird als Lehrer in Berlin vorgestellt. Vorher hatte er unter Kehr an der Ausgabe des Liber pontificalis gearbeitet, s. Harry BressLau: Geschichte der Monumenta Germaniae historica, Hannover 1921 (NA 42), S. 654. Brandi (wie Anm. 14) S. 140 zitiert - wohl aus einem Brief - Kehrs Mitteilung, er habe „ihm, dem reifsten und fähigsten meiner bisherigen Gehilfen, mit vollem Vertrauen die selbständige Bearbeitung des deutschen Materials anvertraut".

104 NGG, Geschäftl. Mitth. 1902 S. 20: „Daneben sind natürlich an mehr als einem Orte Italiens noch genauere Nachforschungen erforderlich. Was hier noch zu geschehen hat, das wird sich aber erst bestimmter feststellen lassen bei der Arbeit für das Manuscript der Italia pontificia“, die Kehr bereits begonnen hatte. „Ich arbeite jetzt gerade an der Italia pontificia“, heißt es in einem der Reiseberichte, der am 28. Juni 1902 vorgelegt worden ist: PUU in Italien, Bd. 3 S. 382. 
klagte er in Briefen an Johannes Haller, daß die Studien zu den Papsturkunden „nur sehr langsam vorwärts" kamen; und „dies Rom ist nicht zu erschöpfen “105.

Aus der Sicht des Jahres 1924 urteilte Kehr über die neue Ausrichtung, also die Kombination einer „urkundlichen Quellenkunde“, wie gleich noch auszuführen ist, und die provisorische Vorlage der gesamten päpstlichen Schreiben in Regestenform bei topographischer Anordnung: „Diese Aufgabe trat so sehr in den Vordergrund, daß sich das Ziel beinahe verschob. "106 Bereits 1903 hatte er öffentlich von seinen Plänen berichtet, das italienische Material in drei Teilen vorzulegen, zuerst „Roma et Italia media“, dann „Italia superior“ - der damit betraute Wilhelm Wendland „hofft sein Manuscript im nächsten Jahre druck-

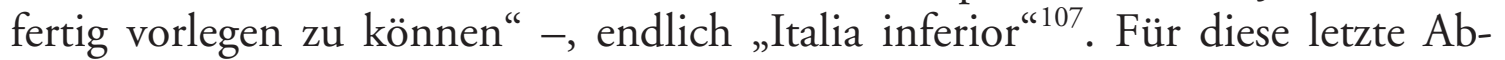
teilung wurde damals Erich Caspar mit dem ministeriellen Stipendium eingestellt ${ }^{108}$. Er arbeitete in Berlin, erst später auch in Italien ${ }^{109}$, und stellte den vorläufigen Entwurf für ein Manuskript her ${ }^{110} .1905$ zeigte Kehr sich wiederum zuversichtlich, es werde "noch in diesem Jahr" mit der Drucklegung des ersten Bandes der Italia pontificia „sicher begonnen werden“, und zwar „zugleich mit dem Material für Süditalien "111. Aus dieser Absicht ist freilich nichts geworden, doch sind aus Caspars damaligem Manuskript im Laufe der Jahrzehnte tatsächlich die Formulierungen entstanden, die man in den Bänden acht bis zehn nachlesen kann.

105 Zitiert von Schubert: Kehr in Göttingen (wie Anm. 14) S. 123 . Noch 1906 nennt der Jahresbericht - gewiß in Kehrs eigenen Worten - „das unerschöpfliche Rom und Mittelitalien“: NGG, Geschäftl. Mitt. 1906 S. 16. Vgl. die Äußerung von 1908 bei Anm. 71.

106 KeHR: Rezension (wie Anm. 21) Sp. 1131.

107 NGG, Geschäftl. Mitth. 1903 S. 19.

108 Ebd. und 1904 S. 13.

109 Seit Januar 1905: ebd. 1905 S. 7.

110 Vgl. Dieter Girgensohn: Miscellanea Italiae pontificia 1, in: NAG, phil.-hist. Kl. 1974 S. $127-196$, dort S. $137 \mathrm{f}$.

111 NGG, Geschäftl. Mitt. 1905 S. 7. In den Berichten von 1906 (S. 17), 1907 (S. 16) und 1908 (S. 13) wird der Druckbeginn von Caspars Band „bald“, dann „nicht so bald, als wir wünschten“, endlich ,in nicht zu ferner Zeit“ in Aussicht gestellt. 1909 (S. 21) endlich heißt es kühl: „Am 1. April 1908 schied Privatdozent Dr. E. Caspar in Berlin aus, nachdem er mehrere Jahre lang seine Kräfte der Bearbeitung des süditalienischen Materials gewidmet hatte." Caspars Nachfolger als Stipendiat, so wird weiter ausgeführt, beschäftige sich mit Mittel- und Norditalien, nun in Göttingen. Der Süden taucht dagegen in den Berichten bis zum Kriegsausbruch nicht mehr auf. 


\section{Wissenschaftliche Früchte}

Nun unterscheiden sich Kehrs Regesta pontificum Romanorum grundsätzlich von den bis dahin entwickelten Regestenwerken. Er charakterisierte sie als „ein Novum, das vielleicht bei der diplomatischen Orthodoxie einiges Kopfschütteln erregen wird" "112. Für die topographische Gliederung war ihm das Corpus inscriptionum Latinarum zum Vorbild geworden. Die hierin „angewandte Methode der Sammlung und Herbeischaffung des Inschriftenmaterials" habe ihn empfinden lassen, „daß wir Historiker diesen Philologen gegenüber Pfuscher und Stümper sind“; dort herrsche „Ordnung, Präzision, Sauberkeit; die Arbeit ruht auf sichern Fundamenten "113. Für den Inhalt stand hingegen, wie Kehr später betonte, der Gesichtspunkt im Vordergrund, „daß der geplanten Edition eine urkundliche Quellenkunde vorausgehen müsse"114. An anderer Stelle präzisierte er: „eine urkundliche Quellenkunde auf breitester Grundlage“, und zwar für ganz Europa und thematisch nicht etwa beschränkt auf die Papsturkunden, vielmehr habe er ,alles herangezogen was mir erreichbar war, um allen denen, die sich mit der urkundlichen Ueberlieferung eines einzelnen Empfängers beschäftigen, den archivalischen Stoff möglichst geordnet und übersichtlich darzubieten "115. Es galt, „die alten zerrissenen Urkundenfonds, wenn auch nur idealiter, wiederherzustellen "116. Nachträglich rechtfertigte Kehr das neu eingeführte Vorausprodukt mit dem „Gewinn, den sowohl die Kirchengeschichte wie die Lokalgeschichte von diesem Versuche einer Rekonstruktion der urkundlichen Überlieferung davongetragen hat und je länger je mehr davontragen wird“, vor allem für „die Feststellung der geschichtlichen und rechtlichen Beziehungen der einzelnen Kircheninstitute zu Rom und zur Kurie “117.

Davon ist nun zu handeln: von der Neuartigkeit dieser Publikation und ihrem Nutzen für die Geschichtsforschung ${ }^{118}$. In der Italia pontificia ist von Anfang an, wie schon bemerkt, mehr Material berücksichtigt worden, als für die eigentliche Ausgabe der Papsturkunden vorgesehen war. Gefallen ist die the-

112 KeHr: Schriften (wie Anm. *) Bd. 1 S. 24.

113 PUU in Italien, Bd. 5 S. 228.

114 KeHR: Rezension (wie Anm. 21) Sp. 1131.

115 KeHr: Schriften (wie Anm. *) Bd. 1 S. 22, 29 f.; teilweise wiederholt 1934: ebd. S. 44, dort charakterisiert als ,eine neue ebenso umfassende wie schwierige konstruktive Aufgabe“, die „sich zwischen unsern primitiven Plan und dessen letztes Ziel“ geschoben habe.

116 Ebd. S. 44.

117 KeHR: Rezension (wie Anm. 21) Sp. 1131, 1132.

118 Bemerkungen - aus der Sicht eines Insiders - über den erzielten Ertrag sind formuliert worden von Hiestand: Italia Pontificia (wie Anm. 11) S. 184 f., 187, und Dems., Die unvollendete Italia Pontificia (wie Anm. 10) S. 49-52, 56 f. Gestattet sei ferner der Hinweis auf eine eigene Skizze, veröffentlicht zum Erscheinen von IP 10: Girgensohn: Miscellanea 1 (wie Anm. 110) S. 131-137. 
matische Einschränkung, die de facto auch eine zeitliche bedeutet hatte, vielmehr werden mit erklärter Absicht sämtliche Schreiben und sonstigen Verlautbarungen der Päpste in Regestenform vorgestellt, dabei auch Akte berücksichtigt, die wahrscheinlich nie einen förmlichen urkundlichen Niederschlag gefunden haben ${ }^{119}$. Zu Beginn, in den ersten Bänden, geschah das freilich noch nicht mit der Vollständigkeit ${ }^{120}$, die inzwischen zum Standard geworden ist. So sind viele Notizen über die Weihe einzelner Kirchen durch die Päpste nicht aufgenommen worden, etwa Inschriften, und das bedeutet gerade für den Anfangsband mit Rom eine empfindliche Minderung. Kehr selbst erwähnt in seiner Selbstanzeige, daß der den Kardinälen gewidmete Abschnitt sehr gut auch die Rechtstexte zur Regelung der Papstwahl hätte bieten können, aber aufgenommen hat er sie nicht - wohl aus Gründen der Arbeitsökonomie, ermangelte es ihm doch am sicheren Umgang mit kanonistischer Überlieferung; vielmehr beabsichtigte er ihre Behandlung ,in einem späteren Heft, das die allgemeinen Dekrete der Päpste enthalten soll“121. Dafür scheint es freilich nie eine konkrete Planung gegeben zu haben. Erst seit dem vierten Bande der Italia pontificia weitete sich der Blick auch zu den wichtigsten Helfern der Päpste bei deren Kontakten mit den lokalen Kirchen, indem zusätzlich die Urkunden von Kardinallegaten, missi und nuntii eingefügt worden sind ${ }^{122}$.

Das methodisch maßgebliche Stichwort für das neue Produkt ist, wie gesagt, die „Rekonstruktion der urkundlichen Überlieferung "123. Als einen grundlegenden Wegweiser zu den einschlägigen Archivalien rühmte Kehr die Italia pontificia in seinem Vorwort zu Band 1: „ut novum idque salutiferum fundamentum huiuscemodi studiis poneremus " ${ }^{\text {"124 }}$. Diese Rekonstruktion richtet sich auf jede einzelne kirchliche Institution sowie auf Herrscher, weltliche Gemeinwesen und sogar Einzelpersonen, soweit sich für sie Nachrichten über Beziehungen zu den Päpsten vor 1198 erhalten haben. Das galt zunächst für Italien, doch war die Ausweitung auf die gesamte Christenheit von vornherein

119 Sogar Aufenthalte der Päpste an bestimmten Orten bieten die neuesten Bände der Germania und die Gallia pontificia - die allerdings romferne Regionen zum Gegenstand haben - in eigenen Regesten, ebenso die Kontakte einzelner Kirchenmänner zu ihnen, etwa den Besuch päpstlicher Konzilien durch die Bischöfe. Solche Notizen sollen selbstverständlich nicht fehlen, doch hat früher dafür der bloße Hinweis in einer Anmerkung genügt. Sie nun mit der gleichen Ausführlichkeit wie die erhaltenen Urkunden oder die Notizen über verlorene zu behandeln und extra zu numerieren, erscheint denn doch als verzichtbarer Aufwand.

120 Siehe Anm. 29.

121 KeHR: Schriften (wie Anm. *) Bd. 1 S. 28.

122 Dagegen sind die Urteile und sonstigen Prozeßakte delegierter päpstlicher Richter wohl nur im Ausnahmefall berücksichtigt worden, jedenfalls soweit es sich nicht um solche von Kardinälen handelt.

123 Siehe Anm. 117.

124 IP 1 S. VI. 
konsequent. Für den Bereich der westlichen Kirche - und eventuell künftig auch für die Kreuzfahrerstaaten - werden die aufgefundenen Papsturkunden in das hierarchische Schema eingeordnet, die Empfänger gegliedert nach Kirchenprovinzen und Diözesen.

Die für diesen Ansatz speziell erforderliche Untersuchung des Materials bedeutet eine enorme Verschärfung des forschenden Blickes. Daran hat Kehr sicherlich gedacht, als er im Jahre 1910 über die Italia pontificia feststellte: „die ich wissenschaftlich für weit wichtiger und bedeutender ansehe als die kritische Ausgabe der Papsturkunden selbst“, die freilich nicht vernachlässigt werden dürfe ${ }^{125}$. Später hob er hervor, sein ursprüngliches Unternehmen sei auf diese Weise „gleichsam über sich selbst hinaus" gewachsen, durch den Methodenwechsel „wollte ich dem Ziele möglichster Vollständigkeit nahekommen “126.

Der Historiker, der sich mit dem Papsttum beschäftigt, läuft stets Gefahr, über den großen Ereignissen der Kirchengeschichte - etwa den Kämpfen zwischen Papst und Kaiser oder den inneren Auseinandersetzungen an der Kurie oder gar den Wirrnissen eines Papstschismas - die Funktion des Kirchenoberhauptes als Lenker der einzelnen Glieder, seine Beziehungen zu den lokalen Institutionen und damit zum größten Teil der Menschen aus dem Auge zu verlieren. Daß Kehr diesem Manko abhelfen wollte, betonte er schon in der ersten öffentlichen Vorstellung seines Planes, als er unterstrich, jede einzelne Urkunde biete einen „Beitrag zur Geschichte des Ausstellers, zur Geschichte des Empfängers, zur Geschichte endlich des Rechtsverhältnisses, dem sie gilt ${ }^{\text {“127 }}$. Seine Regesta pontificum Romanorum bilden die folgerichtige Ausformung dieses methodischen Ansatzes, aber in weit intensiverer Weise, als am Anfang geplant, wie bereits erwähnt worden ist. Einige Erläuterungen sollen diesem Aspekt nun Farbe und Tiefenschärfe verleihen.

Kehrs Grundgedanke zielte nicht allein auf das mechanische Sammeln von Originalen und Abschriften, sondern schon bald nach den ersten, noch tastenden Anfängen - 1910 bemerkte er selbstkritisch, es „lassen unsre ersten Reiseberichte doch sehr zu wünschen übrig" “128 - war er stets bestrebt, die Überlieferung einer Empfänger-Institution so vollständig wie nur möglich zu erfassen, also deren Archiv aufzufinden, soweit noch beieinander, oder aber die

125 PUU in Italien, Bd. 5 S. 228.

126 KEHR: Antrittsrede (wie Anm. 68) S. 690.

127 KeHR: Schriften (wie Anm. *) Bd. 1 S. 16.

128 PUU in Italien, Bd. 5 S. 229. Im Bericht der Kommission aus demselben Jahre (NGG, Geschäftl. Mitt. 1910 S. 21) wird zur Begründung weiterer Nacharbeit und Reisen konkret für die Emilia - ausgeführt: „Allerdings sind für dieses Gebiet wie überhaupt für Oberitalien unsere Sammlungen noch nicht überall vollständig. Jene Archive sind die ersten gewesen, welche unsere Mitarbeiter besuchten; sowohl ihre Praxis wie auch ihre Autorität war damals noch nicht derart, daß ihnen alle Archive und alle Fonds, so wie das heute möglich ist, zugänglich gewesen wären." 
verstreuten Teile ideell zusammenzuführen und dabei die versprengten Trümmer nicht zu vergessen. Diese Ergebnisse nun faßte er mit dem Begriff der „urkundlichen Quellenkunde“ zusammen. Seine Aufmerksamkeit galt nicht allein den erhaltenen Papsturkunden, sondern auch dem sonst überlieferten Material des betreffenden Empfängers. Dessen Kenntnis - das liegt auf der Hand - liefert zugleich einen wichtigen Beitrag zur Beantwortung der grundlegenden Frage der Diplomatik, ob denn eine gegebene Urkunde echt oder unecht oder verfälscht sei.

Bis heute hat die dafür entwickelte Methode nichts von ihrer Gültigkeit verloren: Man schaut zuerst nach den formalen Kriterien, die am einfachsten selbstverständlich bei einem Original zu bewerten sind, die aber auch bei kopialer Überlieferung ein erstes Urteil erlauben, und stellt fest, ob die Gepflogenheiten der ausstellenden Kanzlei zum betreffenden Zeitpunkt anzutreffen sind oder nicht. Doch danach kommt der Vergleich mit den Verhältnissen vor Ort, etwa mit den Informationen über die Rechtsbeziehungen des Empfängers oder über seine Besitzungen. Diese nun lassen sich vor allem aus dem Material erschließen, das im Archiv die jeweilige Papsturkunde umgibt. Hinzutreten muß die gründliche Durchsicht der lokalen Spezialliteratur mit einem doppelten möglichen Nutzen: Sie kann die Spur zur Papsturkundenüberlieferung an entlegener Stelle enthalten, etwa in einem Privatarchiv, und es mögen sich in ihr noch Hinweise auf anderswo nicht erwähnte Deperdita oder einfach auf päpstliche Akte finden. Walther Holtzmann pflegte zu erläutern, durch das Vorgehen nach der Methode von Kehrs Regesta erhalte die Urkundenkritik ein methodisches Schema mit zwei Koordinaten: der allgemeinen, entsprechend den Erkenntnissen der Papsturkundenlehre, und eben der lokalen, der Vertrautheit mit den örtlichen Gegebenheiten. Durch diese Kombination gewinnt die Untersuchung des Diplomatikers eine erhöhte Sicherheit.

Kehr kam im Verlaufe seiner Bemühungen offenbar bald zur Einsicht, er dürfe bei der „reinen Diplomatik“, so wie er sie erlernt hatte, nicht stehenbleiben. Schon 1906 ließ er erkennen, daß er, der als „reinster Diplomatiker“ an sein Unternehmen herangegangen war, sich inzwischen weiterentwickelt habe ${ }^{129}$. Nicht mehr nur die Urkunden standen im Mittelpunkt seines Interesses, sondern ebenso der Kontext ihrer Entstehung unter formalen wie inhaltlichen Gesichtspunkten. Dieser Blick auf die Institutionen und zugleich auf die Entwicklung ihrer gegenseitigen Beziehungen ist aber die genuine Aufgabe des Historikers. Kehr selbst hat wiederholt das Verhältnis zwischen den Päpsten und einzelnen Staaten zum Gegenstand eindringender Studien gemacht, indem er diesen Aspekt „an der Hand der Urkunden“ analysierte ${ }^{130}$ - so nannte er die von

129 Kehr: Schriften (wie Anm. *) Bd. 1 S. 18, 31 Anm. 2. Vgl. Girgensohn: Schriften Kehrs (wie Anm. 9) S. 603.

130 KeHR: Schriften (wie Anm. *) Bd. 1 S. 51. 
ihm bevorzugte Methode historischer Darstellung, konkret mit Hinweis auf seinen buchstarken Aufsatz über die Kontakte der Päpste zur Republik Vene$\operatorname{dig}^{131}$. In ähnlicher Weise hat er sich mit den Normannen Süditaliens, mit dem katalanischen Prinzipat, mit den Königreichen Aragón und Navarra in deren Beziehungen zum Papsttum beschäftigt ${ }^{132}$, um nur wenige Publikationen zu nennen. Und er hat viele seiner Mitarbeiter zu entsprechenden Studien angeregt oder sie doch gewähren lassen ${ }^{133}$. So konnte Urkundenforschung vom Ausgangspunkt der lokalen Überlieferung zu Untersuchungen von allgemeinhistorischem Belang geführt werden.

Das Zwischenprodukt bringt Nutzen nicht nur für die Diplomatik, nicht nur für die Erforschung der Beziehungen zwischen den Päpsten und den Staaten oder einzelnen kirchlichen Institutionen, sondern auch für die lokale Geschichte ganz allgemein, zumal für die Kirchengeschichte. Nirgendwo sonst als in den Bänden der Regesta pontificum Romanorum gibt es eine derartige Fülle von Skizzen über die Entwicklung einer Kirchenprovinz, eines Bistums, eines Klosters. Im quellenarmen Unteritalien, vor allem in Teilen Kampaniens, in der Basilicata und in Kalabrien, war oft wahre Pionierarbeit zu leisten, um wenigstens rudimentäre Bischofslisten darzubieten, denn solche fehlten weitgehend für die dortigen zahllosen kleinen Bistümer. Was sich aus den verstreuten Notizen zusammenstellen ließ, steht nun in den Einleitungen zu den einzelnen Institutionen (wenn nicht besser in Anmerkungen zu passenden Regesten). Auf die historische Skizze folgen die Angaben über die Schicksale des jeweiligen Archivs. Noch einer weiteren Mühe ist zu gedenken: der Bibliographie am Anfang der Abschnitte. Unbestritten bleibt, daß solche Sammlungen von Titeln am schnellsten veralten. Aber der Mediävist hat längst gelernt, daß neuere Literatur in so vielen Fällen die alten Darstellungen, vor allem die alten Quellenausgaben, keineswegs ersetzt, und somit sind Kehrs Regesta zu einem guten bibliographischen Hilfsmittel geworden, weil sorgfältig erarbeitet und breit gefächert. Deshalb wäre es in meinen Augen höchst wünschbar, wenn der Abschlußband der Italia pontificia - neben den unabdingbaren Ergänzungen in Form zusätzlicher Regesten und weiterer Hinweise auf die archivalische Überlieferung - auch Nachträge zu den bibliographischen Verzeichnissen enthalten würde; wenigstens die Arbeiten mit Angaben zu den Papsturkunden und den Archiven der Empfänger von solchen sollten nicht fehlen. Durchgesehen werden

131 Paul Fridolin KeHR: Rom und Venedig bis ins XII. Jahrhundert (zuerst 1927), in: DERs.: Schriften (wie Anm. *) Bd. 1 S. 411-590.

132 Ebd. Bd. 1 S. 591-641 und Bd. 2 S. 853-942, 1003-1030, 1031-1087.

133 Stolz zählte Kehr 1934 nicht weniger als 72 „Vorarbeiten und kritische Untersuchungen“ zum Papsturkundenunternehmen aus eigener und fremder Feder auf: ebd. Bd. 1 S. $52-$ 57. Siehe noch Rudolf Hiestand: Anhang, in: Hundert Jahre Papsturkundenforschung (wie Anm. 8) S. 398 f., speziell zur Germania und zur Gallia pontificia. 
muß die lokale Literatur ja ohnehin, will man wenigstens die veröffentlichten Informationen über mögliche Ergänzungen nicht übersehen.

Der Erfinder der Italia pontificia ist mit seiner Zufriedenheit über das Werk nicht allein geblieben, auch bei der Kritik ist es auf wohlwollende Worte bis Bewunderung gestoßen. Theodor von Sickel, dessen Verhältnis zu Kehr in seinen letzten Jahren stark abgekühlt war, stellte zur Italia pontificia fest, es handele sich um „eine Leistung die gewiss Anerkennung verdient ${ }^{\text {“134 }}$. Überschwenglich fiel das Urteil des Jesuiten Robert von Nostitz-Rieneck ${ }^{135}$ in einer Rezension der ersten Stunde aus: „Dem Urkundenwerk einen topographischen Grundriß zu geben ..., war ein Meistergriff des Herausgebers." Selbst Karl Uhlirz $^{136}$, der Kritik äußerte gegen die Aufblähung eines „Empfängerregisters“, wie man es im Jaffé vermißte, „zu einem selbständigen Werke“ und der einzelne Fehler in der topographischen Anordnung bemängelte, konnte nicht umhin anzuerkennen, daß „die Archiv- und Überlieferungsgeschichte“ bleibende Bedeutung besitze, und maß diesen Absätzen „den größten Wert“ zu. In späteren Würdigungen von Kehrs Lebenswerk rühmte Karl Brandi an dieser „urkundlichen Quellenkunde" die Nähe des Diplomatikers zum eigentlichen historischen Stoff ${ }^{137}$, für Friedrich Baethgen ${ }^{138}$ war das Werk ,vielleicht der entscheidendste Anstoß, den Kehr der mittelalterlichen Geschichtsforschung überhaupt gegeben hat", und Walter Goetz ${ }^{139}$ sah darin "das höchste Ziel an Vollständigkeit und Genauigkeit, an kritischer Schärfe und technischer Vollkommenheit erreicht", für Italien sei hierdurch „die endgültige Grundlage für alle urkundliche Forschung über das Papsttum bis zum Ende des 12. Jahrhunderts geschaffen".

$\mathrm{Da}$ die seit Jahrzehnten beabsichtigte Abrundung der Italia pontificia nicht nur für das ausstehende Regnum Italiae ${ }^{140}$, sondern auch für die Ergänzungen zu den inzwischen hundert bis dreißig Jahre alten Bänden, zur Einbeziehung der seither veröffentlichten oder sonstwie aufgetauchten Papsturkunden für italienische Empfänger notwendig, aber auch sinnvoll ist, scheint mir am stärksten durch den Umstand begründet, daß Kehrs Regesta pontificum Romanorum sich ja längst zu mehr ausgewachsen haben als nur zu dem „Zwischenwerk“, wie

134 Brief vom 21. Februar 1906, gedruckt von Walther Holtzmann: La corrispondenza fra Theodor von Sickel ed Oreste Tommasini, in: ASRSP $79=$ Ser. 3,10 (1956) S. 89-143, dort S. 141 Nr. 66.

135 Wie Anm. 29, dort S. 120.

136 Rezension von IP 1-2 in: HZ 102 (1909) S. 114-119, dort S. 118.

137 Brandi (wie Anm. 14) S. 142.

138 Paul Kehr 1860-1944 (zuerst 1950-1951), in: DERs.: Mediaevalia. Aufsätze, Nachrufe, Besprechungen, Stuttgart 1960 (MGH Schr. 17) Bd. 2 S. 501-504, dort S. 502.

139 Paul Kehr, in: DERs.: Historiker in meiner Zeit, Köln/Graz 1957, S. 318-325, dort S. 320.

140 Dazu s. Hiestand: Die unvollendete Italia Pontificia (wie Anm. 10) S. 55 f. 
er es 1918 nannte $^{141}$. Das läßt sich am besten für die Italia pontificia ausführen, liegt doch in deren Bänden 1-10 das regionale Panorama schon vollständig vor, aber selbstverständlich könnte man für eine ähnliche Darlegung auch die inzwischen fast ebenso umfangreiche Germania pontificia heranziehen. Blickt man nun auf die Apenninen-Halbinsel mitsamt den Inseln als Ganzes ${ }^{142}$, das heißt: auf den gesamten italienischen Sprachraum, unbeschadet seiner vielen Dialekte, wird man feststellen, daß dieses Teilwerk eine komplette kirchliche Topographie bietet, nur mit Ausnahme von Trient ${ }^{143}$, was wegen der politischen Geographie bis zum Ersten Weltkrieg gewiß unvermeidlich war. Die kirchliche Hierarchie $^{144}$ - Metropolen, deren Suffragane, romunmittelbare Bistümer, Klöster im jeweiligen Diözesangebiet, gleichgültig, ob exemt oder nicht - wird nach dem Stande des ausgehenden 12. Jahrhunderts beschrieben, so wie sie sich in den Verzeichnissen des Albinus und des Kämmerers Centius ${ }^{145}$ widerspiegelt, zusätzlich werden die damals nicht mehr existierenden Bistümer innerhalb der späteren Diözesen behandelt, ferner sind sonstige Veränderungen und ebenfalls die weitere institutionelle Entwicklung in den historischen Einleitungen zu den einzelnen Abschnitten skizziert. Eine derart vollständige Übersicht hatte es seit der Italia sacra von Ferdinando Ughelli ${ }^{146}$ aus dem 17. und in bearbeiteter Auflage aus dem 18. Jahrhundert oder den Chiese d'Italia von Giuseppe Cappelletti ${ }^{147}$ aus dem 19. nicht mehr gegeben - und diese Werke sind längst vor dem großen Aufschwung der kritischen Geschichtsforschung entstanden. „So wurde denn die Italia pontificia ... zugleich zur Grundlegung einer Italia sacra im Sinne einer kirchlichen Geographie und Quellenkunde Italiens im Mittelalter", wie Brandi rühmte. ${ }^{148}$

141 Siehe Anm. 77.

142 Hiestand: Die unvollendete Italia Pontificia (wie Anm. 10) S. 49, erläutert im einzelnen das Verhältnis der behandelten Territorien zu den heutigen politischen Grenzen. Ein Irrtum ist jedoch die dortige Angabe, das Bistum Trient hätte im Mittelalter zur Kirchenprovinz Salzburg gehört: Es war ein Suffragan des Patriarchats Aquileia bis zu dessen Aufhebung im Jahre 1751.

143 Siehe GP 1 S. 398-409: als Appendix II nach der Kirchenprovinz Salzburg.

144 Zur Feingliederung s. Anm. 3.

145 Siehe Le Liber censuum de l'Église romaine, hg.v. Paul Fabre/L(ouis) Duchesne/ G(uillaume) Mollat, 3 Bde., Paris 1905-1952 (Bibliothèque des Écoles françaises d'Athènes et de Rome, Ser. 2,6).

146 Italia sacra sive de episcopis Italiae et insularum adiacentium rebusque ab iis praeclare gestis, deducta serie ad nostram usque aetatem, opus singulare provinciis XX distinctum, in quo ecclesiarum origines, urbium conditiones, principum donationes, recondita monumenta in lucem proferuntur, 9 Bde., Rom 1644-1662; 10 Bde., Venedig ${ }^{2} 1717$ 1722; davon Neudrucke: Nendeln 1970 sowie Bologna 1972-1974 u. ö.

147 Le Chiese d'Italia dalla loro origine sino ai giorni nostri, 21 Bde., Venedig 1844-1870.

148 Brandi (wie Anm. 14) S. 141. 
Nicht nur die Gesamtschau ist hervorzuheben, auch die Einzelheiten bieten Gewinn für den Historiker. Und so seien zum Schluß dieses Versuchs einer Würdigung einige Bemerkungen aus der Perspektive des Benutzers gestattet. Meine Erfahrungen mit Kehrs Regesta pontificum Romanorum sind am intensivsten durch die Italia pontificia geprägt worden, das gilt keineswegs nur für die zuletzt erschienenen beiden Bände, an deren Vollendung oder Ausarbeitung ich selbst beteiligt war. Auch als meine Forschungen längst nicht mehr dem hohen Mittelalter galten, habe ich die Bücher oft und oft in die Hand genommen: einmal zur Orientierung über die - so häufig versprengte - archivalische Überlieferung für eine gegebene kirchliche Institution, aber weit häufiger auf der Suche nach lokaler Literatur, wie vorhin erwähnt, oder nach einem versteckten Kloster fahndend.

Nun ersetzt das Werk gewiß nicht das immer noch fehlende Monasticon Italicum $^{149}$, selbst wenn man gemäß italienischem Sprachgebrauch den Blick auf die monaci der alten Orden beschränkt und die frati der neuen mit ihren Konventen außer Betracht läß ${ }^{150}$. Zwar wird in der Italia pontificia - über den Kreis der Empfänger von Urkunden oder sonstigen Gunsterweisen der Päpste hinaus - wohl keine der Abteien fehlen, die einmal im päpstlichen Schutz standen oder gar von der Jurisdiktionsgewalt des Diözesanbischofs befreit waren und die deshalb einen Zins an die Kurie zu leisten hatten, aber daneben gab es andere, die nicht erfaßt worden sind. Es gehörte eben nicht zu dem von Kehr konzipierten Programm, die Klöster, soweit sich von ihnen vor dem Ende des 12. Jahrhunderts eine Spur erhalten hat, ohne Ausnahme aufzuführen. Dennoch bleibt festzuhalten, daß es bislang keine andere Publikation gibt, in der mehr von ihnen behandelt oder wenigstens erwähnt würden. Der routinemäßige Griff zu den Bänden lehrt, daß sich der zu gewinnende Nutzen keineswegs auf die Geschichte der Päpste und auf deren Beziehungen zu den lokalen kirchlichen Einrichtungen oder einzelnen Personen beschränkt, sondern es werden ganz allgemein Aufschlüsse für die Vergangenheit der lokalen Kirchen geboten. Die drei Orts- und Institutionenregister in Band 4, 7/2 und 10 lenken den Neu-

149 Dessen Erarbeitung nannte Kehr 1906 „eine der dringendsten und lohnendsten Aufgaben" (Schriften [wie Anm. *] S. 23) und illustrierte die Notwendigkeit mit dem Hinweis auf einige eklatante Fehlidentifikationen namhafter Gelehrter.

150 Das neue Monasticon Italiae, herausgegeben vom Centro storico benedettino italiano in der Badia di Santa Maria del Monte bei Cesena, schließt die Mendikanten nicht ein, bemüht sich ansonsten aber um größtmögliche Vollständigkeit; s. die bisher erschienenen Bände 1: Roma e Lazio, hg. v. Filippo Caraffa, Cesena 1981; 3: Puglia e Basilicata, hg.v. Giovanni Lunardi, Cesena 1986; 4/1: Tre Venezie, Diocesi di Padova, hg.v. Giannino Carraro, Cesena 2001; 4/2: Tre Venezie, Diocesi di Adria-Rovigo, Diocesi di Belluno-Feltre, Diocesi di Chioggia, Diocesi di Treviso, Diocesi di Vittorio Veneto, hg.v. Gabriele Mazzucco/Pier Angelo Passolunghi, Cesena 2007. 
gierigen zu einer ersten Information ${ }^{151}$. Insgesamt steht somit sehr zu hoffen, daß die Italia pontificia in nicht unendlich ferner Zeit ihren Abschluß finde.

\section{Erfahrungen aus der Arbeit eines Jahrhunderts}

Dieser Ausblick führt unmittelbar zu meinem letzten Punkt, zweifellos dem delikatesten: der Organisation der Arbeit, denn dabei ist auch von ihren Schwächen zu handeln. Diese gehen auf Kehr selbst zurück, das darf das atemberaubende Publikationstempo in den ersten Jahrzehnten des vorigen Jahrhunderts nicht in Vergessenheit geraten lassen. Er hat es versäumt, dem Unternehmen eine solide institutionelle Grundlage zu verschaffen, und eine solche ist auch seither bestenfalls in Ansätzen gelungen. Dagegen lehrt die Betrachtung der großen Unternehmungen in der historischen Zunft, daß sie ohne eine solche Anbindung schwerlich zu gedeihlichem Fortschreiten oder gar zum Abschluß kommen können. Das wußte Kehr selbst, denn sonst hätte er nicht dafür gesorgt, daß für ihn ein eigenes Institut, das Kaiser-Wilhelm-Institut für deutsche Geschichte, gegründet wurde ${ }^{152}$ : zur Bewältigung großer Editionsaufgaben, das war neben der Korrespondenz Kaiser Karls V. vor allem die Germania sacra ${ }^{153}$.

Zunächst ist nochmals hervorzuheben, daß das Papsturkundenunternehmen wohl nie geboren worden wäre, wenn die Gesellschaft der Wissenschaften zu Göttingen nicht nach einem bedeutenden Projekt auf historischem Felde gesucht und Kehr mit mehr Mut als Vorsicht ein solches entworfen hätte. Hinfort hat er die Sammlung selbst und alle ihre Ableitungen strikt als ein Arbeitsgebiet der Göttinger gelehrten Gesellschaft betrachtet - abgesehen von der unterstützenden Funktion der 1931 von ihm gegründeten Pius-Stiftung für Papsturkunden und mittelalterliche Geschichtsforschung ${ }^{154}$. Aber er war es in eigener Person, der den Boden im preußischen Kultusministerium bereitete, so daß zu

151 Diese Register sind nun auch zusammengefaßt benutzbar: Rudolf HiEsTAND: Initienund Empfängerverzeichnis zu Italia Pontificia I-X, München 1983 (MGH Hilfsmittel 6), S. $75-180$.

152 Aus den zahlreichen Darstellungen der Institutsgeschichte genüge hier der Hinweis auf Michèle Schubert: Zum Wirken Paul Fridolin Kehrs für ein deutsches historisches Zentralinstitut oder: Der lange Weg zum Kaiser-Wilhelm-Institut für Deutsche Geschichte, in: Die Kaiser-Wilhelm-/Max-Planck-Gesellschaft und ihre Institute. Studien zu ihrer Geschichte: das Harnack-Prinzip, hg. v. Bernhard vom Brocke/Hubert Laitko, Berlin/New York 1996, S. 423-444.

153 Kehr selbst begründete 1929, warum für diese Aufgabe nicht etwa Akademien oder die preußische Archivverwaltung geeignet gewesen wären, sondern „das Institut, das dazu erforderlich ist": Schriften (wie Anm. *) Bd. 1 S. $66 \mathrm{f}$.

154 Dazu s. Brandi (wie Anm. 14) S. 150; Holtzmann: Kehr (wie Anm. 14) S. 43 f.; Hiestand: 100 Jahre Papsturkundenwerk (wie Anm. 8) S. 15 f. 
den - recht beschränkten - eigenen Mitteln der Gesellschaft von Anfang an immer wieder außerordentliche Zuwendungen für sein Vorhaben zur Verfügung standen, er verstand es, Geldspenden von anderer Seite einzuwerben. Darunter war ein bedeutender Betrag vom Breslauer Fürstbischof und Kardinal Georg Kopp, was anderen Mitgliedern der Gesellschaft offenbar so mißfiel, daß der erste Versuch scheiterte, ihn zum Ehrenmitglied zu wählen ${ }^{155}$. Selbst wenn Kehr also nicht alles im Kreise seiner Kollegen gelungen ist, sieht man doch, daß sein persönliches Engagement ausschlaggebend war.

Trotz seinem Einsatz bleibt nicht zu verkennen, wie schwach die von ihm entwickelte Konstruktion stets war. Die Angaben in den veröffentlichten Berichten ${ }^{156}$ aus den frühen Jahren lassen auf die prekäre Finanzsituation schließen: immer nur geringe Mittel der Gesellschaft der Wissenschaften, sparsame Zuschüsse aus dem Kultusministerium, die zudem von Jahr zu Jahr neu bewilligt werden mußten, dazu Stiftungen von privater Seite, gewiß großherzig, aber wahrscheinlich viel zu selten für die Schaffung einer dauerhaften Basis. Diesem Bild entsprechen die regelmäßigen Mitteilungen über den Bestand der Mitarbeiter ${ }^{157}$ : Die Gesellschaft brachte ein Stipendium auf, außerdem gab es ein weiteres vom Ministerium ${ }^{158}$, dazu gesellten sich Oberlehrer wie Albert Brackmann oder Wilhelm Wiederhold, die ihre Forschungen mit den beruflichen Verpflichtungen vereinbaren mußten, wenn nicht für sie zeitweise Urlaub erwirkt werden konnte, und vor allem Luigi Schiaparelli - „er ist über ein Jahrzehnt mir ein treuer Gefährte und bis zuletzt ein treuer Freund gewesen“, rühmte Kehr später ${ }^{159}$-, der augenscheinlich keinerlei Honorar, sondern nur Reisegeld erhielt ${ }^{160}$, obwohl „die Hauptlast der archivalischen Arbeiten“ auf ihm $\operatorname{lag}^{161}$. Der Initiator selbst konnte die Reisen, die in der Anfangsphase ja bei

155 Siehe Schubert: Kehr in Göttingen (wie Anm. 14) S. 115-120.

156 Siehe Anm. 73.

157 Kehrs Helfer für die italienische Abteilung in jenen Jahren nennt Hiestand: Italia Pontificia (wie Anm. 11) S. 172.

158 Es war mit 1200 Mark jährlich dotiert: NGG, Geschäftl. Mitth. 1898 S. 23. Im zitierten Bericht vom 3.-5. August 1898 (s. Anm. 92) wird jedoch spezifiziert, daß die anspruchsvolle Arbeit eine Erhöhung auf 1500 geraten sein ließ, den Rest fügte die Gesellschaft aus ihren Mitteln hinzu, so daß der Inhaber dem von ihr selbst finanzierten Stipendiaten gleichgestellt war, s. BRANDi (wie Anm. 14) S. 138.

159 KeHR: Schriften (wie Anm. *) Bd. 2 S. 1313. Siehe auch bei Anm. 88 und 90.

1601897 wurden für ihn 500 Mark vorgesehen: Brandi (wie Anm. 14) S. 138; Holtzmann: Kehr (wie Anm. 14) S. 33. Die Kostenaufstellung im Antrag an das Ministerium aus dem folgenden Jahr (s. Anm. 92) machte jährlich 3000 Mark geltend als seine Remuneration für zehn Monate, das entsprach genau den von Kehr selbst beanspruchten 1500 Mark Reisegeld für fünf Monate; aber von der insgesamt berechneten Summe wurde lediglich ein Viertel bewilligt (s. Anm. 97), so daß für Schiaparelli der vorgesehene Betrag kaum verfügbar gewesen sein wird.

161 NGG, Geschäftl. Mitth. 1899 S. 16. 
weitem im Vordergrund standen, zunächst nur in den Ferien unternehmen, Weihnachten nicht ausgeschlossen ${ }^{162}$, erst später wurde der Ordinarius mehrfach für Monate oder sogar Jahre von den Göttinger Lehrverpflichtungen befreit ${ }^{163}$. Doch war zu Beginn wahrscheinlich gar nicht mehr zu erreichen, möglicherweise hätten Forderungen in einem Ausmaß, wie es dem Gedeihen des gewaltigen Unternehmens angemessener gewesen wäre, das zarte Pflänzchen schon nach dem ersten Hervorsprießen erstickt. Der fragile Aufbau funktionierte immerhin, wie die stürmische Erscheinungsfolge der Reiseberichte erkennen läßt.

Aber 1903 ging Kehr weg von Göttingen, und das bewirkte Konsequenzen. Zum einen lief das Unternehmen in den gewohnten Gleisen fort. Die Mitarbeiter saßen weiterhin in Göttingen, Hannover, dann Marburg, Goslar, Berlin und machten bibliographische Vorarbeiten für die Reisen, die sie sodann nach Italien, Frankreich oder durch Deutschland und Nachbarländer führten, und für die Regestenbände. Kehr selbst hatte sich vor seiner Bestallung zum Direktor des Preußischen historischen Instituts in Rom die Erhaltung seines Ordinariats, die weitere Mitgliedschaft in der Göttinger Gesellschaft der Wissenschaften und die Leitung von deren Papsturkundenunternehmen ausbedungen ${ }^{164}$. Von seiner neuen Funktion profitierten die Vorbereitungen für die Germania und die Italia pontificia. Mitarbeiter an diesem Teilwerk, die nicht zum Institutspersonal zählten, hielten sich hinfort auch in Rom auf; Erich Caspar ist schon genannt worden ${ }^{165}$.

Kehr war nun in der Lage, die Möglichkeiten seiner Position direkt für die Zwecke des Unternehmens zu nutzen ${ }^{166}$. Das hat er weidlich getan. Gleich in den Beginn seiner Amtszeit fallen die Bemühungen um den systematischen Ausbau der Bibliothek; viele der Anschaffungen, gelegentlich sogar mit eigenhändigem Namenszug, werden vorrangig den Bedürfnissen der Arbeit an den

162 Ebd. 1900 S. 12.

163 Über die häufigen Urlaube Kehrs s. Schubert: Kehr in Göttingen (wie Anm. 14) S. $103-109,112-115,120,123 \mathrm{f}$.

$164 \mathrm{Zu}$ den Verhandlungen mit dem Kultusministerium s. zuletzt Michèle Schubert: Auseinandersetzungen über Aufgaben und Gestalt des Preußischen historischen Instituts in Rom in den Jahren von 1900 bis 1903, in: QFIAB 76 (1996) S. 383-454, dort S. $442 \mathrm{f}$. Über Kehrs Direktorenzeit berichtet eingehend Gerd Tellenbach: Zur Geschichte des Preußischen historischen Instituts in Rom (1888-1936), in: QFIAB 50 (1970) S. 382-419. Siehe ferner Reinhard ElzE: Das Deutsche historische Institut in Rom 1888-1988, in: Das Deutsche historische Institut (wie Anm. 11) S. 1-31, dort S. 8-20, außerdem die in Anm. 14 zitierten Nachrufe und Lebensskizzen.

165 Siehe Anm. $108 \mathrm{f}$. Sein Name fehlt in der Liste der Institutsmitarbeiter, die dem Jubiläumsband (wie Anm. 11) beigegeben ist: S. 261-270.

166 Zum eigenartig engen, jedoch nie offiziell institutionalisierten Verhältnis zwischen dem Papsturkundenunternehmen und dem Preußischen, dann Deutschen historischen Institut in Rom s. Hiestand: Italia Pontificia (wie Anm. 11) bes. S. 167 f., 188 f. 
Papsturkunden gedient haben. Aber die Literatur zur italienischen Lokalgeschichte, deren Beherrschung für die Methode der Regesta pontificum Romanorum unerläßlich ist, war in gleichem Maße für die von Kehr betriebene Intensivierung, ja Ausweitung der Institutsarbeiten notwendig, für deren Neuorientierung hin zur großflächigen Erfassung der italienischen Archivüberlieferung, weit über Rom hinausgreifend ${ }^{167}$. Elegant konnte sie nicht nur für die Erforschung der deutschen Geschichte mit ihren Verflechtungen nach Süden, sondern ebenso für die Interessen des Papsturkundenunternehmens herangezogen werden. Später bediente Kehr sich durchaus auch der personellen Ressourcen des römischen Instituts: Walther Holtzmann als zunächst dessen einziger Assistent nach dem Ersten Weltkrieg war voll in das Unternehmen eingespannt, daran arbeitete dort zuletzt Hans-Walter Klewitz bis $1934^{168}$. Dieser organisatorische Hintergrund war wahrscheinlich die wichtigste Voraussetzung dafür, daß damals drei weitere Bände der Italia pontificia erscheinen konnten ${ }^{169}$. Walter Goetz, der die Arbeiten Kehrs selbst hat verfolgen können, stellte rückblickend fest: „Nur in Rom und mit der Bibliothek des Institutes konnte er die ,Italia pontificia' zu rascherer Fertigstellung bringen. ${ }^{\text {"170 }}$

Doch im Jahre 1936 endete Kehrs Direktorenzeit auch formal, und von nun an ging es mit dem noch ausstehenden Teil nicht recht weiter. Jedenfalls fehlte die institutionelle Stütze: Die Pius-Stiftung scheint keine wirklich aktive Rolle gespielt zu haben, und ebenso wenig tritt die Göttinger Gesellschaft der Wissenschaften noch öffentlich in Erscheinung. Der Initiator selbst hatte die Regesta pontificum Romanorum keineswegs aus dem Blick verloren, wohl aber dürfte sein direktes Engagement erheblich nachgelassen haben ${ }^{171}$, während er in den dreißiger Jahren seine Energie vorzugsweise den Diplomata der Monumenta Germaniae historica widmete ${ }^{172}$. Er weilte damals vorwiegend in Berlin. Dort war auch sein letzter Mitarbeiter Horst Schlechte für die Italia pontificia tätig, doch war das von diesem teils korrigierte, teils selbst geschriebene Manuskript für die ausstehenden Teile noch nicht ausgereift ${ }^{173}$. Gegenüber

167 Dazu s. jetzt Girgensohn: Schriften Kehrs (wie Anm. 9) S. 611-616.

168 Siehe Das Deutsche historische Institut (wie Anm. 11) S. 264. Speziell zu Holtzmann vgl. Girgensohn: Schriften Kehrs (wie Anm. 9) S. 600 f.

169 Siehe Anm. 5 und 6.

170 Goetz (wie Anm. 139) S. 323.

171 „Das Interesse am neunten Band der Italia Pontificia war dagegen damals nur lau“, vermerkt Tellenbach (wie Anm. 164) S. 406 f. Daß es jedoch anhielt, zeigen die gleich zu nennenden Äußerungen von 1938 und 1940.

172 Siehe Girgensohn: Schriften Kehrs (wie Anm. 9) S. 604.

173 Dazu s. Girgensohn: Miscellanea 1 (wie Anm. 110) S. 139. In den Materialien für IP 9 und 10, die Holtzmann nach dem Zweiten Weltkrieg der Weiterarbeit zugrunde legen konnte, fanden sich einige von Kehr selbst hinzugefügte Regesten auf den Rückseiten von Einzelblättern des handgeschriebenen Vortragsmanuskripts der Erinnerungen von 1940, also sicherlich aus diesem Jahre stammend. 
Holtzmann klagte Kehr in einem Brief von 1938: „die Vorarbeiten dazu sind miserabel“, und ob er den neunten, den abschließenden Band noch herausbringen könne, „ist mir mehr als zweifelhaft ${ }^{\text {“174 }}$. In seinen Italienischen Erinnerungen von 1940 bezeichnete er es als „eine große Enttäuschung“, daß auf Grund „der äußeren Schwierigkeiten (Devisen - Reisen - Mitarbeiter)“ die Vollendung der Italia pontificia - jedenfalls der regionalen Bände bis Kalabrien und zu den Inseln - nicht mehr gelungen sei ${ }^{175}$.

Solche ,äußeren Schwierigkeiten“ haben auch den weiteren Weg der Italia pontificia begleitet. Erst nach dem Zweiten Weltkrieg und Walther Holtzmanns Wechsel nach Rom als Direktor des Deutschen historischen Instituts (seit 1953) fand die Arbeit ihre Fortsetzung. Aber nach seiner Emeritierung Ende 1961 erwies sie sich wiederum als gefährdet. Noch nicht für die Drucklegung des neunten Bandes, denn die hatte vorher begonnen und konnte tatsächlich 1962 beendet werden - inzwischen mit meiner Hilfe ${ }^{176}$. Anschließend machte sich Holtzmann in Bonn mit aller Energie an die Revision des Manuskripts für den Abschlußband der regionalen Reihe, die letzte noch notwendige, wie er meinte. Zunächst konnte ich ihm von Rom aus zuarbeiten ${ }^{177}$, aber Anfang 1963 sah ich mich aus wirtschaftlichen Gründen zur Rückkehr nach Deutschland genötigt; dort gab es für mich keine Möglichkeit zur Weiterarbeit am Papsturkundenunternehmen, vielmehr erlaubte mir ein Stipendium die Aufnahme eines Forschungsvorhabens zur Kirchengeschichte des späteren Mittelalters. Doch nach dem Tode Holtzmanns am 25. November 1963 ergab sich eine völlig neue Situation. Als sein ehemaliger Mitarbeiter war ich mit Material und Arbeitsweise vertraut. Um das Unternehmen nicht schon wieder schiffbrüchig werden zu lassen, fühlte ich mich verpflichtet - entsprechend dem letztwilligen Wunsche des Verstorbenen - meine Bereitschaft zur Fortführung der Italia pontificia 10 zu erklären, unabhängig von eigenen Arbeitsabsichten.

174 Holtzmann: Kehr (wie Anm. 14) S. 56.

175 KeHr: Schriften (wie Anm. *) Bd. 2 S. 1325.

176 Siehe Walther Holtzmann: Die Tätigkeit der Pius-Stiftung für Papsturkunden und für mittelalterliche Geschichtsforschung im Jahre 1960, in: DA 17 (1961) S. 331: „Am 15.9. 1960 ist ein von der Göttinger Akademie besoldeter Hilfsarbeiter, Herr Dr. D. Girgensohn, in Rom eingetroffen, der dem Bearbeiter des Manuskriptes zur Hand geht." Derselbe Text - wie üblich - auch in: MIÖG 69 (1961) S. 239 f. und in: Jahrbuch der Akademie der Wissenschaften in Göttingen. Übergangsband für die Jahre 1944-1960, Göttingen 1962, S. 234. Das Datum ist ungenau, das mag auf eine Verwechslung mit dem Ende der üblichen Sommerpause im Vatikan zurückgehen. Am 1. August hatte mir Holtzmann aus Bonn auf einer Postkarte mitgeteilt: „Es hat keinen Sinn, vor dem 1. Sept. und vor dem Ende der Olympiade nach Rom zu fahren." Entsprechend dieser Vorgabe ließ die Akademie mein Stipendium mit dem September beginnen. Nach meiner Erinnerung habe ich mich am 5. jenes Monats, einem Montag, im Corso Vittorio Emanuele 209 vorgestellt.

177 Angaben dazu in Girgensohn: Miscellanea 1 (wie Anm. 110) S. 139 f. 
Holtzmann hatte ein fast, aber nicht ganz vollständiges Manuskript hinterlassen, größtenteils von seiner Hand geschrieben, mit wenigen Abschnitten von meiner. Trotz seinen intensiven Bemühungen in den Jahren 1962-1963 erwies es sich als revisionsbedürftig ${ }^{178}$, aber das wurde erst nach und nach deutlich. Zunächst waren die wenigen noch fehlenden Teile zu ergänzen, dann hatte - gemäß dem von Kehr an Holtzmann, von diesem an mich weitergegebenen Qualitätsstandard des Werkes - die systematische Überprüfung der zahllosen, im Laufe der Jahrzehnte zusammengetragenen bibliographischen Angaben und die Kontrolle aller Zitate zu folgen, und das war ohne Arbeitsaufenthalte in Rom nicht möglich. 1967 war es endlich so weit, daß aus dem Text eine Schreibmaschinenfassung für die Drucklegung hergestellt werden konnte; deren Vorlage war nun unumgänglich, anders als noch wenige Jahre zuvor für den neunten Band. Nach dem mechanischen Textvergleich, um die Exaktheit der Abschrift zu gewährleisten, nach der Beseitigung weiterer, während der Beschäftigung mit den Papsturkunden und der Literatur aufgetauchter Zweifel lag Ende 1968 ein sauberes Gesamtmanuskript vor. Minimale Unebenheiten ließen sich im nächsten Frühjahr während eines erneuten RomBesuchs glätten, dort ebenfalls die ja immer wieder anfallenden Ergänzungen der Bibliographien erarbeiten. Die dankenswerte inhaltliche und sprachliche Überprüfung durch mehrere Fachkollegen - Paolo Collura, Léon-Robert Ménager, Agostino Pertusi, Paulius Rabikauskas - nahm daneben nicht viel Zeit in Anspruch, noch 1969 hätte die Drucklegung beginnen können ${ }^{179}$. Tatsächlich ist das erst zwei Jahre später geschehen. In einem Überblick stellte Theodor Schieffer ${ }^{180}$ damals fest, der Band sei ,in mühevoller Kleinarbeit zu Ende geführt worden und im Herbst 1971 in den Satz gegangen".

Diese Entwicklung gehört zu einer historia calamitatum, an deren Rande ich gestanden habe - ohne jedoch in die Vorgänge eingeweiht zu sein -, im Mittelpunkt dagegen die Akademie der Wissenschaften zu Göttingen oder besser: deren Papsturkundenkommission und vor allem das Präsidium. Wieweit damals die Pius-Stiftung ebenfalls als Akteurin beteiligt war, entzieht sich meiner Kenntnis. Ich habe bewußt darauf verzichtet, durch Aktenstudium nach Hintergründen und handelnden Personen zu forschen. Es geht hier vielmehr um Strukturen, und der Blick auf erkennbare organisatorische Mängel sollte zum

178 In dem von Theodor Schieffer als Sekretär erstatteten Bericht der Pius-Stiftung für $1967 / 68$ ist die Rede von „den in den Jahren 1962/63 (teilweise wohl etwas eilig) bearbeiteten Teilen“ des Manuskripts, in: DA 24 (1968) S. 608.

179 Der Jahresbericht 1969/70 vermeldet über das Manuskript: „druckfertig und kann in den Satz gegeben werden“, in: DA 26 (1970) S. 651. Vgl. Girgensohn: Miscellanea 1 (wie Anm. 110) S. 140.

180 Der Stand des Göttinger Papsturkunden-Werkes, in: Jahrbuch der Akademie der Wissenschaften in Göttingen 1971 S. 68-79, dort S. 74. 
Nachdenken über effizientere Modelle anregen. Dafür möchte ich einige aus meinen Eindrücken abgeleitete Erwägungen zur Diskussion stellen.

Damals tauchten unerwartete Schwierigkeiten auf: Das Geschäftsverhältnis zwischen der Göttinger Akademie und dem Verlag Weidmann gründete sich meines Wissens immer noch auf den Vertrag von $1900^{181}$; die inzwischen eingetretene Entwicklung muß ihn höchst auslegungsbedürftig gemacht haben. In den daraus folgenden rechtlichen Auseinandersetzungen ${ }^{182}$ erwies sich die Akademie als schwerfälliger Verhandlungspartner. Die von Anfang an eintretenden Verzögerungen waren eine wesentliche Ursache dafür, daß die Auslieferung des Bandes erst fünfeinhalb Jahre später erfolgte, im Sommer 1975. Der überlange Herstellungsprozeß seit der Abgabe eines fertigen Manuskripts machte zunächst noch vor dem Beginn der Drucklegung zusätzliche bibliographische Recherchen notwendig, sie führten - nach erneutem Rom-Aufenthalt - bis März 1971 zu einer ergänzten Fassung; was danach bis Ende 1973, dem Datum der Vorrede, hinzuzufügen war, füllt nicht weniger als vier Seiten am Anfang von Italia pontificia 10; die weitere zeitliche Lücke von anderthalb Jahren bis zum tatsächlichen Erscheinen bleibt ein ärgerliches Faktum. Durch einen früheren Eintritt in konkrete Verhandlungen hätte sich wohl manche Verzögerung vermeiden lassen, die naheliegende Ungeduld der einen Seite schwächte zweifellos deren Position. Zudem denke ich immer noch, daß dieser Prozeß zügiger abgewickelt worden wäre, wenn dem obstinaten Verleger nicht eine Akademie mit ihren gewählten Leitungsmitgliedern, sondern der energische Direktor eines Instituts gegenüber gestanden hätte.

Auch die personelle Basis für die Fortsetzung der Italia pontificia wäre sicherer gewesen, wenn etwa das Deutsche historische Institut in Rom diese Aufgabe zu seiner eigenen gemacht hätte. Nachdem Gerd Tellenbach Nachfolger Walther Holtzmanns geworden war, konnte er in den sechziger Jahren für eine enorme Vermehrung des wissenschaftlichen Personals sorgen ${ }^{183}$; so hätte wahrscheinlich ohne allzu viele Mühe eine weitere Assistentenstelle eingerichtet werden können. Ich bin davon überzeugt, daß der schon früh konzipierte Ab-

181 Siehe Anm. 100.

182 Nur ein schwaches Echo der hindernisreichen Entwicklung findet sich in den Jahresberichten, in: DA 30 (1974) S. 643 und 32 (1976) S. 330. Nach der Erledigung der Fahnen- und Umbruchkorrekturen wird für 1973/74 vermerkt, im Frühjahr seien endlich die Indices fertig gewesen, aber dann: „Der Abschluß des Bandes verzögert sich jedoch auf höchst unerfreuliche Weise durch Zwistigkeiten zwischen dem Verleger (Weidmann) und dem Drucker (Oechelhäuser-Kempten).“ Im Bericht für 1974/75 heißt es: IP 10 „liegt ausgedruckt vor, doch muß noch die Aufteilung der Kosten geklärt werden, ehe Auslieferung und Verkauf einsetzen können."

183 Davon zeugt schon der erste Jahresbericht (für 1963) des neuen Direktors, in: QFIAB 44 (1964) S. VII-XII. Vgl. Elze (wie Anm. 164) S. 25 f., der für die Zeit von 1953 bis 1972 festhält: „Die Zahl der wissenschaftlichen Mitarbeiter und Stipendiaten wurde ... verdoppelt." 
schlußband ${ }^{184}$ - inzwischen wird eine Zweiteilung vorgesehen ${ }^{185}$ - längst vorläge, wäre das damals geschehen. Außerdem wäre es zehn Jahre später wohl nicht schwer gewesen, das Max-Planck-Institut für Geschichte (das es nun ja nicht mehr gibt) ${ }^{186}$ zur institutionellen Unterstützung für das Papsturkundenunternehmen zu gewinnen, hatte doch dessen erster Direktor Hermann Heimpel seinem Wohlwollen ihm gegenüber schon dadurch tatkräftigen Ausdruck verliehen, daß er mich als angestellten Referenten für die Arbeit am zehnten Bande „in großzügigster Weise“ ${ }^{187}$ über Jahre hinweg von den Institutsaufgaben weitgehend freistellte. Allerdings stand ich selbst für eine solche Aufgabe nicht mehr zur Verfügung, nachdem mir während eines kurzen RomBesuchs, als die Drucklegung des Bandes noch andauerte, im Cortile della Biblioteca zugetragen worden war, daß die Pius-Stiftung die Fortsetzung der Italia pontificia einem anderen Bearbeiter übertragen hatte ${ }^{188}$. Verpaßte Gelegenheiten.

184 Am 10. Oktober 1967 hatte ich der Pius-Stiftung ein von deren Sekretär angefordertes Gutachten über den wünschbaren Inhalt erstattet.

185 Darüber s. Hiestand: Die unvollendete Italia Pontificia (wie Anm. 10) S. 52-56, und zuletzt Klaus Herbers: Pius-Stiftung für Papsturkundenforschung. Bericht über das Jahr 2006, in: DA 63 (2007) S. $171-176$.

186 Seit dem 1. April 2007 sind dessen frühere Gebäude dem neu gegründeten Max-PlanckInstitut zur Erforschung multireligiöser und multiethnischer Gesellschaften zugewiesen.

187 So Schieffer: Stand des Papsturkunden-Werkes (wie Anm. 180) S. 74, s. auch S. 77 Anm. 13. Bereits in seinem Jahresbericht für die Pius-Stiftung 1969/70, in: DA 26 (1970) S. 651, hatte er den Dank für meine Freistellung während zweier Jahre öffentlich ausgedrückt, das heißt: praktisch während der gesamten Zeit meiner damaligen Zugehörigkeit zum Institut, denn mein Beschäftigungsverhältnis hatte im Januar 1967 begonnen; bis 1974 sind daraus noch erheblich mehr geworden.

188 Don Raffaello Volpini (später Monsignore) war hervorgetreten als Autor von Additiones Kehrianae 1 und 2, in: RSCI 22 (1968) S. 313-424 und 23 (1969) S. 313-360, mit insgesamt 36 Nummern. In den Jahresberichten der Pius-Stiftung erscheint er erstmals zu 1970/71 mit dem Hinweis auf demnächst vorzulegende "Contributi per l'Italia Pontificia“, die rund 200 neue Texte „zur Vorbereitung des Bandes XI“ bringen sollten; in: DA 27 (1971) S. 658. Nach weiteren vier Berichten mit Angaben über das Fortschreiten der Drucklegung jener Contributi wird zu 1975/76 erstmals präzisiert: „der einen Ergänzungsband XI vorbereitet“, dann zu 1978/79 kleinlaut festgestellt: „Eigentliche Vorarbeiten für den Ergänzungsband XI der IP haben jedoch noch nicht begonnen"; in: DA 33 (1977) S. 338 und 36 (1980) S. 336. Die geplante Publikation segelte inzwischen unter dem Titel „Additiones“, später „Aggiunte“, sie wuchs auf 290 Nummern für den Bereich von IP 1-7, es gesellten sich sogar Nachtragsfunde für die drei letzten regionalen Bände hinzu; in: DA 38 (1982) S. 337 und 41 (1985) S. 340. Mehrere Jahre war anschließend der Kontakt abgebrochen, doch zu 1995/96 - Berichterstatter ist inzwischen Rudolf Hiestand - wird vermeldet, Volpini habe „ein Manuskript mit 151 unbekannten Urkunden aus Ober- und Mittelitalien, davon 68 Originale, angekündigt“, nach erneuter Pause ist die Rede von einer Erweiterung „um nochmals 42 Stücke, vor allem feierliche Privilegien, überwiegend aus Privatarchiven“, zudem habe er die Absicht, „dann den Band Italia Pontificia XII mit den Nachträgen zu 
Dringend wünschbar wäre jetzt ein Neubeginn der Bemühungen um die Italia pontificia. Man mag außerdem überlegen, ob solche nicht in den Rahmen einer gewissen Umstrukturierung der Arbeiten des Papsturkundenunternehmens gestellt werden sollten, resultierend aus einer kritischen Betrachtung der Entwicklung während der letzten Jahrzehnte. Die Veröffentlichung der Germania pontificia hat nach mehr als vierzigjährigem Stillstand enorme Fortschritte gemacht, auch ohne förmliche institutionelle Anbindung - dank persönlichem Engagement. Andererseits erfahren die Papsturkunden Frankreichs seit Jahrzehnten eine förmlich vereinbarte Unterstützung durch das Deutsche historische Institut in Paris ${ }^{189}$; das ist erkennbar eine Voraussetzung für das Gedeihen der Abteilung. Diese Beobachtungen weisen nun die Richtung für die sicherlich solideste Lösung: die Anbindung der einzelnen Teilgebiete des Papsturkundenunternehmens an Institutionen. Kehr hat stets betont, daß er sein Fernziel, die Gesamtausgabe der Papsturkunden, nie aus den Augen verloren habe. Die von ihm gewählte institutionelle Grundlage hat sich jedoch im Laufe der Zeit nicht als tragfähig erwiesen, zumal dann, wenn wegen der Wechselfälle der Zeiten und des individuellen Lebens persönliches Engagement nicht in dem erforderlich hohen Maße zur Verfügung steht.

Eine Arbeitsstelle an einer Akademie bietet vielleicht nicht das Optimum. Ideal wäre vielmehr ein eigenes Institut für Papsturkundenforschung, international konzipiert - als Träger einer Zusammenarbeit, die Paul Kehr vorgeschwebt haben mag, als er gleich im Jahre 1896 an die allen Nationen des Abendlandes gemeinsame Überlieferung erinnerte, zu deren Aufarbeitung „der mittelalterliche Historiker ... im stillen Bündnis mit den Fachgenossen jenseits der Alpen und der Vogesen" aufgerufen sei, als er sein Papsturkundenunternehmen für geeignet erklärte, „diese Liga der an derselben Aufgabe arbeitenden italienischen, französischen und deutschen Gelehrten zu fördern" ${ }^{\text {"190}}$; heute wird man darüber hinaus den Blick zumindest auf die angelsächsischen Kollegen richten, aber gewiß die Beiträge weiterer Nationen nicht verschmähen. Unter den obwaltenden Verhältnissen erscheint freilich der Gedanke an ein eigenes Institut als reine Utopie. Aber die Zuweisung definierter Bereiche an einige solide Forschungseinrichtungen könnte zu einer strukturell tragfähigen Grundlage führen: für die Verwirklichung von Kehrs Vision; das ist es ja, was uns hier zusammengeführt hat.

den Bänden I-X und XI folgen zu lassen“; in: DA 53 (1997) S. 401 und 57 (2001) S. 868. Bis 2006 ist nichts davon erschienen, so daß der Ausgang dieser historia calamitatum ungewiss bleibt.

189 Siehe Schieffer: Stand des Papsturkunden-Werkes (wie Anm. 180) S. 76 f., und Dens.: Geleitwort, in: Papsturkunden in Frankreich, N.F. 7: Nördliche Île-de-France und Vermandois, hg. v. Dietrich Lohrmann, Göttingen 1976 (AAG, phil.-hist. Kl., 3. Folge 95), S. IX.

190 KeHr: Schriften (wie Anm. *) Bd. 1 S. 5. 


\section{Vier Thesen}

Für die konkrete Fortsetzung des Papsturkundenunternehmens - in welchem institutionellen Rahmen und mit welchen Ressourcen auch immer - mag die Diskussion der folgenden Thesen förderlich sein:

1. Zur weiteren Annäherung an das „letzte Ziel“191 Paul Kehrs ist es geboten, die Phase der Reiseberichte, das heißt: die Nachsuche in Archiven und Bibliotheken, möglichst schnell zu einem zufriedenstellenden Ende zu bringen, so vollständig wie das mit den heutigen Hilfsmitteln gelingen kann. Da die Vatikanische Bibliothek dem Vernehmen nach sich stärker finanziell zu engagieren bereit ist, wären zusätzliche Mittel in erster Linie für diese Aufgabe vorzusehen.

2. Die Rückbesinnung auf den grundlegenden Plan gebietet es, die Gesamtausgabe der Papsturkunden wieder stärker in den Vordergrund zu rücken. $\mathrm{Da}$ eine solche Leistung menschenmöglich ist, zeigt die Edition von Harald Zimmermann ${ }^{192}$, der freilich in der Einleitung auch andeutet, wie mühevoll seine Arbeit und die seiner Helfer war. Daher würde es sich empfehlen, die Gesamtaufgabe in handhabbare Portionen zu zerlegen, in Teilbereiche, die sich aus sachlichen Erwägungen heraus abgrenzen lassen. Ihre Publikation wäre an keine feste Reihenfolge gebunden. Als solche Abteilungen bieten sich etwa die Papstbriefe in patristischer und in kanonistischer Überlieferung an - die jedenfalls nicht unberücksichtigt bleiben dürfen, anders als Kehr das ursprünglich vorhatte; aber sie erfordern eigene Bearbeitungsmethoden. Trennen ließen sich zudem die Stücke in den vorgratianischen Sammlungen, jetzt leichter zu überblicken durch das Verzeichnis von Lotte Kéry ${ }^{193}$, und im Decretum Gratians selbst von denen der späteren, für deren Edition dank Walther Holtzmann ja längst weitgehende Vorarbeiten existieren ${ }^{194}$, aus ihnen endlich eine Textausgabe entstehen zu lassen, liegt jetzt an. Für den großen Rest, die archivalisch überlieferten Papsturkunden, sollten am besten geeignete Zeitabschnitte gebildet und einzelnen Bearbeitern anvertraut werden. Denkbar, obwohl viel weniger übersichtlich, wäre auch eine Aufteilung nach Ländern ${ }^{195}$, daneben könnte

191 Siehe Anm. 115.

192 Papsturkunden 896-1046, 3 Bde., Wien 1984-1985 und 1989 (DÖAW, phil.-hist. Kl. 174, 177, 198 = Veröffentlichungen der Historischen Kommission 3-5), Bd. 1-2 auch Wien ${ }^{2} 1988$.

193 Siehe Anm. 25.

194 Besonders zu nennen sind hier Studies in the collections of twelfth-century decretals und Decretales ineditae saeculi XII, beide mit übereinstimmendem Untertitel: From the papers of the late Walther Holtzmann, hg.v. C(hristopher) R. Cheney/Mary G. Cheney bzw. v. Stanley Chodorow/Charles Duggan, Città del Vaticano 1979 und 1982 (MIC B 3-4).

195 Eingeschlagen hat diesen Weg Maurice P. SHeEhy: Pontificia Hibernica. Medieval papal chancery documents concerning Ireland, 640-1261, 2 Bde. Dublin 1962-1965. Allerdings konnte er nur 31 Stücke vor 1198 auffinden. 
eventuell eine gesonderte Gruppe für die zentralisierten Orden erforderlich werden. Unbedingt müßte erreicht werden, daß die Editionsarbeit für den Einzelnen eine menschenmögliche Dimension nicht überschreite. Im Laufe der Zeit könnten die Teile allmählich zu einem Ganzen zusammenwachsen. Dagegen bedürfen die Register vor 1198 vorläufig keiner neuen Edition, jedenfalls nicht im Rahmen des Papsturkundenunternehmens.

3. Das "Zwischenwerk" Kehrs, seine Regesta pontificum Romanorum, ist für den Erforscher des Papsttums wie für den Lokalhistoriker uneingeschränkt nützlich, die Regesten sind jedoch keine unabdingbare Voraussetzung für die Edition. Also sollte die flächendeckende Verwirklichung dieser Stufe auch kein vordringliches Ziel sein, zumal dann, wenn über die Verwendung beschränkter Ressourcen zu entscheiden ist. Vielmehr empfiehlt sich hier eine flexible Vorgehensweise: $\mathrm{Zu}$ prüfen wäre in jedem Einzelfall, ob die Bearbeitung einer nationalen Pontificia nicht eigenverantwortlich einer nationalen Institution übertragen oder einer Einzelperson nahegelegt werden mag. Daß eine solche Ausgliederung prinzipiell möglich ist, dann aber auch zu einer schönen Leistung führen kann, zeigt die Arbeit von Robert Somerville ${ }^{196}$. Dabei scheint die Einhaltung des von Kehr entwickelten Bearbeitungsschemas von zweitrangiger Bedeutung. Ohnehin weichen ja schon die Bände der Gallia pontificia in nicht unwesentlichen Einzelheiten davon ab - und das innerhalb der Publikationen des Göttinger Papsturkundenunternehmens. Dagegen darf ein chronologisch angelegtes Gesamtverzeichnis der Papsturkunden in Regestenform, ein neuer Jaffé, die vorrangigen Aufgaben des Papsturkundenunternehmens nicht behindern, selbst wenn der Nutzen dieser Bearbeitungsmethode gar nicht zu bezweifeln ist und durch die bisher vorliegenden fünf einschlägigen Bände der Regesta imperii handgreiflich unter Beweis gestellt wird ${ }^{197}$.

4. Kehr hat wiederholt eingeräumt, daß die Vorarbeiten für die italienischen Papsturkunden, die er von Anfang an sich selbst vorbehalten hat, nicht durchweg seinen Ansprüchen und den allmählich entwickelten Fertigkeiten genügt haben ${ }^{198}$. Deshalb sind für ihre Ergänzung noch die intensivsten Bemühungen vonnöten. Auch unabhängig von der Frage, ob die Sammlungen Raffaello Volpinis ${ }^{199}$ einmal zugänglich sein werden oder nicht, müßte alsbald die komplette Durchsicht der seit dem Erscheinen der einzelnen Italia-pontificia-Bände veröffentlichten einschlägigen Literatur begonnen werden, der allgemeinen wie der lokalen sowie selbstverständlich der gedruckten Archivin-

196 Scotia pontificia. Papal letters to Scotland before the pontificate of Innocent III, Oxford 1982, mit 166 Nummern.

197 RI 1/4/2/1: 844-858; RI 2/5: 911-1024; RI 3/5/1: 1024-1046; RI 4/4/4/1-2: $1181-1185$; jeweils mit dem Titel Papstregesten.

198 Siehe Anm. 67 und 128.

199 Siehe Anm. 188. 
ventare und Handschriftenkataloge. Soweit sich daraus Hinweise auf Papsturkunden, auch solche von Legaten oder delegierten Richtern ergeben, sollte man ihnen nachgehen; systematische Reisen - unabhängig von derartigen Fingerzeigen - empfehlen sich dagegen nicht wegen des unverhältnismäßigen Aufwandes. Ob die einschlägige Literatur auch in Nachträgen zu den Bibliographien der einzelnen Abschnitte zu sammeln ist oder ob man auf diese Ergänzungen ganz verzichtet, mag nach genauerer Abschätzung des zusätzlichen Arbeitsaufwandes entschieden werden.

\section{Riassunto}

Nel contesto del progetto relativo alla raccolta dei diplomi papali, collocato presso l'Accademia delle scienze di Gottinga, l'Italia pontificia ne costituisce un pilastro portante come parte dei Regesta pontificum Romanorum iniziati da Paul Fridolin Kehr. In un primo momento lo studioso non aveva pensato di presentare il materiale in questa maniera, in quanto alla raccolta negli archivi dei diplomi papali fino al 1198 avrebbe dovuto subito far séguito la loro edizione critica. I sondaggi archivistici in Italia rivelarono però ben presto che Kehr aveva sottovalutato di gran lunga gli sforzi necessari per eseguire tale lavoro. Si scoprirono una gran mole di fondi documentari e diplomi papali sconosciuti. Pertanto l'obiettivo di un'edizione completa si allontanava sempre di più nel tempo.

Per questo motivo Kehr propose un livello intermedio, l'Italia pontificia per l'appunto, che offre il materiale in forma di regesti, strutturandolo sulla base delle province ecclesiali, diocesi e singole istituzioni ecclesiali oppure secondo i destinatari laici. In tal modo è stato creato per l'Italia un panorama complessivo delle istituzioni ecclesiali fino alla fine del XII secolo. I volumi dei Regesta pontificum Romanorum presentano inoltre una ricostruzione dell'archivio della rispettiva istituzione. Tutto ciò e le bibliografie dettagliate di storia locale hanno fatto dei Regesta di Kehr un mezzo di lavoro molto apprezzato.

Nel corso di 100 anni sono stati pubblicati 25 volumi relativi a Italia, Germania e Gallia pontificia; complessivamente, però, non è stata realizzata finora neanche la metà dell'intero programma. La pubblicazione a ritmo intermittente - già da tre decenni ad esempio si stanno aspettando i due volumi conclusivi dell'Italia pontificia - segnala la presenza di non pochi problemi. Causa essenziale ne è lo scarso radicamento istituzionale che potrebbe essere migliorato, collocando il progetto presso istituti di ricerca, nell'intenzione di portare soprattutto avanti lo scopo principale, cioè l'edizione dei diplomi papali fino al 1198. 
Bereitgestellt von | De Gruyter / TCS

Angemeldet | 217.89.40.26

Heruntergeladen am | 21.12.12 10:48 
IV. Nichturkundliche Überlieferung

- eine undankbare Nachlese?

(Register, Briefsammlungen,

Kanonessammlungen, Historiographie,

Kardinalsschreiben, Inschriften) 
Bereitgestellt von | De Gruyter / TCS

Angemeldet | 217.89.40.26

Heruntergeladen am | 21.12.12 10:48 


\section{Die päpstlichen Register vor 1198}

\section{RUdDOLF SCHIEFFER}

1198 ist bekanntermaßen das Epochenjahr der Papstdiplomatik. Seit dem Pontifikatsbeginn Innozenz' III. haben sich in annähernder Vollständigkeit die Registerbände der päpstlichen Kanzlei im Vatikanischen Archiv erhalten. Auch wenn darin zu keinem Zeitpunkt wirklich ausnahmslos alle nach außen versandten päpstlichen Schriftstücke verzeichnet worden sind, erlaubt die Serie der Registra Vaticana zusammen mit den später einsetzenden Registerreihen spezieller kurialer Behörden doch eine Erforschung des päpstlichen Schriftverkehrs von der Zentrale aus, also ohne Rücksicht auf das Überlieferungsschicksal, das dem einzelnen Brief oder Privileg auf dem Wege zum und später beim Empfänger beschieden war $^{1}$. Diese Unabhängigkeit von der Archivsituation in den verschiedenen Ländern und an den zahllosen Orten, wohin Erzeugnisse der päpstlichen Kanzlei gelangt sind, machen sich verschiedene quantifizierende Forschungsansätze zunutze, die für die Jahrhunderte des späteren Mittelalters das Ausmaß der kurialen Zuwendung zu den einzelnen Regionen der Christenheit bzw. deren Hinwendung zum Nachfolger des hl. Petrus vergleichend in den Blick fassen oder gar bis ins einzelne dokumentieren wie etwa das Repertorium Germanicum².

Ganz anders ist die Situation in der Zeit bis 1198, wo die Forschung darauf angewiesen ist, sich von den weitverstreuten Empfängerarchiven her ein Bild von der Reichweite und Intensität des päpstlichen Schriftverkehrs zu machen. Nach der erstmaligen chronologischen Aufreihung der Befunde durch Philipp Jaffé, dessen Regestenwerk 1851 und in wesentlich erweiterter Gestalt 1885/88 erschien $^{3}$, war es der Leitgedanke des 1896 von Paul Kehr auf den Weg ge-

1 Vgl. Othmar Hageneder: Die päpstlichen Register des 13. und 14. Jahrhunderts, in: Annali della Scuola speciale per archivisti e bibliotecari dell'Università di Roma 12 (1972) S. 45-76; Thomas Frenz: Papsturkunden des Mittelalters und der Neuzeit, Stuttgart ${ }^{2} 2000$ (Historische Grundwissenschaften in Einzeldarstellungen 2), S. 59-70.

2 Vgl. Dieter Brosius: Das Repertorium Germanicum, in: Das Deutsche Historische Institut in Rom 1888-1988, hg.v. Reinhard Elze/Arnold Esch, Tübingen 1990 (Bibliothek des Deutschen Historischen Instituts in Rom 70), S. 123-165; Götz-Rüdiger Tewes: Die römische Kurie und die europäischen Länder am Vorabend der Reformation, Tübingen 2001 (Bibliothek des Deutschen Historischen Instituts in Rom 95).

3 Regesta Pontificum Romanorum ab condita ecclesia ad annum post Christum natum MCXCVIII, ed. Philippus JAFFÉ. Editionem secundam et auctam auspiciis Gulielmi Wattenbach curaverunt S. Loewenfeld/F. Kaltenbrunner/P. Ewald, 2 Bde., Leipzig 1885-1888. 
brachten „Göttinger Papsturkundenwerks“, durch eine sorgfältige Umschau in allen Ländern der lateinischen Welt des Hochmittelalters die Materialgrundlage zu schaffen für eine möglichst vollständige Sammlung und Edition der Papsturkunden vor 1198, die der nach Öffnung des Vatikanischen Archivs (1881) rasch in Gang gekommenen Publikation von Registerbänden des 13. und des 14. Jahrhunderts ebenbürtig zur Seite treten sollte ${ }^{4}$. Ein erstes Zwischenergebnis dieser regional aufgefächerten Archiv- und Bibliotheksforschungen, das rasch bleibendes Eigengewicht gewann, war die Italia Pontificia, deren Band 1 vor hundert Jahren herauskam und den Anlaß zur vorliegenden Publikation gibt.

Es war von vornherein klar und hat sich im weiteren Verlauf der Forschung nur noch weiter bestätigt, daß auf dem von Kehr (mangels besserer Alternativen) gewiesenen Wege keinesfalls ein vollwertiger Ersatz für die vor 1198 fehlenden Papstregister zu schaffen war. Das lag nicht allein, wie bereits angedeutet, an der von Ort zu Ort ganz unterschiedlichen, von den Wechselfällen der Geschichte bestimmten Überlieferungslage, die bei nicht wenigen geistlichen Empfängerinstitutionen durch fehlerhafte Abschriften entstellt, durch Fälschungen bzw. Verfälschungen verdunkelt oder gar völliger Vernichtung anheimgefallen sein kann. Stärker noch fällt ins Gewicht, daß Schriftstücke an weltliche Adressaten, die in der Regel keine Archive unterhielten, kaum eine Chance hatten, ins Blickfeld der Forschung zu treten. Das gilt zumal auch für die historisch besonders aufschlußreiche Korrespondenz der Päpste mit den Herrschern, die sich eben nicht in Gestalt von langfristig aufzubewahrenden Privilegien abspielte, sondern in "litterae clausae, deren Erhaltung wegen ihres meist geringen Formats und oft sehr dünnen Pergaments von vornherein unter ungünstigen Voraussetzungen stand. Es handelte sich unter rechtlichem Gesichtspunkt weitgehend um 'Verbrauchs'-Schriftgut, das der Aufbewahrung über einen längeren Zeitraum nicht für wert gehalten wurde" ${ }^{\text {"5 }}$. Was wir davon vor 1198 dennoch kennen, verdankt sich meistens nicht irgendwelchen Archiven, sondern Briefsammlungen oder anderen literarischen Überlieferungskontexten, bei denen nachträgliche Textbearbeitung selten völlig auszuschließen ist.

Die immanenten Defizite, die der auf die Empfängerarchive zurückgreifende Ansatz mit sich bringt, lassen sich wenigstens ein Stück weit ausgleichen,

4 Vgl. Rudolf Hiestand: 100 Jahre Papsturkundenwerk, in: Hundert Jahre Papsturkundenforschung. Bilanz - Methoden - Perspektiven. Akten eines Kolloquiums zum hundertjährigen Bestehen der Regesta Pontificum Romanorum vom 9.-11. Oktober 1996 in Göttingen, hg.v. Rudolf Hiestand, Göttingen 2003 (AAG, phil.-hist. Kl., 3. Folge 261), S. $11-44$.

5 Rudolf Hiestand: Die Leistungsfähigkeit der päpstlichen Kanzlei im 12. Jahrhundert mit einem Blick auf den lateinischen Osten, in: Papsturkunde und europäisches Urkundenwesen. Studien zu ihrer formalen und rechtlichen Kohärenz vom 11. bis 15. Jahrhundert, hg.v. Peter Herde/Hermann Jakoвs, Köln/Weimar/Wien 1999 (ADipl Beih. 7), S. 1-26, Zitat S. 3. 
wenn man in Betracht zieht, daß die päpstlichen Register aus den Jahrhunderten vor 1198 doch nicht sämtlich und spurlos verloren sind. Sicher ist, daß ihr Bestand einst bis in die Spätantike zurückreichte, wo sich gewiß zur Zeit Leos des Großen († 461), vielleicht auch schon im späten 4. Jahrhundert, verläßliche Hinweise finden, doch steht dahin, wie vollständig und kontinuierlich die Verzeichnung der Auslaufstücke (und womöglich auch von Eingängen) während der vielen einzelnen Pontifikate erfolgt ist, ob es längere Unterbrechungen der Registerführung gab, wann man vom Gebrauch des Papyrus zu dem des Pergaments (und damit von der Rolle zum Codex) überging und welche Ereignisse später zum nahezu vollständigen Untergang der Serie geführt haben ${ }^{6}$. Als einziger Originalband hat sich nach heutigem Urteil der Pergamentcodex mit 381 Stücken der Korrespondenz Papst Gregors VII. († 1085) als Reg. Vat. 2 im päpstlichen Archiv erhalten ${ }^{7}$. Dagegen ist Reg. Vat. 1 eine im späten 11. Jahrhundert von Montecassineser Schreibern gefertigte Teilabschrift aus den an sich verlorenen Registern Papst Johannes' VIII. († 882), die 314 Dokumente der Zeit von 876 bis 882 , also aus sechs der zehn Pontifikatsjahre, anscheinend lückenlos wiedergibt ${ }^{8}$. Nicht mehr im Vatikanischen Archiv anzutreffen sind die drei seit dem 8. Jahrhundert unabhängig voneinander aus den ursprünglichen 14 Papyrusrollen der Register Papst Gregors des Großen († 604) geschöpften Abschriftensammlungen, die sich zu rund 850 Texten ergänzen und insgesamt den Eindruck der Vollständigkeit erwecken'. Schließlich kennt man dank einer weiteren Cassineser Handschrift eine Folge von 38 Briefen, die fast alle aus dem Mai 1130 stammen und auf das Register Papst Anaklets II. († 1138) zurückzuführen $\operatorname{sind}^{10}$.

6 Vgl. Harry Bresslau: Handbuch der Urkundenlehre für Deutschland und Italien, Bd. 1, Leipzig ${ }^{2}$ 1912, S. 104-109; Frenz (wie Anm. 1) S. 60 f.

7 Das Register Gregors VII., hg. v. Erich Caspar, 2 Bde., Berlin 1920-1923 (MGH Epp. sel. 2); vgl. Hartmut Hoffmann: Zum Register und zu den Briefen Papst Gregors VII., in: DA 32 (1976) S. 86-130.

8 Registrum Johannis VIII. papae, hg. v. Erich CAspar, in: MGH Epp. 7, Berlin 19121928, S. XIII-XXII, 1-272; vgl. Dietrich Lohrmann: Das Register Papst Johannes' VIII. (872-882). Neue Studien zur Abschrift Reg. Vat. 1, zum verlorenen Originalregister und zum Diktat der Briefe, Tübingen 1968 (Bibliothek des Deutschen Historischen Instituts in Rom 30).

9 Gregorii I papae Registrum epistolarum, hg. v. Paul Ewald/Ludo Moritz Hartmann, 2 Bde., Berlin 1887-1899 (MGH Epp. 1-2); S. Gregorii Magni Registrum Epistularum, hg. v. Dag Norberg, 2 Bde., Turnhout 1982 (CChrL 140-140A); vgl. Ernst Pitz: Papstreskripte im frühen Mittelalter. Diplomatische und rechtsgeschichtliche Studien zum Brief-Corpus Gregors des Großen, Sigmaringen 1990 (Beiträge zur Geschichte und Quellenkunde des Mittelalters 14).

10 Vgl. Paul Ewald: Reise nach Italien im Winter von 1876 auf 1877, 3: Registrum Anacleti II. antipapae, in: NA 3 (1878) S. 164-168, ohne Edition. 
Das ergibt zusammengenommen immerhin fast 1600 Jaffé-Nummern aus verschiedenen Jahrhunderten, die wir noch im Überlieferungskontext der sonst verlorenen älteren Papstregister vor Augen haben. Hinzukommt eine weniger exakt abgrenzbare Anzahl von Stücken, die von meist kanonistisch interessierten Benutzern der päpstlichen Registerbände, solange diese noch vorhanden waren, einzeln abgeschrieben, teilweise auch nur exzerpiert und zu neuen Sammlungen arrangiert worden sind. Sie geben nicht mehr die ursprüngliche Anordung der Registerbände zu erkennen, bezeugen aber wenigstens deren Existenz sowie die Dauer ihrer Zugänglichkeit und vermitteln so in groben Umrissen weitere Eindrücke von der Entwicklung der Gattung ${ }^{11}$. Die quantitativ bedeutendste Trägerin dieser abgeleiteten Registerüberlieferung ist die sogenannte «Collectio Britannica» einer heute Londoner Handschrift des frühen 12. Jahrhunderts von unbekannter Provenienz, die zu Dutzenden Exzerpte aus den Registern der Päpste Gelasius I. aus dem 5., Pelagius I. und Pelagius II. aus dem 6., Leo IV., Johannes VIII. und Stephan V. aus dem 9. sowie Alexander II. und Urban II. aus dem 11. Jahrhundert enthält. Da die Sammlung auch mit Stücken von anderer Herkunft (wie etwa aus dem Briefbuch des Bonifatius) und mit mutmaßlichen Fälschungen angereichert ist, wird sie kaum unmittelbar und vollständig auf die verlorenen Registerbände zurückzuführen sein, spiegelt aber eben doch die Fülle von deren Inhalten in der weiten zeitlichen Spreizung von den $490 \mathrm{er}$ bis zu 1090er Jahren wider ${ }^{12}$. In erheblichem Maße dürften im übrigen schon die Sammlungen päpstlicher Dekretalen, die seit dem 6. Jahrhundert kursierten, aus römischem Material, also Registern und/oder Konzepten, gespeist sein, das wegen der Präzedenzwirkung der erteilten Rechtsauskünfte gewissermaßen nach Verbreitung über den ursprünglichen Adressaten hinaus drängte ${ }^{13}$. Später haben kirchenrechtliche Autoren aus dem Umfeld des Reformpapsttums wie der Kardinal Deusdedit erklärtermaßen und im Falle des erhaltenen Registers Gregors VII. präzise nachprüfbar die kurialen Archivbestände ausbeuten können, wenngleich daneben bei manchen Manifesten dieses Papstes sicher auch eine vom Register unabhängige propagandistische Weiter-

11 Vgl. Othmar Hageneder: Papstregister und Dekretalenrecht, in: Recht und Schrift im Mittelalter, hg.v. Peter Classen, Sigmaringen 1977 (VuF 23), S. 319-347.

12 Vgl. Paul Ewald: Die Papstbriefe der Brittischen Sammlung, in: NA 5 (1880) S. $275-$ 414, 503-596; Klaus Herbers: Leo IV. und das Papsttum in der Mitte des 9. Jahrhunderts. Möglichkeiten und Grenzen päpstlicher Herrschaft in der späten Karolingerzeit, Stuttgart 1996 (Päpste und Papsttum 27), S. 49-91; Lotte Kéry: Canonical Collections of the Early Middle Ages (ca. 400-1140). A Bibliographical Guide to the Manuscripts and Literature, Washington D. C. 1999 (History of Medieval Canon Law), S. $237 \mathrm{f}$.

13 Vgl. Detlev Jaspen: The Beginning of the Decretal Tradition. Papal Letters from the Origin of the Genre through the Pontificate of Stephen V, in: Ders./Horst Funrmann: Papal Letters in the Early Middle Ages, Washington D. C. 2001 (History of Medieval Canon Law), S. 1-133, hier S. $22 \mathrm{ff}$. 
gabe der Texte von seiten der Empfänger in Gang gekommen ist ${ }^{14}$. Durchaus nennenswert sind schließlich die Hinweise in der reichen kanonistischen Überlieferung des 12./13. Jahrhunderts, die sich auf die verlorenen Register etwa Alexanders II., Paschalis' II. oder Alexanders III. beziehen ${ }^{15}$.

Reiht man alle verfügbaren Spuren der Papstregister vor 1198 chronologisch auf, so heben sich lediglich zwei längere Zeiträume ab, aus denen uns alle Nachrichten fehlen, nämlich das 7. Jahrhundert nach Gregor dem Großen sowie das ganze 10. und frühe 11. Jahrhundert. Es muß letztlich offen bleiben, ob damals die Registerführung zeitweilig ruhte oder ob die Bände so früh untergegangen sind, daß keine für uns noch faßbare Benutzung zustande kam. Ohne Frage ist indes im Hochmittelalter die päpstliche Registerführung als ein uraltes Kontinuum betrachtet worden, selbst wenn sie tatsächlich dann und wann unterbrochen gewesen sein sollte.

Natürlich liegt der Gedanke nahe, die trümmerhaften Überreste der älteren Papstregister vergleichend zu konfrontieren mit den Resultaten der Suche in den Empfängerarchiven. Der Ertrag fällt ziemlich ernüchternd aus, denn es gibt nur minimale Überschneidungen zwischen diesen beiden Wegen der Überlieferung. Von den in den Registerabschriften Gregors des Großen, Johannes' VIII. und auch noch Anaklets II. enthaltenen Texten wäre uns so gut wie nichts bekannt, wenn wir uns stattdessen auf die aufbewahrende Sorgfalt der Adressaten verlassen müßten ${ }^{16}$. Anders beim Register Gregors VII., aus dem drei Stücke auch im expedierten Original bis heute in Saint-Omer, Schaffhausen und Marseille anzutreffen sind ${ }^{17}$. Dazu kommt das bekannte Privileg für das Kloster S. Maria di Banzi im Erzbistum Acerenza, dessen Konzept (offenbar als Formulie-

14 Vgl. John Gilchrist: The Reception of Pope Gregory VII into the Canon Law (10731141), in: ZRGKanAbt 59 (1973) S. 35-82 und 66 (1980) S. 192-229; Ian S. Robinson: The Dissemination of the Letters of Pope Gregory VII During the Investiture Contest, in: JEcH 34 (1983) S. 175-193.

15 Vgl. Walther Holtzmann: Die Register Papst Alexanders III. in den Händen der Kanonisten, in: QFIAB 30 (1940) S. 13-87; Tilmann Sснміdт: Alexander II. (10611073) und die römische Reformgruppe seiner Zeit, Stuttgart 1977 (Päpste und Papsttum 11), S. 220-235; Uta-Renate Blumenthal: Bemerkungen zum Register Papst Paschalis II., in: QFIAB 66 (1986) S. 1-19.

16 Inschriftlich in S. Paolo fuori le mura überliefert ist JE 1991 = Gregor I., Registrum XIV/14; vgl. Julius von Pflugk-Harttung: Papsturkunden auf Marmor, in: QFIAB 4 (1902) S. 167-183, hier S. 167-169. - Ungewiß ist der Zusammenhang zwischen dem 38. und letzten Exzerpt aus dem Register Anaklets II. (wie Anm. 10) und dem seinerseits verstümmelt überkommenen Privileg dieses Papstes für Roger II. von Sizilien vom 27.9. 1130 (JL 8411); vgl. IP 8 S. 37 f. Nr. 137. In die Edition von Hartmut Hoffmann: Langobarden, Normannen, Päpste. Zum Legitimitätsproblem in Unteritalien, in: QFIAB 58 (1978) S. 137-180, hier S. 173-176, ist das Register-Exzerpt nicht einbezogen.

17 JL 5088 = Register Gregors VII. (wie Anm. 7) VI/8; JL $5167=$ Register Gregors VII., VII/24 (GP 2/2 S. 11 f. Nr. 3); JL $5211=$ Register Gregors VII., IX/6. 
rungsmuster) dem Reg. Vat. 2 bloß beigebunden ist und das sich zugleich in seiner originalen Ausfertigung in der Vatikanischen Bibliothek erhalten hat ${ }^{18}$. Außerdem sind immerhin 50 weitere päpstliche Schriftstücke (von insgesamt 363) zu nennen, die unabhängig von ihrem Registereintrag abschriftlich auf uns gekommen $\operatorname{sind}^{19}$, vornehmlich weil sie wegen ihres grundsätzlichen Inhalts alsbald von interessierter Seite in Umlauf gebracht wurden, aber gelegentlich auch weil sie für den Empfänger von spezifischem rechtlichen Belang waren.

Damit ist bereits angedeutet, warum die Aussteller- und die Empfängerüberlieferung, abgesehen von so stürmischen Zeiten wie unter Gregor VII., dermaßen weit auseinanderklaffen. In die älteren Papstregister fanden eben durchweg Briefe Eingang, die beim Adressaten wenig Aussicht auf dauerhafte Aufbewahrung oder kopiale Verbreitung hatten, während die Empfängerarchive Privilegien hüteten, die - anders als in den vorhandenen Registerbänden seit dem 13. Jahrhundert - von der Zentrale nicht langfristig registriert wurden. Jedenfalls ist die Suche nach Indizien für verlorene frühe Privilegienregister neben den Briefregistern trotz eifrigen Bemühens der Forschung im Sande verlaufen ${ }^{20}$. Einen realistischen Einblick in die lange recht summarische Dokumentationspraxis der päpstlichen Kanzlei bei Privilegienerteilungen mag das Register Gregors VII. vermitteln, wo sich am Ende des 1. Pontifikatsjahres ein vom Herausgeber Erich Caspar sogenannter "Jahresschlußbericht" findet, in dem u. a. festgehalten ist, der Papst habe den Erzbischöfen von Cagliari und von Porto Torres auf Sardinien sowie dem Bischof von Verona Pallien samt einem Privileg erteilt, das jeweils weder im Register noch beim Empfänger als solches überliefert ist ${ }^{21}$. Für die Erforschung des päpstlichen Schriftverkehrs bis zum Ende des 12. Jahrhunderts folgt aus dieser Sachlage, daß die Auswertung aller nur erreichbaren Empfängerarchive, das Kernstück von Kehrs Konzept, selbst dann ein unumgängliches Erfordernis wäre, wenn sämtliche Registerbände vor 1198 noch intakt vorhanden wären, denn nach allem, was wir erkennen können, enthielten diese eben selten Privilegien und auch die päpstlichen Briefe keineswegs lückenlos.

Tatsächlich hatte Kehr denn auch mit den Registern eigentlich nichts im Sinn, als er 1896 seinen Plan für das „Göttinger Papsturkundenwerk“ entwikkelte. Nach dem Vorbild der Diplomata-Reihe der Monumenta, die sein Lehrer

18 JL 4929 = Leo SANTIFaller: Quellen und Forschungen zum Urkunden- und Kanzleiwesen Papst Gregors VII. 1: Quellen, Città del Vaticano 1957 (StT 190), S. 76-79 Nr. 95 (IP 9 S. 461 f. Nr. 2).

19 Vgl. Hoffmann: Register (wie Anm. 7) S. 113 f., der 46 Briefe zählt. Hinzukommen vier im Register enthaltene Stücke mit Privilegiencharakter: JL 5068 = Register Gregors VII. (wie Anm. 7) II/59, JL 5125 = Register Gregors VII., VI/34 sowie die beiden in Anm. 17 vermerkten Originale von JL 5167 und 5211.

20 Vgl. Hoffmann: Register (wie Anm. 7) S. 98 ff.

21 Register Gregors VII. (wie Anm. 7) I/85a S. 123. 
Theodor Sickel 1879/84 mit den Urkunden Konrads I., Heinrichs I. und Ottos I. eröffnet hatte, wobei er sich mangels jeglicher Reichsregister ausschließlich auf Empfängerüberlieferung stützte, wollte Kehr auf eine entsprechende Edition der von den einzelnen Päpsten ausgestellten Urkunden hinarbeiten und dafür alle erreichbaren Archive auswerten. Die ihm wohlbekannten älteren Papstregister betrachtete er dagegen weiter als Revier der Monumenta, die nicht in ihren Diplomata, sondern in der Abteilung Epistolae 1887/99 das Register Gregors des Großen durch Paul Ewald und Ludo Moritz Hartmann, 1912 das Register Johannes' VIII. und 1920/23 dasjenige Gregors VII., jeweils durch Erich Caspar, in bis heute maßgeblichen Ausgaben herausgebracht haben, während es im Falle des Registerfragments Anaklets II. bei der Bekanntmachung durch Ewald im Neuen Archiv, der Zeitschrift der Monumenta, geblieben ist ${ }^{22}$. Erst als Kehr vor der Fülle der in Italien auf Anhieb gelungenen Neufunde stand, reifte bei ihm der (1902 erstmals faßbare) Entschluß, der ausstellerbezogenen Gesamtedition der Papsturkunden ein empfängerbezogenes Regestenwerk vorzuschalten, das er zunächst für Italien zu realisieren gedachte. Das war nicht bloß eine arbeitstechnische Kurskorrektur, sondern bedeutete nichts weniger als einen Perspektivenwechsel des ganzen Unternehmens, denn fortan ging es nur noch mittelbar um die Rekonstruktion der päpstlichen Beurkundungspraxis, also die tatsächliche oder vermeintliche Kanzleigeschichte (wie bei den Königen und Kaisern); vielmehr trat die Gesamtheit der Beziehungen zwischen den Empfängerinstitutionen und dem Papsttum, ausgehend von der jeweiligen Archivlage, ins Blickfeld. Wie Rudolf Hiestand gezeigt hat, folgte daraus „fast unvermeidlich eine Erweiterung der aufzunehmenden Zeugnisse ${ }^{\text {“23, }}$, und zwar nicht bloß der päpstlichen Deperdita und weiterer literarischer Belege für Papstkontakte, sondern auch von Schreiben an den Papst und konsequenterweise dann auch der päpstlichen Briefe, die zum großen Teil auf Registerüberlieferung zurückgehen, zumal eine messerscharfe Differenzierung zwischen Papstbriefen und Papsturkunden ohnehin bei näherem Hinsehen allerhand Schwierigkeiten bereitet. Damit verbunden war eine zeitliche Ausdehnung des Arbeitsfeldes auch auf die früheste Zeit vor dem 7./8. Jahrhundert, als sich erst das Privileg als Sonderform des päpstlichen Briefes herausgebildet hat ${ }^{24}$.

Da somit die älteren Papstregister von vornherein in die Ausgestaltung der Italia Pontificia einbezogen waren, stellen sie aus heutiger Sicht kein Potential für Ergänzungen mehr dar. Sich mit ihnen an dieser Stelle zu beschäftigen, mag

22 Wie Anm. 7-10.

23 Vgl. Rudolf Hiestand: Die Italia Pontificia, in: Das Deutsche Historische Institut (wie Anm. 2) S. 167-189, Zitat S. 175.

24 Vgl. Hans Hubert Anton: Studien zu den Klosterprivilegien der Päpste im frühen Mittelalter unter besonderer Berücksichtigung der Privilegierung von St. Maurice d'Agaune, Berlin/New York 1975 (Beiträge zur Geschichte und Quellenkunde des Mittelalters 4). 
daher eher Veranlassung geben, im Rückblick auf die zehn, eigentlich zwölf Bände mit ihren über 11000 Regesten das Gewicht der Registerüberlieferung innerhalb dieser regional gegliederten Dokumentation und darüber hinaus den Anteil Italiens am Gesamtumfang der päpstlichen Registerüberlieferung näher auszuloten ${ }^{25}$.

Beginnen wir mit dem vierzehn Jahre umspannenden Register Gregors des Großen, das schon deshalb das Erscheinungsbild dieses Pontifikates vollkommen beherrscht, weil der speziellere Typ des Papstprivilegs um 600 noch gar nicht entwickelt war. Ohne die Registerabschriften gäbe es kaum ein Dutzend echter Briefe Gregors, zumeist Widmungsschreiben seiner theologischen Werke. Die 852 Registerbriefe beziehen sich zu drei Vierteln auf Italien, wobei zu berücksichtigen ist, daß die Schreiben an die langobardischen Herrscher gemäß einer Entscheidung Kehrs dem Schlußband der Italia Pontificia vorbehalten und daher hier nicht mitgezählt sind ${ }^{26}$. Verglichen mit den Registern späterer Zeit ist der erste Gregor der einzige, der mit seinen 634 Briefen in allen Bänden der Italia Pontificia vertreten ist, wenn auch in ganz unterschiedlichem Maße. Den Löwenanteil mit 270 Stücken macht IP 10 mit dem Schwerpunkt Sizilien aus, wo die römische Kirche bis zum Bilderstreit über ausgedehnten und ertragreichen Grundbesitz verfügte und wo die politisch-militärische Entwicklung während der folgenden Jahrhunderte einer bodenständigen Überlieferung päpstlicher Dokumente aus so früher Zeit keinerlei Chance gelassen hat. Beachtlich im Vergleich mit späteren Epochen ist auch der stattliche Anteil der an Laien gerichteten Papstbriefe, nicht bloß an die Verwalter von Patrimonien, sondern ebenso an die patricii oder sonstige Bürger von Syrakus, Palermo oder Catania. Aus ähnlichen Gründen sehr dicht ist ferner die Folge der Briefe Gregors nach Kampanien (IP 8), darunter allein 38, die sich direkt auf das Patrimonium Campaniae und seine Nutzung beziehen. Daneben schlagen enge Beziehungen zu den Kirchen von Neapel, Capua und Sorrent zu Buch. Die hohe Zahl der Briefe Gregors des Großen in IP 5 (Aemilia) erklärt sich durch die rege Korrespondenz mit Ravenna, und zwar den Bischöfen ebenso wie den kaiserlichen Exarchen, den eigenen Apokrisiaren wie Klerus und Volk von Ravenna. Bildet das Register somit deutlich die räumlichen Schwerpunkte der Aktivitäten des Papstes auf der Apenninenhalbinsel ab, so läßt es indirekt auch die Bereiche erkennen, in denen er sich wegen der langobardischen Dominanz nur mit Mühe zur Geltung bringen konnte. Das zeigt sich an den auffallend niedrigen Zahlen für Etrurien (IP 3) im Vergleich mit Umbrien (IP 4) wie auch für den gesamten Norden Italiens, wo die große Provinz Mailand einschließlich von Piemont und Ligurien (IP 6/1 und 6/2) sowie der Nordosten, also Venezien und Istrien (IP 7/1 und 7/2), weit hinter der Frequenz des Südens zurück-

25 Zum Folgenden vgl. die Tabelle im Anhang.

26 Vgl. Hiestand: Italia (wie Anm. 23) S. 180. 
bleiben. Methodisch ist an dieser Stelle daran zu erinnern, daß die gleichermaßen gegebene Basis in den Registern jeden Gedanken an regional unterschiedliche Überlieferungsbedingungen ausschließt. So verdient auch Beachtung, daß Gregor der Große noch Briefe innerhalb der Stadt Rom schrieb, die in seine Register eingingen und daher in IP 1 vermerkt sind.

Das ebenfalls abschriftlich überlieferte Registerfragment Johannes' VIII. spiegelt bloß sechs Jahre wider, steht aber mit insgesamt 314 Briefen, also 52 pro Jahr, dem berühmten Gregor-Register, das es auf einen jährlichen Durchschnitt von 61 Briefen bringt, nicht allzu weit nach, was vor dem Hintergrund geläufiger Vorstellungen über das spätkarolingische Rom im Vergleich mit der Zeit Gregors des Großen überraschen mag. Bloß noch die Hälfte der Texte hatte Platz in der Italia Pontificia zu finden, doch ist auch hier das Bild dadurch verzerrt, daß immerhin sechs Schreiben an die Kaiserinwitwe Angilberga sowie elf an Karl den Kahlen, sechs an den ostfränkischen Karlmann und gar 22 an dessen Bruder Karl III. als Herrscher Italiens in der Zeit von 876 bis 882 noch für den Schlußband vorgesehen sind ${ }^{27}$, was dann zu alles in allem 203 Regesten in der Italia Pontificia aus den Registern Johannes' VIII. führen wird. Auch mit dieser Modifikation bleibt der gegenüber Gregor dem Großen gesunkene Anteil Italiens an der päpstlichen Korrespondenz ein Indiz der wachsenden römischen Aufmerksamkeit für die Länder jenseits der Alpen seit dem Auftreten der Karolinger ${ }^{28}$. Auch innerhalb Italiens haben sich die Gewichte fühlbar verschoben. Während Kalabrien, Sizilien und die anderen Inseln (IP 10) im tiefen Süden, inzwischen in Händen der Byzantiner, wenn nicht der Sarazenen, in den sechs Pontifikatsjahren keinerlei Beachtung finden, bleiben Neapel, Capua, Salerno und Amalfi, alle in IP 8 erfaßt, mit dem Papsttum verbunden. Das Kloster Montecassino spielt übrigens im Register Johannes' VIII. als Adressat ebensowenig eine Rolle wie bekanntlich zur Zeit Gregors des Großen und erhielt lediglich ein Privileg. Deutlich liegt unter Johannes VIII. der Schwerpunkt päpstlicher Interessen und Wirkungsmöglichkeiten nördlich von Rom im sogenannten Reichsitalien, zumal in Ravenna, Parma, Piacenza (jeweils in IP 5),

27 MGH Epp. 7 S. 42 f. Nr. 44, S. 77 f. Nr. 82, S. 86 f. Nr. 91, S. 88 f. Nr. 94, S. 98 f. Nr. 106, S. 190 f. Nr. 212 an Angilberga, S. 8 f. Nr. 9, S. 10 f. Nr. $11-12$, S. 19 ff. Nr. 22, S. 22 ff. Nr. 24-25, S. 26 f. Nr. 28, S. 29 ff. Nr. $31-32$, S. 46 Nr. 48, S. 51 f. Nr. 56 an Karl den Kahlen, S. 57 f. Nr. 64, S. 85 f. Nr. 89-90, S. 143 f. Nr. 179, S. 154 f. Nr. $193-194$ an Karlmann, S. 41 f. Nr. 43, S. 99 f. Nr. 107, S. 102 Nr. 110, S. 119 Nr. 136, S. 136 f. Nr. 168, S. 144 f. Nr. 180, S. 199 f. Nr. 224-225, S. 207 f. Nr. 233-234, S. 215 f. Nr. 247, S. 219 ff. Nr. 251-252, S. 225 f. Nr. 257, S. 230 f. Nr. 260, S. 232 f. Nr. 263, S. 235 f. Nr. 267, S. 245 Nr. 278, S. 252 f. Nr. 287, S. 254 Nr. 290, S. 259 Nr. 297, S. 263 f. Nr. 304 an Karl III.

28 Vgl. jetzt Dorothee ARnOLD: Johannes VIII. Päpstliche Herrschaft in den karolingischen Teilreichen am Ende des 9. Jahrhunderts, Frankfurt 2005 (Europäische Hochschulschriften 23/797). 
aber auch in Mailand und Pavia (zu finden in IP 6/1). In IP 4 geht es mehrfach um die spannungsreichen Beziehungen zu Graf Lambert von Spoleto, dem späteren Kaiser.

Erhellend für die hohe Bedeutung, die der Vollständigkeit der wenigen überlieferten Register zukommt, mag an dieser Stelle ein Seitenblick auf die (nach unbekannten Kriterien) auswählende Überlieferung in der Collectio Britannica sein, die 55 Briefe desselben Papstes Johannes VIII. aus den im ganzen verlorenen Registern der ersten vier Pontifikatsjahre 872 bis 876 präsentiert $^{29}$. Nur 15 dieser 55 Briefe waren in der Italia Pontificia zu verzeichnen, wozu allerdings aus den genannten Gründen auch hier vier Stücke an Kaiser Ludwig II., zwei an seine Gemahlin Angilberga und eines an beide hinzuzuzählen sind ${ }^{30}$. Doch auch dann bleibt der italische Anteil unter der Hälfte, was den Verdacht weckt, daß sich die Redaktoren der Collectio Britannica überproportional für Betreffe nördlich der Alpen interessiert haben. Bei der Streuung über die einzelnen Bände der Italia Pontificia sticht die Bevorzugung Kampaniens (IP 8) ins Auge, die sich indes auf lauter verschiedene Adressaten verteilt: Montecassino, Gaeta, Salerno, Amalfi, Neapel und Capua. Beeinträchtigt wird das Bild überdies dadurch, daß in mehreren Fällen die radikale Verkürzung der Texte bei der Anlage der Collectio Britannica den Adressaten mehr oder minder unkenntlich gemacht hat. Legt man im übrigen die am Registerfragment von 876 bis 882 ablesbare Jahresfrequenz von 52 Briefen Johannes' VIII. zugrunde, so ließen sich für die vier vorangegangenen Jahre gut 200 Stücke erschließen und bei der Collectio Britannica eine Auswahl von rund 25 Prozent annehmen.

Beim berühmten Originalregister Gregors VII., das zu Beginn der Arbeiten an der Italia Pontificia noch für eine kopiale Auswahl aus umfassenderen, verlorenen Registern dieses Papstes gehalten wurde, ist zu bedenken, daß es neben einer dreistelligen Menge von Privilegien, die nur in ganz seltenen Fällen aufgenommen sind, auch noch in der Größenordnung von 60 bis 70 unzweifelhaft echte Briefe Gregors gibt, die nur außerhalb des Registers auf uns gekommen $\operatorname{sind}^{31}$. Anders als bei Gregor dem Großen und Johannes VIII. kann also Vollständigkeit der Registrierung von Briefen keinesfalls vorausgesetzt werden, ohne daß sich konsequente Auswahlkriterien für die Berücksichtigung eines Textes im Register ausmachen ließen. Die Zahl von 363 Registerstücken, die bezogen auf die knapp elf Jahre, in denen das Register überhaupt geführt

29 Fragmenta Registri Johannis VIII. papae ind. VI-IX (a. 872-876), hg. v. Erich CAsPar, in: MGH Epp. 7 S. 273-312 Nr. 1-15, 17-30, 32-35, 37-58. Die übrigen Stücke entstammen nicht der Collectio Britannica.

30 MGH Epp. 7 S. 287 f. Nr. 25, S. 301 f. Nr. 46, S. 302 Nr. 48, S. 304 ff. Nr. 52 an Ludwig II., S. 279 Nr. 11, S. 302 Nr. 47 an Angilberga, S. 303 Nr. 49 an das Kaiserpaar.

31 The Epistolae Vagantes of Pope Gregory VII, ed. by Herbert Eduard John Cowdrey, Oxford 1972 (Oxford Medieval Texts); dazu kritisch Hoffmann: Register (wie Anm. 7) S. $126 \mathrm{ff}$. 
wurde, auf ein Absinken der jährlichen Quote gegenüber Johannes VIII. von 52 auf 33 schließen lassen müßte, ist also kaum für bare Münze zu nehmen. Eher ist darauf hinzuweisen, daß das Register aus den ersten beiden Pontifikatsjahren Gregors 85 bzw. 77 Einträge aufweist und in der stürmischen Folgezeit ab 1075 eher die Stetigkeit der Registerführung als der Eifer im Aussenden päpstlicher Schreiben nachgelassen haben dürfte ${ }^{32}$. Trotz dieser gravierenden Einschränkung kommt der Feststellung durchaus Aussagekraft zu, daß von den 363 Registerstücken bloß 98 in den Bereich der Italia Pontificia gehören, denn von den 65 Stücken der Sonderausgabe, die Herbert Cowdrey den nicht im Register enthaltenen Gregor-Briefen gewidmet hat, gingen überhaupt nur fünf nach Italien $^{33}$, so daß von einer deutlichen Bevorzugung italischer Betreffe bei der Registerführung gesprochen werden kann. Bei der regionalen Verteilung ist zu beobachten, daß auch Gregor innerhalb Roms ebenso wie in Latium keine Briefe geschrieben hat, die des Registers würdig waren. Im übrigen Italien tritt wie auch früher die Aemilia (IP 5) hervor, diesmal nicht allein wegen Ravenna, wo der Widersacher Wibert saß, sondern mehr noch wegen der fortdauernden Kontakte mit den Markgräfinnen Beatrix und Mathilde von Tuszien, die im selben Bande ausgebreitet sind. In Etrurien (IP 3) dominieren die Beziehungen zu den Bischofssitzen Pisa und Lucca, während sich in IP 6/1 und 6/2 der heftige Streit um die Besetzung des Erzbistums Mailand niederschlägt, der auch die Kommune und verschiedene Suffragane involvierte. Verhältnismäßig schwach zeichnet sich der Briefverkehr mit dem Nordosten, d.h. mit Aquileja, Grado und Venedig, in IP 7/1 und 7/2 ab, wohingegen IP 8 die gesteigerte Bedeutung des Südens in Gestalt von Montecassino, Salerno und Robert Guiscard hervorkehrt. Noch eher am Rande steht das wiedererwachte römische Interesse an den Inseln, worüber IP 10 Auskunft gibt.

Bloß eine Momentaufnahme, aber als solche durchaus von Reiz, ist das knappe Registerfragment Anaklets II. vom Mai 1130. Es zeigt den in Italien relativ gut positionierten Papst im eben ausgebrochenen Schisma mit Innocenz II. eifrig um Anerkennung und Autorität in Frankreich, England und Deutschland bemüht, weshalb die nach Italien gerichtete Korrespondenz auf einen Anteil von weniger als zehn Prozent abfällt. Allerdings ist auch hier zu bemerken, daß die verkürzte Wiedergabe einiger Texte auf Kosten der Adresse gegangen und daher die Zuordnung nicht immer möglich ist. Von den drei in die Italia Pontificia eingereihten Texten ${ }^{34}$ haben im übrigen die beiden, die die

32 Vgl. ebd. S. $110 \mathrm{ff}$.

33 Cowdrey (wie Anm. 31) S. 4 f. Nr. $2=$ JL 4814/IP 3 S. 88 Nr. 3, S. 10 f. Nr. $5=$ JL 4911/IP 5 S. 398 Nr. 14, S. 72 ff. Nr. $28-29=$ JL 5129, 5130/IP 8 S. 148 Nr. $117-$ 118, S. 104 f. Nr. 43 = JL 5219/IP 3 S. 482 Nr. 3.

34 JL 8390 = IP 2 S. 68 Nr. 51, JL $8402=$ IP 7/1 S. 34 Nr. 76, JL $8405=$ IP 1 S. 84 Nr. 3. Fraglich ist die Beurteilung von JL 8411, siehe Anm. 16. 
Kanoniker von S. Lorenzo in Lucina in Rom bzw. die Abtei Farfa betreffen, eher den Charakter von Privilegien oder Mandaten als von Briefen.

Mehr hat die Italia Pontificia und hat die Papstdiplomatik überhaupt an direkter, also nicht durch Auswahl verkürzter Registerüberlieferung vor 1198 nicht zu bieten. Trotz des sehr begrenzten und völlig vom Zufall bestimmten Umfangs ist das längst bekannte und historisch ausgewertete Material immer aufs neue dazu angetan, zum Nachdenken über die Bedingungen und Grenzen unserer Kenntnis der älteren Papstgeschichte anzuregen. Darin liegt sein bleibender Wert.

\section{Riassunto}

La trasmissione frammentata dei registri papali relativi ai pontificati fino al 1198 (fondamentalmente quelli di Gregorio VII in originale, quelli di Gregorio il Grande, Giovanni VIII e Anacleto II in copia) riguarda quasi esclusivamente le lettere, sicché solo raramente si trovano dei riscontri nei fondi archivistici dei destinatari che contengono esclusivamente dei privilegi. Nell'impostare l'Italia Pontificia, Kehr non poteva dunque mirare a una ricostruzione dei tanti volumi andati persi; si è piuttosto limitato a utilizzare quelli conservati come documenti complementari alle sue richerche archivistiche. Un'analisi statistica dei dati, i quali sono contenuti nei registri considerati nei singoli volumi dell'IP, rivela che il numero delle occorrenze italiane, confrontato con il contenuto complessivo dei registri da Gregorio il Grande fino ad Anacleto II, diminuisce costantemente (in concomitanza con l'espansione territoriale dell'autorità papale nel mondo cristiano), e che le priorità territoriali dei contatti in Italia variano tra pontificato e pontificato in modo considerevole.

\section{Anhang}

Siehe die Tabelle auf der folgenden Seite. 


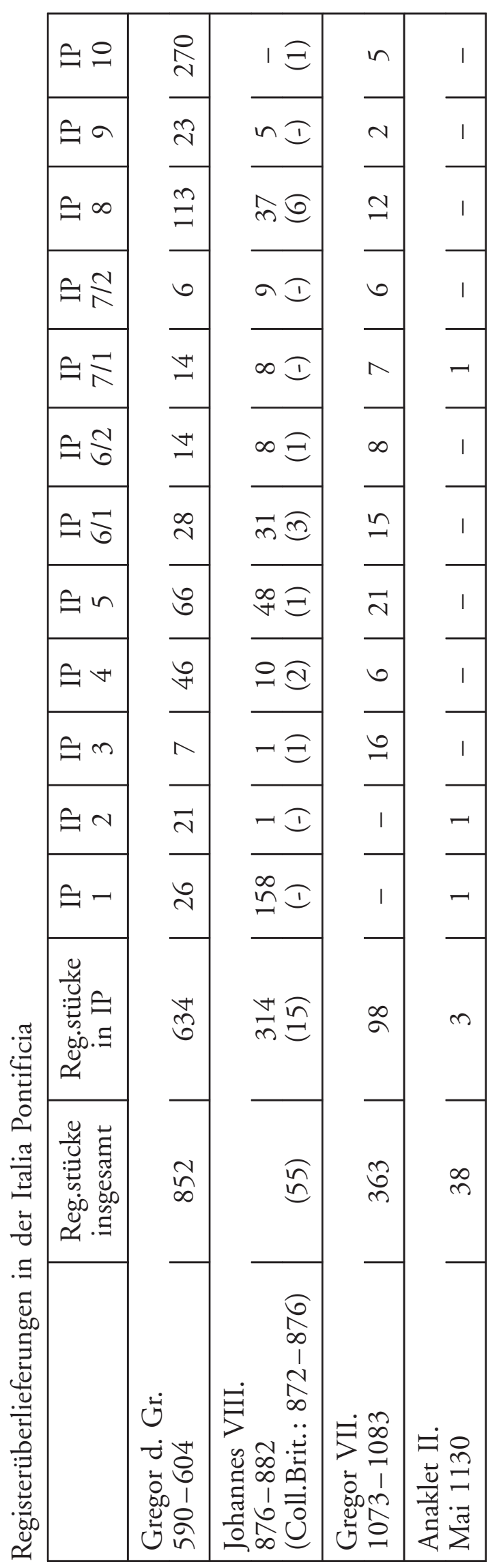


Bereitgestellt von | De Gruyter / TCS

Angemeldet | 217.89.40.26

Heruntergeladen am | 21.12.12 10:48 


\title{
Kanonessammlungen als Fundorte für päpstliche Schreiben
}

\author{
LOTTE KÉRY
}

„Papsturkunden ohne Ende“ - mit diesem Stoßseufzer begann nicht nur Paul Fridolin Kehr im Jahre 1905 den ersten seiner Berichte mit dem Titel „Nachträge zu den Papsturkunden Italiens", sondern auch Rudolf Hiestand stimmte vor 10 Jahren in seinem Göttinger Vortrag „100 Jahre Papsturkundenwerk“ erneut in dieses Lamento ein $^{1}$, das wohl vor allem auf die Italia pontificia zutrifft, die mit bisher 11024 Regesten den größten Umfang der nationalen Papsturkundenwerke darstellt. Vor diesem Hintergrund dürfte es schwerfallen, den Bearbeitern noch weitere Fundorte für ihre Sammel- und Editionstätigkeit päpstlicher Schreiben zu empfehlen, die außerdem noch erhebliche Schwierigkeiten bei der Erschließung bieten - wie die kanonistischen Sammlungen.

Von Anfang an war man sich dieser Schwierigkeiten bewußt. Kehr - nach eigener Einschätzung „,reinster Diplomatiker Sickelscher Observanz “2 - wollte in seinem ursprünglichen Plan noch das ganze in Registern, Brief- und Kanonsessammlungen enthaltene kanonistische Material bewußt ausschließen ${ }^{3}$. Ein halbes Jahrhundert später dehnte dagegen Walther Holtzmann, der um mit den Worten Rudolf Hiestands zu sprechen, „weniger Diplomatiker als Historiker mit ausgeprägten kirchenrechtlichen Interessen" war $^{4}$, schon einmal mit Nachdruck das Aufgabenfeld auf die Kanonistik aus, als er damit begann, die Dekretalensammlungen zwischen Gratian und dem «Liber Extra» Gregors IX. für die Italia pontificia auszuwerten und als erstes eine Liste von Dekretalen

1 Rudolf Hiestand: 100 Jahre Papsturkundenwerk, in: Hundert Jahre Papsturkundenforschung. Bilanz - Methoden - Perspektiven, hg. v. Rudolf Hiestand, Göttingen 2003 (AAG phil.-hist. Kl., 3. Folge 261), S. 11-46, hier S. 44.

2 Vgl. Walther Holtzmann: Kanonistische Ergänzungen zur Italia Pontificia, in: QFIAB 37 (1957) S. 55-102; 38 (1958) S. 67-175 (Separatdruck Tübingen 1959) hier QFIAB 37, S. 55.

3 Hiestand (wie Anm. 1) S. 32; vgl. dazu auch Paul F. Kehr: Ueber den Plan einer kritischen Ausgabe der Papsturkunden bis Innocenz III., in: NGG, Geschäftliche Mitteilungen (1896) S. 72-86, hier S. 76-77 (ND in: Paul Fridolin KeHr: Ausgewählte Schriften, hg.v. Rudolf Hiestand, Bd. 1, Göttingen 2005 [AGG phil.-hist. Kl., 3. Folge 250], S. 3-17). Kehr hatte zwar einzelne dieser Dekretalensammlungen, die schon früher bekannt waren, in den Bänden der Italia pontificia verzeichnet, aber „eine Vollständigkeit der handschriftlichen Quellen für die kanonistisch überlieferten Papstbriefe hat er nicht angestrebt, da von Anfang an ihre Herausgabe dem ursprünglichen Plane ferne lag", Holtzmann: Ergänzungen (wie Anm. 2) S. 56.

4 Hiestand (wie Anm. 1) S. $32 \mathrm{f}$. 
herausgab, die in Sammlungen vor der "Compilatio secunda», also vor 1210/ 1212, zu finden sind ${ }^{5}$.

Holtzmann wollte in diesem Zusammenhang unter Dekretalen, wie er ausdrücklich betont, „diejenigen Briefe und Erlasse [verstehen], die wir nur aus der kanonistischen Überlieferung kennen, aus zunächst privaten und anonymen Sammlungen, wie sie nach dem Erscheinen von Gratians Dekret in großer Fülle entstanden und schließlich einmündeten in die offizielle Kodifikation Gregors IX." ${ }^{~}$ Dem berechtigten Einwand Kuttners, daß diese Definition zu eng gefaßt sei $^{7}$, begegnete er mit dem Hinweis, daß die Bezeichnung Dekretalen für seine Arbeit vor allem die unbeholfene Formulierung „kanonistisch überlieferte Papstbriefe" ersetzen sollte, denn es ging ihm ja hier vor allem um eine überlieferungsbedingte Abgrenzung zu den übrigen Papsturkunden und nicht um eine genauere inhaltliche Beschreibung der Dekretalen ${ }^{8}$.

Mit seinen „Kanonistischen Ergänzungen zur Italia Pontificia“, konnte er an konkreten Fällen zeigen, „wieviel dieser Quellengattung auch für die Regestenbände abzugewinnen war" ${ }^{\text {"9. }}$. Im Sinne des von Kehr formulierten Zieles, eine "möglichste Vollständigkeit in der Sammlung des Materials“ anzustreben ${ }^{10}$, hielt Holtzmann die kanonistischen Quellen für unverzichtbar, da sie vollständige Texte oder zumindest Bruchstücke davon liefern konnten, auf die bei der Herstellung, Datierung und Lokalisierung und schließlich auch bei der Interpretation der eigentlichen „Urkunde“ nicht verzichtet werden konnte ${ }^{11}$. Sein Programm lautete, daß das kanonistisch überlieferte Material insgesamt verzeichnet werden müsse, neugefundene Texte wären zu publizieren und auch für die schon registrierten Papsturkunden könnten schließlich aufgrund des beträchtlich vermehrten Überlieferungsmaterials Korrekturen vorgenommen werden ${ }^{12}$. Prinzipiell sind also von den kanonistischen Sammlungen sowohl neue Texte als auch zusätzliche Überlieferungen bereits bekannter Texte, die ergänzende Informationen zum Inhalt und zur historischen Einordnung der Stücke bieten könnten, zu erwarten.

Gleichzeitig plädierte Holtzmann jedoch auch dafür, die vollständige Aufzählung der gesamten handschriftlichen Überlieferung dieser kanonistisch

5 Ebd. S. 32; Walther Holtzmann: Über eine Ausgabe der päpstlichen Dekretalen des 12. Jahrhunderts, in: NGG phil.-hist. Kl. (1945), S. 15-36; Holtzmann: Ergänzungen (wie Anm. 2).

6 Holtzmann: Ergänzungen (wie Anm. 2) S. 56.

7 Stephan Kuttner: Notes on a Projected Corpus of Twelfth-Century Decretal Letters, in: Traditio 6 (1948) S. 345 Anm. 3.

8 Holtzmann: Ergänzungen (wie Anm. 2) S. 56 Anm. 5.

9 Hiestand (wie Anm. 1) S. $32 \mathrm{f}$.

10 Holtzmann: Ergänzungen (wie Anm. 2) S. 56.

11 Holtzmann: Ergänzungen (wie Anm. 2) S. 57.

12 Holtzmann: Ergänzungen (wie Anm. 2) S. 57. 
überlieferten Texte nicht in den Regesten der Italia pontificia, sondern in ergänzenden Werken vorzunehmen, um den Benutzer nicht zu verwirren ${ }^{13}$ und wie man hinzufügen könnte - das Material mit den Hinweisen auf die zum Teil sehr umfangreiche kanonistische Überlieferung nicht unsachgemäß aufzublähen.

Mit seinen „Kanonistischen Ergänzungen“, die das Regestenwerk nicht nur ergänzen, sondern auch entlasten sollten, stellte Holtzmann also auch die Weichen dafür, daß die Erfassung der Dekretalen zu einer eigenen Abteilung unter der Leitung von Stephan Kuttner († 1996) in Berkeley ausgebaut wurde. Leider ist das Werk der «Regesta decretalium», das einen Gesamtüberblick auf der Grundlage des Nachlasses von Walther Holtzmann liefern sollte und eine hervorragende Ergänzung zum Papsturkundenwerk bieten könnte, bisher über Anfänge nicht hinausgekommen ${ }^{14}$. Inzwischen werden jedoch Holtzmanns Karteikarten in digitalisierter Form auf der Internetseite des Stephan-KuttnerInstitutes in München zugänglich gemacht ${ }^{15}$.

Obwohl Holtzmann selbst sich zunächst den nachgratianischen Dekretalensammlungen zugewandt hatte, sprach er auch die Empfehlung aus, daß die Arbeit, die er für die Zeit zwischen Gratian und der "Compilatio secunda» in Angriff genommen habe, in ähnlicher Weise für die vorgratianischen Sammlungen unternommen werden müßte. Er gesteht zwar zu, daß dies eine noch umfangreichere und - wie man hinzufügen muß - wohl auch noch schwierigere Aufgabe wäre, verweist jedoch hinsichtlich ihres großen Nutzens gerade auch für die Historiker auf den Band von Gassó und Batlle über die Briefe Pelagius' I. ${ }^{16}$

$\mathrm{Da}$ also für die nachgratianischen Dekretalensammlungen zumindest zum Teil schon gezeigt wurde, daß ihre Einbeziehung sinnvoll und ertragreich ist, möchte ich mich heute den vorgratianischen Sammlungen zuwenden und versuchen, in groben Zügen die Bedeutung oder besser gesagt die Problematik dieser Sammlungen als Fundorte für päpstliche Schreiben darzustellen und die Besonderheiten dieser Überlieferung in chronologischer Abfolge an einigen Beispielen aufzuzeigen.

13 Holtzmann: Ergänzungen (wie Anm. 2) S. 57.

14 Vgl. dazu auch schon Peter Landau: Die Entstehung der systematischen Dekretalensammlungen und die europäische Kanonistik des 12. Jahrhunderts, in: ZRGKanAbt 65 (1979) S. 120-148, hier S. 121.

15 Internetadresse: www.kuttner-institute.jura.uni-muenchen.de/holtzmann_formular.htm (01.01.2008).

16 Pius M. Gassó/Columba M. Batlle: Pelagii I papae epistulae quae supersunt, Montserrat 1956 (Scripta et documenta 8); vgl. Holtzmann: Ergänzungen (wie Anm. 2) S. 56 Anm. 5. 
Ähnlich wie die Dekretalensammlungen der nachgratianischen Zeit überliefern auch die kanonistischen Sammlungen, die vor dem «Decretum Gratiani» (um 1140) entstanden sind, nicht nur - wie es der Name zunächst vermuten läßt Kanones oder Konzilsbeschlüsse, sondern auch Dekretalen, epistolae oder litterae decretales, das heißt ganz spezielle Papstbriefe, die sich nicht nur durch die besondere Form ihrer Überlieferung, sondern auch inhaltlich von den feierlichen Privilegien und den übrigen päpstlichen litterae unterscheiden. Dekretalen zeichnen sich dadurch aus, daß sie eine päpstliche Entscheidung übermitteln, ihr Ziel ist die Normgebung und die Festsetzung vor allem disziplinarischer Regeln ${ }^{17}$. Technisch gesprochen handelt es sich dabei meist um Responsa oder Reskripte, die nach dem Vorbild der spätantiken Kaiserreskripte autoritative Antworten gaben auf eine Appellation oder eine Bitte um Rechtsauskunft in einem konkreten Fall, die an den Hl. Stuhl gerichtet wurden.

Diese inhaltliche Einschränkung prädestinierte solche päpstlichen Schreiben für eine Aufnahme in kirchenrechtliche Sammlungen. Das heißt jedoch umgekehrt nicht, daß man in kanonistischen Sammlungen nicht auch andere Papstbriefe findet, die sich etwa mit Verwaltungsangelegenheiten beschäftigen oder auch reine Freundschaftsbriefe, wie z. B. der von Hageneder zitierte Brief Papst Innozenz' I. an eine vornehme Dame Juliana (JK 302), in dem der Papst ihren religiösen Eifer lobt und sie ermahnt, diesen auch in Zukunft beizubehalten ${ }^{18}$.

Dies gilt speziell für die vorgratianischen Sammlungen, denn in ihrer Entstehungszeit hat man unter dem Begriff ,Dekretale' noch in einem sehr weiten Sinne „alle Schreiben von Belang, die für kirchenrechtliche Fragen einmal Bedeutung erlangen konnten "19, verstanden. So enthält etwa die gegen Ende des 11. Jahrhunderts entstandene "Collectio Britannica» noch die in die Jahre 558/60 zu datierende Anweisung Pelagius' I. an einen comes Gurdimer, die Wiesen an der Straße nach Porto mähen zu lassen ${ }^{20}$. Auch Detlef Jasper hat vor

17 Charles Duggan: Art. Decretals (epistolae decretales, litterae decretales); Decretals, Collections of', in: NCE 4 (1967) S. 707-711, hier S. 707; vgl. Detlev Jasper: The Beginning of the Decretal Tradition. Papal Letters from the Origin of the Genre through the Pontificate of Stephen V., in: Ders./Horst Funrmann: Papal Letters in the Early Middle Ages, Washington D.C. 2001 (History of Medieval Canon Law), S. 3-133, hier S. 19.

18 Othmar Hageneder: Papstregister und Dekretalenrecht, in: Recht und Schrift im Mittelalter, hg. v. Peter Classen, Sigmaringen 1977 (VuF 23) S. 319-347, hier S. $327-$ 328; Jasper (wie Anm. 17) S. 36 („private letter[s]“).

19 Hageneder (wie Anm. 18) S. 327.

20 JK 1034; Gassó-Batlle (wie Anm. 16) S. 191; vgl. Hageneder (wie Anm. 18) S. 328; Jasper (wie Anm. 17) S. 65 Anm. 276. 
kurzem noch einmal betont, daß eine absolute Trennung zwischen Dekretalen und Papstbriefen letztlich unmöglich ist ${ }^{21}$ - oder wie Stanley Chodorow es formuliert hat: „Decretals are papal letters, but exactly what type of letters is hard to define." ${ }^{22}$ Im neunten Jahrhundert konnte sogar noch jeder Papstbrief als epistola decretalis gekennzeichnet werden ${ }^{23}$.

Auch diese fehlende Trennschärfe zwischen Dekretalen und Papstbriefen unterstreicht die Notwendigkeit, die päpstlichen Schreiben, die man in Kanonessammlungen findet, in das Papsturkundenwerk miteinzubeziehen, denn wir haben es hier mit päpstlichen Schreiben zu tun, die zwar in erster Linie rechtliche Inhalte transportieren, aber zugleich auch dazu beitragen können, die Beziehungen des Papsttums zu den einzelnen Ortskirchen genauer zu beschreiben.

Obwohl häufig der Eindruck erweckt wird, als gebe es Dekretalen erst seit der zweiten Hälfte des 12. Jahrhunderts ${ }^{24}$, stammt die nach heutigem Kenntnisstand älteste echte Dekretale (JK 255) von Papst Siricius $(384-399)^{25}$ und damit vom Ende des 4. Jahrhunderts - und schon im 5. und 6. Jahrhundert wurden solche päpstlichen Schreiben dann auch zu Sammlungen zusammengestellt bzw. in Kanonessammlungen aufgenommen ${ }^{26}$. Es fällt auf, daß diese frühen Dekretalen sich an weiter entfernte Adressaten wenden - die acht Dekretalen, die in den ältesten italienischen und gallischen Sammlungen des 5. und 6. Jh. gefunden werden, gehen nach Nordspanien (Tarragona), Gallien (Rouen, Toulouse, Vienne, Narbonne), nach Makedonien und Dacien sowie nach Salona an der dalmatischen Küste (heute Kroatien) ${ }^{27}$. Adressat in Italien ist lediglich Decentius von Gubbio in dem bekannten Schreiben Innozenz' I. (JK 311), das ebenfalls zu dieser Gruppe gehört. ${ }^{28}$ Andererseits findet sich etwa die Dekretale des Papstes Siricius an die Bischöfe der römischen Kirchenprovinz über die Weihe von Priestern und Bischöfen (JK 263) allein in der «Collectio Hispana ${ }^{29}$.

21 Jasper (wie Anm. 17) S. 20 Anm. 74. Vgl. dort auch S. 12 (,Definition of a Decretal').

22 Stanley Chodorow: Art. Decretals, in: Dictionary of the Middle Ages 4 (1984) S. $122-$ 124, hier S. 122.

23 Jasper (wie Anm. 17) S. 20 Anm. 74.

24 Vgl. dazu Jasper (wie Anm. 17) S. 12.

25 Peter Landau: Rechtsfortbildung im Dekretalenrecht. Typen und Funktionen der Dekretalen des 12. Jahrhunderts, in: ZRGKanAbt 86 (2000) S. 86-131, hier S. 87; JAsper (wie Anm. 17) S. 9-12; dort auch (S. 11, Anm. 31) die Ankündigung einer Neuedition dieser Dekretale durch Klaus Zechiel-Eckes.

26 Jasper (wie Anm. 17) S. 22-34.

27 Ebd. S. 22; vgl. dort auch S. 20 Anm. 77.

28 Ebd. S. $27 \mathrm{f}$.

29 Später wurde sie in die Sammlung der pseudoisidorischen Dekretalen aufgenommen und auch in vorgratianischen Sammlungen - wahrscheinlich wegen ihres Inhalts - häufig zitiert, JASPER (wie Anm. 17) S. 35. 
Dies zeigt ebenso wie die verbreitete Praxis, Dekretalen oder sogar ganze Dekretalenblöcke aus früheren Kanonessammlungen in neue Sammlungen zu übernehmen, daß man die Suche nach Dekretalen mit italienischen Adressaten keinesfalls auf Sammlungen beschränken kann, die in Italien angelegt wurden, ganz abgesehen davon, daß die Bestimmung des Entstehungsortes sich für so manche Sammlung als äußerst schwierig erweist ${ }^{30}$.

Die bekannteste und wohl auch im Hinblick auf ihre Folgewirkung wichtigste Sammlung aus der frühen Zeit ist die Sammlung von 38 Dekretalen, die Dionysius Exiguus um 500 zusätzlich zu seiner eigentlichen Kanonessammlung, d. h. seiner Sammlung von Konzilsbeschlüssen, zusammenstellte ${ }^{31}$. Dies war für die Kanonistik ein wichtiger Meilenstein, denn mit dieser berühmten Sammlung päpstlicher Schreiben wurde zum erstenmal Dekretalenrecht gleichberechtigt neben Konzilsrecht gestellt ${ }^{32}$. Anschließend wurde dann die «Dionysiana» selbst zu einer wichtigen Quelle für Papstbriefe, denn die Version, die auch die Dekretalen enthält, wurde für die wichtigsten vorkarolingischen systematischen Sammlungen einschließlich der "Concordia canonum» des Cresconius und der «Vetus Gallica» benutzt ${ }^{33}$. Alle päpstlichen Dekretalen der «Dionysiana» wurden zudem in die chronologische Version der "Collectio Hispana» übernommen ${ }^{34}$.

Damit zeigt sich eine weitere grundsätzliche Schwierigkeit für die Erschließung des kanonistisch überlieferten Textmaterials, die darin besteht, daß

$30 \mathrm{Zu}$ dieser Problematik und zu der Frage, ob Anhaltspunkte für den Entstehungsort auch von den Adressaten der Dekretalen abgeleitet werden können, vgl. auch Holtzmann: Ergänzungen (wie Anm. 2) S. 69-71. Er betont, daß „italienische“ Dekretalen nicht nur durch italienische Sammlungen überliefert werden, sondern sie kommen auch in „Zweifelsfrei“ englischen und französischen Sammlungen vor, manchmal sogar „in besserer Textform“. Zudem weist er darauf hin, daß die «Collectiones Cheltenhamenensis» und "Cottoniana» sogar ,italienische“ Texte enthalten haben, die sonst in der gesamten Überlieferung fehlen. Dies sei nur durch „intensive Sammeltätigkeit“ zu erklären, „welche zu verschiedenen Zeiten und durch verschiedene Interessenten aus allen Ländern zentrale kirchliche Quellen, also das päpstliche Archiv, ausgebeutet hat" (S. 70).

31 Hubert Wurm: Studien und Texte zur Dekretalensammlung des Dionysius Exiguus, Bonn 1939 (Kanonistische Studien und Texte 16). Dekretalen der Päpste Siricius, Innozenz I., Zosimus, Bonifacius I., Cölestin I., Leo I., Gelasius I. und Anastasius II. wurden im Nachhinein der zweiten Version der «Dionysiana» hinzugefügt. Linda Fowler-Magerl: Clavis Canonum. Selected Canon Law Collections Before 1140. Access with data processing, Hannover 2005 (MGH Hilfsmittel 21), S. 29-32, v.a. S. 31.

32 Landau: Entstehung (wie Anm. 14) S. 120. Übersicht über Handschriften, Editionen und Literatur zur "Dionysiana»: Lotte Kéry: Canonical Collections of the Early Middle Ages (ca. 400-1140): A Bibliographical Guide to the Manuscripts and Literature, Washington D.C. 1999 (History of Medieval Canon Law), S. 11-21.

33 Fowler-Magerl (wie Anm. 31) S. 31.

34 Ebd. S. 31. 
die Papstbriefe in den Kanonessammlungen in vielen Fällen sogar mehrfach indirekt überliefert sind ${ }^{35}$. Als erstes ist deshalb mit Rudolf Hiestand hervorzuheben, daß die kanonistisch überlieferten Papstbriefe für eine Diplomatik der Papsturkunden im engeren Sinne, d.h. bezüglich Form und Kanzlei, in der Regel nichts ergeben ${ }^{36}$. Auf der anderen Seite verdienen es natürlich gerade die päpstlichen Schreiben, die immer wieder in andere Kanonessammlungen übernommen wurden, als Texte, die weithin zirkulierten und von vielen gelesen und benutzt wurden, auch in besonderer Weise in ihren verschiedenen Versionen rekonstruiert zu werden, was sich jedoch aufgrund der reichen handschriftlichen Überlieferung auch als besonders schwierig erweist ${ }^{37}$.

Gleichzeitig stellt sich die Frage, wie es um die Authentizität dieser in Kanonessammlungen tradierten Papstbriefe bestellt ist. Wie schon Hubert Wurm erkannte, stammen die Papstbriefe, die wir in der "Dionysiana» finden und das gilt auch für die meisten anderen frühen kanonistischen Sammlungen -, nicht unmittelbar aus den päpstlichen Archiven ${ }^{38}$. „Es ist also sicher“, schreibt Wurm, „so sehr die Dekretalensammlung des Dionysius Exiguus in der Wertschätzung steigen müßte, wenn die Registerbücher des päpstlichen Archivs als ihre Quelle erwiesen werden könnten, so steht doch fest, daß alle auffindbaren Kennzeichen bezeugen, daß dies nicht der Fall war. ${ }^{\text {“39 }}$

Registerbenutzung der Sammler gilt demnach als ein wichtiges Kriterium für die Authentizität und Verläßlichkeit der Texte, ein Aspekt der natürlich auch für die Gewinnung und Einschätzung von Texten aus den Kanonessammlungen für die Italia pontificia von großer Bedeutung ist. Im Hinblick auf eine Identifizierung „neuer“ Papsturkunden oder auch Ergänzung und Korrektur bekannter Papsturkunden mit Hilfe der kanonistischen Überlieferung ginge es also nicht nur darum festzustellen, in welchen Sammlungen Papstbriefe mit italienischen Adressaten enthalten sind, sondern auch, in welchen Sammlungen diese erstmals tradiert werden, welche Papstbriefe unmittelbar aus den päpstlichen

35 Dazu auch Kuttner: Notes (wie Anm. 7) S. 345.

36 Hiestand (wie Anm. 1) S. 33.

37 Kuttner: Notes (wie Anm. 7) S. 345.

38 Wurm (wie Anm. 31) S. 190 f.; Fowler-Magerl (wie Anm. 31) S. 31.

39 Dies wird unter anderem daraus abgeleitet, daß Unregelmäßigkeiten im Protokoll vorkommen und die Datierung in den Schreiben fehlt, vgl. JAsper (wie Anm. 17) S. 36. Wurm weist zudem darauf hin, daß Dionysius eigens vermerkte, wenn er Texte aufnahm, die unmittelbar aus den römischen Archiven stammten. Vgl. Wurm (wie Anm. 31) S. 230: „Für eine Benützung des römischen Archivs durch Dionysius ist also keinerlei Anhaltspunkt gegeben; wohl aber bezeugt Dionysius selbst indirekt, daß es nicht der Fall war. [...] Dionysius macht eigens darauf aufmerksam, wenn er Material benützt, das direkt aus dem römischen Archiv stammt; also ist das Schweigen darüber bei der Dekretalensammlung beweiskräftig. [...] Vgl. dort auch S. 228: „Dionysius aber hatte persönlich keinen Zugang zu den päpstlichen Regesten [!], und auch seine Sammlung beruht nicht auf Registerauszügen." 
Archiven oder Registern stammen oder möglicherweise auch nachträglich anhand von Archiv- oder Registerversionen korrigiert wurden.

Als eine solche Sammlung, bei der die unmittelbare Verwendung der Papstregister zumindest für die 138 Briefe des Papstes Hormisda aus den Jahren 515 bis 521 feststeht, hat die um 555 entstandene, chronologisch angelegte «Collectio Avellana» zu gelten ${ }^{40}$, die jedoch nur noch in Handschriften des 11. Jahrhunderts überliefert ist. Neben den Briefen des Papstes Hormisda enthält sie auch Schreiben anderer Päpste des 5. und 6. Jahrhunderts, wie des Simplicius (468-483), Gelasius (492-496), Symmachus (514), Johannes' II. (532-535), Agapet (535/536) und Vigilius (537-555) und stellt auch die einzige Überlieferung für fünf Briefe Papst Leos I. (JK 546-550) dar, die auf den 17. Juni und 18. August 460 datiert sind. Ähnlich wie auch spätere Sammlungen dieses Typs, wie z. B. die noch eingehender zu besprechende "Collectio Britannica», scheint die "Avellana» jedoch keinen größeren Einfluß auf andere vorgratianische Sammlungen ausgeübt zu haben ${ }^{41}$.

Offenbar waren sich auch schon die Sammler bewußt, daß die Überlieferung der Papstschreiben in kanonistischen Sammlungen gewisse Probleme im Hinblick auf die Glaubwürdigkeit der Texte aufwerfen konnten und suchten sich deshalb durch eine nachträgliche Überprüfung abzusichern. So übernahm etwa der Kardinalpriester Gregor von San Grisogono für seine Sammlung «Polycarpus» um die Wende vom 11. zum 12. Jahrhundert Briefe Papst Gregors I. aus früheren Sammlungen, griff jedoch anschließend unmittelbar auf dessen Register zurück, um die Inskriptionen zu vervollständigen ${ }^{42}$. Die hier aufscheinende Problematik, daß die Inskriptionen und damit die Nennung der Adressaten in den Dekretalen - gelinde gesagt - nicht immer zuverlässig und vor allem häufig unvollständig sind, stellt für die Erschließung päpstlicher Schreiben aus Kanonessammlungen ein ganz fundamentales Problem dar, wie später noch an einigen Beispielen zu zeigen sein wird.

40 Vgl. Hageneder (wie Anm. 18) S. 321 (dort auch eine Aufzählung der Indizien für Registerbenutzung).

41 Jasper (wie Anm. 17) S. 84; vgl. auch Otto GüNTHer: Epistulae Imperatorum, Pontificum, aliorum inde ab anno 367 ad annum 553 datae Avellana quae dicitur collectio, Wien 1895-1898 (CSEL 35/1-2). Möglicherweise wurde die "Collectio Avellana» von dem Redaktor der italienischen 2-Bücher-Sammlung des Vat. lat. 3832 für einige Gelasianische Exzerpte benutzt, vgl. Jasper (wie Anm. 17) S. 83-85; sie enthält auch den vollständigen Text von JK 664 (Gelasius' Rechtfertigung der Verhängung des Anathems über Acacius), der sonst immer nur ohne Schluß in zahlreichen Sammlungen überliefert ist (ebd. S. 85).

42 Vgl. Fowler-Magerl (wie Anm. 31) S. 231; zur Benutzung von Gregor-Briefen vgl. auch Jasper (wie Anm. 17) S. 79-80; Ute-Renate Blumenthal stellte zudem fest, daß Gregor von San Grisogono auch die offizielle Version der Dekrete des Konzils von Clermont benutzte, d. h. die Form, die im Register oder für das Register verbessert wurde (Fowler-Magerl S. 231). 
Hageneder hat in seinem Beitrag über Papstregister und Dekretalenrecht die Phase bis ca. 1200 jedenfalls als „Zeit einer losen und eher zufälligen Beziehung zwischen Papstdekretalen und Registern" gekennzeichnet ${ }^{43}$. Die Dekretalen der Päpste seien zwar meist auf dem Wege über Auszüge aus ihren Registern bekannt geworden, diese hätten jedoch nicht immer systematisch alle vorhandenen Bücher erfaßt. Auf solche Exzerpte hätten sich dann die Kompilatoren der kanonistischen Sammlungen wohl vorwiegend gestützt, die diese Schreiben jedoch auch längst nicht immer vollständig in ihre Sammlungen übernahmen ${ }^{44}$.

Vollständige Papstbriefe kann man prinzipiell eher in den chronologisch geordneten Sammlungen erwarten, in denen die Texte zum Teil auch im vollen Wortlaut wiedergegeben werden und nicht schon nach inhaltlich-systematischen Gesichtspunkten zerstückelt und als Einzelexzerpte dann unter den jeweils passenden Rubriken oder Titeln eingeordnet wurden.

Jedoch schon in der "Dionysiana" werden die Papstbriefe offenbar nicht mehr so sehr als Briefe im eigentlichen Sinne betrachtet, sondern in erster Linie als „Steinbruch“ für einzelne päpstliche Rechtsaussagen, die in ihnen enthalten sind. Dies kann man daran erkennen, daß dort die Dekretalen der einzelnen Päpste zwar noch vollständig wiedergegeben werden, jedoch in Abschnitte unterteilt sind, die für jeden Papst separat durchnummeriert werden, nicht einzeln für jeden Brief ${ }^{45}$. Hier zeichnet sich offenbar schon der erste Schritt zur Vorbereitung auf eine thematisch geordnete Erfassung der päpstlichen Aussagen ab.

Die erste größere systematisch geordnete kanonistische Sammlung ist im Westen die «Breviatio canonum», die Fulgentius Ferrandus, Diakon der Kirche von Karthago, zwischen 523 und 546 nach den Anweisungen seines Bischofs zusammenstellte. Er lieferte - was ihm dann später von Cresconius vorgeworfen wurde und die unmittelbare Benutzbarkeit seiner Sammlung natürlich auch erheblich einschränkte - nicht die vollständigen Texte, sondern nur eine Liste von 232 Rubriken zusammen mit Angaben, welche Kanones gemeint seien. Trotzdem sollte er auch mit dieser extremen Vorgehensweise Nachfolger fin$\operatorname{den}^{46}$.

Dies bedeutet jedoch nicht, daß es nicht auch nach systematischen Kriterien angelegte Sammlungen gibt, die vollständige Papstbriefe überliefern. Als Beispiel wäre hier die im letzten Viertel des 9. Jahrhunderts in Norditalien, entweder in Vercelli oder Mailand, entstandene "Collectio Anselmo dedicata" zu nennen, die fast 300 Briefe und Exzerpte aus dem Briefkorpus Gregors I. re-

43 Hageneder (wie Anm. 18) S. 319.

44 Ebd. S. 327.

45 Fowler-Magerl (wie Anm. 31) S. 31.

46 Ebd. S. 27-29. 
zipierte $^{47}$. Aber auch hier wird das Eschatokoll und damit die Datumszeile häufig weggelassen, werden die Inskriptionen auch unvollständig oder gar nicht wiedergegeben.

Die Sammler, die vor der Mitte des 9. Jahrhunderts das pseudoisidorische Corpus zusammenstellten, haben sich wohl auch deshalb für die chronologische Ordnung entschieden, weil solche Sammlungen als vertrauenswürdiger galten. Neben den gefälschten Dekretalen findet man hier jedoch auch zahlreiche echte Konzilskanones und Dekretalen, die vor allem dem Zweck dienen sollten, die gefälschten Dekretalen in ein vertrauenerweckendes Umfeld zu betten ${ }^{48}$.

Besonders interessant für die Erfassung päpstlicher Schreiben sind wohl vor allem die Sammlungen, die nicht nur schon mehrfach tradiertes Material, sondern auch im größeren Umfang „neue“ Papstbriefe aufnahmen. Nach der spätantiken Phase des Dekretalenrechts hat es vor allem im 9. Jahrhundert eine Anreicherung des bisher überlieferten Dekretalenbestands gegeben und zwar zum einen durch Pseudoisidor und zum andern durch die «Collectio Anselmo dedicata", deren Autor, wie eben schon angesprochen - mehr als jeder andere Kanonist vor und nach ihm Gebrauch vom Briefregister Gregors I. machte ${ }^{49}$. Schreiben von Päpsten aus der Zeit von der Mitte des achten bis zur Mitte des neunten Jahrhunderts, also von Stephan II. (752-757) bis zu Gregor IV. (827844) sind dagegen - abgesehen von einigen Fälschungen und Fehlzuschreibungen, in den kanonistischen Sammlungen kaum vertreten ${ }^{50}$.

47 Landau: Rechtsfortbildung (wie Anm. 25) S. 88; Kéry (wie Anm. 32) S. 124-128; Fowler-Magerl (wie Anm. 31) S. 70-74. Vgl. jetzt auch Irene Scaravelli: La collezione canonica Anselmo dedicata: lo status quaestionis nella prospettiva di un'edizione critica, in: Le storie e la memoria. In onore di Arnold Esch, hg.v. Roberto Delle Donne/Andrea Zorzi, Florenz 2003, S. 33-52; vgl. dazu auch DA 62 (2005) S. 612.

48 Fowler-Magerl (wie Anm. 31) S. 50-55, v.a. S. 52. Vgl. jetzt auch Peter Landau: Gratians unmittelbare Quellen für seine Pseudoisidortexte, in: Fortschritt durch Fälschungen? Ursprung, Gestalt und Wirkungen der pseudoisidorischen Fälschungen. Beiträge zum gleichnamigen Symposium an der Universität Tübingen vom 27. und 28. Juli 2001, hg.v. Wilfried Hartmann/Gerhard Schmitz, Hannover 2002 (MGH Studien und Texte 31), S. 161-189.

49 Durch die Zusammenstellung dieser Schreiben in einem eigenen Abschnitt unter dem Titel „Gregorius" zwischen den mit Ius canonicum und Ius romanum überschriebenen Teilen, versuchte er offenbar auch diese neu aufgenommenen Gregorbriefe als Ius novum kenntlich zu machen. Dazu Peter Landau: Das Register Papst Gregors I. im Decretum Gratiani, in: Mittelalterliche Texte. Überlieferung - Befunde - Deutungen, Kolloquium der Zentraldirektion der MGH am 28./29. Juni 1996, hg.v. Rudolf Schieffer, Hannover 1996 (MGH Schr. 42) S. 125-140, hier S. 126; zur Rezeption der Gregorbriefe in kanonistischen Sammlungen vgl. auch Jörg Müller: Die Überlieferung der Briefe Papst Gregors I. im Rahmen der Collectio duodecim partium, in: Licet preter solitum. Ludwig Falkenstein zum 65. Geburtstag, hg. v. Lotte Kéry/Dietrich LohrmanN/Harald MüLler, Aachen 1998, S. 17-31.

50 Jasper (wie Anm. 17) S. 102. 
Der nächste große Schub einer Rezeption von Papstbriefen in Kanonessammlungen erfolgte dann erst wieder in der Zeit der Gregorianischen Reform, als viele neue Fragen zu Struktur und Verfassung der Kirche nach Antworten verlangten, die offenbar verstärkt auch in autoritativen Schreiben der Päpste gesucht wurden. In die zahlreichen Sammlungen der Reformzeit, die hauptsächlich in Italien, aber zum Teil auch nördlich der Alpen zusammengestellt wurden, wie z. B. die 74-Titel-Sammlung, die Sammlung des Kardinals Deusdedit oder Anselms von Lucca, aber auch die Werke Ivos von Chartres und Gratians Dekret, um nur einige der bekanntesten zu nennen, werden jedoch die päpstlichen Schreiben entsprechend der starken Ausrichtung auf bestimmte inhaltliche Leitthemen - wie etwa der unbedingten Unterwerfung unter das Urteil des Apostolischen Stuhls, der Beachtung der hierarchischen Ordnung oder auch der größeren Autorität der kirchlichen Gesetzgebung gegenüber dem weltlichen Recht - in Einzelexzerpte unterteilt und nach systematischen Gesichtspunkten eingeordnet. So enthält zum Beispiel das Dekret des Bischofs Ivo von Chartres 111 Exzerpte aus 44 Briefen Nikolaus' I. ${ }^{51}$ Deusdedit exzerpierte 15 Briefe Nikolaus' I. und teilte sie in 54 Teilstücke auf ${ }^{52}$.

Die Sammler der Reformzeit griffen also auch auf ältere Papstbriefe zurück, die bis dahin noch nicht in Sammlungen aufgenommen worden waren. Man kann sogar sagen, daß erst jetzt die meisten Anordnungen früherer Päpste, wie etwa Nikolaus' I., Leos IV., Pelagius' I., teilweise aber auch Gelasius' I. im kanonischen Recht wirksam wurden ${ }^{53}$. Eine gewisse Ausnahme stellen dabei die Briefe Nikolaus' I. dar, die zum Teil schon zu seinen Lebzeiten verbreitet wurden, jedoch nicht nach Abschriften aus seinen Registern, sondern nach denjenigen der Empfänger ${ }^{54}$. Sie sind also - was für diese Zeit sehr ungewöhnlich ist - bereits in zeitgenössischen Sammlungen zu finden, jedoch mit deutlichem geographischen Schwerpunkt im Frankenreich, unter anderem in Sammlungen Hinkmars von Reims oder auch in der möglicherweise aus Laon stammenden ${ }^{55}$ und im dritten Viertel des 9. Jahrhunderts entstandenen Handschrift Paris lat. 1557, die auch die wichtigste Quelle für Briefe Hadrians II., des Nachfolgers von Nikolaus I., darstellt ${ }^{56}$. Bei den Sammlern der gregorianischen Reformzeit sollten sich die Schreiben Nikolaus' I. dann v.a.

51 Ernst Perels: Die Briefe Papst Nikolaus' I., in: NA 37 (1912) S. 535-586; 39 (1914) S. 43-153, hier S. 105; vgl. Jasper (wie Anm. 17) S. 124.

52 Perels (wie Anm. 51) S. 75-86; vgl. Jasper (wie Anm. 17) S. 121.

53 Landau: Rechtsfortbildung (wie Anm. 25) S. 88.

54 JASPER (wie Anm. 17) S. 111.

55 John J. Contreni: Codices Pseudo-Isidoriani: The Provenance and Date of Paris, B. N. MS lat. 9629, in: Viator 13 (1982) S. 1-14.

56 Jasper (wie Anm. 17) S. 113. 
wegen seiner ausführlichen und klaren Äußerungen zur päpstlichen Autorität und den päpstlichen Vorrechten großer Beliebtheit erfreuen ${ }^{57}$.

Die Kenntnis zahlreicher Papstbriefe verdanken wir vor allem der längst noch nicht abschließend untersuchten, aber "für die Quellengeschichte des kanonischen Rechts kaum zu überschätzenden Collectio Britannica ${ }^{\text {“58 }}$. Sie eignet sich überdies besonders gut, um weitere Möglichkeiten aber auch Schwierigkeiten, die mit einer Auswertung von Kanonessammlungen verbunden sind, beispielhaft aufzuzeigen, denn die Einzigartigkeit der «Britannica» besteht unter anderem darin, daß sie echte päpstliche Dekretalen aus dem früheren Mittelalter von Gelasius I. bis Urban II. überliefert, von denen viele bis dahin noch nicht in den Sammlungen zu finden $\operatorname{sind}^{59}$ und von denen man auch sonst keine Kenntnis hatte. Dies zeigt das Beispiel Leos IV., von dem wir heute fast doppelt so viele Briefe und Brieffragmente kennen wie vor der Entdeckung und Auswertung der "Collectio Britannica» am Ende des 19. Jahrhunderts ${ }^{60}$, wobei jedoch - wie Klaus Herbers errechnet hat - der „Zuwachs an neuen Brieffragmenten Leos IV. durch die Entdeckung der Collectio Britannica nur einen kleinen Ausschnitt aus der gesamten Korrespondenz bieten dürfte ${ }^{\text {“61 }}$.

Die um 1090 (Somerville) oder möglicherweise auch erst nach 1094/1095 (Herbers) entstandene "Collectio Britannica» ${ }^{62}$, die heute nur noch in einer einzigen Londoner Handschrift vorliegt (BL Add. 8873) verweist zwar für ihre 233 Papstschreiben auf die Register Gelasius' I., Pelagius' I., Leos IV., Johannes' VIII., Stephans V., Alexanders II. und Urbans II. als Quelle, schöpfte aber offenkundig nicht unmittelbar aus den Registern, sondern aus Teilsammlungen,

57 Ebd. S. 111 mit Bezug auf Walter Ullmann: The Growth of Papal Government in the Middle Ages: A Study in the Ideological Relation of Clerical to Lay Power, London ${ }^{3} 1970$, S. 190. Im «Decretum Gratiani» rangieren die Texte, die auf diesen Papst zurückgehen, zahlenmäßig sogar unmittelbar hinter den Schreiben Gregors I. und noch vor denjenigen Gelasius' I. und Leos d. Gr.

58 Landau: Rechtsfortbildung (wie Anm. 25) S. 88. Vgl. auch Kéry (wie Anm. 32) S. 237 f.; Fowler-Magerl (wie Anm. 31) S. 184-187.

59 Peter Landau: Gefälschtes Recht in den Rechtssammlungen bis Gratian, in: Fälschungen im Mittelalter. Internationaler Kongreß der Monumenta Germaniae Historica, München, 16.-19. Sept. 1986, Teil II: Gefälschte Rechtstexte. Der bestrafte Fälscher, Hannover 1988 (MGH Schr. 33/2) S. 11-51, hier S. 40; Fowler-Magerl (wie Anm. 31) S. 184.

60 Klaus Herbers: Leo IV. und das Papsttum in der Mitte des 9. Jahrhunderts. Möglichkeiten und Grenzen päpstlicher Herrschaft in der späten Karolingerzeit, Stuttgart 1996 (Päpste und Papstttum 27), S. 49.

61 Ebd. S. 62.

62 Robert Somerville in Zusammenarbeit mit Stephan Kuttner: Pope Urban II, the Collectio Britannica and the Council of Melfi (1089), Oxford 1996, S. 23; dagegen Herbers (wie Anm. 60) S. 77 u. 89; vgl. dort auch S. 56. 
die vorher anhand der Register angefertigt worden waren ${ }^{63}$. Bemerkenswert ist dabei jedoch nicht nur, daß diese Registerauszüge anscheinend nur einige Jahre der jeweiligen Pontifikate umfaßten ${ }^{64}$, sondern daß neben den angeblich so authentischen päpstlichen Registern ${ }^{65}$ auch andere Quellen Material beigesteuert haben. So lieferte etwa die Sammlung des Kardinals Deusdedit die Vorlage für die meisten der vierzig Exzerpte aus 13 Briefen Nikolaus' I. ${ }^{66}$, die jedoch im Unterschied zu den Auszügen aus den Registern der übrigen Päpste erst im letzten Teil der Handschrift London BL Add. 8873, in den sogenannten „Varia 2", zu finden sind ${ }^{67}$. Manche Fragmente stammen aber auch aus viel älteren Sammlungen, wie z. B. dem "Liber auctoritatum ecclesiae Arelatensis» aus dem 6. Jahrhundert ${ }^{68}$, der eine Sammlung von Papstbriefen bis zu Pelagius I. (JK 938 von 557/58) enthält ${ }^{69}$.

Wichtig ist auch, daß fast alle Texte, die in die "Collectio Britannica» aufgenommen wurden, schon rein äußerlich als Fragmente erkennbar sind und auch die Angaben zu Aussteller und Empfänger häufig unvollständig und lükkenhaft sind. Die Anordnung der Sammlung wurde als „weder chronologisch noch systematisch" beschrieben ${ }^{70}$. Selbst die früher angenommene chronologische Abfolge innerhalb der Blöcke zu den einzelnen Päpsten trifft zumindest für Leo IV. nicht $\mathrm{zu}^{71}$ und auch für Alexander II. wurde sie in Frage gestellt ${ }^{72}$. Den Inhalt der "Collectio Britannica» bezeichnet Fowler-Magerl immer noch als „essentially Roman“, auch wenn die Sammlung - nach heutigen Erkenntnissen - offenbar in Nordfrankreich in ihre endgültige Form gebracht wurde, zumal,

63 Hageneder (wie Anm. 18) S. 325. Ausführliche Beschreibung der Handschrift bei Somerville: Urban II (wie Anm. 62) S. 8-14; zu Überlieferung und Struktur der Sammlung auch Herbers (wie Anm. 60) S. 49-51. Immer noch grundlegend für jede Beschäftigung mit der "Collectio Britannica»: Paul Ewald: Die Papstbriefe der Brittischen Sammlung, in: NA 5 (1880) S. 278-596.

64 So etwa die drei letzten Bücher Gelasius' I., die vier ersten Jahrgänge Johannes' VIII. (872-875), die vier ersten Jahre Stephans V. (885-888) und dann wieder die beiden ersten Jahre Urbans II. Hageneder schließt daraus, daß die Auswahl, welche die Sammler getroffen haben, eher zufällig war. HaGeneder (wie Anm. 18) S. 325 („Zwischensammlungen").

$65 \mathrm{Zu}$ der These von Walter Ullmann, daß ein verändertes Register Leos IV. zur Zeit des Investiturstreites für polemische Zwecke genutzt wurde, siehe unten Anm. 77.

66 Jasper (wie Anm. 17) S. 122; Fowler-Magerl (wie Anm. 31) S. 162.

67 Fowler-Magerl (wie Anm. 31) S. 184 f., dazu auch Jasper (wie Anm. 17) S. $122 \mathrm{f}$.

68 Fowler-Magerl (wie Anm. 31) S. $184 \mathrm{f}$.

69 Jasper (wie Anm. 17) S. 85-87, hier S. 87.

70 Somerville: Urban II (wie Anm. 62) S. 4.

71 Herbers (wie Anm. 60) S. 88.

72 Tilmann Sснмidt: Alexander II. (1061-1073) und die römische Reformgruppe seiner Zeit, Stuttgart 1977 (Päpste und Papsttum 11), S. 224-226. 
wie Martin Brett gezeigt hat, für einige Texte ein italienischer Ursprung höchst unwahrscheinlich ist ${ }^{73}$.

Trotz der wiederholten Quellenangabe ex registro in der einzigen Handschrift, London BL Add. 8873, wurden auch immer wieder Zweifel an der Authentizität einiger Stücke geäußert, die in dieser Sammlung überliefert sind ${ }^{74}$. So hat Stephan Kuttner gezeigt, daß der in der «Britannica» überlieferte Brief Urbans II. an Bischof Peter von Pistoia und den Abt von Vallombrosa (JL 5383) über die Weihe Daimberts von Pisa zum Diakon durch die Übernahme von Sätzen über die Interpretation von Kanones in Anlehnung an die berühmte Praefatio Ivos von Chartres zur «Panormia» erweitert wurde ${ }^{75}$. Zudem hat er auf die gegenüber Deusdedit und der "Collectio tripartita» unzuverlässigere Wiedergabe von Fragmenten aus einem Brief Nikolaus I. hingewiesen und gezeigt, daß in einen Brief Nikolaus' I. (JE 2796) an Kaiser Michael ein Text aus einem Brief Cyprians interpoliert wurde ${ }^{76}$.

Walter Ullmann zweifelte vor allem an der Echtheit einiger Briefe Leos IV., die in der "Collectio Britannica» überliefert werden ${ }^{77}$, und in seiner Darstellung des Pontifikats Gelasius' I. hat er sogar die 66 Gelasius-Texte der «Britannica»

73 Martin BREtT: Urban II and the collections attributed to Ivo of Chartres, in: Proceedings 8. IntKongrMK, San Diego, University of California at La Jolla, 21-27 August 1988, hg.v. Stanley Chodorow, Città del Vaticano 1992 (MIC C 9), S. 27-46, hier S. 35-37; vgl. Somerville: Urban II (wie Anm. 62) S. 14; Fowler-Magerl (wie Anm. 31) S. 184.

74 Vgl. dazu v.a. Herbers (wie Anm. 60) S. 53-58.

75 JL 5383; IP 3 S. 119 Nr. 2; Stephan KutTner: Urban II and the Doctrine of Interpretation: A Turning Point?, in: SG 15 (1972) S. 53-85, v. a. S. 58 f. (ND in: DERs.: The History of Ideas and Doctrines of Canon Law in the Middle Ages, London 1980 [Collected studies series 113], IV; ${ }^{2} 1991$ mit neuen ,Retractationes'). Vgl. Robert Somerville: The Letters of Pope Urban II in the Collectio Britannica, in: Proceedings 7. IntKongrMK, Cambridge, 23-27 July 1984, hg. v. Peter Linehan, Città del Vaticano 1988 (MIC C 8), S. 103-114, hier S. 106; Landau: Gefälschtes Recht (wie Anm. 59) S. 40-42; Herbers (wie Anm. 60) S. 55 mit Anm. 48.

76 Kuttner: Doctrine (wie Anm. 75) S. 81-83.

77 JE 2613, 2615 und 2646, CB Nr. 19, 21 u. 40. Vgl. dazu auch Herbers (wie Anm. 60) S. 54; Jasper (wie Anm. 17) S. 110 mit Anm. 93. Ullmann rückt diese Stücke in die Nähe des Investiturstreits. Sein Hauptargument war, daß die Briefe Nr. 19 u. 40 zum ersten $\mathrm{Mal}$ in dem Traktat «De penitentia regum» zitiert wurden, dessen Entstehung er mit dem Bußgang von Canossa 1077 in Verbindung bringt. Vgl. Walter Ullmann: Nos si aliquid competenter ... (Some observations on the Register Fragments of Leo IV in the Collectio Britannica), in: Ephemerides Iuris Canonici 9 (1953) S. 3-11 (ND in: DERs.: The Church and the Law in the Earlier Middle Ages, Selected Essays, London 1975, Nr. VII), hier S. 6, 10 f. Dies wurde jedoch von Claudia Märtl bestritten. Vgl. dazu Claudia MärTL: Ein angeblicher Text zum Bußgang von Canossa: „De paenitentia regum“, in: DA 38 (1982) S. 555-563. 
ganz bewußt nicht berücksichtigt ${ }^{78}$. Janet Nelson untersuchte den Brief Leos IV. über die Salbung König Alfreds d. Gr. und betrachtet ihn aufgrund von Inhalt und Sprache als eine Fälschung der 1060er oder 1070er Jahre, als Alexander II. und Gregor VII. versuchten, England mit Hilfe des Lehnrechts enger an den Hl. Stuhl zu binden ${ }^{79}$. Aufgrund dieses Befundes stellte Peter Landau sogar die Vermutung auf, daß gerade auch über die «Britannica» bzw. ihre unmittelbare Vorlage möglicherweise eine Reihe von Fälschungen ins kanonische Recht Eingang fand, die dann aufgrund der Traditionslinie "Britannica» - Ivo Gratian ins Ius commune der Kirche aufgenommen wurden ${ }^{80}$.

Auch Klaus Herbers knüpfte an seinen genauen Vergleich der von ihm in einer vatikanischen Handschrift neu aufgefundenen früheren Überlieferung des Briefes Leos IV. an die bretonischen Bischöfe (JE 2599) mit den in der "Collectio Britannica» und anderen kanonistischen Sammlungen überlieferten Version dieses Schreibens, der eine Reihe von Änderungen, v. a. von Weglassungen und Hinzufügungen, erbracht hat, die grundsätzliche Frage, wie authentisch

78 Vgl. Walter Ullmann: Gelasius I. (492-496). Das Papsttum an der Wende der Spätantike zum Mittelalter, Stuttgart 1981 (Päpste und Papsttum 18), S. 225-227, v.a. S. 227 Anm. 36. Eine eingehende Analyse der "Britannica» bezeichnete auch er als dringendes Forschungsdesiderat. Vgl. auch Landau: Gefälschtes Recht (wie Anm. 59) S. 41 .

79 CB 31, JE 2645; Janet L. NeLson: The problem of King Alfred's Royal Anointing, in: JEcH 18 (1967) S. 145-163 (ND in: DIEs.: Politics and ritual in early medieval Europe, London 1986 [History Series 42], S. 309-327, hier S. 311-327); JASper (wie Anm. 17) S. 110. Interpolationen wurden schließlich auch in dem Schreiben Leos IV. an die Bischöfe der Bretagne (JE 2599) festgestellt, vgl. LandAu: Gefälschtes Recht (wie Anm. 59) S. 41 und vor allem Herbers (wie Anm. 60) S. 67-78; vgl. dazu Ullmann: Observations (wie Anm. 77) S. 8; zu JE 2599 vgl. jetzt auch Rudolf Schieffer: Zum Umgang der Karolingerzeit mit Simonie, in: Scientia veritatis. Festschrift für Hubert Mordek zum 65. Geburtstag, hg.v. Oliver Münsch/Thomas Zотz, Ostfildern 2004, S. $117-126$, hier S. $117 \mathrm{f}$.

80 Landau: Gefälschtes Recht (wie Anm. 59) S. 41 f.; vgl. auch Herbers (wie Anm. 60) S. 66: „Die von der Forschung gegen die Echtheit mehrerer Leo-Fragmente erhobenen Einwände sind trotz der problematischen - jedoch aufgrund der Voraussetzungen nicht anders möglichen - Methode der inhaltlichen Untersuchung ernst zu nehmen". Zur Rezeption der «Britannica»-Dekretalen bei Ivo von Chartres und Gratian siehe Peter LANDAu: Wandel und Kontinuität im kanonischen Recht bei Gratian, in: Sozialer Wandel im Mittelalter. Wahrnehmungsformen, Erklärungsmuster, Regelungsmechanismen, hg.v. Jürgen Miethke/Klaus Schreiner, Sigmaringen 1994, S. 215-233, hier S. 221-229. Dort auch der für die Einschätzung der "Collectio Britannica» wichtige Hinweis, daß „solche Dekretalen für die Zeitgenossen des frühen 12. Jahrhunderts ius novum “ waren, ,auch wenn sie altehrwürdigen Päpsten zugeschrieben wurden“ (S. 222). Vgl. dort auch S. 230-233 die Zusammenstellung der Gratiantexte aus der «Collectio Britannica». 
eine Überlieferung in der «Collectio Britannica» und anderen kanonistischen Werken überhaupt sein könne ${ }^{81}$.

Allgemein wäre zu antworten, daß es trotz aller entsprechenden Erfahrungen im Einzelfall nicht von vornherein feststeht, daß die Überlieferung in der kanonistischen Sammlung die weniger zuverlässige ist. Grundsätzlich wäre auch noch einmal daran zu erinnern, daß die Unterschiede in der Überlieferung auch mit deren unterschiedlicher Zielsetzung zu tun haben. Wie oben schon im Zusammenhang mit der "Collectio Dionysiana» angesprochen, ging es den Sammlern nicht darum, ihren Benutzern im Stile moderner Textkritiker möglichst authentische päpstliche Schreiben im vollen Wortlaut zur Verfügung zu stellen, sondern bestimmte Rechtsvorstellungen und -vorschriften zu dokumentieren, bei denen es nur wenig darauf ankam, wann, für welchen Adressaten und in welchem Textzusammenhang sie formuliert wurden. Dabei ist sowohl mit Veränderungen der Texte als auch mit Verfälschungen im Dienste bestimmter Aussageabsichten zu rechnen, die möglicherweise mit dem ursprünglichen Inhalt des Schreibens nicht mehr viel zu tun haben, aber auch nicht von vornherein als Fälschungen zu bewerten $\operatorname{sind}^{82}$.

Die für unseren Gesamtzusammenhang ebenfalls lehrreiche Vermutung, daß die verschiedenen Teile der "Collectio Britannica" im Extremfall sogar eine jeweils eigene Vorgeschichte gehabt haben könnten ${ }^{83}$ und deshalb auch eine unterschiedliche historische und quellenkritische Bewertung verlangen, wird durch die Ergebnisse von Somerville bestätigt, der aufgrund seiner Untersuchungen zu den Briefen Urbans II. jedoch ein insgesamt positives Urteil über die Zuverlässigkeit zumindest dieses Teils der Sammlung gefällt hat. So erbrachte z. B. der Vergleich mit einem Brief Honorius' III. an den Erzbischof Rodrigo von Toledo vom 7. Januar 1218, in dem mehrere Briefe Urbans II. ausdrücklich als Kopien nach den Registern übermittelt werden, nur unbedeutende Varian$\operatorname{ten}^{84}$ und es gibt nach Somerville auch keine Anzeichen für weitere Textinterpolationen, wie sie Stephan Kuttner im Fall von JL 5383 festgestellt hat, noch irgendeinen Anlaß, die Authentizität eines der Urban II. zugeschriebenen Brieffragmente in Frage zu stellen ${ }^{85}$.

81 Herbers (wie Anm. 60) S. 72.

82 Ebd. S. 78: „Der Vergleich des Briefes JE 2599 mit der frühen Überlieferung zeigte ferner, daß Auslassungen vor allem das in Briefen übliche Beiwerk betrafen, zuweilen allerdings auch wichtige Sätze oder Satzteile mit der Tendenz zur ,Verfälschung'“.

83 Ebd. S. 63.

84 Vgl. dagegen das Urteil ebd. S. 64, über die Qualität der Hs. London, BL Add. 8873: "Offensichtlich wurde die Handschrift der Britischen Sammlung nicht mit allzu großer Sorgfalt angelegt“, bzw. S. 78: „relativ flüchtige Abfassungsweise“. Vgl. dazu auch BRETT: Collections (wie Anm. 73) S. $33 \mathrm{f}$.

85 Somerville: Letters (wie Anm. 75) S. 111; Herbers (wie Anm. 60) S. 56 f. 
Als besonders schwierig stellt sich natürlich die Einordnung der Papstbriefe dar, die allem Anschein nach allein in der "Collectio Britannica» überliefert sind - im Fall Urbans II. sind das 24 Texte $^{86}$. Die Schwierigkeiten beginnen schon bei der Bestimmung der Empfänger, denn der Abschnitt in der "Collectio Britannica», der Urban II. gewidmet ist, gehört zu dem Teil der Handschrift, dessen Rubriken fehlen ${ }^{87}$. Die einzigen Angaben zu den Adressaten finden sich in stark abgekürzten Randbemerkungen, die offenbar erst in einem späteren Arbeitsgang von einem Rubrikator in den Text eingefügt werden sollten; mehrere von ihnen wurden zum Teil herausgeschnitten, als man die Seiten neu ordnete $^{88}$.

Als ein Beispiel für die daraus resultierenden Schwierigkeiten führt Somerville das Schreiben JL 5380 an, das Paul Ewald auf der Grundlage einer fragmentarischen Inskription Petro ... si episcopo in Analogie zu dem eben schon genannten Schreiben an Bischof Petrus von Pistoia (1085/86-1101 - JL 5383), ebenfalls diesem als Empfänger zuordnete ${ }^{89}$. Im Text von JL 5380 heißt es, der Papst werde pro tempore die Wahl und Weihe des angesprochenen Bischofs tolerieren, obwohl er gehört habe, dass seine Erhebung auf unkanonische Weise vonstatten gegangen $\mathrm{sei}^{90}$. Allein auf diese unsichere, durch keine anderen Argumente abgesicherte Zuschreibung wurde bisher die Behauptung gestützt ${ }^{91}$, daß bei der Erhebung des Bischofs Petrus von Pistoia nicht alles mit Rechten Dingen zugegangen sei - eine, wie Somerville zu Recht moniert, ziemlich gewagte Vermutung, denn es sind auch andere Adressaten denkbar - wie z.B. Petrus von Terrracina, der ebenfalls in einem weiteren Fragment eines Schreibens Urbans II. in der "Collectio Britannica» mit der Inskription Petro Terracinensi auftaucht (JL 5353) ${ }^{92}$. Dieser kurze Text beginnt zudem mit der beziehungsreichen Feststellung: Multa videntur mala, que mala non sunt, quia mala intencione non fiunt, die Somerville treffend als "language of dispensation“ charakterisiert $^{93}$. Als dritte Möglichkeit hat Somerville später auch noch Bischof Petron von León vorgeschlagen, der ebenfalls in einem weiteren Brief der "Collectio Britannica» (CB 37) als Adressat angesprochen und dort auch passend als Sünder bezeichnet wird. Hier weicht jedoch die Schreibweise Petron von allen anderen Randglossen für Petro ab, die jeweils abgekürzt sind ${ }^{94}$. Angesichts

86 Somerville: Letters (wie Anm. 75) S. 108.

87 Ebd. S. 107; DERs.: Urban II (wie Anm. 62) S. 21.

88 Somerville: Urban II (wie Anm. 62) S. 37.

89 JL 5380; IP 3 S. 119 Nr. 1; Somerville: Letters (wie Anm. 75) S. 109; vgl. auch Ewald (wie Anm. 63) S. 359 Nr. 25 mit Anm. 4.

90 Somerville: Urban II (wie Anm. 62) S. $94 \mathrm{f}$.

91 Vgl. z. B. Kuttner: Doctrine (wie Anm. 75) S. 57.

92 Somerville: Letters (wie Anm. 75) S. 109; Ders.: Urban II. (wie Anm. 62) S. 48-50.

93 Ebd. S. 49.

94 Ebd. S. 95 (zu CB 25). 
solcher wenig eindeutigen Konjekturen, die das Problem der Adressatenbestimmung bei den in Kanonessammlungen überlieferten Papstbriefen noch einmal plastisch vor Augen führen, ist festzuhalten, daß sich die Frage nach dem Adressaten von JL 5380 wohl kaum beantworten läßt, solange keine weitere Überlieferung mit vollständigerer Inskription auftaucht - der Inhalt des Schreibens liefert jedenfalls keinerlei Anhaltspunkte.

Wichtige Quellen für päpstliche Briefe in der kanonistischen Literatur des endenden 11. und beginnenden 12. Jahrhunderts stellen neben der «Britannica» auch chronologisch nach Pontifikaten angeordnete Sammlungen von Papstbriefen bzw. Auszügen aus Papstbriefen dar, wie sie in der wohl in Chartres entstandenen "Collectio Tripartita $A »{ }^{95}$ oder der bisher noch nicht genauer untersuchten italienischen Sammlung in der Handschrift BAV, Vat. lat. 3829 vorliegen ${ }^{96}$. Bekannt ist jedoch, daß diese letztgenannte Sammlung einen besseren Text des Briefes Nr. 144 der "Collectio Britannica» (Varia 2.131) aufweist, der auch noch in weiteren Sammlungen zu finden ist. Jedoch allein aus der Version im Vat. lat. 3829 erfahren wir, daß die in diesem Brief enthaltenen Instruktionen Nikolaus' I. an Bischof Braidingus von Mâcon (853-862) gerichtet waren ${ }^{97}$.

Die beiden zuletzt genannten Sammlungen werden ebenso wie die "Collectio Britannica» zur Gruppe der sogenannten „Zwischensammlungen“ gezählt, die man auch als bloße Materialsammlungen bezeichnen könnte, da sie noch nicht über eine deutlich erkennbare inhaltliche Systematik verfügen. Sie stehen für eine Reihe nicht erhaltener Sammlungen, auf deren Spuren man bei einer genaueren Untersuchung der Abhängigkeitsverhältnisse zwischen den heute noch vorliegenden Sammlungen immer wieder trifft und die man sich gemeinhin als längere Exzerptreihen vorstell $t^{98}$. Nach Ansicht von Forschern wie Sickel, Perels, Fournier und Fuhrmann sind sie in den letzten Jahren Gregors VII. entstanden ${ }^{99}$. Auf solche nicht erhaltenen Zwischensammlungen gehen zum Teil bedeutsame inhaltliche Varianten gegenüber den Registerversionen zurück, wie etwa in dem berühmten Brief Gregors VII. an Hermann von Metz, in dem der Papst die Exkommunikation und Absetzung Heinrichs IV. zu

95 Jasper (wie Anm. 17) S. 60 f. Zur «Collectio Tripartita» vgl. Fowler-Magerl (wie Anm. 31) S. 187-190; Kéry (wie Anm. 32) S. 244-250.

96 Vgl. dazu ebenfalls den sehr instruktiven Überblick bei Fowler-Magerl (wie Anm. 31) S. $216-218$.

97 Jasper (wie Anm. 17) S. 123.

98 Zur Problematik der Zwischensammlungen für den Historiker vgl. auch Herbers (wie Anm. 60) S. 63.

99 Vgl. Jasper (wie Anm. 17) S. $121 \mathrm{f}$.: „Scholars believe that these putative collections would have been written in the last years of Pope Gregory VII's pontificate. Since the materials of these collections were generally merged into other collections, they have disappeared“. Vgl. dort auch Anm. 151 u. 152 sowie Herbers (wie Anm. 60) S. 52. 
rechtfertigen versuchte ${ }^{100}$. In der "Collectio intermedia», die Anselm von Lucca und Deusdedit hier als gemeinsame Vorlage diente, wurde das Wort deposuisse gegenüber der Registerversion offenbar ausgelassen, denn die inhaltlich bedeutsame Variante findet sich sowohl bei Anselm als auch bei Deusdedit ${ }^{101}$.

Aber auch „kleinere" und bisher noch weniger bekannte Sammlungen können wichtige Einzelheiten zur besseren Kenntnis der Papsturkunden beitragen. Besonders vielversprechend ist zum Beispiel die erst in den letzten Jahren zu größerer Beachtung gelangte Sammlung in der Handschrift Paris, Bibliothèque de l'Arsenal 713, die inzwischen nicht nur als wichtige Quelle für das Dekret Ivos von Chartres erkannt wurde ${ }^{102}$, sondern auch deshalb zu neuer Bedeutung gelangte, weil ihre Existenz beweist, daß es eine noch ausführlichere Überlieferung der "Collectio Britannica» gegeben haben muß, als sie uns in der einzigen bisher bekannten Handschrift vorliegt ${ }^{103}$.

Der Codex Paris, Biblothèque de l'Arsenal 713 stammt aus der Abtei SaintVictor, die zahlreiche Handschriften aus Chartres besaß, und besteht aus zwei voneinander unabhängigen Teilen ${ }^{104}$. Der erste Teil (fol. $1-116 v$ ) enthält eine Abschrift der «Panormia», der zweite (fol. 117-192v, von Somerville als 713B bezeichnet), dessen Herkunft unbekannt ist, die uns hier interessierende Sammlung. Einige Bruchstücke von Briefen der Päpste Johannes VIII., Alexander II. und Urban II. wurden nach dieser Handschrift schon 1618 in der

100 JL 5201; Das Register Gregors VII., hg.v. Erich Caspar, Berlin 1923 (MGH Epp. sel. 2/ 2), VIII/21 S. 544-563, hier S. 551, Z. 3-7.

101 Anselmi episcopi Lucensis Collectio canonum una cum collectione minore, ed. Friedrich Thaner, Innsbruck 1906, I 80 S. 53-55; Die Kanonessammlung des Kardinals Deusdedit, ed. Victor Wolf von Glanvell, Paderborn 1905, IV 184 S. 489-491; Hageneder (wie Anm. 18) S. 324 f., vermutet sogar, daß Deusdedit selbst eine solche Zwischensammlung kurz vor der Abfassung seiner eigentlichen Kanonessammlung anlegte; jedenfalls ist auch in seiner Sammlung nicht klar, was direkt aus den päpstlichen Archiven stammt und was aus einer Quelle, die gleichzeitig auch von Anselm von Lucca benutzt wurde, ebd. S. 324 Anm. 24.

102 Peter Landau: Das Dekret des Ivo von Chartres. Die handschriftliche Überlieferung im Vergleich zum Text in den Editionen des 16. und 17. Jahrhunderts, in: ZRGKanAbt 70 (1985) S. 1-44, hier S. 33 (ND in: Ders.: Kanones und Dekretalen, Goldbach 1997, S. $117^{*}-160^{*}$ und 473*-474); Somerville: Urban II (wie Anm. 62) S. 16, und vor allem Martin BRETt: The Sources and Influence of Paris, Bibliothèque de l'Arsenal MS 713, in: Proceedings 9. IntKongrMK, Munich, 13-18 July 1992, hg.v. Peter Landau/ Jörg Müller, Città del Vaticano 1997 (MIC C 10), S. 149-167, hier S. 150-156; Fowler-Magerl (wie Anm. 31) S. $192 \mathrm{f}$.

103 Robert Somerville: Papal Excerpts in Arsenal MS 713B: Alexander II and Urban II, in: Proceedings 9. IntKongrMK, Munich, 13-18 July 1992, hg.v. Peter Landau/Jörg Müller, Città del Vaticano 1997 (MIC C 10), S. 169-184, hier S. 173; BRETT: Collections (wie Anm. 73) S. 34; Somerville: Urban II (wie Anm. 62) S. 15-19, 27.

104 Zur Handschrift Brett: Sources (wie Anm. 102) S. 149 f.; Somerville: Papal Excerpts (wie Anm. 103) S. 169-173. 
zweiten Edition der Konziliensammlung des Severinus Binius publiziert, der dieses Material von dem Victoriner Jean Picard erhielt. Aus den «Concilia generalia» des Binius fanden diese Texte auf dem bekannten Weg über die nachfolgenden Konzilssammlungen Eingang in die Editionen von Mansi und Migne und wurden schließlich auch in der zweiten Auflage der Regesta pontificum Romanorum verzeichnet ${ }^{105}$.

Picard hatte Binius jedoch nur mit einer winzigen Probe von päpstlichen Texten versorgt, die in der Sammlung der Arsenal-Handschrift zu finden waren ${ }^{106}$; sie enthält allein 32 Fragmente, die Alexander II. zugeschrieben werden können und alle auch durch die "Collectio Britannica» überliefert werden, sowie 22 Stücke, die auf Urban II. zurückgehen, von denen jedoch nur 16 auch in der "Collectio Britannica» enthalten sind ${ }^{107}$.

Obwohl also schon einige Stücke aus dieser Handschrift seit langem durch die Drucke von Mansi und Migne bekannt und auch in den Regesta pontificum Romanorum zu finden sind, zeigt erst eine genauere Analyse dieser Handschrift in ihrem Gesamtzusammenhang, wie wertvoll ihre Überlieferung von Papstbriefen für die Rekonstruktion der jeweils authentischen Texte ist. Aufgrund ihres äußeren Erscheinungsbildes - es handelt sich um einen weder in Bücher noch in Titel eingeteilten und kontinuierlich in langen Zeilen ohne Kolumnen über die Seiten geschriebenen Text, der ohne Rubriken auskommt und nur in wenige Absätze unterteilt ist - könnte man die Sammlung in der Handschrift Arsenal 713 ebenfalls für eine bloße Materialsammlung halten ${ }^{108}$. Wie Martin Brett jedoch festgestellt hat, wurden ihre Texte, im Unterschied zur «Britannica» in thematisch sinnvollen Abschnitten angeordnet. Das heißt, die Sammlung in der Arsenal-Handschrift repräsentiert eine etwas weiter fortgeschrittene Entwicklungsstufe auf dem Weg zu einer systematischen Sammlung ${ }^{109}$. Zudem machte sie offenbar von einer Vorlage Gebrauch, die zwar der «Collectio Britannica» ähnlich war, aber vollständigere Inskriptionen und bessere Texte bot ${ }^{110}$.

Einige von Somerville angeführte Beispiele beleuchten auch die Möglichkeiten, die die Sammlung in der Handschrift Paris, Bibliothèque de l'Arsenal 713 für das Studium der Papstbriefe bietet, und zeigen, welche Art von neuen Informationen sie über die päpstliche Korrespondenz liefern kann ${ }^{111}$.

105 Ebd. S. 169.

106 Ebd. S. 171.

107 Ebd. S. $171 \mathrm{f}$.

108 Brett: Sources (wie Anm. 102) S. 149 f.; Somerville: Papal Excerpts (wie Anm. 103) S. 171.

109 BRETT: Sources (wie Anm. 102) S. 167: „In the Arsenal collection the re-organisation of material by topic is more or less incomplete".

110 Somerville: Papal Excerpts (wie Anm. 103) S. 173.

111 Ebd. S. 177. 
- Der in der "Collectio Britannica» nur mit Girardo episcopo inskribierte Brief Alexanders II. (JL 4551), dessen Adressat Paul Ewald mit dem Bischof Gerald von St-Paul-Trois-Châteaux und Orange identifizierte, ist aufgrund der Inskription in der Arsenal-Handschrift nun als Schreiben an Bischof Gerald von Sisteron einzuordnen ${ }^{112}$.

- Die ausgedehnte, von Passau bis Pavia reichende Suche nach dem Adressaten des mit Odolrico episcopo inskribierten Briefes JL 4616, der in der Italia pontificia nicht verzeichnet ist ${ }^{113}$, kann aufgegeben werden: Gemäß der vollständigeren Inskription in der Handschrift Arsenal 713 (Alexander II Odolrico Forocornellii episcopo) handelt es sich um den Bischof Odelrich von Imola $^{114}$.

- Auch für den wichtigen Brief JL 5404 (IP -), durch den Urban II. einen Bischof darüber informiert, daß es zweckmäßig sei, ihm, d. h. dem Bischof, die Entscheidung zu überlassen, ob ein gefallener Kleriker wieder in sein Amt eingesetzt werde, bietet Arsenal 713 die gegenüber der "Collectio Britannica» ausführlichere Inskription Mantuano episcopo. Der gregorianische Bischof Ubald von Mantua, der hier allem Anschein nach gemeint ist, wurde 1091 von Heinrich IV. abgesetzt; der Brief kann also zusätzlich auch noch genauer datiert werden und zwar in die Zeit vor April 1091, wenn man mit Somerville voraussetzt, daß Urban II. einen von Heinrich IV. abgesetzten Bischof nicht mehr als solchen angesprochen hätte ${ }^{115}$.

Die aufgrund dieses Befundes wohl nicht ganz unberechtigte Erwartung, daß in der Sammlung der Arsenal-Handschrift auch bisher noch nicht bekannte Papstbriefe oder zumindest Textpassagen aus Papstbriefen enthalten sein könnten, wurde jedoch bisher enttäuscht - mit einer Ausnahme: JL 2965, ein Schreiben Johannes' VIII., enthält in dieser Handschrift eine Zeile mehr als in den anderen von ihm bekannten Versionen: simulque omnibus rebus maritalibus manere privatam ${ }^{116}$. Somerville weist jedoch ausdrücklich darauf hin, daß ähnliche Funde bei den noch nicht näher untersuchten Texten von Päpsten vor dem 11. Jahrhundert in der Handschrift Arsenal 713B zu erwarten seien ${ }^{117}$.

Ein letztes Beispiel soll schließlich auch noch davor warnen, zu schnell und unbesehen die Zuschreibungen in den kanonistischen Sammlungen zu übernehmen. Es geht um den bekannten, bisher Gregor VII. zugeschriebenen Brief an Bischof Guitmund von Aversa (JL 5277), in dem der Papst den Bischof an die Worte Christi im Johannesevangelium $(14,6)$ erinnerte: Ego sum veritas et

112 Ebd. S. 173 f.

113 Ebd. S. 181 Nr. 6: Italia pontificia vacat.

114 Ebd. S. 174.

115 Ebd. S. $174 \mathrm{f}$.

116 JL 2965; IP 4 S. 221 Nr. 2; vgl. Somerville: Papal Excerpts (wie Anm. 103) S. 175.

117 Ebd. S. 175 Anm. 21. 
vita und ihn gleichzeitig daran erinnerte, daß Christus keinesfalls gesagt habe Ego sum consuetudo ${ }^{118}$. Das entsprechende Exzerpt ist weder in der "Collectio Britannica» noch in der «Tripartita A» zu finden. Allem Anschein nach taucht es zum ersten Mal im Dekret Ivos von Chartres auf ${ }^{119}$. Von dort fand es seinen Weg in die "Panormia» und anschließend in die «Collectio decem partium» ${ }^{120}$; über die Neuordnung von Ivos Dekrets im dritten Teil der «Tripartita» wurde es schließlich in das «Decretum Gratiani» aufgenommen (Dist. 8 c. 5$)^{121}$. In allen Handschriften, die Somerville dazu im Einzelnen überprüft hat ${ }^{122}$, wird dieser fragmentarische Text Gregor VII. zugeschrieben, allein in der Handschrift Paris Arsenal 713B wird Urban II. als Absender genannt: U.ii. Wimundo Aversano episcopo, obwohl diese letztgenannte Lesart historisch gesehen wesentlich glaubwürdiger ist, denn Guitmund wurde erst unter Urban II. zum Bischof von Aversa erhoben ${ }^{123}$; zudem konnte das inzwischen berühmte Zitat an keiner anderen Stelle in der Korrespondenz Gregors VII. nachgewiesen werden, wohl aber bei Urban II. in einem Brief an den Grafen Robert I. von Flandern (JL 5471).

Für die vorgratianischen Sammlungen kann also festgehalten werden, daß sie wichtige Beiträge zur Erschließung, Erfassung und historischen Einordnung der päpstlichen Schreiben liefern, auch wenn man die damit verbundenen methodischen Schwierigkeiten nicht unterschätzen sollte, die vor allem aus ihrer speziellen Zielsetzung resultieren. Wie allein schon an den wenigen hier vorgestellten Beispielen gezeigt werden konnte, die bei einer Berücksichtigung weiterer Sammlungen noch deutlich vermehrt werden könnten, enthalten sie nicht nur das ein oder andere Schreiben, das in keiner anderen Überlieferung faßbar ist, oder auch zusätzliche Textpassagen, sondern auch - wenn auch eher selten - zusätzliche Informationen, die für die Identifizierung von Absender und Empfänger der Schreiben und manchmal sogar für eine genauere Datierung genutzt werden können.

Überdies dürfte deutlich geworden sein, daß die Möglichkeiten einer adäquaten Erfassung von Papstbriefen aus den Kanonessammlungen auch in ganz erheblichem Maße von den Fortschritten der kanonistischen Forschung abhängen, die nicht nur für die Erschließung neuen Materials, sondern auch für eine bessere Kenntnis oder gar Neubewertung von Papstbriefen zu nutzen sind.

118 JL 5277; IP -.

119 Decretum Ivonis, IV, c. 213, ed. Migne PL 161 Sp. 311; vgl. Somerville: Papal Excerpts (wie Anm. 103) S. 177.

$120 \mathrm{Zu}$ dieser Sammlung vgl. Kéry (wie Anm. 32) S. 263 f.; Fowler-Magerl (wie Anm. 31) S. 209-214 mit allen weiteren Angaben.

121 Emil Friedberg: Corpus iuris canonici, Bd. 1, Leipzig 1879 (ND Graz 1995), Sp. 14.

122 Somerville: Papal Excerpts (wie Anm. 103) S. 178 Anm. 33 u. 35.

123 Somerville: Papal Excerpts (wie Anm. 103) S. 178 f. 


\section{Riassunto}

Quali fonti che tramandano dei documenti pontifici in modo indiretto, le raccolte canonistische, compilate prima di Graziano, pongono problemi in parte considerevoli per la ricostruzione e classificazione dei testi - analogamente alle successive raccolte delle decretali. Ciò è dovuto soprattutto al fatto che servono a mettere insieme e ordinare il materiale per scopi legati al diritto ecclesiale. I destinatari e le datazioni sono secondari, sicché spesso non si menzionano affatto, o solo in modo incompleto, mentre nelle raccolte sistematiche i testi vengono tagliati e inseriti in diversi settori tematici. Queste riserve possono sì suscitare dei dubbi sull'autenticità dei testi che non sempre provengono direttamente dai registri papali, ma in parte sono stati tramandati indirettamente, e in parte addirittura in più versioni; ciononostante le raccolte canonistiche sono indispensabili per la rilevazione dei documenti quanto più completa possibile, non solo perché esse possono racchiudere brani di testo non rintracciabili da nessun'altra parte, ma anche perché a volte contengono ulteriori informazioni utili sia per l'identificazione di mittenti o destinatari sconosciuti che per una datazione più precisa. Le possibilità di rilevare in modo adeguato le lettere papali dalle raccolte canoniche dipendono pertanto in misura considerevole dai progressi fatti dalla ricerca canonistica. 
Bereitgestellt von | De Gruyter / TCS

Angemeldet | 217.89.40.26

Heruntergeladen am | 21.12.12 10:49 


\title{
Tradizioni storiografiche e agiografiche: alcuni esempi
}

\author{
Giulia Barone
}

L'ampiezza della tematica che è al centro di questo saggio imporrà - come è evidente - una drastica selezione degli oggetti di indagine che saranno illustrati nell'ambito del contributo. E' infatti impossibile, per uno storico che abbia a cuore $\mathrm{i}$ fondamenti del suo metodo di lavoro, proporre correzioni ed integrazioni alla totalità della grandiosa opera del Kehr, attingendo a materiali disparati e di difficilissima collocazione e interpretazione come quelli storiografici ed agiografici. Mi limiterò perciò al contesto romano, quello che conosco meglio per avervi dedicato anni di lavoro, e cui lo stesso Kehr ha attribuito un peso e un valore particolare nell'economia della sua opera: a Roma è infatti dedicato l'intero primo volume dell'Italia pontificia ${ }^{1}$.

Nel rapporto con Roma si manifestano, già in età tardo-antica $\mathrm{e}$ altomedievale, $\mathrm{i}$ due aspetti che sono indissolubilmente legati nella figura del pontefice: quello di successore di Pietro come vescovo di Roma e l'altro, che acquisterà sempre maggior rilievo dalla Riforma ecclesiastica dell'XI secolo in poi, di vicario del principe degli Apostoli (e poi vicarius Christi), come capo della Cristianità ${ }^{2}$.

Il taglio che Kehr ha voluto dare alla sua opera, che si basa sulla distribuzione geografica dei destinatari degli interventi pontifici, ha evidentemente privilegiato, per quanto riguarda Roma, il vescovo dell'Urbe a scapito del capo della Chiesa universale. Ma, in realtà, se allarghiamo lo spettro delle fonti cui attingere, ci renderemo immediatamente conto di quanto la distinzione sia artificiosa e non rispecchi la realtà dell'azione di governo del papa.

Il dialogo tra centro e periferia, tra Roma e l'orbis christianus, non è mai stato, almeno in età medievale, unidirezionale: dal centro - da Roma - sono certo partiti molti impulsi ed iniziative, ma un numero quasi altrettanto grande di innovazioni provengono da regioni a volte anche molto lontane. Il potere papale si è nutrito, per secoli, di questa fruttuosa dialettica.

1 IP 1.

2 Michele Maccar rone: Romana Ecclesia cathedra Petri, a cura di Pietro Zerbi, Raffaello Volpini, Alessandro Galuzzi, 2 voll., Roma 1991 (Italia sacra 47-48); Agostino Paravicini Bagliani: Il trono di Pietro. L'universalità del papato da Innocenzo III a Bonifacio VIII, Roma 1996, e IDEM: Le chiavi e la tiara. Immagini e simboli del papato medievale, Roma ${ }^{2} 2005$ (La corte dei papi 3). 
Questo studio si concentrerà sulle tradizionali fonti scritte; sarebbe certo interessante allargare il discorso al materiale epigrafico, presente in proporzioni non irrilevanti nell'opera del Kehr, ma l'analisi delle epigrafi richiederebbe un diverso tipo di competenze.

Quali sono gli interventi papali più frequentemente reperibili nell'Italia pontificia? La tipologia è relativamente ristretta: fondazione, restauro o decorazione di chiese e monasteri; conferma di beni; traslazione di reliquie; memoria di atti liturgici. In alcuni, rarissimi casi, si accenna anche alla riforma di antichi monasteri romani. Le numerose concessioni di indulgenze invece, nella stragrande maggioranza, sono già state correttamente identificate come spuria dal Kehr, riflesso della crescita esponenziale delle indulgenze cui si assiste dal XIII secolo in poi e che vengono attribuite a pontefici dei primi secoli del Cristianesimo, per attribuire loro maggior valore ed "autenticità".

D’altra parte, anche le fonti che il Kehr e la sua équipe hanno utilizzato per il loro celeberrimo repertorio, sono, per quanto riguarda Roma, relativamente scarse: il «Liber pontificalis» ${ }^{3}$; i documenti, conservati - fino alla fine dell'XI secolo - in numero piuttosto ridotto nei pochi archivi superstiti degli enti ecclesiastici romani ${ }^{4}$; la documentazione papale, in cui una posizione di assoluto privilegio è svolta dai pochi registri pontifici superstiti (quelli di Gregorio $I^{5}$, Giovanni $\mathrm{VIII}^{6}$ e Gregorio VII ${ }^{7}$ ) cui si attinge a piene mani; infine le grandi

3 Le Liber pontificalis. Texte, introduction et commentaire, a cura di Louis Duchesne, 2 voll., Paris 1886-1892. Un interessante utilizzazione delle biografie pontificie per la ricostruzione dell'evoluzione urbana di Roma in Paolo Delogu: The Rebirth of Rome in the Eight and Ninth Centuries, in: The Rebirth of Towns in the West. AD 7001050, a cura di R. Hodges/B. Hobley, London 1988, pp. 32-42, che analizza proprio gli interventi edilizi e i donativi papali in favore degli enti ecclesiastici romani.

4 Negli ultimi cent'anni è fortunatamente continuata, sia pure ad intermittenza, l'edizione di quanto conservato negli archivi delle istituzioni ecclesiastiche romane, mentre ben poco è stato aggiunto a quanto già noto al Kehr e ai suoi collaboratori. Fra le raccolte documentarie principali, edite posteriormente al 1907, si possono citare: Le più antiche carte del monastero di S. Agnese sulla via Nomentana, ed. Isa Lori Sanfilippo, in: Bullettino dell'Archivio paleografico italiano n. s. 2-3 (1956-57) pp. 65-97; I documenti dell'antico Archivio di S. Andrea "de Aquariciariis" (1115-1483), ed. Isa Lori SANFilippo, Roma 1981 (Codice diplomatico di Roma e della regione romana 2); Documenti del monastero di S. Cecilia in Trastevere, ed. Ermanno Loevinson, in: ASRSP 49 (1926) pp. 305-404; Cartario di S. Maria in Campo Marzio (986-1199), ed. Enrico Carusi, Roma 1948 (Miscellanea della Società romana di Storia patria 17); Le carte del monastero di San Paolo di Roma dal secolo XI al XV, ed. B. TRIfone, in: ASRSP 31 (1908) pp. 267-313; 32 (1909) pp. 29-106.

5 Gregorii I papae Registrum epistolarum, ed. Paul Ewald/Ludo Moritz Hartmann, 2 voll., Berlin 1887-1899 (MGH Epp. 1-2), e S. Gregorii Magni Registrum Epistularum, a cura di Dag Norberg, 2 voll., Turnhout 1982 (CChrL 140-140A).

6 Registrum Johannis VIII. papae, ed. Erich CAspar, in: MGH Epp. 7, Berlin 19121928, pp. 1-272, e Fragmenta registri Iohannis VIII papae, ed. Erich CASPAR, ibidem, 
sillogi epigrafiche che hanno fortunatamente trasmesso molto materiale nel frattempo danneggiato o addirittura perduto ${ }^{8}$.

Lo studio si concentrerà su tre diversi aspetti dell'attività pontificia in materia di vita religiosa- tutti presenti nella documentazione del I volume dell'Italia pontificia - fornendo, per ciascuno di essi, uno o più esempi, che paiono particolarmente adatti ad animare un dibattito sulla possibilità di procedere a correzioni e/o integrazioni dell'opera del Kehr utilizzando fonti storiografiche ed agiografiche.

A) gli usi liturgici: le processioni di Gregorio Magno

B) la "distribuzione" di reliquie: Innocenzo ed Anastasio

C) la riforma di S. Paolo nel X secolo

\section{A) Le processioni di Gregorio Magno}

La lunga rubrica che l'Italia pontificia consacra a S. Maria Maggiore riporta, ai numeri 4 e 5 il ricordo di due processioni organizzate da Gregorio I ${ }^{9}$. Nel primo caso, il documento del registro pontificio - datato al settembre del 591 menziona in realtà una processione da S. Lorenzo in Lucina a S. Pietro. La ragione per cui è stata inserito, senza sufficiente motivazione, fra le testimonianze relative alla basilica liberiana è legata alla tradizione manoscritta: nelle copie del registro in cui il testo è stato trascritto - e si tratta di una minoranza dei testimoni -, esso porta l'erroneo titolo: Chartula quae relecta est de laetania maiore in basilica sanctae Mariae. Il più recente editore del Registro di Gregorio Magno l' ha espunta dalla serie cronologica, pubblicandola tra le Appendici ${ }^{10}$. Al di là del problema dell'autenticità del documento e della sua originaria collocazione nei Registri, è comunque evidente che, nel caso di una revisione

pp. 273-312; per questo come per il Registro di Gregorio VII, il Kehr poteva contare solo sull'edizione, non critica, di Migne PL.

7 Gregorii VII Registrum. Das Register Gregors VII., ed. Erich Caspar, 2 voll., Berlin 1920-1923 (MGH Epp. sel. 2)

8 Vanno qui ricordate in primo luogo le raccolte a cura di G. B. De Rossi: Inscriptiones christianae urbis Romae septimo saeculo antiquiores, 2 voll., Roma 1861-1888, e V. ForCELLA: Iscrizioni delle chiese e d'altri edifici di Roma dal secolo XII fino ai nostri giorni, 14 voll., Roma 1869-1884.

9 Cfr. IP 1 p. 55 nr. 4: Gregorius, se sexta feria veniente a titulo b. Laurentii mart. q. app. Lucinae egredientem ad b. Petrum apost. Supplicantem cum hymnis et canticis spiritualibus properaturus esse; nr. 5: Gregorius I invitat ad septiformem laetaniam, ut omnes ad sanctae genitricis Domini ecclesiam conveniant.

10 Norberg: Registrum (cit. nota 5) Appendix IV, vol. 2, pp. 1098sg. Nell'edizione precedente, essa figura invece quale epistola II del II anno di pontificato (cfr. EwALD/ HARTMANN: Registrum [cit. nota 5] vol. 1 p. 102). 
dell'opera del Kehr, il riferimento al registro gregoriano dovrebbe essere inserito, senza alcun dubbio, fra i testi relativi a S. Pietro.

Quanto alle ragioni per cui, in età ben posteriore, è stato tradito con un titolo così evidentemente errato, esse potrebbero essere ricondotte alle vicende che verranno trattate nelle pagine che seguono.

Il numero 5 fra i documenti relativi alla chiesa di S. Maria Maggiore citati dal Kehr si riferisce infatti ad una processione che dovrebbe essersi svolta il 30 agosto del $603^{11}$. In realtà la datazione pone dei problemi: il testo in nostro possesso, che prevede che la popolazione romana partecipi alla leatania septiformis il giorno seguente, è infatti così datato: fecit et in basilica sanctae Savinae sub die IIII Kalendarum Septembrium ${ }^{12}$ indictione VI. L'indizione VI inizia soltanto il $1^{\circ}$ settembre del 603, ma non è possibile ipotizzare che la processione si sia tenuta il 30 agosto del 604, quando Gregorio era scomparso da alcuni mesi.

Ma i problemi non finiscono qui: ben più celebre di questa del 603, è un'altra laetania septiformis, che Gregorio, eletto pontefice, ma non ancora consacrato, avrebbe organizzato per chiedere la fine della pestilenza che aveva infuriato a Roma e della quale era caduto vittima anche il suo predecessore, Pelagio II. Di questa prima, grandiosa processione, durante la quale erano morti decine di romani, è conservato il ricordo nell'opera storica di Gregorio di Tours $^{13}$, che aveva potuto contare sulle informazioni e i testi raccolti a Roma da un diacono della sua chiesa, nonché nella vita di Gregorio ad opera di Giovanni Immonide, del IX secolo ${ }^{14}$.

11 Ewald/Hartmann: Registrum (cit. nota 5) vol. 2 pp. 365-367, e Norberg: Registrum (cit. nota 5) Appendix IX, vol. 2 pp. 1102-1104, da cui citerò. Sul tema delle processioni organizzate da Gregorio I si veda Giulia Barone: Gregorio Magno e la vita religiosa della Roma del suo tempo, in: Scritti per Isa. Raccolto di studi offerti a I. Lori Sanfilippo, a cura di A. Mazzou, Roma 2008 (Nuovi Studi Storici 76), pp. 19-25.

12 Evidentemente il pontefice si era recato presso il titulus Sabinae in occasione della festa della santa, che era celebrata proprio il 29 agosto.

13 Gregorio di Tours, Historiarum libri X, ed. Bruno KRUsch, in: MGH SRM 1/1, Hannover 1939-1951, pp. 479-481.

14 Giovanni Diacono, Sancti Gregorii Magni vita libris quattuor, in Migne PL 75, coll. 79-81. Sulla «Vita Gregorii», composta probabilmente tra l'873 e l'876, si vedano Claudio Leonardi: La "Vita Gregorii" di Giovanni Diacono, in: Roma e l'età carolingia. Atti della giornata di studio, 3-8 maggio 1976, Roma 1976, pp. 381-393, s. v. Iohannes Diaconus, in: Repfont 6 (1990) p. 310 e Girolamo Arnaldi: 'Giovanni Immonide e la cultura a Roma al tempo di Giovanni VIII': una retractatio, in: Europa medievale e mondo bizantino. Contatti effettivi e possibilità di studi comparati, a cura di Girolamo Arnaldi/Guglielmo Cavallo, Roma 1997 (Nuovi Studi Storici 40), p. 169. L'Arnaldi sottolinea il carattere "così poco agiografico" del testo del diacono Giovanni" tutta costruita su documenti d'archivio, in particolare lettere dal registro, cui l'autore rinvia il lettore per eventuali controlli". 
Il cronista franco e il diacono romano riportano però, accanto ad un identico testo dell'esortazione penitenziale attribuita al pontefice, due itinerari diversi della processione; quello presente nell'opera agiografica di Giovanni Immonide corrisponde a quanto leggiamo nel Registro pontificio alla data del 29 agosto. Per una serie di considerazioni che ho avuto modo di illustrare in altra sede ${ }^{15}$, si deve ammettere che le processioni septiformes, cui partecipavano cioè gli abitanti dell'Urbe divisi in sette gruppi, corrispondenti ad altrettanti "stati di perfezione", siano state almeno due (sempre che, invece, non avessero cadenza annuale). In ogni caso, se si volesse procedere ad un'integrazione dell'opera del Kehr, sarebbe doveroso inserire anche la menzione della processione del 590.

E' certo comunque che la grande processione del 590, ricordata in opere storiografiche ed agiografiche largamente diffuse, divenne - nel tempo - la "processione" gregoriana per eccellenza, cancellando praticamente il ricordo delle altre. Si spiegherebbe così il titolo attribuito al documento citato al numero 4 dal Kehr, titolo che doveva evidentemente salvaguardare il ricordo della laetania septiformis del tempo di peste, che non aveva lasciato invece alcuna traccia nel Registro, in quanto si era svolta probabilmente in data anteriore alla consacrazione papale di Gregorio Magno. Né va dimenticato che, a partire forse dal XII secolo, fu attribuita all'immagine della Vergine conservata in S. Maria Maggiore l'intervento miracoloso che avrebbe posto fine alla devastante pestilenza del $590^{16}$; il miracolo si sarebbe prodotto infatti durante l'imponente processione organizzata da Gregorio che aveva avuto come meta la basilica liberiana.

\section{B) La "distribuzione" di reliquie}

Come vescovi di Roma, numerosi sono i pontefici ricordati nell'opera del Kehr per aver traslato reliquie dall'esterno della città al suo interno, come nel caso di Cecilia, il cui corpo, sepolto in una delle catacombe extra-urbane, fu collocato nella chiesa trasteverina che ancor oggi porta il suo nome da Pasquale $\mathrm{I}^{17}$. In altri casi, come quello della chiesa di S. Susanna, l'edificio viene apparentemente

15 Si veda il mio testo citato a nota 11 .

16 Gerhard Wolf: Die Geschichte römischer Kultbilder im Mittelalter, Weinheim 1990, (Acta Humaniora), soprattutto alle pp. 157-160. Sulla fortuna successiva di questa leggenda si veda Giulia Barone: Immagini miracolose a Roma alla fine del Medio Evo, in: The miracolous Image in the Late Middle Ages and Renaissance, Papers from a conference held in the Accademia di Danimarca in collaboration with the Bibliotheca Hertziana, Rome, 31 May-2 June 2002, a cura di E. Thuno/Gerhard Wolf, Rome 2004, pp. 125-129.

17 IP 1 p. 123 ( a. 822). Ecclesia s. Caeciliae, 1: " Paschalis I sanctorum corpora sub altare collocat et ecclesiam dedicat". 
costruito da Leone III, per accogliere le reliquie di s. Felicita ${ }^{18}$. Altre volte, infine, il papa si limita a traslare una preziosa reliquia da un altare ad un altro: è questo il caso della graticola, su cui si diceva fosse spirato s. Lorenzo, che viene trasportata da un altare, evidentemente in cattive condizioni, ad uno nuovo della chiesa di S. Lorenzo in Lucina ai tempi di Pasquale $\mathrm{II}^{19}$.

Molto meno nota, e non menzionata nella documentazione raccolta dal Kehr, è la traslazione di reliquie da Roma verso i diversi paesi della Cristianità. In questi casi, il pontefice agisce nella sua qualità di vescovo, cui compete il compito di trovare una nuova collocazione ai "corpi santi", ma pone questa sua prerogativa al servizio della sua funzione di guida del mondo cristiano.

Il fenomeno assume proporzioni notevoli a partire dal IX secolo: in quella fase, grazie all'ampliamento dei confini della Cristianità, che abbraccia terre in cui, naturalmente, non erano disponibili "corpi santi", a parte i non numerosissimi casi di martiri dell'evangelizzazione ${ }^{20}$, molte sono le istituzioni religiose che avvertono la necessità di procurarsi reliquie per i loro altari. E Roma, è - da questo punto di vista - il "deposito" più abbondante e prezioso.

Celebri reliquie, oggetto da secoli di grande venerazione, furono allora vittime di "furta sacra", di un vero e proprio contrabbando ${ }^{21}$. E' questa la sorte, ben conosciuta grazie alla vivace rappresentazione che ne ha fatto Eginardo, toccata alle reliquie dei ss. Marcellino e Pietro, fino ad allora conservate nel santuario della via Labicana ${ }^{22}$. Presero così la via del nord anche corpi preziosissimi, come quello di s. Sebastiano, giunto in Francia ai tempi di Ludovico il $\mathrm{Pio}^{23}$.

I pontefici, di fronte al dilagare del fenomeno, ritennero opportuno, non solo da un punto di vista religioso ma anche politico, di diventare parte attiva di

18 IP 1 p. 62. Ecclesia s. Susannae, 2 : „aulam a fundamentis erigens, condens corpus b. Felicitatis martyris compte aedificans ornat atque dedicat."

19 IP 1 p. 84. Ecclesia S. Laurentii in Lucina, $1^{*}$ : „craticulam super quam b. Laurentius emisit spiritum, de quodam altari veteri educit ... sub novo altari 9 Kal. Febr. reconditur."

20 E' questo il caso di Kiliano a Würzburg, cfr. Alfred Wendehorst: Art. Kilian, in: LexMA 5 (1991) coll. 1136-1137; di Bonifacio a Fulda, cfr. Josef Semmler: Art. Bonifatius, in: LexMA 2 (1983) coll. 417-431; di Wenceslao a Praga, cfr. Marie BlÀHovà: Art. Wenzel, in: LexMA 8 (1997) coll. 2185-2187, e di Adalberto a Gniezno, cfr. Adalbert von Prag - Brückenbauer zwischen dem Osten und Westen Europas, a cura di Hans Hermann Henrix, Baden Baden 1997 (Schriften der Adalbert-Stiftung 4).

21 Patrick J. Geary: Furta sacra: la trafugazione delle reliquie nel Medioevo (sec. IX-XI), Milano 2000 (ed. or. Princeton 1978).

22 Eginardo, Translatio et miracula ss. Marcellini et Petri, ed. Georg Wartz, in: MGH SS 15/1, Hannover 1887, pp. 239-264.

23 Ibid., p. 240. Sulla traslazione delle reliquie di Sebastiano venne compilato, nel X secolo, un testo agiografico dalla dubbia attendibilità, cfr. Ex translatione s. Sebastiani auctore Odilone, ed. Oswald Holder-Egger, in: MGH SS 15/1, Hannover 1887, pp. $377-$ 391. 
questo grande processo di "ridistribuzione" dei "corpi santi" all'interno del mondo cristiano. Anche per questa via si sarebbero rafforzati i legami tra "centro" e "periferia" della Cristianità e il ruolo del successore di Pietro quale capo della Chiesa universale ne avrebbe tratto indubbio vantaggio.

Uno dei primi e più celebri casi di "esportazione legale" di reliquie, in quanto decisa dal pontefice, se dobbiamo credere a Hrosvita, avrebbe riguardato le reliquie dei santi pontefici Innocenzo ed Anastasio. A metà del IX secolo, infatti, papa Sergio $\mathrm{II}^{24}$ ne avrebbe fatto dono al duca Liudolfo, venuto in pellegrinaggio a Roma insieme alla consorte dalla nativa Sassonia, cristianizzata solo da pochi decenni a seguito della conquista carolingia. E questo dono del pontefice ha assicurato, nel racconto della monaca/poetessa, la fama e la fortuna dell'abbazia di Gandersheim, fondata da Liudolfo per accogliervi le figlie ${ }^{25} \mathrm{e}$ altre nobili fanciulle, discendenti dalle più grandi famiglie sassoni.

Se, nel racconto di Hrosvita, è evidente l'intento celebrativo del cenobio, nondimeno le parole che ella mette in bocca al duca e al pontefice rispondono assai bene ai costumi e alla mentalità del tempo. Liudolfo chiede infatti delle reliquie che siano in grado di "difendere" la fondazione grazie ai meriti acquistati presso Dio dai santi che vi riposeranno ${ }^{26}$; d'altra parte, il monastero viene posto anche sotto la tuitio papale ${ }^{27}$. Altrettanto verisimili sono le parole di

24 Cfr. Ilaria Bonaccorsi: Art. Sergio II, in: Enciclopedia dei papi, vol. 1, Roma 2000, pp. $720-723$.

25 Friedrich Neumann: Der Denkstil Hrotsvits von Gandersheim, in: Festschrift für Hermann Heimpel, Bd.3, Göttingen 1972, pp.37-60. Sulla funzione politica e memoriale svolta da Gandersheim si veda Gerd Althoff: Gandersheim und Quedlinburg. Ottonische Frauenklöster als Herrschafts- und Überlieferungszentren, in: FMSt 25 (1991) pp. 123-144.

26 Hrosvita, Primordia coenobii Gandersheimensis, ed. Paul de Winterfeld, in: Ders.: Opera omnia, in: MGH SRG (in us. schol.) [34], Berlin 1902, vv. 140-157: Inclite papa, tuis ne sis durus peregrinis,/ Qui de longinquis terarrum venimus oris/ Muneribus nostri famulatus te venerari./ Nitimur ardentis toto conamine mentis/ Condere coenobium domini sub honore sacrandum;/ Unde quidem visum nobis est maxime iustum, / A te consilii solamen quaerere certi/ Et studium nostri tibi precando fateri,/ Qui caput ecclesiae toto dominaris in orbe;/ Qui, si forte tibi placeat devotio nostri,/Auxilium praebente tua pietate paterna,/ Quod votis gerimus, factis bene perficiamus./ Ac tu consilium ciuius merito flagitamus,/ Susceptis donis clementi pectore nostris,/ Scilicet et regis compulsus amore perennis,/ Paresta sanctorum nobis sacra pignora, quorum/ Omnis coenobii constructio possit honoril Apte signari, sacris meritisque tueri. L'opera di Hrosvita è ora disponibile anche in una nuova edizione: cfr. Hrotsvit, Opera omnia, ed. Walter Berschin, München/ Leipzig 2001, che non ho avuto modo di consultare. Per quanto riguarda la più recente storiografia sulla poetessa sassone si veda Armando BisAnTI: Un ventennio di studi su Rosvita di Gandersheim, Spoleto 2005; sui «Primordia» si vedano soprattutto le pp. 43sg. e 169-171.

27 Ibid., vv. 158-160: Utque sit absque ingo regum per saecla potentum/ Nec terrenorum patiatur vim dominorum,/ Hoc rectoris apostolici solum ditionil Tradimus ad defendedum pariterque regendum. 
Sergio; il papa ricorda l'uso romano di conservare integri i "corpi santi", contrariamente a quanto avveniva da secoli a Bisanzio ${ }^{28}$, ma dichiara anche di voler accedere alla richiesta di Liudolfo ed Oda, purché essi si impegnino a mantenere la loro promessa di edificare un monastero ove sia praticata la laus perennis, cioè si preghi ininterrottamente giorno e notte.

L'esempio di Gandersheim non restò isolato: un altro santo "romano", Ciriaco, sarà infatti venerato a Gernrode, la fondazione del margravio Gero, forse il più potente signore alla corte di Ottone I alla metà del X secolo ${ }^{29}$. Non sono però altrettanto chiare le modalità con cui le reliquie pervennero alla comunità di canonichesse che avrebbe dovuto assicurare il ricordo di Gero e del figlio Siegfried, morto (959) prima del padre in seguito alle ferite infertegli in combattimento. Si suppone che le reliquie di Ciriaco siano state portate in Sassonia da Gero di ritorno dai suoi due viaggi a Roma, nel 950 e nel 961. Dopo il primo egli fondò il monastero di Frohse, intitolato a S. Ciriaco; dopo la fondazione di Gernrode, Frohse, divenuto a sua volta Kanonissenstift, gli venne assoggettato. Dal pontefice, secondo il racconto di Thietmar, Gero avrebbe ricevuto in dono un braccio intero di s. Ciriaco. La presenza della preziosa reliquia avrebbe in seguito contribuito a cancellare la primitiva intitolazione di Genrode alla Vergine e a S. Pietro, sostituiti ben presto dal martire romano ${ }^{30}$.

28 Ibid., vv. 167-169: Hic due rectores fuerant aliquando potentes,/ Praesul Anastasius sedis sanctissimis huius/ Et coapostolicus sacer Innocentius eius./ Qui post pastorem Petrum Paulumque magistrum/ Ecclesiae meritis celebre fulsere supremis;/ Quorum tam magna servantur corpora cural Hactenus a cunctis huius rectoribus urbis, I Ut nec particulam quisquam subtraxerat umquam, / pleno membrorum numero remanent sacrorum. Sul tema dello statuto giuridico delle reliquie nei primi secoli cristiani si veda Nicole HermanNMascard: Les reliques des saints. Formation coutumière d'un droit, Paris 1975. Di recente Luigi Canetti ha proposto di "sfumare" la tradizionale contrapposizione tra mos romanum e uso bizantino in tema di dissezione di cadaveri o loro amputazione a fini religiosi; cfr. Luigi CanetTr: Frammenti di eternità. Corpi e reliquie tra Antichità e Medioevo, Roma 2002, soprattutto alle pp. 27-29 e 42sg.

29 Hans Kurt Schulze/Reinhold Specht/Günter W. Vorbrodt: Das Stift Gernrode, Köln/Graz 1965 (Mitteldeutsche Forschungen 38), pp. 58-60 e Helmut Beumann: Art. Gernrode, in: LexMA 4 (1989) col. 1348. Sul margravio Gero, cfr. Helmut Beumann: Art. Gero, in: ibid. col. 1349.

30 Sulla fondazione e intitolazione dello Stift di Frohse, si veda D O I 130; nel 961 Ottone I dota Gernrode, alla cui comunità concede anche la libera elezione della badessa, cfr. D O I 229. L’originaria intitolazione alla Vergine e a S. Pietro risulta da un documento, dello stesso anno, emanato da Ottone II, cfr. D O II 3. Secondo Thietmar ... Romam pergens, emeritus iam senex coram altari principis apostolorum Petri arma deposuit victricia et apud domnum apostolicum sancti impetrans brachium Ciriaci ad Deum cum omne suimet hereditate confugit. Patriamque revisens nati suimet viduam, prius velatam monasterio in saltu, quod suo signatur nomine constructo, Hathui vocatam, statuit abbatissam, in: Thietmari Merseburgensis episcopi Chronicon, ed. Robert Holtzmann, Berlin 1935 (MGH SRG [in us. schol.] N. S. 9), II 19 p. 60sg. 
E' evidente - per quanto risulta dalle fonti - che la donazione delle reliquie di Innocenzo ed Anastasio da parte di Sergio II deve trovare la sua giusta collocazione all'interno della Germania pontificia, tra i destinatari degli interventi papali; ma non mi pare si possa negare l'importanza, per Roma, di questo e altri atti di munificenza pontificia, che hanno contribuito - nel tempo - a ridurre la situazione di assoluto privilegio dell'Urbe in materia di reliquie ma, nel contempo, a rafforzare il rapporto tra Sede apostolica e i più remoti angoli della Cristianità.

\section{C) La riforma del monastero di S. Paolo fuori le mura}

Il terzo aspetto dell'attività pontificia di cui ci occuperemo, la riforma monastica, occupa anch'essa uno spazio, anche se piuttosto limitato, nell'Italia pontificia. Il caso che ci avviamo ad illustrare riguarda la basilica romana di S. Paolo fuori le mura, l'unica delle grandi basiliche ad essere officiata da una comunità di monaci quando tutte le altre ( S. Pietro, S. Giovanni in Laterano e S. Maria Maggiore), fra IX e X secolo, erano ormai servite da collegi di chierici secolari ${ }^{31}$.

Il "merito" per questa eccezionale sopravvivenza monastica, in presenza di corposi interessi dell'aristocrazia urbana ad una "secolarizzazione" degli addetti all'ufficiatura liturgica $^{32}$, è stato attribuito da buona parte della storiografia al grande abate di Cluny, Oddone, di cui è ben nota l'attività riformatrice in alcuni importanti cenobi dell'Urbe, ivi compreso S. Paolo ${ }^{33}$.

31 Sul fenomeno della trasformazione delle comunità monastiche in collegi di chierici secolari, si veda Tommaso di Carpegna Falconieri: Il clero di Roma nel medioevo. Istituzioni e politica cittadina ( secoli VIII-XIII), Roma 2002, pp. 157-164. Sulla diffusione del fenomeno in altre regioni europee cfr. Michel PARisse: Noblesse et monastères en Lotharingie, in: Monastische Reformen im 9. und 10. Jahrhundert, Sigmaringen 1989 (VuF 36), p. 183.

32 Cfr. Giulia Barone: Chierici, monaci e frati, in: Roma medievale, a cura di André Vauchez, Roma/Bari 2001, pp. 198sg.

33 Card. Ildefonso Schuster: La basilica e il monastero di S. Paolo fuori le Mura, Torino 1934, pp.44-54; Giovanni Antonellr: L'opera di Oddone di Cluny in Italia, in: Benedictina 4 (1950) pp. 19-40; Bernard Hamilton: The monastical Revival in Tenth Century Rome, in: IDEm: Monastic Reform, Catharism and Crusades (900-1300), London 1979 (Variorum Reprints), pp. 35-68; Guy Ferrari: Early Roman Monasteries. Notes for the history of the monasteries and convents at Rome from the $\mathrm{V}$ through the X century, Città del Vaticano 1957, pp. 363-376; Girolamo Arnaldi: Il biografo romano di Oddone di Cluny, in: BISI 79 (1959) pp. 19-37. In generale, sulla storia di S. Paolo si veda Monasticon Italiane, vol. 1, Roma e Lazio, a cura di Filippo Caraffa, Cesena 1981, pp. 71sg. 
Pare invece molto più probabile che la riforma, avviata da Oddone, sia stata coronata da successo solo grazie all'intervento di un monaco dell'abbazia lotaringia di Gorze, Andrea, chiamato a Roma da papa Agapito II ${ }^{34}$ nel 950. Il pontefice si sarebbe rivolto al centro riformatore in terra d'Impero - e non più a Cluny cui avevano chiesto aiuto i suoi predecessori e il princeps di Roma, Alberico - probabilmente perché il modello benedettino proposto da Gorze, abbazia di fondazione vescovile e riformata grazie al vescovo di Metz Adalberone, concedeva più ampi poteri e un più esteso controllo all'ordinario diocesano ( in questo caso il vescovo di Roma e pontefice) di quanto non avvenisse a Cluny ${ }^{35}$.

Alla luce di questo episodio, pare probabile che la donazione attribuita ad Agapito II, e forse ricordata in una lapide marmorea nel pavimento dell'antica basilica, possa essere considerata autentica, benché il documento che ne ha conservato memoria, una bolla di Gregorio VII, sia stata considerata da molti falsa e dal Kehr quantomeno interpolata ${ }^{36}$. Una volta realizzata la riforma, che garantiva un'attenta ed oculata gestione del patrimonio, è del tutto verisimile che il pontefice abbia voluto ampliare la dotazione di beni di un'abbazia che, oltre tutto, riteneva di poter continuare a controllare da tutti i punti di vista.

Come si può facilmente evincere dai casi qui illustrati, se, nell'intento di correggere e/o integrare l'opera del Kehr, si estende l'indagine a fonti come quelle storiografiche ed agiografiche, l'impresa rischia di sfuggire ad ogni possibilità di programmazione e di controllo. Ogni singolo episodio, ogni attestazione rischia di dover essere vagliata con estrema attenzione, per non introdurre dati erronei o incompleti. Inoltre, le tipologie di fonti cui ho fatto riferimento, e soprattutto quelle agiografiche, difettano, quasi sempre, di quella precisione cronologica che è necessaria per integrare l'Italia pontificia. La presenza a Roma di Andrea di Gorze, datata dall'autore della «Vita Iohannis Gorziensis ${ }^{37}$ al 950, rappresenta un'assoluta eccezione, motivata dal fatto che

34 Girolamo Arnaldi: Art. Agapito II, in: Enciclopedia dei papi, vol. 2, Roma 2000, pp. 77-78.

35 Su questo episodio della riforma di S. Paolo si veda Giulia Barone: Gorze e Cluny a Roma, in: Retour aux sources. Textes, études et documents d'histoire médiévale offerts à Michel Parisse, Paris 2004, pp. 583-590.

36 Cfr. IP 1 p. 168, nr 10*: "Agapitus II possessiones confirmat et donat specialiter medietatem civitatis Manturanae et totius territorii eius cum colonis et colonabus suis, retinens alteram medietatem in dominio suo." L'editore delle carte di S. Paolo, il Trifone, accoglie l'ipotesi di Kehr sull'interpolazione del documento, evidente soprattutto per i beni "de Nepe", donati a S. Paolo da Innocenzo III, ma non è in grado di valutare l'attendibilità degli altri interventi pontifici ivi menzionati; cfr.: Le carte del monastero di S. Paolo (cit. nota 4) p. 278. La bolla di Gregorio VII è tradita grazie ad una copia autentica del 30 dicembre 1281.

37 Iohannes de sancto Arnulpho, Vita Iohannis abbatis Gorziensis, ed. Georg Heinrich Pertz, in: MGH SS 4, Hannover 1841, pp. 335-377, qui p. 352. Della biografia di 
Andrea morì a Roma nel corso della sua missione ed è ben noto che la morte dei membri di una comunità benedettina veniva liturgicamente commemorata all'interno del monastero di appartenenza.

\section{Zusammenfassung}

Der Beitrag geht der zentralen Fragestellung nach, ob und in welchem Umfang das Material der Italia Pontificia für auf hagiographisch und historiographisch ausgerichtete Untersuchungen nutzbar gemacht werden kann. Er konzentriert sich auf drei Aspekte: die Liturgie (die von Gregor dem Großen organisierten Prozessionen), die Translation von Reliquien außerhalb Roms und die päpstlichen Schenkungen an römische Klöster (S. Paolo fuori le mura). In allen drei untersuchten Bereichen besteht eine bemerkenswerte Schwierigkeit, die Ereignisse anhand der narrativen Quellen exakt zu datieren. Insgesamt ist es sehr schwierig und bisweilen sogar wenig nutzbringend, das in der Italia Pontificia gebotene Material in die angesprochenen Untersuchungsfelder einzubinden.

Giovanni è da alcuni anni disponibile un'ottima traduzione, con commento ; cfr. La Vie de Jean, abbé de Gorze, présentée et traduite par Michel Parisse, Paris 1999. Il passo relativo ad Andrea si può leggere alle pp. 86-87. 
Bereitgestellt von | De Gruyter / TCS

Angemeldet | 217.89.40.26

Heruntergeladen am | 21.12.12 10:49 


\section{Berichte von der Kurie über den Erwerb umstrittener Prozeßmandate und Privilegien (12.-13. Jahrhundert)}

\section{Dietrich LohrmanN}

Die Neuigkeiten von der Kurie (Nova curiae), die ich auf dem Programm der Tagung angekündigt habe, hätte man im älteren Deutschen des 17.-18. Jahrhunderts als ,Zeitungen vom Papsthof' bezeichnet. Solche Mitteilungen betrafen unmittelbar aktuelle Vorkommnisse aus dem Umfeld der Kurie, die in Europa an interessierter Stelle verbreitet wurden. Sie sind aus der neueren Geschichte, wie es scheint, in größerer Menge erhalten. Fritz Kern in seinen «Acta Imperii Anglie et Francie» nennt bereits aus dem späteren 13. und dem 14. Jahrhundert eine ganze Reihe von Beispielen ${ }^{1}$. Für die Frühzeit sind sie selten und weit verstreut. Über die entscheidenden Verhandlungen am Papsthof und ihren Verlauf, wie insbesondere über die Reaktionen der Päpste auf den jeweiligen Vortrag der Kläger und Bittsteller, erfahren wir dadurch in der Regel nur Weniges. Für das Regestenwerk Italia pontificia ist das nicht gravierend, denn dort sind Verhandlungen vor dem Papst nicht als Regesten vorgesehen. Sie gehören weder in den Band Rom noch in die entsprechenden Bände der sonstigen Aufenthaltsorte der Kurie. Trotzdem liefern solche Berichte für das Verständnis vieler Entscheidungen sehr wesentliche Gesichtspunkte. Sie lesen sich auch viel lebhafter als die Urkunden selbst und verdienen daher gesammelt zu werden.

Petitionen oder Entwürfe von Urkunden, aus deren Varianten gegenüber den Ausfertigungen wir Erkenntnisse über die Vorverhandlungen ableiten könnten, sind bekanntlich ebenfalls nur selten erhalten ${ }^{2}$. Die am Ende ausgefertigten Papsturkunden liefern in der Narratio zwar knappe zusammenfassende Angaben (etwa so: die streitenden Parteien seien aufmerksam angehört worden, und der Papst entscheide nun nach Beratung durch seine fratres, die Kardinäle), aber Näheres ist auch daraus nicht zu entnehmen. Erst ab 1198 geht es dank den Registerbänden Innozenz'III. des öfteren auch in die verfahrensrechtlichen

1 Fritz Kern: Acta Imperii Anglae et Franciae ab anno 1267 ad annum 1313, Tübingen 1911 (ND 1973), S. VIII: „Es gehört zu den seltenen Freuden heutiger Archivarbeit, solchen frischen Zeugnissen des 13. Jahrhunderts ... zu begegnen“. Die von Kern edierten Berichte (Nr. 2, 8, 19, 38, 48) gehören in die Jahre 1273 bis 1284.

2 Beispiele bei Dietrich Lohrmann: Kirchengut im nördlichen Frankreich. Besitz, Verfassung und Wirtschaft im Spiegel der Papstprivilegien des 11.-12. Jahrhunderts, Bonn 1983 (Pariser Historische Studien 20), S. 90-107. 
Details ${ }^{3}$. Ich überblicke freilich bislang nur einen Teil des französischen Materials, vor allem das nordfranzösische, und kann nicht sagen, was sich bei näherer Prüfung aus den Angaben der Italia pontificia oder den Papstregistern des 13. Jahrhunderts für Italien ergeben würde.

Nicht selten ist schon im 11. Jahrhundert von einer audientia domini papae die Rede, einem Begriff, der vielfach bereits untersucht und schon aus der älteren Zeit wohlbekannt ist ${ }^{4}$. Zitiert sei nur ein früher Brief Gregors VII. aus dem Jahre 1073 an den Erzbischof Manasses von Reims, dieser möchte es nicht länger zulassen, daß die Papstaudienz durch zu viele Klagen bemüht werde: totiens apostolicam audientiam fratrum clamoribus fatigari. Die Kurie widersprach damit nicht ihren sonstigen Erklärungen, in denen sie sich weitherzig zur Zuflucht aller anbot, die Recht und Schutz suchten. Der Erzbischof von Reims soll nur sein persönliches Verhalten ändern und die Zahl begründeter Klagen nicht unnötig anschwellen lassen.

Vier Jahre später reiste Erzbischof Manasses von Reims selbst nach Rom und suchte seine Exkommunikation und Suspension durch den übereifrigen Legaten Hugo von Die rückgängig zu machen. Nach elfwöchigem Warten kam es endlich zur Verhandlung vor dem Papst und einer römischen Fastensynode. Manasses' offensive Strategie gegen den Legaten trug hier offensichtlich Früchte,

3 Die Register Papst Innocenz'III., 8: 8. Pontifikatsjahr 1205/1206, ed. Othmar Hageneder/Andrea Sommerlechner Wien 2001 (Publikationen des Historischen Instituts beim Österreichischen Kulturinstitut in Rom 2/8), S. 351-357 Nr. 205 vom 18. Jan. 1206: Cum igitur ...super monasterii vestri subiectione ac libertate controversia verteretur et nos eam examinandam commisissemus iudicibus delegatis, ipsi causam eandem sufficienter instructam ad nostram presentiam remiserunt, certum partibus terminum prefigentes, quo cum instrumentis et attestationibus nostro se conspectui presentarent sententiam recepture. Partibus igitur in nostra presentia per procuratores idoneos constitutis audientiam prebuimus liberam et benignam. Siehe dazu den unten Anm. 33 angezeigten Bericht des Sachwalters einer der Parteien (Prozeß Evesham gegen Bischof von Worcester).

4 Peter Herde: Beiträge zum päpstlichen Kanzlei- und Urkundenwesen im 13. Jahrhundert, Kallmünz ${ }^{2} 1967$, S. 213-223. In dieser verbesserten und erweiterten Auflage sind die Ergebnisse von Herdes Edition der Formelbücher eingearbeitet, Peter Herde: Audientia litterarum contradictarum. Untersuchungen über die päpstlichen Justizbriefe und die päpstliche Delegationsgerichtsbarkeit vom 13. bis zum Beginn des 16. Jahrhunderts, Tübingen 1970 (Bibliothek des Deutschen Historischen Instituts in Rom 31-32), S. 223-238. Weitere Literatur in den Artikeln ,Audientia litterarum contradictarum " und ,Audientia sacri palatii' von Peter Herde und Gero Dolezalek im: LexMA 1 (1980) Sp. 1192-94. Zur früheren Zeit (Gregor I.) vgl. Ernst Pitz: Papstreskripte im frühen Mittelalter. Diplomatische und rechtsgeschichtliche Studien zum Brief-Corpus Gregors des Großen, Sigmaringen 1990 (Beiträge zur Geschichte und Quellenkunde des Mittelalters 14), S. 243-246, und Hans Gabelmann: Antike Audienz- und Tribunalszenen, Darmstadt 1984.

5 Das Register Gregors VII., hg.v. Erich CAspar, Berlin 1920/1923 (MGH Epp. sel. 2/ 1-2), I/13 S. 21. Mit den fratres sind auswärtige Bischöfe als Kläger gemeint. Das Register enthält zahlreiche andere Belege für apostolica audientia (Index S. 677a unten). 
trotz deutlicher Bedenken Gregors VII., denn der ihm lästige Manasses, den er als selbstbewußten Vertreter des älteren Systems nur schwer ertragen konnte, wurde wieder eingesetzt. Die anwesenden Kardinäle, auf deren Wunsch der Beschluß offenbar erfolgt war, hatten sich beeindrucken lassen durch die Klagen des Manasses und die Beschwerden mehrerer anderer französischer Erzbischöfe, die ebenfalls durch den Legaten suspendiert worden waren. Widerwillig entschloss sich deshalb auch Papst Gregor zur Suspension der Suspensionen, unter der Bedingung freilich, daß sämtliche Beklagten sich noch vor dem Legaten zu entschuldigen hätten. Eine Desavouierung des Gregor eng vertrauten Legaten Hugo von Die war so vermieden ${ }^{6}$.

Beschränken wir uns nun auf die subjektiven Berichte aus der Sicht einzelner Prozeßparteien. Sie bilden die einzige Quellengruppe, die gelegentlich den Verlauf einer mündlichen Verhandlung vor Papst und Kardinälen genauer schildert. Nur in einem Sonderfall liegt für die Jahre 1148-1152 der Bericht eines mehr oder weniger neutralen Dritten vor, Johannes von Salisbury. Er hat als Augenzeuge einige Jahre später eine ganze Folge aufschlußreicher, zum Teil geradezu anrührender Szenen von Verhandlungen vor Konzilien bzw im Konsistorium festgehalten ${ }^{7}$.

\section{Französische Berichte aus dem 12. Jahrhundert}

Im 12. Jahrhundert gibt es, wie angedeutet, noch keine institutionell verfestigte Instanz, die es den streitenden Parteien erlaubt hätte, Einspruch gegen die Ausfertigung einer Papsturkunde zu erheben, welche einen der Prozeßgegner begünstigte. Von contradictio ist zwar die Rede, doch die dringend notwendige

6 Register Gregors VII. (wie Anm. 5) V/17 S. 378-380; dort auch der Eid, den Manasses zu schwören hatte. Der Papst betont ausdrücklich: non sine gravi labore discussimus. Die näheren Umstände des Aufenthaltes an der Kurie und der Verhandlung erfahren wir aus Manasses' zwei Jahre späterem Brief an den Legaten bei Bouquet 14 S. 782: tandem in praesentia domni Apostolici et in concilio generali inter nos et eos qui ibi loco vestro ... aderant, altercatio habita est, et ex eorum accusatione ac nostra defensione quidquid passi eramus temere ac violenter actum esse et constare non debere, judicatum atque correctum est. Tum ego domno Apostolico renunciavi cunctis audientibus. Ipso autem Apostolico subsequenter interrogante. Deinde etiam idem instituit domnus Apostolicus. Die Überlieferung des nachfolgenden Verfahrens gegen Manasses siehe bei Dietrich Lohrmann: Papes et cardinaux en France et en Bourgogne au temps de la Réforme grégorienne, in: L'abbaye d'Ainay des origines au XIIe siècle, dir. Jean-François Reynaud/François Richard, Lyon 2008, S. 161 - 179. In den Briefsammlungen der Zeit Heinrichs IV., ed. Carl ErdmanN/ Norbert Fickermann, Weimar 1950 (MGH Epp. DK 5), S. 243 f., findet sich die Beschreibung einer weiteren Absetzungsverhandlung 1075 an der Kurie, hier aus Bamberger Sicht: Ecce autem Rome, dum terminum vocationis sue supersedisset ...

7 Siehe weiter unten. 
Instanz einer audientia litterarum contradictarum hat erst Innozenz III. kurz nach 1200 geschaffen $^{8}$. Wichtige Rechtsfragen und Einsprüche waren somit in der früheren Zeit vom Papst selbst zu prüfen. Das führte zu Überlastung und gelegentlich auch Fehlentscheidungen oder Urkunden, die ohne Wissen des Papstes herausgingen. Zuweilen, so insbesondere bei Erschleichung von Urkunden mittels Vorspiegelung falscher Tatsachen, beklagten die Päpste selbst den Mißstand: die Fülle der Geschäfte habe sie überfordert, es sei daher zu einem Fehler gekommen?.

Erstes Beispiel: 1107, als Papst Paschalis II. - kein erfahrener Jurist - nach Frankreich kam und bereits in Dijon angelangt war, erhob dort ein angesehener Gelehrter, der Magister Anselm von Laon, Einspruch gegen die Wahl eines neuen Bischofs seiner Stadt. Der Elekt war Kanzler des Königs von England gewesen. Er hatte sich in dieser Funktion massiv bereichern können und war persönlich, glaubt man dem Berichterstatter, vor allem an militärischen Dingen und Fragen der Jagd interessiert. Von kirchlichen Weihegraden preter clericatum war er noch unberührt, die Diakonsweihe nahm er erst nach seiner Wahl entgegen. Mehr lag ihm an der Verbreitung der Kunde von seiner Zahlungsfähigkeit, und damit stieß er am Papsthof auf offene Ohren. Auch die bedürftigen capellani papae und zumindest ein Teil der Kardinäle zeigten sich empfänglich ${ }^{10}$.

Unser Bericht stammt von keinem Unbekannten. Er steht in der Autobiographie eines Abtes der Diözese Laon, Guibert von Nogent ${ }^{11}$. Genau erzählt dieser, wie der Papst ihn zusammen mit zwei anderen Äbten zur Person des Elekten persönlich befragt hatte. Seine Antworten bezeichnet er selbstkritisch als lauwarm, wenn auch nicht ganz falsch: verba tepentia, sed non penitus a vero deviantia. Mit Bestimmtheit bejahen konnte er nur die Frage, ob der Elekt

8 Herde: Audientia (wie Anm. 4). Über die Begriffe consistorium and consilium fratrum nostrorum (Beratung mit den Kardinälen) vgl. die instruktive Untersuchung von Sarah Noethlichs: Das päpstliche Konsistorium im Spiegel der Quellen des 11.-12. Jh., in: ZRGKanAbt 94 (2008) S. 272-287.

9 Vgl. u.a. Herde: Beiträge (wie Anm. 4) S. 93 f., 110 Anm. 197: per falsi suggestionem et veri suppressionem; weiteres ebenda S. 63, 112 f. Vgl. auch Lohrmann: Kirchengut (wie Anm. 2) S. 67 f. ; zu Gregor VII. Pitz: Papstreskripte (wie Anm. 4) S. 56 und Index s. v. Erschleichen. Das reiche Material zu Erschleichungen im 12. Jahrhundert kann ich hier nicht ausbreiten. Sehr aufschlussreich schon der Bericht des Bischofs Hugo von Grenoble zum Streit mit Erzbischof Guido von Vienne um den Pagus von Sermorens und seine Burgen vor Papst Urban II., analysiert von Beate Schilling in GalP 3/1 S. 136-144 Nr. *183-*209. Weiteres bei Alfons BeCker: Päpstliche Gerichtsurkunden und Prozessverfahren zur Zeit Urbans II. (1088-1099), in: Zwischen Saar und Mosel. Festschrift für Hans-Walter Herrmann, hg.v. Wolfgang Haubrichs al., Saarbrücken 1995, S. 39-48.

10 Guibert de Nogent, Histoire de sa vie (1053-1124), ed. Georges Bourgin, Paris 1907, S. 141-143; ders., Autobiographie, ed. Edmond-R. Labande, Paris 1981, S. 286-292. Dazu François Dolbeau: Deux nouveaux manuscrits des «Mémoires» de Guibert de Nogent, in: Sacris Erudiri 26 (1983) S. 155-176.

11 Guibert, ebd. 
rechtmäßiger Geburt sei. Aber auch hier zierte er sich: der Elekt sei neque nothus neque spurius. Klagen oder Einwände in offener, eindeutiger Form äußerte er nicht. Angesichts der vorherrschenden Stimmung unter den Kurialen zugunsten des zahlungskräftigen Kandidaten resignierte jedoch nicht nur er, der kleine Abt. Selbst der mutige Magister Anselm, der zuvor offen Klage geführt hatte, verzichtete im Laufe der weiteren Verhandlung darauf, „dem Herkules (gemeint ist der Elekt) die Keule aus der Hand zu reißen“. Guibert seinerseits wird am Schluß von einer Gruppe Kardinäle wegen seiner gewundenen Erklärungen beglückwünscht: Multum placuerunt nobis verba tua. Er schämt sich, denn er hat es nicht verhindert, daß nun das Bischofsamt, die gratia pontificandi, an einen völlig ungeeigneten Kandidaten gelangt.

Dem neuen Bischof Galterus (Gautier) von Laon sind selbstverständlich die Urkunden und Briefe ausgefertigt worden, die zum Amtsantritt eines Bischofs üblich waren. Das wird in dem literarisch überformten Bericht des Guibert von Nogent nicht ausdrücklich hervorgehoben. Sein Fazit lautet viel allgemeiner: „Geld beherrscht alles, so auch an der Kurie. Wenn keiner ein offenes Wort wagt, wie leider auch ich es getan habe, kommen die falschen Leute in die höchsten Ämter, und das zieht furchtbare Folgen nach sich.“

Der zweite Bericht ist viel kürzer gehalten. Er stammt aus dem Benediktinerkloster Saint-Bertin in der nordfranzösischen Diözese Thérouanne. Diese bedeutende Abtei geriet während der ersten Hälfte des 12. Jahrhunderts in eine schwierige Lage, da sie im Zuge der flandrischen Klosterreform der Oberhoheit des Abtes von Cluny unterstellt worden war. Energisch versuchte man, die alte Freiheit zurückzugewinnen. Die «Gesta abbatum Sancti Bertini» liefern in diesem Zusammenhang eine Reihe von Nachrichten über Romreisen und Appellationen vor verschiedenen Päpsten. Es geht um den Erwerb von Privilegien für die eine wie für die andere Seite und schließlich auch, 1130, um allgemeinere Bemerkungen über das päpstliche Schisma. Besonders aufschlußreich wirkt eine Notiz, die wie unser erstes Beispiel aus Laon noch in die Zeit des leicht zu überzeugenden Mönchspapstes Paschalis II. gehört: Animatus itaque suorum consilio reist der Abt Lambert von Saint-Bertin 1112 nach Rom. Er will an der Kurie die unberechtigten Ansprüche der Cluniazenser darlegen: expositurus Romane curie Cluniacensium iniuriam. Das Glück (fortuna) lächelt ihm so freundlich $\mathrm{zu}, \mathrm{da}$ ihm alle Anträge problemlos (absque ulla difficultate) von Papst und Kurie bewilligt werden. Die Stimmung dort, bemerkt der Text, war gerade stark anticluniazensisch geprägt. Leider nennt er dafür nicht die Gründe, man mag sie in den beginnenden Schwierigkeiten des Abtes Pontius suchen ${ }^{12}$.

12 Gesta abbatum S. Bertini Sithiensium, ed. Oswald Holder-Egger, in: MGH SS 13, Hannover 1881, S. 643 f. Zu Abt Pontius vgl. Gerd Tellenbach: Der Sturz des Abtes Pontius von Cluny und seine geschichtliche Bedeutung, in: QFIAB 42/43 (1963) S. 1355, sowie Neithard Bulst: Art. Pontius 1, in: LexMA 7 (1995) Sp. 98. 
Auch die erworbenen Urkunden sind nicht näher aufgeführt ${ }^{13}$. Aufschlußreicher wirkt, daß der Abt von Saint-Bertin seinem Erfolg selbst nicht traut. Er fürchtet einerseits Romanorum cupiditatem et inconstantiam, zum anderen die cluniazensische constantiam. Cluny läßt sich nämlich auf keinerlei Friedensangebot ein und sendet Boten auf Boten nach Rom, um die Gunst des Papstes zurückzugewinnen ${ }^{14}$.

Wieder unmittelbar in die Einzelverhandlung vor dem Papst, nunmehr 1141 vor Innozenz II., führt unser drittes Fallbeispiel. Es ist ein Bericht über die Romreise des Abtes Hariulf von St. Peter in Oudenbourg (Diözese Tournai). Dieser Text ist nicht unbekannt, aber trotzdem so schön, daß ich ihn hier unmöglich übergehen kann. Dem bereits greisen Abt im schlohweißen Haar hatte sein Gegner, der Abt von Saint-Médard in Soissons, wirksamen Widerstand gegen ein perfides Übernahmemanöver nicht mehr zugetraut; der Alte lasse bereits die Flügel hängen. Frech hatte der Abt aus Soissons sich deshalb ein Schreiben des Papstes verschafft, das den Abt Hariulf kurzerhand aufforderte, sich der Autorität des Abtes von Saint-Médard zu unterstellen. Statt feindlicher Übernahme an der Börse wie in unserer Zeit investierte man in der ersten Hälfte des 12. Jahrhunderts, um sein Ziel zu erreichen, an der Kurie und fügte notorisch falsche Angaben hinzu wie die, Abt Hariulf sei selbst zuvor ein Mönch von Saint-Médard in Soissons gewesen ${ }^{15}$.

Der wackere Greis ermannte sich jedoch. Er nahm alle Mühen der Reise auf sich und erschien, empfohlen durch Briefe des Bischofs von Noyon-Tournai sowie des Abtes Bernhard von Clairvaux, unvermittelt vor dem päpstlichen Kanzler Haimerich. Der verschaffte ihm Zugang zum Papst. Vorauf gingen weitere Gespräche mit mehreren Kardinälen. Um sich vor dem Papst in angenehmer Weise zu präsentieren und nicht gleich mit der Tür ins Haus zu fallen, beginnt unser flandrischer Abt mit einer Fabel: Ein Mann heiratet die ,Exfreundin' eines Rivalen und lebt 35 Jahre lang mit ihr zusammen. Da erscheint der Rivale und will die Frau entführen, da sie ihm als seine Verlobte gehöre. In dieser Weise, so Abt Hariulf zu Innozenz II., sei auch der Abt von Saint-Médard vorgegangen, und der Papst habe ihn dabei unterstützt, indem er den entsprechenden Brief ausstellen ließ. Indes, Nemo absens condempnetur, zitiert Hariulf den sogen. Zephyrinus (Pseudo-Isidor), einen Text, der kurz darauf

13 Gesta, ed. Holder-Egger (wie Anm. 12) S. 643.

14 Mehr zu ermitteln, bleibt eine Aufgabe der Gallia Pontificia. Vgl. einstweilen Laurent Morelle: Par delà le vrai et le faux: trois études critiques sur les premiers privilèges pontificaux de l'abbaye de Saint-Bertin (1057-1107), in: L'acte pontifical et sa critique Études réunies par Rolf Grosse, Bonn 2007 (Studien und Dokumente zur Gallia Pontificia 5), S. 51-86.

15 Ernst Müller: Der Bericht des Abtes Hariulf von Oudenburg über seine Prozessverhandlungen an der römischen Kurie im Jahre 1141, in: NA 48 (1930) S. 97-115. 
auch in der Rechtssammlung Gratians erscheint (C. 3 q. 9 c. 13) ${ }^{16}$. Solche Kritik behagte dem Kanzler Haimerich gar nicht, er schaltet sich ein: Domne abbas, videte quomodo caute loquamini! Doch das bringt den Greis erst wirklich in Fahrt: iste littere ... (gemeint ist der Papstbrief) omni dolo, omni mendacio omnique fallacia plene fuerunt. Im höchsten Maße sei er darüber empört und verwirrt gewesen, daß diese littere ... omni veritate carebant et tamen domini apostolici bullam habebant.

Wichtig ist nachfolgend die Vorgehensweise bei der Auswahl der delegierten Richter, die den Sachverhalt untersuchen sollen. Wir erhalten hier sogar wörtliche Rede. Für die Untersuchung schlägt man dem ungestümen Abt Hariulf drei mögliche Richter vor. Darunter sind zwei Bischöfe, die er in folgender Weise ablehnt: Der Bischof von Châlons sei ein ehemaliger Mönch von SaintMédard, also befangen, und der Bischof von Arras habe die ganze Belästigung persönlich angezettelt. Konsequenz für den Abt: Habet Francia alios viros, non inferioris gracie, quorum iudicium non pavesco. Er wünscht sich den Bischof von Chartres. Den verweigert aber der Kanzler: Non tibi datur dominus Carnotensis ... quia longinquus et Romanis negociis occupatissimus. Auch der Bischof von Laon komme nicht in Frage. Am Ende einigt man sich und die Szene schließt in Wohlgefallen.

Nicht die ganze Verhandlung eines anderen Falles, wohl aber ihr wichtigster Teil, ist ebenfalls aus der Zeit Innozenz' II. überliefert. Das Plädoyer wurde vermutlich Anfang Januar 1136 in Pisa vorgetragen. Es ist ein glänzend durchformulierter Text, der den Papst mehrfach unmittelbar anspricht und ihn auch überzeugt hat, denn die umstrittene Kapelle wird der Klägerpartei un-

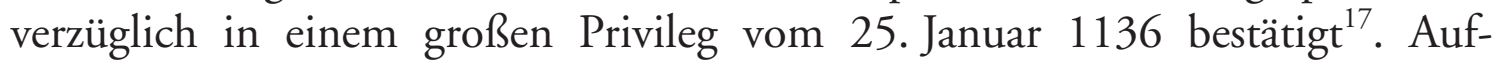
schlußreich schon die unmittelbare Ansprache des Papstes als Weltherrscher: Unice pater orbis et domine. Der Bischof Ulger von Angers referiert die Argumente beider Prozeßparteien, aber von Anfang an macht er sich zum Fürsprecher der armen Regularkanoniker von La Roé gegen die mächtige Abtei Vendôme, die sich in einem höchst bedenklichen Verfahren die besagte Kapelle hat zusprechen lassen, nämlich obwohl La Roé knapp 20 Jahre zuvor von allen zuständigen Instanzen Bestätigungen erhalten hatte. Am Schluß (1117) hatte sogar Papst Paschalis II. seine urkundliche Zustimmung gewährt. Ostentativ hält sie der Bischof dem Papst entgegen: Videte, videte illa, ostendimus et offerimus. Noch bezeichnender wirkt, wie Bischof Ulger die Argumente des

16 Zuvor auch schon in Collectio tripartita 1.13.1 (2. Rez.). Dazu Peter Landau: Gratians unmittelbare Quellen für seine Pseudoisidortexte, in: Fortschritt durch Fälschungen, hg.v. Wilfried Hartmann/Gerhard Schmitz, Hannover 2002 (MGH Studien und Texte 31), S. 184.

17 JL 7755. Das Plädoyer des Bischofs von Angers steht bei Migne PL 179 Sp. 16491654 . 
Gegners zerflückt. Er legt hier dem Abt von La Roé seine Worte in den Mund. Was Vendôme als Urteil zu seinen Gunsten bezeichne, das sei gar kein Urteil, sondern preiudicium oder peregrinum iudicium, et iustum iudicium non fuit quia non fuit factum apud eum quem debuit, nec per eos quos debuit, nec eo modo quo debuit, nec eo loco nec eo tempore, neque circa hos circa quos decuit. Also lauter Verfahrensfehler. Am Schluß heißt es noch einmal in direkter Wendung an den Papst: quia vos estis sustentator pauperum, et pater orphanorum, et advocatus eorum. Vos estis iudex iudicum terre. Sententia vestra definit universas.

Der nächste Fall zeigt zunächst wieder ein mehr anekdotisches Gepräge. Es geht um ein Privileg für die Regularkanoniker von Sainte-Barbe-en-Auge in der Normandie. Wir stehen im Jahr 1147 unter Eugen III. Der Prior von SainteBarbe erscheint an der Kurie mit einem Brief des Grafen von Eu, dem eine lange Besitzliste beigefügt ist. Die in dieser Supplik genannten Güter liegen in der Normandie und in England, sie sollen durch das Privileg des Papstes bestätigt werden. Aus zunächst unklaren Gründen verzögert sich jedoch die Ausstellung. Unser Prior wird immer wieder vertröstet und erfährt die Hintergründe nicht. Bis er am 4. Dezember, dem Fest der Klosterheiligen, der hl. Barbara, persönlich vor dem Papst erscheint und erklärt: Domine, hodie est festum beate Barbare. Memor esto petitionis illius. Antwort Eugens III.: Hodie fiet. Drei Tage später ist das Privileg ausgestellt. Die Chronik von Sainte-Barbe schildert zusätzlich seine Verwendung, denn der wackere Prior reist mit dem kostbaren Dokument unverzüglich nach England und zwingt unter Berufung auf den Papst die widerstrebenden englischen Bischöfe zur Exkommunikation all derer, die noch Güter des normannischen Stiftes in ihrer Hand zurückhalten ${ }^{18}$.

Eine der ausführlichsten Verhandlungsschilderungen des 12. Jahrhunderts gehört 1152 zu dem heftigen, seit langem laufenden Streit zwischen dem päpstlichen Eigenkloster Vézelay und dem Bischof von Autun Heinrich, einem Bruder des Herzogs von Burgund. Der detaillierte Bericht durch den Chronisten der Abtei gewinnt besonderen Wert durch die genau protokollierten Zeugenaussagen, sechs Zeugen, die der Abt aufbietet, zehn Zeugen seitens des Bischofs. In einer Verhandlung muß der Bischof sich so ereifert haben, daß er in Anwesenheit des Papstes erklärte, lieber solle die Abtei Vézelay zerstört werden, als daß sie seinem Befehl nicht gehorchen müsse. Da derselbe Bischof am Ende der Vernehmungen ein ungünstiges Urteil erwartete, erklärte er, weitere für ihn wichtige Zeugen hätten wegen Alter und Schwäche die Reise nach Rom nicht antreten können. Er erwirkte damit Aufschub. Drei delegierte Richter sollten auch diese Zeugen noch vernehmen und ihre Aussagen versiegelt dem Papst

18 Chronique de Sainte-Barbe-en-Auge, ed. René-Norbert Sauvage, Caen 1907, S. 29 36, 40-46. Text des Privilegs Eugens III. in Papsturkunden in Frankreich 2: Normandie, ed. Johannes Ramackers, Göttingen 1937, S. 111-114 Nr. 44, (JL 8964).Vgl. Lohrmann: Kirchengut (wie Anm. 2) S. 90-99. 
zukommen lassen. Die Sache endete seitens des Bischofs und der von ihm angestachelten Bürger von Vézelay mit schweren Übergriffen auf die Abtei, wogegen der Papst in zahlreichen Schreiben Stellung bezog und der Abtei beistand ${ }^{19}$.

Einzuschieben ist hier außerdem der bereits angekündigte Bericht eines langjährigen Dauergastes an der Kurie, Johannes von Salisbury ${ }^{20}$. Seine Erinnerungen gehen auf seine wiederholten Kurienaufenthalte während der Jahre 1148 bis 1152 zurück; eine offizielle Funktion am Papsthof hatte er dabei nicht, weswegen wir ihn durchaus als neutralen Beobachter einstufen können. Die meisten Angelegenheiten erwähnt er nur knapp, so auf dem Konzil von Reims 1148 die Primatsansprüche etlicher Erzbischöfe an Eugen III. und die Versuche einiger Bischöfe, exemte Abteien wieder in ihre Kontrolle zu bekommen. Die Antwort auf diese Eingaben sei in der Regel durch Hinweis auf Verfall der Ansprüche (Präskription) erfolgt, auch hätten die Beklagten darauf verwiesen, daß sie zu dieser Sache nicht geladen seien. Etwas ausführlicher referiert der englische Beobachter den Streit des Erzbischofs von Canterbury mit dem von York; hier zitiert er eine formal begründete Antwort des Papstes wörtlich. Kurz bleiben seine Angaben wieder im Kapitel 4 zur Suspension der Erzbischöfe von Mainz und Köln sowie des Bischofs von Winchester. Gleich zwei ganze Kapitel füllt dagegen die delikate Ehesache des Grafen von Vermandois, bei der es darum ging, Entscheidungen der Vorgängerpäpste aufzuheben; eine unheilvolle Weissagung des Bernhard von Clairvaux zu dieser Sache kam hinzu (Kap. 6 und 7). In dem langen Referat des Johannes über die theologisch begründeten Angriffe gegen den gelehrten Bischof Gilbert von Poitiers spricht Eugen III. an einer Stelle französisch (Gallica utens lingua); die Verhandlung läuft in Paris (Kap. 9-14). In Kapitel 21 (Konzil von Cremona) wehrt der Papst eine Reihe von Primats- und Exemtionsansprüchen ab, diesmal solche von italienischen Prälaten ${ }^{20}$.

Anrührend und aufsehenerregend verläuft schließlich (Kap.41) die von Eugen III. erwirkte Versöhnung des normannischen Grafen Hugo mit dessen Gattin aus dem Hause der Grafen von Tusculum, von der er sich unter Auf-

19 Monumenta Viceliacensia, ed. Robert Buchard Constantijn Huygens, Turnhout 1976 (CChrCM 42), S. 397-408. Dazu die Papstbriefe Nr. 28-50, ebd. S. 314-355. In einem dieser Briefe (Nr. 47) an den Bischof von Autun erinnert sich Eugen III.: de ore tuo audivimus processisse, quia scilicet malebas ut Viceliacense monasterium omnino destrueretur, quam tue non debeat iussioni parere. Der Bericht über die Verhandlung vor Eugen III. wurde schon 1153 an den neuen Papst Anastasius IV. gesandt (ebd. S. 409: qualiter causa ... in presentia Eugenii ventilata per dilatam iurisiudicii diem ... remansisset infecta).

20 S. Anm. 21, Ioannis Saresberiensis Historia pontificalis, ed. Marjorie Chibnall, London 1962. Ausführlicherer Kommentar in der Ausgabe von Iohannis Saresberiensis Historiae pontificalis quae supersunt, ed. Reginald Poole, London/Oxford 1927. 
bietung aller rechtlichen und unrechtlichen Mittel zu trennen versucht hat, falsche Zeugen und die üblichen Bestechungen an der Kurie einbezogen. Der Papst lehnt die Trennung in aller Bestimmtheit ab. Dann erhebt er sich mit Tränen in den Augen, fällt dem Grafen zu Füßen und fleht ihn an, allen Groll zu überwinden und seine Frau wieder zu sich zu nehmen. Selbst seine Mitra ist dem Papst dabei vom Kopf in den Staub gefallen. Dem Grafen, der ihm gerührt zu gehorchen verspricht, schenkt er seinen Ring als signaculum fidei et inite pactionis, quod ego tibi in facie ecclesie tradidi coniugem, et tu eam recepisti in fidem tuam. Diese Szene übertrifft in ihrer Eindringlichkeit die voraufgegangene, am Ende leider mißlungene Versöhnung des Königs von Frankreich mit seiner Gattin Eleonore von Aquitanien durch denselben Papst (Kap. 29). Die Schilderung des normannischen Scheidungsprozesses geht sogar auf verfahrensrechtliche Einzelheiten ein und kommt in dieser Ausführlichkeit in der Italia pontificia, wo sie hingehört, natürlich nicht zur Geltung ${ }^{21}$.

Aus der langen Regierungszeit Papst Alexanders III. ist mir bisher kein auswärtiger Bericht über eine Verhandlung im Konsistorium anläßlich Ausstellung einer strittigen Urkunde bekannt. Dies mag erstaunen: Lief in dieser Zeit alles so geschäftsmäßig, daß es keinen Anreiz zu genauerer Erzählung bot? War der politisch und juristisch höchst versierte Papst gegenüber Bittstellern und Klägern intellektuell so stark überlegen, daß er keine Pannen zuließ? Fehlte in den streng juristischen Untersuchungen das humoristische Element als Anstoß für genauere Berichte oder fehlte nur ein literarisch geübter Beobachter? Erhalten sind immerhin viele hundert Briefe aus den Jahren 1160-1175, die vornehmlich französische Streitsachen betreffen. Auch an Berichten über Verhandlungen mangelt es nicht, aber es sind Angaben des Papstes selbst über seine eigene Vorgehensweise wie etwa in folgendem Fall: „Benevent, (1168-1169) Juni 16. Alexander III. an H(einrich), Erzbischof von Reims. Aus einem Brief des Bischofs (Guido) von Châlons (Deperditum) habe er schon früher erfahren, daß der Überbringer, ein miles $\mathrm{H}$., falsche Zeugen produziert und durch ihr Zeugnis eine Scheidung von seiner Frau erreicht habe. Er und die Zeugen hätten dies dem Bischof eingestanden und von ihm Nachlaß der Missetat gefordert. Daraufhin habe der Papst, wenn er sich recht entsinne, dem Bischof geboten, er solle, falls durch geeignete Zeugen, die keinen Meineid leisten wollten, für ihn feststehe, daß die Zeugen durch Geld zur Aussage veranlaßt worden seien oder zwischen den (ehem. Eheleuten) ein anderer Verwandtschaftsgrad bestehe als sie angäben, dem $\mathrm{H}$. seine Frau zurückgeben und sie zusammenleben lassen, sofern nicht einer von beiden einem anderen sich durch eine Ehe verbunden habe. Dann solle er jenem H. sowie den Zeugen wegen ihres Vergehens eine angemessene Buße auferlegen. Da jedoch der Bischof bisher, wie aus der wiederholten Klage des Mannes, der unter großer Mühe und

21 IP 8 S. 46 Nr. ${ }^{*} 175$. 
Gefahr zum Papst gekommen sei, hervorgehe, nichts davon habe ausführen wollen, habe ihm der Papst durch Schreiben geboten, in derselben Rechtssache gemäß seinem früheren Schreiben unverzüglich und unter Ausschluß einer Appellation vorzugehen. Wolle der Bischof dem vielleicht nicht nachkommen, solle er dies gemäß dem Schreiben, das der Papst dem Bischof habe übermitteln lassen, unverzüglich und ohne die Möglichkeit zur Appellation ausführen“. Das meiste hiervon ist, wie ausdrücklich vermerkt, eigene Erinnerung des Papstes, obwohl dieser an anderer Stelle schreibt (JL 11490), er sei auch nur ein Mensch und erinnere sich nicht an alles ${ }^{22}$.

Nur wenige Hinweise scheinen bisher zur Erklärung des angedeuteten Mangels von Berichten Dritter aus der Zeit Alexanders III. möglich. Zunächst: Der Papst hatte ein phänomenales Gedächtnis. Seine einschränkende Aussage in JL 11490 dient nur dazu, die mühsame Untersuchungsarbeit durch die französischen Bischöfe selbst machen zu lassen. Juristisch ist ihm nicht beizukommen, somit auch nicht viel nach außen zu berichten. Zum anderen: An aufschlußreichen Briefen, die das Getriebe an der Kurie erkennen lassen, ist, wie angedeutet, gerade unter Alexander III. kein Mangel. Sehr viel Licht fällt dort auch auf die Vorgeschichte eines Entschädigungsverfahrens gegen den wegen Veruntreuung eines fremden Depositums angeklagten Abt Ernisius von St. Viktor. Alexander III. überträgt die Untersuchung dieses Falles 1169 dem Erzbischof von Sens und einem künftigen Kardinal, dem Abt Odo von Ours$\mathrm{camp}^{23}$. Seinem Mandat gehen drei Briefe betreffend einen Kanoniker Anselmus von St. Viktor vorauf. Dieser hat versucht, seinem Abt an der Kurie Freunde zu schaffen. Doch der autoritäre Ernisius stößt auch ihn vor den Kopf und empört durch einen ungeschickten Bestechungsversuch die gesamte Kurie ${ }^{24}$.

Im engeren Sinne einschlägig ist eine kurze Mitteilung im letzten dieser Briefe. Dort heißt es, der Kanoniker Anselm habe an der Kurie die Bestätigung

22 Regest von Ludwig Falkenstein für seinen Band Reims innerhalb der Gallia Pontificia nach: Veterum scriptorum et monumentorum historicorum, dogmaticorum, moralium amplissima collectio, ed. Edmond Martène/Ursin Durand, Bd. 2, Paris 1724, Sp. 815 Nr. 229 (JL 11551).

23 Papsturkunden in Frankreich, N. F. 8: Paris I, ed. Dietrich Lohrmann, Göttingen 1989, S. 287 Nr. 108. Als Odo von Ourscamp ein Jahr später die Einladung erhielt, an die Kurie zu kommen, um Kardinal zu werden, antwortete er mit der Wendung: Ut de toto iudicem mundo, pater meus qui me vocavit (Alexander III.) suis collateralibus fecit consedere (Papsturkunden Frankreich, N.F. 7: Nördliche Île-de-France und Vermandois, ed. Dietrich Lohrmann, Göttingen 1976, S. 418 Z. 25). Ähnliche Einschätzungen zur Rolle des päpstlichen Gerichtes 1136 im Plädoyer des Bischofs von Angers (Anm. 17). Die Rolle der Kardinäle im päpstlichen Gerichtsverfahren des 12. Jahrhunderts müßte gesondert behandelt werden. Vgl. u. a. Julius von Pflugk-Harttung, Acta pontificum inedita, Bd. 3, Tübingen 1881, S. 155 Nr. 177 (Urteil von sechs Kardinälen 1139) und weiter unten zu 1195 und 1256.

24 Papsturkunden in Frankreich N.F. 8 (wie Anm. 23) S. 283-286, Nr. 105-107. 
eines Privilegs für das alte Damenkloster Chelles in der Diözese Meaux nur mit größten Schwierigkeiten erreichen können, er übersende dieses nun durch den neuen Archidiakon der Kirche von Meaux ${ }^{25}$. Das ist schon alles, was wir erfahren. Es bleibt der Phantasie des Lesers überlassen, sich vorzustellen, wie die erwähnte maxima difficultas beim Erwerb dieses Privilegs im einzelnen beschaffen gewesen sein mag und mit welchen Mitteln unser wackere Regularkanoniker aus St. Viktor sie überwinden konnte.

Ergiebiger sind die kirchenpolitischen Verhandlungen vor Alexander III. Dafür dürften insbesondere die chronikalischen Nachrichten zum Streit um Thomas Becket etliches Material bieten. Nur eine Szene sei hier herausgegriffen, der Versuch des englischen Königs Heinrichs II., den Papst zur Absetzung des Erzbischofs von Canterbury zu bewegen. Als seine Gesandten dabei auch mit Schmeicheleien und Versprechungen nicht zum Erfolg kamen, gingen sie (AprilMai 1168) zu der Drohung über, der König könne eher zum Glauben des Christenfeindes Nur ad Din, des Vorgängers Saladins, übertreten (Noradini sequeretur errores), als sich länger mit Thomas Bequet als (Erz)bischof von Canterbury abzufinden ${ }^{26}$.

In einem weiteren hochpolitischen Fall geht es Ende 1196 um das Interdikt, das der Erzbischof von Rouen über seine gesamte Kirchenprovinz gelegt hatte, um gegen einen Übergriff des englischen Königs Richard Löwenherz zu protestieren. Das Interdikt erging wegen Übergriffs auf Besitz der Kirche beim Festungsbau des Königs auf einer Seineinsel nahe Les Andelys ${ }^{27}$. Um das Interdikt aufheben zu lassen, appelliert Richard Löwenherz an Papst Cölestin III. Die Chronik des Roger von Howden schildert den Ablauf der Verhandlung im päpstlichen Konsistorium ${ }^{28}$. Zunächst klagt der Erzbischof von Rouen wegen Verletzung des Patrimoniums seiner Kirche durch den Bau der Festung. Die Vertreter des Königs halten dagegen, der König habe sepe et multum Entschädigung angeboten; die Insel sei für ihn unverzichtbar, da an dieser Stelle der König von Frankreich in die Normandie eindringen könne. Beide Parteien unterwerfen sich einer Untersuchung (examini) durch den Papst und die römische Kirche. In ihrer anschließenden Beratung akzeptieren Papst und Kardinäle die Bedürfnisse des Königs bei der Landesverteidigung der Normandie.

25 Ebd. S. 286 Nr. 107.

26 The letters of John Salisbury, Bd. 2: The later letters 1163-1180, ed. W. J. Miller/ C.N.L. Brooke, Oxford 1979 (Oxford Medieval Texts), S. 560 f. Zu dem Interesse König Heinrichs II. für die arabische Wissenschaft vgl. Charles BuRnetT: The Introduction of Arabic Learning into England, London 1997, S. 60 und 101 Anm. 158.

27 Das ist nicht Château-Gaillard. Es erscheint in den Urkunden Richard als Bellum Castrum de Rupe. Vgl. Alexander Cartellieri: Philipp II. August, Bd. 3, Leipzig/Paris 1910, S. 223.

28 Chronica magistri Rogeri de Hovedene, ed. William Stubbs, Bd. 4, London 1871 (RS 51/4), S. $16-18$. 
Sie empfehlen dem Erzbischof, sich mit dem König auszusöhnen, zumal dieser bereit sei, ihn großzügig zu entschädigen. Es kommt zu einer forma pacis ... de consilio domini pape et cardinalium ordinata, die beide Seiten annehmen ${ }^{29}$. Ein umfangreicher Gütertausch wird zunächst vom König beurkundet, nachfolgend vom Erzbischof mit Zustimmung der Bischöfe seiner Kirchenprovinz gebilligt und abschließend am 26. April 1198 durch Innozenz III. mit Insert der Königsurkunde bestätigt ${ }^{30}$. Das Interdikt des Erzbischofs war inzwischen aufgehoben worden.

Abschließend sei für das Ende des 12. Jahrhunderts ein Brief zweier Kardinäle herausgestellt, die 1195 als Auditoren im Auftrag Cölestins III. ein Anliegen der Gräfin von Blois untersuchen sollten. Das Schreiben der Kardinäle zum Streit der Gräfin mit dem Domkapitel von Chartres informiert das Kapitel über den für es günstigen Ausgang. Wie etliche andere Stücke derselben Zeit zeigt es eine ausgeprägt römischrechtliche Terminologie und kündigt mit dem Hinweis auf eine Reihe von ,Artikeln' bereits ein Prozeßverfahren an, das sich voll erst nach 1250 durchsetzen sollte (siehe unten zu 1256). Außerdem zeigt es, daß ein Problem der voraufgehenden Zeit auf dem Weg zu einer institutionell verfestigten Lösung war. Gemeint ist die mangelnde Absicherung Abwesender gegen einseitig erwirkte päpstliche Erlasse, die im 12. Jahrhundert noch häufig vorkommen. In einem bereits laufenden Verfahren vor delegierten Richtern aus Sens, die für Chartres entschieden hatten, versucht die Gräfin sich durch ein einseitig erwirktes Privileg zu schützen. Das Privileg ist bereits bulliert, aber nicht ausgehändigt. Dem Prokurator des Domkapitels von Chartres gelingt es, vor den Kardinälen zu beweisen, daß der Prozeß vor den Delegaten bereits in förmlicher litis contestatio eröffnet worden war. Die Gräfin hatte ferner durch Zeugen auf ,Artikel' des Domkapitels antworten lassen. Dahinter konnte sie prozeßrechtlich nicht mehr zurück. Als deshalb die Kardinäle dem Papst die von ihnen ermittelten Prozeßvorgaben vortrugen, zog Cölestin III. sein Privileg für

29 Erwähnt wird diese Entscheidung Cölestins III. auch bei Radulf von Diceto, Ymagines historiarum, ed. William STubBs, Bd. 2, London 1876 (RS 68/2), S. 158: Haec autem commutatio roborata et confirmata est auctoritate et scripto autentico domini papae ad preces et instantiam domini regis et aliorum magnatum et praelatorum ecclesiae roboranda. Derselbe Chronist hat von Erzbischof Walter von Rouen zum gleichen Streit eine große Zahl weiterer Dokumente erhalten, die er im Wortlaut wiedergibt.

30 Die Register Innocenz' III., 1: 1. Pontifikatsjahr, 1198/1199, bearbeitet von Othmar Hageneder/Anton Haidacher, Graz/Köln 1964 (Publikationen der Abteilung für historische Studien des Österreichischen Kulturinstituts in Rom 2/1), S. 156-160 Nr. 108. Vgl. auch Radulf von Diceto, Ymagines II (wie Anm. 29) S. 160-162. Weitere Chroniken nennt Cartellieri: Philipp II. Augustus, Bd. 3 (wie Anm. 27) S. 139-141. Zur Vorgeschichte vgl. ebd. S. 120, 124-126. 
die Gräfin von Blois sofort zurück und bestätigte statt dessen die Entscheidung der delegierten Richter aus Sens ${ }^{31}$.

Insgesamt zeigt der Überblick über die relativ wenigen Berichte von der Kurie, die wir bisher aus französischer Überlieferung im 12. Jahrhundert haben, noch deutliche Schwächen in der Organisation der Vergabe päpstlicher Gerichtsurkunden und Privilegien. Die Prüfung der gegensätzlichen Interessen und Rechtsansprüche gelingt teilweise nur unvollkommen, da die streitenden Parteien nicht gleichzeitig zur Stelle sind oder die Impetranten es bewußt darauf anlegen, falsche oder lückenhafte Angaben zu machen ${ }^{32}$. So muß unbedingt eine Institution geschaffen werden, die vor der Übergabe der Urkunden an einen Impetranten der Gegenseite Gelegenheit gibt, Einspruch zu erheben und die Aushändigung der Urkunde aufzuhalten. Dies geschieht relativ schnell unter dem jungen rechtserfahrenen Papst Innozenz III.

\section{Berichte des 13. Jahrhunderts}

Kein Text erlaubt es, diese neue Praxis zusammen mit etlichen Einzelberichten über Verhandlungen vor Innozenz III. im Konsistorium besser kennenzulernen, als der soeben neu edierte Text des rechtskundigen Mönches Thomas von Evesham in seiner «Historia abbatie Eveshamensis» ${ }^{33}$. Quantitativ wie qualitativ wird hier ein ganz neues Stadium der Berichterstattung von der Kurie erreicht. Wir hören von erfolgreichen, aber auch verzögerten und gescheiterten Petitionen, von zahlreichen Aktionen vor Papst und Kardinälen, erfahren, auf welche Weise der Papst erkennen läßt, wie er das Verfahren zu lenken gedenkt, wie er eine Zweiteilung des Verfahrens vornimmt, wie er die Einlassungen der beiden Prokuratoren knapp kommentiert, nötigenfalls auch abrupt unterbricht, wenn sie von der erörterten Rechtsfrage zu anderen Erwägungen übergehen. Nicht zuletzt zeigt sich die geradezu prozeßentscheidende Bedeutung der Kreditauf-

31 Papsturkunden in Frankreich, N.F. 6, ed. Johannes Ramackers, Göttingen 1958, S. 267-272 Nr. 206 und 208.

32 Bei Roger von Howden, Chron. 4 (wie Anm. 28) S. 15, sind als Briefe dieser Art auch die „vielen falschen Briefe“ einzustufen, die 1196 ein Kleriker des Erzbischofs von York an der Kurie erwirkt hatte. Als er darauf, noch in Rom, auf den Tod erkrankte, gestand er sein Vergehen ein. Weiteres zum Problem der erschlichenen Briefe im späteren 12. Jahrhundert hat Herde: Beiträge (wie Anm. 4) S. $92 \mathrm{f}$.

33 Thomas of Marlborough, History of the Abbey of Evesham, ed. and transl. Jane E. Sayers/Leslie Watkiss, Oxford 2003 (Oxford Medieval Texts), Buch II S. 266-314 $\$ \$ 263-316$. Vgl. Jane SAYERs: „Original“, Cartulary and Chronicle: the Case of the Abbey of Evesham, in: Fälschungen im Mittelalter. Internationaler Kongreß der Monumenta Germaniae Historica München, 16.-19. September 1986, Hannover 1998 (MGH Schr. 33/4), S. 371-395. 
nahme durch die Parteien bei den sogenannten mercatores Romani $i^{34}$. Nur wer dank solcher Kredite die teuersten Advokaten bezahlen kann, hat eine Chance, sich in der Verhandlung durchzusetzen. Im einzelnen kann ich das hier nicht verfolgen, empfehle deshalb jedem, der noch nicht Gelegenheit dazu hatte, die Lektüre dieses englischen Berichtes wärmstens.

Ein französischer Prozeßbericht vom Juli 1256, den ich vor etwa 35 Jahren in Paris entdeckt habe und jüngst zusammen mit Olivier Guyotjeanmin in der Revue du Nord veröffentlichen konnte, soll hier den Abschluß bilden ${ }^{35}$. Er enthält nicht nur als Hintergrundinformation neue ergänzende Nachrichten zu einem Volksaufstand der Römer im April-Mai dieses Jahres unter Alexander IV. Drohungen gegen einige adlige römische Kardinäle führten damals zur Befreiung des Senators Brancaleone. Wichtig sind hier vor allem die Einzelstadien des Prozesses. Dieser kann erst beginnen, nachdem die Kurie Anfang Juni nach Anagni geflüchtet ist. Was dann folgt erinnert zum Teil an den oben referierten Fall Oudenburg gegen Saint-Médard. Der nun freilich viel längere Bericht des Abtes von Saint-Éloi in Noyon, der sich gegen die Übermacht des Domkapitels von Noyon zur Wehr setzt, schildert zunächst die bessere Ausgangsposition der Gegenpartei: Mehrere päpstliche Kapläne sind zugleich Kanoniker des Domkapitels Noyon. Sie unterstützen selbstverständlich dessen Position und haben jederzeit Zugang zum Papst. Dazu sind mehrere ihrer vielen Advokaten in Anagni Neffen des hochangesehenen (erst vor einigen Jahren verstorbenen) Kardinalbischofs Pietro da Collemedio, während der arme Abt von Saint-Éloi sich gerade einen Advokaten leisten kann, der dazu noch teuer ist, denn er ist von Rom nach Anagni mitgekommen. Der Abt muß dort für ihn ein ganzes

34 Thomas von Marlborough (wie Anm. 33) S. $344 \$$ 358. Schon Abt Hariulf vor Innocenz II. (vgl. oben zu 1141) notierte: sed vereor, ne sacculus inanis victum neget diu moranti. „Aber ich fürchte, mein leerer Geldbeutel wird mir einen längeren Aufenthalt an der Kurie nicht ermöglichen“. Gute Bemerkungen hierzu wie zu dem gesamten Prozeß bei Harald Müller: Der Exemtionsprozeß des Klosters Evesham an der päpstlichen Kurie in den Jahren 1202-1206, Magisterarbeit RWTH Aachen WS 1990-1991, S. 122131 (finanzielle Aspekte). In die Zeit Innocenz' III. gehört auch die Klage des «Dialogus inter euntem ad curiam et venientem a Roma de malis moribus curie», wo es satirisch u. a. heißt: Plena rancoribus est tota curia./ Prodest datoribus sola pecunia./ In cardinalibus viget consilium./ Si donas talibus, vocant te filium, ed. Herde: Beiträge (wie Anm. 4) S. $247-251$.

35 Olivier Guyotjeannin/Dietrich Lohrmann: Labbé de Saint-Éloi de Noyon en cour de Rome (1256), in: Revue du Nord 86 (2004) S. 681-696. Gesamtübersicht über den Prozeß nach Paris BnF ms. lat. 13777 bei Olivier Guyotjeannin: Les reliques de saint Éloi à Noyon: procès et enquêtes du milieu du XIII ${ }^{\mathrm{e}}$ siècle, in: Revue Mabillon n. s. 1 (1990) S. 57-110. 
Haus samt Stallungen für die Pferde mieten. Zum Glück hat ihm sein Konvent eine Vollmacht zur Kreditaufnahme mitgegeben ${ }^{36}$.

Dies war für den Abt eine eher ungünstige Ausgangslage. Beim ersten Konsistorium ergibt sich jedoch eine Vertauschung der Rollen von Kläger und Beklagtem, weil die Vertreter des Domkapitels bei Beginn der Verhandlung gleich ungestüm vorpreschen ${ }^{37}$. Der Abt von Saint-Éloi weiß diesen Fehler geschickt zu nutzen. Während seine Gegner, so führt er aus, nur die Fortsetzung des laufenden Untersuchungsverfahrens in Noyon durch früher ernannte Richter aus Soissons erreichen wollten, forderte er für sein Kloster eine Verhandlung zur Hauptsache, de natura principalis negotii: Das eigentliche Skandalon des Streites um die Reliquien müsse ausgeräumt werden, also seien keine weiteren Ausflüchte, Zänkereien und Gehässigkeiten (diffugia, rixae und odia) zuzulassen. Die seien abzuwenden (avertenda). Auch dürften keine weiteren unnützen Kosten für die streitenden Kirchen entstehen, im päpstlichen Gericht gehe es doch darum, den Hauptstreitpunkt, das principale negotium, abzuschließen. Mit dieser Argumentation gewinnt der Abt bei Papst und Kardinälen Sympathien. Die Sitzung wird unterbrochen und schon am übernächsten Tag weitergeführt. Zwischendurch bleibt Zeit für Lobbyarbeit unter den Kardinälen. Daran läßt es unserer wackerer Abt nicht fehlen: „Wir eilten durch die Reihen der Kardinäle und informierten sie in unserem Sinne" (per cardinales discurrimus ... juxta motum nostrum informantes eosdem).

Im zweiten Konsistorium nach Beratung mit den Kardinälen legt Alexander IV. eingangs sofort den künftigen Kurs fest. 1. Das laufende Untersuchungsverfahren vor Richtern aus Soissons wird eingestellt; die bisherigen Prozeßschritte und Zeugenaussagen zugunsten des Domkapitels von Noyon sind damit nichtig. 2. Ein neues Delegationsmandat soll an eine unvoreingenommene Richterpersönlichkeit im Königreich Frankreich gehen, an einen Unverdächtigen, der omni suspicione careat. 3. Der neue Untersuchungsauftrag zielt auf die Klärung des Verbleibs der Reliquien des hl. Eligius, ubi sit, aber auch auf das, was es mit der eigentlichen Grabstätte auf sich hat, mit der Translation in die Kathedrale, den Wundern und dem Pilgerkult. 4. Außer Zeugenaussagen sind ausdrücklich zu nutzen auch hystoriae, cronicae, legendae, libri antiqui et aliae probationes legitimae.

36 Text der Vollmacht im Anhang. Sehr aufschlußreiche Dokumente zur Kreditaufnahme durch Prokuratoren an der Kurie 1257-1259 veröffentlicht Werner MaLECZEK: Erzbischof Ulrich von Salzburg (1257-1265), die päpstliche Kurie und Bankiers aus Rom, Florenz und Venedig, in: Tirol - Österreich - Italien. Festschrift für Josef Riedmann zum 65. Geburtstag, hg.v. Klaus Brandstätter/Julia Hörmann, Innsbruck 2005 (Schlern-Schriften 330), S. 405-439.

37 Etwas ähnliches zeigt Thomas von Evesham auch im Exemtionsprozess gegen den Bischof von Worcester, ed. SAyers-Watkiss (wie Anm. 33) S. $278 \$ 280$. 
Die Liste der zugelassenen Beweismittel wird hier vom Papst im Interesse des Klosters stark erweitert. Auf diese erweiterten Beweismittel hat 1985 bereits Erika Laquer hingewiesen ${ }^{38}$. Wichtiger für unser Thema scheint eine Innovation bei den Auflagen für das Vorgehen des neu delegierten Richters. Er soll vorgehen secundum articulos. Gemeint sind Prozeßartikel, die von beiden Parteien auszuformulieren und sub bulla dem Mandat an den Richter beizufügen sind. Erwähnt fanden wir solche Artikel bereits im oben behandelten Rechtsstreit der Gräfin von Blois gegen das Domkapitel von Chartres. In der Prozeßdokumentation aus Saint-Éloi haben sich diese Artikel (31 für jede Partei) im Wortlaut erhalten. Hinzu treten Stellungnahmen der jeweiligen Gegenpartei zu den einzelnen Artikeln. Diese sind im Konsens unter Leitung eines Kardinals zu akzeptieren, andernfalls werden sie gestrichen. Vor allem müssen diese Prozeßartikel zur Sache gehören, sie müssen pertinentes sein; articuli impertinentes sind nach Vorgabe der zeitgenössischen ,Regulae iuris' auszuscheiden. Die Aufsicht über diesen Vorgang obliegt an der Kurie einem erfahrenen Juristen, der in vielen Prozessen eine Rolle gespielt hat, dem englischen Zisterzienserkardinal Johannes von Toledo ${ }^{39}$.

Das gesamte Verfahren, das hier in einer frühen Phase aus der Praxis dokumentiert ist, entspricht, wie ich schon andeutete, einer juristischen Innovation des 13. Jahrhunderts, die am Ende des 12. Jahrhunderts schon vorbereitet $\operatorname{war}^{40}$. Mit den Artikeln grenzte jede Partei im vorhinein den Rahmen dessen ein, was sie in der richterlichen Untersuchung zu beweisen vorgab. Es waren Beweisanträge, die dem delegierten Richter seine Aufgabe der Zeugenvernehmung erleichtern sollten. Die Rechtsgeschichte kennt das Verfahren unter der Bezeichnung Positionalverfahren (positiones probandae im Sinne von articuli pro-

38 Erika Laquer: Ritual. Literacy and Documentary Evidence: Archbishop Eudes Rigaud and the Relics of saint Éloi, in: Francia 13 (1985) S. 625-637.

39 Näheres bei Dietrich Lohrmann: Delegatio cum annexis articulis et questionariis. Die prozessrechtliche Wende im Streit um die Reliquien des hl. Eligius von Noyon, in: Grosse: Acte pontifical (wie Anm. 14) S. 229-264. Nur drei Tage nach Ausstellung des neuen Delegationsmandates für den Erzbischof von Rouen folgt eine bemerkenswerte Schilderung von Verfahrensschritten nach römischem Prozeßrecht in der Entscheidung eines Streites um Nutzungsrechte zwischen der Zisterzienserabtei Igny (Diöz. Reims) und der Dorfgemeinde Montigny durch den Kardinal Stephan von Präneste vom 29. Juni 1256: Les Registres d'Alexandre IV, Bd. 3, ed. Auguste Coulon, Paris 1953, S. 47 48.

40 Siehe Anm. 31. Klagelibelli, Petitionen und Zeugenaussagen der Parteien sind spätestens seit dem 12. Jahrhunderts auch aus Prozessen in Italien bekannt. Vgl. u. a. Margarete Pollock: Der Prozess von 1194 zwischen Orvieto und Savona um das Val di Lago, in: QFIAB 70 (1990) S. 46-150; im Anhang dort u.a. die Aussagen von 23 Zeugen für Savona und 34 Zeugen für Orvieto. Dazu Johannes Fried: Der Schleier der Erinnerung. Grundzüge einer historischen Memorik, München 2004, S. 178-183, der sich für die Zuverlässigkeit der „steinalten“ Zeugen interessiert. 
bandi) ${ }^{41}$. So sind all diese Artikel der Parteien am Anfang auch ausformuliert: volumus probare.

Schließlich noch ein Wort zur Auswahl des delegierten Richters in der fortgeschrittenen Phase des über 30-jährigen Prozesses von Noyon, in der alles noch einmal neu auf dem Spiel steht. Es ist wieder eine von den besonders eindrücklichen, filmreifen Kurzszenen: Am Ende des zweiten Konsistoriums nimmt sich der Papst den wackeren Abt von Saint-Éloi zur Seite und flüstert ihm zu, ob für ihn der Erzbischof von Rouen als Richter akzeptabel sei. Der Abt, zu Dank verpflichtet, zögert bei dieser wichtigen Frage, lehnt aber nicht ab wie seinerzeit 1141 der Abt von Oudenburg es wegen Befangenheit der Richter getan hatte. Nein, er überlegt und antwortet vorsichtig, er habe keinen Befangenheitsgrund einzuwenden, keine causa suspicionis. So wird der vielbeschäftigte Erzbischof Odo von Rouen tatsächlich ernannt und hat das zweifelhafte Vergnügen, sich volle fünf Jahre lang mit dem verzwickten Streit um die Reliquien des heiligen Eligius auseinandersetzen zu dürfen ${ }^{42}$.

\section{Anhang}

Vollmacht des Konvents von Saint-Éloi in Noyon für Abt Johannes zur Kreditaufnahme während seiner Romreise.

Noyon, 1256 (Februar März)

Paris BnF, ms. lat. 13777 fol. 297rv (Guyotjeannin, Reliques, wie Anm. 35, S. 101 n. 199).

$\mathrm{Zu}$ den Texten des zugehörigen Prozeßberichtes und des neuen päpstlichen Delegationsmandates samt Anlagen für den delegierten Richter, Erzbischof Odo von Rouen, siehe oben Anm. 36, Weiteres zu Kreditaufnahmen an der Kurie in Anm. 34 und 36.

Universis Christi fidelibus ad quos presentes littere pervenerint, Petrus prior Sancti Eligii Noviomensis et conventus eiusdem loci salutem in Domino. Universitati vestre tenore presentium innotescat, quod cum vir religiosus Jo-

41 Thomas Wetzstein: Heilige vor Gericht. Das Kanonisationsverfahren im europäischen Spätmittelalter, Köln-Weimar/Wien 2004 (Forschungen zur kirchlichen Rechtsgeschichte und zum Kirchenrecht 28), S. 33-56. Für wertvolle Hinweise in diesem Zusammenhang danke ich Martin Bertram, Rom, und Harald Müller, Mainz.

42 Diese vorläufig letzte Phase des Prozesses ist noch nicht näher untersucht. Gesamtübersicht siehe bei Guyotjeannin: Reliques (wie Anm. 35). Vgl. auch Laquer (wie Anm. 38). 
hannes permissione divina noster abbas providus et fidelis, lator presentium, sui et nostri monasterii necessitatibus et angariis pio compatiens affectu, multimoda precum nostrarum instantia per nos fuit ductus, ut sollicitudinibus, periculis et labori pro nobis totaliter se exponens iter arripiat ad Romanam curiam transeundi, nos fidei et diligentie ipsius commendabili pro tot laboribus et angustiis pie non immerito condolentes, et honori eius quantum possumus deferre volentes, et caventes ne aliqua sibi desint ad sumptus utiles et honestos et ad omnimodas expensas pro nostris negotiis promovendis secundum eius arbitrium faciendas, attendentes etiam nobis et sibi fovere commodius per ipsum pecuniam mutuo recipere et in regno Francie reddere, quam cum tot laboribus et sumptibus et per tot pericula transportare, ipsum patrem et dominum nostrum constituimus syndicum seu actorem et ei liberam concedimus potestatem ad recipiendum pro nobis et nomine nostro pecuniam mutuo usque ad quantitatem quam ad nostras utilitates provehendas et nostra negotia procuranda viderit competentem, et ad pecuniam ipsam erogandam prout viderit expedire, et ad obligandum bona monasterii nostri pro dictis mutuis ab ipso contrahendis, promittentes sub ipoteca rerum nostrarum nos reddituros mutua que contraherit cum eorum accessibus in locis terminis et conditionibus queque voluerit inter ipsum et mutuatores quoslibet a quibus duxerit mutua contrahenda. Ratum et gratum habituri quicquid idem patet et abbas noster super predictis omnibus duxerit faciendum. In cuius rei testimonium et munimen presentes litteras eidem tradidimus sigilli nostri conventus impressione munitas. Dat. et cetera.

\section{Riassunto}

Sui processi, svoltisi nei secoli XII e XIII presso la curia, si hanno di norma notizie solo attraverso il risultato, la conferma definitiva del papa e/o le decisioni $o$ indagini preliminari da parte di giudici delegati. Niente invece viene fuori sul dibattimento vero e proprio nel concistorio, a parte la breve annotazione che la questione è stata esaminata davanti al papa e ai cardinali. Nell'Italia pontificia si trovano pertanto solo pochi accenni finora raccolte di questo tipo. Le cronache e gli archivi francesi offrono alcune scene dettagliate e interessanti che qui vengono analizzate, e dove appaiono anche alcuni tratti umani e spiritosi dei papi medievali. Si inizia con il famoso processo contro l'arcivescovo Manasse di Reims e si termina nel 1256 con una delegazione, ottenuta con fatica, dell'arcivescovo Odo di Rouen per il maxiprocesso intorno alle reliquie di S. Eligio di Noyon. In mezzo si hanno importanti innovazioni relative al diritto processuale, la creazione dell'Audientia litterarum contradictarum e l'introduzione del procedimento posizionale per l'interrogatorio dei testimoni. Vengono presentati pure alcuni processi di forte valenza politica. Sarebbero da esaminare più da 
vicino le questioni dei costi e le circostanze, in cui avvenivano le accensioni di credito presso i mercatores Romani. Una relativa procura viene riprodotta in appendice. 


\title{
Die Brüder des Papstes Kardinäle und Schriftgut der Kardinäle
}

\author{
Werner Maleczek
}

Als Paul Fridolin Kehr im Jahre 1896 der damaligen königlichen Gesellschaft der Wissenschaften in Göttingen seinen Plan vortrug, die „kritische Ausgabe der Papsturkunden bis Innocenz III." nach den neuesten diplomatischen Methoden betreiben zu wollen, war allein von Dokumenten die Rede, die im Namen der Päpste ausgestellt waren ${ }^{1}$. Die Schriftstücke, die von Kardinälen ausgingen, sollten noch lange außerhalb des Interesses liegen, und die ersten drei Bände der Italia Pontificia enthalten dementsprechend keinerlei Hinweise auf Legatenurkunden oder auf Urkunden delegierter Richter, hinter denen sich ja immer Papsturkunden verbergen. Erst im vierten, 1909 erschienenen Band, der die Regionen Umbria, Picenum, Marsia umfaßt, sind einige wenige diesbezügliche Hinweise enthalten ${ }^{2}$, und es dauerte bis zum fünften Teil der „Nachträge zu den Papsturkunden Italiens“ im Jahre 1911, bis die ersten Legatenurkunden ediert wurden $^{3}$. Wilhelm Wiederhold hingegen publizierte schon im zweiten, 1906

1 N.B.: Verwendete Abkürzungen: $\mathrm{KB}=$ Kardinalbischof, $\mathrm{KD}=$ Kardinaldiakon, $\mathrm{KP}=$ Kardinalpriester; HüLs = Rudolf HüLs: Kardinäle, Klerus und Kirchen Roms 10491130, Tübingen 1977 (Bibliothek des Deutschen Historischen Instituts in Rom 48); SChiefFer $=$ Theodor SCHIEFFer: Die päpstlichen Legaten in Frankreich vom Vertrag von Mersen (870) bis zum Schisma von 1130, Berlin 1935 (Historische Studien 263); WeIss = Stefan WeIss: Die Urkunden der päpstlichen Legaten von Leo IX. bis Coelestin III., 1049-1198, Köln/Wien 1995 (Beih. zu J. F. Böhmer, RI 13); Zenker = Barbara Zenker: Die Mitglieder des Kardinalkollegiums von 1130 bis 1159, Diss. Würzburg 1964.

Rudolf Hiestand: 100 Jahre Papsturkundenwerk, in: Hundert Jahre Papsturkundenforschung. Bilanz - Methoden - Perspektiven. Akten eines Kolloquiums zum hundertjährigen Bestehen der Regesta Pontificum Romanorum vom 9.-11. Oktober 1996 in Göttingen, hg. v. DEMS., Göttingen 2003 (AAG, phil-hist. Kl., 3. Folge 261), S. 11-44, hier $11 \mathrm{f}$.

2 IP 4 S. 26 Nr. 2: Urkunde eines missus Viktors II.; IP 4 S. 301 Nr. 5: Brief der Mönche von S. Clemente in Casauria an Augustinus, KD von SS. Quattro Coronati, Legat Paschalis' II. (1103). Freilich findet sich schon in IP 1 S. 49 Nr. $3=$ S. 159 Nr. 4 die Entscheidung eines Streites zwischen zwei römischen Klöstern im Auftrag Hadrians IV. vor einer Kommission von Kardinälen und dem römischen Konsul (10.4.1155).

3 Paul Fridolin KeHr: Nachträge zu den Papsturkunden Italiens V, in: Göttinger Nachrichten (1911), S. 282-286 Nr. 6-9 u. ö. (ND in: DERS.: Papsturkunden in Italien. Reiseberichte zur Italia Pontificia 5: Nachträge (1905-1962), Città del Vaticano 1977 [Acta Romanorum pontificum 5], S. 302-306 Nr. 6-9). 
vorgelegten Teil seiner „Papsturkunden in Frankreich“ zwei Legatenurkunden und behielt diesen Usus in den Folgebänden konsequent bei ${ }^{4}$. Heute läßt sich nicht mehr nachweisen, wann Kehr den Beschluß faßte, in das Göttinger Papsturkundenwerk auch die Urkunden der Legaten aufzunehmen ${ }^{5}$, aber in der Folgezeit rückte er davon nicht mehr ab. Wenn wir uns im folgenden dem Schriftgut der Kardinäle zuwenden, gehen wir über die Kardinals-Legatenurkunden hinaus, denn wir schließen in die Betrachtung das weite Feld der Kardinalsbriefe ein und vernachlässigen auch nicht jene Schriftstücke, die innerhalb der Kurie durch die Kardinäle verfaßt wurden. Daß die Grenzen manchmal verfließen, braucht hier nicht besonders hervorgehoben zu werden. Chronologisch halte ich mich nicht ganz an die von Kehr als "natürlich" bezeichnete Grenze von 1198 - die wie vieles Natürliche recht künstlich ist -, sondern gestatte mir vereinzelt Ausblicke ins 13. Jahrhundert. Der Beginn soll, was mit der geänderten Funktion der römischen Kardinäle ohne weiteres plausibel gemacht werden kann, beim Einsetzen der Kirchenreform in der Mitte des 11. Jahrhunderts liegen. Nur angedeutet werden hier die theologischen, kanonistischen und literarischen Werke der Kardinäle, die gleichwohl einen Hinweis auf den Stellenwert der Bildung geben, die die Päpste in ihrer Umgebung als wichtig und notwendig für die Kirchenreform und für den Ausbau des Zentralismus erachteten. Es soll aber gleich festgehalten werden, daß die Werke zumeist v o $r$ der Erhebung in den Kardinalsrang entstanden und daß es tendenziell die Ausnahme darstellt, wenn die vielfältige Beschäftigung in Diensten der Päpste noch Zeit ließ, zur Feder zu greifen.

\section{Kardinäle als Schriftsteller}

Unter den Kardinälen der ersten Generation der Reformer sind tatsächlich einige herausragende Geistesgrößen und produktive Autoren zu finden, wobei die Auswahl Leos IX. und seiner Nachfolger für lange Zeit den Weg wies. - Der 1050 aus Moyenmoutier nach Rom geholte und im Jahr darauf zum KB von Silva Candida erhobene Humbert $(\dagger 1061)$ griff trotz intensiver Beanspruchung als Diplomat und Verwalter immer wieder zur Feder und wir kennen ihn als den hervorragenden Autor von «Libri tres adversus simoniacos» (1058 abgeschlossen), in denen er heftig gegen jede Form von Simonie polemisierte. Im Zuge des

4 Wilhelm Wiederhold: Papsturkunden in Frankreich 2: Burgund mit Bresse und Bugey, in: Göttinger Nachrichten (1906), Beih. S. 21 Nr. 3, S. 57 Nr. 34 (ND in DERS.: Papsturkunden in Frankreich. Reiseberichte zu Gallia Pontificia 1 [1906-1910], Città del Vaticano 1985 [Acta Romanorum pontificum 7], S. 167 Nr. 3, S. 203 Nr. 34).

5 Vgl. Rudolf Hiestand: Die unvollendete Italia Pontificia, in: Ders.: Papsturkundenforschung (wie Anm. 1) S. 47-57, hier S. 50. 
Schismas von 1054 wirkte er an der Abfassung von antibyzantinischen Texten mit, und wohl aus den ersten Jahren in Italien stammen eucharistietheologische Werke $^{6}$. - Einen herausragenden Platz unter den literarisch aktiven Kardinalbischöfen der Reformzeit nimmt der Prior von Fonte Avellana ein, Petrus Damiani, der schon vor seiner widerstrebend akzeptierten Ernennung zum KB von Ostia (1057) mit den Päpsten, besonders Leo IX., Beziehungen hatte und seine Vorstellungen zur sittlichen Erneuerung von Klerus, Kirche und Welt in fordernder und klarer Sprache niederschrieb. Sein hoher Bildungsstand zeigt sich in der meisterhaften Beherrschung der lateinischen Sprache, seiner glänzenden Vertrautheit mit der Bibel und den Kirchenvätern, aber auch in profunden Kenntnissen der antiken Literatur. Der «Liber Gomorrhianus» brandmarkt die Homosexualität, die als Laster im Klerus seiner Zeit verbreitet war $(1049)^{7}$. Der «Liber gratissimus» (1052, Zusatz dann 1061) verdammt zwar die Simonie, tritt aber für die Gültigkeit der simonistischen Weihen ein ${ }^{8}$. Die ihm übertragenen kirchenpolitischen Aufgaben - Legationen nach Oberitalien, Deutschland, Frankreich und Beratung der Päpste an der Kurie - brachten seinen schriftstellerischen Eifer nicht zum Erliegen, im Gegenteil: Bis zu seinem Tod im Jahr 1072 entstand der größere Teil seiner Schriften, die überwiegend als Briefe an die unterschiedlichsten Empfänger überliefert sind, wobei das Themenspektrum von kurzen moralischen Ermahnungen bis hin zu ausgefeilten theologischen Traktaten reicht. In ihnen bezieht er zu fast allen Diskussionen seiner Zeit Stellung und gestattet so tiefe Einblicke in die Geistesgeschichte des 11. Jahrhunderts ${ }^{9}$. Besondere Erwähnung verdienen zwei kirchenpolitisch zentrale Texte: das «Privilegium Romanae aecclesiae» (1059), das in den Bericht über Damianis Legation nach Mailand eingewobene Erörterungen über die Unterordnung der Mailänder Kirche unter die römische, über die Bekämpfung von Simonie und Nikolaitismus sowie über die Auseinandersetzung mit der Pataria enthät; ferner die an einen Brief an den Gegenpapst Cadalus von Parma (Honorius II.) angefügte «Disceptatio Synodalis» (1062), in welcher Petrus Damiani in einem Streitgespräch zwischen einem Vertreter der Kurie und einem Anwalt des Königs die ohne Fühlungnahme mit dem deutschen Königshof

6 Humberti Cardinalis libri III adversus simoniacos, ed. Friedrich Thaner, in: MGH L. d. L. 1, Hannover 1891, S. 95-253. Über die Zuschreibung anderer Werke, die in Repfont 5 (1984) S. 614-618, aufgelistet sind, vgl. Rudolf Schieffer: Art. Humbert, in: LexMA 5 (1991) Sp. 207 f. - Die Münchener Diss. von 1993 (Margit Dischner: Humbert von Silva Candida. Werk und Wirkung des lothringischen Reformmönches [Politik im Mittelalter 2] Neuwied 1996) ist mißlungen.

7 Die Briefe des Petrus Damiani, ed. Kurt Reindel, 4 Bde., München 1983-1993 (MGH Epp. DK 4/1-4), hier Bd. 1 S. 284-330 Nr. 31.

8 Petri Damiani Liber gratissimus, ed. Lothar von Heinemann, in: MGH L. d. L. 1, Hannover 1891, S. 15-75; Briefe, ed. Reindel (wie Anm. 7) Bd. 1 S. 384-509 Nr. 40.

9 Nun in der meisterhaften Edition der Briefe, ed. Reindel (wie Anm. 7). 
erfolgte Erhebung Alexanders II. zu rechtfertigen sucht, aber auch zur Versöhnung aufruft ${ }^{10}$. Darüber hinaus stammen aus seinem Diktat über 50 Sermones, mehrere Heiligenviten und eine große Zahl von Gedichten, Epigrammen, Gebeten und Meßformularen ${ }^{11}$. Auf die kürzeren, mehr der Mitteilung dienenden Briefe wird in einem anderen Zusammenhang noch zurückzukommen sein. - Auf Betreiben Gregors VII. erhielt der mit der Kurie schon in Beziehung getretene, aus der Gegend von Asti stammende Bruno, Kanoniker von Siena, 1079 das Bistum Segni übertragen, wo er die kirchenreformerischen Prinzipien verwirklichen sollte. Aber bis zu seinem Rückzug nach Montecassino (1103; Abt 1107) war er hauptsächlich an der Kurie und im päpstlichen Auftrag auf Legationen tätig und begleitete Urban II. auf der Reise nach Frankreich 1095/ 96. Neben dem Hauptwerk «Libellus de simoniacis» (zwischen 1085 und 1102), das eine Biographie Leos IX. und eine Abhandlung über die Gültigkeit der von simonistischen Bischöfen vorgenommenen Weihen enthält ${ }^{12}$, verfaßte er «Sententiae», ein eher homiletisches Werk, in der die Kirche, Maria und die Heiligen allegorisch gedeutet und wo die Tugenden behandelt werden. Eine Vita des Bischofs Petrus von Anagni († 1105) scheint zwischen 1105 und 1109 komponiert worden zu sein. Das exegetische Werk, das Bruno schon vor der Erhebung zum Bischof begann, umfaßt die Psalmen, das Hohelied, Isaias, den Pentateuch, Hiob, die Sprichwörter, die Evangelien und die Apokalypse, wobei er zwar den traditionellen Bahnen der Interpretation folgte, aber durchaus Originelles schuf. Etwa 150 Predigten sind erhalten. In «De sacramentis ec-

10 Ed. Reindel, MGH Epp. DK 4/2, S. 228-247 Nr. 65, $531-572$ Nr. 89.

11 Petri Damiani vita Beati Romualdi, ed. Giovanni Taвacco, Rom 1957 (Fonti 94); L'opera poetica di S. Pier Damiani, ed. Margarete Lokrantz, Stockholm 1964 (Studia Latina Stockholmensia 12); S. Petri Damiani Sermones, ed. Giovanni LucchesI, Turnhout 1983 (CChrCM 57); San Pier Damiani. Scritti monastici, ed. Bernardo Ignesti, 2 Bde., Siena 1994 (I classici cristiani 173-174). - Die Forschungsliteratur findet sich in der Edition von Kurt ReINDEL und in Repfont 9 (2002) S. 135-139, und rezenter: Glauco Maria Cantarella: Pier Damiani, il „Liber Gomorrhianus“ e Leone IX, in: Ovidio Capitani. Quaranta anni per la storia medioevale, hg. v. Maria Consiglia De Matteis, Bologna 2003, S. 117-125; Nicolangelo D’Acunto: L'aristocrazia del Regnum Italiae negli scritti di Pier Damiani, in: Formazione e strutture dei ceti dominanti nel medioevo, Marchesi, conti e visconti nel regno Italico (secc. IX-XII). Atti del terzo convegno di Pisa, 18-20 marzo 1999, hg. v. Amleto Spicciani, Rom 2003 (Nuovi studi storici 56), S. 321-342; Christian LoHmer: „Quod ex dictis patrum indagare potuerim - Was ich in den Worten der Väter aufspüren konnte ...": die Bedeutung der Patristik für die Ekklesiologie des Petrus Damiani, in: Väter der Kirche. Ekklesiales Denken von den Anfängen bis in die Neuzeit. Festgabe für Hermann Josef Sieben, hg. v. Johannes Arnold, Paderborn 2004, S. 583-601. - Weiters vgl. Giuseppe Fornasari: Art. Petrus Damiani, in: LexMA 6 (1993) Sp. 1970-1972.

12 Brunonis episcopi Signini libellus de symoniacis, ed. Ernst SACKUR, in: MGH L. d. L. 2, Hannover 1892, S. 546-562. 
clesiae» werden die kirchlichen Feiern symbolisch erläutert, und vier im Februar 1111 geschriebene Briefe sollen ebenfalls erwähnt werden ${ }^{13}$.

Die Kardinäle der Reformzeit stellten nicht nur prominente Theologen, sondern auch Kanonisten, die besonders das Papsttum durch die Auswahl und Anordnung der überlieferten Kanones absichern halfen. Im Auftrag Gregors VII., der ihn 1073 zum KP von S. Marco erhoben hatte, komponierte Atto, der sich als Elekt von Mailand nicht hatte durchsetzen können, zwischen 1075 und 1084 eine nicht sehr umfangreiche Sammlung, «Breviarium» genannt, die für den Gebrauch der Kleriker der eigenen Titelkirche gedacht war. Sie enthält in kurzer und klarer Form alle Prinzipien, die den Reformern wichtig schienen ${ }^{14}$. - Der wohl aus Aquitanien stammende Benediktiner Deusdedit wurde ebenfalls von Gregor VII. zum Kardinal erhoben und erhielt 1078 die Titelkirche SS. Apostolorum in Eudoxia (= S. Pietro in Vincoli) übertragen. In den letzten Jahren Gregors begonnen und 1087 abgeschlossen, handelt sein wichtigstes Werk, die "Collectio canonum», von den Vorrechten der römischen Kirche, dem Klerus, dem Kirchengut und - ganz im Sinn der Reform - von deren Freiheit und rechtlicher Absicherung. Seine Sammlung, deren Einfluß freilich nicht besonders groß war, gilt als die am meisten auf die römische Kirche ausgerichtete. Auch andere Werke sind von Deusdedit überliefert: ein «Libellus contra invasores et simoniacos» gegen die Anhänger des Gegenpapstes Clemens (III.), und geistliche Dichtung, vom Autor als «Libellus theopoeseos» bezeichnet, welcher nach einem autobiographischen Einleitungsgedicht ein Lehrgedicht über die Trinität und Hymnen zu den Festen des Kirchenjahres und zu einzelnen Heiligen enthält. Deusdedit starb 1098 oder 1099 ${ }^{15}$. - Der wohl

13 MGH L. d. L. 2, S. 543-562. Ein Teil der anderen Werke, darunter vier Briefe vom Februar 1111 (ebd. S. 563-565), aufgezählt in Repfont 2 (1967) S. 594 f., alle anderen nach der Edition des 17. Jhs. in Migne PL 164, 165. Vgl. noch immer Bernhard Gigalski: Bruno, Bischof von Segni, Abt von Montecassino (1049-1123), Münster 1898 (Kirchengeschichtliche Studien 3/4); Réginald Grégoire: Bruno de Segni, exégète médiéval et théologien monastique, Spoleto 1965, weiters Hartmut Hoffmann: Art. Bruno di Segni, in: DBI 14 (1972) S. 644-647; Girolamo Arnaldi: Art. Bruno, in: LexMA 2 (1983) Sp. 791-793; Bruno di Segni († 1123) e la Chiesa del suo tempo. Giornate di studio, Segni, 4-5 novembre 1999, hg. v. Francesco Cipollini, Venafro 2001 (San Germano 4); István P. BEJCZY: Kings, bishops, and political ethics. Bruno of Segni on the cardinal virtues, in: MS 64 (2002) S. 267-286.

14 Migne PL 134 Sp. 27-52. Vgl. Paul Fournier/Gabriel Le Bras: Histoire des collections canoniques en Occident. Depuis les fausses décrétales jusqu'au décret de Gratien, Bd. 2: De la réforme grégorienne au décret de Gratien, Paris 1932 (ND Aalen 1972), S. 20-25; Roberto Abbondanza: Art. Attone, in: DBI 4 (1962) S. $564 \mathrm{f}$. Weitere Literatur bei Lotte Kéry: Canonical Collections of the early Middle Ages (ca. 4001140). A Bibliographical Guide to the Manuscripts and Literature, Washington, D.C. 1999 (History of Medieval Canon Law 1), S. 233 f.

15 Die Kanonessammlung des Kardinals Deusdedit, ed. Victor Wolf von Glanvell, Paderborn 1905 (ND Aalen 1967). - Deusdedit presbyteri cardinalis libellus contra 
aus Lucca stammende Gregor wurde 1104 von Paschalis II. mit der Titelkirche von S. Grisogono bedacht $(\dagger 1113 / 14)$. Es werden wohl die dramatischen Ereignisse rund um Heinrichs V. Romfahrt gewesen sein, die ihn eine kanonistische Sammlung in acht Büchern zusammenstellen ließ, von ihm selbst "Polycarpus» bezeichnet. Das erste, umfangreichste Buch, das den Primat des Papstes und die Vorrechte der römischen Kirche zum Inhalt hat, wirkt wie ein Kompendium der gregorianischen Ekklesiologie. Die Edition der ziemlich weit verbreiteten Sammlung, in der man die Vorstellungen und Rechtsauffasungen der führenden Köpfe des Reformpapsttums greifen kann, steht noch aus ${ }^{16}$.

Leo Marsicanus, einer der produktivsten Autoren der Abtei Montecassino, deren zentrale Rolle in der gregorianischen Reform wohlbekannt ist, wurde ebenfalls von Paschalis II. ins Kardinalskollegium aufgenommen und mit dem Kardinalbistum Ostia und Velletri ausgestattet (1102/07). Schon als Bibliothekar seiner Abtei war er nicht nur als Schreiber liturgischer und administrativer Codices tätig geworden, sondern auch als Autor einer Vita und Translatio des Hl. Mennas, die er dann als KB ergänzte. Ebenfalls aus diesem Lebensabschnitt stammt das «Corpus hagiographicum» zum Hl. Clemens, dem Patron von Velletri. Sein Hauptwerk, die etwa 1099 begonnene Chronik von Montecassino, war bei seinem Tod (1115) noch nicht vollendet. Kleinere historiographische Schriften, Vorstudien zur Chronik, über das Kloster S. Sofia und die Weihe der Abteikirche von Montecassino stammen ebenfalls aus der Zeit vor der Kardinalserhebung. Die von Petrus Diaconus in seinem «Liber illustrium virorum archisterii Casinensis» ebenfalls erwähnten Predigten, ein Traktat «De signis» und eine unsichere Kreuzzugsgeschichte sind wohl verloren ${ }^{17}$. Viel bescheidener nimmt sich aus, was sein Vorgänger als KB von Ostia, der aus Cluny hervorgegangene Oddo (1094/96-1102/07), über die Auffindung der Reliquien der Hl. Mildburg im Much Wenlock (westl. Birmingham) zu berichten

invasores et symoniacos et reliquos schismaticos, ed. Ernst SACKUR, in: MGH L. d. L. 2, Hannover 1892, S. 292-365. - Die Carmina des Kardinals Deusdedit († 1098/99), ed. Peter Christian Jacobsen, Heidelberg 2002 (Editiones Heidelbergenses 31) - Zu Deusdedit vgl. Fournier/Le Bras: Histoire (wie Anm. 14) Bd. 2 S. 37-53; Harald Zimmermann, in: DBI 39 (1987) S. 504-506. Weitere Lit. bei Kéry: Collections (wie Anm. 14) S. 228-233.

16 Vgl. Uwe Horst: Die Kanonessammlung Polycarpus des Gregor von S. Grisogono, München 1980 (MGH Hilfsmittel 5); Robert Kretzschmar: Art. Polycarp, in: LexMA 7 (1995) Sp. 73 f.; Diego Quaglioni: Art. Gregorio, in: DBI 59 (2002) S. 105-107. Weitere Lit. bei Kéry: Collections (wie Anm. 14) S. 266-269.

17 Die Chronik von Montecassino, hg. v. Hartmut Hoffmann, Hannover 1980 (MGH SS 34), in der Einleitung Leben und Werke. - Zu den anderen Werken vgl. Repfont 7 (1997) S. 177-179. - Petrus Diaconus: Liber illustrorum virorum archisterii Casinensis, in: Migne PL 173 Sp. 1009-1062, hier Sp. 1038 f. - Vgl. Hartmut Hoffmann: Art. Leo v. Ostia, in: LexMA 5 (1991) Sp. 1882; Mariano Dell'Omo: Art. Leone Marsicano, in: DBI 64 (2005) S. 552-557. 
wußte ${ }^{18}$. Und noch einmal bescheidener wirkt die «Laus metrica», die Milo, KB von Preneste (1100-1102), zu Ehren Paschalis' II. verfaßte ${ }^{19}$.

In der ersten Hälfte des 12. Jahrhunderts nimmt die Zahl der Schriftsteller unter den Kardinälen deutlich ab und steigt erst ab der Jahrhundertmitte wieder an. Aegidius (Gilo) von Toucy (bei Auxerre), Mönch in Cluny, wurde 1122/23 unter Calixt II. zum KB von Tusculum erhoben und sollte nach 1130 einer der eifrigsten Anhänger Anaklets II. werden. Noch vor seinem Eintritt in Cluny hatte er in Paris eine «Historia vie Hierosolimitane», eine Geschichte des Ersten Kreuzzuges von der Belagerung Nicaeas bis zur Wahl Gottfrieds von Bouillon mit Hilfe der weit verbreiteten Kreuzzugschroniken - in Versen verfaßt. ${ }^{20} \mathrm{Als}$ Mönch begann er im Auftrag des Abtes Pontius eine umfangreiche Vita des Abtes Hugo von Semur (1049-1109), die er nach der Kanonisierung (1120) in Rom abschloß und wofür er seine brillanten Lateinkenntnisse zur Anwendung brachte. Der intensive Einsatz als Legat in den Zwanzigerjahren erlaubte keine Fortsetzung der schriftstellerischen Tätigkeit ${ }^{21}$. - Der Benediktinerabt Drogo von Saint-Jean in Laon, der zwischen 1136 und 1138 als KB von Ostia bezeugt ist, verfaßte einige, eng an Bernhard von Clairvaux angelehnte theologische Schriften, von denen nur der «Sermo de sacramento dominicae passionis» eine gewisse Eigenständigkeit hat ${ }^{22}$ - Mit dem Engländer Robert Pullus begegnet

18 Paul A. Hayward: The Miracula inventionis beate Mylburge virginis attributed to "the lord Ato, cardinal bishop of Ostia“, in: EHR 114 (1999) S. 543-573.

19 Laus metrica Paschalis II papae auctore Milone cardinali, in: Migne PL 163 Sp. 27 f.

20 The Historia Vie Hierosolymitane of Gilo of Paris and a second anonymous Author, ed. und übers. Chris W. Grocock/Elizabeth Siberry, Oxford 1997 (Oxford Medieval Texts). Die Identifikation von Gilo-Aegidius ist durch Hinweise im Text gesichert. Zur literarischen Einordnung und zum Quellenwert vgl. neben der Einleitung der Edition auch Chris W. Grocock: L'aventure épique: le traitement poétique de la première Croisade par Gilon de Paris et son continuateur, in: Autour de la Première Croisade. Actes du Colloque de la Society for the Study of the Crusades and the Latin East (ClermontFerrand, $22-25$ juin 1995), hg. v. Michel Balard, Paris 1996 (Byzantina Sorbonensia 14), S. $17-28$.

21 Vita sancti Hugonis abbatis, ed. Herbert Edward John Cowdrey, in: Ders.: Two Studies in Cluniac History, Rom 1978 (StGreg 11), S. 30-35, 43-109, zur Einordnung in die Viten Hugos vgl. Armin Kohnle: Abt Hugo von Cluny (1049-1109), Sigmaringen 1993 (Beih. der Francia 32), S. 253 f. - Die biographischen Daten zu Aegidius sind zusammengestellt bei Zenker, S. 43 f.; Hüls, S. 142 f.; zuletzt Frank Barlow: The Canonization and the Early Lives of Hugh I Abbot of Cluny, in: AnalBoll 98 (1980) S. 297-334, hier 308-314, und Werner Maleczek: Art. Egidio (Gilo), in: DBI 42 (1993) S. 305-307.

22 Drogonis cardinalis sermo de sacramento dominicae passionis, in: Migne PL 166, Sp. 1515-1546; "Liber de creatione et redemptione primi hominis», "Opusculum de septem donis S. Spiritus» sind Plagiate nach Bernhard; "Liber de divinis officiis seu horis canonicis», ebd. Sp. 1547-1564. Vgl. Jean LeclercQ: Drogon et Saint Bernard, in: RevBén 63 (1953) S. 106-113; Anselme Dimier: Art. Drogo, in: DBF 11 (1967) Sp. 787 f.; ZeNKer S. 13-15. 
unter den Kardinälen erstmalig der Typus des Gelehrten, der durch seinen Unterricht an verschiedenen renommierten Schulen so viel an Prestige erworben hatte, daß man an der Kurie auf ihn aufmerksam wurde und seine Fähigkeiten in den päpstlichen Dienst zu stellen suchte. Er studierte in Paris, lehrte dann in Oxford, kehrte aber 1142 nach Paris zurück, wo er den Lehrstuhl des Gilbert de la Porrée übernahm und großen Zulauf hatte. Lucius II. gewann ihn für Rom, übertrug ihm 1144 den Titel von SS. Martino e Silvestro und schon im folgenden Jahr das Kanzleramt, das er freilich nur kurz bis zu seinem Tod zu Ende des Jahres 1146 ausfüllen konnte. Während seiner Lehrtätigkeit verfaßte er mehrere theologische Werke, von denen die «Sententiae» in acht Büchern, die gewisse Analogien zu Abaelard, Hugo von St. Viktor und Petrus Lombardus aufweisen, und der Traktat "De contemptu mundi» gedruckt sind. Daneben stammen Kommentare zu den Psalmen und zur Apokalypse und Predigten aus seiner Feder ${ }^{23}$. - In diese Gruppe gehört auch Odo, der ab etwa 1145 als Kanoniker von Notre Dame an der Kathedralschule von Paris lehrte und das Amt eines Kanzlers von 1164 an wahrnahm. Dann trat er in die Zisterze Ourscamp ein, der er als Abt von 1167/8 bis 1170 vorstand. Alexander III. erhob ihn in diesem Jahr zum KB von Tusculum, welche Würde er freilich nur ein Jahr lang bis zu seinem Tod 1171/72 ausfüllte. Aus seiner Pariser Zeit stammen umfangreiche Quästionen, in denen er alle Themen der Theologie behandelte und in denen er öfters im Widerspruch zu Petrus Lombardus steht. Er ist eher der Denkschule der Porretaner zuzuordnen. Odo stand im Briefwechsel mit Hildegard von Bingen, und es sind noch weitere Briefe erhalten. Eine Reihe von Predigten ist ebenfalls überliefert ${ }^{24}$. - Der aus der Gegend von

23 Roberti Pulli sententiarum libri octo, in: Migne PL 186, Sp. 639-1100. Vgl. Francis Courtney: An unpublished treatise of Cardinal Robert Pullen ( $\dagger$ 1146). Sermo de omnibus humane uite necessariis or De contemptu mundi, in: Gregorianum 31 (1950) S. 192-223; DERs.: Cardinal Robert Pullen. An English theologian of the twelfth century, Rom 1954 (Analecta Gregoriana A/10); Zenker S. 89-92; Beryll Smalley: The Becket Conflict and the Schools, Oxford 1973, S. 39-50, 242-246; Johann Baptist Schneyer: Repertorium der lateinischen Sermones des Mittelalters, Bd. 5: R-W, Münster 1974 (BGPhMA 43/5), S. 219-223; Stephen C. Ferruolo: The Origins of the University. The Schools of Paris and their Critics, 1100-1215, Stanford 1985, S. 192 f. u. ö.

24 Quaestiones Magistri Odonis Suessionensis, in: Analecta novissima Spicilegii Solesmensis altera continuatio, ed. Johann Bapt. Pitra, Bd. 2: Tusculana, Paris 1888, S. 3187 (Teiledition mit Fremdelementen, vgl. Ignatius Brady: Peter Manducator and the Oral Teachings of Peter Lombard, in: Antonianum 41 [1966] S. 454-490). - Hildegard von Bingen, Epistolae, Bd. 1, ed. Lieven van Acker, Turnhout 1991 (CChrCM 91), S. 100-105 Nr. 39-40; Jean LeclercQ: Lettres d'Odon d'Ourscamp, in: Analecta monastica. Textes et études sur la vie des moines au Moyen Âge. Troisième série, Rom 1955 (Studia Anselmiana 37), S. 145-157; weitere Briefe bei Pitra: Analecta, S. XXXIX-XLII. - Zu den Sermones Schneyer: Repertorium (wie Anm. 23) Bd. 4 S. 508-510; Paola DE SAnTIS: Un sermone di Oddone di Soissons nel ms. Bruxelles, 
Lucca stammende Boso, der in der Familia des Guido von SS. Cosma e Damiano schon in den Dreißigerjahren mit der Kurie in Kontakt kam, wurde unter Eugen III. 1149 der Nachfolger seines Mentors als Leiter der päpstlichen Kanzlei und 1154 mit dem Regierungsantritt Hadrians IV. Kämmerer der römischen Kirche. Dieser machte ihn 1156 zum KD von SS. Cosma e Damiano $(\dagger$ 1178). Unter Alexander III. verfaßte er ab etwa 1165 die Fortsetzung des «Liber Pontificalis», wobei er seine "Vitae pontificum Romanorum» mit dem späten 9. Jahrhundert einsetzen ließ und zunächst Vorlagen und Archivstücke verarbeitete. Erst die - offiziöse - Berichterstattung für die Pontifikate Hadrians IV. und Alexanders III. ist von hohem Quellenwert. Auch der Kern des Liber Censuum von 1192 enthält Elemente, die von Boso stammen ${ }^{25}$. Bernhard, der Prior der am Lateran etablierten Regularkanoniker, der 1145 zum KP von S. Clemente und 1158 zum KB von Porto ernannt wurde ( $†$ 1176), verfaßte vor seiner Zeit als Kardinal den liturgisch-administrativ orientierten «Ordo officiorum Ecclesiae Lateranensis» ${ }^{26}$. - Alexander III. ernannte auf dem Dritten Laterankonzil einen der prominentesten Zisterzienser seiner Zeit, Heinrich von Marcy, Abt von Clairvaux, zum KB von Albano († 1189). Er war 1177 zusammen mit Petrus von Pavia als Legat ins Albigensergebiet Südfrankreichs zur Abwehr der Häresie entsandt worden und hatte die Bischofswürde von Toulouse und die Abtwürde von Cîteaux ausgeschlagen. Als Kardinal sollte er einer der am meisten eingesetzten Legaten in Frankreich und Deutschland werden, wobei der von ihm geführte Kriegszug im Süden Frankreichs 1179/1181 schon auf sein zentrales Anliegen, den Kreuzzug, verweist.

BR, 10.147-58, in: Aevum 56 (1982) S. 221-244; Jean Longère: Oeuvres oratoires de maîtres parisiens au XII ${ }^{\mathrm{e}}$ siècle, 2 Bde. Paris 1975, Bd. 1 S. 19-24, $91-96$ u. ö. Bd. 2 S. 18 f., 82-85 u. ö. Vgl. u. a. Ferruolo: Origins (wie Anm. 23) S. 190 u. ö., und die beste Zusammenfassung durch Jean Longère: Art. Odo de Soissons, in: Dict. Spiritualité 11 (1982) S. 628-631; Ludwig Höpl: Art. Odo v. Ourscamp, in: LexMA 6 (1993) Sp. 1360; Ders.: Art. Odo v. Ourscamp, in: LThK $^{3} 7$ (1998) Sp. 979; Repfont 8 (2001) S. 340.

25 Le Liber Pontificalis, ed. Louis Duchesne, Bd. 1, Paris ${ }^{2} 1955$, S. 353-446. Vgl. Fritz Geisthardt: Der Kämmerer Boso, Berlin 1936 (Historische Studien 293); Zenker S. 149-152; Zerlina Zafarana: Art. Bosone, in: DBI 13 (1971) S. 270-274; Odilo Engels: Kardinal Boso als Geschichtsschreiber, in: Konzil und Papst. Historische Beiträge zur Frage der höchsten Gewalt in der Kirche. Festgabe für Hermann Tüchle, hg. v. Georg Schwaiger, München u. a. 1975, S. 147-168; Peter Munz: Papst Alexander III. Geschichte und Mythos bei Boso, in: Saeculum 41 (1990) S. 115-129; Walter BerSCHIN: Biographie und Epochenstil im lateinischen Mittelalter, Bd. 4/2: 1070-1220, Stuttgart 2001 (Quellen und Untersuchungen zur lateinischen Philologie des Mittelalters 12/2), S. 473-479.

26 Bernhardi Cardinalis et Lateranensis Ecclesiae prioris Ordo Ecclesiae Lateranensis, ed. Ludwig Fischer, München 1916 (Historische Forschungen und Quellen 2/3). Vgl. Zenker S. 29-32; Pierre-Marie Gy: L'influence des chanoines de Lucques sur la liturgie du Latran, in: Revue des sciences religieuses 58 (1984) S. 31-41. 
Unter den 32 erhaltenen Briefen ragen jene mit der Kreuzzugs- und Albigenserthematik heraus, die vor und nach seiner Kardinalserhebung verfaßt wurden. Der «Tractatus de peregrinante civitate Dei», in den letzten Lebensjahren des Kardinals redigiert, ist ein heterogener, nur in einer Handschrift aus Clairvaux erhaltener Traktat, der Ekklesiologisches, Liturgisches, Geschichtstheologisches und Christologisches enthält ${ }^{27}$. - Einer der wichtigsten Theologen für die lateinisch-griechische Auseinandersetzung in der zweiten Hälfte des 12. Jahrhunderts, Hugo Etherianus, der nach seiner Ausbildung in Paris zusammen mit seinem Bruder an den Hof des byzantinischen Kaisers Manuel I. ging und dessen theologischer Berater bei den Unionsbestrebungen und Verhandlungen mit einer päpstlichen Kommission wurde, die 1166 nach Konstantinopel kam, wurde 1182 von Lucius III. zum KD von S. Angelo ernannt. Aber als solcher ist er nur durch zwei Unterschriften auf päpstlichen Privilegien Mitte Juli 1182 bezeugt. Knapp später ist er verstorben. Sein umfangreiches theologisches Werk, «De sancto et immortali Deo $=$ De haeresibus, quas Graeci in Latinos devolvunt», «De anima corpore iam exuta», «Adversus patarenos», und anderes, wie auch seine Übersetzungen aus dem Griechischen, wurde im Abendland gut rezipiert ${ }^{28}$.

Die Reihe der hochqualifizierten Kanonisten unter den Kardinälen wird nicht mit Rolandus, KD von SS. Cosma e Damiano 1150, KP von S. Marco 1151-1159, dem späteren Alexander III., fortgesetzt, dessen Autorschaft von umfangreichen kanonistischen und theologischen Werken als definitiv widerlegt

27 Domni Henrici tractatus de peregrinante civitate Dei, in: Migne PL 204 Sp. 251-402; Briefe: ebd. Sp. 215-218, 227-252; Walther Holtzmann: Quellen und Forschungen zur Geschichte Friedrich Barbarossas (Englische Analekten I), in: NA 48 (1930) S. $384-$ 413, hier $412 \mathrm{f}$ - - Vgl. Yves Marie Jean Congar: Henri de Marcy, abbé de Clairvaux, cardinal, évêque d'Albano et légat pontifical, in: Analecta monastica 5, Rom 1958 (Studia Anselmiana 43), S. 1-90; DERs.: Église et cité de Dieu chez quelques auteurs cisterciens à l'époque des croisades en particulier dans le 'De peregrinante civitate Dei' d'Henri d'Albano, in: Mélanges offerts à Étienne Gilson, ed. Callistus Edie, Toronto/ Paris 1959, S. 173-202; Christine Thouzellier: Catharisme et valdéisme en Languedoc à la fin du XII et et au début du XIII ${ }^{\text {e }}$ siècle, Paris ${ }^{2} 1969$ (Publications de la Faculté des Lettres et Sciences Humaines de l'Université de Paris. Recherches 27), S. 1450. Sein Wirken als Legat im Süden Frankreichs wird immer wieder behandelt, z. B. Beverly M. Kienzle: Henry of Clairvaux and the 1178 and 1181 Missions, in: Heresis 28 (1997) S. 63-87. - Wichtige weitere Quellen: Weiss S. 272-279. Vgl. auch Gaetano Raciti: Art. Henri de Macy, in: Dict. Spiritualité 7 (1969) Sp. 225-227; Repfont 5 (1984) S. 421 f.; Kurt Zeillinger: Art. Heinrich, in: LThK ${ }^{3} 4$ (1995) S. 1373 f.

28 Werke: Migne PL 202 Sp. 167-396, manches ist unediert, vgl. Repfont. 5 (1984) S. 581 f. Vgl. André Dondaine: Hugues Éthérien et Léon Toscan, in: AHDL 27 (1952) S. 67-134; Otto Volk: Art. Hugo Etherianus, in: LThK $^{3} 5$ (1996) Sp. 307. - Die beiden Unterschriften: RI 4/4/4/2 S. 167 u. 169 Nr. 291 u. 294 (14. und 15.7.1182). 
gelten kann ${ }^{29}$. Der nächste ist hingegen Raimund von Nîmes, de Arenis, KD von S. Maria in Vialata 1158-1176/77. Wie André Gouron und Rudolf Weigand überzeugend plausibel machten, steht hinter der Sigle $C$ oder Car(dinalis) kein anderer als der aus der südfranzösischen Stadt stammende iurisperitus Raimund, der auch über gediegene Kenntnisse aus dem römischen Recht verfügte. Seine Glossen finden sich in zahlreichen frühen Handschriften des Decretum ${ }^{30}$. - Ihm zur Seite zu stellen ist der aus der Toskana stammende Laborans, der 1173 zum KD von S. Maria in Porticu erhoben und 1179 zum KP von S. Maria in Trastevere promoviert wurde $(\dagger 1189)$. Vor und nach seiner Rangerhöhung arbeitete er lange an seiner "Compilatio decretorum», einer Umgruppierung der in Gratians «Decretum» aufgezeichneten Kanones, deren geringfügige Ergänzung und Erläuterung; aber sie blieb unbeachtet. Auch vier theologisch-philosophische Traktate, die in derselben einzigen, vielleicht von Laborans selbst korrigierten Handschrift überliefert sind, stammen aus seiner Feder: «De iustitia et iusto» (schon zwischen 1154 und 1160 entstanden), «De vera libertate» (zwischen 1144 und 1161), «Contra Sabellianos» (aus der Kardinalszeit), «De relativa praedicatione personae in divinis ${ }^{31}$.

29 Die Summa magistri Rolandi, ed. Friedrich Thaner, Innsbruck 1874 (ND Aalen 1962); Die Sentenzen Rolands nachmals Papstes Alexanders III., ed. Ambrosius M. GieTL, Freiburg 1891 (ND Amsterdam 1969); Der Ehetraktat des Magisters Rolandus von Bologna. Redaktionsgeschichtliche Untersuchung und Edition (Studienausgabe), ed. Kerstin Jасові, Hamburg 2004 (Schriften zur Mediävistik 3). Vgl. John T. jr. Noonan: Who was Rolandus?, in: Essays Stephan Kuttner. Law, Church, and Society, ed. Kenneth Pennington/Robert Somerville, Philadelphia 1977, S. 21-48; Rudolf Weigand: Magister Rolandus und Papst Alexander III, in: AKKR 149 (1980) S. 3-44; DERs.: Glossen des Magisters Rolandus zum Dekret Gratians, in: Miscellanea Rolando Bandinelli, Papa Alessandro III, ed. Filippo LiotтA, Siena 1986, S. 389-423.

30 André Gouron: Le cardinal Raymond des Arènes: Cardinalis?, in: RDC 28 (1978) S. 180-192; Rudolf Weigand: Die Glossen des Cardinalis (Magister Hubald?) zum Dekret Gratians, besonders zu C.27 q.2, in: BMCL 3 (1973) S. 73-95; DERs.: Die Glossen des Cardinalis - Raimundus de (Harenis) - zu C.16, in: Recht im Dienste des Menschen: Eine Festgabe für Hugo Schwendenwein zum 60. Geburtstag, hg. v. Klaus LüDicke u.a., Graz 1986, S. 267-83; Luca Loschiavo: Sulle tracce bolognesi del Cardinalis decretista (e legista) del secolo XII, in: Manoscritti, editoria e biblioteche dal medioevo all'età contemporanea. Studi offerti a Domenico Maffei per il suo ottantesimo compleanno, ed. Mario Ascheri/Gaetano Colli, Rom 2006, Bd. 2 S. 515-532.

31 Die "Compilatio decretorum» ist unediert, die anderen Werke: Laborantis cardinalis opuscula, ed. Arthur Michael Landgraf, Bonn 1932 (Florilegium patristicum 32). Vgl. Norbert Martin: Die „Compilatio decretorum“ des Kardinal Laborans, in: Proceedings 6. IntKongMK, Berkeley 1980, ed. Stefan Kuttner/Kenneth Pennington, Città del Vaticano 1985 (MIC C 7), S. 125-39; DERs.: „Mare uitreum“ (Neapel, Bibl. naz. MS. XII A 27): Eine Quelle der „Compilatio decretorum“ des Kardinal Laborans, in: BMCL 15 (1985) S. 51-59 (Der Autor kündigt seit längerem eine Edition der Compilatio an); Horst ENZENSBERgER: Cultura giuridica e amministrazione nel regno normanno-svevo, in: Scuole, diritto e società nel mezzogiorno medievale d'Italia II, hg. v. Manlio BeL- 
Aus der Erfahrung der Arbeit an der Kurie erwuchs das - freilich nur indirekt überlieferte und auch nicht mit Sicherheit zuschreibbare - Werk des Beneventaners Albert von Morra, KD von S. Adriano 1156, KP von S. Lorenzo in Lucina 1158-1187, dann für wenige Wochen Papst Gregor VIII. Aus seiner Bologneser Lehre über das «Decretum» scheinen nur Zitate bei anderen Kanonisten überlebt zu haben ${ }^{32}$. Als Kanzler der römischen Kirche (seit 1178), der besonderes Augenmerk auf die äußere und innere Perfektion der päpstlichen Urkunden legte, mag er eine nicht sehr lange «Forma dictandi», die unter seinem Namen überliefert ist, zusammengestellt haben, die auch erstmals einen Teil über den Cursus, den rhythmischen Satzschluß in den Urkunden, umfaßte ${ }^{33}$. - Ebenfalls aus der Tätigkeit am kurialen Gericht erwuchs der kurze Traktat, eher: ein rechtskundiger Brief, den der juristisch versierte Vivianus, KD von S. Nicola in Carcere Tulliano 1175, noch im selben Jahr KP von S. Stefano in Celiomonte $(\dagger 1184)$, für seinen Kollegen, Kardinal Laborans, über das Appellationsrecht schrieb. Er hielt sich dabei eng an einen einschlägigen (anonymen) legistischen Traktat «Superest videre» ${ }^{34}$. - Albinus, KD von S. Maria Nuova 1182, KP von S. Croce in Gerusalemme 1185, KB von Albano 11891196, ließ ebenfalls seine kuriale Erfahrung in sein schriftstellerisches Werk einfließen. Seine "Digesta pauperis scolaris Albini», geraume Zeit vor der Kardinalskreation begonnen, stellen eine Sammlung aus Sentenzen und Sprichwörtern, Auszügen aus Kirchenvätern, Konzilskanones und anderen theologischen und liturgischen Werken dar. Die letzten beiden Bücher, in der Kardinalszeit angefügt, haben die Rechte und die Liturgie der römischen Kirche

LOMO, Catania 1987 (Università di Catania. Seminario giuridico), S. 171-188, bes. 172 ff.; Luca Loschiavo, in: DBI 62 (2004) S. 798-800.

32 Über ihn vgl. Zenker S. 125-129; Tommaso di Carpegna Falconieri: Art. Gregorio VIII, in: DBI 59 (2002) S. 164-166. Zu den kanonistischen Leistungen Walther Holtzmann: Die Dekretalen Gregorius VIII., in: MIÖG 58 (1950) S. 113-123; Rudolf Weigand: Gandulphglossen zum Dekret Gratians, in: BMCL 7 (1977) S. 39 f.

33 Ann Dalzell: The Forma Dictandi attributed to Albert of Morra and related texts, in: Mediaeval Studies 39 (1977) S. 440-463 (Edition S. 442 f., Kommentar S. 457-461); Harry Bresslau: Handbuch der Urkundenlehre, Bd. 2, Leipzig ${ }^{2}$ 1915, S. 366-369. Skeptisch gegenüber der Verfasserschaft: Tore Janson: Prose Rhythm in Medieval Latin from the $9^{\text {th }}$ to the $13^{\text {th }}$ century, Stockholm 1975 (Acta Universitatis Stockholmensia. Studia Latina Stockholmensia 20), S. $92 \mathrm{ff}$.

34 Vgl. Marlene PoLOcк: Magister Vivianus, ein Kardinal Alexanders III. Prosopographische Anmerkungen, in: Papsttum, Kirche und Recht im Mittelalter: Festschrift für Horst Fuhrmann zum 65. Geburtstag, hg. v. Hubert Mordek, Tübingen 1991, S. 265-276, hier bes. S. 270; Weiss S. 247 ff. - Zum Werk/Brief vgl. Stephan Kuttner: Zur neuesten Glossatorenforschung, in: Studia et documenta historiae et juris 6 (1940) S. $275-$ 319, 424-425, hier: S. 296 ff. - Die Vorlage ist ediert von Antonio Padoa Schioppa: Ricerche sull'appello nel diritto intermedio, 2 Bde., Mailand 1970 (Università di Milano. Pubblicazioni della Facoltà di giurisprudenza. Ser. 2. Studi di storia del diritto 4), Bd. 2 S. 233 ff. 
zum Inhalt. Vielleicht sind die «Digesta» eine der Vorarbeiten, auf die sich der Kämmerer Cencius 1192 bei der Abfassung seines «Liber Censuum» stützte. ${ }^{35}$ $\mathrm{Ab}$ dem letzten Jahrzehnt des 12. Jahrhunderts nimmt die Zahl der Kardinäle, die vor ihrer Kreation schriftstellerisch tätig waren, deutlich zu. Dies entspricht dem Bestreben besonders Innozenz' III., an den Hohen Schulen von Paris und Bologna ausgebildete, geistig hervorragende Männer in seinen Beraterkreis zu berufen. Aus den zahlreichen stadtrömischen Klerikern, die Clemens III. zur Kardinalswürde erhob, ragt Lothar aus der Führungsschichte des im südlichen Latium gelegenen Segni heraus. Er war wohl im Hinblick auf eine kirchliche Karriere in der Mitte der Siebzigerjahre nach Paris auf die Hohen Schulen geschickt worden und hatte in den späten Achtzigerjahren seine Ausbildung in Bologna vervollständigt. Seit dem Herbst 1190 mit der Kardinalsdiakonie von SS. Sergio e Bacco ausgestattet, nutzte er die ruhig verlaufende Zeit des Kardinalates zur Abfassung einiger theologischer Traktate, die die aktuellen kirchenpolitischen Fragen wie das Verhältnis zu den Staufern, den Kreuzzug, die Ausbreitung der Häresie zwar völlig ausblenden, die ihn aber als fest verankert in den geistigen Strömungen seiner Zeit ausweisen. «De miseria humane conditionis» gehört in die Kategorie der Contemptus mundi-Literatur, mit der der Mensch als ein Geschöpf beschrieben wird, das sich von seinem Schöpfer abwendet und als Opfer seines Hochmutes dargestellt wird. Der Erfolg des Werkes war außerordentlich, wofür sowohl das Thema der beklagenswerten menschlichen Existenz als auch die drastische Sprache und die spätere Berühmtheit des Autors verantwortlich sind. Mehr als 700 mittelalterliche Handschriften sind erhalten, was verdeutlicht, daß «De miseria» zu den am meisten gelesenen religiösen Schriften des Mittelalters zählt. «De missarum misteriis», ein liturgisch-allegorischer Traktat, kommentiert ausführlich die Papstmesse und verbindet damit theologische Aussagen über die Eucharistie, wobei die Messe als Erinnerung an das Leben Christi gedeutet wird. In «De

35 Ed.: Le Liber Censuum de l'Église romaine, ed. Paul Fabre/Louis Duchesne, 3 Bde., Paris 1910-1952, hier Bd. 2 S. 90-137. Vgl. Uta Renate Blumenthal: Cardinal Albinus of Albano and the "Digesta pauperis scolaris Albini», Ms. Ottob. lat. 3057, in: AHP 20 (1982) S. 7-49 (Wiederabdr. in : DIEs. : Papal reform and canon law in the 11th and 12th centuries, Aldershot 1998 [Variorum collected studies series 618] XVII S. 7-49); Werner MaleczeK: Papst und Kardinalskolleg von 1191 bis 1216. Die Kardinäle unter Coelestin III. und Innocenz III., Wien 1984 (Publikationen des Historischen Instituts beim Österreichischen Kulturinstituts in Rom Abt. 1/6), S. 76 f.; Thérèse Montecchi Palazzi: Formation et carrière d'un grand personnage de la curie au XII ${ }^{e}$ siècle: le cardinal Albinus, in: MEFRM 98 (1986) S. 623-671. - Zu Cencius vgl. Maleczek: Papst, S. 111-113, mit Ergänzungen durch Ders.: Zwischen lokaler Verankerung und universalem Horizont. Das Kardinalskollegium unter Innocenz III., in: Innocenzo III. Urbs et Orbis. Atti del Congresso internazionale, Roma, 9-15 settembre 1998, hg. v. Andrea Sommerlechner, Rom 2003 (Nuovi studi storici $55=$ Miscellanea della Società romana di storia patria 44), Bd. 1 S. 139 f. 
quadripartita specie nuptiarum» gibt Lothar im ersten Teil eine persönlich gefärbte, stark allegorisierende Auslegung der vier Arten der ehelichen Verbindung, einer fleischlichen und dreier mystischer (Mann-Frau, göttliche und menschliche Natur in der Person Christi, Christus-Kirche, Gott-gerechte Seele), im zweiten, inhaltlich kaum verknüpften Teil einen konventionellen Kommentar zu Psalm $44^{36}$. - Den aus einer Amalfitaner Patrizierfamilie stammenden Petrus Capuanus berief Cölestin III. 1193 ins Kardinalskolleg. Auch er hatte in Paris studiert und dort eine theologische "Summa», eine systematische dogmatische Abhandlung in der Nachfolge des Petrus Lombardus, verfaßt. Das zweite theologische Werk, im Pariser Schulmilieu begonnen und während der Kardinalszeit fertiggestellt, gehört in die Kategorie der Distinctiones, die in alphabetischer Anordnung zahlreiche Begriffe, die ein Prediger oder Exeget für seine Arbeit verwendet, durch Bibelzitate und Väterzitate erläutern. Dieses umfangreiche "Alphabetum in artem sermocinandi» erfreute sich, aus der handschriftlichen Überlieferung zu schließen, im 13. Jahrhundert großer Beliebtheit ${ }^{37}$. - Der Engländer Stephan Langton machte eine glänzende Karriere

36 Lotharii cardinalis (Innocentii III) De miseria humane conditionis, ed. Michele MACCARrone, Lucca 1955. - De sacro altaris mysterio libri sex, in: Migne PL 217 Sp. $773-$ 916; De quadripartita specie nuptiarum, ebd. Sp. 921 - 968; neue Edition durch Connie Munk: A Study of Pope Innocent III's Treatise De quadripartita specie nuptiarum, 2 Bde., PhD Univ. Kansas 1975. Zu Lothars Kardinalszeit vgl. Maleczek: Papst (wie Anm. 35) S. 101-104; Ergänzungen verarbeitet in DERs.: Art. Innocenzo III, in: DBI 62 (2004) S. 419-435, bes. $420 \mathrm{ff}$.

37 Vgl. Werner Maleczek: Petrus Capuanus. Kardinal, Legat am Vierten Kreuzug, Theologe († 1214), Wien 1984 (Publikationen des Historischen Instituts beim österreichischen Kulturinstitut in Rom 1/8), bes. S. 231 ff.; (ital. Übersetzung: Pietro Capuano. Patrizio amalfitano, Cardinale, Legato alla Quarta Crociata, Teologo [† 1214], Amalfi 1997 [Centro di cultura e storia amalfitana. Biblioteca amalfitana 2], bes. S. 255 ff.). - Beide Werke sind nicht zur Gänze ediert. Mit der «Summa» befaßten sich in den vergangenen Jahren besonders die Theologen der römischen Università della Santa Croce, zumeist Schüler von Alfonso CHAcón, der auch schon dazu publiziert hatte: Sobre la autoría de la „Summa Theologiae“ del Cardenal Pedro de Capua ( $†$ 1214), in: Hispania Christiana. Estudios en honor del prof. José Orlandis Rovira, Pamplona 1988, S. 379-388. In den folgenden Dissertationen sind Teile der «Summa» auch ediert: José Ignacio Varela González: La doctrina de la justificación en Pedro de Capua según el Códice Vaticano Latino 4296, Rom 1987; Alfredo Cento: Dottrina sui nomi essenziali di Dio nella Summa Theologiae di Pietro di Capua. Testo delle questioni II-XXIV, Rom 1990; J. Pascual Martínez: Elementos para una teología del pecado en Pedro de Capua en el contexto histórico-teológico de finales del siglo XII, Rom 1990; José Antonio SuÁrez Regueiro: La doctrina trinitaria de la Summa Theologiae de Pedro de Capua en el contexto histórico-teológico de finales dels siglo XII, Rom 1990; Ignacio Fabregat Torrens: Doctrina eucaristica y de la conversion sustancial en Pedro de Capua $(\dagger 1214)$ y sus inmediatos predecesores, Rom 1991; Carlo Lahoz Zamarro: Reglementación del lenguaje trinitario en Pedro de Capua. Análisis semiótico y contextualización histórica, Rom 1992; Pere Domingo i Manero: Angelología en Pedro de 
als akademischer Lehrer in Paris, bevor ihn Innozenz III. 1206 ins Kardinalskollegium berief und im Jahr darauf zum Erzbischof von Canterbury machte. Sein theologisches Werk, das ihm den Übernamen doctor nominatissimus eintrug, ist umfangreich: Schriftkommentare und anderes Exegetisches, zahlreiche Quaestiones, ein Sentenzenkommentar, Distinctiones, eine Summa de vitiis et virtutibus, Predigten und Hymnen ${ }^{38}$. - Ein anderer Mitstudent Lothars in Paris, Hubert von Pirovano, stammte aus einer Mailänder Familie und wurde ebenfalls nach Frankreich zum Studium geschickt, wo er in den Neunzigerjahren eine theologische Summa "Colligite fragmenta» verfaßte. Auch er wird im Frühjahr 1206 als Kardinal in die nächste Umgebung des Papstes berufen werden. Aber schon ein Jahr später wählte ihn das Domkapitel von Mailand zu seinem Oberhirten $(\dagger 1211)^{39}$. - Ebenfalls ein aus England stammender Pariser Professor, Robert de Corson, wurde vor allem durch seine in die Jahre 1208 bis 1212 zu datierende Summa bekannt, die wohl aus dem Lehrbetrieb stammte. Es handelt sich dabei nicht um eine systematische Darlegung des gesamten theologischen Wissens, sondern hauptsächlich um einen Bußtraktat, dem die Darstellung der anderen Sakramente in kürzerer Form angehängt wurden. Daneben sind Quaestiones erhalten, während Predigten und ein Sentenzenkommentar verloren sind. Vor seiner Berufung in das Kardinalskollegium im Jahre 1212 war

Capua, Rom 1995; Daniel Borra Sales: La cristología en Pedro de Capua, Rom 1996; Francisco Armada Martínez-Campos: La doctrina de las virtudes de un autor nominalis del siglo XII: Pedro de Capua. Texto inédito de su Summa Theologiae, Rom 1997; Salvador Gual i García: 'Illatio' e 'instantia' en la Summa Theologiae de Pedro de Capua, Rom 1997; Carlo Pioppr: La dottrina sui nomi essenziali di Dio nella Summa Theologiae di Pietro Capuano. Edizione critica delle quaestiones I-XXIV, Rom 2004 (Dissertationes. Series theologica 14); DERs.: La creazione e lo stato di giustizia originale nella «Summa vetustissima veterum» di Pietro Capuano, in: Dar razón de la esperanza. Homenaje al Prof. Dr. José Luis Illanes, hg. v. Tomás Trigo, Pamplona 2004, S. 441-454; DERs.: Il peccato originale e il „sinus Abrahae“ nella „Summa Vetustissima veterum" di Pietro Capuano, in: Annales Theologici 18 (2004) S. 373-423; Ders.: Teologia e politica in un cardinale del tempo d'Innocenzo III: l'opera di Pietro Capuano, in: Annales Theologici 20 (2006) S. 127-148.

38 Maleczek: Papst (wie Anm. 35) S. 164-166; Ders.: Kardinalskollegium (wie Anm. 35) S. 153 f. - Als letzte umfassende Arbeit mit breitem Literaturverzeichnis: Riccardo Quinto: „Doctor Nominatissimus“: Stefano Langton († 1228) e la tradizione delle sue opere, Münster 1994 (Beiträge zur Geschichte der Philosophie und Theologie des Mittelalters N. S. 39), zu den Werken S. 30-43; Ergänzungen durch Dens.: Stephen Langton. Theology and literature of the pastoral care, in: „In principio erat verbum". Mélanges offerts à Paul Tombeur per des anciens étudiants à l'occasion de son eméritat, ed. Benoît-Michel Тоск, Turnhout 2005 (Textes et études du moyen âge 25), S. 301-355.

39 Maleczek: Papst (wie Anm. 35) S. 153 f.; Ders.: Kardinalskollegium (wie Anm. 35) S. 152. - Ed.: Richard Heinzmann: Die Summe „Colligite Fragmenta“ des Magisters Hubertus (Clm 28799), München 1974 (Veröffentlichungen des Grabmann-Instituts 24). 
er häufig als delegierter Richter eingesetzt ${ }^{40}$. - Nicht eigentlich als schöpferischer Schriftsteller, sondern als kompilierender Kanonist ist Petrus Collivaccinus aus Benevent anzusehen, der als päpstlicher Subdiakon und Notar von Innozenz III. im Jahre 1209 den Auftrag erhielt, ältere Dekretalensammlungen durch eine „authentische“, aus den Papstregistern geschöpfte Sammlung zu ersetzen. Die "Compilatio Tertia» war bis zur Promulgation des «Liber Extra» im Jahr 1234 weit verbreitet. Dem 1212 zum KD von S. Maria in Aquiro erhobenen, später zum KP von S. Damaso und schließlich zum KB von Sabina († 1219/20) promovierten Petrus wurden aber auch andere Werke zugeschrieben: die «Summa Reginensis», ein Bologneser Kommentar zum «Decretum», der von Huguccio beeinflußt ist, und gar die Biographie Innozenz' III., die "Gesta Innocentii papae III», aber der schlüssige Beweis blieb bisher noch aus ${ }^{41}$.

\section{Die Urkunden der Kardinäle als Legaten}

Stefan Weiß hat das Thema in seiner 1995 veröffentlichten Dissertation vorzüglich abgehandelt, so daß hier eine knappe Zusammenfassung des von ihm Erarbeiteten genügen möge ${ }^{42}$. Seine Erkenntnisse beruhen auf etwa 600 Legatenurkunden, von denen nur ein winziger Teil nicht von den über 100 Kardinälen stammt, die mit der Vertretung der Päpste in allen Teilen der Christenheit zwischen der Mitte des 11. und dem Ende des zwölften Jahrhunderts betraut wurden. Seine Schlüsse lassen sich ohneweiters auf die nach 1198 folgenden Pontifikate extrapolieren, wobei der Unterschied nur in der Menge des überlieferten Materials besteht. Die Monographie von Nicolas Vincent über den Kardinal Guala Bicchieri, der in Frankreich 1208/09 und in England 1216/19 wirkte, beruht auf fast 190 von ihm ausgestellten Dokumenten ${ }^{43}$, jene von Falko Neininger, der sich Konrad von Urach und besonders seine Legationen nach Frankreich 1217/24 und anschließend in Deutschland 1224/26 vornahm, auf

40 Maleczek: Papst (wie Anm. 35) S. 175-179; Ders.: Kardinalskollegium (wie Anm. 35) S. 157 f. - Ausführlich auch John W. Baldwin: Masters, Princes and Merchants. The Social Views of Peter the Chanter and His Circle, 2 Bde., Princeton 1970, hier Bd. 1 S. 19-25, Bd. 2 S. 9-15.

41 MaleczeK: Papst (wie Anm. 35) S. 172-174; Ders.: Kardinalskollegium (wie Anm. 35) S. 156 f. - Vgl. Rudolf Weigand: Frühe Kanonisten und ihre Karriere in der Kirche, in: ZRGkanAbt 76 (1990) S. 135-155, hier S. 151. Eine komplette Edition fehlt, eine größere Anzahl von Texten bei Alfons M. STICKLER: Decretisti bolognesi dimenticati, in: SG 3 (1955) S. 375-410, hier S. 391-407. - James M. Powell: Innocent III and Petrus Beneventanus: Reconstructing a Career at the Papal Curia, in: Pope Innocent III and his World, hg. v. John C. Moore, Aldershot 1999, S. 51-62.

42 WeIss.

43 Nicolas Vincent: The Letters and Charters of Cardinal Guala Bicchieri, Papal Legate in England 1216-1218, Woodbridge 1996 (The Canterbury and York Society 83). 
über 160 Legatenurkunden ${ }^{44}$. Überliefert sind Legatenurkunden als Originale oder als Kopien, zumeist in Chartularen jener Institutionen, für die sie ausgestellt wurden. Eigene Legatenregister gibt es erst seit dem 13. Jahrhundert, das früheste von Hugolin, dem späteren Papst Gregor IX., aus den Jahren seiner Oberitalien-Legation der Jahre 1217 bis 1221, das nächste von Ottaviano degli Ubaldini, päpstlicher Legat in der Lombardei von 1247 bis $1251^{45}$. Aus dem 14. Jahrhundert kennt man schon ein eigenes Formularbuch für Legatenurkunden, das Gentile da Montefiore auf seine Legation nach Ungarn 1307/11 mitnahm ${ }^{46}$. Generell kann man sagen, daß sich die Legatenurkunde an der Papsturkunde orientiert, zunächst hinsichtlich der inneren Merkmale. Ab 1124 finden sich dann auch Stücke, die in der Schrift der päpstlichen Kanzlei mundiert sind. Spätestens ab diesem Zeitpunkt wurden Legaten also von Schreibern begleitet, die in der päpstlichen Kanzlei arbeiteten oder mit ihr irgendwie in Beziehung standen. ${ }^{47}$ Die Beeinflussung wird auch dadurch deutlich, daß nicht wenige Kardinallegaten später als Kanzler oder Vizekanzler Vorsteher dieser Institution wurden. Dies gilt beispielsweise für Gerhard von S. Croce, den späteren Papst Lucius II. (1144-1145), oder für Albert von Morra, den späteren Papst Gregor VIII. (1187). Es ist jedoch für den Bereich der Legatenurkunde festzuhalten, was für das gesamte hochmittelalterliche Urkundenwesen gilt: Die Initiative für die Ausstellung der Urkunde lag zumeist

44 Falko Neininger: Konrad von Urach († 1227). Zähringer, Zisterzienser, Kardinallegat, Paderborn 1994 (Quellen und Forschungen aus dem Gebiet der Geschichte NF 17).

45 Registri dei cardinali Ugolino d'Ostia e Ottaviano degli Ubaldini, ed. Guido Levi, Rom 1890 (FSI 8), vgl. DERs.: Documenti ad illustrazione del registro del cardinale Ugolino d'Ostia legato apostolico in Toscana e Lombardia, in: ASRSP 12 (1889) S. 5-90; Christine Thouzellier: La légation en Lombardie du cardinal Hugolin (1221), in: RHE 45 (1950) S. 508-542; Maleczek: Papst (wie Anm. 35) S. 130 f.; Ders.: Kardinalskollegium (wie Anm. 35) S. 142-146. - Guido Levi: Il cardinale Ottaviano degli Ubaldini secondo il suo carteggio, in: ASRSP 14 (1891) S. 231-303; Agostino PAravicini Bagliani: Cardinali di Curia e "Familiae“ cardinalizie dal 1227 al 1254, 2 Bde., Padua 1972 (Italia Sacra 18-19), hier Bd. 1 S. 282-299; vgl. Ders.: Il „Registrum causarum" di Ottaviano Ubaldini e l'amministrazione della giustizia alle Curia Romana nel secolo XIII, in: Römische Kurie. Kirchliche Finanzen. Vatikanisches Archiv. Studien zu Ehren von Hermann Hoberg, hg. v. Erwin Gatz, Bd. 2, Rom 1979 (Miscellanea Historiae Pontificiae 46), S. 635-657; Thérèse Boespflug-Montecchi: Aspects de la justice pontificale au XIII ${ }^{\mathrm{e}}$ siècle: l'audience cardinalice d'Ottaviano Ubaldini (12561266), in: L'écrit dans la société médiévale. Textes en hommage de Lucie Fossier, ed. Caroline Bourlet/Annie Dufour, Paris 1991, S. 139-149. - Hinzuweisen ist auch auf das Register des Guy Foucois, des späteren Papstes Clemens' IV., das er über seine Legation nach England in den Jahren 1263-1264 anlegte, Joseph Heidemann: Papst Clemens IV., 1. Bd.: Das Vorleben des Papstes und sein Legationsregister, Münster 1903 (Kirchengeschichtliche Studien 6, 4), S. 194-248.

46 Acta legationis cardinalis Gentilis, ed. Anton Pór, Budapest 1885 (Monumenta Vaticana historiam regni Hungariae illustrantia 1/2).

47 Weiss S. $328 \mathrm{ff}$. 
beim Empfänger, der sich umstrittene Rechte sichern wollte. Dadurch läßt sich erklären, daß bis ins frühe 13. Jahrhundert Fremdausfertigungen vorkamen.

Aus der zweiten Hälfte des 11. Jahrhunderts sind nur gute zwei Dutzend Legatenurkunden überliefert. Dieser neue Typus des Schriftgutes der Kardinäle entstand überwiegend im Zusammenhang mit den von den Legaten abgehaltenen Konzilen. Dabei verbrieften sie allmählich auch spezielle Vorrechte für einzelne geistliche Institutionen oder ließen Gerichtsurkunden über die von ihnen geleiteten Prozesse ausfertigen. Als frühes Beispiel sei jene Urkunde des KB Gerald von Ostia genannt, die er auf der Synode von Poitiers im Januar 1075 für Sainte-Radegonde ausstellte und die ausdrücklich auf einen Beschluß dieser Kirchenversammlung Bezug nahm ${ }^{48}$. Dieser Kardinal stellte übrigens zwei Jahre vorher auf einer ersten Legation nach Frankreich die erste LegatenSchutzurkunde für ein Kloster überhaupt aus und verwendete dabei die später allgemein übliche Form der Intitulatio, die den Namen des Legaten, den Kardinalstitel und die Formel apostolice sedis legatus enthiel ${ }^{49}$. Den entscheidenden Wendepunkt in der Entwicklung der Legatenurkunde brachte der Pontifikat Paschalis' II. Ihre Zahl steigt sprunghaft an, was wohl damit zu erklären ist, daß einige prominente Kardinäle die Errungenschaften der Kirchenreform europaweit zu festigen suchten und auf diese Weise die Schwäche und den Prestigeverlust des Papstes ausglichen. Seit dieser Zeit ist die Legatenurkunde fest etabliert und nimmt zahlenmäßig kontinuierlich zu. Einen neuerlichen Einschnitt bei ihrer Entwicklung bringt die erste Reise des Kardinals Hyazinth, des späteren Papstes Cölestins III., nach Spanien in den Jahren 1154/55. Seit damals gleicht sich die Legatenurkunde noch stärker an das Formular der Papsturkunde an. In quantitativer und qualitativer Hinsicht ist diese Legation und die nächste der Jahre 1171-1174 ein Höhepunkt. Über 40 überlieferte Stücke, von denen noch 17 im Original erhalten sind, belegen eindrucksvoll die weitgespannte päpstliche Autorität und ihren indirekten schriftlichen Niederschlag ${ }^{50}$. Hyazinth führt bis zum Ende des 12. Jahrhunderts übrigens auch absolut in der Zahl der überlieferten Legatenurkunden. $\mathrm{Zu}$ den oben genannten sind noch fünf weitere zu zählen, die er als Zweitaussteller zusammen mit Heinrich von Pisa ausfertigen ließ ${ }^{51}$. Weit dahinter steht Petrus von Pavia mit 30 Stücken aus zwei Legationen (1174-78 und $1179-82)^{52}$. Das zahlenmäßige Hochschnellen der Legatenur-

48 Pierre de Montsabert: Documents inédits pour servir à l'histoire de Sainte-Croix de Poitiers, in: RevMab 9 (1913/14) S. 50-88, hier 60 Nr. 3; die richtige Datierung nach Schieffer S. 87; Vgl. Weiss S. 28 Nr. 2.

49 Cartulaire di prieuré de Saint-Mont, ed. Jean de Jaurgain, Paris 1904 (Archives historiques de la Gascogne 15/2/7), S. 12 Nr. 6, datiert nach Schieffer S. 84 Anm. 18; vgl. WeIss S. 28 Nr. 1.

50 WeIss S. 173-203.

51 Ebd. S. $221 \mathrm{f}$.

52 Ebd. S. 254-265. 
kunden seit dem Pontifikat Innozenz' III. wurde schon angedeutet. - Die geographische Verbreitung der Legatenurkunde entspricht dem Befund bezüglich der Papsturkunde, d. h. Frankreich führt bei weitem. Relativ wenige gibt es aus England und dem normannischen Königreich in Süditalien, jene aus den anderen europäischen Ländern - Spanien, Deutschland, Oberitalien schwanken je nach politischem Einfluß des Papsttums. In den Randlagen Osteuropa, Skandinavien, Heiliges Land - sind nur vereinzelt Stücke entstanden.

Die erhaltenen Originale setzen erst zu Beginn des 12. Jahrhunderts ein ${ }^{53}$. Tendenziell nimmt die Zahl der Legatenurkunden zu, die in der kurialen Minuskel - wohl von in der päpstlichen Kanzlei geübten Schreibern mundiert gehalten sind, aber bis weit ins 13. Jahrhundert hinein sind auch örtliche Schreiber am Werk. Die Form der Beglaubigung liegt während des gesamten 12. Jahrhunderts nicht fest. Die schon bisher verwendete Unterschrift - mit oder ohne signum, zumeist einem Kreuz - wird im Laufe der Jahrzehnte spärlicher. Das Notariatsinstrument mit seinen spezifischen Beglaubigungsregeln wird überwiegend in jenen Gebieten verwendet, wo es sich seit dem Frühmittelalter ausgebreitet hatte, also im wesentlichen in Italien und im südlichen Frankreich. Vereinzelt werden Chirographen verwendet. Der erste Kardinal, der ein Siegel an seine auf drei Legationsreisen nach Frankreich ausgestellten Urkunden mit einem Pergamentstreifen hängte, war Richard, KB von Albano 1101-1114/ $15^{54}$. Die Übernahme des Siegelbrauches läßt sich unschwer erklären, weil die Urkundenempfänger in jenen Regionen zuhause waren, wo diese Form der Beglaubigung weit verbreitet war und sich auch bei Bischofsurkunden durchgesetzt hatte. Im Laufe des 12. Jahrhunderts ließen sich allmählich alle Kardinäle Siegel anfertigen. Während früher die Kardinäle die Wahl des Beglaubigungsmittels vom Usus abhängen ließen, der im Sprengel ihrer Legation vorherrschte, wird die Besiegelung in kontinuierlich steigendem Ausmaß vorgezogen. Die Form der Siegel wechselt bald vom Rundsiegel zum spitzovalen Siegel. Im Laufe des 13. Jahrhunderts ändert sich daran nichts mehr, sieht man von der künstlerischen Verfeinerung ab.

Eine Beschreibung der inneren Merkmale der Legatenurkunden - hier vergröbert und vereinfacht - ist erst seit der zunehmenden Formalisierung unter Paschalis II. sinnvoll. Die Urkunden enthalten immer eine Bevollmächtigungsformel, die in kurzen Stücken meist auf ein kurzes apostolica autoritate

53 Die ältesten sicheren Originale: Bernhard Uberti, KP von S. Grisogono und Abt von Vallombrosa, 1101-1106; WeIss S. 41-43. Unsicher, ob es sich um ein Original oder um eine zeitgenössische Kopie handelt: Richard, KB und Abt von St. Victor in Marseille, 1084, ebd. S. 32 Nr. 1.

54 Werner Maleczek: Die Siegel der Kardinäle. Von den Anfängen bis zum Beginn des 13. Jahrhunderts, in: MIÖG 112 (2004) S. 177-203, hier: 181. Leider sind heute alle erhaltenen fünf Originale (von insgesamt 28 Texten) ohne Siegel überliefert. 
reduziert ist, dem ein qua fungimur beigefügt sein kann. Neben der Bevollmächtigungsfomel wird die Autorisierung durch den Papst in der Intitulatio deutlich, die neben dem Namen den Kardinalstitel und apostolice sedis legatus enthält. Die im Dativ gehaltene Inscriptio ist entweder allgemein formuliert oder an einen bestimmten Adressaten gerichtet, von dem der Name, Titel und Institution, der er angehört, genannt werden. Bei der Grußformel können viele Varianten vorkommen. Vereinzelt gibt es auch Arengen. Die Dispositio lehnt sich an die entsprechenden Formeln der päpstlichen Mandate an, etwa fraternitati vestre precipientes rogamus, oder precipimus itaque et precipiendo mandamus. In die Dispositio ist oft eine Strafandrohung, meist eine Suspension- oder Exkommunikationsandrohung integriert, während eine eigentliche Poenformel selten ist. Seit der Mitte des 12. Jahrhunderts setzt sich allmählich die Form der kleinen sanctio aus der Papsturkunde durch (Nulli ergo omnino ... Si qua igitur ...). Die Datierung ist in der Regel einfach gehalten, wenn überhaupt eine vorkommt. In der Entwicklung der von Legaten ausgestellten Gerichtsurkunden bemerkt man anfangs eine weitgehende Anpassung an die Formen der Konzilsakte. Sie sind objektiv ausgestellt, ihr Formenapparat besteht meist ausschließlich aus einer langen Narratio, in welcher der Ablauf des Prozesses und das Urteil des Konzils dargelegt werden, wobei die leitende Stellung des Legaten unterstrichen wird. Allmählich verändert sich das Formular, das Stück wird subjektiv gefaßt, der Legat nennt sich in der Intitulatio als Aussteller und der Prozeßverlauf wird als eine Narratio dargestellt. Seit der Mitte des 12. Jahrhunderts verlieren die Gerichtsurkunden der Legaten ihren besonderen Charakter überhaupt und das Formular gleicht sich dem der oben beschriebenen Litterae an.

Von der inhaltlichen Seit her gesehen betreffen die Legatenurkunden die Bestätigung von Rechten, größtenteils stehen sie jedoch im Zusammenhang mit der Schlichtung von Streitigkeiten zwischen kirchlichen Institutionen. Die Legaten nehmen dabei den Platz des obersten päpstlichen Richters ein und überspielen damit die bischöfliche Jurisdiktion, was auch dadurch gefördert wurde, daß zahlreiche exemte Klöster und später Ordensverbände in direkter Abhängigkeit vom apostolischen Stuhl standen. Somit ist die wachsende Verbreitung der Legatenurkunde ein Ausdruck der zunehmenden päpstlichen plenitudo potestatis und ihrer Umsetzung in der gesamten Christenheit.

\section{Briefe der Kardinäle}

Mit Briefen sind hier jene Schriftstücke gemeint, die eher der persönlichen Mitteilung dienten, sich eines ausgeprägt individuellen Stils befleißigten, ein Minimum an formalen Teilen wie Absender und Empfänger, eine Grußformel zu Beginn, Narratio und Petitio und eine Grußformel als Briefschluß enthielten. 
Bei dieser Definition möge mitbedacht werden, daß der Brief und besonders der in Sammlungen überlieferte Brief seit der Antike auch ein literarisches Genus war, das entwickelten Regeln folgte, und daß der mittelalterliche Brief in dieser Tradition stand. Ebenso möge berücksichtigt werden, daß die Grenzen zwischen privatem Brief und amtlichem Schreiben fließend sind. Deshalb wird hier die diplomatische Korrespondenz, d.h. die schriftliche Verbindung zwischen den (Kardinal-)Legaten und der kurialen Zentrale der Kategorie der Briefe zugeordnet. Des weiteren möge festgehalten werden, daß die saubere Scheidung zwischen Brief und Urkunde nicht möglich ist, und daß Briefe sowohl mit literarischer Absicht und entsprechendem Stil für eine weitere Verbreitung als auch mit dem Verlangen nach schlichter Mitteilung formuliert wurden.

Briefe von Kardinälen sind vom 11. zum 13. Jahrhundert in geringer Zahl als Originale erhalten. Dies entspricht insgesamt der Seltenheit von original erhaltenen Briefen aus dem Früh- und Hochmittelalter ${ }^{55}$. Das älteste im Original erhaltene Schreiben eines Legaten an seinen Papst stammt von Petrus Pisanus, KP von S. Stefano, aus dem Jahr 1118. Darin teilte er Gelasius II. in Beantwortung von dessen - verlorenem - Schreiben verschiedene Angelegenheiten seiner Legation in seine Heimatstadt mit ${ }^{56}$. Das nächste Beispiel betrifft eine Reihe von recht kleinformatigen Schreiben aus dem Jahr 1144, die im Kapitelarchiv von S. Ambrogio in Mailand aufbewahrt werden und sich auf den nicht endenwollenden Streit zwischen den Kanonikern und Mönchen um Oblationen und einen Glockenturm beziehen. Neben einem Brief des Goizo, $\mathrm{KP}$ von S. Prassede, an den Abt und einer Mitteilung des anderen Legaten, Hubald, KP von S. Prassede, an den Erzbischof von Mailand ist besonders das Schreiben beider Kardinäle an Papst Lucius II. hervorzuheben, in dem sie ihm die gefällte Entscheidung mitteilen und um die Bestätigung bitten. Obwohl der Brief unzweifelbar seinen Adressaten erreichte - in einer Papsturkunde wird darauf angespielt -, liegt er eigentlich im falschen Archiv. Dies läßt sich wohl so erklären, daß die beiden Legaten ihren Brief dem Propst von S. Ambrogio übergaben, der ihn der päpstlichen Kanzlei vorlegte oder vorlegen ließ und dort zusammen mit der impetrierten Papsturkunde und anderen Schriftstücken zurückerhielt ${ }^{57}$. Eine Sonderstellung nimmt der im Original im Kapitelarchiv von

55 Eine Zusammenstellung der original erhaltenen Briefe: Wolfgang PetKe: Reimser Urkunden- und Siegelfälschungen des 12. und 13. Jahrhunderts für Priorat und Pfarrei Meerssen. Mit einem Originalbrief von 1136, in: Papsturkundenforschung und Historie. Aus der Germania Pontificia Halberstadt und Lüttich, Köln 2008 (Studien und Vorarbeiten zur Germania Pontificia 9) S. 129-276, hier: S. 205 f.

56 Raffaello Volpini: I resti dell' „archivio“ di Gelasio II, in: Lateranum 52 (1986) S. 215 264, hier 259 Nr. 4, mit Faksimile S. 256 f.; Weiss S. 79 Nr. 1.

57 Walter Wache: Eine Sammlung von Originalbriefen des 12. Jahrhunderts im Kapitelarchiv von S. Ambrogio in Mailand, in: MIÖG 50 (1936) S. 261-333; WeIsS S. $149-151$. 
Split (Kroatien) liegende Brief des Petrus de Mizo, KD von S. Eustachio, von 1160 ein, mit dem er den an der Kurie weilenden KB Bernhard von Porto bat, sich bei Alexander III. für die Kirche von Split zu verwenden, und ihm von der Position des Erzbischofs von Zara im Schisma berichtete ${ }^{58}$. Aus dem frühen 13. Jahrhundert stammt eine Reihe von originalen Kardinalsbriefen an den englischen König und andere Würdenträger des Hofes, die im Public Record Office bei der diplomatischen Korrespondenz aufbewahrt werden ${ }^{59}$.

Die schriftliche Verbindung eines Legaten zum Papst ist seit dem späten 11. Jahrhundert immer wieder belegt, wobei die Grenzen zwischen Gesandtschaftsbericht und Brief verschwimmen. Es muß aber gleich festgehalten werden, daß das Erhaltene und hier wohl annähernd vollständig Präsentierte nur einen winzigen Rest des intensiven Briefwechsels zwischen den Legaten und der römischen Kurie darstellt. Verlorene Briefe sind in großer Zahl in den Papsturkunden erwähnt. Bei diesen Schreiben handelt es sich entweder um Suppliken, mit denen die Legaten geistliche Institutionen oder Personen ihres Sprengels zu fördern suchten, oder um Berichte an ihren päpstlichen Auftraggeber. Im Februar 1080 berichtete Petrus, KB von Albano, in einer Art zusammenfassendem Schreiben über seine Maßnahmen zugunsten Clunys, welches wohl von Vertretern der burgundischen Abtei dem Papst auf der Lateransynode ein Monat später vorgelegt wurde ${ }^{60}$. Signifikante Berichte wurden in das päpstliche Register eingetragen, wie etwa jener des nach Katalonien entsandten Rainer, KP von S. Clemente, in dem er 1090 den Streit des Bischofs von Barcelona mit dem Abt von Thomières darlegte ${ }^{61}$. Johannes von S. Anastasia und Benedikt von S. Pudenziana, von Paschalis II. im Jahre 1100 nach Frankreich geschickt, baten gemeinsam den Papst, den Mönchen von Cîteaux ein Privileg auszustellen ${ }^{62}$. Der als Legat in Frankreich und Deutschland vielbeschäftigte KB Richard von Albano setzte sich brieflich im Jahr 1107 bei

58 Codex diplomaticus regni Croatiae, Dalmatiae et Slavoniae, Bd. 2: 1101-1200, ed. Tade Smičiklas, Zagreb 1904, S. 340 Nr. 316 (die dortige Datierung „1199-1200“ ist korrigiert von Werner Ohnsorge: Die Legaten Alexanders III. im ersten Jahrzehnt seines Pontifikats (1159-1169), Berlin 1928 [Historische Studien 175], S. 110). Vgl. WEISS S. 240 Nr. 1.

59 Diplomatic documents preserved in the Public Record Office, Bd. 1: 1101-1272, ed. Pierre Chaplais, London 1964, S. 24 Nr. 10, S. 27 Nr. 17, S. 28 Nr. 18, S. 31 Nr. 23 , S. 33 Nr. 26, S. 34 Nr. 27, S. 38 Nr. 34, S. 83 Nr. 117 f., S. 94 Nr. 139 usw.

60 Bouquet 14 S. 47; Herbert Eduard John Cowdrey: Cardinal Peter of Albano's legatine journey to Cluny (1080), in: JTS 24 (1973) S. 481-491, hier S. 487; SCHIEFFER S. 120 ff.; WeIss S. 31 Nr. 3.

61 Paul Fridolin KeHR: Papsturkunden in Spanien 1: Katalanien, Berlin 1926 (AGG, phil.hist. Kl., N. F. 18/2), S. 279 Nr. 18; vgl. Weiss S. 35 Nr. 1. - Zusatz bei der Überlieferung: Hoc est in quadam cedula consuta in regestro Urbani secundi.

62 Bouquet 14 S. 112; vgl. Schieffer S. 163 ff.; Hüls S. 146; Weiss S. 38 Nr. 1. 
Paschalis II. für Orange gegen den Bischof von St-Paul-Trois-Châteaux ein ${ }^{63}$. Boso, KP von S. Anastasia, berichtete im Jahre 1117 ebenfalls an Paschalis II. über eine auf dem Provinzialkonzil von Burgos getroffene Entscheidung bezüglich der Diözesaneinteilung von Portugal ${ }^{64}$. KB Matthäus von Albano berichtete in Beantwortung eines Schreibens Honorius' II. auch über das Konzil von Reims im Jahre 1128 und legte ihm einen Streitfall zur Entscheidung vor ${ }^{65}$. Von seiner dritten Legation nach Deutschland schickte Dietwin, KB von S. Rufina, im Jahr 1141 einen Brief an Innozenz II., in dem er ihn bat, das von Bischof Otto von Bamberg für die Bamberger Kirche erworbene Kloster Münchsmünster in den päpstlichen Schutz zu nehmen ${ }^{66}$. Mehr den Charakter eines Legatenberichtes weist der Brief des KD Guido auf, in dem er Papst Lucius II. über seine Reise nach Böhmen-Mähren und besonders über seine Versuche zur Hebung der Kirchenzucht informierte ${ }^{67}$. Von der schon erwähnten Legation des Hyazinth von S. Maria in Cosmedin stammt ein Brief an Papst Anastasius IV. vom Frühjahr 1155, der im Kathedralarchiv von Palencia kopial überliefert ist. Es ist ein Bericht über den Streit des dortigen Bischofs mit dem Kapitel von Santa Maria de Valladolid ${ }^{68}$. Ein anderer, an Hadrian IV. adressierter Brief vom Mai 1155 berichtet von der Klage des Bischofs von Calahorra gegen die Cluniazenser in Santa Maria de Nájera und schließt mit der Bitte, den Prozeß vor das kuriale Gericht zu ziehen ${ }^{69}$. Auffallend ist das Dossier von 16

63 Gallia Christiana Novissima 6: Orange, ed. Ulysse Chevalier, Marseille 1916, S. 37 Nr. 65. Vgl. Schieffer S. 178 ff; Hüls S. 93-95; Weiss S. 46 Nr. 7.

64 Carl Erdmann: Papsturkunden in Portugal, Berlin 1927 (AGG, phil.-hist. Kl, N. F. 20/ 3), S. 171 Nr. 18. Vgl. HüLs S. $147-149$; Weiss S. 71 Nr. 4. - Der Papst hatte selbst den Bericht durch einen Brief an die spanischen Bischöfe angefordert, JL 6527.

65 Bouquet 15 S. 266 f. Nr. 21 u. 22; vgl. Schieffer S. 230; Lucchesius Spätling: Kardinallegat Petrus im Pontifikat Honorius' II., in: Antonianum 38 (1963) S. 162-192, hier 183 f.; WeIss S. 108 Nr. 3.

66 Matthias Thiel/Odilo Engels: Die Traditionen, Urkunden und Urbare des Klosters Münchsmünster, München 1961 (Quellen und Erörterungen zur bayerischen Geschichte NF 20), S. 98 Nr. 7; GP 1 S. 312 Nr. 5; vgl. WeIss S. 127 Nr. 6.

67 Der Brief ist auf September/Oktober 1143 zu datieren, ed. Gustav Friedrich: Codex diplomaticus et epistolaris regni Bohemiae, Bd. 1, Prag 1904, S. 136 Nr. 135. Verbesserte Edition bei Jan BistřickÝ: Studien zum Urkunden-, Brief- und Handschriftenwesen des Bischofs Heinrich Zdík von Olmütz, in: ADipl 26 (1980) S. 135-258, hier S. 236 f. Nr. 9. Zu dieser Legation vgl. Lucchesius SpätLING: Kardinal Guido und seine Legation in Böhmen-Mähren (1142-1146), in: MIÖG 66 (1958) S. 306-330; Peter Hilsch: Die Bischöfe von Prag in der frühen Stauferzeit. Ihre Stellung zwischen Reichsund Landesgewalt von Daniel I. (1148-1167) bis Heinrich (1182-1197), München 1969 (Veröffentlichungen des Collegium Carolinum 22), S. 40-51, 234-237.

68 Documentación de la catedral de Palencia (1035-1247), ed. Teresa Abajo Martín, Burgos/Salamanca 1986 (Fuentes medievales Castellano-Leonesas 103), S. 110 Nr. 51. Vgl. Weiss S. 179 Nr. 15.

69 Ed. Paul Fridolin KeHr: Papsturkunden in Spanien 2: Navarra und Aragon, Berlin 1928 (AGG, phil.-hist. Kl., N. F. 22/1), S. 392 Nr. 77. Vgl. Weiss S. 180 Nr. 20. 
Briefen, das aus dem Besitz des Petrus Iterius, KP von S. Grisogono, stammt, der 1174-1178 nach Frankreich gesandt wurde. Es steht am Beginn der umfangreichen Briefsammlung von St. Viktor, von der gleich noch die Rede sein wird. Die meisten Schreiben gehen vom Papst aus, aber eines davon aus dem Sommer 1178 stammt aus der Feder des Kardinals und enthält eine Liste von geeigneten Kandidaten für das Kardinalsamt, um die Alexander III. seinen Legaten gebeten hatte. Elf Männer schlug Petrus vor, fünf Äbte, einen Prior, vier gebildete Magistri, darunter Petrus Manducator und Gerardus Pucella, und einen Archidiakon. Ferner berichtete er von seinen Maßnahmen zu den Deposita des verstorbenen Bischofs von Porto ${ }^{70}$. In der umfangreichen Materialsammlung zum Streit um Thomas Becket sind einige weitere Stücke überliefert: Der Bericht der beiden Legaten Wilhelm von Pavia, KP von S. Pietro in Vincoli, und des Odo, KD von S. Nicola in Carcere Tulliano, vom Spätherbst 1167 an den Papst über ihre Zusammenkunft mit Thomas Becket und König Heinrich II. bei Gisors; die Empfehlung des Londoner Bischofs Gilbert Foliot an Alexander III. im Jahre 1167/68 durch den genannten Wilhelm von Pavia; eine weitere Empfehlung des Londoner Bischofs aus derselben Zeit durch den genannten Odo; der spätere KD von S. Nicola in Carcere Tulliano, Vivianus, berichtete zweimal knapp hintereinander 1169 über seine Legation nach England und sein Zusammentreffen mit dem König und die fehlgeschlagenen Verhandlungen mit dem Erzbischof ${ }^{71}$. In der Briefsammlung, die der Vita des Gilbert von Sempringham beigefügt ist, findet sich der Bericht des Hugo Pierleone, KD von S. Angelo, den er zu Beginn des Jahres 1176 an Alexander III. über die Ordnung des Magisters in seiner geistlichen Institution und über dessen Schwierigkeiten sandte ${ }^{72}$. Konrad von Wittelsbach, der als Mainzer Erzbischof (1161-1177) gleichzeitig KP von S. Marcello (1165) und wenig später KB von Sabina (1166) war, fungierte wiederholt als Legat in Deutschland. 1176/77 bat er Alexander III. um die Bestätigung einer Urkunde zugunsten des Benediktinerklosters Garsten ${ }^{73}$. In die Chronik des Magnus von Reichersberg inseriert ist ein Schreiben des nach Ungarn und Deutschland

70 Palémon Glorieux: Candidats à la pourpre en 1178, in: Mélanges de science religieuse 11 (1954) S. 5-30; Gunnar Teske: Die Briefsammlungen des 12. Jahrhunderts in St. Viktor/Paris. Entstehung, Überlieferung und Bedeutung für die Geschichte der Abtei, Bonn 1993 (Studien und Dokumente zur Gallia Pontificia 2), S. $191 \mathrm{f}$.

71 Materials for the History of Thomas Becket, Bd. 6, ed. James C. Robertson, London 1882 (RS 67/6), S. 280-284, 326 f. Nr. 342, 362 f.; Bd. 7, London 1885 (RS 67/7), S. 78-82, 167-169 Nr. 563, 607. Vgl. Weiss S. 216 Nr. 23, S. 235 Nr. 18, 20.

72 Walther Holtzmann: Papsturkunden in England 3: Oxford, Cambridge, kleinere Bibliotheken und Archive und Nachträge aus London, Göttingen 1952 (AGG, phil.-hist. Kl., N. F. 33), S. 361 Nr. 231; Weiss S. 265 f. Nr. 1.

73 Mainzer Urkundenbuch, ed. Peter Aснт, Bd. 2, Darmstadt 1968-1971, S. 629 Nr. 381; GP 4 S. 175 Nr. 417; WeIss S. 246 Nr. 6. 
entsandten KB Walter von Albano von 1176, in dem er dem Papst einige Begebenheiten von seinem Aufenthalt in Ungarn mitteilte ${ }^{74}$.

Unter Innozenz III. wird wegen der Registerüberlieferung die Zahl der erhaltenen Legatenberichte etwas größer. Im Thronstreitregister finden sich etwa die beiden Berichte des KB Guido von Preneste aus dem Sommer 1201 über seine Tätigkeit in Deutschland und des KB Hugolin aus dem Jahr 1208 über sein Wirken in Deutschland und über die Ermordung Philipps von Schwaben ${ }^{75}$. Im Hauptregister hingegen steht der Bericht des KB Oktavian von Ostia über sein Wirken in Frankreich im Jahre $1200^{76}$. Der Bericht der beiden Kreuzzugslegaten aus Akkon aus dem Jahre 1204 fand den Weg in die "Gesta Innocentii» ${ }^{77}$, ein Bericht des Gerhard, KD von S. Adriano, Legat im Königreich Sizilien, aus dem Jahre 1201 wurde in die Capuaner Briefsammlung kopiert ${ }^{78}$. Als Original erhalten und bis heute im päpstlichen Archiv aufbewahrt ist der Bericht des nach England entsandten Nikolaus, KB von Tusculum, an Papst Innozenz III. aus dem Jahr 1215. Er war über den Kanal gesandt worden, um nach dem großen Interdikt die kirchlichen Verhältnisse wieder zu ordnen ${ }^{79}$. Aber dieser Usus wurde nicht fortgesetzt. Legatenberichte wurden im 13. Jahrhundert nicht mehr registriert und auch im 14. Jahrhundert verzichteten die Registratoren des avignonensischen Papsttums fast völlig auf Eintragungen von Dokumenten, die an die Kurie gelangten.

Sehr viel zahlreicher sind die Briefe von Kardinälen an andere geistliche vereinzelt auch weltliche - Empfänger, wobei zwei Überlieferungsgruppen herausragen. Zum einen ist dies die Publizistik der Reformzeit und des Investiturstreites, zum anderen sind dies die Briefsammlungen des späten 11. und 12. Jahrhunderts. Überschneidungen dieser Überlieferungsgruppen sind

74 Magni presbyteri Annales Reicherspergenses, ed. Wilhelm Wattenbach, in: MGH SS 17, Hannover 1861, S. 439-534, hier S. 501; GP 1 S. 37 Nr. *118; Weiss S. 267 Nr. 1.

75 Regestum Innocentii papae super negotio Romani imperii, hg. v. Friedrich KempF, Rom 1947 (Miscellanea Historiae Pontificiae 12), S. 136-139 Nr. 51, S. $347-349$ Nr. 152.

76 Innocentii III papae registrum liber III, in: Migne PL 214 Sp. 887-891, ursprünglich im dritten, großteils verlorenen Registerjahrgang, Br. 184.

77 Bericht des Petrus Capuanus, KP von S. Marcello, und des Soffred, KP von S. Prassede, vom Herbst 1204 in Gesta Innocentii III papae, Migne PL 214 cap. 118 Sp. CLI-CLIX, und in der Neuedition von David R. Gress-Wright: The "Gesta Innocentii“. Text, introduction and commentary, PhD Bryn Mawr College 1981, S. 294-302; dazu vgl. Maleczek: Petrus Capuanus (wie Anm. 37) S. $166 \mathrm{ff}$.

78 Karl Hampe: Mitteilungen aus der Capuaner Briefsammlung III: Der schlimme Bischof Gentilis von Aversa und sein Nachfolger, Heidelberg 1911 (SB Heidelberg 1911, 5), S. $17-20$.

79 Angelo Mercati: La prima relazione del cardinale Niccolò de Romanis sulla sua legazione in Inghilterra, in: Essays on history presented to Reginald Lane Poole, ed. Henry William Carless Davis, Freeport 1927, S. 274-289 (Wiederabdr. in: Ders.: Saggi di storia e letteratura, Bd. 2 [Storia e letteratura 157], Rom 1982, S. 175-186). 
selbstverständlich. Zur Verbreitung oder Verteidigung ihrer Ansichten griffen reformerisch gesinnte Kardinäle oft zur Feder, und sowohl beim Empfänger als auch beim Absender bewahrte man die Schriftstücke, die nicht selten Grundsätzliches enthalten, für die Nachwelt auf. Hier können freilich nur einzelne Beispiele angeführt werden. KB Odo von Ostia, der spätere Papst Urban II., berichtete in einem Rundschreiben über die Verhandlung zu Gerstungen-Berka vom Januar 1085, die er als päpstlicher Legat geleitet hatte und wo Gregorianer und Heinricianer ihre Argumente ausgetauscht hatten. Knapp danach suchte er Bischof Udo von Hildesheim, der in das Lager des Königs gewechselt war, durch einen verbindlichen Brief zur Umkehr zu bewegen ${ }^{80}$. Knapp vor der Jahrhundertwende wurde eine Sammlung in der Umgebung Wiberts-Clemens' III. zusammengestellt, die neben dem Traktat des Kardinals Beno «Gesta Romanae Ecclesiae contra Hildebrandum» eine Reihe von Briefen wibertinischer Kardinäle an unterschiedliche Empfänger enthält ${ }^{81}$. Einen aufschlußreichen Blick auf das geistige Niveau des Kardinalskollegiums, auf kanonistisches, theologisches und liturgisches Wissen in der Umgebung Paschalis' II., erlaubt der Brief des Albert von S. Sabina (zwischen 1096 und 1099) an den mit ihm befreundeten katalanischen Bischof Pontius von Roda und Barbastro, in dem er auf einige Anfragen antwortete und auf die Konsultation seiner Kollegen unter den Kardinälen hinwies ${ }^{82}$. Einer der engagiertesten Anhänger Paschalis' II., Johannes Marsicanus, KB von Tusculum, konnte sich der Gefangennahme durch Kaiser Heinrichs V. im Jahre 1111 gerade noch entziehen und berichtete seinem in Frankreich weilenden Kollegen Richard von Albano in einem - nicht sehr ausführlichen - Brief von den dramatischen Ereignissen rund um den

80 Aus der Sammlung der Regensburger Rhetorischen Briefe und aus der Hannoverschen Briefsammlung, in: Briefsammlungen der Zeit Heinrichs IV., hg. v. Carl Erdmann/ Nobert Fickermann, Weimar 1950 (MGH Epp DK 5), S. 375-380 Nr. 5; S. 25-27 Nr. 7; GP 4 S. 111 Nr. 179; GP 5/2 S. 37 Nr. *54, 55. Vgl. Alfons Becker: Papst Urban II. (1088-1099), Bd. 1, Stuttgart 1964 (MGH Schr. 19/1), S. 66-68; Jörgen VoGEL: Zur Kirchenpolitik Heinrichs IV. nach seiner Kaiserkrönung und zur Wirksamkeit der Legaten Gregors VII. und Clemens' (III.) im deutschen Reich 1084/85, in: FMASt 16 (1982) S. 161-192, hier: 172-177; Horst Funrmann: Pseudoisidor, Otto von Ostia (Urban II.) und der Zitatenkampf von Gerstungen (1085), in: ZRGromAbt 99 (1982) S. 52-69.

81 Benonis aliorumque cardinalium schismaticorum contra Gregorium VII. et Urbanum II. scripta, ed. Kuno Francke, in: MGH L. d. L. 2, Hannover 1892, S. S. 366-422. Vgl. Carl Mirbt: Die Publizistik im Zeitalter Gregors VII., Leipzig 1894, S. 59 ff.

82 Ed. Paul Fridolin Kenr: Das Papsttum und der katalanische Prinzipat bis zur Vereinigung mit Aragon, Berlin 1926 (AAB, phil.-hist. Kl. 1926/1), S. 81-84, mit S. 55 (Wiederabdr. in: Ders., Ausgewählte Schriften, hg. v. Rudolf Hiestand, Göttingen 2005 [AAG, phil-hist. Kl., 3. Folge 250], Bd. 2 S. 932-935, mit S. 906). Vgl. HüLS S. $203 \mathrm{f}$. 
Ponte Mammolo ${ }^{83}$. Vereinzelt finden sich Briefe von Kardinälen auch in chronikalischer Überlieferung. In der Historia Compostellana, der auf Veranlassung des ersten Erzbischofs von Santiago de Compostela, Diego Gelmirez, redigierten Geschichte seiner Diözese, sind mehrere Schreiben der nach Spanien geschickten Kardinallegaten Boso von S. Anastasia (1113-1122) und Deusdedit von S. Lorenzo in Damaso (1112-1129) an den Erzbischof überliefert. Besonders der jüngere der Kardinäle hatte ein ausgesprochen nahes Verhältnis zu Diego, was sich in Geschenken und in der Verleihung eines Kanonikates an der galicischen Apostelkirche niederschlug. Deusdedit informierte ihn über die Stimmung an der Kurie. ${ }^{84}$

Zwei Beispiele von einzeln überlieferten Kardinalsbriefen aus dem weiteren 12. Jahrhundert: Der Trostbrief des Matthäus von Albano an den Prior Guigo der Grande Chartreuse aus dem Jahr 1132, weil eine Lawine die Klostergebäude schwer beschädigt hatte, ist ein guter Beleg für die engen Kontakte, die zwischen der Kurie und dem extrem strengen, noch jungen Orden der Kartäuser bestanden. Der Brief ist in einer Sammlung von Texten aus der Frühzeit des Ordens überliefert ${ }^{85}$. Das zweite Exempel ist ein Schreiben Lothars von Segni, des späteren Innozenz' III., an Kaiser Heinrich VI., das auf der Rückseite einer Kopie eines Diploms König Arnulfs aus dem 12. Jahrhundert, die im Düsseldorfer Hauptstaatsarchiv liegt, abgeschrieben wurde ${ }^{86}$. Inhaltlich bietet der auf 1195/96 zu datierende Brief nicht viel. Er ist die Aufforderung an den Kaiser, sich in Anbetracht der von Gott verliehenen Wohltaten an die Verpflichtung zu erinnern, dankbar zu sein und Heiden und Ketzer zu bekämpfen. Wahrscheinlich handelt es sich um die Antwort auf einen Brief, den Heinrich VI. im März 1195 an einzelne Kardinäle geschickt hatte, um seinem Brief an Cöle-

83 Die handschriftliche Überlieferung ist unklar; es scheint sich um ein Einzelstück zu handeln, das Baronius edierte, von dort Migne PL 160 Sp. 1037-1040. Vgl. Repfont 6 (1990) S. 362; IP 2 S. 31 Nr. 2; Carlo Servatius: Paschalis II. (1099-1118). Studien zu seiner Person und zu seiner Politik, Stuttgart 1979 (Päpste und Papsttum 14), S. 234, 297 u. ö.; Stephan Freund: Art. Giovanni di Tuscolo, in: DBI 56 (2001) S. 244-247.

84 Historia Compostellana, II, 44.1; II, 44.3; II, 74.1; II, 74.2; II, 76.1; II, 76.2; ed. Emma Falque Rey, Turnhout 1988 (CChrCM 70), S. 295 f., 374 f., 376 f. Vgl. Ludwig Vones: Die „Historia Compostellana“ und die Kirchenpolitik des nordwestspanischen Raumes 1070-1130. Ein Beitrag zur Geschichte der Beziehungen zwischen Spanien und dem Papsttum zu Beginn des 12. Jahrhunderts, Köln (u.a.) 1980 (Kölner Histor. Abh. 29), S. 417, 468-471; Ingo FleisCH: Rom und die Iberische Halbinsel: das Personal der päpstlichen Legationen und Gesandtschaften im 12. Jahrhundert, in: Römisches Zentrum und kirchliche Peripherie. Das universale Papsttum als Bezugspunkt der Kirchen von den Reformpäpsten bis zu Innozenz III., hg.v. Jochen JohrEndt/ Harald MüLler, Berlin/New York 2008 (Neue AAG 2), S. 135-189, hier S. 144.

85 Heinrich RüThing: Ein Brief des Kardinals Matthäus von Albano an die Grande Chartreuse, in: RevBén 78 (1968) S. 145-151.

86 Werner Maleczen: Ein Brief des Kardinals Lothar von SS. Sergius und Bacchus (Innocenz III.) an Kaiser Heinrich VI., in: DA 38 (1982) S. 564-576. 
stin III. wegen der Wiederaufnahme der längere Zeit unterbrochenen Beziehungen größeres Gewicht zu verleihen.

Die große Masse der Kardinalsbriefe ist in Briefsammlungen überliefert, die gerade im 11. und 12. Jahrhundert ihre goldene Zeit erlebten. Ohne hier auf die Probleme der Entstehung und Überlieferung der Briefsammlungen dieser Zeit eingehen zu wollen - Fragen der Absicht, der Erreichbarkeit der Briefe aus verschiedenen Empfängerarchiven, der Auswahl, der Redaktion, der Zielgruppe, der Weiterverwendung und ähnliches sind oft diskutiert worden ${ }^{87}$-, sei festgehalten, daß es kaum eine Sammlung gibt, in der nicht Briefe an Kardinäle und von Kardinälen vorkommen. Dies spiegelt die große Bedeutung, die diese spiritales universalis ecclesie senatores ${ }^{88}$ (Petrus Damiani) erreicht hatten und die Fähigkeit einzelner von ihnen, gekonnt zu stilisieren. In den Sammlungen überwiegen jedoch die Briefe an Kardinäle. Bei Bernhard von Clairvaux sind es beispielsweise über 50 , mit denen er die päpstliche Politik zu beeinflussen suchte und - im modernen Jargon gesprochen - Lobbyismus betrieb, aber kein einziger der an ihn adressierten Briefe von Kardinälen fand seine Gnade ${ }^{89}$. Analoges gilt für einige weitere Sammlungen, die hier mehr aufgezählt als genauer vorgestellt werden: In der Sammlung der Briefe des Anselm von Canterbury (Abt von Le Bec 1078, Ebf. 1093-1109), die in mehreren Etappen schon zu seinen Lebzeiten

87 Vgl. Giles Constable: Letters and Letter-Collections, Turnhout 1976 (Typologie des sources du Moyen Âge occidental 17); The Letters of Peter the Venerable, ed. Giles Constable, 2 Bde., Cambridge 1967, hier Bd. 2 S. 1-12; Franz-Josef Schmale: Art. Brief, Briefliteratur, Briefsammlung, IV. Lateinisches Mittelalter, in: LexMa 2 (1983) Sp. 652-659; Ludwig Отт: Untersuchungen zur theologischen Briefliteratur der Frühscholastik, Münster 1937 (Beiträge zur Geschichte der Philosophie und Theologie des Mittelalters 34), bes. S. 109-125; Hans Martin Schaller: Briefe und Briefsammlungen als Editionsaufgabe. Die Zeit nach 1100, in: Mittelalterliche Textüberlieferung und ihre kritische Aufarbeitung. Beiträge der Monumenta Germaniae Historica zum 31. Deutschen Historikertag Mannheim 1976, S. 63-70 (Wiederabdr. in: DERs.: Stauferzeit. Ausgewählte Aufsätze, Hannover 1993 [MGH Schr. 38], S. 409-416); Rolf KöHN: Zur Quellenkritik kopial überlieferter Korrespondenz im lateinischen Mittelalter, zumal in Briefsammlungen, in: MIÖG 101 (1993) S. 284-310. - In „Medioevo Latino“ wird jährlich die Literatur unter „Forme e generi di testi / Epistolografia e Artes dictandi" verzeichnet.

88 Mario Fors: I compiti e le prerogative dei cardinal vescovi secondo Pier Damiani nel quadro della sua ecclesiologia primaziale, in: AHP 10 (1972) S. 25-105; DERs.: Papa e cardinali nel secolo XI. Una questione di metodo e una replica, in: AHP 14 (1976) S. 383-416.

89 Bernhard von Clairvaux, Sämtliche Werke (doppelsprachige Ausgabe), hg. v. Gerhard WiNKLER, Bd. 2, Innsbruck 1992, Briefe Nr. 15-21, 48, 51-54, 157, 160, 162 f., 168 ; Bd. 3, Innsbruck 1992, Briefe Nr. 181, 188, 192 f., 196, 219, 224, 230-232, 236 f., 287, 295 f., 302, 306 f., 311, 331-335, 338, 362, 367 f., 501, 504, 525-529. Vgl. Sabine Teubner-Schoebel: Bernhard von Clairvaux als Vermittler an der Kurie. Eine Auswertung seiner Briefsammlung, Bonn 1993 (Studien und Dokumente zur Gallia Pontificia 3). 
zusammengestellt wurde, finden sich einige wenige Briefe an die Kardinallegaten Walter von Albano (1095) und Johannes von Tusculum und einen anderen Kardinal Johannes $(1101)^{90}$. Etwas zahlreicher sind die Briefe, die Ivo von Chartres (Bf. 1090-1115/16) an Kardinäle adressierte und in seine umfangreiche, von ihm selbst veranlaßte Sammlung aufnahm ${ }^{91}$. Hildebert von Lavardin, Bischof von Le Mans (1096) und Erzbischof von Tours (1125-1133), der große Stilist und schon von den Zeitgenossen hochgerühmte Autor, hatte als Briefpartner auch ausgesuchte Kardinäle ${ }^{92}$. Einige wenige Stücke stehen in der Sammlung des Gottfried von Vendôme († 1132), der auf zwölf Romreisen die Kontakte zur Kurie festigte und unbedingter Verfechter des Reformpapsttums in Frankreich war ${ }^{93}$. Unter den Briefen, die der Abt von Cluny, Petrus Venerabilis (1122-1156), durch seinen Sekretär Petrus Pictaviensis zusammenstellen ließ, finden sich einige an die prominenteren unter den Kardinälen, was den Wirkungskreis des Abtes unterstreicht ${ }^{94}$. Ein einziger Brief an einen Kardinal(legaten) von 1151 findet sich in der kleinen Ebracher Sammlung ${ }^{95}$. Arnulf,

90 Anselm von Canterbury, Opera Omnia, ed. Franz S. Sснмiтt, Bd. 4, Edinburgh 1949, S. 77-81, 84 Nr. 191 f., 194; Bd. 5, Edinburgh 1951, S. 277 Nr. 339. Dazu gibt es einen Brief des Johannes von Tusculum an Anselm (1102), ebd. Bd. 4 S. 201-203 Nr. 284. Zu den Legationen vgl. Helene Tillmann: Die päpstlichen Legaten in England bis zur Beendigung der Legation Gualas (1218), Diss. Bonn 1926, S. 19-23. Weiters Walter Fröhlich: Die Entstehung der Briefsammlung Anselms von Canterbury, in: HJb 100 (1980) S. 457-466; Thomas Michael KRÜGER: Persönlichkeitsausdruck und Persönlichkeitswahrnehmung im Zeitalter der Investiturkonflikte. Studien zu den Briefsammlungen des Anselm von Canterbury, Hildesheim 2002 (Spolia Berolinensia 22), bes. S. 51 ff., $71 \mathrm{ff}$ - Richard W. Southern: Saint Anselm. A portrait in a landscape, Cambridge 1995, bes. S. 269 ff., 382 ff., 459 ff.

91 Yves de Chartres, Correspondance, Bd. 1 (1090-1098), ed. Jean LeCLERcQ, Paris 1949 (Les Classiques de l'histoire de France au Moyen Âge 22), S. 76-80 Nr. 18. Die übrigen etwa 230 Briefnummern noch in Migne PL 162. Dort sind an Kardinäle (Legaten) adressiert die Nr. 84, 87, 266, 267, 273, 275. Vgl. Alfons Becker: Art. Ivo v. Chartres, in: LexMA 5 (1991) Sp. 839 f., und die breite Darstellung durch Rolf Sprandel: Ivo von Chartres und seine Stellung in der Kirchengeschichte, Stuttgart 1962 (Pariser Historische Studien 1), bes. S. $9 \mathrm{ff} ., 180 \mathrm{ff}$.

92 Migne PL 171 Sp. 216, 224. Vgl. Peter von Moos: Hildebert von Lavardin (10561133). Humanitas an der Schwelle des höfischen Zeitalters, Stuttgart 1965 (Pariser Historische Studien 3), und zusammengefaßt Ders.: Art. Hildebert v. Lavardin, in: LexMA 5 (1991) Sp. $11 \mathrm{f}$.

93 Migne PL 157 Sp. 57-59 Nr. 16, 18. Vgl. Ernst SAckur: Die Briefe Gottfrieds von Vendôme, in: NA 18 (1893) S. 666-673; Joachim EhLERs: Art. Gottfried v. Vendôme, in: LexMA 4 (1989) Sp. 1607.

94 Constable: Letters of Peter the Venerable (wie Anm. 87) Bd. 1 S. 5 f., 109, 134, 144 , 195, 221 Nr. 2f., 34, 40, 47, 66, 84 mit dem entsprechenden Kommentar in Bd. 2. Vgl. Neithard Bulst: Art. Petrus Venerabilis, in: LexMA 6 (1993) Sp. 1985-1987.

95 Werner OHNsorge: Eine Ebracher Briefsammlung des XII. Jahrhunderts, in: QFIAB 20 (1928/29) S. 1-39, hier: 35 f. Nr. VIII. 
Bischof von Lisieux (1141-1182), korrespondierte mit Kardinallegaten in Frankreich und England ${ }^{96}$. Der Brief an alle Kardinäle de electione domini pape Alexandri zeigt die vehementen Auswirkunden der Doppelwahl von 115997. Johannes von Salisbury, der enge Ratgeber der Erzbischöfe von Canterbury, Theobald und Thomas Becket, in den letzten Lebensjahren Bischof von Chartres (1176-1180), der viele Kardinäle auch persönlich kannte, fand weniger als ein Dutzend der Schreiben seiner Auftraggeber und seiner eigenen Schreiben an sie des Aufhebens innerhalb der über 320 Briefe seiner Sammlung für wert ${ }^{98}$. Auch der Bischof von London, Gilbert Foliot (1163-1187) wandte sich an Kardinallegaten, aber auch an prominente Kurienkardinäle und ließ die Texte in seine Sammlung einreihen ${ }^{99}$. Petrus von Celle, Abt von Montier-la-Celle, dann von Saint-Rémi bei Reims und schließlich als Nachfolger seines Freundes Johannes von Salisbury Bischof von Chartres (1180-1183), hatte ebenfalls einige prominente Kardinäle als Briefpartner, die späteren Päpste Alexander III. und Gregor VIII., den Legaten in Frankreich Petrus von Pavia und Berneredus, KB von Tusculum ${ }^{100}$. Die Sammlung des päpstlichen Notars Transmundus, der knapp vor seinem Tod als Vizekanzler 1185/86 bezeugt ist, zeigt nur vereinzelt eigene Briefe, bringt aber jene verschiedener, hochgestellter Persönlichkeiten an Kardinäle $^{101}$. Die Briefe, die der aus Frankreich stammende Wilhelm, Abt von Aebelholt (1165-1203), zusammenstellte, schließen auch einige an Kardinäle ein und betreffen in erster Linie den Ehestreit Philipps II. August mit seiner

96 The Letters of Arnulf of Lisieux, ed. Frank BARLow, London 1939 (Camden Third Series 61), S. 20, 29, 33, 36, 50, 121, 138, 140, 147, 149, 152 f., 187, 191, 205 Nr. 15, 23, 25, 27, 30, 71, 84-86, 91 f., 94 f., 122, 125, 135.

97 Ebd. S. 43 Nr. 29.

98 The Letters of John of Salisbury, ed. by William James Millor S. J. u.a., Bd. 1: The early letters (1153-1161), London 1955; Bd. 2: The later letters (1163-1180), Oxford 1979 (Oxford Medieval Texts), Bd. 1 S. 15-18 Nr. 9-11; Bd. 2 S. 402, 426, 432, 774, 776, 778 Nr. 229, 234 f., 315-318.

99 The Letters and Charters of Gilbert Foliot, ed. Zachary N. Brooke/Adrian Morey/ Christopher N. L. Brooke, Cambridge 1967, mit der vorbereitenden Untersuchung: Adrian Morey/Christopher N. L. Brooke: Gilbert Foliot and his letters, Cambridge 1965 (Cambridge Studies in medieval life and thought N. S. 11).

100 The letters of Peter of Celle, ed. Julian Haseldine, Oxford 2001 (Oxford Medieval Texts), S. 16, 360-387, 490-507 Nr. 7, 83-91, 133-135. Vgl. neben der Einleitung zur Edition die vorbereitende Veröffentlichung von DERs.: The Creation of a Literary Memorial: The Letter Collection of Peter of Celle, in: Sacris erudiri 37 (1997) S. 333378.

101 Sheila J. Heathсоте: The Letter Collections attributed to Master Transmundus, Papal Notary and Monk of Clairvaux in the Later Twelfth Century, in: Analecta Cisterciensia 21 (1965) S. 167 ff. Nr. 23, 26, 43, 61, 89, 113, 115 f., 153. - Vgl. Repertorium der Artes dictandi des Mittelalters, Bd. 1: Von den Anfängen bis um 1200, hg. v. Franz Josef Worstbrock u.a., München 1992 (Münstersche Mittelalter Schriften 66), S. 99-111. 
verstoßenen Frau, Ingeborg von Dänemark ${ }^{102}$. Und schließlich Petrus von Blois $(\dagger 1211 / 12)$, der viele Jahre im geistlichen Hofdienst in England wirkte, unter dessen fast 250 Briefen - in vielen Handschriften überliefert - auch einige an Kardinäle aufscheinen ${ }^{103}$. Mit großer Wahrscheinlichkeit hatten alle die genannten Autoren auch Briefe von Kardinälen erhalten, wie beispielsweise aus Formeln wie legens litteras vestras ${ }^{104}$, oder accepi litteras ... humilitati mee transmissas oder littere quas ad sanctitatis vestre servos direxistis oder sicut litterarum vestrarum pro nobis tenor enunciat ${ }^{105}$ hervorgeht.

Aber nicht wenige Sammlungen des 11. und 12. Jahrhunderts enthalten auch Briefe von Kardinälen. Die 180 Briefe umfassende Sammlung des Kardinals Petrus Damiani, die in dieser Reihe eine Sonderrolle einnimmt, wurde schon kurz gewürdigt, wobei nochmals zu betonen ist, daß nur ein Teil die Bezeichnung „Brief" im herkömmlichen Sinn - also eine mit einem Anliegen verknüpfte persönliche Mitteilung eines Sachverhaltes - verdient. Der Umfang reicht von kurzen Mitteilungen bis zu langen Traktaten. Der Inhalt der Schreiben ist zumeist von grundsätzlicher, über die Person des Empfängers hinausreichender Bedeutung und Petrus entwickelte in ihnen seine philosophischen und theologischen Gedanken ${ }^{106}$. Einzeln steht der Brief des Mainard von Silva Candida an König Heinrich IV. in den Hildesheimer Briefen der Hannoverschen Briefsammlung (ca. 1072 bis 1085) da ${ }^{107}$. Unter den Briefen des berühmten Propstes Gerhoch von Reichersberg $(\dagger 1169)$ überwiegen seine eigenen an verschiedene Kardinäle, aber einige wenige von der Gegenseite fand er des Aufhebens wert ${ }^{108}$. In der

102 Diplomatarium Danicum 1/3/2: Epistolae abbatis Wilhelmi, ed. Carl Andreas CHrisTENSEN u.a., Kopenhagen 1977, S. 476, 496, 510, 524, 544 f., 557; vgl. Thomas Rirs: Art. Wilhelm, in: LexMA 9 (1998) Sp. $152 \mathrm{f}$.

103 Migne PL 207 Sp. 82, 116, 141, 484, 527 Nr. 23, 38, 48, 200, 231. - Nicht jedoch in den späteren Briefen, vgl. The Later Letters of Peter of Blois, ed. Elizabeth Revelt, Oxford 1993 (Auctores Britannici Medii Aevi 12). - Zur erwünschten kritischen Edition des gesamten Epistolars vgl. Lena WAhLGren: The letter collections of Peter of Blois. Studies in the manuscript tradition, Göteborg 1993 (Studia Graeca et Latina Gothoburgensia 58); Richard William Southern: Towards an edition of Peter of Blois's lettercollection, in: EHR 110 (1995) S. 925-937. - Rolf KöHN: Art. Petrus v. Blois, in: LexMA 6 (1993) Sp. 1963 f.; Repfont 9 (2002) S. 116-118.

104 Petrus Venerabilis, ed. Constable (wie Anm. 87) Bd. 1 S. 5 Nr. 2.

105 Ebd. S. 110 Nr. 34. Ähnlich in den Epistolae Cantuarienses (wie Anm. 119) S. 119, 414.

106 Briefe, ed. Reindel (wie Anm. 7) Bd. 1 S. 9.

107 Briefsammlung, hg. Erdmann/Fickermann (wie Anm. 79) S. 67 f. Nr. 30.

108 Vgl. das Verzeichnis der Regesten der Urkunden, Briefe, Widmungen bei Peter Classen: Gerhoch von Reichersberg. Eine Biographie. Mit einem Anhang über die Quellen, ihre handschriftliche Überlieferung und ihre Chronologie, Wiesbaden 1960, S. 327 ff; DERs.: Aus der Werkstatt Gerhochs von Reichersberg: Studien zur Entstehung und Überlieferung von Briefen, Briefsammlungen und Widmungen, in: DERs.: Ausgewählte Aufsätze, hg. von Josef Fleckenstein, Sigmaringen 1983 (VuF 28), S. 379-430. - Briefe an 
kleinen Sammlung der Briefe des Abtes Suger von Saint-Denis $(+1151)$ figuriert hingegen keiner, der an einen Kardinal adressiert gewesen wäre. Zwei Kardinalsbriefe an ihn selbst sind darin jedoch enthalten ${ }^{109}$. Das Briefbuch des Wibald von Stablo († 1158), das er als Handregistratur für seine umfangreiche Verwaltungstätigkeit und diplomatische Missionen im königlichen Auftrag anlegte und welche nicht nur die eigene Korrespondenz, sondern auch von ihm entworfene Urkunden und Stücke allgemeinen Interesses enthält, schließt Briefe an die Kardinäle und von den Kardinälen ein ${ }^{110}$. Die Admonter Briefsammlung, die in der steirischen Abtei auf der Grundlage von Material zusammengestellt wurde, das Erzbischof Eberhard I. von Salzburg (1147-1164) zur Dokumentation von Ereignissen seit dem Ausbruch des Schismas 1159 zur Verfügung stellte, bringt zwei Briefe von Kardinälen und drei Briefe an Kardinäle ${ }^{111}$. Die Tegernseer Briefsammlung, zwischen 1178 und 1186 in der oberbayerischen Abtei redigiert, hat in ihrem Kunterbunt von weltpolitisch Wichtigem und lokal Banalem auch fünf Briefe von Kardinälen und zwei an Kardinäle ${ }^{112}$. Ausschließlich Schreiben von Kardinälen an den Erzbischof weist die breite, fast 330 Nummern umfassenden Briefsammlung des Thomas Becket auf, die ihn in ein dichtes Netz von Freunden und Unterstützern an der Kurie eingewoben zeigt $^{113}$. Hingegen findet sich unter den mehr als 500 Papstbriefen, die das Gros

Kardinäle: Nr. 4, 17, 28, 62, 93, 96, 135-137, 152; Briefe von Kardinälen: Nr. 18, $141 \mathrm{f}$.

109 Suger, Oeuvres, Bd. 2: Lettres de Suger, Chartes de Suger, Vie de Suger par le moine Guillaume, ed. Françoise Gasparri, Paris 2001 (Les Classiques de l'histoire de France au Moyen Âge 41), S. 141 f. Nr. $122 \mathrm{f}$.

110 Wibald von Stablo, Epistolae, ed. Philipp Jaffé, in: Monumenta Corbeiensia, Berlin 1864 (Bibliotheca Rerum Germanicarum 1), Nr. 37, 55, 62-65, 113, 159, 160, 186, 194 f., 252, 378, 426 f. (= Briefe an die Kardinäle) Nr. 47, 66 f., 121 f., 154, 184, 190, 198, 225, 273, 351, 412, 414 f., 417, 431 (= Kardinalsbriefe). - Zum Briefbuch vgl. Friedrich Hausmann: Reichskanzlei und Hofkapelle unter Heinrich V. und Konrad III., Stuttgart 1956 (MGH Schr. 14), S. 178 ff.; Freya Stephan-Kühn: Wibald als Abt von Stablo und Corvey und im Dienste Konrads III., Diss. Köln 1973, S. 7 ff.; Franz Josef Jаковг: Wibald von Stablo und Corvey (1098-1158), benediktinischer Abt in der frühen Stauferzeit, Münster 1979 (Veröffentlichungen der Historischen Kommisson für Westfalen 10/5), S. $24 \mathrm{ff} ., 314 \mathrm{ff.}$

111 Die Admonter Briefsammlung, hg. v. Günther Hödl/Peter Classen, München 1983 (MGH Epp DK 6), S. 84-87, 121, 129, 132 Nr. 42, 66, 72, 75.

112 Die Tegernseer Briefsammlung des 12. Jahrhunderts, ed. Werner Bergmann/Helmut Plechl, Hannover 2002 (MGH Epp DK 8), S. 43 Nr. 29, S. 68 Nr. 46, S. 82 Nr. 59, S. 192 Nr. 162, S. 225 Nr. 193, S. 258 Nr. 228, S. 300 Nr. 270.

113 The Correspondence of Thomas Becket, Archbishop of Canterbury 1162-1170, ed. Anne J. Duggan, 2 Bde., Oxford 2000 (Oxford Medieval Texts), Bd. 1 S. 24, 204, 618, 620, 684, 726, 767 Nr. 9, 47, 130 f., 148, 156, 167; Bd. 2 S. 1136, 1296, 1298, 1316, 1318, 1340, 1343 Nr. 264, 308 f., 316 f., 323-325. - Vgl. DiEs.: Thomas Becket's Italian Network, in: Pope, Church and City. Essays in honour of Brenda Bolton, ed. by Frances Andrews u.a., Leiden 2004 (The Medieval Mediterranean 56), S. 177-201. 
der Sammlung des Erzbischofs Heinrich von Reims (1162-1175) ausmachen, ein einziger Kardinalsbrief: Wilhelm von Pavia, KP von S. Pietro in Vincoli, setzte sich während seiner zweiten Legation 1167/68 für einen armen Priester ein ${ }^{114}$. Ins späte 12. Jahrhundert reicht die Sammlung des Regularkanonikers Stephan von Tournai, der zunächst Abt von Saint-Euverte in Orléans (1172), dann in Saint-Geneviève in Paris (1172) wurde, bevor er 1192 zum Bischof von Tournai gewählt wurde $(\dagger 1203)$. Auch hier wirkt der einzige Brief eines Kardinals wie ein Irrläufer in der großen Zahl der Schreiben Stephans an Kardinäle ${ }^{115}$.

Um diese relativ große Masse von Dokumenten zu strukturieren, sollen hier zwei der noch nicht genannten Sammlungen und die in ihnen enthaltenen Kardinalsbriefe kurz vorgestellt und analysiert werden. Es handelt sich um die Sammlungen von Sankt Viktor und die «Epistolae Cantuarienses». Die beiden Sammlungen des Chorherrenstiftes St. Viktor vor den Mauern von Paris, deren Erforschung und Auswertung für das Papsturkundenwerk wir Dietrich Lohrmann und Gunnar Teske verdanken ${ }^{116}$, gehen auf mehrere Persönlichkeiten wie den königlichen Kanzler Hugo von Champfleury, den schon genannten Kardinal Petrus von S. Grisogono, den römischen Subdiakon Alexius und späteren KP von S. Susanna, den Abt Guarinus von St. Viktor und andere zurück. Sie enthalten eine große Zahl von Kardinalsbriefen -74 , wenn ich mich nicht verzählt habe -, die überwiegend auf die Sechziger- und frühen Siebzigerjahre des 12. Jahrhunderts konzentriert sind. Ein Teil von ihnen könnte auch in die Kategorie „Legatenurkunden“ passen. Die Briefe vermitteln nicht nur den

114 Veterum scriptorum et monumentorum historicorum, dogmaticorum, moralium amplissima collectio, ed. Edmond Martène/Ursin Durand, Bd. 2, Paris 1724, Sp. 928 Nr. 382. - Zu dieser Sammlung vgl. zusammenfassend Ludwig Falkenstein: Alexandre III et Henri de France, in: L'Église de France et la papauté (X'-XIII siècle). Die französische Kirche und das Papsttum (10.-13. Jahrhundert). Actes du XXVI ${ }^{\mathrm{e}}$ colloque historique franco-allemand organisé en coopération avec l'École nationale des chartes par l'Institut historique allemand de Paris (Paris, 17-19 octobre 1990), hg. v. Rolf Grosse, Bonn 1993 (Studien und Dokumente zur Gallia Pontificia 1), S. 103-176, bes. S. 104 f.; Patrick Demouy: Genèse d'une cathédrale. Les archevêques de Reims et leur Église aux $\mathrm{XI}^{\mathrm{e}}$ et $\mathrm{XII}^{\mathrm{e}}$ siècles, Langres 2006, S. 628-631.

115 Lettres d'Étienne de Tournai, ed. Jules Desilve, Valenciennes/Paris 1893, S. 97 Nr. 83 (= einziger Kardinalsbrief), sonst S. 55-57, 64, 70, 77, 85, 91, 100, 138, 151, 170, 172, 187 f., 190, 196, 247, 260, 280, 295 Nr. 42-44, 50, 56, 63, 71, 77, 85, 119, 128, 146, 148, 160 f., 163, 168, 198, 209, 225, 238 (= an Kardinäle). Vgl. Charles Vulliez: Études sur la correspondence et la carrière d'Étienne d'Orléans dit de Tournai († 1203), in: L'Abbaye parisienne de Saint-Victor au moyen âge. Communications présentées au XIII $^{\text {e }}$ Colloque d'humanisme médiéval, hg. v. Jean LongÈre, Turnhout 1991 (Bibliotheca Victorina 1), S. 195-231.

116 Dietrich Lohrmann: Papsturkunden in Frankreich, N.F. 8, Diözese Paris 1: Urkunden und Briefsammlungen der Abteien Sainte-Geneviève und Saint-Victor, Göttingen 1989 (AAG, phil.-hist. Kl., 3. Folge 74); Teske (wie Anm. 70). 
Eindruck von dem engen Geflecht der Beziehungen, das die römische Zentrale mit einzelnen Ländern der Christenheit verband, sondern auch in wie starkem Maße die Kardinäle daran beteiligt waren. Einen kompakten Block bilden die auf 1159 datierbaren Empfehlungsschreiben von einer Gruppe von überwiegend aus Rom und Latium stammenden Kardinälen für den vorhin genannten Alexius, von dessen Familie sie sich offensichtlich gewinnen hatten lassen, z. T. weil sie mit ihm verwandt waren. Er hatte in den späten Fünfzigerjahren in Paris mit Unterstützung des Abtes von Saint-Germain-des Prés und des Erzbischofs von Reims studiert und wurde noch unter Hadrian IV. an die Kurie zurückberufen, weil seine prominente römische Familie die baldige Erhebung zum Kardinal erwartete. Wegen des Todes Hadrians IV. kam die Reise nicht zustande, und als dann feststand, daß er auch unter Alexander III. nicht so bald promoviert werden würde, trat er in St. Viktor ein und verließ die Abtei im Jahre 1168. Die Empfehlungsschreiben sind an eine Reihe von prominenten französischen Äbten - St-Denis, Compiègne, Vézelay und andere - und an die Erzbischöfe und Bischöfe von Reims, Tours, Sens, Auxerre, Lisieux, Angers und andere adressiert und ergänzen direkt an Alexius adressierte Schreiben. In ihnen sind Bitten um Unterstützung - in equitaturis quam in aliis, in expensis, tam in victualibus quam in aliis, ad redeundum necessariis - ausgesprochen und es wird öfters auf seine verheißungsvolle Zukunft an der Kurie angespielt. Eine zweite Serie von Empfehlungsschreiben an hohe französische Geistliche durch andere Kardinäle erging im Jahre 1168, als Alexander III. den genannten Alexius an die Kurie zurückberief. Wieder sind es Bitten sive in bona equitatura sive in eius estimatione. Ein Schreiben des Wilhelm von Pavia, KP von S. Pietro in Vincoli, an Alexius selbst enthält Hinweise auf die geplante gemeinsame Reise und auf die Mittel zu ihrer Finanzierung ${ }^{117}$. - Einen anderen kompakten Block von Kardinalsbriefen in den viktorinischen Sammlungen bilden die auf den königlichen Kanzler Hugo von Champfleury zurückgehenden Stücke. Ein Teil von ihnen ist in der handschriftlichen Überlieferung als zusammengehörig gekennzeichnet und ganz überwiegend sind es Schreiben an König Ludwig VII. in den verschiedensten Betreffen: Empfehlungen, Bitten um Zustimmung zu Pfründenübertragungen, Bitten um königliche Bestätigungen, Berichte von Handlungen als Legaten, Bitte um Interventionen, Übersendung von Geschenken, Bitten um Informationen und anderes mehr ${ }^{118}$. Die Briefe zeigen in aller Deutlichkeit, daß die Kardinäle im politischen Kräftespiel ihr Prestige und ihre Formulierungskünste einsetzten - ein unerwartetes Zeichen für eine frühe internationale Politik.

Die «Epistolae Cantuarienses» sind das Ergebnis eines langen Streites zwischen dem Erzbischof von Canterbury und den Benediktinermönchen von

117 Lohrmann (wie Anm. 116) Nr. 102.

118 Teske (wie Anm. 70) S. 152-154, 374-378. 
Christ Church, die dort als Domkapitel fungierten, wegen der Kollegiatkirche von Hackington, später von Lambeth ${ }^{119}$. Seit 1187 war das kuriale Gericht mit dem Fall befaßt und Vertreter beider Seiten hielten sich in Rom auf, um das Verfahren in ihrem Sinn zu beeinflussen. 1189 war auch ein Kardinallegat an Ort und Stelle, um eine - letztlich nicht tragfähige - Entscheidung zu fällen. Einige Jahre ruhte dann der Streit und brach 1197 neu aus und wurde wieder vor dem kurialen Forum ausgefochten, bis dann schließlich Innozenz III. im Jahre 1201 einen im Vorjahr zwischen dem Erzbischof und den Mönchen geschlossenen Kompromiß bestätigte. Kurz danach stellten die Mönche wohl alle in ihrem Besitz befindlichen Schriftstücke zu dem Prozeß zusammen. Unter den über 550 Dokumenten sind auch über 40 Briefe an Kardinäle und knapp 20 Kardinalsbriefe. Geschrieben wurden sie von einer kleinen Gruppe von Kardinälen, zu denen die Mönche offensichtlich Vertrauen hatten und von ihnen die Förderung ihrer Angelegenheit erhofften: Theobald, der frühere Abt von Cluny und dann KB von Ostia (1184-1188), Johannes Anagninus, ein altgedienter, seit 1160 im Kardinalskollegium tätiger Mann, schließlich KB von Preneste (1190-1196), der 1189 in England gewesen war, Petrus von Piacenza, $\mathrm{KP}$ von S. Cecilia (1188-1206), ein mehrfach erprobter Legat, Johannes von S. Clemente, später KB von Albano (1199-1210/11), der offensichtlich ein besonderer Freund der Mönche war, und noch einige andere. Inhaltlich bieten sie keine besonderen und detaillierten Nachrichten von der Kurie, außer daß das Verfahren wegen des kurzen Pontifikats Gregors VIII. 1187 und der Wechsel zu Clemens III. stockte. Sie sind im wesentlichen Ermunterungen zum Durchhalten und Versicherungen des Wohlwollens. Einige Schreiben von Kardinälen an den englischen König und den Erzbischof von Canterbury mit der Bitte um Begünstigung der Mönche und der Mahnung, die päpstlichen Mandate durchzuführen, wurden den Mönchen offensichtlich abschriftlich mitgeteilt. Stilistisch stehen die Briefe auf hohem Niveau, befolgen durchwegs den an der Kurie üblichen Cursus und setzen Bibelzitate an den passenden Stellen ein ${ }^{120}$.

119 Epistolae Cantuarienses: The letters of the prior and convent of Christ Church, Canterbury. From A. D. 1187 to A. D. 1199, ed. William STubBs, London 1865 (RS 38/2). Vgl. ihre Auswertung bes. durch Christopher R. Cheney: Hubert Walter, London 1967, S. 137 ff.; Ders.: Pope Innocent III and England, Stuttgart 1976 (Päpste und Papsttum 9), S. 208 ff.; Maleczek: Papst (wie Anm. 35) S. 253 ff.

120 Ermunterung zum Durchhalten und zur Einigkeit (Theobald Nr. 91), Verfahrenstechnisches (Theobald Nr. 92), Zusicherung der freundschaftlichen Förderung und Parteinahme, wovon sich die Vertreter der Mönche an der Kurie überzeugen konnten; Bedauern, daß wegen des Pontifikatswechsels von Urban III., Gregor VIII. zu Clemens III. die Sache stockte (Theobald Nr. 163), Beeinflussung eines Exekutors päpstlicher Briefe (Theobald Nr. 217), Brief an den englischen König zugunsten der Mönche, stilistisch vorzüglich; Mahnung, im Königreich Ordnung zu halten, was die Voraussetzung für einen erfolgreichen Kreuzzug ist (Theobald. Nr. 242). - Bedauern über den Tod eines anderen Kardinals, der ein Freund der Mönche war (Petrus Placentinus Nr. 295); un- 


\section{Schriftstücke der Kardinäle innerhalb der Kurie}

Vor der Mitte des 12. Jahrhunderts vereinzelt, seit dem Pontifikat Eugens III. in verstärkten Maße wurden die Kardinäle in das kuriale Gerichtswesen in der Form eingebunden, daß wegen der rasant ansteigenden Zahl von Verfahren und der damit verbundenen Überlastung des Papstes kompliziertere Fälle an einzelne Persönlichkeiten oder kleinere Kommissionen zur Vorbehandlung übertragen wurden. Seit dem späten 12. Jahrhundert werden sie als auditores bezeichnet. Diese führten das Verfahren entweder zu Ende, d. h. sie bewirkten einen Vergleich oder fällten eine sententia definitiva, was vom Papst bestätigt werden konnte oder auch nicht, oder aber sie erstatteten dem Papst nach der Untersuchung der Rechtslage einen mündlichen oder schriftlichen Bericht, der dann zur Grundlage des päpstlichen Urteils wurde. Alle die auf diese Weise entstandenen Schriftstücke sind entweder als Deperditum erwähnt oder im Empfängerarchiv oder in eine Papsturkunde inseriert erhalten ${ }^{121}$. Dieser Befund gilt auch für die Pontifikate der ersten Hälfte des 13. Jahrhunderts, bis das Institut der auditores palatii domini pape die jeweilige Übertragung an einzelne Auditoren aus dem Kardinalsrang überflüssig machte. Eine Aufzählung aller dieser Fälle würde nur langweilen, aber gerade auf diesem Feld könnte eine systematische Nachlese zweifellos noch so manchen Fund bewirken. Nur zwei Beispiele, bislang wenig beachtet, sollen hier vorgestellt werden. Eine Gruppe von sechs Kardinälen entschied im Auftrag Innozenz' II. in den Jahren 1141/43 den Streit zwischen dem Dompropst von Arezzo und dem Abt von S. Trinità in Torre und hielt das Ergebnis urkundlich fest, das heute noch im Domkapitelarchiv von Arezzo im Original erhalten ist und ursprünglich drei Siegel trug ${ }^{122}$. Das andere Beispiel bezieht sich auf Sachsen. Auf Betreiben der Äbtissin Beatrix von Quedlinburg

terstützendes Schreiben an Richard Löwenherz, er möge den Wunsch Innocenz’ III ausführen (Petrus Placentinus Nr. 445). - Ankündigung des Legaten; sein Wohlwollen; Verehrung für Thomas Becket (Johannes Anagninus Nr. 304); Unterstützung; informiert, daß er dem Erzbischof die entsprechenden Befehle erteilt hat (Johannes Anagninus, Nr. 310); Unterstützung; fordert sie auf, dem Subprior zu gehorchen (Johannes Anagninus, Nr. 318); Verfahrenstechnisches; verkündet, daß die Exkommunikation, die der Erzbischof über den Subprior verhängte, ungültig ist (Johannes Anagninus, Nr. 319); allgemeines Rundschreiben: die unter königlichem Zwang erreichte Einigung ist ungültig (Johannes Anagninus, Nr. 336). - Aufforderung an den Erzbischof, keine unpassenden Neuerungen einzuführen und päpstliche Befehle zu befolgen (Johannes v. S. Clemente, Nr. 437); Ermunterung zum Durchhalten; stilistisch anspruchsvoll; Bibelzitate (Johannes v. S. Clemente, Nr. 439). - Aufforderung an den Erzbischof, Lambeth nicht zu bauen (Guido, Nr. 438). - Mehrere Schreiben an den König, das päpstl. Mandat auszuführen (Johannes v. S. Clemente, Nr. 444; Oktavian v. Ostia, Nr. 443).

121 Maleczek: Papst (wie Anm. 35) S. 326 f., wo zahlreiche Beispiele aus dem 12. Jahrhundert angeführt sind.

122 Julius von Pflugk-Harttung: Iter Italicum, Stuttgart 1883, S. 460-463 Nr. 51; IP 3 S. 158 Nr. 6. 
(1138-1160) war die Kirche St. Wiperti in Quedlinburg an den jungen Prämonstratenserorden übergeben worden. Dies hatte der päpstliche Legat Thomas, KP von S. Vitale, bei seinem Aufenthalt in Deutschland (Spätsommer 1145 bis Sommer 1146) vollzogen und Eugen III. am 24. Mai 1146 bestätigt. An St. Wiperti hatte früher ein nicht reguliertes Kollegiatstift bestanden, das bis ins 10. Jahrhundert zurückreichte. Deren Kanoniker waren nicht gewillt, ihre Verdrängung durch die Prämonstratenser ruhig hinzunehmen und erhoben bei Eugen III. Klage. Nach Eröffnung des Verfahrens erschien an der Kurie ein Vertreter der Äbtissin von Quedlinburg und des Prämonstratenserpropstes Gottfried und bot einen Vergleich an, durch welchen den früheren Kanonikern bestimmte jährliche Einkünfte zugesichert wurden. Dies geschah vor Jordan, KP von S. Susanna (1145-1154), und Hyacinth, KD von S. Maria in Cosmedin (1144-1191), denen die Angelegenheit offensichtlich zur Untersuchung übertragen worden war. Die von ihnen darüber ausgestellte, nicht datierte, aber auf die Jahre 1146 bis 1151 einzugrenzende Urkunde gelangte ins Archiv der Kanonissen von Quedlinburg und ist im Original erhalten, liegt aber nur in einem Druck aus dem Jahr 1764 vor und blieb deshalb in der Forschung, die sich mit der Kurie und den Kardinälen befaßte, unbeachtet ${ }^{123}$.

In die Kategorie der Schriftstücke der Kardinäle gehören auch ihre Testamente. Die erste Spur eines Kardinalstestamentes führt zu dem hier schon öfters genannten Petrus von S. Grisogono, seit 1179 KB von Tusculum, der 1182 starb und in Fossanova beigesetzt wurde ${ }^{124}$. Den Text des Testamentes kennt man zwar nicht, aber man weiß von vier Klerikern des Kardinals, die er zu Testamentsvollstreckern einsetzte ${ }^{125}$. Auch vom nächsten bezeugten Kardinalstestament, jenem des Petrus Dianus, KP von S. Cecilia, hat man nur die von Papst

123 Die Urkunde liegt in Magdeburg, Landeshauptarchiv Sachsen-Anhalt, Urk. Stift Quedlinburg A V 1. Druck: Anton Ulrich von Eratr: Codex diplomaticus Quedlinburgensis, Frankfurt 1764, S. 90 Nr. XV. Dort ist der Name Jac. fälschlich mit Jacobus aufgelöst. - Die Bestätigung durch Eugen III., in der auch der Kardinallegat Thomas erwähnt wird: JL 8924. Zu diesem und zu Jordan vgl. Zenker S. 104-106, 114. - Die ungefähre Datierung ergibt sich aus der genannten päpstlichen Bestätigung und der Abreise Jordans als Legat nach Deutschland im Jahre 1151, vgl. Johannes Bachmann: Die päpstlichen Legaten in Deutschland und Skandinavien (1125 bis 1159), Berlin 1913 (Historische Studien 115), S. 91 ff., mit einer Korrektur bei WeIss S. 167 Anm. 61. - Zu St. Wipert vgl. Norbert Backmund: Monasticon Praemonstratense 1/2, Berlin ${ }^{2} 1983$, S. 309-311, und Johannes Bauermann: Die Anfänge der Prämonstratenserklöster Scheda und St. Wiperti-Quedlinburg, in: Sachsen und Anhalt 7 (1931) S. 185-252, bes. S. 236-243, wo die auf vermutlich 1146 datierte Urkunde ausführlicher interpretiert wird.

124 Biographie bei Teske (wie Anm. 70) S. 189-197.

125 Lohrmann (wie Anm. 116) S. 356 Nr. 157. 
Cölestin III. 1191/92 gewährte facultas testandi ${ }^{126}$, das erste im Wortlaut erhaltene stammt von Gregor de Crescentio, KD von S. M. in Aquiro 1188, KP von S. Vitale seit 1200, das er vor Antritt seiner Legation nach Ungarn ausstellte $^{127}$. Aus dem 13. Jahrhundert kennt man dann eine eindrucksvolle Reihe von Kardinalstestamenten.

Zum Abschluß soll noch kurz auf jene Dokumente eingegangen werden, die eine größere Gruppe von Kardinälen ausstellte, im Idealfall alle aus dem Kollegium. In der Regel entstanden sie an Krisenpunkten in der Geschichte des Papsttums, wenn die Kardinäle als Papstwähler als die vornehmsten Repräsentanten der Kirche gemeinsam handelten, um Schaden abzuwenden oder für ihren Standpunkt zu werben suchten. Aus der Zeit des wibertinischen Schismas stammt die im Sommer 1098 redigierte Proklamation, mit der acht Kardinäle Clemens'(III.) im Verein mit anderen Vertretern der römischen Kirche ihre bisherigen Maßnahmen darstellten und ihre Gegenspieler vor eine Synode im November desselben Jahres zitierten. Im Zusammenhang damit entstand auch eine Streitschrift - wohl ebenfalls der wibertinischen Kardinäle - vom Herbst 1098 gegen die Beschlüsse der von Urban II. in Piacenza 1095 abgehaltenen Synode ${ }^{128}$. Im "Codex Udalrici», jener Sammlung von Urkunden, Akten, Briefen, Gedichten und anderen Materialien, die der Bamberger Notar und spätere Dompropst Ulrich (1146-nach 1157) für den rhetorischen Unterricht und die Ausbildung von Notaren zusammenstellte, sind mehrere Schreiben von Kardinalsgruppen vom März 1119 überliefert, die ihre ausdrückliche Zustimmung zur erfolgten Wahl Calixts II. abgaben. Petrus von Porto, der als Stellvertreter Gelasius' II. in Rom zurückgelassen worden war, hatte für den Anfang des Monats eine Versammlung einberufen, die die in Cluny erfolgte Wahl des neuen Papstes nachträglich billigte ${ }^{129}$. Nach der Doppelwahl des Jahres 1130

126 Erhalten in der «Collectio Rotomagensis», ed. Walther Holtzmann: Kanonistische Ergänzungen zur Italia Pontificia, in: QFIAB 37 (1957) S. 74 Nr. 3; vgl. Teske (wie Anm. 70) S. 196.

127 Agostino Paravicini Bagliani: I testamenti dei cardinali del Duecento, Rom 1980 (Miscellanea della Società romana di storia patria 25), S. 107 ff. Zum Kardinal vgl. Maleczek: Papst (wie Anm. 35), S. 90-92.

128 Scripta, ed. Francke (wie Anm. 81) S. 405-407 Nr. V, S. 408-416 Nr. VIII; vgl. Mirbt: Publizistik (wie Anm. 81) S. 63 f.; Jürgen Ziese: Wibert von Ravenna, der Gegenpapst Clemens III. (1084-1100), Stuttgart 1982 (Päpste und Papsttum 20), S. 256-258.

129 Monumenta Bambergensia, ed. Philipp JAfFé, Berlin 1869 (Bibliotheca rerum germanicarum 5), S. 349-352 Nr. 193-197. Zur vieldiskutierten Quelle als letzter Beitrag: Hans-Ulrich Ziegler: Der Kompilator des Codex Udalrici - ein Notar der Bamberger Bischofskanzlei?, in: ADipl 30 (1984) 258-281. - Zusammenfassende Würdigung: Heinrich Appelt: Die Urkunden Friedrichs I., Bd. 5: Einleitung, Verzeichnisse, Hannover 1990 (MGH DD 10/5), S. 118 ff. Vgl. Beate Schilling: Guido von Vienne Papst Calixt II., Hannover 1998 (MGH Schr. 45), S. 405 f. 
entstanden mehrere Schriftstücke, in denen die konkurrierenden Kardinalsgruppen ihren Kandidaten rechtfertigten und die Anhängerschaft zu erweitern suchten. Innozenz II., der sich als Gregorius, quondam sancti Angeli cardinalis diaconus, nunc autem Deo disponente in pontificem Romanum electus bezeichnete, und die Kardinäle, die ihn gewählt hatten, wandten sich schon am 18. Februar 1130 an den deutschen König und forderten ihn zum Romzug und zur Kaiserkrönung auf. Mitte Mai schickten die Kardinäle der Gegenseite - unterstützt von anderen römischen Klerikern - eine Botschaft an Lothar III., schilderten ihre Version von der Wahl und forderten ihn zur Anerkennung auf ${ }^{130}$. Nach der Doppelwahl von 1159 verfaßten die viktorinischen Kardinäle gemeinsam ein erklärendes Rundschreiben, in das sie unter anderem das Übereinkommen des gesamten Kardinalskollegiums wörtlich inserierten, das sie nach Hadrians IV. Tod in Anagni schlossen, um eine geregelte Wahl zu erreichen. Wenig später ließen die alexandrinischen Kardinäle eine feierliche Botschaft an Kaiser Friedrich Barbarossa folgen. Beide Dokumente nahm Rahewin in seine Fortsetzung der "Gesta Frederici imperatoris» auf ${ }^{131}$. Die alexandrinischen Kardinäle zeigten sich flexibel, brachen trotz des unkanonischen Anspruches Barbarossas, den Papst von einer Synode beurteilen zu lassen, die Beziehungen nicht ab und schickten Anfang Dezember 1159 drei von ihnen, die zu den angesehensten zählten, zum Kaiser und gaben ihnen eine Botschaft aller Kardinäle mit, in der sie sich über Pfalzgraf Otto von Wittelsbach beklagten und die Beschickung der geplanten Synode von Pavia ablehnten ${ }^{132}$. Aus den folgenden Jahrzehnten liegen nur sporadisch gemeinsame Briefe der Kardinäle vor. Zu erwähnen ist hier das wohl Anfang 1203 abgefaßte Schreiben der in Rom anwesenden Kardinäle an die geistlichen und weltlichen Fürsten Deutschlands, in welchem sie sich gegenüber umlaufenden Fälschungen verwahrten, in denen ein Dissens zwischen Innozenz III. und den Kardinälen in der Frage des deutschen Thronstreites verbreitet wurde. Sie beteuerten ihr Einverständnis mit dem

130 RI 4/1/1 Nr. 217, 234 (aus dem Codex Udalrici, ed. JAfFÉ [wie vorige Anm.] S. 419 Nr. 241, und Christian Lupo: Ad Ephesinum Concilium variorum Patrum epistolae, Löwen 1682, S. 501 Nr. 10, ohne handschriftliche Überlieferung). Vgl. Werner Maleczek: Das Kardinalskollegium unter Innocenz II. und Anaklet II., in: AHP 19 (1981) S. 27-78, bes. 73-78.

131 Rahewin IV 62, 63, Bischof Otto von Freising und Rahewin, Die Taten Friedrichs oder richtiger Cronica, ed. Franz-Josef Schmale, Darmstadt ${ }^{4} 2000$ (AusgQ 17), S. 634-645. - Der Brief der Viktoriner auch in der Admonter Briefsammlung (wie Anm. 111) S. 8487 Nr. 42. Vgl. Willibald Maderthoner: Die zwiespältige Papstwahl des Jahres 1159, Wien 1978 (Dissertationen der Universität Wien 136), S. 48 ff., 120 ff.; Johannes LAudage: Alexander III. und Friedrich Barbarossa, Köln 1997 (Beih. zu J. F. Böhmer, RI 16), S. $104-106,118-123$.

132 Walther Holtzmann: Quellen und Forschungen zur Geschichte Friedrich Barbarossas, in: NA 48 (1930) S. 384-413, darin: Die Verhandlungen zwischen Friedrich I. und Alexander III. im Herbst 1159, S. 384-400; Edition 398-400. 
Papst ${ }^{133}$. Im 13. Jahrhundert brachten erneute Krisenzeiten gemeinsame feierliche Urkunden der Kardinäle hervor und unterstrichen so das Selbstbewußtsein der engsten Mitarbeiter des Papstes. Drei Beispiele mögen als Ausklang präsentiert werden. Im Jahre 1243, im letzten Abschnitt der langen Sedisvakanz nach Gregors IX. Tod, die nur für einige Tage durch den Pontifikat Cölestins IV. unterbrochen worden war, adressierten alle sieben in Rom anwesenden Kardinäle einen inhaltlich nicht besonders auffallenden Brief an den englischen Abt von Wardon, in dem es um eine Pfründenprovision für einen aus Rom stammenden Kleriker ging. Dieser hatte mangels eines Papstes eine Supplik an das versammelte Kollegium gerichtet. Dessen Begründung, warum sie der Supplik nachkommen sollten, verdient notiert zu werden: Nos autem, penes quos potestas residet apostolica sede vacante könnte komplizierte theologische und rechtliche Fragen aufwerfen und wurde von Matthäus Paris, der den Brief überliefert, in diesem Sinne gedeutet. Es ist ein markantes Zeugnis für das Selbstbewußtsein des Kollegiums, das auf jeden Fall für die ärgerliche NichtBesetzung des apostolischen Stuhles verantwortlich war ${ }^{134}$. Aus der langen Vakanz nach Clemens' IV. Tod gibt es mehrere gemeinsame Schreiben der Kardinäle, die sich auf die vom byzantinischen Kaiser Michael VIII. betriebene Union der griechischen mit der lateinischen Kirche - auch zur Abwehr der Orientpläne des Karl von Anjou - beziehen. Das eine ist ein im Original in den Pariser Archives Nationales erhaltener, langer, mit 18 Kardinalssiegeln versehener Brief vom 15. Mai 1270 an den päpstlichen Legaten im Kreuzzugs-Heer Ludwigs IX. von Frankreich, Radulf Grosparmi, KB von Albano - der wie der König selbst vor Tunis der Pestepidemie erliegen sollte -, in dem der Auftrag zu Verhandlungen mit Konstantinopel nach einer langen Darstellung der Vorgeschichte fixiert war $^{135}$. Das andere vom selben Tag ist ebenfalls an den Legaten

133 Regestum Innocentii, ed. KempF (wie Anm. 75) S. 230 f. Nr. 86.

134 Matthäus Paris, Chronica maiora, ed. Henry Richard Luard, Bd. 4: 1240-1247, London 1877 (RS 57/4), S. 250-252; Роттнаsт 11075.

135 Signatur: J 420 Nr. 3, 4. Ed. Aloysius L. TAutu: Acta Urbani, Clementis IV, Gregorii X (1261 -1276), Città del Vaticano 1953 (Pontificia Commissio ad redigendum codicem iuris canonici orientalis. Fontes 3/5/1), S. 78-84; Potthast 20506; Élie Berger: Layettes du Trésor des Chartes, Bd. 4, Paris 1902, S. 443 f. Nr. 5692. Die drei Dokumente liegen übrigens jeweils in gesiegelten Doppelausfertigungen vor. - Zum politischen Hintergrund vgl. Richard STERnFELD: Ludwigs des Heiligen Kreuzzug nach Tunis 1270 und die Politik Karls I. von Sizilien, Berlin 1896 (Historische Studien 4), bes. S. 213 f.; Burkhard Roberg: Die Union zwischen der griechischen und der lateinischen Kirche auf dem II. Konzil von Lyon (1274), Bonn 1964 (Bonner Historische Forschungen 24), bes. S. 65-75; Jean Longnon: Les vues de Charles d'Anjou pour la deuxième croisade de Saint Louis: Tunis ou Constantinople ?, in: Septième centenaire de la mort de Saint Louis. Actes des colloques de Royaumont et de Paris (21-27 mai 1970), Paris 1976, S. 183-195, bes. 192 f. Zum Adressaten vgl. nun Andreas Fischer: Kardinäle im Konklave. Die lange Sedisvakanz der Jahre 1268 bis 1271, Tübingen 2008 
adressiert, ebenfalls achtzehnfach gesiegelt und enthält als Insert die Aufforderung Clemens' IV. an den byzantinischen Kaiser vom 4. März 1267, zur katholischen Kirche zurückzukehren ${ }^{136}$. Das dritte ist an den französischen König selbst adressiert, in dem er als arbiter der griechisch-lateinischen Verhandlungen gelobt und um Unterstützung gebeten wird. Auch dieses Dokument hat dieselben äußeren Merkmale ${ }^{137}$. Durch die exzellente Untersuchung von Andreas Fischer über die lange Sedisvakanz von 1268 bis 1271 wissen wir nun von noch weiteren gemeinsamen Urkunden der Kardinäle, von denen einige als Original, zum Teil mit Siegeln, erhalten blieben. Als Beispiele seien genannt: Jene vom 9. Mai 1269 zum Konflikt mit einem Annibaldi um das bei Velletri gelegene Kastell Lariano (19 Siegel, davon 13 fragmentarisch erhalten; Velletri, Biblioteca Civica); eine andere vom 28. Juli 1270 zum Konflikt zwischen Kommune und Geistlichkeit von Perugia (17 Siegel, davon 12 erhalten; im Archivio di Stato von Perugia); eine dritte vom 9. Februar 1269 zur Wahl des Eudes de Rougemont zum Erzbischof von Besançon (18 Siegel, alle verlorenen; in Besançon, Archives départementales du Doubs). ${ }^{138}$ Abschließend soll auf entsprechende Urkunden vom Ende des 13. Jahrhunderts hingewiesen werden. (Ein vergleichbares Dokument ist der Brief der elf Kardinäle vom 11. Juli 1294 an den neu gewählten Papst Cölestin V., in dem sie ihm den Gehorsam versprachen und den Einsiedler anflehten, die Wahl anzunehmen. Vom selben Tag stammt ein von denselben Kardinälen eigenhändig unterfertigtes Dekret, mit dem sie die mühevoll errungene Einigung sanktionierten. Beide Urkunden, heute noch im Vatikanischen Archiv aufbewahrt, tragen die Siegel aller elf Kardinäle ${ }^{139}$.

Handelte Paul Fridolin Kehr richtig, als er einige Jahre nach dem Erscheinen des ersten Bandes der Italia Pontificia die von Kardinälen ausgehenden Schriftstücke mit in seine großartige Sammlung der Papsturkunden aufnahm?

(Bibliothek des Deutschen Historischen Instituts in Rom 118), S. 132-142. Ich danke dem Autor, daß er mir die betreffenden Seiten schon im Manuskript zur Verfügung stellte.

136 Signatur: J 420 Nr. 5, 6. Ungedruckt, verzeichnet bei Berger (wie vorige Anm.) S. 444 Nr. 5695. Der Brief Clemens' IV. bei Роттнаsт 19955.

137 Signatur: J $420 \mathrm{~N}^{\circ}$ 1, 2, ediert bei Berger (wie Anm. 135) S. 439-443 Nr. 5691; Роттнаsт 20505. Vgl. den Katalog der Ausstellung: La France de Saint Louis. Septième centenaire de la mort de Saint Louis, Paris 1970-1971, S. 89 Nr. 157. Die Siegel sind beschrieben bei Louis DouËT D'ArcQ: Inventaires et documents. Collection de sceaux 2, Paris 1867, S. 431-434 Nr. 6139-6156.

138 Fischer: Kardinäle (wie Anm. 135) S. 255-365, hier S. 282 mit Anm. 104, S. 305 mit Anm. 205, S. 355 mit Anm. 399.

139 Angelo Mercati: Il decreto e la lettera dei Cardinali per l'elezione di Celestino V, in: BISI 48 (1932) S. 1-17 (mit Abb. des Decretum); Archivio Segreto Vaticano, hg. v. Terzo Natalini/Sergio Pagano u.a., Florenz 1991, S. 109 (Abb. des gesiegelten Briefes). Vgl. Peter Herde: Cölestin V. (1294) (Peter vom Morrone). Der Engelpapst, Stuttgart 1981 (Päpste und Papsttum 16), S. $71 \mathrm{f}$. 
Zweifellos, und - wie mir scheint - aus zwei Gründen. Zum einen stellen die Urkunden der Legaten, die Briefe der Kardinäle und die von diesen innerhalb der kurialen Gerichtsbarkeit verfaßten Texte eine wichtige, ja unverzichtbare Quelle für die Beziehungen zwischen dem Papsttum und den anderen Gliedern der Christianitas dar. Zum anderen spiegeln sie die Verfassungswirklichkeit der kirchlichen Zentrale seit der Mitte des 11. Jahrhunderts, die aus dem Papst und den Kardinälen bestand. Obwohl das Papsttum seit dem Einsetzen der Reform den Anspruch auf seine plenitudo potestatis immer höher auftürmte, ist es ohne das Kardinalskollegium in der Realität der Leitung der Kirche nicht denkbar.

\section{Riassunto}

Le carte dei cardinali, esaminate qui per l'arco cronologico che va dalla metà dell'XI fino al primo XIII secolo, riguardano in un primo momento solo le loro opere, di natura soprattutto teologica, esegetica e catechetica, da loro compilate di norma prima di essere chiamati nelle vicinanze del papa. Per i decenni del periodo riformatore, e poi per la fase tra il tardo XII e primo XIII secolo, si constata una maggiore densità. I diplomi dei cardinali, emessi nella maggior parte nella loro qualità di legati, sono stati analizzati in modo convincente da Stefan Weiss, sicché può bastare in questo contesto un breve riassunto dei risultati. Le loro lettere, di cui solo sporadicamente si sono conservati gli originali o singole copie, ma che per la maggior parte sono state tramandate in diverse raccolte per le quali il periodo tra l'XI e il XIII secolo costituisce un tempo d'oro, dimostrano quanto $\mathrm{i}$ cardinali, cioè i più importanti membri della curia papale, fossero coinvolti in tutte le grandi questioni del tempo. Due ulteriori gruppi di testi sono stati analizzati: le carte che essi producevano all'interno della curia e per la maggior parte nel contesto dei processi giuridici, e le lettere cardinalizie collettive, scritte di norma nei momenti critici della storia del papato, quando i cardinali cercavano dei sostenitori, raccomandandosi come i rappresentanti della vera Chiesa romana, o esponevano il loro punto di vista. 


\title{
Epigraphische Zeugnisse der Päpste in Rom. Ein Desiderat der Italia Pontificia?
}

\author{
Sebastian Scholz
}

Paul Fridolin Kehr erklärte in der Vorbemerkung zum ersten Band der Italia Pontificia, das Werk solle die Privilegien, Briefe und andere Handlungen der Päpste zugunsten der Kirchen, Klöster und Einzelpersonen in Rom nach dem Empfängerprinzip verzeichnen ${ }^{1}$. Die Beschäftigung mit den einzelnen Regesten zeigt dem Benutzer sehr schnell, daß sie außer den Rechtsinhalten von Urkunden auch Weihehandlungen, die Bergung von Reliquien ${ }^{2}$ oder Baunachrichten $^{3}$ vermerken. Schon aufgrund der Aufnahme dieser päpstlichen Handlungen in die Regesten konnten sich Kehr und seine Mitarbeiter nicht damit zufrieden geben, nur auf die vorhandenen Privilegien, Briefe und Dekrete zurückzugreifen. Sie mußten weitere Quellen, wie etwa den «Liber pontificalis», daraufhin untersuchen, ob sich aus den dort berichteten Maßnahmen Hinweise auf päpstliche Entscheidungen und Handlungen ergeben, die nicht in einer Urkunde überliefert sind. Für diesen Nachweis hat Kehr auch Inschriften herangezogen. Dabei haben Kehr und seine Mitarbeiter natürlich besonders jene Inschriften interessiert, die man als Urkunden- oder Rechtsinschriften bezeichnet, weil sie einen Rechtsakt festhalten, und die nach dem Inhalt und zum Teil auch nach dem Formular den Urkunden nahestehen ${ }^{4}$. Hier wäre etwa jenes große Privileg Gregors II. (715-731) an St. Peter zu nennen, in der das Öl aus einer Reihe von Olivenbaumpflanzungen für den Unterhalt von Kirchenlichtern reserviert wird, die zu Ehren von Petrus und Paulus brennen ${ }^{5}$. Auch die auf drei Marmortafeln publizierten Beschlüsse der Synode, die Papst Gregor III. (731 741) am 12. April 732 in St. Peter in Rom abhielt, um die Gottesdienstordnung für das neue Oratorium festzulegen, das er dort hatte errichten lassen, finden in

1 IP 1 S. VI: „Erunt igitur in hoc Italiae pontificiae primo volumine sub suo cuiusque titulo privilegia, litterae aliaque acta, quae Romani pontifices urbis Romae ecclesiis monasteriis singulisque personis concesserunt".

2 Vgl. etwa IP 1 S. 50 Nr. 1 und S. 123 Nr. 1.

3 Vgl. etwa IP 1 S. 46 Nr. 5 und 6, S. 51 Nr. 2.

4 Zur Definition vgl. Wolfgang MüLLER: Urkundeninschriften des deutschen Mittelalters, Kallmünz 1975 (Münchener Historische Studien. Abteilung Geschichtliche Hilfswissenschaften 13), S. 1 f.; Rudolf M. KLoos: Einführung in die Epigraphik des Mittelalters und der frühen Neuzeit, Darmstadt 1980, S. $51 \mathrm{f}$.

5 Giovanni Baptista De Rossi: Inscriptiones Christianae Urbis Romae septimo saeculo antiquiores Bd. 2/1, Rom 1888, S. 209 f.; IP 1 S. 136 f. Nr. 8. 
der Italia Pontificia breite Erwähnung ${ }^{6}$. Ebenso werden die in einer Inschrift festgehaltenen Oblationsstiftungen Gregors III. für San Paolo fuori le mura vermerkt ${ }^{7}$. Schon diese drei Beispiele machen deutlich, wie breit das Spektrum rechtlich relevanter Inschriften in Rom ist. Aber Kehr hat sich bei seiner Auswertung keineswegs auf Inschriften beschränkt, die in Form und Sprache den Urkunden ähnlich sind, sondern er hat auch metrische Inschriften herangezogen. So diente ihm, um nur ein Beispiel zu nennen, die in Hexametern abgefaßte Inschrift unter dem Apsismosaik von Santa Cecilia zum Nachweis dafür, daß Papst Paschalis I. (817-824) die Körper zahlreicher Märtyrer dort bestatten ließ und die Kirche weihte ${ }^{8}$. Die Berücksichtigung der Inschriften in der Italia Pontificia scheint somit umfassend zu sein, so daß die Frage nach einem Desiderat gar nicht erst gestellt werden müßte, hätten die Inschriften als Quelle nicht eine besondere Eigenart, die in der Italia Pontificia nicht berücksichtigt wird, und die uns nötigt, doch noch einmal genauer hinzuschauen.

Die Italia Pontificia bietet von allen Inschriften ebenso wie von den Urkunden ein Regest des dispositiven Teils. Festgehalten werden also Rechtsakte und entsprechende Handlungen der Päpste. Bei den Inschriften findet sich im Kommentar zudem noch eine Angabe des genauen Anbringungsorts, da dieser für die Aussage und Interpretation der Texte oft von wesentlicher Bedeutung ist. In der neueren Forschung gilt denn auch die Präsenz in der Öffentlichkeit als wesentliches Merkmal von Inschriften". Im Gegensatz zu Urkunden, die im Archiv verschwinden, sind Inschriften auf ständige Wahrnehmung angelegt. Und hier liegt das eigentliche Problem! Inschriften besitzen normalerweise keine klare Ausrichtung auf einen bestimmten Empfänger wie es bei Urkunden der Fall ist, sondern sie richten sich an eine mehr oder weniger große Öffentlichkeit.

6 IP 1 S. 137 Nr. 9; vgl. dazu Hubert Mordek: Rom, Byzanz und die Franken im 8. Jahrhundert. Zur Überlieferung und kirchenpolitischen Bedeutung der Synodus Romana Papst Gregors III. vom Jahre 732 (mit Edition), in: Person und Gemeinschaft im Mittelalter. Karl Schmid zum fünfundsechzigsten Geburtstag, hg.v. Gerd Althoff u. a., Sigmaringen 1988, S. 123-156, hier S. 147-154, mit der maßgeblichen Edition der Beschlüsse; vgl. zu den Hintergründen Sebastian Scholz: Politik - Selbstverständnis Selbstdarstellung. Die Päpste in karolingischer und ottonischer Zeit, Stuttgart 2006 (Historische Forschungen 26), S. 36-42.

7 IP 1 S. 166 f. Nr. 5. Die heute nur noch in Fragmenten vorhandene Inschrift ist wiedergegeben bei Hartmann Grisar: Analecta Romana I, Roma 1899, S. 169 f. mit Abb.; vgl. auch die Abbildung bei Franz Alto Bauer: Das Bild der Stadt Rom im Frühmittelalter. Papststiftungen im Spiegel des Liber pontificalis von Gregor dem Dritten bis zu Leo dem Dritten, Wiesbaden 2004 (Palilia 14), S. 59; eine neue Edition des Textes bietet Angelus Albert Hëussling: Mönchskonvent und Eucharistiefeier, Münster 1973 (Liturgiewissenschaftliche Quellen und Forschungen 58), S. 364; zur Wertung der Inschrift vgl. Scholz: Politik (wie Anm. 6) S. 43 f.

8 IP 1 S. 123 Nr. 1.

9 Robert Favreau: Épigraphie médiévale, Turnhout 1997 (L'Atelier du médiéviste 5), S. $31 \mathrm{f}$. 
Diese Öffentlichkeit wird durch die Kriterien Zugangsmöglichkeit und Verständnismöglichkeit definiert ${ }^{10}$. Zudem geht es in den Inschriften häufig nicht in erster Linie darum, einen dispositiven Akt zugunsten einer bestimmten Person oder Institution festzuhalten, sondern sie dienen in besonderer Weise der Selbstdarstellung der Päpste. Öffentlichkeitscharakter und Funktion der Inschriften sind also eng mit einander verflochten.

Dies soll hier exemplarisch an einigen Inschriften aus dem 4., dem 9. und dem frühen 10. Jahrhundert erläutert werden. Mit einer Ausnahme werden dabei päpstliche Bauinschriften in Rom behandelt, weil sich an ihnen besonders gut zeigen läßt, daß die Texte sehr viel mehr bezwecken, als nur über den Bau einer Kirche oder einer Verteidigungsanlage zu informieren. Kehren wir zunächst zu der schon erwähnten Inschrift unter dem Apsismosaik der Kirche Santa Cecilia zurück, die im Jahr 820 fertiggestellt wurde ${ }^{11}$. Das Regest der Inschrift ist kurz und bündig: Paschalis I. setzte die Körper der Heiligen unter dem Altar bei und weihte die Kirche ${ }^{12}$. Vollständig lautet der Text der Inschrift folgendermaßen: „Dieses Haus, das einst unter dem Alter der Zeit zerfallen war, erstrahlt prächtig, weil es mit verschiedenen Metallen errichtet wurde. Der segensreiche Bischof Paschalis hat diese Kirche des Herrn in einen besseren $\mathrm{Zu}-$ stand versetzt, die er auf einem berühmten Grund errichtete. Dieses goldgeschmückte Geheimnis erstrahlt für jene, welche die Edelsteine der Kirche sind. Froh durch die Liebe Gottes hat Paschalis die heiligen Körper vereinigt - durch den Schmuck Caecilias und durch ihre Gefährten erstrahlt hier die Jugend deren heilige Glieder zuvor in den Krypten ruhten. Durch die Jahrhunderte für immer geschmückt jubelt Rom vor Freude." ${ }^{13}$

10 Der Begriff „Öffentlichkeit“ läßt sich für das Mittelalter nicht genau abgrenzen. Peter von Moos: Das Öffentliche und das Private im Mittelalter. Für einen kontrollierten Anachronismus, in: Das Öffentliche und Private in der Vormoderne, hg.v. Gert MeLville/Peter von Moos, Köln/Weimar/Wien 1998 (Norm und Struktur 10), S. 3-83, hier S. 23-25, hat sich mit den Dimensionen Zugänglichkeit, Handlungsbefugnis und Interesse zur Charakterisierung des Öffentlichen und des Privaten auseinandersetzt. Davon ausgehend scheint sich die Öffentlichkeitsfunktion der Inschriften am besten durch die genannten Kriterien Zugangsmöglichkeit und Verständnismöglichkeit definieren zu lassen, vgl. auch Scholz: Politik (wie Anm. 6) S. 17 mit Anm. 27 und S. $20-$ 23.

11 Zur Datierung vgl. Antonella Ballardini: Dai gesta di Pasquale I secondo il Liber Pontificalis ai monumenta iconografici delle basiliche romane di Santa Prassede, Santa Maria in Domnica e Santa Cecilia in Trastevere (I), in: ASRSP 122 (1999) S. 5-67, hier S. 22.

12 IP 1 S. 123 Nr. 1: „Paschalis I sanctorum corpora sub altari collocat et ecclesiam dedicat."

13 Vgl. Liber pontificalis, Bd. 2, hg.v. Louis Duchesne, Paris ${ }^{2}$ 1955, S. 66 Anm. 22: Haec domus ampla micat variis fabricata metallis / Olim quae fuerat confracta sub tempore prisco I Condidit in melius Paschalis praesul opimus / Hanc aulam domini formans fundamine claro / Aurea gemmatis resonant haec Dindima templi / Laetus amore Dei coniunxit corpora sancta 
Die Inschrift thematisiert die Sorge des Papstes um die Instandsetzung der Kirche und um eine angemessene Verehrung Caecilias und ihrer Gefährten. Zugleich wird die Bedeutung der Heiligen für Rom betont. Es geht also um den korrekten Kultvollzug, um die angemessene Verehrung der Heiligen, die Rom auf ewig schmücken. Indem Paschalis seine Bemühungen um diese Dinge öffentlich machte, dokumentierte er seine korrekte Amtsführung und sorgte zugleich für seine Memoria als Stifterpapst ${ }^{14}$. Das zitierte Regest erfaßt von diesen Aussagen kaum etwas. Zudem ist die Angabe über die Weihe lediglich erschlossen, denn sie wird weder in der Inschrift, noch im «Liber pontificalis» erwähnt.

Ein weiteres Problem besteht darin, daß in dem Regest der Zusammenhang mit dem Apsisbild, zu dem die Inschrift gehört, ausgeblendet wird. Dieses Apsismosaik zeigt in der Mitte Christus, der den rechten Arm im Segensgestus erhoben hat, während er mit der Hand des angewinkelten linken Arms eine geschlossene Schriftrolle hält. Zur Linken und Rechten Christi stehen Petrus und Paulus ${ }^{15}$. Neben Paulus befindet sich die Titelheilige Caecilia, die ihren Arm um Paschalis gelegt hat und ihn dadurch Christus anempfiehlt. Paschalis ist durch einen eckigen Nimbus, seine liturgische Tracht mit dem Pallium sowie durch das Kirchenmodell gekennzeichnet. Auf der rechten Bildseite erscheinen neben Petrus die Heiligen Tiburtius und Agatha. Nach unten wird die Darstellung von einem Lämmerfries und der Stiftungsinschrift in Hexametern abgeschlossen ${ }^{16}$.

/ Ceciliae et sociis rutilat hic flore iuventus / Quae pridem in cruptis pausabant membra beata / Roma resultat ovans semper ornata per evum; vgl. auch De Rossi: Inscriptiones 2/1 (wie Anm. 5) S. 151; Gerhart B. Ladner: Die Papstbildnisse des Altertums und des Mittelalters, Bd. 1, Città del Vaticano 1941, S. 140; Favreau: Épigraphie médiévale (wie Anm. 9) S. 118.

14 Vgl. dazu Scholz: Politik (wie Anm. 6) S. 156 f.

15 Die Kerngruppe des Mosaiks ist nach dem Vorbild der Traditio-legis-Darstellungen gestaltet, doch im Gegensatz zu dem Apsisbild in S. Cecilia übergibt Christus auf den eigentlichen Traditio-legis-Darstellungen die entrollte Gesetzesrolle an Petrus, der mit ihm ebenso wie Paulus durch entsprechende Gesten verbunden ist; vgl. dazu Caecilia Davis-Weyer: Das Traditio-Legis-Bild und seine Nachfolge, in: Münchner Jahrbuch der bildenden Kunst 12 (1961) S. 7-45, hier S. 7-21; Charles Pietri: Roma christiana. Recherches sur l'Église de Rome, son organisation, sa politique, son idéologie de Miltiade à Sixte III (311-440), 2 Bde., Rome 1976 (Bibliothèque des Écoles françaises d'Athènes et de Rome 224), hier Bd. 2 S. 1414-1427.

16 Ladner: Papstbildnisse 1 (wie Anm. 13) S. 139 f.; Rotraut Wisskirchen: Das Mosaikprogramm von S. Prassede in Rom. Ikonographie und Ikonologie, Münster 1990 (Jahrbuch für Antike und Christentum, Ergänzungsband 17), Taf. 26, Abb. 82a und Taf. 27, Abb. 82b; Klaus Gereon Beuckers: Stifterbild und Stifterstatus. Bemerkungen zu den Darstellungen Papst Paschalis I. (817-24) in Rom und ihren Vorbildern, in: Form und Stil. Festschrift für Günther Binding zum 65. Geburtstag, hg. v. Stefanie Lieb, Darmstadt 2001, S. 56-74, hier S. 56-58 mit Abb. $1 \mathrm{f}$. 
Da die Aussage des Bildprogramms und der dazu gehörigen Inschrift nicht isoliert betrachtet werden können, müssen Mosaik und Inschrift noch einmal im Zusammenhang untersucht werden. Die im Mittelpunkt des Apsismosaiks von Santa Cecilia stehende Gruppe aus Christus, Paulus und Petrus kann als Hinweis auf Rom als Zentrum des Glaubens gedeutet werden. Denn beide Apostel, deren Nähe zu Christus unmißverständlich zum Ausdruck gebracht wird, waren in Rom begraben. In Verbindung mit der Inschrift weisen die Bilder Rom zugleich als Ruhestätte der Heiligen und als Hort ihrer Verehrung schlechthin aus. Der Papst erscheint dabei als der Garant des Kultes und der Verehrung. Die römische Kirche, die durch die Apostel, die den Glauben verkündet haben und durch die Märtyrer, die für den Glauben gestorben sind, geschmückt ist, sollte als Wahrerin des richtigen Glaubens gezeigt werden. In solchen Aussagen liegt die eigentliche Bedeutung päpstlicher Bauinschriften, die hierin eine lange Tradition haben, die mit Papst Damasus (366-384) im vierten Jahrhundert beginnt.

Um den Anfang dieser Tradition deutlich zu machen, sollen hier zwei Inschriften des Papstes Damasus vorgestellt werden, von denen sich eine im vatikanischen Baptisterium, die andere an der Kultstätte für die Apostel Petrus und Paulus an der Via Appia befand. Beide Inschriften sind nicht in der Italia Pontificia verzeichnet. Die leider nur unvollständig überlieferte Inschrift am vatikanischen Baptisterium lautet:

"Nicht durch menschliche Kraft und nicht durch die Kunst als Lehrerin ... sondern mit Hilfe des Petrus, dem das Tor zum Himmel anvertraut worden ist, hat Damasus, der Bischof Christi, dies erstellt. Einen einzigen Sitz des Petrus und eine einzige wahre Taufe gibt es, und keine Fesseln binden ..." ${ }^{\text {17 }}$

Ein Regest dieser Inschrift würde nach dem Modell der Italia Pontificia wohl so lauten: Damasus I. errichtet ein Baptisterium. Doch im Kern geht es in dieser Inschrift um etwas völlig anderes. Zunächst wird hier die Nähe des Damasus zu Petrus hervorgehoben. Denn nicht durch menschliche Kraft ist der Bau des Baptisteriums ermöglicht worden, sondern durch die von Petrus gewährte Hilfe, der seinem Nachfolger beisteht. Anschließend spielt Damasus auf Matthäus 16, 19 an, wo es heißt: "Ich werde dir die Schlüssel des Himmelreiches geben; was du auf Erden binden wirst, das wird auch im Himmel gebunden sein, und was du auf Erden lösen wirst, das wird auch im Himmel gelöst sein”. Diese Bibelstelle wurde immer wieder als Beleg für die besondere Stellung Petri unter den Aposteln angeführt, und bei Damasus ergibt sich aus

17 Epigrammata Damasiana, hg.v. Antonio Ferrua, Città del Vaticano 1942, Nr. 4: Non haec opibus non arte magistra ... / Sed praestante Petro cui tradita ianua caeli est / antistes Christi conposuit Damasus. / Una Petri sedes unum verumque lavacrum / Vincula nulla tenent ...; vgl. auch Ursula Reutter: Damasus, Bischof von Rom (366-384). Leben und Werk, Diss. masch. Jena 1999, S. 76. 
ihr auch der Vorrang Roms vor allen anderen Bischofssitzen ${ }^{18}$. Deshalb kann es auch nur einen einzigen Sitz des Petrus geben, was im nächsten Vers betont wird. Ebenso gibt es nur eine einzige wahre Taufe. Die Verbindung dieser beiden Aussagen - ein einziger Sitz und eine einzige wahre Taufe - läßt Rom als den Ort erscheinen, an dem durch die Autorität des Petrus der wahre Glaube gesichert wird.

Die Bedeutung Roms als Sitz der Apostel unterstreicht auch die Inschrift an der Via Appia an der Kultstätte für die Apostel Petrus und Paulus:

"Du, der du nach den Namen von Petrus und Paulus fragst, sollst erfahren, daß hier einst diese Heiligen wohnten. Der Osten schickte sie als Jünger, was wir gern bekennen. Wegen des Verdienstes ihres Blutes folgten sie Christus durch die Sterne und gelangten in den himmlischen Schoß und in das Reich der Frommen; und Rom kam das Verdienst zu, sie als seine Bürger zu beanspruchen. Dies will, ihr neuen Sterne, Damasus zu eurem Lob verkünden." ${ }^{19}$

Rom war also die wahre Heimat und der wahre Sitz der Apostel Petrus und Paulus. Hier in Rom hatten sie zuletzt gewirkt und nur Rom konnte sie deshalb als seine Bürger beanspruchen. Damit trat Damasus Vorstellungen entgegen, wie sie etwa im Jahr 338 im Brief der östlichen arianischen Bischöfe an Papst Julius (337-352) formuliert worden waren ${ }^{20}$. Die Bischöfe hatten Rom zwar einen besonderen Rang zugebilligt, weil Petrus und Paulus dort das Martyrium erlitten hatten, aber zugleich hatten sie ihre eigene Bedeutung daraus abgeleitet, denn schließlich war es der Osten gewesen, der Rom diese Männer gesandt hatte. Nach Damasus ist es aber nur Rom, das diese neuen Sterne für sich beanspruchen darf. Für ein Regest in der Form, wie sie in der Italia Pontificia üblich ist, kommt die Inschrift nicht in Frage. Und doch handelt es sich hier um einen Text, den Damasus selbst verfaßt und dessen inschriftliche Ausführung er selbst veranlaßt hat ${ }^{21}$. Für die Erforschung der Papstgeschichte ist die Kenntnis dieser Texte deshalb von großer Bedeutung, weil Damasus in diesen und weiteren Inschriften seine Auffassung in Rom öffentlich machte, die er auch auf den römischen Synoden und in den Synodalschreiben verkündete: Rom ist das Haupt der Christenheit und der Hort der Orthodoxie. Dieses Beispiel zeigt, daß

18 Zum Pontifikat des Damasus und seiner Primatslehre vgl. umfassend Reutter (wie Anm. 17) passim.

19 Ferrua: Epigrammata Damasiana (wie Anm. 17) Nr. 20: Hic habitasse prius sanctos cognoscere debes / Nomina quisque Petri pariter Paulique requiris. / Discipulos Oriens misit quod sponte fatemur / Sanguinis ob meritum Christum per astra secuti / Aetherios petiere sinus regnaque piorum: / Roma suos potius meruit defendere cives. / Haec Damasus vestras referat nova sidera laudes; vgl. REuTTER (wie Anm. 17) S. 98; zur Bedeutung der Inschrift für die Bewertung der Primatslehre des Damasus vgl. ebd. S. $516 \mathrm{ff}$.

20 Vgl. dazu Reutter (wie Anm. 17) S. 520.

$21 \mathrm{Zu}$ Damasus als Verfasser und Auftraggeber von Inschriften vgl. Reutter (wie Anm. 17) S. $62-66$. 
Inschriften schon sehr früh ein wichtiges Medium für die Formulierung päpstlicher Ansprüche sowie der päpstlichen Selbstdarstellung waren. Sie sind dies das ganze Mittelalter über geblieben, auch wenn sie bisher von der Forschung kaum zur Kenntnis genommen worden sind.

Kehren wir in das 9. Jahrhundert zurück, und zwar zu einer Bauinschriften, die unter Leo IV. (847-855) entstand, heute jedoch verloren ist. Die älteste Abschrift stammt aus dem Ende des 15. Jahrhunderts und wurde von Pietro Sabino erstellt ${ }^{22}$. Die Inschrift befand sich in der Kirche des heiligen Silvester und des heiligen Martin, heute San Martino ai Monti, unter dem ebenfalls nicht erhaltenen Apsismosaik, dessen Darstellung unbekannt ist. Das Gedicht lobt die Vollendung der Kirche und wurde in der Italia Pontificia in einem Regest festgehalten, das knapp berichtet, Leo habe bei der Kirche des heiligen Silvester und des heiligen Martin ein Kloster gegründet und Mönche angesiedelt, die Gott beständig Lobgesänge darbringen sollten ${ }^{23}$. Der immerhin zwölf Hexameter umfassende Text der Inschrift lautet:

„Der Bischof Sergius hat diese Kirche, die ihr seht, begonnen, der er im Sterben liegend keine Zierde mehr verschaffen konnte. Aber sobald Papst Leo IV. die Höhe des römischen Stuhles empfangen hatte, hat er, von göttlicher Liebe angerührt, sie kunstvoll besser vollendet, als sie vorher geblieben war. Und er hat die ganze Kirche mit frommen Bildern ehrenvoll geschmückt. Er hat auch ein ehrwürdiges Kloster eingerichtet und Mönche dort eingesetzt, die dem Herrn fortwährende Lobgesänge darbringen sollen ${ }^{24}$, damit er (Leo) durch solche Geschenke zu den himmlischen Reichen emporsteigen kann, in denen der frohlockende Martin und der segenspendende Silvester erstrahlen und sich zugleich mit dem Vorsteher Christus freuen, für deren Verdienste diese ihnen geweihte Kirche erstrahlt. ${ }^{\prime 25}$

22 De Rossi: Inscriptiones 2/1 (wie Anm. 5) S. 437 Nr. 119; Angelo Silvagni: La basilica di S. Martino ai Monti, l'oratorio di S. Silvestro e il Titolo constantiniano di Equizio, Roma 1912, S. $91 \mathrm{f}$.

23 IP 1 S. 46 Nr. 6; zur Baugeschichte vgl. René Vielliard: Les origines du titre de SaintMartin aux Monts a Rome, Rom/Paris 1931 (Studi di Antichità cristiana 4), S. 72-101.

24 Diese Stelle wurde bereits 983 im Epitaph für Benedikt VII. zitiert, vgl. Renzo U. Montini: Le tombe dei papi, Rom 1957, S. 160 f. mit Abb. 45: Hiccae monasterium statuit monachosque locavit / Qui laudes domino nocte diequae canunt; dies ist ein wichtiger Anhaltspunkt dafür, daß die Inschrift Leos tatsächlich zeitgenössisch ist; zu dem Epitaph Benedikts VII. vgl. grundsätzlich Angelo Silvagni: Note d'epigrafia medievale, in: ASRSP 32 (1909) S. 445-463, hier S. 453-460.

25 Liber pontificalis 2 (wie Anm. 13) S. 139 Anm. 60; Silvagni: Basilica di S. Martino (wie Anm. 22) S. 92: Sergius hanc coepit quam cernitis aulam / Cui moriens nullum potuit conferre decorem / Sed mox papa Leo quartus dum culmina sumpsit / Romanae sedis divino tactus amore / Perfecit sollers melius quam coepta manebat / Atque pia totam pictura ornavit honeste / Coenobiumque sacrum statuit monachos locavit / Qui domino assiduas valeant persolvere laudes / Talibus ut donis caelestia scandere possit / Regna quibus Martinus ovans 
Die Bedeutung der Inschrift lag für die Italia Pontificia vor allem darin, daß sie die Einrichtung des Klosters durch Leo IV. bezeugte, während die Vita des Papstes im «Liber pontificalis» darüber nichts berichtet. Nach dem Bericht des «Liber pontificalis» hat Leo vor allem für die farbige Fassung des Innenraums der Kirche gesorgt und einen Altar gestiftet ${ }^{26}$. Warum verschweigt der «Liber pontificalis» die übrigen Maßnahmen des Papstes für die Kirche, die von der Inschrift so gepriesen werden? Ein Blick in die Vita Sergius' II. liefert die Antwort. Danach war der Neubau der zuvor verfallenen Kirche nämlich bereits unter Sergius fertiggestellt und reich ausgestattet worden, unter anderem mit dem Apsismosaik, das dann unter Leo IV. um die besagte Inschrift ergänzt wurde $^{27}$. Auch das Kloster war bereits von Sergius gebaut worden, der dort eine Mönchsgemeinschaft eingerichtet hatte ${ }^{28}$. Was war hier passiert? Offenbar hat Leo IV. die Inschrift bewußt dazu genutzt, seinen Anteil an den Baumaßnahmen aufzuwerten. Denn die Inschrift läßt keinen Zweifel daran, daß Leo sowohl für die Wandmalereien als auch für den übrigen Schmuck der Kirche gesorgt hat. Unter Sergius habe die Kirche noch keine Zierde besessen und erst Papst Leo habe sie vollendet, indem er sie kunstvoll in einen bessern Zustand als zuvor brachte. Die Gründung des Klosters und die Einrichtung des Konvents nimmt die Inschrift ebenfalls für Leo in Anspruch und hebt hervor, er habe dies getan, um durch solche Geschenke zu den himmlischen Reichen emporsteigen zu können. Leo hat sich damit in die Rolle des Stifterpapstes gedrängt, ihm sollte das Verdienst des eigentlichen Stifters angerechnet werden und ihm die besondere Memoria des Stifters zuteil werden. Während die Angaben des «Liber pontificalis» im Archiv schlummerten, konnte sich hier jeder Kirchenbesucher davon überzeugen, daß die Vollendung der Kirche und die Errichtung des Klosters von Leo veranlaßt worden waren. Wie erfolgreich diese Maßnahme war, sieht man daran, daß Leo IV. in der Forschungsliteratur zur Kirche des heiligen Silvester und des heiligen Martin stets ein erheblicher Anteil am Bau der Kirche und des Klosters eingeräumt wird. So hat Renè Vielliard in seiner wichtigen Arbeit über die Gründung und die Baugeschichte der Kirche die Inschrift und den entsprechenden Eintrag aus der Vita Leos im «Liber pontificalis» sogar hintereinander gestellt, ohne auf den Unterschied hinzuweisen ${ }^{29}$. Später machte Guy Ferrari zwar auf den Widerspruch zwischen dem Text im «Liber pontificalis» und der Inschrift aufmerksam, doch schloß er daraus, daß

Silvester et almus / Praefulgent gaudentque simul cum praesule Christo / Quorum pro meritis haec templa dicata coruscant.

26 Liber pontificalis 2 (wie Anm. 13) S. 131.

27 Ebd. S. 93-96, besonders S. 93.

28 Ebd. S. 97; IP 1 S. 46 Nr. 5.

29 Vielliard: Origines (wie Anm. 23) S. 71. 
tatsächlich erst Leo IV. das Kloster endgültig fertiggestellt habe ${ }^{30}$. Und auch der entsprechende Eintrag in der Italia Pontificia ist irreführend. Sie meldet für Sergius II. zu Recht den Bau des Klosters und die Einrichtung des Konvents ${ }^{31}$. Doch zu Leo IV. heißt es dann, Leo habe das von Sergius begonnene (!) Kloster gebaut und den Konvent eingerichtet ${ }^{32}$. So führt Leo IV. durch seine Inschrift die Forschung noch heute in die Irre!

Mit den Inschriften, die zu Beginn des 10. Jahrhunderts unter Papst Sergius III. (904-911) entstanden, und die alle in der Italia Pontificia fehlen, betreten wir die politische Bühne Roms. Die Geschichte Sergius' III. ist eng mit dem Schicksal Papst Stephans VI. (896-897) verknüpft. Dieser hatte im Jahr 897 die berüchtigte Leichensynode gegen seinen Vorgänger Formosus abgehalten. Dabei war der tote Papst aus seinem Grab gerissen, vor die Synode gestellt, wegen des unerlaubten Wechsels von seinem Bistum Porto auf die Kathedra Petri als illegitim verurteilt, verstümmelt und schließlich in den Tiber geworfen worden ${ }^{33}$. Bald darauf kam es jedoch zu einem Aufstand, in dessen Verlauf Stephan gefangengenommen und später ermordet wurde. Nach dem keine vier Monate dauernden Pontifikat des Romanus bemühte sich Papst Theodor II., Formosus zu rehabilitieren, doch starb er schon nach zwanzig Tagen. Bei der folgenden Wahl kam es dann zu einem Schisma zwischen Johannes IX. (898-900), der die Politik Theodors fortsetzen wollte, und dem Formosusgegner Sergius, der sich aber nicht durchsetzen konnte und vertrieben wurde. Johannes IX. ließ 898 auf der Synode von Ravenna seinen Widersacher Sergius absetzen und verdammen sowie den Pontifikat des Formosus wieder für gültig erklären ${ }^{34}$. Seine drei Nachfolger Benedikt IV. (900-903), Leo V. (Juli-September 903) und Christophorus (903-904) hielten an dieser Entscheidung fest. Erst als der 898 gescheiterte Sergius im Jahr 904 Christophorus beseitigen und doch noch als Papst in Rom einziehen konnte, kam es zu einem

30 Guy Ferrari: Early Roman Monasteries. Notes for the History of the Monasteries and Convents at Rome from the V through the X Century, Città del Vaticano 1957 (Studi di Antichità Cristiana 23), S. 300.

31 IP 1 S. 16 Nr. 5.

32 IP 1 S. 16 Nr. 6.

33 Harald Zimmermann: Papstabsetzungen des Mittelalters, Graz/Wien/Köln 1968, S. 5458; Wilfried Hartmann: Die Synoden der Karolingerzeit im Frankenreich und in Italien, Paderborn u.a. 1989 (Konziliengeschichte, Reihe A: Darstellungen), S. $388-$ 390; Michael Borgolte: Petrusnachfolge und Kaiserimitation. Die Grablege der Päpste, ihre Genese und Traditionsbildung, Göttingen 1989 (Veröffentlichungen des MaxPlanck-Instituts für Geschichte 95), S. 124 f.; Sebastian SchOlz: Transmigration und Translation. Studien zum Bistumswechsel der Bischöfe von der Spätantike bis zum Hohen Mittelalter, Köln/Weimar/Wien 1992 (Kölner Historische Abhandlungen 37), S. 219-224.

34 Vgl. Zimmermann: Papstabsetzungen (wie Anm. 33) S. 59-63; Hartmann: Synoden (wie Anm. 33) S. 390-395; Scholz: Transmigration (wie Anm. 33) S. 225-228. 
Umschwung, denn Sergius setzte die Verurteilung des Formosus wieder in $\mathrm{Kraft}^{35}$. Wie sehr er dabei unter Rechtfertigungsdruck geriet, kann man vor allem den von ihm gesetzten Inschriften entnehmen.

Im Jahr 907 ließ Sergius Papst Stephan VI., den man zuvor einer Bestattung in St. Peter für unwürdig erachtet hatte, dorthin überführen und mit einem Grabdenkmal ehren. Die Inschrift lautete:

"Von dieser Kapelle werden die Glieder des Papstes Stephan umschlossen, der in der Reihe der Väter der sechste genannt war. Dieser hat zuerst die Frechheit des hochmütigen Formosus zurückgewiesen, der sich der Höhe des apostolischen Stuhles bemächtigt hatte. Er berief ein Konzil ein, dem er als Bischof vorsaß. Den völlig erschöpften Dienern verschaffte er durch das Gesetz ihre Rechte. Und weil er als Papst sehr für die heilige Lehre kämpfte, ist er gefangen genommen und von seinem Sitz in die Tiefe gestoßen worden. Bei alledem wurde er mit Fesseln in der Tiefe des Kerkers gebunden, wo er erwürgt wurde und die menschliche Hülle abstreifte. Zehn Jahre später hat Papst Sergius in seiner Regierungszeit diesen hierhin übertragen und für ein heiliges Begräbnis gesorgt." 36

Die Italia Pontificia hat, soweit ich sehe, die Grabinschriften für Päpste grundsätzlich nicht aufgenommen, da sie keine rechtlich relevanten Handlungen überliefern. Trotzdem vermerken diese Inschriften eine durchaus wichtige Handlung des Papstes, nämlich die Sorge für die Memoria seines Vorgängers. Hier wie auch in anderen Fällen nennt sich der Papst ausdrücklich selbst als Auftraggeber ${ }^{37}$. Ziel der Inschrift war es, Stephan als guten Papst zu zeigen. Sein Kampf für die heilige Lehre manifestierte sich im Vorgehen gegen einen Invasor des Papststuhls und war zugleich der Grund für das tragische Ende Stephans. Auf diese Weise wurden seine Handlungen gerechtfertigt und er wurde zum Märtyrer stilisiert, dessen Gedächtnis' sich Sergius annahm. Aber auch das Verhalten des Sergius fand in der Inschrift seine Rechtfertigung. Da Stephan zu

35 Zimmermann: Papstabsetzungen (wie Anm. 33) S. 63 f.; Scholz: Transmigration (wie Anm. 33) S. 228-230.

36 De Rossi: Inscriptiones 2/1 (wie Anm. 5) S. 215 Nr. 81: Hoc Stephani papae clauduntur membra sacello / (2) Sextus dictus erat ordine quippe patrum / Hic primum reppulit Formosi spurca superbi /(4) Culmina qui invasit sedis apostolicae / Concilium instituit praesedit pastor et ipsi / (6) Lege satis fessis iura dedit famulis / Cumque pater multum certaret dogmate sancto / (8) Captus et a sede pulsus in ima fuit / Carceris interea vinclis constrictus in imo / (10) Stranguilatus ubi exuerat hominem / Post decimumque diem regnanti transtulit annum / (12) Sergius huc papa funera sacra colens; vgl. auch Liber pontificalis 2 (wie Anm. 13) S. 229 Anm. 4.

37 Vgl. dazu Sebastian Scholz: Papstepitaphien vom 6. bis zum 10. Jahrhundert. Eine Quellengattung zwischen „Memoria“, „Gesta“ und „Vita“, in: Mittellateinische Biographie und Epigraphik. Biografía latina medieval y epigrafiá, hg.v. Walter Berschin/ Juan Gómez Pallarès/José Martinez Gázquez, Heidelberg 2005, S. 89-106, hier S. 91 mit Anm. 11. 
Recht gegen Formosus vorgegangen war, war es nur konsequent, zu seinen Beschlüssen zurückzukehren und ihm die in Anbetracht seiner Taten und Leiden verdiente ehrenhafte Bestattung zukommen zu lassen ${ }^{38}$.

Auch den Wiederaufbau der unter Stephan VI. eingestürzten Lateranbasilika ${ }^{39}$ hat Sergius genutzt, um sich als rechtmäßigen und guten Papst darzustellen. Daß Sergius sich um die Erhaltung und Wiederherstellung von Kirchen bemühte, gehörte, wie längst bekannt ist, allgemein zu den Charakteristika einer guten Amtsführung. Doch zur Zeit Sergius' III. wurde der «Liber pontificalis», dessen Schenkungslisten früher über die entsprechenden päpstlichen Maßnahmen informiert hatten, nicht mehr weitergeführt ${ }^{40}$, und nur einige Inschriften, wie die folgende, geben über die Baumaßnahmen der Päpste Auskunft:

"Als der Augustus und Caesar (Konstantin) die ganze Welt lenkte, hat er diese heilige Halle für Silvester aufgrund der Salbung gegründet. Schon durch das heilbringende Wasser von der Lepra gereinigt, hat dieser als erster in der Welt eine Kirche für den Erlöser errichtet, der alles heilbringend vollbracht hat, und er hat dich, heiliger Johannes, als Schützer des Ortes kundgetan. Während die Jahre verflossen, sank die Kirche durch das Alter nieder, und als schon keine Hoffnung mehr da war, daß die alten Trümmer erhalten werden, hat Papst Sergius III. sie vom untersten Boden bis zum Dach wieder aufgerichtet und er hat diese Mauern reichlich geschmückt. “41

Sergius hat hier die Bedeutung der Lateranbasilika unter Hinweis auf die Silvesterlegende hervorgehoben, nach der Kaiser Konstantin der Große die Basilika als ersten offiziellen Kirchenbau überhaupt errichtet hatte, weil er von Papst Silvester durch die Taufe vom Aussatz geheilt worden war ${ }^{42}$. Aufgrund dieser historischen Bedeutung der Basilika leuchtete das Verdienst des Sergius

38 Vgl. dazu Scholz: Politik (wie Anm. 6) S. 260 f.

39 Vgl. Liber pontificalis 2 (wie Anm. 13) S. 229; Annales Alamannici zu 896, hg. v. Georg Heinrich Pertz, in: MGH SS 1, Hannover 1826, S. 47-56, hier S. 53; vgl. auch Zimmermann: Papstabsetzungen (wie Anm. 33) S. 59.

40 Die ausführlichen Papstviten des «Liber pontificalis» enden endgültig mit der fragmentarischen Vita Papst Stephans V. (885-891), vgl. dazu Harald Zimmermann: Das Papsttum im Mittelalter. Eine Papstgeschichte im Spiegel der Historiographie, Stuttgart 1981, S. $89 \mathrm{f}$.

41 Liber pontificalis 2 (wie Anm. 13) S. 236 f. Anm. 3: Augustus Caesar totum cum duceret orbem / Condidit hanc aulam Silvestri chrismate sacram / Iamque salutifera lepra mundatus ab unda / Ecclesiae hic sedem construxit primus in orbe / Salvatori Deo qui cuncta salubriter egit / Custodemque loci pandit te sancte Iohannes / Inclinata ruit senio volventibus annis / Spes dum nulla foret vestigia prisca recondi / Sergius ad culmen produxit tertius ima / Cespite et ornavit pingens haec moenia papa; vgl. auch die Edition bei Philippe Lauer: Le Palais de Latran, Paris 1911, S. 139.

42 Tatsächlich hängt die Errichtung der Lateranbasilika mit der Hinwendung Konstantins zum Christentum nach seinem Sieg über Maxentius im Jahr 312 zusammen, vgl. Richard Krautheimer: Rom. Schicksal einer Stadt 312-1308, München 1987, S. 13 und S. 33. 
um so heller, weil er, als man die Hoffnung bereits aufgegeben hatte, die eingestürzte Kirche wieder aufrichtete. Und in einer weiteren Inschrift, deren Textbeginn sich eindeutig auf die vorangehende Inschrift bezieht, mit der sie zusammengehörte ${ }^{43}$, setzte Sergius seine Leistung deutlich von dem Verhalten seiner unmittelbaren Vorgänger ab:

"Nachdem der vorgenannte Herr, Papst Sergius III., zur Ehre deines Namens, Erlöser der Welt, und zu deinem Andenken, heiliger Johannes der Täufer, durch deine Gaben in vielen Kämpfen und Mühen diese in Ruinen daliegende Basilika von Grund auf neu errichtet hat, hat er, weil aller goldener, silberner und eherner Schmuck von den Invasoren aus der Kirche fortgenommen worden war, sich mit demütigem Sinn bemüht, den Schmuck wiederherzustellen und Dir anderen Schmuck darzubringen. Und obgleich er in unruhigen Zeiten eingesetzt worden ist, hat er es doch nicht unterlassen, deiner Majestät zu dienen." ${ }^{44}$ Es folgt anschließend eine Liste der Kreuze, Bilder, Kelche und anderer Dinge, die Sergius für die Lateranbasilika stiftete.

Sergius weist ausdrücklich auf die unruhigen Zeiten hin, in denen er als Papst eingesetzt worden ist, doch habe ihn das nicht davon abgehalten, Gott zu dienen. Denn der Wiederaufbau der Lateranbasilika ist in erster Linie ein Dienst an Gott, indem die Stätte seiner Verehrung erneuert wird. Aber diese Erneuerung wird dadurch erschwert, daß die unmittelbaren Vorgänger des Sergius, die Invasoren des Papststuhls, die Kirche ihres Schmucks beraubt haben. Als Invasoren bezeichnete Sergius hier niemand anderen als seine vier Vorgänger Johannes IX., Benedikt IV., Leo V. und Christophorus, die er alle als illegitim ansah. Sein Epitaph verwendete dieselbe Wortwahl und ließ keinen Zweifel daran, daß Sergius bereits nach dem Tode Theodors im Jahr 898 rechtmäßig zum Papst gewählt worden war ${ }^{45}$. Doch hier in der Lateranbasilika, der Kirche der päpstlichen Residenz, wog diese Aussage um so schwerer. Sergius war immer rechtmäßiger Papst, seine Vertreibung war Unrecht. Und in seinem Handeln wird diese Rechtmäßigkeit sichtbar. Denn während die Invasoren die Kirche auch noch ihres Schmucks beraubten, statt sie wieder aufzubauen, hat Sergius

43 Vermutlich waren die Inschriften auf gesonderten Tafeln untereinander oder nebeneinander angebracht.

44 Johannes Diaconus, Liber de ecclesia Lateranensi, cap. XIX, hg. v. Philippe Lauer, Palais de Latran, Paris 1911, S. 392-408, hier S. 406; Liber pontificalis 2 (wie Anm. 13) S. 237 Anm. 4: Postquam in honore tui nominis, mundi Salvator, et commemoratione tui, sancte Iohannes Baptista, de tuis donis per multa certamina et labores praefatus domnus Sergius tertius papa hanc basilicam in ruinis positam a fundamentis construxit, cum omnia ornamenta aurea et argentea atque aenea ex ea ablata fuissent ab invasoribus, reparare et offerre tibi alia cum devoto animo studuit, quamvis in multis esset perturbationibus constitutus, non omisit tamen tuae servire maiestati.

45 Scholz: Politik (wie Anm. 6), S. 261-263. 
sie, vom Geist Gottes gelenkt, wie die Inschrift am Schluß betont, wieder errichtet und neu ausgestattet ${ }^{46}$.

Die Inschrift wurde in der Italia Pontificia nicht regestiert, weil es sich nicht um den Bau einer neuen Kirche, sondern nur um die Wiederherstellung einer verfallenen Kirche handelte, und über eine Neuweihe der Kirche durch Sergius nichts gesagt wird. Sonst wäre die Weihe in einem Regest vermerkt worden. So bleibt dem Leser jedoch nicht nur der hier erörterte Teil der Inschrift verborgen, sondern auch die anschließende Schenkungsliste, die ebenfalls von erheblicher Bedeutung ist. Denn sie zeigt in einer Zeit, in der wir nicht mehr durch die Schenkungslisten im «Liber pontificalis» über die entsprechenden Maßnahmen der Päpste informiert werden, eindrucksvoll die Leistungsfähigkeit der Päpste als Stifter selbst in den unruhigen Jahren zu Beginn des 10. Jahrhunderts. Allerdings wäre auch bei einer Regestierung der Inschrift kaum einem Leser des Regests bewußt geworden, wie politisch der Text der Inschrift ist.

In den politischen Kontext läßt sich auch noch eine weitere Inschrift einordnen, die Sergius in der Apsis der Lateranbasilika ${ }^{47}$ anbringen ließ. Über der Inschrift befand sich vermutlich eine Traditio-legis-Darstellung ${ }^{48}$, die den göttlichen Auftrag der Glaubensverkündigung symbolisiert ${ }^{49}$. Die Inschrift lautet:

"Dieses Haus Gottes gleicht dem Sinai, der die heiligen Satzungen überbringt $^{50}$, so wie sich hier das Gesetz zeigt, das einst erlassen worden ist. Von hier ging das Gesetz aus zu den Menschen, das sie vom tiefsten Grund heraufführt, und in der ganzen Welt verbreitet, machte es seinen Namen bekannt." ${ }^{51}$

Die Inschrift hebt die Bedeutung der Lateranbasilika hervor. Sie gleicht dem Berg Sinai, auf dem Moses von Gott das Gesetz empfing, denn hier, in Rom

46 Johannes Diaconus, Liber de ecclesia Lateranensi, cap. XIX (wie Anm. 44) S. 406; Liber pontificalis 2 (wie Anm. 13) S. 237 Anm. 4: Haec omnia devotus tibi praeparavit et non cessabit, dum spiritus eius rexerit artus, praeparare et offere tibi domnus Sergius papa tertius.

47 Lauer: Palais de Latran (wie Anm. 41) S. 49, geht davon aus, daß sich die Inschrift in der Apsis befand; vgl. ebenso Ursula Nilgen: Texte et image dans les absides, in: Épigraphie et iconographie, hg. von Robert Favreau, Poitiers 1996 (Civilisation médiévale 2), S. 153-164, hier S. 158.

48 So Nilgen: Texte (wie Anm. 47) S. 158; zwar erwähnen die Quellen kein Bild, doch eine Apside, die kein Bild trägt und nur von einer Inschrift geschmückt wird, ist zu dieser Zeit kaum denkbar. Auch der Text der Inschrift spricht für die Verbindung mit einer Traditio-legis-Darstellung.

49 Vgl. Pietri: Roma christiana 2 (wie Anm. 15) S. 1427-1442.

50 Anspielung auf die Gesetzesübergabe Gottes an Moses auf dem Berg Sinai, Exodus $19 \mathrm{ff}$.

51 De Rossi: Inscriptiones 2/1 (wie Anm. 5) S. 149 mit Kommentar: Aula dei haec similis Synai sacra iura ferenti / Ut lex demonstrat hic quae fuit edita quondam / Lex hinc exivit mentes quae ducit ab imis / Et vulgata dedit nomen per climata saecli. vgl. Liber pontificalis 2 (wie Anm. 13) S. 236 Anm. 1; Lauer: Palais de Latran (wie Anm. 41) S. 49; Nilgen: Texte (wie Anm. 47) S. 157. 
wird das Gesetz und das heißt, die rechte Lehre bewahrt. Von Rom aus ist die wahre Lehre zu den Menschen gebracht worden und von hier hat sie sich in der ganzen Welt verbreitet. Auf die Bedeutung Roms als Lehrerin der Welt und Hort des wahren Glaubens haben die Päpste immer wieder hingewiesen und sie haben sich dazu, wie das Beispiel des Damasus gezeigt hat, auch immer wieder des Mediums der Inschriften bedient. Solche Inschriften entstanden häufig in Krisensituationen, in denen die Päpste ihren Anspruch auf den Primat verteidigen mußten. Zur Zeit des Sergius handelte es sich dabei vor allem um eine innerrömische Krise. Zwar hatte die Leichensynode Stephans VI. auch außerhalb Roms Aufsehen erregt und Kritik am Verhalten sowie am Charakter des Papstes hervorgerufen ${ }^{52}$, doch scheint es dadurch nicht zu einem grundsätzlichen und längerfristigen Ansehensverlust der Päpste gekommen zu sein. Doch durch den Kampf um den Papstthron und die nachträgliche Nichtanerkennung von Päpsten, die Zeit ihres Lebens unangefochten ihr Amt ausgeübt hatten, war der römische Klerus in sich zerrissen und vermutlich auch zutiefst verunsichert $^{53}$. Dies scheint Sergius dazu veranlaßt zu haben, das Amtsverständnis der römischen Kirche an der Hauptkirche der Päpste noch einmal öffentlich zu machen. Damit wollte er die ungebrochene Bedeutung Roms zu Bewußtsein bringen und zudem zeigen, wie sehr ihm selbst die Reinheit der Kirche und die Verteidigung des rechten Glaubens am Herzen lagen.

Die von Sergius gesetzten Inschriften zeigen also sehr deutlich sein Bemühen, die Richtigkeit des eigenen Handelns und seine feste Verwurzelung in der päpstlichen Tradition zu verdeutlichen. Zudem sollte klar werden, daß Sergius von Anfang an rechtmäßiger Papst gewesen war, während seine unmittelbaren Vorgänger sich unrechtmäßig in den Besitz der Papstwürde gebracht hatten. Ein Blick in die Urkunden Sergius' III. zeigt jedoch ein ganz anderes Bild. Sergius zählte seine Pontifikatsjahre erst ab 904, nicht ab 898, dem Jahr seiner Vertreibung, und erkannte damit seine Vorgänger stillschweigend $a n^{54}$. Und auch später wurden die Vorgänger des Sergius stets als rechtmäßige Päpste anerkannt. Blieben die Inschriften des Sergius also ohne Wirkung? Und wie konnte dieser

52 Vgl. etwa Annales Fuldenses zu 896, hg.v. Friedrich Kurze, Hannover 1891 (MGH SS rer. Germ. in usum schol. 7), S. 129: In cuius sedem successit apostolicus nomine Stephanus, vir fama infamandus, qui antecessorem suum, Formosum videlicet, inaudito more de sepulcro eiectum et per advocatum suae responsionis depositum foras extra solitum sepulturae apostolicis locum sepeliri precepit; Annales Laubacenses zu 896, hg. v. Georg Heinrich PeRTz, in: MGH SS 1, Hannover 1826, S. 53; Annales Alamannici zu 896 (wie Anm. 39) S. 53.

53 Das macht auch die in Rom geführte literarische Kontroverse über die Rechtmäßigkeit des Formosus deutlich, vgl. dazu Zimmermann: Papstabsetzungen (wie Anm. 33) S. 6573; Scholz: Transmigration (wie Anm. 33) S. 230-242.

54 Harald Zimmermann: Papsturkunden 896-1046, 3 Bde. Wien ${ }^{2}$ 1988/1989 (DÖAW, phil.-hist. Klasse 174, 177, 198), hier Bd. 1 Nr. 21 S. 36, Nr. 22 S. 38, Nr. 23 S. 41, Nr. 28 S. 50 , Nr. 32 S. 57. 
Widerspruch zwischen den Urkunden und den Inschriften entstehen? Die Antwort ist vergleichsweise einfach: Mit der Datierung der Urkunden nach dem tatsächlichen Pontifikatsantritt ordnete sich Sergius in eine lückenlose und konfliktfreie Kontinuität ein, die es im Sinne der apostolischen Tradition fortzuführen galt. In den Urkunden trat Sergius den Empfängern in Sankt Gallen, Silva Candida, Vézelay oder auch in Rom als Inhaber eines Amtes gegenüber, dessen Kontinuität für Rechtssicherheit bürgte. In den römischen Inschriften ging es dagegen um die Rechtfertigung eines einst vertriebenen, abgesetzten und exkommunizierten Priesters, der die Legitimität seiner Papstwürde und seine gute Amtsführung in einem durch Parteikämpfe zerrissenen Rom öffentlich und aggressiv betonte.

Daß Inschriften eine wichtige Quellengattung für die Erforschung der Geschichte des Papsttums sind und ihren ganz eigenen Wert haben, dürfte unbestreitbar sein. Aber sind sie ein Desiderat der Italia Pontificia? Wenn man sich an den engen, von Kehr vorgegebenen Rahmen hält, nur rechtlich relevante Aussagen und Handlungen zu berücksichtigen, sind die Inschriften, mit Ausnahme der wenigen Stücke, die in diesen Zusammenhang gehören und die Kehr und seinen Mitarbeitern unbekannt blieben, kein Desiderat. Wenn man jedoch die „acta pontificum“ weiter faßt, können die Inschriften Quellen für zahlreiche sonst nirgends überlieferte Handlungen und Maßnahmen der Päpste sein, in denen die Amtsauffassung und das Selbstverständnis der Päpste ebenso zum Ausdruck kommt, wie die politische Situation, in der sie agierten. Dabei ist allerdings zu bedenken, daß die Regesten keine ausführliche Analyse der Texte bieten können und die Regestierung der entsprechenden Inschriften somit eine schwierige Aufgabe ist. Doch solche Regesten könnten den Benutzer stärker, als dies bisher geschehen ist, auf die verschiedenen Facetten der einzelnen Texte hinweisen. Wünschenswert wäre aber auch eine Gesamtedition aller Inschriften, welche die Päpste und ihr Umfeld betreffen, wodurch der Zugriff auf dieses bisher stark vernachlässigte Quellenmaterial verbessert und ihm der gebührende Platz eingeräumt werden könnte.

\section{Riassunto}

Paul Fridolin Kehr ha compreso nella documentazione, raccolta dall'Italia Pontificia, anche le iscrizioni, e non solo quelle dei diplomi, ma anche la maggior parte di tutte le altre, purché contenessero informazioni relative alle decisioni e azioni papali. Nella loro elaborazione però ha trattato tutti i testi epigrafici come diplomi, annotando nel regesto solo gli accenni agli atti giuridici e le corrispondenti azioni del papa. Questo metodo non considera tuttavia il differente carattere e contenuto delle iscrizioni. Diversamente dai diplomi, le iscrizioni sono dirette a una percezione costante, e di norma non si rivolgono 
con chiarezza a un determinato destinatario, ma a un pubblico più o meno vasto. Inoltre le iscrizioni spesso non si riferiscono, in prima linea, a un atto dispositivo a favore di una determinata persona o istituzione, ma servono in particolar modo all'autorappresentazione dei pontefici. Il carattere pubblico e la funzione delle iscrizioni sono dunque strettamente collegati tra di loro. Sulla base di iscrizioni provenienti dai secoli IV, IX e X viene rilevato nel presente contributo come le iscrizioni già a partire dalla tarda antichità fossero utilizzate dai papi nelle più diverse situazioni quale importante mezzo per formulare le loro rivendicazioni e per la loro autorappresentazione. 


\title{
Osservazioni sulle edizioni dei documenti romani dei secoli IX-XII, con particolare riferimento alla storia ecclesiastica
}

\author{
Tommaso di Carpegna Falconieri
}

\section{Introduzione}

Cento anni fa usciva il primo volume dell'Italia Pontificia di Paul Fridolin Kehr, opera monumentale che fu inaugurata, come era giusto che fosse, con il volume dedicato all'Urbe ${ }^{1}$. Kehr raccolse i regesti delle lettere che i pontefici romani avevano spedito agli organi di amministrazione e governo, alle chiese, ai monasteri e ai cittadini di Roma, nel periodo compreso fra l'età tardoantica e il 1198, data dell'elezione di Innocenzo III. Nel secondo volume, consacrato al Lazio e uscito nel 1907, Kehr regestò, tra le altre, le disposizioni pontificie emanate a favore delle diocesi suburbicarie, i cui vescovi, come è noto, celebravano la liturgia in Laterano e avevano giurisdizione su alcune chiese romane ${ }^{2}$. L'opera di Kehr, sotto molti aspetti, è rimasta insuperata, ed è ancora oggi uno strumento indispensabile di lavoro per tutti noi.

L'occasione di questo convegno mi consente di presentare, in forma rapida ma problematica, alcune considerazioni sullo status quaestionis delle edizioni e degli studi relativi alle fonti romane, in prevalenza di quelle documentarie, per il periodo che va dal secolo IX al XII, con particolare riferimento alla storia ecclesiastica ${ }^{3}$.

Quali sono le principali tipologie della documentazione romana nel medioevo centrale? Sorvoliamo, come un elemento non ovvio ma comunque dato per acquisito, sul fatto che lo studio della documentazione riguardante Roma soffre di un problema iniziale di classificazione, poiché la città è contemporaneamente un luogo, un simbolo e un'idea: 'Roma' è infatti un

$1 \quad$ IP 1.

2 IP 2.

3 Non parlerò delle epigrafi, alle quali è stata dedicata una lezione apposita, né delle fonti materiali, archeologiche e storico artistiche. Ciò non toglie, naturalmente, che queste tipologie di fonti siano da considerarsi tra i maggiori documenti/monumenti che si conservano, anche immettendole nella problematica peculiare della «Roma ecclesiastica». È per questo auspicabile - considerazione banale ma che è sempre utile formulare un'interazione sempre più forte tra gli storici che si servono prevalentemente delle fonti scritte e gli storici che si servono prevalentemente delle fonti materiali. 
termine estremamente polisemico. E dunque si possono considerare fonti romane non solo, poniamo, le carte prodotte da un ente ecclesiastico urbano, ma anche, naturalmente, le lettere pontificie, o un cerimoniale, o i sigilli imperiali, pontifici e cardinalizi, o i "Mirabilia», o perfino, per fare un esempio limite, fonti quali L' «Antapodosis» di Liutprando e i «Gesta Romanae Ecclesiae contra Hildebrandum», che di romano hanno poco ${ }^{4}$. In questa occasione non posso discutere il tema del rapporto tra Roma come luogo geografico e Roma come simbolo universale, ma tengo a rammentare come questo rapporto complesso si rifletta nella documentazione e dunque abbia prodotto tipologie documentarie originali, non necessariamente e non sempre legittimamente distinguibili: come le invettive e le «Laudes civitatis», $\mathrm{i}$ «Mirabilia», le profezie e gli itinerari di viaggio ${ }^{5}$. Oggi, però, osserviamo solamente le fonti prodotte a Roma o comunque per Roma intesa, essenzialmente, come una città vivente.

Per i secoli dei quali ci stiamo occupando, la documentazione romana è quasi esclusivamente ecclesiastica. In pratica, solo le chiese e i monasteri, il patriarchio, il palazzo lateranense e la Curia hanno trasmesso documentazione ${ }^{6}$. Si deve dunque osservare, prima di tutto, la documentazione prodotta dagli organi di amministrazione e governo pontifici, che è costituita essenzialmente dalle lettere inviate ai romani, sulle quali si concentrò l'attenzione di Kehr. Dei circa 450 documenti regestati per il periodo compreso tra la metà del secolo VIII e il 1198, l'assoluta maggioranza è perduta e non è rimasta altro che la notizia. Gli originali, poi, non arrivano alla trentina, e il primo di essi è solamente del 1072. Possiamo affermare che la documentazione raccolta da Kehr al principio del secolo corrisponda grossomodo a quella che conosciamo anche oggi: in questa direzione, le ricerche non sono avanzate significativamente. Nei cartari romani, con l'eccezione delle tre basiliche di S. Paolo, di S. Pietro e di S. Maria Maggiore, le lettere pontificie sono relativamente rare ${ }^{7}$.

4 Liutprandus Cremonensis, Antapodosis, in: Die Werke Liudprands von Cremona, ed. Joseph Becker, Hannover/Leipzig 1915 (MGH SRG [in us. schol.] [41]); Beno cardinalis, Gesta Romanae Ecclesiae contra Hildebrandum, ed. K. Francke, in: MGH L. d. L. 2, Hannoverae 1892, pp. 369-380.

5 Utili riferimenti in proposito nel volume Roma antica nel Medioevo. Mito, rappresentazioni, sopravvivenze nella "Respublica Christiana", Milano 2001.

6 Mi permetto di rimandare in generale a Tommaso di CAR PEgnA FALCONIERI: Il clero di Roma nel medioevo. Istituzioni e politica cittadina (secoli VIII-XII), Roma 2002, spec. pp. 273-307.

7 Collectio bullarum sacrosanctae basilicae Vaticanae, vol. 1, Romae 1747; Bullarium Lateranense sive Collectio privilegiorum apostolicorum a Sancta Sede canonicis regularibus Ordinis Sancti Augustini Congregationis Salvatoris Lateranensis concessorum, editio novissima et locupletissima, Romae 1727; Patriarchalis basilicae Sanctae Mariae Maioris de Urbe romanorum pontificum auctorum regesta, ed. Carlo CALlovinJ, Città del Vaticano 1960. 
La rimanente documentazione prodotta dalla Cancelleria e ancora oggi conservata, è quella raccolta nei registri pontifici, i quali, come è noto, per il periodo precedente il pontificato di Innocenzo III sono solamente tre, quelli di Gregorio I, di Giovanni VIII e di Gregorio VII, ai quali è stata dedicata una lezione specifica in questo convegno ${ }^{8}$. La serie è invece pressoché completa a partire dal pontificato di Innocenzo III; da decenni è stato avviato il grande sforzo di edizione di questi registri, che per il Duecento è ormai quasi concluso 9 .

Scorrendo rapidamente la documentazione pontificia, e destinando una frase sola a monumenti di una importanza tale che a ciascuno di essi sarebbe necessario dedicare un convegno intero, ricorderemo solamente altri quattro gruppi di testimonianze fondamentali per la storia di Roma e del papato.

Prima di tutto il «Liber diurnus», che è un formulario compilato nello Scrinium tra la fine del VII e la metà dell'VIII secolo, e che sembra sia restato in uso fino al secolo $\mathrm{XI}^{10}$.

Il secondo tipo di testimonianza è dato dalle biografie pontificie, cioè il «Liber pontificalis», che copre l'alto medioevo fino alla fine del secolo IX, i cataloghi di pontefici del X e della prima metà del secolo successivo, le ricche vitae di papi che si conoscono a partire dalla metà del secolo XI e che in alcuni casi, come nelle redazioni del cardinale Bosone, nei «Gesta Innocentii» e nelle biografie del secolo XIII, rappresentano fonti narrative di primaria importan$\mathrm{za}^{11}$. Spesso, anche queste testimonianze sono prodotto di chierici dello Scrinium e in seguito della Cancelleria ${ }^{12}$.

8 S. Gregorii Magni Registrum Epistularum, ed. Dag Norberg, 2 Bde., Turnhout 1982 (CChrL 140-140A); Registrum Johannis VIII. papae, ed. Erich Caspar, in: MGH Epp. 7, Berlin 1912-1928, pp. 1-333; Das Register Gregors VII., ed. Erich Caspar, 2 Bde., Berlin 1920-1923 (MGH Epp. sel. 2).

9 Si veda in generale Olivier Poncet: Les entreprises éditoriales liées aux Archives du Saint-Siège, Rome 2003. L'Archivio Segreto Vaticano mette a disposizione i CD-Rom di tutti i registri.

10 Liber diurnus Romanorum pontificum ex unico codice Vaticano, ed. Theodor Sickel, Vindobonae 1889; nuova ediz. di Liber Diurnus Romanorum Pontificum, ed. Hans Foerster, Bern 1958. Si veda Leo Santifaller: Liber diurnus. Studien und Forschungen, a cura di Harald ZimmermanN, Stuttgart 1976 (Päpste und Papsttum 10).

11 Le Liber pontificalis. Texte, introduction et commentaire, ed. Louis Duchesne, 2 voll., Paris 1886-1892, vol. 3: Addictions et corrections de Mgr L. Duchesne, a cura di Cyrille Vogel, Paris 1957 (rist. anast. Paris 1981). Si vedano in proposito Ottorino Bertolini: Il Liber pontificalis, in: La storiografia altomedievale, Atti della XVII Settimana di studio del Centro italiano di studi sull'alto medioevo, Spoleto, 10-16 aprile 1969, Spoleto 1970, vol. 1 pp. 387-445; Cyrille VoGEL: Le Liber pontificalis dans l'édition de Mgr Duchesne, in: Monseigneur Duchesne et son temps, Actes du Colloque, Rome, 23-25 mai 1973, Rome 1975 (Collection de l'École française de Rome 23), pp. 99-127.

12 Poche le biografie pontificie che non sono confluite (o che non sono state fatte confluire dagli editori) nel «Liber pontificalis»: per esempio Iohannes Hymmonides: S. Gregorii 
Il terzo gruppo di testimonianze è quello che, diremmo, gira intorno alla Camera apostolica: sono il «Liber censuum», compilato verso il 1192 da Cencio camerario e proseguito per tutto il secolo XIII ${ }^{13}$, e le tracce di documentazione patrimoniale e fiscale, le quali, tuttavia, non raggiungono una consistenza significativa prima dell'inizio del Trecento ${ }^{14}$.

Abbiamo citato la Cancelleria e la Camera. Collocandoci idealmente nel maturo secolo XII, in questa elencazione di fonti a partire dagli organi che le hanno prodotte manca la Cappella pontificia. L'espediente mi è utile per ricordare, anche questa volta solo di sfuggita, l'estrema importanza che rivestono le fonti liturgiche, "Ordines», pontificali, per la storia della Chiesa, del clero e della città di Roma: a partire dai più antichi sacramentari, fino agli «Ordines» di incoronazione o al messale romano ${ }^{15}$.

Sull'altro versante, quello delle fonti prodotte dalla città, ricorderemo l'esistenza di alcune cronache, in verità poche ${ }^{16}$, le due fondamentali descrizioni

Magni vita, in: Migne PL 75 coll. 61-242; Gesta Innnocentii III ab auctore anonymo sed coetaneo scripta, in: Migne PL 214 coll. 15-228.

13 Le Liber censuum de l'Eglise romaine, edd. Paul Fabre/Louis Duchesne, 3 voll., Paris 1899-1952. Si veda Reinhard Elze: Der Liber Censuum des Cencius (Cod. Vat. lat. 8486) von 1192 bis 1228, in: Bull. Arch. paleogr. ital. n. s., 2-3 (1956-1957) pp. 251-270; Thérèse Montecchi Palazzi: Cencius camerarius et la formation du Liber censuum de 1192, in: Mél. Rome 96/1 (1984) pp. 49-93.

14 Cfr. in generale Joseph DE Loye: Les archives de la Chambre Apostolique au XIV ${ }^{\mathrm{e}}$ siècle, $\mathrm{I}^{\mathrm{e}}$ partie: Inventaire, Paris 1899 (Bibliothèque des Écoles françaises d'Athènes et de Rome 80); William Edward Lunt: Papal Revenues in the Middle Ages, 2 voll., 1934 (Records of civilization. Sources and studies 19) (rist. New York 1964); Paolo Cammarosano: Italia medievale. Struttura e geografia delle fonti scritte, Roma 1992, pp. 217-225.

15 Les ordines Romani du haut moyen âge, ed. Michel Andrieu, 5 voll., Louvain 19371961; Le pontifical romain au moyen âge, ed. Michel Andrieu, 4 voll., Città del Vaticano 1938-1941; Ordines coronationis imperialis. Die ordines für die Weihe und Krönung des Kaisers und der Kaiserin, ed. Reinhard Elze, Hannover 1960 (MGH Fontes 9); Jean Deshusses: Le sacramentaire grégorien. Ses principales formes d'après les plus anciens manuscrits, 3 voll., Fribourg 1977 (Spicilegium Friburgense 16, 24, 28); Le Pontifical de la Curie romaine au XIII ${ }^{e}$ siècle, texte latin, traduction, introduction par Monique Goullet/Guy Lobrichon/Éric Palazzo, Paris 2004 (Sources liturgiques 4).

16 Annales Romani (1044-1187), in: Liber pontificalis, ed. Duchesse (cit. nota 11) vol. 2 pp. 329-350. Parzialmente editi come Notae Romanae, aa. 1111-1123, ed. Georg Heinrich Pertz, in: MGH SS 5, Hannoverae 1844, pp. 468-480, e ed. Georg Heinrich Pertz, in: MGH SS 19, Hannoverae 1866, p. 273; Cronica pontificum et imperatorum Romani (‘Cronaca di S. Bartolomeo all'Isola), ed. Oswald Holder-EgGer, in: MGH SS 31, Hannoverae 1903, pp. 189-222. Vanno inoltre ricordate alcune opere scritte nelle vicinanze di Roma: soprattutto Gregorius Catinensis, Il Chronicon Farfense di Gregorio da Catino, ed. Ugo Balzani, 2 voll., Roma 1903; Hugo abbas Farfensis, Destructio monasterii Farfensis, in: Gregorius Catinensis, Chronicon Farfense, vol. 1 pp. 25-51; Benedictus monachus S. Andreae de Soracte, Il Chronicon di Benedetto Monaco di S. Andrea del Soratte e il Libellus de Imperatoria Potestate in Urbe Roma, ed. Giuseppe Zucchetti, Roma 1920; Chronicon Sublacense (aa. 593-1369), ed. Raf- 
delle basiliche lateranense e vaticana, opere di canonici romani del secolo $\mathrm{XII}^{17}$, le numerose redazioni di itinerari e di "Mirabilia», che tuttavia sono spesso il prodotto di autori non romani ${ }^{18}$, gli obituari delle chiese urbane, il più antico dei quali rimonta solo al secolo $\mathrm{XI}^{19}$, alcuni statuti di chiese urbane, che però sono più $\operatorname{tardi}^{20}$, e la molto più numerosa documentazione privata, la quale costituisce la fonte più cospicua per la storia di Roma nel medioevo centrale ed è quasi interamente di matrice ecclesiastica ${ }^{21}$. Con poche eccezioni, infatti, le

faello Morghen, Bologna 1927 (Rerum Italicarum Scriptores 24/6) (rist. anast. con trad. it. a cura di Arturo Carucci, Roma 1991).

17 Iohannes diaconus Romanus, canonicus Lateranensis, Descriptio Lateranensis ecclesiae, in Codice topografico della città di Roma, a cura di Roberto VALEnTini/Giuseppe Zucchetтi, 4 voll., Roma 1940-1953, vol. 3 pp. 326-373; Petrus Mallius canonicus S. Petri, Descriptio basilicae Vaticanae aucta atque emendata a Romano presbytero, ivi, vol. 3 pp. $382-442$.

18 Oltre che in singole edizioni, moltissime sono pubblicate complessivamente nel Codice topografico (cit. nota 17).

19 Necrologi e libri affini della provincia romana, ed. Pietro EgIDI, 2 voll., Roma 1908 (Fonti [44, 45]).

20 Per il capitolo di S. Pietro in Vaticano (1279) cfr. Les registres de Nicolas III, ed. Jules GaY, Paris 1898-1938 (Bibliothèque des Écoles françaises d'Athènes et de Rome Sér. 2), pp. 197-213 n. 517; per il capitolo di S. Giovanni in Laterano cfr. Jochen JohrendT: Die Statuten des regulierten Laterankapitels im 13. Jahrhundert - mit einer Edition der Statuten Gregors IX. (1228) und Nikolaus' IV. (1290), in: QFIAB 86 (2006) pp. 95143; per S. Maria Maggiore Matthias Thumser: Die ältesten Statuten des Kapitels von Santa Maria Maggiore in Rom $(1262 / 1271,1265)$, in: QFIAB 74 (1994) pp. 294-334.

21 Segnaliamo solo i lavori più importanti, relativi ai secoli che qui interessano: Il regesto di Farfa compilato da Gregorio da Catino, e pubblicato dalla Società romana di storia patria, edd. Ignazio Giorgi/Ugo Balzani, 5 voll., Roma 1879-1888 (Biblioteca della R. Società romana di storia patria); Il regesto sublacense dell'XI secolo, edd. Leone Allodi/Guido Levi, Roma 1885 (Biblioteca della R. Società romana di storia patria); Pietro Fedele: Carte del monastero dei SS. Cosma e Damiano in Mica Aurea, secoli XXI, in: ASRSP 21 (1898) pp. 459-534, 22 (1899) pp. 25-107 e 343-487. Ristampa con premessa, appendice e indice di Paolo Pavan, Roma 1981 (Codice diplomatico di Roma e della regione romana 1); Ecclesiae S. Mariae in via Lata Tabularium, edd. Ludwig Moritz Hartmann/ Margarete Merores, 5 voll., Vindobonae 1899-1905; Vincenzo Federici: Regesto del monastero di S. Silvestro de Capite, in: ASRSP 22 (1899) pp. 213-300 e 489-538, 23 (1900) pp. 67-128 e 441-447; Pietro Fedele: Tabularium S. Mariae Novae ab anno 982 ad ann. 1200, in: ASRSP 23 (1900) pp. $171-$ 237, 24 (1901) pp. 159-196, 25 (1902) pp. 169-209, 26 (1903) pp. 21-141; Luigi Schiaparelli: Le carte antiche dell'Archivio capitolare di San Pietro in Vaticano, in: ASRSP 24 (1901), pp. 393-496, 25 (1902) pp. 273-354; Pietro Fedele: Tabularium S. Praxedis, in: ASRSP 27 (1904) pp. 27-78, 28 (1905) pp. 41-114; G. Ferri: Le carte dell'Archivio Liberiano dal sec. X al XV, in: ASRSP 27 (1904) pp. 147-202 e 441-459, 28 (1905) pp. 23-39, 30 (1907) pp. 119-168; Alfredo MonaCi: Regesto dell'abbazia di S. Alessio all'Aventino, in: ASRSP 27 (1904) pp. 351-398, 28 (1905) pp. 151-200 e 395-449; Basilio Trifone: Le carte del monastero di San Paolo di Roma dal sec. XI al XV, in: ASRSP 31 (1908) pp. 267-313, 32 (1909) pp. 29-106; Cartario di S. Maria in Campo Marzio (986-1199), ed. Enrico Carusi, Roma 1948 
raccolte di atti privati che ci sono giunte, appartengono a chiese e monasteri dell'Urbe.

\section{Le lacune della documentazione superstite}

La situazione della documentazione romana nel medioevo centrale è dunque varia per tipologia, ma piuttosto lacunosa per quantità. Mancano all'appello soprattutto le cronache, cioè quelle testimonianze che permetterebbero di ricostruire il tessuto connettivo e il filo della storia intesa come racconto e memoria. E mancano, come è ben noto, le testimonianze prodotte dagli organi del governo civile ${ }^{22}$. Se ci limitiamo al campo di osservazione della documentazione ecclesiastica, però, possiamo ritenerci moderatamente soddisfatti.

Sulle ragioni della dispersione o della relativa scarsità di documentazione romana, molto è stato scritto. Ricordiamo rapidamente alcune di queste cause:

a) Il X secolo - che ritengo a giusto titolo essere il "secolo di ferro" per la città di Roma - ha rappresentato una vera e propria cesura, non solo nella capacità di conservare, ma soprattutto nella capacità o volontà di produrre documentazione: prova ne siano l'interruzione del «Liber pontificalis» alla fine del secolo IX, la perdita quasi completa degli usi liturgici originali, la quasi assoluta mancanza di codici copiati a Roma durante quel periodo. Non si tratta, dunque, solamente della perdita di fonti, ma della vera e propria interruzione di tradizioni documentarie, che si è naturalmente affiancata all'incapacità di conservare la documentazione preesistente.

b) Mancano per Roma, e questo a prima vista può apparire strano, le «Rationes decimarum» ${ }^{23}$. Inoltre la città è poco testimoniata nei «Libri rationum Camerae», anche di secoli bassi come il XIV e il $X^{24}$. Questo significa, a mio avviso, che le istituzioni ecclesiastiche romane sono state sottoposte, nel medioevo, a regimi fiscali propri. La documentazione ad esse relativa, anziché confluire, come negli altri casi, nelle serie camerali, ha forse avuto

(Miscellanea della Societa romana di storia patria 17); Le più antiche carte del convento di S. Sisto in Roma (905-1300), ed. Cristina Carbonettri Vendittelli, Roma 1987 (Codice diplomatico di Roma e della regione romana 4); Il regesto del monastero dei SS. Andrea e Gregorio ad Clivum Scauri, ed. Alberto Bartola, Roma 2003 (Codice diplomatico di Roma e della regione romana 7).

22 Cfr. Codice diplomatico del Senato romano dal MCXLIV al MCCCXLVII, ed. Franco Bartoloni, Roma 1948 (Fonti 87); si veda anche Sonia Bonamano: Nuovi documenti sul Senato romano conservati presso l'Archivio di Stato di Genova, in: ASRSP 123 (2000) pp. 41-57.

23 Rationes decimarum Italiae nei secoli XIII e XIV, Latium, ed. Giulio BATTELLI, Città del Vaticano 1946 (StT 128).

24 Per es. in Tilmann Sснміdт: Libri rationum Camerae Bonifatii papae VIII, Città del Vaticano 1984 (Littera antiqua 2). 
altri luoghi di conservazione. È verosimile dunque che la documentazione si sia perduta proprio perché si sono perduti interamente quegli archivi.

c) La situazione della documentazione degli organi ecclesiastici di governo urbano, principalmente la Romana Fraternitas e il Vicariato di Roma, va dunque posta in comparazione con la documentazione delle magistrature civili: nell'uno e nell'altro caso non si sono conservati gli archivi, né serie documentarie apprezzabili, anteriormente al secolo XVI. L'Archivio della Romana Fraternitas, cioè dell'associazione del clero urbano, è irrimediabilmente perduto, quello del Vicariato di Roma non prende consistenza prima del Cinquecento ${ }^{25}$. E opinione diffusa, e a mio avviso ampiamente giustificata, che gravi responsabilità nella perdita di questa documentazione vadano assegnate al Sacco del 1527. Inoltre ricordiamo che buona parte della documentazione romana si conservava, dal tardo secolo XV, nell'Archivum Arcis, cioè di Castel S. Angelo: in un posto, dunque, non propriamente estraneo a fatti di guerra.

d) Tuttavia, ancora nel Seicento e nel Settecento furono compiute, da parte di eruditi romani, trascrizioni di pergamene e di interi fondi oggi scomparsi. Il loro lavoro paziente consente oggi di avere a disposizione materiale altrimenti irrecuperabile: valga per tutti il lavoro, ampio e meticoloso, condotto da Pierluigi Gallettii ${ }^{26}$. Per questo, in un primo tempo avevo ritenuto che la perdita della documentazione romana andasse imputata a due dei maggiori avvenimenti che interessarono la città nel corso del XIX secolo: l'occupazione napoleonica e la soppressione degli istituti religiosi dopo il 1870. Senza scartare del tutto questa ipotesi, gli scandagli disordinati che ho compiuto in alcuni archivi ecclesiastici romani mi portano a congetturare che, in realtà, il fatidico 1870 abbia assunto un significato diverso. Una parte della documentazione ecclesiastica fu inviata in Vaticano, un'altra, notevole, essendo rimasta presso enti che lo Stato italiano avrebbe soppresso, confluì nell'Archivio di Stato di Roma. Ma ritengo probabile che, nel lento approssimarsi degli italiani a Roma, cioè nel decennio 1860-1870, le chiese e i monasteri romani abbiano avuto tutto il tempo di selezionare, di spostare e di occultare le proprie carte, e che per questo vi siano ancora, a Roma, diversi archivi ecclesiastici che conservano documenti medievali del tutto sconosciuti. Quando Leone XIII aprì l'Archivio Segreto agli studiosi, provocando in tal modo il fiorire di una fecondissima stagione di studi della quale proprio Kehr rappresenta un testimone mirabile - gli enti ecclesiastici romani generalmente non fecero altrettanto, né lo hanno fatto in

25 Annibale Ilari: Gli archivi istituzionali del Vicariato di Roma, in: Archivi e archivistica a Roma dopo l'Unità. Genesi storica, documenti, interrelazioni, Atti del Convegno, Roma 12-14 marzo 1990, Roma 1994, pp. 114-152

26 Carpegna Falconieri: Clero (cit. nota 6) pp. 277-278. 
seguito. Varrebbe davvero la pena, se ve ne fosse la possibilità, di verificare meglio questa ipotesi.

\section{I lavori sulle fonti romane}

Nel frattempo, riscontriamo in rapida sintesi i principali lavori che sono stati già compiuti sulle fonti romane, da quelli meno recenti, fino alle opere degli ultimi decenni e ai lavori in corso dei quali sono a conoscenza. Per concludere infine con alcuni semplici pensieri su quello che, forse, si potrebbe ancora fare.

Ricorderemo la stagione d'oro delle edizioni di fonti romane, che va dagli anni Ottanta del secolo XIX fino, all'incirca, allo scoppio della Seconda Guerra Mondiale. Durante quel periodo è stato pubblicato - prevalentemente dalla Società romana di storia patria, dall'Istituto storico italiano e dagli istituti esteri fondati a Roma - un numero considerevole di carte romane e delle abbazie vicine che conservano documentazione utile per Roma.

Si tratta di lavori notevoli sotto ogni aspetto, ancora impiegati correntemente nei nostri studi. Certamente essi non sono del tutto privi di mende. Alcuni mostrano il pregiudizio per il quale, invece di far aderire l'edizione alla fonte, si fa aderire la fonte alla ratio che informa di sé le scelte dell'editore: così il «Liber pontificalis» di Duchesne, pur essendo un'edizione ottima, dà l'impressione di editare un' unica opera, organica e coerente; così il "Codice topografico» di Valentini e Zucchetti, pur essendo in assoluto la maggiore raccolta di fonti scritte romane medievali, seleziona le testimonianze e le stralcia, e dunque di tante fonti non abbiamo che un'edizione parziale, relativa alla parte "topograficamente più rilevante" di esse. Oppure, altre edizioni, pur raccolte in collane, obbediscono a regole e criteri che cambiano di volta in volta a seconda dell'editore: tali sono a volte i registri pontifici pubblicati dai membri dell'École française.

Dopo la Seconda Guerra Mondiale, l'interesse per l'edizione diretta delle testimonianze è diminuita. Almeno per una trentina d'anni si assiste a una netta rarefazione delle opere di questo genere. Ricordiamo tuttavia almeno l'inizio dell'edizione dei registri di Innocenzo III da parte degli studiosi dell'Istituto austriaco, impresa che si avvia alla conclusione ${ }^{27}$. Negli ultimi trent'anni, le imprese editoriali sono ricominciate e, anche se mi sembrano lontane, dal punto di vista dell'organizzazione e della sistematizzazione, rispetto a quelle della prima metà del secolo, esse sono tuttavia significative. Soprattutto vale la pena di

27 Die Register Innocenz' III. 1. Pontifikatsjahr, 1198/99, bearb. v. Othmar Hageneder/ Anton Haidacher, Graz/Köln 1964 (Publ. der Abt. für hist. Studien des Österr. Kulturinst. in Rom II.1.1). Cfr. Werner MALECZEK: L'édition autrichienne des registres d'Innocent III, in: MEFRM 112 (2000) pp. 259-272. 
ricordare la collezione della Società romana di storia patria intitolata "Codice diplomatico di Roma e della regione romana», che è arrivata al settimo numero di $\operatorname{corda}^{28}$, e i numerosi documenti editi singolarmente a corredo di saggi, contenuti specialmente nell'Archivio della Società Romana di Storia Patria e in Quellen und Forschungen aus Italienischen Archiven und Bibliotheken. Inoltre, alcuni lavori storiografici, benché non siano delle edizioni di fonti, affrontano in maniera molto estesa $\mathrm{i}$ problemi della documentazione romana: tra questi ricordiamo almeno, per i secoli X-XII, gli studi di Pierre Toubert e di Étienne Hubert e, per i secoli XIII e XIV, quelli di Sandro Carocci e di Isa Lori Sanfilippo $^{29}$. Sul versante della storia propriamente ecclesiastica o di enti ecclesiastici, si possono ricordare gli studi, anch'essi molto attenti alle fonti, di Pierre Jounel, Sible de Blauuw, Michael Jost, Victor Saxer, oltre ai più recenti volumi di sintesi sulla storia medievale ${ }^{30}$.

28 1: Fedele: Carte (cit. nota 21); 2: I documenti dell'antico archivio di S. Andrea de Aquaciariis (1115-1483), ed. Isa Lori SANFilippo, Roma 1981; 3: Il protocollo notarile di Lorenzo Staglia (1372), ed. Isa Lori SAnfilippo, Roma 1986; 4: Carbonetti Vendittelli: Carte (cit. nota 21); 5: Le pergamene di Sezze (11811347), ed. Maria Teresa Caciorgna, Roma 1989; 6: Il protocollo notarile di Pietro di Nicola Astalli (1368), ed. Isa Lori Sanfilippo, Roma 1989; 7: Bartola: Regesto (cit. nota 21).

29 Pierre Toubert: Les structures du Latium médiéval: Le Latium méridional et la Sabine du $\mathrm{X}^{\mathrm{e}}$ siècle à la fin du XII ${ }^{\mathrm{e}}$ siècle, Rome 1973 (Bibliothèque des Écoles françaises d'Athènes et de Rome 221); Étienne Hubert: Espace urbain et habitat à Rome du X siècle à la fin du XIII e siècle, Rome 1990 (Nuovi Studi Storici 7 = Collection de l'École française de Rome 135); Sandro Carocci: Baroni di Roma. Dominazioni signorili e lignaggi aristocratici nel Duecento e nel primo Trecento, Roma 1993 (Nuovi Studi Storici 23 = Collection de L'École française de Rome 181); Isa Lori SANFILIpPo: La Roma dei romani. Arti, mestieri e professioni nella Roma del Trecento, Roma 2001 (Nuovi studi storici 57).

30 Pierre Jounel: Le culte des saints dans les basiliques du Latran et du Vatican au douzième siècle, Rome 1977 (Collection de l'École française de Rome 26); Sible DE BlaAuw: Cultus et decor. Liturgia e architettura nella Roma tardoantica e medievale. Basilica Salvatoris, Sanctae Mariae, Sancti Petri, 2 voll., Città del Vaticano 1994 (StT 355, 356); Federico Marazzi: I «patrimonia Sanctae Romanae Ecclesiae» nel Lazio (secoli IV-X). Struttura amministrativa e prassi gestionali, Roma 1998 (Nuovi Studi Storici 37); Michael Fr. P. Jost: Die Patrozinien der Kirchen der Stadt Rom vom Anfang bis in das 10. Jahrhundert, Neuried 2000; Victor SAXER: Sainte Marie-Majeure. Une basilique de Rome dans l'histoire de la ville et de son Eglise, Rome 2001 (Collection de l'École Française de Rome 283). Tra i più recenti volumi di sintesi sulla storia romana medievale ricorderemo almeno Roma medievale. Aggiornamenti, a cura di Paolo Delogu, Firenze 1998; Roma nell'alto medioevo, Atti della XLVIII Settimana di studio del Centro italiano di studi sull'alto medioevo, Spoleto 27 aprile- $1^{\circ}$ maggio 2000, 2 voll., Spoleto 2001; Storia di Roma dall'antichità a oggi. Roma medievale, a cura di André Vauchez, Roma/Bari 2001; Roma fra oriente e occidente, Atti della XLIX Settimana di studio del Centro italiano di studi sull'alto medioevo, Spoleto 19-24 aprile 2001, 2 voll., Spoleto 2002; La nobiltà romana nel Medio Evo, Atti del Convegno 
Tra le edizioni e gli strumenti di studio più importanti degli ultimi anni, ritengo ne vadano ricordati almeno alcuni; l'edizione dei testamenti dei cardinali del Duecento, del $1980^{31}$; l'edizione delle carte del monastero di S. Sisto, del $1987^{32}$; i regesti duecenteschi dell'archivio di S. Maria in Via Lata, pubblicati nel 1994 e $1995^{33}$; e infine alcuni studi sul notariato romano nel medioevo centrale ${ }^{34}$.

Tra gli esperimenti più interessanti va segnalata l'opera di Giulio Savio, Monumenta onomastica Romana medii aevi (X-XII sec.), del 1999, che fornisce in cinque volumi un repertorio degli antroponimi dell'Italia centrale, in larga parte relativi alla città di Roma, per un totale di 136.000 voci $^{35}$. Dovendo compiere una qualsiasi ricerca sui secoli centrali del medioevo romano, i "Monumenta» vanno considerati come un valido punto di partenza, perché permettono, a partire dal nome di un individuo, di risalire alla documentazione edita che lo riguarda. L'opera, invero utilissima, per essere impiegata con frutto necessita tuttavia di alcune cautele particolari ${ }^{36}$.

E cosa si sta facendo oggi? Per quanto è a mia conoscenza sono in corso almeno due imprese molto importanti che riguardano le fonti romane. La prima è la schedatura su supporto informatico delle pergamene dell'Archivio di Stato di Roma, parte del progetto "Imago II», nel quale sono state scansionate e regestate le pergamene romane, credo circa 2500, possedute da quell'archivio ${ }^{37}$.

La seconda operazione di ampio respiro, che coinvolge nel profondo la documentazione romana, è l'annunciata edizione e/o regestazione, da parte dell'Istituto storico italiano per il medio evo, dei documenti dell'Archivum

internazionale Roma 20-22 novembre 2003, a cura di Sandro CARocci, Roma 2006 (Collection de l'École Française de Rome 359). Fuorviante il libro di Ludovico GatTo: Storia di Roma nel medioevo, Roma 1999, che è un riassunto dei volumi di O. Bertolini, P. Brezzi ed E. Duprè Theseider pubblicati dall'Istituto nazionale di studi romani negli anni '40 e '50 del secolo scorso.

31 I testamenti dei cardinali del Duecento, ed. Agostino Paravicini Bagliani, Roma 1980 (Miscellanea della Società romana di storia patria 25).

32 Cfr. nota 22.

33 Ingrid Baumgärtner: Regesten aus dem Kapitelarchiv von S. Maria in via Lata (12011259), in: QFIAB 74 (1994) pp. 42-171, 75 (1995) pp. 32-177.

34 Per es. Cristina Carbonettr: Tabellioni e scriniari a Roma tra IX e XII secolo, in: ASRSP 102 (1979) pp. 77-155; Jürgen Petersohn: Kaiserliche Skriniarie in Rom bis zum Jahre 1200, in: QFIAB 75 (1995) pp. 1-31.

35 Monumenta onomastica Romana Medii Aevi, a cura di Giulio SAvio, Roma 1999.

36 Mi permetto di rinviare a una mia recensione comparsa sulla Rivista italiana di onomastica 6 (2000) 2, pp. 516-519.

37 Il Progetto Imago II è stato realizzato nel periodo 1997-2000 ed è disponibile in rete dal 2002. Sono stati digitalizzati moltissimi documenti, in modo da avere a disposizione una sorta di "sala di studio virtuale". Cfr il sito http//www.cfrl.beniculturali.it/Imago/ Index.html (consultato il 27 settembre 2007). 
Arcis, oggi confluito nell'Archivio Segreto Vaticano. Si tratta di circa 1800 documenti relativi all'Italia dei secoli dall'XI al XIV ${ }^{38}$.

Se molto già è stato fatto, certamente si potrebbe fare ancora molto e molto di più, poiché è mia personale convinzione che gli studi storici romani, a fianco di alcuni campi illuminati, continuino a incontrare anche ritardi considerevoli. Per esempio (l'esempio è sorprendente, ma particolarmente pertinente in questa occasione) non esiste ancora un'edizione delle carte antiche di S. Giovanni in Laterano, mater omnium ecclesiarum ${ }^{39}$. Per avere un nuovo ampliamento sensibile delle fonti edite a nostra disposizione, occorrerebbe tornare a pubblicare sistematicamente, o almeno a regestare, le carte e i cartari romani, sia di fondi ancora quasi inesplorati, sia dei fondi editi solo parzialmente, soprattutto considerando che le edizioni degli anni a cavallo tra XIX e XX secolo molto spesso si arrestavano a date troppo alte. Così, per esempio, il consistente fondo del monastero dei SS.Cosma e Damiano in Mica Aurea, conservato presso l'Archivio di Stato di Roma, è edito solo fino all'anno $1100^{40}$. E qui si affaccia un problema che è ben presente a chi si occupa di storia del papato, o che si serve delle fonti pontificie per i propri studi specifici. Un problema che è dunque sotto gli occhi di tutti: i regesti delle lettere pontificie sono stati indicizzati seguendo un principio geografico (proprio da Kehr), fino al fatidico 1198, mentre i regesti successivi, dovuti al grande lavoro di Potthast e dei suoi collaboratori, sono stati ordinati secondo un criterio strettamente cronologico ${ }^{41}$. Questo significa che per recuperare i dati di una singola località successivamente al 1198, dobbiamo ripercorrere faticosamente tutto l'elenco, oppure, utilizzando le edizioni dei registri, dobbiamo servirci di indici non sempre accurati e non sempre omogenei.

Sarebbe dunque utile eliminare - per quanto possibile - la cesura rappresentata dall'anno di elezione di Innocenzo III, tentando di creare strumenti più versatili e completi di quanto non disponiamo ora. Oltre a ciò, si

38 L'Archivum Arcis contiene documenti originali dal X al XIX secolo e copie di documenti dei secoli IX-XI, per un totale di oltre 8000 cartelle, pergamene e volumi. Il progetto portato avanti dall'Istituto storico italiano per il medio evo permette una consultazione online dei regesti di pergamene del secolo XIII (tra i pontificati di Innocenzo III e di Bonifacio VIII) relative all'Italia, accessibili attraverso le due chiavi di ricerca dei nomi di luogo e dei nomi di persona. Inoltre, è in corso di costituzione la banca dati denominata "Censimento di edizioni e regesti dei documenti dell'Archivum Arcis del XIV secolo", anch'essa consultabile in rete: cfr. il sito www.isime.it/attivita/arc_arcis/archi vum_arcis.htm (consultato 27 settembre 2007).

39 Archivio storico del Vicariato, Archivio capitolare lateransense, Armadio delle pergamene.

40 Fedele: Carte (cit. nota 21). Le carte sono in ASR, Collezione pergamene, cass. 12, 13, $14,15,16,17$.

41 Potthast. 
potrebbero proporre anche nuove edizioni critiche delle fonti narrative, quali soprattutto le biografie dei pontefici duecenteschi ${ }^{42}$.

Una prima lacuna che avverto sta, dunque, nel diradamento delle edizioni. Tutto sommato, il rapporto tra edito e inedito, relativamente alla documentazione privata romana, non è molto cambiato dopo la Seconda Guerra Mondiale. Tuttavia, è pur vero che le edizioni di fonti, anche se a ritmo non propriamente sostenuto, e pur nell'assenza evidente di un progetto sistematico, continuano a uscire. La vera lacuna, dunque, non mi sembra risieda nella mancanza di edizioni, bensì nella limitatezza o ancor più nell'assenza degli strumenti di corredo e di raccordo che dovrebbero consentirci di conoscere e di raggiungere la documentazione. Questa limitatezza o assenza di strumenti fa sì che la nostra conoscenza della situazione romana sia ancora largamente imperfetta. Al giorno d'oggi, un lavoro lento di ricerca personale può portare, nel migliore dei casi, a una padronanza non organica della documentazione romana medievale. I diversi testi di riferimento che ho citato, anche, per esempio, la magistrale raccolta e descrizione della documentazione romana e laziale contenuta nella prima parte della thèse di Toubert, sono largamente insufficienti se presi da soli.

In definitiva, come studioso di storia romana medievale, avverto in modo sensibile la mancanza di un repertorio generale della documentazione: una sistematizzazione, per così dire, proprio "alla Kehr", che segua un progetto e che persegua un obbiettivo dichiarato ${ }^{43}$. Un repertorio del genere dovrebbe trattare tutte le fonti - suddivise nelle varie tipologie - relative alla storia medievale di

42 Vedi Agostino Paravicini Bagliani: La storiografia pontificia del secolo XIII. Prospettive di ricerca, in: RHMitt 18 (1976) pp. 45-54. Al contrario, mentre nel 1998 è stato celebrato con larghezza l'ottocentesimo anniversario dall'incoronazione di Innocenzo III, per studiare i «Gesta Innocentii III» si deve ricorrere ancora all'edizione di Migne, che a sua volta si serviva di edizioni più antiche. Esiste in realtà un'edizione americana risalente al 1981, ma essa appare non molto migliore rispetto a quella di Migne PL 214 coll. 15-228 (anni 1198-1208); David R. Gress-Wright: The "Gesta Innocentii". Text, introduction and commentary, PhD Bryn Mawr College 1981, ediz. anastatica UMI Dissertation Services, Ann Arbor (Michigan), 1999. Sulla fonte cfr. ora Giulia Barone: I Gesta Innocentii III: politica e cultura a Roma all'inizio del Duecento, in: Studi sul medioevo per Girolamo Arnaldi, a cura di Giulia Barone, Lidia Capo, Stefano Gasparri, Roma 2001, pp. 1-24. Frutto delle celebrazioni del centenario sono stati i due volumi Innocenzo III. Urbs et Orbis. Atti del Congresso internazionale, Roma, 9-15 settembre 1998, a cura di Andrea Sommerlechner, Roma 2003 (Nuovi studi storici $55=$ Miscellanea della Società romana di storia patria 44).

43 Per alcune considerazioni analoghe cfr. Tommaso di Carpegna Falconieri: La Curia romana tra XI e XIII secolo: a proposito di libri già scritti e di libri che mancano ancora, in: A Igreja e o Clero Português no Contexto Europeu - The Church and the Portuguese Clergy in the European Context - La Chiesa e il Clero Portoghese nel Contesto Europeo - L'Église et le Clergé Portugais dans le Contexte Européen (Atti del Colloquio internazionale, Roma-Viterbo, 4-8 ottobre 2004), Lisboa 2005, pp. 195-203. 
Roma, proponendo un inventario esaustivo della documentazione edita e una ricerca approfondita del materiale inedito, sia di quello prodotto in età medievale, sia del moltissimo materiale documentario relativo al medioevo ma giunto fino a noi attraverso trascrizioni di età moderna. A partire dalla nostra conoscenza degli archivi più importanti, si potrebbero raggiungere anche luoghi non ancora aperti alla ricerca. Ritengo che un'operazione di questo genere, anche se indubbiamente molto impegnativa, è tuttavia alla nostra portata, almeno per i secoli fino al XIII compreso, prima cioè che la documentazione diventi troppo abbondante per poter essere maneggiata.

\section{Zusammenfassung}

Der vorliegende Beitrag enthält einige Überlegungen über den status quaestionis der Schriftquellen und der Edition von Quellen, die für eine Rekonstruktion der mittelalterlichen Geschichte Roms vor allem mit Blick auf die Kirchengeschichte nützlich sind. Der Autor behandelt in groben Umrissen das Problem der Lücken in der Überlieferung der römischen Dokumente aus dem Früh- und Hochmittelalter, beleuchtet die Phase intensivsten Einsatzes für die Veröffentlichung von Quelleneditionen (zwischen dem Ende des 19. Jahrhunderts und dem Zweiten Weltkrieg) und stellt am Ende einige der wichtigsten und interessantesten Arbeiten vor, die in den letzten Jahrzehnten entstanden oder momentan in Bearbeitung sind. 
Bereitgestellt von | De Gruyter / TCS

Angemeldet | 217.89.40.26

Heruntergeladen am | 21.12.12 10:50 


\section{Auf den Spuren mittelalterlicher Urkunden in neuzeitlicher Überlieferung: Beispiele aus Süditalien}

\section{Hubert Houben}

Bekanntlich hat sich nur ein Bruchteil der mittelalterlichen Urkundenproduktion bis heute erhalten, während die große Masse verloren gegangen ist ${ }^{1}$. Wer sich mit der mittelalterlichen Geschichte von Gebieten befaßt, in denen die Überlieferungsverluste besonders stark sind, wie etwa Süditalien, ist also zwangsläufig darauf angewiesen, nach Spuren verlorener Urkunden in neuzeitlicher Überlieferung Ausschau zu halten. Welche Funde man dabei noch machen kann, sei zunächst am Beispiel der Benediktinerabtei der Santissima Trinità in Venosa in der heutigen Provinz Potenza in der Region Basilicata gezeigt; anschließend sei auf die Urkunden der Deutschordensballei Apulien und abschließend auf eine die Weihe der Kathedrale von Otranto betreffende Legatenurkunde von 1088 eingegangen.

Die Urkunden und Handschriften der 1297 dem Johanniterorden übertragenen Benediktinerabtei der SS. Trinità in Venosa gingen zwischen dem Ende des 17. und der Mitte des 18. Jahrhunderts unter unbekannten Umständen so gut wie vollständig verloren ${ }^{2}$. Diese Verluste können teilweise ausgeglichen werden durch die Aufzeichnungen von Gelehrten des 16. bis 18. Jahrhunderts, die Abschriften, Auszüge und Regesten von damals noch vorhandenen Dokumenten enthalten ${ }^{3}$. Wie viel neues Material bei der gründlichen Durcharbeitung solch neuzeitlicher Überlieferung noch herauskommen kann, soll im folgenden am Beispiel der Papsturkunden des 11. und 12. Jahrhunderts gezeigt werden.

Die Kirche der um 1041 in der ersten Phase der normannischen Eroberung Süditaliens gegründeten Abtei wurde am 17. August 1059 von Papst Nikolaus II. geweiht, welcher das Kloster eine Woche später unmittelbar dem Apostolischen Stuhl unterstellte. Aufgrund der erwähnten großen Überlieferungsverluste des einst so reichen Klosterarchivs - Archivum olim chartis principum et baronum

1 Vgl. Arnold Esch: Überlieferungs-Chance und Überlieferungs-Zufall als methodisches Problem des Historikers, in: HZ 240 (1985) S. 529-570 (ND in: DERs.: Zeitalter und Menschenalter. Der Historiker und die Erfahrung vergangener Gegenwart, München 1994, S. 39-69).

2 Vgl. Hubert Houben: Die Abtei Venosa und das Mönchtum im normannisch-staufischen Süditalien, Tübingen 1995 (Bibliothek des Deutschen Historischen Instituts in Rom 80), S. 111.

3 Vgl. ebd. S. $112 \mathrm{ff}$. 


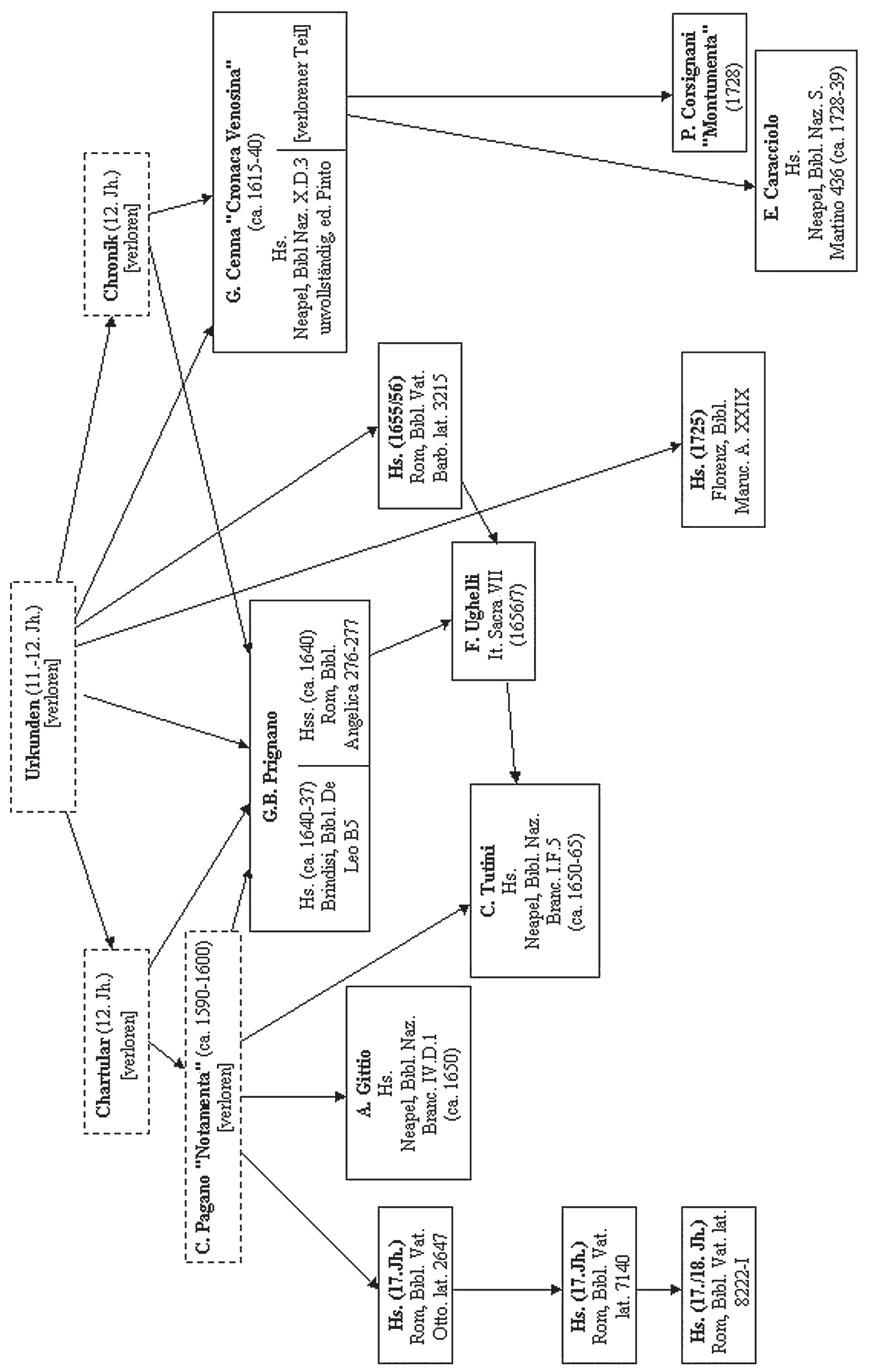


Normannorum ditissimum frustra quaesivimus, liest man in den Italia Pontificia ${ }^{4}$ - wundert es nicht, daß im Göttinger Papsturkundenwerk nur neun Urkunden aufgeführt sind, darunter eine Weihenotiz, eine Legatenurkunde und zwei Fälschungen. Nur von einer einzigen Papsturkunde, nämlich derjenigen Nikolaus' II. vom 24. August 1059, die sich in einer Abschrift des 18. Jahrhunderts in einer Florentiner Sammelhandschrift erhalten hat, war der Text seit seiner Edition durch Julius von Pflugk-Harttung bekannt ${ }^{5}$.

Eine lange Zeit unbeachtet gebliebene Neapolitaner Handschrift aus den zwanziger oder dreißiger Jahren des 18. Jahrhunderts enthält jedoch Texte aus einem verlorenen Teil einer zwischen 1614 und 1640 von Giacomo Cenna einem Kanoniker aus Venosa, der das Klosterarchiv konsultierte - verfaßten Chronik, in der zahlreiche Papsturkunden eingearbeitet waren. Es handelt sich um das zweibändige «Dictionarium universale totius Regni Neapolitani» des Theatinerpaters Eustachio Caracciolo aus Neapel (1667 - nach 1739) (Neapel, Bibl. Nazionale S. Martino 435-436), das, abgesehen von dem Venosa betreffenden Artikel, nur eine Kompilation bekannter Quellen darstellt ${ }^{6}$.

Die folgende Übersicht verdeutlicht den Umfang des hier überlieferten neuen Materials:

\begin{tabular}{|c|c|c|c|}
\hline \multicolumn{2}{|c|}{ Italia Pontificia 9 (1962) } & $\begin{array}{l}\text { Houben, Abtei Venosa } \\
\text { (1995) }\end{array}$ & \multirow{2}{*}{$\begin{array}{l}\text { VolpinI, Contributi (in } \\
\text { Vorber.) }^{7}\end{array}$} \\
\hline nr. ${ }^{*} \dagger 1$ & (1053) & & \\
\hline nr. ${ }^{*} \dagger 2$ & $(1055)$ & & \\
\hline nr. ${ }^{*} 3$ & 1059 aug. 17 & & \\
\hline \multirow{2}{*}{\multicolumn{2}{|c|}{1059 aug. 25}} & & \\
\hline & & $\begin{array}{l}\text { nr. } 17 \text { (1071 oct. - } \\
1072 \text { sept.) }\end{array}$ & nr. ${ }^{*} 1$ \\
\hline \multicolumn{4}{|c|}{ nr. ${ }^{* 5} \quad(1066-73)$} \\
\hline & & $(1073-85)$ & nr. $* 2$ \\
\hline & & (1089 sept. 24) & nr. 3 \\
\hline & & $\begin{array}{ll}\text { nr. } 78 \quad(1096-99)\end{array}$ & nr. *4 \\
\hline
\end{tabular}

4 IP 9 S. 491.

5 Ebd. S. 493 Nr. 4, ed. Julius von Pflugk-Harttung: Acta Pontificum Romanorum inedita, Bd. 2, Stuttgart 1884 (ND Graz 1958), S. 86 f. Nr. 120; Houben: Venosa (Anm. 2) Nr. 8 S. 239-241.

6 Vgl. ebd. S. 117 f., sowie die folgende Graphik.

7 Raffaello Volpini: Documenti pontifici in Italia. Contributi per l'Italia Pontificia (Acta Romanorum Pontificum 8), in Vorbereitung, II 5. 


\begin{tabular}{|c|c|c|c|}
\hline \multicolumn{2}{|c|}{ Italia Pontificia 9 (1962) } & $\begin{array}{l}\text { HoubEn, Abtei Venosa } \\
\text { (1995) }\end{array}$ & \multirow[t]{2}{*}{$\begin{array}{l}\text { VOLPINI, Contributi (in } \\
\text { Vorber.) }\end{array}$} \\
\hline \multirow[t]{11}{*}{ nr. 6} & 1101 apr. & & \\
\hline & & S. 149 Anm. 87 (1121-22) & \\
\hline & & nr. $99 \quad 1123$ sept. 20 & nr. 5 \\
\hline & & nr. $102 \quad$ (ante 1131 jul.) & nr. ${ }^{*} 6$ \\
\hline & & nr. $102 \quad$ (ante 1131 jul.) & nr. $* 7$ \\
\hline & & nr. $103 \quad$ (ante 1131 jul.) & nr. ${ }^{*} 8$ \\
\hline & & nr. $104 \quad$ (ante 1131 jul.) & nr. ${ }^{*} 9$ \\
\hline & & nr. $105 \quad$ (ante 1131 jul.) & nr. ${ }^{*} 10$ \\
\hline & & nr. 109, 1137 (aug. 3-5) & nr. 11 \\
\hline & & nr. $111 \quad$ (1141?) & nr. ${ }^{*} 12$ \\
\hline & & nr. 112,1141 dec. 31 & nr. 13 \\
\hline \multirow[t]{12}{*}{ nr. ${ }^{*} 7$} & $(1152)$ & & \\
\hline & & nr. 132,1156 dec. 12 & nr. 14 \\
\hline & & nr. $134 \quad(1158-59)$ & nr. ${ }^{*} 15$ \\
\hline & & nr. $135 \quad(1158-59)$ & nr. ${ }^{*} 16$ \\
\hline & & nr. 136,1159 dec. 12 & nr. 17 \\
\hline & & nr. $137 \quad$ (1159) dec. 12 & nr. 18 \\
\hline & & nr. $138 \quad(1167)$ & nr. ${ }^{*} 19$ \\
\hline & & nr. 141,1167 sept. 11 & nr. 20 \\
\hline & & nr. 142,1168 ian. & nr. 21 \\
\hline & & nr. $163 \quad(1181-82)$ & nr. $* 22$ \\
\hline & & nr. $163 \quad(1181-82)$ & nr. $* 23$ \\
\hline & & nr. $164 \quad$ (1182) & nr. $* 24$ \\
\hline \multirow[t]{3}{*}{$\begin{array}{l}\text { nr. }{ }^{*} 8 \\
1183]\end{array}$} & (1182) [corr. in & & \\
\hline & & nr. 165,1183 feb. 5 & nr. 25 \\
\hline & & nr. $166 \quad$ (1183) apr. 21 & nr. 26 \\
\hline nr. $* 9$ & $(1181-83)$ & $(1182-83)$ & \\
\hline
\end{tabular}


So eindrucksvoll auf den ersten Blick der Gewinn an neuem Material ist, das die Beziehungen des Papsttums mit der süditalienischen Benediktinerabtei widerspiegelt, so problematisch ist aber auch die Art seiner Überlieferung aus dritter Hand: Da der größte Teil von Cennas Chronik verloren ist, haben wir keine Möglichkeit festzustellen, wie zuverlässig Caracciolo die Texte von Cennas Chronik überliefert. Der Vergleich der Urkunde Urbans II. von 1089 bei Caracciolo mit dem zeitgenössischen Formular zeigt, daß der Lokalhistoriker eher frei mit den Texten umgegangen ist; zudem hat Cenna den größten Teil der von ihm mitgeteilten Papsturkunden der mittelalterlichen Chartularchronik der Abtei entnommen und nur ausnahmsweise, wie bei der erwähnten Urkunde Urbans II., das Original herangezogen ${ }^{8}$.

Ähnlich problematisch wie die Urkunden aus Venosa sind die vielfach nur in Form neuzeitlicher Regesten überlieferten Dokumente der Deutschordensballei Apulien, die ursprünglich in Barletta, dann vom 14. bis 16. Jahrhundert in San Leonardo in Siponto (bei Manfredonia, Provinz Foggia), anschließend in der ehemaligen Ordenskommende Corneto - Torre Alemanna (Gemeinde Cerignola, Provinz Foggia) und seit Beginn des 19. Jahrhunderts im Staatsarchiv Neapel aufbewahrt wurden. Hier gehörten sie zum sog. Fondo Monasteri soppressi, in dem die Urkundenbestände der Anfang des 19. Jahrhunderts säkularisierten Klöster des Königreichs (mit Ausnahme von Montecassino, Cava, Montevergine und der Klöster Siziliens) ohne Rücksicht auf das Provenienzprinzip zusammengefasst waren. Bekanntlich fielen die älteren Bestände des Staatsarchivs Neapel, die im Zweiten Weltkrieg nach einer Bombardierung der Stadt durch die englische Luftwaffe aus Sicherheitsgründen nach San Paolo Belsito (bei Nola, Provinz Neapel) ausgelagert worden waren, 1943 einem von deutschen Soldaten verursachten Brand zum Opfer. Durch dieses traurige Ereignis gewannen die Aufzeichnungen von Gelehrten an Bedeutung, die vor diesem Zeitpunkt die Neapolitaner Archivbestände benutzt hatten' ${ }^{9}$. Im Falle der Urkunden des Deutschen Ordens war dies Heinrich Volbert Sauerland (18391910), der um 1900 Regesten angefertigt hatte, die bis vor wenigen Jahren so gut wie unbeachtet in den Findbüchern 177-178 (Apulien I-II) des Zentral-

8 Ein Beispiel für die Paraphrasierung eines Urkundeninhalts durch Cenna-Caracciolo bei Houben: Venosa (wie Anm. 2) S. 229. Übersicht über die komplizierte Überlieferung der Urkunden der Abtei Venosa ebd. S. 120.

9 So konnte nach der 1993 erfolgten Auffindung des verlorenen geglaubten Teils des Nachlasses von Eduard Sthamer (1883-1938), dessen vor hundert Jahren begonnene Edition der Urkunden zur Geschichte der Kastellbauten des Königreichs Sizilien unter Friedrich II. und Karl I. von Anjou vollendet werden: Dokumente zur Geschichte der Kastellbauten Kaiser Friedrichs II. und Kars I. von Anjou, Bd. 3: Abruzzen, Kampanien, Kalabrien und Sizilien, auf der Grundlage des von Eduard STHAMER gesammelten Materials bearb. v. Hubert Houben, Tübingen 2006. Vgl. Ders.: Hundert Jahre deutsche Kastellforschung in Süditalien, in: QFIAB 84 (2004) S. 103-136. 
archivs des Deutschen Ordens in Wien lagen ${ }^{10}$. Vor ihm hatte Julius Ficker (1826-1902) im Frühjahr 1876 im Staatsarchiv Neapel gearbeitet; unter den von ihm für seine rechtsgeschichtlichen Studien vollständig oder auszugsweise transkribierten Urkunden fanden sich auch einige, die aus dem Archiv der Deutschordensballei Apulien stammten ${ }^{11}$.

Weitere moderne Abschriften mittelalterlicher Urkunden, die bisher nicht zur Kenntnis genommen wurden, befinden sich in den jüngeren Beständen des Staatsarchivs Neapel, die seinerzeit nicht nach San Paolo Belsito ausgelagert wurden. Es handelt sich um zwei Mappen mit losen Blättern (Staatarchiv Neapel, Museo 99 C 19, III 16-17), die 1846/47 von Schülern der Archivschule des Staatsarchivs angefertigte Abschriften von vorwiegend Papst- und einigen wenigen Bischofsurkunden für meist süditalienische Empfänger enthalten. Darunter sind 42 bisher unbekannte Papsturkunden aus dem 13. Jahrhundert $(1200-1285)$ und eine von $1446^{12}$. Unter den sieben bisher unbekannten Papsturkunden für den Deutschen Orden (1219-1261) enthält eine einen Hinweis auf ein Deperditum Cölestins III. (1191-1198), in dem dieser dem Orden seine Kirche in Brindisi mit dem Recht, dort Laien zu begraben, bestätigt hatte ${ }^{13}$.

Erfolgreich waren auch Nachforschungen in dem in der Bibliothek der Società Napoletana di Storia Patria im Castel Nuovo (sog. Maschio Angioino) in Neapel aufbewahrten Nachlaß des aus der Basilicata gebürtigen Politikers und Historikers Giustino Fortunato (1848-1932), der zahlreiche Dokumente aus dem Staatsarchiv Neapel abschreiben ließ, die die Geschichte seiner Heimatregion betrafen ${ }^{14}$, sowie im ebenfalls dort aufbewahrten Teil des Nachlasses des Neapolitaner Gelehrten und langjährigen Mitarbeiters des dortigen Staatsarchivs Giuseppe Del Giudice (1819-1909), der u.a. zahlreiche notarielle Abschriften

10 Ders.: Zur Geschichte der Deutschordensballei Apulien. Abschriften und Regesten verlorener Urkunden aus Neapel in Graz und Wien, in: MIÖG 107 (1999) S. 50-110.

11 Ders.: Urkunden zur italienischen Rechtsgeschichte. Abschriften aus dem Staatsarchiv Neapel im Nachlaß Julius Ficker, in: QFIAB 79 (1999) S. 28-98.

12 Übersicht: DERs.: Neuentdeckte Papsturkunden für den Deutschen Orden (1219-1261) im Staatsarchiv Neapel, QFIAB 83 (2003) S. 41 -82, hier S. 67 f.; DERs.: Un inedito privilegio di Innocenzo III per i cistercensi di S. Maria di Ripalta in Puglia, in: RSCI 56 (2002) S. 149-157.

13 Ders.: Neuentdeckte Papsturkunden (wie Anm. 12) S. 73 f. Nr. 1.

14 Ders.: Torre di Mare (Metaponto) al tempo di Federico II: un inedito documento del 1239, in: Mediterraneo, Mezzogiorno, Europa. Studi in onore di Cosimo Damiano Fonseca, hg. v. Giancarlo Andenna/Hubert Houben, Bari 2004, S. 581-592; Hubert Houben: Der Deutsche Orden in Melfi. Urkunden (1231-1330) aus dem Nachlass Giustino Fortunato, in: De litteris, manuscriptis, inscriptionibus ... Festschrift zum 65. Geburtstag von Walter Koch, hg. v. Theo Kölzer/Franz-Albrecht Bornschleged/ Christian Friedl/Georg Vogeler, Wien/Köln/Weimar 2007, S. 113-143. 
von Urkunden aus dem Archiv der ehemaligen Deutschordensballei Apulien enthält, die im zweiten Jahrzehnt des 17. Jahrhunderts angefertigt wurden ${ }^{15}$. Abgesehen von der Spurensuche in neuzeitlicher Überlieferung lohnt sich gelegentlich auch die Durchsicht von scheinbar bereits vollständig edierten Quellen: Im heute im Geheimen Staatsarchiv Berlin aufbewahrten sogenannten „großen Privilegienbuch“ des Deutschen Ordens, einem Kopialbuch des 14./15. Jahrhunderts (Ordensfoliant 69), das im 19. Jahrhundert von Ernst Strehlke für seine «Tabulae ordinis Theutonici» weitgehend ausgeschöpft und im 20. Jahrhundert von Kurt Forstreuter einer Nachlese unterzogen worden war, fand sich eine beiden Forschern entgangene unedierte Urkunde Honorius' III. ${ }^{16}$

Aber auch bereits seit langem bekannte Urkunden bedürfen oft einer näheren Betrachtung, zumal wenn sie nur in älteren unkritischen Editionen vorliegen. So hat der bei Ughelli nur ungenau wiedergegebene Text des Privilegs Alexanders II. für den Erzbischof von Acerenza von 1068 (JL 4647) zu verfehlten Folgerungen Anlass gegeben, die erst durch eine Neuedition korrigiert werden konnten ${ }^{17}$, während die zeitliche Einordnung einer weiteren Urkunde dieses Papstes für die Kanoniker von Ferrara, die ohne Datierung überliefert ist (JL 4651), durch die unzulängliche Edition der Namen der sie unterschreibenden Bischöfe erschwert wurde, bis auch hier eine Neuedition Klarheit schaffte $^{18}$. Dies konnte gelingen, weil in neuzeitlicher Überlieferung eine ausreichende Grundlage für die Herstellung eines besseren Textes vorhanden war.

Abschließend soll nun aber ein Fall vorgestellt werden, in dem eine solche Quellenkritik auf erhebliche Schwierigkeiten trifft, da die entsprechende Urkunde nur in einem Druck des ausgehenden 19. Jahrhunderts vorliegt, dessen Vorlage bisher nicht auffindbar war. Es handelt sich um die im neunten Band

15 Vgl. Hubert Houben: Raimondo del Balzo Orsini e l'Ordine Teutonico, in: L'Ordine Teutonico tra Mediterraneo e Baltico: incontri e scontri tra religioni, popoli e culture. Der Deutsche Orden zwischen Mittelmeerraum und Baltikum: Begegnungen und Konfrontationen zwischen Religionen, Völkern und Kulturen, hg.v. Hubert HoubeN/ Kristjan Toomaspoeg, Galatina 2008 (Acta Theutonica 5), S. 195-212, bes. S 199 f., 205. Zum Nachlaß Del Giudice s. Stefano Palmieri: I manoscritti dei Giuseppe Del Giudice. Una fonte per la ricostruzione dell'Archivio della Cancelleria Angioina, in: Atti della Accademia Pontaniana n. s. 46 (1997) (ersch. 1998) S. 49-61, bes. S. 54 f.

16 Hubert Houben: Friedrich II., der Deutsche Orden und die Burgen im Königreich Sizilien. Eine unbekannte Urkunde Honorius' III. von 1223, in: DA 56 (2000) S. 585591.

17 Ferdinandus Ughelli: Italia Sacra, Bd. 7, 2. Ed. hg. v. Nicola Coleti, Venedig 1721, S. 25-26; IP 9 S. 456 f. Nr. 6; Hubert Houben: Il privilegio di Alessandro II per l'arcivescovo Arnaldo di Acerenza (JL. 4647), in: RSCI 53 (1999) S. 109-118.

18 Giuseppe Cappellettr: Le chiese d'Italia dalla loro origine sino ai nostri giorni, Bd. 4, Venedig 1846, S. 47-49; IP 5 S. 210 Nr. 9; Hubert Houben: Die Teilnehmer der Synoden Alexanders II. (1061-1073). Mit Neuedition von JL. 4651, in: QFIAB 77 (1997) S. 1-17. 
der Italia Pontificia von Walther Holtzmann ohne Bedenken zitierte Urkunde über die Weihe der Kathedrale von Otranto (im äußersten Süden Apuliens) im Jahre 1088 durch den apostolischen Legaten Erzbischof Roffrid von Benevent ${ }^{19}$. Bekannt ist dieses Dokument nur durch seine Edition im Anhang einer 1893 von dem Lokalgelehrten und Bürgermeister des Ortes Muro Leccese (bei Otranto) Luigi Maggiulli (1828-1914) publizierten Geschichte der Stadt Otranto $^{20}$. Nach Maggiulli stammt die Urkunde aus dem Vatikanischen Archiv (,documento inedito estratto dagli Archivi Vaticani“), aber da er keine Archivsignatur angab, gelang es bisher nicht, diese Angabe zu verifizieren. Maggiulli hat selber keine Archivforschungen angestell $t^{21}$, hat aber offensichtlich von Korrespondenten eine Reihe von Urkundenabschriften erhalten, die er dann im Anhang seiner Monographie über Otranto publizierte. Leider teilt er nicht mit, wer diese Korrespondenten waren, aber in seinem heute in der Bibliothek der Familie Maggiulli-Cacciatore in Morciano di Leuca (Provinz Lecce) aufbewahrten Nachlaß befindet sich das Konzept eines Briefes an den Leiter der Vatikanischen Bibliothek, den Vice-Bibliotecario Abate Cozza-Luzi ${ }^{22}$. In diesem Brief vom 8. Juli 1892 bittet Maggiulli um Informationen über den genauen Zeitpunkt der Weihe der Kathedrale von Otranto: Er verweist auf nicht näher erläuterte Angaben von älteren Lokalhistorikern, nach denen die Weihe am zweiten Sonntag des Monats September des Jahres 1088 durch den von Urban II. damit beauftragten päpstlichen Legaten Erzbischof Roffredus von Benevent erfolgt sei und auf ein entsprechendes, im Vatikanischen Archiv aufbewahrtes Dokument, das bisher vergeblich gesucht worden $\operatorname{sei}^{23}$.

19 IP 9 S. 409: „A. 1088 m. aug. ecclesia cathedralis Hydruntina a Roffredo Beneventan. archiep., apost. sedis legato, adstantibus Rogerio duce Apuliae, Urso Baren., Alberto Tarentin. et Godino Brundusin. archiepp. consecrata est (...)“. Keine Erwähnung der Urkunde bei Stefan WeIss: Die Urkunden der päpstlichen Legaten von Leo IX. bis Coelestin III. (1049-1198), Köln/Weimar/Wien 1995 (Beih. zu J. F. Böhmer, RI 13).

20 Luigi Maggiuldi: Otranto. Ricordi, Lecce 1893, S. 372 f.

21 Vgl. Salvatore Panareo: Luigi Maggiulli, in: Rivista Storica Salentina 9 (1914) S. 171 172: „uno studioso relegato in un oscuro paesello (...). Comunque, nel giudicare l'opera del Maggiulli, si dovranno sempre tenere presenti le singolari condizioni in cui egli lavorò, condizioni che sono comuni a quanti vivono lontani dalle grandi biblioteche e dagli archivi, e che importano difficoltà e ostacoli grandissimi e insieme amarezze e scoggiamenti insuperabili“.

22 Zu ihm s. Vittorio Peri: Cozza Luzi, Giuseppe, in: DBI 30 (1984) S. 547-551.

23 Morciano di Leuca, Biblioteca Maggiulli-Cacciatore, ms. 36 (Monografia di Castro), fol. 65v-66r, transkribiert in der unveröffentlichten Tesi di Laurea in Bibliografia e Biblioteconomia (Università degli Studi di Lecce, Facoltà di Beni Culturali, a. a. 20002001, relatore: prof. Donato Valli) von Annarosa MArra: Il fondo manoscritto della biblioteca «Maggiulli-Cacciatore» in Morciano di Leuca, S. 380-382, hier S. 382: „ (...) i patri scrittori asseriscono che venne consacrata e benedetta per ordine di Urbano II dal Legato Pontificio Roffredo Arcivescovo di Benevento, con l'assistenza dell'Arcivescovo Otrantino Guglielmo e da altri Vescovi ed Arcivescovi nella seconda domenica di Set- 
Leider ist eine Antwort aus Rom nicht erhalten ${ }^{24}$, aber ihr war wohl eine Transkription des Textes der Urkunde beigelegt, die Maggiulli dann in seinem 1893 erschienenen Buch veröffentlichte. Dass Maggiulli den Text vorher nicht kannte, geht außer aus seinem Brief vom 8. Juli 1892 auch aus der ersten (handschriftlichen) Fassung seiner Monographie von 1889 hervor, in der von dieser Urkunde noch keine Rede ist ${ }^{25}$.

Bevor wir auf den Inhalt der Urkunde eingehen, geben wir den Text nach Maggiulli wieder, da seine Monographie nur in wenigen Bibliotheken vorhanden ist $^{26}$ :

- In nomine Domini nostri Iesu Christi. - Anno ab ejus incarnatione Millesimo octuagesimo octavo, Mensis Augusti, Indictione .... Regnante Domino Nostro Rogerius, Dux Italiae, Calabriae et Siciliae, etc.

- Roffridus Dei Gratia humilis Archiepiscopus Beneventanus, Apostolice Sedis Legatus.

Praesenti scripto posterorum notitiae tradimus quod Hydruntum venientes rogati fuimus a Gullielmo Vener: Archiepiscopo et Capitulo ejus, ut Ecclesiam Hydruntinam, nusquam tamen consacrata fuerat, consacrare solemniter deberemus, quorum precibus grato concurrentes assensu praesente Domino Rogerio Du. Sic: etc. cum Venerabilis Urso Baren: Alberto Tarent: Godino Brun: astante Cleri et populi multitudine copiosa, dedicavimus Ecclesiam, et consacravimus manibus nostris Altare majus ad honorem Dei et Beatissimae Dei Genitricis, semperque virginis Mariae, in quo recondimus reliquias istas. - De ligno crucis: Stephani Prothomartyris: Laurentii Levitae et martyris: Silvestri Papae: Agathae et Luciae virginum et martyrum: Gervasii et Prostasii martyrum: Eleuterii martyris: Pantaleonis martyris: Primi et Feliciani martyrum.

Quae utique consacratio celebrata est anno Domini Incarn: 1088 .... Kalendas Augusti, Pontif. Domin. Urbani Papae II, an. primo.

Secunda vero die perambulavimus ${ }^{27}$, et benediximus Coemeterium ipsius Ecclesiae per partes quattuor: ut est moris ad Salutem et requiem sepultorum et

tembre del 1088. Il documento relativo si assicura esistere negli Archivi Vaticani, ma non fu possibile rinvenirlo sinora dai profani in quell'Archivio. Ella che sì degnamente regge la carica di Vice-Bibliotecario, sperasi non riuscirà difficile di averne notizia, per chiarire un punto sì importante della storia religiosa di questa città $(\ldots)^{\text {“. }}$.

24 Freundliche Auskunft von Dr. Massimo Ceresa (vom 24.1.2007) mit Hinweis auf eine entsprechende Recherche von Frau Dr. Christine Grafinger, Vatikanische Bibliothek Rom.

25 Morciano di Leuca, Biblioteca Maggiulli-Cacciatore, ms. 34.

26 Wie oben Anm. 20. - Handschriftliche Vorlage (endgültige Redaktion) von Maggiullis Monographie über Otranto: Morciano di Leuca, Biblioteca Maggiulli-Cacciatore, ms. 35. Der Text der Urkunde von 1088 ebd. S. 48-49 des Anhangs.

27 Im Druck (S. 372) perambilavimus, was aber lediglich ein Druckfehler ist, wie aus dem Vergleich mit der Vorlage (ms. 35) hervorgeht. 
sepeliendorum ibidem. Sane universis fidelibus Ecclesiam ipsam devote visitantibus usque ad proximas Kal. Aprilis indulsimus annos duos, et carinas duas injunctae illis pro criminalibus poenitentiae; in Anniversario vero ipsius consecrationis perpetuis temporibus indulsimus unum annum, et carinam unam visitantibus eandem Ecclesiam per totam octavam. Ad indicium autem hujus consecrationis et indulgentiae praesens scriptum fieri jussimus per manus Reginaldi Clerici et publici Notarii Hydrunt. et praedictorum Archiepiscoporum subscriptionibus et sigillorum impressionibus communitum.

Ego Roffridus Arch. Benev. et Apostolicae Sedis Legatus. - Ego Gullielmus Arch. Hydrunt. - Ego Ursus Arch. Baren. - Ego Albertus Arch. Brund. - Simeon Iudex, quod chartula signat. - Ego Rodegarius Presbyter me subscripsi. - Ego Leo Presbyter. - Signum † factum per manus Nicolai Presbyteri. - Ego Guilelmus Presbyter subs. Ego Landus Sacerdos. - Ego Alferius Diac. subs. - Ego Ubertus Diac. subs. - Ego Bonifacius humilis Diaconus. - Ego Iohannes subdiaconus subs. - Ego Bernardus Clericus.

Das vorliegende Dokument, an dessen Echtheit Holtzmann keinen Zweifel gehabt zu haben scheint, ist, besonders was seine zweite Hälfte betrifft, problematisch. Im Eschatokoll ist nach Albertus Arch(iepiscopus) zu ergänzen Tarent(inus). - Ego Godinus, denn es muß sich bei den unterschreibenden Erzbischöfen um Wilhelm von Otranto, Urso von Bari, Albert von Tarent und Godinus von Brindisi handeln, die allesamt auch in einer im August 1088 von Herzog Roger Bursa in Venosa ausgestellten Urkunde bezeugt sind ${ }^{28}$. Sie könnten also durchaus in der zweiten Julihälfte oder Anfang August in Otranto gewesen sein.

Der genaue Zeitpunkt der Weihe der Kathedrale von Otranto geht aus der Urkunde, die Mensis Augusti ausgestellt ist, nicht hervor. Als Zeitpunkt der Konsekration ist nämlich angegeben anno Domini Incarn(ationis) $1088 \ldots$. Kalendas Augusti, Pontifactus Domin(i) Urbani Papae II. an(no) primo. Wenn die Punkte vor Kalendas eine Lücke im Text andeuten, was wahrscheinlich ist, so würde hier eine Zahl zwischen $I I$ und $X V I I$ fehlen, was den Tagen zwischen dem 16. und 31. Juli entsprechen würde. Daraus ergibt sich, dass die Weihe der Kathedrale zwischen dem 16. Juli und dem 1. August erfolgte. Merkwürdig bleibt allerdings die Anwesenheit des Herzogs Roger in Otranto, denn im Jahre 1086 hatte er den Süden Apuliens an seinen Halbbruder Boemund I. abge$\operatorname{treten}^{29}$.

28 Houben: Venosa (wie Anm. 2) S. 284-287 Nr. 54.

29 Vgl. Dieter Girgensohn: Boemondo, in: DBI 11 (1969) S. 117-124; Cosimo Damiano Poso: Il Salento normanno. Territorio, istituzioni, società, Galatina 1988 (Università degli Studi di Lecce, Dipartimento di Scienze Storiche e Sociali, Ser. 2, Saggi e Ricerche 2), S. 43; Hubert Houben: Comunità cittadina e vescovi in età normanno- 
Größte Zweifel erhebt der zweite Teil der Urkunde, der wenn nicht ganz gefälscht so doch mindestens in späterer Zeit erheblich ,überarbeitet' worden sein muß. Hier ist nämlich die Rede von Ablässen und Karenen, die den Besuchern der Kirche gewährt wurden: denjenigen, welche die frisch geweihte Kathedrale bis zum 1. April (1089) besuchten, ein Ablaß von zwei Jahren und zwei Karenen; denjenigen, welche die Kirche am Jahrestag der Weihe und der darauf folgenden Woche besuchten, perpetuis temporibus ein Ablaß von einem Jahr und einer Karene. Die hier verliehenen Ablässe sind außergewöhnlich lang und für das 11. Jahrhundert ungewöhnlich ${ }^{30}$.

Bedenken erheben auch die Namen der im Eschatokoll genannten Personen, die allesamt lateinische Namen tragen (Reginaldus, Rodegarius, Landus, Alferius, Ubertus, Bonifacius, Bernardus), die nicht so recht zu dem Ende des 11. Jahrhunderts noch stark griechisch geprägten Ambiente Otrantos passen ${ }^{31}$.

Wenn auch die Quellenkritik an solchen nur in neuzeitlicher Überlieferung erhaltenen Urkunden vor neue Probleme gestellt wird, so zeigt sich doch, daß hier noch viele bisher unbekannte Spuren verloren gegangener mittelalterlicher Zeugnisse zu finden sind.

\section{Riassunto}

Sulla base di alcuni esempi documentari dell'Italia meridionale vengono illustrati le possibilità e i limiti di trovare nella documentazione moderna tracce di documenti medievali andati dispersi. Il caso dell'abbazia benedettina della SS. Trinità di Venosa dimostra le possibilità di rintracciare ancora numerose testimonianze medievali nonostanto che il suo archivio sia andato completamente disperso tra fine del Settecento e la metà dell'Ottocento. Tracce, cioè regesti e/o trascrizioni parziali o integrali, di documenti provenienti dall'archivio del baliato pugliese dell'Ordine Teutonico, confluito all'inizio dell'Ottocento nel Fondo Monasteri Soppressi dell'Archivio di Stato di Napoli, sono state trovate in lasciti di studiosi che consultarono l'Archivio napoletano prima della distruzione dei suoi fondi più antichi, avvenuta nel 1943. Infine ci si sofferma, dopo un rapido accenno a due documenti di Alessandro II, in cui la documentazione moderna è stata di aiuto per la ricostruzione del testo originario non

sveva, in: Otranto nel Medioevo tra Bisanzio e l'Occidente, hg.v. DEms., Galatina 2007 (Università del Salento, Dipartimento dei Beni delle Arti e della Storia, Saggi e Testi 33), S. $61-97$, bes. S. $74-76$.

30 Vgl. Nikolaus Paulus: Geschichte des Ablasses im Mittelalter. Vom Ursprunge bis zur Mitte des 14. Jahrhunderts, Darmstadt ${ }^{2} 2000$ (1. Aufl. 1922), Bd. 1 S. $94-109$, Bd. 2 S. $47 \mathrm{ff}$.

31 Vgl. Vera von Falkenhausen: Tra Occidente e Oriente: Otranto in epoca bizantina, in: Otranto nel Medioevo (wie Anm. 29), S. 13-60, bes. S. 51-54. 
conservato, sul documento relativo alla consacrazione della cattedrale di Otranto nel 1088 ad opera del legato pontificio Roffredo arcivescovo di Benevento. 


\title{
„Verborgene Schätze“ Nichtitalienische Stücke in den „Papsturkunden in Italien“
}

\author{
Rudolf Hiestand
}

Als vor zwanzig Jahren Regestenentwürfe für die Dalmatia-Croatia Pontificia erarbeitet wurden, begegnete ein Schreiben Alexanders III. von (1181) Juli 7 an den Grafen Miroslav von Zachulmia, der unter offen erklärter Verweigerung des Grußes und apostolischen Segens wegen seines Ungehorsam gegen einen päpstlichen Legaten, wegen der ausgebliebenen Restitution von geraubtem Kirchengut und wegen der Weigerung, alte Bischofssitze wieder herzustellen, schärfsten Tadel erhielt. Eine handschriftliche Basis fand sich in den dalmatinischen Archiven nicht. Der erste Herausgeber, der Präfekt des vatikanischen Archivs Augustin Theiner, hatte das Stück in seinen Vetera monumenta Slavorum meridionalium ohne weitere Angaben ex originali gedruckt, so daß die Bearbeiter der großen Urkundensammlungen des südslavischen Raumes, Ivan Kukuljević und Tade Smičiklas, entgegen ihrer Gewohnheit für dieses Stück keinen Aufbewahrungsort angaben ${ }^{1}$, und der Entwurf des Regests für die Dalmatia-Croatia den vorläufigen Vermerk erhielt Originale periisse videtur.

In Wirklichkeit gab es einen zweiten Druck bei Pflugk-Harttung ebenfalls aus dem Original, als dessen Aufbewahrungsort er auf das Vatikanische Archiv verwies, und der bereits zu einem Eintrag in die zweite Auflage des Jaffé geführt hatte (JL 14408) ${ }^{2}$, den auch Smičiklas anführte. Doch auch Pflugk-Harttung machte keine näheren Angaben über den Fundort, so daß sich die Frage stellte, wo in den riesigen Beständen des päpstlichen Archivs diese littera clausa aufbewahrt sei. Weiter half erst der von Raffaello Volpini erstellte Registerband zum Nachdruck der „Papsturkunden in Italien“. Eine Jaffé-Konkordanz führte zu den im ersten Bericht Kehrs über die römischen Archive und Bibliotheken aus dem Jahre 1900 verzeichneten Originalen in den Instrumenta miscellanea des Archivio Vaticano segreto, wo aus der Zeit vor 1198 neben fünf anderen Stücken weitgestreuter Herkunft aus Silva Candida, Vallombrosa, Maguelonne,

1 Vetera monumenta Slavorum Meridionalium, ed. Augustin Theiner, Romae/Zagrabiae 1863, Bd. 1 S. 1 Nr. 1; Codex diplomaticus regni Croatiae, Dalmatiae et Slavoniae, ed. Izdaje Ivan Kukuljević-SAKcinski, Zagreb 1863-1874, Bd. 2 S. 121 Nr. 167 (zu 1181 Juni 5); Codex diplomaticus regni Croatiae, Dalmatiae et Slavoniae, ed. T. SmičikLAs/ Marko Kostrenčić, Zagreb 1904-1906, Bd. 2 S. 176 Nr. 174.

2 Acta Pontificum Romanorum inedita, ed. Julius v. Pflugk-Harttung, 3 Bde., Tübingen 1881-1886, Bd. 2 S. 377 Nr. 431. 
S. Maria di Reno (D. Bologna) und Canterbury in der Tat auch das Original der littera clausa an den Grafen Miroslav aufbewahrt wird ${ }^{3}$. Nun war klar, weshalb die Suche an Ort und Stelle ohne Ergebnis geblieben war, wenn auch immer noch ungeklärt ist, weshalb es wieder sozusagen an seinem Ausgangspunkt liegt ${ }^{4}$. Der genaue Fundort war erst auf dem Weg über die Acta Romanorum Pontificum zu ermitteln gewesen, in umgekehrter Blickrichtung wäre erst bei einer mühsamen Kontrolle von Jaffé-Nummer um Jaffé-Nummer zu erkennen gewesen, daß es sich im Archivbericht um ein Original für einen nichtitalienischen Empfänger handelt. Es zeigte sich an diesem Beispiel, von welch hohem Wert die "Papsturkunden in Italien“ für andere Pontificiae sein können und wie unumgänglich eine Durchsicht des in ihr verzeichneten Materials ist, wie wünschenswert, ja eigentlich unentbehrlich ein rascher Zugriff auf solche Angaben wäre.

Solche „Funde“ wiederholten sich in der Folge für die neuen Bände der Gallia und der Germania Pontificia und bei anderen in Vorbereitung befindlichen Teilen des Papsturkundenwerkes. Nicht selten kamen mit Hilfe der Register Volpinis und vor allem eines heute in Göttingen liegenden Zettelkatalogs ${ }^{5}$ für alle Nennungen von Jaffé-Nummern sowohl in den Regestenbänden der bisher drei Pontificiae als auch in der langen Reihe von über 100 Vorarbeiten Überlieferungen zu Tage, die übersehen worden waren, weil solche Querverbindungen zwischen den einzelnen Teilen des Unternehmens verborgen geblieben waren ${ }^{6}$.

3 NGG, phil.-hist. Kl. 1898, S. 121 = Paul Fridolin KeHR: Papsturkunden in Italien. Reiseberichte zur Italia Pontificia, Nachdruck hg. v. Raffaello Volpini, 6 Bde., Città del Vaticano 1977 (Acta Romanorum Pontificum 1-6), Bd. 2 S. 303. Die Berichte in den Nachrichten der kgl. Gesellschaft der Wissenschaften zu Göttingen werden künftig stets mit GN und der gekürzten Jahrzahl zitiert und die Band- und Seitenzahl im Nachdruck hinzugefügt. Wird hingegen allein die von Volpini besorgte Ausgabe zitiert, so als ND bzw. Volpini mit der Angabe von Band, Seitenzahl und Nummer.

4 Bei Pflugk-Harttung: Acta (wie Anm. 2) wird auch die Frage erörtert, wie dieses Original (wieder) in das vatikanische Archiv gekommen sein könnte. Siehe dazu auch unten.

5 Dieser Zettelkatalog, der mit Hilfe von wissenschaftlichen und studentischen Mitarbeitern am Historischen Seminar der Universität Düsseldorf und meiner damaligen Sekretärin, Frau Karin Heemskerk, aufgebaut und seither fortlaufend aus den neuen Bänden ergänzt wird, liegt heute in der Arbeitsstelle des Papsturkundenwerkes in Göttingen und wird auch die im Gange befindliche Erstellung eines neuen Jaffé unterstützen.

6 Die letzte Zusammenstellung aller bisher erschienenen Bände der Regesta Pontificum Romanorum und der Vorarbeiten der verschiedensten Art in: Hundert Jahre Papsturkundenforschung. Bilanz - Methoden - Perspektiven. Akten eines Kolloquiums zum hundertjährigen Bestehen der Regesta Pontificum Romanorum vom 9.-11. Oktober 1996 in Göttingen, hg.v. Rudolf Hiestand, Göttingen 2003 (AAG, phil-hist. Kl. 3. Folge 261), S. 391-400. In einem weiteren Sinne hinzuzurechnen sind die Aufsätze von 
Es sei daher die Frage gestellt, was die Vorbereitung der Italia Pontificia und insbesondere die Berichte Kehrs und seiner Mitarbeiter über ihre Arbeiten in den Archiven und Bibliotheken Italiens für geographische Räume außerhalb Italiens erbrachten, was sie an solchen „verborgenen Schätzen“ wie die littera clausa für den Grafen Miroslav zu Tage gefördert haben. „Verborgen“ sind sie im strikten Wortsinn freilich alle nicht mehr, sondern durch die Papsturkunden in Italien erfaßt, aber in vielen Fällen noch nicht wirklich wahrgenommen. Es soll also ausschließlich um Nichtitalica aus der Arbeit an der Italia Pontificia gehen, nicht um die viel zahlreicheren neuen Funde für die Italia selbst, denn diese sind in die bisher erschienenen zehn bzw. zwölf Bände eingegangen. In den meisten Fällen handelt es sich bei solchen Nichtitalica um vereinzelte Zufallsfunde, nicht um das Ergebnis einer gezielten Suche nach Urkunden für einen bestimmten Empfänger. Von einer gezielten Verschleppung geschlossener Archive oder wenigstens eines größeren Urkundenbestandes mit Papsturkunden vor 1198 aus einem anderen Lande nach Italien ist im Gegensatz zum umgekehrten Fall weder für das Mittelalter noch für die Neuzeit etwas bekannt, mit der einzigen Ausnahme von Archiven, genauer Archivtrümmern einiger kirchlicher Institutionen der Kreuzfahrerstaaten, die aber hier nur gestreift werden sollen ${ }^{7}$. Dagegen gab es bekanntlich solche, zum Teil rückgängig gemachte Verlagerungen aus Rom nach Paris, aus Venedig nach Wien, aus der Toscana nach Berlin, aus Sizilien nach Spanien usw., mit dem heute bei weitem bedeutendsten Fall des immer noch erst zum Teil erfaßten und zugänglichen Archivs des Duca de Medinaceli in Sevilla für sizilische Archive, die im 17. Jahrhundert auf die iberische Halbinsel verbracht worden sind.

Eine weitere Einschränkung kommt hinzu. Zwar ist jede Überlieferung einer als Nichtitalica zu bezeichnenden Urkunde ein wichtiger Mosaikstein für die von Kehr als eigentliches Ziel ausgegebene „urkundliche Archivgeschichte “8 doch im Mittelpunkt werden im Sinne des für diesen Beitrag gewählten Titels nur die bei der Arbeit an der Italia Pontificia erstmals bzw. neu gefundenen Urkunden stehen, nicht die Überlieferungen für damals bereits bekannte, nicht für Italien bestimmte Urkunden, ob sie einzig nur aus einem Archiv oder einer Bibliothek südlich der Alpen bekannt sind oder ob es sich um weitere Überlieferungen bereits erfaßter, im Jaffé verzeichneter Stücke handelte. Die littera clausa für den Grafen Miroslav steht also eigentlich außerhalb des Rahmens unserer Überlegungen, da sie nur als „Wiederentdeckung" eines verschollen gewähnten Stückes zu gelten hat.

Walther Holtzmann: Papst-, Kaiser- und Normannenurkunden aus Unteritalien I. II, in: QFIAB 35 (1955) S. 46-85 und 36 (1956) S. 1-85. Der angekündigte dritte Teil ist nicht mehr erschienen.

7 Siehe zu diesem Problemkreis den Beitrag Die Italia Pontificia und das Kreuzzugsgeschehen in diesem Band.

8 Selbstanzeige von Italia Pontificia I, in: GGA 1906, S. 595 ff. 
Daß es überhaupt solche Neufunde von Nichtitalica, solche „verborgenen Schätze", gibt, die heute eigentlich keine solche mehr sind, verdankt man den Anfängen des Papsturkundenunternehmens. Denn mit dem Plan einer kritischen Edition der älteren Papsturkunden bis zum Jahre 1198, die Kehr der Gesellschaft der Wissenschaften zu Göttingen im Sommer 1896 als ein ihr zu ewigem Ruhm verhelfendes Unternehmen vorschlug, verband sich eine „Nachlese" in den Archiven und Bibliotheken, um Lücken bei Jaffé zu schließen und für Hunderte von dort als Inedita verzeichnete Urkunden die Texte zu besorgen'. Sie hatte in Wirklichkeit bereits vor der öffentlichen Ankündigung im Herbst 1896 mit den ersten von der Akademie bewilligten Mitteln begonnen und gleichzeitig mit ihr zu einem ersten Bericht über „Papsturkunden in Venedig" mit 15 neuen Stücken geführt. Er gab das Muster für die Folgezeit ab. In einem festen Schema erfolgte zuerst ein Überblick über die aufgesuchten Archive und Bibliotheken, dann über alle durchgesehenen Bestände, auch wenn sie keine Ausbeute ergeben hatten, um später neue Sucharbeiten an scheinbar übersehenen Stellen zu vermeiden, und schließlich eine Auflistung aller für wen auch immer und wie auch immer überlieferten und selbst nur in Inventaren und ähnlichen Aufzeichnungen erwähnten Papsturkunden bis 1198. Im Anhang folgte jeweils eine Edition der unbekannten oder bisher nur ungenügend edierten Urkunden, wiederum gleichgültig für welchen Raum sie bestimmt waren, um sie alle sogleich der Forschung zugänglich zu machen, im vollen Bewußtsein, daß gerade für „fremde“ Bestände vielleicht später noch weitere, oft auch bessere Überlieferungen zu Tage kommen könnten. Es ist daher der Nachteil, aber auch der besondere Reiz dieser Berichte, daß sie inhaltlich nicht geschlossen sind und immer wieder Überraschungen bieten. Einige werden uns im folgenden begegnen.

Seit um 1900 als Erweiterung des ursprünglichen, auf eine kritische Edition ausgerichteten Vorhabens die Erstellung von räumlich geordneten Pontificiae mit Bistum um Bistum, Kirche um Kirche, Kloster um Kloster zusammengestellten Nachrichten über die Beziehungen von und zu der Zentrale ins Auge gefaßt wurde ${ }^{10}$, war ein solches Vorgehen, alles an einem Ort vorhandene Material einzubeziehen, erst recht unumgänglich geworden. Es wäre in der Tat

9 Paul KeHr: Über den Plan einer kritischen Ausgabe der Papsturkunden bis Innocenz III., in: GN 96 S. 72-86 (ND in: Ders.: Ausgewählte Schriften, hg.v. Rudolf Hiestand, 2 Bde., Göttingen 2005, [AAG, phil.-hist. Kl., 3. Folge 250/1-2], Bd. 1 S. 3-17). Vgl. dazu auch Rudolf Hiestand: 100 Jahre Papsturkundenwerk, in: DeRs.: Papsturkundenforschung (wie Anm. 6), S. 11-44, und für die Italia Pontificia DERs.: Die Italia Pontificia, in: Das Deutsche Historische Institut in Rom 1888-1988, hg.v. Reinhard Ezze/Arnold Esch, Tübingen 1990 (Bibliothek des Deutschen Historischen Instituts in Rom 70), S. 167-189; und DERS.: Die unvollendete Italia Pontificia, in: DERS.: Papsturkundenforschung (wie Anm. 6), S. 47-57.

10 Vgl. Hiestand: 100 Jahre (wie Anm. 9) S. 25 ff. 
eine unnötige Verschwendung von Zeit und Kraft gewesen, nachher für eine Germania, eine Gallia, eine Anglia, eine Hispania Pontificia jedes Mal von neuem große Bestände, wie etwa das vatikanische Archiv, durchsehen zu müssen.

Die Geschichte dieser Nachlese und ihr zunächst alle Erwartungen, später alle Befürchtungen Kehrs übersteigender Ertrag ist hinlänglich bekannt. Er mündete schon nach etwas mehr als zehn Jahren in den Stoßseufzer „Papsturkunden ohne Ende! ${ }^{(11}$, der auch nach 100 Jahren seine Richtigkeit bewahrt, denn noch immer, wenn auch nicht für Italien, so doch für Kastilien und Teile des nördlichen Frankreichs, steht der Abschluß dieses ersten Arbeitsschrittes aus $^{12}$. Aus seinen eigenen Aufenthalten in Rom und Venedig für das sächsische Urkundenbuch und für die Diplomataabteilung der Monumenta Germaniae Historica und vor allem aus der jahrzehntelangen Arbeit von Mitarbeitern der Monumenta, von Ferdinand Kaltenbrunner und Julius v. Pflugk-Harttung, um nur einige seiner Vorgänger zu nennen ${ }^{13}$, war Kehr von Anfang an bewußt, daß in Italien auch Papsturkunden für Empfänger außerhalb Italiens überliefert sind. Daher lautete der Titel der meisten Berichte „Papsturkunden in ...", die seit 1905 erscheinenden Berichte über einen zweiten Durchgang, eine Art NachNachlese, „Nachträge zu den Papsturkunden in Italien“14. In ihrer Mehrzahl sind es gewiß nicht nur „Papsturkunden in Italien“, sondern zugleich Papsturkunden für Italien. Doch die gewählte Formulierung deutete eben von Anfang an darauf hin, daß die Nachlese auch Ergebnisse für die anderen Teile der Latinitas bringen könne. Dabei machte das eigentliche Ziel, jene „urkundliche Archivgeschichte", die Kehr selbst im Jahre 1906 hervorhob, jeden Aufbewahrungsort, jede Urkunde und jede Handschrift an ihrem augenblicklichen Lagerort zum Überlieferungsträger, dessen Schicksal es dann zurückzuverfolgen galt $^{15}$.

11 GN 05 S. 321 (ND Bd. 5 S. 1).

12 Zum aktuellen Stand vgl. die jährlich erscheinenden Tätigkeitsberichte in: Jahrbuch der Akademie zu Göttingen, DA, MIÖG und SZG.

13 Pflugk-Harttung: Acta (wie Anm. 2); Ders.: Iter Italicum, Stuttgart 1883; Ferdinand Kaltenbrunner: Papsturkunden in Italien, in: SAW, phil.-hist. Kl. 94 (1879) S. $627-$ 705.

14 GN 1905-1962 (ND Bd. 5), zum Gesamtverzeichnis dieser Beiträge siehe Anm. 6.

15 Selbstanzeige (wie Anm. 8) S. 593-610 (ND KeHR: Schriften [wie Anm. 9] Bd. 1 S. 18-39), S. 595 ff. (20 ff.) mehrfach. Zu dieser auf die Überlieferungsgeschichte ausgerichteten Blickweise wäre natürlich umgekehrt die Frage zu stellen, wie viele der in der Italia Pontificia enthaltenen Stücke auch oder sogar ausschließlich auf Überlieferungen außerhalb der Halbinsel zurückgehen. Vor allem spanische Archive und Bibliotheken haben eine ganze Reihe von Überlieferungen für Sizilien geliefert wie z.B. GN 05 S. 332 (ND Bd. 5 S. 12) Nr. 6: Anaklet II. erhebt Messina zum Erzbistum (JL 8423; IP 10 S. 339 Nr. 23) in Kopie saec. XII in Madrid, Biblioteca Nacional ms. 198. $\mathrm{Zu}$ dieser ältesten, von Ewald bei seiner Spanienreise gefundenen Kopie des 12. Jahr- 
Die Änderung des Gesamtplanes fiel zeitlich zusammen mit der Hinwendung der Nachlese zu den römischen Archiven und Bibliotheken. In der Tat brachte gleich der erste Bericht aus Rom aus den von Kehr ziemlich eigenmächtig verlängerten Semesterferien des Frühjahrs 1900 neben dem versteckten Hinweis auf das Original der littera clausa an den Grafen Miroslaw von Zachulmia den historisch vielleicht wichtigsten Fund der ganzen Nachlese in Italien: das noch eingehender zu erörternde feierliche Privileg Clemens' III./ Wiberts für Antivari/Bar im südlichen Dalmatien ${ }^{16}$ - zweifellos ein verborgener Schatz, der nun ans Tageslicht kam.

Nicht nur, wenn auch vor allem in den Berichten über die römischen Archive konnten auch neugefundene Papsturkunden für Empfänger außerhalb Italiens veröffentlicht werden. Raffaello Volpini hat im Empfängerverzeichnis für den Nachdruck der „Papsturkunden in Italien“ auch diese nichtitalienischen Lemmata größtenteils ausgeworfen ${ }^{17}$, doch in der Liste der in den "Papsturkunden in Italien" gedruckten Urkunden fehlen die Nichtitalica erklärtermaßen ${ }^{18}$. Sie sind auch nicht in einem Sonderverzeichnis zusammengestellt, wie auch eine größere Zahl von nur als Regesten zu verlorenen Bänden der päpstlichen Register gefundenen Stücken, ob Italica oder Nichtitalica, nicht in das Empfängerverzeichnis aufgenommen wurde ${ }^{19}$. Weggelassen wurde im Nachdruck zudem der Bericht Kehrs über die Papsturkunden für S. Maria im Tale Josaphat $^{20}$, wohl weil der Sitz der Abtei im Hl. Land war. Doch alle ihre Urkunden befinden sich heute in sizilischen Archiven und Bibliotheken, sind also durchaus „Papsturkunden in Italien“, ja bei der Mehrzahl der dort im

hunderts, sind unterdessen eine Reihe späterer Kopien gekommen. Dagegen sind die Abschriften der Mauriner in einer Pariser Handschrift (Bibliothèque Nationale de France, fonds lat. 11887 aus St-Germain-des-Prés) GN 05 S. 334 (ND Bd. 5 S. 14) Nr. 8 von Innozenz II. 1138 Juni 27 für San Pancrazio an der Via Aurelia, dessen Archiv 1849 bei der Belagerung der Stadt untergegangen ist, und von Clemens III. von 1189 Januar 31 für S. Michele sub ripa bei Cervetri, dessen Archiv in San Pancrazio aufbewahrt worden war, ebd. S. 369 (ND Bd. 5 S. 49) Nr. 40, die einzige Überlieferung geblieben. Ebenfalls aus Paris Agapit II. für Ravenna von 948 Oktober, JL *3665, RI 2/5 Nr. 220, ed. Harald Zimmermann: Papsturkunden 896-1046, 3 Bde. Wien ${ }^{2} 1988 /$ 1989 (DÖAW, phil.-hist. Klasse 174, 177, 198), Bd. 1 S. 207 Nr. 118, ed. GN 10 S. 232 (ND Bd. 5 S. 230) Nr. 1, IP 5 S. 50 Nr. 156, ein Vidimus von 1224 als heute einzige Überlieferung.

16 GN 99 S. 508 (ND Bd. 1 S. 447) Nr. 1 und GN 00 S. 148 (ND Bd. 2 S. 330) Nr. 7. Von Kehrs meist erfolgreichen Bemühungen, den Aufenthalt in Italien während der Semesterferien zu verlängern und die Rückkehr nach Göttingen solange als irgend möglich zu verzögern, gibt sein Briefwechsel mit Rudolf Smend, der durch das freundliche Entgegenkommen des gleichnamigen Enkels und langjährigen Präsidenten der Göttinger Akademie eingesehen werden konnte, ein plastisches Bild.

17 ND Bd. 6 S. 33-62.

18 ND Bd. 6 S. 65-121

19 Siehe auch unten.

20 GN 99 S. 338-368 (ND KeHr: Schriften [wie Anm. 9] Bd. 1 S. 290-320). 
Anhang gedruckten Urkunden handelt es sich um „Papsturkunden für Italien“, denn die Serie von Spuria auf den Namen Innozenz' II. betraf trotz der Adresse an den Abt des Mutterhauses in Jerusalem nicht den transmarinen Besitz, sondern denjenigen auf der Insel und in Süditalien (Nr. 1-3), zwei echte Stücke den Besitz in Galiläa und auf Sizilien (Nr. 4 und 5) und ausschließlich das Hl. Land nur die beiden letzten (Nr. 6 und 7) - auch eine Art „verborgener Schatz“.

Insgesamt umfaßt der Nachdruck nach Volpini 1213 Urkunden mit italienischem Betreff, die letzten 26 als Vorarbeiten für den Band 9 der Italia nicht mehr von Kehr, sondern von Walther Holtzmann herausgegeben ${ }^{21}$; 285 waren schon im Jaffé verzeichnet, wenn auch öfters mit Asterisk, weil sie nur in beiläufigen Angaben oder Regesten vor allem in Pflugk-Harttungs Iter Italicum und bei Kaltenbrunner erwähnt worden waren. Nicht ganz 900 Italica sind aber erstmals erfaßt, wenn auch darunter eine größere Anzahl nur in Auszügen oder Regesten erhaltener Stücke. In 36 Fällen handelt es sich um Urkunden von Legaten und delegierten Richtern, sechs Stücke stammen aus der Zeit nach 1198. Doch zu diesen 1213 Italica kommen einerseits die nur geschätzte Zahl von vielleicht etwa 100 weiteren Papsturkunden, die ebenfalls italienische Empfänger betreffen und für die nur im fortlaufenden Text der Archivberichte regestenartige Notizen aus alten Inventaren usw. wiedergegeben werden, ohne daß sie nachher unter den neu edierten Urkunden erscheinen noch in die Gesamtliste im Nachdruck aufgenommen worden sind, und andererseits diejenigen Papsturkunden, die nicht Italien betreffen und von Volpini wie gesagt nicht in seine chronologische Liste aufgenommen wurden.

Diesen etwas über 200 Nichtitalica sollen die folgenden Ausführungen gelten. Sie betreffen fast den ganzen geographischen Raum der Latinitas: von Dalmatien und dem Hl. Land ist schon die Rede gewesen, doch außer Polen, Böhmen-Mähren und Ungarn sind alle ihre Teile vertreten. Sie lassen sich in drei Gruppen gliedern: Urkunden für die großen „internationalen“ Reformund vor allem Ritterorden - 85 Stücke -, Inserte in den Registern des 13.-16. Jahrhunderts - 66 Stücke - und als heterogenste Gruppe weitgehend einzeln überlieferte Urkunden aus den verschiedensten Überlieferungen - 72 Stücke. Dabei gibt es unvermeidlicherweise einige Überschneidungen sowohl zwischen italienischen und nichtitalienischen Betreffen wie zwischen den drei Gruppen von Nichtitalica, zahlenmäßig am wenigsten bei der Überlieferung aus den Registern, in denen sich nur zwei unbekannte Stücke, darunter eine fast groteske

21 ND Bd. 6 S. 63-121. Daß einige Urkunden als Ergebnis des Arbeitsfortschrittes in den Berichten zweimal erscheinen, weil man zuerst nur ein Regest oder eine unvollständige Abschrift gefunden hatte, die später durch einen verbesserten Druck ersetzt oder ergänzt werden konnte, wie beim Privileg Clemens' III. (Wibert) für Antivari, siehe oben Anm. 16, ist in der Liste von Volpini bereits berücksichtigt. 
Fälschung, für die Orden finden ${ }^{22}$, wie nur zwei vorher unbekannte Stücke in Einzelüberlieferung nachher auch noch in den Registern zum Vorschein gekommen $\operatorname{sind}^{23}$. Dagegen betreffen je sechs Stücke sowohl die Reform- und Ritterorden als auch Kirchen und Klöster außerhalb Italiens ${ }^{24}$ bzw. die Registerüberlieferung, die damit doppelt erscheinen, während zehn weitere die Reform- und Ritterorden und italienische Kirchen und Klöster betreffen.

Betont sei nochmals, daß es im folgenden nur um die als neue oder verbesserte Texte in den Berichten Kehrs und seiner Mitarbeiter in der einen oder anderen Form veröffentlichten Stücke geht, nicht um Tausende, unter Verweis auf Jaffé-Nummern erwähnte Überlieferungen von Originalen und Kopien ${ }^{25}$, unter denen sich auch solche für Gebiete außerhalb Italiens befinden ${ }^{26}$, und ebenso auch unter den „neuen“ Stücken nur um diejenigen, die nicht Italien betreffen, eben die Nichtitalica. Die ersteren sind über eine Konkordanz zwischen diesen Nennungen von Jaffe-Nummern und den fünf Bänden des Nachdruckes zu ermitteln, die letzteren, d.h. die neuen Italica über die chronologische Liste und das Empfängerverzeichnis im Registerband des Nachdruckes. Sie sind zudem in die Überlieferungsvermerke für das ihnen entsprechende Regest in den Bänden der Italia Pontificia aufgenommen worden. Da diese im Anhang zu den Kehrschen Berichten erfolgten Drucke von Nichtitalica dagegen leicht übersehen werden, was vereinzelt auch für die nachher erschienenen nichtitalienischen Regestenbände und für die Zusammenstellung der Überlieferung in den vorbereitenden Bänden für die anderen Pontificien gilt ${ }^{27}$, sollen sie für jede der drei Gruppen chronologisch (Tabelle I-III) und dann für alle Gruppen in einem Empfängerregister (Tabellen IV) zusammengestellt

22 Tabelle III Nr. 1 und 55.

23 Tabelle III Nr. 13 und 60.

24 Tabelle I Nr. 5, 20, 73, 78, 83

25 Es ist zu beachten, daß vor allem für Rom die in Handschriften enthaltenen Kopien nicht einzeln verzeichnet werden, wenn bereits frühere Romreisende diese beschrieben hatten, und damit auch nicht in die Jaffé-Konkordanz im Registerband des Nachdruckes eingehen konnten. Auch dies ist eine Quelle für Lücken in späteren Arbeiten geworden.

26 Vgl. die Konkordanz mit Jaffés Regesta Pontificum Romanorum im Registerband des Nachdruckes (S. 123-166), die für Recherchen weiterführen kann, wobei das dort genannte Auswahlkriterium für die Nichtitalica keine größere Einschränkung nach sich zieht, sondern sich vor allem auf die Italien betreffenden Stücke auswirkt.

27 Bei GP 1 fehlt für Klosterneuburg das von Kehr nach Garampi angeführte Insert in den Registern Pauls III., vgl. GN 02 S. 511 (ND Bd. 3 S. 485), während Ramackers die Kopie von Urban II. (†5680) für Glanfeuil ebenfalls im vatikanischen Archiv entgangen ist, siehe unten Anm. 70. - Hingewiesen sei darauf, daß die in der Jaffé-Konkordanz aus GN 03 S. 85 (ND Bd. 4 S. 85) verzeichnete Überlieferung von JL 9136 Eugen III. für Prüll-Karthaus einem Irrtum entspringt, denn es handelt sich dort um einen Verwies auf die Handschrift Vat. Lat. 9136. 
werden. Das Schwergewicht liegt aber im folgenden auf der Geschichte und der Bedeutung dieser Funde.

\section{a) Papsturkunden für die Reformorden und die Johanniter und Templer}

Nur knapp betrachtet werden sollen die 85 neuen Urkunden mit 101 Betreffen für die großen „internationalen“ Reformorden und die Ritterorden mit allgemeiner Adresse. Dagegen bleiben die an namentlich genannte Zisterzen oder Karthausen in Italien gerichteten Stücke außer Betracht. Umgekehrt werden für die Cruciferi, die als ein italienischer Orden gelten können, nur Stücke für ihre Besitzungen außerhalb der Apenninenhalbinsel berücksichtigt ${ }^{28}$. Von vorneherein fällt die geringe Zahl von Stücken für die Reformorden auf, und kennzeichnend für die italienischen Verhältnisse findet sich unter ihnen kein Stück für die Prämonstratenser, wie auch keines für die Zisterzienser oder die Karthäuser Einzelpersonen oder Orte außerhalb Italiens nennt.

Bei den Ordensarchiven und -überlieferungen steht man freilich für die räumliche Zuordnung, damit auch für die Trennung Italica/Nichtitalica vor einem erst in jüngster Zeit genauer erkannten Problem. Für Besitzbestätigungen in der Form feierlicher Privilegien und die Verleihung von Rechten stellte die einzelne Zisterze oder Karthause je eine eigene Rechtspersönlichkeit dar und erhielt dementsprechend an sie im Protokoll oder in der Narratio individuell gerichtete Urkunden ${ }^{29}$, was für die viel zentralistischer in die Hierarchie des Ordens eingebauten Häuser der Johanniter und Templer mit den sich daraus ergebenden Folgen für den Verkehr mit der Kurie nur ausnahmsweise der Fall

28 Für die Cruciferi und einzelne ihrer Niederlassungen sind bestimmt GN 1898 S. 40 (ND Bd. 1 S. 213) Nr. 16, 99 S. $227-249$ (ND Bd. 2 S. 535-557) Nr. 9-12, 18, 19, 24, 27, 29-35, 41, 42; 09 S. 496 (ND Bd. 5 S. 204) Nr. 27, 12 S. 450 (ND Bd. 5 S. 457 ) Nr. 22, 24 S. 168 (ND Bd. 5 S. 535) Nr. 8. Zu Tab I Nr. 77 und $79=99$ S. 245 (ND Bd. 1 S. 553) Nr. $36=09$ S. 496 (ND BD. 5 S. 204) Nr. 27 und GN 98 S. 40 (ND Bd. 1 S. 213) Nr. 16 siehe unten. Zum Orden und seinem Haupthaus bei Bologna vgl. IP 5 S. 284; zuletzt Katrin BAAKen: Papsturkunden für die Cruciferi, in: Ex ipsis rerum documentis. Beiträge zur Mediävistik. Festschrift für Harald Zimmermann zum 65. Geburtstag, hg.v. Klaus Herbers/Hans Henning Kortüm/Carlo Servatius, Sigmaringen 1991, S. 335-343. Eine knappe Notiz von H. L. M. van RooiJen/G. D. Gordini, Art. Crocigeri italiani, in: Dizionario degli Istituti di Perfezione, Bd. 3, Roma 1973, Sp. 311-313, ist enttäuschend. Auf seinem Höhepunkt hatte der Orden über 200 Hospitäler bis ins Hl. Land unter sich.

29 In die Tabelle I sind demgemäß nur allgemeine Verfügungen für die Zisterzienser und Karthäuser aufgenommen. Unbekannte Stücke für Zisterzen oder Karthausen außerhalb Italiens sind in den Papsturkunden in Italien keine enthalten. 
$w^{30}{ }^{30}$. In den meisten Stücken, in denen ein Orden und eine einzelne Kirche Italiens genannt wurden, handelte es sich um Rechtsstreitigkeiten ${ }^{31}$. Waren diese Fälle eindeutig, so stellte sich die Frage der Zuordnung für die mit feststehendem Formular den Orden erteilten litterae de gratia über spezielle Rechte. Sie waren in der Regel mit einer allgemeinen Adresse versehen. Wie weit aber für solche, heute in einer Zisterze oder einer Karthause oder einer Niederlassung der Ritterorden als Einzelkopie oder in einer Sammelkopie bzw. einem Chartular oder Bullar überlieferte Stücke schon die zugrundeliegenden Originale an die betreffende Niederlassung gegangen waren, ob umgekehrt ein heute dort aufbewahrtes Original mit allgemeiner Adresse und allgemeinen Verfügungen erst nachträglich dorthin kam und damit im Regestenwerk nur unter dem Orden als Ganzem oder als eine in Wirklichkeit von Anfang an für die betreffende einzelne Niederlassung bestimmte Ausfertigung der päpstlichen Kanzlei unter deren Regesten aufzunehmen ist, läßt sich sehr oft kaum mehr festzustellen. Hinzukommt für die Frage Italica oder Nichtitalica bei Kopien allgemeiner Privilegien, daß die Zisterzienser, die Karthäuser, die Prämonstratenser zu Beginn des 14. Jahrhunderts, und im 15. Jahrhundert auch die Johanniter Bullarien anlegten und vervielfältigten, um den einzelnen Niederlassungen die erforderlichen Rechtstitel zur Verteidigung ihrer Interessen zur Verfügung zu stellen $^{32}$.

Um wenigstens zwei Beispiele für die dadurch entstehenden Probleme bei der Frage Italica/Nichtitalica zu nennen: Es ist sehr fraglich, ob für zwei, im Fonds von Lucedio (D. Ivrea) im Staatsarchiv in Turin in einer Sammelkopie enthaltene Zistenzienserprivilegien Lucius' III. schon die Originale in Lucedio lagen oder nicht in einer anderen Zisterze, wo dann die später in Lucedio aufbewahrten Kopien erstellt wurden ${ }^{33}$. Ähnlich verhält es sich mit einer Reihe von Urkunden für die Karthäuser aus den Registern, wo zwar die neuen Rahmenurkunden an genannte Karthausen in Nordfrankreich und Süddeutschland gingen, aber die inserierten allgemeinen Privilegien für den Orden weitgehend identisch sind. Daß der Registerschreiber einmal am Rande hinzufügt Scripta est in quaterno diversarum formarum und auf eine Stelle im betreffenden Band verweist $^{34}$, deutet auf eine gemeinsame Vorlage für die verschiedenen Inserte hin, die bekannte allgemeine Rechtsverleihungen für den Orden enthielt ${ }^{35}$.

30 Tabelle I Nr. 6, 7, 21, 25, 46, 48, 73. Für die Ritterorden siehe den Beitrag in diesem Band: Rudolf Hiestand: Die Italia Pontifica und das Kreuzzugsgeschehen.

31 SieheTabelle I Nr. 17, 34, 50, 55, 75, 77 79, 85.

32 Siehe auch unten Anm. 35 und S. 425.

33 GN 01 S. 60 (ND Bd. 3 S. 30) und S. 110 (ND Bd. 3 S. 80) Nr. 24 und 25.

34 GN 02 S. 444 (ND Bd. 3 S. 418).

35 GN 02 S. 443 f. (ND Bd. 3 S. 417 f.) mit Inserten von JL 15141, 16208, 16507, 16508, 16912 und 16915. Acht Sammelkopien aus den päpstlichen Registern Johannes' XXII. der Jahre 1331-1333 (Reg. Avign. 38, 42, 43 und 44 = Reg. Vat. 100, 103, 104 und 
Andererseits sind Ausfertigungen bekannter Formulare mit abweichenden Daten wohl öfters vorschnell auf Kopisten- oder Kanzleifehler zurückgeführt worden, während sie in Wirklichkeit, vor allem wo es um Originale geht, eine für die betreffende Zisterze oder Karthause ausgestellte Ausfertigung darstellen, wie andererseits am gleichen Tage Mehrfachausfertigungen erstellt wurden, die von Anfang an für verschiedene Ordensniederlassungen bestimmt waren ${ }^{36}$. Solche Überlieferungen sind in den letzten Bänden der Germania und der Gallia Pontificia jeweils unter der Institution ihres heutigen Überlieferungsortes als eigenes Regest aufgenommen worden ${ }^{37}$. Daher ist ein im Archiv der Certosa di Trisulti (D. Alatri) aufbewahrtes Original Urbans III. von (1186-1187) März 29 „Cum dilectos filios“ gegen diejenigen, welche die Privilegien der Karthäuser verletzen, nicht mit Ausfertigungen von (1186-1187) März 19 in anderen Karthäuserarchiven gleichzusetzen, sondern ein neues Stück, wenn auch ein Italicum, das unter Trisulti ein Regest hätte erhalten müssen und historisch den Übergang der alten Benediktinerabtei an die Karthäuser um über 20 Jahre vorverlegt ${ }^{38}$.

\section{b) Einzelstücke für nichtitalienische Empfänger}

Unter den nichtitalienische Empfänger betreffenden Stücken sind - abgesehen von denjenigen für die großen Orden - wie angedeutet zwei Gruppen zu trennen: einerseits die Inserte von Papsturkunden aus der Zeit vor 1198 in den päpstlichen Registern des 13.-16. Jahrhunderts, andererseits die in einer Vielzahl von Archiven und Bibliotheken Italiens überlieferten einzelnen Stücke, die

105) mit insgesamt sechs allgemeinen Privilegien des 12. Jahrhunderts in wechselnder Zusammenstellung (JL 15141 - dreimal, 16208 - dreimal, 16507 - zweimal, 16508 zweimal, 16912 - dreimal und 16915 - dreimal). Gesichert um Gallica bzw. Germanica handelt es sich nur bei den Sammeltranssumpten des 14. Jahrhunderts, während offen bleibt, woher die inserierten Vorlagen des 12. Jahrhunderts kamen, die weder in der Adresse noch im Text spezifizierende Angaben aufweisen.

36 Vgl. Rudolf Hiestand: Die Leistungsfähigkeit der päpstlichen Kanzlei im 12. Jahrhundert mit einem Blick auf den lateinischen Osten, in: Papsturkunde und europäisches Urkundenwesen. Studien zu ihrer formalen und rechtlichen Kohärenz vom 11. bis 15. Jahrhundert, hg.v. Peter Herde/Hermann Jakobs, Köln/Weimar/Wien 1999 (ADipl Beih. 7), S. 1-26, hier S. 15 ff.

37 Vgl. z. B. die Nachweise bei Volpini (wie Anm. 3) Bd. 6 S. 158 ff. für JL 15141 (Bd. 1 S. 147; Bd. 3 S. 311, 418; Bd. 4 S. 75), JL 16208 (Bd. 1 S. 148; Bd. 3 S. 417 f.), wobei diese Kopien an Karthausen in Italien gingen, JL 16507 (Bd. 3 S. 517 f.), 16508 (Bd. 1 S. 148 ; Bd. 3 S. 311, 417, 418) JL 16912 (Bd. 1 S. 148; Bd. 3 S. 311, 417 f.) und JL 16915 do.

38 GN 00 S. 329 (ND Bd. 2 S. 496) Nr. 17 und IP 2 S. 152 einzureihen ebd. S. 154 nach Nr. 6. Dieses als Original erhaltene Stück gehört durch die Überlieferung archivalisch zu Italien, umso mehr als aus anderer Überlieferung eine Ausfertigung von März 19 bekannt ist. 
nicht Italien betreffen. Zahlenmäßig handelt es sich um zwei, in ihrem Umfang nicht sehr stark abweichende Gruppen, wobei zwei nachträglich aus den Registern edierte Stücke bei diesen behandelt werden.

Wenn angesichts der Funktion der Register, in mehr oder weniger chronologischer Reihenfolge Kanzleiauslauf ohne Rücksicht auf die geographische Zuordnung des Adressaten festzuhalten ${ }^{39}$, von vorneherein klar ist, daß sich dort auch Stücke für nichtitalienische Empfänger als Inserte finden können und sich eine, wenn auch angesichts der Masse der Überlieferung mühsame Suche aufdrängte, so ist es mit den übrigen Überlieferungen anders. Sie können nur in Sonderfällen an einer bestimmten Stelle vermutet werden. Um ein Beispiel für Italica außerhalb Italiens anzuführen, würde niemand auf die Idee kommen, sozusagen aufs Geratewohl nach Chartres zu fahren, um dort Urkunden für den Dogen von Venedig und den Patriarchen von Grado aus der Zeit um $1000 \mathrm{zu}$ suchen $^{40}$, sowenig man alle französischen Archive durchsuchen könnte, um Stücke für Venedig aufzuspüren. Wie solche Nichtgallica nicht genuin aus Frankreich überliefert sein können, so auch Nichtitalica nicht genuin aus Italien, soweit sie nicht gleichzeitig auch Italien betreffen, was nur in wenigen Fällen zutriff $\mathrm{t}^{41}$. Daher handelt es sich in dieser Gruppe auch fast ausschließlich um Kopien und nicht um Originale. Dennoch ist jedes Mal im Sinne der von Kehr angestrebten urkundlichen Archivgeschichte zu prüfen, wie sich die Überlieferung in einem Archiv oder einer Bibliothek der Apenninenhalbinsel erklärt. Insgesamt handelt es sich außerhalb der Register um 72 Urkunden mit 112 Betreffen (Tabelle II) ${ }^{42}$.

Am Anfang soll ein kurzer Blick auf den Verlauf der Nachlese stehen. Zum ersten Mal stieß Kehr auf eine unbekannte Urkunde, die über Italien hinauswies, als er 1897 in San Severino (Marche) im Archiv der dortigen Kreuzträger das Original eines Privilegs Cölestins III. von 1191 Juni 21 fand (II Nr. 65) ${ }^{43}$. Mit ihm nahm der Papst die dem Orden bzw. seinem Hospital s. Petri de Bojsce gehörende Kirche S. Croce in Non vor den Toren Zaras in Dalmatien unter päpstlichen Schutz und bestätigte - wie schon in einer damals noch als verloren

39 Die Frage von Expeditionsbündeln spielt hier keine Rolle.

40 Vgl. Papsturkunden in Frankreich, N.F. 6: Orléanais, ed. Johannes Ramackers, Göttingen 1958 (AAG, phil-hist. Kl., 3. Folge 41), S. 32 f., in einer Handschrift mit Briefen Ivos von Chartres.

41 Z. B. Bd. 2 Nr. 55, 56, 61, 65, 70?, 72.

42 Die Entscheidung, für welche Stücke künftig auch Nebenregesten in einem Band der Regesta zu erstellen und damit hier als Betreffe auszuwerfen sind, kann erst vorläufig sein. Es wird den Kopfregesten gefolgt, die den edierten Urkunden vorangehen.

43 GN 98 S. 40 Nr. 16 (ND Bd. 1 S. 213); zu den Kreuzträgern siehe oben Anm. 28; bei BaAken: Papsturkunden (wie Anm. 28) wird die Urkunde Cölestins III. nicht erwähnt. Um den Anmerkungsapparat zu erleichtern, wird im folgenden zu den einzelnen Stücken jeweils auf die Tabelle II bzw. III verwiesen, wo sich die Verweise auf GN und den Nachdruck bei Volpini (wie Anm. 3), evtl. auch weitere Drucke finden. 
geltenden Urkunde Clemens' III. - ein in päpstlichem Auftrag ergangenes Urteil einiger Geistlicher aus Zara über einen Streit der Kreuzträger mit den Templern in Zara. Ein Jahr darauf fand sich in der handschriftlichen Ordensgeschichte in Treviso auch eine Abschrift dieser Urkunde Clemens' III., die vorerst nur in Regestenform veröffentlicht wurde; zehn Jahre später folgte bei der NachNachlese nach einem Textvergleich, der entgegen der ersten Annahme doch gewisse Abweichungen aufzeigte, ein Druck des Volltextes (II Nr. 61). Wenn beide Stücke sicher Nichtitalica sind, wie es sich schon beim Adressaten frater Matthaeus nicht um den Ordensmeister ${ }^{44}$, sondern den Vorsteher des Hauses in Zara handelt, so andererseits doch auch Italica, weil die Kreuzträger wie gesagt ein im wesentlichen auf Oberitalien und die angrenzenden Gebiete beschränkter Orden waren, dessen Haupthaus in Bologna lag. So ergänzen diese Stücke, die auch in die Italia Pontificia aufgenommen wurden ${ }^{45}$, in wertvoller Weise die Nachrichten über die dalmatinische Kirche und ihre Beziehungen zum Papsttum am Ende des 12. Jahrhunderts ${ }^{46}$.

Als Zufall mag es vorerst erscheinen, daß auch die letzte von Kehr im Jahre 1924 in den Berichten veröffentlichte, von heute her gesehen nichtitalienische Urkunde für den gleichen Raum bestimmt war: eine Urkunde Clemens' III. für das Bistum Koper (Capodistria), jetzt im schmalen Küstenstreifen Sloweniens an der Adria. Capodistria war jedoch damals ein Suffragan des Patriarchen von Aquileia und die Urkunde ist daher zu Recht in der Italia als ein Haupteintrag verzeichnet (II Nr. 63) ${ }^{47}$. Dennoch: um einen reinen Zufall handelt es sich nicht, weil der Beitrag „Nachträge zu den Papsturkunden in Italien IX“ der Vorbereitung von Italia 7/1 und 7/2 diente, mit denen im Jahre 1925 die Bearbeitung von Oberitalien mit den Kirchenprovinzen Aquileia und Grado abgeschlossen wurde. Auch wenn unsere übliche Betrachtungsweise als Folge der politischen Lage nach dem zweiten Weltkrieg oft einen tiefen Graben zwischen der Apenninenhalbinsel und den an der Adria gegenüberliegenden Gebieten sieht, spielte Dalmatien im Mittelalter für die römische Kirche, die dort in der Spätantike ein reiches Patrimonium besessen hatte ${ }^{48}$, das sie mit der fortschreitenden Rückdrängung des byzantinischen Einflußbereiches wiederzugewinnen suchte, im 11. und 12. Jahrhundert eine bedeutende Rolle. Ebenfalls nach Dalmatien gehört das zeitlich vorletzte der neuen Stücke, ein Privileg Cölestins III. für S. Grisogono in Zara, das Kehr aufgrund der Abschrift von Margarini auf 1196 März 5 datierte, aber wie seither aus lokaler Überlieferung

44 Der Meister heißt im März 1187 Benencasa, im August 1195 Johannes, er wird aber immer ausdrücklich als magister bezeichnet, während Matthaeus in beiden Papsturkunden frater genannt wird, vgl. IP 5 S. 287 Nr. 8 und 10.

45 IP 4 S. 132 Nr. 2 und 3.

46 Zur Überlieferungsproblematik siehe unten.

47 IP 7/1 S. 54 Nr. 5.

48 Vgl. künftig die Dalmatia-Croatia Pontificia. 
bekannt ist, in Wirklichkeit zu 1195 Mai 5 gehört und im Jahre 1900 bereits im "Codex diplomaticius" von Kukuljević veröffentlicht war (II Nr. 71) ${ }^{49}$. Wissenschaftsgeschichtlich erinnern diese Stücke an die Bemerkung des bereits 78jährigen Kehrs aus einem Urlaub in Dalmatien im Jahre 1938, daß er sich gerne diesem Raum zuwenden würde, wenn er nur „die grässlichen (!) slavischen Sprachen verstünde ${ }^{\text {" } 50}$. Immerhin machte er damals Aufzeichnungen in den dortigen Archiven, die heute in Göttingen aufbewahrt werden.

Kehrt man zum Fortgang der Nachlese und der Frage von Nichtitalica zurück, so wies im gleichen Jahr 1898 eine Urkunde Paschalis' II. für die „Königin Konstanze von Frankreich“, wie im Kopfregest steht (II Nr. 4), nur auf den ersten Blick über die Alpen. In einer Handschrift in Brindisi überliefert, war sie in Wirklichkeit an die filia regis Franciae adressiert, jene Konstanze, Tochter Philipps I. von Frankreich, die im Jahre 1106 mit dem Kreuzzugsführer und Fürsten Bohemund von Antiochia verheiratet worden war. Zum Zeitpunkt der Ausstellung führte sie offensichtlich die Geschäfte ihres abwesenden Gatten oder bereits nach dessen Tode diejenigen ihres Sohnes Bohemund II. und erhielt vom Papst die Mahnung, zusammen mit dem Klerus und Volk von Oria, der cosedes von Brindisi, dem dortigen Erzbischof die schuldige Obödienz zu erwiesen. Trotz der Adresse „an die Tochter des französischen Königs“ gehört dieses Stück daher unstrittig zur Italia und wird in einem künftigen Band für die Beziehungen zu den französischen Königen wie auch im Abschnitt für das Fürstentum Antiochia im Oriens Pontificius latinus höchstens in einer Anmerkung anzuführen sein.

Nach Dalmatien zurück führt der nächste Fund, der wirklich zu den Nichtitalica zählt. Noch immer im Jahre 1898 kam zuerst als Auszug des Sekretärs des Tridentiner Konzils und Bischofs von Telese (Samnium) Angelo Massarelli († 1566) jenes zu Beginn erwähnte feierliche Privileg Clemens' III. (Wibert) von 1089 Januar 8 für den Erzbischof von Antivari/Bar im südlichen Dalmatien ans Licht; zwei Jahre später folgte aus einer anderen Handschrift des Massarelli in den Armarien des Vatikanischen Archivs der vollständige Text (II Nr. 1). Mit dieser für die dalmatinische Kirchengeschichte und die Geschichte Wiberts, ja für die Kirchengeschichte überhaupt außerordentlich wichtigen Urkunde schuf der (Gegen-)Papst in Erfüllung einer Bitte des serbischen Herrschers Konstantin Bodin gegen die zurückhaltende Politik Gregors VII. eine eigenständige serbische, nach Rom orientierte Kirche in einem Gebiet, auf das auch der Basileus und der Patriarch von Konstantinopel Anspruch erhoben. Die antibyzantinische Stoßrichtung war klar, wie die ekklesiologische Begrün-

49 Kunuljević (wie Anm. 1) Bd. 2 S. 173 Nr. 232; jetzt auch bei Smičiklas (wie Anm. 1) Bd. 2 S. 273 Nr. 256.

50 Zitiert von Walther Holtzmann, im Nachruf, in: DA 8 (1950/1951) S. 33 aus einem Brief Kehrs. 
dung für die Errichtung eines neuen Erzbistums in auffälliger Parallele zu Sätzen des «Dictatus Papae» seines Gegners Gregors VII. steht ${ }^{51}$. Die Kopie Massarellis, der ausdrücklich vermerkt, daß die einzelnen Zeilen je zwei Finger breit voneinander getrennt waren, Rota und Bene Valete genau nachzeichnete und deren Platz auf dem Original angab, muß auf ein ungewöhnlich aufwendig gestaltetes Original zurückgehen, das auch durch die äußeren Merkmale bezeugt, daß der Papst sich der Bedeutung seines Schrittes wohl bewußt war ${ }^{52}$. Die so in vielfacher Hinsicht paläographisch, diplomatisch, für das Itinerar Wiberts und nicht zuletzt kirchenpolitisch wichtige Urkunde Clemens' III. zeigte nun, daß Dalmatien Ende der 1080er Jahre im Schisma auf der Seite des Gegenpapstes stand, mehr noch, wie sehr das übliche Bild des Gegenpapstes einseitig war. Zusammen mit anderen Neufunden wurde sie zwanzig Jahre später Anlaß zu einem größeren Aufsatz Kehrs zur Geschichte Wiberts ${ }^{53}$, doch die dort angekündigte diplomatische Untersuchung des Privilegs für Antivari/Bar, die sich auf eine Prüfung der Urkunden in den Archiven von Zagreb, Zara, Split und Dubrovnik stützen sollte, ist nicht mehr erschienen ${ }^{54}$.

Überlieferungsgeschichtlich kann als sicher gelten, daß das Original der Wibert-Urkunde Massarelli vorgelegen hat. Als älteste echte Urkunde, welche die Rangerhöhung Antivaris belegt, war sie trotz ihrer Herkunft von einem Gegenpapst noch im 16./17. Jahrhundert ein wichtiges Beweismittel, das erhalten geblieben war. Verständlicherweise stellte sich Kehr die Frage, wo das Original im 16. Jahrhundert lag, genauer wo Massarelli seine Kopie angefertigt haben könnte. Daran knüpfte sich gleich die weitergezogene Frage nach dem Verbleiben des Archivs von Antivari, denn wie Kehr in den Vorbemerkungen erwähnte, hatte Baronius die - falsche - Vorurkunde Alexanders II. (JL †4628) aus „fragmenta Antonii Augustini“, das heißt des bekannten Kirchenrechtlers und Erzbischofs von Tarragona (16. Jh.), ediert, während das Privileg Calixts II. für Antivari (JL 7009) aus der Handschrift Vat. lat. 7109 bekannt war. Offensichtlich hatte man im 16./17. Jahrhundert Zugang nicht nur zu einem vereinzelten Stück, sondern eben wirklich zum Archiv, mindestens größeren Teilen des Archivs von Antivari/Bar. Nachdem in den Sammlungen des vatikanischen Archivs auch das Original jener littera clausa Alexanders III. für den

51 Das Register Gregors VII., hg. v. Erich Caspar, 2 Bde., Berlin 1920-1923 (MGH Epp. sel. 2), II/55a S. 201-208.

52 Jürgen Ziese: Wibert von Ravenna. Der Gegenpapst Clemens III. (1084-1100), Stuttgart 1982 (Päpste und Papsttum 20), ist in seiner ausführlichen Interpretation dieses Stückes (S. 153-161) auf die diplomatisch-paläographsichen Aspekte, die wichtig als Unterstützung seiner Thesen gewesen wären, nicht eingegangen.

53 Paul KeHR: Zur Geschichte Wiberts von Ravenna (Clemens III.) Teil I in:, SPA, phil.hist. Kl. Heft 19 (1921) 355-368, Teil II in: ebd. 54, S. 973-988 (ND KeHr: Schriften [wie Anm. 9] Bd. 1 S. 209-238).

54 Ebd. S. 367 (ND KeHr: Schriften [wie Anm. 9] Bd. 1 S. 221). 
Grafen von Zachulmia zum Vorschein gekommen ist, dessen Sitz im Sprengel von Antivari lag ${ }^{55}$, liegt die Annahme nahe, daß nach dem Vorrücken der Osmanen im 16. Jahrhundert einzelne Archive dalmatinischer Kirchen nach Italien bzw. nach Rom überführt wurden ${ }^{56}$, was auch für die Urkunden der Cruciferi in Zara gelten könnte, von denen das Original Cölestins III. sich in einer Niederlassung in den Marken befindet ${ }^{57}$.

Archivalisch leichter zu erklären ist die ein Jahr später im Archiv von Montecassino aufgefundene Kopie eines bisher unbekannten Stückes Anaklets II. für Glanfeuil (St-Maur-sur-Loire) (II Nr. 9) ${ }^{58}$, das Urban II. im Jahre 1096 gegen die Ansprüche von St-Maur-des-Fossés als selbständige Abtei sub magisterio et tutela Montecassinos wiederhergestellt hatte, wo der frei gewählte Abt von Glanfeuil die Weihe empfangen sollte (JL 5635). Zwar ohne das ganze Eschatokoll, das weggeschnitten ist, kann sie doch wegen des parallelen Schreibens für Montecassino auf den 11. Oktober 1133 datiert werden und diente vermutlich als Vorlage für die bekannte Fälschung auf den Namen Urbans II. für Glanfeuil $(\mathrm{JL}+5680)^{59}$. Sie findet von der Überlieferung her gleichsam ihr Spiegelbild in einem im Fonds von Chaise-Dieu im Departementalarchiv in Le Puy aufbewahrten Original Eugens III. für das auf Bitten des Abtes der auvergnatischen Abtei ihr unterstellte Kloster S. Marino in Padua (II Nr. 16) als ein Italicum bzw. ein Nichtgallicum in Frankreich.

Eine Reihe von neugefundenen Urkunden, welche - wie wenigstens am Rande die Urkunde Paschalis' II. für die Königstochter Konstanze - die nach dem ersten Kreuzzug neu entstandene Kreuzfahrerkirche in Syrien betreffen, soll gesondert behandelt werden. Hervorgehoben sei hier nur der als sensationell zu bezeichnende Fund eines feierlichen Privilegs Lucius' III. für Beirut, der einzigen als Original erhaltenen Papsturkunde für ein Bistum der Kreuzfahrerstaaten (II Nr. 53).

Von der Überlieferung her handelte es sich in allen bisher erwähnten Fällen um Einzelfunde, gelegentlich um zwei zusammengehörende Stücke wie für die Kreuzträger in Zara, die aber an verschiedenen Orten überliefert sind. Erst der zweite Bericht über Papsturkunden in Rom von 22. Dezember 1900 enthält einen geschlossenen größeren Bestand an neuen Urkunden für einen Empfänger

55 Siehe oben.

56 Vgl. dazu künftig die Dalmatia-Croatia Pontificia.

57 Siehe oben.

58 Miscellanea Cassinese 2 (1899) S. 61 (Bd. 2 S. 187) Nr. 11, JL -; IP 8 S. 174 Nr. 231; Pier Fausto Palumbo: Lo Scisma del MCXXX. I precedenti, la vicenda romana e le ripercussioni europee della lotta tra Anacleto e Innocenzo II; col regesto degli atti di Anacleto II, Rom 1942 (Miscellanea della R. Società romana di storia patria 13), S. 674 Nr. 59.

59 Das Stück ist Papsturkunden in Frankreich, N.F. 5: Touraine, Anjou, Maine et Bretagne, ed. Johannes Ramackers, Göttingen 1956, S. 58 und Anm. 5, entgangen. 
außerhalb Italiens. Durch Paul Maria Baumgarten war Kehr auf einen Band in den sog. Kollektorien aus der Zeit des avignonesischen Papsttums mit dem Titel Uticensia Varia 1326-1373 (Vol. 276) mit zwei feierlichen Privilegien Eugens III. von 1150 Oktober 31 und Hadrians IV. von 1158 Januar 18 für das Kathedralkapitel St-Thierry in Uzès hingewiesen worden. Es sind die einzigen überhaupt bekannten älteren Papsturkunden für die ganze Diözese Uzès (II Nr. 17 und 23). Viel bedeutender konnte im gleichen Bericht aus der riesigen Abschriftensammlung von Cornelio Margarini aus dem 17. Jahrhundert im Vatikanischen Archiv ${ }^{60}$ ein Bündel von weit über einem Dutzend seither verlorener Papsturkunden aus den Jahren 1158 bis 1193 aus dem Archiv des Klosters Lérins mitgeteilt werden, darunter zwei feierliche Privilegien ${ }^{61}$. Sie vermehrten den bekannten Bestand um mehr als die Hälfte und ließen mit den Urkunden Lucius' III. von 1184 Juni 10 aus S. Flaviano und Juni 14 aus dem Spital am Potenza (Marche) zwei wichtige Mosaiksteine für das Reiseitinerar des Papstes von Anagni nach Verona gewinnen ${ }^{62}$. Da zudem einer der anderen großen Sammler der frühen Neuzeit, Onofrio Panvinio, das Eschatokoll einer weiteren Urkunde Clemens' III. für Lérins in seine Sammlungen aufnahm (II Nr. 62), befand sich dieses Archiv vielleicht zeitweise an der Kurie. In jedem Fall waren angesichts der bekannten Urkundenarmut der südfranzösischen Kirchen die insgesamt 19 neuen Texte für Uzès und Lérins ein unschätzbarer Gewinn für die künftige Gallia Pontificia.

Doch die in ihrer Fragestellung ganz moderne Zusammenstellung von Eschatokollen feierlicher Privilegien des Panvinio, die die Zusammensetzung des Kardinalkollegiums aufzeigen sollte, enthielt auch je ein Stück Eugens III. und Alexanders III. für S. Maria la Mayor (del Pilar) in Zaragoza (II Nr. 15 und $42)^{63}$, ebenso ein Privileg Alexanders III. für S. Maria de Fitero (D. Pamplona) (II Nr. 43), die zur künftigen Hispania Pontificia zu zählen sind, und ein viertes für Villeneuve-lès-Avignon, ebenfalls von Alexander III. (II Nr. 39), von dem

60 Armarium LIV, Band III, vgl. GN 1900 S. 377 (ND Bd. 2 S. 530).

61 Tabelle II Nr. 24, 25, 34, 35, 44, 45, 49, 51, 52, 58-60, 64, 67-69, ed. GN 00 S. 419, 422 Nr. 7, S. 423 Nr. 9, S. 424 Nr. 10, S. 425 Nr. 12, S. 426 Nr. 13, S. 427 Nr. 15, S. 428 Nr. 17. S. 430 Nr. 18, S. 432 Nr. 21, S. 433 Nr. 23, S. 435 Nr. 26, S. 436 Nr. 27 und S. 436 Nr. 29 (ND Bd. 2 S. 572 Nr. 7, S. 575 Nr. 9, S. 576 Nr. 10, S. 577 Nr. 12 , S. 578 Nr. 13, S. 579 Nr. 15, S. 580 Nr. 17, S. 581 Nr. 18, S. 583 Nr. 21, S. 584 Nr. 22, S. 584 Nr. 23, S. 586 Nr. 26, S. 587 Nr. 27 und S. 587 Nr. 28), vgl. Wilhelm Wiederhold: Papsturkunden in Frankreich, Bd. 4.: Provence mit Venaissin, Uzegois, Alais, Nemosez und Nizza, Berlin 1930 (NGG, phil.-hist. Kl. Beih.), S. 53 f., wo sie in die bekannten Überlieferungen aufgenommen werden konnten.

62 Vgl. RI 4/4/4/1 1145 und 1148.

63 GN 01 S. 13 (ND Bd. 3 S. 13) Nr. 10 und S. 15 (ND Bd. 3 S. 15) Nr. 14, je fälschlich auf das Bistum bezogen. In den Papsturkunden in Spanien, Bd. 2 S. 356 Nr. 53 und S. 483 Nr. 142 wird die Zuordnung korrigiert. 
dann Wiederhold aus anderer Überlieferung den Volltext veröffentlichen konnte.

Die der Chronologie der Berichte folgende Erörterung der Neufunde sei hier abgebrochen und das Ergebnis an Nichtitalica räumlich zusammengefaßt. Es war nicht nur Rom, wo Urkunden für Empfänger außerhalb Italiens zum Vorschein kamen. Angesichts der engen politischen Verbindung zwischen dem Nordwesten Italiens und den jenseits des Alpenkamms liegenden, heute zu Frankreich und zur Schweiz gehörenden Gebieten des späteren Savoyens, überrascht es nicht, daß in Turin eine größere Zahl vorher unbekannter Urkunden für Klöster und Kirchen jenseits der heutigen Landesgrenze zum Vorschein kamen: für Aulps (D. Genf), Saint-Irénée in Lyon, Talloires (D. Genf), Entremont (D. Genf) und das Nonnenkloster Betton (D. Maurienne). Griffen die eben genanten Teileditionen für spanische Empfänger und Villeneuve-lèsAvignon späteren Volleditionen aus Überlieferungen an Ort und Stelle vor, so besitzt man für Saint-Irénée neben der in Turin gefundenen Kopie eines Privilegs Paschalis' II. (II Nr. 3) sonst nur noch ein Original Eugens III. im Départementalarchiv Lyon ${ }^{64}$. Für Entremont (II Nr. 40) ist das Schutzprivileg Alexanders III. wieder die einzige erhaltene Papsturkunde überhaupt ${ }^{65}$, für Aulps mit je einem Stück Paschalis' II. (II Nr. 2) und Calixts II. (II Nr. 6) nicht anders, wenn auch letzteres noch in einem weiteren Inventar erwähnt zu sein scheint ${ }^{66}$. Dagegen war das in Turin nur in Regestenform überlieferte Privileg Eugens III. für Talloires (II Nr. 14), was Kehr entging, schon 1896 aus dem Original in Privatbesitz veröffentlicht worden und wird ebenfalls zusätzlich in einem Inventar von 1720 erwähnt ${ }^{67}$. Die gleiche Sachlage besteht für das Nonnenkloster Le Betton bzw. Betton-en-Maurienne (II Nr. 50), wo das damals in der Biblioteca di Sua Maestà, heute Nationalbibliothek in Turin überlieferte Privileg Lucius' III. allein steht ${ }^{68}$.

Einen der überraschendsten Funde an Nichtitalica außerhalb Roms, der einer genaueren Erklärung harrt, stellte ein im Archiv der Curia vescovile in Pavia aufbewahrter Band mit Urkunden über die Bischöfe von Burgos und Toledo dar. Er enthält vier Papsturkunden des 12. Jahrhunderts von Urban II., Paschalis II., Hadrian IV. und Lucius III, von denen die beiden letzteren vorher nicht bekannt waren ${ }^{69}$, unterdessen freilich auch in der Edition der Urkunden von Burgos aus lokaler Überlieferung zugänglich $\operatorname{sind}^{70}$. Mit dem Privileg

64 Vgl. FW Bd. 3 S. 3.

65 Vgl. FW Bd. 3 S. 13.

66 Vgl. ebd.

67 Vgl. ebd.

68 Vgl. FW Bd. 3 S. 12.

69 GN 02 S. 134 (ND Bd. 3 S. 309).

70 Vgl. Luciano Serrano: El obispado de Burgos y Castilla primitiva del s. V al XIII, 3 Bde., Madrid 1935-1936, Bd. 3 S. 203 Nr. 121 zu (1157) und S. 269 Nr. 165. 
Hadrians IV. bestätigte der Papst die Romunmittelbarkeit des Bistums, also die Exemtion von einer Metropolitankirche (II Nr. 26), was Lucius III. wiederholte und freiwillig geleistete Ehrenbezeugungen des Bischofs von Burgos an den Erzbischof von Toledo ohne Präjudizwirkung für weitergehende Ansprüche sein ließ (II Nr. 48). Die beiden anderen Stücke waren bereits aus der España sagrada von Florez bekannt und enthalten die Herauslösung von Burgos aus der bestehenden Kirchenorganisation im Jahre 1095 nach Verhandlungen im Umfeld des Konzils von Clermont (JL 5651) und einen Befehl an den Erzbischof von Toledo, die Exemtion von Burgos zu respektieren und es gegen Übergriffe von Osma zu verteidigen (JL 6439). Weitere neue Urkunden für die Iberische Halbinsel aus der Nachlese in Italien stammen aus zwei großen Codices mit Urkundenabschriften in der Vaticana: ein Privileg für S. Maria de Refoyos (D. Tuy) (II Nr. 30) und aus einem ebendort aufbewahrten Orosius-Codex ein Aufruf des Kardinallegaten Hyazinth für einen von ihm geplanten Kreuzzug gegen die Mauren (II Nr. 21) ${ }^{71}$. Immer noch für die iberische Halbinsel kam kurz darauf aus einer heute in der Biblioteca Vallicelliana liegenden Handschrift (C 23 saec. XVII) zum Streit um den Primat von Toledo mit einer großen Zahl der Kurie unter Honorius III. und Gregor IX. vorgelegten Beweisstücke, die auch in die Register eingetragen wurden ${ }^{72}$, wieder eine sachlich geschlossene Gruppe von Nichtitalica hinzu, unter denen sich auch sechs Inedita befanden (II Nr. 8, 20, 22, 33, 41, 46), darunter auch zwei Urkunden des Kardinallegaten Hyazinth (II Nr. 20 und 22). Für die Einordnung dieser unterdessen auch aus lokalen Überlieferungen erfaßten Stücke in die Gesamtüberlieferung muß freilich noch auf den ausstehenden Band der Nachlese für Spanien mit Papsturkunden für Kastilien und Galizien gewartet werden.

In der räumlichen Verteilung gehört erstaunlicherweise, sieht man von zwei Stücken für die Johanniter aus dem Archiv auf Malta ab (II Nr. 38 und 57), kein Stück auf die britischen Inseln, noch erstaunlicher fand sich neben dem in Montecassino aufbewahrten Stück für Glanfeuil (II Nr. 8) für ganz Nordfrankreich nur eine Regelbestätigung für Bourgmoyen in Blois durch Innozenz II. (II Nr. 7). Und gleichfalls nur ein einziges Stück betrifft Deutschland, das freilich weit über eine lokale Bedeutung hinaus in die großen kirchenpolitischen Auseinandersetzungen des 12. Jahrhundert führt, wenn es auch mitten im Text abbricht (II Nr. 27). In eine wohl aus Deutschland stammenden Bibelhandschrift (Bibl. Chigi A VII 197 f. 170') war nach der Abschrift des «Ludovicianums» der an Mainz gerichtete Text der Wahlanzeige Alexanders III. «Aeterna et incommutabilis» eingetragen worden, der von den anderen be-

$71 \mathrm{Zu}$ diesem Unternehmen siehe in diesem Band den Beitrag über die Italia Pontificia und das Kreuzzugsgeschehen.

72 Siehe unten. GN 03 S. 126 ff. (ND Bd. 4 S. 126 ff.) und die Editionen ebd. S. $146 \mathrm{ff}$. (Bd. 4 S. 146 ff.) Nr. 1, 3, 5, 7, 13 und 14; Legatenurkunden sind Nr. 13 und 14. 
kannten Exemplaren dieses Rundschreibens abweicht und im ersten Bericht der Nach-Nachlese veröffentlicht wurde $(\mathrm{Nr} .27)^{73}$.

\section{c) Nichtitalienische Betreffe aus den päpstlichen Registern des 13.-15. Jahrhunderts}

Eine beträchtliche Zahl von Stücken, die nicht Italien betreffen, umfaßt die dritte Gruppe: die als Inserte in den päpstlichen Registern des 13.-15. Jahrhunderts überlieferten älteren Papsturkunden (siehe Tabelle III). Sie sollen, soweit es sich um Nichtitalica handelt, hier gesondert betrachtet werden, weil durch den spezifischen Charakter dieser Überlieferung von vornherein klar ist, daß sich unter den inserierten Stücken auch Nichtitalica befinden können, aber auch andere Fragen für die Beziehungen der einzelnen Kirchen zum Papsttum aufgeworfen werden. Die Inserte gehen alle darauf zurück, daß eine Kirche sich an die Kurie wandte und um die Bestätigung von Rechten bat, für die sie bereits früher einmal eine Papsturkunde erhalten hatte. Die Überlieferung in den päpstlichen Registern war daher kein Zufall, sondern das Ergebnis eines gezielten Vorstoßes, der genau dieses Ergebnis einer schriftlichen Wiederholung einer früheren Verfügung und deren Fixierung in den Unterlagen der Kurie erreichen wollte. Im Augenblick der Erstellung des Insertes war es eine zusätzliche Fixierung zur vorgelegten Vorlage und daher historisch für den ursprünglichen Vorgang nichts Neues. Für die Nachwelt stellt sich jedoch die Frage, ob die Vorlage heute noch als Original vorhanden ist, was das Insert in seiner Bedeutung für den ursprünglichen Vorgang überflüssig macht und höchstens einen Einblick in die Arbeitsweise der Kanzlei gestattet, ob die Vorlage noch als Kopie überliefert ist, worauf dann der Textbestand und das Textverhältnis zu klären ist, oder ob schließlich das Insert nach Verlust des Originals oder gar des ganzen Archivs jetzt die einzige Überlieferung darstellt und damit überhaupt erst die Rekonstruktion des ursprünglichen Vorgangs erlaubt.

Trotz der bereits in Gang befindlichen Edition der Register des 13. Jahrhunderts durch die École française de Rome und der umfangreichen Schedarien und Indices-Bände des Vatikanischen Archivs war es eine gewaltige Arbeit, die Kehr auf sich nahm, als er sich im Jahre 1902 den Registerserien zuwandte. In vier Monaten sah er 1500 Bände (!) durch ${ }^{74}$, was er selber nachher als „eine sehr strenge Busse für die Sünden der letzten anderthalb Jahre", einige Seiten später

73 Vgl. jetzt Mainzer Urkundenbuch, hg. v. Peter Аснт, Bd. 2/1, Darmstadt 1971, S. 445 Nr. 246.

74 GN 02 S. 394 (ND Bd. 3 S. 368). 
als eine „Poenitenz" bezeichnete ${ }^{75}$. Doch bleibt auch hier zu beachten, daß in den drei, nach der Chronologie der Registerbände angelegten Berichten zwar alle ermittelten Inserte erfaßt, aber wieder nur die vorher unbekannten Texte gedruckt sind. [ $\mathrm{Da}$ es oft wertvoll wäre, auch zu wissen, welche bei JL bereits verzeichneten Papsturkunden, Italica und Nichtitalica, sich in den päpstlichen Registern finden, folgt für diesen Überlieferungsblock eine zusätzliche Konkordanz zwischen Jaffé und den Registern mit eigenem Empfängerverzeichnis (Tabelle V)] .

Insgesamt hat Kehr, wenn man zwei nachträgliche Funde einbezieht ${ }^{76}$, für die Zeit bis Bonifaz VIII. 134 Inserte ermittelt, für die Periode des avignonesischen Papsttums einschließlich der nach 1378 dort und dann in Spanien residierenden Päpste bis Benedikt XIV., also in der ganzen Serie der avignonesischen Register, 90 Inserte und erstaunlicherweise nicht in abnehmender, sondern steigender Zahl für die Päpste von Bonifaz IX. bis Pius II., also in den lateranensischen Registern, 164 Inserte. Die letzten noch untersuchten 115 Jahre von Paul II. bis Paul III. (1464-1579) erbrachten nur noch 3 Volltexte, darunter ein Ineditum, wobei die Durchsicht nicht mehr Band um Band und Folio um Folio erfolgte, sondern auf Angaben vor allem im Schedario Garampi beruhte $^{77}$. Im Gegensatz zur Erwartung zeigt sich so, daß man es mit einer Art Wellenbewegung zu tun hat, in der Pontifikate mit zahlreichen Inserierungen und solche mit wenigen oder zum Teil sogar überhaupt keinen aufeinanderfolgen. Eine Erklärung für diesen Befund gibt es meines Wissens bisher nicht ${ }^{78}$. Höhepunkte der Insertionstätigkeit liegen in der Zeit von Honorius III. bis Alexander IV. - dagegen unter Innozenz III. auffällig wenige -, im 14. Jahrhundert unter Johannes XXII. und im 15. Jahrhundert in den vier Jahrzehnten von Martin IV. bis Nikolaus IV. Für eine erhebliche Zahl von Pontifikaten findet sich dagegen überhaupt kein Insert aus der Zeit vor 1198. Genannt seien, wenn man die ganz kurzen Pontifikate und die Gegenpäpste wegläßt, vor allem Urban IV., Gregor X., Martin IV. aus dem 13. Jahrhundert, Benedikt XII. und Urban VI. aus dem 14. Jahrhundert, Innozenz VII. und Gregor XII. aus dem 15. Jahrhundert. Erst für die letzten hundert Jahre nach Pius II. erweist sich die Annahme bestätigt: je später, desto weniger. Auf die Durchsicht der Supplikenregister hat Kehr bewußt verzichtet, obwohl er sich

75 GN 02 S. 406 (ND Bd. 3 S. 380).

76 Der Registertext aus Martin V. von 1430 Juli 25 mit Cölestin III. 1193 April 3 für SS. Pietro e Paolo in Rimini konnte in GN 09 S. 509 (ND Bd. 5 S. 217) Nr. 34 aus lokaler Überlieferung vervollständigt werden. Nachträglich aus den Registern wurden gewonnen: Honorius II. für Kenilworth aus Nikolaus V., ed. GN 14 S. 54 (ND Bd. 5 S. 491) Nr. 1, und Lucius III. für Monkton Farleigh aus den Registern Bonifaz' IX., ed. GN 03 S. 576 (ND Bd. 4 S. 234) Nr. 19. Siehe auch oben.

77 Vgl. GN 02 S. 401 ff. (ND Bd. 3 S. 375 ff.).

78 Ich behalte mir vor, auf dieses Problem zurückzukommen. 
sicher war, auch dort wie in einigen anderen beiseite gelassenen Serien weitere Funde machen zu können, erschöpft von einer Parforceleistung und im Blick auf das Verhältnis von Zeitaufwand und Ertrag ${ }^{79}$.

Von den insgesamt 390 (134, 90, 164 und 2) aufgefundenen Inserten, worunter hier auch Inserte ohne Kardinalsunterschriften oder mit verkürzter bzw. manchmal ganz fehlender Datumszeile gerechnet werden, druckte Kehr nach üblichem Vorgehen $83\left(20^{80}, 28\right.$ und 35) in den Anhängen zu den drei Berichten als bisher unbekannt, von denen 48 Nichtitalica sind, zu denen noch die beiden nachträglich gefundenen Inserte, ebenfalls Nichtitalica, kommen. Ihr Anteil an den neuen Stücken beträgt mit 50 von 85 fast zwei Drittel. Doch 18 weitere Stücke, elf Italica und sieben Nichtitalica, waren zwar ebenfalls bei Jaffé noch nicht erfaßt, doch in der Zwischenzeit an anderer Stelle, vereinzelt auch in den Göttinger Nachrichten selbst ediert worden ${ }^{81}$. Es handelt sich dabei, einschließlich der Italica, unter Angabe des Druckortes und des inserierenden Papstes in der Reihenfolge ihrer Erwähnung in den Berichten um die folgenden Stücke ${ }^{82}$ :

1. Alexander III. (1159-1181): Horoy Bd. 4 S. 27 Nr. 31; Pressutti Bd. 2 S. 318 Nr. 3578; nur Erwähnung für St-Étienne in Caen, vgl. FR Bd. 2 S. 29 u. Anm. 4, keine andere Überlieferung bekannt (Honorius III., GN 02 S. 412)

2. Cölestin III., 1197 Sept. 6: Lucien Auvray, in: Moyen Age 6 (1893) S. 161; Auvray Nr. 1812 für Prato (D. Pistoia) (Gregor IX., GN 02 S. 413; IP 3 S. 141 Nr. 30 fälschlich zu 1196 Sept. 6)

3. Cölestin III., 1195 März 8: Monumenta vetera Hibernorum et Scotorum, ed. Augustin Theiner, Roma 1864, S. 153 Nr. 335; Potthast 23400; Langlois 3486; Scotia pontificia. Papal letters to Scotland before the pontificate of Innocent III., ed. Robert Somer ville, Oxford 1982, S. 145 Nr. 158 für Lindores (D. St. Andrew's), als einzige PU s. XII, aber Original erhalten (Nikolaus IV., GN 02 S. 417)

4. Urban III., (1186-1187) Febr. 6: Langlois Nr. 4901 für das Hospital in Wissant (D. Thérouanne), als einziges älteres päpstliches Privileg, keine andere Überlieferung, vgl. FR Bd. 3 S. 15 und Anm. 3 (Nikolaus IV., GN 02 S. 417)

79 Vgl. GN 02 S. 406 (ND Bd. 3 S. 380).

80 Für die erste Periode nennt Kehr GN 02 S. 395 (ND Bd. 3 S. 369) 19 unbekannte oder mangelhafte edierte Stücke. Der Druck umfaßt aber 20 Stücke, so daß wohl nachträglich ein Stück hinzugekommen ist. Um welches es sich dabei handelt, läßt sich nicht mehr feststellen.

81 Alle diese Stücke fehlen in der Liste bei Volpini und zwar auch die Italica.

82 Die Nichtitalica werden in die folgenden Erörterungen und in die Tabelle III mit aufgenommen. 
5. Alexander III., 1176 Jan. 13: Mittarelli Bd. 5 S. 443 für S. Savino de Montione (D. Pisa) (Johannes XXII., GN 02 S. 443; IP 3 S. 374 Nr. 5)

6. Cölestin III., 1193 April 23: Mittarelli Bd. 5 S. 445 für S. Savino de Montone (D. Pisa) (Johannes XXII., GN 02 S. 443; IP 3 S. 375 Nr. 8)

7. Lucius III., 1182 Juni 8: Desimoni S. 480 Nr. 30 für Ventimiglia (Urban V., GN 02 S. 447; IP 6/2 S. 366 Nr. 7; RI 4.4.4.1. 262)

8. Innozenz II., 1140 Mai 18: GN 99 S. 348 Nr. †1 für S. Maria im Tale Josaphat, Spurium (Urban V., GN 02 S. 447)

9. Paschalis II., 1112 Mai 11: GN 00 S. 150 (lies 155) Nr. 11 für SS. Agnese u. Costanza in Rom (Urban V., GN 02 S. 448; IP 1 S. 159 Nr. 2)

10. Cölestin III., 1193 Sept. 26: GN 00 S. 193 Nr. 43 für die Lazariter (Clemens VII., GN 02 S. 449; IP 4 S. 42 Nr. 1)

11. Cölestin III., 1193 April 3: GN 98 S. 41 Nr. 18 für SS Pietro e Paolo in Rimini (Martin V., GN 02 S. 501; IP 4 S. 172 Nr. 7)

12. Alexander III., 1171 Nov. 19: GN 00 S. 325 Nr. 14 für Figarolo (D. Ferrara) (Eugen IV., GN 02 S. 503; IP 5 S. 239 Nr. 7)

13. Clemens III., 1188 März 31: GN 00 S. 342 Nr. 29 für Figarolo (D. Ferrara) (Eugen IV., GN 02 S. 503; IP 5 S. 240 Nr. 10)

14. Eugen III., 1151 Mai 7: GN 1897 S. 376 Nr. 3 für S. Andrea in Mantova (Eugen IV.; GN 02 S. 503; IP 7/2 S. 315 Nr. 6)

15. Honorius I., 624 Febr. 7: Dyer für Cambridge (Eugen IV., GN 02 S. 503 f.)

16. Sergius II., 699 Mai 3: Dyer für Cambridge (ebd.), die beiden bekannten Fälschungen

17. Gregor VIII., 1187 Dez. 14: Desimoni S. 482 Nr. 31 für Luni (Nikolaus V., GN 02 S. 506; IP 6/2 S. 383 Nr. 10)

18. Cölestin III., 1194 Nov. 26: Luigi Schiaparelli: in: Memorie R. Accademia di Torino ser. II 46 (1896) S. 241 Nr. 2 für Biella (D. Vercelli) (Pius II., GN 02 S. 509; IP 6/2 S. 52 Nr. 1)

Neben den Inserten mit mehr oder weniger vollständigem Text setzt in den Berichten mit Bonifaz IX. (1389-1404) eine Reihe von Verweisen auf Urkunden ein, die wegen des Verlusts der Registerbände nur noch durch regestenförmige Angaben in Indicesbänden und nur z. T. mit sicherer Zuweisung zu einem Papst des 12. Jahrhunderts zu erschließen waren ${ }^{83}$. Es handelt sich nochmals um 48 Stücke bis Pius II. und weitere neun bis Paul III., von denen drei auch in erhaltenen Registerbänden eines anderen Papstes überliefert sind und nur eines im Anhang erscheint. Um mögliche Nichtitalica aus der Zeit vor

83 Weshalb solche Hinweise für die verlorenen Registerbände der vorangehenden Perioden, wie etwa die Rubrizellen für den Pontifikat Innozenz' III., nicht herangezogen wurden, wird nicht erwähnt. 
1198 handelt es sich in neun Fällen, die hier einbezogen und im Anhang nochmals gedruckt werden. Denn auch für die 57 nur in Regestenform überlieferten Urkunden wurde das Grundschema, alles Unbekannte bzw. Ungedruckte zu drucken, aus ungenannten Gründen und zwar nicht nur wegen der manchmal zweifelhaften Zuschreibungen an einen Papst des 11./12. Jahrhunderts, wo es sich eher um einen solchen gleichen Namens aus dem 13.-15. Jahrhundert handelte, nur z. T. eingehalten, wie diese Stücke auch im Empfängerverzeichnis bei Volpini durchgehend nicht erscheinen, auch wenn es Italica sind.

Insgesamt befinden sich so unter den 390 erhaltenen oder verlorenen Inserten 66 unbekannte Nichtitalica und zwar 50 Volltexte in den Berichten Kehrs, sieben an anderer Stelle gedruckte Stücke und neun Regesten. Die letzteren werden im Anhang nochmals abgedruckt, weil sie im Registerband des Nachdrucks nicht erfaßt $\operatorname{sind}^{84}$. Wie für die einzeln überlieferten Stücke läßt sich für die in den Registern enthaltenen Inserte mit Hilfe der nachher erfolgten Nachlesen in Frankreich und England eine Wertung der Registertexte in der Gesamtüberlieferung der betreffenden Institutionen und derjenigen der einzelnen Stücke vornehmen. Sie zeigen, wie wichtig in einzelnen Bereichen die Inserte sind, bei denen es in der Mehrzahl um feierliche Privilegien und Besitzbestätigungen als eher Routinegeschäfte geht, was sich bei den Vorarbeiten von Wiederhold, Meinert und Ramackers in Frankreich ebenso wie Holtzmann in England zeigte, die sich stets die Ergebnisse der Durchsicht der Register für die Erfassung der Überlieferungen für eine Institution zunutze machen konnten.

Zeitlich setzen die echten Nichtitalica unter den Inserten mit einer Urkunde Alexanders II. für Maillezais (D. Poitiers) von 1066 ein, so daß sich unter den neuen Texten kein einziges, vorher unbekanntes Papyrus-Stück aus der Zeit bis zur Mitte des 11. Jahrhunderts befand, obwohl die Begründung für die Neuinserierung ob vetustatem, $o b$ antiquitatem, ob textum corrosum u.ä. sehr oft nahegelegen haben dürfte. Es wird sich zeigen, daß gerade hier die vorangehende Forschung bereits sehr gründlich gearbeitet hatte.

Unter den 66 Inedita, welche die Beziehungen des Papsttums zu nichtitalienischen Räumen betreffen, kommt sieben am Anfang des 13. Jahrhunderts transsumierten Urkunden aus den Jahren 1114 bis (1160/1161) über die Primatial- und Metropolitanrechte Toledos historisch und kirchenpolitisch besonderes Gewicht $\mathrm{zu}^{85}$. Sie sind der Kanzlei zum Teil mehr als einmal zur

84 Für die Italica kann darauf verzichtet werden, weil sie in der Regel, wenn auch nicht lückenlos, in den IP-Bänden berücksichtigt wurden. Es fehlt z. B. in IP 5 ein Hinweis auf die GN 02 S. 511 (ND Bd. 3 S. 485) aus den Registern Clemens' VII. a. VI erwähnte Urkunde Urbans II. an die civitas von Piacenza mit dem Recht, eine capella s. Mariae zu errichten.

85 Tabelle III Nr. 6. 7, 19, 20, 21, 23, 25. 
Bestätigung und Insertion vorgelegt worden. Die iberische Halbinsel betreffen noch sieben weitere Urkunden, die einzige ältere Papsturkunde für den Bischof und das Domkapitel Lissabon über eine zwischen ihnen vereinbarte Aufteilung der Einkünfte (III Nr. 65), je ein Stück für das noch unter muslimischer Herrschaft stehende Malaga (III Nr. 8), Silos (III Nr. 9) und Castañeda (III Nr. 59), ein an Ort und Stelle besser überliefertes Privileg Eugens III. für Grijó (D. Porto) (III Nr. 17) und eines ohne Eschatokoll von Lucius III. für die Santiagoritter, das unterdessen aus anderer Überlieferung mit vollständiger Datierung bekannt geworden ist (III Nr. 47).

Neben diesen 13 Stücken für die iberische Halbinsel ${ }^{86}$ betraf eine zweite große Gruppe von 20 Stücken die britischen Inseln, davon je eines Irland mit St. Mary's in Dublin (III Nr. 55) und Schottland mit der Abtei Lindores (D. St. Andrew's) (III Nr. 63) ${ }^{87}$. Die anderen 18 waren vor allem feierliche Privilegien für Kirchen und Klöster Englands, einschließlich der zwei berühmten Fälschungen, welche die Gründung der Universität Cambridge ins 7. Jahrhundert zurückverlegen (III Nr. 2-3). Dagegen betraf keines die großen Streitfragen der englischen Kirche, sei es den Primatskonflikt zwischen Canterbury und York oder den Streit zwischen Erzbischof und Christ Church in Canterbury. Viel auffälliger sind 13 von ihnen, darunter die beiden Privilegien für Canterbury, die erst im 15. Jahrhundert in kurzem Abstand zweimal nacheinander der Kanzlei zur Bestätigung vorgelegt worden waren. Diese 13 Urkunden waren zu einem beträchtlichen Teil während der Forschungen Walter Holtzmanns in den englischen Archiven nicht mehr aufzufinden. Zum Teil bilden sie deshalb für die Zeit vor 1198 Unikate für die betreffenden Institutionen.

Im Einzelnen kennen wir nur aus den Registern eine Papsturkunden für Kingswood (D. Worcester) - Alexander III. von 1175 Februar 19 (III Nr. 30) ${ }^{88}$ -, für Great Malvern - Alexander III. von 1180 Mai 13 (III Nr. 35) -, für Bicester (D. Oxford) - zwei Stücke von Alexander III. und Cölestin III. (III Nr. 47 und 58) -, für Barnwell (D. Ely) - Lucius III. (III Nr. 41) - und für das Hospital St. Mary's in Dublin (III Nr. 55) - ein feierliches Privileg von Clemens III. von 1188 Nov. 15, das gleichzeitig mit einem anderen für St. John in Dublin ausgestellt wurde ${ }^{89}$.

Neben anderen in englischen Archiven und Bibliotheken erhaltenen Stücken sind für die gleiche Institution zusätzlich aus den Registern bekannt: die feierlichen Privilegien Lucius' III. von 1183 März 30 für Lanercost (D.

86 Tabelle III Nr. 6-9, 17, 19-21, 23, 25, 47, 59, 65.

87 Tabelle III Nr. 2, 3, 12, 30, 31, 34-37, 41, 43, 46, 50, 55, 58, 61-63, 66.

88 In E Bd. 1-3 wird keine Papsturkunden des 12. Jahrhunderts für Kingswood erwähnt.

89 Bei Maurice P. Sheeny: Pontificia Hibernica, Bd. 1, Dublin 1962, ist das Stück übersehen oder trotz anderer Adresse und Arenga mit jenem, ed. Bd. 1 S. 61 Nr. 18, gleichgesetzt worden. 
Carlisle) (III Nr. 42) ${ }^{90}$, für die Zisterze Farleigh bzw. Monkton Farleigh (D. Salisbury), für die sonst aus dem 12. Jahrhundert nur noch ein Original Innozenz' II. von 1131 im Public Record Office vorhanden ist ${ }^{91}$, ebenfalls ein Privileg Lucius' III. von 1184 August 22 (III Nr. 46) und für die Gilde der Bürger von Beverlery (D. York) eine Urkunde Cölestins III. von 1194 Juni 5 (III Nr. 61) als Nachurkunde zur Urkunde Lucius' III. von 1183 August $20^{92}$.

Dagegen ist das im Register nur im Auszug ohne Datierung inserierte Privileg Alexanders III. für Thame (D. Lincoln) (III Nr. 36) durch englische Überlieferung auf 1179 Mai 15 zu datieren ${ }^{93}$, wie für das durch Kehr erstmals bekanntgewordene Privileg Lucius' III. für das Hospital St. Bartholomew's (West-Smithfield) (D. London) (III Nr. 43) seither auch englische Überlieferung gefunden wurde ${ }^{94}$ und es sich nur um eine von vielen Papsturkunden für das Hospital vor den Toren Londons handelt ${ }^{95}$. Ähnlich verhält es sich mit dem Privileg Honorius' II. für Kenilworth (D. Worcester), die älteste Papsturkunde für das Kloster, die Kehr nachträglich als Auszug aus dem Register Nikolaus' V. bekannt wurde (III Nr. 12), aber von Holtzmann dann aus einer englischen Überlieferung in vollem Wortlaut ediert werden konnte ${ }^{96}$. Ebenso ist außerhalb des Registers das feierliche Privileg Cölestins III. für Holy Trinity in Norwich auch im «Registrum primum» von Norwich überliefert (III Nr. 62) ${ }^{97}$, und für das in den Registern Clemens' VI. inserierte Privileg Alexanders III. für Sempringham (D. Lincoln) von (1160-1176) Mai 20 (III Nr. 31) fand sich in der englischen Überlieferung wenigstens ein Auszug ohne Datierung ${ }^{98}$. Für Lindores (D. St. Andrew's) (III Nr. 63) konnte Somerville für die Scotia Pontificia den vollständigeren Text des freilich nicht über jeden Verdacht erhabenen Originals beiziehen, während das aus dem Register Bonifaz' VIII. bekannt gewordene Stück Alexanders III. für das Domkapitel von Canterbury mit der Befreiung von der Zehntenzahlung (III Nr. 34) in den drei Bänden Holtzmanns vorerst vergeblich gesucht wurde. Dies zeigt, wie gerade für England, wo in der Zeit Heinrichs VIII. schmerzliche Lücken in die Überlieferung der Papsturkunden gerissen wurden, die Registerüberlieferung vielfach von großer Bedeutung wird.

90 Bei E Bd. 2 S. 426 Nr. 234 in der Vorbemerkung zur Nachurkunde Lucius' III. von 1185 Febr. 13 erwähnt.

91 Ed. E Bd. 1 S. 238 Nr. 15.

92 Ed. E Bd. 1 S. 489 Nr. 215.

93 Ed. E Bd. 3 S. 398 Nr. 269.

94 Ed. E Bd. 1 S. 490 Nr. 216.

95 Vgl. E Bd. 1 S. 202 f.

96 In vollständigerer Form aus einer englischen Abschrift, ed. E Bd. 3 S. 138 Nr. 14.

97 E Bd. 2 S. 33 mit Verweis auf Kehr, GN 02.

98 E Bd. 1 S. 109. 
Für die Reichskirche bzw. die Germania Pontificia ist dagegen wie bei den aus verstreuten Beständen überlieferten neuen Nichtitalica auch aus den Registern nur ein einziges unbekanntes Stück zum Vorschein gekommen, eine Urkunde Lucius' III. für den Erzbischof von Salzburg in einer Inventarnotiz aus einem heute verlorenen Registerband Nikolaus' V. ohne nähere Angaben zum Inhalt (III Nr. 49) ${ }^{99}$. Ebenfalls nur einmal um einen Empfänger in Skandinavien könnte es sich bei einem von Nikolaus V. inserierten Privileg Clemens' III. für die Johanniter handeln, falls schon die Inserte in die Dacia geschickt worden waren und nicht viel später ein allgemeines Ordensprivileg für die skandinavische Ordensprovinz kopiert wurde (III Nr. 57) ${ }^{100}$. Kein Insert war dagegen für einen Empfänger in den östlichen und südöstlichen Randgebieten der Latinitas, Polen, Böhmen, Ungarn und im Gegensatz zur zweiten Gruppe für den Balkan bestimmt. Drei gingen an Empfänger, die dem lateinischen Osten zugerechnet werden können, eines an S. Maria im Tale Josaphat, wenn es sich auch um eine jener Fälschungen handelt, die vor allem den sizilischen und kalabrischen Besitz schützen sollten (III Nr. 13), eines an die Johanniter (III Nr. 24), ohne daß zu erkennen ist, weshalb der vielfach ausgefertigte Text im 14. Jahrhundert nochmals zur Inserierung vorgelegt wurde, und schließlich eines an die Lazariter, das in der Zeit des großen Schismas vom avignonesischen Papst bestätigt wurde (III Nr. 60).

Es bleiben die Inserte für französische Empfänger, mehr als ein Drittel aller Nichtitalica (27 von 66) ${ }^{101}$. Im Gegensatz zu den britischen Inseln, wo von der Überlieferung ausgegangen wurde, sei hier die Chronologie der Inserierungen, also die drei großen Phasen: 13. Jahrhundert, 14. Jahrhundert und 15./ 16. Jahrhundert zugrundegelegt. Es beginnt - sieht man von drei Spuria ab mit dem ältesten Stück überhaupt, einer nur aus den Registern bekannten Urkunde Alexanders II. für St-Pierre-de-Maillezais (D. Poitiers) von 1066 (III Nr. 5), die sich freilich neben viele andere für die Abtei reiht. Es folgt noch aus dem 13. Jahrhundert für Besançon das Insert einer Entscheidung Calixts II. in dem langen Streit über das Verhältnis der beiden Domkapitel Saint-Étienne und Saint-Jean-l'Évangeliste (III Nr. 10) und eine wieder nur aus den Registern bekannte Urkunde Alexanders III. für Vézelay (D. Autun) (III Nr. 28).

99 GP 1 S. 44 Nr. *145.

100 Bei einem anderen, gleichfalls in die Register Nikolaus' V. inserierten Stück für die Johanniter, das Gregor VIII. zugeschrieben wird, vgl. GN 02 S. 507 (ND Bd. 3 S. 481) $\mathrm{Nr}$. 4, handelt es sich wie sehr oft in solchen Inventaren und Registern in Wirklichkeit um Gregor IX., vgl. ebd. S. 506 Nr. 10 für eine Urkunde Gregors IX. für St. Arbogast in Straßburg.

101 Tabelle III Nr. 4, 5, 10, 11, 14-16, 18, 22, 26-29, 32, 33, 38-40, 44, 45, 48, 52-54, 56, 64. Es bleiben einmal Deutschland (Nr. 49), einmal Skandinavien (Nr. 57), viermal Orient (Nr. 1, 13, 24, 60). 
Wesentlich öfters traten französische Empfänger an das Papsttum in der zweiten Periode heran, die mit dem Aufenthalt der Kurie in Avignon zusammenfällt. Hier beginnt die Reihe mit einem Unikat für das Hospital NotreDame in Le Puy, das sich von Eugen III. seine Rechte bestätigen ließ (III Nr. 15), dann suchte Saint-Victor in Marseille zweimal päpstliche Hilfe in einem Streit um sein Priorat Milhau gegen den Bischof von Rodez (III Nr. 22 und 29), nur aus den Registern bekannt. Es folgen Stücke für das Domkapitel von Gap, wieder die einzige erhaltene ältere Papsturkunde (III Nr. 32), NotreDame de Lyre in der Normandie (D. Évreux) - bereits bei Jaffé verzeichnet, aber nicht gedruckt - (III Nr. 44), den Erzbischof und Saint-Paul in Narbonne (III Nr. 45), auch in einem Inventar des 17. Jahrhunderts angeführt, und wieder mit zwei kurz nacheinander ausgestellten Urkunden Saint-Étienne in Besançon (III Nr. 51 und 52), schließlich Marmoutier (D. Tours) (III Nr. 54). Wie für England ist die Zahl der Inserte am größten in der dritten Periode: das Dekanat von Clermont (III Nr. 4), Saint-Salvy in Albi als alleinige Überlieferung (III Nr. 11), ebenso Bonnevaux in der Diözese Poitiers (III Nr. 16), während für Saint-Eusèbe in Apt die Urkunde Eugens III. (III Nr. 18) ebenso wie die Urkunden für Terrasson (D. Périgueux/Sarlat) (III Nr. 26) und das Priorat SaintDonat von Oulx (D. Vienne) (III Nr. 33) und zwei fragliche Stücke für Valence (III Nr. 40) und Taillebourg (III Nr. 39), die zwar alle ohne andere Überlieferung bleiben, aber weitere Papsturkunden für die gleichen Institutionen neben sich haben. Ein zweites Stück für Lyre (D. Évreux) von Cölestin III. (III Nr. 44) ist dagegen wieder ein Unikat. Schließlich gehen zwei Stücke Cölestins II. und Alexanders III. an die Erzbischöfe von Rouen, Sens und Tours (und Lyon) wegen des Streites um den Primat von Lyon in der gallischen Kirche, beide auch in Kopien überliefert, die zeitlich dem Registereintrag vorangehen (III Nr. 14 und 27) ${ }^{102}$. Sie sind die einzigen Stücke für Frankreich, die eine größere rechtliche und politische Dimension besitzen, über Routinegeschäfte hinausgehen und die Kirche Frankreichs als Ganzes betreffen, wenn auch ohne grundsätzlich Neues zu bringen, sondern nur unsere Kenntnisse ergänzen. Es bleibt das feierliche Privileg Clemens' III für Watten (D. Thérouanne), das auch in einem Chartular des 15. Jahrhunderts erhalten ist und die letzte, sonst freilich unbekannte Papsturkunde des 12. Jahrhunderts in einer langen Reihe von anderen Stücken für das flandrische Stift bildet (III Nr. 56) ${ }^{103}$. Nicht in Jaffé verzeichnet, aber bereits gedruckt war ein feierliches Privileg für das Hospital in Wissant (D. Thérouanne) (III Nr. 53) ebenso wie der Verweis auf ein Privileg für St-Étienne in Caen, für das es keine andere Überlieferung gibt (III Nr. 38).

102 Vgl. FW Bd. 3 S. 2 f. (ND Bd. 3 S. 246 f.).

103 Papsturkunden in Frankreich, N. F. 3: Artois, ed. Johannes Ramackers, Göttingen 1940, S. 230 Nr. 175. 
Inhaltlich zeigt sich überall ein hoher Anteil von feierlichen Privilegien, die durch ihre Besitzlisten und die Aufzählung der Rechte und auf kurialer Seite durch die manchmal freilich weggelassenen Kardinalsunterschriften wichtige Informationen liefern. Zum anderen ist ebenfalls überall der Anteil an Unikaten hoch. Für England kennen wir für sechs Institutionen nur aus den päpstlichen Registern eine Urkunde, für vier weitere ist die Registerüberlieferung die einzige des betreffenden Stückes. Dies ist für Frankreich nicht anderes. Dagegen betrifft für Spanien ein erheblicher Teil der zur Inserierung vorgelegten Stücke den kirchenorganisatorischen Streit um den Primat und die gegenseitige Stellung von Toledo, Tarragona und Braga.

Noch bleibt aber die Frage, ob sich die vorher unbekannten Stücke aus den Registern von denjenigen unterscheiden, die bereits bei JL erfaßt waren. Ein Unterschied zeigt sich einmal in der zeitlichen Streuung. Von den etwas über 330 Stücken aus den Registern, die bereits bekannt waren, gehören fast 80 oder ein Viertel der Zeit vor 1100 an, von den neuen nur sechs von 66. Die älteste unter jenen ist von Gregor dem Großen für S. Andrea ad clivum Scauri in Rom (JE 1082), gefolgt von einem Stück von Papst Adeodatus für St-Martin in Tours $(J E \nmid 2105)$ und Papst Zacharias für Montecassino (JE †2281). Bei genauerem Hinsehen sind jedoch unter den 35 inserierten Stücken aus der Zeit bis Sutri (1046) fast die Hälfte, nämlich 14, Spuria, von den zwölf ältesten sogar alle bis auf eines, wie die eben erwähnten Privilegien für Saint-Martin in Tours und für Montecassino. Von den folgenden 250 Stücken tragen nur noch drei eine Crux. Auf die 35 Inserte aus der Zeit bis zur Mitte des 11. Jahrhunderts folgen 42 aus der zweiten Hälfte des 11. Jahrhunderts, dann 55 bis zum Tode Innozenz' II. und die restlichen 145 verteilen sich in rasch steigender Dichte auf die letzten sechzig Jahre des 12. Jahrhunderts, wie bei Jaffé die Mitte der Zählung unter Eugen III. erreicht wird. Auch die Zahl der Empfänger weitet sich rasch aus, während für die Frühzeit einige wenige Klöster im Vordergrund stehen: fünf Stücke für Montecassino, alles Fälschungen, eine lange Serie von elf echten Privilegien für die suburbikarischen Bistümer Silva Candida und Porto, die unter Gregor IX. als Papyri zur Umschrift vorgelegt wurden, fünf für SaintMartin in Tours, davon wieder vier Spuria, und drei für Nonantola, darunter zwei Spuria. Unter Urban II. beginnen die den Streit um den Primat Toledos betreffenden Inserte mit einem Block von acht Stücken aus den Jahren 1095-1097. Dagegen befinden sich unter den 270 bei JL erfaßten Inserten nur je eines für Skandinavien, Polen (Trzemeszno), Ungarn und drei für Dalmatien (Zara, Split und Antivari), was mit der spärlichen Einzelüberlieferung für diesen Raum übereinstimmt. Dagegen betreffen nicht weniger als 32 der bei Jaffé schon erfaßten Inserte den Raum der Germania Pontificia. Dies kann wiederum kein Zufall sein, sondern war das Ergebnis der schon vor 1888 von deutschen und österreichischen Gelehrten wie bekanntlich Kehr selber unternommenen Forschungen auch in den päpstlichen Registern, wobei jeweils als Nebenertrag 
auch Inserte älterer Papsturkunden bekannt wurden. Auch für den deutschen Raum steht am Anfang ein Spurium, Leo III. für die Kapelle in monte Eresburg (JE †1502), dann folgen zwei Urkunden von Agapit II. und Johannes XIII. für Gandersheim, Johannes XV. für Selz und Johannes XIX für Naumburg-Zeitz. Umgekehrt finden sich unter den bereits bei Jaffé verzeichneten Stücken keines für Schottland, immerhin drei für Irland und nur eines für England.

Kommt man zur Gesamtüberlieferung in den päpstlichen Registern zurück und blickt auf die künftige Arbeit an den Regesta Pontificum Romanorum, so sind neben den Supplikenregistern als einer gewaltigen Archivserie noch keineswegs ausreichend ausgewertet die Verweise auf ältere Papsturkunden in den päpstlichen Registern, die sich in der ad instar- bzw. ad exemplar- Formel der feierlichen Privilegien oder im Kontext, vor allem in der Narratio, von einzelnen Bestätigungen und Rechtsentscheiden finden, wie sich bei der Vorbereitung des Oriens Pontificius an feierlichen Privilegien des 13. Jahrhunderts für Valenia, Tortosa und Tyrus gezeigt hat ${ }^{104}$. Hier wartet der künftigen Forschung ihrerseits noch ein großes Stück „Poenitenz“.

\section{Anhang:}

In den Berichten Kehrs nicht gedruckte Verweise auf Inserte älterer Papsturkunden in den päpstlichen Registern ${ }^{105}$

In den drei Berichten Kehrs über die Inserte älterer Papsturkunden in den päpstlichen Registern des 13.-16. Jahrhundert finden sich für das 15. und 16. Jahrhundert insgesamt 48 Verweise auf Papsturkunden, die entgegen dem üblichen Vorgehen im Anhang nicht gedruckt werden. Darunter handelt es sich um neun bisher unbekannte Nichtitalica, wobei die Zuschreibung an einen Papst des 11./12. Jahrhunderts nicht immer gesichert ist, in einigen Fällen wohl Verschreibungen zugrunde liegen. In die Erörterung der Registerstücke sind sie dennoch einbezogen worden.

1) Pro ordine b. Mariae de Mercede confirmatio privilegiorum concessorum a Bonifacio IV.

(608-615). - JE - . GN 02 S. 511 (ND Bd. 3 S. 485) Julius II. a. III. Entweder handelt es sich um eine grobe Fälschung oder um eine Verschreibung bei der Ordnungszahl des Papstes statt Bonifaz VIII. oder Bonifaz IX.

104 Vgl. O Bd. 3 S. 375 Nr. 189, 383 Nr. 191, 384 Nr. 192.

105 Siehe oben S. 436. 
2) Pro Johanne de Angevolis sumptum ex regesto litterarum Nicolai II super decantu Claromontano.

(1058-1061)?. - JL - . GN 02 S. 510 (ND Bd. 3 S. 484) Nr. 1 Paul II. a. II.

Ein solches Stück Nikolaus' II. für Clermont ist unbekannt. Kehr erwägt, ob es sich nicht eher um Nikolaus III., IV. oder V. handle.

3) Pro rectore et fratribus hospitalis s. Iacobi de Taleburgo (Taillebourg) Xanctonen. dioc. sumptum litterarum Alexandri pape III.

(1159-1181). - JL - . GN 02 S. 501 (ND Bd. 3 S. 475) Nr. 2 Martin V. a. III.

In FW 6 nicht verzeichnet. Schon Kehr versieht die Zuschreibung mit Fragezeichen. Die Angabe Xanctonen. dioec. entspricht dem Kanzleibrauch des 13. Jahrhunderts, doch sie braucht nicht schon in der Adresse der inserierten Urkunde gestanden zu haben.

4) Pro decano et capitulo Valentin. confirmatio indulti Alexandri III. (1159-1181). - JL - . GN 02 S. 502 (ND Bd. 3 S. 476) Nr. 7 Martin V. a. IX.

FW 3 S. 16 und Anm. 2 verzeichnet Alexander III. von (1166-1167) Jan. 27 für Bourg-lès-Valence, das in JL 4561 als Alexander II. ausgewiesen wird. Vgl. auch Collection des cartulaires dauphinois Bd. 6/1: Cartulaire du prieuré de Saint-Pierre du Bourg-Lès-Valence, ed. Ulysse Joseph Chevalier, Paris 1875, S. 6.

5) Pro archiepiscopo Salisburgen. mandatum pro confirmatione litterarum apostolicarum Lucii III super indulto providendi de nonnullis ecclesiis.

(1181-1185). - JL - . GN 02 S. 507 (ND Bd. 3 S. 481) Nr. 1 Nikolaus V. a. 1.

Vgl. jetzt GP 1 S. 43 Nr. ${ }^{*} 145 \mathrm{zu}(1181-1185)$ und RI 4/4/4/2 2073.

6) Lucius papa III per litteras suas probibuit canonicis Maurianensis ecclesiae, ne feuda vel decimas que pertinent ad episcopum Maurianensem sine ipsius assensu recipere a quoquam alterius praesumerent. Sed quia dictae litterae incipiebant vetustate consumi, Alexander $V$ illas auctoritate apostolica innovavit.

(1181-1185). - JL - . GN 02 S. 498 (ND Bd. 3 S. 472) Nr. 2 Alexander V. 1410 Jan 18.

Keines der in FW 3 S. $11 \mathrm{f}$. verzeichneten fünf Stücke Lucius' III. für Maurienne kann vom Inhalt her mit dem im Register genannten Stück identisch sein. Vgl. Gallia christiana Bd. 16 S. 628; jetzt auch RI 4/4/4/2 2194.

7) Pro monasterio monialium B. Marie de Fonterlicor. (sic statt de Fonte Clericorum) extra muros Londonienses confirmatio protectionis concesse ab Urbano III.

(1185-1187). - JL - . GN 02 S. 508 (ND Bd. 3 S. 482) Nr. 8 Nikolaus V. a. V. 
Vgl. jetzt ed. E Bd. 3 S. 487 Nr. 381 zu (1186) Okt. 19 für Clerkenwell, doch ohne Verweis auf die Register Nikolaus' V.

8) Pro Benedicto Petro priori in Ardwortschon (statt Andvordskov) hospitalis s. Johannis Jerusalemitan. in regnis Dacie, Suetie et Norwegie sumptum litterarum Clementis III, Honorii et Gregorii VIII.

(1187-1191). - JL - . GN 02 S. 507 (ND Bd. 3 S. 481) Nr. 6 Nikolaus V. a. 2 .

Es ist nicht sicher, ob schon die inserierten Urkunden an die Johanniter in Skandinavien gerichtet waren oder wahrscheinlicher allgemeine Bestätigungen von Besitz und Rechten von Nikolaus V. in ein an den Norden adressiertes Stück inseriert wurden. Statt Gregor VIII. ist sicher zu lesen Gregor IX.

9) Pro abbate et conventu monasterii s. Marie Eboracensis confirmatio litterarum Celestini papae III super excommunicatione fulminanda contra raptores bonorum dicti monasterii cum exemptione a iurisdictione ordinaria.

(1191-1198). - JL - . GN 02 S. 499 (ND Bd. 3 S. 473) Nr. 3 Johannes XXIII. a. 4.

E Bd. 1-3, erwähnt mehrfach (Bd. 1 S. 58, 120; Bd. 2 S. 108; Bd. 3 S. 70), daß in der englischen Überlieferung keine Papsturkunden für St. Mary's zu finden seien. Es handelt sich also um ein Unikat.

\section{Riassunto}

Parlando delle „Papsturkunden in Italien“ non si pensa certo dapprima a bolle che non erano destinate per l'Italia. Eppure fra i oltre 1200 documenti publiccati dal Kehr e i suoi collaboratori dal 1896 al 1962 quasi la sesta parte riguarda chiese e persone in tutte le parti del mondo cristiano medievale, dall'Iberia alla Terra Santa. Essi sono spesso sfuggiti anche all'attenzione dei singoli autori delle Regesta Pontificum Romanorum.

Perciò questo studio si propone di dare una rassegna dei tre gruppi più importanti di tali bolle, un primo per gli ordini militari, sopratutto Templari ed Ospedalieri, mentre quasi non ce sono per gli ordini della riforma ecclesiastica, un secondo per singole chiese ed istituti religiosi e laici da Gerusalemme fino all'Irlanda e finalmente bolle spedite prima del 1198, ma poi inserte nei registri papali dei secoli XIII-XVI. Mentre i primi si ritrovano sparsi tra materiale italiano quasi tali relitti stranieri, gli ultimi già per la loro transmissione fanno parte di un materiale „internazionale“, dove costuiscono anzi la maggioranza. Fra di loro spiccano copie collettive per i conflitti sulla primazia di Toledo ed un numero elevato di privilegi per chiese inglesi.

Lasciando da parte le bolle per la Terra Santa studiate in altro luogo, fra le quali sarà solo menzionato un privilegio per Beirut, si ritrovava p. es. un altro 
privilegio per Antivari nella Dalmazia, concesso da Clemente III/Guiberto e riportando nuova luce sulla politica papale nella penisola balcanica alle fine del secolo XI, poi una serie di documenti per il monastero di Lerins ed una versione sconosciuta dell'enciclica di Alessandro III dopo lo scisma del 1159. Insomma, il contributo cerca di riportare, anche con vari indici, l'attenzione su questi documenti che facilmente rischiano di rimanere all'obblio, bensi siano di alto valore per la storia della Chiesa romana e per la storia degli archivi dove oggi essi sono conservati. 


\begin{tabular}{|c|c|c|c|c|c|c|c|c|c|c|c|c|}
\hline & है & $\begin{array}{l}n \\
\infty \\
+ \\
\dot{n} \\
n \\
\dot{D} \\
\dot{n}\end{array}$ & $\begin{array}{l}\vec{\sigma} \\
\dot{n} \sim \\
\sim \\
\dot{D} \\
\dot{\infty}\end{array}$ & $\begin{array}{l}\infty \\
\stackrel{0}{0} \\
\dot{s} \\
\sim \\
\dot{\vec{n}} \\
\dot{\vec{n}}\end{array}$ & $\begin{array}{l}\infty \\
0 \\
\dot{\omega} \\
\sim \\
\sim \\
\dot{\vec{n}} \\
\dot{\infty} \\
\end{array}$ & $\begin{array}{l}\infty \\
\dot{n} n \\
\sim \\
\dot{\vec{z}} \\
\dot{\infty}\end{array}$ & $\begin{array}{l}\infty \\
\stackrel{1}{1} \\
\dot{\triangleright}= \\
\dot{\vec{z}} \\
\dot{\vec{n}}\end{array}$ & 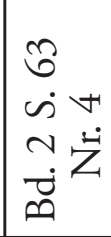 & 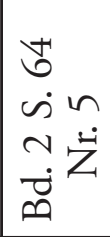 & $\begin{array}{l}\infty \\
\stackrel{0}{0} \\
\dot{s} \\
\sim \\
\sim \\
\dot{\vec{n}}\end{array}$ & $\begin{array}{l}\tilde{w} \\
\dot{f} \\
\dot{n} \\
m \\
\dot{n} \\
\dot{n}\end{array}$ & 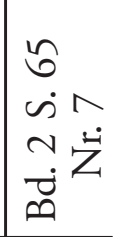 \\
\hline & 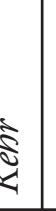 & $\begin{array}{l}\overrightarrow{\tilde{n}} \\
\dot{\omega} \\
\tilde{\sigma}\end{array}$ & $\begin{array}{l}\overrightarrow{\bar{n}} \\
\dot{n} \vec{z} \\
\alpha\end{array}$ & $\begin{array}{l}\infty \\
\infty \\
i \\
\dot{n} \vec{z} \\
\alpha\end{array}$ & 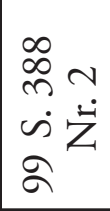 & $\begin{array}{l}m \\
\vec{n} n \\
\dot{n} \vec{z} \\
\sigma\end{array}$ & 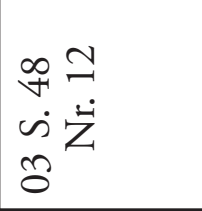 & $\begin{array}{l}n \\
n \\
\dot{n} \\
\dot{z} \\
\tilde{\sigma}\end{array}$ & 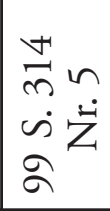 & $\begin{array}{l}\infty \\
\infty \\
\infty \\
\dot{n} \\
\dot{z} \\
\alpha\end{array}$ & 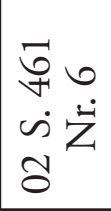 & 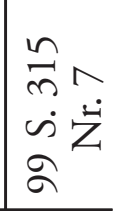 \\
\hline & 参 & 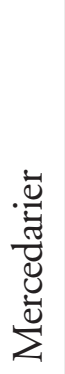 & 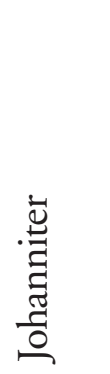 & 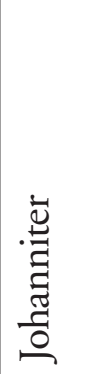 & 岕 & 离 & 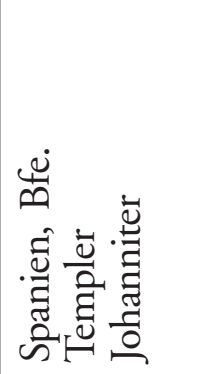 & 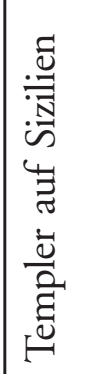 & 节 & $\frac{\overrightarrow{\vec{u}}}{\stackrel{\vec{a}}{\vec{U}}}$ & 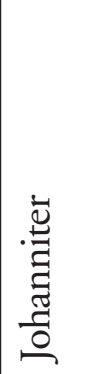 & 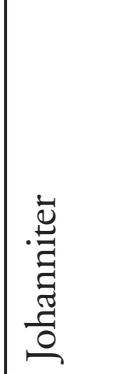 \\
\hline & है & 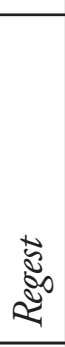 & 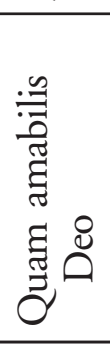 & 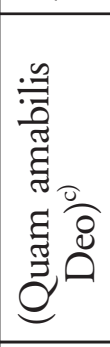 & 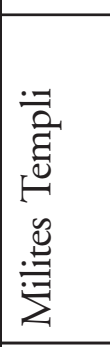 & 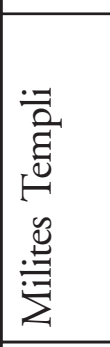 & 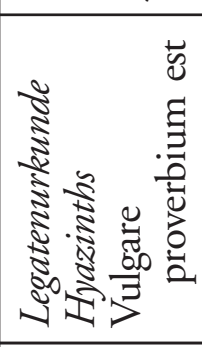 & 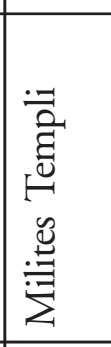 & 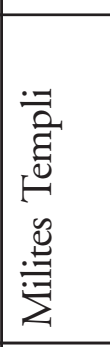 & 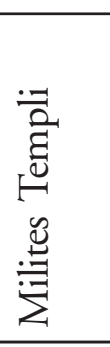 & 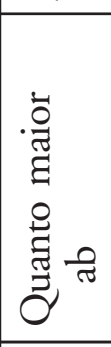 & 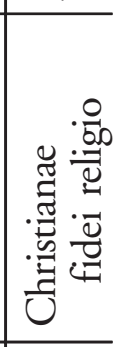 \\
\hline & $\xi$ & 1 & 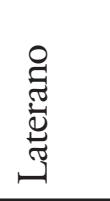 & 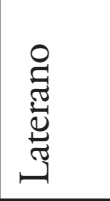 & 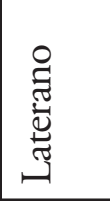 & 咅 & 1 & $\begin{array}{l}\overrightarrow{\tilde{\sigma}_{0}} \\
\stackrel{\leftrightarrow}{\circ}\end{array}$ & 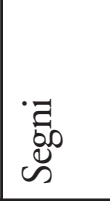 & 咅 & $\stackrel{\mathscr{g}}{\varrho}$ & 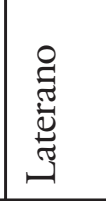 \\
\hline & ל. & $\begin{array}{l}1 \\
\pm\end{array}$ & $\stackrel{1}{\lrcorner}$ & $\stackrel{1}{=}$ & $\stackrel{1}{=}$ & $\stackrel{1}{=}$ & 1 & $\stackrel{1}{=}$ & $\stackrel{1}{=}$ & $\stackrel{1}{\Perp}$ & $\stackrel{1}{\lrcorner}$ & $\stackrel{1}{=}$ \\
\hline & 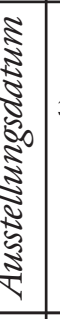 & $\begin{array}{l}0 \\
\tilde{\sigma} \\
\bar{\sigma} \\
1 \\
\infty \\
0 \\
0 \\
\end{array}$ & 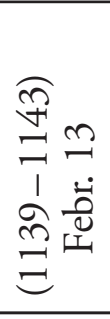 & 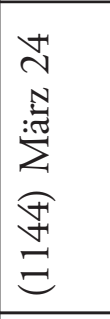 & 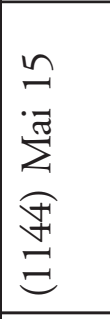 & 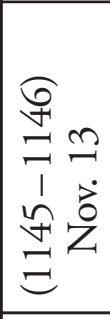 & 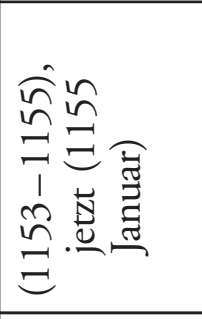 & $\begin{array}{l}n \\
\dot{a} \\
\bar{a} \\
\hat{n} \\
\hat{n} \\
\Xi \\
\Xi\end{array}$ & 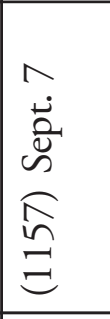 & 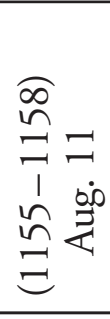 & 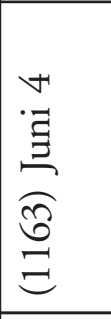 & 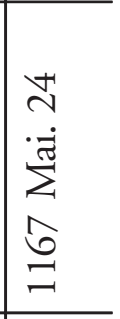 \\
\hline & & $-\dot{ }$ & $i$ & $\dot{r}$ & $\stackrel{+}{+}$ & $i n$ & $\dot{0}^{\circ}$ & $\wedge^{\circ}$ & $\infty$ & $\sigma^{\circ}$ & $\stackrel{0}{\circ}$ & $\Xi$ \\
\hline
\end{tabular}


„Verborgene Schätze“. Nichtitalienische Stücke in den „Papsturkunden in Italien“

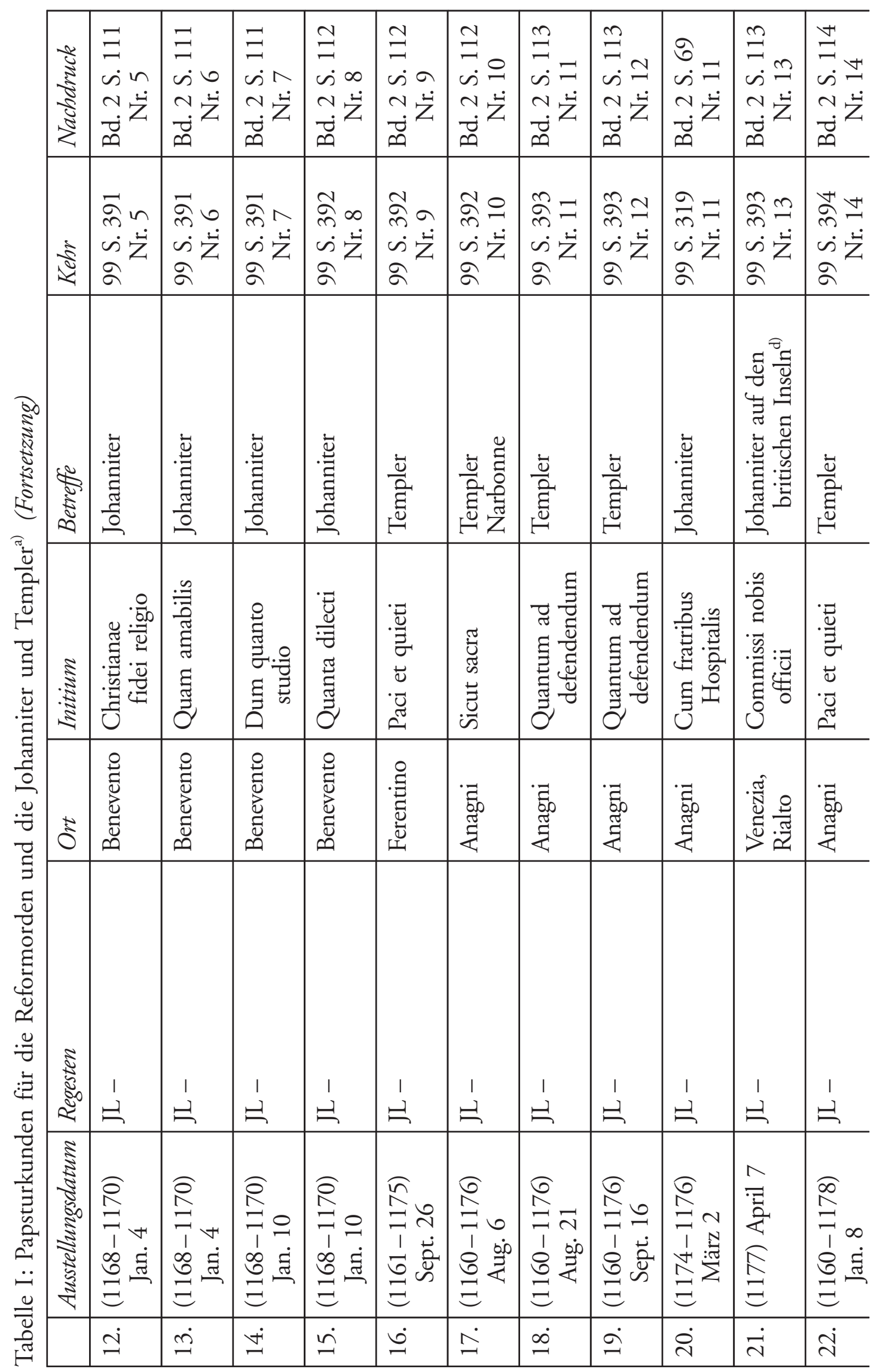




\begin{tabular}{|c|c|c|c|c|c|c|c|c|c|c|c|}
\hline & & 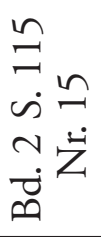 & 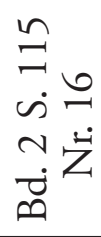 & 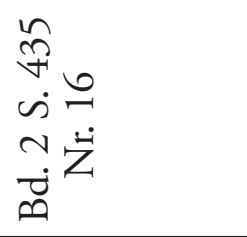 & 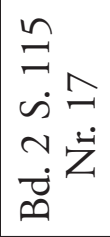 & $\begin{array}{l}0 \\
= \\
\dot{n}= \\
\sim \\
\stackrel{\dot{z}}{\dot{z}}\end{array}$ & 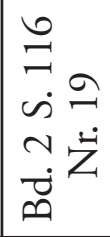 & $\begin{array}{l}\hat{\Xi} \\
\dot{\vec{n}} \\
\sim \\
\sim \dot{z} \\
\dot{\vec{n}}\end{array}$ & 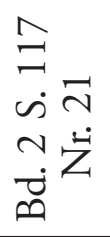 & 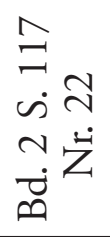 & $\begin{array}{l}\triangleq \\
\exists \\
\dot{\sim} \\
\sim \\
\dot{n} \\
\dot{\infty}\end{array}$ \\
\hline & & 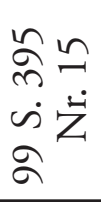 & 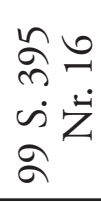 & $\begin{array}{l}\approx 10 \\
i z \\
\dot{w} \dot{z} \\
8\end{array}$ & $\begin{array}{l}n \hat{n} \\
\hat{n}= \\
\dot{n} \vec{z} \\
\alpha\end{array}$ & 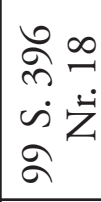 & 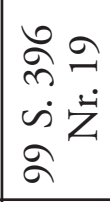 & $\begin{array}{l}\hat{\sigma} \bar{z} \\
\dot{\omega} \dot{z} \\
\hat{\sigma}\end{array}$ & $\begin{array}{l}\hat{\sigma} \bar{r} \\
\dot{n} \vec{z} \\
\alpha \\
\alpha\end{array}$ & $\begin{array}{l}\hat{a} \pi \\
\dot{n} \dot{z} \\
\dot{\sigma}^{2}\end{array}$ & $\begin{array}{l}\hat{\sigma} \approx \\
\dot{\gamma} \\
\dot{\omega} \vec{z} \\
\tilde{\sigma}\end{array}$ \\
\hline & & 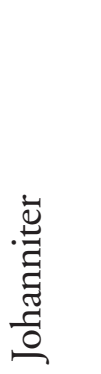 & 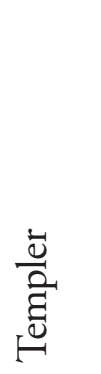 & 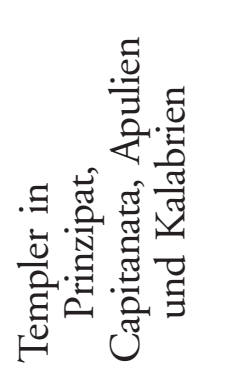 & 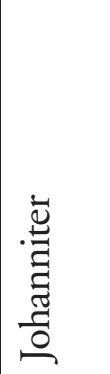 & 离 & 离 & 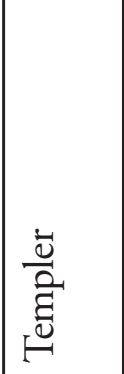 & 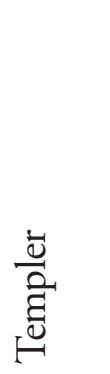 & 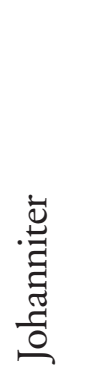 & 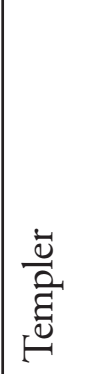 \\
\hline & & 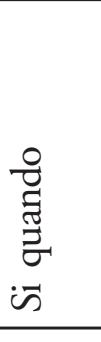 & 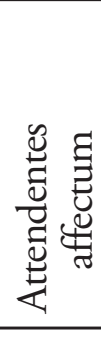 & 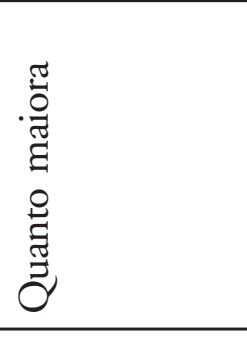 & 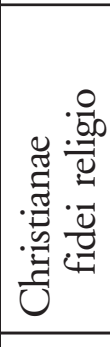 & 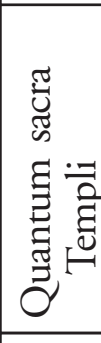 & 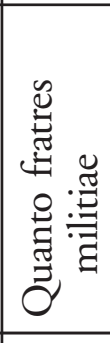 & 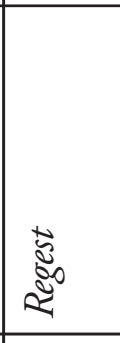 & 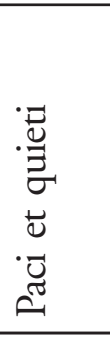 & 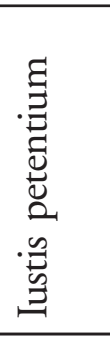 & 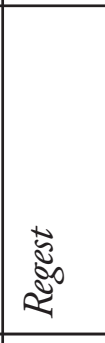 \\
\hline & & 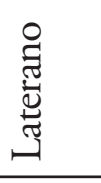 & 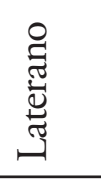 & 茕 & 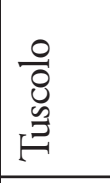 & 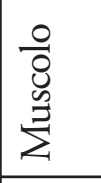 & 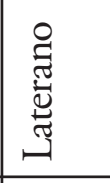 & 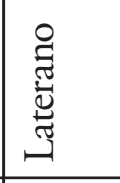 & 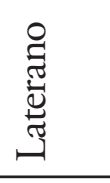 & 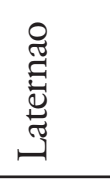 & 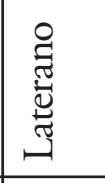 \\
\hline & & $\stackrel{1}{\lrcorner}$ & $\stackrel{1}{=}$ & 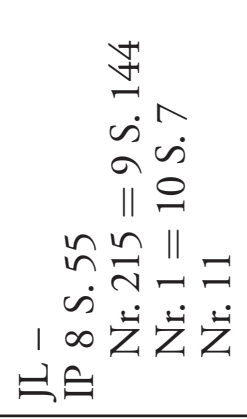 & $\stackrel{1}{=}$ & $\stackrel{1}{=}$ & $\stackrel{1}{=}$ & $\stackrel{1}{=}$ & $\stackrel{1}{=}$ & $\stackrel{1}{\lrcorner}$ & $\stackrel{1}{=}$ \\
\hline & & 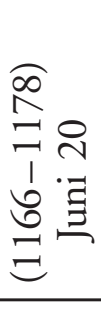 & 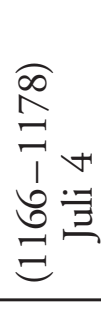 & 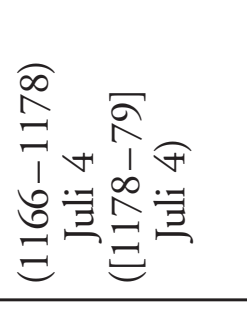 & $\begin{array}{l} \pm \\
\pm \\
\overrightarrow{0} \\
z \\
\infty \\
ٍ \\
\Xi \\
\end{array}$ & 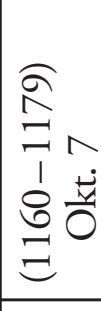 & 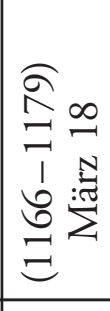 & 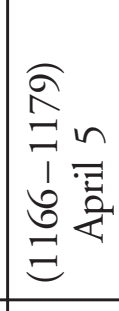 & 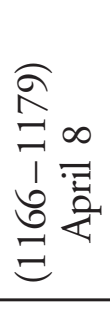 & 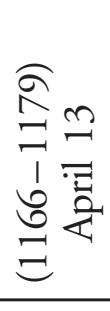 & 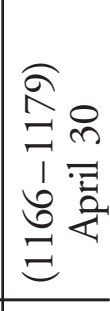 \\
\hline & & $\dot{\sim}$ & $\stackrel{\leftrightarrow}{\sim}$ & $\ddot{\imath}$ & $\dot{\sim}$ & $\dot{\hat{v}}$ & $\stackrel{\dot{\sim}}{\sim}$ & $\ddot{\imath}$ & $\dot{m}$ & $\dot{m}$ & శี่ \\
\hline
\end{tabular}


„Verborgene Schätze“. Nichtitalienische Stücke in den „Papsturkunden in Italien“

\begin{tabular}{|c|c|c|c|c|c|c|c|c|c|c|}
\hline $\begin{array}{l}\frac{\pi}{3} \\
\frac{2}{3} \\
\frac{3}{8} \\
z\end{array}$ & $\begin{array}{l}\infty \\
\exists \\
\dot{\sim} \\
\sim \\
\sim \\
\dot{\infty}\end{array}$ & 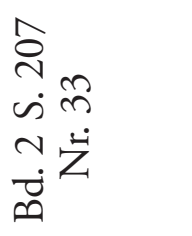 & 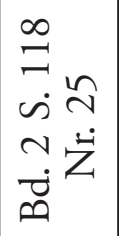 & $\begin{array}{l}\infty \\
\exists \\
\dot{\sim} \\
\sim \\
\sim \\
\dot{\infty} \\
\dot{n}\end{array}$ & 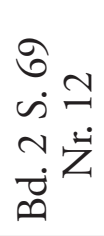 & $\begin{array}{l}\infty \\
\exists \\
\dot{\sim} \\
\sim \\
\stackrel{\vec{Z}}{\vec{n}} \\
\dot{\infty}\end{array}$ & $\begin{array}{l}\varrho \\
\exists \dot{~} \\
\dot{\sim} \\
\sim \\
\dot{\infty} \\
\dot{\infty}\end{array}$ & 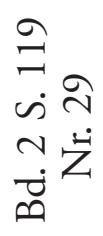 & 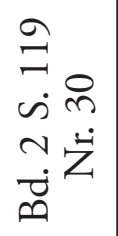 & 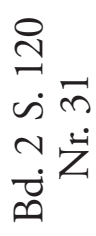 \\
\hline$\stackrel{\Sigma}{d}$ & $\begin{array}{l}\infty \\
\dot{n} \\
\dot{\sim} \\
\dot{z} \\
\check{\sigma}\end{array}$ & $\begin{array}{l}\vec{\infty} m \\
=\dot{n} \\
u \dot{z}\end{array}$ & 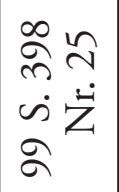 & $\begin{array}{l}\infty \\
\hat{n} \\
\dot{\sim} \\
\check{\sigma} \\
\check{z}\end{array}$ & $\begin{array}{l}\hat{\sigma} \sim \\
\dot{\vec{z}} \\
\stackrel{a}{\sigma}\end{array}$ & 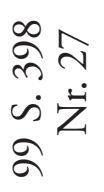 & 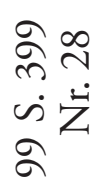 & 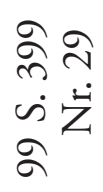 & 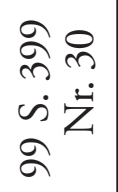 & 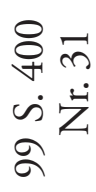 \\
\hline 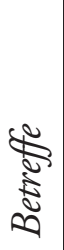 & 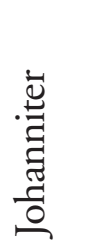 & 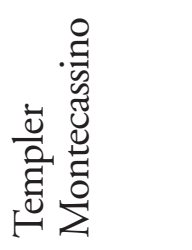 & 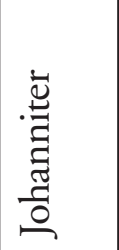 & 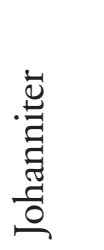 & 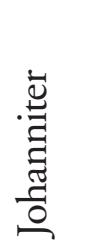 & 离 & 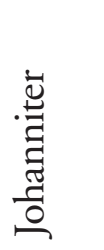 & 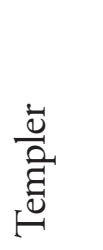 & 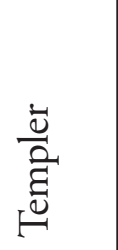 & 离 \\
\hline $\begin{array}{r}\text { ₹ } \\
\text { : } \\
\text { है } \\
\end{array}$ & 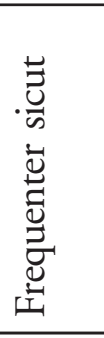 & 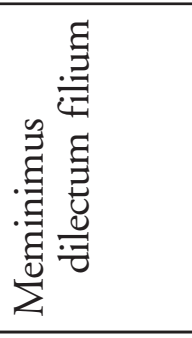 & 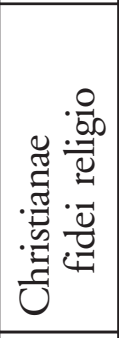 & 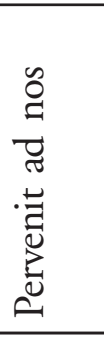 & 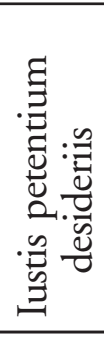 & 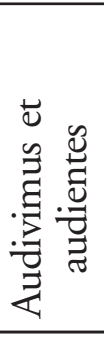 & 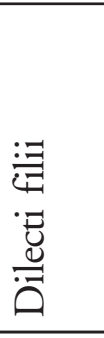 & 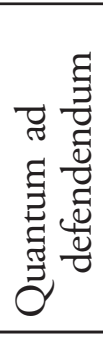 & 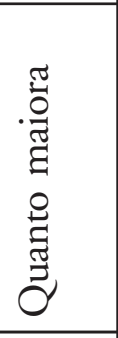 & 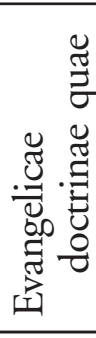 \\
\hline $0^{ \pm}$ & 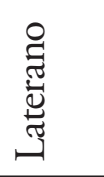 & 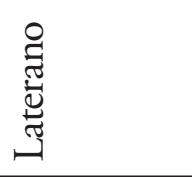 & 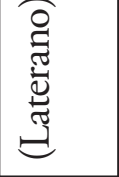 & 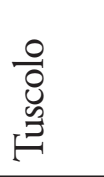 & $\begin{array}{l}\frac{0}{8} \\
\stackrel{0}{0} \\
ٍ\end{array}$ & 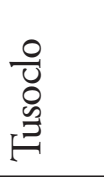 & $\begin{array}{l}\frac{0}{8} \\
\dot{0} \\
ٍ\end{array}$ & 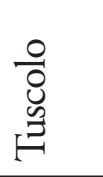 & 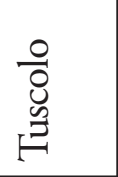 & 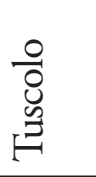 \\
\hline 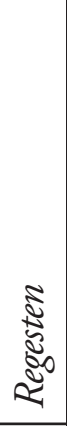 & $\stackrel{1}{\leftrightarrows}$ & 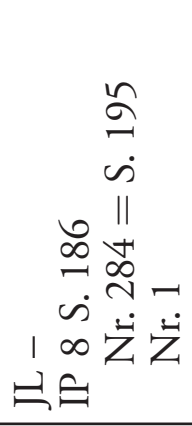 & $\stackrel{1}{\varrho}$ & $\stackrel{1}{\ominus}$ & $\stackrel{1}{\leftrightarrows}$ & $\stackrel{1}{\varrho}$ & $\stackrel{1}{\ominus}$ & $\stackrel{1}{\triangleq}$ & $\stackrel{1}{\ominus}$ & $\stackrel{1}{\ominus}$ \\
\hline 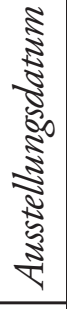 & 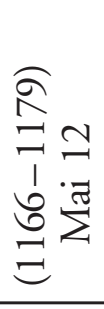 & 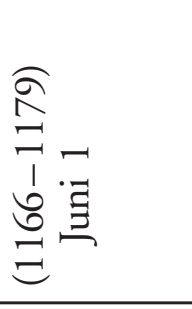 & 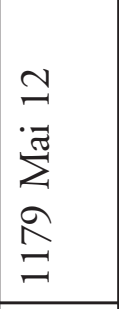 & 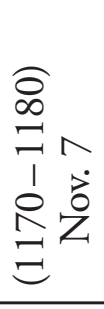 & 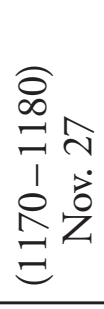 & 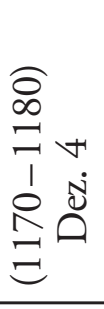 & 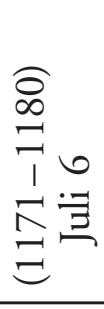 & 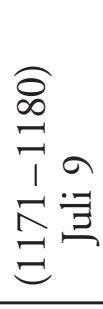 & 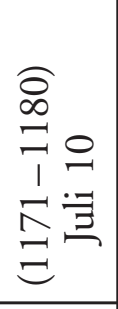 & 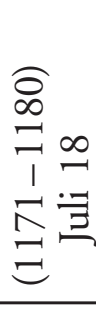 \\
\hline & $\dot{m}$ & 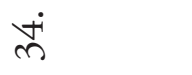 & $\dot{n}$ & $n$ & $\hat{n}$ & $\stackrel{\infty}{\infty}$ & $\dot{m}$ & $\stackrel{\dot{T}}{\dot{\gamma}}$ & $\dot{F}$ & $\stackrel{\dot{f}}{\mathrm{f}}$ \\
\hline
\end{tabular}




\begin{tabular}{|c|c|c|c|c|c|c|c|c|c|c|c|c|}
\hline & & 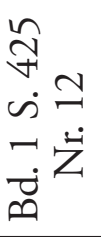 & $\begin{array}{l}R \\
\dot{n}= \\
\sim \dot{z} \\
\dot{\vec{c}}\end{array}$ & $\begin{array}{l}\vec{\beth} \\
\dot{\sim} \\
\sim \\
\sim \\
\dot{n} \\
\dot{n}\end{array}$ & $\begin{array}{l}\vec{\Xi} \\
\dot{\sim} \\
\dot{n} \\
\sim \\
\vec{n} \dot{z} \\
\dot{n}\end{array}$ & 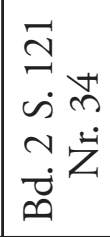 & $\mid \begin{array}{l}R \\
\dot{R} \\
\sim \\
\sim \\
\dot{D} \\
\dot{\infty}\end{array}$ & 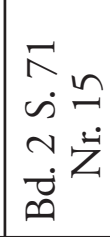 & 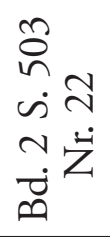 & 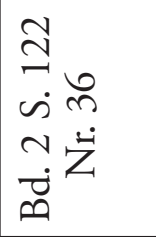 & $\begin{array}{l}\tilde{J} \\
\dot{n} \hat{n} \\
\sim \\
\dot{n} \\
\dot{n}\end{array}$ & $\begin{array}{l}\approx \\
\beth \\
\dot{\omega} \\
\sim \\
\sim \\
\dot{m} \\
\dot{n}\end{array}$ \\
\hline & & 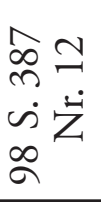 & 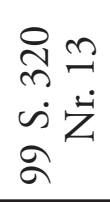 & $\begin{array}{l}\vec{\sigma} \tilde{\gamma} \\
\dot{\omega} \vec{z} \\
\alpha \\
\sigma\end{array}$ & 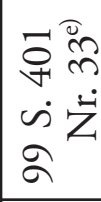 & 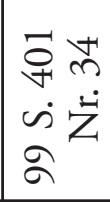 & 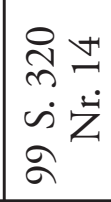 & 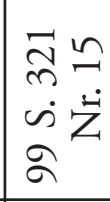 & 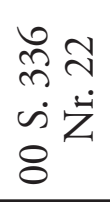 & 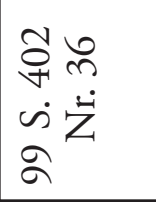 & 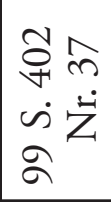 & 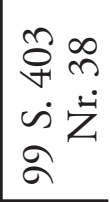 \\
\hline & & 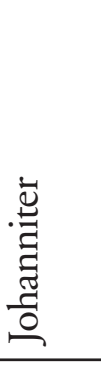 & 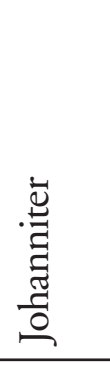 & 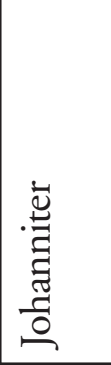 & 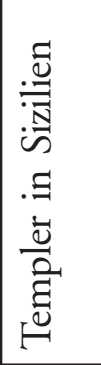 & 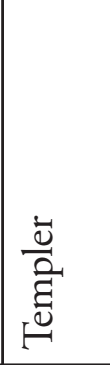 & 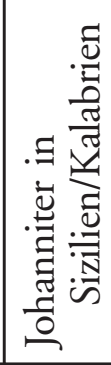 & 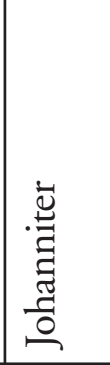 & 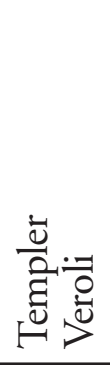 & 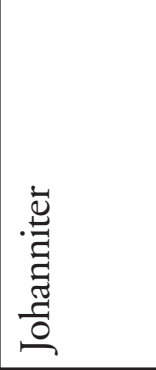 & 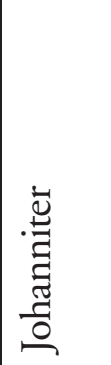 & 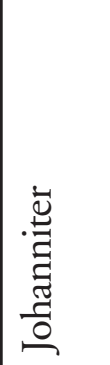 \\
\hline & & 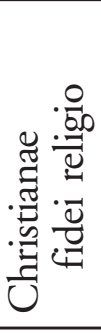 & 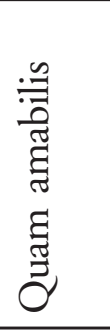 & 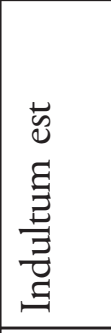 & 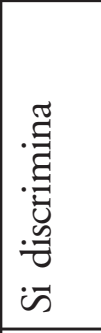 & 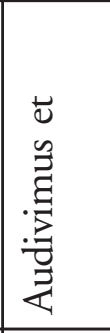 & 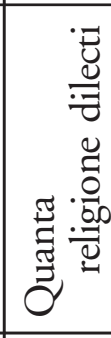 & 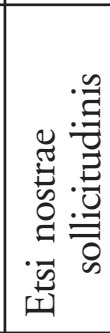 & 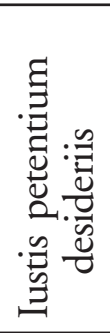 & 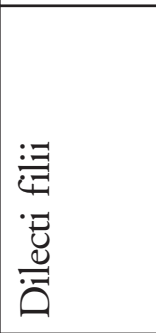 & 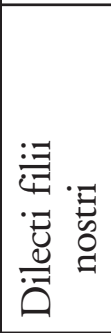 & 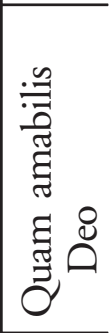 \\
\hline & & $\frac{E}{0}$ & 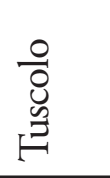 & 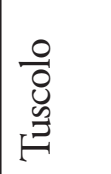 & $\begin{array}{l}0 \\
0 \\
0 \\
0 \\
3 \\
1\end{array}$ & $\begin{array}{l}0 \\
0 \\
0 \\
0 \\
19\end{array}$ & 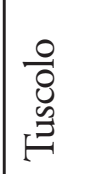 & 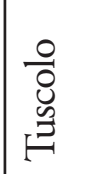 & $\begin{array}{l}\frac{0}{8} \\
\stackrel{0}{0} \\
ٍ\end{array}$ & 苞的离 & $\frac{E}{\frac{E}{0}}$ & $\frac{E}{\frac{E}{0}}$ \\
\hline & & $\stackrel{1}{\varrho}$ & $\stackrel{1}{=}$ & $\stackrel{1}{=}$ & $\begin{array}{cc}1 & 1 \\
= & E\end{array}$ & $\stackrel{1}{=}$ & $\begin{array}{c}1{ }_{1} \\
\Leftrightarrow \Leftrightarrow\end{array}$ & $\stackrel{1}{1}$ & 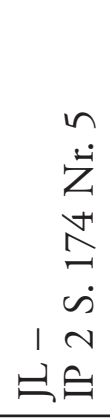 & 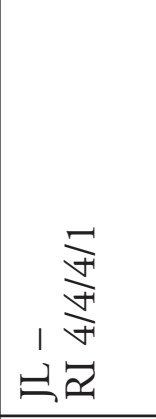 & 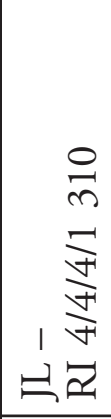 & 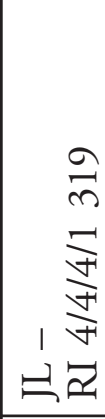 \\
\hline & & 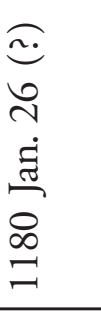 & 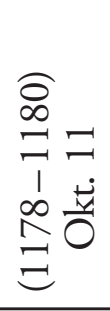 & 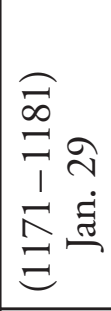 & 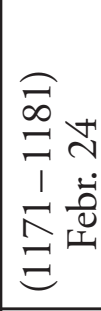 & 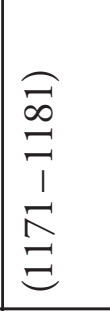 & 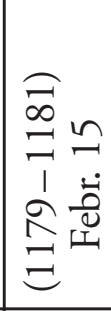 & 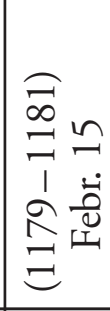 & 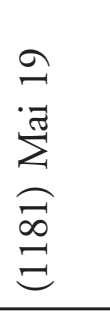 & 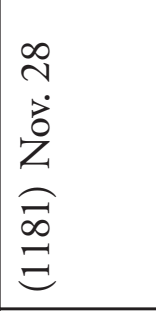 & 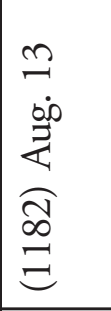 & 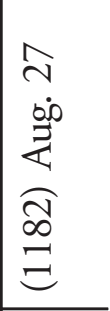 \\
\hline & & $\dot{\leftrightarrow}$ & $\underset{F}{+}$ & $\dot{f}$ & 宗 & $\stackrel{\dot{f}}{\circ}$ & $\stackrel{\infty}{+}$ & $\stackrel{\leftrightarrow}{\dot{T}}$ & $\dot{\ominus}$ & $\dot{n}$ & กี่ & $\ddot{n}$ \\
\hline
\end{tabular}




\begin{tabular}{|c|c|c|c|c|c|c|c|c|c|c|}
\hline 3 & 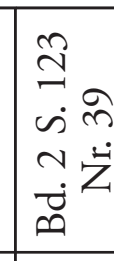 & 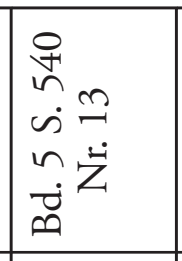 & 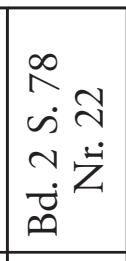 & 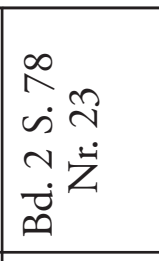 & 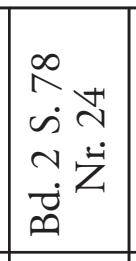 & 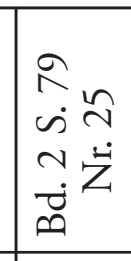 & 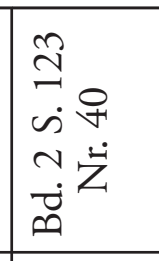 & 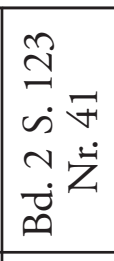 & 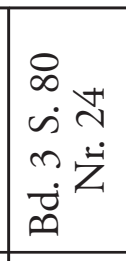 & 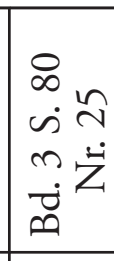 \\
\hline 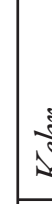 & 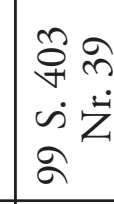 & 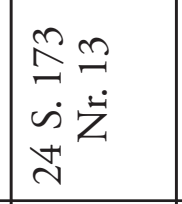 & 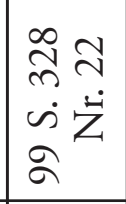 & 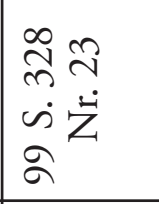 & 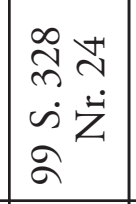 & 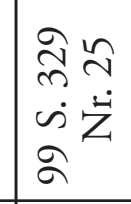 & 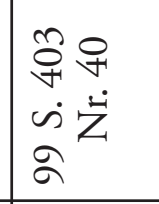 & 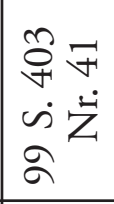 & 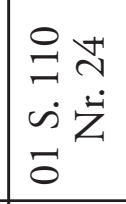 & 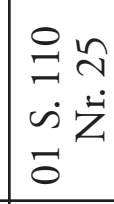 \\
\hline & 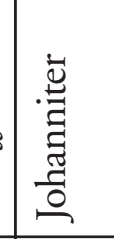 & 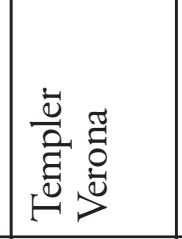 & 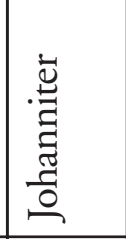 & 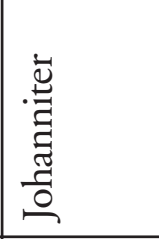 & 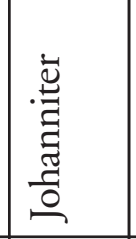 & 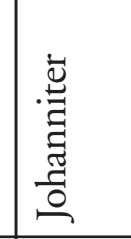 & 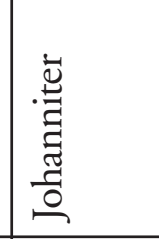 & 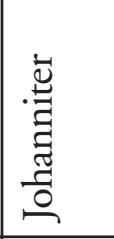 & 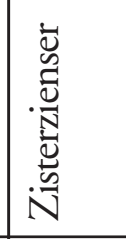 & 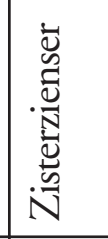 \\
\hline & 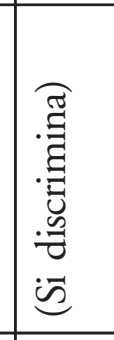 & 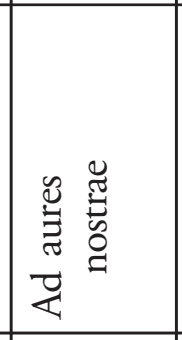 & 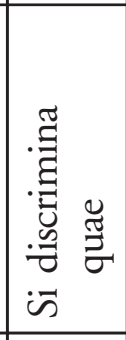 & 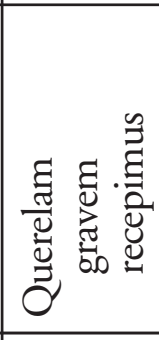 & 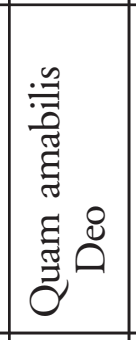 & 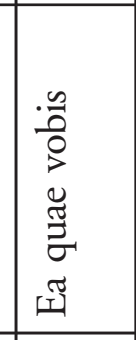 & 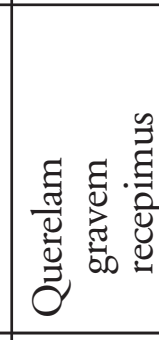 & 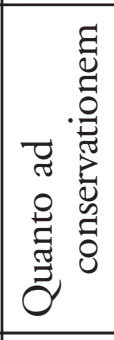 & 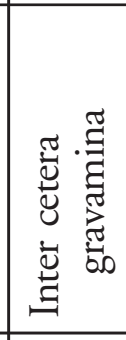 & 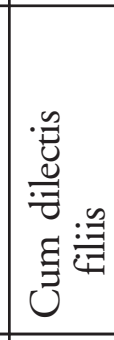 \\
\hline d & $\frac{\mathrm{E}}{\overline{\mathrm{E}}}$ & 竞 & 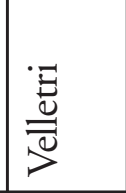 & 焉 & 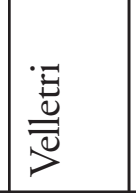 & 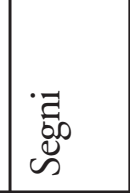 & $\begin{array}{l}\ddot{\overline{0}} \overline{0} \\
\overline{\bar{y}}\end{array}$ & 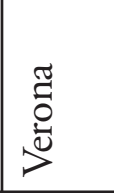 & & \\
\hline & 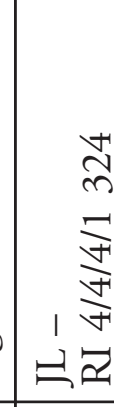 & 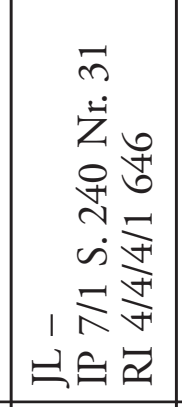 & 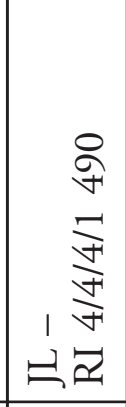 & 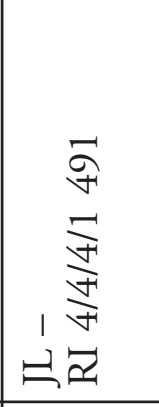 & 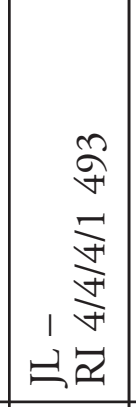 & 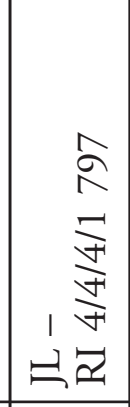 & 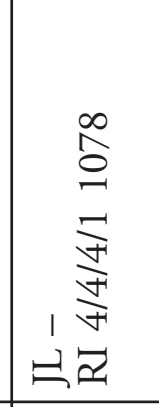 & 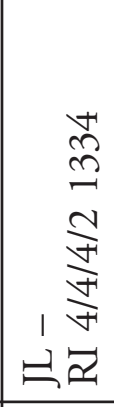 & 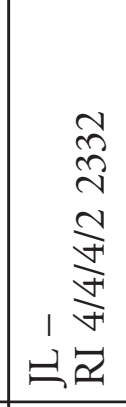 & 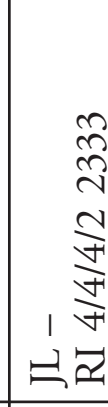 \\
\hline & 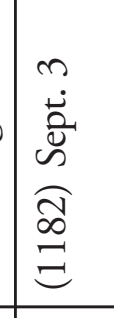 & 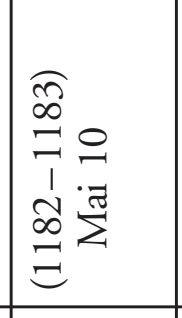 & 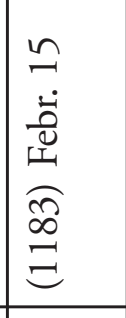 & 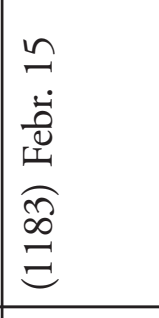 & 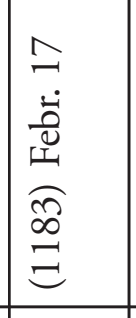 & $\begin{array}{l}n \\
\dot{a} \\
\stackrel{\Delta}{0} \\
\stackrel{\infty}{\infty} \\
\infty \\
\Xi \\
\end{array}$ & 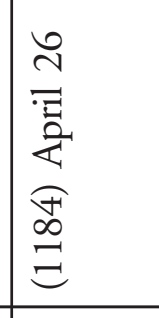 & 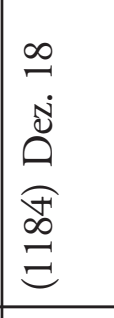 & 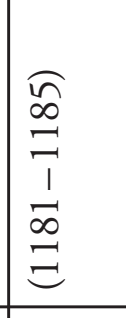 & $\begin{array}{l}\widetilde{\Omega} \\
\stackrel{\infty}{=} \\
1 \\
1 \\
\infty \\
\Xi \\
\Xi\end{array}$ \\
\hline & in & $\ddot{n}$ & \begin{tabular}{|l} 
\\
\end{tabular} & $\dot{n}$ & $\begin{array}{l}\infty \\
i \\
n\end{array}$ & $\ddot{n}$ & 8 & $\dot{0}$ & Sิ & هి \\
\hline
\end{tabular}




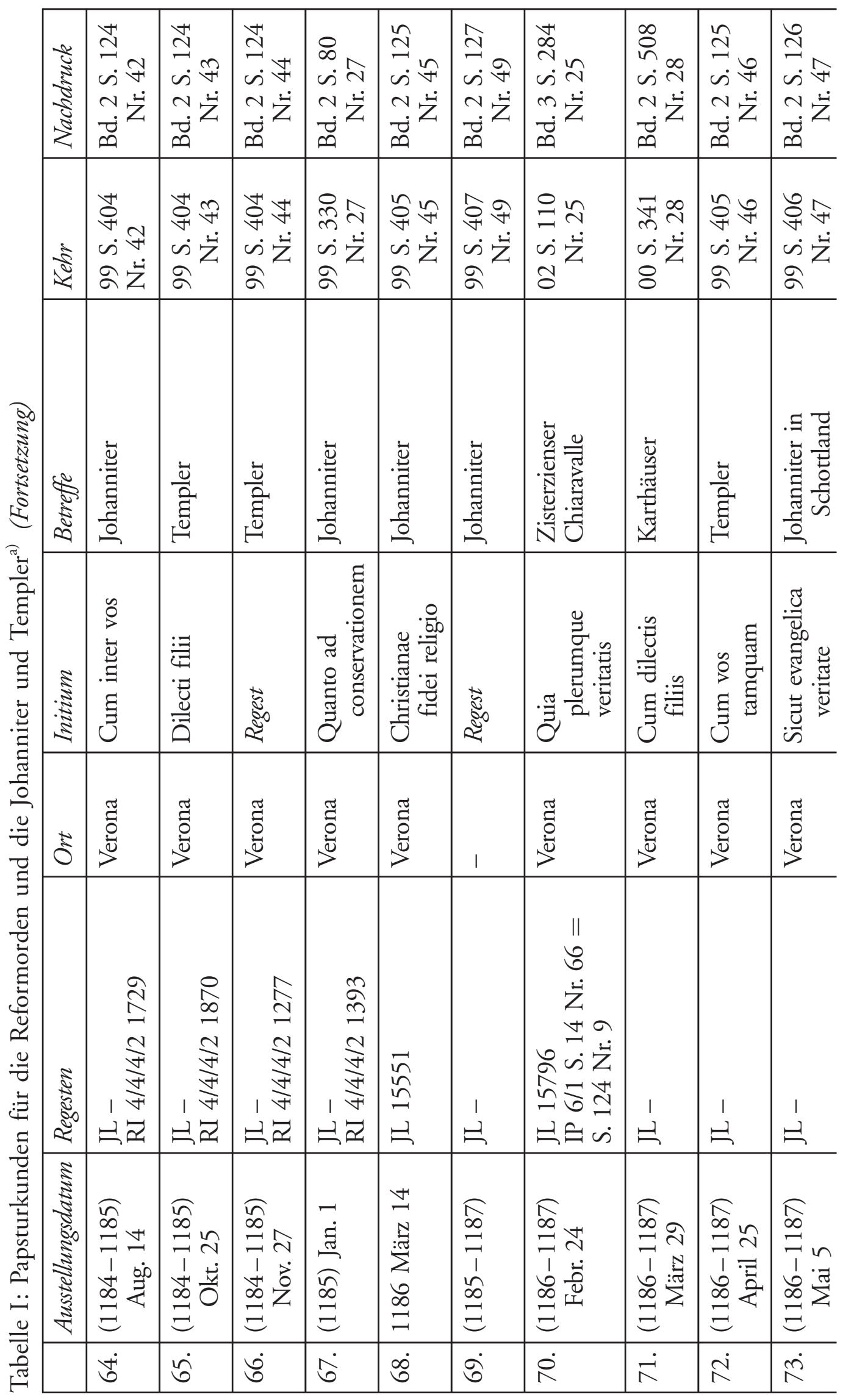




\begin{tabular}{|c|c|c|c|c|c|c|c|}
\hline 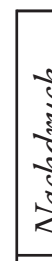 & 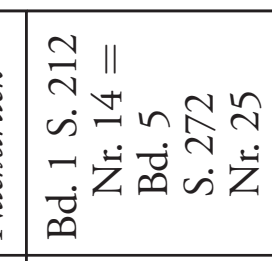 & 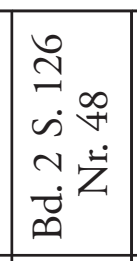 & 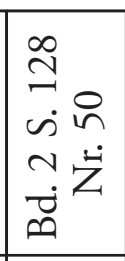 & 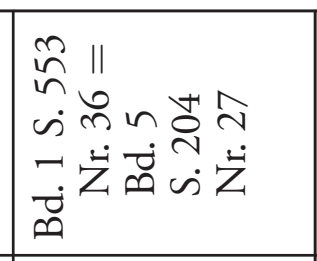 & 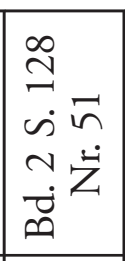 & 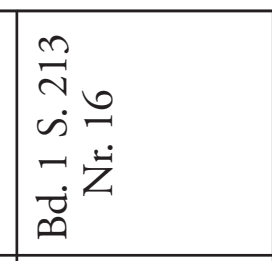 & 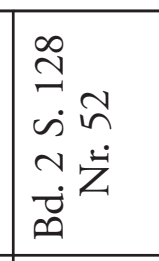 \\
\hline 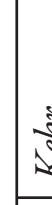 & 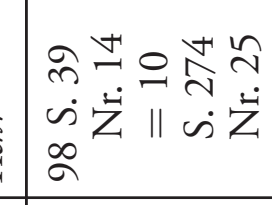 & 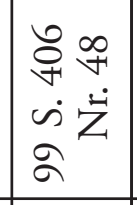 & 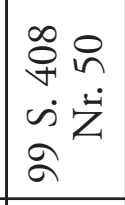 & 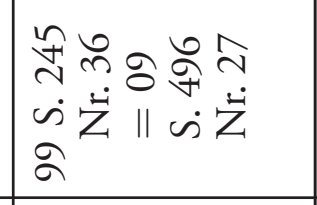 & 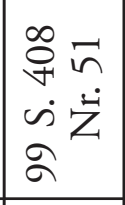 & 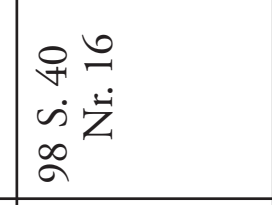 & 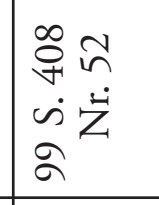 \\
\hline & 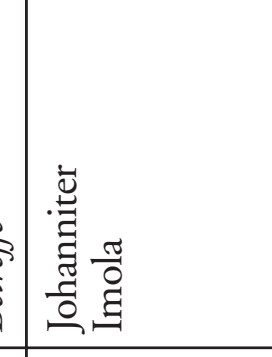 & 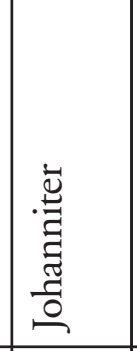 & 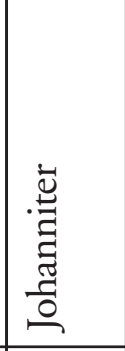 & 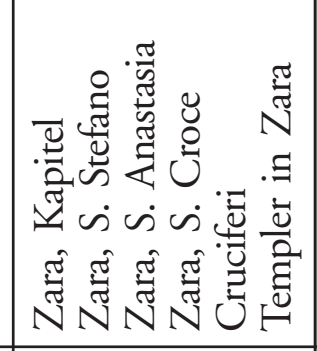 & 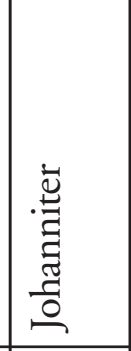 & 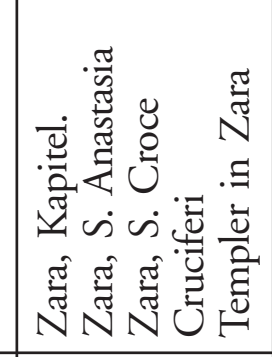 & 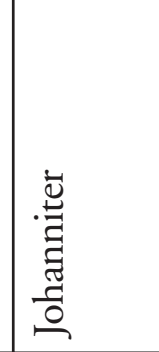 \\
\hline & 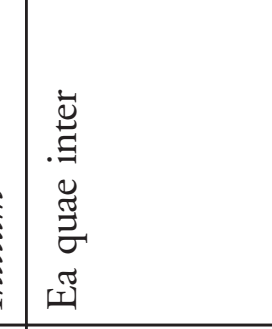 & 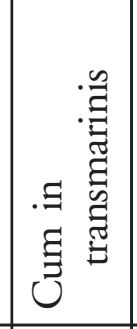 & 范 & 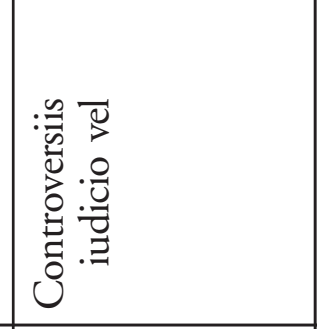 & 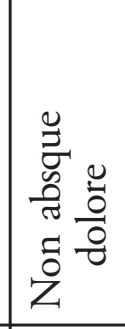 & 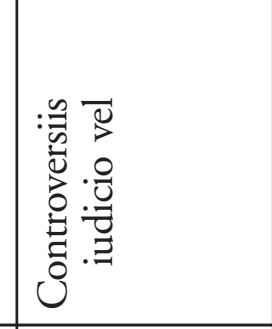 & 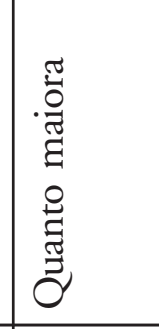 \\
\hline c & 竞 & 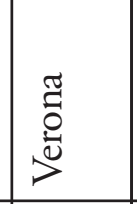 & 1 & 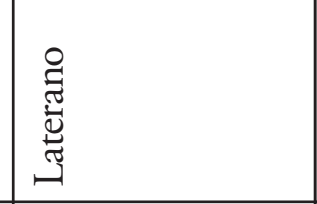 & 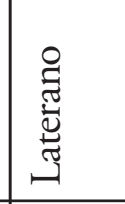 & 芯的离 & 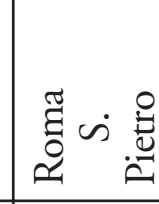 \\
\hline & 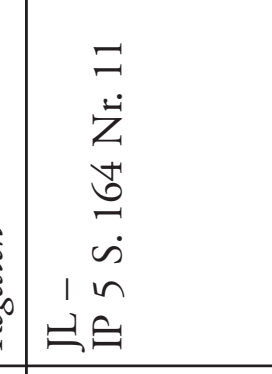 & $\begin{array}{l}\infty \\
\infty \\
\stackrel{\infty}{n} \\
= \\
=\end{array}$ & $\stackrel{1}{ }$ & 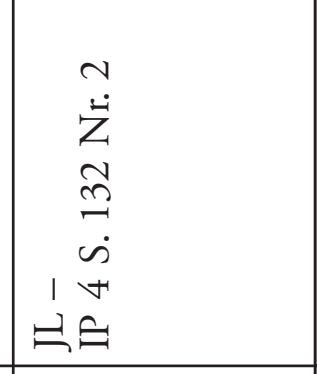 & $\stackrel{1}{=}$ & 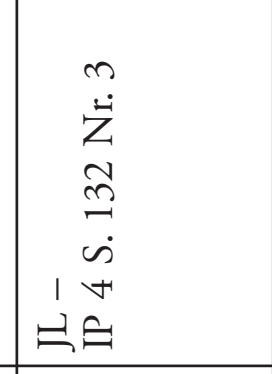 & $\stackrel{1}{=}$ \\
\hline & 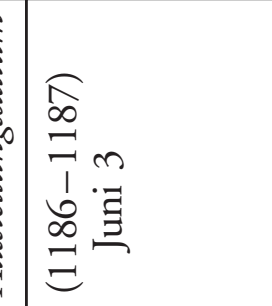 & 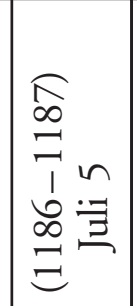 & 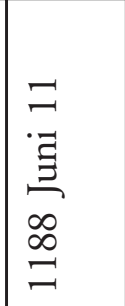 & 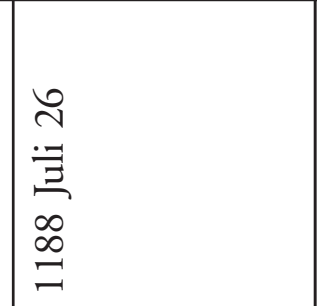 & 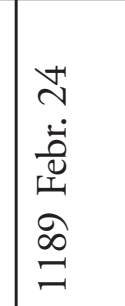 & 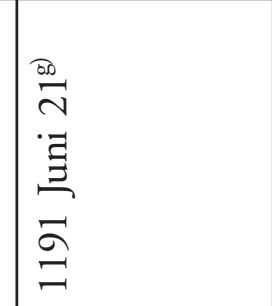 & 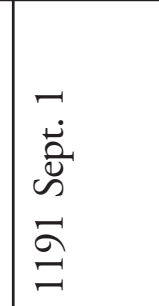 \\
\hline & $\grave{i}^{+}$ & $\stackrel{n}{\wedge}$ & $\dot{2}$ & $\dot{R}$ & $\stackrel{\infty}{\infty}$ & $\frac{1}{1}$ & $\dot{\infty}$ \\
\hline
\end{tabular}




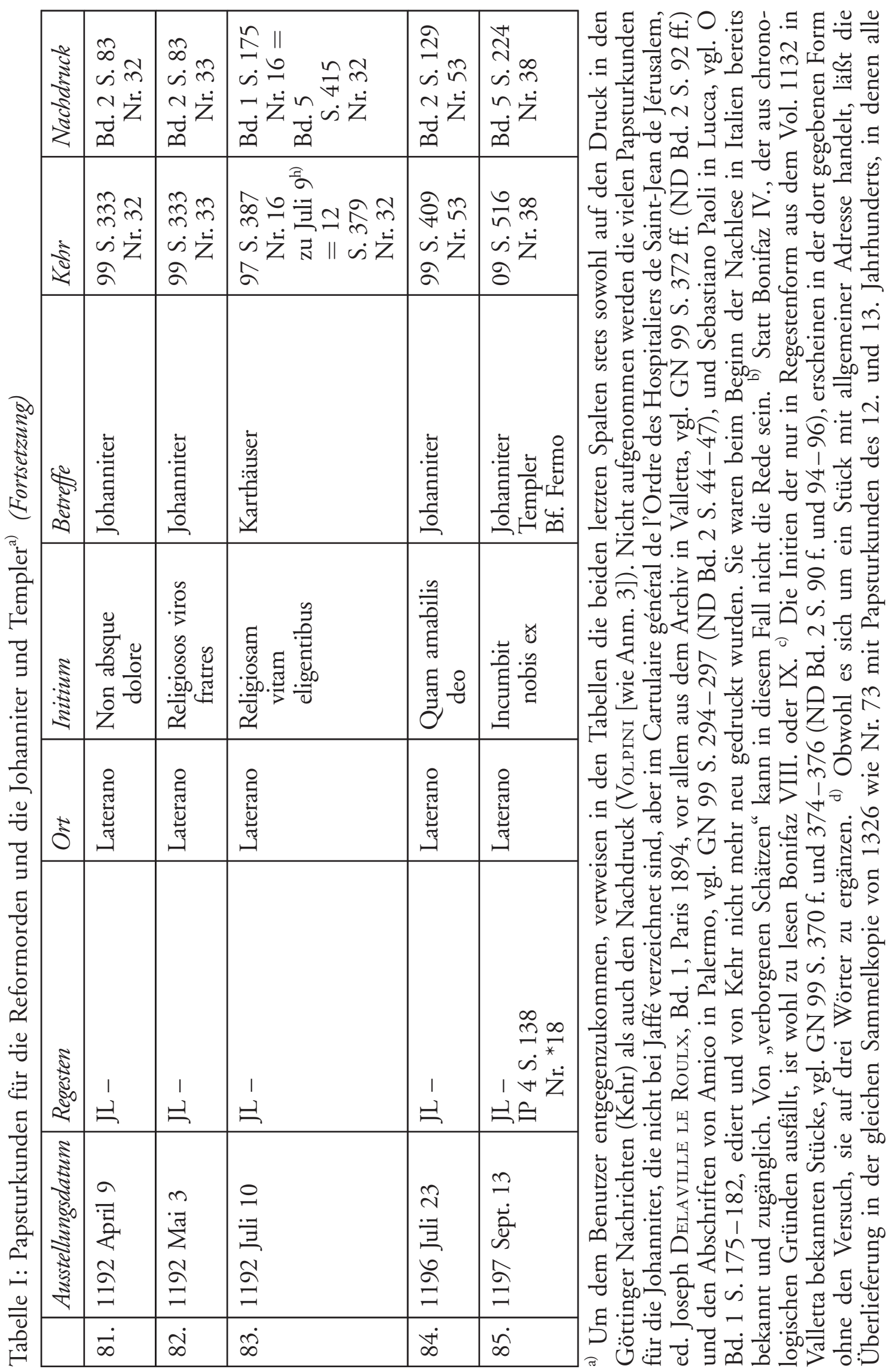




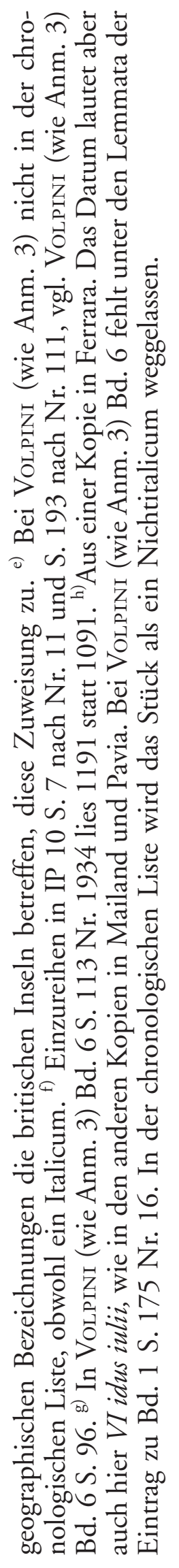




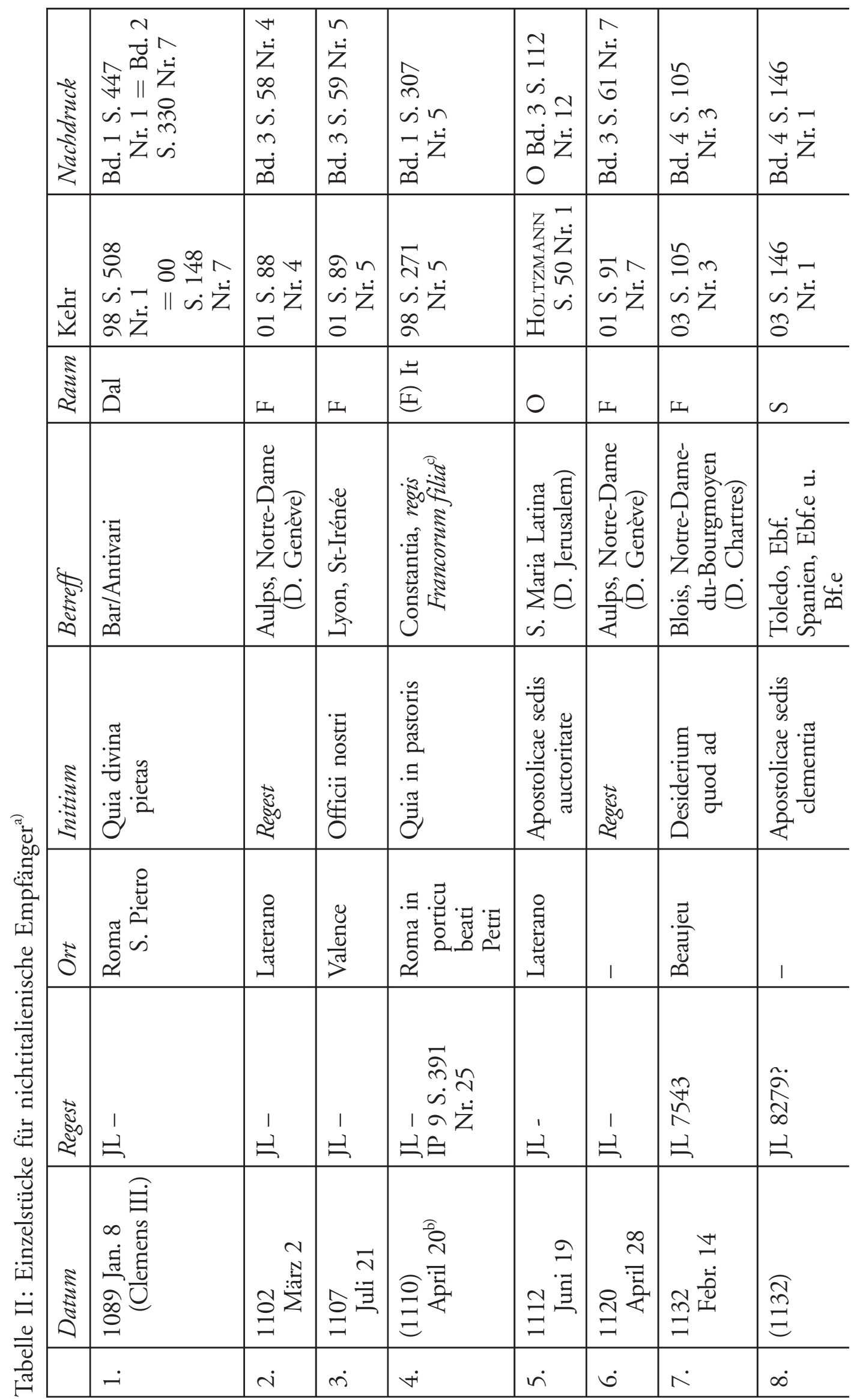


„Verborgene Schätze“. Nichtitalienische Stücke in den „Papsturkunden in Italien“

459

\begin{tabular}{|c|c|c|c|c|c|c|c|c|}
\hline $\begin{array}{l}\frac{\pi}{3} \\
\frac{2}{z} \\
\frac{2}{2} \\
z\end{array}$ & $\begin{array}{l}\hat{\infty} \\
\vec{\sim} \\
\dot{\sim} \\
\sim \\
\dot{\vec{n}}\end{array}$ & 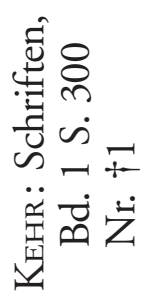 & 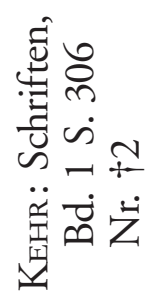 & 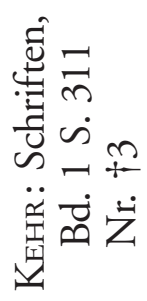 & 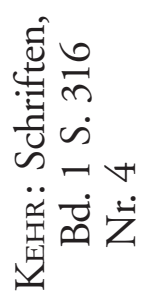 & $\begin{array}{l}\hat{b}= \\
\dot{n}= \\
\dot{n} \dot{Z} \\
\dot{\vec{n}}\end{array}$ & 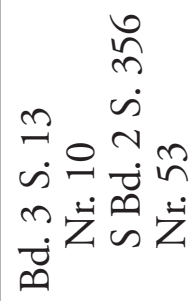 & 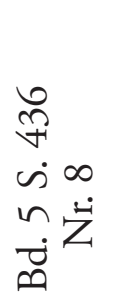 \\
\hline$\frac{\vec{\Xi}}{\Delta}$ & 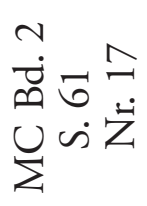 & 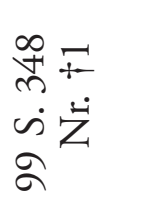 & 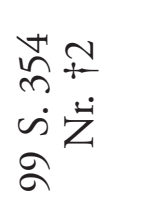 & $\begin{array}{l}\hat{b}+ \\
\dot{n}+\dot{z} \\
\dot{n} \dot{z} \\
\hat{a}\end{array}$ & 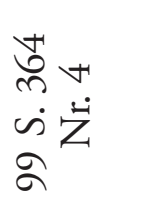 & $\begin{array}{l}\hat{a}= \\
\dot{\omega} \ddot{Z} \\
\sigma\end{array}$ & $\begin{array}{l}m \stackrel{0}{二} \\
\dot{n} \dot{Z} \\
\sigma\end{array}$ & 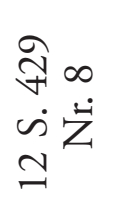 \\
\hline 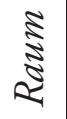 & IL & 0 & 0 & 0 & 0 & L & $\infty$ & L \\
\hline 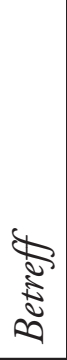 & 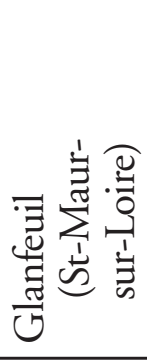 & 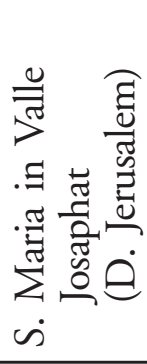 & 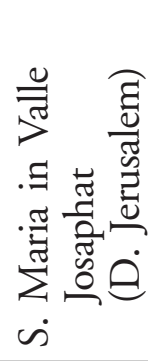 & 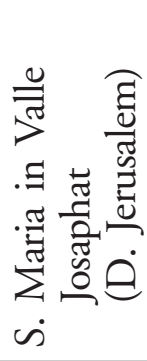 & 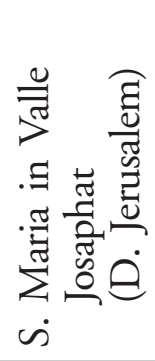 & 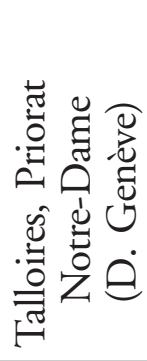 & 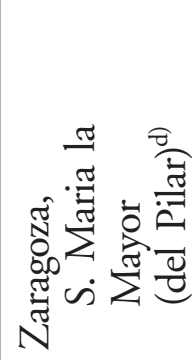 & 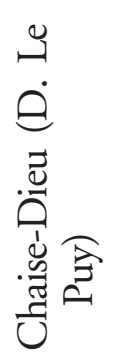 \\
\hline 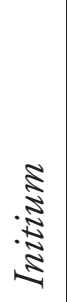 & 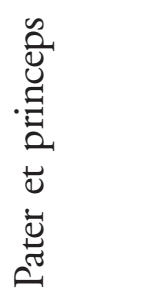 & 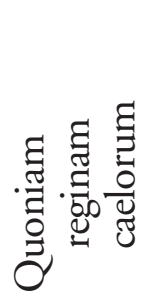 & 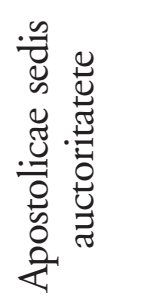 & 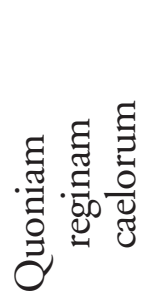 & 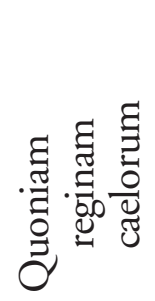 & 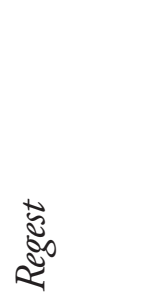 & 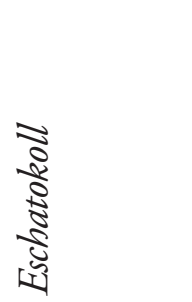 & 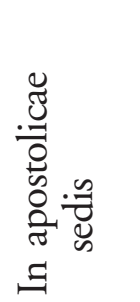 \\
\hline $0^{*}$ & 1 & 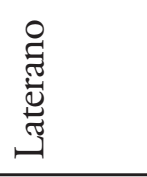 & 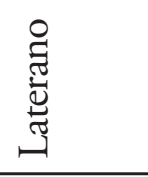 & 莺 & 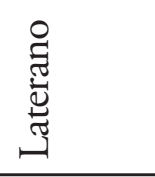 & 1 & 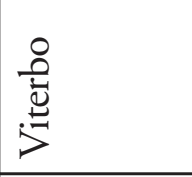 & 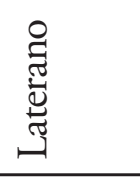 \\
\hline 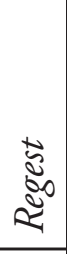 & 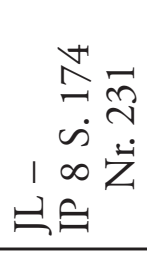 & $\stackrel{1}{\ominus}$ & $\stackrel{1}{\varrho}$ & $\triangleq$ & $\stackrel{1}{\models}$ & $\stackrel{1}{\varrho}$ & $\stackrel{1}{\triangleq}$ & 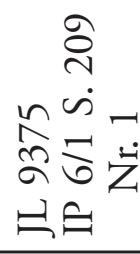 \\
\hline 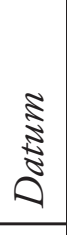 & $\begin{array}{l}\text { } \\
\stackrel{\cong}{\Xi}\end{array}$ & 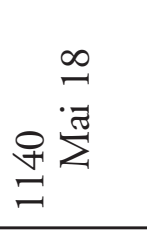 & 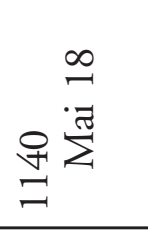 & $\underset{\Xi}{\stackrel{\infty}{ \pm}} \stackrel{\infty}{\sum^{\pi}}$ & 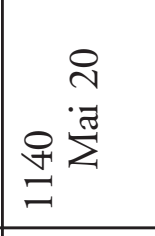 & $\stackrel{n}{\beth}$ & 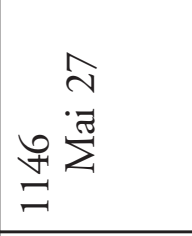 & 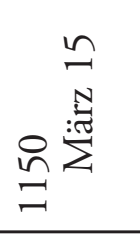 \\
\hline & $\sigma^{\circ}$ & $\stackrel{0}{\circ}$ & $\doteq$ & ㄱ & $\ddot{7}$ & $\stackrel{\text { \} }{\sqcup}} &{\ddot{n}} &{\stackrel{\circ}{-}} \\
$\hline
\end{tabular}




\begin{tabular}{|c|c|c|c|c|c|c|c|}
\hline$\frac{\frac{\pi}{2}}{\frac{2}{2}}$ & 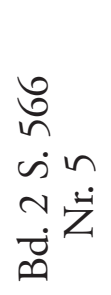 & 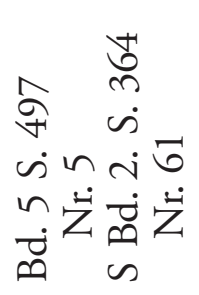 & 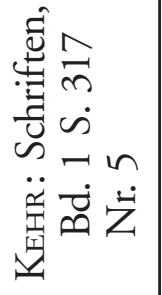 & 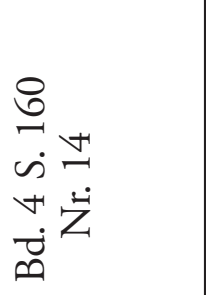 & $\begin{array}{l}\stackrel{\infty}{+} \sim \\
\dot{\sim} \sim \\
\dot{\nabla} \cdot \dot{\vec{Z}} \\
\dot{\infty}\end{array}$ & $\begin{array}{l}\infty \\
\stackrel{n}{n} n \\
\dot{n} \\
\dot{n} \\
\dot{n} \\
\dot{n}\end{array}$ & 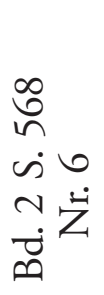 \\
\hline$\frac{\overrightarrow{0}}{\sqrt{2}}$ & $\begin{array}{l}m n \\
\forall n \\
\dot{\infty} \dot{Z} \\
8\end{array}$ & $\begin{array}{l}\text { 으 } \\
\dot{\sim} \ddot{Z} \\
\pm\end{array}$ & 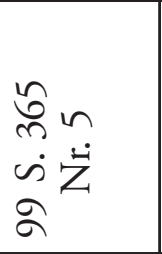 & 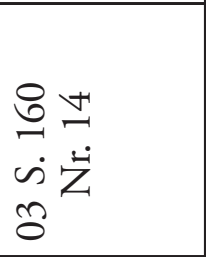 & 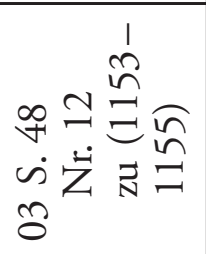 & $\begin{array}{l}\infty \\
\stackrel{n}{n} \\
\dot{n} \ddot{Z} \\
n\end{array}$ & $\begin{array}{l}\stackrel{n}{F} 6 \\
\dot{\forall} \dot{z} \\
\dot{8}\end{array}$ \\
\hline \begin{tabular}{l}
5 \\
\multirow{2}{5}{} \\
2
\end{tabular} & L & $\infty$ & 0 & $\infty$ & $\infty$ & $\infty$ & IL \\
\hline 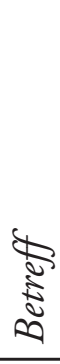 & 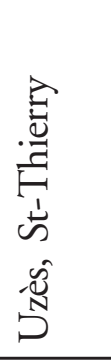 & 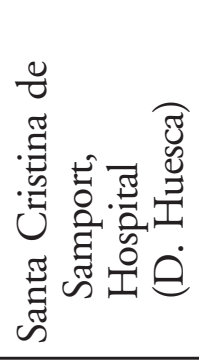 & 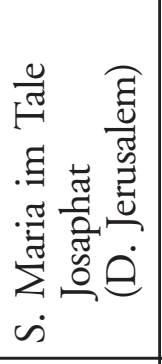 & 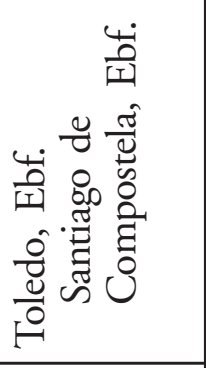 & 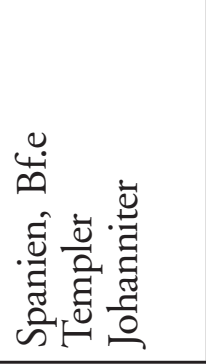 & 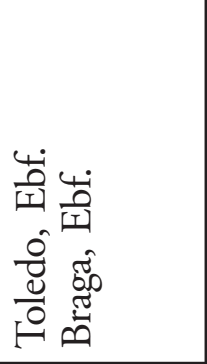 & 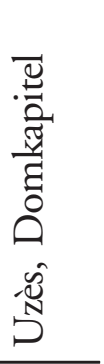 \\
\hline 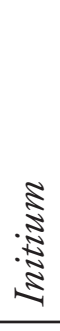 & 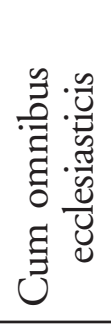 & 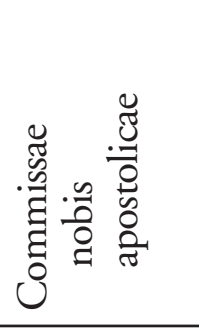 & 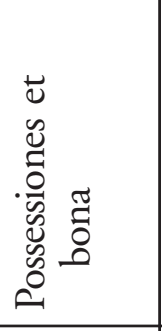 & 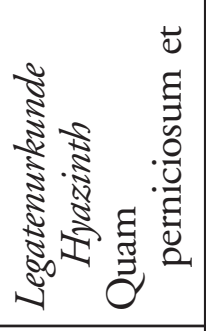 & 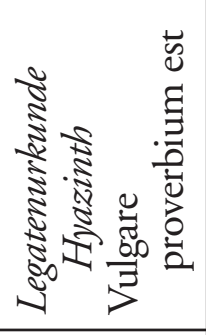 & 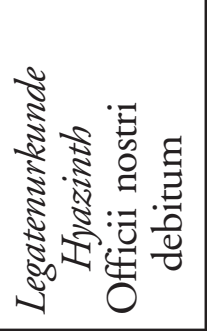 & $\begin{array}{l}\pi \\
\tilde{\sigma} \\
\tilde{\Xi} \\
\tilde{\pi}\end{array}$ \\
\hline$\overbrace{}^{*}$ & Б્ప్ర్ & 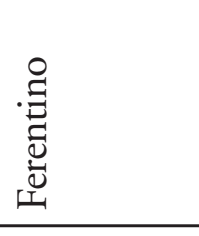 & . & 1 & 1 & 1 & 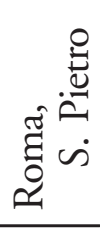 \\
\hline 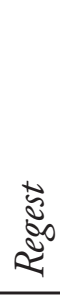 & $\stackrel{1}{=}$ & $\stackrel{1}{\Xi}$ & $\stackrel{1}{\Xi}$ & 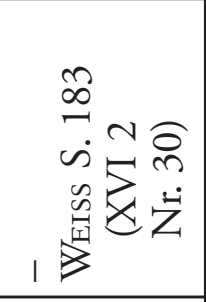 & 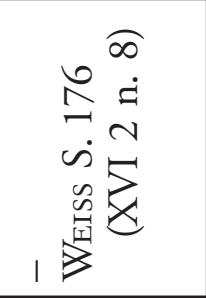 & 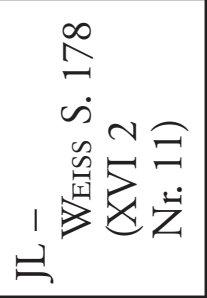 & $\stackrel{1}{\boxminus}$ \\
\hline 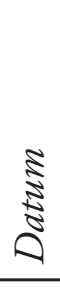 & 윰 & $\bar{n} \sum^{\stackrel{n}{i \pi}}$ & 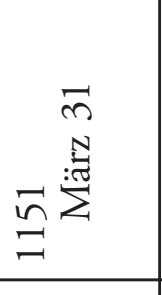 & 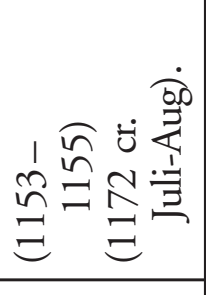 & 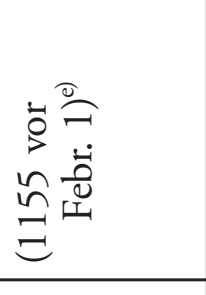 & $\sum_{n}^{n} \sum^{\infty}$ & 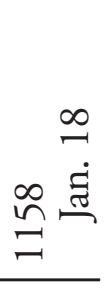 \\
\hline & 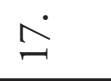 & $\stackrel{\infty}{=}$ & $\stackrel{\imath}{\beth}$ & $\dot{\sim}$ & $\dot{\vec{\lambda}}$ & ते & $\dot{\sim}$ \\
\hline
\end{tabular}


„Verborgene Schätze“. Nichtitalienische Stücke in den „Papsturkunden in Italien“

461

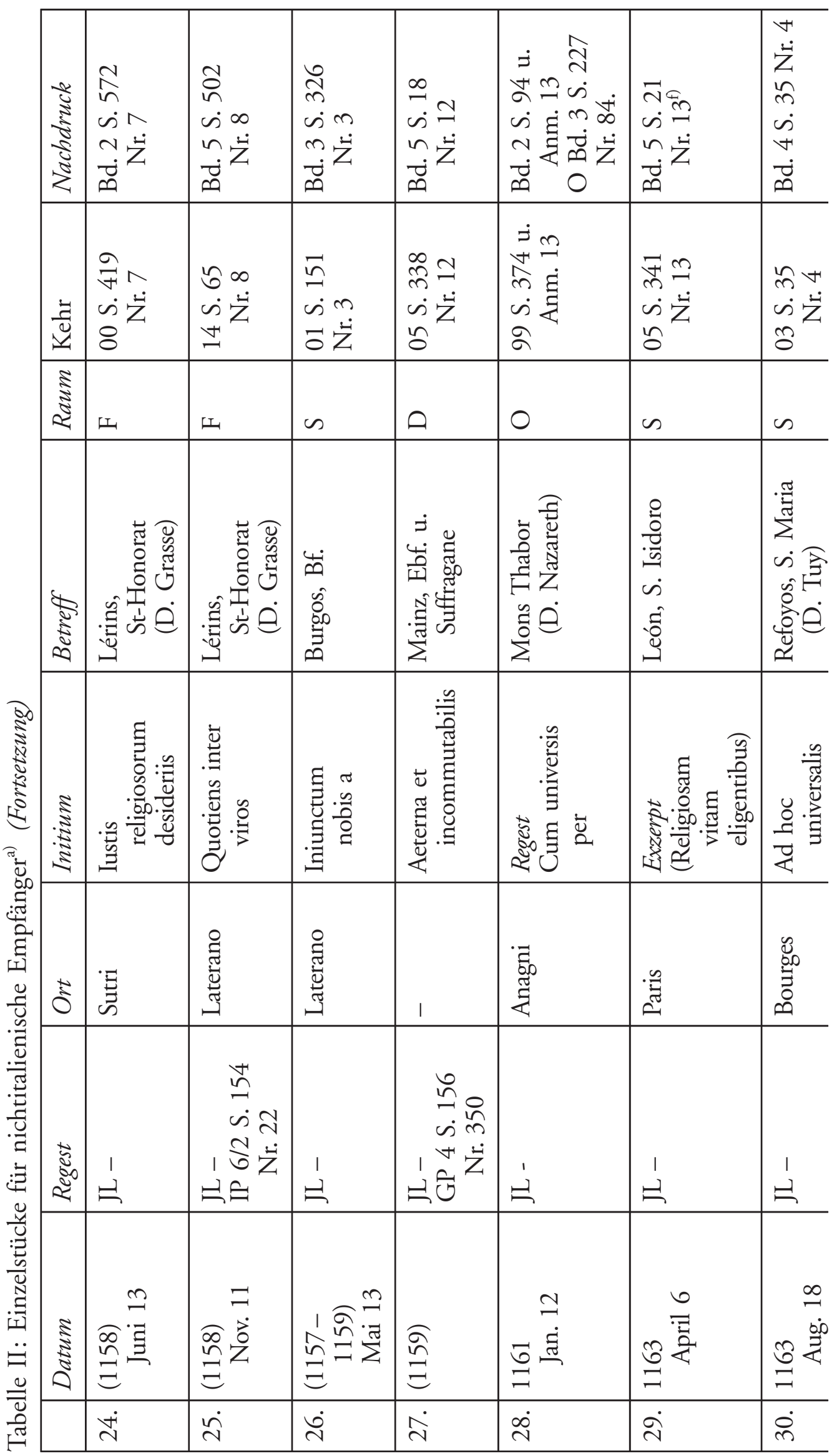




\begin{tabular}{|c|c|c|c|c|c|c|c|c|}
\hline & & 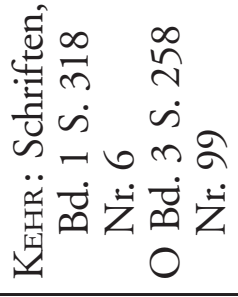 & 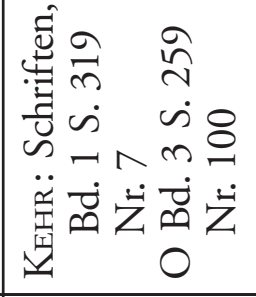 & 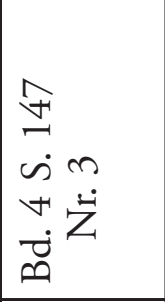 & $\begin{array}{l}n \\
\hat{n} \\
\dot{n} \sigma \\
\sim \\
\dot{n} \\
\dot{n}\end{array}$ & $\begin{array}{l}0 \\
i n \\
\dot{n} \\
\dot{n} \\
\dot{n} \vec{z} \\
\dot{\infty}\end{array}$ & $\begin{array}{l}\vec{\lambda} \\
\dot{n} \\
\dot{m} \\
\dot{0} \\
\dot{\vec{n}} \\
\dot{m} \\
0\end{array}$ & 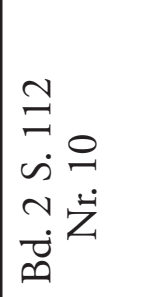 \\
\hline & & 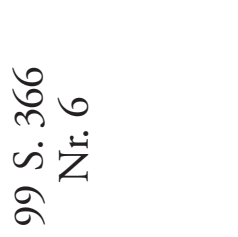 & $\begin{array}{l}\hat{\sigma} \bar{r} \\
\dot{n} \dot{z} \\
\hat{\sigma}\end{array}$ & $\begin{array}{l}\dot{y} n \\
\dot{\omega} \\
\dot{n} \\
\infty\end{array}$ & $\begin{array}{l}\text { तै } \\
\dot{y} \vec{z} \\
\dot{8}\end{array}$ & 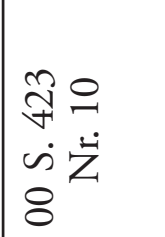 & 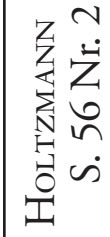 & 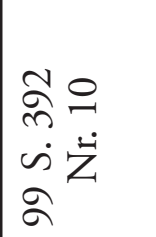 \\
\hline & & 0 & 0 & is & ш & $\omega$ & 0 & 山 \\
\hline & & 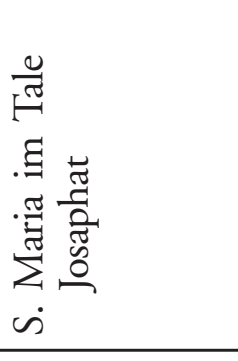 & 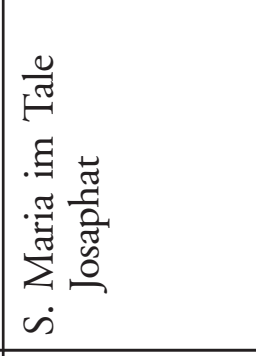 & 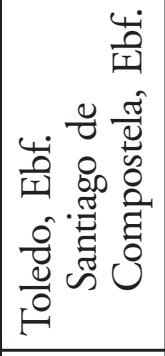 & 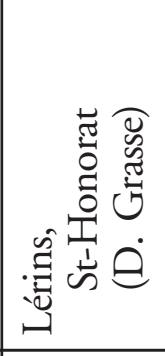 & 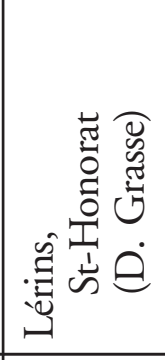 & 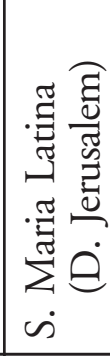 & 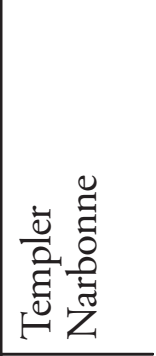 \\
\hline & & 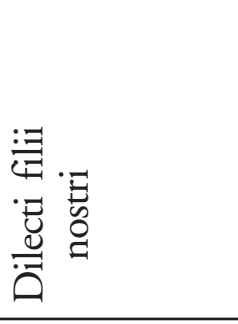 & 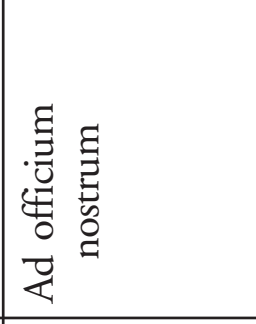 & 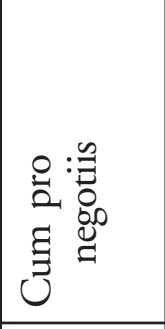 & 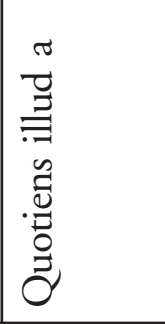 & 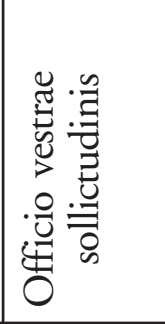 & 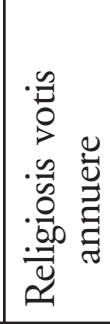 & 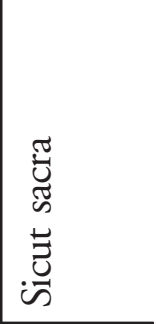 \\
\hline & & 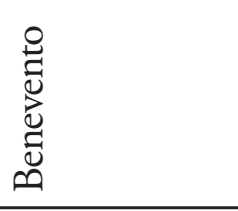 & 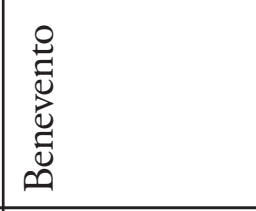 & 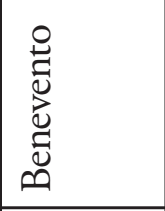 & $\begin{array}{l}0 \\
0 \\
0 \\
\underline{3} \\
1\end{array}$ & 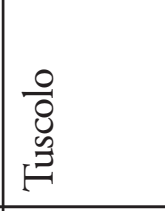 & 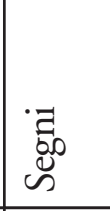 & 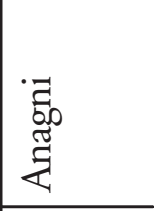 \\
\hline & & $\stackrel{1}{\varrho}$ & $\Leftrightarrow$ & 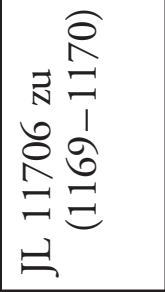 & $\stackrel{1}{\prime}$ & $\stackrel{1}{\varrho}$ & $\stackrel{1}{1}$ & $\stackrel{1}{=}$ \\
\hline & & 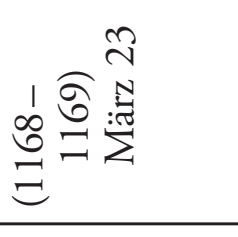 & 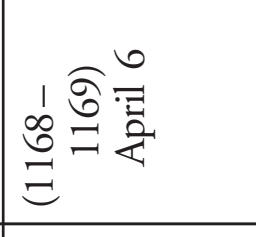 & 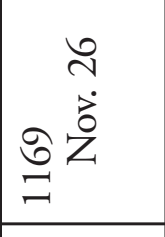 & 츨 & 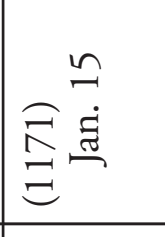 & 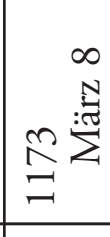 & 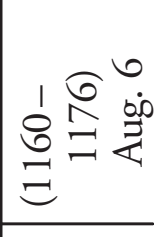 \\
\hline & & $\dot{m}$ & ก่ & $\dot{m}$ & mí & $\dot{n}$ & $\dot{n}$ & $\dot{m}$ \\
\hline
\end{tabular}


„Verborgene Schätze“. Nichtitalienische Stücke in den „Papsturkunden in Italien“

463

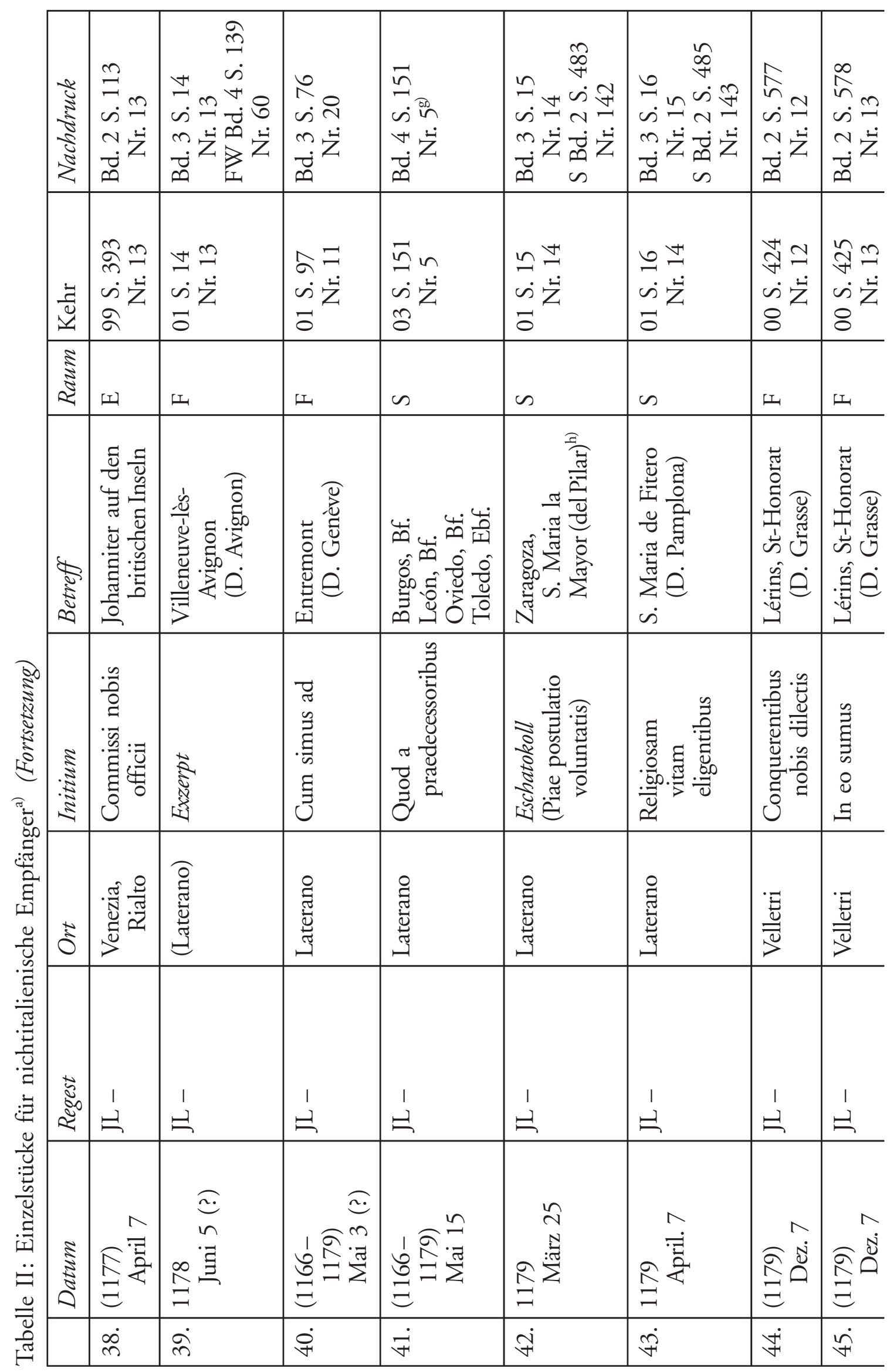




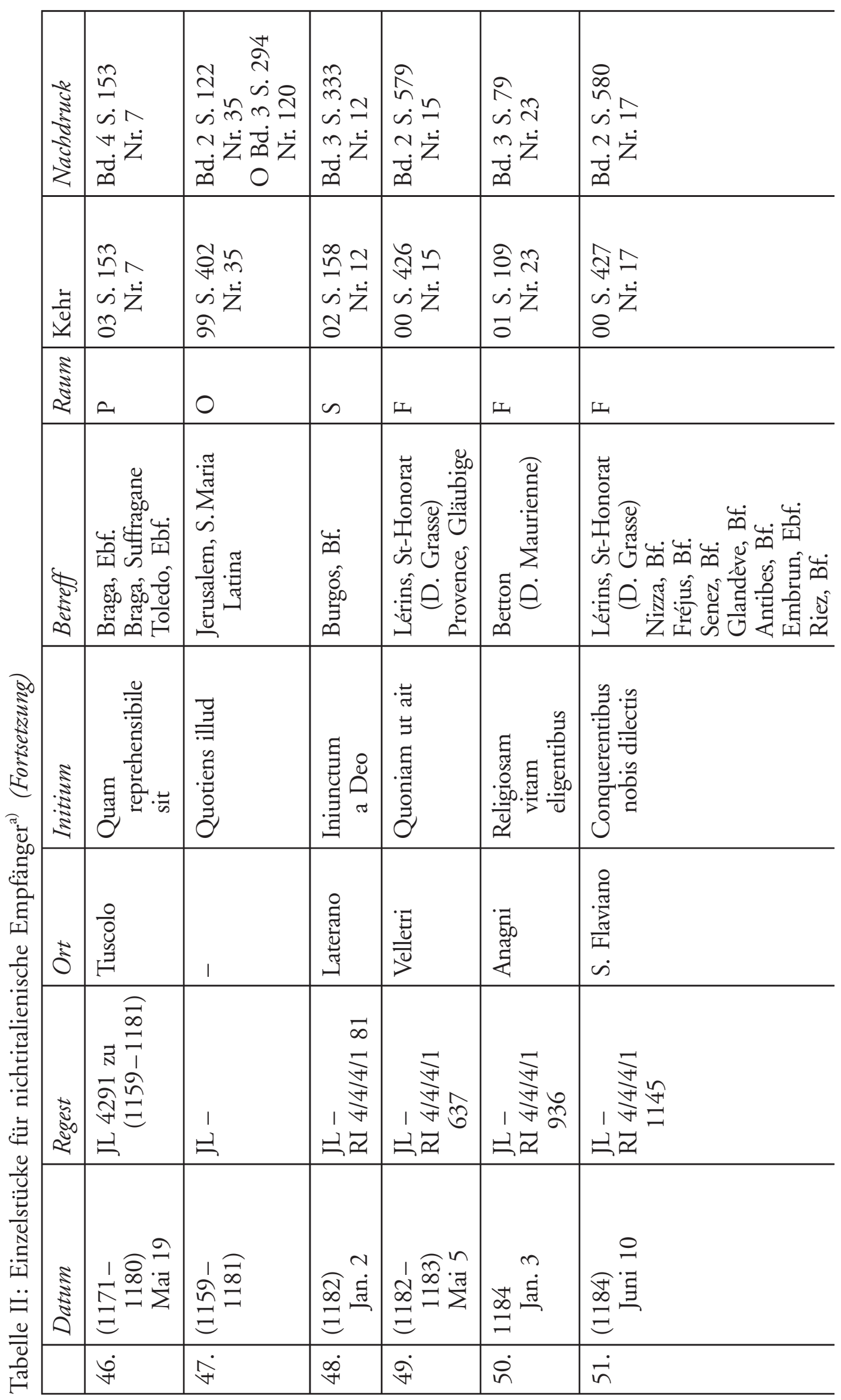


„Verborgene Schätze“. Nichtitalienische Stücke in den „Papsturkunden in Italien“

465

\begin{tabular}{|c|c|c|c|c|c|}
\hline $\begin{array}{l}\frac{\pi}{3} \\
\frac{2}{z} \\
\frac{1}{2} \\
z\end{array}$ & $\begin{array}{l}\vec{\infty} \\
\stackrel{\infty}{\infty} \\
\dot{\sim} \\
\dot{n}\end{array}$ & 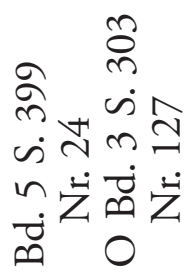 & 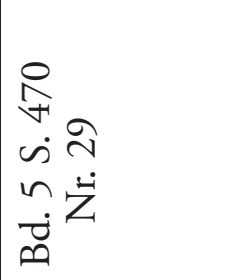 & 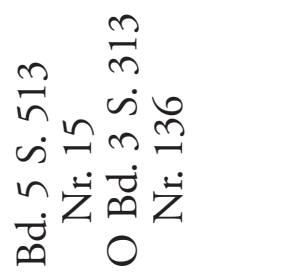 & 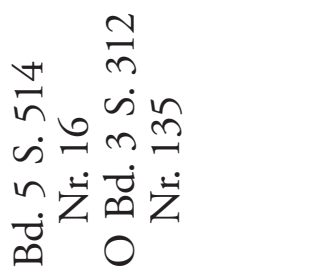 \\
\hline$\frac{\vec{\Xi}}{2}$ & 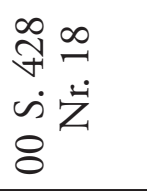 & 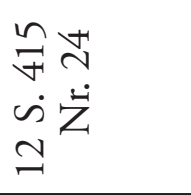 & 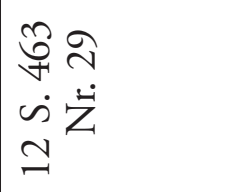 & $\begin{array}{l}Ð \stackrel{n}{N} \\
\dot{\sim} \ddot{Z} \\
\pm\end{array}$ & 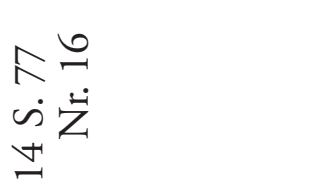 \\
\hline 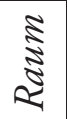 & IL & 0 & $L$ & 0 & 0 \\
\hline 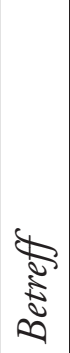 & 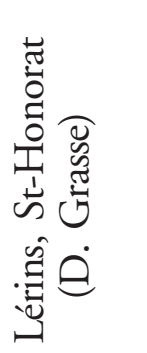 & 泀 & 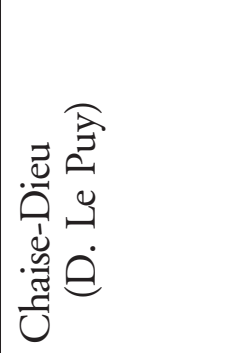 & 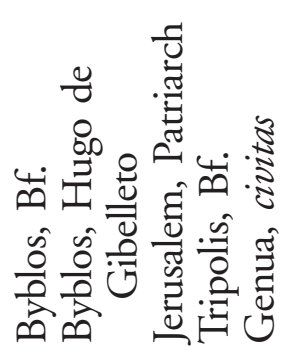 & 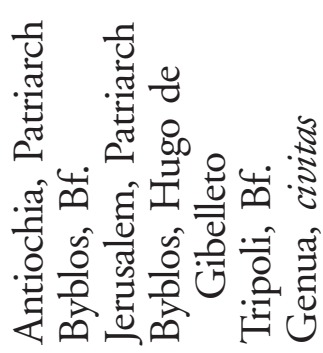 \\
\hline $\begin{array}{r}-5 \\
5 \\
5 \\
5 \\
5 \\
5\end{array}$ & 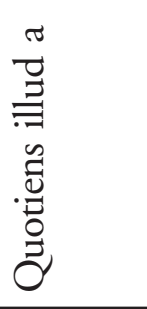 & 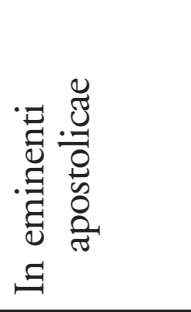 & 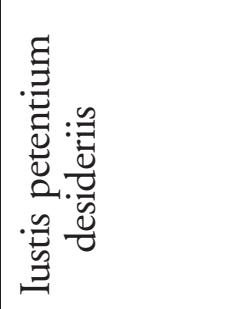 & 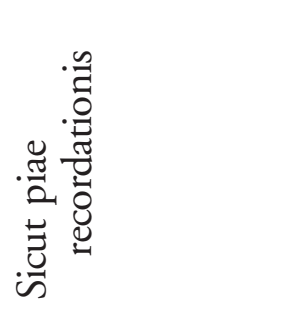 & 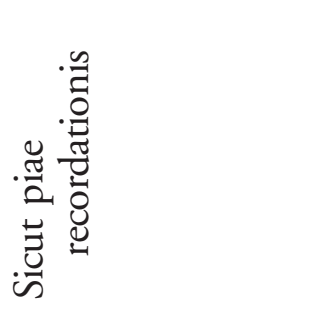 \\
\hline$\Xi$ & 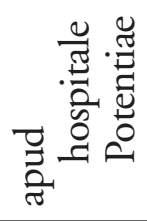 & 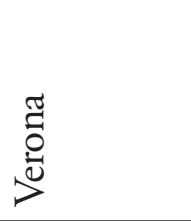 & 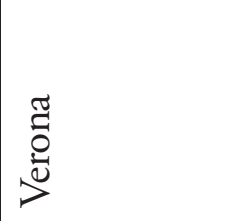 & 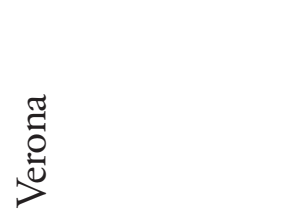 & 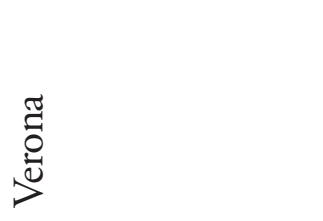 \\
\hline $\begin{array}{l}\vec{\Xi} \\
\stackrel{\Xi}{0} \\
\approx\end{array}$ & 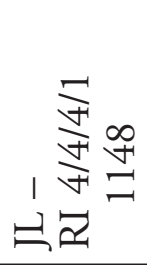 & 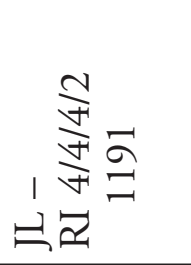 & 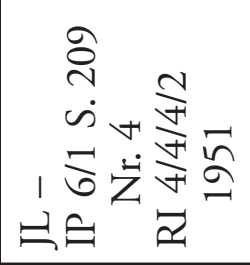 & $\begin{array}{l}\hat{m} \\
\dot{n} \mathbb{b} \\
\stackrel{v}{\sigma} \dot{Z} \\
=\Xi\end{array}$ & $\begin{array}{l}m \\
m \\
\dot{n} \tilde{b} \\
\stackrel{N}{\sigma} \dot{Z} \\
=\tilde{E}\end{array}$ \\
\hline $\begin{array}{c}\tilde{5} \\
\frac{5}{2} \\
0 \\
0\end{array}$ & 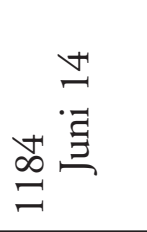 & 芯 & 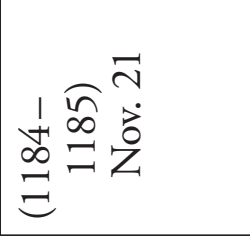 & $\underbrace{\substack{n \\
\Xi}}_{\Xi}$ & $\underbrace{\substack{n \\
\vdots}}_{\substack{\infty \\
\infty}}$ \\
\hline & กี & $\dot{n}$ & $\stackrel{\forall}{n}$ & $\ddot{n}$ & $\ddot{\curvearrowleft}$ \\
\hline
\end{tabular}




\begin{tabular}{|c|c|c|c|c|c|c|c|c|c|}
\hline & & 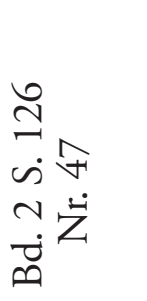 & $\begin{array}{l}\infty \\
\infty \\
\sim \\
\dot{n} \vec{n} \\
\sim \\
\dot{n} \vec{z} \\
\dot{n}\end{array}$ & 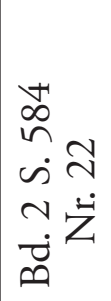 & $\begin{array}{l}+\infty \\
\infty \\
\sim \\
\dot{n} \\
\sim \\
\sim \\
\dot{\sim} \\
\dot{\infty}\end{array}$ & 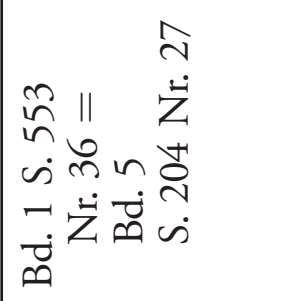 & 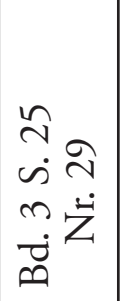 & $\begin{array}{l}\tilde{N} \\
\dot{n} \\
\dot{n} \\
\sim \dot{z} \\
\dot{\vec{n}}\end{array}$ & 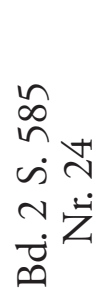 \\
\hline & & 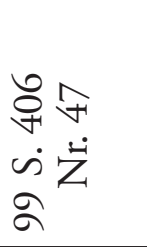 & $\begin{array}{l}\dot{P} \vec{n} \\
\dot{\gamma} \vec{z} \\
\dot{8}\end{array}$ & $\begin{array}{l}\overrightarrow{3} \tilde{z} \\
\dot{\vec{n}} \\
\dot{8}\end{array}$ & $\begin{array}{l}\overrightarrow{\widetilde{\sigma}} \approx \\
\dot{\sim} \\
\dot{\sim} \vec{z} \\
8\end{array}$ & 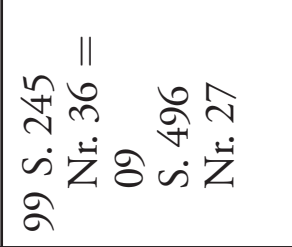 & 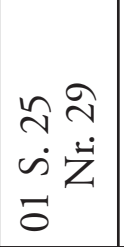 & 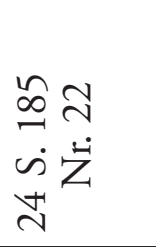 & 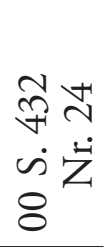 \\
\hline & 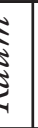 & ज్ & Ш & 山 & L & ๑ొ & L & $\bar{\omega}$ & 山 \\
\hline & 8 & 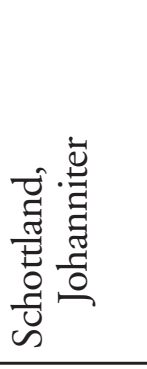 & 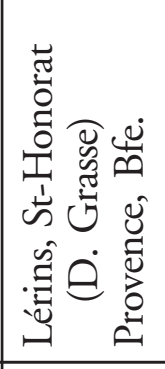 & 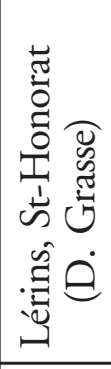 & 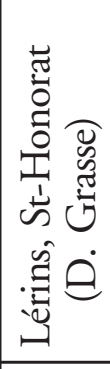 & 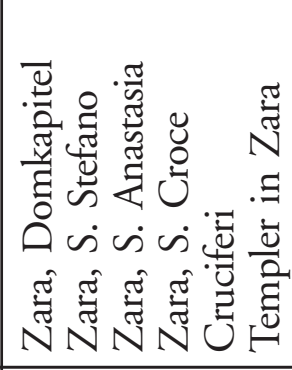 & 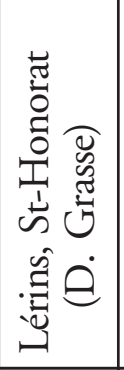 & 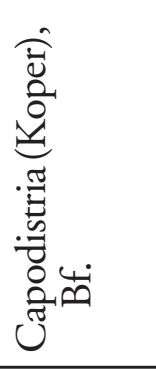 & 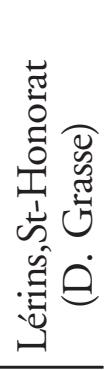 \\
\hline & 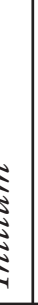 & 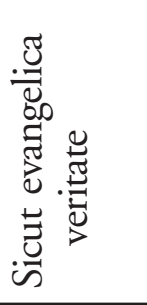 & 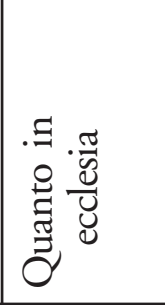 & 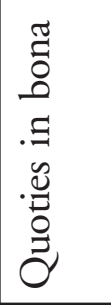 & 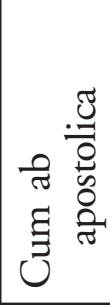 & 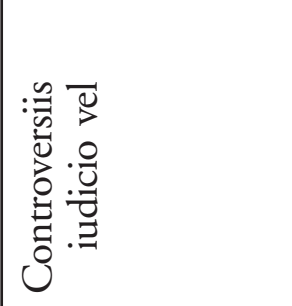 & 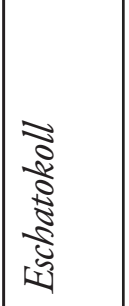 & 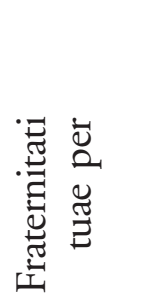 & 急这 \\
\hline & 5 & $\begin{array}{l}\frac{\pi}{0} \\
\stackrel{0}{0} \\
\stackrel{0}{\nu}\end{array}$ & 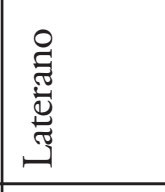 & 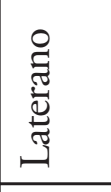 & 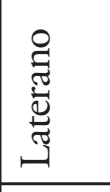 & 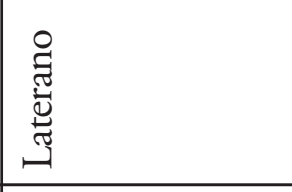 & 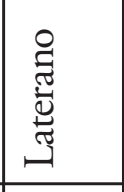 & 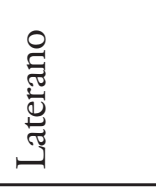 & 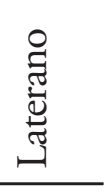 \\
\hline & 8 & $\stackrel{1}{\varrho}$ & I & $\stackrel{1}{=}$ & $\stackrel{1}{\Xi}$ & 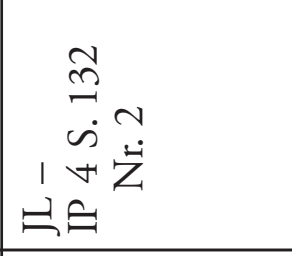 & $\stackrel{1}{=}$ & 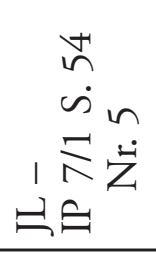 & $\stackrel{1}{\varrho}$ \\
\hline & & 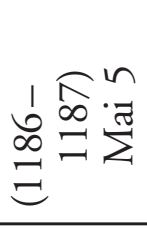 & 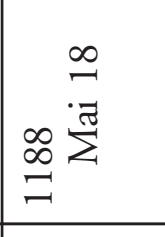 & $\begin{array}{r}\stackrel{2}{\infty} \\
\infty \\
= \\
=\end{array}$ & 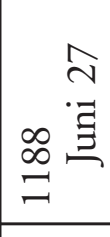 & 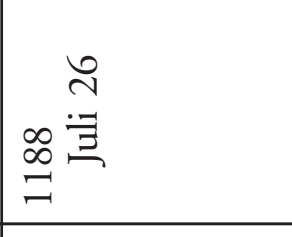 & 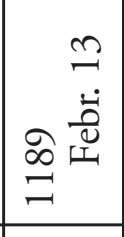 & $\underset{\infty}{\infty}$ & 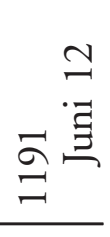 \\
\hline & & $\hat{n}$ & $\stackrel{\infty}{\curvearrowleft}$ & $\ddot{n}$ & : & $\dot{\sigma}$ & ชู่ & $\dot{\sigma}$ & ث্் \\
\hline
\end{tabular}


„Verborgene Schätze“. Nichtitalienische Stücke in den „Papsturkunden in Italien“ 467

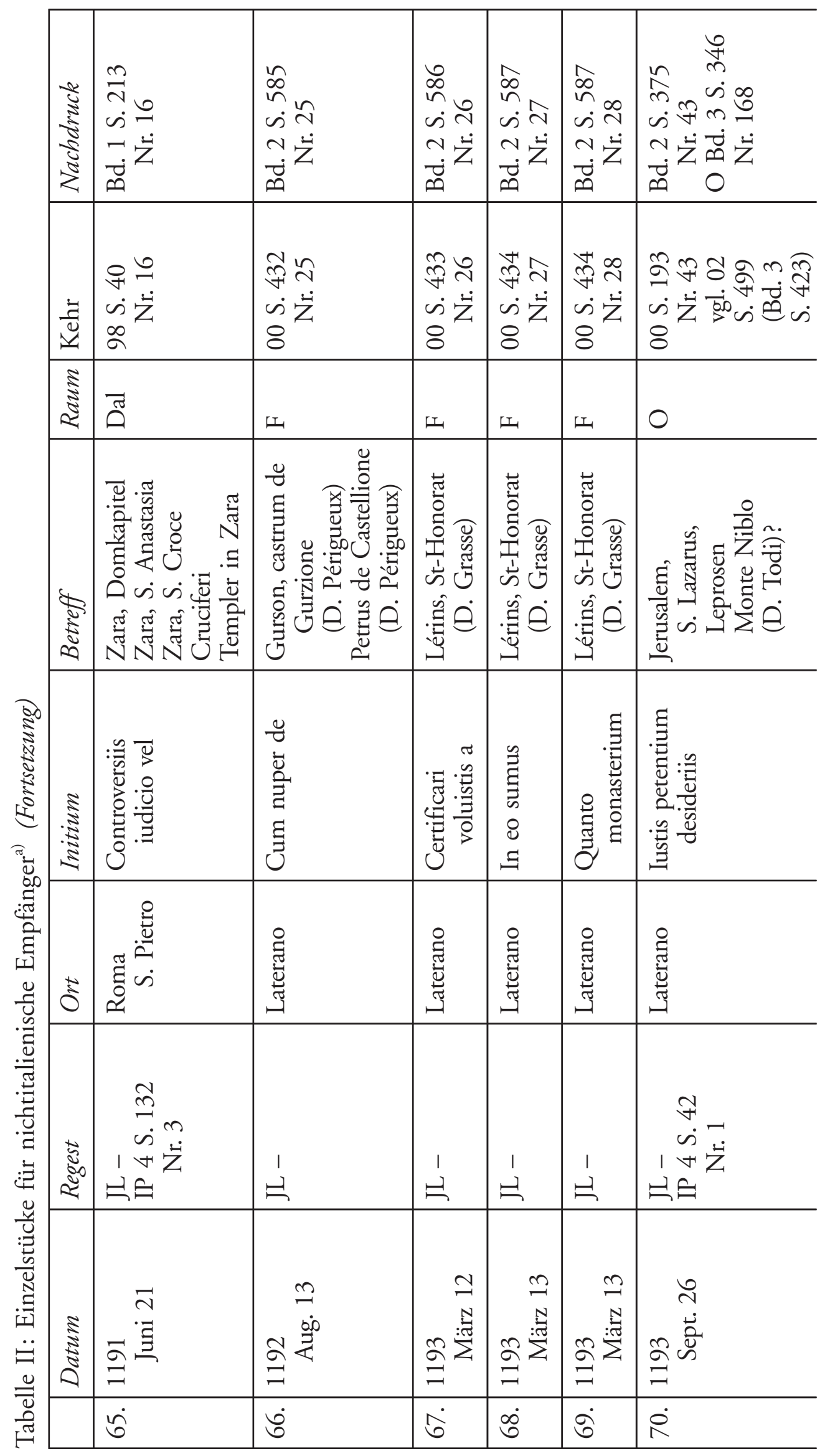




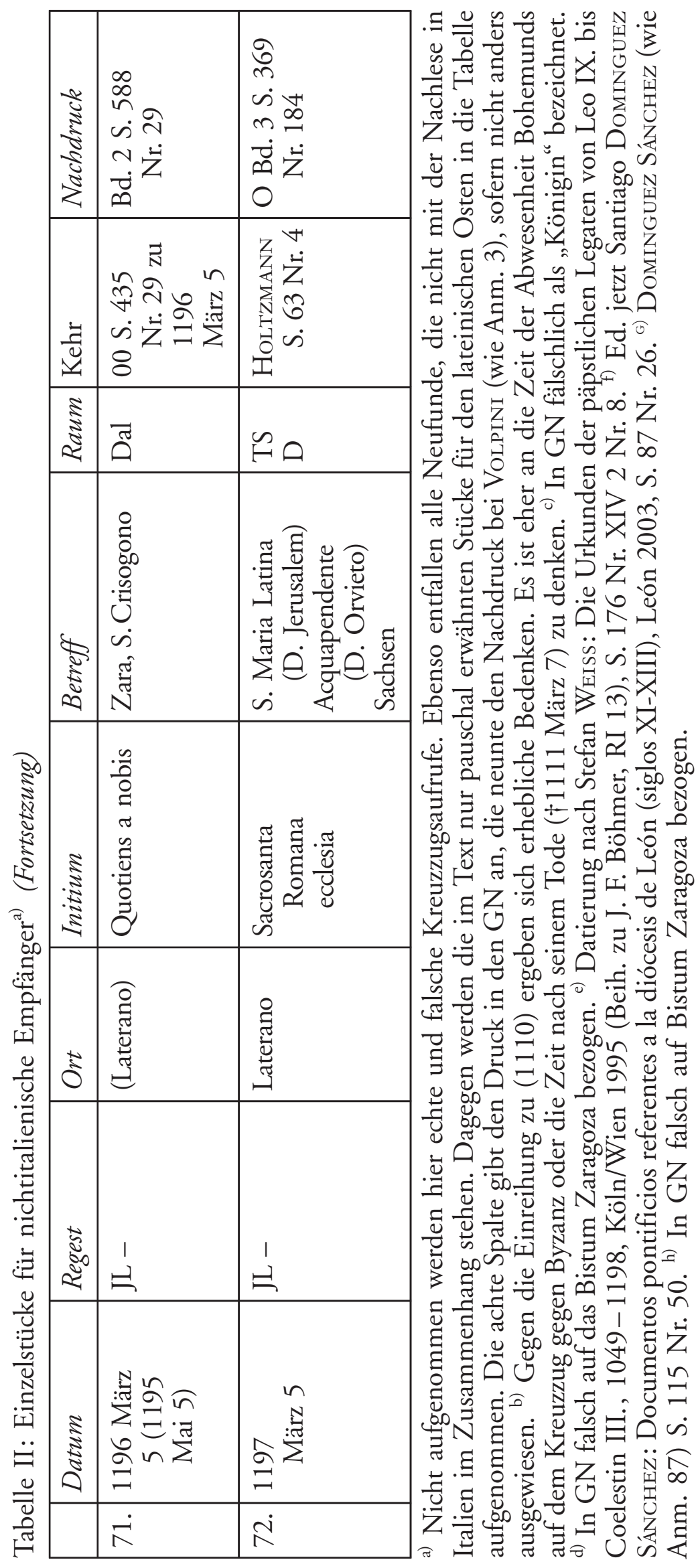


„Verborgene Schätze“. Nichtitalienische Stücke in den „Papsturkunden in Italien“

469

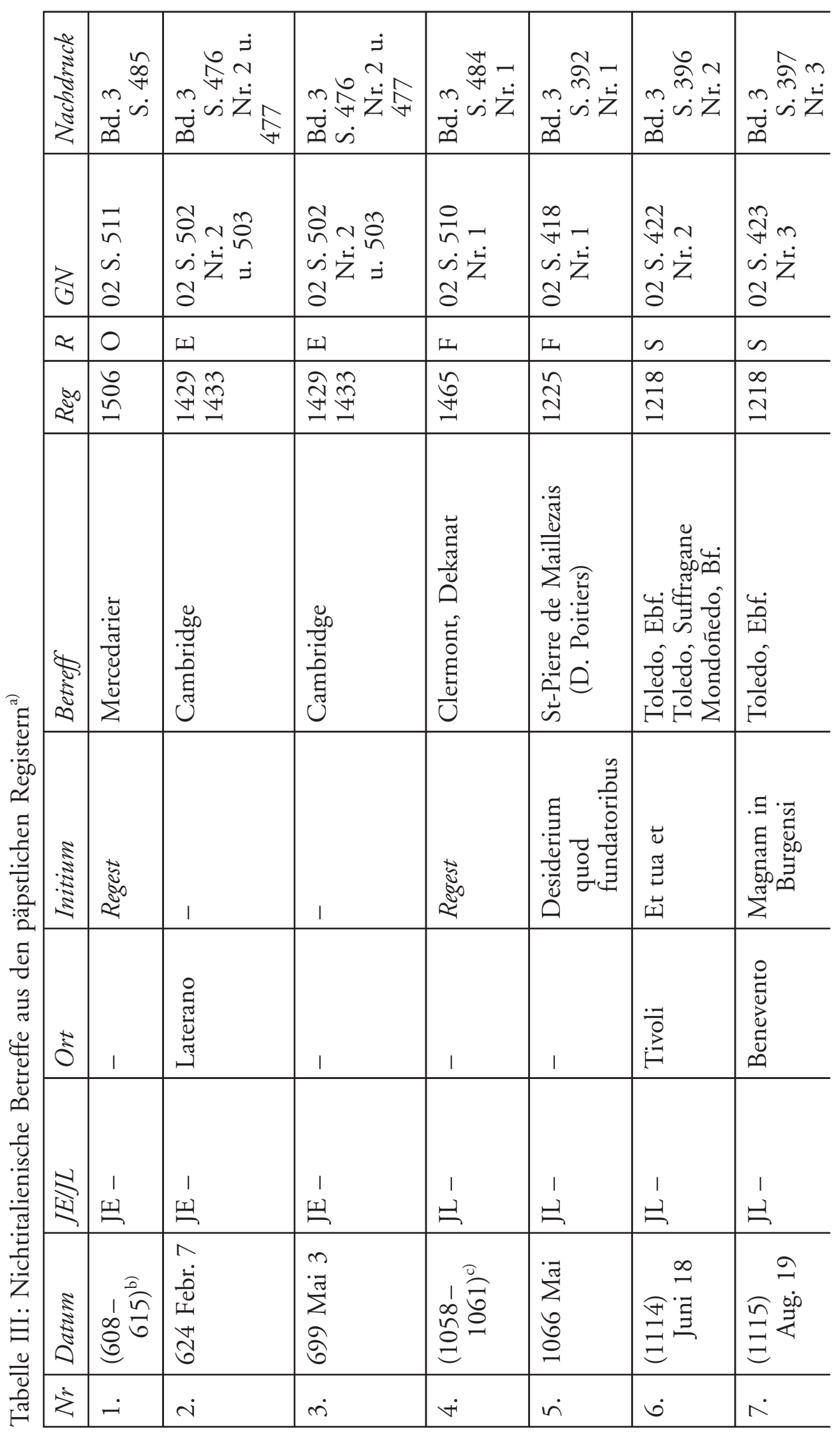




\begin{tabular}{|c|c|c|c|c|c|c|c|}
\hline & & 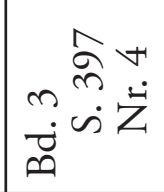 & 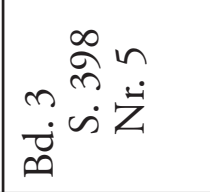 & 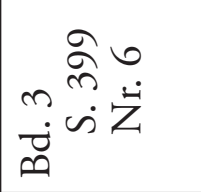 & 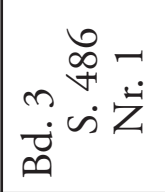 & 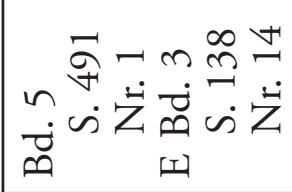 & 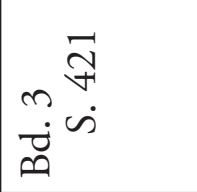 \\
\hline & & \begin{tabular}{l}
$\widetilde{7}$ \\
\multirow{7}{}{} \\
$\dot{n}$ \\
$\widetilde{z}$ \\
$\widetilde{z}$
\end{tabular} & 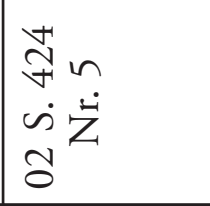 & 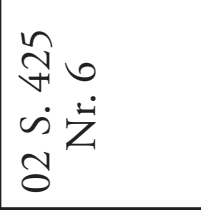 & $\mid \begin{array}{l}\tilde{v} \\
\tilde{n} \\
\dot{w} \\
\tilde{z}\end{array}$ & 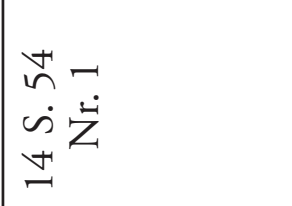 & 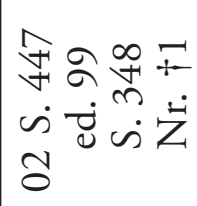 \\
\hline & & in & in & L & 山 & I & 0 \\
\hline & & $\begin{array}{l}\infty \\
\stackrel{\sim}{\beth}\end{array}$ & $\begin{array}{l}\infty \\
\stackrel{\infty}{\beth} \\
\end{array}$ & $\begin{array}{l}\text { ָิ } \\
\text { I }\end{array}$ & $\overrightarrow{\widetilde{J}}$ & $\underset{f}{\stackrel{f}{f}}$ & $\begin{array}{l}\infty \\
\infty \\
\infty \\
-\end{array}$ \\
\hline & & 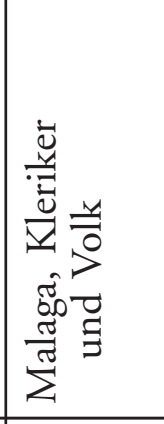 & 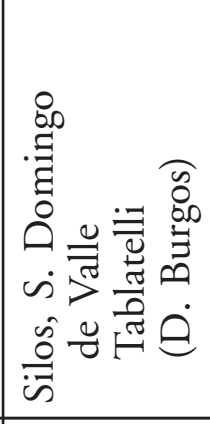 & 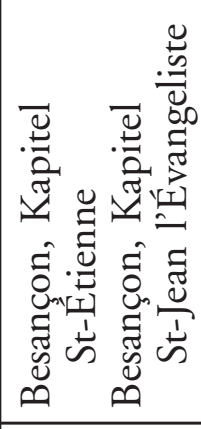 & 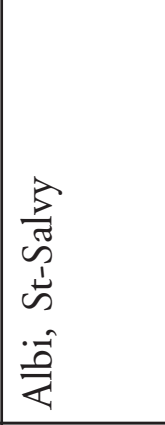 & 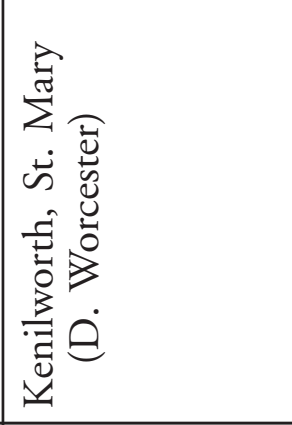 & 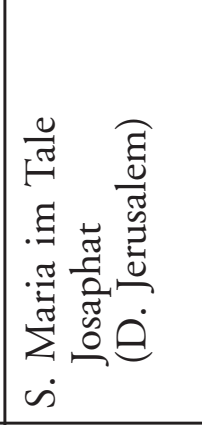 \\
\hline & & 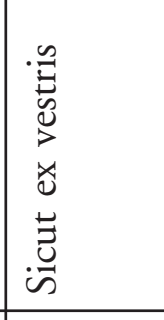 & 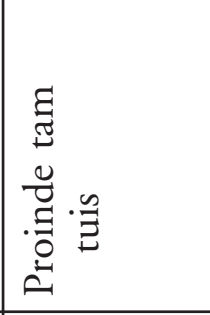 & 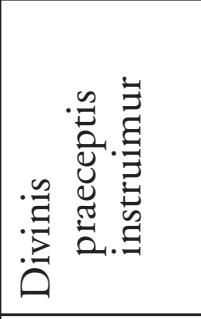 & 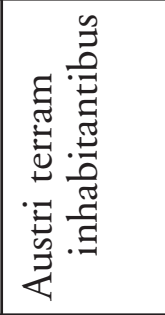 & 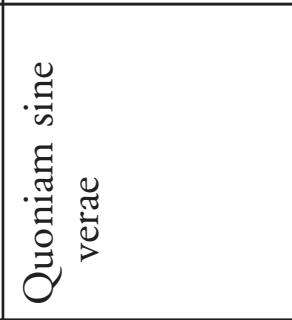 & 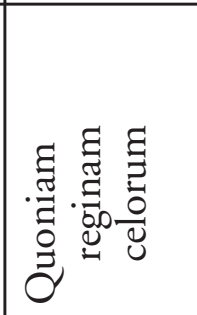 \\
\hline & & 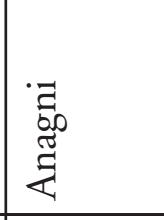 & 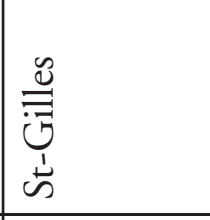 & 1 & 1 & 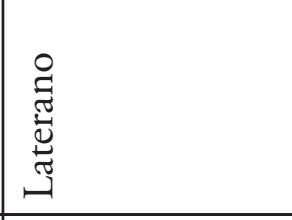 & 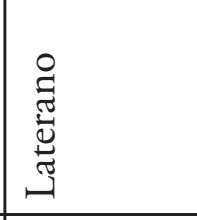 \\
\hline & & $\stackrel{1}{=}$ & $\stackrel{1}{=}$ & $\stackrel{1}{=}$ & $\stackrel{1}{=}$ & $\stackrel{1}{=}$ & $\stackrel{1}{=}$ \\
\hline & & 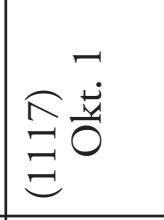 & 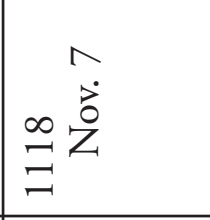 & 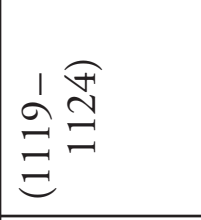 & 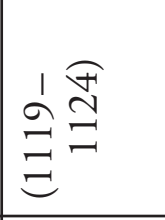 & $\begin{array}{l}1 \\
\stackrel{1}{\cong} \\
\stackrel{\Xi}{\Xi} \\
\Xi\end{array}$ & 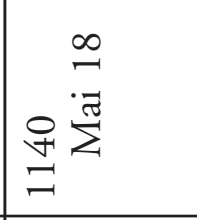 \\
\hline & & $\infty$ & $\dot{a}$ & $\stackrel{0}{0}$ & $\dot{\Xi}$ & $\stackrel{1}{\check{1}}$ & $\ddot{n}$ \\
\hline
\end{tabular}


„Verborgene Schätze“. Nichtitalienische Stücke in den „Papsturkunden in Italien“

\begin{tabular}{|c|c|c|c|c|c|c|c|}
\hline$\frac{\frac{\pi}{2}}{\frac{3}{2}} \frac{5}{2}$ & 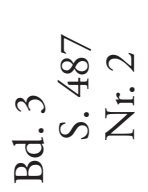 & 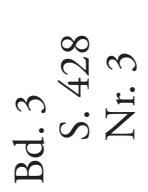 & 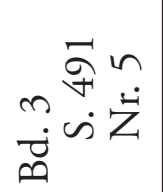 & 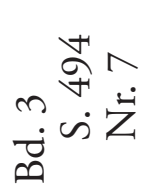 & 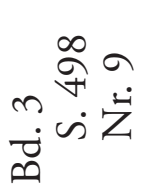 & 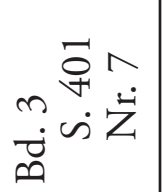 & 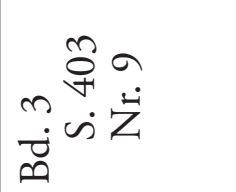 \\
\hline ঝ & $\begin{array}{l}m \\
\tilde{n} \\
\dot{n} \\
\tilde{\sigma}\end{array}$ & 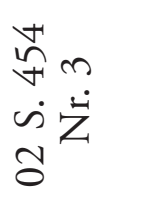 & 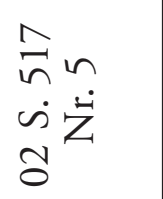 & 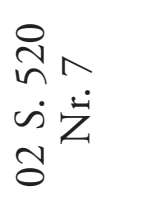 & 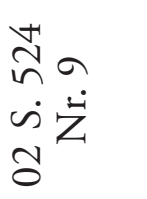 & 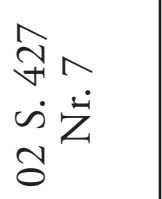 & 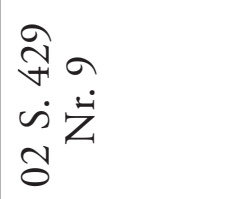 \\
\hline$\approx$ & 工 & 工 & I & a & I & $a$ & $a$ \\
\hline 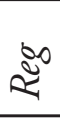 & $\stackrel{\infty}{\rightleftarrows}$ & $\begin{array}{l}\infty \\
\infty \\
n\end{array}$ & 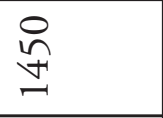 & $\stackrel{\vec{n}}{ \pm}$ & 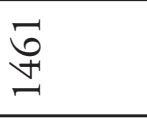 & 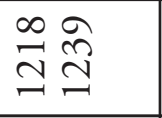 & 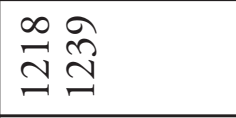 \\
\hline 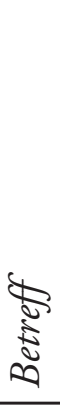 & 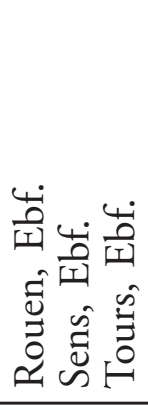 & 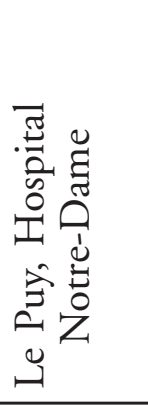 & 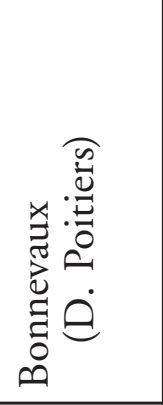 & 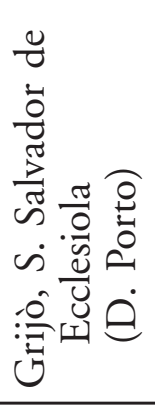 & 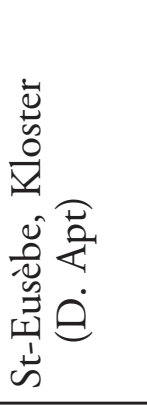 & 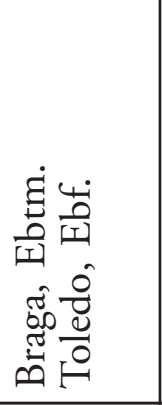 & 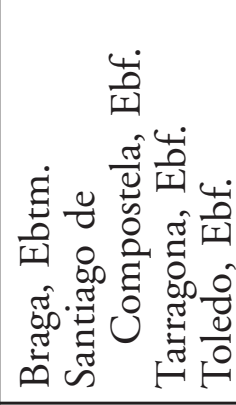 \\
\hline 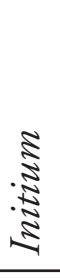 & 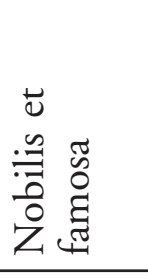 & 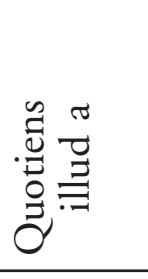 & 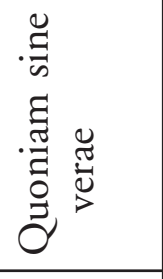 & 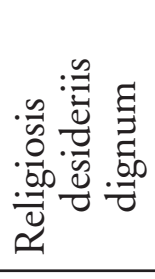 & 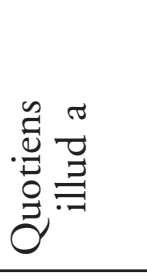 & 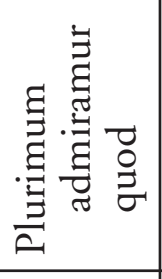 & 苞 \\
\hline $0^{*}$ & 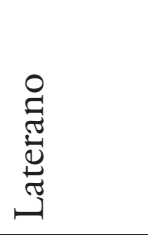 & 离 & $\frac{\pi}{\bar{\pi}}$ & 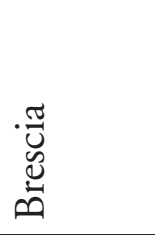 & 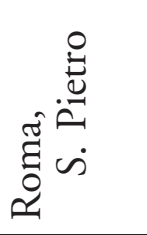 & 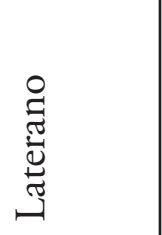 & I \\
\hline$\stackrel{ }{\stackrel{ }{ }}$ & $\stackrel{1}{\ominus}$ & $\stackrel{1}{\ominus}$ & $\stackrel{1}{\triangleq}$ & $\stackrel{1}{\ominus}$ & $\begin{array}{l}\stackrel{n}{N} \\
\text { ڤ }\end{array}$ & $\stackrel{1}{\triangleq}$ & $\begin{array}{l}\bar{\curvearrowright} \\
\curvearrowright \\
ٍ\end{array}$ \\
\hline $\begin{array}{c}0 \\
\frac{8}{3} \\
5 \\
5\end{array}$ & 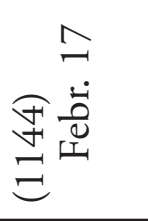 & 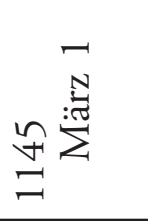 & 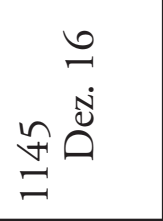 & 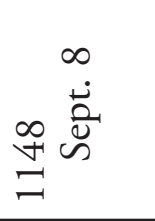 & 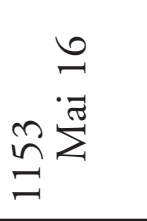 & 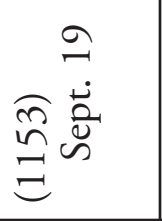 & 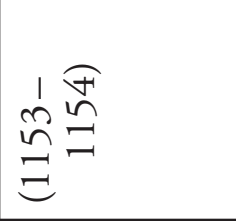 \\
\hline$\dot{z}^{2}$ & $\stackrel{+}{-}$ & $\ddot{n}$ & $\stackrel{\circ}{\sim}$ & 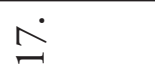 & $\stackrel{\infty}{-}$ & $\ddot{\beth}$ & $\dot{\sim}$ \\
\hline
\end{tabular}




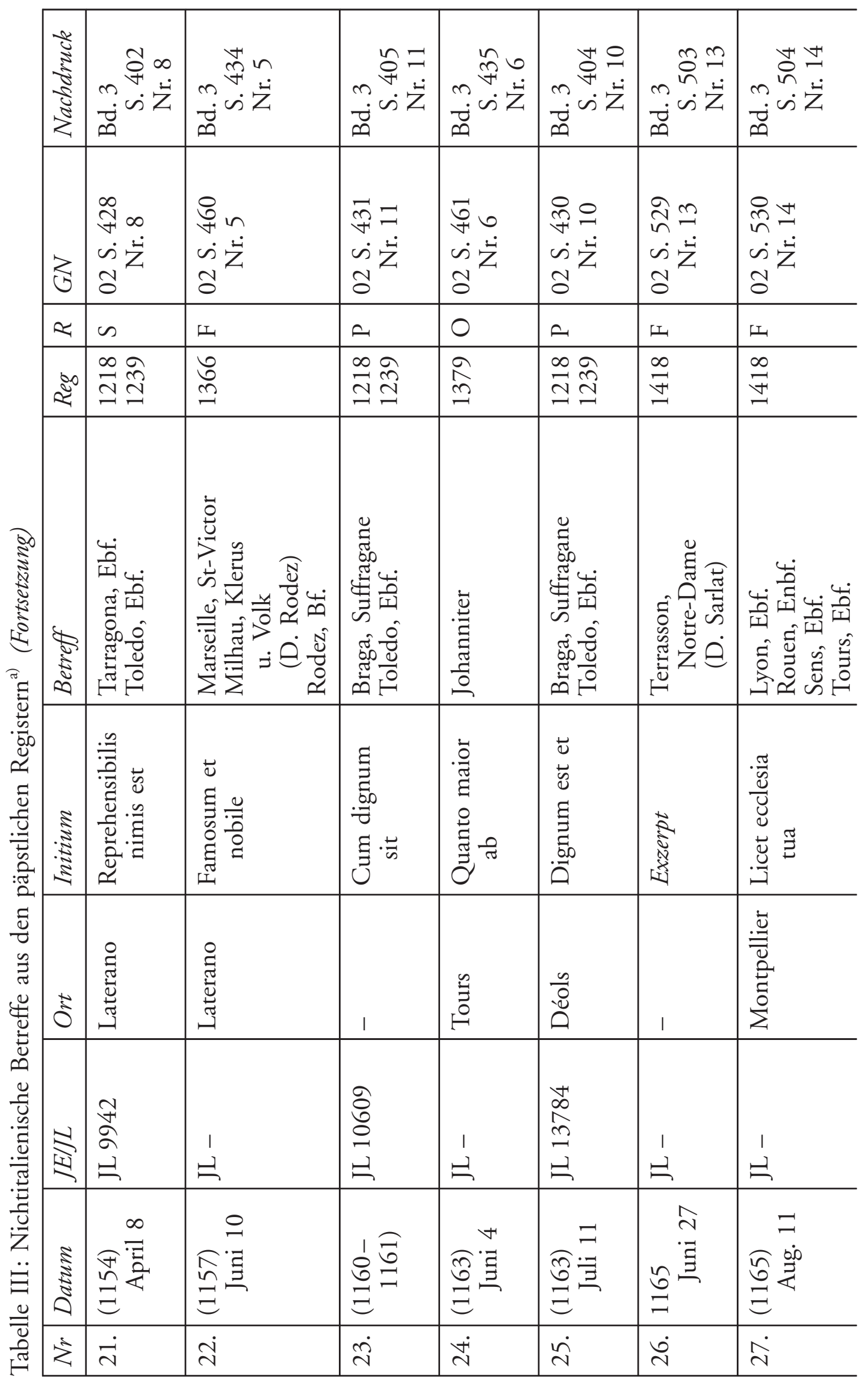


„Verborgene Schätze“. Nichtitalienische Stücke in den „Papsturkunden in Italien“

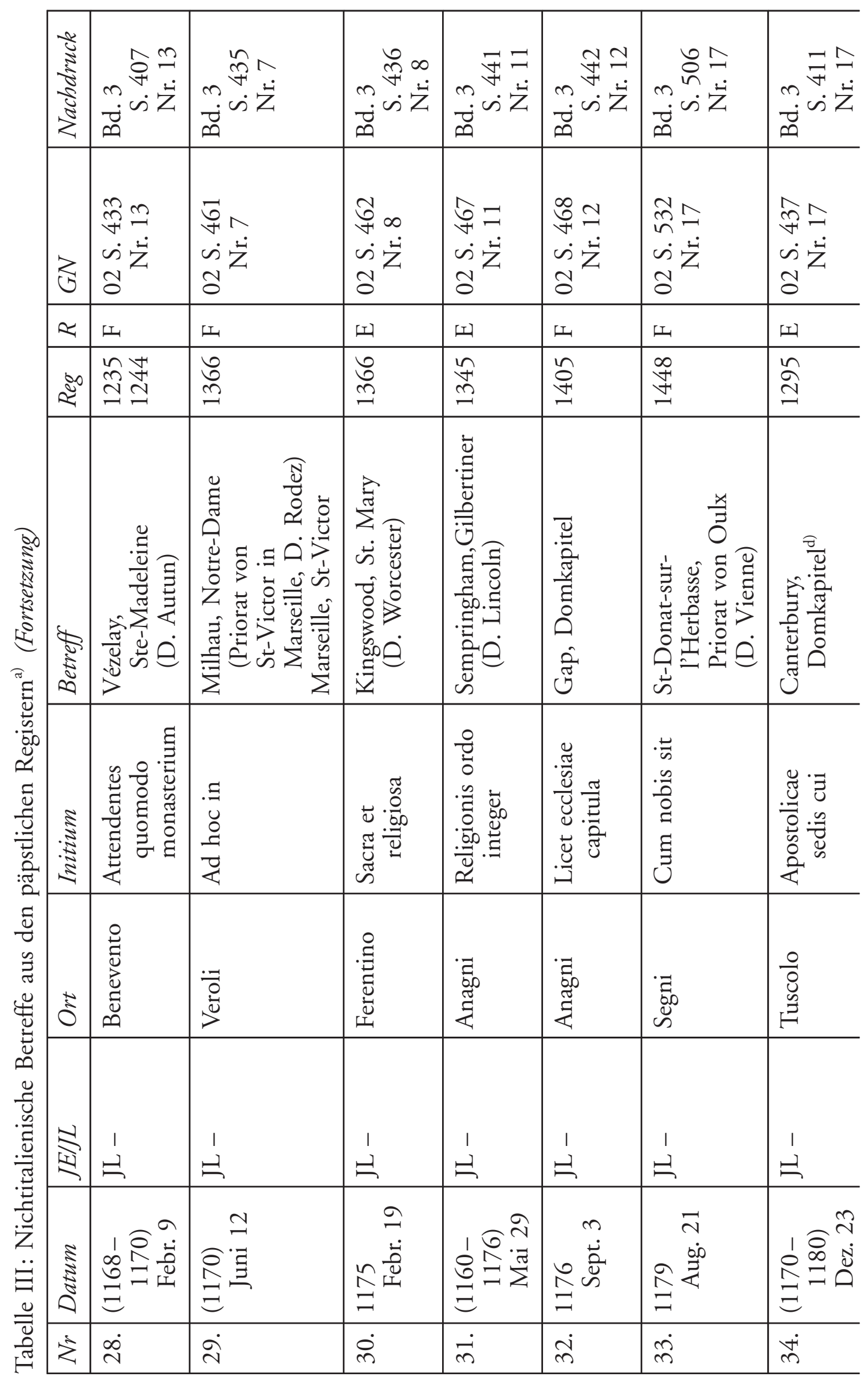




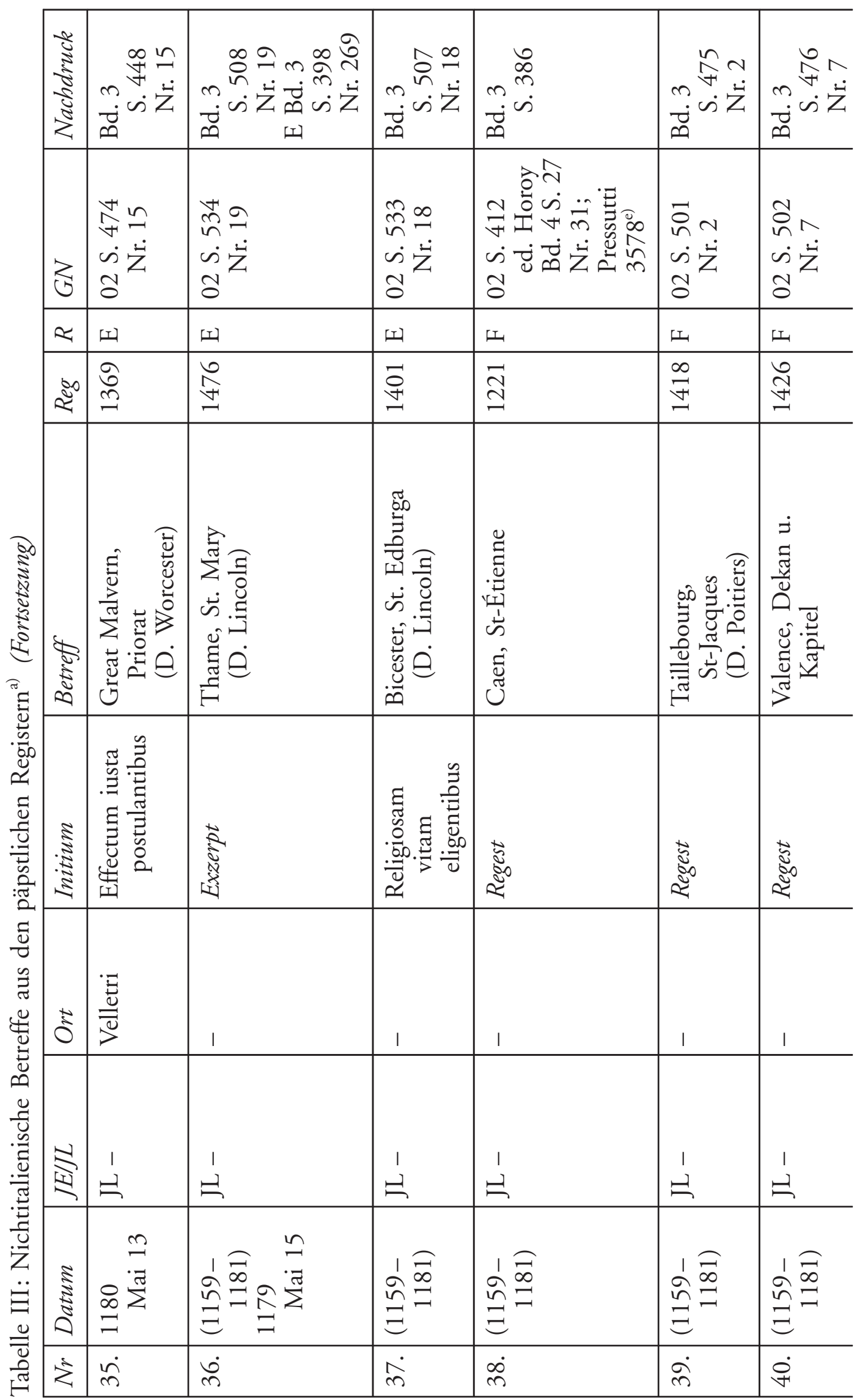


„Verborgene Schätze“. Nichtitalienische Stücke in den „Papsturkunden in Italien“ 475

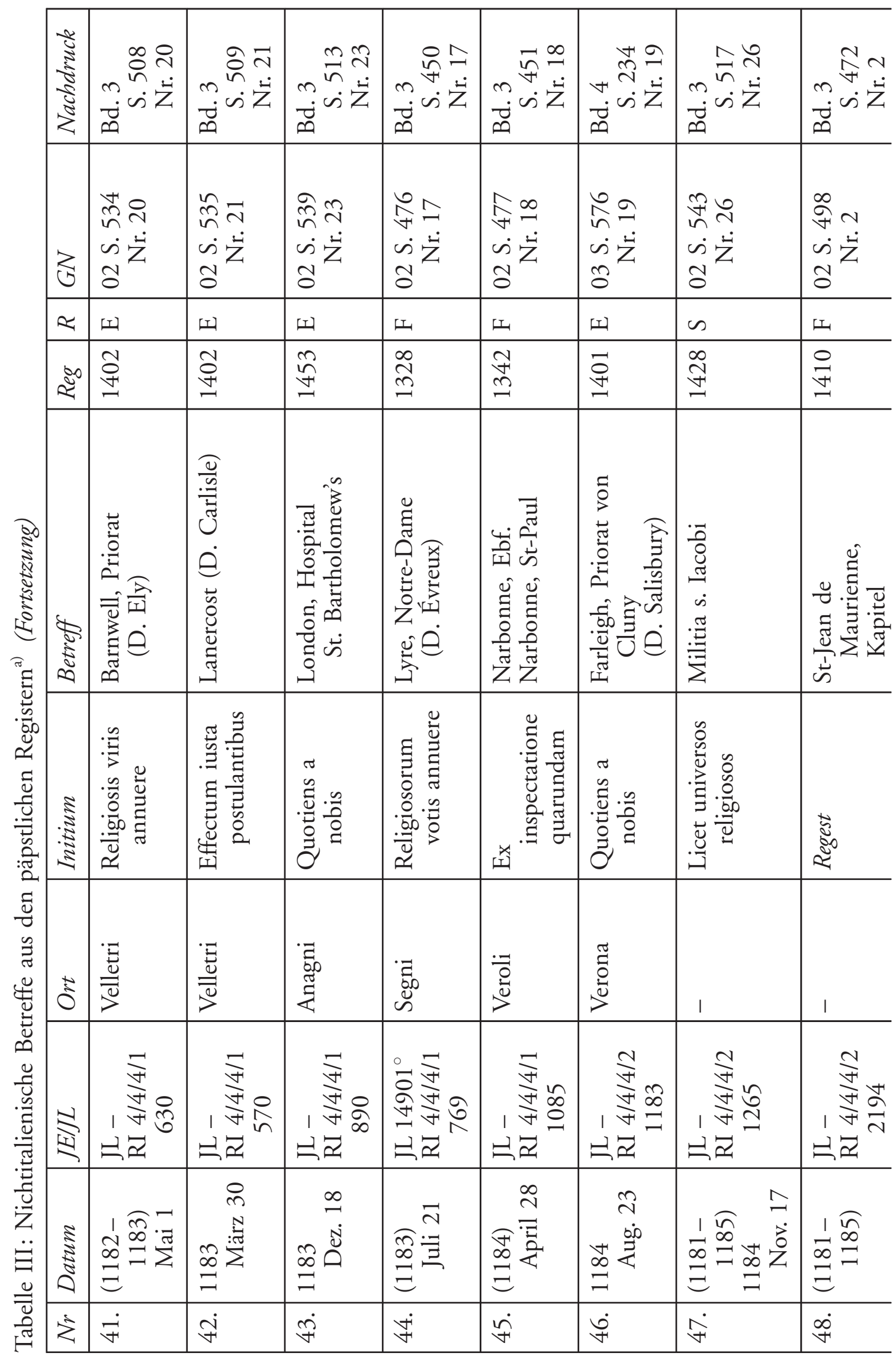




\begin{tabular}{|c|c|c|c|c|c|c|c|c|}
\hline & & 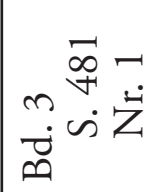 & 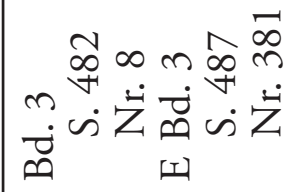 & 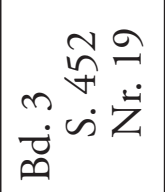 & 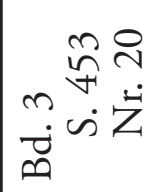 & $\begin{array}{l}\overrightarrow{\tilde{n}} \\
\dot{n} \dot{\infty} \\
\vec{\infty}\end{array}$ & 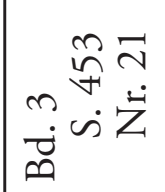 & 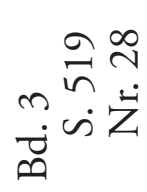 \\
\hline & 5 & 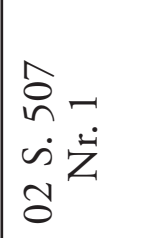 & $\mid \begin{array}{l}\infty \\
0 \\
i \\
\dot{n} \\
\dot{z} \\
\tilde{z}\end{array}$ & 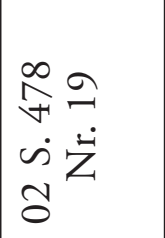 & 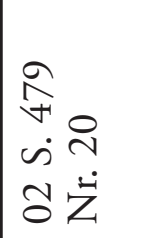 & 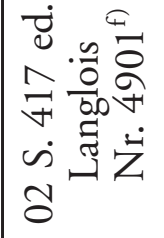 & 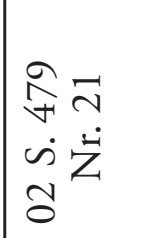 & 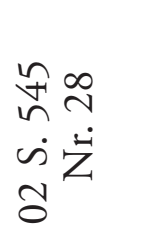 \\
\hline & & 0 & س & L & ш & ш & ш & - \\
\hline & : & 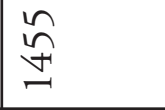 & W & $\begin{array}{l}\vec{\infty} \\
\stackrel{n}{n}\end{array}$ & $\begin{array}{l}\vec{\infty} \\
\stackrel{2}{n}\end{array}$ & $\overrightarrow{\widehat{I}}$ & 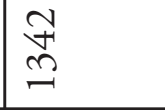 & $\stackrel{\infty}{\underset{\varpi}{\Psi}}$ \\
\hline & 5 & 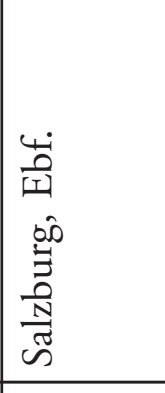 & 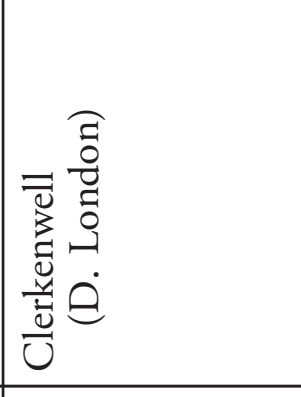 & 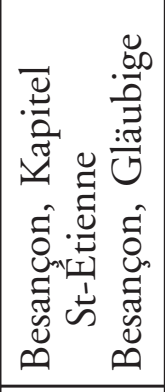 & 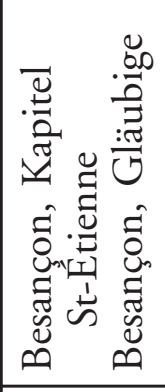 & 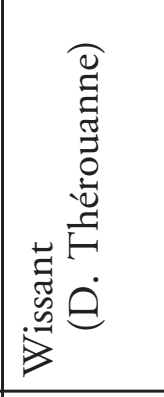 & 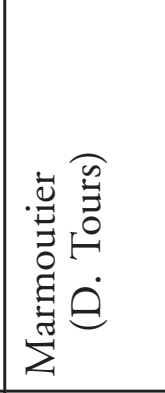 & 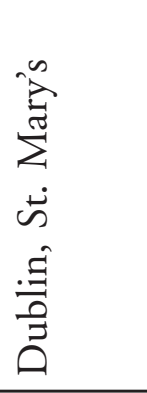 \\
\hline & 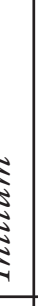 & 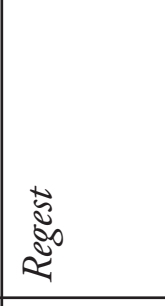 & 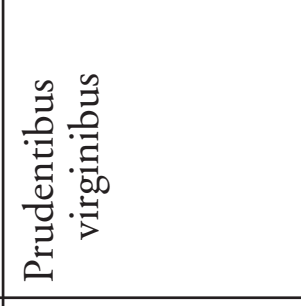 & 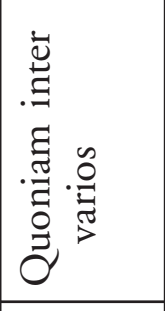 & 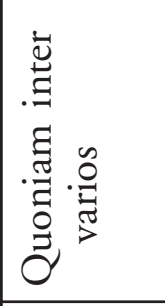 & 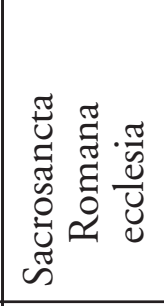 & 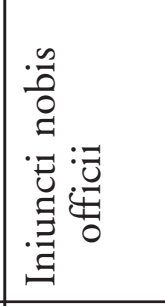 & 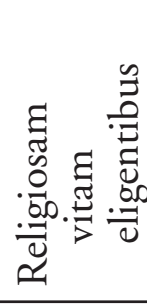 \\
\hline & 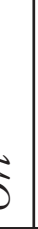 & 1 & 泀 & 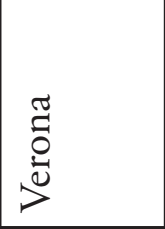 & $\begin{array}{l}\pi \\
0 \\
0 \\
0 \\
0 \\
\nu\end{array}$ & 泀 & 范 & 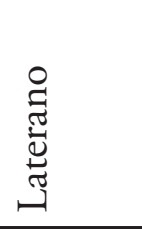 \\
\hline & 5 & 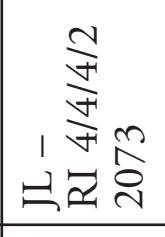 & $\stackrel{1}{=}$ & $\stackrel{1}{=}$ & $\stackrel{1}{=}$ & $\stackrel{1}{\Xi}$ & $\stackrel{1}{\Xi}$ & 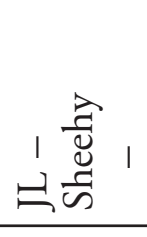 \\
\hline & & 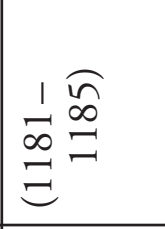 & 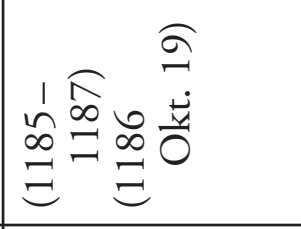 & 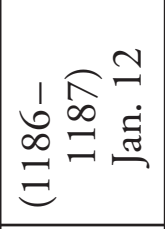 & 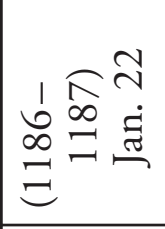 & 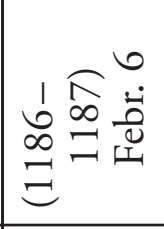 & 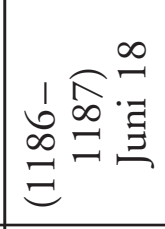 & $\begin{array}{l}n \\
\infty \\
\infty \\
\infty \\
= \\
=\end{array}$ \\
\hline & & $\underset{\sigma}{\sigma}$ & $\dot{i n}$ & $\ddot{n}$ & in & $\ddot{n}$ & in & $\ddot{n}$ \\
\hline
\end{tabular}


„Verborgene Schätze“. Nichtitalienische Stücke in den „Papsturkunden in Italien“

477

\begin{tabular}{|c|c|c|c|c|c|c|}
\hline 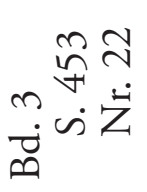 & 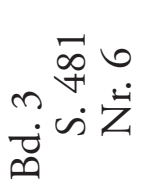 & 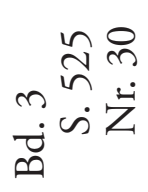 & 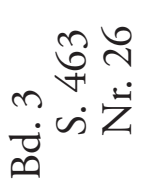 & $\begin{array}{l}\stackrel{n}{\sim} \\
\dot{n} \\
\dot{n}\end{array}$ & 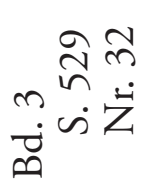 & 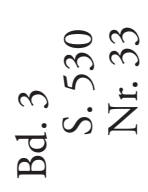 \\
\hline 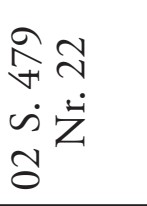 & 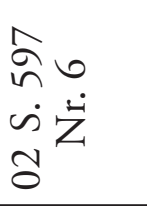 & 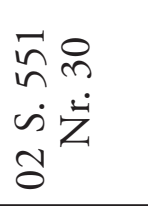 & 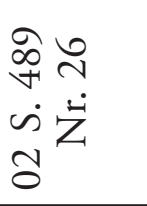 & 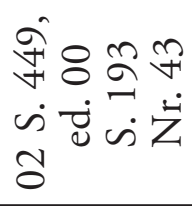 & 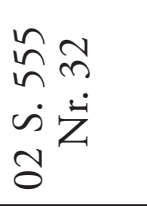 & 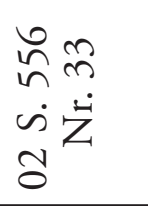 \\
\hline L & $\frac{y}{\omega}$ & 디 & $\infty$ & 0 & 피 & 디 \\
\hline $\begin{array}{l}\hat{\infty} \\
\stackrel{n}{n}\end{array}$ & $\begin{array}{l}\infty \\
\stackrel{\infty}{\Downarrow} \\
\Downarrow\end{array}$ & 호 & 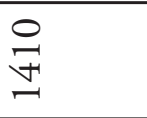 & 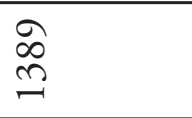 & $\stackrel{\mathscr{n}}{ \pm}$ & $\hat{\approx}$ \\
\hline 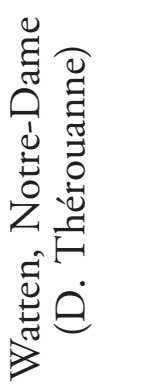 & 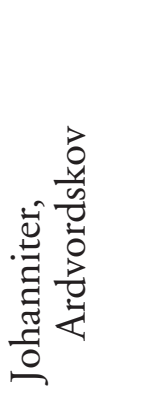 & 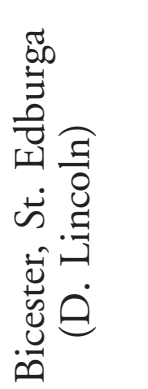 & 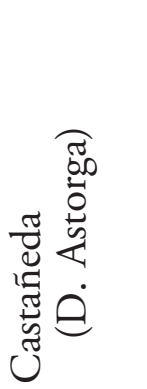 & 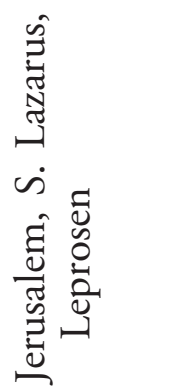 & 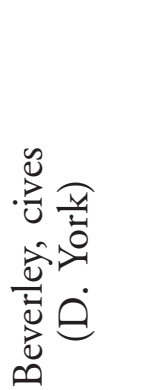 & 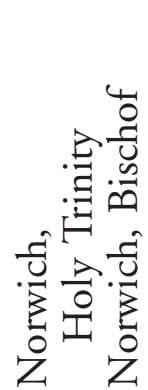 \\
\hline 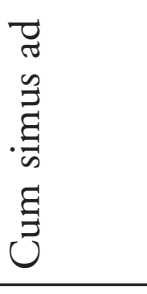 & 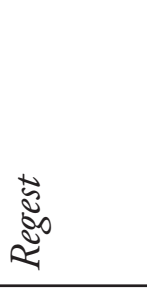 & 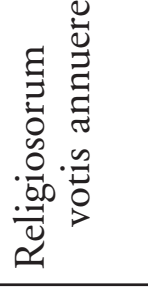 & 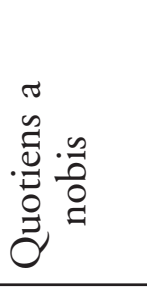 & •气 & $\begin{array}{l}0 \\
0 \\
0 \\
0 \\
0 \\
\Xi \\
\Xi \\
3\end{array}$ & 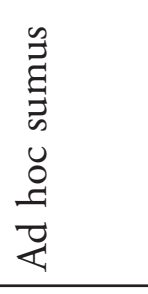 \\
\hline 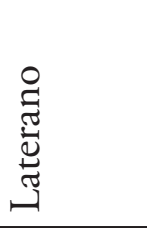 & I & 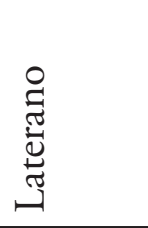 & 营 & 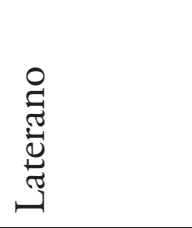 & 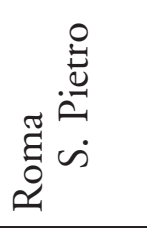 & 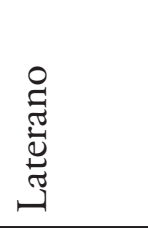 \\
\hline$\stackrel{1}{\triangleq}$ & $\stackrel{1}{\triangleq}$ & $\stackrel{1}{\Xi}$ & $\stackrel{1}{\models}$ & $\stackrel{1}{\ominus}$ & $\stackrel{1}{\models}$ & $\stackrel{\text { I }}{\ominus}$ \\
\hline 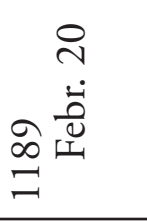 & 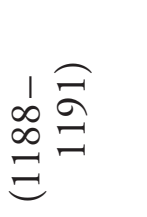 & $\approx \stackrel{\substack{n \\
\Xi}}{\sum^{N}}$ & 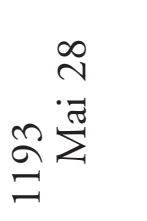 & 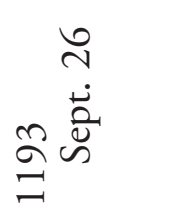 & 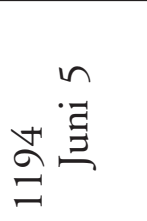 & 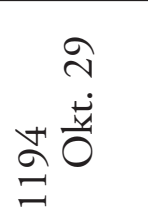 \\
\hline 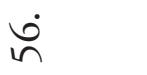 & $\hat{n}$ & $\stackrel{\infty}{n}$ & $\stackrel{\sim}{n}$ & $\dot{8}$ & $\dot{\sigma}$ & ชె่ \\
\hline
\end{tabular}




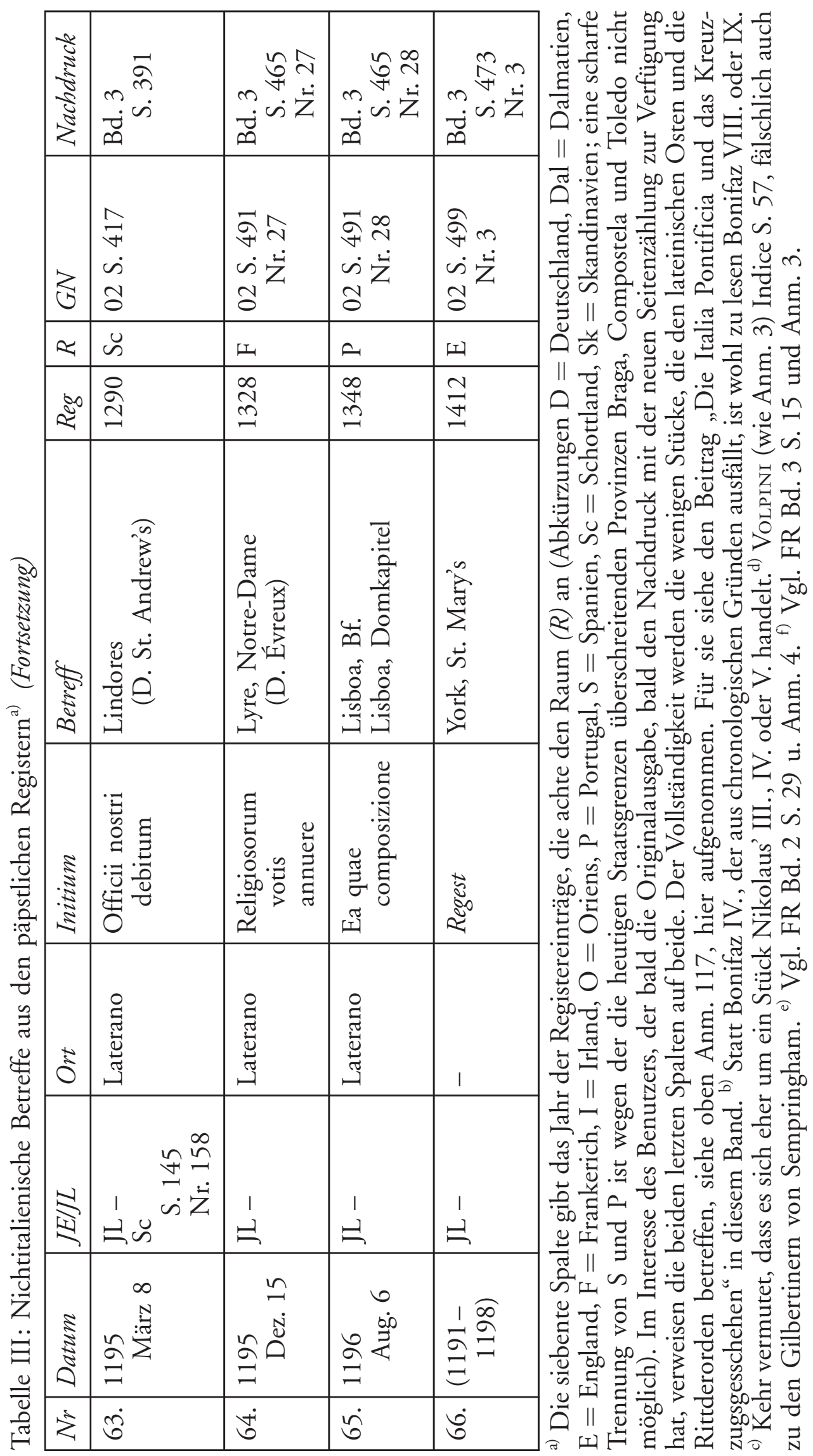


„Verborgene Schätze“. Nichtitalienische Stücke in den „Papsturkunden in Italien“ 479

Tabelle IV: Empfängerverzeichnis für Tabellen I-III

\begin{tabular}{|c|c|c|}
\hline Albi, St-Salvy & $\mathrm{F}$ & III 11 \\
\hline Antibes, Bf. & $\mathrm{F}$ & II 51 \\
\hline Antiochia, Patr. & $\mathrm{O}$ & II 56 \\
\hline \multicolumn{3}{|l|}{ Antivari siehe Bar } \\
\hline Apulien, Templer & $\mathrm{O}$ & I 25 \\
\hline Aulps, Notre-Dame (D. Genève) & $\mathrm{F}$ & II 2,6 \\
\hline Bar/Antivari & $\mathrm{D}$ & II 1 \\
\hline Barnwell, Priorat (D. Ely) & $\mathrm{E}$ & III 41 \\
\hline Beirut & TS & II 53 \\
\hline Besançon, Domkapitel St-Etienne & $\mathrm{F}$ & III $10,51,52$ \\
\hline Besançon, Domkapitel St-Jean-l'Évangeliste & $\mathrm{F}$ & III 10 \\
\hline Besançon, Gläubige & $\mathrm{F}$ & III 51,52 \\
\hline Betton (D. Saint-Jean-de-Maurienne) & $\mathrm{F}$ & II 50 \\
\hline Beverley, cives (D. York) & $\mathrm{E}$ & III 61 \\
\hline Bicester, St. Edburga (D. Lincoln) & $\mathrm{E}$ & III 37,58 \\
\hline $\begin{array}{l}\text { Blois, Notre-Dame-du-Bourgmoyen (D. } \\
\text { Chartres) }\end{array}$ & $\mathrm{F}$ & II 7 \\
\hline Bonnevaux (D. Poitiers) & $\mathrm{F}$ & III 16 \\
\hline Braga, Ebf. & $\mathrm{P}$ & II 22, 46; III 19, 20 \\
\hline Braga, Suffragane & $\mathrm{P}$ & II 46 ; III 23,25 \\
\hline Britsche Inseln, Johanniter & $\mathrm{E}$ & I $21=$ II 38 \\
\hline Burgos, Bf. & $S$ & II $26,41,48$ \\
\hline Byblos, Bf. & TS & II 55,56 \\
\hline Byblos, Hugo de Gibelleto & TS & II 55,56 \\
\hline Caen, St-Étienne & $\mathrm{F}$ & III 38 \\
\hline Cambridge & $\mathrm{E}$ & III 2,3 \\
\hline Canterbury, Domkapitel $^{\text {a) }}$ & E & III 34 \\
\hline Capitanata, Templer & $\mathrm{O}$ & I 25 \\
\hline Capodistria (Koper), Bf. & $\mathrm{Sl}$ & II 63 \\
\hline Carcassonne, Dekanat & $\mathrm{F}$ & III 4 \\
\hline
\end{tabular}


Tabelle IV: Empfängerverzeichnis für Tabellen I-III (Fortsetzung)

\begin{tabular}{|l|l|l|}
\hline Castañeda (D. Astorga) & S & III 59 \\
\hline Chaise-Dieu (D. Le Puy) & F & II 16,54 \\
\hline $\begin{array}{l}\text { Chiaravalle, Zisterzienser } \\
\text { (D. Milano) }\end{array}$ & O & I 70 \\
\hline Clermont, Kapitel & F & III 4 \\
\hline Clerkenwell (D. London) & E & III 50 \\
\hline $\begin{array}{l}\text { Constantia, regis Francorum filia } \\
\text { Cruciferi }\end{array}$ & $\begin{array}{l}\text { F/ } \\
\text { It }\end{array}$ & II 4 \\
\hline Dioclea siehe Antivari/Bar & O & I $77=$ II 61, I 79= II 65 \\
\hline Djebail siehe Byblos & & \\
\hline Dublin, Domkapitel & & \\
\hline Embrun, Ebf. & Irl & III 55 \\
\hline Entremont (D. Genève) & F & II 51 \\
\hline $\begin{array}{l}\text { Farleigh, Priorat von Cluny } \\
\text { (D. Salisbury) }\end{array}$ & F & II 40 \\
\hline Fermo, Bf. & E & III 56 \\
\hline Fitero, S. Maria (D. Pamplona) & & \\
\hline Fréjus, Bf. & I & I 85 \\
\hline Gap, Domkapitel & S & II 43 \\
\hline Gibelletum siehe Byblos & F & II 51 \\
\hline Glandève, Bf. & F & III 32 \\
\hline Glanfeuil (St-Maur-sur-Loire) & & \\
\hline $\begin{array}{l}\text { Great Malvern, Priorat } \\
\text { (D. Worcester) }\end{array}$ & F & II 51 \\
\hline Grijò, S. Salvador de Ecclesiola (D. Porto) & F & II 9 \\
\hline $\begin{array}{l}\text { Gurson, castrum de Gurzione } \\
\text { (D. Périgueux) }\end{array}$ & E & III 35 \\
\hline Imola, Johanniter & F & II 66 \\
\hline Jerusalem, Patr. & TS & T 73 \\
\hline Jerusalem, S. Lazarus, Leprosen & II 47 \\
\hline Jerusalem, S. Maria Latina & II 55,56 \\
\hline
\end{tabular}


Tabelle IV: Empfängerverzeichnis für Tabellen I-III (Fortsetzung)

\begin{tabular}{|c|c|c|}
\hline Johanniter & $\mathrm{O}$ & $\begin{array}{l}\text { I } 2,3,6,10-15,20,21,23, \\
\quad 26,31,33,35-37,39, \\
\quad 43-45,48,49,51-54, \\
\quad 56-61,64,67-69,73-76, \\
\quad 78,80-82,84,85 ; \text { II } 21, \\
\quad 38,57 ; \text { III } 24\end{array}$ \\
\hline $\begin{array}{l}\text { Johanniter auf den britischen } \\
\text { Inseln }\end{array}$ & $\mathrm{E}$ & I $21=$ II 38 \\
\hline Johanniter in Schottland & Sc & I $72=$ II 57 \\
\hline Johanniter in Spanien & $S$ & I $4=$ II 21 \\
\hline Johanniter in Sizilien/Kalabrien & $\mathrm{O}$ & I 46 \\
\hline Johanniter, Ardvordskov & Sk & III 57 \\
\hline Kalabrien, Templer & $\mathrm{O}$ & I 25 \\
\hline Karthäuser & $\mathrm{O}$ & I $71,75,79,80,85-87$ \\
\hline $\begin{array}{l}\text { Kenilworth, St. Mary } \\
\text { (D. Worcester) }\end{array}$ & E & III 12 \\
\hline $\begin{array}{l}\text { Kingswood, St. Mary } \\
\text { (D. Worcester) }\end{array}$ & E & III 30 \\
\hline $\begin{array}{l}\text { Lanercost, St. Mary Magdelene } \\
\text { (D. Carlisle) }\end{array}$ & $\mathrm{E}$ & III 42 \\
\hline Lazariter & $\mathrm{O}$ & III 60 \\
\hline Le Puy, Hospital Notre-Dame & $\mathrm{F}$ & III 15 \\
\hline León, Bf. & $S$ & II 41 \\
\hline León, S. Isidoro & S & II 29 \\
\hline Lérins, St-Honorat (D. Grasse) & $\mathrm{F}$ & $\begin{array}{l}\text { II } 24,25,34,35,44,45,49 \\
\quad 51,52,58,59,60,62,67 \\
\quad 68,69\end{array}$ \\
\hline Lindores (D. St. Andrew's) & Sc & III 63 \\
\hline Lisboa, Bf. & $\mathrm{P}$ & III 65 \\
\hline Lisboa, Domkapitel & $\mathrm{P}$ & III 65 \\
\hline $\begin{array}{l}\text { London, Hospital } \\
\text { St. Bartholomew's }\end{array}$ & E & III 43 \\
\hline Lyon, Ebf. & $\mathrm{F}$ & III 27 \\
\hline Lyon, St-Irénée & $\mathrm{F}$ & II 3 \\
\hline
\end{tabular}


Tabelle IV: Empfängerverzeichnis für Tabellen I-III (Fortsetzung)

\begin{tabular}{|l|l|l|}
\hline Lyre, Notre-Dame (D. Évreux) & F & III 44,64 \\
\hline $\begin{array}{l}\text { Maillezais, Saint-Pierre } \\
\text { (D. Poitiers) }\end{array}$ & F & III 5 \\
\hline Mainz, Ebf. u. Suffragane & D & II 27 \\
\hline Malaga, Kleriker und Volk & S & III 8 \\
\hline Marmoutier (D. Toutrs) & F & III 54 \\
\hline Marseille, St-Victor & F & III 22,29 \\
\hline Maurienne, Kapitel & F & III 48 \\
\hline Mercedarier & S & I 1 III 1 \\
\hline Milhau, Klerus u. Volk (D. Rodez) & F & III 22 \\
\hline $\begin{array}{l}\text { Milhau, Notre-Dame (Priorat von } \\
\text { St-Victor in Marseille, } \\
\text { D. Rodez) }\end{array}$ & F & III 29 \\
\hline Militia s. Iacobi & & \\
\hline Mondoñedo & S & III 47 \\
\hline Montecassino & S & III 6 \\
\hline Narbonne & I & I 32 \\
\hline Narbonne, Ebf. & F & I 17 \\
\hline Narbonne, St-Paul & F & II $77 ;$ III 45 \\
\hline Narbonnais, Templer & F & III 45 \\
\hline Nizze, Bf. & F & I $17 ;$ II 37 \\
\hline Norwich, Bf. & F & II 51 \\
\hline Norwich, Holy Trinity & E & III 62 \\
\hline Oviedo, Bf. & E & III 62 \\
\hline $\begin{array}{l}\text { Petrus de Castellione } \\
\text { (D. Périgueux?) }\end{array}$ & S & II 41 \\
\hline Prinzipat, Templer & F & II 66 \\
\hline Provence, Bfe. & O & I 25 \\
\hline Provence, Gläubige & F & II 58 \\
\hline Refoyos, S. Maria (D. Tuy) & F & II 49 \\
\hline Riez, Bf. & S & II 30 \\
\hline
\end{tabular}


Tabelle IV: Empfängerverzeichnis für Tabellen I-III (Fortsetzung)

\begin{tabular}{|c|c|c|}
\hline Rodez, Bf. & $\mathrm{F}$ & III 22 \\
\hline Rouen, Ebf. & $\mathrm{F}$ & III 14,27 \\
\hline $\begin{array}{l}\text { S. Maria im Tale Josaphat } \\
\text { (D. Jerusalem) }\end{array}$ & TS & III 13 \\
\hline $\begin{array}{l}\text { Saint-Donat-sur-l'Herbasse, } \\
\text { Priorat von Oulx } \\
\text { (D. Vienne) }\end{array}$ & $\mathrm{F}$ & III 33 \\
\hline Saint-Eusèbe, Kloster (D. Apt) & $\mathrm{F}$ & III 18 \\
\hline Salzburg, Ebf. & $\mathrm{D}$ & III 49 \\
\hline $\begin{array}{l}\text { Samport (Santa Cristina de Summo Portu, } \\
\text { D. Huesca) }\end{array}$ & $S$ & II 18 \\
\hline Santiago de Compostela, Ebf. & $S$ & II 120,33 ; III 20 \\
\hline Schottland, Johanniter & Sch & I 73; II 57 \\
\hline $\begin{array}{l}\text { Sempringham, Gilbertiner } \\
\text { (D. Lincoln) }\end{array}$ & $\mathrm{E}$ & III 31 \\
\hline Senez, Bf. & $\mathrm{F}$ & II 51 \\
\hline Sens, Ebf. & $\mathrm{F}$ & III 14,27 \\
\hline $\begin{array}{l}\text { Silos, Santo Domingo de Valle Tablatelli } \\
\text { (D. Burgos) }\end{array}$ & $S$ & III 9 \\
\hline Sizilien, Templer & $\mathrm{O}$ & I 7 \\
\hline Spanien, Bfe. & S & I 6; II 21 \\
\hline Spanien, Johanniter & S & I 6; II 21 \\
\hline Spanien, Templer & S & I 6; II 21 \\
\hline \multicolumn{3}{|l|}{ St-Maur-sur-Loire siehe Glanfeuil } \\
\hline $\begin{array}{l}\text { St-Pierre de Maillezais } \\
\text { (D. Poitiers) }\end{array}$ & $\mathrm{F}$ & III 5 \\
\hline $\begin{array}{l}\text { Taillebourg, St-Jacques } \\
\text { (D. Poitiers) }\end{array}$ & $\mathrm{F}$ & III 39 \\
\hline $\begin{array}{l}\text { Talloires, Priorat Notre-Dame } \\
\text { (D. Genève) }\end{array}$ & $\mathrm{F}$ & II 14 \\
\hline Tarragona, Ebf. & $S$ & III 20,21 \\
\hline
\end{tabular}


Tabelle IV: Empfängerverzeichnis für Tabellen I-III (Fortsetzung)

\begin{tabular}{|c|c|c|}
\hline Templer & $\mathrm{O}$ & $\begin{array}{l}\text { I } 4-9,16-19,22,24,25, \\
\quad 27-30,32,34,38,40-42, \\
46,47,50,55,65,66,72, \\
77=\text { II } 61,79=\text { II } 65,85 ; \\
\text { II } 21,37,61=\text { I } 77, \\
65=\text { I } 82\end{array}$ \\
\hline Templer, Apulien & $\mathrm{O}$ & I 25 \\
\hline Templer, Capitanata & $\mathrm{O}$ & I 25 \\
\hline Templer, Kalabrien & $\mathrm{O}$ & I 25 \\
\hline Templer, Montecassino & $\mathrm{O}$ & I 34 \\
\hline Templer, Prinzipat & $\mathrm{O}$ & I 25 \\
\hline Templer auf Sizilien & $\mathrm{O}$ & I $7,25,46$ \\
\hline Templer im Narbonnais & $\mathrm{O}$ & I $15=$ II 37 \\
\hline Templer in Spanien & $\mathrm{O}$ & I $4=$ II 21 \\
\hline Templer in Zara & $\mathrm{O}$ & I $77=$ II 61, I $79=$ II 65 \\
\hline Terrasson, Notre-Dame (D. Sarlat) & $\mathrm{F}$ & III 26 \\
\hline Thame, St. Mary (D. Lincoln) & $\mathrm{E}$ & III 36 \\
\hline Toledo, Ebf. & S & $\begin{array}{l}\text { II } 8,20,22,33,41,46 ; \text { III } 6 \text {, } \\
7, \\
\quad 19-21,23,25\end{array}$ \\
\hline Toledo, Suffragane & S & III 6,7 \\
\hline Tours, Ebf. & $\mathrm{F}$ & III 14,27 \\
\hline Tripoli, Bf. & TS & II 45,46 \\
\hline Uzès, Domkapitel & $\mathrm{F}$ & II 17,23 \\
\hline Valence, Dekan u. Kapitel & $\mathrm{F}$ & III 40 \\
\hline Veroli, Templer & TS & I 50 \\
\hline Verona & I & I 55 \\
\hline Vézelay, Ste-Madeleine (D. Autun) & $\mathrm{F}$ & III 28 \\
\hline $\begin{array}{l}\text { Villeneuve-lès-Avignon } \\
\text { (D. Avignon) }\end{array}$ & $\mathrm{F}$ & II 39 \\
\hline $\begin{array}{l}\text { Watten, Notre-Dame } \\
\text { (D. Thérouanne) }\end{array}$ & $\mathrm{F}$ & III 56 \\
\hline Wissant (D. Thérouanne) & $\mathrm{F}$ & III 53 \\
\hline
\end{tabular}


Tabelle IV: Empfängerverzeichnis für Tabellen I-III (Fortsetzung)

\begin{tabular}{|l|l|l|}
\hline York, St. Mary's & E & III 66 \\
\hline $\begin{array}{l}\text { Zara, Domkapitel, Archidiakon I., } \\
\text { Erzpriester A. }\end{array}$ & Dal & II 61, 65 \\
\hline Zara, Kapitel & Dal & I $77=$ II 61, I 79 = II 65 \\
\hline Zara, S. Anastasia & Dal & I $77=$ II 61, I 79= II 65 \\
\hline Zara, S. Crisogono & Dal & II 61 \\
\hline Zara, S. Croce & Dal & I $77=$ II 61, I 79= II 65 \\
\hline Zara, S. Stefano & Dal & I $77=$ II 61 \\
\hline Zara, Templer & Dal & I $77=$ II 61, I 79= II 65 \\
\hline $\begin{array}{l}\text { Zaragoza, S. Maria la Mayor } \\
\text { e del Pilar }\end{array}$ & S & II 15,42 \\
\hline Zisterzienser & O & I 63, 64, 70 \\
\hline
\end{tabular}

a) Volpini (wie Anm. 3) Indice S. 57, fälschlich auch an die Gilbertiner von Sempringham. 


\begin{tabular}{|c|c|c|c|c|c|c|c|c|c|c|c|c|c|c|c|}
\hline 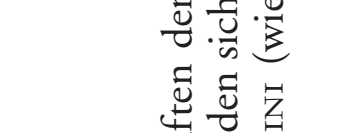 & $\gtreqless$ & $\begin{array}{l}\infty \\
\infty \\
\infty \\
\infty\end{array}$ & $\begin{array}{l}m \\
\stackrel{\infty}{+} \\
\dot{\omega}\end{array}$ & $\begin{array}{l}\hat{\infty} \\
i \\
\dot{n}\end{array}$ & $\begin{array}{l}\overrightarrow{7} \\
\dot{s}\end{array}$ & $\begin{array}{l}\underset{+}{~} \\
\dot{s}\end{array}$ & $\begin{array}{l}\vec{F} \\
\dot{s}\end{array}$ & $\begin{array}{l}\stackrel{N}{\stackrel{F}{*}} \\
\dot{s}\end{array}$ & $\begin{array}{l}\infty \\
\stackrel{\infty}{F} \\
\dot{\infty}\end{array}$ & $\begin{array}{l}+\dot{\infty} \\
\infty \\
\dot{n}\end{array}$ & $\begin{array}{l}m \\
\infty \\
\dot{+} \\
\dot{n}\end{array}$ & $\begin{array}{l}\infty \\
\infty \\
n \\
\dot{n}\end{array}$ & $\begin{array}{l}m \\
\infty \\
\dot{\infty} \\
\dot{\infty}\end{array}$ & $\begin{array}{l}+ \\
\infty \\
n \\
\dot{n}\end{array}$ & $\begin{array}{l}\stackrel{+}{\infty} \\
\stackrel{n}{n} \\
\dot{\omega}\end{array}$ \\
\hline 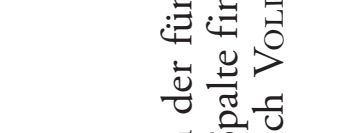 & $\frac{\Sigma}{2}$ & $\begin{array}{l}\stackrel{+}{F} \\
\dot{s}\end{array}$ & $\begin{array}{l}\hat{\partial} \\
\dot{n} \\
\dot{n}\end{array}$ & $\begin{array}{l}\stackrel{m}{\forall} \\
\dot{s}\end{array}$ & $\begin{array}{l}\stackrel{F}{F} \\
\dot{\psi}\end{array}$ & 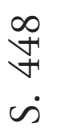 & $\begin{array}{l}\hat{\sigma} \\
\dot{+} \\
\dot{s}\end{array}$ & $\begin{array}{l}\stackrel{\infty}{\stackrel{+}{+}} \\
\dot{s}\end{array}$ & $\begin{array}{l}\stackrel{+}{0} \\
\stackrel{n}{n} \\
\dot{s}\end{array}$ & $\begin{array}{l}\circ \\
\forall \\
\dot{v}\end{array}$ & $\begin{array}{l}\text { ेे } \\
\dot{n} \\
\dot{n}\end{array}$ & $\begin{array}{l}\stackrel{\forall}{\forall} \\
\dot{s}\end{array}$ & $\begin{array}{l}2 \\
\dot{0} \\
\dot{n}\end{array}$ & $\begin{array}{l}\stackrel{0}{F} \\
\dot{\forall} \\
\dot{s}\end{array}$ & $\begin{array}{l}\stackrel{0}{\forall} \\
\dot{\forall}\end{array}$ \\
\hline 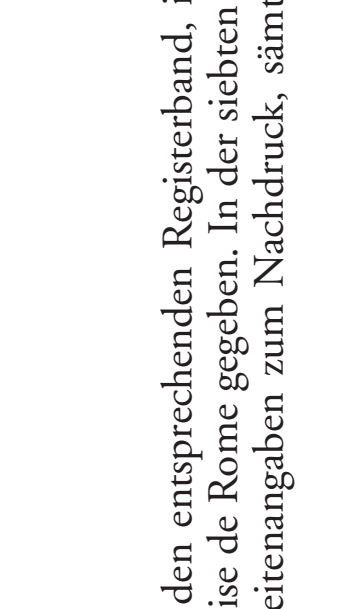 & 这 & 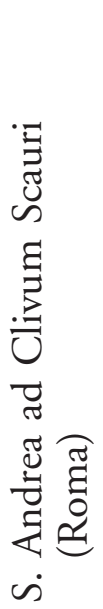 & 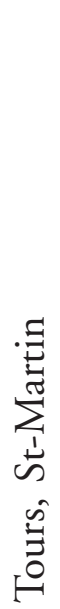 & 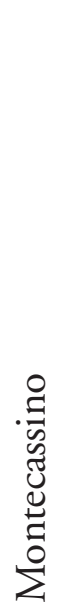 & 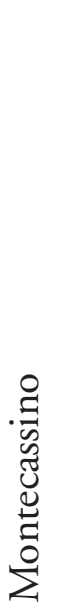 & 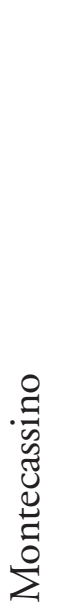 & 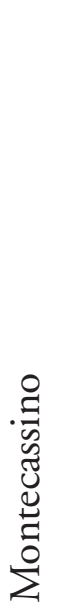 & 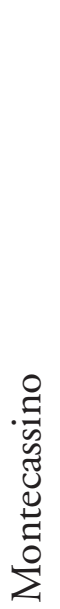 & 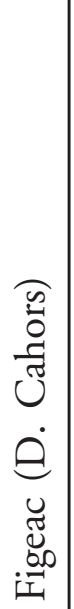 & 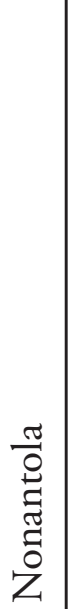 & 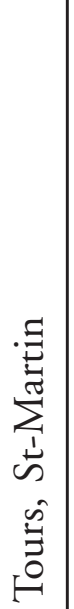 & 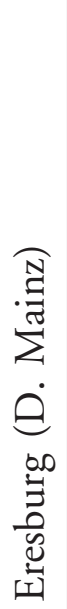 & 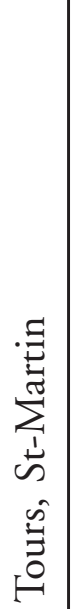 & 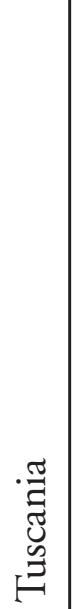 & 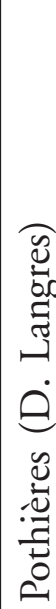 \\
\hline 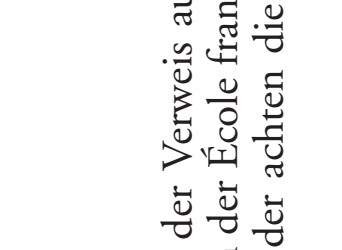 & 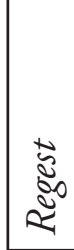 & 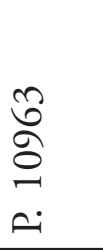 & & $\begin{array}{l}\stackrel{2}{\infty} \\
\infty \\
\text { ᄃ. }\end{array}$ & & & & & & \begin{tabular}{l}
$\stackrel{\wp}{\curvearrowleft}$ \\
\multirow{+}{*}{} \\
$\sim$
\end{tabular} & & 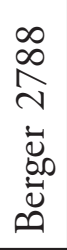 & & $\begin{array}{l}\text { ๖ } \\
\text { } \\
\text { ñ } \\
\text { ᄃi }\end{array}$ & $\begin{array}{l}\hat{\curvearrowright} \\
\text { กิ } \\
\text { ni }\end{array}$ \\
\hline 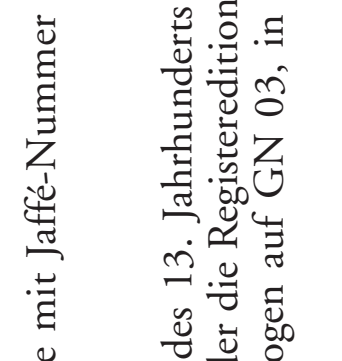 & 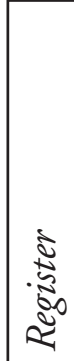 & 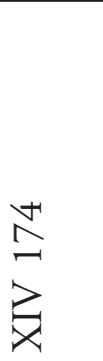 & & $\bar{n}$ & & & & & & $\begin{array}{l}0 \\
0 \\
1 \\
6 \\
6 \\
\vdots \\
x\end{array}$ & & $\begin{array}{l}\Re \\
\nwarrow \\
z\end{array}$ & & $\begin{array}{l}\underset{+}{ \pm} \\
\underset{x}{x}\end{array}$ & $\begin{array}{l}\stackrel{y}{*} \\
\not{E}\end{array}$ \\
\hline 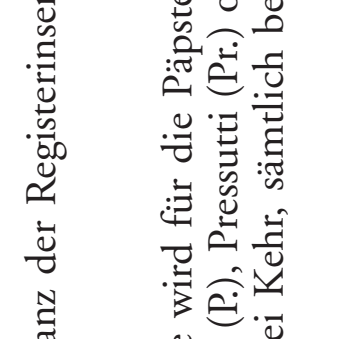 & 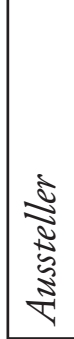 & 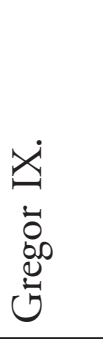 & 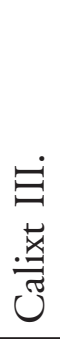 & $\begin{array}{l}\dot{x} \\
\dot{0} \\
\dot{0} \\
\dot{0} \\
\dot{0}\end{array}$ & 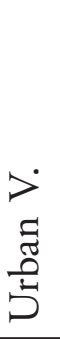 & 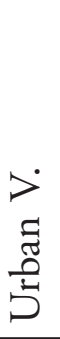 & 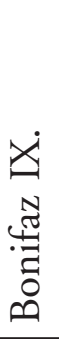 & 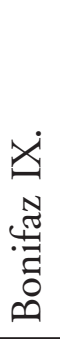 & 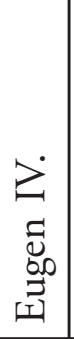 & 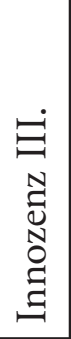 & 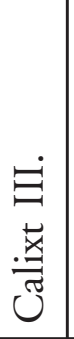 & $\begin{array}{l}E \\
\text { N } \\
\text { N } \\
0 \\
\Xi \\
\Xi \\
\end{array}$ & 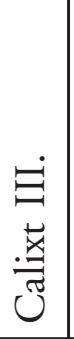 & 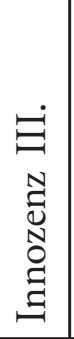 & $\begin{array}{l}\Xi \\
\Xi \\
\mathcal{\Xi} \\
\mathcal{D} \\
0 \\
\Xi \\
\Xi\end{array}$ \\
\hline 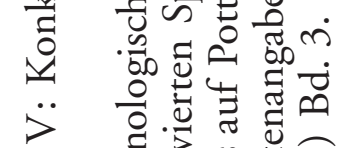 & 迩 & 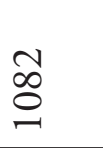 & $\stackrel{0}{2}$ & $\underset{\mathbb{N}}{\stackrel{\infty}{ \pm}}$ & $\begin{array}{l}\underset{\infty}{\infty} \\
\stackrel{+}{+}\end{array}$ & $\begin{array}{l}\underset{\infty}{\infty} \\
\stackrel{+}{+} \\
+\end{array}$ & $\begin{array}{l}\underset{\infty}{\infty} \\
\underset{+}{+}\end{array}$ & $\begin{array}{c}\underset{\infty}{N} \\
\stackrel{+}{+}\end{array}$ & 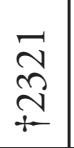 & 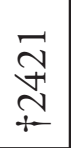 & $\begin{array}{l}\underset{N}{N} \\
\stackrel{+}{\sim} \\
+\end{array}$ & \begin{tabular}{l}
\multirow{2}{0}{} \\
$\stackrel{n}{1}$ \\
+
\end{tabular} & $\begin{array}{l}+1 \\
\stackrel{n}{n} \\
\stackrel{+}{t}\end{array}$ & in & $\begin{array}{l}\infty \\
\infty \\
m\end{array}$ \\
\hline 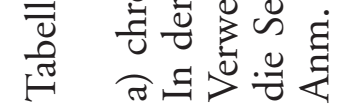 & $\sum$ & $\stackrel{-}{-}$ & $\dot{i}$ & $\dot{r}$ & $\underset{\forall}{ }$ & $\dot{n}$ & 6 & $\wedge$ & $\infty$ & $\dot{0}$ & 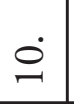 & $\Xi$ & J & $\stackrel{n}{=}$ & 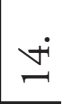 \\
\hline
\end{tabular}




\begin{tabular}{|c|c|c|c|c|c|c|c|c|c|c|c|c|c|c|c|c|c|c|c|c|}
\hline & & & & $\begin{array}{c}\infty \\
\infty \\
\dot{\infty} \\
\dot{\omega}\end{array}$ & 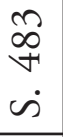 & $\begin{array}{l}\vec{\delta} \\
\dot{m} \\
\dot{\omega}\end{array}$ & $\begin{array}{l}\vec{\infty} \\
\infty \\
\infty \\
\dot{\omega}\end{array}$ & $\mid \begin{array}{l}+ \\
\infty \\
\infty \\
\dot{m}\end{array}$ & $\mid \begin{array}{l}\bigotimes \\
\text { on } \\
\dot{\omega}\end{array}$ & $\mid \begin{array}{l}\infty \\
\infty \\
\infty \\
\dot{\omega} \\
\dot{n}\end{array}$ & {$\left[\begin{array}{l}\infty \\
\infty \\
\infty \\
c\end{array}\right.$} & $\mid \begin{array}{l}\infty \\
\infty \\
\sim \\
w\end{array}$ & 1 & 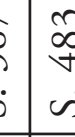 & 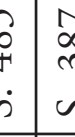 & $\stackrel{b}{b}$ & 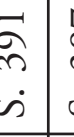 & & & $\mid \begin{array}{c}\infty \\
\infty \\
\dot{\omega}\end{array}$ \\
\hline & & & e & $\begin{array}{c}\vec{m} \\
\vec{\forall} \\
\dot{v}\end{array}$ & $\begin{array}{l}\hat{D} \\
\text { in } \\
\dot{s}\end{array}$ & $\begin{array}{l}\vec{\forall} \\
\dot{s}\end{array}$ & $\begin{array}{l}\vec{g} \\
\vec{\nabla} \\
\dot{s}\end{array}$ & $\mid \begin{array}{l}\stackrel{9}{\vec{y}} \\
\dot{\omega}\end{array}$ & $\mid \begin{array}{l}0 \\
\vec{y} \\
\dot{\omega}\end{array}$ & $\mid \begin{array}{l}\vec{t} \\
\vec{f} \\
\dot{\omega}\end{array}$ & $\vec{v}$ & $\stackrel{\pi}{\exists}$ & & 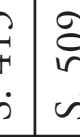 & $\hat{b}$ & $\vec{f}$ & $\begin{array}{l}\vec{y} \\
\dot{s}\end{array}$ & $\begin{array}{c}\vec{m} \\
\vec{\forall} \\
\dot{s}\end{array}$ & & $\mid \begin{array}{l}m \\
\vec{y} \\
\dot{\omega}\end{array}$ \\
\hline & & & & 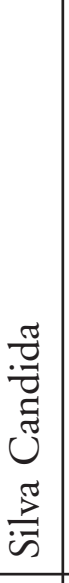 & 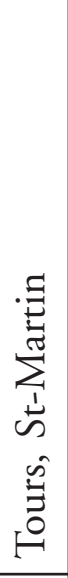 & 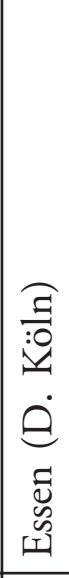 & 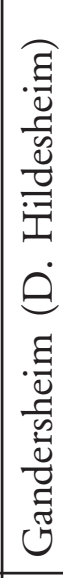 & 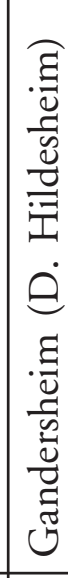 & 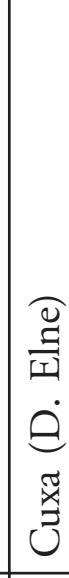 & 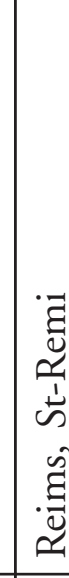 & $=$ & 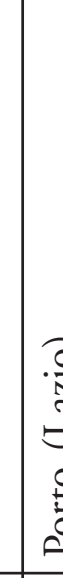 & 6 & 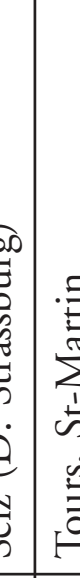 & 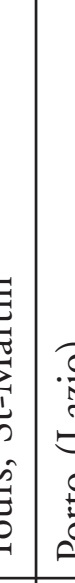 & 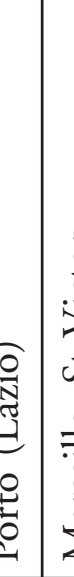 & 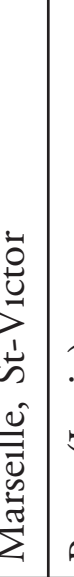 & 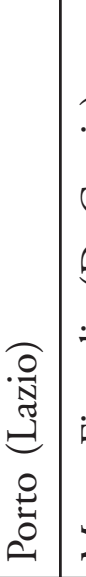 & & 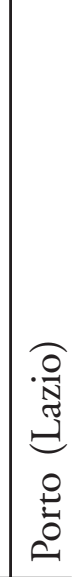 \\
\hline & & & & 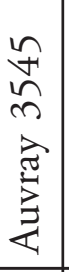 & & 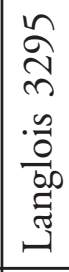 & 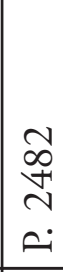 & 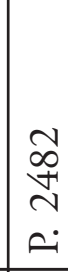 & 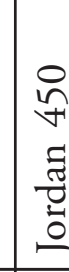 & 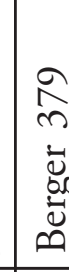 & 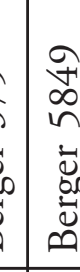 & d & 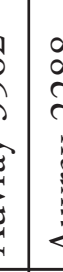 & & & 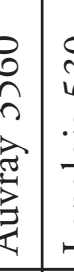 & 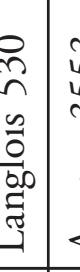 & 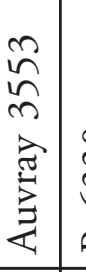 & & 蛋 \\
\hline & & & $\begin{array}{l}8 \\
1 \\
6 \\
6 \\
\end{array}$ & $\vec{x}$ & & 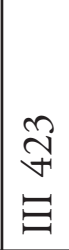 & 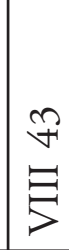 & $\stackrel{\infty}{\stackrel{P}{F}}$ & $\Xi$ & $\begin{array}{l}1 \\
0 \\
0\end{array}$ & $\underset{\square}{\bar{F}}$ & 5 & 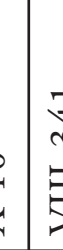 & & $\begin{array}{l}\dot{0} \\
\dot{x}\end{array}$ & $\begin{array}{c}x_{x} \\
3\end{array}$ & $\begin{array}{c}\infty \\
\stackrel{m}{\infty}\end{array}$ & $\underset{x}{\simeq}$ & & $\underset{x}{x}$ \\
\hline & & & & 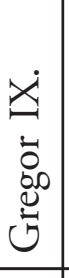 & 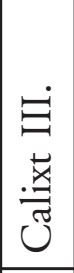 & 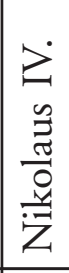 & 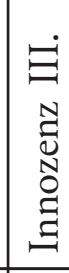 & 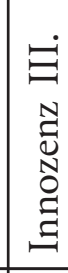 & $\begin{array}{l}\dot{z} \\
\tilde{\Xi} \\
\tilde{\Xi} \\
\tilde{U} \\
\end{array}$ & 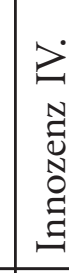 & 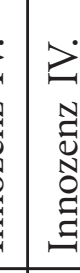 & $\check{z}$ & $>$ & $\begin{array}{ll} \\
\vdots \\
0\end{array}$ & 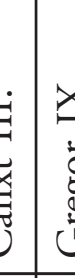 & 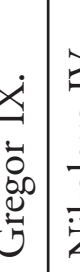 & 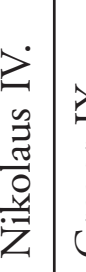 & 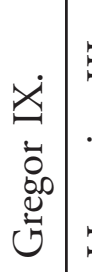 & & 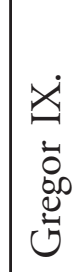 \\
\hline & & & & 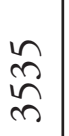 & 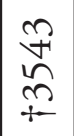 & 单 & 胥 & $\underset{\sim}{\mathbb{N}}$ & $\stackrel{2}{\tilde{n}}$ & 点 & 5 & 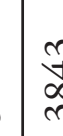 & & {$\left[\begin{array}{l}\mathbb{D} \\
\infty \\
\infty\end{array}\right.$} & 0 & 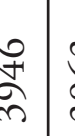 & 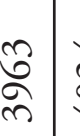 & & & 灾 \\
\hline & & & & & $\stackrel{\infty}{\rightarrow}$ & - & 2 & 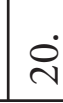 & $\pi$ & i & & & & 10 & $\dot{v}$ & $\therefore$ & 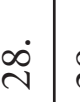 & iे & & \\
\hline
\end{tabular}




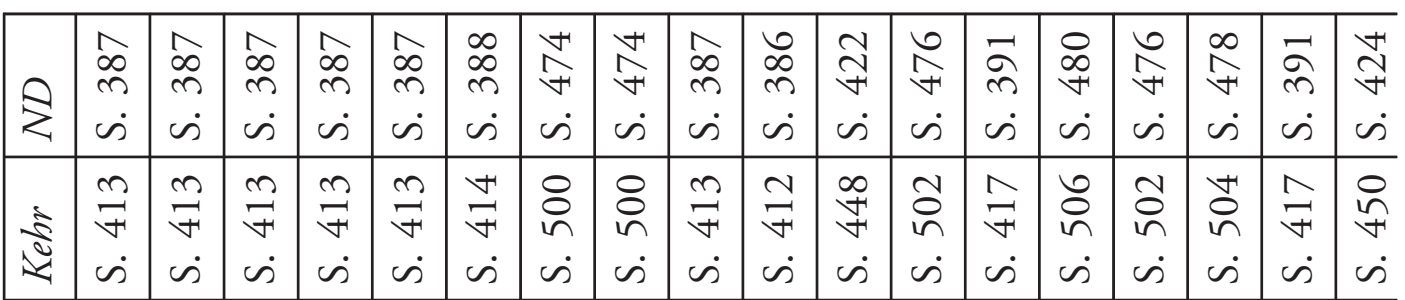

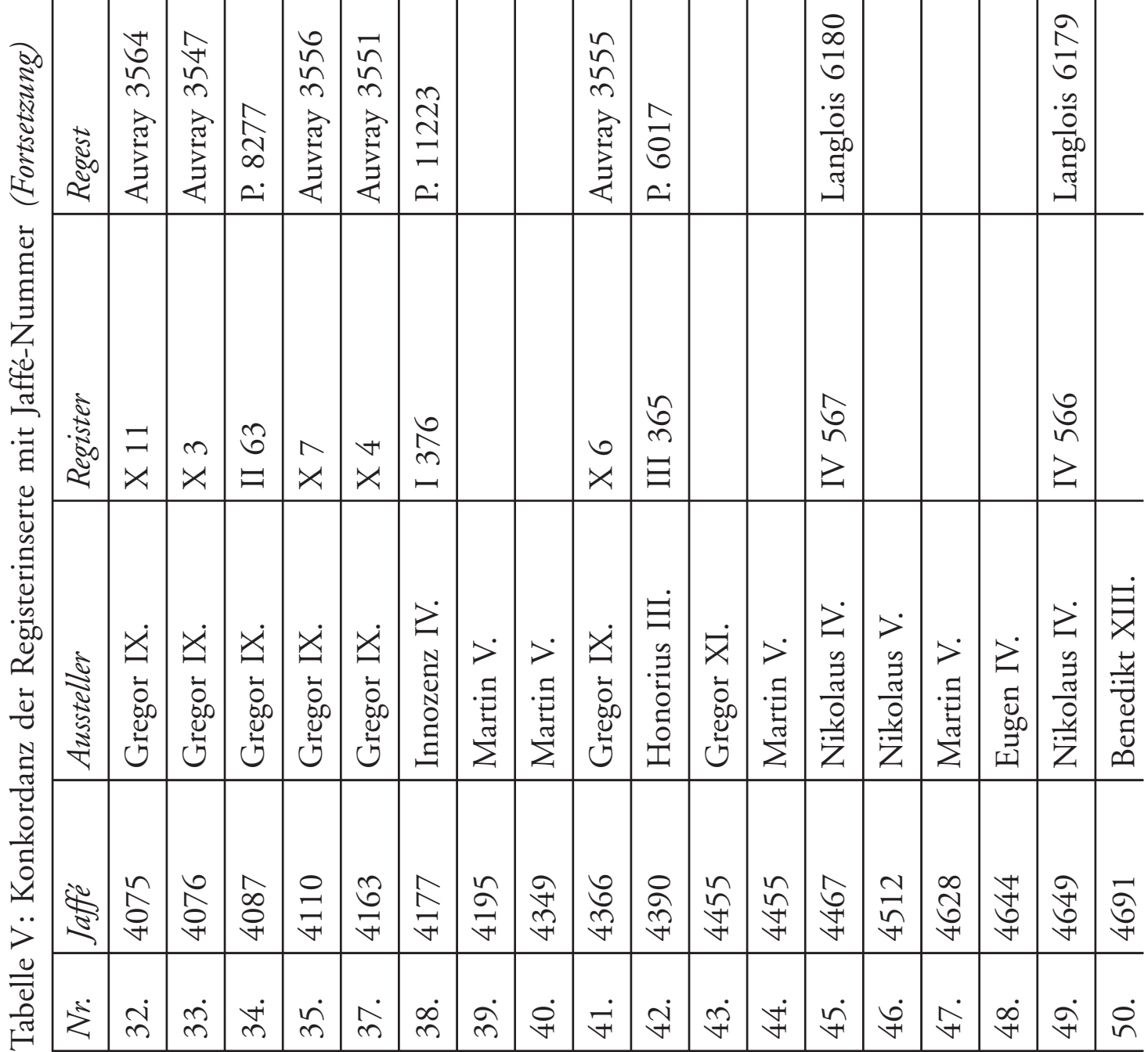

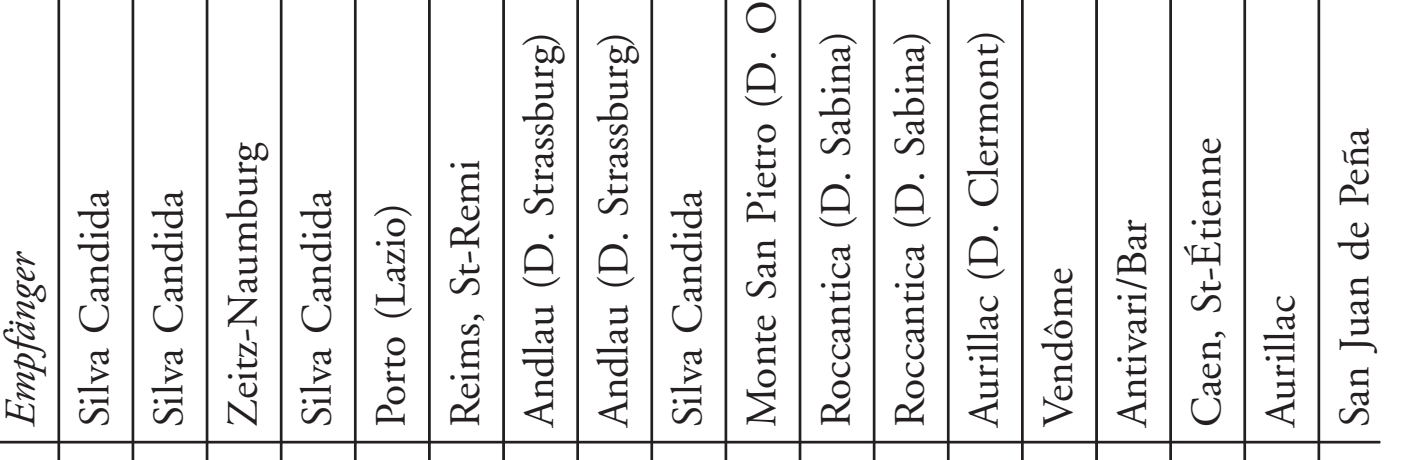

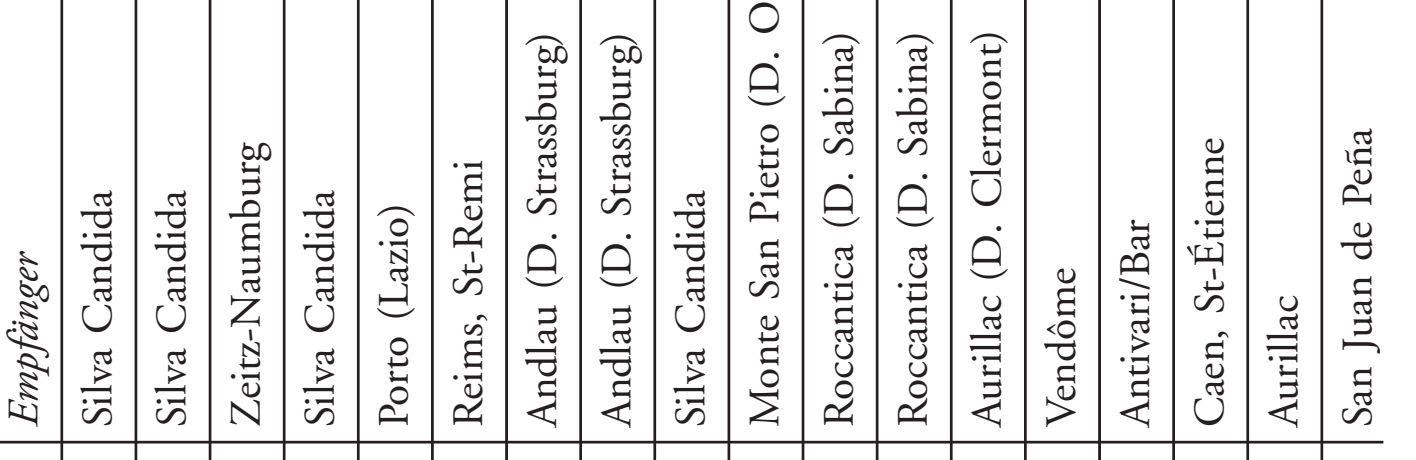
ह

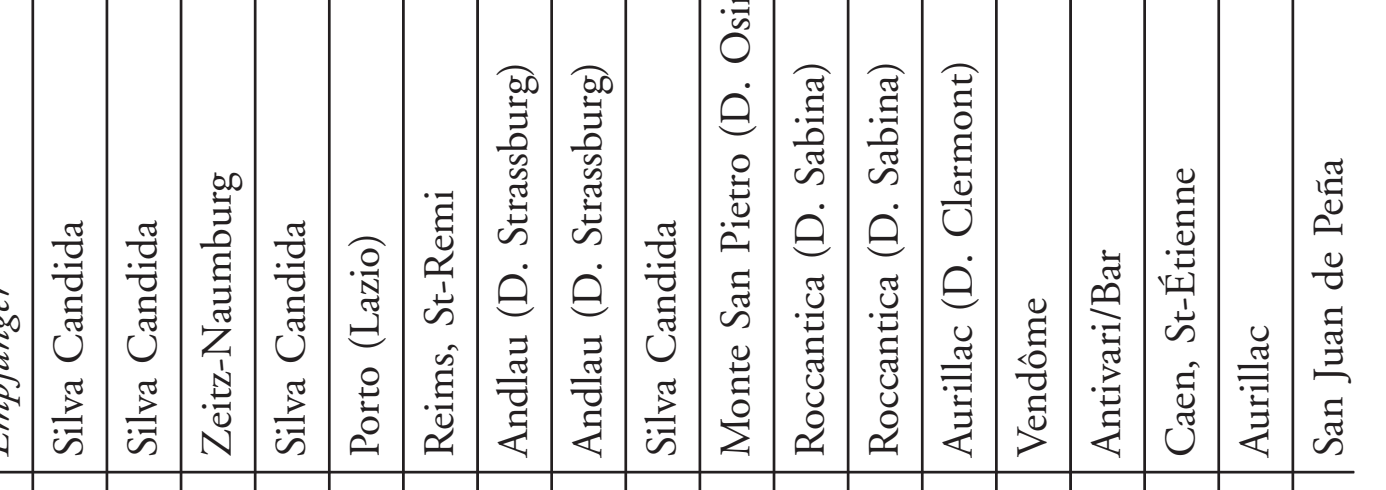

ิㅗำ 


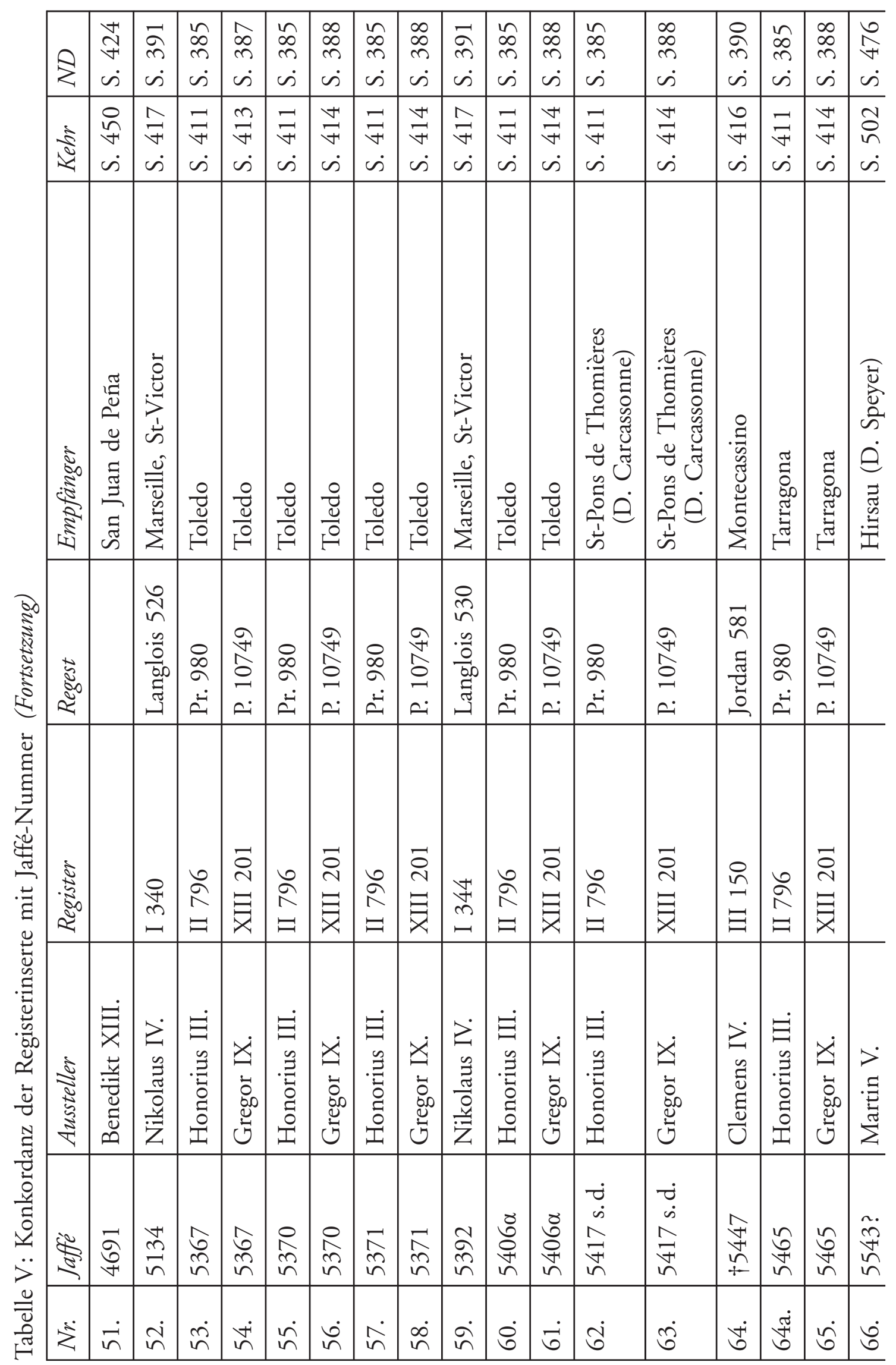




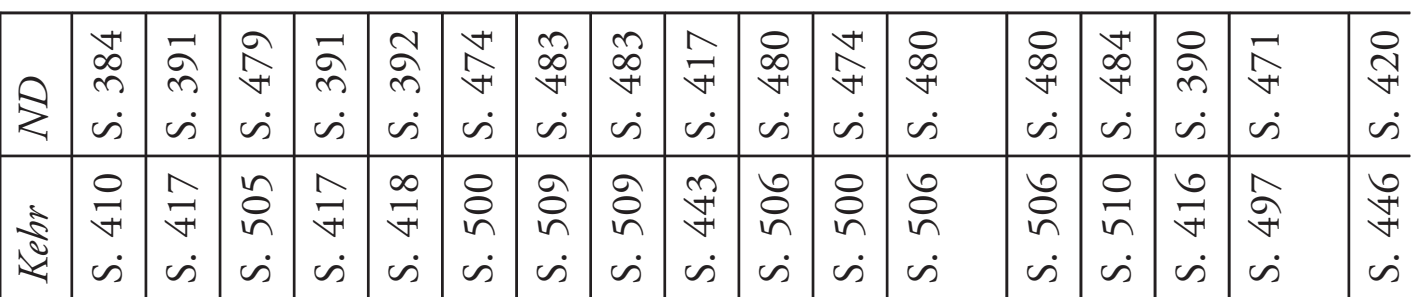

\begin{tabular}{|c|c|c|c|c|c|c|c|c|c|c|c|c|c|c|c|c|c|}
\hline 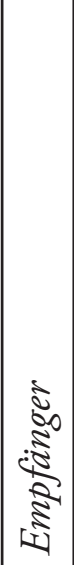 & 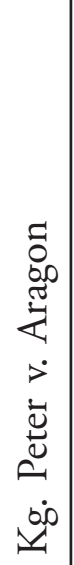 & 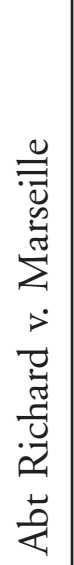 & 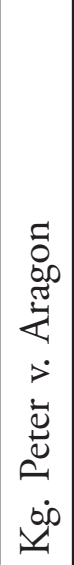 & 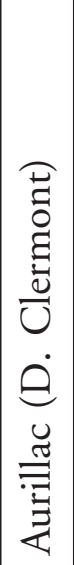 & 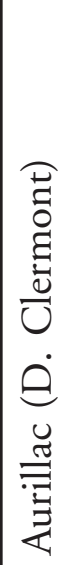 & 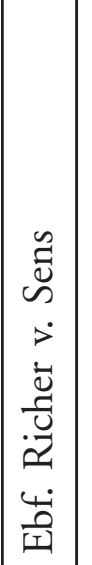 & 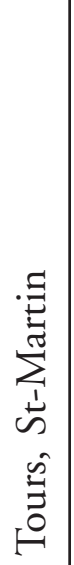 & 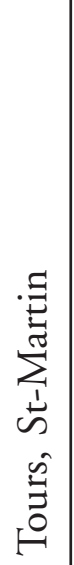 & 预 & $\begin{array}{l}\tilde{0} \\
0 \\
0 \\
0 \\
0 \\
0\end{array}$ & 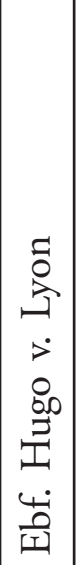 & 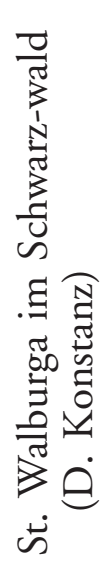 & 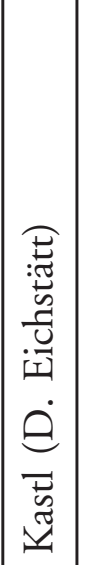 & 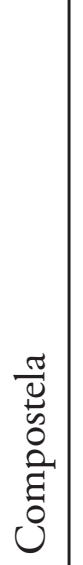 & 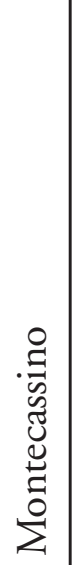 & 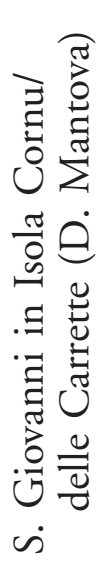 & 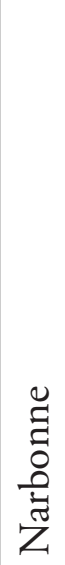 \\
\hline 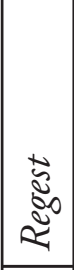 & 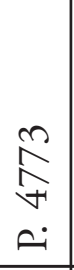 & 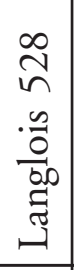 & & 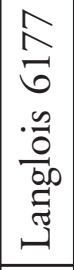 & 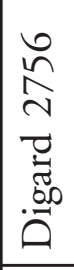 & & & & & & & & & & 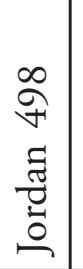 & & \\
\hline 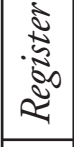 & $\begin{array}{l}2 \\
\dot{x} \\
2\end{array}$ & $\begin{array}{c}\mathcal{N} \\
\stackrel{2}{\varpi} \\
\end{array}$ & & \begin{tabular}{l}
\multirow{2}{}{} \\
$\curvearrowleft$ \\
$Z$ \\
\end{tabular} & $\begin{array}{l}\frac{n}{n} \\
5\end{array}$ & & & & & & & & & & $\begin{array}{l}\hat{\sigma} \\
\Xi\end{array}$ & & \\
\hline 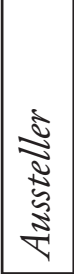 & 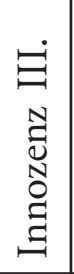 & 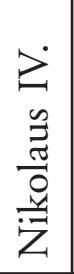 & 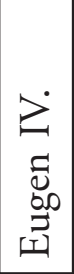 & 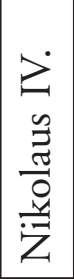 & 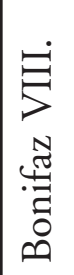 & 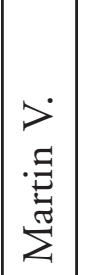 & 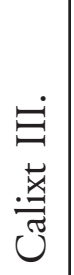 & 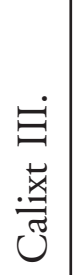 & 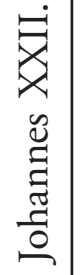 & 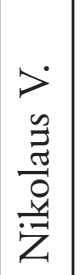 & 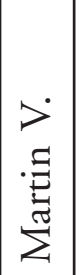 & 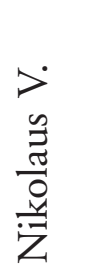 & 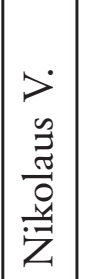 & $\begin{array}{l}\dot{A} \\
\stackrel{0}{\Xi} \\
\dot{\theta}\end{array}$ & 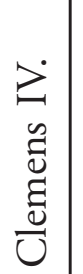 & 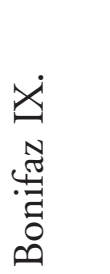 & 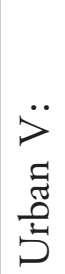 \\
\hline 透 & $\begin{array}{l}\tilde{n} \\
n \\
n\end{array}$ & $\begin{array}{l}8 \\
i n \\
n\end{array}$ & $\begin{array}{l}\tilde{\sigma} \\
\tilde{n} \\
n\end{array}$ & $\begin{array}{l}\tilde{0} \\
\tilde{n}\end{array}$ & $\begin{array}{l}\tilde{0} \\
\tilde{n}\end{array}$ & $\begin{array}{l}8 \\
0 \\
0 \\
n\end{array}$ & $\begin{array}{l}\text { त్ర } \\
\stackrel{n}{n}\end{array}$ & $\begin{array}{l}\overrightarrow{\widetilde{b}} \\
\curvearrowleft\end{array}$ & $\begin{array}{l}\text { ज্े } \\
\text { }\end{array}$ & $\begin{array}{l}2 \\
\infty \\
n \\
n\end{array}$ & $\mid \begin{array}{l}\infty \\
\infty \\
n \\
n\end{array}$ & $\begin{array}{l}\stackrel{0}{n} \\
\stackrel{n}{n}\end{array}$ & $\overrightarrow{\hat{n}}$ & $\begin{array}{l}\text { 우 } \\
\text { ñ }\end{array}$ & $\begin{array}{l}\circ \\
\stackrel{0}{0}\end{array}$ & $\underset{\tilde{n}}{\tilde{\sigma}}$ & $\begin{array}{l}\hat{n} \\
\sigma\end{array}$ \\
\hline$\dot{z}$ & ते & $\dot{\infty}$ & $\dot{\sigma}$ & $\dot{R}$ & $\dot{R}$ & $\stackrel{i}{i}$ & $\dot{N}$ & $\stackrel{+}{\wedge}$ & $\dot{n}$ & $\stackrel{0}{n}$ & $\stackrel{\wedge}{\wedge}$ & $\stackrel{\infty}{\wedge}$ & $\stackrel{R}{\circ}$ & $\dot{\infty}$ & $\dot{\infty}$ & 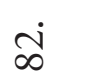 & $\dot{\infty}$ \\
\hline
\end{tabular}




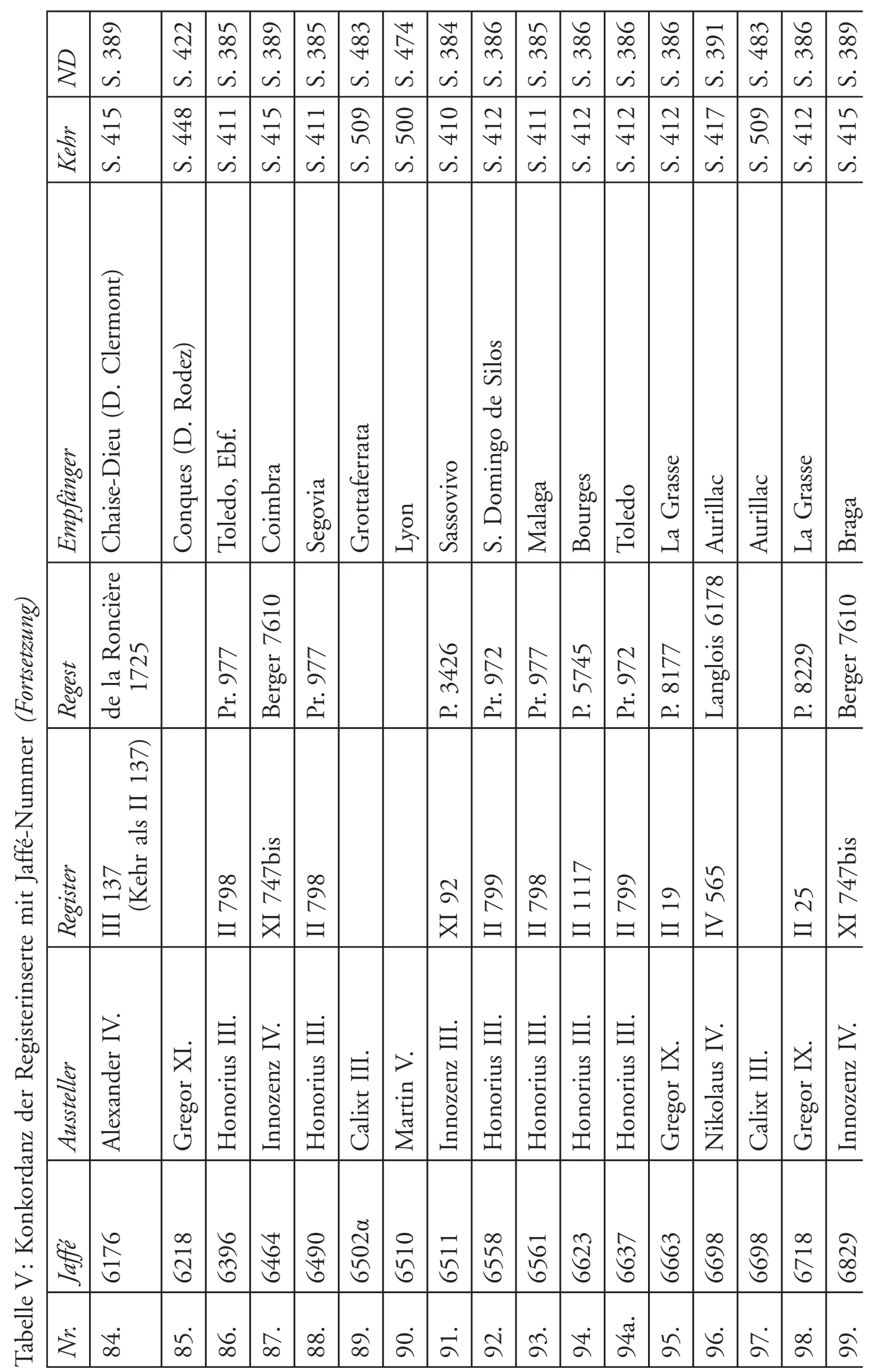




\begin{tabular}{|c|c|c|c|c|c|c|c|c|c|c|c|c|c|c|c|c|}
\hline$\stackrel{\gtrless}{z}$ & $\begin{array}{l}\stackrel{\infty}{\infty} \\
\dot{m} \\
\dot{\omega}\end{array}$ & $\begin{array}{l}\hat{\tilde{n}} \\
\dot{\omega}\end{array}$ & $\begin{array}{l}\widetilde{F} \\
\dot{f} \\
\dot{s}\end{array}$ & $\begin{array}{l}\stackrel{+}{f} \\
\dot{f} \\
\dot{\omega}\end{array}$ & $\begin{array}{l}\infty \\
\& \\
+ \\
\dot{\infty} \\
\dot{\infty}\end{array}$ & $\begin{array}{l}\tilde{J} \\
\dot{H} \\
\dot{s}\end{array}$ & $\begin{array}{l}\overrightarrow{\tilde{n}} \\
\dot{\omega}\end{array}$ & $\begin{array}{l}\hat{\infty} \\
\tilde{m} \\
\dot{\omega}\end{array}$ & $\begin{array}{l}\text { శै } \\
\dot{s}\end{array}$ & $\begin{array}{l}\overrightarrow{7} \\
\dot{\forall} \\
\dot{s}\end{array}$ & $\begin{array}{l}\hat{\kappa} \\
\hat{f} \\
\dot{v}\end{array}$ & $\begin{array}{l}\vec{\sigma} \\
\dot{\omega}\end{array}$ & $\begin{array}{l}\overrightarrow{\vec{\gamma}} \\
\dot{\omega}\end{array}$ & $\mid \begin{array}{l}\infty \\
\infty \\
+ \\
\dot{p}\end{array}$ & 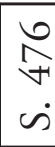 & \\
\hline 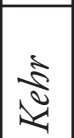 & $\begin{array}{l}\underset{y}{F} \\
\dot{s} \\
\dot{s}\end{array}$ & $\begin{array}{l}\infty \\
\vec{\forall} \\
\dot{v}\end{array}$ & \begin{tabular}{l}
$\infty$ \\
\multirow{+}{+}{} \\
$\dot{\sim}$
\end{tabular} & $\begin{array}{l}8 \\
i n \\
\dot{n}\end{array}$ & $\begin{array}{l}8 \\
\text { in } \\
\dot{s}\end{array}$ & \begin{tabular}{l}
$\infty$ \\
\multirow{+}{*}{} \\
$\forall$ \\
$\dot{v}$
\end{tabular} & $\begin{array}{l}\vec{F} \\
\forall \\
\dot{s}\end{array}$ & $\begin{array}{l}m \\
F \\
\dot{m}\end{array}$ & $\begin{array}{l}\stackrel{\vartheta}{f} \\
\dot{f} \\
\dot{s}\end{array}$ & $\begin{array}{l}\stackrel{8}{f} \\
\dot{s}\end{array}$ & $\begin{array}{l}\vec{\circ} \\
n \\
\dot{m}\end{array}$ & $\begin{array}{l}\vec{\gamma} \\
\dot{\omega}\end{array}$ & $\begin{array}{l}\stackrel{f}{f} \\
\dot{s}\end{array}$ & $\begin{array}{l}\hat{\partial} \\
i n \\
\dot{\omega}\end{array}$ & $\begin{array}{l}\text { Oे } \\
\stackrel{n}{n} \\
\text { is }\end{array}$ & \\
\hline
\end{tabular}

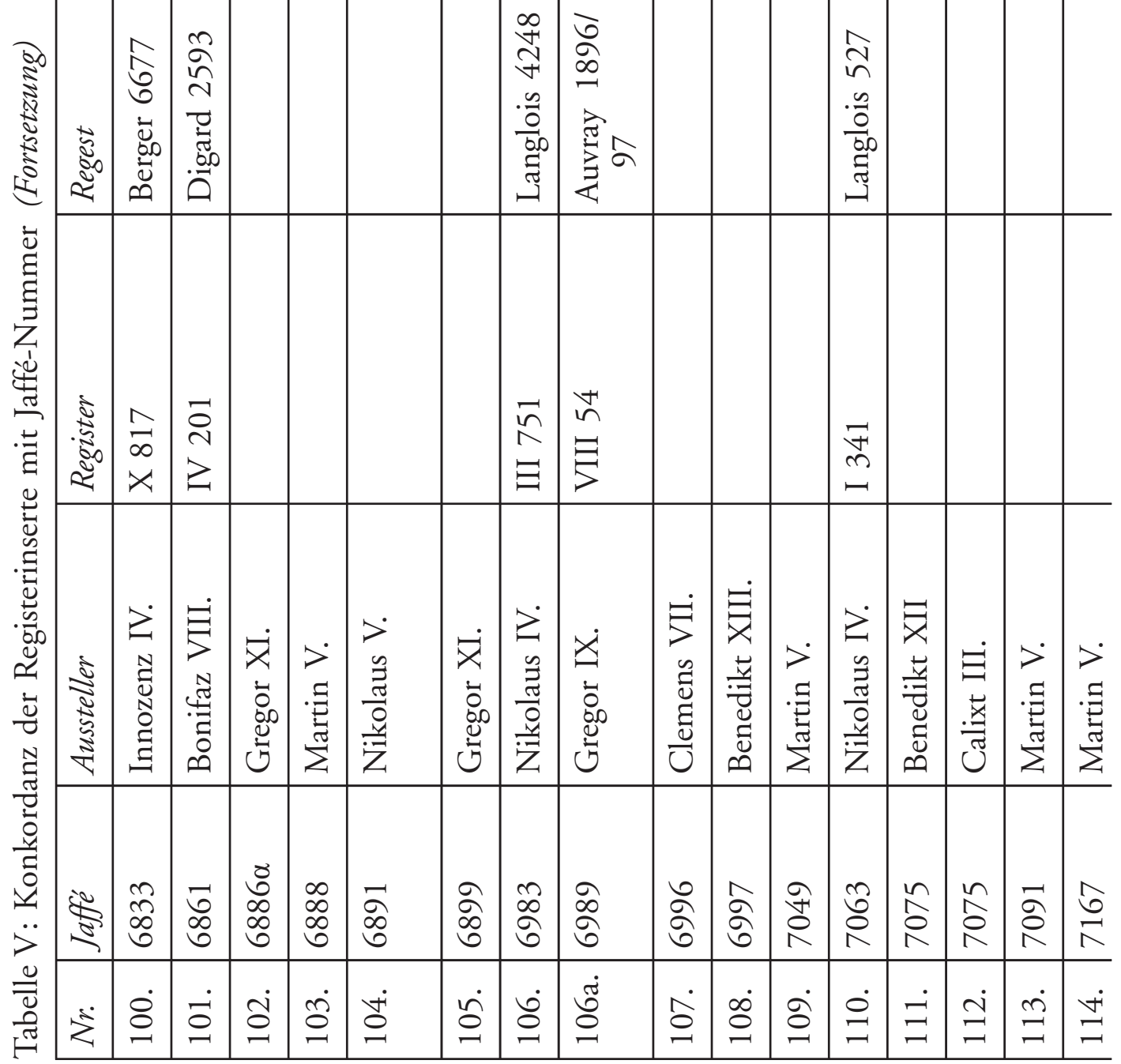




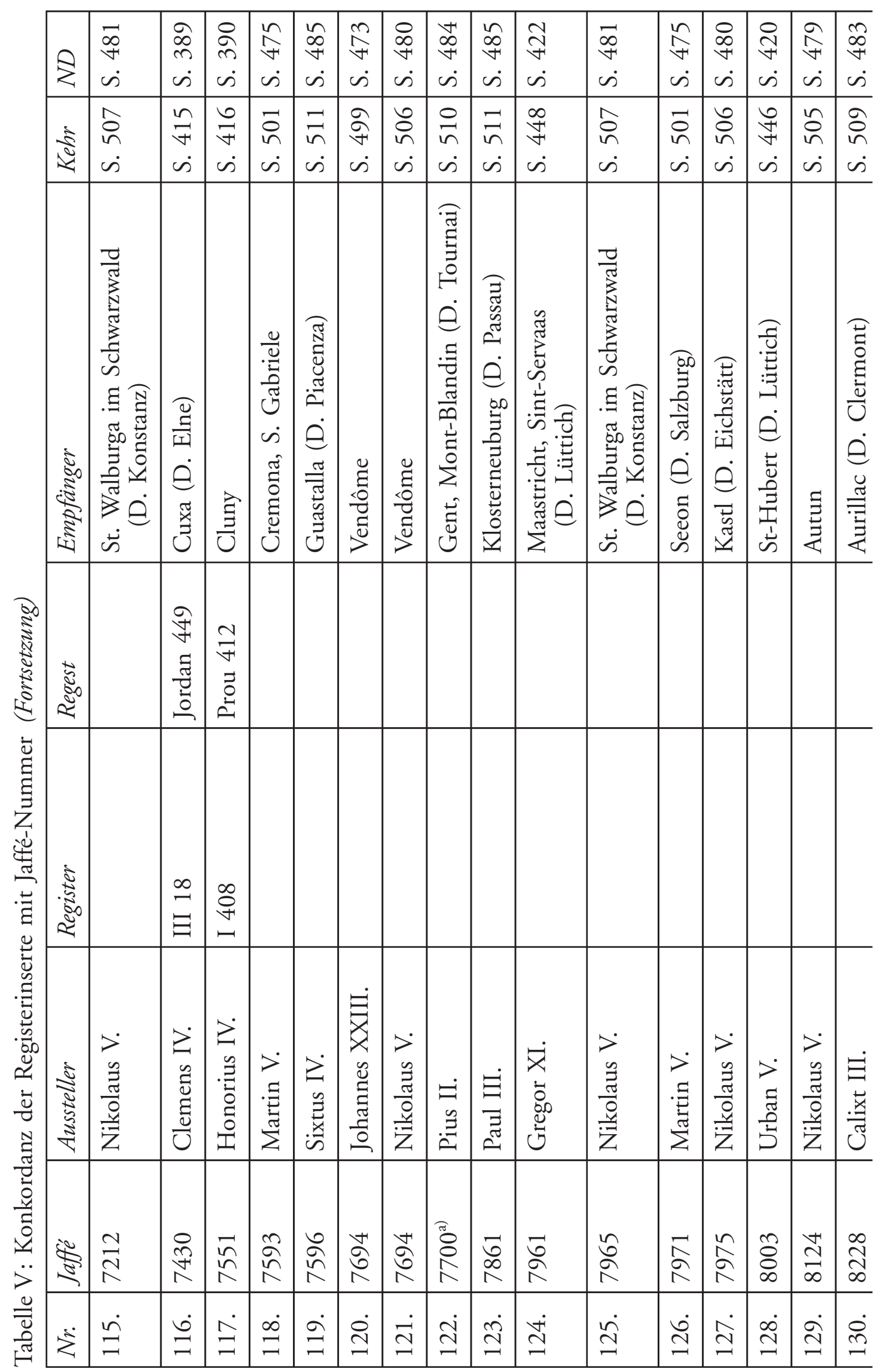




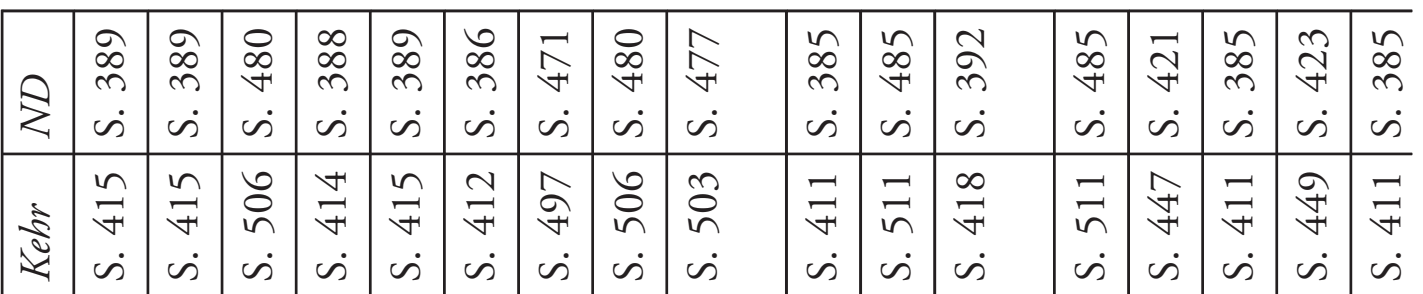

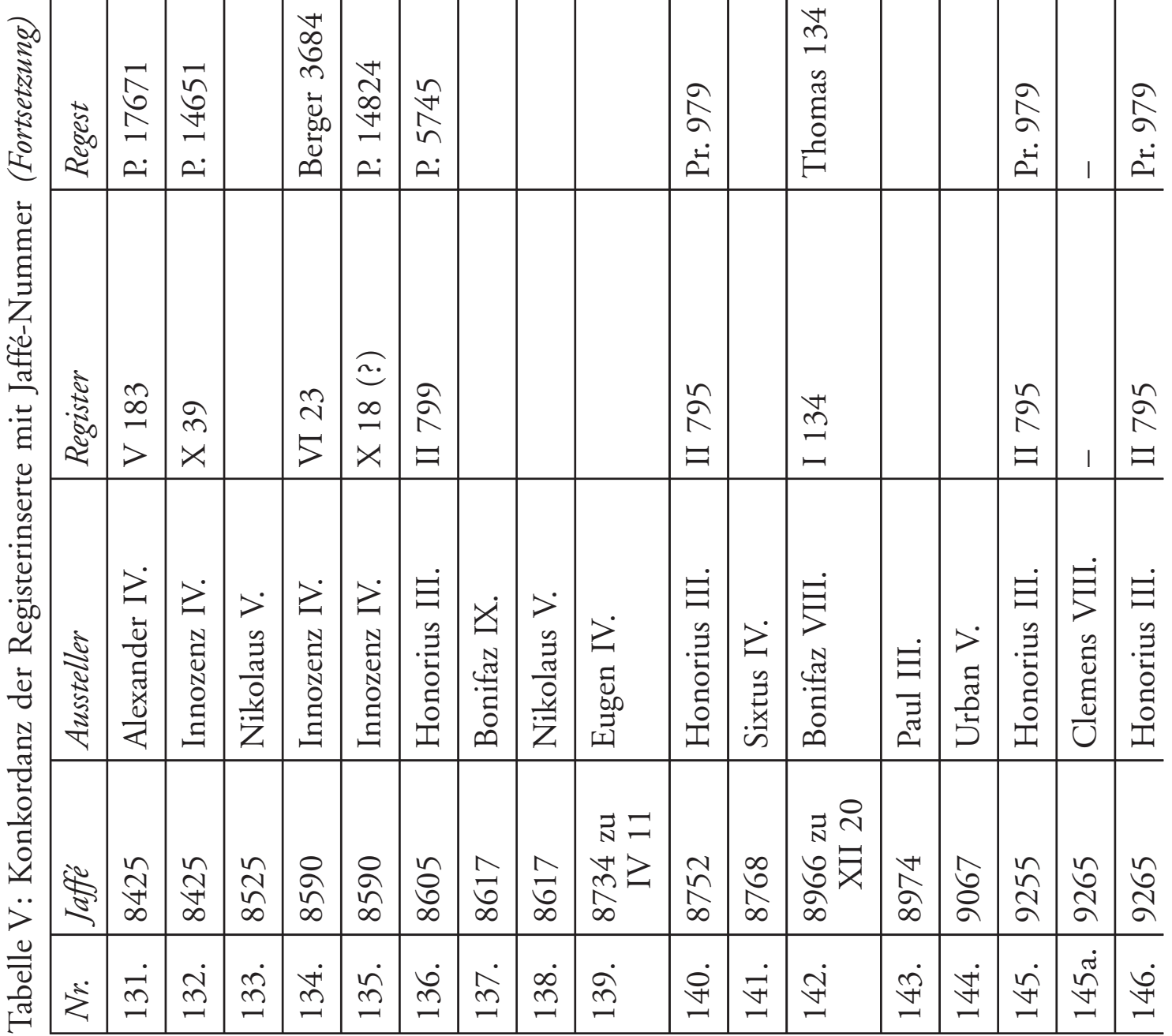




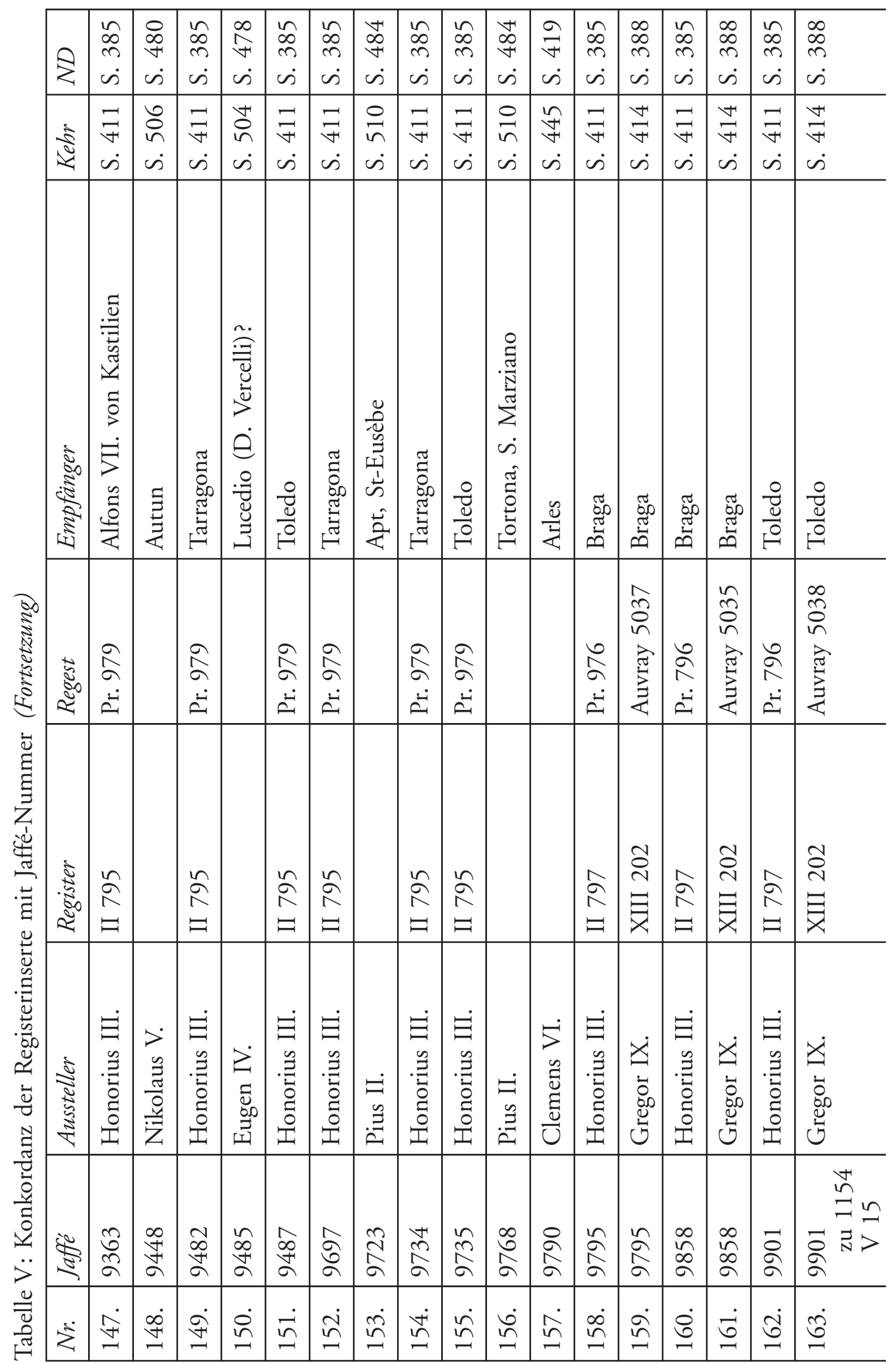




\begin{tabular}{|c|c|c|c|c|c|c|c|c|c|c|c|c|c|c|c|c|c|}
\hline$\stackrel{\gtrless}{\gtrless}$ & $\begin{array}{l}\hat{\psi} \\
\dot{\omega}\end{array}$ & $\begin{array}{l}\infty \\
i \\
\dot{m} \\
\dot{s}\end{array}$ & $\begin{array}{l}\infty \\
\infty \\
i \\
\dot{w}\end{array}$ & $\begin{array}{l}8 \\
\stackrel{\infty}{+} \\
\dot{\sim}\end{array}$ & 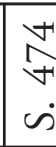 & $\begin{array}{l}\hat{f} \\
\dot{f} \\
\dot{\omega}\end{array}$ & $\mid \begin{array}{l}n \\
\infty \\
m \\
\dot{w}\end{array}$ & $\begin{array}{l}\infty \\
\infty \\
m \\
\dot{m}\end{array}$ & 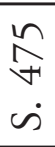 & $\begin{array}{l}\mathbb{N} \\
\forall \\
\dot{v}\end{array}$ & $\begin{array}{l}\hat{f} \\
\dot{s} \\
\dot{s}\end{array}$ & $\begin{array}{l}\vec{\Im} \\
\dot{s}\end{array}$ & $\begin{array}{l}n \\
\infty \\
\infty \\
\dot{m} \\
\dot{s}\end{array}$ & $\begin{array}{l}\infty \\
\infty \\
m \\
\dot{m} \\
\dot{m}\end{array}$ & $\begin{array}{l}\infty \\
\stackrel{+}{+} \\
\dot{s}\end{array}$ & $\begin{array}{l}\stackrel{\vec{D}}{+} \\
\dot{v}\end{array}$ & $\begin{array}{l}+ \\
\infty \\
\dot{m} \\
\dot{m}\end{array}$ \\
\hline 依 & $\begin{array}{l}n \\
\stackrel{n}{n} \\
\dot{n}\end{array}$ & $\begin{array}{l}\vec{\nabla} \\
\dot{s}\end{array}$ & $\begin{array}{l}\underset{\forall}{\forall} \\
\dot{s}\end{array}$ & $\begin{array}{l}\stackrel{8}{ } \\
\text { in } \\
\text { is }\end{array}$ & $\begin{array}{l}8 \\
\text { in } \\
\text { is }\end{array}$ & $\begin{array}{l}\tilde{n} \\
\text { nn } \\
\dot{s}\end{array}$ & $\begin{array}{l}\vec{F} \\
\dot{s}\end{array}$ & $\begin{array}{l}\forall \\
\forall \\
\dot{v}\end{array}$ & $\begin{array}{l}\vec{n} \\
\dot{n} \\
\dot{m}\end{array}$ & 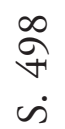 & $\begin{array}{l}n \\
\hat{n} \\
\dot{n}\end{array}$ & $\begin{array}{l}\stackrel{f}{f} \\
\dot{s}\end{array}$ & $\begin{array}{l}\vec{\forall} \\
\dot{s}\end{array}$ & $\begin{array}{l}\vec{\forall} \\
\vec{t} \\
\dot{s}\end{array}$ & $\begin{array}{l}\text { \& } \\
\text { in } \\
\dot{s}\end{array}$ & $\begin{array}{l}\hat{o} \\
\dot{n} \\
\dot{s}\end{array}$ & $\begin{array}{l}\stackrel{\circ}{\forall} \\
\dot{v}\end{array}$ \\
\hline
\end{tabular}

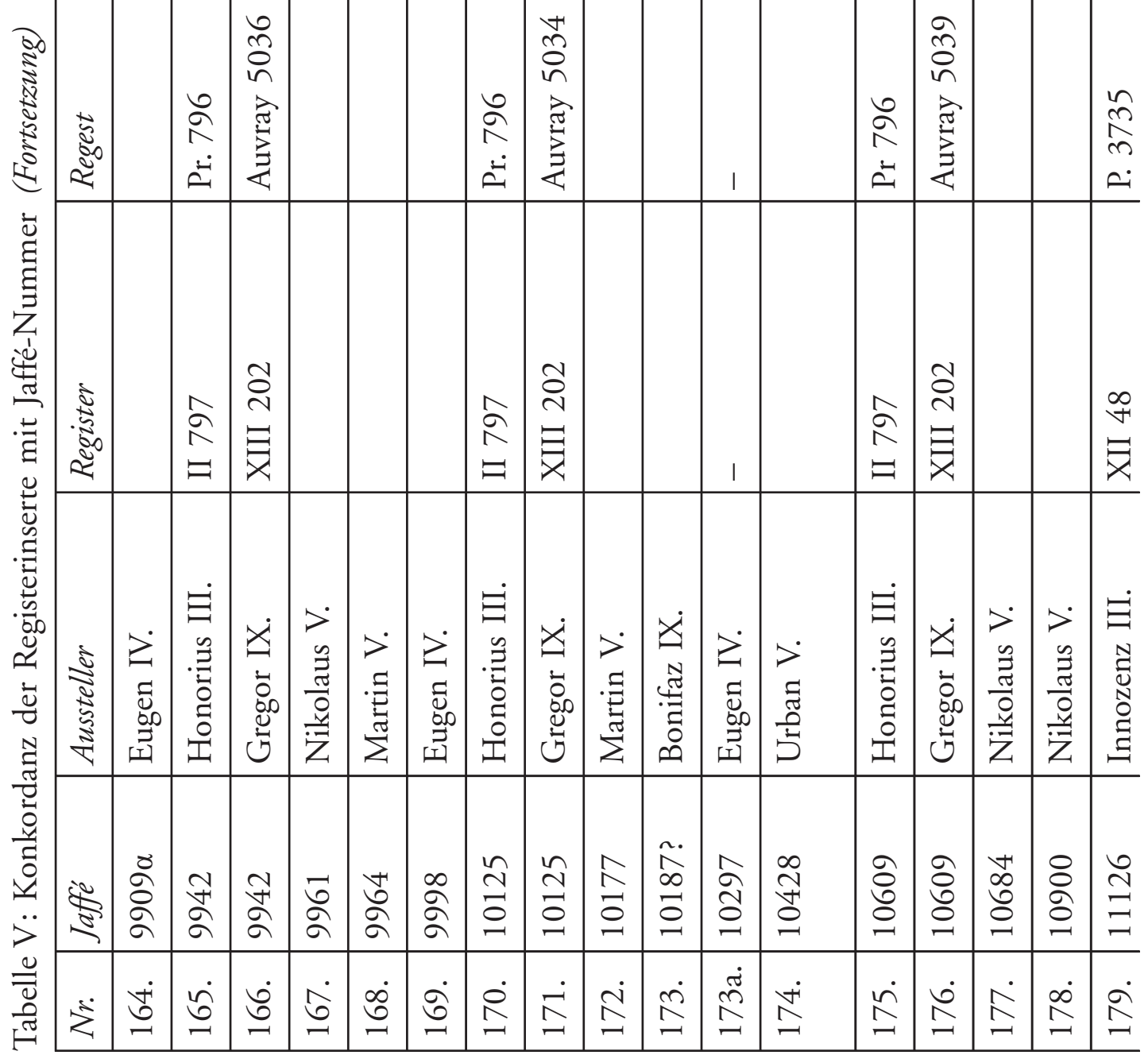


„Verborgene Schätze“. Nichtitalienische Stücke in den „Papsturkunden in Italien“

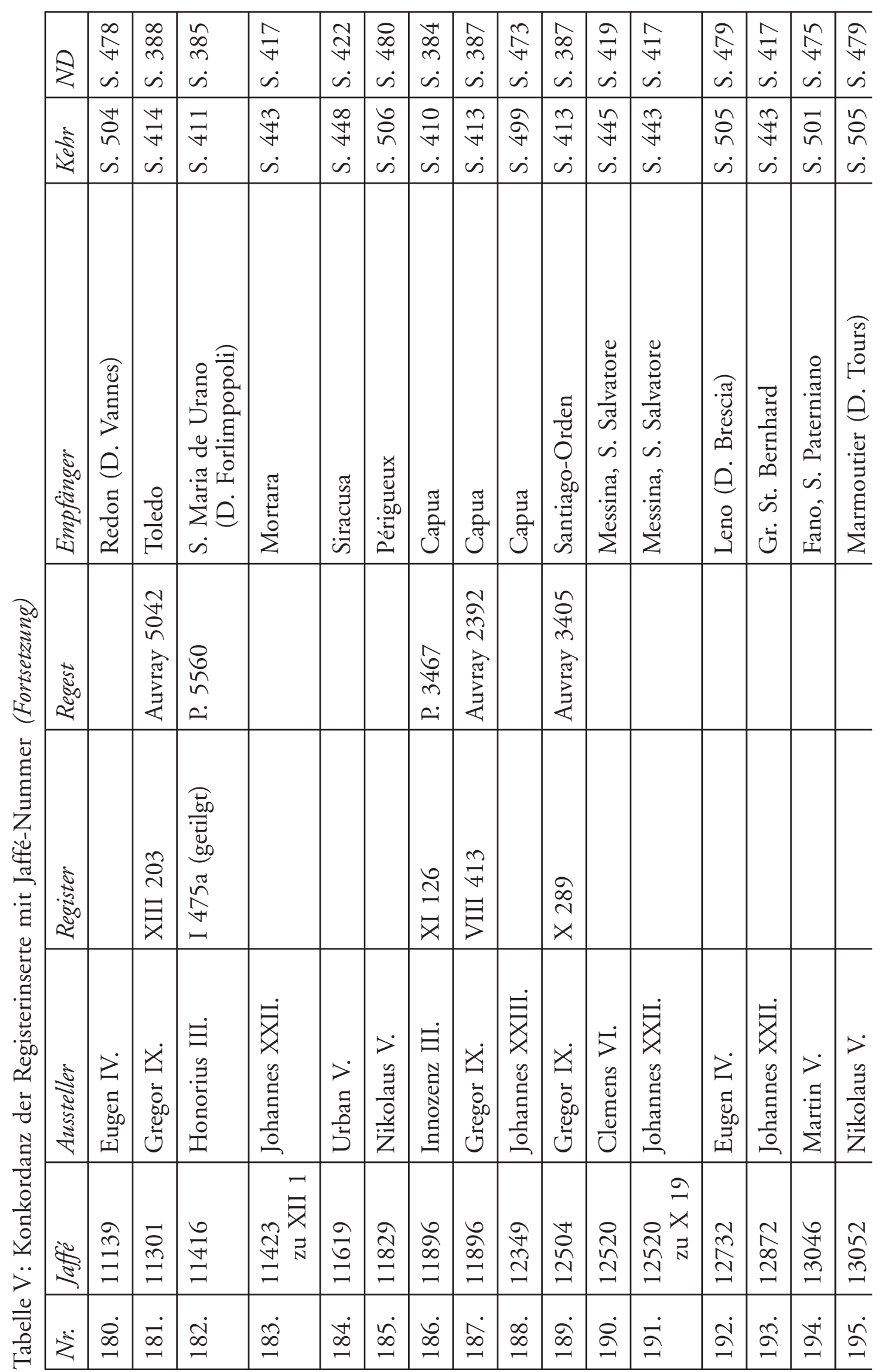




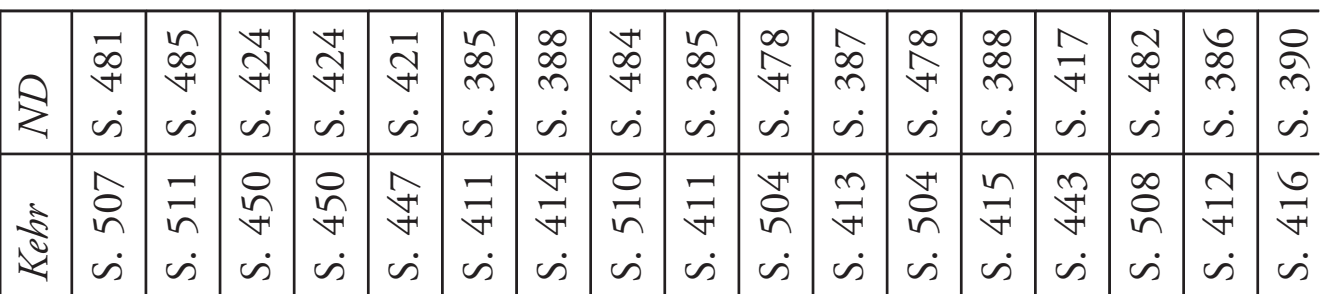

\begin{tabular}{|c|c|c|c|c|c|c|c|c|c|c|c|c|c|c|c|c|c|c|}
\hline & 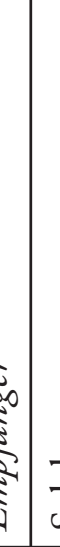 & 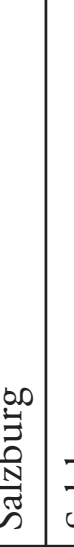 & 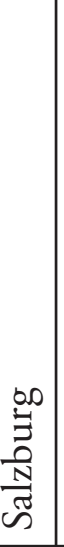 & 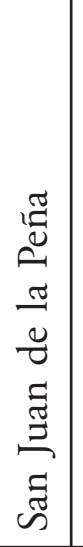 & 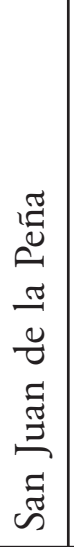 & 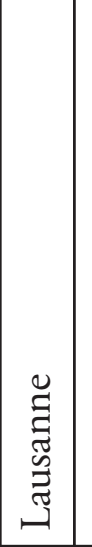 & 苟 & 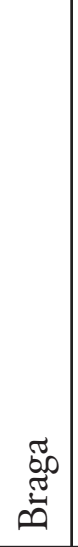 & 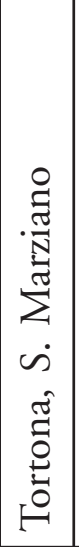 & 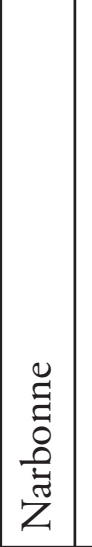 & 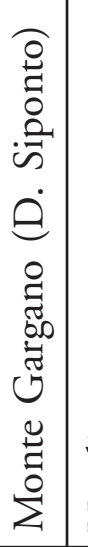 & 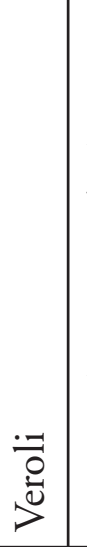 & 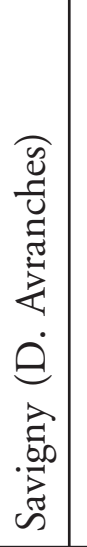 & 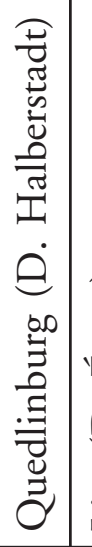 & 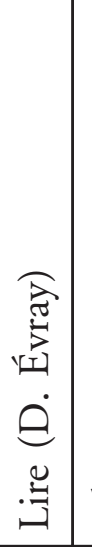 & 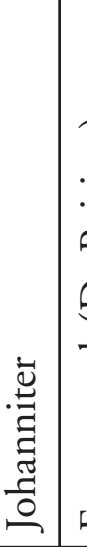 & 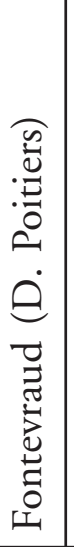 & 氞 \\
\hline & 3 & & & & & & 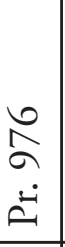 & 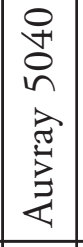 & & 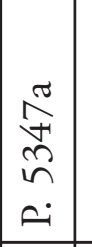 & & 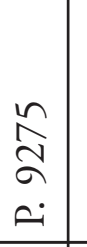 & & $\begin{array}{l}\stackrel{\Xi}{\Xi} \\
\Xi \\
\Delta\end{array}$ & & & $\begin{array}{l}\hat{\hat{n}} \\
\hat{n} \\
\dot{n}\end{array}$ & \begin{tabular}{l}
$\infty$ \\
\multirow{2}{+}{} \\
$\overrightarrow{0}$ \\
$\stackrel{0}{0}$
\end{tabular} \\
\hline & & & & & & & $\begin{array}{l}\hat{\curvearrowright} \\
= \\
=\end{array}$ & $\begin{array}{l}\text { c) } \\
\text {. } \\
\text { 齐 }\end{array}$ & & (5) & & $\begin{array}{l}\infty \\
\stackrel{\infty}{\infty} \\
\stackrel{F}{\mid}\end{array}$ & & $\begin{array}{l}\text { సे } \\
\text { 当 }\end{array}$ & & & $\begin{array}{l}\stackrel{\infty}{\tilde{\sim}} \\
\underset{v}{u}\end{array}$ & 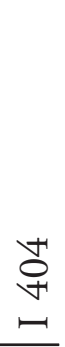 \\
\hline & & 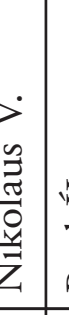 & 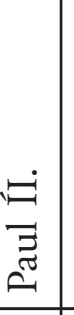 & 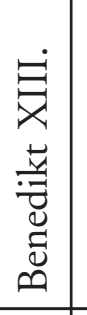 & 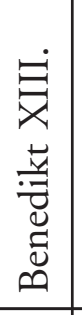 & 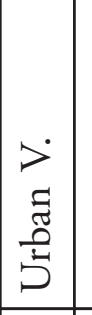 & 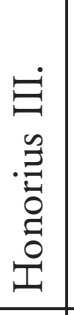 & \begin{tabular}{|c|}
$\dot{x}$ \\
$\vec{b}$ \\
$\dot{0}$ \\
$\dot{0}$ \\
$\dot{U}$
\end{tabular} & 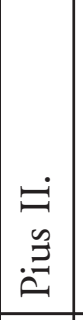 & 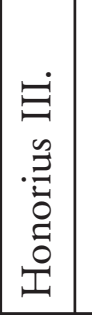 & 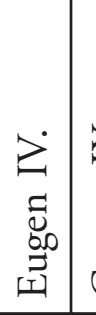 & $\begin{array}{l}x \\
\ddot{u} \\
\overrightarrow{0} \\
\dot{0} \\
\dot{U}\end{array}$ & 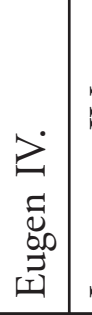 & 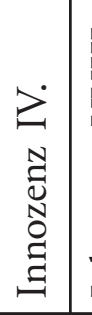 & 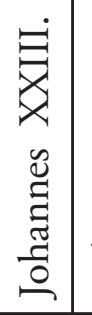 & 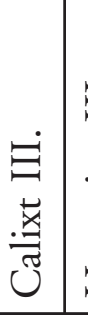 & 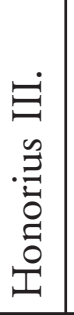 & 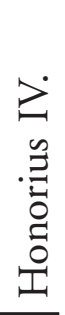 \\
\hline & & $\begin{array}{l}\infty \\
\infty \\
n \\
n\end{array}$ & $\begin{array}{l}\infty \\
\infty \\
\ddot{n}\end{array}$ & 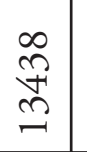 & \begin{tabular}{l}
$\infty$ \\
\multirow{2}{*}{} \\
$\stackrel{2}{\sim}$
\end{tabular} & $\begin{array}{l}\stackrel{n}{\sim} \\
\stackrel{\sim}{\sim}\end{array}$ & 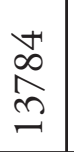 & $\mid \begin{array}{l}+ \\
\infty \\
2 \\
2\end{array}$ & $\begin{array}{l}\stackrel{8}{n} \\
\stackrel{\sim}{\Xi} \\
\Xi\end{array}$ & $\begin{array}{l}\stackrel{\Xi}{\mathbb{Z}} \\
\underset{\sim}{\mid}\end{array}$ & $\begin{array}{l}\underset{J}{\Xi} \\
\underset{\Xi}{*}\end{array}$ & $\begin{array}{l}\mho \\
\approx \\
\approx\end{array}$ & $\begin{array}{l}\stackrel{\infty}{\mathbb{N}} \\
\underset{J}{\sim}\end{array}$ & \begin{tabular}{l}
$\hat{n}$ \\
\multirow{\pm}{\pm}{}
\end{tabular} & $\begin{array}{l}\vec{\circ} \\
\stackrel{+}{ \pm}\end{array}$ & $\begin{array}{l}a \\
\stackrel{\Xi}{ \pm} \\
\stackrel{\sigma}{2}\end{array}$ & $\begin{array}{l}n \\
\tilde{o} \\
n \\
n\end{array}$ & 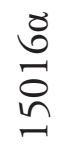 \\
\hline & & $\Xi$ & $\lesssim$ & $\stackrel{\infty}{\beth}$ & 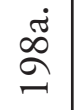 & $\stackrel{2}{\Omega}$ & $\vec{\sim}$ & రิ & సิ & 坣 & $\stackrel{n}{\tilde{N}}$ & $\underset{\sim}{\stackrel{\sim}{~}}$ & $\stackrel{\tilde{\nu}}{ }$ & $\stackrel{\infty}{\stackrel{\sim}{\sim}}$ & 离 & ڤ્े & $\stackrel{\dot{\vec{v}}}{\vec{v}}$ & $\dot{\vec{v}}$ \\
\hline
\end{tabular}




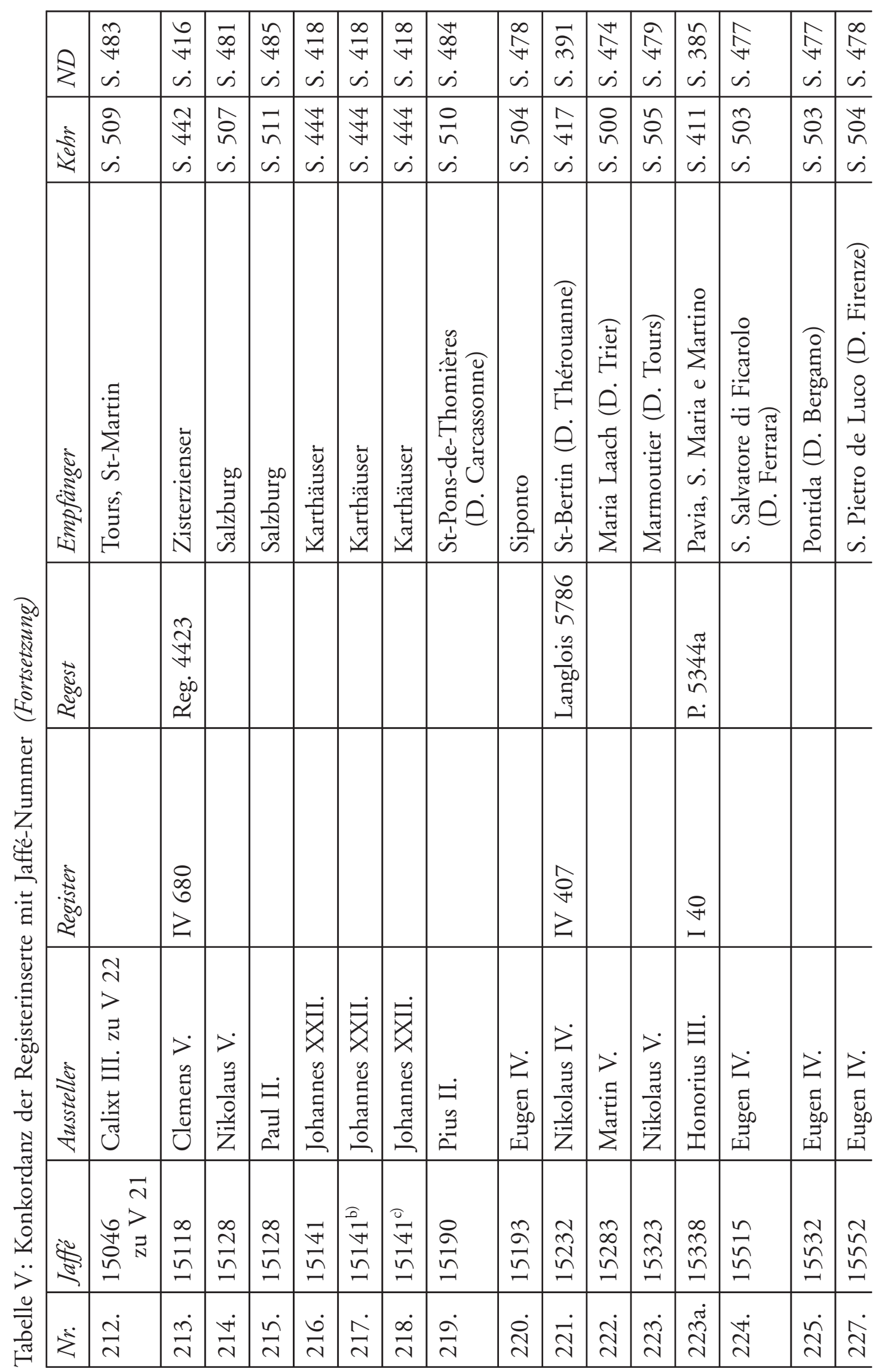




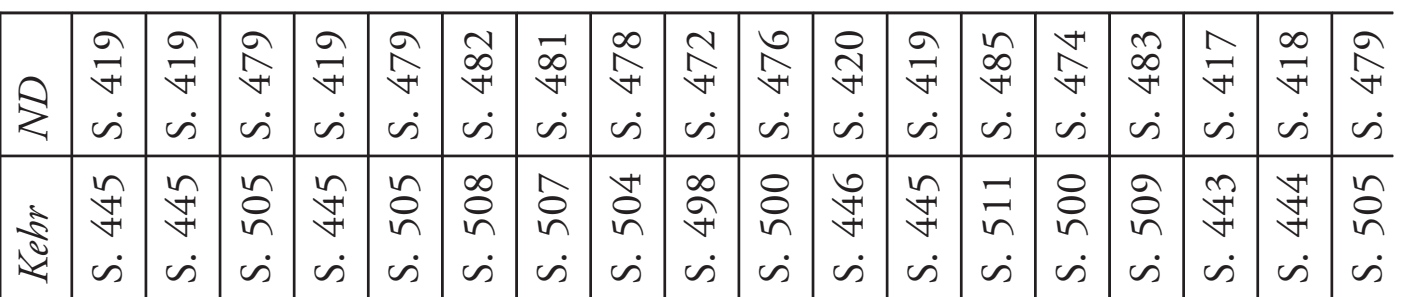

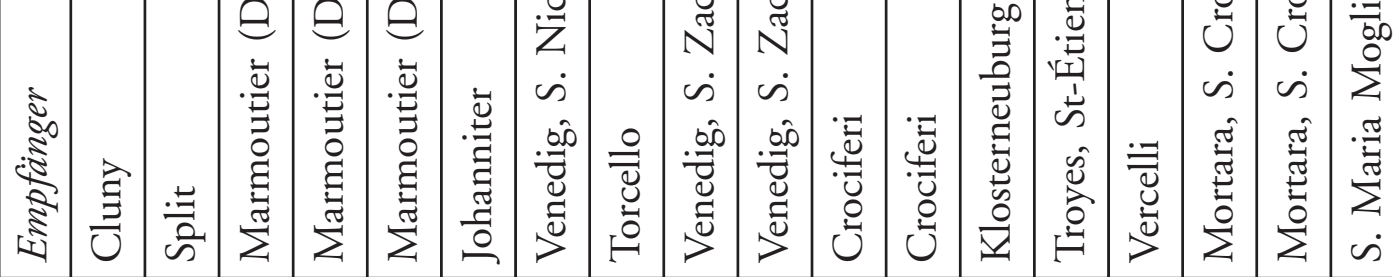

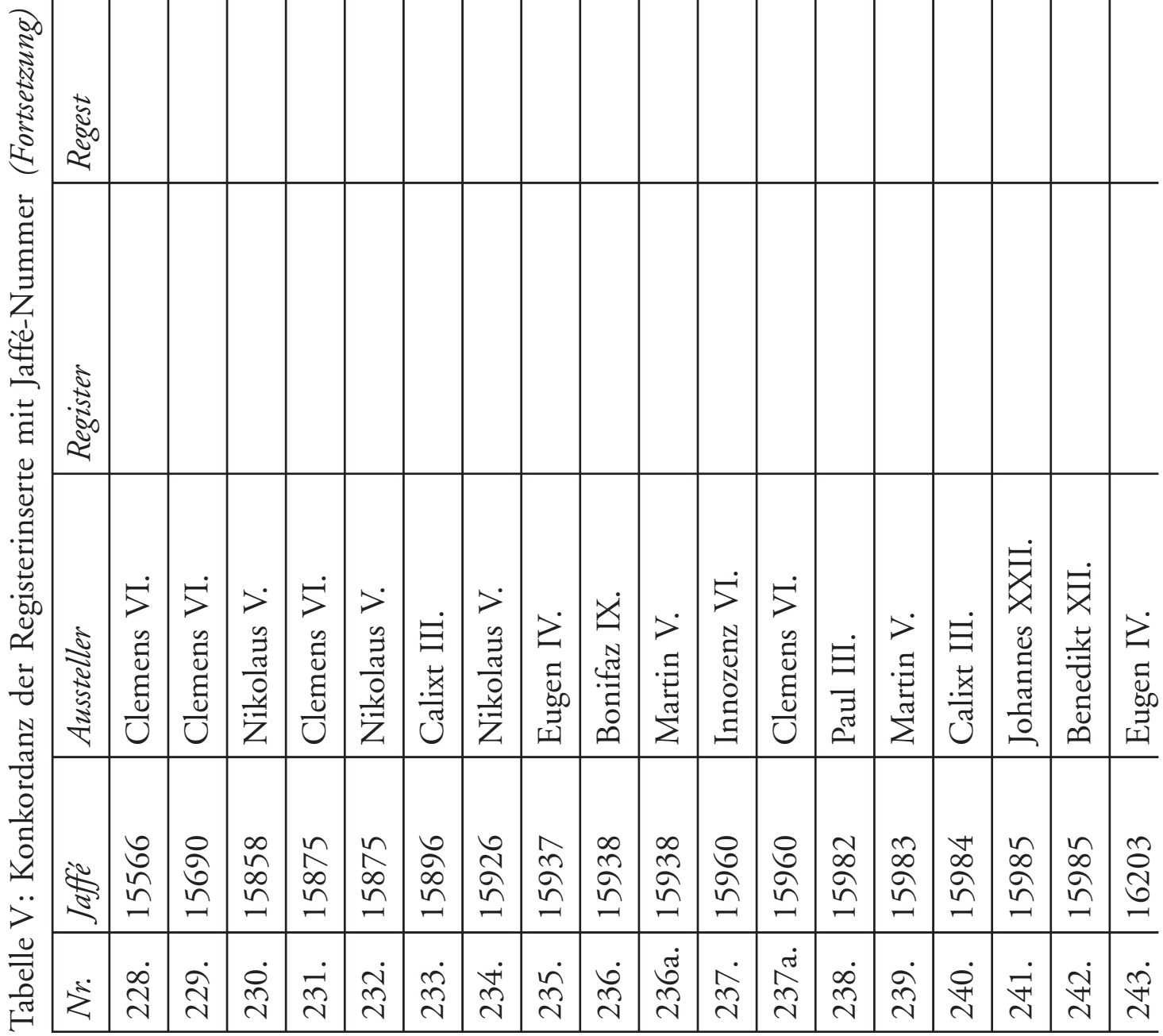


„Verborgene Schätze“. Nichtitalienische Stücke in den „Papsturkunden in Italien“ 501

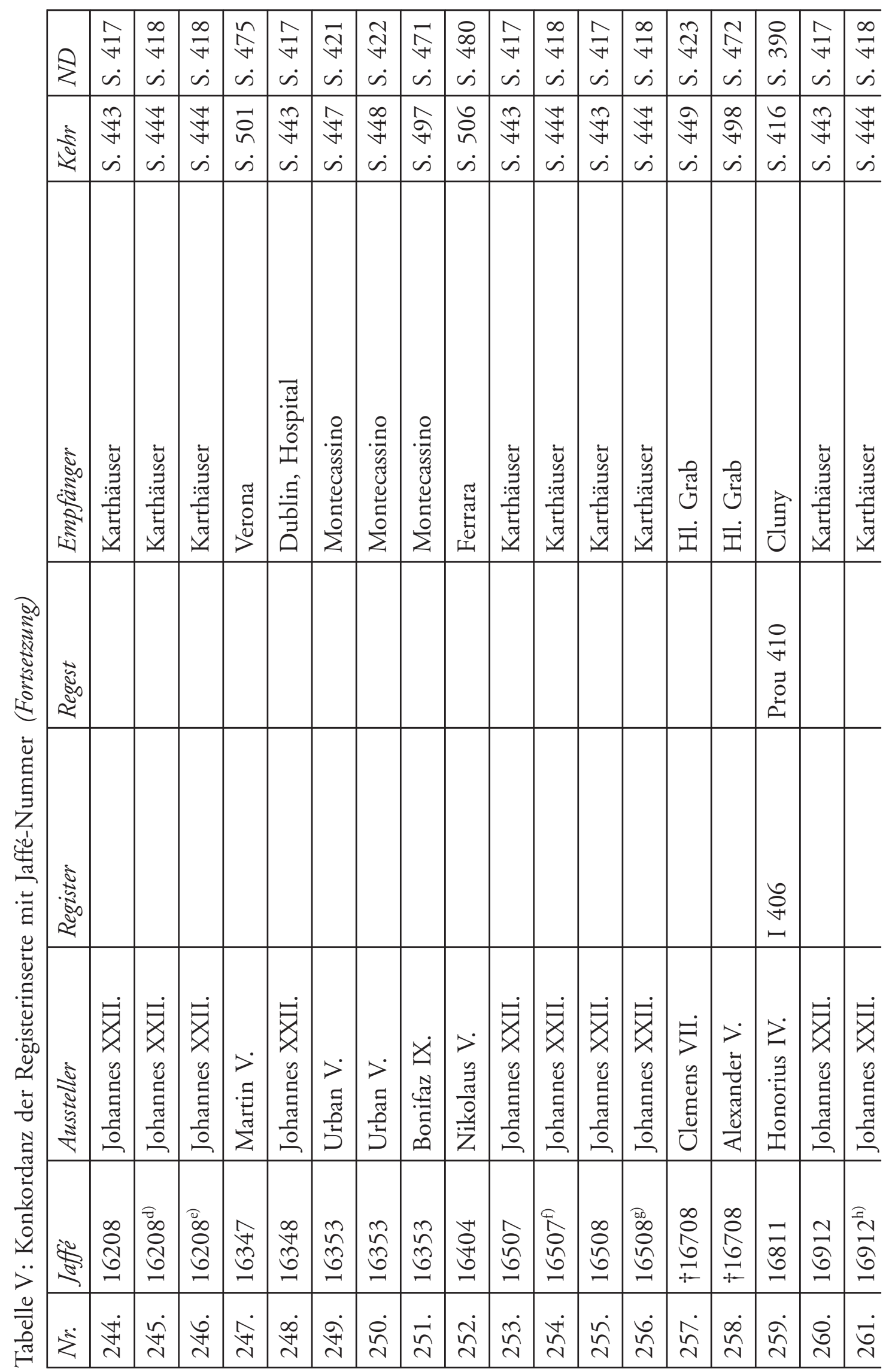




\begin{tabular}{|c|c|c|c|c|c|c|c|c|c|c|c|c|c|c|c|}
\hline & & $\theta$ & $\begin{array}{l}\vec{F} \\
\dot{v} \\
\dot{v}\end{array}$ & $\begin{array}{l}\infty \\
\vec{\nabla} \\
\dot{\omega}\end{array}$ & $\begin{array}{l}\infty \\
\vec{\forall} \\
\dot{v}\end{array}$ & $\mid \begin{array}{l}\infty \\
\text { of } \\
\text { w }\end{array}$ & $\begin{array}{l}\infty \\
\infty \\
i \\
\dot{n}\end{array}$ & $\begin{array}{l}\infty \\
\stackrel{\infty}{+} \\
\dot{v}\end{array}$ & $\begin{array}{l}\stackrel{2}{\infty} \\
\dot{\omega}\end{array}$ & $\begin{array}{l}\vec{F} \\
\dot{v}\end{array}$ & $\begin{array}{l}\vec{y} \\
\underset{7}{ } \\
\dot{w}\end{array}$ & $\begin{array}{l}\text { के } \\
\dot{s}\end{array}$ & $\begin{array}{l}\stackrel{M}{\forall} \\
\dot{\omega}\end{array}$ & $\begin{array}{l}m \\
\infty \\
\stackrel{+}{+} \\
\dot{\omega}\end{array}$ & $\begin{array}{l}\vec{H} \\
\dot{H} \\
\dot{v}\end{array}$ \\
\hline & & $\dot{0}$ & \begin{tabular}{l}
$\infty$ \\
\multirow{f}{*}{} \\
$\dot{\infty}$
\end{tabular} & $\begin{array}{l}\stackrel{+}{*} \\
\dot{+} \\
\dot{s}\end{array}$ & $\begin{array}{l}\underset{f}{+} \\
\dot{v} \\
\text { i }\end{array}$ & $\begin{array}{l}\vec{n} \\
\dot{n} \\
\dot{m}\end{array}$ & $\begin{array}{l}m \\
\forall \\
\dot{7} \\
\dot{m}\end{array}$ & $\begin{array}{l}\dot{r} \\
i n \\
\dot{n}\end{array}$ & $\begin{array}{l}0 \\
\neq \\
\dot{r} \\
\dot{\omega}\end{array}$ & $\begin{array}{l}\hat{\sigma} \\
\dot{\forall} \\
\dot{\omega}\end{array}$ & $\begin{array}{l}\text { in } \\
\text { in } \\
\text { is }\end{array}$ & $\begin{array}{l}\stackrel{0}{*} \\
\dot{y}\end{array}$ & $\begin{array}{l}\stackrel{\partial}{+} \\
\dot{s}\end{array}$ & $\begin{array}{l}\hat{\circ} \\
\ddot{n} \\
\dot{s}\end{array}$ & $\begin{array}{l}8 \\
i n \\
\dot{n}\end{array}$ \\
\hline & & : & 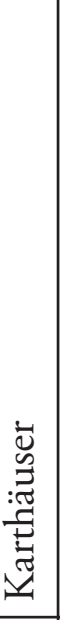 & 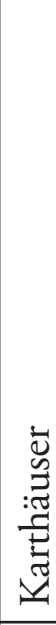 & 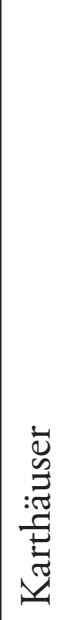 & 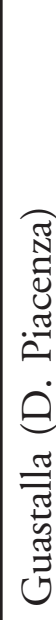 & 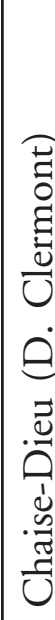 & 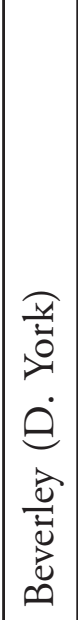 & $\frac{y}{0}$ & $\frac{\vec{u}}{0}$ & 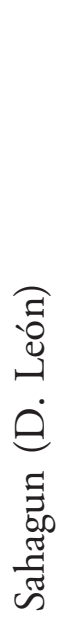 & 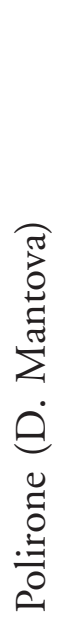 & 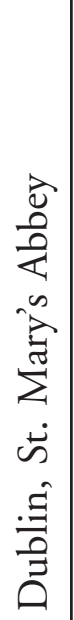 & 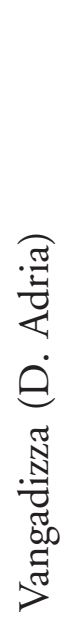 & 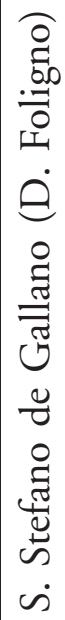 \\
\hline & & & & & & & 年 & & 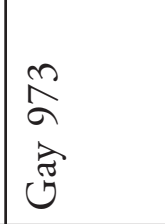 & & & 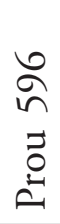 & & & \\
\hline & & & & & & & $\begin{array}{l}\infty \\
0 \\
x\end{array}$ & & 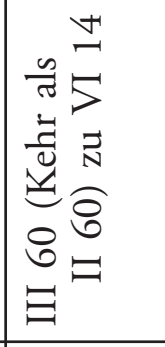 & 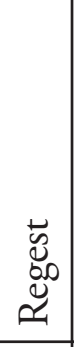 & & $\begin{array}{l}\curvearrowright \\
\Xi\end{array}$ & & & \\
\hline & & 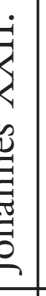 & 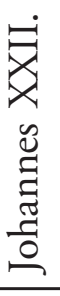 & 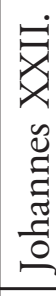 & 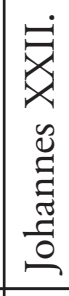 & $\begin{array}{l}\exists \\
.9 \\
.3 \\
.3 \\
\end{array}$ & 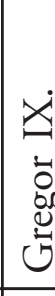 & 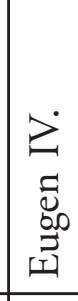 & 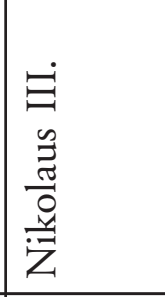 & 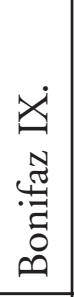 & 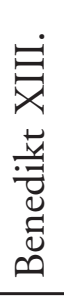 & $\begin{array}{l}\dot{Z} \\
0 \\
. \\
0 \\
0 \\
0 \\
0 \\
1\end{array}$ & 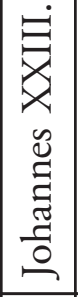 & $\begin{array}{l}\dot{\Xi} \\
\frac{\vec{x}}{\tilde{J}} \\
\tilde{J}\end{array}$ & 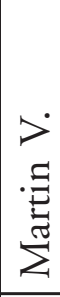 \\
\hline & & 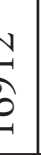 & $\stackrel{n}{\stackrel{n}{\sigma}}$ & $\begin{array}{l}\tilde{n} \\
\widehat{\sigma} \\
-\end{array}$ & $\frac{\sqrt{2}}{\sqrt{n}}$ & 菅 & ָ̊? & 兄 & $\begin{array}{l}\widehat{N}^{S} \\
\underset{N}{\Sigma}\end{array}$ & 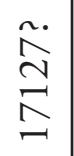 & $\stackrel{\infty}{\stackrel{\infty}{\Sigma}}$ & તิ & $\begin{array}{l}0 \\
\stackrel{0}{a} \\
\underline{N}\end{array}$ & 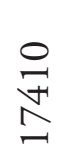 & 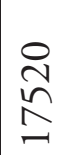 \\
\hline & & $\vec{v}$ & ָे & స్ & ì & i & ì & $\begin{array}{l}\dot{\infty} \\
\stackrel{0}{0} \\
\text { in }\end{array}$ & 灾 & $\widehat{\imath}$ & & $\stackrel{\widehat{N}}{N}$ & $\begin{array}{l}\stackrel{\dot{\Omega}}{\sim} \\
\text {. }\end{array}$ & $\stackrel{+}{\stackrel{+}{*}}$ & $\stackrel{n}{\curvearrowright}$ \\
\hline
\end{tabular}




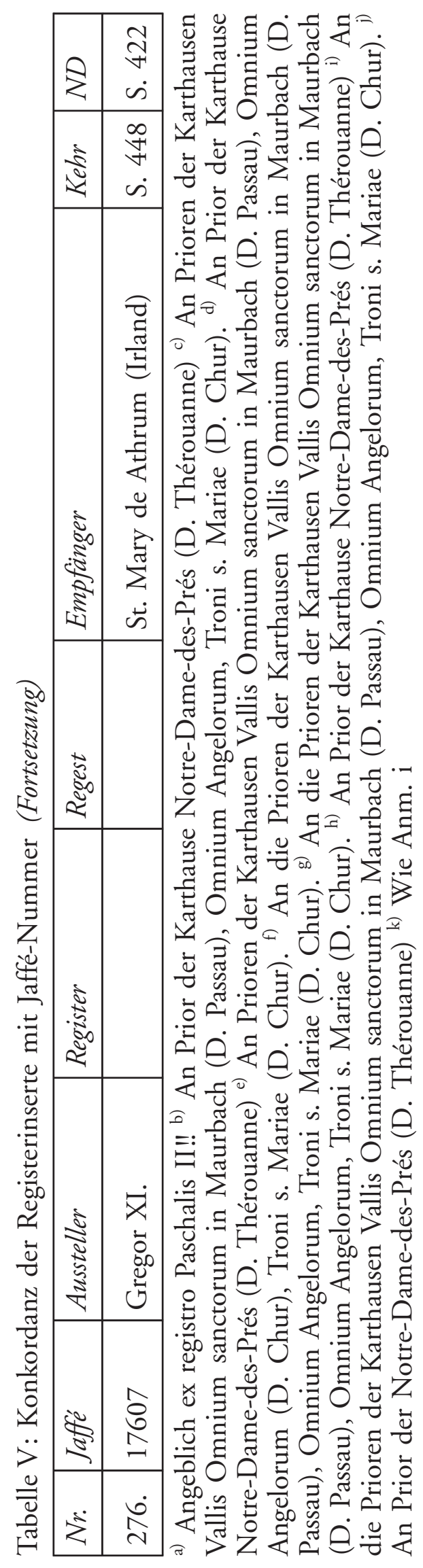




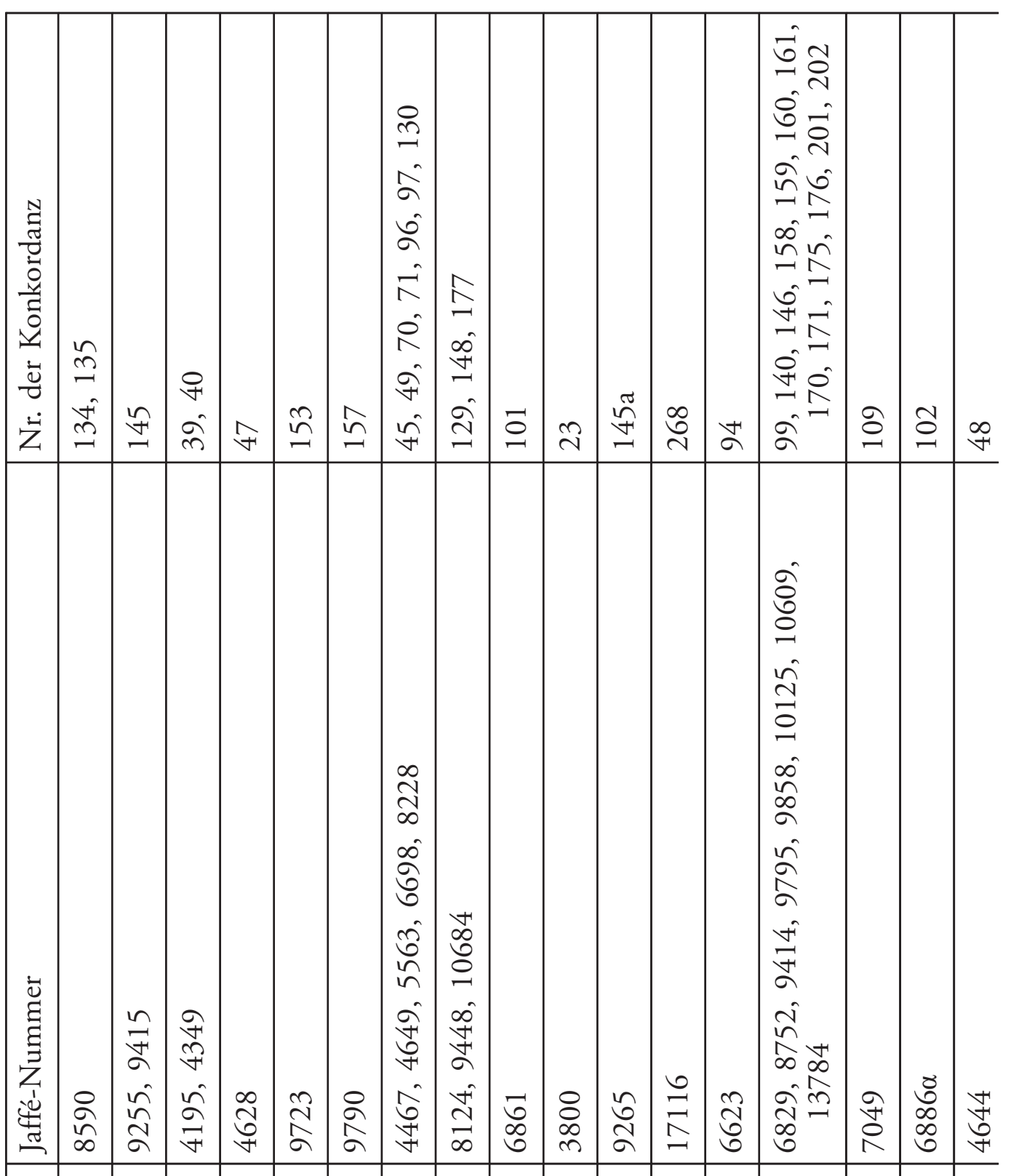

范

|

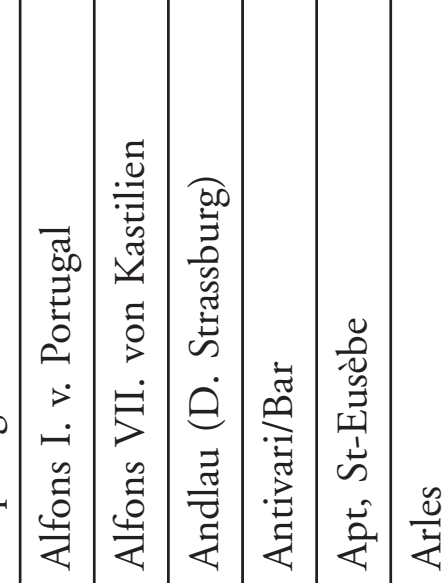

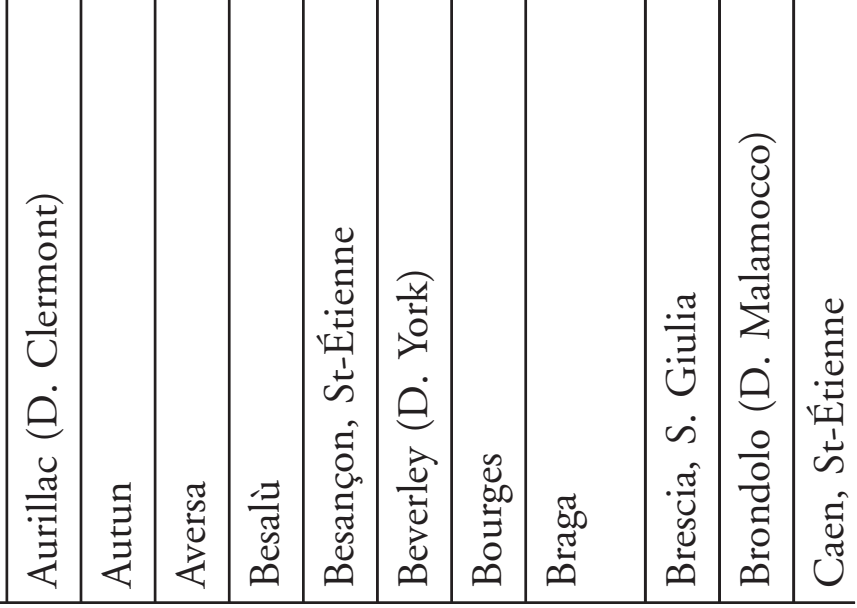


„Verborgene Schätze“. Nichtitalienische Stücke in den „Papsturkunden in Italien“ 505

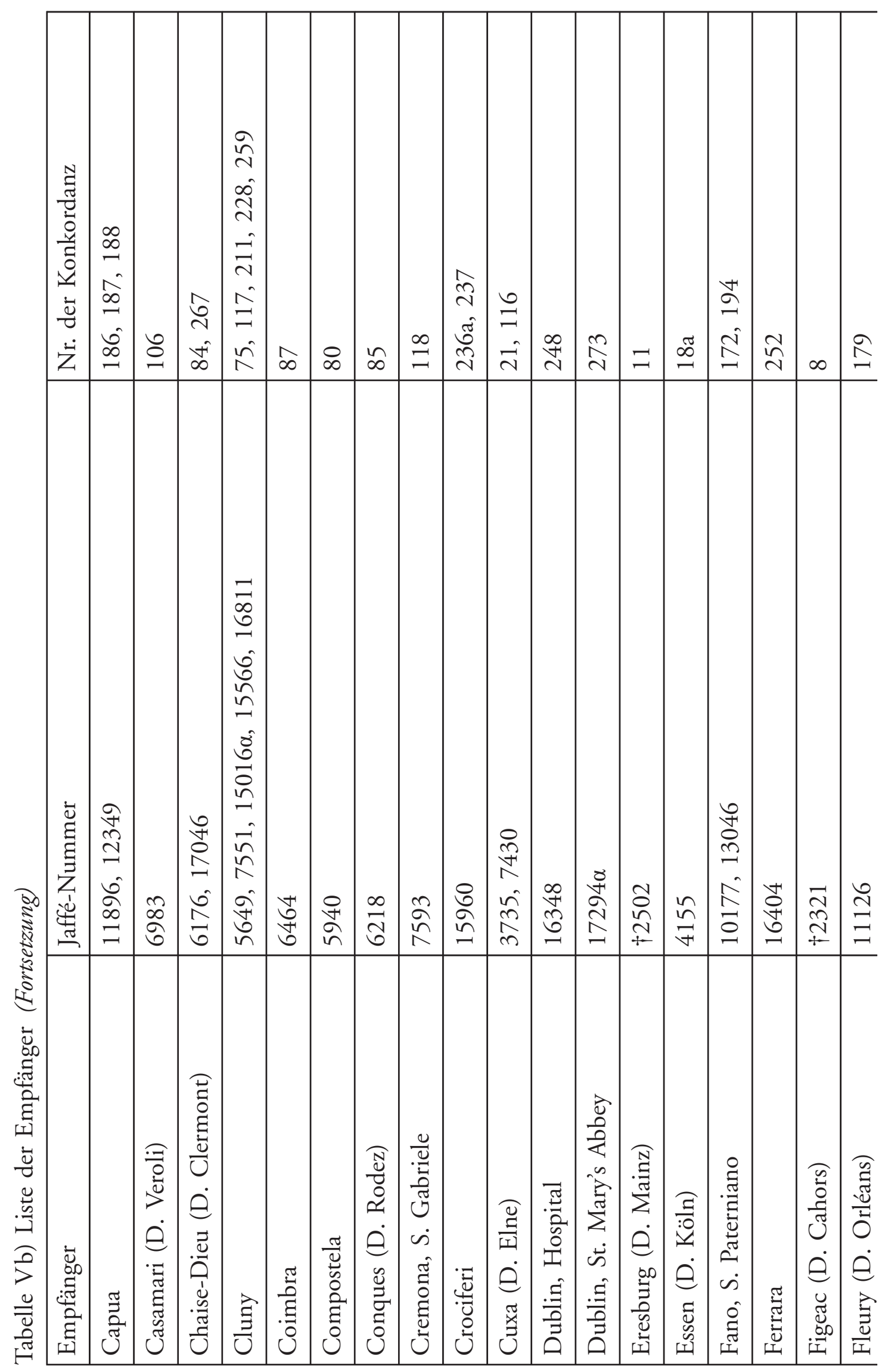




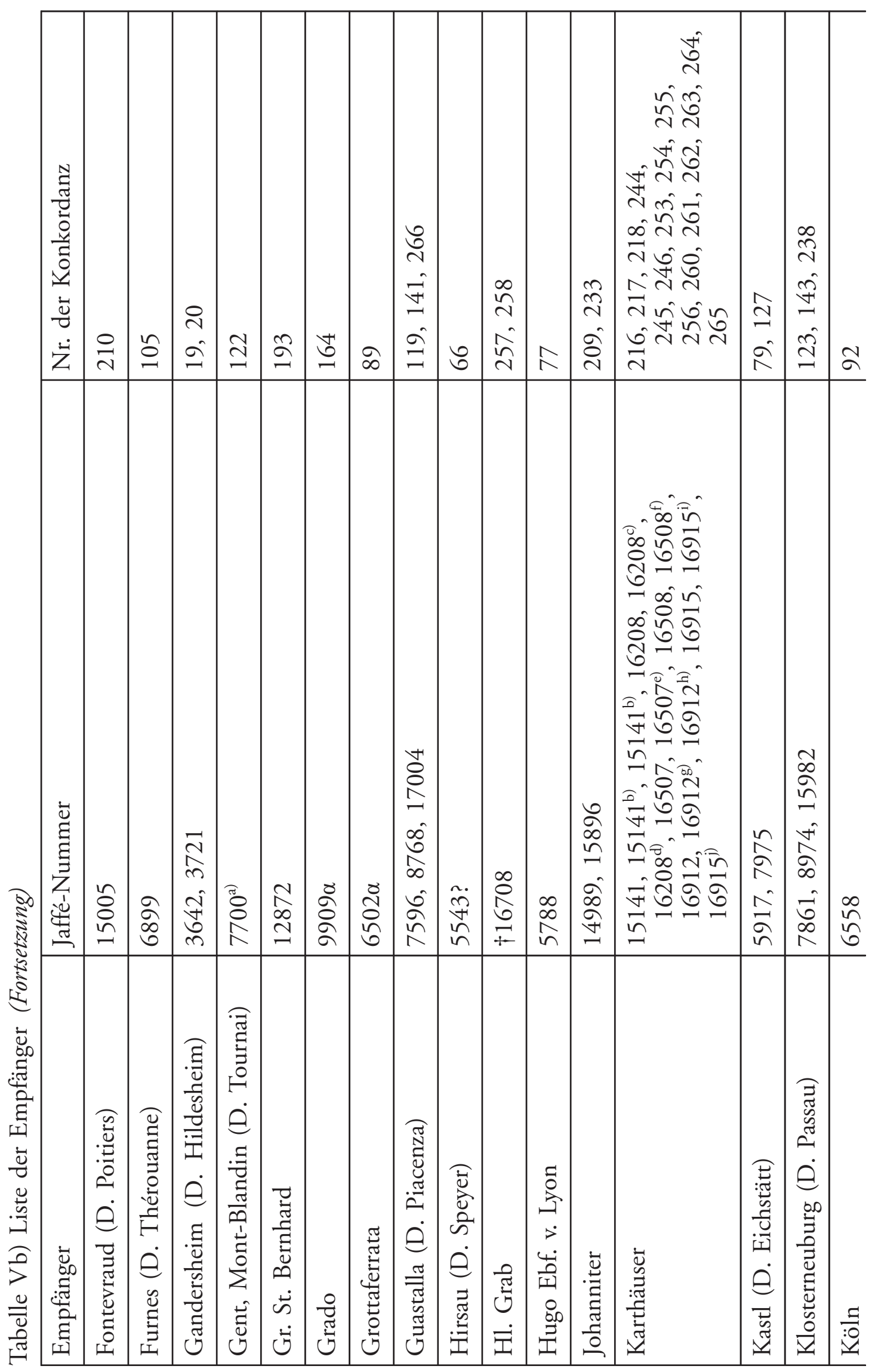


„Verborgene Schätze“. Nichtitalienische Stücke in den „Papsturkunden in Italien“ 507

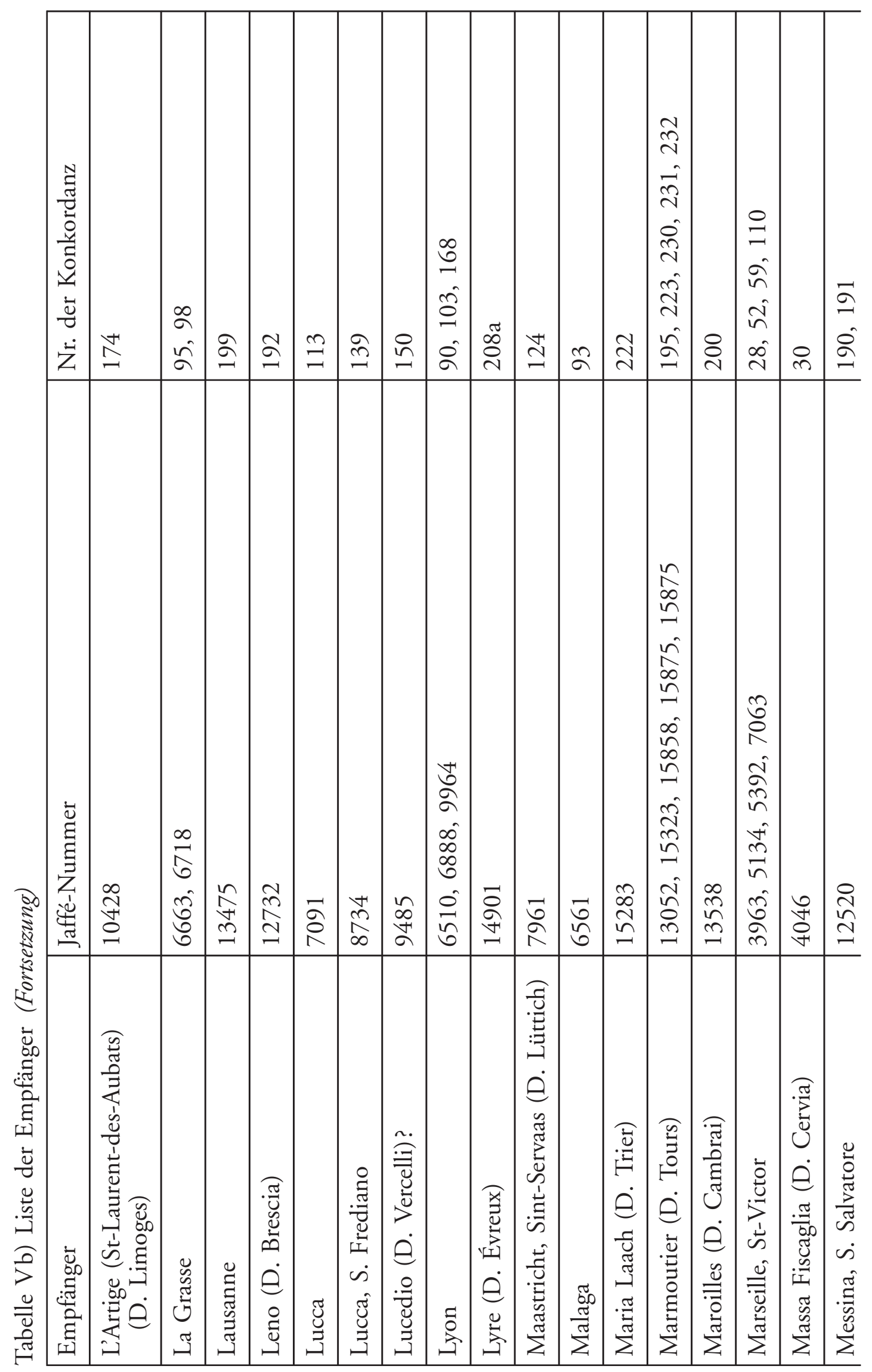




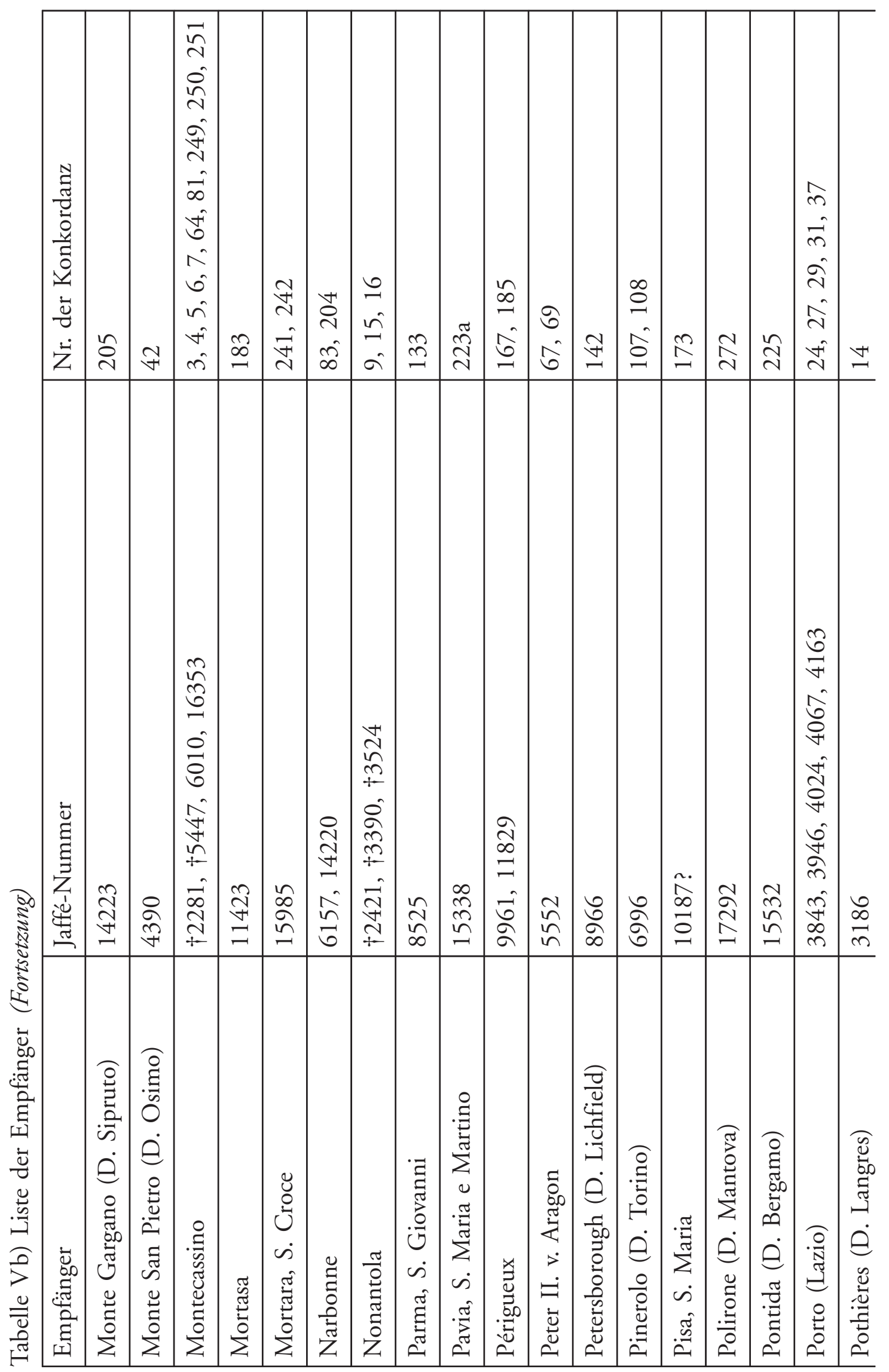




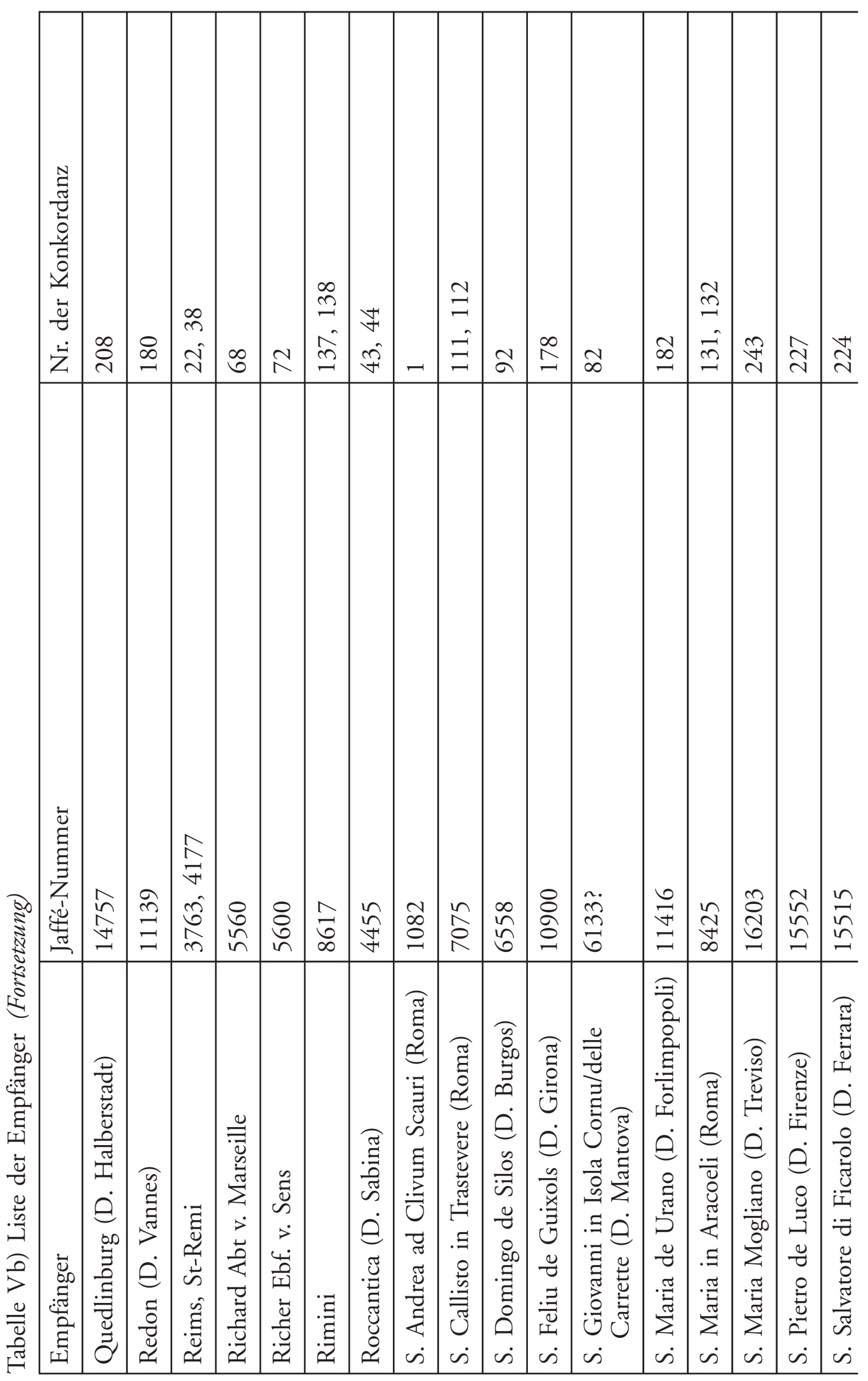




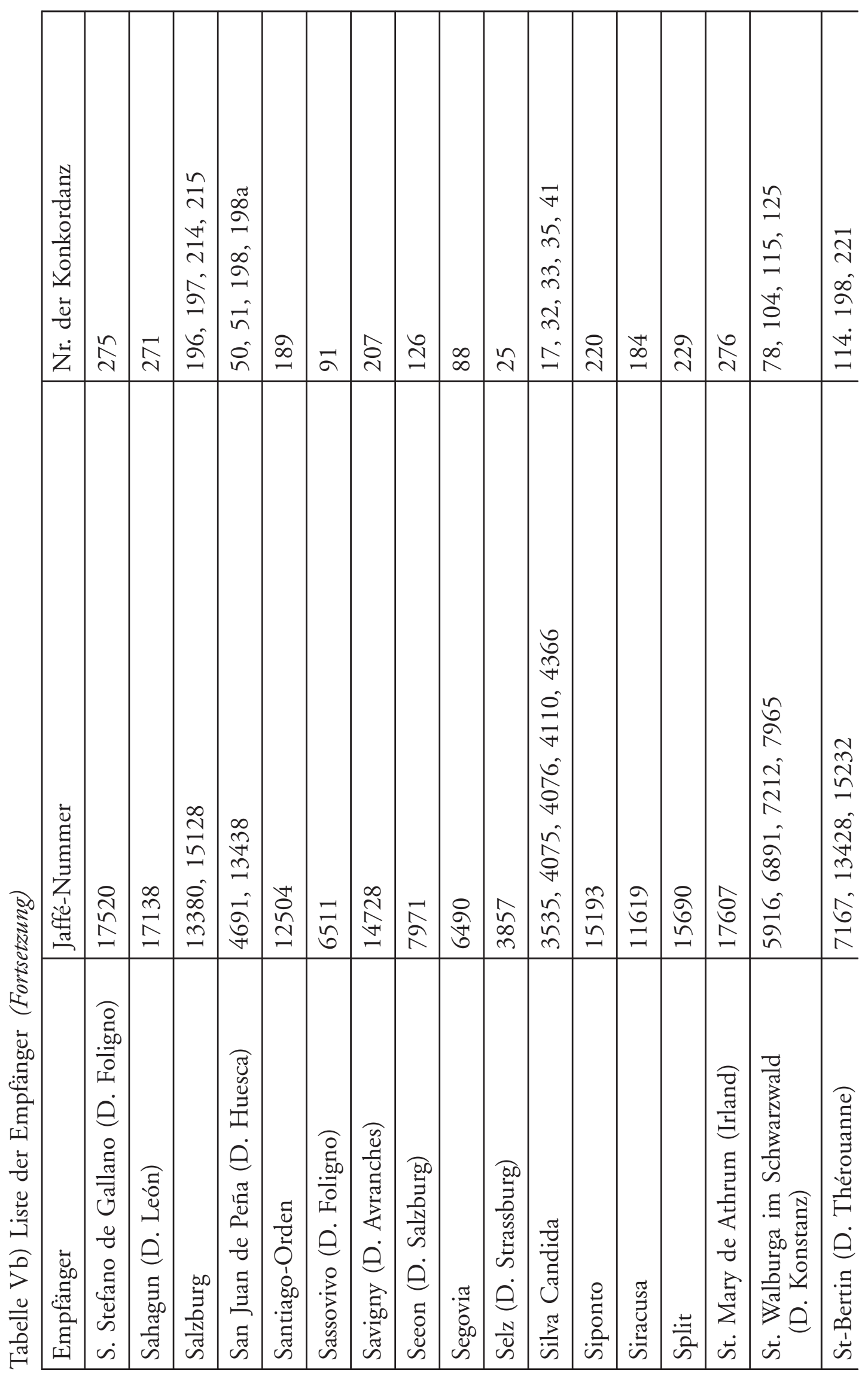




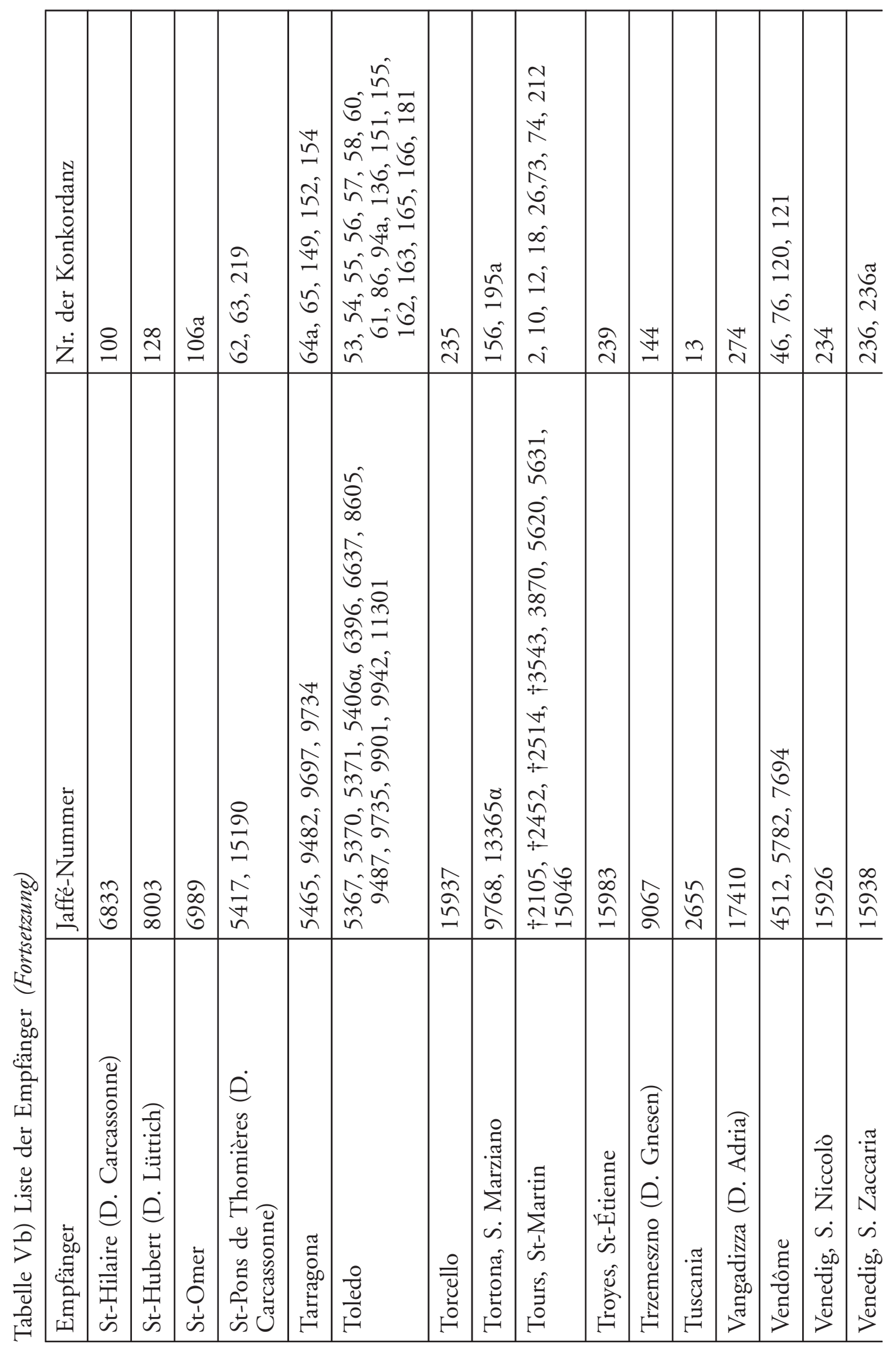




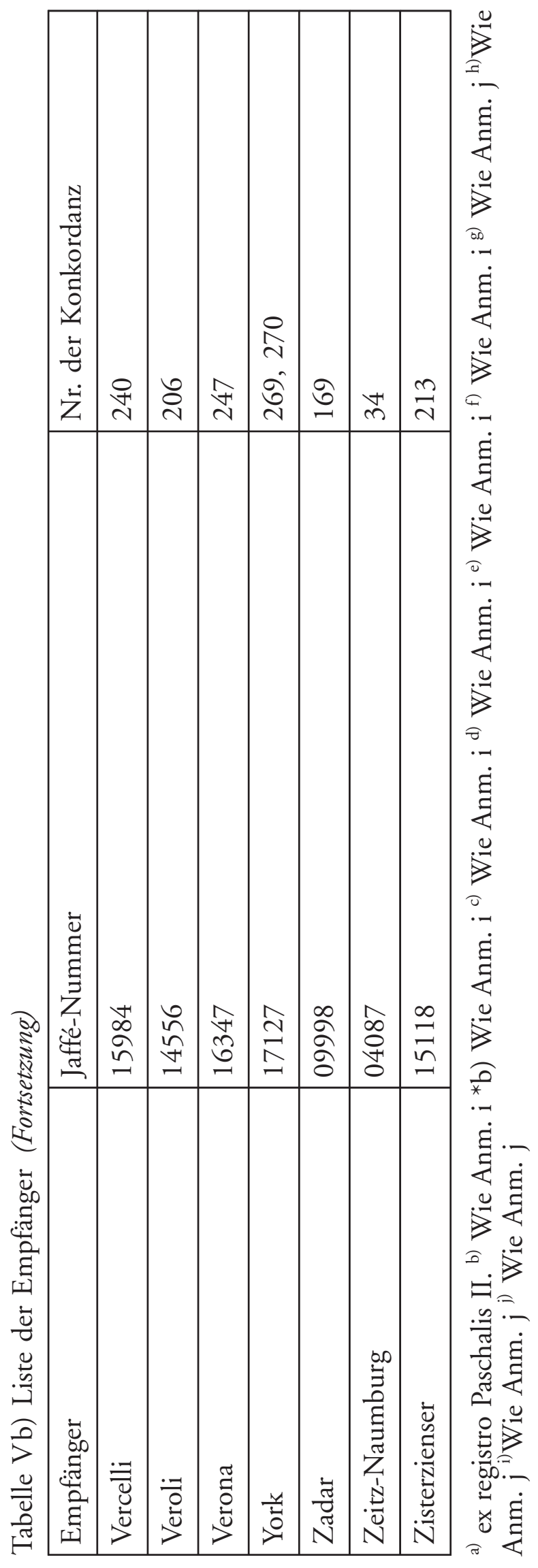




\section{Die universal agierenden Orden in Italien}


Bereitgestellt von | De Gruyter / TCS

Angemeldet | 217.89.40.26

Heruntergeladen am | 21.12.12 10:50 


\title{
I monaci bianchi e il papato in Italia: caratteri e metamorfosi delle identità e idealità cistercensi nella prima metà del XII secolo
}

\author{
Rinaldo Comba
}

Nell'ultimo trentennio l'indagine storiografica sui monaci di Cîteaux, stimolata dal dibattito fra ideali e realtà nella storia dell'Ordine, in un quadro di riferimento generale che, attorno al 1980, sulla scia degli studi di padre Louis Jean Lekai ${ }^{1}$, ancora tendeva a sottolineare fortemente gli aspetti unitari dell'esperienza cistercense, ha sempre più evidenziato i 'volti' regionali di quella esperienza. In Italia lo ha fatto, inizialmente, prendendo in considerazione soprattutto alcuni aspetti della vita economica di singole abbazie, le caratteristiche specifiche delle aree in cui erano insediate, e, di conseguenza, le interpretazioni che i monaci bianchi diedero delle possibilità di sfruttamento agro-pastorale di tali aree, in ciò sorretti, mi si passi il termine troppo moderno, da una 'cultura imprenditoriale' talora confliggente con le loro idealità di vita monastica $^{2}$. Le ricerche evidenziarono poi soluzioni spesso originali, sia nei confronti delle 'culture' tecniche, materiali e gestionali locali, comunque

1 Louis Jean Lekai: The Cistercians: Ideals and Reality, Kent (Ohio) 1977, trad it. I cistercensi: ideali e realtà, Pavia 1989; ID.: Ideals and Reality in Early Cistercian Life and Legislation, in: Cistercian Ideals and Reality, a cura di John R. Sommerfeldt, Kalamazoo (Michigan) 1978 (Studies in Medieval Cistercian History 3), pp. 4-29.

2 Come primo, essenziale, tentativo di sintesi, in vista di accertamenti ulteriori: Rinaldo Сомва: Aspects économiques de la vie des abbayes cisterciennes de l'Italie du NordOuest $\left(\mathrm{XII}^{\mathrm{e}}-\mathrm{XIII}{ }^{\mathrm{e}}\right.$ siècles), in: L'économie cistercienne. Géographie - mutations du Moyen-Âge aux temps modernes, Auch 1983 (Flaran 3. Troisièmes journées internationales d'histoire, 16-18 septembre 1981), pp. 137sg. Un quadro assai più articolato emerse alla metà degli anni Ottanta dai seguenti approfondimenti coordinati sull'economia monastica nell'Italia nord-occidentale pubblicati in: Studi Storici 36 (1985): ID.: I cistercensi fra città e campagne nei secoli XII e XIII: una sintesi mutevole di orientamenti economici e culturali nell'Italia nord-occidentale, pp. 237-261 (comparso anche, con diverso titolo, in: ID.: Contadini, signori e mercanti nel Piemonte medievale, Roma/Bari 1988, pp. 21 -39); Luisa Chiappa Mauri: La costruzione del paesaggio agrario padano: la grangia di Valera, pp. 263-313; Elisa Occhipintr: Fortuna e crisi di un patrimonio monastico: Morimondo e le sue grange fra XII e XV secolo, pp. 315-336; Marisa Bellero: I cistercensi e il paesaggio rurale: l'abbazia di S. Maria di Lucedio fra XII e XV secolo, pp. $337-351$. 
profondamente assimilate dai monaci ${ }^{3}$, sia nei confronti dei problemi di 'sovrappopolamento', evidenti per alcuni cenobi ${ }^{4}$, sia, infine, in rapporto al troppo spesso mitizzato "fenomeno cistercense". Non soltanto: portarono talora alla luce, soprattutto per l'Italia Nord-occidentale, ma anche per la Calabria ${ }^{6}$, tratti sino ad allora inesplorati delle rispettive economie rurali.

Quella che un giovane e promettente medievista, assai attento alle forme di istituzionalizzazione dell'Ordine secondo una tendenza presente nella storiografia germanica, Guido Cariboni, considera oggi - e in più di un caso ha ragione - una "sterile e moralistica opposizione fra ideali e realtà" ${ }^{7}$, non fu mai

3 Luisa Chiappa Mauri: Monasteri ed economia rurale in Lombardia nei secoli XII e XIII, in: Il monachesimo italiano nell'età comunale, Atti del IV Convegno di studi storici sull'Italia Benedettina, Abbazia di S. Giacomo Maggiore, Pontida (Bergamo), 3-6 settembre 1995, a cura di Francesco Giovanni Battista Trolese, Cesena 1998 (Italia benedettina 16), pp. 199-218 (soprattutto a p. 215); Сомва: Cistercensi (cit. nota 2).

4 Rinaldo Сомва: Dal Piemonte alle Marche: esperienze economiche cistercensi nell'età di Bernardo di Chiaravalle, in: San Bernardo e l'Italia, Atti del Convegno di studi, Milano, 24-26 maggio 1990, a cura di Pietro Zerbi, Milano 1993 (Bibliotheca erudita. Studi e documenti di storia e di filologia 8), pp. 315-344, alle pp. 328-329, con riferimento soprattutto all'abbazia di Casanova; ID.: L'abbazia di Casanova, un polo di attrazione di esperienze religiose e monastiche nei secoli XII-XIII, in: Santa Maria di Casanova. Un'abbazia cistercense fra i marchesi di Saluzzo e il mondo dei comuni, Relazioni al Convegno, Casanova, 11-12 ottobre 2003, a cura di Rinaldo Comba/Paolo Grillo, Cuneo 2006 (Marchionatus Saluciarum Monumenta, Studi 5), pp. 29-41 (a p. 34). Da un punto di vista più generale, con riferimento a La Ferté per quanto riguarda il sovrappopolamento dei cenobi, v. ID.: Identità cistercensi delle origini nel primo quarto del XII secolo, in: L'abbazia di Lucedio e l'ordine cistercense nell'Italia occidentale nei secoli XII e XIII, Atti del terzo congresso storico vercellese, Vercelli, 24-26 ottobre 1997, Vercelli 1999, pp. 7-24 (a p. 17), ripreso, con altro titolo in: "Monachi heremum diligentes": els monjos cistercencs dels orígens i la seua identitat, in: El Císter, ideals i realitat d'un ordre monàstic, Actes del simposi internacional sobre el Císter, Valldigna (1298-1998), a cura di Ferran Garcia-Oliver, València 2001, pp. 17-29.

5 Per una felice messa a punto del problema vedasi Luisa Chiappa Mauri: L'economia cistercense fra normativa e prassi. Alcune riflessioni, in: Gli spazi economici della Chiesa nell'Occidente mediterraneo (secoli XII - metà XIV), Atti del XVI Convegno internazionale di studi: Pistoia, 16-19 maggio 1997, Pistoia 1999, pp. 63-88. Cfr. EAD.: Paesaggi rurali di Lombardia: secoli XII-XV, Roma/Bari 1990, passim.

6 Rinaldo Comba: Le scelte economiche dei monaci bianchi nel Regno di Sicilia (XII-XIII secolo): un modello cistercense?, in: I cistercensi nel Mezzogiorno medioevale, Atti del Convegno internazionale di studio in occasione del IX centenario della nascita di Bernardo di Clairvaux (Martano - Latiano - Lecce, 25-27 febbraio 1991), a cura di Hubert Houben/Benedetto Vetere, Galatina 1994 (Saggi e ricerche 24), pp. 117-164.

7 Guido Cariboni: "Il nostro ordine è la carità". Osservazioni sugli ideali, i testi normativi e le dinamiche istituzionali presso le prime generazioni cistercensi, in: Regulae Consuetudines - Statuta. Studi sulle fonti normative degli ordini religiosi nei secoli centrali del Medioevo, Atti del I e del II seminario internazionale di studio del Centro italo-tedesco di storia comparata degli ordini religiosi (Bari, Noci, Lecce, 26-27 ottobre 2002 / Castiglione delle Stiviere, 23-24 maggio 2003), a cura di Cristina Andenna/ 
considerata in verità, negli studi più avvertiti anche di carattere economico e sociale, un' 'opposizione'. Fu considerata piuttosto una sorta di 'tensione' fra due elementi, che offriva occasioni di verifica degli scarti eventualmente presenti fra $\mathrm{i}$ progetti e la loro concretizzazione, $\mathrm{o}$, in altri termini, del grado di inveramento delle "intentions des fondateurs" (e non soltanto di loro), come le chiamava, quasi quarant'anni or sono, Jean Leclercq ${ }^{8}$. Insomma: una tensione da cui localmente nascevano "sintesi mutevoli di orientamenti economici e culturali"" che rendevano assai variegato il quadro monoliticamente unitario offerto dalla storiografia tradizionale dell'Ordine. Sarà appena il caso di ricordare, da questo punto di vista, che le norme cistercensi più antiche suggerivano l'esistenza di uno stretto rapporto tra le forme organizzative della loro attività economica e le loro scelte di vita monastico-religiosa. Tali forme, oltre ad avere una valenza simbolica, costituivano un forte elemento di identità e di strutturazione originale dei loro patrimoni e delle modalità del loro sfruttamento. Allo stesso modo, anche più esplicito era il rapporto tra forme istituzionali e spiritualità, messo a fuoco da Hans Martin Klinkenberg nel 1982 in un contributo al tomo supplementare dell'opera collettiva, curata da Kaspar Elm e altri, dal titolo significativo: "Die Zisterzienser. Ordensleben zwischen Ideal und Wirklichkeit" ${ }^{10}$.

La presente ricerca parte da questo ordine di problemi e si pone due altri interrogativi: quale fu l'evoluzione, nella prima metà del XII secolo degli elementi ideali e identitari che caratterizzavano l'universo cistercense e ne ispiravano le forme istituzionali ed economiche ? quale peso ebbero, sulla loro evoluzione, l'incontro e la sempre più intensa collaborazione con la sede apostolica?

Gert Melville, con la consulenza scientifica di Cosimo Damiano Fonseca/Hubert Houben/Giorgio Picasso, Münster 2005 (Vita Regularis, Abhandlungen 25), pp. 276310.

8 Jean LeClercQ: Les intentions des fondateurs de l'Ordre cistercien, in: COCR 30 (1968) pp. 233-271.

9 Cfr. Comba: Cistercensi (cit. nota 2) pp. 237sg.

10 Hans Martin Klinkenberg: Cîteaux - Spiritualität und Organisation, in: Die Zisterzienser. Ordensleben zwischen Ideal und Wirklichkeit. Ergänzungsband, a cura di Kaspar Elm/Peter Joerissen, Köln 1982 (Schriften des Rheinischen Museumsamtes 18), pp. 13-27 (alle pp. 18sg.). Il primo volume dell'opera era apparso, l'anno precedente, nel decimo volume della stessa collana (cfr. oltre, nota 31). Cfr., per i rapporti fra spiritualità ed economia, Werner RösENER: Spiritualität und Ökonomie im Spannungsfeld der zisterziensischen Lebensform, in: CCCist 34 (1983) pp. 245-271. 
1. Ideali e realtà, unanimità e diversità, identità: vent'anni di ricerche e qualche problema aperto

Insistere sul problema-chiave dei nessi fra ideali e realtà significa analizzare dall'interno una forma specifica di monachesimo, identificarne i caratteri, le contraddizioni, l'evoluzione, le forme assunte nelle diverse regioni. Si presti tuttavia attenzione al fatto che, nel rapporto dialettico fra 'ideali' e 'realtà', come sul significato dei due termini, occorre non cadere in fraintendimenti. Gli ideali, per dirla con Grado Giovanni Merlo, "non sono da intendere come modelli di perfezione letterari, astratti, angelici": "sono quelli ricavabili dai documenti, per dir così, istituzionali dell'autocoscienza cistercense, e la realtà non è costituita dall'applicazione meccanica e dagli inevitabili 'tradimenti', più o meno ravvicinati, di quegli stessi ideali. La realtà è l'universo cistercense: un universo non compatto né omogeneo, dove una 'unanimità' forse non è mai esistita nemmeno nei primi decenni delle origini" 11 .

Siamo così entrati, quasi impercettibilmente, nel cuore delle problematiche di storia cistercense che hanno caratterizzato l'ultimo ventennio, affrontate per lo più attraverso indagini di ambito regionale, spesso svolte alla luce della storiografia europea, ma emerse finalmente allo scoperto con affondi storiografici relativi ad alcuni grandi paesi nel convegno organizzato nel 1998 dal CERCOR a Digione, sotto la presidenza di Pierrette Paravy, per il nono centenario della fondazione di Cîteaux ${ }^{12}$. Il titolo, "Unanimité et diversité cisterciennes", era esplicitamente e felicemente evocativo di problemi ormai da tempo maturi nell'intera medievistica occidentale, anche perché erano stati portati all'attenzione di un pubblico più vasto di quello degli stretti specialisti da Jean Baptiste Auberger, una dozzina di anni prima ${ }^{13}$.

11 Grado Giovanni Merlo: Prolusione, in: L'abbazia di Staffarda e l'irradiazione cistercense nel Piemonte meridionale, a cura di Rinaldo Comba/Grado Giovanni Merlo, Cuneo 1998 (Storia e storiografia 21), p. 14. Desidero ringraziare Grado G. Merlo per aver discusso con me l'impianto di questo lavoro e per avermi elargito suggerimenti preziosi durante la stesura del testo.

12 Per affinità tematica e geografica specifica con il presente lavoro mi limito qui a rimandare a Cécile CABY: Les cisterciens dans l'espace italien médiéval, in: Unanimité et diversité cisterciennes. Filiations - Réseaux - Relectures. Actes du quatrième Colloque international du C.E.R.C.O.R.: Dijon, 23-25 septembre 1998, Saint-Étienne 2000 (C.E.R.C.O.R., Travaux et recherches 12), pp.567-594. Per il Veneto nello stesso volume e con riferimento particolare all'abbazia di Follina e al periodo qui analizzato, è d'obbligo il rimando ad Antonio Rigon: Présence cistercienne dans le Veneto médiéval, pp. 595-610 (a p. 598).

13 Cfr. Jean Baptiste Auberger: L'unanimité cistercienne primitive: mythe ou réalité?, Achel 1986 (CCCist, Studia et documenta 3), con il commento di François de PlaCE: L'unanimité cistercienne primitive: mythe ou réalité? Notes de lecture, in: COCR 49 (1987) pp. 347-353. 
Le riflessioni avviate in occasione delle celebrazioni per il nono centenario di Cîteaux chiusero per l'Italia un assai fertile decennio di studi cistercensi, apertosi nel 1989 con il primo dei convegni dedicati alla nona ricorrenza centenaria della nascita di Bernardo di Claivaux ${ }^{14}$. Oltre alla già notissima, ma sempre interessante e significativa, figura di Bernardo e ai contesti storici in cui visse e operò $^{15}$, fu dedicato, per la prima volta, un volume ai monaci bianchi nel Mezzogiorno $^{16} \mathrm{e}$ un altro affrontò in chiave comparativa la storia dei certosini e dei cistercensi nella penisola ${ }^{17}$, mentre singole opere, spesso collettive, tentavano un quadro di sintesi di situazioni regionali, toccando la Liguria, l'Umbria, la Basilicata, la Calabria, la Sardegna ${ }^{18}$. E poi ancora una ricca serie di rassegne, di sguardi di sintesi, di monografie e di opere collettive su singole abbazie: Chiaravalle Milanese, Morimondo, Lucedio, Staffarda, Rifreddo, Chiaravalle della Colomba, Rivalta Scrivia ${ }^{19}$, San Salvatore al Monte Amiata, Fossanova,

14 Bernardo cistercense, Atti del XXVI Convegno storico internazionale: Todi, 8-11 ottobre 1989, Spoleto 1990 (Atti dei Convegni dell'Accademia Tudertina e del Centro di studi sulla spiritualità medievale, n.s. diretta da Enrico Menestò, 3). Una rassegna degli studi sulla figura di Bernardo e sui monaci bianchi pubblicati in occasione del IX centenario della nascita si trova in Robert Godding: Bernardina et Cisterciensia: au lendemain du IX centenaire de la naissance de St. Bernard, in: AnalBoll 111 (1993) pp. $189-214$.

15 Il riferimento è agli atti del convegno: San Bernardo e l'Italia (cit. nota 4). Mi limito inoltre a citare: Saint Bernard et le monde cistercien, a cura di Léon Pressouyre/Terryl N. KInder, Paris 1990; Bernard de Clairvaux. Histoire, mentalités, spiritualité, Actes du colloque: Lyon, Cîteaux, Dijon, 1990, Paris 1992 (SC 380).

16 I cistercensi nel Mezzogiorno medioevale (cit. nota 6).

17 Certosini e cistercensi in Italia (secoli XII-XV), a cura di Rinaldo Comba/Grado Giovanni Merlo, Cuneo 2000 (Storia e storiografia 26). Nello stesso volume, per uno sguardo complessivo alla storia cistercense della penisola, mi limito qui a richiamare i contributi di Cécile Caby: L'espansione cistercense in Italia, pp. 143-155, e Giorgio Picasso: Certosini e Cistercensi: i ritmi della preghiera e del lavoro nella vita quotidiana, pp. 295-306.

18 Monasteria Nova. Storia e architettura dei cistercensi in Liguria: secoli XII - XIV, a cura di Colette Bozzo Dufour/Anna Dagnino, Genova 1998; San Bernardo e i cistercensi in Umbria, a cura di Goffredo Viti, Firenze 1995; Pietro Dalena: Basilicata cistercense: il codice Barb. Lat. 3247, Galatina 1995; Pietro De Leo: Certosini e cistercensi nel regno di Sicilia, Soveria Mannelli 1993; I cistercensi in Sardegna. Aspetti e problemi di un Ordine monastico benedettino nella Sardegna medioevale, Atti del Convegno: Silanus 14-15 novembre 1987, a cura di Giuseppe Spiga, Nuoro 1990.

19 Chiaravalle: arte e storia di un'abbazia cistercense, a cura di Paolo Tomea, Milano 1992; Elisa Occhipintr: Il monastero di Morimondo in Lombardia tra tensioni sociali e antagonismi di potere (secolo XII - inizi XIII), in: Nuova rivista storica 67 (1983) pp. 528sg.; EAD.: Fortuna (cit. nota 2) pp. 315-336; Un'abbazia lombarda: Morimondo, la sua storia e il suo messaggio, Morimondo 1998 (con riferimento particolare ai saggi di Pietro Zerbi, Rinaldo Comba, Mirella Ferrari, Sandrina Bandera); Labbazia di Lucedio (cit. nota 4); Bellero (cit. nota 2) pp. 337-351; L’abbazia di Staffarda (cit. nota 11); Il monastero di Rifreddo e il monachesimo cistercense femminile nell'Italia 
Valvisciolo ${ }^{20}$. Infine, studi, talora innovativi, sull'architettura cistercense anche con riferimento al suo rapporto con l'edilizia rurale ${ }^{21}$, e una piccola, ma significativa serie di edizioni documentarie, ancora in corso d'opera, relative a Morimondo, Chiaravalle Milanese, Chiaravalle di Fiastra, Lucedio, Staffarda ${ }^{22}$.

occidentale (secoli XI-XIV), a cura di Rinaldo Сомва, Cuneo 1999 (Storia e storiografia 22); Anna Maria Rapetti: La formazione di una comunità cistercense. Istituzioni e strutture organizzative di Chiaravalle della Colomba tra XII e XIII secolo, Roma 1999 (Italia Sacra 62). Su Rivalta Scrivia, attualmente in corso di studio da parte di Maria Grazia Re, alcune anticipazioni sono reperibili nel lavoro di Andrea Piazza: Ascherio di Rivalta, un quasi-monaco fondatore di abbazie, in: Vite di eretici e storie di frati. A Giovanni Miccoli, a cura di Marina Benedetti/Grado Giovanni Merlo/Andrea Piazza, Milano 1998, pp. 115-155. Per un repertorio sistematico dei personaggi vedasi Giuseppe Bonavoglia: Labbazia di Rivalta Scrivia: abati e monaci (1150-1320), Tortona 1998.

20 Wilhelm Kurze: Dai benedettini ai cistercensi: il passaggio del monastero di S. Salvatore al Monte Amiata ai cistercensi, in: ID.: Monasteri e nobiltà nel Senese e nella Toscana medievale. Studi diplomatici, archeologici, genealogici, giuridici e sociali, Siena 1989, pp. 391-415; Tersilio Leggio: Momenti della riforma cistercense nella Sabina e nel Reatino, in: Rivista storica del Lazio 2 (1994) fasc. 2 pp. 17-61; Clemente Ciammaruconi: Da Marmosolio a Valvisciolo. Storia di un insediamento cistercense nella Marittima medievale, prefazione di Maria Teresa Caciorgna, Sermoneta 1998; Il monachesimo cistercense nella Marittima medievale. Storia e arte, Atti del convegno: Abbazie di Fossanova e Valvisciolo, 24-25 settembre 1999, Casamari 2002 (Bibliotheca Casaemariensis 5).

21 Marina Righetti Tosti Croce: Architettura per il lavoro. Dal caso cistercense a un caso cistercense: Chiaravalle di Fiastra, Roma 1993 (Studi di arte medievale 8); Laura PAlmucci: Le grange di Lucedio: persistenza e mutamenti nell'architettura dei fabbricati rurali, in: L'abbazia di Lucedio (cit. nota 4) pp. 351-363; EAD.: Le grange dell'abbazia di Staffarda a Lagnasco e Scarnafigi: otto secoli di storia, in: L'abbazia di Staffarda (cit. nota 11) pp. 287-303; Maria Carola Morozzo della Rocca: Tracce documentarie medievali e verifiche sul terreno: il 'tectum' delle monache di Pogliola a Margarita, in: All'ombra dei signori di Morozzo: esperienze monastiche riformate ai piedi delle Marittime (XI-XV secolo), Atti del Convegno: San Biagio Mondovì - Rocca de' Baldi Mondovì, 3-5 novembre 2000, a cura di Rinaldo Comba/Grado Giovanni Merlo, Cuneo 2003 (Storia e storiografia 32), pp. 509-521.

22 Le carte del monastero di Santa Maria di Morimondo, vol. 1 (1010-1170), a cura di Michele Ansani, Presentazione di Ettore Cau, Spoleto 1992 (Fonti storico-giuridiche, Documenti 3); Le carte dell'abbazia di Chiaravalle di Fiastra, vol. 1 (1006-1180), a cura di Attilio De Luca, Spoleto 1997; Le pergamene milanesi del secolo XII dell'abbazia di Chiaravalle (1102-1160) conservate presso l'Archivio di Stato di Milano, a cura di Anna Maria RapetTi, Milano 2004 (Pergamene milanesi dei secoli XII-XIII 17); Guido Cariboni: La via migliore. Pratiche memoriali e dinamiche istituzionali nel liber del capitolo dell'abbazia cistercense di Lucedio, Berlin 2005 (Vita regularis, Editionen 3); Documenti dell'abbazia di Santa Maria di Staffarda. Integrazione al Cartario, a cura di Patrizia Merati, Cuneo 2007 (Marchionatus Saluciarum Monumenta, Fonti 5). 
L'elenco potrebbe continuare, con accenni alle opere più recenti ${ }^{23}$. In questa sede, però, più che la completezza dell'informazione bibliografica, interessa una prima messa a punto di problemi, temi e metodi di studio che vengono via via emergendo dalle indagini più recenti. Su queste ultime, almeno nell'Italia nordoccidentale, hanno sicuramente influito, a partire dagli ultimi anni del XX secolo, le ricerche di Grado Giovanni Merlo sulla capacità di attrazione religiosa dei cenobi cistercensi e le sue riflessioni sulle specificità della storia monastica. Soprattutto direi però che ha influito molto positivamente sulle indagini l'uso massiccio di un'ampia documentazione, spesso inedita, e di una più raffinata ed esegeticamente scaltrita capacità di interpretazione delle fonti, che hanno consentito, per esempio, di sfatare miti storiografici recenti su pretesi "Eigenkloster", nati da una anacronistica trasposizione nell'XI e XII secolo delle tematiche sviluppate con successo per ben altri periodi dalla scuola di Gerd Tellenbach ${ }^{24}$. Inoltre, proprio la riflessione sistematica sulla documentazione può oggi consentire di versare ai dossier di Italia Pontificia qualche elemento aggiuntivo o correttivo e qualche nota critica su privilegi papali ritenuti autentici ma probabilmente spuri ${ }^{25}$.

A partire da questa produzione che si è enormemente dilatata e che, soprattutto, ha il pregio di aver messo mano a un'abbondante documentazione inedita, vale senzaltro la pena di riprendere il discorso su ideali e realtà

23 Paolo Grillo: L'abbazia cistercense dell'Acquafredda fra contado e città (metà XII metà XIII secolo), in: Lombardia monastica e religiosa: per Maria Bettelli, a cura di Grado Giovanni Merlo, Milano 2001, pp. 129-176; Badia di Tiglieto 1120-2001 ... la storia ricomincia, a cura di Simone Repetto, Ovada 2001; All'ombra dei signori di Morozzo (cit. nota 21), per Pogliola; Santa Maria di Casanova (cit. nota 4); L'abbazia di Rivalta di Torino nella storia monastica europea, Atti del Convegno: Rivalta di Torino, 6-8 ottobre 2006, a cura di Rinaldo Comba/Luca Patria, Cuneo 2007 (Storia e storiografia 46). Degne di attenzione due rassegne sui cistercensi e la vita rurale di Anna Maria RapeTtr: Grange e paesaggio rurale nell'Europa medievale (XII-XIII secolo), in: El Císter, ideals i realitat (cit. nota 4) pp. 101-123; EAD.: Alcune considerazioni intorno ai monaci bianchi e alle campagne nell'Europa dei secoli XII-XIII, in: Dove va la storiografia monastica in Europa? Temi e metodi di ricerca per lo studio della vita monastica e regolare in età medievale alle soglie del terzo millennio, Atti del Convegno internazionale, Brescia-Rodengo, 23-25 marzo 2000, a cura di Giancarlo AndennA, Milano 2001 (Storia e ricerche), pp. 323-351.

24 Rinaldo Сомва: Le terre dei Morozzo: uno straordinario punto di concentrazione di esperienze religiose e monastiche nei secoli XI - XIII, in: All'ombra dei signori di Morozzo (cit. nota 21) pp. 3-38 (alle pp. 5sg.). Cfr. Kurze (cit. nota 20) pp. XXIXsg., 275sg., 391sg.

25 Patrizia Merati: Diplomi imperiali e bolle pontificie a favore delle monache di Pogliola, in: All'ombra dei signori di Morozzo (cit. nota 21) pp. 381-404 (alle pp. 391sg.); EAD.: I documenti della canonica di Rivalta: produzione, ricezione, conservazione, in: L'abbazia di Rivalta (cit. nota 23) pp. 425-443 (alle pp. 428-430, 436-442), con riferimento a IP 6/2 pp. 99sg. nn. 1 e 2; Documenti dell'abbazia di Santa Maria di Staffarda (cit. nota 22) pp. 44 sg. doc. 10; p. 93 doc. 20. 
approfondendolo dall'angolo visuale, in verità non inedito, dei rapporti fra i Cistercensi, con la loro articolata identità in evoluzione, e il papato nella prima metà del XII secolo. A interessarci in primo luogo non è tanto l'“interscambio fra l'ideale che plasmava le forme istituzionali e le istituzioni che tentavano di perpetuare le intuizioni ideali” 26 , ossia non è tanto la messa a fuoco di un rapporto strettamente giuridico, già abbondantemente discusso in sede storiografica e oggi riletto in chiave sociologizzante da Gert Melville e dalla sua scuola: sono, invece, sia le metamorfosi stesse delle identità e delle idealità cistercensi nella loro concretizzazione in specifiche forme organizzative a contatto - e non sempre in sintonia - con la sede apostolica, sia le differenziazioni avvenute in quel periodo nell'universo cistercense, in quanto a osservanza degli instituta dell'Ordine.

Nell'elaborazione delle identità, nella loro difesa, nel confronto fra le istituzioni, molto contano gli uomini: le personalità che le guidano o che, più semplicemente, vi operano o vi aderiscono. La storia dei monaci bianchi è fatta anche, e forse soprattutto, da loro. Cercheremo di non dimenticarlo nella ricostruzione.

\section{Il papato e i monaci bianchi: da Urbano II a Callisto II}

In un'indagine di qualche anno fa sulle identità cistercensi delle origini espresse nell' "Exordium parvum» e in altre fonti coeve, estesa all'escussione sistematica delle fonti di tutto il primo quarto del XII secolo, ho evidenziato quelli che, dalla loro analisi, appaiono come i tratti distintivi dell'identità cistercense in quel periodo: un desiderio vivissimo di osservare rigorosamente la Regola di Benedetto, provocando nel mondo monastico una "restaurazione innovatrice" e una forte istanza di povertà volontaria che si voleva incarnare in un austero cenobitismo eremitico ${ }^{27}$. Va precisato, tuttavia, che la sicura coscienza della superiorità del proprio modo di vita che caratterizzava i monaci di Cîteaux, contrastava con l'ancor debole percezione che se ne aveva dall'esterno ${ }^{28}$.

La stessa indagine ha consentito di individuare il senso preciso dell'evoluzione dell'atteggiamento papale nei confronti del Novum monasterium, il nome con cui l'abbazia di Cîteaux fu chiamata negli anni a cavallo fra l'XI e il XII secolo. Nel volgere di poco più di una anno e mezzo, da quando cioè papa Urbano II durante un concilio romano fu informato, sembra per la prima volta, dell'esistenza di monaci di Molesmes che desideravano vivere una vita eremitica

26 CARIBOni: "Il nostro ordine è la carità" (cit. nota 7) p. 310.

27 Cомва: Identità cistercensi delle origini (cit. nota 4).

28 Grado Giovanni Merlo: L'identità cistercense nei documenti pubblici e privati dei secoli XII e XIII, in: L'abbazia di Lucedio (cit. nota 4) pp. 25-43. 
(heremum diligentes) proprio attraverso il clamor dei loro confratelli, al momento in cui Pasquale II emanò, nell'ottobre 1100, il privilegio Desiderium quod in favore del Nuovo Monastero, tale atteggiamento passò dal riconoscimento informale di uno stato di fatto alla conferma della nuova osservanza che venne presa sotto la 'speciale' tutela della sede apostolica ${ }^{29}$.

È noto che il concetto giuridico di 'conferma papale', trasformatosi a partire dall'XI secolo con lo spostamento dell'accento dalla protezione di un patrimonio a quello della disciplina regolare osservata in una casa religiosa, divenne nel secolo successivo "uno strumento della riforma monastica condotta dal papato e dell'inserimento della vita religiosa nelle strutture canoniche" ${ }^{30}$. Nel caso specifico, nel privilegio pontificio dell'anno 1100, la conferma fu subordinata all'osservanza nel Novum Monasterium della disciplina regolare che vi era stata instaurata: quamdiu vos ac successores vestri in ea quam hodie observatis disciplina ac frugalitatis observantia permanseritis, recita una discussa, ma quasi certamente autentica clausola del privilegio non trascritta nell' «Exordium parvum» ${ }^{31}$. Si

29 Narrative and Legislative Texts from Early Cîteaux, a cura di Chrysogonus Waddell, Cîteaux 1999 (Studia et documenta 9), pp. 241 cap. 6; pp. 251-253 cap. 14; СомвA: Identità cistercensi delle origini (cit. nota 4) p. 20; cfr. Michele Maccarrone: Primato romano e monasteri dal principio del sec. XII ad Innocenzo III, in: Istituzioni monastiche e istituzioni canonicali in Occidente (1123-1215), Atti della settima Settimana di studio, Mendola, 28 agosto - 3 settembre 1977, Milano 1980, pp. 49132; ora in: ID.: Romana ecclesia cathedra Petri, a cura di Piero Zerbi/Raffaello Volpini/Alessandro Galluzzi, vol. 2, Roma 1991 (Italia sacra 48), pp. 821 -927 (a p. 854), a cui si farà d'ora in poi riferimento nelle citazioni. Sempre utili le osservazioni di Georg Schreiber: Kurie und Kloster im 12. Jahrhundert. Studien zur Privilegierung, Verfassung und besonders zum Eigenkirchenwesen der vorfranziskanischen Orden vornehmlich auf Grund der Papsturkunden von Paschalis II. bis auf Lucius III. (10991181), vol. 1, Stuttgart 1910 (Kirchenrechtliche Abhandlungen 65), p. 91. Importante punto di riferimento sono gli studi sul periodo di Wilfried Hartmann: Verso il centralismo papale (Leone IX, Niccolò II, Gregorio VII, Urbano II), in: Il secolo XI: una svolta?, a cura di Cinzio Violante/Johannes Fried, Bologna 1993 (Annali dell'Istituto storico italo germanico. Quaderno 35), pp. 99-130.

30 Maccarrone: Primato romano (cit. nota 29) pp. 852-853.

31 Chartes et documents concernant l'abbaye de Cîteaux (1098-1182), a cura di Jean Marilier, Roma 1961 (Bibliotheca Cisterciensis 1), p. 48 doc. 21; Les plus anciens textes de Cîteaux: Sources, textes et notes Historiques, a cura di Jean de la Croix Bouton/Jean Baptiste Van Damme, Achel 1985 (CCCist, Studia et documenta 2), pp. 74-75. Sulla clausola condizionale citata nel testo mi limito a citare, anteriormente al 1982, Louis Jean Lekar: Nicholas Cotheret and the Conditional Nature of the "Privilegium Romanum", in: CCCist 31 (1980) pp. 1-7, secondo il quale essa è da considerarsi autentica dal momento che è contenuta in trascrizioni basate sull'originale. In effetti essa può essere stata realmente contenuta nell'originale, come annota Bernhard Schimmelpfennig: Zisterzienser, Papsttum und Episkopat im Mittelalter, in: Die Zisterzienser. Ordensleben zwischen Ideal und Wirklichkeit, a cura di Kaspar ELm/Peter Joerissen/Hermann Joseph Roth, Köln 1981 (Schriften des Rheinischen Museumsamtes 10), pp. 69-85, a p. 70. Per la sua assenza nell' "Exordium parvum» e per 
avviò in tal modo una 'canonizzazione' pontificia della riforma cistercense, come nel XII secolo avvenne di altre riforme monastiche o canonicali, che "da private e locali, come erano in origine", entrarono "nel diritto pubblico della Chiesa grazie alle conferme papali” ${ }^{32}$ : tanto più che un ulteriore, grande passo in tale direzione fu compiuto con l'approvazione delle costituzioni cistercensi.

Il 23 dicembre 1119, a poco più di vent'anni dalla nascita del Nuovo Monastero, papa Callisto II riconosceva ufficialmente la nuova religio monastica, ormai adottata da una dozzina circa di cenobi, confermando per la prima volta con l'autorità della sede apostolica quedam de observatione Regule beati Benedicti e soprattutto i capitula contenuti nella Charta caritatis $^{33}$. La virtù teologale della carità, da cui si facevano discendere la dilectio vicendevole e la pace fra le abbazie, entrava così come elemento forte, legittimante, sicuramente innovativo, della nuova identità dei monaci bianchi, che faceva ora dell'unanimità di intenti il pilastro essenziale del "Klosterverband" appena nato: Carta caritatis et unanimitatis si legge significativamente in un resoconto della fondazione dell'abbazia di Pontigny redatto verso la metà del XII secolo ${ }^{34}$.

È opportuno sottolineare che la conferma della Charta avvenne in un momento di rapida proliferazione delle abbazie cistercensi, a cui Guido di Borgogna, il futuro papa Callisto II, aveva contribuito quando, ancora arcivescovo di Vienne, aveva vigorosamente sostenuto la creazione del cenobio di Bonnevaux, fondato nel 1117 dopo una trattativa biennale con alcuni enti ecclesiastici della zona ${ }^{35}$. Le ricerche di Aldo A. Settia confermano con grande

argomentazioni decisamente opposte sulla sua autenticità, si veda per contro quanto ne dice il Waddell in: Narrative and Legislative (cit. nota 29) pp. 251-253, 432-434 (alle pp. 253 nota 11, e pp. 433sg. nota 5), che riprende ampiamente da un suo lavoro precedente: Prelude to a Fest of Freedom, in: CCCist 33 (1982) pp. 247-303. L'autore, in base soprattutto a considerazioni stilistiche e a comparazioni con il testo di altri privilegi cistercensi, ritiene che si tratti di un'interpolazione. Non tiene però a sufficienza conto degli orientamenti della cancelleria pontificia al tempo di papa Urbano II, "che introduce il principio che la conferma papale ad una determinata casa religiosa può non essere perpetua", tanto che "precisamente la subordina all'osservanza in essa della disciplina regolare che vi era stata instaurata": Maccarrone: Primato romano (cit. nota 29) p. 853. Cfr. ID.: I papi del secolo XII e la vita comune del clero, in: La vita comune del clero nei secoli XI e XII, Atti della Settimana di studio: Mendola, settembre 1959, vol. 1, Milano 1962, pp. 356, ora in: ID.: Romana ecclesia (cit. nota 29) p. 766.

32 Maccarrone: Primato romano (cit. nota 29) p. 854.

33 Narrative and Legislative (cit. nota 29) pp. 259 e 295-297; Les plus anciens textes de CCCist (cit. nota 31) pp. 84 e 104 sg.

34 Le premier cartulaire de l'abbaye cistercienne de Pontigny (XII ${ }^{\mathrm{e}}-\mathrm{XIII}{ }^{\mathrm{e}}$ siècles), a cura di Martine Garrigues, Paris 1981 (CDHistFr, s. in $8^{\circ}$, vol 14), p. 153 doc. 84; Chartes et documents concernant l'abbaye de Cîteaux (cit. nota 30) p. 66 doc. 43. Cfr. in merito le puntuali osservazioni di CARIBOni: "Il nostro ordine è la carità" (cit. nota 7) p. 283.

35 Cfr. Hélène Morin Sauvade: La filiation de l'abbaye de Bonnevaux, in: Unanimité et diversités cisterciennes (cit. nota 12) pp. 103-119 (alle pp. 110sg.). Su Guido di 
chiarezza il ruolo determinante di questo papa, che direttamente o indirettamente fu il "tramite" della prima diffusione dei monaci bianchi al di qua delle Alpi, promuovendone la conoscenza presso i suoi parenti aleramici. Tale diffusione avvenne con la fondazione nel 1120 dell'abbazia di Tiglieto e, nel 1123, di Lucedio, ambedue figliazioni di La Ferté, che rispondevano alla necessità dei rami scaturiti dalla discendenza di Aleramo "di affermare la propria identità separata e di mettere autonome radici in una propria area geografica: come Tiglieto fu il monastero dei marchesi di Bosco e di Ponzone, così Lucedio lo fu dei marchesi di Monferrato"36.

La conferma della Charta caritatis da parte di Callisto II e il suo sostegno alle fondazioni di Bonnevaux, Tiglieto e Lucedio evidenziano bene un orientamento tutto nuovo delle alte gerarchie ecclesiastiche, e del papato in particolare, nei confronti dell'Ordine, a cui veniva ormai garantita una protezione esplicita ${ }^{37}$. La religio cistercense, incarnazione di un eremitismo cenobitico austero, che, facendo proprie istanze diffuse di operosa povertà volontaria, proponeva una vita regularis basata sull'applicazione stretta della Regola di Benedetto, appariva ormai come un referente affidabile a cui appoggiarsi per riformare la vita monastica ${ }^{38}$ : uno dei non pochi referenti, è però qui il caso di precisare, fra le tante istituzioni monastiche e canonicali che assicuravano quello spirito di riforma a cui il papato appariva sempre più affezionato e alle quali veniva concessa la conferma pontificia. Quest'ultima, elargita a un cenobio subordinatamente all'osservanza in esso della disciplina regolare, divenne poi, con papa Innocenzo II, una norma - la cosiddetta "Clausola della regolarità", come la

Borgogna mi limito a citare Giovanni Miccoli: voce Callisto II, in: Enciclopedia dei papi, vol. 2, Roma 2000, pp. 248-254.

36 Aldo Angelo Settia: Santa Maria di Lucedio e l'identità dinastica dei marchesi di Monferrato, in: L'abbazia di Lucedio (cit. nota 4), le citazioni dalle pp. 54 e 56.

37 Significativo è il privilegio di protezione e di conferma dei beni rilasciato il 7 febbraio 1120 da Callisto II al cenobio di Santa Maria di Bonnevaux, dove vivevano monaci (fratres) provenienti dall'abbazia madre di Cîteaux (assensu charissimi filii nostri Stephani, Cisterciensis abbatis, de ipso venerabili ac religioso Cisterciensi monasterio assumptos). Seguendo un principio innovatore nel concetto di conferma, che consente al Reformpapsttum "di spostare l'accento dalla protezione alla riforma, favorendo le istituzioni monastiche e canonicali che assicuravano quello spirito" (MACCARrone: Primato romano [cit. nota 29] p. 853), il pontefice, prima di passare alla conferma dei beni, stabilisce ut deinceps religionis monastice disciplina, protegente Domino, conservetur. Edizione in: Bullaire du pape Calixte II, 1119-1124: essai de restitution, a cura di Ulysse Robert, Paris 1891, doc. 134; Migne PL 163 coll. 1157sg. Cfr. JL 6812. Cfr. supra, nota 31, e infra, testo corrispondente alle note 40 e 41.

38 Сомва: Identità cistercensi delle origini (cit. nota 4) pp. 20sg.; ID.: Cistercensi, certosini, eremiti: intrecci e istituzionalizzazioni di esperienze monastiche nel XII secolo, in: Certosini e cistercensi (cit. nota 17) pp. 9-32 (a p. 32). 
definì il Dubois ${ }^{39}$-, "introdotta in genere nei privilegi di conferma papale ad un monastero o a una canonica regolare", grazie alla quale l'osservanza di una regola divenne l' "oggetto primario della conferma accordata dal papa", mentre la protezione dei possedimenti monastici passava in secondo piano ${ }^{40}$. In primis siquidem statuentes - così si legge in un privilegio rilasciato il 26 luglio $1132 \mathrm{al}$ monastero di Santa Maria e Santa Croce di Tiglieto - ut ordo monasticus, secundum beati Benedicti regulam et formam religionis fratrum Cisterciensis monasterii, futuris temporibus ibidem inviolabiliter conservetur, bona igitur, que ad eundem locum impresentiarum iuste et canonice pertinere noscuntur, [...] illibata permaneant ${ }^{41}$. Ai rapporti fra Innocenzo II e i cistercensi è però necessario dedicare un'attenzione specifica.

\section{Il decennio decisivo dello scisma e il pontificato di Innocenzo II}

A partire dal 1130, con lo scisma di Anacleto II, i rapporti fra sede apostolica e i monaci di Cîteaux mutarono sensibilmente per le difficoltà in cui si venne a trovare Innocenzo $\mathrm{II}^{42}$. Questi, che guardava con favore al monachesimo riformatore ${ }^{43}$, bisognoso di aiuto, giocò con l'Ordine per quasi un decennio una lunga partita di sostegno reciproco, ormai approfondita storiograficamente da più punti di vista ${ }^{44}$, in cui va inquadrata anche, nel febbraio 1132, l'esenzione

39 Jacques Dubois: Les ordres religieux au XII ${ }^{\mathrm{e}}$ siècle selon la Curie romaine, in: RevBén 78 (1968) pp. 283-309 (alle pp. 286sg.).

40 Maccarrone: Primato romano (cit. nota 29) p. 853.

41 Carte inedite e sparse del monastero di Tiglieto (1127-1341), a cura di Francesco Guasco/Ferdinando Gabotto/Ambrogio Pesce, in: Cartari minori, vol. 3, Pinerolo 1912-1923 (BSSS 69), p. 230sg. doc. 3. Cfr. IP 6/2 p. 198. Cfr. Maccarrone: Primato romano (cit. nota 29) p. 853. Per una documentazione convergente più tarda: Cartario della abazia di Staffarda, a cura di Ferdinando Gaвотто/Giuseppe Roвerti/ Domenico Chiattone, vol. 1, Pinerolo 1901 (BSSS 11), pp. 17 e 19 docc. 5 e 6 cit.; IP 6/2 p. 103.

42 Sulla figura di Innocenzo II mi limito qui a rimandare ai due medaglioni che ne fa Tommaso di Carpegna Falconieri: voce Innocenzo II, in: Enciclopedia dei papi (cit. nota 35) vol. 2 pp. 261 -268; ID.: voce Innocenzo II, in: DBI 62 (2004) pp. 410-416. Per Anacleto II: Raoul Manselli: voce Anacleto II, in: Enciclopedia dei papi (cit. nota 35) vol. 2 pp. $268-270$.

43 Franz-Josepf Schmale: Studien zum Schisma des Jahres 1130, Köln/Graz 1961 (Forschungen zur kirchlichen Rechtsgeschichte und zum Kirchenrecht 3), pp. 46-47. Cfr. le recensioni di Piero Zerbi in: Aevum 34 (1961) pp. 557-560, e in: StM, s. III, 2 (1961) pp. 625-628 rispettivamente alle pp. 557-558 e 626-627. Per una succinta ripresa del tema dal punto di vista della storia cistercense: SchimmelpFennig (cit. nota 31) p. 71.

44 Pietro Zerbi: Tra Milano e Cluny. Momenti di vita e cultura ecclesiastica nel secolo XII, Roma 1978 (Italia sacra 28), pp. 3-119; ID.: San Bernardo di Clairvaux e Milano, in: 
dal pagamento delle decime per le terre lavorate direttamente dai monaci e per gli animali che essi allevavano ${ }^{45}$. Se il partito innocenziano riuscì alla fine vincitore, il bilancio per i monaci bianchi non fu meno favorevole, perché in pochi anni, a quanto sembra coincidenti con un periodo di parziale rielaborazione delle idealità cistercensi anche a fini propagandistici ${ }^{46}$, il numero dei cenobi cistercensi nell'Italia del Nord quadruplicò, numerose divennero le abbazie figlie di Clairvaux, i monaci consolidarono i loro rapporti con potenti stirpi aristocratiche e, soprattutto, come negli ultimi tre lustri è stato approfondito da una fitta serie di buoni studi, entrarono in contatto con alcune fra le più robuste e vitali realtà urbane della penisola: da Genova ${ }^{47}$, a Piacenza $^{48}$, a Milano ${ }^{49}$.

San Bernardo e l'Italia (cit. nota 15) pp. 61-68, e, nello stesso volume: Valeria PolONio: San Bernardo, Genova e Pisa (pp. 69-99); Giorgio Picasso: Fondazioni e riforme monastiche di san Bernardo in Italia (pp. 147-163). Il saggio di Annanaria АмвroSIONI: San Bernardo, il papato e l'Italia (pp. 25-49), è ora ripubblicato in EAD.: Milano, papato e impero in età medievale. Raccolta di Studi, a cura di Maria Pia Alberzoni/ Alfredo Lucioni, Milano 2003, pp. 549sg.

45 L'esenzione dalle decime, che va letta nel contesto delle numerose concessioni analoghe rilasciate a vari monasteri a partire da papa Pasquale II, trova spiegazione anche nelle esigenze della lotta di Innocenzo II contro Anacleto e nel sostegno che in essa gli veniva dai monaci bianchi e soprattutto da Bernardo abate di Clairvaux. Cfr. Gille Constable: Monastic Tithes from their Origins to the Twelfth Century, Cambridge 1964, pp. $242-$ 248, e, più in generale, Jean-Berthold MAHN: Lordre cistercien et son gouvernement des origines au milieu du XIII e siècle (1098-1265), Paris 1951 (2a edizione, Paris 1982), pp. 102-118; Catherine Boyd: Tithes and Parishes in Medieval Italy. The Historical Roots of a Modern Problem, Ithaca/New York 1952. Edizione dei privilegi di esenzione per Cîteaux e per Clairvaux rispettivamente in: Chartes et documents concernant l'abbaye de Cîteaux (cit. nota 31) p. 92 doc. 90 rilasciato a Cluny il 10 febbraio 1132, e in: Recueil des chartes de l'abbaye de Clairvaux au XII ${ }^{e}$ siècle, commencé par JeAN Waquet/Jean-Marc Roger et achevé par Laurent Veyssière, Paris 2004 (CDHistFr, s. in $8^{\circ}$, vol. 32), pp. 5 sg. doc. 4 rilasciato a Lione il 17 febbraio 1132. Cfr. JL 7544. Nel privilegio a favore di Clairvaux si fa esplicito riferimento alla riconoscenza di papa Innocenzo verso Bernardo per il suo impegno "incandescente Petri Leonis scismate". Cfr., per un'eco di tale orientamento in materia di decime nell'Italia del nord: RAPETTI: La formazione di una comunità (cit. nota 19) pp. 18sg. Per una succinta contestualizzazione in rapporto anche all'episcopato: SCHIMmelpFenNig (cit. nota 31) pp. 71sg.

46 Cfr. Сомва: Dal Piemonte alle Marche (cit. nota 4) pp. 316sg., con riferimento anche alla bibliografia ivi citata.

47 Valeria Polonio: La precoce vicenda di Sant'Andrea di Sestri presso Genova (1131), in: L'abbazia di Rivalta di Torino (cit. nota 23) pp. 31-67. Cfr. EAD.: I Cistercensi in Liguria (secoli XII-XIV), in: Monasteria Nova (cit. nota 18) pp. 3-78.

48 RApetti: La formazione di una comunità (cit. sopra 19) pp. 13sg.

49 Pietro Zerbi: San Bernardo di Clairvaux e Milano, in: San Bernardo e l'Italia (cit. nota 4) pp. 51-68; ID.: La rinascita monastica nella Bassa Milanese dopo l'anno 1000, in: Ricerche storiche sulla Chiesa Ambrosiana. Nel XV centenario della nascita di san Benedetto (480-1980), vol. 9, Milano 1980 (Archivio Ambrosiano 40). 
Il contatto con la metropoli lombarda, da cui tra la fine del 1134 e l'inizio del 1135 era stato allontanato l'arcivescovo anacletista Anselmo della Pusterla e dove occorreva consolidare la causa innocenziana, divenne da subito, grazie probabilmente al prestigio di Bernardo di Clairvaux, un rapporto con l'intera civitas. È infatti significativo che per Chiaravalle Milanese, la cui nascita viene riferita dai catalogi abbatiarum al luglio $1135^{50}$, a differenza di molti altri insediamenti promossi in Italia da La Ferté, Cîteaux, Morimond e dalla stessa Clairvaux, non si registrò in quegli anni alcuna donazione dell'aristocrazia militare: fu la città stessa di Milano a fondare il monastero ${ }^{51}$. Nell'aprile 1136 grazie al sostegno concreto di alcuni esponenti della società milanese, nonché del vescovo di Pavia, dotati di vasti beni presso Coronate (a metà strada fra Milano e Pavia), dove da un biennio circa si stava costruendo il monastero cistercense de Morimundo, figliazione diretta del cenobio francese di Morimond, il nuovo insediamento poté essere dotato di un più solido patrimonio: ad agire ad partem monasterii era lo stesso arcivescovo di Milano, Robaldo d'Alba ${ }^{52}$. Ancora in quell'anno a Piacenza fu l'intero gruppo dirigente cittadino a essere protagonista, accanto al suo vescovo, Arduino, nella fondazione di Chiaravalle della Colomba. Accanto a quello dei cives, nell'area lombardo-emiliana, fu dunque assai attivo il ruolo dell'episcopato ${ }^{53}$.

50 Léopold Janauschek: Originum Cisterciensium, vol. 1, Vindobonae 1877, p. 39.

51 Picasso: Fondazioni e riforme (cit. nota 44) p. 153; Annamaria Ambrosioni: Chiaravalle e Milano. Le origini e il primo secolo di una lunga vicenda, in: Chiaravalle: arte e storia (cit. nota 19) pp. 18-30 (a p. 21). Per i rapporti fra cistercensi e città, con particolare riferimento alla metropoli lombarda, Paolo Grillo: Il "desertum" e la città: cistercensi, certosini e società urbana nell'Italia nord-occidentale dei secoli XII-XIV, in: Certosini e cistercensi (cit. nota 17) pp. 363-412.

52 In particolare: Le carte del monastero di Santa Maria di Morimondo (cit. nota 23) pp. 109-115 doc. 56 e 57 del gennaio e febbraio 1136 (per il vescovo di Pavia), doc. 58 del 6 aprile 1136 (per l'arcivescovo di Milano). Cfr. Pietro Zerbi: I rapporti di san Bernardo di Chiaravalle con i vescovi e le diocesi d'Italia, in: Vescovi e diocesi in Italia nel Medioevo (sec. IX-XIII), Atti del Convegno di storia della Chiesa in Italia: Roma, 5-9 settembre 1961, Padova 1964 (Italia sacra 5), pp. 219-313, ora in: ID.: Tra Milano e Cluny (cit. nota 44) pp. 46-54. Cfr. inoltre i lavori di Elisa Occhipinti citati alla nota 19. Nel 1142-43 Morimondo fondò l'abbazia dell'Acquafredda di Lenno, diocesi di Como, sulle rive del Lario. Il nuovo cenobio nacque in piena autonomia dall'intraprendenza e da una forte capacità di irradiazione spirituale sorretta da contatti sociali ad alto livello dell'abbazia madre, grazie alla donazione di un personaggio, Atto del fu Lamberto Pellegrino di Isola, dotato di consistenti risorse economiche: Grillo: L'abbazia cistercense dell'Acquafredda (cit. nota 23) pp. 135sg.

53 Sulla fondazione mi limito a citare RApETtr: La formazione di una comunità (cit. nota 19) p. 21. Su Arduino v. Simona Rossi: Arduino vescovo di Piacenza $(1121-1147)$ e la Chiesa del suo tempo, in: Aevum 66 (1982) n. 2 pp. 197-231 (alle pp. 205-209). Una posizione di sostegno patrimoniale in qualche modo analoga avuta dal vescovo di Piacenza nella fondazione di Chiaravalle, ebbe nella dotazione di Fontevivo, nata intorno al 1140 come figlia dell'abbazia piacentina, Lanfranco, vescovo di Parma, che "donò ai 
L'intreccio fra espansione cistercense e vicende dello scisma, già intuito quarant'anni or sono dal Manselli ${ }^{54}$, è dunque oggi confermato dalle ricerche $e^{55}$, soprattutto con riferimento alle fondazioni della cosiddetta 'linea claravallense'. A ben guardare, tuttavia, la documentazione rivela in più di un caso almeno due fatti ulteriori di non secondaria importanza, che arricchiscono, sfumano e problematizzano di molto il panorama storico e istituzionale dell'espansione cistercense negli anni dello scisma e nel decennio successivo: l'appartenenza al Patrimonio di san Pietro di una parte significativa degli enti monastici da riformare o appena fondati, e, nel caso di cenobi preesistenti, la loro concessio a un'abbazia cistercense in cambio del versamento di un censo annuale ricognitivo alla Sede Apostolica.

Da questo punto di vista una lettura attenta del «Liber censuum» della Chiesa romana può fornire indicazioni preziose. Innanzitutto, ai nostri fini, appare illuminante la presenza fra gli "Eigenkloster" papali del monasterium Sancti Andree de Sexto, situato in Ianuensi archiepiscopatu ${ }^{56}$, che potrebbe anche essere posteriore alla sua incorporazione nell'ordine cistercense avvenuta, secondo i catalogi abbatiarum il 5 novembre $1131^{57}$. L'appartenenza, comunque molto antica, dell'abbazia di Sant'Andrea di Sestri al Patrimonio di san Pietro ${ }^{58}$, in ricognizione della quale alla fine del XII secolo essa ancora versava alle casse pontificie un marabotino d'oro all'anno ${ }^{59}$, sembra confermare ulteriormente quel "collegamento diretto" fra papa Innocenzo II e il cenobio di Cîteaux,

monaci provenienti da Piacenza non solo le decime, ma anche la chiesa e il terreno su cui venne costruito il monastero": CARIBONi: Esenzione cistercense (cit. nota 87) p. 92. Sulla storia di Fontevivo è ancor oggi utile Ireneo AfFò: Storia della città di Parma, vol. 2, Parma 1793, pp. 151-163, e soprattutto Giovanni MariotTi: L'abbazia di Fontevivo nel Parmigiano e l'unica sua figlia: l'abbazia di San Giusto presso Tuscania, in: Archivio Storico per le province parmensi 27 (1927) pp. 75-188.

54 Raoul Manselli: Fondazioni cistercensi in Italia settentrionale, in: Monasteri in alta Italia dopo le invasioni saracene e magiare (sec. X e XII), Relazioni e comunicazioni presentate al XXXII Congresso storico subalpino / III Convegno di Storia della Chiesa in Italia (Pinerolo, 6-9 settembre 1964), Torino 1966, pp. 201-222 (a p. 212).

55 Per una breve rassegna, Rinaldo Сомва: Da Tiglieto a Staffarda: gli esordi cistercensi nella regione ligure-subalpina, in: L'abbazia di Staffarda (cit. nota 11) pp. 69sg.

56 Le Liber censuum de l'Église romaine, a cura di Paul Fabre/Louis Duchesne, vol. 1, Paris 1910, p. 75; vol. 2, Paris 1905, p. 113.

57 JanauscheK (cit. nota 50) p. 22 n. 50. Sui catalogi abbatiarum: Comba: Da Tiglieto a Staffarda (cit. nota 55) pp. 77sg. Per il caso, apparentemente consimile, dell'abbazia di Cheminon, nella diocesi di Châlon sur Marne, trasformata verso il 1138 in cenobio cistercense: Ludwig Falkenstein: La papauté et les abbayes françaises aux XI ${ }^{\mathrm{e}}$ et $\mathrm{XII}^{\mathrm{e}}$ siècles. Exemption et protection apostolique, Paris 1997, pp. 27sg.: l'autore giudica il cenobio "un très rare exemple d'abbaye cistercienne payant un cens à l'Église romaine".

58 Il censo pagato potrebbe tuttavia costituire un corrispettivo per la protezione ricevuta dalla sede apostolica: FALKENSTEIN (cit. nota 57) p. 28.

59 Liber censuum (cit. nota 56) vol. 1 p. 75: Monasterium Sancti Andree de Sexto I marabotinum; IP 6/2 p. 342. 
"espressione di una volontà centrale senza passaggi in qualche modo diluiti", che Valeria Polonio ha felicemente intuito ${ }^{60}$. Tale rapporto diretto può essere meglio compreso se si pensa che, da un lato, esso appare contemporaneo alla presenza del pontefice in terra di Francia e, da un altro lato, avviene proprio con il monasterium, per dirla con un privilegio papale in suo favore ${ }^{61}$, che costituisce l'origo e il principium della religio cisterciense e al cui abate, Stefano Harding ${ }^{62}$, sono affidate dal pontefice in quegli anni alcune delicate funzioni giudiziarie da svolgere talvolta in compagnia di Bernardo, abate di Clairvaux ${ }^{63}$.

Non meno significative sono le vicende dell'abbazia di San Pietro di Cerreto presso Lodi, che si trovava sub beati Petri dicione ${ }^{64}$ per l'oblazione che ne aveva fatto il suo fondatore, Bennone, nel $1084^{65}$. Essa, accusata di essere in temporalibus et spiritualibus imminuta, il 18 novembre 1139, dopo ripetute richieste (postulationes) di Brunone, abate di Chiaravalle Milanese ${ }^{66}$, fu affidata, anzi "concessa" a tale cenobio, grazie a una precisa dispensa (apostolica dispensatio) di papa Innocenzo II, ut ibidem honestas et religio reformetur et idem locus tam temporaliter quam spiritualiter, gratum incrementum suscipiens, monasterio Claravallensi subiaceat. Il censo ricognitivo annuale, fissato in duodecim nummos Mediolanensis monete ${ }^{67}$, fu in seguito regolarmente registrato nel «Liber censuum» citato $^{68}$.

60 Polonio: La precoce vicenda di Sant'Andrea di Sestri (cit. nota 47) p. 39.

61 Chartes et documents concernant l'abbaye de Cîteaux (cit. nota 31) p. 92 doc. 90 rilasciato a Cluny il 10 febbraio 1132: Quia vero Cisterciense monasterium huius religionis origo est atque principium, nostra concessione hac prerogativa non inmerito gaudeat, ut, quando fuerit pastore proprio viduatum, quemlibet abbatem de omnibus abbatibus vestri ordinis vel monachum, salva nimirum sedis apostolice reverentia, sibi libere preficiendum eligat et absque aliqua confirmatione obtineat. Cfr. FalKensTeIn (cit. nota 57) p. 207sg.

62 Su Stefano Harding: Claudio Stercal: Stefano Harding. Elementi biografici e testi, Milano 2001 (Fonti cistercensi 1), con riferimento anche alla bibliografia ivi citata.

63 JL 7434, 7505 e 7524.

64 Codice diplomatico di Laus Pompeia, a cura di Cesare Vignati, Milano 1879, p. 131 doc. 102. Sull'abbazia di Cerreto, che mutò in seguito la sua intitolazione da San Pietro in Santa Maria, è ancor oggi utile: Giovanni Agnelli: Monasteri lodigiani. Cistercensi: San Pietro di Cerreto, in: Archivio storico per la città e comuni del circondario di Lodi 30 (1911) pp. $145-164$.

65 Il Liber iurium del Comune di Lodi, a cura di Ada Grossi, Roma 2004 (Pubblicazioni degli Archivi di Stato, Fonti 42), pp. 151sg. doc. 66 del 6 dicembre 1084. Cfr. Codice diplomatico di Laus Pompeia (cit. nota 64) vol. 1 p. 72 doc. 45.

66 Sull'abate Brunone v. Mauro TAgliabue: Gli abati di Chiaravalle nel Medioevo (11351465), in: Chiaravalle: arte e storia (cit. nota 19) pp. 50-91 (alle pp. 58-59). Cfr. il Commento storico di Ferruccio Gastaldelli a San Bernardo: Lettere, vol. 2 (211548), Milano 1987 (Opere di san Bernardo 6/2), pp. 242-244 ep. 281.

67 Codice diplomatico di Laus Pompeia (cit. nota 64) p. 131sg. doc. 102: ad inditium vero quod eadem abbatia beati Petri iuris existat, singulis annis duodecim numos Mediolanensis monete nobis nostrisque successoribus census nomine persolvetis. Cfr. PICAsso: Fondazioni e 
Un altro esempio interessante, anche se la documentazione sembra essere un po' meno esplicita, è quello di Chiaravalle di Fiastra nelle Marche. Qui, stando a una tradizione documentaria esile ma cronologicamente convergente, la più antica attestazione di una presenza dei monaci bianchi sembra infatti coeva al loro insediamento nel cenobio lodigiano ${ }^{69}$. Di poco posteriore, del 1141 in base a un'annotazione di fine XII - inizio XIII, vergata di seguito a una nota di possesso di un manoscritto vaticano ${ }^{70}$, sarebbe l'acquisizione del locus ad abbatiam construendam, che la stessa nota dice sorta l'anno successivo ${ }^{71}$. A tale data di completamento della costruzione del primo cenobio ${ }^{72}$, tramandata anche dai catalogi abbatiarum ${ }^{73}$, fa riferimento un falso in forma di originale, scritto dal notaio Cencio e datato al mese di marzo 1142, contenente una donazione pro anima del neonato monastero di Santa Maria ordinis Clarevallensis, edificato sotto il monte di Collalto, da parte di Guarnerio, duca di Spoleto e marchese di Ancona, agli abati Bernardo e Brunone, non meglio identificati ${ }^{74}$. Contrariamente a quanto è stato sostenuto ${ }^{75}$, il documento è soltanto apparentemente simile ad altro, scritto di mano dello stesso notaio e di contenuto in parte analogo, ma certamente autentico, dell'aprile 1145, che da esso differisce in alcuni punti sostanziali. L'attore è sempre Guarnerio e l'oggetto della sua generosità è ancora il monasterium da lui fondato, qui però localizzato nel comitato di Camerino presso il Chienti, ma la donazione appare fatta al solo Brunone, che si specifica essere abate di Chiaravalle Milanese: l'abate Bernardo, che sappiamo reggere in quegli anni il cenobio marchigiano, non vi è nominato. In compenso vi si trovano due clausole dense di significato: esso dovrà innanzitutto essere collocato subtus ordine Claravallensium e attenersi all'ordo Claravallensis; in secondo luogo, ogni suo futuro abate dovrà essere eletto

riforme (cit. nota 44) p. 154. Per il principio, di origine gregoriana, "che il papa, per il suo stesso ufficio, deve occuparsi dell'osservanza religiosa, in particolare nei monasteri che sono proprietà della Chiesa romana", v. Maccarrone: Primato romano (cit. nota 29) pp. 839sg.

68 Liber censuum (cit. nota 56) vol. 1 p. 110 , vol. 2 p. 112.

69 Le carte dell'abbazia di Chiaravalle di Fiastra (cit. nota 22) vol. 1 p. 85 doc. 38. Anche p. 88sg. doc. 41 e p. 93 doc. 43.

70 Giulio Battelli: I più antichi codici della badia di Fiastra, in: Annali della Facoltà di Lettere e Filosofia dell'Università di Macerata III-IV (1970-71) pp. 469-490 (a p. 488), ora in: ID.: Scritti scelti. Codici - documenti - archivi, Roma 1975, pp. 421-440 (a p. 438).

71 Cfr. Attilio De Luca: Introduzione, in: Le carte dell'abbazia di Chiaravalle di Fiastra (cit. nota 22) vol. 1 p. LXXIV.

72 Sulla possibile, diversa ubicazione del primo cenobio rispetto alla sede attuale dell'abbazia: De LucA: Introduzione (cit. nota 71) pp. LXXVIIsg.

73 JanAuscheK (cit. nota 50) p. 66.

74 Le carte dell'abbazia di Chiaravalle di Fiastra (cit. nota 22) vol. 1 pp. 99sg. doc. 48.

75 Le carte dell'abbazia di Chiaravalle di Fiastra (cit. nota 22) vol. 1 pp. $100-102$, apparato critico al doc. 48; pp. 107sg., apparato critico al doc. 51. 
regolarmente e ricevere la benedizione dal papa, sub cuius tuitiones semper manead, senza che né gli eredi del donatore, né alti funzionari pubblici, né vescovi o prelati possano mai rivendicare su di esso diritti di avvocazia ${ }^{76}$. In altri termini la neonata abbazia vi viene sottoposta a una doppia tutela: da parte dei Claravallenses, per quanto riguarda l'ordo monasticus da seguire, e della sede apostolica, di cui si prepara a diventare un monastero privato quod beati Petri iuris esse dignoscitur, come qualche tempo dopo riconosce papa Eugenio III $^{77} \mathrm{e}$ come conferma un privilegio Religiosam vitam eligentibus di papa Lucio $\mathrm{III}^{78}$ e il «Liber censuum» già citato ${ }^{79}$.

La vicenda dell'inclusione di Chiaravalle di Fiastra fra i monasteri appartenenti alla Chiesa romana è quanto mai significativa. Essa mostra che l'inserimento di un cenobio, anche fondato da poco, fra le proprietà della Chiesa romana ${ }^{80}$, poteva essere contemporaneo o addirittura posteriore alla sua acquisizione di fatto in una delle reti monastiche cistercensi (di Clairvaux, nel caso specifico, ma anche, per esempio, di La Ferté), ma non sempre, come probabilmente avvenne anche nel nostro caso, tale acquisizione, grazie alla collocazione giuridica peculiare rispetto alla struttura ecclesiastica diocesana, consentiva a un cenobio di raggiungere di fatto l'esenzione ${ }^{81}$.

Lo dimostra il caso di Staffarda, nata con molta probabilità nel luglio 1135, più o meno negli stessi giorni a cui i catalogi abbatiarum attribuiscono la fondazione di Chiaravalle Milanese ${ }^{82}$. Essa in due privilegi papali - di Celestino II e di Eugenio III - risulta annoverata fra i religiosa loca que beati Petri iuris existunt et ad Romanam specialiter spectant ecclesiam ${ }^{83}$, anche se della sua

76 Le carte dell'abbazia di Chiaravalle di Fiastra (cit. nota 22) vol. 1 p. 108 doc. 51 dell'aprile 1145 .

77 Le carte dell'abbazia di Chiaravalle di Fiastra (cit. nota 22) vol. 1 p. 142 doc. 73, probabilmente non di molto posteriore al documento citato nella nota precedente. Cfr. PUU in Italien, vol. 5 pp. 15sg. n. 9, con le correzioni di lettura apportate in: IP 4 p. 128 n. 1 sotto la data 1150 .

78 PUU in Italien, vol. 5 p. 43 n. 33 s. d.: Ad inditium autem quod monasterium vestrum specialiter beati Petri iuris sit, unam libram cere nomine census ... annis singulis persolvetis. Cfr. IP 4 p. 129 n. 6, sotto la data $1181-1185$.

79 Liber censuum (cit. nota 56) vol. 1 coll. 78 sg., vol. 2 col. 109.

80 Per il significato delle dizioni beati Petri iuris e Patrimonium beati Petri rimando a Maccarrone: Primato romano (cit. nota 29) pp. 822sg.

81 Falkenstein (cit. nota 57) pp. 159sg. Cfr. oltre, nota 87.

82 JanauscheK (cit. nota 50) p. 39.

83 Cartario della abazia di Staffarda (cit. nota 41) pp. 16sg. doc. 5 del 29 febbraio 1144; doc. 6 del 22 settembre 1146, inizialmente ed erroneamente riferiti dagli editori al 28 marzo 1144 e al 22 ottobre 1146 (v. Cartario cit., vol. 2 p. 365). Cfr. JL 8506 e 8948; IP 6/2 p. 103 nn. 1 e 2 . Sul privilegio di papa Eugenio III, che in realtà riprende il testo di quello di Celestino II: Julius v. Pflugk-Harttung: Acta pontificum Romanorum inedita, 3 vol., Tübingen $1881-1886$, qui vol. 3 p. 79 n. 77 , con le osservazioni di Schreiber (cit. nota 29) vol. 1 p. 91, e, da ultimo, di Guido Cariboni: I monasteri 
appartenenza alla Chiesa romana non c'è traccia nel «Liber censuum». Considerata nel suo contesto geo-politico-ecclesiastico, l'inclusione di Staffarda fra gli "Eigenkloster" papali, risalente con ogni probabilità al periodo della fondazione, potrebbe essere considerata un espediente per affrancare di fatto il cenobio dalla giurisdizione episcopale, considerata la scarsa autorevolezza dei vescovi che ressero la sede episcopale di Torino negli anni Trenta del XII secolo $^{84}$; nello stesso tempo tale obiettivo potrebbe apparire funzionale anche ai progetti di potenziamento nel Saluzzese dei fondatori dell'abbazia, i figli del marchese Bonifacio del Vasto ${ }^{85}$. I due privilegi citati, però, sia pure ad alcuni anni dalla fondazione, lungi dal riconoscere a Staffarda l'autonomia dalla potestas vescovile, confermata per esempio in quegli stessi anni a San Michele della Chiusa $^{86}$, ne sottolineano esplicitamente e contemporaneamente la sottomissione alla canonica iustitia dell'ordinario diocesano e all'auctoritas della sede apostolica $^{87}$; non ne resta turbato in alcun modo il rapporto fra primato romano

associati e incorporati nell'ordine cistercense: percorsi storiografici in area tedesca, in: L'abbazia di Rivalta di Torino (cit. nota 23) pp. 69-83 (a p. 73).

84 MGH Const. 1 p. 578 n. 402, «Breviarium gestorum» del concilio di Pisa (maggio giugno 1135): Uberto, Taurinensis electus, è deposto quia, cum ecclesia per quinquennium iam vacasset, ipse, ecclesiastico spreto officio, militie soli vacabat. Cfr. IP 6/2 p. 84 n. 16. Sui vescovi di Torino in quegli anni: Fedele SAvio: Gli antichi vescovi d'Italia dalle origini al 1300, Torino 1898, pp. 357sg.; Renato Bordone: Il primo diploma di Enrico V ai Torinesi e il fallimento cittadino nel controllo dei pedaggi, in: Storia di Torino, vol. 1, Dalla preistoria al comune medievale, a cura di Giuseppe SERGI, Torino 1997, pp. $470-$ 482 (alle pp. 479-480), e, nello stesso volume, pp. 566-572, Giuseppe SERGi: Torino nello scacchiere delle concorrenze successive alla marca, a p. 569. Innocenzo II risulta invece avere ottimi rapporti sia con l'abbazia di San Michele della Chiusa, di cui nel 1134 conferma l'autonomia dalla potestas del vescovo di Torino già concessa un ventennio prima da papa Pascale II (IP 6/2 p. 125 n. 14; p. 126 n. 16), sia, soprattutto, con il conte Amedeo III di Moriana Savoia, su istanza del quale il 22 ottobre 1136 dichiara il priorato di Saint Maurice-en-Valais, che iuris et proprietatis beati Petri esse cognoscitur, direttamente soggetto alla sede apostolica (solummodo Romano pontifici subiaceat) e conferma ad esso tutti i diritti e i privilegi di cui gode. Edizione del privilegio: Pflugk-Harttung: Acta (cit. nota 83) vol. 2 pp. 227sg. n. 326; Documenti sulle relazioni diplomatiche tra la casa di Savoia e la Santa Sede nel Medioevo (10661268), a cura di Pierina Fontana, Torino 1939 (BSSS 142), pp.15sg. doc. 9. Regesti: JL 7791; GP 2/2 p. 143 n. 11, p. 162 n. 1.

85 SeRGi: Torino nello scacchiere delle concorrenze successive alla marca (cit. nota 84) p. 571; Luigi Provero: Dai marchesi del Vasto ai marchesi di Saluzzo. Sviluppi signorili entro quadri pubblici (secoli XI-XII), Torino 1992 (BSS 209), p. 77sg.

86 Cfr. sopra, nota 84.

87 Cartario della abazia di Staffarda (cit. nota 41) pp. 17 e 19 docc. 5 e 6 cit. Si confronti su questo tema la diversa evoluzione, in quegli stessi anni, dei rapporti fra vescovo di Piacenza e sede apostolica per quanto concerne il cenobio di Chiaravalle della Colomba: Vito Tirelli: Di un privilegio dell'abbazia di Chiaravalle della Colomba nel Piacentino: una nota sulla "exemptio" dell'Ordine cistercense, in: BISI 72 (1960) pp. 191-217, e, con sviluppi ulteriori in tema di esenzione, Guido Cariboni: Esenzione cistercense e 
ed episcopato, centrale nella costituzione della Chiesa, mentre si evidenzia indirettamente come alla proprietà papale non necessariamente seguiva l'esenzione $^{88}$.

In sintesi: nel decennio dello scisma e negli anni immediatamente seguenti, l'inclusione di nuovi cenobi fra $\mathrm{i}$ beni della Chiesa romana e la loro incorporazione nell'universo cistercense, assieme a quella di altri che già vi appartenevano, fu considerata in Italia, a quanto pare dalla scarsa documentazione sopravvissuta, una 'via privilegiata' relativamente seguita. Il pontificato di Innocenzo II, che da questo punto di vista trova forti elementi di continuità nell'operato di Eugenio III, si presenta così, a un primo sguardo d'insieme, molto diverso da quello di Callisto II per quanto concerne i rapporti della sede apostolica con i cistercensi. Questi ultimi, grazie prevalentemente a Bernardo di Clairvaux, evidenziarono allora e misero a frutto un tratto non ancora esplicitato della loro identità: l'adesione assoluta allo schieramento di quello che ritenevano il papa legittimo e l'opposizione altrettanto netta alla parte di Anacleto II.

In altri termini: a favorire la moltiplicazione dei loro cenobi in Italia nel quarto decennio del XII secolo non furono tanto il desiderio di divulgare un ideale di vita monastica, la speranza di diffondere l'osservanza della Regola, o la necessità di soddisfare $\mathrm{i}$ bisogni materiali di comunità di monaci in rapida crescita numerica $^{89}$; fu piuttosto, in una "prospettiva ecclesiale dai complessi risvolti politici" 90 , l'adesione decisa alla causa innocenziana. Bernardo, come è stato appurato da tempo, non venne in Italia come "fondatore di monasteri". Quando, infatti, "vi mise piede per la prima volta agli inizi del 1133, era diretto

formazione del "Privilegium commune". Osservazioni a partire dai cenobi dell'Italia settentrionale, in: Papato e monachesimo "esente" nei secoli centrali del Medioevo, a cura di Nicolangelo D’Acunto, Firenze University Press 2003 (Reti Medievali), pp. 65107. Più in generale cfr. Luis García-Gujjarro Ramos: El Císter y la Iglesia romana: la exención, in: El Císter ideals i realitat (cit. nota 4) pp. 31-46 (alle pp. 35sg.). Per la clausola salva sedis apostolice auctoritate, a cui corrisponde la canonica iustitia del vescovo diocesano: Falkenstein (cit. nota 57) pp. 175-176; Maccarrone: Primato romano (cit. nota 29) pp. 864-865; Johann Baptist SäGmüLler: Die Entstehung und Bedeutung der Formel. "Salva sedis apostolicae auctoritate" in den päpstlichen Privilegien um die Mittel des 12. Jahrhunderts. Eine Studie zur Geschichte der Entwicklung des päpstlichen Gesetzgebungs rechtes, in: Acta congressus iuridici internationalis VII saeculo a Dectetalibus Gregorii IX et XIV a Codice Iustiniano promulgatis, Roma, $12-17$ novembre 1934, vol. 3, Roma 1936, pp. 155-171; sempre utile Schreiber (cit. nota 29) vol. 1 pp. 56-63. Per un riferimento anteriore alla giustizia vescovile in un privilegio a favore di un cenobio cistercense subalpino: Carte inedite e sparse del monastero di Tiglieto (cit. nota 41) p. 231 doc. 3 del 1132: salva nimirum, Aquensis episcopi iusticia et debita reverencia.

88 Cfr. Maccarrone: Primato romano (cit. nota 29) pp. 835, 846sg.; Falkenstein (cit. nota 57) pp. 159sg.

89 Cfr. Comba: Identità cistercensi delle origini (cit. nota 4) p. 17.

90 Picasso: Fondazioni e riforme (cit. nota 44) p. 150. 
a Pisa, chiamato da Innocenzo II, perché gli fosse vicino e collaboratore nel guadagnare quella cospicua parte dell'Italia che ancora era rimasta con Anacleto II"'1. Indispensabile, in questo contesto, non appariva ormai tanto l'adesione totale agli ideali primitivi di Cîteaux, quanto il sostegno convinto al "giusto" schieramento nella lotta nata dallo scisma. Non stupisce pertanto che ne derivasse un appannamento delle idealità cistercensi delle origini, o meglio il loro passaggio in secondo piano, di fronte all'urgenza di trovare proseliti nella contesa nata dallo scisma.

Tale appannamento si risolse, relativamente presto, per Morimondo e per almeno quattro fondazioni della linea di Clairvaux (Chiaravalle Milanese, San Pietro di Cerreto e Chiaravalle di Fiastra, Chiaravalle della Colomba) nell'applicazione di schemi di comportamento economico relativamente liberi e disinvolti rispetto alla normativa dell'Ordine, comunque abbastanza lontani, a quanto risulta dalle ricerche più recenti, dalle scelte effettuate in quegli stessi anni nelle aree più occidentali della penisola dai cenobi che facevano capo alle linee di Cîteaux, come Sant'Andrea di Sestri ${ }^{92}$, o di La Ferté, come Tiglieto, Lucedio, Staffarda e Casanova ${ }^{93}$. Morimondo possedette diritti di decima sin dal 1137 e avviò nel 1151 l'acquisto del castello di Farabasiliana con annessi diritti giurisdizionali. Chiaravalle Milanese acquistò, fin dal 1139, un sedime presso la Vettabbia al fine di erigervi un mulino, e prima del 1148 era già entrata in possesso di un altro mulino e di vari diritti di decima. Il significato da attribuire a tali attestazioni è tuttavia dubbio ${ }^{94}$. Assai più esplicito è il caso di San Pietro di Cerreto che conservò, sin dalla sua sottomissione a Chiaravalle nel 1139, l'honor et districtus sul villaggio di Plazano e il diritto di ricevere l'omaggio dei vassalli del luogo, per il quale ottenne nel maggio 1146 una dispensa indiretta di papa Eugenio III: questi, avvalendosi evidentemente del fatto che il cenobio era sub beati Petri dicione, ordinò a quattro nobiles viri già vassalli di Ogerio e Dondeo di Plazano, di prestare fidelitatem et debitum servitium all'abate di San Pietro ${ }^{95}$. A Fiastra, infine, nel gennaio 1143, a meno di un anno dalla dotazione del nuovo cenobio da parte del duca Guarnerio, l'abbazia ebbe in donazione, e li

91 Loc. cit.

92 Polonio: La precoce vicenda di Sant'Andrea di Sestri (cit. nota 47) pp. 41sg.

93 Comba: L'abbazia di Casanova (cit. nota 4) pp. 34sg.

94 Occhipinti: Il monastero di Morimondo (cit. nota 19) pp. 537sg.; Comba: Dal Piemonte alle Marche (cit. nota 4) pp. 341sg.

95 Codice diplomatico di Laus Pompeia (cit. nota 64) p. 149 doc. 119 del 4 maggio 1146; p. 152 doc. 122 del 5 marzo 1147. Cfr. IP 6/1 p. 122 n. 2. L'omaggio doveva essere prestato, dice la lettera papale, senza particolare riguardo per il vescovo locale con cui l'abbazia aveva una controversia giudiziaria (Matutino abbati de Cerreto pro ipso feudo fidelitetem et debitum servitium exhibeatis, nec Laudensis episcopi, vel cuiuslibet alterius suggestione id dimittatis) terminata l'anno dopo con una sentenza che attribuiva la curtis di Plazano cum honore et districto al monastero e le chiese di San Nabore e di San Silvestro all'ordinario. 
riconcesse immediatamente in enfiteusi ai donatori con canone annuo di una cannata di olio, certi beni nel fondo di Montesanto (Potenza Picena) e in altri fondi consistenti in terra, vinea et molendina, casa et platia et homini ${ }^{96}$ : mulini, cioè e, molto probabilmente, diritti su persone (hominia) $)^{97}$, ritenuti dalla normativa cistercense "contrari" alla "purezza monastica", come sicuramente in contrasto con essa era il contratto di enfiteusi a cui si fece ricorso ${ }^{98}$. Occorre per contro precisare che due donazioni di terre avvenute alcuni anni dopo, su probabile suggerimento dei monaci, escludevano dai beni ceduti all'abbazia proprio i mulini che vi si trovavano. Poco oltre la metà del secolo, infine, alcuni cenobi accrebbero sensibilmente i propri beni entrando in possesso di veri e propri diritti giurisdizionali ${ }^{99}$.

\section{Da Innocenzo II a Eugenio III nel Patrimonio di san Pietro: i beni dei cenobi incorporati, fra l'accettazione come stato di fatto e la dispensa pontificia}

A prima vista non perspicuo è il contesto inerente all'ingresso nell'universo cistercense di alcune abbazie laziali, quasi sicuramente appartenenti al Patrimonio di san Pietro, che ebbero grande importanza negli sviluppi dell'Ordine nell'Italia centro-meridionale.

Il cenobio di Santo Stefano di Fossanova, documentato per la prima volta nel 1089, era situato "lungo il tracciato viario, la via pedemontana, che, dal XII secolo, sarebbe diventata il percorso principale e l'itinerario più frequentato per raggiungere Terracina" ${ }^{100}$. La sua incorporazione, che non dovette avvenire senza il consenso dei monaci, probabilmente in contatto diretto o indiretto con Clairvaux $^{101}$, fu realizzata attorno al 1135 , data a cui fanno riferimento

96 Le carte dell'abbazia di Chiaravalle di Fiastra (cit. nota 22) pp. 103sg. doc. 49.

97 Jan Frederick Niermeyer: Mediae latinitatis lexicon minus, Leiden 1976, pp. 492sg., voce hominium. Per il significato di questo termine nelle Marche del XII secolo: Le carte dell'abbazia di Chiaravalle di Fiastra (cit. nota 22) pp. 111sg., 161.

98 Narrative and Legislative (cit. nota 29) p. 328.

99 Cомва: Dal Piemonte alle Marche (cit. nota 4) p. 343.

100 Maria Teresa Caciorgna: L'abbazia di Fossanova. Vicende e problemi di un'abbazia tra Stato della Chiesa e Regno, in: Il monachesimo cistercense nella Marittima medievale (cit. nota 20) pp. 91-128 (a pp. 95sg.).

$101 \mathrm{E}$ probabile che l'incorporazione di Fossanova nell'Ordine cistercense sia avvenuta in seguito a un contatto indiretto con Bernardo di Clairvaux o con l'ambiente claravallense, preceduto dalla fama dei monaci bianchi e forse mediato da sostenitori di papa Innocenzo II: JANAUSCHEK (cit. nota 50) pp. $37 \mathrm{sg}$. n. 90. Si pensava qualche decennio fa a un passaggio immediato del monastero laziale alla "filiation d'Hautecombe, au mois d'octobre 1135, c'est-à-dire après que celle-ci se fut donnée elle-même aux Cisterciens"; cfr. Anselme Dimier: Amédée de Lausanne, Rouen 1949, p. 65; id.: Les fondations de 
numerosi catalogi abbatiarum ${ }^{102}$, presumibilmente molto vicina nel tempo a quella di un privilegio deperdito di papa Innocenzo II (abbastanza noto nel suo contenuto grazie a quanto lascia intendere una lettera pontificia del gennaio 1207), che "donava" e "concedeva" all'ordo Cisterciensis il venerabile monasterium Fosse Nove, quod Sancti Stephani dicitur, cum ecclesia Sancte Marie de Fossanova eorumque pertinentiis omnibus ${ }^{103}$. L'ubicazione dell'abbazia in una regione ancora segnata da forti resistenze anacletiane ${ }^{104}$ e, soprattutto, lungo una via che ne "accresceva l'importanza e la funzione di controllo della parte meridionale del Patrimonio di san Pietro" 105 , dovette avere un peso non indifferente nella scelta del pontefice, che, in un momento particolarmente difficile per l'antagonista Anacleto $\mathrm{II}^{106}$, creò ai limiti meridionali del Patrimonio di san Pietro, proprio grazie all'incorporazione dell'antico cenobio nell'Ordine dei monaci bianchi,

saint Bernard en Italie, in: AnalCist 13 (1957) pp. 63-68 (a p. 67). Tale passaggio è stato contraddetto da nuove e più approfondite ricerche del ID.: voce Fossanova, in: DHGE 16 (1971) coll. 1208-1213, che riferisce dettagliatamente sulla non precisamente databile affigliazione ad Altacomba, da cui comunque Fossanova risulta dipendere come figlia alla fine del XII secolo. Per un rapido aggiornamento v. soprattutto Knut Schulz: voce Fossanova, in: LexMA 4 (1989) coll. 671sg., e, per il riferimento diretto alle fonti, Goffredo Viтi: voce Fossanova, in: Monasticon Italiae, vol. 1, Roma e Lazio, Cesena 1981, pp. 159sg. Di scarsa utilità è Balduino Gustavo Bedini: Le abazie cistercensi d'Italia: sec. XIII-XIV, Casamari 1987 (quinta ristampa, prima ed. 1964), pp. 19sg. Su Altacomba: Romain Clair: Les origines de l'abbaye de Hautecombe, in: Mélanges à la mémoire du père A. Dimier, vol. 4, Arbois 1984, pp. 615-627.

102 JanAuscheK (cit. nota 50) pp. 37sg. n. 90. Il riferimento prevalente è all'ottobre 1135 . 103 IP 2 p. 126 n. 1; Ротthast, vol. 1 p. 253; edizione in: Migne PL 215 col. 1055.

$104 \mathrm{Si}$ noti che nel 1135 Anacleto è ancora riconosciuto come papa a Terracina, il cui vescovo, del resto, nel maggio-giugno 1135 non compare fra i prelati presenti al concilio di Pisa (MGH Const. 1 p. 578): Caciorgna: L'abbazia di Fossanova (cit. nota 100) p. 106 nota 35. Il 22 aprile 1137 Anacleto II ancora rilascia un privilegio per la collegiata di Santa Maria di Piperno, nel cui territorio attualmente l'abbazia di Fossanova si trova: IP 2 p. 123 n. 1; Pier Fausto Palumbo: I precedenti, la vicenda romana e le ripercussioni europee dello scisma di Anacleto II, Roma 1995 (seconda ed.), pp. 416 e 719; prima ed., col titolo Lo scisma del MCXXX, Roma 1942, pp. 559 e 677. Cfr. Mary Stroll: The Jewish Pope. Ideology and Politics in the papal Schism of 1130, Leiden 1987, p. 93.

105 Caciorgna: L'abbazia di Fossanova (cit. nota 100) p. 92. Cfr., per il rapporto fra insediamenti e poteri: EAD.: Marittima medievale. Territori, società, poteri, Roma 1996; Paolo Delogu: Territorio e domini della regione pontina nel Medio Evo, in: Ninfa, una città, un giardino, Atti del Colloquio della Fondazione Camillo Caetani, Roma Sermoneta - Ninfa, 7-9 ottobre 1988, a cura di Luigi FIorani, Roma 1990, pp. 17-32 (a p. 23).

106 Palumbo: Precedenti (cit. nota 104) p. 512 (prima ed. cit., p. 543): “... dal 1135 - e in qualche modo lo rivela anche l'estremo diradarsi del bollario anacletiano - Roma è come isolata, compresa fra il vasto mondo che fa partito per Innocenzo e il Mezzogiorno in endemico stato di rivolta. Giungono per Anacleto e il gruppo superstite dei suoi elettori e seguaci gli anni ed i mesi dell'abbandono ...”. Cfr. Schmale (cit. nota 43) pp. 168sg. 
una sorta di enclave monastica a lui fedele incuneata fra le aree di obbedienza anacletiana.

A che titolo tale incorporazione avvenne? La terminologia riportata nella lettera citata del gennaio 1207 e il riferimento che vi si faceva ai privilegia e alle concessiones che l'avevano determinata sembrano non lasciare molti dubbi sull'originaria natura di "Eigenkloster" papale del cenobio di Santo Stefano di Fossanova, il cui patrimonio venne fra l'altro arricchito nel 1158 da una "donazione", da parte di papa Adriano IV, della chiesa della Santa Trinità nel territorio di Sezze e di una grangia ad ius beati Petri specialiter pertinente ${ }^{107}$. Va poi ricordato che Fossanova, già al momento del suo passaggio all'Ordine, si trovava ad annoverare fra i propri possedimenti una chiesa privata dotata di molti beni che divenne parte integrante della struttura patrimoniale dell'abba$\mathrm{zia}^{108}$.

Qualcosa di simile dovette avvenire per il monastero dei Santi Vincenzo e Anastasio delle Tre Fontane alle Acque Salvie, situato nei pressi di Roma in un'area paludosa, che, secondo l'erudizione cistercense, Innocenzo II avrebbe assegnato nel 1140 ai monaci di Clairvaux come atto di riconoscenza per il loro sostegno durante lo scisma ${ }^{109}$. Se la data dell'incorporazione, fornita dai catalogi abbatiarum, sembra compatibile con quanto si ricava dal testo di una lettera del 1153, indirizzata da Gozvino, abate di Cîteaux, e dall'intero capitolo generale dell'Ordine a papa Anastasio IV, la terminologia con cui vi si accenna - vi si parla infatti esplicitamente di donazione da parte del pontefice al monastero (ecclesia) di Clairvaux e all'ordo di Cîteaux ${ }^{110}$ - non sembra, anche in questo caso, lasciare dubbi sulla natura di "Eigenkloster" papale del cenobio, ceduto o perché spopolato o per la necessità di riformarlo.

L'interesse dell'incorporazione di Sant'Anastasio per la storia dei monaci bianchi non consiste tanto nella condizione fisica delle sue terre e nelle febbri malariche che vi erano diffuse, a cui accenna una austera lettera di Bernardo di Chiaravalle al primo abate cistercense di quel cenobio, il monaco Bernardo Paganelli in seguito papa col nome di Eugenio III $^{111}$, né consiste nella sua

107 IP 4 p. 225 sg. n. 11; IP 3 pp. 165sg. n. 5. Cfr. IP 2 pp. 126sg. n. 3-4. Per l'ubicazione e la storia dei beni donati: CACiorgna: L'abbazia di Fossanova (cit. nota 100) pp. 110sg.

108 Caciorgna: L'abbazia di Fossanova (cit. nota 100) pp.91-128 (a p. 96), con riferimento a un privilegio deperdito di papa Innocenzo II regestato in: IP 2 p. 126 n. 1.

109 Janauschek (cit. nota 50) p. 62 n. 151.

110 Statuta Capitulorum Generalium Ordinis Cisterciensis ab anno 1116 ad annum 1786, a cura di Joseph Marie Canivez, vol. 1, Louvain 1933, p. 51, lettera di Gozvino e del Capitolo Generale a papa Anastasio IV sul patrimonio di Sant'Anastasio: Quo circa supplicamus vestre beatitudini ut domum ipsam, secundum domini Innocentii donationem et domini Eugenii confirmationem Clarevallis ecclesie et ordini nostro, in his que ad animarum curam et disciplinam religionis pertinent, confirmetis. Cfr. anche p. 52.

111 San Bernardo: Lettere (cit. nota 66) vol. 2 pp. 394-397 ep. 345. 
ubicazione alle porte della città eterna, in modo da costituire un preciso punto di riferimento per i contatti con la curia pontificia. Consiste invece nella struttura tradizionale del suo patrimonio monastico, che lo rendeva incompatibile con il "rigore" dell'Ordine a cui era stato associato. Non a caso: a quanto risulta dalla scarsissima documentazione sopravvissuta, l'abate Paganelli, fra il 1140 e il settembre 1143, interessò del problema Innocenzo II. Egli voleva vendere o permutare certi beni, senza capire in quel momento - come avrebbe scritto più tardi ${ }^{112}$ - quanto ciò fosse difficile. Il pontefice non diede però il suo consenso all'operazione e tali beni rimasero proprietà del cenobio in attesa di tempi migliori ${ }^{113}$. Passò qualche anno e il Paganelli, divenuto papa a sua volta, si convinse che, nell'impossibilità di permutare o alienare parte dei beni per acquistarne altri, la necessitas loci indirizzasse verso una sola direzione: mantenere il patrimonio così com'era, perché senza di esso sarebbero venute a mancare le risorse necessarie per il sostentamento dei monaci. Così, probabilmente alla fine dei suoi giorni, nel 1153, impossibilitato ormai a risolvere il problema, pur dopo aver forse già rilasciato un privilegio di conferma dei beni dell'abbazia ${ }^{114}$, suggerì al Capitolo generale di mitigare per essa il rigor ordinis, accettando una dispensa pontificia che le consentisse di conservare il proprio patrimonio nella situazione in cui si trovava ${ }^{115}$ : un patrimonio, invero, di entità non trascurabile - e di struttura assai poco cistercense! - se si presta fede a un privilegio di conferma rilasciato da papa Alessandro III nel 1161, che riconosceva al cenobio il controllo di almeno tre chiese, due casali, sei castra e numerosi altri beni ${ }^{116}$.

La proposta fu probabilmente discussa dal Capitolo generale, insieme a richieste analoghe di Fossanova e di Casamari sostenute da una lettera di raccomandazione di Ugo, cardinale vescovo di Ostia, anche lui cistercense, che annunciava l'avvenuta morte di Eugenio III e "prevedeva il sorgere di un magnum scandalum se le petizioni dei tre cenobi non fossero state accolte" ${ }^{\text {"117 }}$. Da che cosa sarebbe nato lo scandalo non è detto, ma è probabile che un diniego avrebbe sottolineato importanti differenze di impostazione del problema da

112 Cfr. nota seguente.

113 Statuta Capitulorum Generalium Ordinis Cisterciensis (cit. nota 110) p. 44, lettera di Eugenio III al Capitolo generale sui beni temporali dell'abbazia di Sant'Anastasio, riferita dall'editore all'anno 1152, ma certamente del 1153: Ipse autem [Innocentius] necessitatem rei sanioris consilii gravitate dimetiens super his nobis noluit prebere consensum et possessiones illas usque in aliud commodius penes ecclesiam constituit retinendas.

114 IP 2 p. 174 n. 4, p. 175 n. 11. Cfr. oltre, nota 148.

115 Statuta Capitulorum Generalium Ordinis Cisterciensis (cit. nota 110) p. 44: nostra dispensatione utamini.

116 Per il privilegio di Alessandro II: PUU in Italien, vol. 4 pp. 34sg.; JL 10.670. Cfr. oltre, nota 135.

117 Comba: Le scelte economiche dei monaci bianchi (cit. nota 6) p. 151, con il contesto citato. Per la lettera del cardinale Ugo d'Ostia: Statuta Capitulorum Generalium Ordinis Cisterciensis (cit. nota 110) p. 51. 
parte dell'Ordine e da parte del pontefice, che, come il suo predecessore, aveva lasciato gli antichi patrimoni monastici come stavano, riconoscendone di fatto la liceità anche in forma ufficiale ${ }^{118}$. È nota, invece, la risposta del Capitolo a papa Anastasio IV, successore del Paganelli sulla cattedra di Pietro: De facienda autem dispensatione ut [fratres Sancti Anastasii] possessiones suas retineant in beneplacito vestro et in vestra relinquimus potestate. In altre parole l'organo supremo che reggeva l'Ordine di Cîteaux lasciò al beneplacito pontificio di concedere in merito una dispensa che, come si è accennato, era già stata disposta di fatto da Eugenio III ${ }^{119}$.

Il ricorso alla dispensa pontificia per sanare una situazione evidentemente incongruente dal punto di vista patrimoniale, anche se per noi oggi non del tutto chiaramente definibile, è documentato, come si è accennato, già da parte di Innocenzo II per l'incorporazione (anzi, la sottomissione) di San Pietro di Cerreto al cenobio di Chiaravalle Milanese nel $1139^{120}$. Nel caso dei tre cenobi laziali mancano documenti per dire se la dispensa papale fu formalmente concessa. È però certo che, anche se non lo fu, la loro struttura patrimoniale anteriore fu di fatto accettata, come risulta da privilegi papali di poco posteriori ${ }^{121}$.

Uno di essi, rilasciato da papa Alessandro III il 9 maggio 1170, riguarda il cenobio dei Santi Giovanni e Paolo di Casamari presso Veroli, che nel 1151, se non prima ${ }^{122}$, era stato concesso ai monaci bianchi ${ }^{123}$. Si trattava, anche in questo caso di un "Eigenkloster" papale, come espressamente risulta dal documento ${ }^{124}$ : un monastero molto importante dal punto di vista economico e politico. Nella clausola di salvaguardia del patrimonio (assolutamente non strutturato secondo gli antichi orientamenti dell'Ordine) erano infatti confermate undici chiese, la maggior parte delle quali già attestate nel noto privilegio di Callisto II per Casamari del 1122, a cui se ne aggiungevano altre due,

118 Cfr. sopra, nota 108.

119 Cfr. sopra, nota 110.

120 Sopra, testo corrispondente alla nota 67.

121 Comba: Le scelte economiche dei monaci bianchi (cit. nota 6) p. 151. Per Fossanova e Sant'Anastasio cfr. sopra, testo corrispondente alle note 107sg., 112-115.

122 Cfr. Picasso: Fondazioni e riforme (cit. nota 44) p. 157.

123 Cfr. IP 2 p. 169 nn. 1 e 9

124 Migne PL 200 coll. 671-674 n. 728: monasterium vestrum quod ad ius et proprietatem beati Petri pertinere dignoscitur; Bullarium diplomatum et privilegiorum Romanorum Pontificum. Taurinensis editio, vol. 2, Torino 1858, pp. 731sg. doc. 46. Cfr. IP 2 p. 169 n. 9; JL 11.789. Per il possesso di chiese da parte dei monasteri cfr. Giles Constable: Monastic Possession of Churches and 'spiritualia' in the Age of Reform, in: Il monachesimo e la riforma ecclesiastica $(1049-1122)$. Atti della quarta Settimana di studio, Mendola, 23-29 agosto 1968, Milano 1971 (Miscellanea del Centro di studi medievali 6) pp. 304-335. 
concesse da Eugenio III, distribuite in più località del Lazio meridionale ${ }^{125}$. Inoltre, fatto significativo, ogni nuovo abate doveva essere consacrato direttamente dal pontefice dopo un'elezione che, si legge nei due privilegi, doveva avvenire seguendo la regola di Benedetto da Norcia ${ }^{126}$ scegliendolo all'interno della comunità $o$, se fosse necessario, "de alieno collegio". Anche per la successione abbaziale il privilegio di Callisto fu dunque ricalcato fedelmente su quello alessandrino, con la sola significativa differenza che, in quest'ultimo caso, la scelta doveva avvenire all'interno dell'Ordine di Cîteaux ${ }^{127}$. Poco di nuovo, dunque, salva la coscienza di appartenere all'ordo cistercense e di dover vivere secondo le institutiones Cisterciensium fratrum, caratterizzava la struttura patrimoniale del monastero, cambiata pochissimo in quasi mezzo secolo.

Ancora una volta la dispensa, rilasciata di fatto con la conferma papale dei beni dell'abbazia, riguardò un patrimonio monastico strutturato secondo le forme tradizionali dei patrimoni signorili, in cui soprattutto spiccava per importanza il possesso di chiese, pascoli, boschi. Poi il patrimonio di Casamari, nei quasi vent'anni che separano il privilegio alessandrino da quello, deperdito, con cui nel 1151 papa Paganelli aveva concesso al cenobio terre, pascoli, selve e tutta la castellania di Montenero, oltre a due chiese, era rimasto nella sostanza immutato ${ }^{128}$.

Più confuso per la consueta carenza di documenti, ma cronologicamente e strutturalmente ricostruibile con una certa precisione, è il panorama che si presenta con tre incorporazioni di antichi cenobi situati nel Patrimonio di san Pietro in Tuscia: Santa Maria di Faleri nella diocesi di Civita Castellana e San Martino al Cimino presso Viterbo, di cui la tradizione erudita cistercense fa rimontare rispettivamente l'associazione all'Ordine al 1143 e al 1150 grazie a monaci provenienti da Saint Sulpice in Savoia, della linea di Pontigny, e San Giusto di Tuscania, che sarebbe stata invece popolata nel dicembre 1146 da monaci provenienti da Fontevivo nel Parmense, figlia di Chiaravalle della

125 Edizione del privilegio in: Les registres de Nicolas IV, a cura di Ernest LangLois, vol. 1, Paris 1905, pp. 620sg. doc. 4248. Cfr. IP 2 p. 168 n. 4.

126 Nel privilegio del 1122 si legge che l'elezione deve avvenire secundum timorem Dei et beati Benedicti regulam, dizione che nella sua prima parte già costituisce una citazione del capitolo De ordinando abbate della Regola di Benedetto. In un privilegio del 1170 si legge invece più semplicemente che essa deve avvenire secundum Deum et beati Benedicti regulam. Viene eletto, e si tratta anche qui di un prestito dalla Regola, quem fratres communi consensu, vel fratrum pars consilii sanior [...] elegerint.

127 Migne PL 200 col. 673: de alieno Cisterciensis ordinis, si oportuerit, collegio. Diversa interpretazione del testo in CARIBONI: I monasteri associati (cit. nota 83) p. 75.

128 Il privilegio deperdito di Eugenio III è menzionato in una rinuncia di certi possessi fatta il 26 marzo 1157 da parecchi uomini di Montenero, abitanti in Veroli, all'abate Gregorio di Casamari, oltre che nella successiva conferma di Alessandro III (sopra, nota 121): Federico Tonetti: Alcuni documenti del territorio verolano, in: ASRSP 25 (1902) pp. $228-237$, doc. 1 . 
Colomba $^{129}$. In realtà, la documentazione conservata, sia pure posteriore, se da un lato conferma l'appartenenza dei cenobi associati alle famiglie monastiche indicate, da un altro lato, pur non contraddicendo nella sostanza questi riferimenti cronologici, di per sé soltanto indicativi, apporta in due casi qualche elemento ulteriore di datazione. Per San Giusto sappiamo che ottenne privilegi da Lucio II, pontefice dal marzo 1144 al febbraio 1145; per San Martino un inventario trecentesco dell'archivio monastico menziona inoltre l'esistenza di un privilegium quod incipit Eugenius episcopus et finit anno I: si tratta evidentemente dello stesso documento a cui accennano privilegi di successivi pontefici, che venne evidentemente rilasciato nel primo anno di pontificato di questo papa, consacrato il 18 febbraio $1145^{130}$. Per Santa Maria di Falleri il più antico privilegio conservato riguarda una conferma di beni da parte di Adriano IV, in cui però si cita la precedente donazione di una grangia da parte di Eugenio III $^{131}$.

$\mathrm{Si}$ trattava anche in questo caso di monasteri privati dei papi? Non sappiamo, anche se è certo, per Faleri, che almeno la grangia citata aveva questa provenienza ed era stata donata da papa Eugenio con il consenso di alcuni esponenti dell'aristocrazia consolare romana ${ }^{132}$. Né abbiamo conferma, se non nel caso del pauperculum monasterium di San Martino, come fu retrospettivamente definito a inizio Duecento ${ }^{133}$, che si trattasse di incorporazioni effettuate con scopi di riforma monastica e di assestamento finanziario ${ }^{134}$. Sembra comunque probabile, considerata l'ubicazione delle tre abbazie ai margini settentrionali del Patrimonio di san Pietro, che le esigenze di riforma convergessero con opportunità di un più serrato controllo pontificio della zona, come sembrerebbero confermare la modicità dei rispettivi patrimoni

129 JanauscheK (cit. nota 50) pp. 77, 88, 124; Monasticon Italiae (cit. nota 101) pp. 139, 186sg., 195; BEDini (cit. nota 101) pp. 40, 45, 55sg. Per qualche considerazione sulla mancata introduzione della riforma cistercense in un'altra area del Lazio attuale v. LEGGIO (cit. nota 20) pp. 21-33.

130 PUU in Italien, vol. 5 p. 261 n. 21; IP 2 p. 199; JL 13.038. Pietro EgIDI: L'abbazia di San Martino sul monte Cimino con documenti inediti, in: RSB 1 (1906) p. 586; 2 (1907) p. 165.

131 Pflugk-Harttung: Acta (cit. nota 83) vol. 3 pp. 162sg. n. 151; IP 2 p. 188; JL 9978.

132 Pflugk-Harttung: Acta (cit. nota 83) vol. 3 pp. 162sg. n. 151: grangiam quoque de ponte Sambuci, quam dedit vobis sancte memorie papa Eugenius, cum consensu Oddonis Frangentispanem et Petri Latri et Stefani qui Gencius vocatur et Theodore. Su questi personaggi mi limito a rimandare al bel volume di Matthias Thumser: Rom und der römische Adel in der später Stauferzeit, Tübingen 1995 (Bibliothek des Deutschen Historischen Instituts in Rom 81), pp. 107, 111, 231. Cfr. ID.: Die Frangipane. Abriß der Geschichte einer Adelsfamilie im hochmittelalterlichen Rom, in: QFIAB 71 (1991) pp. 106-173.

133 EGIDI (cit. nota 130) 2 (1907) p. 169.

134 EGIDI (cit. nota 130) 2 (1907) p. 164. 
fondiari e l'evidente necessità di integrarne la consistenza con l'aiuto dell'aristocrazia.

Va da sé che anche in questo caso i patrimoni dei singoli cenobi, di impostazione assolutamente signorile, vennero incorporati senza procedere a mutazioni di rilievo, come confermano i privilegi papali successivi. Soltanto per Santa Maria di Faleri è documentabile un aggiustamento patrimoniale nella direzione indicata dalla normativa cistercense: le uniche due chiese di cui si dichiarava il controllo nel 1155 più non risultano nella conferma dei beni effettuata da Alessandro III nel $1179^{135}$. Per San Giusto un privilegio dello stesso papa rilasciato nel 1178 menziona il controllo del castello omonimo, una rocca, una decina di chiese e altri diritti su chiese, castelli, mulini. Simile la struttura del patrimonio di San Martino, tutto raccolto nel territorio viterbese e alla fine del XII secolo composto essenzialmente di diritti su chiese di cui l'abbazia cercava disperatamente di impedire il calo delle rendite. Il monastero si adoperò pertanto al fine di ottenere, e ottenne nel $1182-83$ da Lucio III, la proibizione che si erigessero chiese e oratori nel territorio che gli era soggetto ${ }^{136}$.

A parte la mancanza di congruità con il tradizionale orientamento cistercense, il pur ampio controllo di chiese non sempre riusciva a garantire ai cenobi incorporati le rendite necessarie al sostentamento dei monaci. Si spiega così come nel 1199 le tre abbazie fossero cadute in tantam dissolutionem da non avere le risorse necessarie per mantenere il numero minimo di monaci previsto dall'Ordine ${ }^{137}$. Si conosce quali misure furono prese per il cenobio San Martino. Esso era talmente indebitato e a inizio Duecento era caduto in tanta povertà che in eo appena tres monachi remansissent. Papa Innocenzo III, non desiderando affatto che il monastero fosse chiuso, come invece desiderava il Capitolo generale, contribuì con 1000 lire a riscattare certe possessiones e in più concesse un'altra chiesa, San Salvatore d'Orcla con ogni suo possesso, ordinando a Pontigny di adottare la loro piccola abbazia della Tuscia in specialem filiam per riformarla ancora inviando altri monaci e conversi ${ }^{138}$. Il rimedio, a quanto pare, funzionò, tanto che, sia pure a fatica, fu avviata la costruzione di una nuova chiesa, di un chiostro e di un nuovo monastero ${ }^{139}$.

135 Docc. cit. sopra, rispettivamente alle note 132 e 130.

136 IP 2 p. 214; EGIDI (cit. nota 130) 2 (1907) p. 169.

137 Statuta Capitulorum Generalium Ordinis Cisterciensis (cit. nota 110) p. 243.

138 EgIDI (cit. nota 130) 2 (1907) pp. 169sg.

139 Lelia Fraccaro de Longhi: L'architettura delle chiese cistercensi italiane, Milano 1958, pp. 260-266; cfr. Bedini (cit. nota 101) pp. 55sg. 
6. Uno sguardo d'insieme: papi, dispense e Capitolo generale

L'espansione dei monaci bianchi in Italia era giunta in una ventina d'anni alle porte di Roma, dove, con l'incorporazione del cenobio di Sant'Anastasio, essi avevano ottenuto una sorta di testa di ponte nei confronti della curia che avrebbe loro consentito di avere, in Eugenio III, l'ex abate Bernardo Paganelli, il primo papa cistercense $\mathrm{e}^{140}$. Condotta con l'aiuto esplicito del papato, tale diffusione era certo servita a sostenere nel mondo monastico italiano un orientamento riformatore aggiornato con la sensibilità religiosa dei tempi, soprattutto negli "Eigenkloster" papali, gli unici, in quegli anni, che consentissero legalmente ai pontefici di compiervi direttamente interventi di rifor$\mathrm{ma}^{141}$. Non è un caso, lo si è visto per Staffarda e per Chiaravalle di Fiastra, che, anche quando si trattasse di nuove fondazioni, si tendesse a garantirsi il controllo della loro vita interna inglobandole, grazie alla oblazione fattane dai fondatori, fra i religiosa loca que beati Petri iuris existunt et ad Romanam specialiter spectant ecclesiam ${ }^{142}$ : l'affermazione del primato romano in fatto di riforma monastica ancora passava, alla metà degli anni Quaranta del XII secolo, attraverso l'antico strumento del controllo dei monasteri privati del papa.

L'orientamento riformatore dei pontefici, tuttavia, dovette necessariamente fare i conti con le concrete realtà di questo mondo, imporsi cercando alleanze, venire incontro, come nel caso dell'assoggettamento di San Pietro di Cerreto a Chiaravalle Milanese, alle probabilmente non disinteressate postulationes di un abate ${ }^{143}$, confrontarsi con gli inevitabili risvolti politici della politica ecclesiale: soprattutto in quel Patrimonio di san Pietro in cui il rafforzamento del primato convergeva assai spesso con il potenziamento della dominazione temporale pontificia. Altro, infine, era imporre una nuova forma di monachesimo ad abbazie in via di formazione, dal patrimonio ancora interamente plasmabile secondo i principi di quel rapporto strettissimo fra scelte di vita monastica e organizzazione delle attività economiche dei singoli cenobi che caratterizzava i monaci bianchi, ben altro - lo si è visto chiaramente per gli "Eigenkloster" incorporati da Clairvaux nel Patrimonio di san Pietro - era 'amputare' da un

140 Michael Horn: Studien zur Geschichte Papst Eugen III. (1145-1153), Frankfurt am Main 1992 (Europäische Hochshulschriften: Reihe 3/508), pp. 40sg. Cfr. Werner MaleczeK: voce Eugen III. (Bernhard) Ocist., in: LexMA 4 (1989) coll. 79sg.; Harald Zimmermann: voce Eugenio III in: DBI 43 (1993) pp. 490-496, a p. 490: l'elezione a papa di Bernardo "era dettata non solo da considerazioni riformatrici nel Collegio cardinalizio di cui facevano parte in quel momento tre cardinali pisani, ma anche dalla difficile situazione politica a Roma”; ID.: voce Eugenio III, in: Enciclopedia dei papi (cit. nota 35) vol. 2 pp. 279-284.

141 Maccarrone: Primato romano (cit. nota 29) pp. 839-841.

142 Cfr. sopra, nota 83.

143 Sopra, testo corrispondente alla nota 66. 
patrimonio monastico ormai consolidato i beni ritenuti 'incongrui' rispetto a tali principi ${ }^{144}$.

Per contro, l'ambiziosa volontà di ritorno alle origini del monachesimo cistercense dovette fare i conti con le rapide metamorfosi della monarchia pontificia e del diritto ecclesiastico, espressione di quel rafforzamento del papato, a cui, nel decennio dello scisma, i monaci di Cîteaux avevano decisamente contribuito. Fu forse perché le constitutiones contenute nella Charta caritatis erano entrate da tempo nel diritto pubblico della Chiesa grazie alla conferma di papa Callisto II ${ }^{145}$, che papa Innocenzo II poté pensare di risolvere con una dispensatio il problema dell'adeguamento patrimoniale alle norme cistercensi del cenobio di San Pietro di Cerreto. La dispensa del resto, aveva precisato qualche decennio prima Ivo di Chartres, era pensata come una mitigatio ad tempus rigoris iuris ob necessitatem temporum vel utilitatem Ecclesie ${ }^{146}$. Quando però papa Eugenio III suggerì nel 1153 al Capitolo generale di contare sulla disponibilità papale a far uso di tale istituto giuridico per sanare, evidentemente post factum, la situazione di Sant'Anastasio che egli giudicava diversamente irrisolvibile ${ }^{147}$, la nozione di dispensatio, senza che nulla di sostanziale mutasse nella sua definizione, appariva in rapida evoluzione grazie al consenso incontrato dall'insegnamento di Graziano, per il quale il potere di dispensa del papa procedeva dalla plenitudo della giurisdizione di cui egli godeva in materia legislativa ${ }^{148}$. La metamorfosi in atto del modo di essere cistercensi, evidente soprattutto nelle grandi abbazie laziali incorporate, si intrecciava ormai con un'elaborazione giuridica che sempre più giustificava i pieni poteri del

144 Statuta Capitulorum Generalium Ordinis Cisterciensis (cit. nota 110) p. 43: Vobis autem, fratres carissimi, iuxta rivum aque in exploratione manentibus et ea que forte in aliquibus ecclesiarum ordinis vestri apparent incongrua cupientibus amputare.

145 Maccarrone: Primato romano (cit. nota 29) pp. 854-855. Cfr. sopra, testo corrispondente alle note $32-34$.

146 Migne PL 161 col. 236 n. 57, col. 242 n. 62.

147 Statuta Capitulorum Generalium Ordinis Cisterciensis (cit. nota 110) p. 44: Hec ideo diximus, filli dilectissimi ut, circa ecclesiam Sancti Anastasii, pro commonitione nostra, dispensatione utamini et quoniam adhuc retinet castrum quoddam et alias quasdam possessiones ad eius ius antiquitus pertinentes, aliquorum ex vobis animi non turbentur. Sulle reali dimensioni e sulla composizione del patrimonio di sant'Anastasio v. Cомва: Le scelte economiche dei monaci bianchi (cit. nota 6) p. 151.

148 Raoul NAz: voce Dispense, in: Dictionnaire de droit canonique 4 (1949) coll. 12841296. Le argomentazioni di Eugenio III a sostegno dell'opportunità di concedere una dispensa sembrano tuttavia avere un carattere prammatico e procedere dal concetto di necessitas (cfr sopra, testo corrisp. a nota 114), che, come è noto, legem non habet. Cfr. Glauco Maria Cantarella: Sondaggio sulla dispensatio (sec. XI-XII), in: Chiesa, diritto e ordinamento della societas christiana nei secoli XI e XII. Atti della nona Settimana internazionale di studio, Mendola, 28 agosto-2 settembre 1983 Milano 1986 (Miscellanea del Centro di studi medioevali 11), pp. 461-487 (alle pp. 462sg.). 
pontefice applicando testi di diritto romano che attribuivano all'imperatore una sovranità assoluta ${ }^{149}$.

Il fatto poi che Eugenio consigliasse (anzi 'ammonisse') il Capitolo generale a far conto su una concessione certa della dispensa papale, con ogni probabilità non nasceva tanto da incertezze sull'uso, forse ancora sperimentale, in forme eccessivamente autoritarie di tale istituto, ma dall'opportunità di non turbare la sensibilità monastico-religiosa di una parte, sicuramente assai consistente, degli abati presenti all'assemblea al fine di evitare ogni possibilità di 'scandalo' e di 'mormorazione ${ }^{\prime 150}$. A ragione: la discussione interna all'Ordine sulle incorporazioni e sull'accettazione in deroga di situazioni patrimoniali precostituite era allora vivacissima tanto che nel 1151 il Capitolo, nel desiderio evidente di imporre un ritorno alle origini, aveva richiesto la conferma della Charta caritatis. Il $1^{\circ}$ agosto del 1152 Eugenio III ne aveva sancito l'ulteriore inserimento nello ius commune della Chiesa, con una nuova conferma che si estendeva a tutto quello che era stato ordinato regulariter ${ }^{151}$, e qualche settimana dopo il Capitolo generale aveva vietato per il futuro la costruzione e l'incorporazione di nuove abbazie stabilendo che si rinunciasse, remota omni dispensatione, ai luoghi donati per farvi sorgere un'abbazia, se questa non poteva esservi eretta. ${ }^{152}$

L'ampiezza di tale dibattito, l'evidente coinvolgimento diretto del papato a sostegno delle posizioni meno rigoriste e la sconfitta di queste ultime al Capitolo generale del 1152 evidenziano ad abundantiam la vastità e la drammaticità dei problemi di sintonizzazione con gli orientamenti economici caratterizzanti $a b$ origine l'esperienza cistercense posti dalle incorporazioni. Fra queste ultime la storiografia ha largamente enfatizzato le associazioni, nel 1147, di due abbazie d'Oltralpe, indipendenti o già strutturate in congregazione: quella creata nel Limousin dall'eremita Stefano di Obazine e, soprattutto, quella, più antica e di

149 Cfr. Walter Ullmann: Il papato nel Medioevo, Roma 1975 (ed. orig. col titolo: A Short History of the Papacy in the Middle Ages, London 1972), pp. 184sg.

150 Statuta Capitulorum Generalium Ordinis Cisterciensis (cit. nota 110) p. 44: Quocirca necessitate loci nostroque consilio utiliori sicut arbitramur inspecto, rigorem ordinis in hac parte circa ipsam ecclesiam temperate ac de medio vestrum omne scandalum super his et murmur auferte.

151 Migne PL 180 coll. 1541 -1543 n. 581; JL 9600; Narrative and Legislative (cit. nota 29) pp. 390sg. Cfr. Maccarrone: Primato romano (cit. nota 29) p. 855; Cariboni: Esenzione cistercense (cit. nota 87) p. 70.

152 Statuta Capitulorum Generalium Ordinis Cisterciensis (cit. nota 110) p. 45: Anno ab incarnatione Domini MCLII statutum est in Capitulo generali abbatum ne ulterius alicubi construatur nova abbatia nostri ordinis, neque aliquis locus alterius religionis per subiectionem nostro ordini societur [...] Quod, si ante illud Capitulum [generale subsequentis anni] convenienter, ut dictum est, accepta loca in abbatiam surgere non possent, ex tunc, remota omni dispensatione, dimittentur, nisi grangia ibi secundum Ordinem fieri posset. Cfr. LeKaI: Cistercians (cit. nota 1) pp. 36 e 48 (trad. it cit., pp. 48 e 61). 
ispirazione cluniacense, di Savigny ${ }^{153}$. A Obazine, dove esisteva una comunità doppia, di uomini e di donne che vivevano a qualche chilomentro di distanza, ci si accordò, recita la «Vita Sancti Stephani Obazinensis», per l'inquadramento (assolutamente inconsueto) nell'Ordine della comunità monastica femminile e per l'abolizione graduale, ma a quanto pare efficace, di ciò che non si confaceva alle istituzioni di Cîteaux ${ }^{154}$. Per quanto riguarda invece Savigny, un privilegio papale del 10 aprile 1148 stabilì che in tutti i monasteri della congregazione si seguissero l'ordo monasticus e le istituzioni dei cistercensi, ma, per quanto riguarda la struttura dei patrimoni, confermò il controllo delle abbazie dipendenti, nominativamente elencate, cum omnibus earum pertinentiis, lasciando in sostanza la situazione immutata ${ }^{155}$. In ambedue $\mathrm{i}$ casi, poi, l'incorporazione avvenne con il beneplacito, se non addirittura (come per Obazine) in seguito a un preciso ordine di Eugenio III ${ }^{156}$.

La conservazione a Savigny di strutture patrimoniali lontane dai modelli proposti dalla normativa più antica di Cîteaux è stata considerata in passato dalla storiografia come il più macroscopico fattore di rottura dell'unanimitas dell'Ordine negli anni Quaranta del XII secolo in quanto ad omogeneità di forme organizzative della vita economica delle singole abbazie ${ }^{157}$. Anche se,

153 Mary Suydam: Origins of the Savigniac Order. Savigny's Role Within Twelfth-Century Monastic Reform, in: RevBén 86 (1976) pp. 94-108, con ampia bibliografia.

154 Vie de saint Étienne d'Obazine, a cura di Michel Aubrun, Clermont-Ferrand 1970 (Publications de l'Institut d'Études du Massif Central 6), p. 112. Sull'osservanza della Regola e delle consuetudines cistercensi a Obazine: Le cartulaire de l'abbaye cistercienne d'Obazine (XII ${ }^{e}$-XIII ${ }^{e}$ siècle), a cura di Bernadette BARrière, Clermont-Ferrand 1989 (Publications de l'Institut d'Études du Massif Central 33), p. 23; EAd.: Cîteaux et le Limousin, in: Moines en Limousin. L'aventure cistercienne, a cura di EAD., Limoges 1998, pp. $13-33$ (a p. 26).

155 Thesaurus novus anecdotorum, vol. 1, a cura di Edmond Martène/Ursin Durand, Paris 1717, coll. 404-406; JL 9235. Per una conferma successiva: PU England 2 p. 366 n. 174. Cfr. David Knowles: The Monastic Order in England. A History of Its Development from the Times of St. Dunstan to the Fourth Lateran Council (9401216), Cambridge 1959, pp. 251 e 351; Maccarrone: Primato romano (cit. nota 29) p. 872. Per il possesso di chiese cfr. Constable: Monastic Possession (cit. nota 124) p. 330.

156 Cfr., per Obazine: La Vie de saint Étienne (cit. nota 143) p. 112, con le osservazioni di Comba: Certosini, cistercensi, eremiti (cit. nota 38) p. 32. Per Savigny: Migne PL 180 col. 1282 n. 227; JL 9139.

157 Cfr. Lekar: The Cistercians (cit. nota 1) pp. 36, 48, 353sg. (trad. it cit., pp. 48, 61, 292sg.). Su Savigny e sulla sua incorporazione nell'Ordine, oltre al lavoro di Mary Suydam (cit. nota 142), mi limito a menzionare: Jacqueline Bинот: Labbaye normande de Savigny, chef d'ordre et fille de Cîteaux, in: M-A 46 (1936) pp. 1-19, 104-121, 178-190, 249-272, e, da ultimo, anche con riferimento alla bibliografia precedente, Janet Burton: Rapport sur l'espace anglais, in: Unanimité et diversité cisterciennes (cit. nota 12) pp. 299-319. Andrebbe attentamente verificata e discussa la posizione, molto critica sull'argomento ma non sempre accettabile, della Berman: The Cistercian 
soprattutto per la vicina Francia, molti aspetti attendono di essere chiariti e verificati, i risultati della presente indagine, che retrodatano e precisano di molto anche dal punto di vista giuridico analoghi elementi di diversificazione delle strutture patrimoniali cistercensi accertabili nella penisola italiana, consuonano invece grosso modo con quelli di una linea di indagine, impostasi nell'ultimo trentennio a partire dagli studi del Lekai ${ }^{158}$, che ha moltiplicato le attestazioni concernenti le diversità di vita e comportamenti dei vari cenobi nel secondo quarto del XII secolo ${ }^{159}$.

La vivace discussione suscitata dalla complessa situazione, che questa e altre ricerche vengono chiarendo, prefigurò un confronto durissimo fra la sede apostolica e l'Ordine, pur se non noto nei particolari ${ }^{160}$, che avrebbe potuto dare luogo a un grande scandalum, ma che si stemperò invece nel 1153 grazie a un accomodamento proposto dal Capitolo generale a papa Anastasio IV. Esso proponeva la conferma, a Clairvaux e all'Ordine, della donazione innocenziana del cenobio delle Tre Fontane quo ad animarum curam et disciplinam religionis pertinet e lasciava, come si è accennato, al beneplacito e alla potestas papale l'eventuale concessione di una dispensa per gli aspetti patrimoniali non congrui con la normativa cistercense ${ }^{161}$. Il continuo riproporsi del problema stimolò tuttavia un'elaborazione giuridica e concettuale ulteriore, cresciuta a partire dalle dispensationes di Innocenzo II e di Eugenio III in materia patrimoniale. A poco più di tre lustri dalla morte di quest'ultimo papa, segnati da un nuovo scisma, nella lettera Inter innumeras, inviata nel 1169 al Capitolo generale di Cîteaux da

Evolution (cit. nota 128) pp. 142sg. Per un avvio di dibattito critico su questo volume v. Brian Patrick McGuire: Charity and Unanimity: the Invention of the Cistercian Order, in: CCCist 51 (2000) pp. 285-297; Chrysogonus Waddell: The Myth of Cistercian Origins: C. H. Berman and the Manuscript Sources, CCCist 51 (2000) pp. 299-386; Constance Hoffman Berman: A Response to McGuire and Waddell, in: CCCist 53 (2002) pp. 333-337; Chrysogonus Waddell: A Reply, ibidem, pp. 339-344; Brian Patrick McGuire: A Reply, ibidem, pp. 345sg. Cfr. da ultimo Cariboni: Esenzione cistercense (cit. nota 87) p. 68.

158 Cfr. sopra, nota 1.

159 Cfr. Constance Hoffman Berman: Medieval Agriculture, the Southern-French Countryside and the Early Cistercians. A Studi of Forty-three Monasteries, Philadelphia 1986, pp. 2sg., 31sg. Cfr. EAD.: Cistercian Development and the Order's Acquisition of Churches and Tithes, in: Southern France, in: RevBén 91 (1981) pp. 192-203; Constance B. Bouchard: Cistercian Ideals versus Reality: 1134 Reconsidered, in: CCCist 39 (1988) pp. 217-231. Particolare, e molto ben studiata, è la vicenda dell'abbazia di Balerne: Benoît Chauvin: Les débuts de l'abbaye de Balerna (1100?1138) ou l'autre chemin de Molesme à Cîteaux, in: Unanimité et diversités cisterciennes (cit. nota 12) pp. 233-262.

160 Cfr. Lekar: The Cistercians (cit. nota 1) p. 47 (trad. it cit., p. 60).

161 Statuta Capitulorum Generalium Ordinis Cisterciensis (cit. nota 110) pp. 51sg. Cfr. sopra, testo corrisp. alla nota 119 . Sulla storia e la struttura del Capitolo generale v. Florent Cygler: Das Generalkapitel im hohen Mittelalter. Cisterzienser, Prämonstratenser, Kartäuser und Cluniazenser, Münster 2002 (Vita regularis 12), pp. 23-118. 
Alessandro III, la riflessione del pontefice era sfociata nella distinzione fra le domus che a prima sui origine in ordine sunt fundate e le domus che, invece, de aliis institutionibus ad vestrum se ordinem transtulerint; in altre parole, fra le abbazie fondate dai cistercensi e quelle incorporate. Soltanto per queste ultime era prevista, certa ratione inspecta, la dispensa papale, che nessun cenobio non dispensato era autorizzato a prendere come modello (exemplum) per il proprio patrimonio. Si trattava di una importante messa a punto del problema, che, per la chiarezza con cui esplicitava e razionalizzava i criteri giuridici ispiratori delle dispense concesse a vari monasteri nell'ultimo trentennio, sarebbe poi confluita nella decretale Recolentes ${ }^{162}$, quasi a sottolineare, se ancora ve ne fosse stato bisogno, l'ormai consolidata integrazione dello ius proprium cistercense nello ius commune del diritto canonico.

Chi osservi attentamente gli esiti di tale integrazione non potrà tuttavia non rilevare che la distinzione operata da Alessandro III, se riconosceva formalmente alla più antica legislazione cistercense (peraltro più volte confermata dalla sede apostolica ${ }^{163}$ ) e agli statuta via via emanati dal Capitolo generale il compito di disciplinare la vita interna dei singoli cenobi, riservava al pontefice, tramite la concessione di motivate dispense, il diritto di sostituirsi a quest'ultimo nell'emanazione di norme ${ }^{164}$. Si proponevano così, involontariamente, nei fatti - il papa ne era ben conscio ${ }^{165}$ - degli exempla da seguire alternativi ai modelli costitutivi e caratterizzanti dell'Ordine, ma che contribuivano in tal modo, direttamente e indirettamente, a una grave crisi dell'unanimitas cistercense. È indubbio che tale crisi aveva avuto origine e ricevuto un forte impulso proprio dalle incorporazioni claravallensi a cui si è sopra fatto più volte riferimento: da quella di San Pietro di Cerreto e di Santo Stefano di Fossanova,

162 La lettera circolò a lungo in edizioni soltanto parziali: CомBA: Le scelte economiche dei monaci bianchi (cit. nota 6) p. 151; la ripubblica integralmente Constance Hoffman Berman: The Cistercian Evolution. The Invention of a Religious Order in TwelfthCentury Europe, Philadelphia 2000, pp. 255-257. Sulla decretale Recolentes (edita nel Corpus iuris Canonici, a cura di Emil Friedberg, vol. 2, Lipsiae 1879, coll. 597sg., X, 3. 35. 3) cfr. Maccarrone: Primato romano (cit. nota 29) pp. 875sg., e Cariboni: I monasteri associati (cit.nota 83) p. 76.

163 Maccarrone: Primato romano (cit. nota 29) pp. 855 e $871 \mathrm{sg}$.

164 Maccarrone: Primato romano (cit. nota 29) pp. 880sg.: "E forse questo il punto più importante della lettera Inter innumeras, perché il papa con la sua piena autorità si sostituisce al capitolo generale, dando ordini per la vita interna di alcune abbazie, la cui disciplina negli stessi privilegi papali era riservata a quell'organo collegiale che reggeva l'Ordine cistercense".

165 Berman: The Cistercian evolution (cit. nota 128) p. 257: Sane si super possessionibus ipsis in aliquo de monasteriis vestris apostolice sedis auctoritas dispensavit, a nullo vestrum sumendum est in exemplum, quia temerarium est penitus et indignum aliquem sibi sua auctoritate presumere quod Romana ecclesia alicui monasterio, certa ratione inspecta, singularibus voluit beneficiis indulgere. 
avvenute già ai tempi di Innocenzo II, a quelle, decisive, di Sant'Anastasio e di Casamari concluse ai tempi di Eugenio III, tutte concernenti cenobi da cui nell'Italia centrale e meridionale sarebbero in breve venuti a dipendere decine di monasteri caratterizzati da forme di organizzazione economica estranee alle tradizioni dell'Ordine ${ }^{166}$.

\section{7. "Magna ordinis confusio": quali identità?}

Occorre riflettere sul significato dell'abbandono, in questa vastissima area della Penisola, delle tradizionali forme organizzative dell'attività economica dei monaci bianchi, che, per il nesso strettissimo con le loro scelte originarie di vita monastico-religiosa, di povertà volontaria e di valorizzazione del lavoro manuale, avevano una esplicita valenza simbolica e costituivano un elemento assai importante dell'identità cistercense. Tale abbandono, accuratamente descritto da papa Alessandro nella lettera citata quando ormai esso era diventato relativamente diffuso in tutto l'Occidente ${ }^{167}$, stava così pericolosamente minacciando uno degli elementi-chiave della identità dei monaci di Cîteaux da renderli praticamente simili a tutti gli altri monaci, i cui cenobi possedevano chiese, altari, mulini, decime, diritti signorili sugli uomini. Ne erano scaturiti un declino e una magna ordinis confusio che avevano provocato una mutazione profonda dell'ordinamento cistercense (leditur hinc ordo et mutatur, annotava il papa), intaccando il principio-base della paupertas volontaria e provocando una dissolutio caritatis che si univa a un pericoloso tepor ordinis, non senza possibili conseguenze giuridiche, ventilate dal pontefice. Fra queste, l'allontanamento dalla prima institutio dei cistercensi, interpretato da Alessandro III in primo luogo come una violazione canonica del loro ordinamento (ordo), suggeriva di ridurli "allo ius commune degli altri monasteri, poiché ormai non si distinguevano più da essi"168: quello ius commune su cui di fatto i monaci bianchi si basavano per rivendicare il possesso di chiese e altari contra antiquam consuetudinem et institutionem del loro Ordine ${ }^{169}$. L'abbandono - in una parte dei monasteri, che è difficile quantificare - degli elementi caratterizzanti (gli originalia ordinis instituta) della vita cistercense, non soltanto aveva minacciato alla base l'unanimitas e la credibilità dell'Ordine, ma ne stava annullando la specifica identità e l'appiattiva, assimilandola a una qualunque esperienza monastica.

166 Сомва: Le scelte economiche dei monaci bianchi (cit. nota 6) pp. 151sg.

167 Berman: The Cistercian evolution (cit. nota 128) p. 256.

168 Maccarrone: Primato romano (cit. nota 29) p. 879, con riferimento all'opera classica dello Schreiber (cit. nota 29) p. 91.

169 Maccarrone: Primato romano (cit. nota 29) p. 882; Schreiber (cit. nota 29) p. 69. 
Davvero dovunque (e fino a che punto?), nel terzo e quarto decennio del XII secolo, la presenza cistercense era stata percepita come 'nuova' e 'unitaria', caratteristica di un tipo di monachesimo 'diverso' dal passato? E, al tempo di Eugenio III, rispetto a quella realtà 'originaria' quali "aspetti di novità" erano percepiti dai contemporanei? Per il periodo qui analizzato gli scarsi documenti sopravvissuti non lasciano molto spazio alle indagini, al di là di un'esegesi sistematica, in rapporto alle realtà locali, delle formule utilizzate dalla cancelleria pontificia. Del resto alcuni privilegi papali rilasciati ai cenobi 'neo-claravallensi' di Savigny, Sant'Anastasio alle Tre Fontane e Casamari evidenziano come il richiamo all'institutio Cisterciensium fratrum o all'ordo Cisterciensis non sempre corrispondesse a un reale adeguamento, da parte dei cenobi alla normativa dell'Ordine $e^{170}$.

Nella consapevolezza che il lessico monastico e religioso veicolato dai documenti sopravvissuti - di entità e completezza molto diverse fra loro rimane, salvo che per il Piemonte ${ }^{171}$, in gran parte da studiare, ci si limita qui a qualche riflessione sulla percezione nitida dell'identità specifica di Clairvaux, che emerge dai documenti e dalla toponomastica monastica, per così dire 'programmatica', delle nuove fondazioni claravallensi ${ }^{172}$, e che entro certi limiti sembra obnubilare la più generale identità cistercense.

I riferimenti documentari più espliciti a questa forte identità claravallense riguardano senza dubbio l'abbazia marchigiana di Santa Maria di Chiaravalle di Fiastra, figlia dell'omonimo cenobio di Milano: nel 1145, come si è accennato, nella donazione fattane da Giacomo Guainerio duca di Spoleto a Bruno, abas de Claravalle de Mediolana (sic!), si specifica per esempio che il nuovo monastero dovrà essere subtus ordine Claravallensium, ad tenendum ordinem Claravallen$\operatorname{sem}^{173}$. Il notaio Cencio, che scrisse il documento, utilizzò qui il termine ordo in due accezioni diverse: di congregazione monastica, prima, e di ordinamento o regola, poi ${ }^{174}$. Nel primo caso l'interpretazione del termine sembra trovare conferma in un documento, di tre anni anteriore, relativo a Chiaravalle Milanese, dove Bruno è definito abbas monasterii de congregatione de Creravalle

170 Documenti citati alle note 116, 122, 144.

171 Dove è stato studiato da Merlo: Identità cistercensi (cit. nota 28).

172 Quattro, se si tiene conto anche di Chiaravalle di Castagnola presso Ancona che sarebbe stata fondata nel 1147 e di cui, per la mancanza di documenti, si conosce assai poco (JANAUSCHEK [cit. nota 50] p. $91 \mathrm{n}$. 126), sono le nuove fondazioni il cui nome riprende quello di Clairvaux sorte nel periodo qui preso in esame: Chiaravalle Milanese, Chiaravalle della Colomba e Chiaravalle di Fiastra. Una, fra Milano e Pavia, rievoca il nome dell'abbazia madre di Morimond. Nessuna, nonostante non manchino abbaziefiglie che ad esse fanno riferimento, richiama i nomi dei cenobi di Cîteaux, La Ferté e Pontigny.

173 Cfr. sopra, nota 76 e testo corrispondente.

174 Cfr. Niermeyer (cit. nota 97) pp. 745-747. 
situm non multum longe a suprascripta civitate Mediolani ${ }^{175}$. L'uso di ordo nella seconda accezione è invece confermato da un altro documento, del novembre 1163, anch'esso scritto dal notaio Cencio e conservato in originale nell'archivio dell'abbazia marchigiana. Con esso, Ubaldo, abate del monastero di Grotta, e Berardo, priore di Belliccione, giunsero alla composizione di una lite fra loro vertente grazie all'arbitrato di Biagio, abate di Fiastra, che dovette giudicare secundum ordinem Claravallensem. Il suo responso fu che l'abate di Grotta avesse la giurisdizione spirituale, con annessa potestas corrigendi sul priore di Belliccione e su tutti i confratelli della sua comunità monastica, potestà che doveva essere esercitata secundum oc quod Claravallenses patres abates habent potestatem in suis abbatiis $^{176 .}$.

L'ordo Claravallensis, a cui i documenti citati si riferiscono, probabilmente coincideva con la normativa cistercense sui rapporti di giurisdizione spirituale fra abbazie madri e abbazie figlie, che Ubaldo e Berardo non avevano certo difficoltà ad applicare poiché i rispettivi enti monastici vivevano, stando al documento del 1163, secondo la Regola di Benedetto. È comunque significativa la percezione assai forte che localmente si aveva della congregatio de Claravalle e delle forme con cui vi si esercitava la giurisdizione spirituale: risultato di un modo originale di vivere l'esperienza cistercense o non, piuttosto, esito, più o meno scontato della fama di Bernardo di Clairvaux e della sua capacità di veicolare messaggi di propaganda anche attraverso scelte toponomastiche? È difficile rispondere. Certo è che a tale spiccata identità claravallense, sottolineata da precisi vincoli istituzionali fissati talora per iscritto, corrispose negli stessi anni una 'politica' delle incorporazioni ${ }^{177}$ dai risultati assai discussi dai contemporanei (si pensi alle vicende dei tre cenobi laziali e di Savigny). Essa, se certo appariva motivata ai tempi dello scisma, altrettanto certamente era vista da gran parte degli abati e dei vescovi riuniti nel Capitolo generale nei primi anni Cinquanta del XII secolo come piuttosto lontana dal rigor ordinis che ispirava la normativa cistercense e che essi ancora vagheggiavano.

E Cîteaux? La forma religionis Cisterciensis monasterii e l'institutio dei fratres Cistercienses compaiono per il periodo e per l'area qui studiati esclusivamente nei privilegi pontifici, come del resto, forse relativamente tardi, compare nello stesso tipo di documentazione il riferimento all'ordo Cisterciensis ${ }^{178}$. Non se ne trova invece traccia nelle edizioni documentarie relative ai due cenobi claravallensi

175 Le pergamene milanesi (cit. nota 22) p. 158 doc. 78 del luglio 1142.

176 Le carte dell'abbazia di Chiaravalle di Fiastra (cit. nota 22) p. 188 doc. 105.

177 Cfr. René Locatelli: Les cisterciens dans l'espace français: filiations et réseaux, in: Unanimité et diversité cisterciennes (cit. nota 12) p. 63; ID.: L'expansion de l'ordre cistercien, in: Bernard de Clairvaux: histoire, mentalités, spiritualité, Paris 1992, pp. 103-140 (alle pp. 111-114). Cfr. Ursmer Berlière: L'ordre monastique des origines au XIIe siècle, Paris 1921 ( $2^{\circ}$ ediz.), p. 246.

178 Cfr. sopra, note $41,61,103,110,127$ e testo corrispondente. 
appena menzionati, per i quali non sono sopravvissuti privilegi papali relativi al periodo che esse ricoprono, né compare alcun riferimento a Cîteaux prima del 1160, per Chiaravalle Milanese, e prima del 1180, per l'abbazia di Fiastra ${ }^{179}$ : non diversamente da quanto avviene prima del 1170 per l'edizione delle carte di Morimondo, curata tre lustri or sono da Michele Ansani ${ }^{180}$. Una conferma ulteriore, se ve ne fosse bisogno, del ruolo preponderante di Clairvaux nell'espansione cistercense nella Penisola.

Nonostante l'incremento di edizioni critiche delle carte cistercensi sopravvissute, il breve excursus documentario sulle identità dei monaci bianchi alla metà del XII secolo ha confermato le difficoltà che si incontrano nell'analisi comparativa del lessico utilizzato nei documenti redatti da cancellerie e da notai ${ }^{181}$, ma, con riferimento a Clairvaux, ha anche evidenziato la fertilità di un tale percorso di ricerca: esso può incrociarsi proficuamente con la storia delle grandi "familles cisterciennes" e delle loro reti organizzative, verso cui, in sintonia con un orientamento relativamente recente della storia monastica, si sta avviando anche parte della ricerca sull'Ordine ${ }^{182}$.

Da un punto di vista più generale, è emerso con chiarezza dalla ricerca che, sulla riplasmazione delle identità cistercensi molto pesarono le scelte dei pontefici, le cui aspirazioni di riforma, talora convergenti con urgenze di consolidamento territoriale, furono sostenute, in Italia, dalla concreta messa a disposizione di "Eigenkloster" papali che furono incorporati nell'Ordine. Attraverso la contemporanea concessione di dispense e la conferma, a una parte dei monasteri incorporati, di beni e possessi non congrui con gli orientamenti della Charta caritatis e degli statuta emanati dal Capitolo generale, la sede apostolica tuttavia minò di fatto alle fondamenta il nesso fra scelte pauperistiche di vita monastica e struttura dei patrimoni abbaziali che costituiva un elemento forte dell'identità dei monaci di Cîteaux: come ben comprese Alessandro III, a ingigantire gli effetti delle 'deroghe' fu l'imitazione delle strutture patrimoniali dei cenobi dispensati, che vennero prese a modello da altri monasteri. Se si pensa che il numero delle abbazie associate e non create in ordine, pur con differenze significative da paese a paese ${ }^{183}$, andò progressivamente e consisten-

179 Cfr. IP 4 pp. 128sg. (per Fiastra): IP 6/1 p. 122 (per Chiaravalle Milanese). Cfr. sopra, note $164-165$.

180 Le carte del monastero di Santa Maria di Morimondo (cit. nota 22). Cfr. IP 6/1 p. 130.

181 Cfr. Merlo: Identità cistercensi (cit. nota 28) p. 26.

182 Locatelli: Les cisterciens (cit. nota 177) pp. 51-85 (soprattutto a p. 67).

183 Rinaldo Сомва: Rivalta nella storiografia monastica europea, in: L'abbazia di Rivalta di Torino (cit. nota 23) pp. 11-30 (alle pp. 23sgg.), e, nello stesso volume alle pp. 637- 
temente aumentando a partire dal quarto decennio del XII secolo (senza peraltro che se ne conosca il numero preciso) ${ }^{184}$ e che sempre più spesso i loro beni erano confermati dal papa nello stato in cui si trovavano al momento dell'incorporazione, ci si rende conto di quanto gli anni qui presi in considerazione siano stati decisivi per la storia dell'Ordine e dei rapporti più complessivi del papato con la vita monastica, con la Chiesa e con il problema della cura d'anime.

Non si è con ciò inteso portare nuovi elementi alla diffusa mitizzazione del periodo delle origini. Se si è studiata la prima metà del XII secolo, lo si è fatto per comprendere meglio gli sviluppi successivi in una prospettiva di lungo periodo con cui si è recentemente avuto modo di confrontarsi ${ }^{185}$. Da questo punto di vista, sarà d'obbligo individuare meglio, approfondire e contestualizzare le grandi 'ondate' di incorporazioni e varrà certamente la pena di studiare più a fondo, nei loro rapporti specifici con l'Ordine e con il movimento monastico riformatore, alcune figure di papi, fra le quali spiccano, come si è visto, per l'importanza delle decisioni prese, quelle di Innocenzo II e di Eugenio III, nonché molte figure di vescovi e cardinali cistercensi su cui si sente la necessità di indagini più sistematiche e problematicamente aggiornate ${ }^{186}$. Non

641, Antonio Riera Melis: La penisola iberica: qualche elemento di confronto. Per qualche dato ulteriore: Adeline RuCQuor: Les cisterciens dans la péninsule ibérique, in: Unanimité et diversités cisterciennes (cit. nota 12) pp. 487-524 (alle pp. 489-490). Per l'area germanica v. Cariboni: I monasteri associati (cit. nota 83) pp. 69sg. Per l'Italia, con riferimento soprattutto a un periodo successivo a quello qui esaminato, v. CABY: Les cisterciens dans l'espace italien (cit. nota 12) pp. 577sg. Per qualche altro dato relativo al XIII secolo: Leggio (cit. nota 20) pp. 33sg. Per un rapido sguardo all'Occidente v. Marcel Pacaut: Les moines blancs, Paris 1993, pp. 131sg.

184 Difficoltà di accertamento suggeriscono infatti spesso agli autori di rinunciare a calcolare a parte il numero delle incorporazioni o affigliazioni all'Ordine, come ammette onestamente René Locatelli: L'expansion (cit. nota 177) pp. 105sg.: "De leur côté, les cas d'incorporation ou de substitution, c'est-à-dire de communautés préexistentes qui s'affilient à l'ordre, auraient exigé un traitement à part, faisant apparaître leur importance numérique, leur observance originelle: groupements d'ermites, chanoines, moines traditionnels, etc. Si l'obédience des grands monastères ne pose pas de problème, celle de petits établissements demeure souvent douteuse et leur prise en considération aurait considérablement accru la marge d'incertitude".

185 L'abbazia di Rivalta (cit. nota 23), con riferimento soprattutto ai saggi di Giovanni Coccoluto, Giancarlo Comino, Almerino De Angelis, Teresa Mangione, Paolo Grillo. Nella stessa direzione di ricerca, Marie-Élisabeth HennEAu: Visites régulières au XVII siècle: des indices révelateurs d'une relecture cistercienne au sein d'un réseau d'inflences diverses, in: Unanimité et diversités cisterciennes (cit. nota 12) pp. 613-627. Cfr., nello stesso volume, l'invito di Kaspar ELm (Mythos oder Realität? Fragestellungen und Ergebnisse der Zisterzienserforschung, p. 47) ad approfondire le indagini "all'intera vita dell'Ordine e delle sue funzioni”.

186 Sempre utile è l'ormai quasi centenario lavoro di Domenicus WiLLi: Päpste, Kardinäle und Bischöfe aus dem Cistercienserorden, Bregenz 1912, e spunti interessanti possono essere attinti dalla sistematica indagine di Norbert Kamp: Kirche und Monarchie im Staufischen Königreich Sizilien, I, Prosopographische Grundlegung: Bistümer und 
sarà tuttavia meno interessante indagare ancora sul funzionamento patrimoniale, religioso-disciplinare e pastorale - considerato il notevole controllo di chiese che assai spesso rendeva i cistercensi non dissimili dagli altri monaci - dei cenobi incorporati e riformati nel mezzo millennio che seguì la metà del XII secolo.

\section{Zusammenfassung}

Zisterzienser und Papsttum waren zumal während des innocentianischen Schismas eng an einander gebunden. Dies gilt sowohl für den gesamten Orden als auch für einzelne Zisterzen in Italien. Zum Ausdruck kommen diese engen Bindungen beispielsweise in den Weihen, die manche Zisterzienseräbte durch den Papst erhalten mussten. Die Päpste verstanden es darüber hinaus, die Zisterzienser integrierend für die gesamte Kirche und ihre Ziele einzusetzen. Die führte jedoch innerhalb des Ordens verstärkt zur Frage nach der eigenen - von den Päpsten unabhängigen - Identität.

Bischöfe des Königreich 1194-1266, 4 voll. München 1973-1982 (Münstersche Mittelalter-Schriften, 10/I, 1-4). Per un'indagine attenta e aggiornata, sia pure riferibile a un periodo più tardo v. Maria Pia Alberzoni: Dal cenobio all'episcopio: vescovi cisterciensi nell'Italia nord occidentale all'inizio del XIII secolo, in: L'abbazia di Lucedio (cit. nota 4) pp. 139-182, ora con diverso titolo in EAD.: Città, vescovi e papato nella Lombardia dei comuni, Novara 2001, pp. 111-136. Colgo l'occasione per ringraziare l'autrice per aver discusso con me alcune questioni e per la sua consueta, cordiale, disponibilità. 
Bereitgestellt von | De Gruyter / TCS

Angemeldet | 217.89.40.26

Heruntergeladen am | 21.12.12 10:50 


\title{
Movimenti riformatori nell'Italia centrale
}

\author{
Mario Sensi
}

La riforma appartiene all'essenza stessa della Chiesa; anzi, non c'è Chiesa senza un bisogno continuo di conversione, di ricostruzione di ciò che era perduto ${ }^{1}$. Sotto un certo aspetto, tutta la storia della Chiesa è storia della riforma, alla ricerca dell'unico formato con pienezza, ossia il Cristo. Mentre conoscere come e perchè le istituzioni ecclesiastiche si siano formate e riformate, costituisce una delle fonti della conoscenza teologica e pertanto è un "luogo teologico", secondo l'accezione data da Melchior Cano².

Diversamente, il lemma 'movimenti' rimanda -in particolare- a due saggi: quello di Gioacchino Volpe, Movimenti religiosi e sette ereticali nella società medievale italiana, uscito nel $1922^{3}$ e l'altro di Herbert Grundmann, Religiöse

1 Sul tema cfr. Yves Congar: Vrai et fausse réforme de l'Eglise, Parigi 1950; Brenda Bolton: Lo spirito di riforma nel Medioevo, Napoli Liguori 1988 (trad. it. dell'ed. di London 1983); AA. VV., Riforme, in: Dizionario degli Istituti di Perfezione, vol. 7 (1983) coll. $1748-1763$.

2 L'espressione "luogo teologico" fu coniata da Melchior Cano ( $† 1560)$ per designare le diverse fonti della conoscenza teologica, qualificate secondo le regole della criteriologia teologica: cf. Melchior Cano, Opera, ed. Serry, Padova 1714, pp. 271-272 (De locis theologicis, XI, c. $2 \$ 3$ ), cfr. anche Bernhard KöRner: Melchior Cano. De locis theologicis. Ein Beitrag zur Theologischen Erkenntnislehre, Graz 1994; inoltre, Yves Congar: «La storia della Chiesa 'luogo teologico'», in: Concilium VI/7 (1970) pp. $103-115$.

3 Su Movimenti religiosi e sette ereticali nella società medievale, Gioacchino Volpe pubblicò, tra il 1907 e il 1912 una serie di saggi, poi ristampati dall'editore Vellecchi, Gioacchino VOLPE: Movimenti religiosi e sette ereticali nella società medievale italiana, (Secoli XI-XIV), Firenze 1922 (2a edizione, Firenze 1971). Intento dell'Autore - nella prima parte del volume -, è quello di "esaminare in mezzo a quali condizioni della società specialmente cittadina e a quali situazioni politiche le eresie crescono e si diffondono, quali esigenze pratiche e sentimentali esse soddisfano, quali gruppi sociali ne sono più pervasi e perché [...] Non le ho considerate come un capitolo della storia del dogma o delle religioni, nel qual rapporto la loro importanza è scarsa, ma come un capitolo della comune storia" (pp. VI-VII); per cui, nella seconda parte, l'attenzione è incentrata sui fatti economici, sociali e politici connessi alla lotta religiosa, rinunciando così, di fatto, a comprendere l'effettiva importanza dei movimenti spirituali da cui prende l'avvio la sua riflessione. Per uno sguardo d'insieme su questo fecondo filone storiografico, cfr. Raffaello Morghen: Medioevo cristiano, Bari ${ }^{4} 1968$, pp. $204-281$ (L'eresia nel Medioevo); Grado Giovanni Merlo: Eretici ed eresie medievali, Bologna 1989; Medioevo ereticale, a cura di Ovidio Capitani, Bologna 1977. 
Bewegungen im Mittelalter, uscito nel $1935^{4}$. Questo ultimo lavoro, divenuto ben presto un punto di riferimento per gli storici della Chiesa, fu però conosciuto dal vasto pubblico italiano solo a partire dal 1970, all'indomani della morte dell'Autore ( $† 20$ marzo 1970), quando appunto il compianto Raoul Manselli, ne promuoveva la versione italiana. In apertura Manselli salutava l'Autore come "una delle più fini personalità di storico della Germania contemporanea" ". A distanza di un quarto di secolo va preso atto come le ricerche degli studiosi italiani, condotte su questo nuovo filone storiografico, nel giro di pochi anni, hanno fatto notevoli passi in avanti, a cominciare della seconda Settimana di studio, tenutasi a La Mendola nel 1962, sul tema della Settimana, L'eremitismo in Occidente nei secoli XI e XII ${ }^{6}$. Vi si tennero una serie di lezioni magistrali che hanno dato un nuovo impulso alla successiva storiografia; d'obbligo ricordare i saggi sui movimenti riformatori nell'Italia centrale: da quello di Giovanni Tabacco, su Romualdo di Ravenna ${ }^{7}$ a quello di Ovidio Capitani, su s. Pier Damiani ${ }^{8}$, fino a quello di Kaspar Elm - discepolo del Grundmann -, sulle Comunità eremitiche italiane del XII e XIII secolo?. Nel frattempo usciva la voce di Jean Sainsaulieu, Ermites en Occident, in “Dictionnaire d'Histoire et de Géographie Ecclésiastique ${ }^{10}$. Ebbe così inizio, per

4 Herbert Grundmann: Religiöse Bewegungen im Mittelalter. Untersuchungen über die geschichtlichen Zusammenhänge zwischen der Ketzerei, den Bettelorden und der religiösen Frauenbewegung im 12. und 13. Jahrhundert und über die geschichtlichen Grundlagen der deutschen Mystik, Berlin 1935 (Historische Studien 267).

5 Raoul MansELli: Introduzione, all'edizione italiana (fatta sulla seconda edizione riveduta e aumentata Darmstadt 1961), in: Movimenti religiosi nel Medioevo. Ricerche sui nessi storici tra l'eresia, gli Ordini mendicanti e il movimento religioso femminile nel XII e XIII secolo e sui presupposti storici della Mistica tedesca, Bologna 1970, p. 11.

6 L'eremitismo in Occidente nei secoli XI e XII. Atti della seconda Settimana internazionale di studio, Mendola, 30 agosto - 6 settembre 1962, a cura di Cinzio Violante/ Cosimo Damiano Fonseca, Milano 1965 (Università Cattolica del Sacro Cuore, Miscellanea del Centro di Studi Medioevali 4). Fa il paio con questo convegno, l'altro su Il monachesimo e la riforma ecclesiastica (1049-1122). Atti della IV settimana internazionale di studi, Mendola 23-29 agosto 1968, Milano 1971.

7 Giovanni TAвACCO: Romualdo di Ravenna e gli inizi dell'eremitismo camaldolese, in: L'eremitismo in Occidente (cit. nota 6) pp. 73-119, riedito in ID.: Spiritualità e cultura nel Medioevo. Dodici percorsi nei territori del potere e della fede, Napoli 1993, pp. $195-248$.

8 Ovidio Capitani: S. Pier Damiani e l'istituto eremitico, in: L'eremitismo in Occidente (cit. nota 6) pp. 122-163.

9 Kaspar Elm: Italienische Eremitengemeinschaften des 12. und 13. Jahrhunderts. Studien zur Vorgeschichete des Augustiner-Eremitenordens, in: L'eremitismo in Occidente (cit. nota 6) pp. 491-559.

10 Jean Sainsaulieu : Ermites en Occident, in: Dictionnaire d'Histoire et de Géographie Ecclésiastique 15 (1963) coll. 771-787, sp. 773-774. La voce era stata preceduta dall'Enquête sur l'érémitisme, Sorbonne, 1950 per una Gallia Eremitica, tesi dottorale 
l'eremitismo, una felice stagione storiografica su cui, nel 1995 hanno fatto il punto Sophia Boesch Gajano, Cecile Caby, Odile Redon ${ }^{11}$. Mentre l'ulteriore balzo in avanti è costituito dal Convegno tenutosi alla certosa di Pontignano su Ermites de France et d'Italie i cui Atti sono stati editi, nel 2003, a cura di André Vauchez ${ }^{12}$.

\section{1 - Movimenti riformatori del secolo XI}

Giova qui ricordare come, dopo il crollo dell'impero carolingio, si era accentuato il particolarismo locale, favorendo così la crisi delle istituzioni ecclesiastiche. Da più parti si sentì allora l'esigenza di una riforma radicale monastica ed ecclesiastica. Questa esigenza trovò in Francia uno sbocco naturale nella corrente monastica di Cluny, monastero divenuto faro di irradiazione della regola di S. Benedetto, riformata da Benedetto di Aniane, grazie a Oddone (926-942), secondo abate, succeduto a Bernone ${ }^{13}$. Nel giro di alcuni decenni cominciarono a farsi strada, seppur lentamente, tutta una serie di riforme: un fenomeno di controcorrente che interessò monaci, canonici regolari e laici, molti dei quali scelsero di vivere in estrema povertà ${ }^{14}$. Fu un ritorno all'ideale della Chiesa primitiva ${ }^{15}$. Specie nel secolo successivo, quanti furono catturati

all'Università di Paris-Sorbonne che il Sainsaulieu pubblicò, senza l'apparato critico, con il titolo, Les ermites français, preface par Henri-Irénée Marrou, Paris 1974.

11 Sofia Boesch Gajano/Cécile Caby/Odile Redon: Bibliographie (1963-1994), in: Le choix de la solitude, in: "Medievales: langue textes histoire", n. 28 (printemps 1995) pp. 113-117.

12 Ermites de France et d'Italie (XI-XV siècle). Atti del colloquio organizzato dall'École française de Rome (Certosa di Pontignano, 5-7 maggio 2000) a cura di André Vauchez, Roma 2003 (Collection de l'École française de Rome 313).

13 Sull'originalità e sul significato di Cluny nella riforma ecclesiastica dei secoli XI e XI, cfr. Cluny, Beiträge zur Geschichte und Wirkung der cluniazensischen Reform, a cura di Helmut Richter, Darmstadt 1975 (Wege der Forschung 241). Sulla povertà a Cluny, Jean LeclercQ: Culto e povertà a Cluny, in: Liturgia e povertà, Vicenza 1966, pp. 4976. Va pure aggiunto come, sotto il priorato di Pietro il Venerabile (1122-56), anche a Cluny, roccaforte del cenobitismo, ebbe cittadinanza la scelta eremitica, cfr. Jean LeclercQ: Pierre le Vénérable et l'érémitisme clunisien, in: Petrus Venerabilis, 11561956, a cura di Giles Constable/James Kritzeck, Roma 1956, pp. 99 - 120 (Studia Anselmiana 40); G. Снасниат: L'érémitisme à Cluny sous l'abbatiat de Pierre-leVénérable, in: Annales de l'Académie de Mâcon 58 (1982) pp. 89-96.

14 Almeno quattro le riforme monastiche del secolo X, nell'Italia centro settentrionale: quelle di s. Romualdo e di s. Pier Damiani; di Fruttuaria e di s. Alessio sull'Aventino, luogo questo di ritrovo per i rappresentanti dei vari movimenti di riforma tra di loro e con s. Nilo di Grottaferrata, che animava un monastero orientale. Mi limito ad accennare alle prime due, rimandando per le restanti a Jean LECLERCQ: Le riforme del secolo X, in: Dizionario degli Istituti di Perfezione 7 (1983) coll. 1752-1754.

15 Giovanni Mrccolr: Chiesa gregoriana. Ricerche sulla Riforma del secolo XI, Firenze 1966 (Storici antichi e moderni N. S. 17), in particolare il capitolo "Ecclesiae primitivae 
dall'utopia della povertà evangelica, riscoprirono l'adagio di Girolamo, nudus nudum Christum sequi, dove la povertà va intesa come mezzo e non come fine ${ }^{16}$. La riforma, che si dispiegò all'insegna della spontaneità e della diversità, riguardò la Chiesa secolare -con la sua struttura diocesana di arcivescovi, vescovi e sacerdoti- e la chiesa regolare, fatta di monaci, di monasteri e di canoniche, istituzioni autonome e vagamente collegate fra di loro. Questo vasto movimento di riforma, diffuso in tutta Europa, dalla seconda metà del secolo XI ebbe l'appoggio dei papi, da Niccolò II (1059-1061) ad Alessandro II (10611073), da Gregorio VII (1073-1085) a Urbano II (1088-1099): è la cosiddetta riforma gregoriana che, insistendo sulla centralizzazione e sulla dipendenza dalla Sede apostolica, diede uno statuto teorico e istituzionale al movimento riformista, mentre fino ad allora era stato spontaneo e aveva rivestito un carattere pratico ${ }^{17}$.

L'attenzione è per quel vasto movimento di riforma, a carattere segnatamente pauperistico, contrassegnato, anche nell'Italia centrale, da due caratteristiche: la prima rivolta al passato, cercando di ricreare un ambiente che facesse rivivere l'età di Cristo e degli Apostoli e l'altra protesa verso il futuro, a una vita riformata, al regno di Dio; fu un movimento che partì dall'eremo e si dispiegò su tre distinti filoni: monastico, canonicale e penitenziale. A cominciare dal movimento che fece capo a s. Romualdo di Ravenna ( $† 1027)$ cui ben presto fu riconosciuto il ruolo di restauratore dell'Ordine monastico in Italia ${ }^{18}$ e di evangelizzatore tra i gioghi dell'Appennino umbro marchigiano, dove predicò soprattutto con la testimonianza di vita (tacente lingua et predicante vita), ottenendo conversioni e facendo persino conquiste al martirio dell'eremo tra i

forma”, pp. 225-299; ID.: La storia religiosa, in: Storia d'Italia, vol. 2/1: Dalla caduta dell'Impero romano al secolo XVIII, Torino 1974, pp. 429-1079, sp. 480-516 (La riforma gregoriana).

16 Sull'adagio, Reginald Gregorre: L'adage ascetique "nudus nudum Christum sequi”, in: Studi storici in onore di Ottorino Bertolini, vol. 1, Pisa 1972, pp. 395-409. La nudità di Cristo in Croce - attestata dagli Atti di Pilato, conosciuti come Vangelo apocrifo di Nicodemo $(10,2-4)$ - costituì un richiamo, anzi una conversione alla povertà la quale fu, appunto, una delle risposte alla crisi religiosa, cfr. Bolton (cit. nota 1): La reazione alla crisi: il monachesimo, p. 24sg.; La Chiesa secolare, p. 27sg.; La crescita della pietà dei laici, p. 29sg.; Il rischio dell'eresia, p. 32sg.; inoltre: La conversione alla povertà nell'Italia dei secoli XII-XIV. Atti del XXVII Convegno storico internazionale, Todi 1417 ottobre 1990, Spoleto 1991.

17 D’obbligo il rimando ad Augustin Fliche: La réforme grégorienne, 3 voll., Louvain $1924-1937$.

18 Nel prologo delle consuetudini cluniacensi di Farfa si legge che Romualdo "normam prisce iustitie in sexu renovavit utroque et ordine" (cfr. Il "Chronicon Farfense" di Gregorio di Catino, a cura di Ugo Balzani, vol. 1, Roma 1903, p. 50 n. 3), con ciò estendendo la sua azione riformatrice anche ai monasteri femminili, notizia confermata peraltro dalla Vita, Petri Damiani Vita beati Romualdi, a cura di Giovanni TABAcco, Roma 1957, c. 35 p. 76; c. 63 p. 103. 
famuli e custodes pecorum ${ }^{19}$. Romualdo si era fatto monaco nel monastero benedettino di S. Apollinare in Classe, appena fuori Ravenna, ma non trovando modo per soddisfare le sue aspirazioni spirituali si fece eremita. Per qualche tempo andò errando da un luogo solitario all'altro, giungendo fino al monastero catalano di S. Michele di Cuxà, un santuario micaelico 'ad instar Gargani', dove trascorse il decennio 978-988 ${ }^{20}$. Meditando su le «Vitae Patrum» e le «Collactiones» di Cassiano, Romualdo era giunto alla conclusione che la vita eremitica costituisse il vertice dell'esperienza monastica ${ }^{21}$. Tornato in Italia, per le insistenze di Ottone III, nel 998 fu eletto abate di S. Apollinare in Classe, ma l'anno appresso rinunciò riprendendo le sue peregrinazioni e fondando monasteri bipartiti, formati da un convento vero e proprio -in cui i monaci lavoravano e pregavano in comune, dedicandosi soprattutto agli studi- e da un eremo, dove ogni religioso viveva isolato nella mortificazione e nella preghiera: isolato e protetto dal mondo dai confratelli, ai quali erano delegate, sotto il controllo del superiore dell'eremo, le inevitabili cure e funzioni di carattere

19 Se ne parla, specie in occasione dei reiterati soggiorni fatti da Romualdo negli eremi di Val di Castro -in diocesi di Camerino - (quattro volte, morendovi durante l'ultimo soggiorno) e di Sitria - ai confini della diocesi di Gubbio - (quattro volte), dove il santo compì opera di evangelizzazione tra le classi più umili, Vita beati Romualdi (cit. nota 18) cap. 35 p. 75 , c. 52 p. 9 , c. 64 p. 105 . A informarci sui fatti, oltre alla citata Vita di s. Romualdo, scritta da Pier Damiani verso il 1042, è la «Vita dei cinque fratelli», composta da Bruno di Querfurt, verso il 1006-1008: Brunonis Querfurtensis Vita quinque fratrum eremitarum [seu] Vita vel Passio Benedicti et Iohannis sociorumque suorum, ed. Jadwiga Karwasinska, Varsavia 1973 (MPH NS 4/3).

20 In questo monastero, posto nella contea di Conflent, nel Rossiglione, ai piedi del monte Canigou e protetto dalla casa di Barcellona, era abate dal 965, Guarino. Questi aveva incontrato a Venezia Romualdo che, dopo aver lasciato il monastero di Classe, si era messo alla scuola dell'eremita Marino. Dopo questo incontro i due eremiti, insieme al doge Pietro Orseolo con i compagni Giovanni Morosini e Giovanni Gradenigo, si misero al seguito dell'abate, giungendo al monastero di S. Michele di Cuxà cfr. Vita beati Romualdi (cit. nota 18) cap. 5 p. 23sg. e nota 1; TABACCO: Spiritualità (cit. nota 7) p. 232 nota 120. S. Romualdo, ritornato in Italia fondò il monastero di S. Michele di Verghereto, a monte di Bagno in un luogo di difficile accesso nei pressi di una grotta: $a$ quo non longe cellam habitaturus intravit, Vita beati Romualdi, cap. 18 p. 42 . Questo monastero, costruito sopra uno sperone, finì però col franare in parte nel sottostante fiume Savio, Emanuele Repettr: Dizionario geografico fisico storico della Toscana, Firenze $1833-1845$, vol. 5 p. 691.

21 Vita beati Romualdi (cit. nota 18) cap. 6 p. 26. Per TAвасCO: Romualdo (cit. nota 7) p. 85, non è ben fondata l'ipotesi di Walter Franke: Romuald von Camaldoli und seine Reformtätigkeit zur Zeit Ottos III, Berlino 1913, pp. 158-180, in quanto "nulla vi è in Romualdo che si debba necessariamente dedurre dai monaci greci contemporanei anziché da Cassino e dalla Vitae patrum". 
economico e amministrativo: la vita cenobitica divenne così funzionale, in una organica integrazione, alla conquista della perfezione ascetica ${ }^{22}$.

Questa eredità fu raccolta dall'eremo di Camaldoli (in diocesi di Firenze, fondato nel 1012) - collegato all'ospizio di Fontebuono - da cui si sviluppò nel sec. XI, l'ordine dei Camaldolesi: una congregazione costituita dall'unione di eremi e cenobi non rigidamente inseriti in una struttura di dipendenze organizzate, ma depositari di una larga autonomia nella comune fedeltà alla regola benedettina e alle consuetudini di Camaldoli, le cosiddette «Eremiticae Regulae», redatte e commentate, tra il 1080-5, da Rodolfo I (1074-1088/ 1089), quarto priore ${ }^{23}$.

Altra fondazione romualdina fu Fonte Avellana, in diocesi di Gubbio, di cui fu priore s. Pier Damiani $(\dagger 1072)$ di Ravenna il quale, sulla scia di s. Romualdo, volle ricreare l'antico anacoretismo, promovendo la vita monastica nella forma semi-eremitica, divenendo il teologo di questo movimento eremitico ${ }^{24}$. Nomi-

22 Vita beati Romualdi (cit. nota 18) cap. 18sg. p. 42sg.; inoltre TABACCO: Romualdo (cit. nota 7) pp. 106-113; ID.: Eremo e cenobio, in: Spiritualità cluniacense. Convegni del Centro di studi sulla spiritualità medievale, II, $12-15$ ottobre 1958, Todi 1960, pp. 326-335, ora in ID.: Spiritualità (cit. nota 7) pp. 159-166.

23 Sull'eremo e la sua congregazione IP 3 p. 171sg.; inoltre TAвACCO: Romualdo (cit. nota 7) pp. 113-119 (Il destino di Romualdo a Camaldoli); Gregorio Penco: Storia del monachesimo in Italia alle origini alla fine del Medioevo, Milano 1983, p. 197-204 (Complementi alla storia della Chiesa); Cécile CABY: "Camaldulensis heremi sive cenobii religio": nascita e sviluppo dell'ordine camaldolese (sec. XI-XIV), in: San Romualdo. Storia, agiografia e spiritualità. Atti del XXIII convegno del Centro di studi avellaniti, Fonte Avellana, 23-26 agosto 2000, Negarine (Verona) 2002, pp. 221-241; EAD.: De l'eremitisme rural au monachisme urbain. Les Camaldules en Italie à la fin du Moyen Age, Roma 1999.

24 Sull'eremo, divenuto capo di una propria congregazione, IP 4 pp. 92-97; Penco: Storia (cit. nota 23) pp. 202sg. Di Pier Damiani sono gli Opuscoli XIV («De ordine eremitarum», Migne PL 145, coll. 327 D - 336A = Epistula XVIII) e XV («De suae congregationis institutis», Migne PL 145, coll. 335B - 364D = Epistula 50) dove vengono descritte le consuetudini eremitiche di Fonte Avellana, caratterizzate da povertà e austerità, mentre nella Lettera 28 («Liber qui appellatur Dominus vobiscum», Migne PL 145, coll. 231A-252B) l'eremita è proposto come modello spirituale dato alla Chiesa perché "essa veda ricapitolati in lui tutti i suoi carismi", Benedetto Calati/ Innocenzo Gargano, Introduzione generale, a Pier Damiani, Lettere (1-21), a cura di Guido Innocenzo Gargano/Nicolangelo D'Acunto, Roma 2000, 7-41, ibidem, 38 [dell'epistolario sono finora usciti i primi quattro volumi: il volume $1 / 4$, giunge fino alla lettera 90 (giusto la metà delle Lettere) ed è uscito nel 2005, a cura di Nicolangelo D’AcunTo/ L. Saraceno. Si rimanda al citato saggio di Ovidio Capitani: San Pier Damiani e l'Istituto eremitico, in: L'eremistismo in occidente (cit. nota 6) pp. 122-163, inoltre, Jean LeclercQ: Saint Pierre Damien eremite et homme d'église, Roma 1960; Giovanni Miccoli: Pier Damiani e la vita comune del clero, in: La vita comune del clero nei secoli XI e XII, 2 voll., Milano 1962, qui vol. 1 pp. 186-211 (riedito in: ID.: Chiesa gregoriana. Ricerche sulla Riforma del secolo XI, Firenze 1966); Massimo Petrocchi: Note su Fonte Avellana. Gli opusculi 14 e 15 di san Pier Damiani e l'ideale eremitico, in: 
nato da Stefano IX cardinale vescovo di Ostia, la sua azione fu contrassegnata da due grandi ideali: la riforma della Chiesa (meritando l'appellativo di martello della simonia) e la promozione della vita monastica, nella forma semi-eremitica favorendo, tra l'altro, l'introduzione della flagellazione ${ }^{25}$. All'azione dello stesso Pier Damiani si deve pure l'avvio della riforma della vita comune in Umbria: è quanto si apprende da una sua lettera a papa Alessandro II, riferita dal Kehr in apertura alla presentazione della diocesi di Gubbio ${ }^{26}$. In questa diocesi, che la Sede apostolica aveva dato in affidamento al Damiani, la situazione era omnino confusa et velut area quae pedibus conculcatur ${ }^{27}$; da qui l'azione riformatrice teste il suo biografo Giovanni da Lodi $(\dagger 1085)$, poi vescovo di Gubbio ${ }^{28}-$, riforma che fu quindi ripresa da s. Ubaldo $(\dagger 1160)^{29}$ il quale, prima ancora di diventare vescovo della sua città, aveva introdotto a $S$. Secondo - la canonica dove era entrato da fanciullo ${ }^{30}$-, una vita religiosa secondo lo spirito della riforma -inizialmente con regola portuense, la regola di Pietro de Honestis ${ }^{31}-$, la stessa imposta nella canonica cattedrale eugubina di S. Mariano dove, intorno al 1116, fu sostituita con la vita canonica regolare, secundum regulam beati Augustini, che Innocenzo II approvò, il 23 marzo 1142, con lettera «Religiosis

Aspetti dell'Umbria dall'inizio del secolo VIII alla fine del secolo XI. Atti del III Convegno di Studi Umbri, Gubbio 23-27 maggio 1965, Perugia 1966, pp. 243-254; Nicolangelo D'Acunto: I laici nella chiesa e nella società secondo Pier Damiani. Ceti dominanti e riforma ecclesiastica nel secolo XI, Roma 1999 (Nuovi studi storici 50).

25 Jean LeCLercQ: La flagellazione volontaria nella tradizione spirituale dell'Occidente, in Il movimento dei disciplinati nel settimo centenario del suo inizio (Perugia 1260), Perugia 1962, pp. 73-83.

26 IP 4 p. 81.

27 Migne PL 144, col. 224.

28 Vita Petri Damiani, Migne PL 144, col. 125 e 132. Su questa riforma, Cosimo Damiano Fonseca: Medioevo canonicale, Milano 1970; inoltre Mrccoli: Chiesa gregoriana (cit. nota 15) p. 99sg.

29 Giorgio Picasso: Ubaldo e la vita comune del clero, in: Nel segno del santo protettore: Ubaldo vescovo, taumaturgo, santo. Atti del Convegno internazionale di studi, Gubbio, 15-19 dicembre 1986 a cura di Stefano Brufani/Enrico Menestò, Spoleto 1992 (Quaderni del Centro per il collegamento degli studi medievali e umanistici nell'Università di Perugia 22), pp. 117-129. Ma si veda anche C. EGGER: La vita comune del clero a Gubbio nei secoli XI e XII e la personalità di s. Ubaldo, in: Aspetti dell'Umbria (cit. nota 24 ) pp. 387-396.

30 François Dolbeau: La vita di S. Ubaldo vescovo di Gubbio, attribuita a Giordano di Città di Castello, in: Bollettino della Deputazione di storia patria per l'Umbria 74 (1977) pp. 81 - 116, ibid. p. 96 (Vita beati Ubaldi 2. 1). Sulla canonica dei SS. Agapito e Secondo IP 4 pp. 85sg.

31 Su questa regola, FonSECA: Medioevo canonicale (cit. nota 28) p. 147sg. Sulla regola di sant'Agostino, Luc Verheijen: La règle de saint Augustin, vol. 2: Recherches historiques, Paris 1967; Jacques Dubors: Institutio, in: Dizionario degli Istituti di Perfezione 4 (1977) col. 1721. 
desideriis ${ }^{32}$. Detta vita canonica regolare, peraltro introdotta anche in altre cattedrali umbre - come Città di Castello e Perugia ${ }^{33}$ - fu un contributo fattivo alla riforma; ma i risvolti non superarono gli stretti ambiti diocesani.

Contemporaneo di s. Pier Damiani fu Giovanni Gualberto $(\dagger 1073)$ che, da S. Miniato di Firenze, dove era abate, nel 1039 si ritirò a Vallombrosa - a $30 \mathrm{~km}$. da Firenze -, per fondarvi un monastero, analogo per struttura a quelli di s. Romualdo, al fine di accostare la vita cenobitica a quella eremitica. Ben presto il piccolo eremo fu trasformato in cenobio da dove uscì un movimento destinato a una crescita rapida e feconda. Organizzatosi in congregazione, riconosciuto da Urbano II nel 1090, l'ordine assunse una struttura ispirata al modello cluniacense, ma dove i singoli monasteri, governati da propri abati, conservavano una posizione di reciproca parità giuridica. I monaci, dediti alla contemplazione e animati da una severità schiettamente eremitica, diedero la loro disponibilità ad agire all'interno della società civile, appoggiando movimenti di origine popolare, come il moto degli umiliati, contro eretici e simoniaci, contribuendo così fattivamente alla riforma della Chiesa ${ }^{34}$.

32 Detta lettera, già menzionata da IP 4 p. 86 n. 1, è stata poi edita da PUU in Italien, vol. 5 pp. $158-160$ n. 5. Su s. Ubaldo ricostruttore, vedi, Giuseppe Fornasari: Spiritualità avellanita e spiritualità ubaldina, in: Nel segno (cit. nota 29) pp. 269-292, riedita in: ID.: Medioevo riformato del secolo XI: Pier Damiani e Gregorio VII, Napoli 1996, pp. 491-509.

33 Sul movimento canonicale di riforma a Perugia (cui Clemente III nel 1189 ingiunse di abbracciare la regola di s. Agostino IP 4 p. 65 n. 9) e Città di Castello (dove Pasquale II [1099-1118] introdusse i Canonici Regolari di s. Frediano, IP 4 pp. 100-103; PUU in Italien, vol. 5 p. 165 n. 8, p. 169 n. 10, p. 193 n. 21), cfr. Ugolino Nicolini: La vita comune del clero a Perugia nei secoli XI e XII, in: Vita comune (cit. nota 24) vol. 2 pp. 260-264, riedito in ID.: Scritti di storia, Napoli 1993, pp. 221-226.

$34 \mathrm{Su}$ Vallombrosa si vedano le indicazioni di IP 3 p. 83sg.; l'aggiornamento, con un quadro d'insieme sul fondatore, in Raffaello Volpini: Giovanni Gualberto, fondatore dell'Ordine dei Vallombrosani, santo, in: Bibliotheca Sanctorum 6 (1965) coll. 10121030. Le antiche biografie in Acta SS. Iulii, III, Anversa 1723, pp. 343-65 (Andrea di Strumi), 365-382 (Atto di Pistoia); ma si veda ora Antonella Degl'InNocentr: Le Vite antiche di Giovanni Gualberto: cronologia e modelli agiografici, in: Studi medievali s. terza 25 (1984) pp. 31 -91. Sulla Congregazione e la riforma ecclesiastica, Penco: Storia (cit. nota 23) pp. 215-226; Sofia Boesch: Giovanni Gualberto e la vita comune del clero nelle biografie di Andrea da Strumi e di Atto da Vallombrosa, in: Vita comune (cit. nota 24) vol. 1 pp. 228-235; Réginald Grégoire: Giovanni Gualberto e il suo messaggio, Vallombrosa 1996. Sulla Congregazione, Nicola Vasaturo: L'espansione della congregazione vallombrosana fino alla metà del secolo XII, in: RSCI 16 (1962) pp. 465-485; AA. VV, Vallombrosa, Firenze 1973; Giustino Rossi: Alle origini di Vallombrosa. Giovanni Gualberto nella società dell'XI secolo, Novara 1991; I Vallombrosani nella società italiana dei secoli XI e XII. Atti del Convegno, Vallombrosa, 3-4 settembre 1993, a cura di Giordano Monzio Compagnoni, Vallombrosa 1995 (= 1996). Sulla chiesa di S. Michele a Passignano, in diocesi di Fiesole, dove nel 1073 s. Gualberto morì e fu sepolto, IP 3 pp. 104-115. 
Recente è invece l'interesse per il movimento riformatore che fa capo a Domenico da Foligno ( $†$ 1031), detto pure di Cucullo o di Sora, luoghi dove viene particolarmente venerato ${ }^{35}$. La Cronaca di Montecassino, roccaforte italiana del cenobitismo, ricorda s. Domenico come multorum fundator cenobiorum, ragione non ultima perché due dei monasteri da lui fondati, S. Salvatore di Scandriglia (Rieti) e s. Pietro di Avellana, presso il Sangro, furono donati all'abbazia di Cassino ${ }^{36}$. Su s. Domenico ci sono pervenute due Vite: una scritta - forse intorno al 1067 - da un suo discepolo, di nome Giovanni, cui ha allegato una raccolta di miracoli ${ }^{37}$; l'altra, firmata dal retore Alberico di Montecassino, fu compilata intorno al 1060 per correggere alcune inesattezze trovate in un precedente lavoro, perduto ${ }^{38}$. E' stato già sottolineato, dal Cowdrey e recentemente da Sansterre, come questi due testi agiografici, oltre a presentare il Santo come un modello di monaco-eremita, offrono anche un contributo fattivo per la causa dei fautori della riforma gregoriana ${ }^{39}$. Dette Vite, giustamente interpretate come portatrici di due tradizioni agiografiche diverse,

35 Si rimanda alla voce di Sofia Boesch Gajano: Domenico di Sora, santo, in: DBI 40 (1991) pp. 673-678.

36 Die Chronik von Montecassino (Chronica monasterii Casinensis), II 59, ed. Hartmut Hoffmann, Hannover 1980 (MGH SS 34), p. 283. Il santo fondò altri dieci monasteri; d'obbligo ricordare S. Bartolomeo di Trisulti, S. Domenico di Sora e un eremo ai piedi del monte 'Cacume', presso un ruscello; dedicò l'oratorio a $S$. Michele e lasciò questo luogo, che ha tutte le caratteristiche di un santuario micaelico, in custodia "ad un uomo religioso e pio, di nome Pietro", è quanto narra il biografo Giovanni, di cui appresso, $\$ 11$, cfr. inoltre Penco: Storia (cit. nota 23) p. 195.

37 BHL, vol. 1 p. 338 n. 2241: Vita et obitus B. Dominici confessoris de Sora per Johannem, ipsius Dei viri peregrinationis individuum comitem et venerabilem discipulum, in: AnalBoll 1 (1882) pp. 279-322; vedi ora, Carmela Vircillo Franklin: The restored «Life and miracles of St. Dominic of Sora» by Alberic of Monte Cassino, in: Medieval Studies 55 (1993) pp. 285-385.

38 BHL, vol. I p. 338 n. 2244: Vita auctore Alberico cardinale, in: Acta Sanctorum, Ianuarii, vol. 2, Venezia 1734, pp. 442-446, ibidem 443 nota a (vedi ora, François Dolbeau: Le dossier de saint Dominique de Sora, d'Alberic du Mont Cassin a Jacques de Voragine, in: MEFRM 102 [1990] pp. 7-78). Sul retore Alberico, Penco: Storia (cit. nota 23) pp. $424-425$.

39 Già il Cowdrey aveva scritto che compito di Domenico era stato quello di risollevare il livello dei comportamenti cristiani delle popolazioni con cui venne a contatto, H. E. J. Cowdrey: The Age of Abbot Desiderius. Montecassino, the Papacy, and the Normans in the Eleventh and Early Twelfth Centuries, Oxford 1983 (trad. it., L'abate Desiderio e lo splendore di Montecassino. Riforma della Chiesa e politica nell'XI secolo, Milano 1986). Sul tema è tornato Jean-Marie Sansterre: Recherches sur les ermites du MontCassin et l'érémitisme dans l'agiographie cassinienne, in: Agiographica 2 (1995) pp. 57-92; ID.: Le monachisme bénédictin d'Italie et les bénédictins italiens en France face au renoveau de l'érémitisme à la fin du $\mathrm{X}^{\mathrm{e}}$ et au XI $\mathrm{XI}^{\mathrm{e}}$ siècle, in: Ermites de France (cit. nota 12) pp. 29-46, ibid. pp. 34sg. Vedi anche John Howe: Church reform and social change in eleventh-century Italy. Dominic of Sora and his patrons, Philadelphia 1997. 
concordano nel dire che Domenico nacque a Foligno e ricevette gli ordini minori nel monastero di S. Silvestro 'curasero', posto nei pressi del guado del fiume Topino, sulla sponda opposta al sito dove era stata eretta la tomba del martire Feliciano ${ }^{40}$. Il giovane Domenico era ormai preparato per ricevere l'ordinazione sacerdotale quando se ne partì -forse perché, al pari di s. Romualdo e s. Giovanni Gualberto, aveva subito l'influsso negativo dalla vita rilassata di quei monaci -, girovagando nella Sabina, finché, approdò a Pietra del Demonio, nel monastero di S. Maria. Quivi Domenico - stando al biografo Giovanni - "ottenne, secondo la Regola dall'abate Dionisio, di poter rivestire l'abito monastico [...] e fu promosso al sacerdozio" 41 , precisazione questa ultima omessa da Alberico ${ }^{42}$, il quale prosegue dicendo che Domenico, dopo aver raggiunto la perfezione eremitica nella vita cenobitica, pienamente preparato con l'aiuto della comunità fraterna alle lotte spirituali, con il permesso del proprio abate salì sulla vetta di un monte, per lottare con il solo suo braccio e con la sola sua mano contro l'antico nemico del genere umano ${ }^{43}$. A differenza di Giovanni, il retore Alberico mette così l'accento sulla conformità di Domenico

40 Una tradizione locale precisa che il Santo nacque a Colfornaro, un villaggio collinare, a nord di Foligno, oggi Capodacqua, «Breve compendio della vita e miracoli del glorioso s. Domenico di Foligno detto di Cocullo, monaco ed abbate dell'ordine benedettino", già stampato in Napoli nel 1815, ora però corretto ed accresciuto di ulteriori notizie e con l'aggiunta di un sacro triduo, in preparazione alla festa del medesimo glorioso santo, Foligno 1844, p. 5 s. La notizia però non trova riscontro in Ludovico Iacobilli: Vite de' santi e beati dell'Umbria et di quelli i corpi de' quali riposano in essa provincia, vol. 1, Foligno 1647, pp. 114-116. A questi si deve l'identificazione del monastero di S. Silvestro con il complesso trasformato, nel 1311 in Ospitale di S. Spirito e assoggettato a S. Spirito in Saxia: lo dice inizialmente intitolato alla Trinità e legato al monachesimo prebenedettino della valle di Campi, in Valnerina, i cui campioni furono Spes ed Eutizio, Ludovico Iacobilli: Vite de' santi e beati di Foligno et di quelli i corpi de' quali si riposano in essa città e diocesi, Foligno 1628, pp. 135-141. Stando alla Vita di Giovanni, di cui sopra, il Santo morì, alla veneranda età di 80 anni: se non si tratta di un topos agiografico, poiché l'anno di morte è il 1031 (errata è la data 1101, fornita dall'apografo edito dai Bollandisti, cfr. Vita et obitus [cit. nota 37] p. 24 n. 35), la sua nascita va posta intorno alla metà del secolo $\mathrm{X}$, quando cioè non era ancora sorta la Foligno medievale attorno alla tomba del martire Feliciano. Mentre la scelta topica del monastero di s. Silvestro va messa in relazione con il pellegrinaggio locale (alla tomba del martire Feliciano) e di transito: quivi passava infatti una strada tra i due mari, con uno snodo di vie frequentate dai pellegrini di Roma, Gargano, Terrasanta e Compostella; da qui la viciniore chiesa di S. Giacomo 'ab aqua', eretta forse alla fine del secolo XII.

41 Vita et obitus (cit. nota 37) p. 282 n. 2.

42 per manus Donnosi mira abbatis sanctitate conspicui, sancti ordinis indutus est habitu, Vita auctore Alberico (cit. nota 38) p. $443 \mathrm{~b}$.

43 Vita auctore Alberico (cit. nota 38) p. 443b; Vita et obitus (cit. nota 37) p. 282 n. 2 , precisa che si tratta del monte Scandriglia, che si innalzava non lontano dal monastero di S. Maria. 
alla disciplina benedettina ${ }^{44}$. E' questa la ragione per cui, nel raccontare gli anni in cui il santo alternò la fase eremitica alla predicazione riformatrice e alla fondazione di monasteri, Alberico pone l'accento sulle già ricordate fondazioni passate sotto la giurisdizione di Montecassino ${ }^{45}$; mentre il modello agiografico è la vita di s. Benedetto ${ }^{46}$ e fa da conclusione il fatto che Domenico finì i suoi giorni, nel 1031, non in uno degli eremi dove aveva passato gran parte della sua vita errabonda, ma nel monastero di Sora di lui stesso fondato ${ }^{47}$. Mentre la Vita "tramandata da Giovanni, compagno inseparabile di viaggio e venerabile discepolo del santo", pone l'accento sulle attività esterne del Santo, cioè sul suo ruolo di predicatore, di taumaturgo e di costruttore di monasteri, chiese ed eremi: fondazioni tutte sorte in ambiti montani o rurali, strettamente legate ai patroni fondatori e svincolate dall'autorità dell'ordinario diocesano, con le quali Domenico mantiene un costante contatto. Questa attività di predicatore e di fondatore di "chiese private" viene posta, dal discepolo-biografo, dopo un viaggio di Domenico a Roma, dove fu ricevuto da papa Giovanni XVIII (10031009). Domenico vi si era recato per supplicarlo di "accogliere sotto la cura e la protezione della Santa Chiesa Romana, la chiesa di San Bartolomeo e le cose che

44 Il rimando è alla «Regula s. Benedicti» dove si parla di eremiti, come di coloro che, per aver percorso un lungo tirocinio nel monastero ed essere stati addestrati con l'aiuto di molti erano "divenuti esperti a combattere contro il demonio [...] senza il soccorso di altri ma solo col vigore delle mani e delle braccia proprie, contro i vizi della carne e dei pensieri” (Regula I, 3-5).

45 Coenobia variis locis aedificata [...] in Scandrilia [...] monasterium S. Salvatoris [...] in Sangro [...] S. Petri de Avellana, Vita auctore Alberico (cit. nota 38) p. 443b-445a, con i quali rispettivamente apre i capitoli II e IV.

46 Mentre Alberico dedica il solo capitolo III a "visiones, miracula", appena due visioni celesti e tre 'miracoli' (Vita auctore Alberico [cit. nota 38] p. 444b); Giovanni ai "miracula" dedica ben 38 paragrafi, dove si descrivono altrettanti eventi: rilevanti, ai fini della riforma, quelli dove vengono stigmatizzati i preti sposati e le loro concubine Vita et obitus (cit. nota 37) pp. 298-322, ibidem 300ss, nn. 5-12; uno dei temi della sua predicazione itinerante cosi ad esempio a Guarcino, dopo aver convocato in chiesa clero e popolo, "coepit sanctus omnem praedicare et admonere populum et sacerdotes, ut in eo servitio, videlicet in vigiliis, orationibus, jejuniis et eleemosynis vigilanter persisterent, et coepit corrigere et reprehendere sacerdotes de avaritia, luxuria et omnibus vitiis, et maxime ut ab illicitis se abstinuerent conjugiis", ivi p. 288 s, n. 16. Vedi inoltre Sofia Boesch Gajano: Santità di vita, sacralità dei luoghi. Aspetti della tradizione agiografica di Domenico di Sora, in: Scritti in onore di Filippo Caraffa, Anagni 1986, pp. 187 204, ibid. 198; EAD.: Domenico (cit. nota 35) pp. 676sg. Sulle singolari manifestazioni del culto prestato al Santo, attraverso i secoli fino ai nostri giorni, d'obbligo il rimando ad Alfonso M. di Nola: Gli aspetti magico-religiosi di una cultura subalterna italiana, Torino 1976; id.: Scritti rari, vol. 1, a cura di I. Bellotta/E. Giancristofaro/Edizioni Amaltea, in: Rivista Abruzzese 53 (2000) pp. 162-213.

47 Vita auctore Alberico (cit. nota 38) p. 445b. Il privilegio di Alessandro III del 24 aprile (1179-79) indirizzato al monastero di Sora, dedicato al santo, in: PUU in Italien, vol. 4 p. 232 n. 17. 
ad essa appartenevano e che in futuro avrebbero potuto ricevere" e il pontefice non solo annuì, ma concesse anche "la libera facoltà di nominare un abate", inoltre "la cura degli infermi e la libera sepoltura", facendo così di S. Bartolomeo - un monastero fondato e dotato dagli abitanti di Castro, Vico, Guarcino e Collepardo - un'abbazia esente ${ }^{48}$. Il riconoscimento del papa, oltre a sottolineare la funzione pastorale svolta dall'abate Domenico, colloca questa fondazione come le altre che il Santo andava promuovendo -, nel contesto di una riforma che precede e prepara quella gregoriana ${ }^{49}$.

\section{2 - I monasteri di famiglia}

Detti monasteri fondati da san Domenico - per lo più di iuspatronato signorile - e indicati con il termine tecnico di Eigenkloster, oltre ad essere frutto di una genuina scelta religiosa -procurarsi dei meriti a vantaggio della propria salvezza eterna e garantire un servizio religioso al territorio- costituivano anche un prezioso strumento politico ed economico a servizio dei locali feudatari ${ }^{50}$. Alcune chiese erano tuttavia sorte su richiesta di uno o più centri demici - come nel caso del già citato monastero di S. Bartolomeo -, erano quindi di dominio valligiano, permettendo così, anche a delle comunità rurali, di usufruire, specie

48 Vita et obitus (cit. nota 37) p. 288 n. 15.

49 Su questi monasteri, A. Martini: Le fondazioni monastiche di san Domenico di Sora e poteri locali tra fine X e XI secolo, in: Società e storia 86 (1999) pp. 693-713: Per il contesto in cui operò il Santo, cfr. Dionigi Antonelli: Abbazie, prepositure e priorati benedettini nella diocesi di Sora nel medioevo (secc. VIII-X), Roma 1986.

50 Il termine, che sta ad indicare il rapporto di subordinazione di un convento al dominio di un nobile, fu coniato da Ulrich STUtz: Die Eigenkirche als Element des mittelalterlich-germanischen Kirkenrechts. Antrittsvorlesung 23. Oktober 1984, Berlin 1985; ID.: Geschichte des Benefizialwesens von seinen Anfängen bis auf die Zeit Alexanders III., Aalen 1961 (anastatica dell'edizione 1895). Su questo fenomeno si vedano le precisazioni fatte da Wilhelm Kurze: Monasteri e nobiltà nella Tuscia altomedievale, in: Lucca e la Tuscia nell'Alto Medioevo, Atti del $5^{\circ}$ congresso internazionale di studi sull'alto medioevo, Lucca, 3-7 ottobre 1971, Spoleto 1973 (Atti del Congresso internazionale di studi sull'alto medioevo 5), pp. 339-362; vedi inoltre, Forme di potere e struttura sociale in Italia nel Medioevo, a cura di Gabriella Rossetтi, Bologna 1977 (per le analogie con il territorio preso in esame, cfr. Mario Del Treppo: Frazionamento dell'unità curtense, incastellamento e formazioni signorili sui beni dell'abbazia di San Vincenzo al Volturno tra X e XI secolo, pp. 285-304); Réginald GrÉgoire: Casati nobiliari e monasteri in epoca medievale, in: Cairati, Castiglioni, Martignoni ed altri casati locali nel medioevo. Atti del convegno di studio promosso nel centenario della Fondazione della Società Gallaratese per gli Studi Patri (1896-1996) con un'introduzione illustrativa del suo Museo di Archeologia, Storia e Arte Antica (Cairate, Monastero di Santa Maria Assunta, 11-12 maggio 1996), a cura di Claudio Tallone, Varese 1998, pp. $171-186$. 
in periodo di anarchia, degli stessi benefici goduti dai domini, la difesa sacrale delle terre, dei boschi e dei pascoli ${ }^{51}$. Ad amministrare detti patrimoni erano monaci la cui storia non ci è nota, ma è presumibile che molti di loro avessero fatto una scelta di vita religiosa, abbandonando ricchi possessi di famiglia, per amministrare un patrimonio collettivo, comunitario e sociale. Da parte sua s. Pier Damiani, in una lettera, scritta nel 1064, ricorda con compiacimento il caso del signore feudale che aveva lasciato gran parte del suo patrimonio feudale alla Chiesa e spiega come questi, nel donare alla chiesa grosse proprietà, non aveva diseredato i suoi discendenti, perché costoro in breve tempo avevano visto fruttare in modo straordinario le terre rimaste nell'asse ereditario ${ }^{52}$.

Il fenomeno dei monasteri di famiglia ebbe una larga diffusione, specie tra Tuscia, Umbria e Marche, dove un po' ovunque si trovano storie di signori che, in alternativa alla scelta assoluta di povertà - con l'ingresso in un monastero o in eremo -, fondano monasteri cui donano, pro rimedio animae, una parte consistente del patrimonio ${ }^{53}$. Valga l'esempio dei conti Foligno, città rifondata nel secolo $\mathrm{XI}^{54}$. Proprio mentre la Foligno medioevale si andava costruendo attorno alla tomba del martire Feliciano e la nova civitas s. Feliciani stava esercitando una forte attrattiva sui contadini e sui pastori che passarono così ad altra attività, i locali conti fondarono, in zone di frontiera e lungo le strade di attraversamento della dorsale appenninica umbro-marchigiana, gli insediamenti eremitici di Salvinum, Veccli e Sansuvinum, S. Stefano di Gallano e S. Pietro di

51 Cito il caso dell'eremo-santuario della Madonna del Sasso sul quale, la communitas di S. Martino in pieno Umanesimo, continua a rivendicare la propria dominatio, ordinando al cappellano - a motivo della sua presunta indegnità- di lasciare immediatamente quel beneficio che però questi aveva legittimamente ottenuto dall'ordinario diocesano. Ho pubblicato il relativo atto, rogato da un notaio del posto, in: Laici a servizio della comunità parrocchiale: l'Istituto medievale del santesato, in: Servire Ecclesiae, miscellanea in onore di mons. Pino Scabini, Bologna 1999, pp. 147-179, ibid. pp. 176-178 (quivi altri esempi, ancorché tardivi -in quanto posteriori alla metà del secolo XIV-, di chiese di iuspatronato della collettività che agiva tramite l'Istituto del santesato).

52 Petri Damiani Epistulae, ep. 110. Su questa lettera riflette, Giacomo Todeschini: Ricchezza francescana. Dalla povertà volontaria alla società di mercato, Bologna 2004, p. 40.

53 Per la Toscana, Giovanni Miccoli: Aspetti del monachesimo toscano nel secolo XI, in: ID.: Chiesa gregoriana (cit. nota 15) pp. 47-73; Kurze (cit. nota 50) pp. 347sg.; Giuseppe Sergi: Vescovi, monasteri, aristocrazia militare, in: La chiesa e il potere politico dal Medioevo all'età contemporanea, a cura di Giorgio Chittolini/Giovanni Miccoli, Torino 1986 (Storia d'Italia, Annali 9), pp. 73-98 (in particolare, Fondazione e protezione di monasteri, pp. 79-84). Pur presente nelle Marche e nell'Umbria, in queste due regioni il fenomeno è decisamente poco studiato.

54 Sulla civitas altomedievale, Michele Faloci Pulignani: S. Valentino di Civitavecchia presso Foligno, in: Archivio per la storia ecclesiastica dell'Umbria 4 (1917-19) pp. 635-651; sulla nuova cattedrale, AA.VV., Foligno A. D. 1201. La facciata della cattedrale di San Feliciano, a cura di G. BenAzzi, Milano 1993. 
Landolina: i primi tre stanno alla base di quella che divenne la congregazione monastica di S. Croce di Sassovivo ${ }^{55}$. Il Kehr ricorda, per la diocesi di Foligno, Santa Croce di Sassovivo e S. Stefano di Gallano; per quella di Nocera Umbra, S. Pietro di Landolina ${ }^{56}$.

Il monastero di S. Stefano, che sorgeva nei pressi del Castello di Gallano, nella viscontea della Valtopina, era stato fondato nel 1086, con donazioni di Berardo, Bruco e Attone degli Atti dei conti di Nocera. Dopo due secoli di autonomia, nel 1291, fu unito a Sassovivo ${ }^{57}$. Dal privilegio di Alessandro III (31 dicembre 1172) confermato da Celestino III (16 aprile 1197) si apprende che da Gallano dipendevano nove chiese $^{58}$, mentre dalla conferma di Celestino III

55 Il ricco archivio dell'abbazia, costituito da circa 7500 pezzi si trova all'Archivio della Curia arcivescovile di Spoleto. Catalogato e diviso in due serie, è stata edita, presso l'Editore Leo Olschki, la prima, con le carte più antiche. Questo il relativo elenco i cui volumi recano lo stesso titolo iniziale: Le carte dell'abbazia di S. Croce di Sassovivo: vol. 1: Documenti degli anni 1023-1115, a cura di Giorgio CenCETTI, con prefazione di Alessandro Pratesi e indici di Giovanna Petronio Nicolaj, Firenze 1973; vol. 2: Documenti degli anni 1116-1165, a cura di Vittorio de Donato, Firenze 1975; vol. 3 : Documenti degli anni 1166-1200, a cura di Riccardo Capasso, con premessa di Alessandro Pratesi, Firenze 1983; vol. 4: Documenti degli anni 1201-1214, a cura di Attilio Bartoli Langeli, Firenze 1976; vol. 5: Documenti degli anni 1215-1222, a cura di Giovanna Petronio Nicolaj e Attilio De Luca, Firenze 1979; vol. 6: Documenti degli anni 1223-1227, a cura di Attilio DE LuCA, Firenze 1976; vol. 7: Documenti degli anni 1228-1231, a cura di Giovanna Petronio Nicolaj, Firenze 1974. Per una bibliografia ragionata, cfr. AA. VV., L'abbazia di Sassovivo a Foligno, Foligno 1992, pp. $155-157$.

56 IP 4 pp. 46-49 (Sassovivo), 49-50 (Gallano), 52-53 (Landolina).

57 L'unione fu confermata da Bonifacio VIII, nel 1301, cfr. Ludovico Iacobilli: Cronica della chiesa e monastero di S. Croce di Sassovivo nel territorio di Foligno ..., Foligno 1653, pp. 235-243; Placido Lugano: Le chiese dipendenti dall'abbazia di Sassovivo presso Foligno ed un elenco del card. Rusticucci (1586), in: Rivista Storica Benedettina 7 (1912) pp. 47-94, ibid. pp. 57, 77sg. Il relativo archivio è confluito tra le carte dell'abbazia, di S. Croce di Sassovivo. Per ricostruire il quadro genealogico dei comites del Comitatus Nucerinus, d'obbligo il rimando a Durante Dorio: Istoria della famiglia Trinci, Foligno 1648; quanto poi alla sua affidabilità e alle difficoltà che lo storico vi incontra cfr. DE LuCA: Documenti (cit. nota 55) vol. 6 p. LXXI; Gino Sigismondi: Nuceria in Umbria, Foligno 1979, pp. 324-334.

58 Le due bolle, in Capasso: Documenti (cit. nota 55) vol. 3 pp. 35-39; 203-205. Solo quella di Celestino III era sta edita da PUU in Italien, vol. 5 p. $57 \mathrm{sg}$. n. 48. Questo l'elenco delle chiese: S. Pietro di Serra, S. Cristoforo, S. Michele arcangelo 'de Rotunduro' (santuario micaelico dirimpettaio alla rocca di Serra), S. Maria de Villa Alva, S. Maria di Afrile, S. Giovanni di Talogna (Talonge), S. Sisto di Gallano, S. Croce di Serra e la chiesa di Castelreale (castri Regalis). Per le vicende del monastero, Lugano: Chiese dipendenti (cit. nota 57) p. 57. Per l'identificazione delle chiese, soggette alla giurisdizione del vescovo di Foligno, ID.: Delle chiese della città e diocesi di Foligno nel secolo XIII secondo una sentenza del 1239 e la 'Libra' del 1295, in: Bollettino della r. Deputazione di Storia Patria per l'Umbria 10 (1904) - 12 (1907) e a parte, Roma 1907, pp. $102-104$. 
veniamo a sapere che sul monastero gravitavano insediamenti rurali che effettivamente costituivano l'intero feudo di Valtopina; dal che occorre dedurre che al monastero era stata completamente affidata la cura animarum di questo lembo territorio che fungeva da cuscinetto tra Nocera e Foligno, ma in diocesi di questa ultima ${ }^{59}$. Mentre S. Pietro di Landolina, posto in diocesi di Nocera, era stato fondato nel 1090 da Bucco, detto Lupo, dei conti di Nocera, inter montes Appininos, laddove confluivano gli interessi di altre tre città emergenti: Foligno, Camerino e Spoleto ${ }^{60}$. Suo figlio Monaldo e Rodolfo, figlio del conte Lamberto, nel 1114 trasferirono i loro diritti di iuspatronato sul monastero al priore della canonica di Foligno, elencando, oltre al monastero e le servitù dovute, tre chiese donate dallo stesso Bucco e sette mansi posti tra la Valle di Vaccagna, il piano di Annifo e il versante occidentale del Monte Pennino, a patto che nulla di quanto donato pervenisse al vescovo di Foligno ${ }^{61}$. Sono queste le ragioni per cui le ricordate chiese, cui facevano capo le contrade di Annifo, Marte e S. Cristoforo, rimasero sotto la giurisdizione del vescovo di Nocera ${ }^{62}$. Con bolla "Quotiens illud» del 4 aprile 1174, diretta all'abate Atto, il pontefice Alessandro III accolse il monastero sotto la protezione, confermò la regola di s. Benedetto e i possedimenti che, quanto al territorio, sembrano coincidere con i precedenti confini mentre, a seguito di nuovi insediamenti, furono costruite altre chiese ${ }^{63}$.

59 possessiones et homines di Fondi, Base, Afrile, Rio (Rigu), Palarne, Polveragna (Bolferangia), Porcarella, Forcatura,Villalva, Carpelle, Annifo (Andifo), Talogna, Arvello (Alvello), Cassignano, Mosciano (Musano), Sorifa (Surrifa), Stravignano, Capodacqua, Orchi (Orcli), Gallano, Marcillone, Podio, Caprilla, Castillone, Aqui, Caparanica "et possessiones que olim fuerunt domine Marie a Roveiano", infra, PUU in Italien, vol. 5 p. $57 \mathrm{sg}$. n. 48; Capasso: Documenti (cit. nota 55) vol. 3 p. 204.

60 IP 4 pp. 49sg.; inoltre, IAcobilli: Cronica (cit. nota 57) pp. 243-250.

61 Le tre chiese sono S. Nicolò, S. Silvestro e S. Apollinare; mentre i sei mansi sono posti tra i confini della Valtopina, il Monte Pennino e il Monte Acuto: "de Capu de limiti da Villalva, fini rigu de Musanu, fini Appinino vecclu et perveniente a Cornu Valleranu et perveniente a lu Gallulu et mergit in Capu de limiti qui est prima finis, et circum ipsa ecclesia Sancti Petri inter finis desingnata Gravaia, Tralassera et vadit ad Appenninum vecclu et fini Valle de Ofu in Monte Acutu et venit per senaita inter nos et Cono", Michele Faloci Pulignani: I priori della cattedrale di Foligno, memorie, Perugia 1914, pp. 19-20; Concetti: Documenti (cit. nota 55) vol. 1 pp. 306-310. L'identificazione delle contrade, ivi, p. 333 (regesto di mano dello Iacobilli di un documento datato 1114, con le decime dovute al vescovo di Nocera) tratto forse dal privilegio di Alessandro III del 1174, di cui appresso.

62 La diocesi di Nocera ha ceduto la parrocchia di Annifo a quella di Foligno nel 1937, Mario Sensi: Visite pastorali della diocesi di Foligno. Repertorio ragionato, Foligno 1991, p. 24, 275.

63 terram de Cutis et ecclesiam eiusdem loci, ecclesiam Sancte Elene et ecclesiam Sancte Lucie cum pertinentiis suis, ecclesiam Sancti Cristofori de Robertiski cum pertinentiis suis, ecclesiam Sancti Pauli de Colle Iuvenis cum pertinentiis suis, ecclesiam Sancti Laurentii de Musano et ecclesiam Sancti Hylarii cum pertinentiis suis, CAPAsso: Documenti (cit. nota 55) vol. 3 pp. 35-39. 
Stante la piccola porzione del territorio gestito da questa abbazia -corrispondente pressappoco all'attuale parrocchia di Annifo -, gli impegni di evangelizzazione dovettero essere minimi; rilevante appare invece un ruolo di controllo dei passi e dei crinali della montagna, dotata com'è di pascoli ubertosi, dove fu anche eretto - si ignora quando ${ }^{64}$ - a mezza costa del Monte Pennino, in territorio di Bagnara, un santuario micaelico che ebbe come pellegrino lo stesso s. Francesco d'Assisi, quivi portato sulla fine dell'estate del 1226, durante la sua ultima malattia ${ }^{65}$.

A Sansuvinum si era stabilito certo Mainardo il quale - se da identificare con il Mainardo dell'Op. XIII di Pier Damiani ${ }^{66}$-, proveniva dal monastero di Sitria presso il Catria, il monastero romualdino legato a s. Pier Damiani ${ }^{67}$. Mainardo $(†$ 1096) - attestato dalla carte di Sassovivo nel 1077 come eremita, dal 1081 monacus et prepositus; quindi, dal 1083, abbas di Maria in Vecli, con la variante di S. Croce e S. Trinità e, dal 1089, abbas monasterii S. Crucis et S. Trinitatis in Sassovivo, titolo infine stabilizzatosi in S. Croce - nel giro di circa venti anni, attraverso la costruzione del monastero nel fortilizio di Sassovivo e una serie di acquisti - tra donazioni e permute di terreni e case, sparsi tra la montagna folignate e la valle spoletana -, gettò le premesse per la nascita di una federazione di "chiese di Famiglia" e di "monasteri di Famiglia" travolti dalla decadenza economica e morale, per cui ebbe origine la congregazione di Sassovivo $^{68}$. I monaci di Sassovivo erano eremiti che probabilmente, agli inizi,

64 Indubbiamente fu un santuario micaelico voluto dai domini del luogo, i comites del comitatus nucerinus. Da una transazione tra il vescovo di Nocera e i conti di Tripozzo, patroni fondatori del Monastero di S. Croce di Sassoferrato, si apprende infatti che questo monastero, in cambio di due chiese, cedette al vescovado di Nocera la chiesa di S. Angelo "de Bagnaria, sive de Appenino", con le relative chiese dipendenti: "S. Lucie de Agio, S. Nicolai de Annifo, S. Antimi de Bagnaria et S. Felicissimi de Avegna, subiectis eidem ecclesie S. Angeli", cfr. A. Castellucci: Il vescovo di Nocera e i monaci di S. Croce di Sassoferrato, in: Archivio per la storia ecclesiastica dell'Umbria 1 (1913) pp. 217-226, ibid. p. 223. Su queste chiese, poste lungo la lingua di terra che da Annifo conduce a Bagnara, Mario SENsi: Il 'Liber beneficiorum' della diocesi di Nocera Umbra, in: Bollettino storico della città di Foligno 11 (1987) pp. 55-94 nn. 1, 40, 41, 84, 283, 296, 376, 419.

65 Sul santuario micaelico di Bagnara rimando al mio, Santuari micaelici e primordi del francescanesimo, in: Collectanea Franciscana 72 (2002) pp. 5-104, ibid. pp. 26-35.

66 Migne PL 145, coll. 324-326.

67 Su questo monastero, fondato da san Romualdo, ai confini tra le diocesi di Gubbio e di Nocera U., ma in territorio di questa ultima, cfr. Vita beati Romualdi (cit. nota 18) n. 49 p. 90; IP 4 p. 55. Gli «Annales Camaldulenses» mettono in stretto rapporto questa fondazione con Fonte Avellana, in quanto così la localizzano: distat Sitria duobus milliaribus ab Avellanensi abbatia ex qua per montem Nocri ad illam Sitriae est iter, Annales Camaldulenses ordinis sancti Benedicti, vol. 1, Venezia 1755, p. 403.

68 La più antica ed unica testimonianza della dizione congregatio Sancte Crucis risale al 1149, de Donato: Documenti (cit. nota 55) vol. 2 p. 176. Mentre la prima menzione 
non ebbero una regola precisa, né ci fu una ordinata struttura della comunità, anche se è ipotizzabile una certa analogia con le fondazioni romualdine, cioè con un unico superiore, di norma residente nell'eremo principale. A favorire il monastero, prima e, quindi, la congregazione erano stati i conti di Foligno, poi conti di Uppello, con generose donazioni, cui si aggiunsero anche quelle dei privati per cui il monastero, già nei primissimi anni, raggiunse un notevole livello economico, grazie anche a una gestione economica oculata, condotta attraverso acquisti e permute ${ }^{69}$. Come avevano fatto i domini del basso Lazio e dell'Abruzzo nei confronti di san Domenico, anche i Conti di Foligno promisero a Mainardo il rispetto delle libertà, dell'indipendenza e della defensio; ricevendo, in cambio, il diritto di patronato e la rinuncia di Mainardo ad acquistare beni dagli angariales dei conti, onde evitare ut caput mansi frangantur $^{70}$. E' probabile che, oltre agli innegabili motivi religiosi di fondo, $\mathrm{i}$ conti siano stati particolarmente munifici nei confronti di Sassovivo anche nell'intento di fare del monastero un valido ostacolo al nascente comune di Foligno $^{71}$. Non meno importante però, per il successo dell'abbazia, fu l'apporto dato dalla Sede apostolica che, nel 1116, preso atto che a Sassovivo per Dei gratiam disciplina noscitur ac religione pollere, affida a questi monaci il compito di riformare il monastero di S. Apollinare del Sambro, della diocesi di Assisi, in quo nimirum loco iam dudum disciplinae dissolutio contigit, esortando detti monaci di Sassovivo ad reformandam igitur ordinis monastici disciplinam ${ }^{72}$. Si

dell'«Ordo Saxivivi» si trova nel privilegio di Onorio III del 1217, cfr. Nicolaj/DE Luca: Documenti (cit. nota 55) vol. 5 p. 86. Sul fondatore e sui primi insediamenti religiosi che costituiscono gli inizi della Congregazione, cfr. Cencettr : Documenti (cit. nota 55) vol. 1 indice, s. v. "Mainardus", "Sassumvivum", "Salvinum", "Veccli", "S. Crucis de Veccli"; inoltre, Iacobilli: Vite (cit. nota 40) vol. 3 pp. 180-183; Riccardo Capasso: Sulla data della morte di Mainardo primo abate di S. Croce di Sassovivo e della successione di Dionisio secondo abate, in: Annali della Scuola speciale per archivisti e bibliotecari dell'Università di Roma 6 (1966) pp. 131-135. Sulla crisi del monachesimo nell'XI e XII secolo, Jean LeclercQ: La crise du monachisme au XI ${ }^{\mathrm{e}}$ et $\mathrm{XII}^{\mathrm{e}}$ siècles, in: BISI 70 (1958) pp. 19-41.

69 Sull'amministrazione di questo vasto patrimonio si veda Riccardo Capasso: Il libro dei censi del sec. XIII dell'abbazia di S. Croce di Sassovivo, Perugia 1967 (Deputazione di Storia Patria per l'Umbria. Fonti per la storia dell'Umbria 4).

70 Con due documenti paralleli i discendenti del conte Monaldo giurarono, intorno al 1084, di rispettare la libertà e l'indipendenza del monastero edificato in Vecli, in onore di s. Croce e di s. Maria, di cui era abate Mainardo (ma nei due testi compare con la qualifica di priore), excepto quod non acquirat de meis angarialibus ut caput mansi frangantur, Cencetti: Documenti (cit. nota 55) vol. 1 p. 46sg. n. 29.

71 Alessandro Pratesi: Prefazione, a Cencettr: Documenti (cit. nota 55) vol. 1 pp. VXXII, ibid. p. VIII.

72 De Donato: Documenti (cit. nota 55) vol. 2 pp. 4sg. Attraverso le Carte di Sassovivo è possibile ricostruire, seppure a grandi linee, le vicende di altri monasteri di famiglia passati all'obbedienza di Sassovivo, perché in decadenza, dal secolo XII al secolo XIV: tra le ultime accessioni, S. Stefano di Gallano (1301), S. Pietro di Landolina (1323), S. 
aggiunga che, mentre il pontefice Pasquale II (1099-1118) riconosce ai monaci di Sassovivo una funzione di restaurazione della regola dell'Ordine di san Benedetto, Innocenzo II (1130-1143) addita in Mainardo - l'iniziatore del movimento eremitico di Sassovivo, qualificato come magister sancte Romane Ecclesie, - un riformatore poiché, in un tempo di scismatici ed eretici, aveva servito con alacrità la Chiesa e le era stato fedele ${ }^{73}$.

Oltre ad acquistare terre, homines, molini, selve e case in montagna, in collina e lungo la valle Umbra da Foligno a Spoleto, il monastero, dalla fine del secolo XI cominciò a riunire - per donazione, per costruzione o per annessione - monasteri, chiese e cappelle: una rete di obedientiae che, nel 1138 - privilegio di Innocenzo II - era costituita da 34 chiese e cappelle, da Roma a Camerino ${ }^{74}$. Mentre un secolo dopo i monasteri erano saliti a 92 e le chiese a 41, in più 7 ospitali, dal che parrebbe dedursi un indirizzo assistenziale ed ospitaliero della congregazion $\mathrm{e}^{75}$. Specchio di questa potenza economica è lo splendido chiostro cosmatesco, firmato dal marmoraio romano Pietro de Maria ed eseguito negli anni 1229-1233, al tempo dell'abate Angelo dei conti di Uppello (1222$1260)^{76}$. Di fatto la Curia romana, a partire da Innocenzo II (1138), mostrò sollecitudine verso questa Congregazione e con più privilegi la protesse e

Angelo di Limigiano (1333), S. Pietro di Bovara (1334). Le ragioni della decadenza di un Eigenkloster, o monastero di famiglia, vanno ricercate sia nelle alterne vicende della famiglia dei fondatori o patroni, sia nel venir meno delle funzioni per cui detti monasteri erano sorti, cfr. De Luca: Documenti (cit. nota 55) vol. 6 p. LXVIII.

73 magistrum sancte Romane Ecclesie laboribus instituisse atque pro ea tempore scismaticorum et hereticorum fideliter estitisse, IACOBILLI: Cronica (cit. nota 57) pp. 301-306, vedi ora DE Donato: Documenti (cit. nota 55) vol. 2 pp. 116-121; inoltre, Attilio Bartoli LANgeli: Una storia medievale, in: L'abbazia di Sassovivo a Foligno, pp. 45-78, ibid. p. 58.

74 I sospetti del Kehr su possibili interpolazioni circa i beni attribuiti al monastero (IP 4 p. 48) sono condivisi poiché "eccessivamente numerosi" da DE Donato: Documenti (cit. nota 55) vol. 2 p. 117.

75 Privilegio di Clemente III [(1188, giugno 4), ed. PUU in Italien, vol. 5 pp. 46sg. n. 37 e ora vedi Capasso: Documenti (cit. nota 55) vol. 3 pp. 124-127. L'ipotesi che detta congregazione abbia svolto un ruolo assistenziale e ospitaliero è di Penco: Storia (cit. nota 23) pp. 195sg. Alcuni possessi dovettero essere contestati se, ad esempio, nel giro di due anni da questo privilegio l'abbazia ottenne la conferma di S. Nicolò di Bevagna della diocesi di Spoleto ([1188, ottobre 26], PUU in Italien, vol. 5 48sg. n. 38; Capasso: Documenti [cit. nota 55] p. 130sg.], di S. Angelo di Camerino ([1189, gennaio 16], PUU in Italien, vol. 5 p. 49 n. 39; Capasso: Documenti, p. 131sg.) e di S. Nicolò di Foligno ([1189, aprile 27], PUU in Italien, vol. 5 p. 52sg. n. 42; CAPAsso: Documenti, p. 132sg.). Mentre per altre chiese si dovette giungere alla divisione del beneficio, come nel caso di S. Giovanni 'de Colle', S. Maria 'de Capronaco' e S. Sisto, i cui frutti Celestino III ordinò di spartire con il vescovo di Foligno ([1197, febbraio 12], PUU in Italien, vol. 5 p. 56 sg. n. 47; CAPasso: Documenti, p. 200sg.].

76 Michele Faloci Pulignani: Il chiostro di Sassovivo, Foligno 1879; id.: I marmorai romani a Sassovivo, in: Archivio per la storia ecclesiastica dell'Umbria 2 (1915) pp. 561 600 . 
l'appoggiò, prendendola sotto la sua protezione ed esentandola dalla giurisdizione vescovile ${ }^{77}$. In cambio la Chiesa romana trovò in Sassovivo un valido alleato nel portare avanti in loco la riforma promossa dalla Sede apostolica: l'abate di Sassovivo godeva presso Innocenzo III di indubitata fiducia se, insieme al vescovo di Città di Castello, al priore di Camaldoli e a quello di S. Frediano di Lucca fu chiamato a collaborare e a coordinare il capitolo regionale dei monasteri esenti centro italiani tenutosi a Perugia il 2 ottobre 1203 e cinque anni dopo lo stesso pontefice affidò a tre degli stessi - al vescovo di Firenze Giovanni, già priore di s. Frediano, al priore di Camaldoli e a Nicola abate di Sassovivo - cum inter ceteros prelatos Tuscie geramus de vobis fiduciam pleniorem, la visita super omnibus monasteriis tam in Tuscia usque Viterbium et Reatem quam etiam in Marchia constitutis ${ }^{78}$. Ma già intorno alla metà del secolo successivo il monastero era in decadenza per cui, dopo tentativi non riusciti di riforma, Paolo II, nel 1467, lo diede in commenda e nel 1486 Innocenzo VIII dichiarò estinta la congregazione di Sassovivo, affidando il monastero alla congregazione di Monte Oliveto $^{79}$.

S. Croce di Sassovivo non è l'unico esempio di congregazione costituita da 'monasteri di Famiglia'. Cito fra Umbria e Marche quella di S. Croce dei Conti, fondata dagli Atti, signori di Sassoferrato - già Sentino - intorno al 1150, un monastero di frontiera posto in località Tripozzo, con monaci provenienti forse dall'abbazia di S. Vittore delle Chiuse, in quel di Genga, dove si vestiva di bianco. Una bolla di Innocenzo IV del 1252 enumera per questa congregazione 44 tra chiese ed eremi: 15 nella diocesi di Camerino, altrettante in quella di Nocera Umbra e il restante terzo in altre diocesi marchigiane ${ }^{80}$. Come Sassovivo anche Sassoferrato fu un monastero benedettino di stretta osservanza -tra i suoi

77 L'esenzione e l'immediata soggezione alla Sede apostolica del monastero di Sassovivo, concessa da Innocenzo II il 21 maggio 1138, venne poi confermata da Alessandro III (1172, perduto), Clemente III (1188, giugno 4), Celestino III (1191, giugno 19), Innocenzo III (perduto), Onorio III (1216 febbraio 19) e Gregorio IX (1227 giugno 8), Innocenzo IV (1244), Alessandro IV (1256), Nicolò IV, Bonifacio VIII ... fino a Paolo III (1536, agosto 11), cfr. IP 4 p. 46-49; DE LuCA: Documenti (cit. nota 55) vol. 6 p. 278; la relativa edizione nelle carte dell'abbazia di S. Croce di Sassovivo, ad annum.

78 La lettera di indizione del capitolo generale del 15 febbraio 1203 in Migne PL 214, col. 1173; Potthast 1828. Sulla visitatio, cfr. Migne PL 215, col. 1490; Роттнаst 3539; vedi inoltre Michele Maccarrone: Studi su Innocenzo III, Padova 1972 (Italia Sacra 17), pp. 242-243, 331. Riduttivo, a mio parere, il giudizio di Attilio Bartoli Langeli che, leggendo la politica di riforma religiosa di Innocenzo III "in termini disciplinari e organizzativi”, ritiene "innegabile l'esistenza di una forte unità ideologica che lega recuperatio del Patrimonio e lotta all'eresia, riforma della vita regolare e affermazione della "cristianità romana", ridimensionando così anche l'operato delle persone di sua fiducia, Bartoli Langeli: Documenti (cit. nota 55) vol. 4 pp. XXI-XXIII.

79 Cfr. Lugano: Chiese dipendenti (cit. nota 57) pp. 65-72; Penco: Storia (cit. nota 23) p. 196.

80 Alberico Pagnani: Storia dell'abbazia di S. Croce dei Conti, Fabriano 1969, pp. 21-31. 
monaci vanno ricordati il ven. Ranieri $(\dagger 1268)$, confessore di san Francesco ${ }^{81}$ e il B. Gherardo ( $\dagger$ 1280), protettore di Serradeconti ${ }^{82}$. Ma, a differenza di Sassovivo, i monaci eremiti di Sassoferrato era addetti alla cura animarum e, in qualità di parroci, risiedevano non nel monastero, ma presso le rispettive chiese curate o anche in grancie, dove si custodiva il grano e altri raccolti delle terre dell'abbazia. Come la stragrande maggioranza dei monasteri di origine 'feudale' anche S. Croce dei Conti fu dato in commenda (1448), mentre Paolo V, nel 1612, lo annesse ai cenobiti camaldolesi ${ }^{83}$.

Queste due congregazioni, dove operarono monaci di santa vita ${ }^{84}$, sono punte di iceberg di un reticolato di monasteri e di eremi autonomi, di iuspatronato signorile, operanti tra i secoli XI-XIII lungo la catena dell'Appennino centrale, alcuni dei quali anche di notevole peso socio-religioso, si pensi $S$. Vittore delle Chiuse ${ }^{85}$. Loro comune denominatore era l'esaltazione della vita eremitica, intesa come ritorno alla semplicità dell'antica ascesi monastica di origine orientale e una vita di povertà, secondo la formula nibil habentes; mentre dal punto di vista religioso costituirono, per usare una felice espressione del Lemarignier, un "encadremant religieux de campagnes" ${ }^{"}$.

81 Su don Raniero, già pievano di Civita e confessore di s. Francesco, poi frate Minore, Giacinto Pagnani: I viaggi di s. Francesco d'Assisi nelle Marche, Milano 1962 (Studi e testi. Deputazione di storia patria per le Marche 2), p. 23 s, 26-29.

82 Iacobilli: Vite (cit. nota 40) vol. 3 pp. 366-368; Pagnani: Storia (cit. nota 80) pp. $51-55$.

83 Pagnani: Storia (cit. nota 80) pp. 33-46; id.: Storia di Sassoferrato dalle origini al 1900, seconda edizione migliorata e accresciuta, Sassoferrato 1959, p. 229-231; PENCO: Storia (cit. nota 23) p. 267.

84 Ne tesse gli elogi Iacobilli: Cronica (cit. nota 57) pp. 261-301; id.: Vite (cit. nota 40) vol. 3 pp. 366-368 (S. Croce di Sassoferrato).

85 Fondato agli inizi del sec. XI dai "domicelli del contado fabrianese", alla fine del secolo XII Clemente III si rivolse ai monaci di Fonte Avellana per la riforma del monastero ut reducatur in statum meliorem, Celestino Pierucci/Alberto Polverari: Carte di Fonte Avellana, vol. 2 (1144-1202), Roma 1977, p. 241 (Thesaurus ecclesiarum Italiae 9/2). Nel Trecento il monastero, da cui dipendevano quarantadue chiese e vari castelli, era di nuovo in decadenza, a motivo di abati indegni, per cui fu dato in commenda, Romualdo SAssi: Chiese dipendenti da monasteri benedettini nel contado fabrianese, in: Benedictina 4 (1950) pp. 87-131; ID.: Le carte del monastero di S. Vittore delle Chiuse sul Sentino, Milano 1962 (Deputazione di Storia Patria per le Marche, Studi e Testi 1). Il resto delle chiese sparse nel territorio fabrianese era spartito tra Valdicastro che possedeva quarantasette chiese, S. Croce dei Conti trentacinque, S. Elena quarantadue, cfr. Abbazie e castelli della Comunità Montana Alta Valle dell'Esino, a cura di Giancarlo Castagnari, Fabriano 1990, pp. 234, 322, 366, 416, 438.

86 Cfr. Jean-François Lemarignier: Le monachisme et l'encadrement religieux des campagnes du royaume de France, situées au nord de la Loire de la fin du $\mathrm{X}^{\mathrm{e}}$ à la fin du XI' siècle, in: Le istituzioni ecclesiastiche della 'Societas christiana' dei secoli XI e XII. Diocesi, pievi e parrocchie. Atti della sesta Settimana internazionale di studio, Milano 1974, Milano 1977, pp. 357-394. 
Altra realtà è il movimento dei cosiddetti eremiti neri, diffuso nei territori settentrionali del Patrimonium S. Petri, nella Marca anconitana, nella Toscana e nella Lombardia. Dopo il ricordato saggio di Kaspar Elm, ci sono state nuove acquisizioni su questi eremiti di vita mista i quali, istituzionalizzati con la regola sant'Agostino, confluirono in un solo ordine giuridico, quello degli eremitani di sant'Agostino: dagli eremitani della Tuscia, con le due congregazioni di Lucca e di Siena, cui è stato dedicato un recente convegno tenutosi a Siena ${ }^{87}$, all'Ordine di s. Guglielmo di Malavalle, nel grossetano ${ }^{88}$; dai frati eremiti di Brettino agli eremiti di fra Giovanni Bono, fino ai frati eremiti di s. Benedetto di Monte Favale $^{89}$. Studiato è anche l'Ordine di S. Benedetto di Montefano, uno dei frutti autunnali del movimento eremitico dovuto a s. Silvestro Guzzolini, canonico della cattedrale di Osimo il quale, verso il 1227, si ritirò a vita eremitica fra i dirupi della gola della Rossa, a Grottafucile, dove ben presto lo raggiunsero altri compagni, per condurvi una vita di povertà, austerità e semplicità ${ }^{90}$. Secondo un copione che durava da secoli, a dar inizio al patrimonio monastico fu il feudatario del posto, Corrado, signore di Rovellone il quale, il 29 maggio 1235, regalò donno Silvestro heremite, priori heremi de Focile, una chiesa posta in fundo Serralte presso Serra San Quirico ${ }^{91}$. Di lì a poco, abbandonato Grottafocile, il Guzzolini fondò altri eremi "scegliendo piuttosto luoghi solitari e deserti a preferenza della città", muovendosi così controcorrente, sia rispetto al movi-

87 Santità ed eremitismo nella Toscana meridionale. Atti delle giornate di studio $(11-12$ giugno 1999), a cura di Alessandra Gianni, Siena 2000.

88 Si rimanda inoltre a Benignus van LujJK: Gli eremiti neri nel Dugento, con particolare riguardo al territorio pisano e toscano. Origini, sviluppo ed unione, Pisa 1968 (Biblioteca del Bollettino Storico Pisano, Collana Storia 7). Per un quadro d'insieme, Luis Marín: La storia. Dalla morte di s. Agostino al 1244-1256, in: Gli agostiniani. Radici storia prospettive, a cura di Vittorio Grossi/ Luis Marín/ Gino Colini, Palermo 1993, pp. 69-188, ibid. pp. 116-125.

89 Su queste comunità eremitiche delle Marche d'obbligo il rimando al citato studio di Kaspar ELm: Italienische Eremitengemeinschaften, in: L'eremitismo in Occidente (cit. nota 6) pp. 491-559; inoltre, Réginald GrÉGOIRE: Eremitismo nella Marca d'Ancona: L'«Ordo» di Brettino e l'«Ordo Silvestri». Parallelismo o affinità?, in: Il monachesimo silvestrino nell'ambiente marchigiano del Duecento, Atti del Convegno di Studi, Fabriano 30 maggio 2 giugno 1990, a cura di Ugo Paoli, Fabriano 1993 (Bibliotheca Montisfani 22), pp. 179-190. Mario SENSI: Movimenti penitenziali nella Marca d'Ancona, ivi, pp. $151-178$. Si vedano anche le relative voci nel Dizionario degli Istituti di Perfezione.

90 Si rimanda ad, Aspetti e problemi del monachesimo nelle Marche, Atti del Convegno di studi tenuto a Fabriano, Monastero S. Silvestro abate 4-7 giugno 1981, voll. 2, Fabriano 1982, in particolare i saggi di Ugo PAOLI: La congregazione silvestrina nei secoli XIV$\mathrm{XV}$, pp. 575-741; inoltre ai citati Atti su Il monachesimo silvestrino nell'ambiente marchigiano del Duecento.

91 San Silvestro di Fabriano. Antiche pergamene, a cura di Ugo Paoli, Fabriano 1984, pp. $25-26$. 
mento eremitico, a lui contemporaneo, che andava un pò ovunque facendo una scelta urbana - i reclusi della città e del suburbio, di cui appresso - sia perché non intitolò all'arcangelo Michele né il suo primo eremo in grotta, né i successivi come avevano fatto molti degli eremiti irregolari, specie durante il secolo $\mathrm{XI}^{92}$, penitenti delle grotte che non seguivano nessuna delle regole approvate e sfuggivano al controllo della gerarchia ${ }^{93}$.

\section{3 - Eremitismo irregolare}

La catena degli Appennini dell'Italia centrale, grazie alla presenza di grotte, circondate da boschi e affiancate da rigogliose sorgenti, permetteva di ricreare spazi simili a quelli frequentati dai Padri del deserto con la rioccupazione, talvolta, di habitat rupestri ${ }^{94}$. Il che aveva favorito, a partire dai primi anni del secolo XI, la ripresa lungo questo territorio dell'eremitismo ${ }^{95}$. Ripresa, in quanto questa stagione dello Spirito, che interessò gran parte d'Europa, era stata preceduta, nella Provincia Valeria e nello Spoletino, da quel vasto movimento di monaci itineranti, provenienti dalla Siria, di cui scrive Gregorio Magno nei

92 Vita Silvestri, cap. 6 (trad. it. di Lorenzo SENA, in: Alle fonti della spiritualità Silvestrina, vol. 2: Vita di san Silvestro, beato Giovanni dal Bastone, beato Ugo san Bonfilio. Testo latino e versione italiana a cura di Ugo PAOLI, Fabriano 1991, p. 23 [Bibliotheca Montisfani 10]).

93 Costituiscono un capitolo a parte gli eremi dipendenti dalle fondazioni romualdine e da Vallombrosa, alcune con storie che meritano attenzione per i risvolti nella storia della pietà popolare. Da Vallombrosa, ad esempio, dipese fin dal secolo XII S. Maria dell'Eremita in Valnerina: l'eremo, che era posto lungo una via del pellegrinaggio, divenne un frequentato santuario mariano, con annesso ospizio. Di questo santuario, da cui proviene una statua lignea del sec. XIII, raffigurante una Madonna del latte, si fa menzione nello "Speculum Cerretanorum» di Teseo Pini (1485), con l'appellativo di "cenobio de Paterno", Piero CAmporesi: Il libro dei vagabondi: Lo «Speculum cerretanorum» di Teseo Pini, «Il Vagabondo» di Rafaele Frianoro e altri testi di «furfanteria», Torino 1973, p. 23 e 107; sul santuario, cfr. Ansano FabBr: Storia dei comuni della Valnerina, Abeto/Assisi 1976, pp. 423-425.

94 Mancano indagini su insediamenti rupestri tra Umbria e Marche. Parrebbe che uno degli 'habitat' rupestri umbri sopravvissuti in età medievale sia il paese di Grotti, in provincia di Perugia, lungo un declivio prospiciente il massiccio del monte Coscerno e del monte dell'Eremita in posizione dominante la Valnerina, le cui grotte continuarono ad essere a lungo frequentate nonostante la costruzione del sottostante castello, attestato dalla fine del sec. XI, cfr. Ubaldo Santi: Grotti e la sua storia, Spoleto 1977.

95 Sulle ragioni di questa scelta di solitudine riflette, G. Turbassi: La solitudine dell'asceta come espressione ideale della vocazione cristiana, in: Benedictina 8 (1954) pp. 43-55. Sull'eremitismo irregolare, F. Ferrero: Eremitismo individuale, in: Dizionario degli Istituti di Perfezione, vol. 3 col. 246; per i secoli XI-XII, cfr. Gregorio Penco: L'eremitismo irregolare in Italia nei secoli XI-XII, in: Benedictina 32 (1985) p. $201-$ 221. 
Dialogi $^{96}$. Su questo movimento si cominciò a riflettere, tra Umbria e Marche Umbria, già nei secoli XI-XII: il che diede luogo a una fioritura di leggende agiografiche - la più famosa è la Passio XII fratrum ${ }^{97}$ - e di santuari terapeutici, dedicati ad eremiti-evangelizzatori dell'Umbria, come S. Felice, in Val di $\mathrm{Narco}^{98}$. Altrettanto significativo il culto prestato verso eremiti venerati in regioni limitrofe: valga l'esempio di s. Senzias venerato a Blera e introdotto nella basilica di S. Concordio a Spoleto, facendone così un santo tutto spoletino ${ }^{99}$. Ritengo che sia la migrazione di questi culti, sia soprattutto il proliferare di santuari micaelici 'ad instar Gargani ${ }^{100}$ siano da mettere in relazione con il fenomeno della transumanza, che consiste nello spostamento stagionale delle greggi dai monti al piano e viceversa ${ }^{101}$. Nell'Italia centrale, in particolare tra

96 Gregorii Magni Dialogi libri IV, a cura di Umberto Moricca, Roma 1924; Réginald Grégolre: L'agiografia spoletina antica: tra storia e tipologia, in: Il Ducato di Spoleto, Atti del IX Congresso int. di studi sull'Alto Medioevo, Spoleto 27 settembre - 2 ottobre 1982, vol. 1, Spoleto 1983, pp. 335-365, qui 348sg.

97 Emore PAoli: I santi siri dell'Umbria e della Sabina, in: Agiografia e strategie politicoreligiose. Alcuni esempi da Gregorio Magno al Concilio di Trento, Spoleto 1997, pp. 3 50 (Biblioteca del Centro per il collegamento degli Studi Medievali e Umanistici in Umbria 19).

98 Eugenio Susi: La 'Vita beati Mauri Syri abbatis et Felicis eius filii apud Vallem Narci prope Naris ripam' del Codice Alessandrino 89, in: Hagiographica 2 (1995) pp. 93136; Mario SENsi: La preghiera di intercessione nelle tavolette votive. Lesempio di Spoleto, in: Dimensioni e problemi della ricerca storica, rivista del Dipartimento di studi storici dal Medioevo all'età contemporanea dell'Università 'La Sapienza' di Roma, $\left(2^{\circ}\right.$ semestre 1994), pp. 246-261.

99 Spoleto, Archivio del Duomo, Leggendario di S. Felice di Narco, I, Vita et obitus S. Sentie conf. et sociorum eius, ff. 216r-218v, ibid. f. 218 s (ff. 228r-230v) compilato sul finire del secolo XII, cfr. Baudouin DE GAIfFier: Les légendiers de Spolète, in: AnalBoll 74 (1956) pp. 313-348, ibid. p. 333; inoltre Silvestro Nessi: Il culto di s. Ponziano e dei patroni di Spoleto, in: Martiri ed evangelizzatori della Chiesa spoletina. Atti del primo convegno di studi storici ecclesiastici, Spoleto 1977, pp. 137-158; Aldo Angelo Settia: Le pievi della diocesi di Spoleto: dati e problemi, in: Il Ducato di Spoleto (cit. nota 96) pp. 367-396, qui pp. 371sg.

100 Santuari 'ad instar' sono quelli che, replicando le caratteristiche del prototipo, ne svolgono le stesse funzioni: da quelle sacrali che fanno del luogo una speciale dimora del titolare, fino a quelle terapeutiche, per cui sia il pellegrinaggio, come il ricorso al santuario 'ad instar' hanno la stessa valenza del pellegrinaggio al prototipo.

101 Il fenomeno è conosciuto dai Romani, che spostavano gli armenti dai monti dell'Appennino al piano, cfr. Emilio Gaввa: Sulle strutture agrarie dell'Italia romana fra III e I sec. A.C., in: Emilio GabBa/Marinella PAsQuinuCCI: Strutture agrarie e allevamento transumante nell' Italia romana, III-I sec. a.C., Pisa 1979, pp. 39-43, sembra che sia proseguito in età altomedievale, Emilio GABBA: La transumanza nell'Italia romana, evidenze e problemi, qualche prospettiva per l'età altomedievale, in: L'uomo di fronte al mondo animale nell'alto medioevo., vol. 1, Spoleto 1975 (Sett. cent. it.), pp. 378-387. Connesso a questo passaggio delle greggi è l'Istituto tardomedievale della dogana che, in cambio del libero passaggio, richiedeva il pagamento di una tassa. Si va 
Umbria e Marche, ancora alla fine del secolo XV il ricorso al santuario di Montesantangelo al Gargano era ancor vivo, come si evince da un sorprendente numero di pellegrinaggi vicari ${ }^{102}$. Sulle origini e sugli sviluppi del successo di questo culto siamo però scarsamente informati. Luogo di ierofanie dell'arcangelo Michele -divenuto da modesto santuario bizantino, il santuario nazionale dei Longobardi, grazie anche al favore di principi, come il duca Romualdo I (662-687) e di regine, come Ansa, la moglie di Desiderio (756-774), la quale, a beneficio dei pellegrini, costrù un ospizio -, indubbiamente ebbe grande risonanza il fatto che Ottone III, su consiglio di s. Romualdo, suo confessore, tra il febbraio-marzo 999 vi avesse compiuto, a piedi nudi, un pellegrinaggio espiatorio $^{103}$. Ma il grande flusso di pellegrini al santuario garganico probabilmente si ebbe solo qualche decennio più tardi, dopo la nuova consacrazione della chiesa, avvenuta nel $1021^{104}$. L'anno successivo [1022] vi pellegrinò Enrico $\mathrm{II}^{105}$. Papa Leone IX nel 1049, lo stesso anno in cui fu eletto papa, si recò al santuario causa orationis; quindi vi tornò altre due volte: nel 1050, in occasione del concilio riformatore, celebrato a Siponto e nell'anno successivo, insieme ad Alinardo di Liegi con cui stava progettando una 'guerra santa' contro i Normanni. Riferendosi a questa terza visita del pontefice, l'anonimo Autore del

dagli ordinamenti della mesta o meseta spagnola, istituita nel 1272 e alla quale - tra il 1443 e il 1447 - fu dato un assetto definitivo con la Regia Dogana per la Mena delle pecore in Puglia alla Dogana pecudum, istituita da Bonifacio IX nel 1402 (Dogana di Roma e Dogana del Patrimonio), fino alla dogana organizzata da Siena sin dal 1453, Luchino Franciosa: La transumanza nell'Appennino centro-meridionale, Napoli 1951; Jean-Claude Maire Vigueur: Les pâturages de l'Église et la douane du bétail dans la province du Patrimonio (XIV $-X^{\mathrm{e}}$ siècle), Roma 1981; R. Garbuglio: La transumanza umbro marchigiana nei secoli XV e XVI, in: Orientamenti di una regione attraverso i secoli, Gubbio 1976, Gubbio-Perugia 1978, pp. 139-147; Italo Palasciano: Le lunghe vie erbose, Lecce 1999.

102 Ho pubblicato una rassegna di questi testamenti in Pellegrinaggi a Montesantangelo al Gargano nei Notarili della Valle Spoletana sul calare del Medio Evo, in: Campania Sacra 8/9 (1977/78) pp. 81-120; Pellegrini dell'arcangelo Michele e santuari garganici 'ad instar' lungo la dorsale appenninica umbro-marchigiana, in: Compostella, Rivista de Centro italiano di studi compostellani, 27, gennaio-dicembre 2000 (ma Pistoia, settembre 2001) pp. 19-50; Santuari micaelici e primordi del francescanesimo, in: Collectanea Franciscana 72 (2002) pp. 5-104; Santuari, pellegrini, eremiti nell'Italia centrale, Spoleto 2003 (Uomini e mondi medievali 6), pp. 65-166.

103 Cfr. Vita beati Romualdi (cit. nota 18) cap. 25 p. 53: penitentie causa nudis pedibus de Romana urbe progrediens, sic usque Garganum montem ad sancti Michaëlis perrexit aecclesiam; inoltre Jean-Marie SANSTERrE: Otton III et les saints ascètes de son temps, in: RSCI 43 (1989) pp. 377-412, sp. 390sg.

104 Ekkehardi Uraugiensis cronica, ed. Georg WaITz, in: MGH SS 6, Hannover 1844, pp. $1-267$, ad annum (1021), p. 194.

105 La notizia è inserita in un tardo 'additamentum' della Vita di Enrico scritta da Adalberto, Vitae S. Heinrici additamentum, ed. Georg WAITz, in: MGH SS 4, Hannover 1841, pp. $816-820$, p. 818 . 
Chronicon di S. Benigno di Digione ebbe a sottolineare - come scrive il Petrucci - "il nesso esistente fra i pellegrinaggi meridionali di Leone IX e la sua progettata "guerra santa": egli voleva infatti avvalersi del culto micaelico, particolarmente sentito da bizantini e longobardi, per favorire l'ideale della riforma della Chiesa nel mezzogiorno d'Italia" 106.

I risvolti più significativi di questa 'impennata' del culto micaelico furono i pellegrinaggi a Montesantangelo, cioè al santuario prototipo ${ }^{107}$ e l'erezione di santuari 'ad instar', con trasferimento di reliquie, come a Mont-Saint-Michel au péril de la mer, in Normandia ${ }^{108}$. Ma, nella stragrande maggioranza dei casi, il trasferimento della sacralità avvenne con la semplice ricostruzione su modello del santuario pugliese. Ora a partire dal secolo XI, tra Umbria e Marche, due regioni limitrofe che hanno in comune ubertosi pascoli alpestri, videro, in prossimità di questi, una larga diffusione di luoghi di culto dedicati all'arcangelo Michele. Alcuni - una minoranza- sono sopravvissuti fino ai nostri giorni, ma quasi tutti ridedicati; mentre la maggior parte sono solo attestati dagli elenchi delle chiese e dagli agiotoponimi. Custoditi da eremiti, variegato fu il loro esito istituzionale: alcuni diedero vita a monasteri, per lo più Eigenkloster; altri rimasero semplici santuari, a lungo custoditi da uno o più eremiti.

$\mathrm{Su}$ questo fenomeno di lunga durata, presente in tutta l'area appenninica - e non solo - indubbiamente legato allo spostamento stagionale degli armenti - le due feste micaeliche 8 maggio e 29 settembre segnavano l'inizio e la fine dell'alpeggio - si è cominciato a riflettere da qualche anno in qua, mettendo l'accento sulla cultura pastorale, legata a doppio filo con questo culto ${ }^{109}$; sugli

106 A. Petrucci: Aspetti del culto e del pellegrinaggio di S. Michele sul monte Garagano, in: Pellegrinaggi e culto dei santi in Europa fino alla $I^{a}$ crociata. Atti del IV Convegno del Centro di studi sulla spiritualità medievale. Todi, 8-11 ottobre 1961, Todi 1963, pp. 145-180: 173.

107 Giorgio Otranto: Il pellegrinaggio micaelico dal Gargano all'Europa, in: «Munera amicitiae». Studi di storia e cultura sulla Tarda Antichità offerti a Salvatore Pricoco, a cura di Rossana Barcellona/Teresa Sardella, Soveria Mannelli 2003, pp. 329-360.

108 L'erezione di questo santuario va messa in relazione con il crescendo di pellegrini che, fra VIII e X secolo, giungevano d'oltralpe alla grotta del Gargano. Il racconto di fondazione è contenuto nella Revelatio seu apparitio s. Michaëlis Archangeli in partibus occiduis, hoc est in monte Tumba in Gallia, scripta ... ancte saec. X, in: Jean Mabillon: Annales ordinis sancti Benedicti saec. III, p.1, Paris 1672, pp.84-88, ma ora si veda AA. VV., Les sources: textes et traductions, in: Culte et pèlerinages à saint Michel en occident. Les trois monts dédiés à l'Archange, a cura di Pierre Bouet/Giorgio Otranto/André Vauchez, Roma 2003 (Collection de l'École Française de Rome 316), pp. 1-41, ibidem, 10-26. In questi stessi Atti i temi connessi a questo e ad altri santuari 'ad instar'.

109 Relativamente alla Puglia si veda Giovanni Battista BRonzins: Transumanza e religione popolare, in La cultura della transumanza, Atti del Convengo promosso dal Comune di Santa Croce del Sannio ... 12-13 novembre 1988, Napoli 1991, pp. 111-131, qui p. 114; Religiosità e territorio nell'Appennino dei tratturi, a cura di Ernesto Narciso, Atti del VII Convegno di studi, Istituto storico "Giuseppe Maria Galanti”, 20-21 agosto 
insediamenti ispirati al modello garganico, appunto $i$ santuari ad instar Gargani $^{110}$; o sulle loro peculiarità, una grotta naturale, con acqua sorgiva o stillante cui vengono attribuite particolari virtù terapeutiche ${ }^{111}$, o sul fatto che sorgessero su terra pubblica, appunto su terre fiscali ${ }^{112}$. In questi santuari in grotta, per lo più rupestri, si venerava non solo il terapeuta, ma anche il difensore nella lotta contro le insidie del diavolo - il quale appunto si aggira nei luoghi deserti - e il protettore delle anime nel terribile giudizio. Quivi si insediò una categoria di eremiti su cui ebbe a prestare attenzione Étienne Delaruelle ${ }^{113}$. Si tratta di eremiti senza fondatore, non legati ad alcuna delle regole approvate e senza rapporti con istituti monastici, o canonicali, i quali riscoprirono in san Michele il grande patrono dei combattenti contro il demonio; da qui l'invocazione, sancte Michaël arcangele defende nos in praelio contra nequitias diaboli; ut non pereamus in tremendo iudicio ${ }^{114}$. Le prime avvisaglie di questo fenomeno sembrano legate a un movimento millenaristico che spinse uomini e donne a fuggire dalle città, per rifugiarsi nelle spelonche e fra le rocce dei monti,

1996, S. Croce del Sannio 1997. Mentre, riflettendo sulla realtà umbro marchigiana, Egildo Spada, sulla scorta del catalogo delle chiese dedicate all'Arcangelo, redatto da Sandro Ceccaroni (Il culto di S. Michele Arcangelo nella religiosità medievale del territorio spoletino, in: Quaderni di "Spoletium" 6, Spoleto 1993, pp. 15-90), preso atto come nella diocesi spoletina il culto micaelico si diffuse fin dall'alto medioevo in prossimità di fonti e sorgenti "corrispondenti alla prerogativa risanatrice e a quella di protettore delle greggi e dei raccolti", così prosegue: "sono le chiese isolate che più interessano la presente ricerca, perché legano la figura dell'Arcangelo alle attività agricolepastorali”, segnalando alcune chiese che però non sembra abbiano svolto la funzione di santuari micaelici 'ad instar', E. SpADA: La transumanza. Transumanza e allevamento stanziale nell'Umbria sud orientale, in: Quaderni del CEDRAV 2, Cerreto di Spoleto 2002, pp. $124-129$.

110 Appena quarantuno i santuari micaelici censiti sotto "Dedicazione angelo", nel sito, http://www.santuaricristiani.iccd.beniculturali.it/ (28.11.2007); per l'Italia centro meridionale figurano però solo la Madonna del Riparo a Foligno, San Galgano (a Chiusino), S. Michele sul Monte Tancia, S. Michele arcangelo di Liscia, S. Angelo di Civitella del Tronto. Mentre la stragrande maggioranza di questi santuari 'ad instar' è assente, essendo stati dismessi sulla fine del medioevo, o ridedicati, in genere alla Madonna (è il caso dell'appena citata Madonna del Riparo a Foligno), ma anche a santi terapeuti (Sant'Eustachio di Domora, presso San Severino Marche, ma nel secolo XI monasterium sancti Michaëlis quod vocatur de Domora, cfr. infra).

$111 \mathrm{Su}$ queste due peculiarità del santuario garganico, cfr. Giorgio Otranto: Genesi, caratteri e diffusione del culto micaelico del Gargano, in: Culte et pèlerinages (cit. nota 108) pp. 43-64, qui pp. 49-56.

112 Eugenio Susi: San Michele nel territorio del Ducato spoletino nell'alto medioevo, in: Culte et pèlerinages (cit. nota 108) pp. 105-138, ibid. 118sg.

113 Étienne Delaruelle: Les ermites et la spiritualité populaire, in: L'eremitismo in Occidente (cit. nota 6) pp. 212-241, ibidem, 234-235, nota 102 (riedito in ID.: La piété populaire au Moyen âge, Torino 1975).

114 Cfr. il versetto dell'Alleluia, nella Messa dei defunti; inoltre Delaruelle: Piété (cit. nota 113) pp. 125-154 (Les ermites et la spiritualité populaire), ibidem $147 \mathrm{sg}$. 
in attesa della fine dei tempi. Proprio quando, per dirla con Rodolfo il Glabro, "la terra, come scrollandosi e liberandosi della vecchiaia, pareva si rivestisse tutta di un candido manto di chiese" - una santa emulazione, alla quale non vollero sottrarsi neppure " $i$ piccoli oratori di campagna" presero a fuggire dagli uomini per rifugiarsi nelle spelonche e fra le rocce dei monti: ebbero così origine gli 'eremiti dell'Apocalisse" ${ }^{116}$, degli oranti i quali avevano scelto, per dimora, ripari di fortuna, appunto delle grotte naturali: heremiti in vilibus locis pro Dei amore morantes et pro Ecclesia ne deficiat orantes $^{117}$, riprendendo il modello orientale di s. Daniele lo Stilita $(\dagger 493)^{118}$.

Questi eremiti vanno distinti dai movimenti rivoluzionari di ispirazione più o meno escatologica di fine secolo $\mathrm{XI}^{119}$. Grazie alla preghiera e alla testimonianza di vita, questi "eremiti dell'Apocalisse" diedero un contributo fattivo alla riforma della Chiesa non solo con la preghiera, ma anche con una singolare azione pastorale: loro campo d'azione non fu la città, né i villaggi sparsi nelle campagne, ma i pastori, gente cui nessuno fino ad allora aveva portato il Vangelo. Siamo tuttavia scarsamente informati sul loro numero effettivo, come sulla loro dislocazione. Ritengo che la traccia da seguire siano i santuari micaelici di altura, oggetto però solo da un decennio in qua di studi a diversi livelli. Laddove si crearono comunità eremitiche, alcune entrarono a far parte della strategia insediativa di potenti abbazie: così mentre il Monastero di Farfa ebbe dai duchi di Spoleto S. Michele sul Monte Tancia, in Sabina ${ }^{120}$; i

115 Rodolfo il Glabro, Cronache dell'anno Mille (Storie), a cura di Guglielmo Cavallo/ Giovanni Orlandi, Milano 1989, p. 133.

116 Si legge infatti nel libro dell'Apocalisse: "il cielo si ritirò come un volume arrotolato e ogni montagna e isola furono smosse dai loro posti. Re della terra, magnati e capitani, ricchi e potenti, schiavi e liberi si nascosero nelle spelonche e nelle rocce dei monti. E dissero ai monti e alle rocce: cadete su noi e nascondetici dalla faccia di colui che siede sul trono e dall'ira dell'Agnello; perché è venuto il giorno della loro ira. Chi mai può stare in piedi?" (Apoc 6, 14-17).

117 Il testo, tratto da un commentario dell'Apocalisse proveniente dall'abbazia cistercense di Fiastra (Biblioteca Apostolica Vaticana, Vat. Lat. 134 XII, 3/3, ff. 71r-110v), è riferito da Guy Lobrichon: Erémitisme et solitude, in: Monteluco e i monti sacri. Atti dell'incontro di studio, Spoleto, 30 settembre - 2 ottobre 1993, Spoleto 1995 (Centro Italiano di Studi sull'alto medioevo, Miscellanea 8), pp. 125-148, ibid. p. 140 n. 34; lo stesso che dà al paragrafo il titolo di «eremiti dell'Apocalisse», ibid. 138sg.

118 Cfr. Victor SAXER: Jalons pour servir à l'histoire du culte de l'archange saint Michael en Orient jusqu'à l'iconoclasme, in: Noscere Sancta, Miscellanea in memoria di Agostino Amore, vol. 1, Roma 1985, pp. 357-426, qui pp. 404-407.

119 Norman Cohn, trattando di "nuove masse alla ricerca del Millennio", scrive che "non sembrano esserci prove di una loro presenza prima degli ultimi anni dell'XI secolo", Norman Cohn: I fanatici dell'Apocalisse, Vicenza, Edizione di Comunità 1965 (1975, seconda edizione), p. 44.

120 La leggenda di fondazione di S. Michele sul Monte Tancia in BHL 5947. Sul santuario, M. G. Mara: Contributo allo studio del culto di s. Michele nel Lazio, in: ASRSP 83 
monaci dell'abbazia imperiale di S. Salvatore Maggiore di Rieti gestirono il santuario micaelico di Morro Reatino, oggi Scoglio di S. Michele, sui Monti reatini - tuttora attivo - S. Angelo ad pontem fractum e S. Angelo di Voltorino $^{121}$. Quest'ultimo, santuario -al pari degli altri- in grotta e di iuspatronato dei Signori di Macchia, ebbe una singolare vicenda perché, nel 1234, da monastero manuale divenne archicenobio, immeditamente soggetto alla Sede Apostolica e gli eremiti custodi della grotta micaelica - oggi in completo abbandono - ebbero l'appellativo ufficiale di "eremiti benedettini" 122 .

Altre comunità eremitiche furono sottoposte a fondazioni romualdine di indirizzo eremitico, come Sant'Angelo de Gruttis, nel territorio di Foligno ${ }^{123}$;

(1960) pp. 269-290, qui pp. 271sg.; Maria-Aleksandra Radozycka-Paolettr: Sulle origini del santuario di S. Michele sul Monte Tancia, in: AnalBoll 106 (1988) pp. 99111; Immacolata Aulisa: Le fonti e la datazione della 'Revelatio seu apparitio S. Michaëlis Archangeli in monte Tancia', in: Vetera Christianorum 31 (1994) pp. 315331.

121 Sull'abbazia di S. Salvatore Maggiore, IP 4 pp. 24-26. La bibliografia è da aggiornare con Ildefonso Schuster: Il monastero del Salvatore e gli antichi possedimenti farfensi nella Massa Torana, in: ASRSP 41 (1918), pp. 5-58; G. Chiari/C. De Polis: L'abbazia di S. Salvatore Maggiore, in: Tra le abbazie del Lazio, a cura di Renato Lefevre, Roma 1987 (Lunario romano 17), pp. 111-126; L'abbazia di S. Salvatore Maggiore e la massa Torana, a cura di G. Maceroni/A. M. TAssi, Concerviano 1990, ristampa - con aggiunte - di P. Desanctis: Notizie storiche del monastero di S. Salvatore e del seminario di Rieti, Rieti 1884, e di Ildefonso Schuster, Il monastero imperiale del Salvatore sul Monte Laterano, in: ASRSP 37 (1914) pp.391-451; AA. VV., Monasticon Italiae, vol. 1: Roma e Lazio, Cesena 1981, pp. 138-139, n. 95; Eugenio Susi: San Michele nel territorio del Ducato spoletino nell'alto medioevo, in: Culte et pèlerinages (cit. nota 108) p. 121.

$122 \mathrm{Su}$ questo archicenobio di cui - grazie agli Olivetani, ultimi possessori -, ci è pervenuto un discreto archivio, cfr. R. Giorni: La grotta di S. Angelo e l'ordine eremitico di S. Benedetto, Ascoli 1963; inoltre G. Fabiani: Monaci eremiti, incarcerati, reclusi in Ascoli nei secoli XIII e XIV, in: Studia Picena 32 (1964) pp. 152-156; V. Di Flavio: Amatrice, S. Croce (eremiti di S. Benedetto dipend. di S. Angelo in Voltorino), in: Monasticon Italiae (cit. nota 121) p. 119; Mario SENSI: Storie di bizzoche tra Umbria e Marche, Roma 1995 (Storia e Letteratura, Raccolta di Studi e Testi 192), pp. 163-207.

123 Lo Iacobilli afferma che a fondare, intorno al 1050, S. Angelo 'de Gructis' fu il conte Offredo di Monaldo il quale vi introdusse una comunità di eremiti, Lodovico IACOBILLI: Degli Angeli, de benefitii che fanno agli huomini, dell'opere, e devotioni che piacciono ad essi e de' beni e gloria che godono in cielo detti angeli e tutte l'anime beate, Foligno 1663, p. 246; lo stesso, nella Cronaca di Sassovivo, afferma che il patrono unì l'eremo " l'anno 1063 al monastero di S. Salvatore di Acquapagana, diocesi di Spoleto, membro dell'abbatia di s. Romualdo della valle di Castro, nella diocesi di Camerino", IACOBILLI: Cronica (cit. nota 57) p. 72; iD.: Vite (cit. nota 40) vol. 3 p. 359. Lo iuspatronato su questo santuario in grotta -singolarmente integro e ancor oggi attivo, seppure ridedicato alla Madonna-, è rimasto fino all'età moderna ai discendenti dei conti di Turri, vedi M. Faloci Pulignani, Foligno e la Madonna, a cura di L. Sensi, Foligno 2006, pp. 124132 [ristampa dell'articolo La Madonna del Riparo, uscito in: Gazzetta di Foligno VI, n. 41 (10.10.1891), p. 2]; Mario SENSI: Vita di pietà e vita civile di un altopiano tra 
altre furono istituzionalizzate con regola benedettina, come S. Michele di Domora, poi reintitolato a S. Eustachio, in diocesi di Camerino ${ }^{124}$; o con regola canonicale, come S. Angelo di Ninfa, poi S. Maria di Monte Mirteto super Nympham ${ }^{125}$, o S. Angelo de Prefolio, in territorio di Camerino, oggi "I Santi”" ${ }^{\prime 26}$.

Dalla toponomastica, come dai vari elenchi di chiese di età medievale si evince che il movimento eremitico, a partire dal secolo XI interessò Toscana,

Umbria e Marche (secc. XI-XVI), Roma 1984 (Storia e Letteratura, Raccolta di Studi e Testi 159), p. 226, 304-307.

124 Il più antico documento papale pervenuto risale al 1194: è una conferma di Celestino III fatta a Rinaldo abate 'de Domora' dei privilegi e delle immunità (cfr. IP 4 pp. 132sg.); ma le origini del monastero risalgono al sec. XI (la più antica menzione è del 1086). Nel 1119 Lorenzo, vescovo di Camerino, cedette in enfiteusi al marchese Warnerio e a sua moglie contessa Altruda il castello di S. Severino e alcune chiese, fra cui "monasterium de Domora cum omnibus sibi ubique pertinentibus". I patroni si assunsero l'obbligo di dare annualmente al vescovo di Camerino, "in signum recognitionis", un bisanzio nel giorno dell'Assunta. Quindi, nel 1171, il vescovo Acceptabilis, donò a Pietro, abate "in cenobio S. Michaëlis Archangeli, quod est edificatum in loco, qui dicitur Domorum", la pieve di S. Zenone, cfr. O. Turchi: De ecclesiae Camerinensis pontificibus Libri VI, vol. 1, Praecedit eiusdem auctoris de Civitate et Ecclesia Camerinensi Dissertatio, Roma 1767, p. 179; vol. 2, Appendix documentorum, Roma 1767, XXV-XXVI, doc. VIIII; XXVIII, doc. XIII. Nel 1294 il santuario micaelico fu reintitolato a sant'Eustachio martire; mentre, in data imprecisata, i monaci si erano trasferiti a San Severino Marche, nel monastero di S. Nicolò, posto poco fuori le mura della città. Il santuario restò tuttavia attivo fino al secolo XIX, teste il conte Severino Servanzi Collio. Attualmente la chiesa romanica, in parte ricavata dalla roccia e affiancata da grotte eremitiche, è in stato di grave degrado, cfr. S. Servanzi Collio: Notizie storiche intorno al monastero di S. Michele o S. Eustachio di Domora presso la città di San Severino e descrizione di un breviario quivi adoperato fin dal secolo XIII, San Severino Marche 1884, pp. 9, 13, 1521; B. Feliciangeli/R. Romani: Di alcune chiese rurali della diocesi di Camerino, in: Atti e Memorie, Deputazione di storia patria per le province delle Marche, s. (II), v. IV, fasc. III, (1907), p. 309; O. Ruggeri: Carte perdute delle abbazie unite di San Severino, in: Miscellanea Septempedana 3 (1982) pp. 157-162; R. Ranciano: La gola di Sant'Eustachio, aspetti naturalistici e storici, Sanseverino Marche 1998.

125 Su questo santuario micaelico, sottratto da Gregorio IX a una comunità canonicale che lo gestiva per affidarlo ai monaci della congregazione florense che vi costruirono sopra una chiesa dedicata alla Vergine, lasciando così che il precedente culto micaelico si esaurisse spontaneamente, M. CASSONi: La badia ninfana di San'Angelo o del Monte Mirteto nei Volsci fondata da Gregorio IX, in: Rivista Storica Benedettina 14 (1923) pp. 170-189, 252-263; 15 (1924) pp. 51-77; Lydie Hadermann-Misguich: Images de Ninfa. Peintures médiévales dans une ville ruinée du Latium, preface par Paul Рнгціррот, Roma 1986, pp. 32sg., 93sg.

126 Fondato dai i domini del Prefoglio, castello dirimpettaio, questo santuario in grotta è ancor oggi attivo, ancorché ridedicato a "I Santi" ed è meta di un pellegrinaggio annuale il martedì di pasqua, cfr. Milziade Santoni: La cripta di S. Angelo di Prefoglio nell'archiocesi di Camerino e le sue memorie, Camerino 1892; Sensi: Vita (cit. nota 123) p. 286sg.; Angelo A. Bittarelli: Itinerario storico artistico, in: AA. VV. Pieve Torina, Recanati 1979, pp. 171-254, qui pp. 174-179. 
Umbria, Marche, Lazio e Abruzzi in maniera così capillare da non esserci centro demico di una certa consistenza senza il riferimento di uno o più eremi. Ma mentre la lista degli eremi, come dei santuari micaelici in grotta si va - tessera dopo tessera - lentamente ampliando -in votis una Italia eremitica - sono invece decisamente modesti i risultati a seguito gli scavi archivistici sugli eremiti 'irregolari' che diedero l'avvio a questa singolare stagione dello Spirito. Uno dei pochi ad essere stato biografato è sant'Amico il quale, dopo un lungo periodo di eremitismo indipendente condotto, come recluso, in una grotta micaelica ai confini tra Abruzzo e Marche, morì tra il 1040 e il 1050, a S. Pietro di Avellana, una delle due fondazioni legate a s. Domenico di Foligno e passate all'abbazia di Montecassino $^{127}$.

Non si può non accennare a un altro fenomeno, quello che, sempre a partire dal secolo XI, diede vita a delle laure, tra di loro collegate da una catena di eremi: un movimento cui aderirono non solo uomini, ma anche donne; valga l'esempio della comunità femminile di Fabriano che cedette il proprio convento eremitico a s. Romualdo ${ }^{128}$. Uno dei campioni di questo movimento è santa Caledonia, eremita nella Valle dell'Alto Aniene in quel di Tivoli ${ }^{129}$, una laura che gode di una propria letteratura ${ }^{130}$, per non dire delle laure umbre del Monteluco sopra Spoleto ${ }^{131}$, di Serrasanta sopra Gualdo Tadino ${ }^{132}$ e delle

127 Questo monastero era stato fondato da s. Domenico intorno al 1025, su richiesta del nobile Borrello, «Vita prima S. Amici» (BHL, 388, seconda metà del secolo XI), ed. Carolus de Smedt: Acta Sanctorum, Novembris, vol. 2, Bruxelles 1894, pp. 92-99; cfr. inoltre Bernardo Cignitti: Amico di Avellana, in: Bib. SS 1 (1861) coll. 1006sg.; SANSTERre: Recerches (cit. nota 39) pp. 79sg. Lo Iacobilli individua la grotta, dove s. Amico visse ora solo, ora in compagnia di qualche discepolo, in S. Angelo de Criptis, un santuario micaelico presso Ripa di Salino, a destra della Vibrata e in territorio di Civitella del Tronto (Abruzzo), Iacobilli: Vite (cit. nota 40) vol. 3 pp. 6-12. Su questo santuario micaelico, di recente ripristinato al culto, mi permetto di rimandare al mio Santa Maria di Montesanto, un monastero benedettino di frontiera tra Regno di Napoli e Stato Pontificio, San Benedetto del Tronto 1996, pp. 50-68.

128 Hic itaque locus Vallis de Castro antiquitus vocabatur, ubi iam parva erat aecclesia, in qua conversarum quarundam mulierum videbatur esse conventus. His itaque loco cedentibus, constructis cellulis illic habitare cum suis discipulis vir venerabilis coepit, Vita beati Romualdi (cit. nota 18) cap. 35, p. 74.

129 Sofia Boesch Gajano: Terreurs et tourments. Formes d'érémitisme en Italie centrale entre le XII ${ }^{e}$ et le XIII ${ }^{e}$ siècle, in: Médiévales: langue textes histoire 28 (1995), pp. 11 23.

130 F. CARAFFA: L'eremistismo nella Valle dell'alto Aniene dalle origini al secolo XIX, in: Miscellanea Antonio Piolanti, vol. 2 , Roma 1964, pp. 223-237.

131 Dopo il lavoro di sintesi di Giuseppe Chiarettr : Eremiti del Monteluco, in: Dizionario degli Istituti di Perfezione 3 (1976) coll. 1167-1175, si è tornati sul tema in Monteluco e $i$ monti sacri. Atti dell'incontro di studio, Spoleto, 30 settembre - 2 ottobre 1993, Spoleto 1994 (in particolare gli interventi di Letizia PANi Ermini: All'Origine degli insediamenti eremitici e monastici sul Monteluco, pp. 149-169; Mario Sensi: 
montagne eremitiche che fanno corona a Gubbio ${ }^{133}$. Non meno importanti le comunità eremitiche che, tra XII e XV secolo, si insediarono sulle Montagne circostanti Ascoli Piceno ${ }^{134}$. Per non dire delle piccole laure di reclusi, presenti lungo tutta la Valle spoletana, ma rimaste celebri solo le Carceri del Subasio, sopra Assisi, dove per qualche tempo si ritirò s. Francesco d'Assisi ${ }^{135}$. Il fenomeno proseguì anche nei secoli XIII e XIV: si pensi all'esperienza di santa Sperandia di Cingoli $(\dagger 1262)^{136}$, o all'”alveare umano" di S. Croce in Val di Noce (già S. Benedetto 'in foribus'), non lungi da Cascia, un insediamento, dove ancora si intravedono una decina di grotte eremitiche incastonate lungo la

Movimento eremitico femminile nel Monteluco, pp. 195-272; Giulia BArone: Monteluco e i francescani, 273-286; Emore PAOLI: Questioni di agiografia montelucana, pp. 287-317).

132 Sul movimento eremitico di Serrasanta, Ruggero Guerrieri: Storia civile ed ecclesiastica del comune di Gualdo Tadino, Gubbio 1933, pp. 17-18; 287-300; André Vauchez: Ordini mendicanti e società italiana, XIII-XV secolo, Milano 1990, pp, 274-305 (= Frati minori, eremitismo e santità laica: Le «Vite» dei santi Maio 8 m. 1270 ca) e Marzio (m. 1301) di Gualdo Tadino); inoltre Mario SENSI: Le osservanze francescane nell'Italia centrale (secoli XIX-XV), Roma 1985, pp. 75-135.

133 In attesa di uno studio d'insieme sul movimento eremitico a Gubbio si rimanda a Mauro SARTr: De episcopis eugubinis, Pesaro 1755, p. 185sg., 191sg.; Pio Cencr: Costituzioni sinodali della diocesi di Gubbio dei secoli XIV-XV, in: Archivio per la storia eccl. dell'Umbria 1 (1913) pp. 286-379, qui pp. 339-341, 364; U. PArIs: S. Francesco, i francescani e la città di Gubbio, Assisi 1941, pp. 82-86, 201-207.

134 Sugli eremiti delle montagne circostanti Ascoli sono tornato in: Dagli eremiti benedettini al movimento fraticelliano ad Ascoli, in: Gli ordini mendicanti nel Piceno, vol. 1: I francescani dalle origini alla controriforma, Atti del corso del piano provinciale di aggiornamento per docenti e dirigenti delle scuole elementari e delle medie inferiori e superiori, Ascoli Piceno 2002-2003, a cura di Giannino Gagliardi, Ascoli 2005, pp. $87-111$.

135 Carcere è sinonimo di eremo, è quanto tra l'altro si evince dal "lodo di frate Elia", un arbitrato letto e pubblicato nel 1237 ad Assisi, nel palazzo episcopale: heremum sive carcerem sancti Francisci, Marcella Gatтi: Le carceri di san Francesco del Subasio, Assisi 1969, p. 21. Per uno sguardo di sintesi su questi insediamenti eremitici rimando al mio, Osservanze francescane (cit. nota 132) pp. 140-146; inoltre ID.: Comunità di penitenti francescani nella Valle Spoletana, dai primi gruppi spontanei al tentativo di centralizzazione, in Prime manifestazioni di vita comunitaria maschili e femminili nel movimento francescano della penitenza (1215-1447), in: Analecta TOR 16/135 (1982) pp. 481 505.

136 Cenni di questa esperienza fatta, non solo a Sasso Citona - tra Cingoli e San Severino, dirimpetto al santuario micaelico di S. Angelo delle Grotte, dove nel 1526 trovò rifugio Matteo da Bascio, l'iniziatore del movimento dei Cappuccini- ma anche in altre località umbre si hanno nella Vita, di cui si ha una recente edizione, cfr. Marco Paggiossi: Santa Sperandia. Testo e fortuna dell' «Antica Vita latina», Ancona 2001, p. 32 n. 5, 33 n. 8, p. 38 nn. 21-23, p. 48 n. 64. Vedi, inoltre, Santità femminile nel Duecento. Sperandia patrona di Cingoli, Atti del Convegno di studi, Cingoli 23-24 ottobre 1999, a cura di Giuseppe Avarucci, Ancona 2001, sp. 194-199. 
parete rocciosa e raggiungibili solo mediante corde: quivi, nel 1308, si ritirarono eremiti agostiniani svincolati dalla Magna Unio ${ }^{137}$.

Questo movimento eremitico, pur legato agli stessi eremi, tra la fine del secolo XII e gli inizi del successivo aveva dato però origine a un'altra stagione dello Spirito: un movimento cui, oltralpe, fu dato il nome di begardi/beghine, mentre nell'Italia centrale ebbe gli appellativi di bizzochi/bizzoche, incarcerati/ incarcerate ${ }^{138}$. Distinto dal movimento eremitico dei boschi, in quanto $i$ penitenti avevano abbandonato l'aspra solitudine per trasferirsi nel pomerio, questi penitenti erano riusciti ad infrangere la barriera tra chierici, monaci e laici, dimostrando come dette istituzioni potevano essere aggirate da uno stadio intermedio, né monaci, né laici, ma penitenti. Così, accanto al movimento eremitico di tipo monastico o canonicale, ci fu un movimento penitenziale, autonomo rispetto alle contemporanee istituzioni claustrali, da collegare invece a quel remoto movimento penitenziale dei primi secoli che aveva dato vita all' 'Ordo conversorum et conversarum» e che era stato oggetto di un'apposita legislazione ecclesiastica ${ }^{139}$. A queste comunità "semireligiose" - fenomeno

137 Questo insediamento eremitico detto di S. Croce in Vallecroce, dove ancora si intravedono una decina di grotte eremitiche - "alveare umano" le definisce Morini -, incastonate lungo la parete rocciosa e raggiungibili solo mediante corde, era di pertinenza dell'abbazia di S. Pietro in Valle e, da questa, passò sotto Bonifacio VIII, alla Basilica lateranense che, tramite l'arciprete, il 24 marzo 1308 autorizzò Giovanni da Norcia e Andrea da Cascia a condurvi vita eremitica dietro un censo annuo di un denaro da versare al rettore 'pro tempore' dell'abbazia di s. Benedetto in Valle. La chiesa, con affreschi a partire dal 1416, da secoli svolge il ruolo di santuario, detto della Madonna della Stella, cfr. Adolfo Morini: Il santuario della Madonna della Stella presso Cascia, già eremo agostiniano di S. Croce, Firenze 1933 (Monografie storiche Agostiniane 32), pp. 2-3; Ansano Fabbi: Storia e arte nel Comune di Cascia, Spoleto 1975, pp. $380-$ 383; Vittorio Giorgettil Omero Sabatini/ Sabatino di Lodovico: L'Ordine agostiniano a Cascia. Nuovi dati storici sulla vita di santa Rita e di altri illustri agostiniani. Ricerca storica su fonti ignote, inedite e sottoutilizzate, Perugia 2000, pp. $46-54$.

138 Sul movimento dei reclusi o incarcerati, che Gregorio Penco giustamente definisce "caratteristica forma di libero eremitismo maschile e femminile, insediato nel suburbio, in remota relazione con la regola di san Benedetto", PeNco: Storia (cit. nota 23) p. 268, manca uno studio d'insieme. Scarne le ricerche sul movimento al maschile; più numerose quelle al femminile, per le quali si veda, Romana Guarnieri: Donne e Chiesa tra mistica e istituzione (secoli XIII-XV), Roma 2004; Anna Benvenuti PAPI: «In castro poenitentiae». Santità e società femminile nell'Italia medievale, Roma 1990 (Italia Sacra 45); Giovanna Casagrande: Religiosità penitenziale e città al tempo dei Comuni, Roma 1995 (Bibliotheca Seraphico-capuccina 48); Sensi: Storie di (cit. nota 122) pp. 3-29 e passim; ID.: La scelta topotetica delle penitenti fra Due e Trecento nell'Italia centrale, in: Collectanea franciscana 68 (1998) pp. 245-275.

139 D'obbligo il rimando a Gilles Gerard MeErsseman/E. Adda: Pénitents ruraux communitaires en Italie au XII siécle, in: RHE 49 (1954) pp. 343-390 (ora in trad. it. in: Gilles Gerard Meerssemann: Ordo fraternitatis: Confraternite e pietà dei laici nel 
iniziato nell'ultimo quarto del secolo XII e fino alla metà del secolo successivo praticamente rimasto immune dall'eresia ${ }^{140}$ - guardarono inizialmente, con un certo fascino, s. Francesco d'Assisi e la stessa s. Chiara, per poi subito prendere le distanze: Francesco e i suoi primi compagni, dagli eremiti del Monteluco ${ }^{141}$; Chiara e sua sorella Agnese dalle custodi del santuario micaelico di Panzo ${ }^{142}$.

medioevo, in collaborazione con Gian Piero PAcini, vol. 1, Roma 1977 [Italia sacra 24], pp. 305-394); ID.: Dossier de l'Ordre de la pénitence au XIII.e siècle, Friburgo 1961 ; inoltre, P. Galtier: Pénitents et «convertis», in: RHE 33 (1937) pp. 1-26; 277-305; ID.: Conversi, in: Dictionnaire de Spiritualité 2/2 (1953) coll. 2218-2224; Jean LeCLERCQ: Spiritualità del Medioevo da S. Gregorio a S. Bernardo (sec. VI-XII) (trad. italiana), Bologna 1969, pp. 93-96 (ordine dei penitenti).

140 Praticamente rismasti immuni dal catarismo, che pure nell'Italia centrale ebbe due chiese la "ecclesia florentina sive Tusciae" e la "ecclesia de valle spoletana", le quali ebbero invece l'adesione della nobiltà e persino dei chierici (Vincenzo Natalizi: S. Pietro Parenzo. La leggenda scritta dal maestro Giovanni canonico di Orvieto. Studi e testo, Roma 1936 [«Lateranum», 3, a, II, n. 2]; Ilarino DA Milano: Il dinamismo cataro in Umbria al tempo di san Francesco, in: Filosofia e cultura in Umbria tra Medioevo e Rinascimento. Atti del IV Convegno di Studi umbri, Gubbio 22-26 maggio 1966, Perugia 1967, pp. 175-216), alcuni bizzochi e bizzoche dell'Italia centrale legate al francescanesimo, subirono suggestioni gioachimite; mentre, sulla fine del secolo XIII, fecero su di loro presa movimenti pre-quietisti, come la setta del Libero Spirito, cfr. Romana Guarnieri: Il movimento del Libero Spirito, testi e documenti, in: Archivio Italiano per la Storia della Pietà 4 (1965) pp. 351-708; EAD.: Fratelli del Libero Spirito, in: Dizionario degli Istituti di Perfezione 4 (1977) coll. 633-652; Massimo Petrocchi: Correnti e linee della spiritualità umbra ed italiana del Duecento, in: Filosofia e cultura, pp. 133-173.

141 Nel 1209 Francesco d'Assisi e i suoi primi compagni erano di ritorno da Roma, quando all'altezza del Monte Luco - il monte eremitico che sovrasta Spoleto -, suoi frati andavano interrogandosi "se dovevano svolgere la loro vita tra gli uomini, o ritirarsi negli eremi". Scrive Tommaso da Celano che "Francesco, il quale, non fidandosi mai di sé stesso, in ogni decisione cercava ispirazione da Dio nella preghiera, scelse di vivere per Colui che morì per tutti ben consapevole di essere stato inviato da Dio a conquistare le anime che il diavolo tentava di rapire", 1 Cel 14, 35, cfr. Fontes franciscani, a cura di Enrico Menestò/Stefano Brufani et alii, S. Maria degli Angeli/Assisi 1995, p. 309sg. (la versione italiana è tratta da Fonti francescane ..., Assisi Movimento francescano 1977, p. 440, n. 381).

142 Dagli Atti del processo si apprende che Chiara dopo aver fatto esperienza presso le benedettine di S. Paolo della badesse, presso Bastia, l'insediamento monastico più vicino alla Porziuncola, passò ad ecclesiam S. Angeli de Panso, un santuario micaelico a mezza costa del Monte Subasio; quivi, sedici giorni dopo la sua conversione, fu raggiunta dalla sorella Agnese, al secolo Caterina. Le due sorelle rimasero a Panzo qualche tempo, finché si traferirono in S. Damiano "nel quale loco lo Signore le dette più sore nel suo regimento". Processo di Canonizzazione di S. Chiara, in: Fonti Francescane, (cit. nota 141) vol. 2 teste XII n. $4 \$ 3089$ p. 2365 sg. Fu a questo punto che Francesco scrisse per Chiara e le sue compagne una regola o forma di vita in forza della quale la comunità di $S$. Damiano entrò a far parte della fraternità fondata da s. Francesco; mentre, di lì a qualche anno, venne l'approvazione dalla Chiesa, grazie all'intervento del card. Ugolino, cfr. Marco Bartoli: Chiara d'Assisi, con appendice iconografica a cura di Servus Gieben, Roma 1989 (Bibliotheca Seraphico-capuccina 37). 
Fu nei pressi del monte eremitico di Spoleto, all'epoca popolato da bizzochi, che Francesco prese la decisione di rivolgere la propria opera non per la salvezza individuale, ma per l'aiuto e la salvezza del prossimo: il che diede origine a una nuova stagione dello Spirito quella dei frati minori mendicanti. Non per questo si esaurì il fenomeno degli eremiti urbani; anzi, gli ultimi secoli del Medioevo rappresentano, per dirla con Vauchez, l'età d'oro della santità eremitica ${ }^{143}$.

Mentre uno dei frutti più significativi di questa rinnovata stagione del movimento eremitico di impronta bizzocale, che operò nell'Italia centrale durante i secoli XIII e XIV, è costituito dalle osservanze: da quelle francescane a quelle agostiniane nelle quali Uberto Jedin, lo storico moderno del Concilio di Trento, ha intravisto le prime, ma autentiche, avvisaglie della riforma cattolica ${ }^{144}$. Fece da battistrada l'esperienza eremitica degli "Zoccolanti di Foligno": la gestazione del movimento risale agli ultimi anni della cattività avignonese; i primi difficili passi si muovono nel contesto del grande scisma di Occidente (1378-1417); mentre il futuro successo venne preconizzato dall'atto di totale obbedienza fatto a Mantova, nel 1418, a papa Martino V, il neo eletto pontefice, da parte di alcuni rappresentanti del movimento che poi diedero vita all'osservanza delle cosiddette "Quattro colonne" ${ }^{45}$.

\section{Zusammenfassung}

In Mittelitalien ging die gregorianische Reform von der Einsiedelei aus und nahm dabei zwei verschiedene Formen an, d.h. die einer monastischen Bewegung und einer Bußbewegung. Im Anschluß an Kehr und die Italia Pontificia haben die Studien über die durch den hl. Romuald von Ravenna $(† 1027)$ begründete monastische Bewegung zugenommen. Erst in jüngerer Zeit stößt hingegen die vom hl. Dominikus von Sora eingeleitete Reformbewegung

143 Vauchez, dopo aver distinto gli anacoreti di fine secolo XII e inizi XIII, da quelli vissuti dopo il 1348, sottolinea il carattere elitario di questi ultimi, facendo notare come gli eremiti secolari che vivono nella selva (da qui l'appellativo di selvatici), abbondino nell'Italia centrale più che altrove, André Vauchez: La sainteté en Occident aux derniers siècles du Moyen Age d'après les procès de canonisation et les documents hagiographiques, Roma 1981 (Bibliothèque des Ėcoles françaises d'Athènes et de Rome 241), pp. 227-234, 380-388.

144 Hubert Jedin: Storia del Concilio di Trento, vol. 1, Brescia 1973, p. 160. Sul contributo dato dall'eremitismo apostolico alla Riforma cattolica vedi Eremiti e pastori della Riforma cattolica nell'Italia del '500, Atti del VII Convegno del centro di studi avellaniti, Fonte Avellana 31 Agosto - 2 settembre 1983, Urbino 1984.

145 Grado Giovanni Merlo: Tra eremo e città, studi su Francesco d'Assisi e sul francescanesimo medievale, Assisi 1991, pp. 131-147; inoltre Duncan Nimmo: Reform and Division in the Medieval Franciscan Order from saint Francis to the Foundation of the Capucins, Roma 1987 (Bibliotheca Seraphico-capuccina 33). 
auf Interesse. Dieser Mönch und Eremit rief auf dem flachen Land verschiedene religiöse Einrichtungen ins Leben, die an die Gründungspatrone gebunden blieben und vom Diözesanbischof unabhängig waren. Für das weit verbreitete Phänomen der Familienklöster stellen Sassovivo (Foligno) und S. Croce dei Conti (Sassoferrato) bedeutsame Beispiele dar.

Neben diesen monastischen Bewegungen entstanden in demselben Gebiet auch hochinteressante kleine Eremitenzentren, die von den ,irregulären', nach der agostinischen Regel institutionalisierten Eremiten bis zu den Eremiten der Apokalypse reichten. Einen Fall für sich bildeten die an keine millenaristische Bewegung gebundenen Eremiten, die sich seit dem 11. Jahrhundert als Wächter in den Michaelswallfahrtsstätten ad instar Gargani niederließen, über die wir aber ansonsten wenig wissen. Einige dieser Höhlen, die sich in Umbrien und in den Marken verbreiteten, gingen an die Franziskaner über, die sie in Klöster umwandelten (LaVerna und die Wallfahrtsstätten im reatinischen Tal). Es handelte sich dabei um eine von den zeitgenössischen Klostereinrichtungen unabhängige Bußbewegung; sie hing vielmehr mit jener Bußbewegung aus den frühen Jahrhunderten zusammen, aus welcher der Ordo conversorum et conversarum hervorging, der eine eigene kirchengesetzliche Regelung fand. Die geistige Erneuerung, die in Mittelitalien vom Eremitentum getragen wurde, bewirkte ein Aufblühen des monastischen Lebens sowie eine Läuterung und einen Aufschwung der eremitischen Bewegung. 
Bereitgestellt von | De Gruyter / TCS

Angemeldet | 217.89.40.26

Heruntergeladen am | 21.12.12 10:50 


\title{
L'„Italia Pontificia“ e le vicende degli ordini religioso-militari nella Penisola
}

\author{
Kristjan Toomaspoeg
}

Il convegno dedito al centesimo anniversario dell'impresa editoriale dell'Italia Pontificia ospita due relazioni che riguardano gli ordini religioso-militari medievali: quella del prof. Rudolf Hiestand, incentrata sulla storia generale degli ordini in Terra Santa e in Europa e sui destini dei loro archivi ${ }^{1}$, e la presente, finalizzata a illustrare gli aspetti della presenza dei tre principali ordini militari, ovvero quelli dei Giovanniti, Templari e Teutonici, nel preciso ambito della Penisola Italiana.

Come è noto, la Curia pontificia medievale ha emesso numerosi atti relativi agli ordini militari nella Penisola, il che spiega il ruolo rilevante avuto da queste fonti nel lavoro di Paul Fridolin Kehr e dei suoi collaboratori. Da questo punto di vista, si distingue soprattutto la sezione dell'Italia Pontificia che riguarda l'isola di Malta: essa si basa sulla documentazione giovannita e templare, rintracciata negli antichi archivi centrali dell'Ordine di Malta ${ }^{2}$. Però, delle unità archivistiche sull'argomento sono state individuate anche in altri ambiti geografici studiati dagli storici tedeschi.

Ad esempio, nella Biblioteca Comunale di Palermo, Kehr consultò le copie degli atti dei Templari e degli Ospitalieri di Sicilia realizzate nel Seicento dallo storiografo regio Antonino Amico ${ }^{3}$. Il manoscritto di Amico contiene molte

1 Si veda in questo volume, pp. 615-672.

2 Paul Fridolin KeHR: Papsturkunden in Malta, in: NGG phil.-hist. Klasse (1899) pp. 369-409 (rist. in Paul Fridolin KeHR: Papsturkunden in Italien. Reiseberichte zur Italia Pontifica, vol. 2, Città del Vaticano 1977 [Acta Romanorum pontificum 2], pp. 89-130). Nell'introduzione di questa opera, basata sulle ricerche condotte da Luigi Schiaparelli, Kehr spiega anche le ragioni della decisione di includere Malta nel progetto dell'Italia Pontificia, motivata più che altro dalla necessità di confrontare gli atti degli antichi archivi dell'Ordine di Malta nell'isola, in sé allora già abbastanza noti, con i documenti, spesso sconosciuti, conservati tra i resti dell'archivio priorale giovannita di Messina, in Sicilia. Nel volume sono pubblicate 53 lettere apostoliche che riguardano sia i Giovanniti che i Templari e sono presentati i regesti di molte decine di altri documenti.

3 Si tratta del manoscritto numero Qq H 12 della Biblioteca Comunale di Palermo, redatto fra il 1625 e il 1629, dal titolo: Diplomata, litterae etc. ad sacram domum militum S. Joannis Hyerosolymitani et militum Templariorum pertinentia. Per Antonino Amico e il suo manoscritto, si veda Raffaele Starrabba: Scritti inediti o rari di Antonino Amico e documenti relativi al medesimo, Palermo 1891; Giuseppina Pecorella: I Templari nei manoscritti di Antonino Amico, Palermo 1921; Kristjan Toomaspoeg: 
lettere apostoliche del XII secolo tra cui alcune erano sconosciute prima della loro presentazione nell'Italia Pontificia ${ }^{4}$. Altri atti sulla storia dei Templari o degli Ospitalieri si trovano nei fondi delle Chiese capitolari o delle congregazioni religiose moderne in tutto il territorio italiano.

Al tempo stesso, alcuni cartulari degli ordini militari non censiti all'interno dell'Italia Pontificia, come quelli dei Teutonici a Palermo ${ }^{5}$ e a Padova ${ }^{6}$,

Templari e Ospitalieri nella Sicilia Medievale, Bari 2003 (Gran Priorato di Napoli e Sicilia del Sovrano Militare Ordine di Malta, Melitensia 11), pp. 26-36.

4 Paul Fridolin KeHR: Papsturkunden in Sizilien, in: NGG, phil.-hist. Klasse (1899) pp. 283-337 (rist. in KeHR, Papsturkunden in Italien [cit. nota 2] pp. 33-87). In Sicilia, le ricerche archivistiche furono condotte da Luigi Schiaparelli e Paul Fridolin Kehr con il contributo del giovane Karl Andreas Kehr. Il volume si compone in gran parte da documenti del manoscritto di Antonino Amico: così gli atti pubblicati con numeri 2, pp. $311-312$, 3, p. 313 (abbreviato), 4, pp. 313-314, 5, p. 314 (abbr.), 7, p. 315, 11, p. 319 (abbr.), 12, pp. 319-320, 13, p. 320 (abbr.), 14, p. 321, 15, pp. $321-322$, 16, pp. $322-333,18$, pp. $324-325,20$, pp. $326-327,22$, p. 328 (abbr.), 23, p. 328 (abbr.), 24, pp. 328-329, 25, p. 329 (abbr.), 27, p. 330 (abbr.), 33, pp. 333-334. Il manoscritto Qq H 12 era indubbiamente la principale fonte inedita degli studiosi dell'Italia Pontificia nell'isola, e troviamo nel volume anche una brevissima presentazione del manoscritto e del suo autore (KeHR: Papsturkunden in Sizilien [cit. questa nota] pp. 294-295), completata e resa più esaustiva in KeHR: Papsturkunden in Malta (cit. nota 2) p. 370.

5 Palermo, Archivio di Stato, Tabulario della Magione. A questa raccolta di 801 pergamene si aggiungono molte copie degli atti medievali, custodite nei fondi Commenda della Magione e Miscellanea Archivistica II. In tutto, troviamo tra la documentazione ,teutonica' dell'Archivio di Stato 20 lettere apostoliche. Per gli studiosi dell'Italia Pontificia, il fondo del Tabulario della Magione era „ohne Papsturkunden“ (KeHR: Papsturkunden in Sizilien [cit. nota 4] p. 287).

6 Nell'Archivio di Stato di Padova, nel fondo Corporazioni Religiose Soppresse, Gesuiti, sono state individuate 422 pergamene provenienti dall'antico archivio della provincia di ,Lombardia' dell'Ordine Teutonico, tra le quali 17 sono delle lettere apostoliche medievali. Si veda la breve presentazione del fondo in Kristjan Toomaspoeg: La fondazione della provincia di "Lombardia“ dell'Ordine dei Cavalieri Teutonici (secoli XIII-XIV), in: Sacra Militia 3 (2003) pp. 111-159. Gli studiosi dell'Italia Pontificia non ebbero grande interesse per questo fondo archivistico: esso si compone di manoscritti moderni e le pergamena medievali sono state rilegate all'interno di alcuni volumi del fondo, cosicché bisognava prima di tutto individuare la loro collocazione. Questo lavoro è stato svolto solo molti decenni più tardi da Carlo Polizzi nella sua Tesi di laurea rimasta inedita: Comune, signoria ezzeliniana e Chiesa di Padova nel secolo XIII attraverso le carte dei frati alemanni. Con due appendici: 1. Edizione di 57 documenti inediti (1232-1463), 2. Regesto e regesto-estratto di 316 documenti inediti (1219-1399), tesi di laurea, Università degli Studi di Padova, 1981-1982. Si veda anche Carlo Polizzi: Proprietà, feudi e livelli di molini e canali della Padova comunale. Pubblicato a cura dell'autore (art. 9 L 2-2-1939 n. 374), Padova 1989 e Sante Bortolami: Acque, mulini e folloni nella formazione del paesaggio urbano medievale (secoli XI-XIV): l'esempio di Padova, in: Paesaggi urbani dell'Italia padana nei secoli VIII-XIV, Bologna 1988, pp. 277-330, che si servono entrambi dei documenti dell'archivio teutonico. 
conservano ancora delle lettere apostoliche inedite; inoltre si continuano a scoprire documenti nuovi anche tra i numerosi transunti e copie realizzati in epoca moderna ${ }^{7}$ : questo fatto induce a continuare le ricerche intraprese a loro tempo da Kehr e i suoi collaboratori e a completare il quadro delle relazioni intercorse tra il papato e gli ordini militari, anche se sembra ancora lontana la possibilità della creazione di un corpus diplomatico esaustivo degli ordini militari in Italia ${ }^{8}$.

In Italia esiste una tradizione storiografica di studi sulla storia degli ordini religioso-militari che risale al XVI secolo ${ }^{9}$. Durante gli ultimi decenni, la ricerca ha fatto notevoli progressi, anche se, a tutt'oggi, poche sono le monografie che trattano l'argomento per l'intera Penisola, ovvero al di fuori dei confini regionali ${ }^{10}$. Di recente, i lavori preliminari alla stesura del „Dictionnaire des

7 Nell'ambito delle ricerche sull'Ordine Teutonico, Hubert Houben ha individuato a Brindisi, Graz, Napoli, Vienna e altrove numerose copie dei documenti sulla provincia pugliese dei Teutonici, compensando in questo modo la perdita degli atti originali avvenuta nel 1943 con la distruzione del deposito dell'Archivio di Stato di Napoli a San Paolo Belsito: si vedano in particolare Hubert Houben: Zur Geschichte der Deutschordensballei Apulien. Abschriften und Regesten verlorener Urkunden aus Neapel in Graz und Wien, in: MIÖG 107 (1999) pp. 50-110; ID.: Friedrich II., der Deutsche Orden und die Burgen im Königreich Sizilien. Eine unbekannte Urkunde Honorius' III von 1223, in: DA 56 (2000) pp. 585-591; ID.: Neuentdeckte Papsturkunden für den Deutschen Orden (1219-1261) im Staatsarchiv Neapel, in: QFIAB 83 (2003) pp. 41-82. Nell'ambito delle ricerche templari e giovannite, si veda ad esempio Antonella Pellettieri: Militia Christi in Basilicata. Storia e diffusione degli Ordini religioso-cavallereschi (secc. XII-XIX), Potenza 2005 (Quaderni di Leukanikà 4) che si basa sulle copie manoscritte napoletane.

8 Un tentativo di questo genere, che avrebbe potuto seguire l'esempio di Rudolf Hiestand: Papsturkunden für Templer und Johanniter. Archivberichte und Texte, Göttingen 1972 (AAG, phil.-hist. Klasse, 3. Folge 77, Vorarbeiten zum Oriens Pontificius 1) non è mai stato effettuato. Di qualche limitato aiuto è Gaettano Lamattina: Regesta pontificum romanorum. Erga Templarios (1139-1313), Roma 1984 (manoscritto in libera consultazione nella Biblioteca Apostolica Vaticana) e tutte le edizioni dei fondi archivistici ,centrali' degli ordini religioso-militari che comprendono anche la documentazione emessa dai pontefici.

9 Le problematiche della storiografia degli ordini religioso-militari in Italia sono state affrontate nel corso del recente seminario internazionale di studi: Le Crociate: nuove prospettive di ricerca (Roma, Consiglio Nazionale delle Ricerche, 16-17 marzo 2006). Si aspetta la (prossima) pubblicazione degli atti di questo seminario per aggiungere delle informazioni ad un argomento ancora poco studiato.

10 L'unica monografia scientifica ed esaustiva (con dovute critiche) sulla storia di un ordine religioso-militare nell'ambito di tutta la Penisola è Fulvio Bramato: Storia dell'Ordine dei Templari in Italia, Roma 1991-1994. Per il resto possediamo dei saggi su alcuni aspetti specifici degli ordini in Italia, come ad esempio Anthony LutTrell: Templari e Ospitalieri in Italia, in: La chiesa di San Bevignate a Perugia, a cura di Mario RoncetTi/ Pietro Scarpellini/Francesco Tommasi, Perugia 1987, pp. 19-26, e gli articoli contenuti in Anthony Luttrell: The Hospitallers of Rhodes and their Mediterranean 
ordres militaires", un ambizioso progetto europeo che si concretizzerà con un'edizione prevista per il 2009, hanno reso possibile l'incontro e la collaborazione di tutti gli studiosi che lavorano sul territorio italiano ${ }^{11}$.

La mia comunicazione propone una riflessione sui rapporti diretti fra la Sede Apostolica e le rappresentanze in Italia dei tre maggiori ordini religiosomilitari. In questa occasione, presenterò la rilettura di una serie di fonti pontificie, che provengono da quattro diversi secoli, per riflettere sul ruolo svolto dal papato nell'insediamento degli Ospitalieri e dei Templari nella Penisola nel XII secolo; sulla relazione tra la Sede Apostolica e i Teutonici, i Templari e gli Ospitalieri nel XIII secolo e sul quadro storico successivo al Processo ai Templari e all'indebolimento della Sede Apostolica nel XIV secolo. Infine, concluderò portando alcuni esempi della trasformazione dei possedimenti dei Teutonici in benefici ecclesiastici soggetti al potere pontificio nel XV secolo.

\section{Il papato e il primo insediamento italiano degli ordini religioso-militari nel XII secolo}

Non esiste alcun dubbio sul fatto che la creazione degli ordini religioso-militari nella prima metà del XII secolo sia stata voluta e favorita dalla Sede Apostolica, unica autorità predisposta a dare corpo all'ideologia di san Bernardo di Chiaravalle, malgrado la sua evidente contraddizione con lo spirito della riforma ecclesiastica, dal momento che riunì in sé due categorie sociali, i monaci e $\mathrm{i}$ cavalieri, capovolgendo l'ordine della società ${ }^{12}$.

Il papa divenne, almeno in teoria, l'unica autorità ecclesiastica e politica alla quale gli ordini dovevano obbedienza e rimase sempre il loro principale interlocutore. Il ruolo e l'influenza esercitati dal papato risultano evidenti anche guardando alle vicende storiche degli ordini religioso-militari nella Penisola Italiana. Dalle fonti emesse dalla Sede Apostolica si evince un'attività abbastanza intensa di preparazione finalizzata all'insediamento degli ordini in Italia, intrapresa già prima della creazione del concetto di militia Christi, quando gli Ospitalieri di San Giovanni di Gerusalemme, così come altre congregazioni

World, Aldershot 1992, o sulle vicende degli ordini in singole aree geografiche della Penisola.

11 Dictionnaire des ordres militaires au Moyen Âge (Paris 2009), frutto della collaborazione degli storici di quasi tutti i paesi europei, compresi, per la parte italiana, gli studiosi come Pier Carlo Begotti/Elena Bellomo/Renato Bordone/Giampaolo Cagnin/Fulvio Delle Donne/Hubert Houben/Andrea Lercari/Francesco Tommasi.

12 Si veda il riassunto in Alain Demurger: Vie et mort de l'ordre du Temple, Paris 1993 (edizione aggiornata) e ID.: Chevaliers du Christ. Les ordres religieux-militaires au Moyen Âge $\left(\mathrm{XI}^{\mathrm{e}}-\mathrm{XVI}^{\mathrm{e}}\right.$ siècle), Paris 2002. 
religioso-assistenziali della Terra Santa, furono oggetto di particolare attenzione da parte del papato per il loro ruolo di difesa e assistenza dei pellegrini.

Questo interesse divenne manifesto con l'emanazione, a Benevento, di due lettere apostoliche di Pasquale II del 15 febbraio del 1113: Latorem presencium, con cui si ordinava ai prelati e ai fedeli di collaborare per la raccolta delle elemosine degli Ospitalieri in Occidente ${ }^{13}$, e Pie postulatio voluntatis ${ }^{14}$. Questo secondo documento, come è noto, dichiarava gli Ospitalieri sotto la speciale protezione del pontefice e confermava all'institutor ac prepositus dell'Ospedale gerosolimitano, Geraudo, il possesso di una serie di ospedali, ubicati a SaintGilles, Asti, Pisa, Bari, Otranto, Taranto e Messina. La lettera, emessa non molto tempo dopo l'avvenuta emancipazione dell'Ospedale dalla tutela dei Benedettini e l'inizio della sua espansione, serve ancora oggi agli storici per datare la presenza dei Giovanniti in tutte le località che vi sono elencate, quindi in territorio provenzale e italiano. Però, mentre il documento papale afferma con chiarezza che l'Ospedale gerosolimitano era già presente in queste località, un esame approfondito delle altre fonti disponibili ci obbliga ad ammettere che la lettera non era una conferma per il possesso di questi beni, bensì un atto programmatico, con cui si approvava la linea che gli Ospitalieri intendevano seguire nel loro insediamento.

Infatti, la stessa Casa di Saint-Gilles non è documentata prima del $1121^{15}$, benché i Giovanniti fossero già presenti in Provenza (a Tolosa e Béziers) intorno al $1110^{16}$; ad Asti la chiesa dell'Ordine viene menzionata solo nel $1169^{17}$; a Bari e Otranto, esso non ebbe mai beni rilevanti ${ }^{18}$; mentre le Case di Taranto e Messina sono state fondate vari decenni più tardi ${ }^{19}$. La lettera Pie postulatio voluntatis non diede quindi risultati immediati e le strade seguite dai Giovanniti nel loro insediamento furono spesso diverse da quelle indicate nel documento,

13 Cartulaire général de l'Ordre des Hospitaliers de S. Jean de Jérusalem (1100-1310), a cura di Joseph Marie Antoine Delaville Le Roulx, Paris 1894-1904, vol. 1 p. 30 n. 31.

14 Ibid. vol. 1 pp. $29-30$ n. 30 .

15 Ibid. vol. 1 pp. $45-46$ n. 54.

16 Si veda ivi pp. 2-24 nn. 3, 7, 15, 17, 18, 23.

17 Renato Bordone/Donatella GNeTtr: Distribuzione geografica delle „domus“ gerosolimitane in Piemonte e situazione patrimoniale del gran priorato di Lombardia (commenda di Asti), in: „Gentilhuomini christiani e religiosi cavalieri“: nove secoli dell'Ordine di Malta in Piemonte, a cura di Tomaso Ricardi di Netro/Luisa Clotilde Gentile, Milano 2000, pp. 142-145.

18 Mariarosaria Salerno: Gli ospedalieri di San Giovanni di Gerusalemme nel Mezzogiorno d'Italia (secc. XII-XV), Bari 2001 (Gran Priorato di Napoli e Sicilia del Sovrano Militare Ordine di Malta, Melitensia 8)

19 Per Messina, si veda Kristjan Toomaspoeg : Templari e Ospitalieri nella Sicilia Medievale, Bari 2003 (Gran Priorato di Napoli e Sicilia del Sovrano Militare Ordine di Malta, Melitensia 11), pp. 54sg. 
tuttavia era manifesta la volontà di Pasquale II di collocare la congregazione lungo le vie di transito dall'Occidente verso la Terra Santa.

Le circostanze mutarono con la creazione dell'Ordine del Tempio e la progressiva trasformazione dell'Ospedale in un ordine religioso-militare. I nuovi ordini furono protetti e favoriti dal papato nei loro possedimenti in Terra Santa, mentre il loro stanziamento nell'attuale territorio italiano si inserisce all'interno di un contesto politico molto particolare, venutosi a creare con la doppia elezione pontificia del 14 febbraio 1130 dei due papi rivali, Anacleto II e Innocenzo II.

Anacleto esercitò il suo potere per lo più a Roma e nell'Italia meridionale, dove fece incoronare il suo alleato Ruggero II come primo re di Sicilia. Innocenzo, influente nel resto della Penisola, fu sostenuto da Bernardo di Chiaravalle e dai suoi protetti, i Cistercensi e i Templari. Di conseguenza, nell'Italia meridionale i Templari furono praticamente assenti fino alla pacificazione avvenuta tra Ruggero II e Innocenzo II nel $1140^{20}$, mentre nell'Italia centrale dove erano favoriti da Innocenzo, essi riuscirono a fondare alcune delle loro Case principali, come quelle di Pisa, Lucca e Siena ${ }^{21}$.

Tra il 1130 e il 1150, i Templari e gli Ospitalieri, grazie al sostegno di Innocenzo II e dei suoi successori, crearono le basi della loro presenza nel territorio italiano, ricevendo ovunque donazioni da parte di privati e autorità pubbliche. Il papato, senza concedere beni immobiliari agli ordini, favorì il loro insediamento tramite l'emanazione di privilegi che ricordavano gli esoneri e la protezione speciale dei quali entrambi godevano e anche tramite una serie di lettere indirizzate ai prelati di determinate aree geografiche, destinate a facilitare le attività dei frati quali la raccolta delle donazioni e dell'elemosina. Ad esempio, la lettera Milites Templi Jherosolimitani di Lucio II, del 5 giugno $1144^{22}$, ribadita nel novembre del 1145 o 1146 da Eugenio III $^{23}$, chiede agli ecclesiastici siciliani

20 Si veda Kristjan Toomaspoeg: L'insediamento dei grandi ordini militari cavallereschi in Sicilia, 1145-1220, in: La presenza dei cavalieri di San Giovanni in Sicilia. Convegno internazionale, Palermo, Palazzo dei Normanni, 17 giugno 2000 - Messina, Palazzo Zanca, 18 giugno 2000, Roma 2001 (Fondazione Melitense „Donna Maria Marullo di Condojanni“, Collana di Studi 1/1), pp. 41-51, e iD.: Le patrimoine des grands ordres militaires en Sicile, 1145-1492, in: Mélanges de l'École française de Rome, Moyen Âge 113/1 (2001) pp. 313-341.

21 Anthony LutTRell: The Hospitallers of Rhodes between Tuscany and Jerusalem, 1310 1431, in: Revue Mabillon 64 (1992) pp. 117-138 (rist. in: Anthony LutTrell:, The Hospitallers State of Rhodes and its Western Provinces, 1306-1462, Aldershot 1999 [Variorum Collected Studies Series 655], n. XVII).

22 Regesto in Lamattina: Regesta (cit. nota 8) p. 11. Questa lettera non è identica all'altra con gli stessi incipit e data, più nota, indirizzata a tutti i prelati della Chiesa: Hiestand: Papsturkunden (cit. nota 8) pp. 215sg. n. 9.

23 Regesto in KeHr: Papsturkunden in Sizilien (cit. nota 4) p. 63 n. 3; ed. Cartulaire général de l'Ordre du Temple 1119?-1150. Recueil des Chartes et des Bulles relatives à 
di assistere i Templari con donativi e sussidi; così la lettera Milites Templi Domini di Adriano IV, del 7 settembre $1157^{24}$, tratta della conservazione dei beni dei Templari. A queste lettere apostoliche, destinate a contesti specifici, se ne aggiungono molte altre di contenuto generico, trascritte e confermate dalle autorità locali: ad esempio, la lettera Cum fratribus Hospitalis di Alessandro III, del 2 marzo 1174, 75 o $76^{25}$, nota solo grazie ad una copia messinese, riassunta dal Kehr in „Papsturkunden in Sizilien“, che ricorda a tutti i prelati della Chiesa alcuni dei principali privilegi degli Ospitalieri.

A partire dal quarto decennio del XII secolo, si forma quindi un corpus di lettere apostoliche piuttosto consistente riguardante i diritti dei Templari e degli Ospitalieri in Italia e attestante la preoccupazione del papato per la conservazione del patrimonio locale degli ordini, considerato come una garanzia di assistenza ai pellegrini e agli altri viaggiatori diretti in Terra Santa e, sempre più spesso, anche come un vero e proprio sostegno logistico della Terra Santa.

Questo specifico aspetto ricorre con frequenza nella corrispondenza pontificia di Eugenio III (1145-53) e Alessandro III (1159-1181), l'uno in origine Cistercense, l'altro molto favorevole ai Templari. Al termine del pontificato di Alessandro III, i due ordini maggiori si erano stabiliti in Toscana, Emilia e Romagna, Lombardia, Marche, Basilicata, Campania, Puglia e Sicilia e presto riuscirono a stanziarsi nelle restanti aree geografiche, come la Liguria, il Friuli e la Calabria.

A questa epoca si attesta la presenza degli ordini anche nel Patrimonio di San Pietro, in particolare a Roma ${ }^{26}$, dove i Templari si insediarono probabilmente subito dopo la morte di Anacleto II, avvenuta nel gennaio 1137: nel 1138, Bernardo di Chiaravalle visitò la loro nova domus in Urbe. Tuttavia, come abbiamo detto, il sostegno del papato agli ordini non consisté in donazioni d'immobili: è noto infatti che sia la chiesa templare di Santa Maria all'Aventino che quella giovannita di San Basilio al Foro di Augusto $^{27}$ furono acquisiti da

l'Ordre du Temple, a cura del marchese D’Albon, Paris 1913, p. 383 n. XIV; Lamattina: Regesta (cit. nota 8) p. 12 (datazione errata).

24 KeHR: Papsturkunden in Sizilien (cit. nota 4) pp. 63sg. n. 4.

25 Ibid. p. 69 n. 11.

26 Si veda L'ordine templare nel Lazio meridionale: atti del convegno, Sabaudia, 21 ottobre 2000, a cura di Clemente Ciammaruconi, Casamari 2003 (Ministero per i beni e le attività culturali. Direzione generale per i beni librari e gli istituti culturali. Biblioteca statale del monumento nazionale di Casamari); Anne Gilmour-Bryson: The Trial of the Templars in the Papal State and Abruzzi, Città del Vaticano 1982; Annibale Ilari: Il Granpriorato giovannita di Roma: ricerche storiche ed ipotesi, Bari 1998 (Gran Priorato di Napoli e Sicilia del Sovrano Militare Ordine di Malta, Melitensia 4); Giulio Silvestrelli: Le chiese e i feudi dell'Ordine dei Templari e dell'Ordine di San Giovanni di Gerusalemme nella regione romana, in: Rendiconti della Reale Accademia dei Lincei 5, 26 (1917) pp. 490-520.

27 Sulle chiese romane degli ordini militari si veda Mariano Armellini: Le chiese di Roma dal secolo IV al XIX, Roma ${ }^{2} 1891$, pp. 146sg., 501-503, 587sg. 
terzi, anche se è lecito pensare ad un intervento confermativo della Sede Apostolica. Nel Lazio, i possedimenti degli ordini rimasero per molti decenni poco significativi, e anche altrove furono rari gli esempi di città pontificie, come Ascoli Piceno nelle Marche $^{28}$, dotate di importanti insediamenti templari o ospitalieri.

Il caso del Patrimonio di San Pietro è indicativo dell'atteggiamento tenuto dalla Sede Apostolica rispetto allo stanziamento degli ordini religioso-militari in Italia nel XII secolo: l'arrivo e le attività degli ordini furono facilitati e privilegiati in tutti i modi da quasi tutti i pontefici, ma senza però intaccare il proprio patrimonio.

\section{Il papato e gli ordini religioso-militari nel XIII secolo}

La presenza degli ordini religioso-militari, come di tutte le congregazioni della Terra Santa, fu rafforzata nella Penisola Italiana dopo la sconfitta del 1187 e la perdita di Gerusalemme. Si tratta di un fenomeno che accompagnava la ricerca di una base logistica europea per la Terra Santa, descritto, per quanto riguarda il Mezzogiorno d'Italia, da Geneviève Bresc-Bautier ${ }^{29}$. Nell'arco dei tre primi decenni del XIII secolo, il Tempio, l'Ospedale e il nuovo ordine dei frati dell'Ospedale di Santa Maria dei Teutonici ultimarono la creazione della rete dei loro possedimenti in territorio italiano, trasformando spesso i loro primi nuclei, dediti all'assistenza dei pellegrini e degli infermi, in centri di produzione agricola. La potenza del patrimonio degli ordini fece sì che le loro sedi nei principali centri politici della Penisola giocassero anche il ruolo di vere e proprie rappresentanze diplomatiche.

Nel XIII secolo gli Ospitalieri di San Giovanni stabilirono i loro principali priorati italiani a Venezia, Pisa, Roma, Capua, Barletta e Messina, mantenendo, delle sedi indicate nella lettera di Pasquale II nel 1113, solo quelle di Pisa e Messina. I possedimenti dell'Ospedale coprirono quasi tutto l'odierno territorio italiano divenendo quindi l'ordine religioso-militare più presente nella Peniso$\mathrm{la}^{30}$.

28 Anthony Lutrrell: The Hospitaller Priory of Venice, in: Militia Sacra. Gli ordini militari tra Europa e Terrasanta, a cura di Enzo Coli/Maria De Marco/Francesco Tommasi, Perugia 1994, pp. 101-143; Gabriele Petromilli: I Templari della Marca Centrale, Ancona 1984.

29 Geneviève Bresc-Bautier: Les possessions des églises de Terre Sainte en Italie du Sud (Pouille, Calabre, Sicile), in: Roberto il Guiscardo e il suo tempo. Relazioni e comunicazioni nelle prime Giornate normanno-sveve (Bari, maggio 1973), Roma 1975 (Fonti e studi del Corpus membranarum italicarum 11), pp. 13-39.

30 Francesco Tommasi: L'ordinamento geografico-amministrativo dell'Ospedale Gerosolimitano di San Giovanni in Italia (secc. XII-XIV), in: Religiones Militares. Contributi 
I Templari furono particolarmente presenti in alcune regioni, come la Toscana e le Marche, e possederono beni rilevanti in altre; ma, per una serie di circostanze politiche e diplomatiche, acquistarono relativamente pochi beni nel Regno di Sicilia ${ }^{31}$.

I Teutonici seguirono strade completamente diverse nel loro stanziamento: da un lato, perché questo avvenne quasi un secolo dopo rispetto ai Templari e Ospitalieri, dall'altro, per un indiscusso legame con la politica imperiale tedesca d'Enrico VI e Federico II e con la Sede Apostolica d'Innocenzo III e, soprattutto, di Onorio III. Nella prima metà del XIII secolo i Teutonici crearono i loro baliati in Sicilia, nel Mezzogiorno continentale e in „Lombardia“, ovvero nel territorio veneto, friulano e emiliano, avevano beni anche in Toscana e nel Lazio, senza dimenticare la loro presenza nel Tirolo meridionale, nei territori di lingua tedesca ${ }^{32}$.

L'insediamento dell'Ordine Teutonico fornisce un altro esempio interessante della politica pontificia rispetto agli ordini religioso-militari. Innocenzo III, sebbene avesse riconosciuto l'Ordine, ebbe per molto tempo un atteggiamento cauto riguardo la sua presenza italiana (che, all'epoca, consisteva solo nei possedimenti di Puglia e Sicilia). Così, il 2 agosto del 1198, in una lettera indirizzata all'arcivescovo palermitano ${ }^{33}$, il papa risolse il problema dell'occupazione manu militari del monastero cistercense della Santissima Trinità di Palermo da parte dell'esercito di Enrico VI e dei Teutonici in modo ambiguo, consentendo ai Teutonici di rimanere nel monastero, a patto che si comportassero „senza eccessi“, ovvero senza eccedere troppo nella loro adesione al partito imperiale.

alla storia degli Ordini religioso-militari nel medioevo, a cura di Anthony LutTrelL/ Francesco Tomması, Città di Castello 2008 (Biblioteca di “Militia sacra” 2), pp. 61 130.

31 Bramato: Storia (cit. nota 10); Toomaspoeg: Templari (cit. nota 19); Luttrell: Templari e Ospitalieri (cit. n. 10); Elena Bellomo: The Templar Order in North-West Italy (1142-c. 1330), Leiden/Boston 2008 (The Medieval Mediterranean 72).

32 L'Ordine Teutonico nel Mediterraneo. Atti del Convegno internazionale di studio Torre Alemanna (Cerignola)-Mesagne-Lecce 16-18 ottobre 2003, a cura di Hubert Houben, Galatina 2004 (Acta Theutonica 1), offre un quadro aggiornato della presenza dei Teutonici in Italia, per quanto riguarda le aree di lingua tedesca della Penisola, si veda Der Deutsche Orden in Tirol. Die Ballei an der Etsch und im Gebirge, a cura di Heinz Noflatscher, Marburg 1991 (Quellen und Studien zur Geschichte des Deutschen Ordens 43).

33 Antonio Mongitore: Monumenta historica sacrae domus mansionis SS. Trinitatis militaris ordinis Theutonicorum urbis Panormi et magni ejus praeceptoris. Origo, privilegia, immunitates, praeceptores, commendatarii, ecclesiae suffraganae, proventus, aliaque memorabilia ejusdem sacrae domus recensentur et illustrantur. Auctore sacrae theologiae doctore D. Antonio Mongitore, Palermo 1721, p. 15. Si veda anche, per il quadro storico, Friedrich BaEthGen: Die Regentschaft Papst Innozenz III. im Königreich Sizilien, Heidelberg 1914.. 
Durante gli anni dell'alleanza fra Federico II e Onorio III l'Ordine Teutonico, sotto la guida di Ermanno di Salza, visse una delle fasi di massima espansione giuridica, politica ed economica. Senza entrare nel merito dei numerosi privilegi concessi ai Teutonici da Onorio III, noti attraverso molti studi, vorrei fare alcune osservazioni sulla loro concreta applicazione in territorio italiano.

Innanzitutto, si assiste ad alcune concessioni di beni e redditi a favore dell'Ordine Teutonico effettuate da Federico II con l'approvazione del papato, sia perché il sovrano doveva obbedienza al papa per il Regno di Sicilia, sia per il fatto che si trattava di concessioni fatte nell'ambito dei preparativi delle spedizioni in Terra Santa. Così, nel dicembre del $1216^{34}$ e il 24 giugno del $1217^{35}$, Federico II diede ai Teutonici dei redditi fiscali rispettivamente nei porti di Brindisi e Messina, ma solo quelli di Messina furono confermati da Onorio III il 21 marzo 1218, con la lettera Iustis petentium desideriiis ${ }^{36}$. In questo ultimo caso, il reddito di 200 once d'oro doveva servire ai frati in attesa di partire per la Terra Santa per procurarsi mantelli per l'inverno, mentre la concessione di Brindisi, ignorata dal papa, fu fatta in cambio di alcuni non precisati beni in Germania che i Teutonici consegnarono a Federico II. Nel 1219, il re, senza volerlo, violò i diritti giurisdizionali della Sede Apostolica quando diede ai Teutonici alcuni terreni a Medicina, vicino Bologna: il conflitto fu risolto con una lettera di scuse di Federico a Onorio III e la tacita approvazione del papato ${ }^{37}$.

In Italia il legame tra i Teutonici, il papato e l'autorità reale e poi imperiale di Federico II si concretizzò inizialmente nell'ambito dei preparativi della crociata, ma presto il sostegno di Onorio III trovò altre motivazioni. Una lettera del papa dell'11 dicembre del 1223, recentemente scoperta e pubblicata da

34 Jean Louis Alphonse Huillard-BrÉHolles: Historia diplomatica Friderici secundi, Paris 1859-1861, vol. 1, pp. 488-490; Codex diplomaticus ordinis sanctae Mariae Theutonicorum, a cura di Johann Heinrich Hennes, Mainz 1845, vol. 2, p. 5, Gaston von Pettenegg: Die Urkunden des Deutsch-Ordens Zentralarchives zu Wien, vol. 1 (1170-1809), Praga/Leipzig 1887, p. 9 n. 22, regesto in RI 5/1 p. 214 n. 887.

35 Hennes: Codex diplomaticus (cit. nota 34) vol. 1 p. 31; Pettenegg: Die Urkunden (cit. nota 34) pp. 2-3 n. 6 (datazione errata); Huillard-BréHolles (cit. nota 34) vol. $1 / 2$ pp. 510 sg.; RI 5/1 p. 218 n. 910.

36 Originale in Archivio di Stato di Palermo, Tabulario della Magione, 21, copie in Archivio di Stato di Palermo, Miscellanea Archivistica, II, 22, f. 55r-55v, Archivio Segreto Vaticano, Reg. Vat. 9, ff. 233v-234r, regesto in Petrus Pressuttr : Regesta Honorii papae III, Roma 1888, vol. 1, p. 195 n. 1172.

37 Huillard-BréHolles (cit. nota 34) vol. 1/2 p. 673-674, regesto in: RI 5/1 p. 242 n. 1049. Si veda anche Giuseppe Simoni: Cronistoria del Comune di Medicina, Bologna 1880, pp. 78sg.; Kurt Forstreuter: Der Deutsche Orden am Mittelmeer, Bonn 1967 (Quellen und Studien zur Geschichte des Deutschen Ordens 2), p. 147; Mario Fanti/ Giancarlo Roversi: S. Maria degli Alemanni in Bologna, Bologna 1969, p. 17. 
Hubert Houben, Dilectis filiis magistro, concede ai Teutonici il diritto di prendere le armi per difendere i castelli lasciati sotto la loro custodia da Federico II anche contro i cristiani ${ }^{38}$. I Teutonici che, in realtà, furono impegnati in azioni militari solo a partire dal 1210 incirca $^{39}$, avevano già combattuto contro gli Arabi insorti in Sicilia nel $1219^{40}$, giocando quindi ormai un ruolo di esperti di guerra e di tecniche di fortificazione, esattamente come i Templari e gli Ospitalieri, anche nei territori italiani.

I Teutonici furono anche i primi frati di un ordine religioso-militare ad ottenere dalla Sede Apostolica una concessione diretta di beni a Roma: nel 1220, Onorio III diede loro la chiesa di Santa Maria in Domnica al Celio che rimase per quasi un secolo la Sede romana dell'Ordine. Tuttavia, la chiesa, una delle principali arcidiaconie della città, non fu data ai Teutonici a titolo definitivo, bensì in concessione temporanea che fu revocata nel 1310 da Clemente $\mathrm{V}^{41}$.

Il conflitto tra Federico II e la Chiesa romana non determinò mai effetti davvero negativi sugli ordini religioso-militari della Penisola: per quanto riguarda il Regno di Sicilia, la problematica delle perdite subite dagli ordini a seguito dello scontro fra $\mathrm{i}$ due poteri è stata molto ridimensionata dalla storiografia recente ${ }^{42}$; mentre, dal canto suo, il papato non operò mai distinzioni tra gli ordini in base alla loro lealtà verso la Chiesa o l'imperatore. Ovviamente, le missioni della difesa della Terra Santa o dell'evangelizzazione dell'Europa nord-orientale prevalsero sul contesto locale della Penisola.

Abbiamo ricordato il ruolo dei frati degli ordini religioso-militari come custodi dei castelli nel Regno di Sicilia all'epoca di Federico II. Nel 1265, con l'avvento di Carlo I d'Angiò, a causa della speciale predilezione del sovrano per gli ordini militari, gli esponenti dei Templari, degli Ospitalieri e, talvolta, anche dei Teutonici svolsero nel Regno delle mansioni di ufficiali regi in ambiti legati alle attività militari, la tesoreria e la navigazione, ma anche in altri settori, come la gestione delle miniere ${ }^{43}$. Negli stessi anni, anche la Sede Apostolica cominciò

38 Houben: Friedrich II. (cit. nota 7).

39 Marie Luise Favreau-Lilie: L'Ordine Teutonico in Terrasanta (1198-1291), in: Houben: L'Ordine Teutonico nel Mediterraneo (cit. nota 32) pp. 53-72, qui pp. 5960.

40 Kristjan Toomaspoeg: Les Teutoniques en Sicile (1197-1492), Roma 2003 (Collection de l'École française de Rome 321), p. 49.

41 Kristjan Toomaspoeg: Die Deutschordenskirche Santa Maria in Domnica im Licht eines unbekannten Inventars von 1285, in: QFIAB 83 (2003) pp. 83-101.

42 Si veda Toomaspoeg: Templari (cit. nota 19) pp. 65-67.

43 Sull'argomento degli ordini militari a servizio dei poteri laici ed ecclesiastici, si veda Henri Bresc: Gli Ordini ospedalieri e militari nel Mediterraneo, in: I Teutonici tra Sicilia e Mediterraneo. Atti del Convegno Internazionale (Agrigento, 24-25 marzo 2006), a cura di Antonino Giuffrida/Hubert Houben/Kristjan Toomaspoeg: Galatina 
a servirsi di frati degli ordini militari, soprattutto nella loro veste di difensori armati.

É abbastanza difficile datare la comparsa dei primi cubiculari, ossia le guardie del corpo del papa, templari e ospitalieri. Il circondarsi di membri degli ordini religioso-militari diventa un'abitudine dei papi più o meno all'epoca della conquista angioina della Sicilia: da una parte, deve essere considerato il risultato di un preciso disegno politico dei capitoli degli ordini, che volevano essere presenti presso tutte le corti europee, compresa la Curia romana, dall'altra, i decenni precedenti alla caduta di Acri accentuarono il ruolo dei cavalieri e dei preti degli ordini quali difensori della Terra Santa, ben accolti e influenti in Europa.

I Teutonici, benché non facessero parte degli ordini più rappresentati presso la Curia, trovarono il modo per accrescere la loro influenza, affidando l'incarico di procuratore generale dell'Ordine presso il papa ad un importante notaio apostolico, Giovanni da Capua ${ }^{44}$. Questi, membro della cancelleria pontificia dal 1230, in seguito divenne un frate dell'Ordine Teutonico, fatto piuttosto raro trattandosi di un nativo della Penisola, e dal 1257 viene citato come procuratore dell'Ordine.

L'adesione di Giovanni da Capua sembra essere stato un successo diplomatico per l'Ordine, come fanno supporre i risultati concreti delle sue attività. Così, papa Alessandro IV (1254-1261) fu uno dei pontefici più favorevoli ai Teutonici, sia in generale che rispetto alle singole Case ${ }^{45}$, e proprio nel caso dei Teutonici si manifestò per la prima volta la nuova politica pontificia di concedere agli ordini religioso-militari grandi proprietà monastiche abbandonate $o$ in stato di degrado.

Infatti tra il novembre del 1260 e il gennaio dell'anno successivo, Alessandro IV affidò ai Teutonici la canonica di San Leonardo di Siponto con il suo immenso patrimonio ubicato in Puglia e in Basilicata ${ }^{46}$. Questa concessione ebbe una duplice motivazione: da una parte, essa risale a pochi mesi dopo la cocente sconfitta dell'Ordine contro i Lituani nella battaglia di Durbe cosicché avrebbe dovuto dare un nuovo sostegno economico e morale ai Teutonici;

2007 (Acta Theutonica 4), pp. 17-46. Sui membri degli ordini militari a servizio della corte angioina, Toomaspoeg: Templari (cit. nota 19) pp. 70-72.

44 Jan-Erik Beuttel: Der Generalprokurator des Deutschen Ordens an der römischen Kurie. Amt, Funktionen, personelles Umfeld und Finanzierung, Marburg 1999 (Quellen und Studien zur Geschichte des Deutschen Ordens 55); Fulvio Delle Donne: Giovanni da Capua, in: DBI 55 (2000) pp. 759-761.

45 Ad esempio, i numerosi atti emessi a favore della Casa padovana dell'Ordine cf. Toomaspoeg: La fondazione (cit. nota 6).

46 Regesto di S. Leonardo di Siponto, a cura di Fortunato Camobreco, Roma 1913 (Regesta Chartarum Italiae 10), p. 130 n. 195, p. 132 n. 197. 
dall'altra, la canonica, situata vicino ad uno dei più importanti assi viari del Mezzogiorno, era diventata da tempo una spelunca latronum ${ }^{47}$.

In realtà, non fu certo questa la prima volta che un ordine religioso-militare si era impossessato di un'istituzione ecclesiastica italiana tanto che casi di compravendite, acquisizioni per donazione e anche usurpazioni di chiese e monasteri da parte dei Templari, Ospitalieri e Teutonici sono frequenti in tutta la Penisola. Il possesso a lungo termine di queste chiese, come la Santissima Trinità dei Teutonici a Palermo, acquisita manu militari, o Santa Maria dell'Aventino dei Templari, ricevuta in donazione da parte dei Benedettini cluniacensi ${ }^{48}$, implicava sempre una esplicita o tacita approvazione da parte del papato. Tuttavia, la concessione diretta di un monastero o di un qualunque bene ecclesiastico da parte della Sede Apostolica ad un ordine militare costituì senza dubbio una rarità almeno sino al 1260 .

Un'altro esempio della politica pontificia di concessione di monasteri ci viene dal pontificato di Clemente IV, seppure secondo modalità diverse, dal momento che il bene in questione, il priorato benedettino di Santa Eufemia in Calabria, fu semplicemente occupato dagli Ospitalieri, azione in seguito approvata dal papa ${ }^{49}$.

Comunque, gli esempi più rilevanti di concessioni pontificie provengono da un'epoca più tardiva, successiva alla caduta di Acri, nel corso degli ultimi tentativi di espansione militare verso Oriente.

Il 22 settembre del 1297, con le lettere apostoliche Dum paterne considerationis $^{50}$ e Inter cetera mundi loca ${ }^{51}$, Bonifacio VIII diede agli Ospitalieri, principale ordine militare presente nel Regno di Sicilia, due importanti monasteri benedettini nel Mezzogiorno continentale, Sant'Angelo del Palazzo, presso Acquaviva Colle di Croce, e la Santissima Trinità di Venosa. Le due concessioni furono effettuate secondo modalità lievemente diverse: Sant'Angelo era un monastero che soffriva da tempo per l'incuria e la povertà della comunità, al punto di essere temporaliter et spiritualiter collapsum, cosicché i monaci l'avevano già consegnato, con il benestare del vescovo locale, agli Ospitalieri. Il cenobio venusino era invece direttamente soggetto alla Sede Apostolica e il papa motivò la sua concessione da una parte con le meritevoli attività dei Giovanniti, intrepidi pugiles, e, dall'altra, con l'incuria e la cattiva amministrazione in cui

47 Hubert Houben: „Iuxta stratam peregrinorum“: la canonica di S. Leonardo di Siponto (1127-1260), in: RSCI 56 (2002) pp. 323-348; San Leonardo di Siponto. Cella monastica, canonica, domus Theutonicorum. Atti del Convegno internazionale (Manfredonia, 18-19 marzo 2005), a cura di Hubert Houben, Galatina 2006 (Acta Theutonica 3).

48 Silvestrelli: Le chiese (cit. nota 26).

49 Salerno: Gli ospedalieri (cit. nota 18); Toomaspoeg: Templari (cit. nota 19) pp. 73sg.

50 Delaville Le Roulx: Cartulaire (cit. nota 13) vol. 3 pp. 721 sg. n. 4386.

51 Ibid. pp. 722 sg. n. 4387. 
versava il monastero. In entrambi i casi, i Benedettini rimasti potevano continuare a risiedere nei loro monasteri. Inoltre, nel gennaio dell'anno successivo, Bonifacio VIII fece annullare tutti i contratti di locazione con i beni della Santissima Trinità di Venosa stipulati in passato dalla comunità benedettina $^{52}$.

Sebbene esclusi dalla categoria dei beneficiari di speciali concessioni, i Templari godettero di un'altra forma di riconoscimento da parte del papato nell'ultimo quarto del XIII secolo, quando la Sede Apostolica mise sotto la loro custodia una serie di siti fortificati nel Patrimonium Beati Petri. Di norma si trattava di fortificazioni situate nell'area centrale e meridionale del Lazio e nell'Abruzzo, fra cui alcuni siti davvero prestigiosi, come il castrum di Cencelle (Tarquinia) o il castello di Santa Maria di Scurcola ${ }^{53}$, che non furono, contrariamente a quanto talvolta viene riportato, date in proprietà, bensì solo in custodia temporanea ai Templari. Certamente, anche la semplice custodia implicava l'usufrutto delle rendite di questi siti e procurò all'Ordine delle risorse notevoli.

3. Gli ordini militari in Italia dopo il Processo ai Templari

I Templari di stanza presso la Curia, cubiculari o castellani che fossero, vissero la loro stagione più felice sotto il pontificato di Bonifacio VIII, quindi solo pochi anni prima della soppressione dell'Ordine. Non vorrei entrare nell'argomento del processo ai Templari, peraltro oggetto di una sezione dell'ultimo convegno dei medievisti a Leeds, e vorrei solo fare alcune osservazioni sul suo impatto nel territorio italiano.

Le trasformazioni subite dagli ordini religioso-militari dopo la caduta di Acri non provocarono effetti immediati nella Penisola Italiana. Così, i grandi cambiamenti avvenuti all'interno dell'Ospedale di San Giovanni di Gerusalemme a seguito delle riforme di Guglielmo di Santo Stefano e il trasferimento del suo capitolo a Rodi, all'inizio del XIV secolo, o anche l'evoluzione simile, forse ancora più radicale, subita dall'Ospedale di Santa Maria dei Teutonici, non determinarono echi profondi in Italia e non si manifestarono nei rapporti degli ordini con il papato ${ }^{54}$.

Il caso dei Teutonici è emblematico: è vero che nel 1310, in un momento difficile della loro storia, trovandosi anch'essi sotto processo, Clemente V tolse

52 Pridem diligentius attendentes, ibid. pp. 729 sg. n. 4399.

53 Si veda Silvestrelli: Le chiese (cit. nota 26).

54 Si veda Anthony Luttrell: The Hospitallers and the Papacy, 1305-1314, Stuttgart 1998 (Forschungen zur Reichs-, Papst- und Landesgeschichte 2). 
loro la chiesa di Santa Maria in Domnica a Roma ${ }^{55}$ e si potrebbe pensare ad una politica repressiva della Sede Apostolica nei confronti dei possedimenti italiani dell'Ordine, se non fosse che il papa, allo stesso momento, intervenne in favore dei Teutonici nel corso della loro lite con il vescovo di Cefalù per il possesso della chiesa della Santissima Trinità di Polizzi in Sicilia ${ }^{56}$.

Il processo ai Templari ebbe invece un impatto diretto sul territorio della Penisola Italiana, dove fu celebrato con delle modalità particolari. Prima di tutto, in Italia non fu seguita una linea unitaria riguardo al destino dei Templari e in ogni singola regione, l'azione giudiziaria si svolse e si concluse in modi diversi. In alcune aree geografiche, come quelle direttamente soggette alla Curia $^{57}$ o il Regno angioino di Sicilia ${ }^{58}$, il processo implicò l'estorsione delle confessioni con la tortura e terminò con la condanna assoluta ed inappellabile degli accusati; in altre, come quelle sottoposte al giudizio del commissario pontificio Rinaldo da Concorezzo nell'Italia centro-settentrionale ${ }^{59}$, i Templari furono invece addirittura assolti; mentre in altre ancora, come la Sicilia aragonese, non vi fu un vero e proprio processo e i Templari rimasti furono fatti tacitamente confluire nelle fila degli Ospitalieri ${ }^{60}$.

Anche il destino dei possedimenti templari non fu univoco: come era stato predisposto dalla lettera apostolica Ad providam Christi del 2 maggio $1312^{61}$, per

55 Forstreuter: Der Deutsche Orden (cit. nota 37) p. 160; Toomaspoeg: Santa Maria in Domnica (cit. nota 41).

56 Una prima lettera del pontefice, Conquesti sunt nobis, fu indirizzata alle autorità ecclesiastiche palermitane nel luglio (1-7) del 1309, il papa invocò allora del diritto dei Teutonici di poter costruire delle chiese e cappelle, diritto che il vescovo di Cefalù non aveva rispettato quando aveva vietato la costruzione della chiesa teutonica di Polizzi, e ordinò di convocare una riunione per risolvere il contenzioso: la lettera è pubblicata in: Mongitore: Monumenta (cit. nota 33) p. 214, dall'originale nell'Archivio di Stato di Palermo, Tabulario della Magione, 496, regesto in: Toomaspoeg: Les Teutoniques (cit. nota 40) p. 729 n. 520 . Il 13 marzo del 1311, con la lettera Qua nobis, Clemente V indirizzò un simile ordine alle autorità ecclesiastiche di Monreale: la lettera, custodita in Tabulario della Magione, 516, è inedita, regesto in ibid. pp. 734sg. n. 535. In realtà, il diritto al quale si riferivano i Teutonici riguardava sì l'edificazione delle chiese e cappelle, ma solo nei territori appena conquistati dalle mani degli ,infedeli' e quindi la sua applicazione nel contesto siciliano indica la benevolenza del papa al riguardo dei Teutonici e, forse, anche una percezione della Sicilia aragonese come terra da ,riconquistare alla religione'.

57 Gilmour-Bryson: The Trial (cit. nota 26).

58 Giovanni Guerrieri: I Cavalieri Templari nel Regno di Sicilia, Trani 1909; Cristian Guzzo: Templari in Sicilia. La storia e le sue fonti tra Federico II e Roberto d'Angiò, Verbania 2003 (Insignia et Arma).

59 Come dimostra bene Elena Bellomo: The Templer Order (cit. nota 31) pp. 175-208.

60 Litterio Villari: Templari in Sicilia, Latina 1993; Kristjan Toomaspoeg: La fine dei Templari in Sicilia (1305-1326), in: Religiones Militares (cit. nota 30) pp. 155-170.

61 Johann Christian LüNIG: Codex Italiae Diplomaticus quo non solum multifariae Investiturarum Literae, ab Augustissimis Romanorum Imperatoribus Italiae Principibus 
lo più questi furono consegnati agli Ospitalieri, ma in molti casi il passaggio di proprietà fu disturbato o impedito dalle usurpazioni da parte di privati o dall'interferenza dei poteri pubblici, come quello angioino. Per quanto riguarda i territori direttamente sottoposti alla Sede Apostolica, l'Ospedale non ebbe difficoltà nel prendere possesso della case templari, compreso il complesso monumentale di Santa Maria all'Aventino, ma non ebbe alcun diritto sui siti che erano stati tenuti in custodia dal Tempio su incarico del papato ${ }^{62}$.

Successivamente, la Curia avignonese e romana del XIV secolo non esercitò sugli ordini religioso-militari la stessa influenza del secolo precedente, benché fosse rimasta il loro diretto superiore e uno dei loro principali interlocutori. Nel Trecento, i più importanti ordini militari rimasti nella Penisola Italiana, l'Ospedale di San Giovanni e quello di Santa Maria dei Teutonici, accrebbero il loro patrimonio e la loro potenza economica, ma le loro singole Case, malgrado i tentativi di controllarle, svolsero spesso per proprio conto attività politiche e diplomatiche in base al contesto in cui si trovarono. Inoltre, nel caso dei Giovanniti, le loro commende furono spesso gestite come semplici benefici ecclesiastici da commendatori locali, come ad esempio Roberto Diana in Sicilia ${ }^{63}$.

Il papato dovette riflettere sul ruolo degli ordini militari nel nuovo quadro politico occidentale dopo la perdita della Terra Santa e l'evangelizzazione definitiva dei confini occidentale e nord-orientale dell'Europa. Al centro di questa riflessione erano anche i possedimenti italiani degli ordini, in particolare del più ricco e potente di essi, l'Ospedale di San Giovanni.

I primi a voler conoscere l'effettivo stato dell'economia e del personale degli ordini militari in Italia furono gli stessi capitoli degli Ospitalieri e dei Teutonici che, a partire dal XIV secolo disposero che si realizzassero regolarmente delle visite nei loro distaccamenti nella Penisola e fecero stilare inventari dei beni posseduti. Un buon esempio è costituito dall'inventario dei beni del priorato giovannita di Roma, redatto nel 1334, contenuto nel «Liber Prioratus Urbis», recentemente pubblicato da Dominique Moullot ${ }^{64}$, che resta la fonte più dettagliata e precoce per la conoscenza del patrimonio dell'Ordine nell'Italia centrale.

$\&$ Proceribus concessae atque traditae; verum etiam alia insignia varii generis Diplomata, tam edita quam multa anecdota, ipsos concernentia continentur, Francoforte Meno/ Leipzig 1725-1735, vol. 2, col. 1651-1656; Regestum Clementis Papae V ex Vaticanis archetypis sanctissimi domini nostri Leonis XIII Pontificis Maximi iussu et munificentia nunc primum editum. Cura et studio monachorum Ordinis S. Benedicti, Roma 1887, anno VII, pp. 65-68 n. 7885; Lamattina: Regesta (cit. nota 8) pp. 248-252 n. 1106.

62 Gilmour-Bryson: The Trial (cit. nota 26); Silvestrelli: Le chiese (cit. nota 26).

63 Toomaspoeg: Templari (cit. nota 19) pp. 88-96.

64 Dominique Moullot: Le Liber Prioratus Urbis de l'Ordre de Saint-Jean-de-Jérusalem: édition critique du Vat. Lat. 10372, Bari 2004 (Gran Priorato di Napoli e Sicilia del Sovrano Militare Ordine di Malta, Melitensia 12). 
Non è un caso che l'inventario del 1334 sia finito in possesso della Curia pontificia (l'originale del manoscritto si trova oggi nella Biblioteca Vaticana) che mise in atto essa stessa dei tentativi al fine di conoscere l'entità dei beni degli Ospitalieri per capire se fossero stati in grado di combattere i Turchi nel Mediterraneo.

Il 10 febbraio del 1373, negli anni immediatamente precedenti al ritorno della Sede Apostolica a Roma, Gregorio XI, ancora ad Avignone, con la lettera Ex certis rationabilibus causis, ordinò un'inchiesta di vastissime dimensioni sul patrimonio europeo dell'Ospedale, compresi i suoi beni nella Penisola Italiana ${ }^{65}$. Come dichiarava il pontefice (nella sua missiva), l'inchiesta era destinata alla riforma dell'intero ordine, in spiritualibus ac temporalibus, per migliorare la difesa e la diffusione della fede cristiana. L'indagine doveva essere svolta dai vescovi locali, in ogni singola diocesi, e doveva fornire informazioni sullo stato del personale, dei beni e dei redditi delle commende giovannite locali. I verbali di queste inchieste diocesane costituiscono una delle fonti principali per la storia dell'Ospedale di San Giovanni e si trovano nell'Archivio Segreto Vaticano; essi sono stati pubblicati per la parte riguardante la Francia e alcuni altri territori ${ }^{66} \mathrm{e}$, di recente, anche per le parte rignardente il Mezzogiorno d'Italia ${ }^{67}$

L'inchiesta del 1373 fu percepita dagli stessi Ospitalieri come una grave intromissione nei loro affari interni. Si trattava di un procedimento finora sconosciuto in Italia, dal momento che i rappresentanti della Sede Apostolica non avevano mai avuto accesso ai possedimenti degli ordini religioso-militari per i quali la riservatezza e la separazione della vita conventuale dal mondo esterno erano alle basi della loro esistenza. Certo, i possedimenti templari erano stati inventariati, ma solo dopo il loro sequestro, nel corso del processo all'Ordine. Inoltre i Giovanniti temevano che i risultati dell'inchiesta fossero utilizzati per imporre ai loro possedimenti europei nuovi obblighi fiscali.

Di conseguenza, vi fu una certa resistenza da parte dell'Ospedale di San Giovanni che fece dell'inchiesta pontificia un esempio delle difficoltà incontrate dalla Sede Apostolica nell'esercitare un controllo sull'Ospedale stesso e sugli

65 Si veda Anthony LutTrell: Introduzione, in : L'enquête pontificale de 1373 sur l'ordre des Hospitaliers de Saint-Jean-de-Jérusalem, a cura di Jean GLÉnisson, vol. 1: L’enquête dans le prieuré de France, a cura di Anne-Marie Legras/Robert Favreau, Paris 1987.

66 Ibid.

67 Sull'inchiesta nel Mezzogiorno si vedano: Raffaele Iorio: L'inchiesta di papa Gregorio XI sugli Ospedagliere della diocesi di Trani, Taranto 1996 (Gran Priorato di Napoli e Sicilia del Sovrano Ordine di Malta, Melitensia 1; Salvatore Fodale: San Giovanni in Sicilia: l'inchiesta di Gregorio IX sull'ordine gerosolimitano, in: Società, istituzioni, spiritualità. Studi in onore di Cinzio Violante, Spoleto 1994 (Centro italiano di studi sull'alto medioevo, Collectanea 1) e, adesso, L'inchiesta pontificia del 1373 sugli Ospedalieri di San Giovanni di Gerusalemme nel Mezzogiorno d'Italia, a cura di Mariarosaria Salerno/Kristjan Toomaspoeg, Bari 2008 (Università degli Studi della Calabria, Corso di Laurea in Storia e Conversazione dei Beni Culturali, Itinerario 10). 
ordini religioso-militari in generale. I prelati incaricati dell'indagine fornirono al papa dei verbali che, quasi sempre, rispecchiavano la volontà degli Ospitalieri di diminuire l'entità del loro patrimonio, sostenuti in quest'azione dai loro buoni rapporti con le gerarchie ecclesiastiche locali. Così, ad esempio nell'ambito siciliano, i vescovi delle due diocesi principali dove si concentravano le commende dell'Ospedale, Messina e Catania, arrivarono addirittura a non rispondere al papa. Tra gli altri prelati, solo il vescovo di Cefalù, tradizionalmente in conflitto con gli ordini militari, fornì a Gregorio XI una descrizione più dettagliata del loro patrimonio ${ }^{68}$, ma anche in questo caso gli Ospitalieri riuscirono a sminuire il reale valore della loro ricchezza ${ }^{69}$.

Peraltro, proprio in ambito siciliano si manifesta con più chiarezza l'effetto dello scisma del 1378, dal momento che i priori locali dell'Ospedale di San Giovanni oscillarono sempre tra l'obbedienza romana ed avignonese, a seconda degli orientamenti delle dinastie al potere ${ }^{70}$.

\section{La trasformazione dei baliati teutonici in benefici ecclesiastici nel XV secolo}

L'Ospedale rappresentò sempre un avamposto della Cristianità nelle lotte contro i Turchi e i suoi diritti patrimoniali non furono mai seriamente minacciati dal papato, anche dopo il deludente risultato dell'inchiesta del 1373. Diverso fu invece il caso dei possedimenti locali dell'Ordine Teutonico, il che mi porta all'ultimo argomento che mi ero proposto di affrontare nel corso di questa comunicazione, dedicato alla trasformazione delle commende degli ordini religioso-militari in benefici ecclesiastici.

Prima della fine del XIV secolo, l'Ospedale di Santa Maria dei Teutonici non era particolarmente noto in Italia per le sua attività nell'Europa nordorientale e le sue commende nella Penisola beneficiarono del sostegno della popolazione locale - se prendiamo in considerazione, ad esempio, le motivazioni espresse da coloro che fecero donazioni a suo favore - per lo più grazie alle loro attività caritative e assistenziali ${ }^{71}$. Il contesto mutò fra la fine del XIV e

68 Archivio Segreto Vaticano, Instr. Misc., 2807; L'inchiesta (cit. nota 67) pp. 271-274.

69 FodAle: San Giovanni (cit. nota 67).

70 Si veda ID.: Scisma ecclesiastico e potere regio in Sicilia, I. Il duca di Montblanc e l'episcopato tra Roma e Avignone (1392-1396), Palermo 1979; ID.: Il clero siciliano tra ribellione e fedeltà ai Martini (1392-1398), Palermo 1983.

71 Sulle donazioni patrimoniali a favore dei Teutonici, Kristjan Toomaspoeg: Base économique de l'expansion des bourgs siciliens. Éxemple des possessions de l'Ordre Teutonique dans la zone Corleone-Vicari-Castronovo, 1220-1310, in: Actas del XVII Congreso de Historia de la Corona de Aragón, „El món urbà a la Corona d'Aragó del 1137 als decrets de Nova Planta", Barcelona-Lleida, 7-12 septiembre 2000, Barcelona 2003, vol. 1, pp. 595-604. 
l'inizio del XV secolo, quando nella nobiltà italiana, in alcuni casi direttamente partecipante alle spedizioni dell'Ordine in Lituania, si diffuse la nuova ideologia dei Teutonici, quali combattenti contro i pagani della Prussia e della Livonia ${ }^{72}$. Nel Quattrocento, l'Ordine Teutonico fu spesso chiamato dagli abitanti della Penisola come „'Ordine di Prussia“, e, per la prima volta nella loro storia, i distaccamenti italiani dei Teutonici furono percepiti come possedimenti di un'istituzione, straniera'.

Questi beni, amministrati da pochi frati dislocati nel territorio italiano, avevano un valore economico considerevole, espresso nelle elevate rendite annue dei baliati teutonici. Nel XV secolo, la Chiesa romana cambiò visibilmente atteggiamento nei confronti di questi distaccamenti, considerandoli non più la base logistica di una guerra combattuta altrove - dopo la conversione dei Lituani alla fine del XIV secolo i Teutonici avevano perso il loro ruolo di difensori della Fede contro i pagani -, bensì semplici benefici monetari. Dunque la Sede Apostolica, che in passato aveva espropriato istituzioni monastiche del Regno di Sicilia a favore degli ordini religioso-militari, applicava adesso la stessa politica ai possedimenti teutonici, ma a suo proprio beneficio.

Di conseguenza, nel Quattrocento i Teutonici persero i loro due più ricchi baliati italiani, la Puglia e la Sicilia ${ }^{73}$, mentre il terzo, la ,Lombardia', resisté sino alla Riforma protestante, venendo poi in parte incorporato nel baliato austriaco dell'Ordine e in parte diviso tra la Repubblica veneziana e alcune congregazioni religiose, soprattutto i Gesuiti ${ }^{74}$.

Le modalità dell'esproprio furono diverse: in Puglia, il commendatore regionale dei Teutonici, Stefan Grube, che era anche un alto prelato (arcivescovo di Riga), entrato in conflitto con l'Ordine, affidò il baliato alla Curia pontificia

72 Kristjan Toomaspoeg: La guerre baltique au regard des sociétés de l'Europe méditerranéenne à la fin du Moyen Âge, in: Regards croisés sur la guerre sainte. Guerre, religion et idéologie dans l'espace méditerranéen latin $\left(\mathrm{XI}^{\mathrm{e}}-\mathrm{XIII}{ }^{\mathrm{e}}\right.$ siècle). Actes du Colloque international tenu à la Casa de Velázquez (Madrid) du 11 au 13 avril 2005, a cura di Daniel Baloup/Philippe Josserand, Toulouse 2006, pp. 399-412. Dei nobili della Penisola Italiana che hanno combattuto in Prussia si conosce prima di tutti Raimondo del Balzo Orsini: Hubert Houben: Raimondo Del Balzo Orsini e l'Ordine Teutonico, in: L'Ordine Teutonico tra Mediterraneo e Baltico: incontri e scontri tra religioni, popoli e culture. Atti del convegno internazionale. Bari/Lecce/Brindisi, settembre 2006, Galatina 2008 (Acta Theutonica 5), pp. 195-217.

73 Sulla perdita di questi due baliati, Bruno Schumacher: Studien zur Geschichte der Deutschordensballeien Apulien und Sizilien, in: Altpreußische Forschungen 18 (1941) pp. 187-230, 19 (1942) pp. 1-25.

74 Karl Schellhass: Die Deutschordenskommende zu Padua und die Jesuiten. Ein Beitrag zur Geschichte des Deutschordens in den Jahren 1511-1575, in: QFIAB 7 (1904) pp. 91-120; Johann RaIner: Zur Geschichte des Deutschordenspriorates SS. Trinità in Venedig vornehmlich im 16. Jahrhundert, in: Acht Jahrhunderte Deutscher Orden in Einzeldarstellungen, a cura di Klemens Wieser, Bad Godesberg 1967 (Quellen und Studien zur Geschichte des Deutschen Ordens 1), pp. 357-370. 
di Sisto IV. In Sicilia, il caso fu molto più complesso, dal momento che un ruolo importante fu giocato anche dal cardinal protettore dell'Ordine presso la Curia, Rodrigo Borgia. In un primo tempo, il commendatore locale dei Teutonici, temendo di essere punito dai superiori per la sua condotta indecorosa, consegnò il baliato al Borgia che ottenne il 2 maggio del 1492 da Innocenzo VIII la conferma per godere dei redditi dei possedimenti teutonici ${ }^{75}$, prima di trasformarli in un beneficio ecclesiastico quando egli stesso divenne papa (Alessandro VI) e cederli al cardinale Federico di Sanseverino a titolo di ringraziamento per il suo voto nel conclave ${ }^{76}$. Alla fine, la Corte di Ferdinando il Cattolico, che in realtà era all'origine di tutta la vicenda ${ }^{77}$, comprò il baliato dal cardinale di Sanseverino per creare sulla sua base una riserva patrimoniale di beni ecclesiastici vacanti, nota più tardi come la Commenda della Magione ${ }^{78}$.

\section{Conclusioni}

Gli esempi che ho riportato illustrano le varie fasi della politica pontificia nei confronti degli ordini religioso-militari nella Penisola Italiana. L'arrivo degli ordini, prima in veste di congregazioni assistenziali (gli Ospitalieri), poi come ordini militari veri e propri (i Templari), fu possibile grazie al costante sostegno del papato, in particolar modo di pontefici come Innocenzo II e Alessandro III che, agendo da diretti ed unici superiori degli ordini, intervennero presso le gerarchie ecclesiastiche e i poteri laici locali perché consentissero l'insediamento di Case ospitaliere e templari lungo le principali vie di comunicazione che conducevano da Occidente all'Oriente. Questo fenomeno corrispose cronologicamente alla diffusione in Italia delle congregazioni assistenziali della Terra Santa e dei Cistercensi.

Con Innocenzo III e Onorio III, gli ordini militari furono a servizio delle ambizioni politiche del papato nella Penisola, come illustra bene il caso dell'Ordine Teutonico, autorizzato dalla Sede Apostolica a combattere (nel Regno di Sicilia) anche contro i cristiani. Peraltro, le attività degli ordini in Oriente gli procurarono la speciale protezione del papato che prevalse nelle vicende politiche locali della Penisola. Così, anche in contesti difficili, come nel Mezzogiorno alla fine del regno di Federico II, o durante i diversi conflitti

75 Ad personam tuam, Mongitore: Monumenta (cit. nota 33) pp. 145-147.

76 Toomaspoeg: Les Teutoniques (cit. nota 40) pp. 895-898 nn. 1058-1070.

77 Antonio de la Torre: Unas noticias de la Orden militar de Caballeros teutones, in: Gesammelte Aufsätze zur Kulturgeschichte Spaniens 13/3, Münster 1958, pp. 270-274.

78 Antonino Giuffrida: Il potere del segno. La transizione della Magione da baliato a commenda in: Giuffrida/Houben/Toomaspoeg: I Teutonici (cit. nota 43), pp. 159202. 
veneto-genovesi, non vi furono ripercussioni notevoli sul patrimonio degli ordini militari in Italia.

Nella seconda metà del XIII secolo, i distaccamenti italiani degli ordini furono chiaramente percepiti come una base economica della Terra Santa e il papato intensificò il suo sostegno agli ordini, concedendo ai Teutonici, indeboliti dopo la battaglia di Durbe nel 1260, la canonica di San Leonardo di Siponto e incorporando nell'Ospedale, dopo la caduta di Acri, i monasteri benedettini di Sant'Angelo del Palazzo e Santissima Trinità di Venosa. I membri degli ordini militari entrarono a servizio diretto della Santa Sede, come esperti di questioni militari, e gli ultimi papi del secolo furono attorniati da Templari, Ospitalieri e Teutonici.

Il periodo avignonese del papato si apre con il Processo ai Templari che in Italia presenta delle modalità assai diverse a seconda delle singole regioni e illustra la mancanza di un progetto unico sul destino dell'Ordine. Al tempo stesso, dopo la perdita della Terra Santa, i due rimanenti grandi ordini religiosomilitari dovettero giustificare la loro esistenza presso il papato. Gli Ospitalieri ripiegarono a Rodi per combattere contro i Turchi, impresa che gli assicurò per secoli il sostegno della Sede Apostolica e del mondo cristiano, mentre i Teutonici si riservarono il più effimero ruolo di difensore della Cristianità contro i pagani del Baltico.

Di conseguenza, il destino dei possedimenti italiani dei due ordini fu diverso. Gli Ospitalieri continuarono ad usare la Penisola come base logistica per le lotte combattute nel Mediterraneo, prima di trasferire, nel XVI secolo, il loro capitolo in un territorio allora, italiano', l'isola di Malta. Il papato fece alcuni tentativi per conoscere lo stato dell'economia e del personale dei distaccamenti italiani dell'Ospedale, ma non riuscì mai a ricevere informazioni precise a loro riguardo o ad intromettersi nella distribuzione delle risorse monetarie prodotte dall'Ordine in Italia. L'Ordine Teutonico invece, a causa del suo allontanamento geografico dalla Penisola Italiana, non fu in grado di mantenervi la sua presenza e, dopo la sconfitta inflittagli dai Lituani e dai Polacchi, i suoi possedimenti più rilevanti furono espropriati dalla Santa Sede.

In questa comunicazione ho tentato di illustrare tre aspetti diversi dei rapporti intercorsi tra il papato e gli ordini militari, ovvero il sostegno, la collaborazione e l'interferenza. L'atteggiamento della Santa Sede dipese dal ruolo che si attribuiva ai possedimenti degli ordini militari in ogni singola epoca: luoghi di cura e di assistenza dei pellegrini e di raduno dei crociati, avamposti militari a servizio degli interessi del papato o centri di produzione di risorse economiche. Il caso italiano è interessante, sia per il grande impatto esercitato dagli ordini militari sul territorio, sia per la presenza della stessa Santa Sede nella Penisola e la sua vicinanza geografica con gli insediamenti degli ordini. 
Le lettere apostoliche relative agli ordini religioso-militari raccolte da Paul Fridolin Kehr e dai suoi collaboratori riguardano quindi un aspetto importante e caratteristico della storia medievale d'Italia.

\section{Zusammenfassung}

Die neudurchgesehenen Akten der Ritterorden waren eine wichtige Quelle im Editionsunterfangen der Italia Pontificia. Für die Mitarbeitern von Paul Fridolin Kehr waren sie ein Mittel, um viele unedierte Dokumente zu diesem Thema aufzuspüren.

Bringt man die Unterlagen der Italia Pontificia mit jenen zusammen, die bisher zwar unbekannt waren, aber in einschlägigen Studien publiziert oder aufgelistet sind, kann man versuchen, den logischen Weg der direkten Beziehungen zwischen den drei großen Militärorden, das heißt den Templern, den Johannitern und dem Deutschen Orden, und dem apostolischen Stuhl innerhalb der italienischen Halbinsel nachzuvollziehen.

Durch die Neulektüre einer Reihe von päpstlichen Quellen, die aus vier verschiedenen Jahrhunderten stammen, kann man die Entwicklung der Haltung nachvollziehen, die die Päpste bezüglich der Militärorden einnahmen, ausgedrückt in vier Paragraphen, die jeweils betreffen: - die Regel, die das Papsttum zur Gründung der Templer und Johanniter auf der Halbinsel im 12. Jahrhundert erlassen hat; - die Beziehung zwischen dem apostolischen Stuhl, den Templern, den Johannitern und dem Deutschen Orden im 13. Jahrhundert; das Schilderung zum Prozess über die Templer und die Schwächung des Papsttums im 14. Jahrhundert; - die Umgestaltung der Besitztümer des Deutschen Ordens in kirchliche Güter, die der päpstlichen Macht des 15. Jahrhunderts unterlagen.

Zum Schluss ist zu unterstreichen, dass die apostolischen Briefe für die Militärorden, gesammelt von Paul Fridolin Kehr und seinen Mitarbeitern, die einen wichtigen und charakteristischen Aspekt des mittelalterlichen Italiens betreffen. 


\title{
Die „Italia Pontificia“ und das Kreuzzugsgeschehen
}

\author{
Rudolf Hiestand
}

Italien ist nicht das Land des Kreuzzuges. Urban II., ein Franzose aus der Champagne, rief ihn in Clermont auf französischem Boden aus, und läßt man die alte Streitfrage offen, ob Gottfried von Bouillon ein Franzose oder ein Deutscher war, so waren in mittelalterlicher Sicht alle Anführer des ersten Kreuzzug Franzosen: Gottfrieds Brüder Balduin und Eustach, Robert von der Normandie, Robert von Flandern, die drei Angehörigen einer Königsfamilie Hugo von Vermandois, Bruder Philipps I., Robert von der Normandie, ältester Sohn Wilhelms des Eroberers, und sein Schwager Stephan von Blois, Raimund von St-Gilles und der päpstliche Legat Adhemar von Le Puy. Kein Angehöriger des Kardinalkollegiums oder des weiteren kurialen Personals, kein Erzbischof aus Italien zog mit, nur eher zweitrangige Bischöfe aus Adria, Ariano Irpino, Martirano, von denen letzterer in wenig rühmlicher Art hervortrat ${ }^{1}$. Franzosen waren auch die meisten Chronisten des ersten Kreuzzuges und in der Folge Bernhard von Clairvaux und Ludwig VII., Philipp II. Augustus und der letzte regierende abendländische Herrscher, der sich vor 1291 auf einen Kreuzzug begab, Ludwig IX. bzw. Saint Louis, wie wohl die Mehrzahl der im 12. und 13. Jahrhundert in den Osten aufbrechenden Kreuzfahrer und Pilger aus Frankreich $\mathrm{kam}^{2}$.

In Frankreich hatten ebenso alle Herrscher der Kreuzfahrerstaaten des 12. Jahrhunderts ihre familiären Wurzeln, die lothringischen Herrscher in Jerusalem, die Angevinen, die Lusignans, die tolosanische Dynastie in Tripolis und die

1 Siehe zu ihnen unten S. 645-647. Im Beitrag wurden folgende Abkürzungen verwendet: O 1-3 = Rudolf Hiestand: Papsturkunden für Templer und Johanniter, Göttingen 1972-1985 (Vorarbeiten zum Oriens Pontificius 1-3); RRH = Reinhold RöнRiснт: Regesta Regni Hierosolymitani 1097-1291, Innsbruck 1893; Ders., Additamentum, Innsbruck 1904.

2 Zur Geschichte der Kreuzzüge und der Kreuzfahrerstaaten sei hier aus der Überfülle an Gesamtdarstellungen der letzten Jahrzehnte generell verwiesen auf Hans Eberhard Mayer: Geschichte der Kreuzzüge, 10. Aufl., Stuttgart 2005 mit der Rezeption der aktuellen Forschung, A History of the Crusades, hg.v. Kenneth M. Setron, 6 Bde., Madison 1955-1989, die knappe Zusammenfassung bei Nikolas JASPERT: Geschichte der Kreuzzüge, 3. Aufl., Darmstadt 2006 (Geschichte kompakt), für die Kirchengeschichte auf Wilhelm Нотzецт: Kirchengeschichte Palästinas im Zeitalter der Kreuzzüge, Köln 1980 (Palästinahefte des deutschen Vereins vom heiligen Lande) und Bernard Hamilton: The Latin Church in the Crusader States. The Secular Church, London 1980. Auf die Aufführung von Einzelnachweisen wird bewusst verzichtet. 
Poitevins in Antiochia. Auch der erste lateinische Fürst von Antiochia, Bohemund, war ein nach Süditalien verpflanzter Normanne, der gleichsam zur Rückbindung im Jahre 1106 in das kapetingische Königshaus einheiratete ${ }^{3}$.

Dennoch war der Kreuzzug eine ,internationale“ Bewegung, die alle Teile des Abendlandes umfaßte und unter der führenden Rolle des Papsttums auch die Apenninenhalbinsel religiös, personell, politisch und logistisch einbezog. Und „international“ waren die mit Kreuzzugsidee und -geschehen existentiell verbundenen geistlichen Ritterorden mit den Templern und den Johannitern an erster Stelle. Daher stellt sich die Frage: Was tragen die Forschungen Paul Fridolin Kehrs in den Archiven und Bibliotheken Italiens und die „Italia Pontificia“ zur Geschichte der militärischen Unternehmen in den Osten, der Kreuzfahrerstaaten und der Kreuzfahrerkirche, und was trägt der lateinische Osten zur „Italia Pontificia“ bei? Welches Bild des Kreuzzugsgeschehens und des Anteils des Papsttums an ihm läßt sich aus der „Italia Pontificia“ gewinnen? Angedeutet ist damit schon, daß wir es mit drei, genauer gesagt vier Aspekten zu tun haben: den eigentlichen Kreuzzügen, den Kreuzfahrerstaaten und -kirchen, den Niederlassungen italienischer Seestädte im lateinischen Osten und den Ritterorden, und daß zu trennen ist zwischen der Rolle dieser Kreuzzugswelt in den Beziehungen der Päpste des 12. Jahrhunderts zu den Kirchen und politischen Kräften Italiens ${ }^{4}$ und den neuen Materialien für die Kreuzzugsgeschichte, die als Ergebnis der jahrzehntelangen Forschungen auf der Apenninenhalbinsel in Dutzenden von Berichten unter dem Titel „Papsturkunden in

3 Es ist vielleicht kein Zufall, daß es aus italienischer Sicht keine größere Gesamtdarstellung der Kreuzzüge gibt, die ,kanonischen' Charakter erhalten hätte.

4 IP 1-10; vgl. Paul Fridolin KeHR: Ueber den Plan einer kritischen Ausgabe der Papsturkunden bis Innocenz III., NGG 1896 S. $72-86$ (wieder abgedruckt in: Ders., Ausgewählte Schriften, Bd. 1, hg.v. Rudolf Hiestand, Göttingen 2005 [AAG, phil.hist. Kl., 3. Folge 250], S. 3-17); die Selbstanzeige von IP 1, in: GGN 168 (1906) S. 593-610 (wieder abgedruckt in: KeHR, Schriften [in dieser Anm.] S. 18-35), vgl. dazu auch den Band Hundert Jahre Papsturkundenforschung, Bilanz - Methoden Perspektiven, Akten eines Kolloquiums zum hundertjährigen Bestehen der Regesta Pontificum Romanorum vom 9.-11. Oktober 1996 in Göttingen, hg.v. Dems., Göttingen 2003 (AAG, phil.-hist. Kl., 3. Folge 261); mit dem einleitenden Beitrag: 100 Jahre Papsturkundenwerk, S. 11-44 und für die Italia Pontificia Ders.: Die Italia Pontificia, in: Das Deutsche historische Institut in Rom 1888-1988, hg.v. Reinhard Elze/Arnold Esch, Tübingen 1990 (Bibliothek des Deutschen Historischen Instituts in Rom 70), S. 167-189 und Ders.: Die unvollendete Italia Pontificia, in: Hundert Jahre Papsturkundenforschung (in dieser Anm.) S. 47-57. 
Italien" zusammengefaßt worden sind". Jene ist ein Ausschnitt aus der Geschichte des Papsttums und der Geschichte von Hunderten von Kirchen, Klöstern und politischen Gebilden auf der Apenninenhalbinsel, diese sind ein Teil der „Nachlese“ als erstem Schritt auf dem Weg zur Edition als Krönung des Ganzen und zur „urkundlichen Archivgeschichte“, die Kehr beim Erscheinen des ersten Bandes der „Italia Pontificia“ als das eigentliche Ziel des Unternehmens bezeichnete ${ }^{6}$. Wenn jene sich damit auf den Raum Italiens bezieht und die Kreuzzüge, erst recht die Kreuzfahrerstaaten und die Kreuzfahrerkirche in ihr eo ipso keinen Platz haben können, es sei denn durch Begleiterscheinungen auf italienischem Boden, sind diese ohne jede vorgegebene räumliche oder sachliche Einschränkung nur abhängig von der Überlieferung und hier interessant, soweit dabei aufgrund der streng archivalischen Vorgehensweise nebenbei Nicht-Italica zum Vorschein kamen, Stücke, die nicht Italien, sondern den lateinischen Osten betrafen.

Eine klare Trennung zwischen Italica und Nicht-Italica ist oft deswegen schwierig, weil viele transmarine Kirchen und Klöster und vor allem die großen Ritterorden auch Besitz in Italien hatten, andererseits die italienischen Seestädte und ihre Kirchen durch Niederlassungen im Osten präsent waren ${ }^{7}$. Unübersehbar besteht jedoch in dieser Reziprozität von Anfang an ein Ungleichgewicht, denn eine Nachlese im Osten, die nebenbei Italica zu Tage gefördert hätte, konnte es nicht geben, weil es Archive von lateinischen Kirchen und weltlichen Herrschaften auf dem Boden der einstigen syrischen Kreuzfahrerstaaten seit dem Fall von Akkon 1291 nicht mehr gab, auf Zypern solche spätestens 1571 restlos untergegangen waren. Doch einen gewissen Ausgleich schufen in den Westen gerettete Archive oder Archivtrümmer solcher Institutionen des lateinischen Ostens, was allerdings für unsere Fragestellung eine Reihe von schwierigen Problemen nach sich zieht, die im Vorgriff auf den Oriens Pontificius Latinus noch zu erörtern sein werden.

Wissenschaftsgeschichtlich entstand das Göttinger Papsturkundenwerk, dessen Zeitfenster dem ersten Jahrhundert der Kreuzzugsgeschichte bis zum Vorabend des vierten Kreuzzuges entsprach, als sich die Kreuzzugsforschung auf einem ersten Höhepunkt befand und eine Reihe wichtiger Arbeitsinstrumente geschaffen hatte, die für die "Italia Pontificia“ und die Nachlese nutzbar gemacht werden konnten. Drei Jahre vor Kehrs öffentlicher Vorstellung seines

5 Paul Fridolin KeHR: Papsturkunden in Italien. Reiseberichte zur Italia Pontificia 1-5, Città del Vaticano 1977 (Acta Romanorum pontificum 1-5), mit Registern von Raffaello Volpini in Bd. 6.

6 Ders.: Selbstanzeige (wie Anm. 4) S. 595-597 mehrfach (wieder abgedruckt in: KeHr, Schriften [wie Anm. 4] S. 20-22).

7 Vgl. auch die Zusammenstellung der Lemmata in Rudolf Hiestand: Initien- und Empfängerverzeichnis zu Italia Pontificia 1-10, München 1984 (Hilfsmittel der MGH 6). 
Planes veröffentlichte Reinhold Röhricht nach dem Muster der Regesta Imperii die „Regesta Regni Hierosolymitani“ über alle bisher bekannten Urkunden, die die Kreuzfahrerstaaten und die nach dem ersten Kreuzzug entstandene Kreuzfahrerkirche - nicht die Kreuzzüge und die Pilgerfahrten - betrafen ${ }^{8}$. Im gleichen Jahr erschien der erste Band der „Revue de l'Orient latin“, die sich die Aufgabe stellte, unbekannte erzählende und urkundliche Quellen zu publizieren?. Ein Jahre darauf legte Joseph Delaville le Roulx den ersten Band des monumentalen „Cartulaire général de l'Ordre des Hospitaliers de Saint-Jean-deJérusalem " vor, der in rascher Folge bis 1906 in vier Bänden über 5000 Urkunden für den Johanniterorden, darunter nicht wenige Papsturkunden, meist im Volltext, den Rest in Auszügen oder Regesten herausgab ${ }^{10}$, nachdem er Ende der 1870er Jahre in einer Art Wettlauf mit Hans Prutz die gewaltigen Schätze des Ordensarchivs auf Malta ins Bewußtsein zurückgerufen hatte ${ }^{11}$. Prutz veröffentlichte neben Johanniter- und Templerurkunden auch eine große Zahl von Papsturkunden für die Templer ${ }^{12}$, denen er im Jahre 1888 die erste wissenschaftliche Geschichte des Templerordens mit weiteren Papsturkunden ${ }^{13}$ und im Jahre 1908 eine Gesamtdarstellung der geistlichen Ritterorden folgen ließ ${ }^{14}$, die in ihrer umfassenden Sicht erst in jüngster Zeit durch die Bücher von Alan Forey und Alain Demurger überholt worden ist ${ }^{15}$.

Durch den 1841 begonnenen „Recueil des Historiens des Croisades“ der Académie des Inscriptions et Belles-Lettres, dessen letzter Band im gleichen Jahr 1906 erschien wie der erste Band der „Italia Pontificia“ und der letzte Band des "Cartulaire" von Delaville le Roux, der nun die Berichte Paul Fridolin Kehrs und Luigi Schiaparellis über ihre neuen Funde im Archiv auf Malta und in Palermo in einem Anhang zum ersten Band auswertete, standen die Chroniken des ersten Kreuzzuges Wilhelms von Tyrus und seiner Fortsetzungen zur Ver-

8 RRH (wie Anm. 1).

9 Revue de l'Orient latin 1 (1893)-12 (1911) als Fortsetzung der Archives de l'Orient latin 1 (1881)-2 (1884).

10 Joseph Delaville le Roulx: Cartulaire général de l'Ordre des Hospitaliers de SaintJean de Jérusalem, 4 Bde., Paris 1894-1906.

11 Ders.: Documents concernant les Templiers extraits des archives de Malte, Paris 1882; Ders. : Les archives, la bibliothèque et le trésor de l'Ordre de Saint-Jean de Jérusalem à Malte, Paris 1883. Zur Forschungsgeschichte vgl. auch O 1 S. 12-38.

12 Hans Prutz: Malteser Urkunden und Regesten zur Geschichte der Tempelherren und der Johanniter, München 1883.

13 Ders.: Entwicklung und Untergang des Templerordens, Berlin 1888.

14 Ders.: Die geistlichen Ritterorden, Berlin 1908.

15 Alain Forey: The Military Orders from the Twelfth to the Early Fourteenth Centuries, Basingbroke 1992 (New studies in medieval history) und Alain Demurger: Chevaliers du Christ. Les ordres religieux-militaires au Moyen Age. XI $-\mathrm{XVI}^{\mathrm{e}}$ siècle, Paris 2002. 
fügung ${ }^{16}$, während Röhricht 1898 eine nach dem Muster der "Jahrbücher des deutschen Reiches" mit enormem Fleiß zusammengestellte „Geschichte des Königreichs Jerusalem“ auf über tausend Seiten veröffentlichte, bis heute in der Fülle des Materials unübertroffen und oft zu Unrecht übergangen ${ }^{17}$.

Auch die Edition der Urkunden des lateinischen Ostens hatte rasche Fortschritte gemacht. Mit Ausnahme des "Cartulaire général de l'Ordre du Temple (1119?-1150)" des Marquis d'Albon, der die Papsturkunden bis zum Ende des Pontifikats Eugens III. (1145-1153) einschloß, lagen so 1896 schon fast alle großen Urkundenfonds für den lateinischen Osten, seien sie archivalisch oder in Chartularen überliefert, vor ${ }^{18}$. Die beiden Chartulare des Kapitels des Hl. Grabes in der vatikanischen Bibliothek mit 38 Papsturkunden bis 1198, davon neun feierliche Privilegien, in denen Besitz in Italien aufgezählt wird, hatte 1849 Eugène de Rozière herausgegeben ${ }^{19}$. Mit dem in Venedig liegenden Chartular der Kathedrale von Nikosia auf Zypern veröffentlichte wenig später Louis de Mas Latrie auch drei Papsturkunden des 12. Jahrhunderts, die jedoch außer ihrem Überlieferungsort keinen Bezug zu Italien besitzen ${ }^{20}$, Ernst Strehlke 1869 in den „Tabulae ordinis Theutonici“ aus dem Königsberger Archiv zwei Urkunden Clemens' III. und Coelestins III., die ebenfalls Italien nicht betrafen ${ }^{21}$, während das 1881 veröffentlichte Chartular der Lazariter in Turin keine

16 Recueil des Historiens des Croisades, 16 Bde., Paris 1841-1906. Übersicht in Repfont I 5-7. Die wichtigste Chronik des 12. Jahrhunderts Wilhelm von Tyrus jetzt Wilhelmi Tyrensis archiepiscopi chronicon, ed. Robert B. C. HuYgens, Turnhout 1986 (CChrCM 86 und 86A).

17 Vgl. Reinhold Röнricht: Geschichte des Königreich Jerusalem 1109-1291, Innsbruck 1898.

18 Paris 1913.

19 Cartulaire de l'église du Saint-Sépulcre de Jérusalem, Paris 1849; jetzt auch Geneviève Bresc-Bautier: Le cartulaire du chapitre de l'église du Saint-Sépulcre de Jérusalem, Paris 1986 (Documents relatifs à l'histoire des croisades 15), dazu Rudolf Hiestand in: Francia 16 (1989) S. 282-287, die Papsturkunden auch in O 3. Eine in den Chartularen nicht enthaltene Ausfertigung Lucius' III. von 1182 Juli 14 aus Barletta fügte 1886 Acta Pontificum Romanorum inedita, ed. Julius von Pflugk-Harttung, 3 Bde., Tübingen 1881-1886, hier 3 S. 293 Nr. 322, hinzu (auch O 3 S. 298 Nr. 125), siehe zu ihr unten S. 651 f. Feierliche Privilegien mit Nennung von Besitz in Süditalien sind O 3 Nr. 28, 37, 39, 47, 52, 62, 102, 172 aus den Chartularen und Nr. 125 aus Barletta. In IP 9 S. 302 werden unter Barletta in der Narratio die dortigen Besitzungen der Ritterorden und der Kirchen des Hl. Landes hervorgehoben, wie dann auch für den Deutschen Orden und die Johanniter eigene Lemmata (IP 9 S. 304 f.) folgen; für das Hl. Grab und die Kirche von Nazareth wird erwähnt, daß sie nach dem endgültigen Fall von Akkon um 1310 in Barletta Zuflucht fanden.

20 Histoire de l'Ile de Chypre sous le règne des princes de la maison de Lusignan, 3 Bde., Paris 1855-1861, hier 3 S. 599-606.

21 Tabulae ordinis Theutonici, Berlin 1869, S. 263-266. 
Papsturkunden enthält ${ }^{22}$. Aus den nach Sizilien geretteten Urkundenbeständen der Abteien im Tale Josaphat und S. Maria Latina wurden 1880 von HenriFrançois Delaborde für jene elf ${ }^{23}$, 1890 von Reinhold Röhricht für diese zwei Papsturkunden des 12. Jahrhunderts ediert ${ }^{24}$, die zum Teil auch italienischen Besitz aufführen. Schon als eine Art erster Summe erstellte Paul Riant eine Übersicht über die kleineren Überreste von Archiven und Archivtrümmern von Klöstern des Hl. Landes ${ }^{25}$, während Delaville le Roulx als Vorspann des „Cartulaire" in eine detaillierte Übersicht über die Archivbestände zur Geschichte der Johanniter auf über 200 Folioseiten, z. T. Aktenbündel um Aktenbündel auch die nach der Aufhebung des Templerordens in die Johanniterarchive integrierten Urkunden einbezog ${ }^{26}$.

Auf diese Vorarbeiten konnten sich Kehr und Schiaparelli stützen, als sie die „Nachlese" in Italien begannen ${ }^{27}$. Von 1896 an liefen die Kreuzzugsforschung und das Papsturkundenwerk parallel, doch zu einem wirklichen Austausch kam es nur ansatzweise. Zum ersten Mal wurde dies deutlich an der Jahrhundertwende, als Schiaparelli im Jahre 1899 im Auftrage Kehrs in Palermo Archive und Bibliotheken aufsuchte und in einer Handschrift des sizilischen Hofhistoriographen Antonino Amico (1586-1641) zwei unbekannte Urkunden Alexanders III. für die Abtei S. Maria im Tale Josaphat fand $^{28}$, während gleichzeitig, ohne Kenntnis vom Vorhaben des anderen, Charles Kohler aus Kopien, die Riant hatte erstellen lassen, eine Edition aller unbekannten Texte aus der gleichen Handschrift zum Teil im Volltext, zum Teil wie für die beiden gleichen Papsturkunden in Regestenform vorbereitete und im Jahre 1900 in der „Revue de l'Orient latin“"veröffentlichte ${ }^{29}$. Nicht zu ihrem Vorteil hat die

22 Comte de Marsy, Fragment d'un cartulaire de l'ordre de St-Lazare en Terre-Sainte, in: Archives de l'Orient latin IIB (1884) S. 121-157.

23 Chartes de la Terre Sainte provenant de l'abbaye de Notre-Dame de Josaphat, Paris 1880 (Bibliothèque des Écoles françaises d'Athènes et de Rome 19).

24 Reinhold Rӧнгіснт: Zur Geschichte der Kirche S. Maria Latina in Jerusalem, in: Neues Archiv 15 (1890) S. 203-206.

25 Comte Paul Riant: Les archives des établissements latins d'Orient. À propos d'une publication récente de l'École de Rome, in: Archives de l'Orient latin 1 (1881) S. $705-$ 710 (gemeint ist die Edition von Delaborde, vgl. Anm. 23).

26 Delaville le RoulX: Cartulaire (wie Anm. 10) 1 S. XI-CCXXX; vgl. jetzt auch für die Papsturkunden der beiden Ritterorden O 1 S. 41-200 und O 2 S. 15-64.

27 Siehe dazu unten S. 621-623.

28 Paul Fridolin Kenr: Ueber die Papsturkunden für S. Maria de Valle Josaphat, NGG 1899 S. 338-368, hier S. 366 Nr. 6 und 367 Nr. 7 (wieder abgedruckt in: Ders., Ausgewählte Schriften [wie Anm. 4] S. 318 f.) und O 3 S. 258 f. Nr. 99 f.

29 Charles Kohler, Chartes de l'abbaye de Notre-Dame de la vallée de Josaphat en Terre Sainte, in: Revue de l'Orient latin 7 (1900) S. 108-222, hier S. 141 Nr. 31 und S. 145 Nr. 35. Trotz der Ortsangabe Dat. Beneventi stellte Kohler die erste der beiden Urkunden zu 1159-1180 und erwähnte nur in einer Anmerkung, daß der Papst 1168 und 1169 in 
englisch- und französischsprachige Kreuzzugsforschung die Ergebnisse des Göttinger Papsturkundenwerkes erst sehr spät zu rezipieren begonnen.

II.

Beginnen wir mit der Nachlese und den Kreuzfahrerstaaten und der $\mathrm{Kreuzfahrerkirche.} \mathrm{In} \mathrm{einem} \mathrm{umfassenderen} \mathrm{Blick} \mathrm{konnte} \mathrm{man} \mathrm{sich} \mathrm{im}$ Jahre 1896 fragen, ob aus einer neuen Durchsicht von Archiven und Bibliotheken Italiens wie in allen anderen Teilen Europas noch Unbekanntes hervorgehen werde. Möglich schien dies höchstens in Beständen, die auf die eine oder andere Weise vor 1291 oder 1571 in den Westen gerettet worden waren, aber dem suchenden Auge der Kreuzzugshistoriker bisher entgangen waren. $\mathrm{Da}$ Chartulare des Hl. Grabes und eine vereinzelte Papsturkunde und Chartulare der Kathedrale von Nikosia und der Lazariter in italienischen Archiven lagen, Urkunden von S. Maria Latina und von S. Maria im Tale Josaphat und von S. Maria auf dem Sionsberg nach Messina, mindestens eine Königsurkunde des Templum Domini nach Apulien und dann nach Cava de' Tirreni, die Urkunden der Abtei auf dem Thabor in Galiläa schon 1256 mit dieser an die Johanniter gelangt waren und deren Archivgeschichte geteilt hatten, war bekannt $^{30}$. Dagegen waren weder vom Erzbistum Nazareth, das sich in Barletta neu konstituiert hatte, vom Erzbistum Tyrus, das mit Oristano auf Sardinien als neuem Sitz verbunden worden war $^{31}$, oder vom Patriarchat Antiochia, dessen Titular noch vor der Eroberung durch Baybars zuerst Limassol auf Zypern, dann Genua als Ausstattung erhielt und sehr wohl die Möglichkeit besessen hätte, Urkunden in Sicherheit zu bringen, ältere Papsturkunden in italienischen Archiven erhalten geblieben. Dies gilt auch für alle anderen Archive der Diözesanorganisation außer der Kopie einer Urkunde Innozenz' II. in einem genuesischen Kopialbuch. Neben Einträgen in den päpstlichen Registern mit der Erwähnung von Vorurkunden des 12. Jahrhunderts für die Diözesen Nazareth, Valenia, Tyrus und Tortosa haben wir für Bethlehem nur als Kopien, die vor dem Ende der Kreuzfahrerstaaten im Osten erstellt wurden, in Varazze in Ligurien und in Bologna feierliche Privilegien des 13. Jahrhunderts, die wiederum Vorurkunden des 12. Jahrhunderts erwähnen ${ }^{32}$. Zwar weiß man, daß St. Lazarus in Bethanien Besitz in der Diözese Agrigento hatte, die Zisterzienserabtei Belmont in der Diözese Tripolis ebensolchen auf Sizilien und daß zwischen S. Samuel auf dem Freudenberg und S. Samuel in Barletta vielleicht eine Ab-

Benevent geweilt habe, die zweite wegen des Abtes Petrus als Adressat zu 1164-1176, mit dem gleichen Hinweis auf das Itinerar.

30 Vgl. Riant: Les archives (wie Anm. 25) und O 3 S. 68-71 für Mons Thabor.

31 IP 10 S. 453.

32 Vgl. O 3 passim. 
hängigkeit bestand ${ }^{33}$, doch für sie alle sind keine Papsturkunden und vor allem keine feierlichen Privilegien der päpstlichen Kanzlei mit Besitzlisten weder des 12. noch des 13. Jahrhunderts erhalten.

$\mathrm{Zu}$ den für ihren heutigen Aufbewahrungsort ,fremden' Beständen aus dem lateinischen Osten, in der Regel dort, wo die einzelnen Kirchen und Klöster spätestens nach 1291 institutionell und personell einen Zufluchtsort fanden, konnten jedoch, wenn auch in einer oft nur schwer zu trennenden Gemengelage gerade Papsturkunden kommen, die trotz des anderen Anscheins als genuiner Besitz gelten müssen. Denn die Niederlassungen von Kirchen und Klöstern der Kreuzfahrerstaaten im Westen besaßen oft aus logistischen Gründen angesichts der großen Entfernung vom Mutterhaus eigene Papsturkunden für die der Institution zugestandenen Vergünstigungen, die dennoch, weil ihr Inhalt der ganzen Gemeinschaft zustand, weder in der Adresse noch im Kontext ihren nachgeordneten Empfänger angaben ${ }^{34}$, scheinbar also aus dem Osten stammten, in Wirklichkeit nie die Apenninenhalbinsel verlassen hatten.

Dementsprechend enthielten die bis 1896, dem Beginn der Nachlese für das Göttinger Unternehmen, bzw. 1906, dem Erscheinen des ersten Bandes der „Italia Pontificia“, von der Kreuzzugsforschung veröffentlichten Papsturkunden außer wenigen Stücken für die Ritterorden keine an einen italienischen Empfänger gerichteten Papsturkunden, die offenkundig zu einem Regest in ihr hätten führen müssen. Zudem ergaben nach dem von Kehr für die „Italia Pontificia" entwickelten Arbeitsprinzip die in Papsturkunden für Abteien und Kirchen im Hl. Land aufgeführten Besitzungen in Italien keine Regesten für die „Italia Pontificia“. Erst mit dem Fortschreiten der „Italia Pontificia“ wurde, wenn auch ganz unsystematisch, in den einleitenden Narrationes der einschlägigen Diözesen oder Orte wie etwa unter Barletta, Agira, Messina, Agrigento usw. ein knapper Hinweis auf solchen (Fremd-)Besitz und gegebenenfalls dort aufbewahrte Papsturkunden eingefügt.

Die Hoffnung, auf italienischem Boden weitere Reste der geistlichen Archive aus den Kreuzfahrerstaaten zu finden, die nach Hattin, in der Zeit Friedrichs II. oder beim Fall von Akkon 1291 in den Westen verbracht worden wären, erfüllte sich in der Tat nicht. Kehr hat keinen großen, bisher unbekannten Bestand mit Papsturkunden für die Kreuzzugsgeschichte ,entdeckt'.

33 Neben Riant: Les archives (wie Anm. 25) vgl. Lynn Townsend White jr.: Latin Monasticism in Norman Sicily, Cambridge/Mass. 1938, passim; Geneviève Bresc-BAUTIER: Les possessions des Églises de Terre-Sainte en Italie du Sud (Pouille, Calabre, Sicile), in: Roberto il Guiscardo e il suo tempo (Relazioni e comunicazioni nelle prime Giornate normanno-sueve), Rom 1975 (Fonti e studi del corpus membranarum italicarum 11), S. 13-24.

$34 \mathrm{Zu}$ den „cismarinen“ Archiven vgl. Riant: Les archives (wie Anm. 25), zur Überlieferung der Papsturkunden vgl. O 3 S. 19-83, für die Templer und Johanniter vgl. Anm. 26, für die Kanoniker des Heiligen Grabes vgl. vor allem O 3 S. 29-32. 
Solche Funde waren nach den intensiven vorangehenden Forschungen von Delaville, Prutz, Riant, Delaborde und Röhricht von vorneherein wenig wahrscheinlich. Erst Walther Holtzmann gelang bei der Vorbereitung der beiden letzten Bände der "Italia Pontificia“ in Agira, das Schiaparelli und Kehr nicht aufgesucht hatten, mit dem Archiv von S. Maria Latina ein solcher Fund ${ }^{35}$.

Dennoch war der Ertrag der Nachlese für die Kreuzfahrerkirche nicht unbedeutend. Vor allem auf Sizilien und Malta hat die nochmalige Durchsicht von Urkundenfonds und Handschriften die bisherigen Ergebnisse z.T. erheblich erweitert $^{36}$. Von den zwei Stücken Alexanders III. für S. Maria im Tale Josaphat aus den Handschriften Amicos in Palermo ist schon die Rede gewesen. Sie sicherten Ende der 1160er Jahre der jerusalemitanischen Abtei Schutz gegen Leistungsforderungen des Patriarchen von Jerusalem ${ }^{37}$ und erweiterten die einige Jahre zuvor vom Legaten Johannes von SS. Giovanni e Paolo als Dank für die Unterstützung Alexanders III. im Kampf gegen Viktor IV. verliehenen Rechte des Abtes auf die Pontifikalinsignien als die letzten Papsturkunden des 12. Jahrhunderts für die Abtei ${ }^{38}$. Zu ihnen und den von Delaborde und PflugkHarttung edierten Papsturkunden ${ }^{39}$ kamen nun im Staatsarchiv Palermo und im bisher nicht beachteten Museo Civico in Catania fünf weitere, darunter drei Spuria aus mehreren aufeinanderfolgenden Fälscheraktionen, die vermutlich wegen königlicher Revokationen im 13. Jahrhundert ausgedehnten Besitz in Sizilien und in Kalabrien sichern sollten und von Delaborde wohl bewußt beiseite gelassen worden waren ${ }^{40}$. Daneben bestätigten zwei neue Papsturkun-

35 Walther Holtzmann: Papst-, Kaiser- und Normannenurkunden aus Unteritalien 1, in: Quellen und Forschungen aus italienischen Archiven und Bibliotheken 35 (1955) S. 47 49. Genau genommen war ihm G. Pietro Sinopoli di Giunta: La badia regia di S. Maria Latina in Agira, Acireale 1913, und Ders.: Tabulario di S. Maria Latina di Agira, in: Archivio storico per la Sicilia orientale 22 (1926) S. 135-190, vorangegangen, doch erst durch Holtzmann kam das schwer zugängliche Archiv ins allgemeine Bewußtsein. Vollständig ist das Archiv freilich für den transmarinen Besitz nicht. Es fehlen alle Königsurkunden und fast völlig Privaturkunden. Drei Urkunden für Tripolis hat Jean Richard: Le chartrier de Sainte-Marie-Latine et l'établissement de Raymond de SaintGilles à Mont-Pèlerin, in: Mélanges de l'histoire du Moyen Âge dédiés à la mémoire de Louis Halphen, Paris 1951, S. 605-611, herausgegeben.

36 Als „neu“ galten im Sinne Kehrs die in Jaffés zweiter Auflage nicht verzeichneten Stücke.

37 O 3 S. 258 Nr. 99.

38 O 3 S. 259 Nr. 100.

$39 \mathrm{Zu}$ den zehn bei Delaborde, Chartes (wie Anm. 23) edierten Stücken kam noch JL $\dagger 8096$ bei Pflugk-Harttung, Acta (wie Anm. 19) 2 S. 312 Nr. 350 hinzu.

40 Sie wurden von Kehr in einem eigenen Bericht, der nicht in den Nachdruck von Volpini aufgenommen wurde, zusammen mit den vier anderen echten Urkunden ediert, KEHR, Papsturkunden (wie Anm. 28) S. 338-368 (wieder abgedruckt: Ders., Schriften [wie Anm. 4] S. 290-320). Die Frage ihrer Entstehungszeit und Intention ist freilich bis in die jüngste Zeit mehrfach kontrovers erörtert worden, vgl. zuletzt Theo Kölzer: Neues 
den, ein Original Innozenz' II. und die Kopie einer Urkunde Eugens III., beide aus Catania ${ }^{41}$, eine Kirche und Zehnten in Galiläa und Besitz in Paternò auf Sizilien als Sonderbesitz unter Zinspflicht an die päpstliche Kammer ${ }^{42}$. Sie betrafen damit sowohl den Westen als auch den Osten, gingen aber aus den genannten Verfahrensgrundsätzen nicht als Regesten in die "Italia Pontificia“ ein, wo sie unter Paternò wenigstens in der Narratio erwähnt wurden. Ob das Original Innozenz' II. überhaupt über Jerusalem und Akkon oder nicht unmittelbar nach Sizilien gekommen ist, bleibe offen. Als Ergebnis der Nachlese waren so achtzehn Stücke für die jerusalemitanische Abtei statt elf bekannt.

Für S. Maria Latina, für das vorher nur zwei Urkunden Hadrians IV. und Alexanders III. bekannt waren ${ }^{43}$, kam aus dem Archiv in Agira als älteste Papsturkunde für die Abtei ein Privileg Paschalis' II. hinzu ${ }^{44}$, das vor allem die innere Ordnung und den Ritus der Gemeinschaft und ihre Rechte regelt, aber nur allgemein den Besitz im Osten bestätigt, und eine Besitzbestätigung Coelestins III. für Kirchen in Sachsen und Acquapendente im nördlichen Latium ${ }^{45}$. Eine weitere Papsturkunde Alexanders III., als Regest in einem riesigen Inventar von Papsturkunden auf Malta (Vol. 1132) verzeichnet, war wohl im 13. Jahrhundert bei den Johannitern hinterlegt worden ${ }^{46}$. Hier hatte sich der Bestand an Papsturkunden für die älteste lateinische Abtei im Hl. Land so mehr als verdoppelt.

Auch für die Abtei auf dem Berge Thabor, für die bisher an Papsturkunden des 12. Jahrhunderts bisher nur zwei feierliche Privilegien Paschalis' II. und Eugens III. überliefert waren, ließen sich in Valletta zusätzliche Angaben zu einem verlorenen, auch historisch interessanten Privileg Alexanders III. gewinnen, von dem erst seit kurzem ein Regest aus einem Inventar von verlorenen Johanniterurkunden aus der Provence bekannt gewesen $\operatorname{war}^{47}$. Denn das gleiche

zum Fälschungskomplex von S. Maria de Valle Josaphat, in: DA 37 (1981) S. 140-161. Die insgesamt fünf Spuria sind in O 3 nicht neu ediert worden, weil ihre sich auf den Besitz im lateinischen Osten und die allgemeinen Rechte beziehenden Abschnitte wörtlich den entsprechenden Abschnitten in den echten Privilegien Paschalis' II. von 1113 Januar 2, ed. O 3 S. 117 Nr. 14, und Innozenz' II. von 1140 Mai 18, ed. O 3 S. $156 \mathrm{Nr}$. 44, entnommen sind.

41 Vgl. die Übersicht über die Überlieferung in O 3 S. 38-41.

42 O 3 S. 159 Nr. 45 und S. 199 Nr. 66.

43 Vgl. Anm. 24.

44 O 3 S. 112 Nr. 12.

45 O 3 S. 369 Nr. 184. Für eine Aufnahme in IP 2 kam auch das Regest bei Sinopoli (wie Anm. 35) S. 141 Nr. 6 zu spät, doch wäre es nach dem waltenden Prinzip höchstens zu einer Erwähnung in der Narratio gekommen, für GP 5/2 ist die Urkunde dagegen übersehen worden. Zum Vol. 1132 siehe unten S. 659-661.

46 Kenr, Papsturkunden in Italien (wie Anm. 5) 2 S. 122; O 3 S. 294 Nr. 120.

47 Joseph Delaville le Roulx : Inventaire de pièces de l'Ordre de l'Hôpital, in: Revue de l'Orient latin 3 (1895) S. 36-106, hier S. 55 Nr. 72; Ders.: Cartulaire (wie Anm. 10) 2 S. 904 Nr. XII zu (1159-1163). 
Inventar in Vol. 1132 auf Malta gab aus dem verlorenen Original das bisher unbekannte Datum von 1161 Januar $12^{48}$. Es zeigt die Abtei gleich nach dem Konzil von Nablus im Sommer 1160, das sich im Schisma für Alexander III. entschied, an der Kurie Roland Bandinellis, um eine neue Bestätigung ihrer Rechte zu erlangen ${ }^{49}$.

In der anderen Blickrichtung kamen für abendländische Institutionen, deren Kontakte mit dem Hl. Land bereits bekannt waren, neue Papsturkunden nur für die Kommune von Genua hinzu. Sie hatte ihren Besitz in Byblos in der Grafschaft Tripolis einem Hugo de Embriaco aus einer der führenden Familie der Stadt gegen einen Treueid und jährlichen Zins verpachtet. Doch seit den 1160 er Jahren trachteten die Embriaci, ihre Verpflichtungen gegenüber der Mutterstadt abzuschütteln. Ohne Möglichkeiten, direkt in Byblos einzugreifen, suchten die Genuesen daher neben den lokalen Mächten die Unterstützung des Papsttums, zuerst Alexanders III., dann Lucius' III., schließlich in den Jahre 1186-1187 Urbans III., um in einer konzertierten Einschüchterungsaktion, bei der es auch um weitere Konfliktpunkte ging, mit Hilfe des Grafen von Tripolis, der Patriarchen von Jerusalem und Antiochia und der Bischöfe von Byblos und Tripolis weltlichen und kirchlichen Druck auf den Rebellen auszuüben ${ }^{50}$. In der ältesten Handschrift des Liber iurium Genuensium, des offiziellen Urkundenbuches der Kommune, die damals noch in Paris lag, fand Léopold Delisle, der sie auf Bitten Kehrs durchsah, zu vier bereits bekannten päpstlichen Schreiben Urbans III. für die causa Embriaci noch zwei weitere. Da sie mehr Parallelurkunden zu den anderen darstellen, als zu den Rechten der Kommune Neues beitragen, waren sie vielleicht in den vorher allein zugänglichen Abschriften des

48 KeHr, Papsturkunden in Italien (wie Anm. 5) 2 S. 94 und Anm. 13.

49 O 3 S. 227 Nr. 84. Es war Schiaparelli noch entgangen, daß im Vol. 1132 ein ausführlicheres Regest über die Aufnahme in den päpstlichen Schutz, die Zehntenbefreiung, die Sepultur und die Exemtion, wenn auch leider ohne Besitzliste, nicht unter den Originalen Alexanders III., sondern unter einer langen Reihe von Transsumpten für die Abtei aus dem Jahre 1255 steht, vgl. jetzt O 3 S. 227 ff. Zum Bullarium Melitense des Sebastiano Paoli in der Biblioteca Governativa in Lucca, wo sich ein Auszug aus dem Transsumpt von 1255 findet, den Delaville, Cartulaire (wie Anm. 10) 2 S. 825 Nr. 2830 ediert hatte, vgl. unten. Die Abtei auf dem Thabor hatte zwar am Anfang des 12. Jahrhunderts Besitz in den Abruzzen erhalten, vgl. ebd. S. 899 Nr. V, doch war dieser anscheinend rasch verloren gegangen und erscheint schon in der Urkunde Eugens III. von 1146, ed. O 3 S. 187 Nr. 61 nicht mehr.

50 Vgl. auch Marie-Luise Favreau-Lilie: Die Italiener im Heiligen Land vom ersten Kreuzzug bis zum Tode Heinrichs von Champagne (1098-1197), Amsterdam 1989, S. 169-172, 226 f.; zum Stammvater der Embriaci, der schon 1100/1101 im Osten ist, auch Franco Cardini: Profilo di un crociato: Guglielmo Embriaco, in: Ders.: Studi sulla storia e sull'idea di Crociata, Rom 1993, S. 63-80. 
Liber iurium im Sinne rationeller Arbeitsweise als überflüssig weggelassen worden ${ }^{51}$.

Wenn die zwei Stücke für Byblos sachlich keine neuen Erkenntnisse vermittelten, nur durch den Textvergleich einen Einblick in die Arbeitsweise der Kanzlei bei einer Vielzahl von Parallelurkunden an verschiedene Empfänger gewähren, die im 13. Jahrhundert unter eodem modo in die Register eingetragen worden wären, also kanzleitechnisch von Interesse sind, so verhält es sich ganz anders mit den zwei letzten hier noch zu erwähnenden neu aufgefundenen Urkunden. Sie gehören nun wieder zur Diözesankirche des Ostens. Im Archiv von S. Paolo fuori begegnete Kehr der Kopie einer Verfügung Coelestins III. von 1193 September 26 zugunsten der Lazariter. Sie wurde vorerst nur in gekürzter Form ediert und trotz allgemeiner Adresse an den Meister des Leprosenhauses und die Brüder entgegen dem leitenden Prinzip in die „Italia Pontificia“ mit einem Regest unter einem Leprosenhaus in der Diözese Todi, S. Maria Maddalena de Monte Niblo, aufgenommen ${ }^{52}$. Einen Hinweis auf diese Zugehörigkeit gibt die Urkunde freilich nicht ${ }^{53}$. Der Inhalt mit der Bestätigung einer confraternitas ihrer Priester - nicht eine Aufnahme in den päpstlichen Schutz, wie sowohl in der Edition als auch im Regest in der „Italia Pontificia“ steht - stellt nichts außergewöhnliches dar. Doch erstens handelt es sich um die einzige im Volltext erhaltene Papsturkunde des 12. Jahrhunderts für die Lazariter überhaupt, und zweitens wirft die Überlieferung bisher nicht beachtete Probleme auf. Gegen eine angesichts der Überlieferung in S. Paolo fuori naheliegende Annahme schließt die Tatsache, daß sie - als fast einziges aller hier zu behandelnden Stücke - auch in den päpstlichen Registern und zwar in einer Urkunde Clemens' VII. von 1389 als Insert überliefert ist, de facto sowohl eine römische Niederlassung der Leprosen als auch die von Kehr angegebene in Umbrien als ursprüngliche Empfängerin aus, denn mit Clemens VII. war die Urkunde mitten im großen abendländischen Schisma einem avignonesischen Papst zur Inserierung vorgelegt worden ${ }^{54}$. Es ist daher nicht sicher, ob das Original an eine Niederlassung in Italien gegangen war oder ob die Kopie erst später nach Rom gekommen ist. In jedem Fall ist hinter die Aufnahme in die „Italia Pontificia“ ein Fragezeichen zu setzen.

Zum anderen brachte die Nachlese in Italien nebenbei einen Fund, der an Bedeutung für die Geschichte der Kreuzfahrerstaaten alle bisher genannten weit

51 Es könnte sich auch um einen Kopistenfehler gehandelt haben, der sich perpetuierte.

52 KeHr, Papsturkunden in Italien (wie Anm. 5) 2 S. 375 Nr. 43 (nur Auszug); dann in IP 4 S. 42 Nr. 1; der volle Text jetzt in O 3 S. 346 Nr. 168.

53 Dem Hinweis Kehrs, daß das Archiv der Leprosen sich in San Paolo befinde, müßte nochmals genau nachgegangen werden; einschlägig sind vor allem Vat. Lat. 7927 und 7932 und das Kopialbuch in S. Paolo fuori saec. XVIII, in dem auch die Urkunde Celestins III. enthalten ist. Zum Chartular für die Lazariter siehe oben.

54 Dies ist auch in O 3 S. 346 Nr. 168 nicht beachtet worden. 
übertrifft, ohne einen erkennbaren Zusammenhang mit den Beziehungen des Papsttums zu Italien und hier ohne zu einem Regest in der „Italia Pontificia“ zu führen. Es handelt sich um eines jener Nicht-Italica in den Papsturkunden in Italien, die wir zu Beginn erwähnt haben. Als Kehr im Jahre 1912 in der Ambrosiana in Mailand eine Nach-Nachlese für den Abschluß des Bandes 6/1 für die Lombardei hielt, stieß er auf ein feierliches Privileg Lucius' III. für das Bistum Beirut unter Bischof Odo von 1184 September 5, das sogleich in den Göttinger Nachrichten veröffentlicht wurde ${ }^{55}$. Es war ein schlagender Beleg, wie richtig die Entscheidung gewesen war, den Berichten den Titel „Papsturkunden in Italien“ und nicht etwa „Papsturkunden für Italien“ zu geben und jeweils alle neugefundenen Papsturkunden, nicht nur diejenigen für die „Italia Pontificia“ zugänglich zu machen. Weitere Urkunden für Beirut finden sich in der Ambrosiana nicht, was auch für die unbekannte Herkunftsinstitution gelten muß, aus der das Stück nach Mailand kam, denn schon im Mittelalter schrieb eine ordnende Hand auf die Rückseite knapp Nihil ad nos. Glücklicherweise blieb soviel Ehrfurcht vor dem prächtigen Exemplar eines feierlichen Privilegs mit Elongata, Rota, Benevalete und Kardinalsunterschriften, daß es nicht wie so manches „unnütze“ Pergament weggeworfen oder für andere Zwecke verwendet wurde. Weder Bischof Odo noch die namentlich erwähnten Kanoniker noch die angeführten Besitzungen, ausschließlich im Osten gelegen, haben etwas mit Oberitalien zu tun. Sollte es sich etwa um ein nachher nicht mehr ausgelöstes Depositum des vielleicht wegen seiner Reise an die Kurie in finanzielle Schwierigkeiten geratenen Bischofs handeln? ${ }^{56}$ Doch dies sind Spekulationen. In jedem Fall verdanken wir der auf vollständige Erfassung aller Überlieferungen von Papsturkunden für wen auch immer ausgerichteten „Nachlese“, ohne die es vielleicht noch lange unbemerkt geblieben wäre, das einzige erhaltene Original eines feierlichen Privilegs für ein Bistum der Kreuzfahrerstaaten von ihrer Gründung bis zum Untergang im Jahre 1291, das zudem neben der üblichen Besitzliste und der Aufzählung der Rechte wertvolle Angaben über die kirchenrechtlich heikle Zehntenregelung für die im Bistum lebenden Angehörigen der anderen christlichen Gemeinschaften, Maroniten und Griechen, brachte ${ }^{57}$.

Faßt man das Ergebnis der Archivforschungen in Italien im Blick auf die Kreuzfahrerkirche zusammen, so sind es in absoluten Zahlen nicht viele neue Stücke. Einschließlich der beiden Stücke für Byblos kamen 16 unbekannte

55 KeHr, Papsturkunden in Italien (wie Anm. 5) 5 S. 399 Nr. 24; O 3 S. 303 Nr. 127, vgl. O 3 S. $57 \mathrm{f}$.

56 Bischof Odo wird in der Totenliste der Belagerung von Akkon aufgeführt, vgl. Roger de Hovedene: Chronica, London 1868-1871 (Rolls Series 51), 3 S. 87; hier aus geht hervor, daß er in den Osten zurückgekehrt und nicht etwa unterwegs verstorben ist.

57 Vgl. Rudolf Hiestand: Die Integration der Maroniten in die römische Kirche. Zum ältesten Zeugnis der päpstlichen Kanzlei (12. Jh.), in: Orientalia christiana periodica 54 (1988) S. 119-152. 
Papsturkunden zum Vorschein. Schon die Gegenüberstellung zu den 63 vorher bekannten Stücken zeigt jedoch den sehr beträchtlichen Zugewinn, der von der sachlichen Bedeutung her noch bestätigt wird: non multa, sed multum. Er wird sich in seinem vollen Gewicht im künftigen Oriens Pontificius Latinus zeigen, in die „Italia Pontificia“ ist dagegen außer den beiden Stücken für Byblos und, vielleicht zu Unrecht, in jedem Fall gegen das sonst waltende Prinzip, dem Stück für die Lazariter keines als Regest eingegangen.

Von der Nachlese zu den Regestenbänden: Was trägt die „Italia Pontificia“ zur Geschichte der Kreuzfahrerkirche und der Kreuzfahrerstaaten bei? Noch einmal ist zu betonen, daß Papsturkunden für einen Empfänger außerhalb Italiens, auch wenn sie Besitz in Italien anführen, ja ggf. ausschließlich solchen betreffen, als Nicht-Italica galten. Für keine Diözesankirche oder Abtei des lateinischen Ostens findet sich daher in der „Italia Pontificia“ ein eigener Abschnitt. Erwähnt wurden sie, wenn sie nach 1291 ihren Sitz im Exil in Italien hatten oder in den Archiven ihrer abendländischen Niederlassungen Papsturkunden für die Institution als Ganzes aufbewahrt wurden, höchstens in den Narrationes. Dies war in größerem Umfang aus historischen Gründen fast nur für Süditalien der Fall ${ }^{58}$, und aus der wachsenden Erkenntnis, daß dem Benutzer sonst wesentliche Informationen entgehen, steigt mit dem Fortschreiten der "Italia Pontificia“ die Zahl solcher Hinweise. Dennoch wirkt sich der Nachteil dieses Vorgehens gerade bei der Frage nach den Beziehungen des Papsttums zum lateinischen Osten aus ${ }^{59}$. Denn noch immer müssen, um Niederlassungen und Archivreste zu erfassen, Band um Band, Narratio um Narratio einzeln durchgelesen werden, weil die Überschriften der einzelnen Abschnitte diese rechtlichen Bindungen nur selten ausweisen. Weder unter Agira, Monasterium s. Philippi noch unter Paternò, Ecclesiae s. Mariae virg. et s. Mariae Magdalenae oder Messina, Ecclesia s. Mariae Magdalenae ${ }^{60}$ ist ohne Vorkenntnis ersichtlich, daß es sich beim ersten um eine frühe Niederlassung, nach 1291 den Sitz von S. Maria Latina handelt, beim zweiten um Besitz von S. Maria im Tale Josaphat, ebenso beim dritten und zugleich den späteren Sitz dieser Abtei. Ähnlich findet sich nur in der Narratio zum Kapitelarchiv von Agrigento der Hinweis, daß S. Spirito in Caltanissetta eine Kopie eines verfälschten feierlichen Privileg Alexanders III. für die Abtei auf dem Berge Sion besaß ${ }^{61}$, in dem es als Besitz der Abtei in Jerusalem aufgeführt wurde, und erst auf dem Umweg über dessen in der „Italia Pontificia“ nicht erwähnte Edition in der Sicilia Sacra des Pirro ${ }^{62}$

58 Also die Bände IP 9 und IP 10; Band IP 8 erweist sich unergiebig.

59 Diese Fragestellung wurde auch für den Indexband Initien- und Empfängerverzeichnis zu IP 1-10 (wie Anm. 7) nur ansatzweise berücksichtigt.

60 IP 10 S. 294, 295 und 344.

61 Ebd. S. 262. Dort findet sich auch ein Hinweis auf Besitz von S. Maria Latina in der Diözese Agrigento.

62 Rocco Pirro: Sicilia Sacra, 2. Aufl., Panormi 1731, 2 S. 584. 
erfährt man, daß im 17. Jahrhundert das Original dieses Stückes in Messina lag. Alle Angaben über sizilischen Besitz transmariner Kirchen und deren Archive stehen zudem unter dem Vorbehalt, daß im 17. Jahrhundert riesige Urkundenbestände aus der Insel nach Spanien verschleppt wurden, deren Existenz im Archiv des Duque de Medinaceli in Sevilla unterdessen zwar bekannt ist, die Bestände selbst aber noch teils unerschlossen, teils unzugänglich sind. Man wird wohl eines Tages größere Abschnitte der Sicilia neu schreiben können bzw. müssen.

Bei der Suche nach dem Niederschlag solcher Beziehungen über das östliche Mittelmeer hinweg sei wieder getrennt zwischen Regesten für Niederlassungen transmariner Institutionen auf italienischem Boden, also im Blick von Osten nach Westen, und Regesten für Kirchen und Rechte italienischer Seestädte in Syrien, also im Blick von Westen nach Osten. Bei diesen handelt es sich um genuine Teile der „Italia Pontificia“63. Doch zahlenmäßig ist ihr Anteil an der „Italia Pontificia“ überraschend gering. Erstmals wird eine solche Urkunde unter Pisa verzeichnet, das sich angesichts des raschen Herrscherwechsels auf dem Thron von Jerusalem nach dem Zusammenbruch des Königreichs im Jahre 1187 die Freiheiten und Immunitäten, die ihm König Guido mit seiner Gattin Sybille, Richard Löwenherz und dann der ermordete Konrad von Montferrat gewährt hatten, im Jahre 1193 von Coelestin III. bestätigen ließ ${ }^{64}$. Sie bleibt aber zugleich die einzige erhaltene Urkunde für Pisas Stellung im Osten, denn weder die Kathedrale noch eine andere Kirche ließen sich im 12. Jahrhundert dortigen Besitz vom Papsttum bestätigen. Ohne eine solche Papsturkunde blieben Siena und Florenz, deren große Zeit erst im 13. Jahrhundert kam. Lucca, das am ersten Kreuzzug noch regen Anteil genommen hatte, erscheint in der Folge nicht mehr. Ob es für Ancona die historischen Fakten spiegelt oder nur eine Folge der Überlieferung ist, wenn man im 12. Jahrhundert nichts von transmarinem Besitz erfährt, muß offen bleiben ${ }^{65}$. Selbst für Venedig sind nur wenige Regesten für den lateinischen Osten zu finden, für S. Marco drei Besitzbestätigungen für Jerusalem, Tripolis, Antiochia, Cayphas und die Kirche S. Marco in Akkon ${ }^{66}$, und für S. Niccolò al Lido eine solche für seinen Besitz im

63 Vgl. generell Favreau-Lilie: Die Italiener (wie Anm. 50) und Dies.: Die italienischen Kirchen im heiligen Land 1098-1291, in: Studi veneziani n. s. 12 (1987) S. 15-101.

64 IP 3 S. 363 Nr. 46.

65 Noch im 13. Jahrhundert trägt eine paläographische Schwierigkeit dazu bei, daß es bei manchen Nachrichten unsicher bleibt, ob Acon oder mit einem Kürzungsstrich über dem a Ancon zu lesen ist.

66 Alexander III. von 1165 Mai 13; JL 11189; ed. O 3 S. 241 Nr. 89, vgl. IP 7/2 S. 147 Nr. 2, für den Procurator von S. Marco. Weiteres ist wohl durch den Verlust des Archivs bei einem Brand im Jahre 1232 verloren, aber vgl. Favreau-Lilie: Die Italiener (wie Anm. 50) S. 382 ff.; Dies.: Die italienischen Kirchen (wie Anm. 63). 
Königreich Jerusalem und in Akkon ${ }^{67}$. In Süditalien trat Amalfi, das im 10./ 11. Jahrhundert in den Beziehungen zum östlichen Mittelmeer eine wichtige Rolle gespielt hatte und dessen Kaufleuten die Gründung des Spitals in Jerusalem verdankt wurde, aus dem der Johanniterorden hervorging, bei allerdings desolaten Archivverhältnissen bereits völlig zurück, so daß bis zum Ende des 12 . Jahrhunderts keine erhaltene Papsturkunde für Besitz in Syrien überliefert ist.

In einem auffälligen Gegensatz zu dem dichten Netz von Besitzungen, die die jerusalemitanischen Abteien, das Hl. Grab, auch die Kirchen von Nazareth und Bethlehem in Süditalien hatten ${ }^{68}$, steht erstaunlicherweise ein völliges Fehlen an Zeugnissen trotz ihrer entscheidenden Rolle für den Transport von Leuten und Gütern für die apulischen und sizilischen Städte und Kirchen; für keine hört man etwas über Besitz in Syrien, selbst nicht für Bari und S. Nicola, ohne daß wir wissen, ob die normannischen Herrscher solche Verknüpfungen über das Mittelmeer hinweg bewußt verhinderten.

Ganz anders findet sich in der "Italia Pontificia“ dank der "offiziellen“ Stadtchronistik des Caffaro und seiner Fortsetzer, die zudem einzelne Papsturkunden im vollen Wortlaut anführen, und dank der reichen Bestände der Archive für das Erzbistum, für die Kathedrale und für die Civitas eine lange Reihe von Regesten. Sie beginnen mit einer Bestätigung der Rechte Genuas in Syrien (in partibus Syriae) durch Lucius II. im Jahre $1144^{69}$, der ältesten Papsturkunde dieser Art für alle italienischen Seestädte, denn eine päpstliche Bestätigung der bereits im Juli 1098, wenige Wochen nach der Eroberung Antiochias und dem Sieg über Kerbogha, von Bohemund verliehenen Rechte, der ersten in ganz Syrien von einem Kreuzfahrer ausgestellten Urkunde überhaupt ${ }^{70}$, ist nirgends bezeugt. Seit der Jahrhundertmitte führten Streitpunkte zwischen der ligurischen Metropole und den Kreuzfahrerstaaten immer wieder zur Einschaltung der Kurie und entsprechenden Papsturkunden. Von 74 Regesten für die Civitas Ianuensis aus den Jahren 1144 bis 1198 betreffen nicht weniger als 33, also fast die Hälfte, transmarine Angelegenheiten, einschließlich des dritten Kreuzzuges: die in den letzten Jahren viel diskutierte goldene Inschrift in der Grabeskirche, die Beschlagnahmung von Schiffen und Geld und vor allem der erwähnte politisch-feudale Streit mit den Herren von Byblos ${ }^{71}$. Über sie sind fast keine anderen Quellen, vor allem keine aus dem Osten erhalten, so daß ganze Kapitel der Geschichte der Kreuzfahrerstaaten nur dank der in der "Italia Pontificia“ verzeichneten Urkunden geschrieben werden können. Ein letztes Mal sieht man

67 Urban III., JL 15926, ed. (exc.) O 3 S. 394 Nr. 200, vgl. IP 7/2 S. 191 Nr. 7.

68 Vgl. dazu auch Bresc-Bautier: Les possessions (wie Anm. 33) mit instruktiven Karten.

69 IP 6/2 S. 326 Nr. * 18.

70 RRH Nr. 12 und Heinrich Hagenmeyer: Epistulae ad historiam primi belli sacri spectantes, Innsbruck 1901, S. 155 Nr. 13.

71 IP 6/2 S. 335 ff. Nr. 56-70 nicht weniger als 15 Mandate Urbans III. vom 11.-13. März 1186, vgl. auch Favreau-Lilie: Die Italiener (wie Anm. 53). 
Genua wegen seines Besitzes im lateinischen Osten im Kontakt mit der Kurie, als das Kapitel der Kathedrale im Jahre 1192 ähnlich wie die Pisaner im folgenden Jahr angesichts des rasch aufeinanderfolgenden Herrscherwechsels und einer dynastischen Spaltung des Königreichs Jerusalem in zwei Parteien den Papst um die Bestätigung einer ihm von Erzbischof Joscius von Tyrus geschenkten Kapelle bat ${ }^{72}$.

Hinzu kommt für Genua eine ganz andere Verknüpfung mit dem Papsttum und dem lateinischen Osten. Erstmalig am 25. April 1162 begegnet auch im Regest eines feierlichen Privilegs für den Erzbischof eine legatio transmarina als Dank für die Alexander III. in den ersten Jahren des Schismas gewährte Unterstützung ${ }^{73}$. Alle acht Jahre sollte der Erzbischof in partibus transmarinis zusammen mit einem Kardinal oder Bischof - gemeint ist wohl ein Kardinalbischof oder ein Kardinalpriester bzw. -diakon - die vices des Papstes wahrnehmen als eine frühe, unabhängig vom jeweiligen Titular nicht personal, sondern lokal an eine Kirche gebundene, ständige' Legation. Sie wurde im Abstand von ca. acht und einmal sechzehn Jahren bis ans Ende des Jahrhunderts immer von neuem bestätigt. So eindrucksvoll diese einmalige und für das 12. Jahrhundert einzigartige Verleihung sich ausmacht, muß gleich hinzugefügt werden, daß zwischen 1162 und 1198 kein einziger Fall zu belegen ist, wo sie eine praktische Umsetzung gefunden hätte. Weder ein Erzbischof von Genua noch ein von ihm Beauftragter noch ein Kardinal allein erscheinen in den folgenden 40 Jahren je im Osten, um dort eine Legation oder Visitation durchzuführen. Es bleibt bei einem Ehrenrecht des Erzbischofs von Genua ohne reale Wirkung, das nach 1191 ,einschläft'.

Neben diesen, letztlich doch an berechenbarer Stelle in die „Italia Pontificia“ eingebauten Regesten, die auch den lateinischen Osten betreffen, sind andere als zufällig zu bezeichnen. Im Regest eines Privilegs Paschalis' II. von 1113 Februar 13 für Montecassino folgt für das Eschatokoll in gewohnter Weise nach Datum und per manum-Vermerk die Erwähnung der eigenhändigen Unterschrift des Papstes, von drei Kardinälen und weiterer Prälaten, nämlich 10 Erzbischöfen und Bischöfen sowie des Abtes von S. Salvatore di Telese. Dann schließt sich jedoch an et Antiochenae eccl. legati ${ }^{74}$. Im Volltext der Urkunde lauten die beiden letzten Unterschriften Ego Rollandus Antiochenae ecclesiae legatus interfui et subscripsi und Ego Pontius Antiochenae ecclesiae legatus interfui et subscripsi. Zwar ist aus Wilhelm von Tyrus, aus einer Notiz im Chartular des Hl. Grabes und aus

72 IP 6/2 S. 291 Nr. 60.

73 Ebd. S. 268 Nr. 13; wiederholt in ebd. S. 271 Nr. ${ }^{*} 26$ und S. 272 Nr. 27 von 1179, S. 276 Nr. 46 von Clemens III. (1187-1188) und S. 277 Nr. *54 von Coelestin III. von 1192.

74 IP 8 S. 161 Nr. 174; JL 6340; ed. Migne, PL 163, 312 Nr. 356. Das Original befindet sich im Archiv von Montecassino. 
einer zweiten in einer kirchenrechtlichen Handschrift aus dem Hl. Land (Vat. Lat. 1345) bekannt, daß im Februar/März 1113 in Benevent vor Paschalis II. über die territoriale Abgrenzung der beiden Patriarchate Jerusalem und Antiochia und andere kirchenrechtliche Fragen verhandelt wurde, doch die Namen der antiochenischen Legaten, die im Auftrage des Fürsten und des Patriarchen in den Westen gereist waren, gibt allein die Papsturkunde für Montecassino. Rollandus und Pontius sind anderweitig im lateinischen Osten nicht nachzuweisen, den Namen nach zweifellos Lateiner, auch wenn sie, wie ein Augenzeuge hinzufügt, als Zeichen einer rasch erfolgten Akkulturation in östlichem Habitus mit wirrem Haupthaar und Bart aufgetreten sein sollen ${ }^{75}$. Mit Montecassino hatte ihre Gesandtschaft soweit wir wissen nichts zu tun, wie die Abtei auch nie Besitz oder abhängige Kirchen im Osten erhielt, sondern allein die zufällige zeitliche Koinzidenz mit der Anwesenheit syrischer Boten an der Kurie führte zu ihrer Unterschrift und so zu einer für die Prosopographie der lateinischen Kirche Antiochias wichtigen Nachricht.

Ganz ähnlich bringt eine am 3. April 1139 in Rom ausgestellte Urkunde einen Mosaikstein für die Biographie eines hochrangigen Mitglieds der Kreuzfahrerkirche. Als Abt Azo von S. Paolo fuori auf einer Sitzung des zweiten Laterankonzils Klage erhob gegen einige Mitglieder der gens Tebaldi wegen Besitzstreitigkeiten, wird als anwesend an dieser Verhandlung nach dem Papst und vor den Patriarchen von Aquileia und Grado der patriarcha Antiochenus angeführt ${ }^{76}$. Gemeint ist Radulf von Domfront, der Antiochia seine frühere Selbständigkeit im Sinne der Pentarchie wiedergeben wollte ${ }^{77}$. Ein besonderes Interesse an der Kreuzfahrerkirche bestand für den Urkundenschreiber evidenterweise nicht, noch für den Patriarchen an den Tebaldi, wohl aber an der Nennung hochgestellter Personen, wie sie Patriarchen darstellten, als Zeugen. Das Regest in der "Italia Pontificia“ 1 ist das erste für die „Italia Pontificia“ erstellte Regest überhaupt, das einen Bezug zur Kreuzzugsbewegung hat. Ihm verdanken wir so die sonst nirgends belegte Teilnahme des Leiters der lateinischen Kirche Nordsyriens am Konzil, dem sein Amtskollege aus Jerusalem fernblieb, ja die erste gesicherter Teilnahme eines Bischofs der Kreuzfahrerkirche

75 O 3 S. 119 Nr. 15: viri duo crinibus et barba concreti, calamistrati non ex industria, sed ut apparebat ex incuria.

76 IP 1 S. 169 Nr. 20, Capena municipio de Romani, ed. Pierluigi Gallettri, Rom 1756, S. 65 Nr. 3.

$77 \mathrm{Zu}$ ihm vgl. Bernard Hamilton: Ralph of Domfront, Patriarch of Antioch 1135-1140, in: Nottingham Medieval Studies 28 (1984) S. 1-21 und Rudolf Hiestand: Ein neuer Bericht zum Konzil von Antiochia 1140, in: Annuarium historiae Conciliorum 20 (1988) S. 314-350. 
an einem allgemeinen Konzil überhaupt ${ }^{78}$ und zugleich den Beleg, daß eine von Wilhelm von Tyrus dramaturgisch ausgestaltete Verhandlung gegen den Patriarchen wegen Mißachtung des päpstlichen Primatsanspruchs mit folgender Absolution wohl auch auf dem Konzil selbst stattgefunden hat ${ }^{79}$.

III.

An einer Scharnierstelle zwischen den Beziehungen des Papsttums zu den Kreuzfahrerstaaten, deren Niederschlag in der „Italia Pontificia“ hier untersucht werden soll, und den Kreuzzügen in den Osten stehen unter personellem Blick die päpstlichen Legaten ${ }^{80}$. Denn seit Clermont bis ans Ende des 12. Jahrhunderts wurde jeder Kreuzzug von Legaten begleitet und jede Legation für einen Kreuzzug in den Osten führte eo ipso auch zu Kontakten mit der Kreuzfahrerkirche auf syrischem Boden. Genuin gehörten wie die allgemeinen Kreuzzugsaufrufe auch die Legatenbestellungen für die Kreuzzüge als solche nicht in die „Italia Pontificia“. Gleich zu Beginn des Bandes für Rom hatte Kehr im Abschnitt „Cardinales SRE“ erklärt, deren Tätigkeit als Legaten außerhalb von Rom jeweils an der betreffenden Stelle behandeln zu wollen, d. h. hier im künftigen Oriens Pontificius, dagegen Urkunden, die sich auf einzelne Kardinäle beziehen, unter ihrem Bistum, ihrer Titelkirche oder ihrer Diakonie anzuführen $^{81}$. Nicht gemeint war damit, wie sich sogleich zeigt, die Einsetzung von Kardinälen als Legaten, auch wenn dafür schriftliche Zeugnisse, manchmal sogar eigentliche Bestellungsschreiben mit der Empfehlung an Personen des künftigen Wirkungskreises vorliegen. Doch auch die Ernennung von Angehörigen des Diözesanklerus zum Legaten erhielt weder ein eigenes Regest noch eine Erwähnung in den einleitenden Narrationes.

Es geht damit gerade für diesen Teil der Blick auf die Nachrichten, die sich in der "Italia Pontificia“ finden, einher mit der Gegenfrage, was fehlt. Die Lücken sind in der Tat beträchtlich. Für den ersten Kreuzzug ist sowohl die Bestellung von Erzbischof Daimbert von Pisa im Jahre 1097/1098 zum Legaten mindestens für die von ihm angeführte pisanische Flotte, wenn nicht zum

$78 \mathrm{Zu}$ den seit 1138 nachgewiesenen Templern auf dem Aventin, die zweifellos mit den stadtrömischen Äbten und Klerikern das Konzil aus der Nähe verfolgten, siehe unten. S. 657.

79 Wilhelm von Tyrus: Chronicon (wie Anm. 16) XV 12 S. 691.

80 Dieser Abschnitt stützt sich auf Rudolf Hiestand: Die päpstlichen Legaten auf den Kreuzzügen und in den Kreuzfahrerstaaten vom Konzil von Clermont (1095) bis zum vierten Kreuzzug, masch.schr. Habil., Kiel 1972. Künftig zum ganzen Problemkreis auch die Habilitationsschrift von Claudia ZeY, Die päpstliche Legatenpolitik im 11. und 12. Jahrhundert, masch.schr. Habil., München 2002.

81 IP 1 S. 5. 
Nachfolger des im Sommer 1098 in Antiochia verstorbenen Kreuzzugslegaten Adhemar von Le Puy ${ }^{82}$ als auch die Bestellung von Erzbischof Anselm von Mailand für den Kreuzzug der Lombarden im Jahre 1100/1101 ${ }^{83}$ und die erst sehr spät überlieferte, zweifelhafte Bestellung von Bischof Heinrich Contarini von Castello für das Unternehmen der Venezianer im Jahre $1100^{84}$ nicht aufgenommen. Ausdrücklich in ein Regest gefaßt wird dagegen die Bestellung Bohemunds vor seiner Reise nach Frankreich ${ }^{85}$.

Am Ende des 12. Jahrhunderts erhält die Bestellung von Erzbischof Gerhard von Ravenna im Jahre 1188 für die Kreuzzugspredigt (nicht aber diejenige für den dritten Kreuzzug selber ${ }^{86}$ und die in dieser Eigenschaft in Florenz durchgeführte Weihe von S. Donato a Torri ${ }^{87}$ ein Regest, ebenso die von Kehr als zweifelhaft bewertete chronikalische Nachricht über die Bestellung von Erzbischof Hubald von Pisa mit der gleichzeitigen Übergabe einer Petrusfahne, freilich nicht unter dem Erzbistum, sondern unter der Civitas ${ }^{88}$, weil er die pisanische Flotte in den Osten führen sollte, also nicht wegen der Person, sondern wegen der Sache ${ }^{89}$. Ein Regest für die Bestellung fehlt auch beim einzigen, nicht dem Kardinalkollegium angehörenden italienischen Legaten in die Kreuzfahrerstaaten außerhalb der Kreuzzüge, Abt Gaufried von Fossanova, unter dem Abschnitt für die in Latium gelegene Zisterzienserabtei zum Jahre

82 IP 3 S. 359 Nr. 23 gibt nur den auf Befehl Urbans II. erfolgten Aufbruch der pisanischen Flotte. Zu Daimbert vgl. jetzt vor allem Michael Matzke: Daibert von Pisa zwischen Pisa, Papst und Kreuzzug, Sigmaringen 1998 (Vorträge und Forschungen, Sonderband 44).

83 IP 6/1 S. 54 Nr. ${ }^{*} 122$ in ähnlicher Weise nur der Aufruf an Anselm, ein Heer zur Befreiung des Hl. Landes zu sammeln.

84 IP 7/2 S. 130 nach Nr. 4 einzufügen.

85 IP 9 S. 443 Nr. *6 unter dem Principatus Tarantinus mit einem terminus technicus: Paschalis I legat Bohemund in den Westen und setzt ihn zum signifer des exercitus Christi ein und gibt ihm das vexillum s. Petri. Die Einordnung wäre besser unter Bari (IP 9 S. 336 oder einem neuen Lemma ebd.) erfolgt.

86 IP 5 S. 72 Nr. 267. Zu Gerhard von Ravenna jetzt auch Karl Borchardt: Archbishop Gerard of Ravenna and Bishop John of Faenza, in: Proceedings of the Eighth International Congress of Medieval Canon Law, Città del Vaticano 1992, S. 574-592 und DBI 53 (1999) S. 543-545 (A. Ilari).

87 IP 3 S. 38 Nr. 2.

88 Ebd. S. 362 Nr. $\dagger^{*} 39$.

89 Die Angabe in der Narratio zum Bistum Verona IP 7/1 S. 217, daß Clemens III. Bischof Adelard als seinen Legaten zu Richard Löwenherz und Philipp II. August geschickt habe, ist unhaltbar. Die Gesandtschaft fällt wohl ins Jahr 1201, vgl. Edmond MARTĖNE/Ursin Durand: Thesaurus novus anecdotorum, Paris 1717, 3 S. 956. Zu Adelard vgl. auch Werner Maleczek: Papsttum und Kardinalkolleg im 12. Jahrhundert, Wien 1984 (Publikationen des Historischen Instituts beim Österreichischen Kulturinstitut in Rom 1), S. 68; Klaus Ganzer: Die Entwicklung des auswärtigen Kardinalats im hohen Mittelalter, Tübingen 1963 (Bibliothek des Deutschen Historischen Instituts in Rom 26), S. $137-140$. 
$1173^{90}$, dessen Legation auch in der Narratio nicht erwähnt wird. Neben ihrer Bedeutung für die Kreuzzugsbewegung im weiteren Sinne bilden Legatenernennungen ganz allgemein wichtige Nachrichten für das Verhältnis ihrer Herkunftskirche oder ihrer Person zum Papsttum und wären mit Gewinn an der jeweiligen Stelle einzuordnen.

Noch drei Regesten in der „Italia Pontificia“ sind zu erwähnen, deren Zusammenhang mit dem Kreuzzug und Kreuzzugslegationen vorerst überhaupt nicht erkennbar ist. Der Sache nach sind es Italica. Unter Genua findet sich aus einem Werk des 18. Jahrhunderts ein Regest für die Weihe der Kirche S. Teodoro und S. Salvatore in Fasiolo vor den Toren der Stadt am 20. Juli 1100 durch den Kardinal Mauritius von Porto, Legat Paschalis' II., und den Bischof Ayraldus von Genua. Gestützt wird die Nachricht durch eine Privaturkunde vom gleichen Tag, welche der Bischof und Mauritius de Portu Romano episcopus unterschreiben ${ }^{91}$. Dieser Bischof des suburbikarischen Porto und damit Mitglied des Kardinalkollegium scheint auf den ersten Blick auf dem Weg zu einer Legation in Frankreich zu sein, doch im November 1100 trifft er in Laodicea in Nordsyrien auf Balduin von Edessa, den Bruder des im Juli verstorbenen Gottfried von Bouillon, zieht mit ihm nach Süden und trägt die päpstliche Zustimmung zur Erhebung Jerusalems zum Königreich und zur Wahl eines lateinischen Patriarchen mit sich. Er war am 28. April 1100 den Kreuzfahrern im päpstlichen Glückwunschschreiben für die Eroberung Jerusalems als Legat angekündigt worden, um die neu entstandene Kreuzfahrerkirche den kanonischen Vorschriften entsprechend einzurichten ${ }^{92}$, und brach dann am 1. August, wie der Stadtchronist Caffaro überliefert, mit der zweiten genuesischen Flotte in den Osten auf ${ }^{93}$. Sein Legationsbereich wird in der genuesischen Urkunde und der Weihenotiz nicht erwähnt, doch durch Weihenotiz und Urkunde, beide in ein Regest in der „Italia Pontificia“ gefaßt, erhält man einen weiteren Hinweis auf den zeitlichen Ablauf seiner Legation.

Zwanzig Jahre später schreibt Calixt II. am 24. Juli 1121 aus Aversa an den Kleriker Markus in Venedig, der dem Hl. Petrus ein Grundstück aufgelassen hatte, um dort die künftige Kirche $S$. Maria della Carità zu bauen, er schicke ihm nun auf Bitte des clarissimus et venerabilis frater noster et legatus P. Portuensis

90 Einzureihen IP 2 S. 127 nach Nr. 4; zur Legation im Osten vgl. O 2 S. 230 ff. Nr. 21a und $21 \mathrm{~b}$.

91 IP 6 S. 314 Nr. 1; zu Mauritius vgl. Rudolf HüLs: Kardinäle, Klerus und Kirchen Roms 1049-1130, Tübingen 1977 (Bibliothek des Deutschen Historischen Instituts in Rom 48), S. 121 f., der aber die Urkunde aus Genua zu 1100 Januar 3 setzt und das Schreiben Paschalis' II. nicht erwähnt.

92 JL 5835 zu (1100) Mai 4, ed. O 3 S. 90 Nr. 4.

93 Caffaro: Annali Genovesi, ed. Luigi Tommaso Belgrano, Rom 1890 (Fonti per la Storia d'Italia 11), S. 51. 
episcopus einen Stein für die Grundsteinlegung des Gebäudes ${ }^{94}$. Wieder wäre aus dieser Erwähnung nicht zu erkennen, was Petrus von Porto, den Nachfolger des Mauritius und Senior des Kardinalkollegiums, in Wirklichkeit nach Venedig geführt hatte, wenn nicht vierzehn Tage zuvor am 8. Juli 1121 der Papst dem Erzbischof Ebremar von Caesarea, den übrigen Prälaten und König Balduin II. von Jerusalem ihn als seinen Legaten für das Hl. Land angekündigt hätte ${ }^{95}$. Ursprünglich hatte er mindestens die doppelte Aufgabe, dem neuen Patriarchen von Jerusalem Warmund von Picquigny (seit 1118) das Pallium zu überbringen, was nun auf anderem Wege erfolgen sollte, weil die Reise des Petrus sich verzögere, andererseits den Kreuzfahrern nach der vernichtenden Niederlage der Antiochener im Jahre 1119 mit einer venezianischen Flotte militärische Hilfe zuzuführen. Denn der zeitliche Ablauf legt nahe, daß Petrus der Überbringer einer aus der venezianischen Chronistik bekannten Aufforderung Calixts II. an den Dogen und die Venezianer zu solcher Unterstützung ${ }^{96}$ und einer Petrusfahne für den Dogen als äußeren Zeichens eines päpstlichen Auftrags war ${ }^{97}$, wie sie einst Urban II. dem Erzbischof Anselm von Mailand für den Kreuzzug von $1100 / 1101$ verliehen hatte ${ }^{98}$. Anders als für Mauritius, der wahrscheinlich im Osten gestorben ist, wissen wir nicht, ob Petrus in der Folge wirklich nach Syrien reiste. An der Kurie ist er erst während des ersten Laterankonzils, zwei Jahre nach seiner Abreise aus Rom, am 6. April 1123 wieder nachzuweisen ${ }^{99}$, doch aus dem Osten fehlt jedes urkundliche oder chronikalische Zeugnis.

Weder in Genua noch in Venedig hatte der Vorgang, der zur Ausstellung einer Urkunde führte, in der ein Legat für den Osten erschien, auch nur entfernt etwas mit dem Kreuzzug zu tun, dennoch verdanken wir jener ein weiteres Datum für die Reise des Legaten Mauritius von Porto, dieser einen weiteren Mosaikstein für die Legation des Petrus von Porto und ebenso einen zusätzlichen zeitlichen Anhaltspunkt, in beiden Fällen zugleich eine wertvolle Nachricht über die Kommunikationswege zwischen Papsttum und Hl. Land.

Wie diese Nachrichten aus der Frühphase der Kreuzzüge betrifft auch eines der letzten Zeugnisse in der „Italia Pontificia“ über die Kreuzzüge wieder einen Legaten, ohne ihn als solchen zu kennzeichnen. Unter S. Nicola in Bari wird eine Inschrift verzeichnet, wonach Bischof Konrad von Hildesheim und Kanzler

94 IP 7/2 S. 168 Nr. *1 und 2. Zu Petrus von Porto vgl. Hüls, Kardinäle (wie Anm. 91) S. 122-124. Beate Schilling: Guido von Vienne - Papst Calixt II., Hannover 1998 (Schriften der MGH 45) und Mary Stroll: Calixtus II (1119-1124): A Pope born to rule, Leiden 2004 (Studies in the history of Christian traditions 116) führen nicht über Hüls hinaus.

95 JL 6922, ed. O 3 S. 128 Nr. 22.

96 IP 7/2 S. 21 Nr. *38.

97 Ebd. S. 21 Nr. ${ }^{*} 39$.

98 IP 7/1 S. 54 Nr. *129 aus der Chronik Landulfs.

99 JL 7056 für die Kirche von Pisa. 
Kaiser Heinrichs VI. am 27. Juni 1197 in Gegenwart von fünf Erzbischöfen, 28 Bischöfen und sieben Äbten im Auftrage Coelestins III. die Kirche geweiht habe ${ }^{100}$. Damit sind wir im unmittelbaren Vorfeld des Kreuzzuges des Staufers. Konrad war mit den sich sammelnden Rittern nach Apulien gekommen, wo er längere Zeit in der Umgebung Heinrichs nachzuweisen ist. Damit erhält die Weihe von S. Nicola den Charakter einer Huldigung und Intervention beim Patron der Seefahrt vor der bevorstehenden Überfahrt nach Syrien, wie wir Eugen III. zu Beginn seiner Reise nach Frankreich in einer ähnlich symbolischen Handlung sehen werden. Konrad von Hildesheim ging dann mit Aufträgen des Kaisers und des Papstes in den Osten, wo er im Spätherbst 1197 dem Herrn von Zypern, Aimerich von Lusignan, die Königskrone überbrachte, wenn auch nicht sicher ist, wie weit dies auch im Namen des Papstes bzw. in Vertretung des anderen päpstlichen Legaten Erzbischof Konrad von Mainz erfolgte ${ }^{101}$.

\section{IV.}

Sieht man von dem feierlichen Privileg für Beirut und der Urkunde für die Lazariter ab, so war zweifellos von größerer Bedeutung als für die Kreuzfahrerstaaten die Nachlese für das eigentliche Kreuzzugs geschehen. Hier steht im zeitlichen Ablauf unter den Neufunden am Anfang ein Schreiben Urbans II. von 1096 Oktober 7 an die Mönche von Vallombrosa, das Wilhelm Wiederhold im Jahre 1901 aus einer Handschrift der Biblioteca Riccardiana in seinem Bericht über Papsturkunden in Florenz veröffentlichte ${ }^{102}$. Es tritt neben die beiden bekannten Schreiben des Kreuzzugspapstes, das erste vom Jahreswechsel 1095/1096 im Sinne des Aufrufs von Clermont um Beteiligung werbend an die Gläubigen in Flandern ${ }^{103}$, das andere aus dem Sommer 1096 eher eindämmend an die Bewohner von Bologna ${ }^{104}$, nachdem die Sprengkraft eines von Begeisterung getragenen Aufbruchs auf die bestehenden gesellschaftlichen Strukturen deutlich geworden war. Für Bologna legte der Papst fest, daß weder Kleriker noch Mönche ohne Erlaubnis ihres Bischofs oder Abtes aufbrechen dürften, ebenso wenig Männer im besten Alter (iuvenes) ohne die Zustimmung ihrer Frauen - in einer deutlichen Parallele zum Eintritt ins Kloster, der kirchenrechtlich ein beidseitiges Einverständnis erforderte, was die Nähe des

100 IP 9 S. 328 Nr. *4; jetzt auch GP 5/2 S. 57 Nr. 123.

101 GP 5/2 S. 57 Nr. *? 124.

102 Kehr, Papsturkunden in Italien (wie Anm. 5) 3 S. 216 Nr. 6; O 3 S. 88 Nr. 2.

103 JL 5608; ed. Hagenmeyer: Epistulae (wie Anm. 70) S. 136 Nr. 2.

104 JL 5670, ed. Hagenmeyer: Epistulae (wie Anm. 70) S. 137 Nr. 3. 
Kreuzzuges zu einer wandernden Klostergemeinschaft auf Zeit unterstreicht ${ }^{105}$. Das neue Schreiben, das dritte schriftliche Zeugnis des Papstes zum Kreuzzug aus der Zeit nach Clermont, schließt in seinem Tenor an das Schreiben nach Bologna an. Ging es dort um die Gesamtheit der städtischen Bevölkerung, vor allem auch der Laien, so richtete der Papst nun ein Verbot der Teilnahme an eine monastische Gemeinschaft, die wie ihre ganze Umwelt von der Kreuzzugsidee ergriffen worden war. Der Ruf von einem Plenarablaß, den man sich erwerben könne, hatte auch die Klostermauern durchdrungen. Ganz scharf wurde festgehalten, daß ein Mönch, sei es auch um des vom Papst initiierten Kreuzzuges willen, nur mit Erlaubnis seines Abtes das Kloster verlassen dürfe. Wie die Seelsorge durch eine Kreuzzugsteilnahme des Klerus und die Ehe durch einen „wilden“ Aufbruch gefährdet war, wenn der eine Partner ohne Rücksicht auf den anderen in den Osten zog, so erst recht die auf Gehorsam und Trennung von der Welt ausgerichtete klösterliche Gemeinschaft durch die Beteiligung an einem, wie der Papst noch einmal betonte, militärischen Unternehmen (armis Saracenorum feritatem debellare).

Wann genau die damit unübersehbare Abkehr von der uneingeschränkten Kreuzzugspropaganda des Jahres 1095/1096 eingetreten ist, läßt sich nicht mehr feststellen. Aus Frankreich werden in den Monaten nach Clermont trotz zahlreicher Nachrichten über die Kreuzzugswerbung des Papstes solche Töne nirgends laut, obwohl sich auch dort eine große Zahl nichtritterlicher Leute auf den Weg machte; nun schlägt die Haltung des Papstes um, kaum hatte er wieder italienischen Boden betreten, und er differenziert. Fügen wir hinzu, daß die Forschung den Fund Wiederholds, der in den Abschnitt über Vallombrosa in der „Italia Pontificia“ einging ${ }^{106}$, über ein halbes Jahrhundert de facto nicht rezipierte, auch weil er wieder wissenschaftsgeschichtlich aus chronologischen Gründen nicht in die als abschließend angesehene Ausgabe der Briefe zum ersten Kreuzzug von Heinrich Hagenmeyer aus dem gleichen Jahr 1901 aufgenommen worden war ${ }^{107}$. Dabei braucht die Bedeutung eines weiteren authentischen Schreibens des Papstes, das unmittelbar in die Zeit nach Clermont zurückging, als anders als nachher für die ex eventu schreibenden Kreuzzugschronisten der Erfolg des Unternehmens noch nicht abzusehen war, nicht betont zu werden. Es gewährt wie die beiden schon bekannten Schreiben Einblick in das Denken des Papstes nach dem auch für ihn unvorhergesehenen Erfolg des Aufrufes in Clermont.

105 Zum päpstlichen Widerstand gegen die Kreuzzugsteilnahme von Mönchen vgl. vor allem Giles Constable: Opposition to Pilgrimage in the Middle Ages, in: Studia Gratiana 19 (1976) S. 123-146.

106 IP 3 S. 89 Nr. 8.

107 Hagenmeyer: Epistulae (wie Anm. 70). Er fehlt daher auch bei Ursula Schwerin: Die Aufrufe der Päpste zur Befreiung des Heiligen Landes von den Anfängen bis zum Ausgang Innozenz' IV., Berlin 1937 (Historische Studien 301). 
Unter den neuen Schreiben für die Geschichte der Kreuzzüge schließt sich ein von Walther Holtzmann in einer Ivo-Handschrift in Lincoln entdeckter Brief Bohemunds von Antiochien an Paschalis II. vom Herbst 1106 an, also ein Nicht-Anglicum der dortigen Nachlese, das nicht völlig korrekt in den Abschnitt Regnum Normannorum aufgenommen wurde ${ }^{108}$. Verfaßt nach der Rückkehr aus Frankreich und unmittelbar vor dem Aufbruch über die Adria, bestätigt es einerseits Bohemunds Ernennung zum Legaten vor der Reise nach Frankreich als eines der ganz wenigen Beispiele von Laien als Legaten im 12. Jahrhundert, andererseits forderte der Normanne den Papst auf, unter Berufung auf einen entsprechenden Beschluß Urbans II. auf dem Konzil von Bari im Herbst 1098, dessen Umsetzung nur der Tod des Papstes verhindert habe, selber in den Osten zu ziehen oder wenigstens einen Legaten zu bestellen. Ausführlich legt es schließlich den Zwist mit dem Basileus dar, um den Zug gegen einen christlichen Herrscher zu rechtfertigen und wird daher auch in den Oriens graecus gehören. Zusammen mit der verfälschten Fassung des Briefes der Kreuzfahrer aus dem Lager bei Antiochia, im gleichen Abschnitt der „Italia Pontificia“ unter dem „Principatus Tarantinus“ eingereiht ${ }^{109}$, ist es zugleich ein wichtiges Zeugnis der sich nach dem ersten Kreuzzug ausbreitenden antibyzantinischen Stimmung.

Von allgemeiner Bedeutung für die Kreuzzugsgeschichte ist auch der dritte Neufund, der freilich im Gegensatz zu den Briefen Urbans II. und Bohemunds bisher keinen Niederschlag im Regestenwerk gefunden hat. In zwei Handschriften auf Malta stieß Luigi Schiaparelli auf einen Kreuzzugsaufruf Eugens III. von 1146 Oktober 5 Divini dispensatione consilii ${ }^{110}$. An die Geistlichkeit Italiens (prelatis per Italiam constitutis) gerichtet, belegt er zum ersten Mal eindeutig, daß die Konzeption Eugens III. sich nicht auf die Teilnahme des französischen Königs und dann eher widerwillig des deutschen Herrschers mit ihren Gefolgsleuten beschränkte, sondern schon vor dem Aufbruch nach Frankreich auch die Apenninenhalbinsel in die Werbung einbezog und damit den im berühmten Aufruf nach Frankreich Quantum praedecessores eher überraschend betonten Anteil der Italiener am ersten Kreuzzug (Francorum regni

108 IP 8 S. 27 Nr. 91; ed. O 3 S. 102 Nr. 7. Besser wäre die Einreihung unter Bari erfolgt, wie sich Bohemund stets als Barensis dominus bezeichnet, nie als Tarantinus princeps o. ä. wie üblicher-, aber fälschlicherweise angenommen wird.

109 Ed. Hagenmeyer: Epistulae (wie Anm. 70) S. 191 Nr. 15 und IP 9 S. 442 Nr. 4.

110 KeHr, Papsturkunden in Italien (wie Anm. 5) 2 S. 108 Nr. 3; ed. O 3 S. 193 Nr. 63. Er verdankt seine Überlieferung, wie die beiden Handschriften zeigen, offensichtlich der Zuschreibung an Eugen IV. In der Tabelle bei Schwerin, Aufrufe (wie Anm. 107) Nr. VI ist statt La Valletta vol. 1132 zu lesen vol. 1141. 
fortissimi et strenui bellatores et illi etiam de Italia) nicht nur als historische Reminiszenz, sondern auch als Projektion für die Gegenwart ansah ${ }^{111}$.

Im Text, der anscheinend eher als ein Begleitschreiben eines an weltliche Empfänger gerichteten eigentlichen Aufrufes anzusehen ist ${ }^{112}$, sind zwar längere Abschnitte über den Schutz der Kreuzfahrer, ihrer Familien und ihres Besitzes und über den Ablaß wörtlich aus den Aufrufen nach Frankreich vom 1. Dezember 1145 und 1. März $1146^{113}$ übernommen, doch anderes ist neu formuliert und bezieht sich gezielt auf die Empfängergruppe, wenn man in der Exhortatio liest: quoniam Italia viris potentibus et strenuis bellatoribus ... abundat. Allgemeiner gesprochen macht der nun mögliche Textvergleich mit den beiden Fassungen von Quantum praedecessores und mit dem Aufruf für den Wendenkreuzzug deutlich, wie sorgfältig der Papst und die Kanzlei empfängerbezogen formulierten. Vor allem der Abschnitt mit den Privilegia über das Schuldenmoratorium und die Mittelbeschaffung der Teilnehmer zeigt ein bewußtes Eingehen auf die anderen Rahmenbedingungen südlich der Alpen und die bereits weiter vorangeschrittene Geldwirtschaft ${ }^{114}$. Da der Aufruf nicht nur aus zwei Bullarien stammt, die, wie sich noch ergeben wird, auf süditalienische Ordensarchive zurückgehen ${ }^{115}$, sondern auch die Adresse ausdrücklich Italien nennt, gehört er ohne jeden Zweifel in die „Italia Pontificia“, wenn auch in den noch ausstehenden Band für allgemeine Stücke, wobei die archivalische Überlieferung hier im Gegensatz zum Schreiben Bohemunds eine zusätzliche Einordnung unter dem Regnum Normannorum rechtfertigen könnte. Auch dieses Schreiben ist lange weitgehend unbeachtet geblieben ${ }^{116}$ und zeigt fast exemplarisch den Nachteil einer auf einen Empfänger eingeschränkten Archivrecherche gegenüber einer umfassenden Zielsetzung, wie sie Kehr vor Augen stand. Denn Delaville le Roulx und Prutz hatten nachweislich die beiden Bände

111 JL 8796; ed. in: Otto von Freising: Gesta Frederici, ed. Adolf Schmidt und Franz-Josef Schmale, Darmstadt 1965 (Ausgewählte Quellen zur deutschen Geschichte des Mittelalters 17), hier I 37 (36) S. 200.

112 Vgl. Schwerin, Aufrufe (wie Anm. 107) S. 26 f.

113 JL 8876; ed. Peter Rassow in: Erich Caspar: Die Kreuzzugsbullen Eugens III. (11451153), in: NA 45 (1924) S. 283-305, hier S. 300; jetzt auch Rolf Grosse, Überlegungen zum Kreuzzugsaufruf Eugens III. von 1145/46. Mit einer Neuedition von JL 8876, in: Francia 18/1 (1991) S. 85-92, hier S. 90-92.

114 Zusatz zu den Vorurkunden nach Frankreich: si fideiussores etiam vel obsides dederunt... Si qui vero possessiones aliquorum in pignore vel pignora etiam pro pecunia uel pro alia re ab aliquibus receperint, nihilominus ... precipimus, ut receptis his tantum que susceptis pignoribus illis tradiderunt, in eadem specie, in auro videlicet sive argento vel aliis possessionibus, ipsas et pignora eis libere restituantur et nihil ab eis amplius exigant.

115 Siehe unten S. 662-664.

116 Die volle Rezeption setzt ein mit Schwerin, Aufrufe (wie Anm. 107) passim und Nr. VI, und Giles Constable: The Second Crusade as Seen by the Contemporaries, Traditio 9 (1953) S. 213-279. 
im Archiv in Valletta in der Hand gehalten, aber den Text, weil in ihm weder von Templern noch von Johannitern die Rede ist, nicht beachtet. Wie der Brief an Vallombrosa rückt er die Rolle Italiens in den Kreuzzugsplanungen stärker ins Blickfeld.

Diesen drei neuen päpstlichen Aufrufen gegenüber treten drei weitere, bei der Nachlese in Italien neugefundene Kreuzzugstexte deutlich zurück. In der zeitlichen Abfolge gehörte zwar zu den Papsturkunden in Italien, aber nicht in die "Italia Pontificia“ der in einer Orosius-Handschrift der Vatikana eingetragene Aufruf des päpstlichen Legaten Hyazinth von S. Maria in Cosmedin Vulgare proverbium est ${ }^{117}$. Wohl im Zusammenhang mit dem Konzil von Valladolid Anfang 1155 bat der spätere Papst Coelestin III. den Klerus Spaniens, für einen von ihm geplanten Feldzug gegen die Mauren multi saumarii et alia tante expeditionis necessaria zur Verfügung zu stellen, eine bisher in der Kreuzzugsgeschichte und der Geschichte der Reconquista ebenfalls wenig beachtete Episode $^{118}$, weil sie zu keinem erkennbaren Ergebnis geführt hat, aber sie zeugt von den Bemühungen, nach dem zweiten Kreuzzug den Kampf gegen die Mauren fortzuführen. Beachtung verdienen zwei Punkte: Einmal werden in der Adresse neben den Geistlichen, soweit ich sehe zum ersten Mal, auf gleicher Ebene die Templer und Johanniter angesprochen, was ihre auf dem zweiten Kreuzzug gewonnene Stellung spiegelt, zum anderen erklärt der Legat, auf Drängen der Könige und Fürsten, des Klerus und des Volkes selber das Kreuz genommen zu haben, und tritt als Organisator für ein Unternehmen unter seiner unmittelbaren Leitung auf, nicht nur begleitend und geistlich stützend, wie die Legaten auf dem ersten und dem zweiten Kreuzzug und wie es ebenso auf dem dritten Kreuzzug sein wird.

Wenig neue Ideen oder Fakten für die Kreuzzugspropaganda des 12. Jahrhunderts bringt ein bisher nicht in die "Italia Pontificia“ aufgenommener Kreuzzugsaufruf Lucius' III Cor nostrum von (1184) November/Dezember $10^{119}$ an die Könige, Herzöge, Fürsten, Grafen und alle Gläubigen. Er ging, wie ein

117 KeHr, Papsturkunden in Italien (wie Anm. 5) 4 S. 48 Nr. 12. Bei Kehr noch auf (11531155) datiert. Vgl. aber Carl Erdmann: Das Papsttum und Portugal im ersten Jahrhundert der portugiesischen Geschichte, Berlin 1928 (AAB, phil.-hist. Kl. 5), S. 37 Anm. 3 und Gerhard S̈̈векоw: Die päpstlichen Legationen nach Spanien und Portugal bis zum Ausgang des 12. Jahrhunderts, Diss. Berlin 1931, S. 50 Anm. 179, zu Anfang 1155; Stefan WeIss: Die Urkunden der päpstlichen Legaten von Leo IX. bis Coelestin III. (1049-1198), Köln/Wien 1995 (Forschungen zur Kaiser- und Papstgeschichte des Mittelalters. Beihefte zu J. F. Böhmer, RI 13), S. 176 Nr. 8 zu 1155 vor Februar 1.

118 Vgl. dazu Erdmann, Papsttum (wie Anm. 117) a.a.O.; S̈̈векow, Legationen (wie Anm. 117) a.a.O.

119 O I S. 352 Nr. 165, Schwerin, Aufrufe (wie Anm. 107) Nr. 8, B-B/S Nr. 1924. 
gleichzeitig nach England geschickter Aufruf Cum cuncti praedecessores ${ }^{120}$ aus den Beratungen von Kaiser und Papst mit dem Patriarchen Heraklius von Jerusalem und dem Johannitermeister Roger de Molinis in Verona hervor und folgt bis auf einen deutlich als Zusatz gekennzeichneten letzten Abschnitt mit der Absolution für Turnieropfer, die nach Kirchenrecht eo ipso der Exkommunikation verfallen waren, dem nur aus England überlieferten Aufruf Alexanders III. von 1181 Januar $16^{121}$.

Überliefert in drei Handschriften aus Palermo und Agrigento mit Urkunden zu den Beziehungen zwischen dem Papsttum und den Normannenherrschern und mit dem Hinweis, daß die Originale sich im Besitz von Antonino Amico befänden, muß der neue Aufruf Lucius' III. in das Normannenreich gegangen sein und könnte angesichts der zeitlichen Koinzidenz indirekt vielleicht ein Anstoß für die sizilische Flottenaktion gegen Thessalonike im Jahre 1185 geworden sein. Obwohl sich eine weitere Abschrift als die zeitlich älteste in einem Chartular des 16. Jahrhunderts aus Santo Crucifijo de Puente la Reina bei Pamplona findet ${ }^{122}$ und damit eine breite Streuung der Empfänger gegeben scheint, beruht dieses Bullar in Wirklichkeit auf den Beständen des Johanniterpriorats in Messina ${ }^{123}$. Auch wenn es weitere Ausfertigungen gab, wie die Adresse regibus, ducibus, principibus, comitibus et universis Christi fidelibus nahelegt, war mindestens die bisher allein nachweisbare Ausfertigung für Sizilien bestimmt und gehört damit auch zur „Italia Pontificia“, während eine textlich fast identische mit gleicher Adresse, wie die Überlieferungslage in diesem Falle ergibt, wenige Wochen später in der zweiten Januarhälfte 1185 nach Deutschland ging ${ }^{124}$. In einem größeren Rahmen werden einmal mehr die schon aus Handschriften in Barcelona, Inserten in englischen Chronisten und deutschen Johanniterchartularen erkennbaren Bemühungen des Papsttums nach dem dritten Laterankonzil in den Jahren 1181-1185 um breite Unterstützung für das zunehmend von Saladin bedrohte Königreich Jerusalem deutlich, vor allem aber rückt wie mit dem Kreuzzugsaufruf Eugens III. der Anteil Siziliens in der Kreuzzugspolitik des Papsttums in helleres Licht. Diese Linie fände geradlinig ihre Fortsetzung in einem Schreiben Clemens' III. an den Basileus Isaak II. Angelos von 1188 mit der Mitteilung, König Wilhelm II. werde die Kreuzfahrer mit Proviant und Waffen zum Kampf gegen Saladin unterstützen, wenn die

120 JL 15151, Gesta Henrici II, ed. William StubBs, London 1867 (Rolls Series 49), I S. 332; RI 4/4/2 1564 zu (1184 Nov.-1185 März); Schwerin, Aufrufe (wie Anm. 107) Nr. 7 zu 1184 (Nov.-Dez.).

121 JL 14360, Gesta Henrici II (wie Anm. 120) 1 S. 272; Schwerin, Aufrufe (wie Anm. 107) Nr. 6.

122 Vgl. die Vorbemerkung in O 1 S. 352 Nr. 165.

123 Ebd. S. $150 \mathrm{ff}$.

124 Ebd. S. 363 Nr. 175. 
modern anmutende, generalstabmäßig Plan und Durchführung umfassende Darlegung nicht ein Spurium, diesmal des 16. Jahrhunderts, wäre ${ }^{125}$.

Der letzte neue Text zu den eigentlichen Kreuzzügen ist ein Schreiben Clemens' III. von 1188 Juli 5 an die Gläubigen in der Toskana, die zwar das Kreuz genommen hatten, aber nun im Gegensatz zu den Pisanern den Aufbruch hinauszögerten ${ }^{126}$. Erst 1959 aus einer Handschrift der Vallicelliana in Rom bekannt geworden, konnte es nicht in die Nachlese und erst recht nicht in den Regestenband für die Toskana eingehen, sondern stellt gewissermaßen eine Additio Kehriana dar. Während jene für Frankreich zahlreichen Papsturkunden über eingegangene und nicht erfüllte oder aufgeschobene Kreuzzugsgelübde und über die Verletzung des Rechtsschutzes einzelner Kreuzfahrer und Pilger in der „Italia Pontificia“ völlig fehlen ${ }^{127}$, was, abgesehen vom zahlenmäßigen Unterschied in der Kreuzzugsbeteiligung diesseits und jenseits der Alpen, wohl auch die andere Struktur des städtischen Italiens spiegelt, wo sich die Probleme für einen Kreuzzugsteilnehmer anders stellten als für den kreuzfahrenden Ritter im agrarischen Frankreich, wird in der bisherigen Überlieferung für das 12. Jahrhundert einmalig ein scharfer Tadel an ein ganzes Kollektiv gerichtet, zugleich der terminus technicus der päpstlichen Kanzlei für die Kreuzfahrer, die signaculis crucis insigniti, verwendet.

Für das Verhältnis von Nachlese und Regestenwerk gingen in die „Italia Pontificia" von diesen Kreuzzugsschreiben, wie erwähnt, nur der Brief Urbans II. an Vallombrosa und das Schreiben Bohemunds ein, so daß sich erst recht die Frage stellt, was sie zur Geschichte der Kreuzzüge beiträgt und welches Bild der Kreuzzüge im Rahmen der Beziehungen des Papsttums zu Italien sich aus ihr ergibt. Da der Kreuzzug als solcher keinen eigenen Abschnitt bilden kann noch ein einzelnes Unternehmen, handelt es sich immer nur um vereinzelte, weit verstreute Nachrichten, die zusammenzufügen sind. Ein geschlosseneres Bild könnte sich höchstens eines Tages im ausstehenden allgemeinen Band ergeben.

Blickt man auf die großen Etappen der päpstliche Kreuzzugspolitik, so findet das Konzil von Piacenza, das mit der Gesandtschaft des Basileus und einem ersten, weitgehend ohne Echo bleibenden Aufruf des Papstes auf italie-

125 JL 16373, IP 8 S. 56 Nr. *223, Epistulae Turcicae, ed. Nicolaus Reusner, Frankfurt/ Main 1598, S. 16.

126 Ed. Mundò in: Rivista di storia della chiesa in Italia 13 (1959), vgl. O 3 S. 333 Nr. 155; einzuordnen in IP 3 S. 4 nach Nr. 15.

127 Die einzige derartige Urkunde in den „Papsturkunden in Italien“ stammt aus der Handschrift des damals noch ungedruckten Liber Censuum und betrifft die Festlegung eines Rekognitionszinses durch Coelestin III. von 1192 Aug. 13, ed. KeHr, Papsturkunden in Italien (wie Anm. 5) 2 S. 585 Nr. 25, jetzt Le Liber Censuum de l'Église romaine, ed. Louis Duchesne/Paul Fabre, Paris 1905, 2 S. 39 zu einem nach dem dritten Kreuzzug aus dem Heiligen Land zurückkehrenden französischen Kreuzfahrer, der der römischen Kirche seine Burg in der D. Périgueux aufgelassen hatte. 
nischem Boden vor Clermont am Anfang der Kreuzzugsbewegung steht, etwas überraschend selbst in der Narratio zum oberitalienischen Bistum keine Erwähnung ${ }^{128}$. Daß die Kreuzzugspredigt in Clermont nicht in die „Italia Pontificia" aufgenommen wurde, ist klar, doch für die nicht der Kurie angehörenden italienischen Teilnehmer wie die Erzbischöfe Daimbert von Pisa und Rangerius von Reggio di Calabria wäre nach der neueren Konzeption der Germania und der Gallia Pontificia ein Regest zu erstellen ${ }^{129}$.

Läßt man vorerst eine lange Serie von Spuria für einzelne Kreuzzugsteilnehmer beiseite, so bildet zeitlich das erste Regest in der „Italia Pontificia“ die Nachricht bei Caffaro, daß Urban II. nach dem Konzil von Clermont die Bischöfe Hugo von Grenoble und Wilhelm von Orange nach Genua geschickt habe, um die Genuesen zur Befreiung des Hl. Grabens anzustacheln ${ }^{130}$. Damit ist auch in der "Italia Pontificia“ die ligurische Hafenstadt als erste in die Kreuzzugsbewegung einbezogen, vor Pisa und vor Venedig und vor dem allgemeinen Aufbruch im Sommer 1096 und zwar in ihrer Kernfunktion für die künftige lateinische Herrschaft im Hl. Land als logistisches Zentrum für den Transport von Leuten und Material. Offensichtlich zögerten die Genuesen als vorsichtige Kaufleute jedoch, so daß von einer größeren Zahl von Kreuzfahrern, die 1096/1097 von Genua aus in den Osten gefahren wären, nichts verlautet, wenn auch einige genuesische Schiffe während der Belagerung von Antiochia im Winter 1097/1098 Proviant heranführten ${ }^{131}$. Selbst die Provenzalen, für die sich ein Weg zu See am ehesten angeboten hätte, waren am Ende des 11. Jahrhunderts noch ,Landratten' und nahmen lieber die Strapazen des Weges durch Dalmatien auf sich.

Ohne Erwähnung bleibt in der „Italia Pontificia“ aus dieser Frühphase des Kreuzzuges auch ein Vorfall, der den Kreuzzug und die päpstliche Herrschaft in Rom verband. Denn im Herbst 1096 geleiteten die französischen Kreuzfahrer, sozusagen als der erste Kreuzzug gegen einen innenpolitischen Gegner, Urban II. aus der Toskana in das in der Hand des Gegenpapstes befindliche Rom, wo sie als Pilger vor dem endgültigen Aufbruch in eine den meisten unbekannte Welt

128 Mindestens zu erwähnen in der Narratio IP 5 S. 442 f. Das Konzil erscheint genannt als Hintergrund für die Nachricht, daß Urban II. im März 1095 der Kirche von S. Maria de Campagnola einen Ablaß von so vielen Jahren zugesprochen habe, wie der jeweilige Gläubige Sandkörner in seiner Hand halten könne, vgl. IP 5 S. 487 Nr. $\dagger 1$.

129 Für die Konzilsteilnehmer siehe Robert Somerville: The Council of Clermont and Christian Society, in: Archivum Historiae Pontificiae 12 (1974) S. 55-90, hier S. 73. Er nennt außer Daimbert und Rangerius noch die suburbikarischen Bischöfe Walter von Albano, Johannes von Porto, Bruno von Segni. Zu ihnen vgl. HüLs, Kardinäle (wie Anm. 91) passim.

130 Caffaro: Annali (wie Anm. 93) 1 S. 101; IP 6/2 S. 323 Nr. *5.

131 Erwähnt werden u. a. bei Baudri de Dol: Historia Hierosolymitana, Paris 1879 (Recueil des Historiens des Croisades, Historiens Occidentaux 4), hier 1 8, S. 18. 
mit einer gefährlichen Reise über das Meer die Apostelgräber aufsuchen wollten. In St. Peter erwartete sie allerdings die böse Überraschung, daß die Anhänger Clemens' III. während ihres Gebetes auf das Dach stiegen, Ziegel abdeckten und die unten im Kirchenschiff betenden Kreuzfahrer mit Steinen bewarfen ${ }^{132}$ - eine Nachricht, die unter den seither geänderten Maßstäben zweifellos in einen Regestenband aufzunehmen wäre.

Nur fragmentarisch finden sich in der "Italia Pontificia“ Regesten über die Unternehmen, die noch mit dem ersten Kreuzzug verbunden sind oder unmittelbar an ihn anschließen: Unter Lucca wird der Brief seines Klerus an die Gläubigen über einen auf dem Konzil von Bari im Herbst 1098 von Urban II. beschlossenen eigenen Aufbruch cum multis terrae senatoribus nach Jerusalem ${ }^{133}$ nicht aufgenommen, auch nicht als Kommentar oder in der Narratio, sondern erscheint erst im Kommentar zum Brief Bohemunds und der anderen Kreuzzugsführer an Urban II. aus Antiochia von 1098 unter dem Principatus Tarantinus ${ }^{134}$. Der Aufbruch der Pisaner auf Befehl Urbans II. im Jahre 1098 wird unter Pisa, Civitas, erwähnt, nicht aber wie gesagt die Bestellung ihres Erzbischofs Daimberts zum Legaten ${ }^{135}$ noch die venezianische Expedition des Jahres 1100/1101. Nur nebenbei erfährt man wie erwähnt vom Aufenthalt des Legaten Mauritius von Porto in Genua ${ }^{136}$, dagegen erhält die Aufforderung an Erzbischof Anselm von Mailand zur Hilfe für das Hl. Land ein volles Regest ${ }^{137}$. Daß dies in den späten Bänden der "Italia Pontificia“ auch für die Bestellung Bohemunds zum Legaten für seine Werbereise nach Frankreich ${ }^{138}$ und, unter dem Regnum Normannorum, wo er eben eigentlich fehl am Platz ist ${ }^{139}$, für seinen Brief an Paschalis II. nach der Rückkehr aus Frankreich und vor seinem Aufbruch zum Kreuzzug gegen Byzanz ${ }^{140}$ erfolgt, zeigt die sich ausweitende Konzeption.

Für die Kreuzzugsbeteiligung erfährt man im Gegensatz zu der nicht erwähnten Anwesenheit italienischer Prälaten in Clermont und auf den folgenden Versammlungen in Frankreich wieder in den späten Bänden der „Italia Ponti-

132 Fulcher von Chartres: Historia Hierosolymitana, ed. Heinrich HagenmeYer, Heidelberg 1913, hier 1 7, 1-2, S. 163-166.

133 disponens ad Ierusalem profecto tendere.

134 IP 9 S. 442 Nr. 4. Zur Einordnung vgl. Anm. 108.

135 IP 3 S. 359 Nr. *23.

136 Siehe oben S. 635.

137 IP 6/1 S. 54 Nr. *129.

138 IP 9 S. 443 Nr. *6. Das Regest ist nicht ganz korrekt, denn nach dem päpstlichen Auftrag soll er in Frankreich nicht gegen Alexius werben, sondern für das Hl. Land. Jenes ist dann Bohemunds eigene Interpretation und Umsetzung, so daß er nachher wohlweislich einer Begegnung mit dem Papst aus dem Wege geht und sich aufs Briefeschreiben verlegt.

139 IP 8 S. 27 Nr. 91.

140 Wie Anm. 108. 
ficia“, ausgehend von dem Bemühen, die Bischofslisten zu ergänzen, unter Ariano Irpino im Samnium, daß der dortige Bischof Gerard am ersten Kreuzzug teilgenommen habe ${ }^{141}$, unter Martirano in Kalabrien von der Anwesenheit des Bischofs Arnulf bei der Eroberung von Jerusalem, nicht aber von seinen Aspirationen auf das Bistum Bethlehem ${ }^{142}$, während unter Adria im Podelta noch übergangen worden war, daß auch sein Bischof auf dem ersten Kreuzzug gewesen sein soll.

Als nächste und für Jahrzehnte einzige Regesten für den Kreuzzug folgen für 1121/1122 die Entsendung von Boten Calixts II. nach Venedig, um dort zur Hilfe für das Hl. Land aufzufordern, und die Übersendung der Petrusfahne an den Dogen ${ }^{143}$, jedoch ohne den Zusammenhang mit der Intervention des Legaten Bischof Petrus von Porto zugunsten von S. Maria della Carità herzustellen ${ }^{144}$. Mit dem venezianischen Unternehmen der Jahre 1122-1124 bricht in der „Italia Pontificia“ wegen der noch nicht rezipierten Aufrufe Eugens III. und Lucius' III., jener für den künftigen allgemeinen Band ein ,Muß', dieser wegen der durch die Überlieferung gesicherten Adressaten mindestens ein ,Soll', für Jahrzehnte ein völliges Schweigen über die Kreuzzugsbewegung herein. Erst die auf die Nachricht von Hattin und des Falls von Jerusalem am 2. Oktober 1187 folgenden Bemühungen Gregors VIII. und Clemens' III. und der Legaten Petrus von S. Cecilia und Soffred von S. Maria in Via lata ${ }^{145}$ um Hilfe für die bedrohten Kreuzfahrerstaaten und im Vorfeld um einen Friedensschluß zwischen den beiden tyrrhenischen Seestädten, erhalten unter Pisa mit fast einem Dutzend Regesten breiten Raum. Freilich wird eine chronikalische Nachricht, daß der Papst den Pisanern und ihrem Erzbischof Hubald, als dem Fahnenträger des Heeres und aller Christen und Legat des apostolischen Stuhls für alle Christen bei der Rückgewinnung Jerusalems, eine Petrusfahne übergeben habe, zu Recht mit einem Fragezeichen versehen ${ }^{146}$. Ein Teil dieser Regesten findet sich entsprechend unter Genua wieder, mit teilweise leicht abweichenden zeitlichen Einordnungen, die den Forschungsfortschritt spiegeln ${ }^{147}$.

141 IP 9 S. 137.

142 IP 10 S. 118.

143 IP 7/2 S. 91 Nr. *38 und *39; vgl. auch unten. Die auch in diesem Zusammenhang wichtige Chronik des Martino da Canal wird aber nicht herangezogen. Zum Unternehmen von 1122-1124, vgl. Jonathan Riley-Smith: The Venetian Crusade of $1122-$ 1124, in: I comuni italiani nel regno crociato di Gerusalemme, hg. v. Gabriella Arraldi/ Benjamin Z. Kedar, Genua 1986, S. 339-350 und Stroll, Calixtus II (wie Anm. 94) S. $451 \mathrm{ff}$.

144 Siehe Anm. 106.

145 IP 3 S. 362 f. Nr. $38, * 40-44$.

146 IP 3 S. 362 Nr. $\dagger^{*} 39$.

147 IP 6/2 S. 338 ff. Nr. 71 ff. Wieder Fälschungen sind zwei Schreiben Gregors VIII. an die Kanoniker und das Kapitel der Kathedrale von Pisa, die Herzen der Pisaner zum Kreuzzug anzuspornen, IP 3 S. 345 Nr. †72, und Clemens' III., eine Versammlung der 
Chronologisch reihen sich an die bereits erwähnte Bestellung von oberitalienischen Legaten der 1959 aufgefundene Brief Clemens' III. an die Kreuzzugsteilnehmer in der Toskana ein wie auch der wohl aus der Überlieferungssituation nur für Genua in einer eigenen Ausfertigung von 1188 Mai 27 erhaltene, aber sonst weit gestreute Kreuzzugsaufruf Clemens' III. Quam grave $e^{148}$. $\mathrm{Da}$ er mindestens auch nach Pisa geschickt wurde, darf man annehmen, ob auch nach Venedig, ist weniger sicher. Denn für die Hafenstadt an der Adria erscheint zu keinem der drei großen Kreuzzüge ein Regest, bis Coelestin III. dem Dogen im Jahre 1192 befiehlt, dem päpstlichen Legaten, dem Subdiakon N., Rektor von Massa, Getreide für die Christen im Hl. Land zur Verfügung zu stellen, zusammen mit einem Lastschiff für solche Transporte, das einst schon auf Betreiben des Kardinals und Legaten Rufinus bereitgestellt worden sei ${ }^{149}$. Wenn zudem bereits nach dem dritten Laterankonzil die Ausfuhr von Waffen, Eisen und Holz aus Venedig in die islamischen Gebiete unterbunden werden sollte ${ }^{150}$, zeigt beides die dominierende logistische Funktion für den Nachschub in die Kreuzfahrerstaaten, aber auch den Papst nicht auf einen Anstoß von außen reagierend, sondern selber aktiv eingreifend, wie der Kreuzzug seit 1095 zunehmend zum eigentlichen Handlungsraum und zur primären Aufgabe des Papsttums an der Spitze der Christianitas geworden war.

Wie angedeutet spielt in der „Italia Pontificia“ eine Reihe von S p u ri a für die Kreuzzüge, insbesondere für die Kreuzzugsbeteiligung, eine große Rolle, wie überhaupt in ihr unter den Spuria des 12. Jahrhunderts der Anteil solcher, die den Kreuzzug betreffen, überproportional hoch ist. Sie sollen hier zusammenfassend untersucht werden. Ganz offenkundig regte auch in Italien der Kreuzzug Fälscher an, wie dies aus dem neuzeitlichen Frankreich mit der berühmten Collection Courtois bekannt ist. Dabei läßt erst die zusammenfassende Betrachtung der einzelnen Nachrichten ihre Bedeutung erfassen. Die meisten hängen mit dem ersten Kreuzzug zusammen. Doch auf dieser Ebene beginnt der Beitrag der „Italia Pontificia“ lange vor 1095. Unter „Civitas Ianuensis“ erscheint als erstes Regest überhaupt der berühmte Brief auf den Namen Papst Sergius' IV. mit dem Versprechen aller Bürger Italiens (d.h. der Poebene), Venetiens und Genuas, tausend Schiffe auszurüsten, um das von den Agareni zerstörte Grab Christi zu rächen ${ }^{151}$. Entgegen der heute mehrheitlich vertretenen

Suffraganbischöfe und anderer tuszischen Prälaten, der Grafen und Markgrafen, Ritter usw. in der Kathedrale für die Wiedergewinnung des Hl. Landes einzuberufen, IP 3 S. 345 Nr. $† 74$.

148 IP 6/2 S. 290 Nr. 55, ed. O 3 S. 332 Nr. 154.

149 IP $7 / 2$ S. 26 Nr. 63.

150 IP $7 / 2$ S. 25 Nr. ${ }^{*} 60$ zu $(1179-1181)$, ebd. Nr. 61.

151 IP 6/2 S. 322 Nr. ${ }^{*} 1$. 
Auffassung, daß es sich um eine Fälschung handle ${ }^{152}$, sah Kehr den Fälschungsverdacht nulla ratione begründet und wiederholte das Regest dem Text entsprechend ohne Crux unter Venetien, behielt aber die dritte Erwähnung für „Italien“ dem allgemeinen Band vor.

Es folgt unter Civitas Ianuensis auf der nächsten Seite das Regest einer vom 1. Mai 1094 (!), also über ein Jahr vor Clermont, datierten littera Urbans II. an alle Christen von Osten nach Westen und von Süden nach Norden mit der Aufforderung, den genuesischen Brüdern Jakob und Ottobonus Belmusto, den Söhnen des Roger Belmusto, der unter Robert Guiscard Krieg führe, und den sie begleitenden 300 Rittern bei ihrem Durchzug zum großen Herzog Buglioni (!) Hilfe zu gewähren. Als Belohnung sollte den Wohltätern ein Plenarablaß in der Form eines Anno Santo winken ${ }^{153}$. Daß es sich um eine Fälschung handelt, braucht kaum betont zu werden. Aus derselben Werkstatt stammt auch ein von Kehr erstmals ediertes Privileg Urbans II. von 1097 aus einer anderen vatikanischen Handschrift für die edlen Brüder Spinelli aus Neapel, ebenfalls mit dem Ablaß eines Jubeljahres ${ }^{154}$. Zeitlich nochmals ein Jahr vor dem Brief für die Belmusti soll ein drittes dieser päpstlichen Schreiben am 24. Februar 1093 dem populus libertatis von Bisantium, gemeint mit antikisierendem Namen Prato, unter dem Fischerring (!) auf Bitte Peters des Einsiedlers befohlen haben, binnen Jahresfrist 30 Adlige für den Kreuzzug auszurüsten ${ }^{155}$. Bezieht man entsprechende Nachrichten in italienischen Stadtchroniken und -geschichten des 15.-17. Jahrhundert ein, ließe sich die Zahl leicht vermehren. So berichtet die venezianische Cronaca Navagera des 16. Jahrhunderts von einer Aufforderung Urbans II. auf dem Konzil von Clermont in Cilicia (!) an die Venezianer zur Teilnahme am Kreuzzug und von der Übertragung einer Kreuzzugslegation an den Bischof Heinrich Contarini von Castello für die venezianische Flotte in mari, wie sie Adhemar von Puy in terra erhalten habe ${ }^{156}$. Beides wurde nicht in die „Italia Pontificia“ aufgenommen.

Was für die Belmusto, die Spinelli usw., isoliert gesehen, als phantasievolle Kuriositäten abgetan werden könnte, bildete in Wirklichkeit Teil eines weit

152 JL $† 3972$; vgl. jetzt auch RI 2/5 Nr. †1049 und Papsturkunden 896-1046, hg. v. Harald Zimmermann, 3 Bde., 2. Aufl., Wien 1988-1989, hier 2 S. 845 Nr. 445.

153 IP 6/2 S. 323 Nr. †4.

154 KeHR, Papsturkunden in Italien (wie Anm. 5) 5 S. 6 Nr. †2, IP 8 S. 465 Nr. †1, O 3 S. 89 Nr. $† 3$ mit dem Hinweis auf ein Privileg Kaiser Heinrichs VI. für einen Rupert Belmosto (Stumpf 5078).

155 IP 3 S. 142 Nr. †1, ed. Kenr, Papsturkunden in Italien (wie Anm. 5) 5 S. 6 Nr. $\nmid 2$; O 3 S. $391 \mathrm{Nr}+1196$.

156 Andreas Naugerius: Historia Veneta (Cronaca Navagera), ed. Ludovico Antonio Muratori, Mailand 1723 (Rerum Italicarum Scriptores 23), S. 962; vgl. Fortunatus Olmus: Historia translationis s. Nicolai, Venedig 1626, S. 32. Regest einzureihen in IP 7/2 S. 20 nach Nr. 36. 
verbreiteten Bestrebens, sich als Individuum, als Familie oder als staatlichkommunales Kollektiv einen Platz in dem ruhmbringenden Kreuzzugsgeschehen zu sichern. Die Absicht, das im 11. Jahrhundert noch unbedeutende Prato oder das erst um 1100 in den Kreuzzug eingreifende Venedig schon in Clermont oder gar zuvor als beteiligt darzustellen, ist evident, und die abwegigen Datierungen sollen Italien gegenüber der im allgemeinen Bewußtsein dominierenden Stellung Frankreichs eine Art Erstgeburtsrecht am Kreuzzug verschaffen.

$\mathrm{Zu}$ diesen Bemühungen gehört auch eine lange Reihe von Fälschungen, die den Anteil Pisas am Kreuzzug glorifizieren und keinen geringen Teil der Regesten für die „Civitas Pisana“ ausmachen. Darunter befindet sich ein seit dem 17. Jahrhundert als eine Zimelie der pisanischen Geschichte verehrter Brief Paschalis' II. an die pisanischen Konsuln Gloria in altissimis, mit dem er für ihre Hilfe beim ersten Kreuzzug dankt und verspricht, er werde ihren Erzbischof Daimbert, jetzt Patriarch von Jerusalem, an Gottfried von Bouillon und die anderen Kreuzzugsführer in Syrien empfehlen. Jaffé wie die ganze Kreuzzugsforschung hatte ihn ohne jedes Bedenken rezipiert, weil er scheinbar präzise Angaben über die Überlieferung macht, doch Kehr wies nun nach, daß auch er ein Machwerk des 17. Jahrhunderts darstellt ${ }^{157}$. Aus der gleichen Quelle stammt eine nicht minder falsche littera Calixts II., die den in Jerusalem weilenden pisanischen Kanonikern P. und C. außer der ihnen vom Patriarchat gewährten Unterstützung den Ertrag ihrer Pfründen und die übrigen Zuwendungen der Kirche von Pisa zubilligt, als ob sie anwesend wären ${ }^{158}$. Es folgt immer gleicher Herkunft eine Befreiung der Kathedrale von Pisa von Kreuzzugssteuern durch Innozenz II. im Jahre 1138, ein Aufruf Gregors VIII. und ein solcher Clemens' III. zur Hilfe für das Hl. Land ${ }^{159}$. Die große Zahl solcher Spuria aus Pisa ist kein Zufall, sondern diente offensichtlich dazu, durch angebliche Papsturkunden „Lücken“ in der historischen Überlieferung über die eigene Beteiligung an den Kreuzzügen insbesondere gegenüber dem konkurrierenden Genua zu überbrücken.

\section{V.}

In mancher Hinsicht in einer Art Zwischenstellung zwischen der Diözesanorganisation und den Ritterorden, denen der letzte Abschnitt gelten wird, steht das Kapitel des Hl. Grabes. Dabei ist zu beachten, daß wie in Frankreich und England keineswegs alle Kirchen Italiens mit diesem Patrozinium

157 IP 3 S. 359 Nr. $† 24$.

158 IP 3 S. 360 Nr. $† 30$.

159 IP 3 S. 345 Nr. $† 72$ und $\dagger^{*} 39$. Ein zweiter, von Kehr verworfener, chronikalisch überlieferter Aufruf, mit dem Erzbischof Hubald zum Legaten für das ganze Kreuzzugsheer ernannt wird, ist dagegen höchstens verfälscht, vgl. IP 3 S. 345 Nr. †*74. 
auch institutionell zur Grabeskirche in Jerusalem gehörten. Papsturkunden etwa für S. Sepolcro in Piacenza ${ }^{160}$ sind daher nicht dem lateinischen Osten zuzurechnen. Andererseits hatte die Grabeskirche in Jerusalem schon lange vor den Kreuzzügen Besitz in Italien, Südfrankreich und Spanien und scheint mit regelmäßigen Botenreisen die ihr zustehenden Abgaben und gleichzeitig Almosen eingesammelt zu haben ${ }^{161}$, was es dem Kapitel nach 1291 erlaubte, zeitweise seinen Sitz in Perugia zu nehmen, wo auch noch lange Archivteile aufbewahrt worden sein sollen ${ }^{162}$. Ältere Papsturkunden für die Grabeskirche in Jerusalem sind freilich bei der Nachlese für die „Italia Pontificia“ nicht zum Vorschein gekommen. Es bleibt bei der Erwähnung von einzelnen Niederlassungen.

Auf diese Beziehungen verweist in der „Italia Pontificia“ zuerst der - sit venia verbo - etwas chaotische Abschnitt über die Abtei S. Sepolcro in Acquapendente im nördlichen Latium ${ }^{163}$. Wenig klar erwähnt die Narratio, die zwölf Regesten vorausgeht, die Abtei sei eine Niederlassung der Zisterzienser und ein Haus der Templer gewesen, aber auch Acquapendente gehöre zum Hl. Grab, sei jedoch von Innozenz III. als Eigentum der römischen Kirche angesehen worden, das er den Vallombrosanern zur Reform übergeben habe. Damit läßt sich freilich das einzige feierliche Privileg des 12. Jahrhundert von Lucius II. von 1144 Mai $21^{164}$ nur schwer verbinden, das den Ort in den apostolischen Schutz aufnimmt, ohne die Templer oder die Zisterzienser oder das Hl. Grab zu erwähnen, während in der von Holtzmann in Agira neugefundenen Urkunde von 1196 die Kirche S. Sepolcro in Acquapendente der Abtei S. Maria Latina in Jerusalem, nicht dem Hl. Grab, als Besitz bestätigt wird ${ }^{165}$. Ebenso unklar bleibt, wie in diesen Ablauf die wohl nicht rein zufällige Weihe der Kirche durch Eugen III. im Januar 1147, d.h. bereits auf seiner Reise nach Norden, um jenseits der Alpen die Kreuzzugsvorbereitungen zu fördern, einzureihen sei ${ }^{166}$. Mit ihr scheint der Papst ein symbolisches Zeichen für seine Bemühungen um Hilfe für das Hl. Land gesetzt zu haben, was aber nur Sinn macht, wenn Acquapendente schon damals einer Kirche in Syrien gehörte.

Als Besitz der Grabeskanoniker wird in der „Italia Pontificia“ ferner ein Hospital des Hl. Grabes vor der Porta S. Pietro in Perugia erwähnt, das Lucius

160 IP 5 S. $504 \mathrm{f}$.

161 Vgl. Paul Riant: Inventaire des lettres historiques des croisades, in: Archives de l'Orient latin 1 (1881) S. 1-224. Einige Angaben bei Johannes Pahlitzsch: Graeci und Suriani im Palästina der Kreuzfahrerzeit, Berlin 1998 (Berliner historische Studien 33, Ordensstudien 15), S. 40-52.

162 In IP 4 nicht erwähnt. Vgl. Riant: Inventaire (wie Anm. 161).

163 IP 2 S. $227-229$.

164 JL 8618, ed. Codice diplomatico della città di Orvieto, ed. Luigi Fumi, Florenz 1884 (Documenti di storia italiana VIII), S. 109 zu Nr. 169.

165 Holtzmann, Papsturkunden (wie Anm. 35) S. 63 Nr. 4.

166 IP 2 S. 229 Nr. ${ }^{*} 12$. 
II. aufgrund einer gefälschten Urkunde Calixts II. der dortigen Abtei S. Pietro übertrug, Eugen III. jedoch wieder absprach ${ }^{167}$. Ein Hospital und die Kirche des Hl. Grabes in Jerusalem in Nervi bei Genua wird dagegen nur unter der dortigen Pfarrkirche S. Siro angeführt, mit der die Kanoniker einen längeren Streit austrugen, den der Kardinalpriester Petrus von S. Cecilia mit folgender Bestätigung durch Coelestin III. beilegte ${ }^{168}$. Dies alles sind übliche Konflikte, die nur zeigen, daß die Niederlassungen des Hl. Grabes wegen der großen Distanz zum Mutterhaus oft gefährdet waren, in anderen Fällen wie in Nervi jedoch gestützt auf ihre Privilegien durchaus aggressiv gegen Konkurrenten vorgingen.

Ohne folgende Regesten erscheint unter Barletta neben den Templern und Johannitern die Kirche S. Sepolcro ${ }^{169}$ und unter dem Erzbistum Brindisi ein dort gelegenes Priorat ${ }^{170}$. Ebenso wird für Rom nur in der Narratio zu S. Egidio im Borgo Angelico erwähnt, daß Alexander III. während seines ersten Aufenthaltes in der Stadt nach der Rückkehr aus Frankreich im Jahre 1166/1167 die Kirche dem Prior und den Brüdern des Hl. Grabes zur inneren Reform und personalen Erneuerung durch erfahrene Leute geschenkt habe ${ }^{171}$, doch erscheint dieses im Titel des Abschnittes nicht, so daß die Zugehörigkeit zu einer Kirche des Hl. Landes erst bei genauer Lektüre erkennbar wird. Auffälligerweise fehlt auch jeder Hinweis auf die bereits von Coelestin II. 1144 erfolgte Schenkung einer von ihm ohne Patrozinium genannten Kirche in Rom ${ }^{172}$. Diese scheint in der Zwischenzeit verloren gegangen zu sein, wenn es sich unter Alexander III. nicht um eine Neuschenkung bzw. unter Auflagen ausgesprochene Bestätigung der in der Zwischenzeit heruntergekommenen - oder etwa in die Hand der Anhänger des Gegenpapstes geratenen? - Kirche handelt, auf die die Kanoniker ihre Rechte verwirkt hatten. Auch die von Coelestin II. hervorgehobene Zweckbestimmung als Unterkunft für die in Geschäften des Hl. Grabes an die Kurie kommenden Brüder aus dem Hl. Land, wird 1166/1167 nicht wiederholt ${ }^{173}$. Sie stellte jedoch die Niederlassung in einen direkten Bezug zum Papsttum und hätte daher eigentlich unter 1144 zu einem eigenen Regest führen müssen. Von Bedeutung ist sie als Beleg für eine bereits kurz nach dem zweiten

167 IP 4 S. $71 \mathrm{f}$.

168 IP 6/2 S. 344 Nr. 1-3. In der Edition von Pflugk-Harttung, Acta (wie Anm. 19) 2 S. 398 Nr. 454 wird sie fälschlich den Johannitern zugeschrieben.

169 IP 9 S. 302.

170 Ebd. S. 385.

171 IP 1 S. 153 f., JL 13184, ed. O 3 S. 176 Nr. 54; ed. BresC-Bautier: Le cartulaire (wie Anm. 19) S. 273 Nr. 140.

172 JL 8482, ed. O 3 S. 176 Nr. 54; ed. Bresc-Bautier (wie Anm. 19) S. 58 Nr. 13.

173 In qua Domino serviatis et cum pro negociis ecclesie vestre ad curiam veneritis, honestum hospicium habeatis. 
Laterankonzil institutionell verankerte Präsenz der Grabeskirche in Rom bzw. an der Kurie ${ }^{174}$.

Am wichtigsten für das Verhältnis des Hl. Grabes zum Papsttum und Italien im 12. Jahrhundert ist freilich jenes in der Narratio zu Barletta erwähnte, weil dort als Original aufbewahrte feierliche Privileg Lucius' III. ${ }^{175}$. Es ist nicht in den Chartularen des Kapitels enthalten und stellt daher wohl im angedeuteten Sinn eine spezielle Ausfertigung für die apulischen Niederlassungen dar, die eine Art Generalpriorat mit Sitz in Barletta gebildet haben könnten. In Erweiterung der Vorurkunden enthält es neben der allgemeinen Bestätigung von Besitz in Sizilien, Kalabrien und Apulien, Rom und Toskana eine nur hier überlieferte Liste von zwölf einzeln aufgeführten Kirchen in Apulien und der Basilicata, über die wir sonst meist nichts wissen und die in der nächsten, wieder an das Mutterhaus gegangenen Bestätigung durch Coelestin III. am Ende des Jahrhunderts wegfallen ${ }^{176}$.

\section{VI.}

Weitgehend übergangen wurden bisher die großen Ritterorden der Te m ple r und Joh an nit e r ${ }^{177}$. Dabei ist stets zu beachten, daß als Folge der Aufhebung des Templerordens auf dem Konzil von Vienne und der Integration seiner Güter in den Johanniterorden in der Regel auch die Urkunden an die neuen Eigentümer übergingen, so daß sich heute außer auf der Iberischen Halbinsel, wo eine andere Lösung für den Ordensbesitz erfolgte, im Prinzip überall in den Archiven der Johanniter auch Urkunden für die Templer finden ${ }^{178}$. Weil durch die beiden großen Urkundenbücher von Delaville le Roulx und d'Albon ${ }^{179}$ umfassende Vorarbeiten geleistet worden sind, sei hier mit dem Bild begonnen, das sich aus den Bänden der „Italia Pontificia“ ergibt und dann erst die Frage nach der Nachlese gestellt.

Wie für die großen Abteien von S. Maria Latina, S. Maria im Tale Josaphat, S. Maria auf dem Berge Sion lag für beide Orden das Haupthaus bis zur Krise des Jahres 1187 in Jerusalem, nach 1191 in Akkon. Doch ihr Besitz im Westen wuchs im Laufe des 12. Jahrhunderts fast explosionsartig und übertraf rasch

174 Für die Niederlassungen der Templer, der Johanniter und des Hl. Grabes in Rom vgl. künftig meinen Beitrag „Esser presente alla curia“.

175 Siehe oben S. 619 Anm 19.

176 O 3 S. 298 Nr. 125. Vgl. dazu auch Bresc-Bautier: Les possessions (wie Anm. 33).

177 Auf den deutschen Orden wird hier nicht besonders eingegangen, da er an anderer Stelle behandelt wird.

178 Vgl. die Übersicht über die Aufbewahrungsorte der Johanniterurkunden in Delaville LE Roulx: Cartulaire (wie Anm. 10).

179 Siehe oben Anm. 10 und 18. 
auch denjenigen des Hl. Grabes bei weitem. Sie wurden zu ,internationalen Orden, die überall präsent waren und über eine Fülle von Privilegien verfügten, was zu einer Vielzahl von Konflikten mit der Diözesangeistlichkeit führte, gegen die sie ihre Privilegien bald offensiv und oft rücksichtslos ausspielten, bald auch angegriffen verteidigen mußten. Dies führte zu einem zunehmend komplexeren hierarchischen Aufbau von einzelnen Häusern und Kommenden über sogenannte Bailliages und (Groß-)Priorate zu Provinzen und Zungen und einer Zentrale mit dem Konvent am Sitz des (Groß-)Meisters, was freilich erst am Ende des 13. Jahrhunderts voll ausgebildet war ${ }^{180}$.

Auch auf der Apenninenhalbinsel war der Besitz der Templer und Johanniter beträchtlich. Als Folge bildete sich anscheinend weitgehend parallel eine Reihe von Ordensprovinzen heraus, die zum Teil durch die politische Struktur vorgegeben waren, denn der Besitz im normannischen Süditalien, im Kirchenstaat und im kleinräumiger gegliederten Oberitalien konnte nicht von einer für die ganze Halbinsel zuständigen Instanz geleitet werden. Daß es sich gerade in Süditalien um umfangreichen Besitz handelte, zeigt die Einrichtung von drei Johanniter-Großprioraten in Messina, Barletta und Capua, die den drei Teilen des normannisch-staufischen Königreichs entsprachen, während für die Mitte und den Norden vier weitere in Rom, Pisa, Venedig und in der Lombardei zuständig waren ${ }^{181}$. Welche Befugnisse und welchen Amtsbezirk der magister Italiae hatte, der am Ende des 12. Jahrhunderts bei den Templern begegnet, ist noch nicht abschließend geklärt ${ }^{182}$. In der "Italia Pontificia“ hatten weder die Ordenszentralen noch die Orden als Ganzes Platz, die in den Oriens Pontificius Latinus gehören. Doch die nachgeordneten Verwaltungseinheiten mußten neben den Besitztiteln für den lokalen Besitz aus logistischen Gründen auch an Ort und Stelle über die dem Orden verliehenen allgemeinen Rechtstitel verfügen und erhielten daher im eingangs erwähnten Sinne nicht nur Kopien von Privilegien aus dem Mutterhaus, sondern auch Originalausfertigungen aus der päpstlichen Kanzlei, die aber in der Adresse oder im Kontext fast immer den Orden allgemein, nicht eine nachgeordnete Organisationsebene oder einen Raum nennen. Daher standen auch die einzelnen Häuser und vor allem die zusammenfassenden Organisationseinheiten der Orden in unmittelbarem Kontakt mit der Kurie. Es sind allein die Überlieferung und die Kommuni-

180 Für die Templer vgl. Malcolm BARBER: The New Knighthood. A history of the order of the Temple, Cambridge 1994, und Alain Demurger: Les Templiers. Une chevalerie chrétienne au Moyen Âge, 2. Aufl., Paris 1993; für die Johanniter Jonathan RiLEYSмiтн: The Knights of St. John in Jerusalem and Cyprus (c. 1050-1310), London 1967.

181 Vgl. für die Johanniter Delaville le Roulx: Cartulaire (wie Anm. 10) 1 S. CXICXXXV.

182 Vgl. Fulvio Bramato: Storia dell'Ordine dei Templari in Italia, 2 Bde., Rom 1994, hier 1 S. 153-159. 
kationswege von der Kanzlei zum heutigen Aufbewahrungsort, die über die Zuordnung für eine vom Empfängerprinzip her konzipierte Zusammenstellung entscheiden, so daß selbst von zwei völlig identischen Ausfertigungen eines feierlichen Privilegs oder eines Mandats beide an die Zentrale oder beide an dieselbe nachgeordnete Instanz oder die eine an die Zentrale und die andere an eine nachgeordnetete Instanz gegangen sein können und dementsprechend im Regestenwerk an verschiedenen Stellen einen Haupteintrag erhalten.

Dennoch bleibt die Zahl der Regesten für die beiden großen Ritterorden in der „Italia Pontificia“ gering und ihre Organisationsstruktur kommt selbst in den Narrationes nur ganz undeutlich zum Ausdruck. Die Großpriorate und Ordensprovinzen spielen keine Rolle als Überlieferungsträger, denn ihre Archive sind, soweit es um ältere Bestände und insbesondere um ältere Papsturkunden geht, im Laufe der Jahrhunderte anscheinend fast restlos verloren gegangen, was auch dazu beiträgt, daß es bis heute keine umfassende Darstellung der Geschichte der Johanniter in Italien gibt, während Fulvio Bramato in zwei Bänden eine Geschichte der Templer in Italien vorgelegt hat, deren zweiter Band 647 Regesten von 1130 bis 1394 enthält ${ }^{183}$, davon 19 für Papst- und Legatenurkunden bis 1198.

Entsprechend klein ist in der „Italia Pontificia“ die Zahl der selbständigen Abschnitte für Templer- und Johanniterniederlassungen. Da diese zudem häufig aus Schenkungen bereits bestehender Kirchen herrührten, wurden sie meist mit Einschluß der vorangehenden Zeit unter dem ursprünglichen Patrozinium behandelt, wie auch die anschließenden Regesten sich oft nicht auf die Ordenszeit beziehen, so daß erst aus der Narratio die Zugehörigkeit zu einem der beiden Orden ersichtlich wird. Nur vereinzelt wird als Untertitel etwa Mansio Templariorum $^{184}$ oder Domus Hospitalariorum ${ }^{185}$ hinzugefügt, wie es auch nie ein Ziel der „Italia Pontificia“ war, einen Gesamtblick auf den Ordensbesitz, seien es die Ritterorden oder die großen Reformorden, zu vermitteln. Häufig finden sich daher Erwähnungen von Templern und Johannitern unter den Regesten für

183 Ebd. 2 S. 71-235. Papst- und Legatenurkunden werden erwähnt bis 1198 in 19 Regesten, einem Fünftel von 85: S. 77 Nr. 2 für Lucca, S. 82 Nr. 25 für Sizilien, S. 83 Nr. 30 für Capitanata, Apulien und Kalabrien, S. 84 Nr. 35 für Reggio Emilia, S. 85 Nr. 41 für Ceprano, S. 86 Nr. 45 und 46 für Termoli/Tremiti, S. 87 Nr. 50 für Principato, Capitanata, Apulien und Kalabrien, S. 88 Nr. 52 für San Germano bei Montecassino, S. 89 Nr. 56 für Verona und Nr. 58 für Ceprano, S. 90 Nr. 61 für Verona und Nr. 64 für Acqui, S. 90 Nr. 65 und S. 91 Nr. 66 Legaten für Verona mit päpstlicher Bestätigung, S. 92 Nr. 72 für Zara und Nr. 74 für Apulien, Kalabrien und Sizilien, S. 93 Nr. 79 päpstliche Legaten für Moncalieri, S. 94 Nr. 84 für Fermo. Die Liste bei Bramato ist unvollständig, so fehlt z. B. Clemens III. für die Crociferi und Zara.

184 IP 3 S. 215 Nr. *1 für Siena.

185 Siehe unten Anm. 209. 
andere Kirchen, vor allem wenn es um Besitzstreitigkeiten oder Auseinandersetzungen über die Sonderrechte der Orden ging.

Es kann nicht darum gehen, jeden einzelnen Beleg in einer Narratio, einem Regest oder einem Kommentar in der „Italia Pontificia“, der auf Templer und Johanniter weist, zu erörtern. Nur die lokale Verteilung der Niederlassungen mit der Zahl der ihnen zugeordneten Regesten sei genannt. Auf der Ebene der Großpriorate hat nur Barletta für die Johanniter einen eigenen Abschnitt mit vier Regesten ${ }^{186}$, während in den Narrationes zum Erzbistum dasjenige für Messina $^{187}$, als einfache Domus hospitalis jenes für Capua erwähnt wird, im Band für Rom S. Maria auf dem Aventin den Untertitel S. Maria del Priorato erhält. Unter Pisa, Venedig und für die Lombardei sucht man vergeblich nach einem entsprechenden Abschnitt, für die Templer entfällt überhaupt jeder Hinweis auf die höheren Verwaltungseinheiten, obwohl Schiaparelli in seinem Bericht über Sizilien ausdrücklich festgehalten hatte, einzelne Abschriften in Palermo seien dem Tabularium domus Templi nobilis civitatis Messanae entnommen ${ }^{188}$.

Auf der Ebene der Kommenden weist die „Italia Pontificia“ für die Templer nur wenige nach, die im Laufe des 12. Jahrhunderts in Kontakt mit dem Papsttum getreten sind. Sie folgen hier in der Abfolge der Bände der „Italia Pontificia": Ceprano für S. Paterniano mit Erwähnung in der Narratio und zwei Regesten ${ }^{189}$, und das bereits bei den Kanonikern des Hl. Grabes erörterte Acquapendente als Templariorum militum domicilium in der Narratio ${ }^{190}$, Lucca mit der Bestätigung einer Schenkung durch Innozenz II. von 1138 Dezember 2 als der ältesten Papsturkunde für die italienischen Niederlassungen (ein Regest) ${ }^{191}$ und als erstes eigenes Lemma die Mansio Templariorum in Siena (ein Regest) ${ }^{192}$, Fermo in einer Verfügung Coelestins III. zugunsten des Bischofs ${ }^{193}$, ReggioEmilia für S. Stefano mit dem Untertitel Domus templariorum und einem Re-

186 IP 9 S. 305.

187 IP 10 S. 322.

188 Kehr, Papsturkunden in Italien (wie Anm. 5) 2 S. 45 zu Cod. Qq. H. 12.

189 IP 2 S. 173; die Kirche S. Paterniano wird 1173 von Alexander III. den Templern gegeben; JL 2 S. 263; IP 2 S. 173 Nr. * 4 aus der Chronik von Fossanova. 1181 wird eine weitere Schenkung des Bischofs von Veroli durch Alexander III. bestätigt, JL -; KEHR, Papsturkunden in Italien (wie Anm. 5) 2 S. 503 Nr. 22. Im Kommentar wird erwähnt, daß schon Bf. Faramundus von Veroli den Templern die Kirche geben wollte auf Intervention von Franco, dem Kämmerer Alexanders III. (Archiv von Veroli Nr. 656). Dieser Franco war jedoch selber ein Templer, vgl. O 2 S. 235 Nr. $24 \mathrm{~b}$ und Marie Luise Bulst-Thiele: Templer in königlichen und päpstlichen Diensten, in: Festschrift Percy Ernst Schramm, hg.v. Peter Classen, 2 Bde., Wiesbaden 1964, 1 S. 289-308, S. 301.

190 IP 2 S. 227.

191 IP 3 S. 448 und 449 Nr. 1; JL 7916.

192 IP 3 S. 204 Nr. 37 an den Bischof von Siena = S. 215 Nr. ${ }^{*} 1$ an die Templer.

193 IP 4 S. 138 Nr. ${ }^{*} 18$. 
gest ${ }^{194}$, Moncalieri in Piemont für S. Egidio als Templerbesitz mit einem Regest $^{195}$, ferner in Acqui die Ecclesia s. Margaritae Templariorum mit einem Regest ${ }^{196}$, Verona mit der Ecclesia s. Vitalis Templariorum mit fünf Regesten ${ }^{197}$. Es folgen im Süden in San Germano zu Füßen von Montecassino eine Domus Templariorum mit zwei Regesten ${ }^{198}$ und schließlich ein Haus in der Capitanata mit drei Regesten, wohl identisch mit der in der Narratio zu einer Domus misericordiae apud Foiam sita (kein Regest) erwähnten Niederlassung oder der mit der Abtei auf den Isole di Tremiti prozessierenden Templer (zwei Regesten $)^{199}$ und zuletzt Barletta unter der Narratio ohne Regest ${ }^{200}$. Sizilien bleibt ein weißer Fleck.

Nicht besser ist es mit den Johannitern bestellt. Zwar ist hier neben den bereits erwähnten Großprioraten Capua, Barletta und Messina in Asti eine domus hospitalis iuxta civitatem belegt, bei der es sich um das schon 1113 erwähnte Hospital handeln könnte, wenn auch der Bischof von Asti sie 1182 als Gründung eines Petrus Fantinus und eines Soldanus dem Meister und dem praeceptor Hospitalariorum de Lombardia verleiht ${ }^{201}$. Weitere Häuser erhalten z.T. einen eigenen Abschnitt wie Imola mit einer Domus fratrum hospitalis Hierosolymitani mit einem Regest ${ }^{202}$, Foggia dagegen nur in der Narratio der Domus misericordiae ohne Regest ${ }^{203}$, daneben nur vier weitere Orte, wo sich aus Rechtsstreitigkeiten Regesten ergeben, die die Existenz von Ordensniederlassungen belegen: Fermo mit der schon bei den Templern erwähnten Verfügung

194 IP 5 S. 325 Nr. 8 = S. 377 Nr. 1. Eine erste Nachricht über ein Haus in Mussadella stammt von 1144 .

195 IP 6/2 S. 92 Nr. 1; Bramato, Storia (wie Anm. 182) 2 S. 93 Nr. 79, dessen Regest aber fälschlich den Legaten statt des Bischofs von Turin als Schenkenden ausweist, der auf Bitten des Legaten handelt.

196 IP 6/2 S. 195. Frühere Nachrichten über ein Templerhaus in Acqui sind nicht bekannt. 197 IP $7 / 1$ S. 265 f.

198 IP 8 S. 194 f. Nr. 1 und 2, zuerst Alexander III. bestätigt Kirche S. Angelo von Abt von Montecassino geschenkt und dann kurz darauf Spezifizierung mit Schutz von Montecassino, daß sie keine Kirche bauen und Montecassino nicht schädigen sollen (ed. JL - , KeHr, Papsturkunden in Italien [wie Anm. 5] 2 S. 81 Nr. 33 und JL 13590). Für die jeweilige Zahl der Regesten wird hier nicht geschieden zwischen Hauptregest und Nebenregesten für Papsturkunden an andere Empfänger, die auch einen der beiden Orden betreffen, und ebenfalls nicht zwischen Papsturkunden, Legatenurkunden und anderen Urkunden, die zu der betreffenden Niederlassung gehören.

199 IP 9 S. 144. Es dürfte sich dabei um das in IP 9 S. 226 unter der Domus misericordiae bei Foggia genannte Templerhaus handeln oder die mit dem Abt von Tremiti einen Konflikt austragenden Templer vgl. IP 9 S. 185 Nr. * 12 und 13.

200 IP 9 S. 302.

201 IP 6/2 S. 180 Narratio ohne Regest.

202 IP 5 S. 171.

203 IP 9 S. 226. 
Coelestins III. zugunsten des Bischofs als einzigem Beleg ${ }^{204}$, Acqui für die Ecclesia s. Caloceri Hospitalariorum mit einem Regest ${ }^{205}$, Tortona für die Domus Hospitalariorum s. Crucis mit einem Regest ${ }^{206}$, und Genua unter Ecclesia s. Fidis nur in der Narratio ohne Regest ${ }^{207}$. Nur in einem Kommentar kommt schließlich im äußersten Süden des Festlandes Cosenza hinzu ${ }^{208}$. Diese Liste ist von den genannten Niederlassungen her zweifellos wesentlich repräsentativer, wenn man bedenkt, daß im ersten feierlichen Privileg Paschalis' II. im Jahre 1113 Asti, Pisa, Bari, Otranto, Taranto und Messina als nachgeordnete Häuser des Hospitals in Jerusalem genannt werden ${ }^{209}$, doch zahlenmäßig mit acht Regesten (und einem räumlich definierten) gegen 21 (und drei räumlich definierten) für die Templer noch kläglicher sind ${ }^{210}$.

Unter archivalischem Gesichtswinkel lassen sich in Italien in chronologischer Abfolge für das feierliche Privileg der Johanniter Christianae fidei religio Originale oder alte Kopien nachweisen aus Barletta für 1154 Oktober 21, in Messina von 1167 Juni 23, in Assisi von 1180 Januar 26 von unbekannter Herkunft $^{211}$, aus Capua Kopie von 1304 des feierlichen Privilegs Urbans III. (JL 15551) jetzt in Montecassino ${ }^{212}$, und wieder für Barletta von 1186 März $14^{213}$, dagegen auf der ganzen Apenninenhalbinsel kein Exemplar des Templerprivilegs Omne datum optimum, sei es als Original oder als Kopie. Weil diese Ausfertigungen stets an den Meister des Hauses in Jerusalem gerichtet sind, erhielten sie dem gewählten Prinzip folgend, wenn auch unberechtigterweise, nie ein eigenes Regest, obwohl sie in Wirklichkeit, wie heute feststeht, für die entsprechenden Priorate ausgestellt worden waren.

204 IP 4 S. 138 Nr. * 18.

205 IP 6/2 S. 195.

206 Ebd. S. 228.

207 Ebd. S. 303.

208 IP 10 S. 114 Nr. 8, Kommentar erwähnt zu Erzbischof Sanctus Alexander III. (11791181) November 27, ed. KeHr, Papsturkunden in Italien (wie Anm. 5) 2 S. 76 Nr. 12.

209 Diese Liste ist in den letzten Jahren heftig umstritten, nachdem Michael Matzke darin nicht den Niederschlag realer Gegebenheiten, sondern m.E. völlig mittelalterfremd, einen groß angelegten Plan künftiger Besitzerwerbungen zu erkennen glaubte, der nachher nicht habe verwirklicht werden können. Vgl. Ders.: De Origine Hospitalariorum Hierosolymitanorum - Vom klösterlichen Pilgerhospital zur internationalen Organisation, in: Journal of Medieval History 22 (1996) S. 1-23.

210 Templer auf Sizilien, Kenr, Papsturkunden in Italien (wie Anm. 5) 2 S. 63 Nr. 4 und S. 121 Nr. 33, Templer in Prinzipat, Kapitanat, Apulien und Kalabrien, ebd. S. 435 Nr. 15 und Johanniter in Sizilien/Kalabrien, ebd. S. 70 Nr. 14.

211 Die handschriftlichen Aufzeichnungen Kehrs führten nicht weiter, weil ihm abgesehen von der Unterschriftenliste das Stück als uninteressant galt. Es konnte daher auch nicht für die Entwicklung des Formulars verwendet werden, vgl. O 2 S. 108-135.

212 Kehr, Papsturkunden in Italien (wie Anm. 5) 2 S. 142. Das ist ein drittes Original. 213 Vgl. Delaville le Roulx: Cartulaire (wie Anm. 10) passim und O 2 S. 108 f. 
Wie sehr sich die restriktive Auswahl von Nachrichten bei der Erstellung von Regesten auf das Bild auswirkt, das die „Italia Pontificia“ von den Beziehungen der beiden Orden zum Papsttum entwirft, zeigen am deutlichsten die römischen Niederlassungen, was schon für das Hl. Grab galt. Weder ein Abschnitt für die Johanniter noch für die Templer wird offen ausgewiesen. Vergeblich sucht man daher die brisante Nachricht, daß der Meister des Templerhauses auf dem Aventin mit seinen Brüdern im Jahre 1159 dem frisch gewählten Papst Viktor IV. die Obödienz erwies. Sie steht nicht an abgelegener Stelle, sondern in Rahewins Bericht über die Untersuchung des Wahlvorgangs auf dem Konzil von Pavia, wo unter den Anhängern Viktors IV. der magister fratrum templi Hierosolimitani in monte Aventino cum suis (fratribus) genannt wird $^{214}$, was eine direkte Beziehung der lokalen Templer zur Person des Papstes dokumentiert und ein eigenes Regest hätte erhalten müssen, nun aber dem Benutzer der „Italia Pontificia“ entgeht. Mindestens in einem Kommentar wäre schon für 1138 das Templerhaus als Ausstellungsort einer im Rahmen eines kurialen Prozesses ausgestellten Urkunde für St-Florent in Saumur zu erwähnen, die beweist, daß sich der erste abendländische Ritterorden ganz früh in der Nähe des Papsttums niederließ und eine wichtige Funktion auch für andere Bittsteller an der Kurie zu spielen begann ${ }^{215}$. In der Narratio zum alten Kloster S. Maria in monte Aventino, dessen Abschnitt als Untertitel den modernen, für Eingeweihte in die richtige Richtung weisenden Namen S. Maria del Priorato erhielt, liest man, daß im 13. (!) Jahrhundert die Templer dieses zu ihrer Prioratskirche gewordene Kloster besiedelten und der Besitz dann an die Johanniter überging, die bis heute dort seien ${ }^{216}$. Im 12. Jahrhundert scheinen so für den Benutzer der „Italia Pontificia“ beide Orden in Rom nicht präsent zu sein.

Auf einer anderen Ebene bringen Regesten für Urkunden anderer Empfänger beiläufig wertvolle prosopographische Hinweise für die Geschichte der Orden in Italien ${ }^{217}$. Wie schon nur aus dem Prozeß um die in Nervi errichtete Kirche der Name des Priors Nikolaus des Hl. Grabes für die Lombardei am Ende des 12. Jahrhunderts und damit zugleich die Existenz einer größeren Zahl

214 Rahewin: Gesta Frederici (wie Anm. 111) IV 77 S. 674.

215 Cartulaire d'argent de Saint-Florent de Saumur saec. XII f. 86, Angers, Archives départementales, H 3714. - Copia saec. XVIII, Paris, Bibl. nat. de France, Collection de Touraine IV 1606 fol. 317. Teiledition in D’Albon, Cartulaire du Temple (wie Anm. 18) S. 107 Nr. 153.

216 IP 1 S. 116 und S. 117 Nr. *1. Bramato, Storia (wie Anm. 182) 1 S. 112-114, ohne die Nachricht zu 1138. Auch Barber, Knighthood (wie Anm. 180) S. 385 Anm. 167 führt sie nicht an, betont aber 1159 .

217 Für diesen Aspekt der Italia, wo vor allem die beiden letzten Bände der Italia den Bischofslisten erhöhte Aufmerksamkeit schenkten vgl. jetzt Dieter Girgensohn: Miscellanea Italiae Pontificiae 1, Göttingen 1974, S. 135 f.; für das ausgehende 12. Jahrhundert jetzt die ausführlichen Zusammenstellungen in Norbert Kaмp: Kirche und Monarchie im staufischen Königreich Sizilien 1-4, Münster 1973-1982. 
von Häusern in Oberitalien bekannt ist, wird für die Johanniter mit einem Fulco im Jahre 1179 gegenüber den früheren Annahmen sechzig Jahre früher ein Prior in Capua greifbar ${ }^{218}$, ein Templermeister der Lombardei namens Bonifatius bereits $1169^{219}$, und für den Templermeister der Lombardei (?) Albert ist eine Legatenurkunde von 1196 für die Templer in Moncalieri die einzige Nachricht ${ }^{220}$. Die Ordensforschung hat diesen Zugang, der auch für die Organisation des Ordensbesitzes von großer Bedeutung ist, bis heute kaum wahrgenommen, weil er nicht aus den Ordensarchiven allein gewonnen werden kann.

Wichtiger und weit über den engen Raum hinaus weisen freilich für die Geschichte der Orden auf der Apenninenhalbinsel die Ergebnisse für die Geschichte der Archive. Die spärliche Überlieferung von Papsturkunden als Originale oder Kopien aus den lokalen Ordensarchiven ließ sich auch durch die Nachlese nicht wesentlich verbessern. Die genannten Zahlen von Templer- und Johanniterregesten in der „Italia Pontificia“ sprechen für sich. Es kam kein von Delaville le Roulx oder Prutz übersehener Ordensfonds zum Vorschein, sondern außer in Valletta und Palermo nur neun neue Stücke mit einer örtlichen $\mathrm{Zu}$ weisung $^{221}$ und ein allgemeines Stück aus den päpstlichen Registern ${ }^{222}$.

Dennoch kann das bisherige Bild einer tiefgreifenden Revision unterzogen werden, wenn auch auf einem Umweg. Zwar hatte Delaville le Roulx feststellen müssen, daß die ehemaligen Archive der Großpriorate der Johanniter in Messina, Capua, Brindisi wie auch in Roma, Pisa, Venedig und Mailand im Laufe der Jahrhunderte verloren gegangen waren und für das 12. Jahrhundert, soweit es Papsturkunden betrifft, im Wesentlichen nur späte Abschriftensammlungen des 17. und 18. Jahrhunderts zur Verfügung stehen. Unter ihnen stützte sich das Bullarium Melitense von Sebastiano Paoli aus Lucca zum ersten Mal auf die Originalurkunden aus der syrischen Zeit im Ordenszentralarchiv in Valletta und eine Reihe heute z.T. verlorener Bullarien und war von Delaville le Roulx ausgiebig ausgewertet worden ${ }^{223}$. Kehr ließ es daher beiseite.

Doch das Archiv auf Malta und zwei Handschriften in der Biblioteca Comunale in Palermo erwiesen sich für die Nachlese als unerwartet ergiebig ${ }^{224}$. Es bewährte sich, auch von früheren Forschern benutzte Archivalien noch

218 IP 8 S. 236 Nr. 1 = S. 359 Nr. 48. Das Stück fehlt bei Delaville Le Roulx: Cartulaire (wie Anm. 10), der S. CXXXIf. das Haus in Capua erst seit 1237 nachweist.

219 IP 5 S. 325 Nr. $8=$ S. 377 Nr. 1.

220 Vgl. oben Anm. 195.

221 Ein Stück aus dem Staatsarchiv in Neapel, KeHR, Papsturkunden in Italien (wie Anm. 5) 2 S. 435 Nr. 15, ist im Zweiten Weltkrieg vernichtet worden.

222 Sie sind in die Untersuchung aufgenommen und erscheinen meist als Nebenregest in der Italia Pontificia.

223 Vgl. die genaue Übersicht über die dort kopierten Stücke in O 1 S. 175-182.

224 Kenr, Papsturkunden in Italien (wie Anm. 5) 2 S. 89-129 und S. 44-47, 60-87. 
einmal genau durchzusehen. Auf Malta verzeichnete Schiaparelli insgesamt 21 Originale, 16 Kopien und 161 Abschriften in Bullarien. Sie waren alle von Delaville le Roulx erfaßt und, soweit sie die Johanniter betrafen, in das Cartulaire aufgenommen worden. Doch in archivalischer Vorgehensweise, entdeckte' Schiaparelli ein riesiges, zweibändiges Inventar der Papsturkunden des Ordensarchivs, den bereits für die Kreuzfahrerkirche wegen der darin verzeichneten Urkunden für S. Maria Latina und die Abtei auf dem Berge Thabor erwähnten Vol. 1132, mit weit über tausend Regesten für Papsturkunden von den Anfängen bis 1700, die für jede einzelne Urkunde Aussteller, Initium, Datum und den Überlieferungsort im Archiv nennen. Es führt dabei auch heute verlorene Originale und Bullarien an, die sich so recht genau rekonstruieren lassen. Dadurch kamen für das 12. Jahrhundert noch einmal 73 Originale, worunter sich einige frühe Kopien befinden können, und 142 kopiale Abschriften aus fünf verlorenen Bullarien hinzu. Aus diesen 413 Texten $^{225}$, darunter fünf für die Abtei auf dem Berge Thabor mit dem feierlichen Privileg Alexanders III. ${ }^{226}$, dem Regest eines feierlichen Privilegs des gleichen Papstes für S. Maria Latina ${ }^{227}$ und dem Kreuzzugsaufruf Eugens III. ${ }^{228}$, die alle bereits erörtert worden sind, wurden $51 \mathrm{im}$ Volltext oder als Regest überlieferte unbekannte Urkunden für Templer und Johanniter ediert. Aus Sizilien kamen aus zwei Handschriften in der Biblioteca comunale weitere 18 für die beiden Orden hinzu $^{229}$, zusammen also 69 neue Stücke. Jene stellen in der Nachlese aus Italien, sieht man von den päpstlichen Registern mit ihren über 300 Inserten ab, bei weitem den größten geschlossenen Überlieferungsblock überhaupt dar, diese den zweitgrößten. Anders als für Sizilien mit 15 Johanniter- und drei Templerstücken betraf der Neugewinn auf Malta die beiden Orden zu etwa gleichen Teilen $^{230}$. Über 150 weitere, bei JL auch nicht verzeichnete Texte für die Johanniter, die jedoch Delaville le Roulx eben erstmals ediert hatte, und ein halbes Dutzend solcher für die Templer, die bei Prutz standen, wurden nicht mehr neu ediert $^{231}$. Von den zehn an verstreuter Stelle gefundenen Stücken war schon die Rede, so daß 89 unbekannte Texte ediert und insgesamt fast 250 unbekannte Texte für die beiden Ritterorden erschlossen wurden.

225 Dabei sind die zahlreichen Mehrfachüberlieferungen eingerechnet.

226 Siehe oben Anm. 49.

227 Siehe oben Anm. 46.

228 Siehe oben Anm. 110.

229 KeHr, Papsturkunden in Italien (wie Anm. 5) 2 S. 92-107.

230 Mindestens einmal, KeHr, Papsturkunden in Italien (wie Anm. 5) 2 S. 112 Nr. 10, hat der Regestator freilich ein Stück durch Flüchtigkeitsfehler statt den Templern den Johannitern zugeschrieben. Das kann auch für andere Stücke, für die eine Parallelüberlieferung fehlt, nicht völlig ausgeschlossen werden.

231 Die Zahl neuer Stücke wäre erheblich kleiner, weil das gleiche Stück z.T. mehrfach überliefert ist. 
Daß die für die Nachlese in den abendländischen Reichen zum Teil sehr ergiebigen päpstlichen Register wie für die Diözesankirche des Hl. Landes auch für die Ritterorden (fast) nichts beitrugen, ergibt sich aus der rechtlichen Lage der Orden. Sie hatten längst durch Tausende von Papsturkunden sich die Fülle ihrer Rechte immer wieder bestätigen lassen, und diese waren seit dem 12. Jahrhundert ständig fortentwickelt und in der Kanonistik festgeschrieben worden, so daß sich ein Rückgriff auf ältere Papsturkunden in der Regel erübrigte. Die Templer fielen zudem nach dem Jahre 1312 als mögliche Petenten für eine Bestätigung und Inserierung ihrer Urkunden in eine neue Papsturkunde weg. Die einzige Ausnahme eines Inserts in die Register bildet eine Ausfertigung einer vielfach wiederholten Verfügung Alexanders III. zum Schutz der Personen und Güter der Johanniter Quanto maior ab, die während des Schismas dem avignonesischen Papst zur Bestätigung vorgelegt wurde ${ }^{232}$. Was zu diesem sachlich ungewöhnlichen Schritt veranlaßt haben könnte ist nicht ersichtlich. Ein zweites Insert in den Registern sei noch erwähnt, obwohl es nicht zu den bisher unbekannten Urkunden zählt. Wie die Zisterzienser und die Karthäuser zu Beginn des 14. Jahrhunderts bis heute in vielen Exemplaren überlieferte Sammeltranssumpte erstellen ließen, mit denen die einzelnen Niederlassungen die Rechtstitel für Prozesse zur Verfügung hatten, wurden in einem parallelen Vorgang im Jahre 1454 an der Kurie von einem päpstlichen Notar und Richter, dem Auditor der Audientia litterarum contradictarum Andreas de Viterbo, große Sammlungen niedergeschrieben, beglaubigt und dann von Calixt III. mit einer Mantelurkunde versehen und später von Sixtus IV. und anderen Päpsten ihrerseits bestätigt ${ }^{233}$. Die beiden einzigen darin enthaltenen Papsturkunden des 12. Jahrhunderts, Lucius III. (JL 14989; RI 4/4/4/1 971) und Urban III. (JL 15896), sind daher, vom Rechtsinhalt nichts Außergewöhnliches, die vielleicht am häufigsten überlieferten Papsturkunden für den Orden geworden.

Freilich bleibt die Frage, woher die Originale und Kopien auf Malta und die Vorlagen für die dort aufbewahrten Bullarien und die Vorlagen für die zwei Abschriftensammlungen in Palermo des Antonino Amico aus dem 17. Jahrhundert (Ms. Qq. H. 12) ${ }^{234}$ und eines Anonymus aus dem 18. Jahrhundert (Ms. Qq. H. 203) ${ }^{235}$ stammen. Zwar steht heute fest, daß große Teile der Originale und Kopien der älteren Papsturkunden auf Malta aus dem einstigen Ordenszentralarchiv über die Provence dorthin $\operatorname{kamen}^{236}$, daneben mindestens einige

232 KeHr, Papsturkunden in Italien (wie Anm. 5) 3 S. 435 Nr. 6.

$233 \mathrm{Zu}$ diesen Bullarien vgl. O 1 S. 133 ff. und O 2 S. 163-192.

234 KeHr, Papsturkunden in Italien (wie Anm. 5) 2 S. $44 \mathrm{f}$.

235 Ebd. S. 46 f. Diese Handschrift ordnet die ältere Sammlung Amicos mehr oder weniger chronologisch, fügt aber eine Reihe von Stücken anderer Herkunft hinzu, die u.a. auf das Großprioratsarchiv Böhmen zurückgehen.

236 Vgl. O 1 S. 22 f. 
Kopien des 14. Jahrhunderts aus dem englischen Großpriorat ${ }^{237}$. Alle 18 bisher unbekannten Stücke aus Sizilien stammen aus der Sammlung Amicos, der nach eigenen Aussagen Vorlagen aus dem Archiv des Großpriorats in Messina hatte, so daß auch seine Abschriften mit einer allgemeinen Adresse oder Bestimmung unmittelbar an das Großpriorat Messina gegangen sein dürften ${ }^{238}$. Den Beweis liefert das bereits für den Kreuzzugsaufruf Lucius' III. erwähnte Chartular aus Santo Crucifijo in Puente la Reina im Archiv von Pamplona. Trotz seines heutigen Lagerortes stammen seine Texte, wie die erste kopierte Urkunde Clemens' V. Ad providam von 1312 in der an die Prälaten von Trinacriba (sic) gerichteten Ausfertigung, und die fast völlige Übereinstimmung mit den Kopien Amicos zeigen, aus dem Archiv des Großpriorats Messina.

Damit sind als Ergebnis unter Messina zwei neue Abschnitte für die Großpriorate der beiden Ritterorden mit etwa 30 Regesten für die Johanniter ${ }^{239}$ und drei für die Templer einzufügen. Die Ergebnisse gehen freilich weiter, denn aus einer Verfügung Alexanders III. zugunsten der Kollektensammlungen für die Johanniter ergibt sich, daß bei ihnen Kalabrien organisatorisch zu Sizilien gehörte ${ }^{240}$, während nach einer anderen Verfügung des gleichen Papstes bei den Templern anscheinend die Straße von Messina die Verwaltungsgrenze bildete ${ }^{241}$.

Es bleiben die Bullarien im Archiv von Valletta. Wie das Chartular in Pamplona begann das verlorene, aber nun dank Vol. 1132 rekonstruierbare Bullarium B quintum, das 30 Papsturkunden des 12. Jahrhunderts für die Johanniter und acht für die Templer enthält, von denen nur fünf bereits bei Jaffé verzeichnet sind, mit Clemens' V. „Ad providam“, hier freilich an die Erzbischöfe von Bari und Brindisi und den Bischof von Canosa di Puglia gerichtet. Auch weitere Stücke des 12. Jahrhunderts im Bullarium B betreffen Apulien ${ }^{242}$, keines eine andere Region. Als Basis diente damit offensichtlich das Archiv in Barletta, so daß dort der bereits vorhandene Abschnitt für das Großpriorat der Johanniter mit 28 Regesten für allgemeine Verfügungen und einem neuen

237 So z. B. eine an die Johanniter in Schottland gerichtete Verfügung Urbans III. Sicut evangelica veritate über die Entgegennahme von testamentarischen Verfügungen in einer Sammelkopie von 1326, ed. KeHr, Papsturkunden in Italien (wie Anm. 5) 2 S. 126 Nr. 47. Dadurch steht auch für Alexander III. Commissi nobis offici von 1177 April 7, ed. ebd. S. 113 Nr. 13 und Lucius III. Dilecti filii von (1182) August 13, ed. ebd. S. 122 Nr. 37 die Herkunft aus dem englischen Ordensarchiv fest. So ergibt die Nachlese in Italien auch einen Beitrag für die Anglia Pontificia.

238 Die meisten finden sich auch in der Sammlung des 18. Jahrhunderts (Qq. H. 203), die auch Texte aus anderen Archiven zur Verfügung hatte, aber keines ist nur dort überliefert.

239 Die Zahl steht wegen Doppelungen und einem leicht abweichenden Bestand im Bullarium von Pamplona noch nicht fest.

240 Alexander III. Quanta religione dilecti von (1179-1181) Februar 15, ed. KeHR, Papsturkunden in Italien (wie Anm. 5) 2 S. 70 Nr. 14.

241 Alexander III. Quanto maiora von (1166-1178) Juli 4, ed. ebd. S. 435 Nr. 15.

242 Vgl. IP 9 S. 306 Nr. 3 und 4 zu (1186-1187) Juli 18. 
Abschnitt für das Großpriorat der Templer mit acht Regesten erweitert werden kann.

Offen bleibt die Herkunft des verlorenen Bullarium A quartum und des erhaltenen Bullarium C sextum. Jenes stammt, wie eine Reihe von Stücken zeigt, die entweder das nördliche Gebiet des Normannenreiches oder Verfügungen König Rogers II. nennen, ebenfalls aus dem festländischen Süditalien, könnte aber Material aus Capua und aus Barletta enthalten, dieses, ein mixtum compositum, enthält Urkunden aus Rom und Mittelitalien. Für eine sichere Zuweisung ist es freilich noch zu früh.

Doch die genaue Untersuchung von Bullarium B und Bullarium A werfen ein historisches Problem auf. Beide enthalten eine Ausfertigung des kleinen Privileg für die Johanniter Quam amabilis deo mit der Ablaßzusage für Wohltäter des Ordens durch Viktor IV. vom Herbst 1159, obwohl sie in einem Gebiet entstanden sind, das nach allgemeiner Auffassung zur Oboedienz Alexanders III. gehörte. Selbst wenn man daraus schließen muß, daß die süditalienischen Johanniter wie nachweislich die Templer des Hauses auf dem Aventin und anfangs die Kirche der Kreuzfahrerstaaten auf der Seite Viktors IV. gestanden hatten und sich von ihm Urkunden ausstellen ließen, so wird doch auffälligerweise noch im 15. Jahrhundert eine Urkunde des Gegenpapstes, die mit Leichtigkeit gegen eine gleichlautende eines anderen ,rechtgläubigen' Papstes hätte ausgetauscht werden können, in eine offizielle Sammlung von Ordensurkunden aufgenommen und selbst an der Kurie anstandslos von einem höchsten päpstlichen Beamten beglaubigt ${ }^{243}$.

Als Ergebnis läßt sich festhalten, daß für die Templer und Johanniter neben dem erheblichen Zuwachs an bisher unbekannten Stücken durch die Nachlese mit dem Auffinden von Vol. 1132 in Valletta und später durch die Nachlese für den Oriens Pontificius in Spanien die Überlieferungswege der Papsturkunden in den erhaltenen und den verlorenen Bullarien erfaßbar geworden sind. Auf diese Weise lassen sich nun dank dieses methodischen Ansatzes viele Stücke trotz allgemeiner Adresse einem bestimmten Raum bzw. einem bestimmten Archiv auf der mittleren Ebene der Ordenshierarchie, hier den Großprioraten Messina und Barletta, weniger eindeutig denjenigen von Capua und Rom zuordnen. Wenigstens deren einstige Bestände an originalen Papsturkunden des 12.-15. Jahrhunderts können teilweise rekonstruiert und der „Italia Pontificia“ zugewiesen werden. Auf dem gleichen methodischen Wege lassen sich andere Stücke

243 Es sei daran erinnert, daß das berühmte Privileg Paschalis’ II. nicht nur nachträgliche Unterschriften Calixts II. und einiger Kardinäle und Bischöfe aus seinem Pontifikat aufweist, sondern zwei Nachzeichnungen des 17. Jahrhunderts aus dem Großpriorat Navarra anstelle von anno quarto der Datierung für Calixt II. noch als Ansatz zu einer dritten Papstunterschrift ein Ego Vict. folgen lassen, was kaum auf jemand anderen als Viktor IV. bezogen werden kann, vgl. O 2 S. 194 f. Nr. 1, hier S. 195. 
des Archivs in Valletta dem englischen Ordensarchiv zuweisen. Dies zeigt aber auch, wie entscheidend für ,internationale' Orden, hier die Templer und Johanniter, für ,internationale' Bewegungen, hier den Kreuzzug und erst recht für das ,internationale‘ Wirken des Papsttums und der päpstlichen Kanzlei das den einzelnen Raum übergreifende Zusammenwirken der Forschung ist.

Zum anderen wird durch die Überlieferung von zwei neuen Kreuzzugsaufrufen in Handschriften in Malta und in Palermo, aber auch in dem zuerst so fern scheinenden Navarra mitten unter Papsturkunden für die Ritterorden einerseits der Anteil Italiens an den Kreuzzügen deutlicher, andererseits die bisher weitgehend übersehene Rolle der Ritterorden für die Verbreitung der päpstlichen Kreuzzugsaufrufe ins Licht gerückt. Dies kann nur auf einen ganz gezielten Einsatz der zentralistisch-hierarchischen Ordensstruktur durch die päpstliche Kanzlei zurückgeführt werden ${ }^{244}$.

\section{VII.}

Faßt man die Ergebnisse zusammen, so hat die Nachlese in den italienischen Archiven und Bibliotheken nicht viel an neuen Texten, aber einiges sehr Wichtiges für die Geschichte der Kreuzfahrerkirche und der Kreuzzüge ergeben ${ }^{245}$, allerdings nur sehr weniges für die abendländischen Niederlassungen im lateinischen Osten. Noch einmal hervorgehoben seien das Original des feierlichen Privilegs für Beirut als Unikat aus der ganzen Kreuzzugszeit und die Kopie einer Verfügung Coelestins III. für die Lazariter. Sie öffnen je ein neues Feld für den künftigen Oriens Pontificius latinus, wie zahlenmäßig die 26 neuen Papsturkunden für die Diözesankirchen aus italienischen Überlieferungen angesichts der kläglichen Überlieferung an Papsturkunden aus dem Hl. Land eine beträchtliche Vermehrung der Quellenbasis darstellen. Für die beiden großen Ritterorden brachte die Arbeit an der „Italia Pontificia“ insgesamt 79 neue Stücke ${ }^{246}$, prozentual sicher weniger, doch hier gelingt es, mit den Ergebnissen der Nachlese für den Oriens die Archivgeschichte auf eine neue Grundlage zu stellen. Dies zeigt, wie viel die Kreuzzugsforschung der Nachlese Kehrs in Italien und dem Papsturkundenunternehmen schuldet. Es wäre zu wünschen, daß sie sich dessen stärker bewußt wird.

Andererseits verdankt man von der „Italia Pontificia“ her den Papsturkunden des 12. Jahrhunderts für Institutionen des Hl. Landes Nachrichten über

244 Vgl. dazu meinen Beitrag "The Military Orders and Papal Crusading Propaganda“, in: The Military Orders, Volume 3: History and Heritage, hg. v. Victor Mallia-Milanes, Aldershot 2008, S. 155-165.

245 Siehe die Einzelnachweise oben.

246 Diese Zahl wie erwähnt ohne die von Delaville zwischen dem Erscheinen der zweiten Auflage des Jaffé und dem Beginn der Nachlese neu zugänglich gemachten Stücke. 
Dutzende von Kirchen und Klöstern auf italienischem Boden von Agrigento bis Varazze, die dem Hl. Grab, den Abteien S. Maria Latina, S. Maria im Tale Josaphat und S. Maria auf dem Sionsberg gehörten und ohne entsprechende lokale Überlieferung nur auf diesem Umweg ins Bewußtsein der Kurie gebracht wurden. Ihre Auswertung ist noch keineswegs abgeschlossen.

Es bleibt freilich auch die andere Seite. Mehrfach wurde von der Kreuzzugsforschung her auf Lücken in der "Italia Pontificia“ hingewiesen, die über einzelne Fakten hinaus methodische Fragen aufwarfen und auch für die künftige Arbeit an anderen Pontificiae gelten, zum Teil dort schon Beachtung gefunden haben. Sie schmälern nicht die Bewunderung für die Leistung Kehrs, der in den acht Jahren von 1906 bis 1914 sieben Bände der „Italia Pontificia“ vorlegte, bis der erste Weltkrieg und die neuen Aufgaben in Berlin nur noch beschränkt Zeit für die „Italia Pontificia“ ließen. Sie wirkten sich auf allen drei Feldern, vor allem auf das Bild der Kreuzzüge aus und gehen zu einem erheblichen Teil auf die restriktive Konzeption zurück, die Kehr in den ersten Bänden leitete und bis zum Band X in hohem Maße von jenem Ziel der urkundlichen Archivgeschichte als Vorbereitung der künftigen Edition bestimmt war. So blieben anfänglich Nachrichten über Beziehungen, die mehr die Person als die jeweilige Kirche betrafen, wie die Einsetzung von Bischöfen, Äbten usw. als Legaten und delegierte Richter, aber auch Vorgänge außerhalb Roms unter Mitwirkung der Päpste unberücksichtigt. Für das Verhältnis von Papsttum und Kreuzzug beginnt dies schon mit dem Konzil von Piacenza von 1095 und dem berühmten Hilferuf des Basileus Alexios I. Komnenos, die nicht einmal in der Narratio zu Piacenza erwähnt wurden ${ }^{247}$ und schließt die nicht aufgenommene Bestellung von italienischen Geistlichen zu Legaten als Vertretern des Papstes auf den Kreuzzügen und im lateinischen Osten ein.

Neben diesen personenbezogenen Nachrichten läßt sich strukturell bedingt aus der „Italia Pontificia“ nicht erkennen, wo überall, wie nochmals wiederholt sei, auf der Apenninenhalbinsel und Sizilien die Kirchen des Hl. Landes vom Papsttum bestätigten Besitz hatten, wie solcher selbst, wo er erwähnt wird, oft nur versteckt in den Narrationes begegnet. Komplexer ist diese Frage bei den Ritterorden. Feierliche Privilegien für die Templer und die Johanniter mit Besitzlisten für Italien besitzen wir anders als für die Kanoniker der Grabeskirche nicht. Doch übersehen worden sind auch, wohl aus der Geschichte des Unternehmens, das erst nach dem Abschluß von Mittel- und Norditalien (IP 1 -7) sich der Nachlese auf der Iberischen Halbinsel zuwandte, der Besitz des kurzlebigen Ordens vom Mons Gaudii, der Santiagoritter, des Ordens von Calatrava und auch der Kathedrale von Santiago de Compostela in Oberitalien, den sie sich von der Kurie ausdrücklich bestätigen ließen. Ähnliches gilt für den südlich der Alpen gelegenen Besitz großer französischer Abteien, was alles Aufgaben für

$247 \mathrm{Zu}$ erwähnen in IP 5. 
die künftige Arbeit an den Regesta Pontificum Romanorum aufzeigt. Das Bild des Kreuzzuges und des Anteils des Papsttums an ihm bleibt in der „Italia Pontificia" wie nicht anders zu erwarten ein Mosaik mit vielen Lücken, doch die Nachlese Kehrs und seiner Mitarbeiter hat diesem Mosaik nicht wenige neue Steine hinzufügen können.

\section{Riassunto}

Nella storia delle crociate l'Italia, a parte il papato, non gioca un ruolo preponderante se non come terra di passaggio per l'Oriente e per i quartieri delle città marinare sulla costa siriana. In più, quando il Kehr cominciò la revisione degli archivi, la ricerca sulla crociata aveva raggiunto un primo apogeo coll'edizione delle fonti documentarie grazie ai Röhricht, Delaville le Roulx, Prutz ecc. Perciò non erano da aspettarsi nuovi fondi sconosciuti per le istituzioni ecclesiastiche o secolari dell'Oriente, tratti in salvo dopo il 1187 o il 1291, mentre in Oriente Turchi e Mamlucchi avevano fatto tabula rasa.

Malgrado ciò la „vendemmia“ ha dato frutti molto importanti aumentando la documentazione pontificia per la chiesa diocesana in Oriente di un quarto come p. es. un privilegio di Lucio III per la chiesa di Beirut, singolare per l'Oriente latino. Ma sia le ricerche archivistiche del Kehr che l'Italia Pontificia sono stato per lungo tempo tralasciate dagli storici delle crociate. Ancora più rilevante si rivelò un gruppo d'appelli papali a partire d'Urbano II per i monaci di Vallombrosa fino a Clemente III per i crociati toscani, mettendo l'Italia nella propaganda papale accanto alla Francia ecc. che fin'oggi a torto domina il quadro generale. Particolarmente importanti furono inoltre le nuove bolle per gli ordini militari, Templari e Ospedalieri, conservatici in manoscritti a Palermo e Malta, il cui valore era sfuggito al Delaville, in modo minore tali per i canonici del S. Sepolcro ed i lebbrosi di San Lazzaro. In quanto ai dieci volumi dell'Italia un numero non esiguo di regesti riguarda le crociate che non entravano originariamente nel progetto, come tante notizie tralasciatevi saranno da riassumere in un volume di additamenta.

Per tale rivalutazione segue una lista di 57 nuove bolle per il movimento crociato nel senso largo che serviranno a future ricerche. 


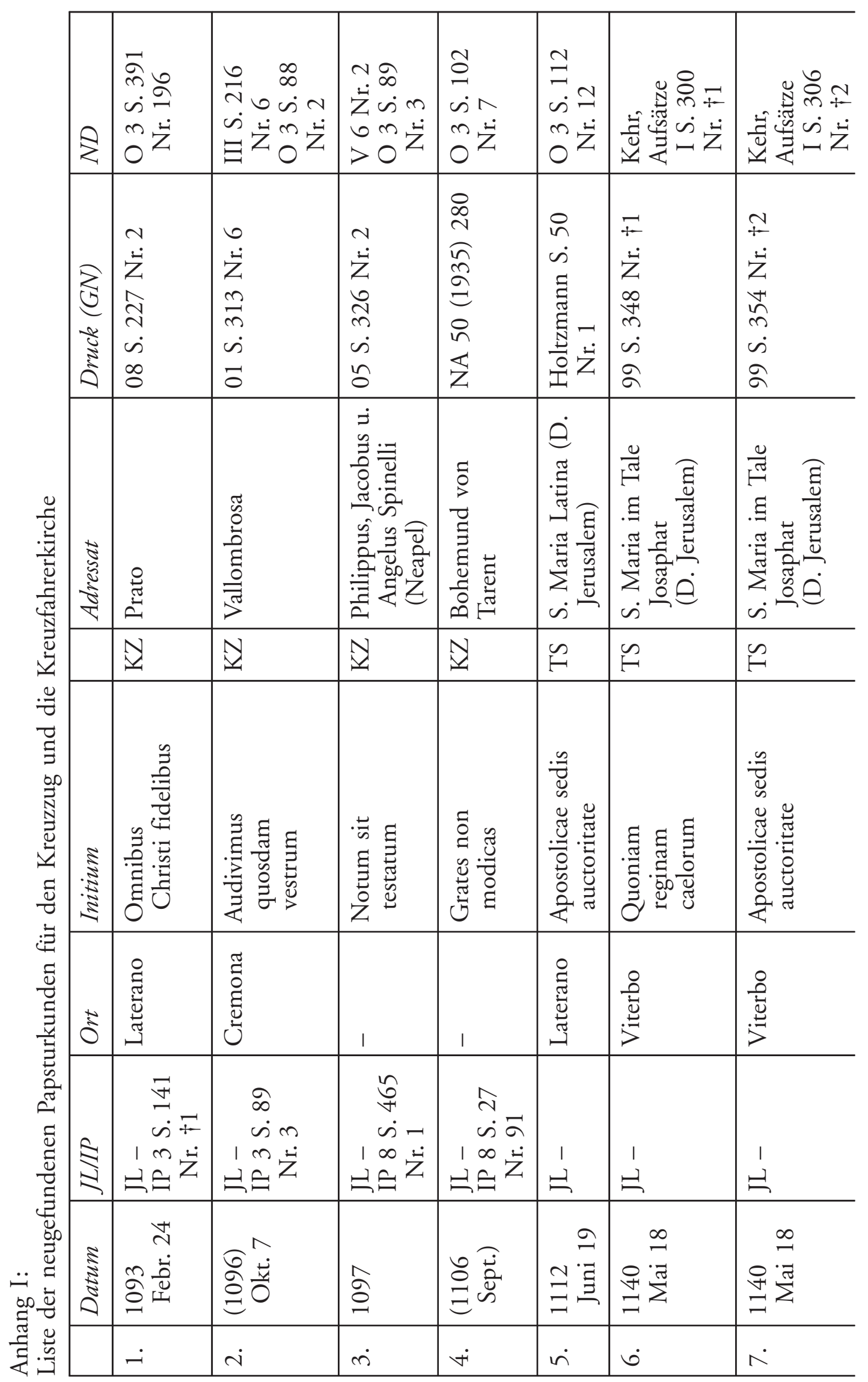




\begin{tabular}{|c|c|c|c|c|c|}
\hline & 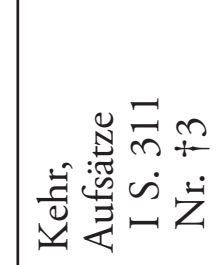 & 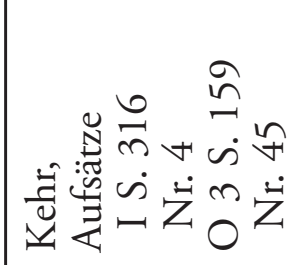 & 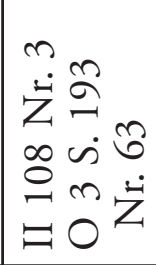 & 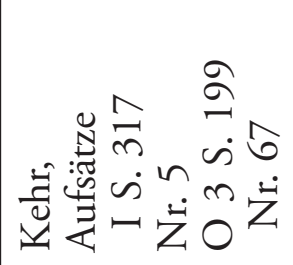 & $\begin{array}{l}\sim \\
\sim \\
\dot{z} \\
\infty \\
\infty \\
+1 \\
Z\end{array}$ \\
\hline & $\begin{array}{l}m \\
\dot{H} \\
\dot{z} \\
\tilde{\hat{े}} \\
\dot{\omega} \\
2 \\
\sigma\end{array}$ & 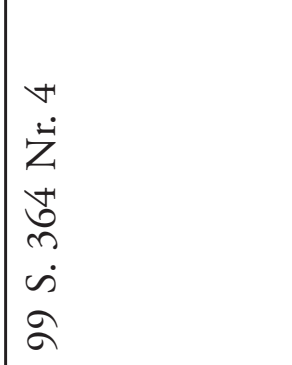 & $\begin{array}{l}n \\
\dot{z} \\
\infty \\
\infty \\
n \\
\dot{n} \\
a \\
a\end{array}$ & $\begin{array}{l}n \\
\dot{z} \\
n \\
\tilde{n} \\
\dot{n} \\
2 \\
\sigma\end{array}$ & 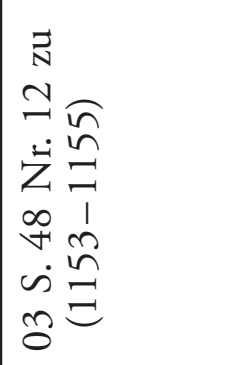 \\
\hline & 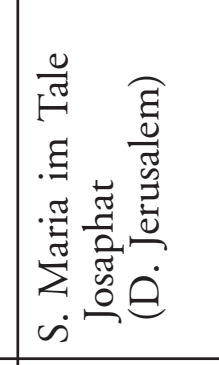 & 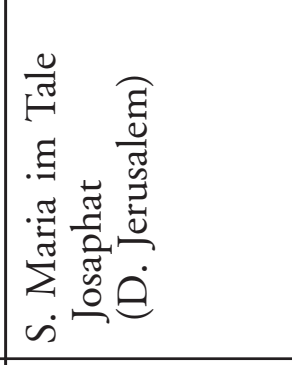 & 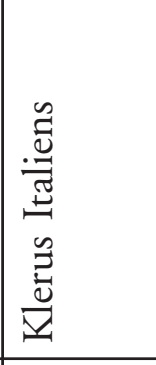 & 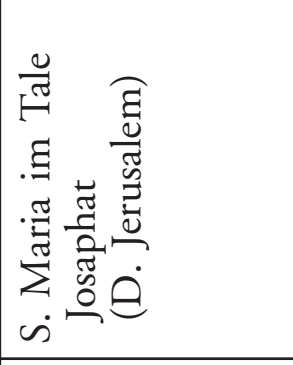 & 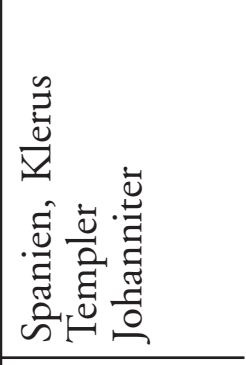 \\
\hline & $\tilde{H}$ & $\mathscr{H}$ & \pm & $\mathscr{H}$ & 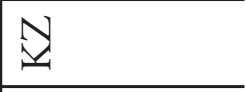 \\
\hline & 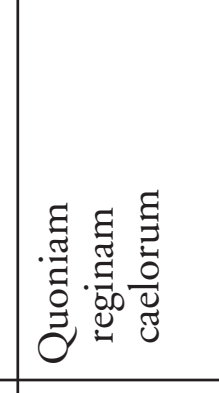 & 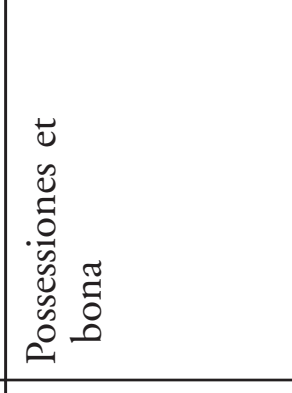 & 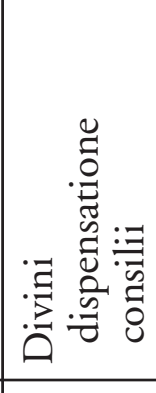 & 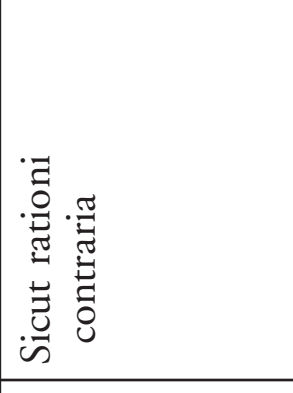 & 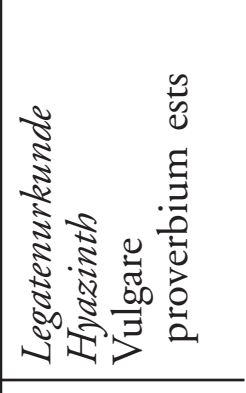 \\
\hline & 离 & 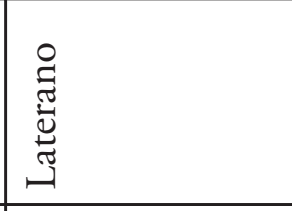 & 咅 & 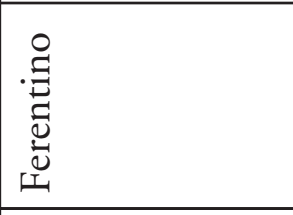 & \\
\hline & $\stackrel{1}{\varrho}$ & $\stackrel{1}{=}$ & $\begin{array}{ll}1 & 1 \\
\Leftrightarrow & E\end{array}$ & $\stackrel{1}{=}$ & 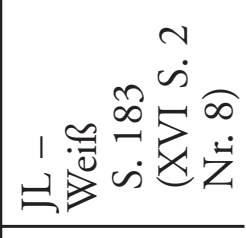 \\
\hline & 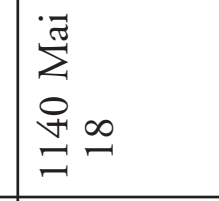 & $\underset{\substack{i\\
}}{\stackrel{i}{\pi}}$ & 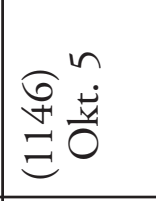 & 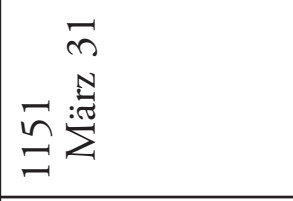 & 点 \\
\hline & $\infty$ & $a^{\circ}$ & $\stackrel{9}{\circ}$ & $\doteq$ & $\stackrel{i}{\sim}$ \\
\hline
\end{tabular}




\begin{tabular}{|c|c|c|c|c|c|c|c|}
\hline$\xi$ & 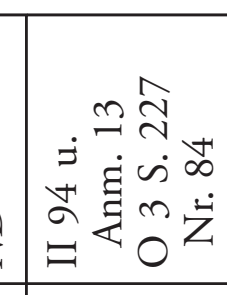 & 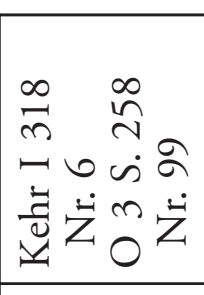 & 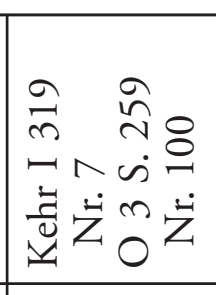 & 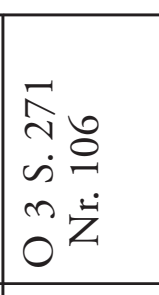 & 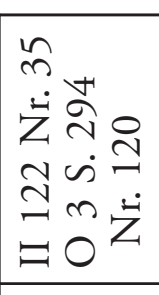 & 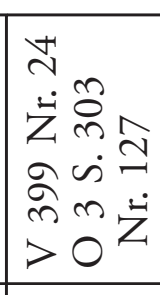 & 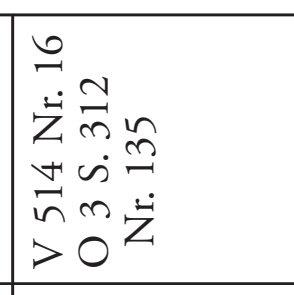 \\
\hline కְ & 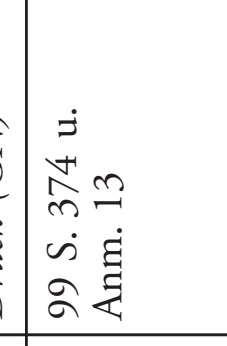 & $\begin{array}{l}0 \\
\dot{z} \\
0 \\
0 \\
\infty \\
\dot{c} \\
2 \\
\sigma \\
\end{array}$ & $\begin{array}{l}n \\
\dot{z} \\
0 \\
0 \\
\infty \\
\omega \\
\sigma \\
\sigma \\
\end{array}$ & 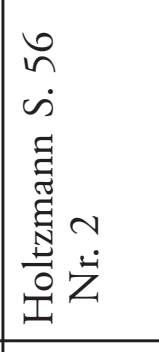 & 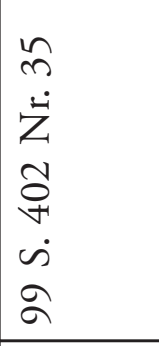 & 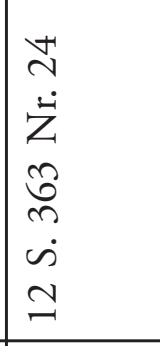 & 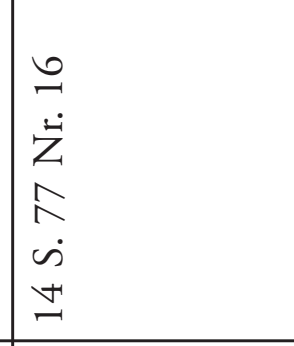 \\
\hline 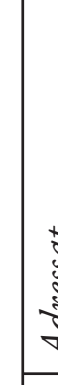 & 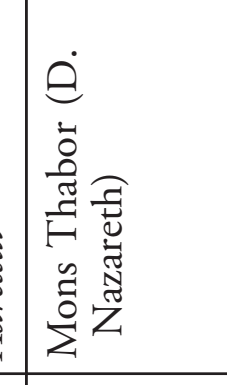 & 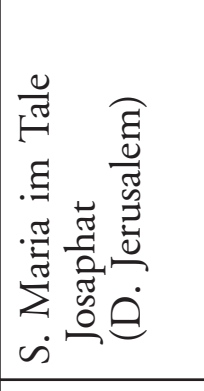 & 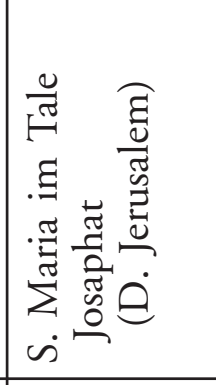 & 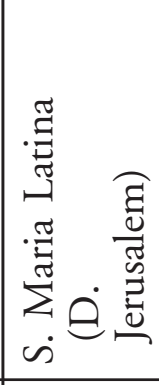 & 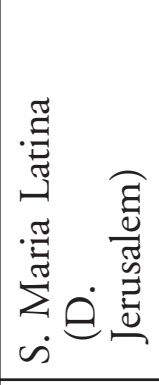 & 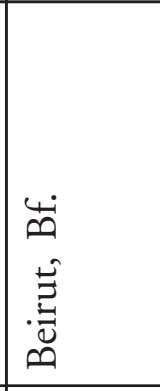 & 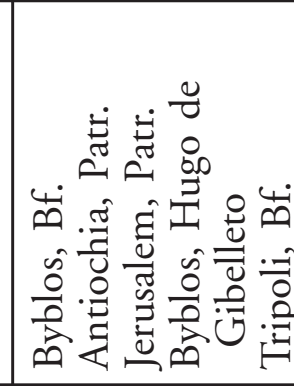 \\
\hline & $\tilde{H}$ & $\tilde{\xi}$ & $\mathscr{H}$ & 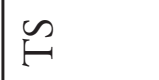 & $\tilde{\xi}$ & $\mathscr{H}$ & $\mathscr{H}$ \\
\hline$=$ & 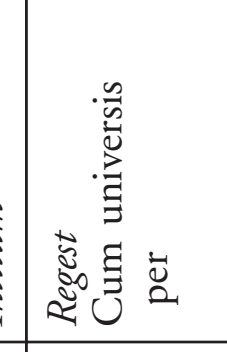 & 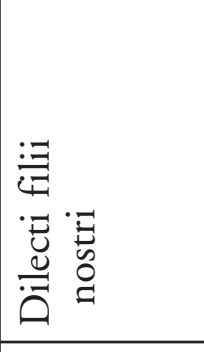 & 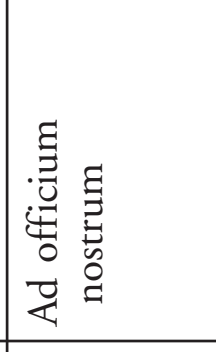 & 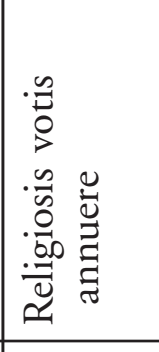 & 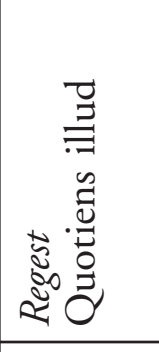 & 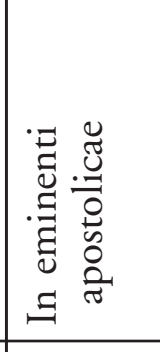 & 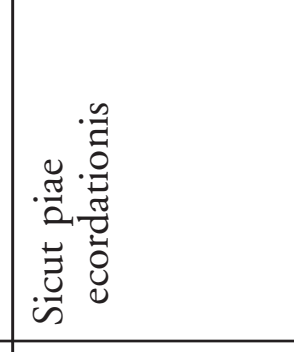 \\
\hline c & 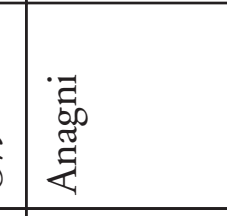 & 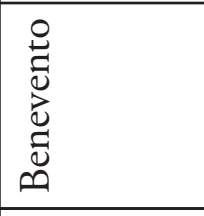 & 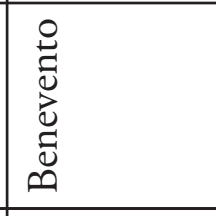 & 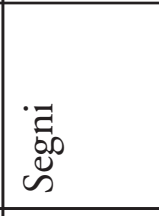 & 1 & 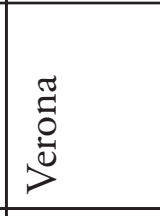 & 苋 \\
\hline & $\stackrel{1}{\lrcorner}$ & $\stackrel{1}{\Perp}$ & $\stackrel{I}{I}$ & $\stackrel{1}{=}$ & $\begin{array}{l}1 \\
1 \\
\Xi\end{array}$ & \begin{tabular}{|l}
$I$ \\
$\stackrel{I}{E}$
\end{tabular} & 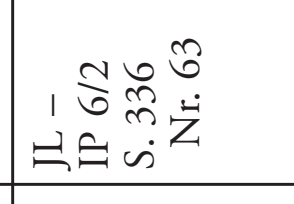 \\
\hline 4 & 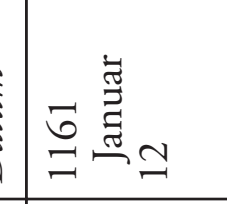 & 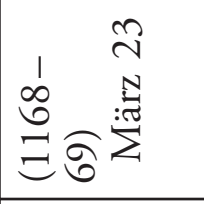 & 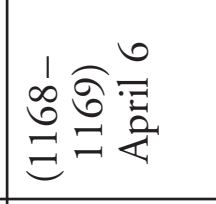 & 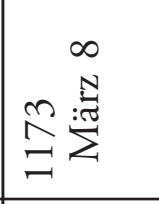 & $\begin{array}{l}\stackrel{1}{\widehat{D}} \\
\Xi\end{array}$ & 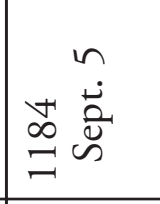 & 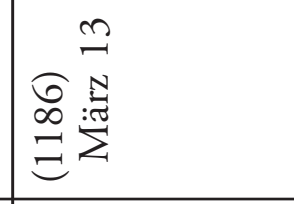 \\
\hline & $\dot{\vec{g}}$ & $\stackrel{+}{ \pm}$ & $\ddot{n}$ & $\stackrel{\dot{\omega}}{\circ}$ & $\therefore$ & $\stackrel{\infty}{\rightarrow}$ & $\dot{2}$ \\
\hline
\end{tabular}




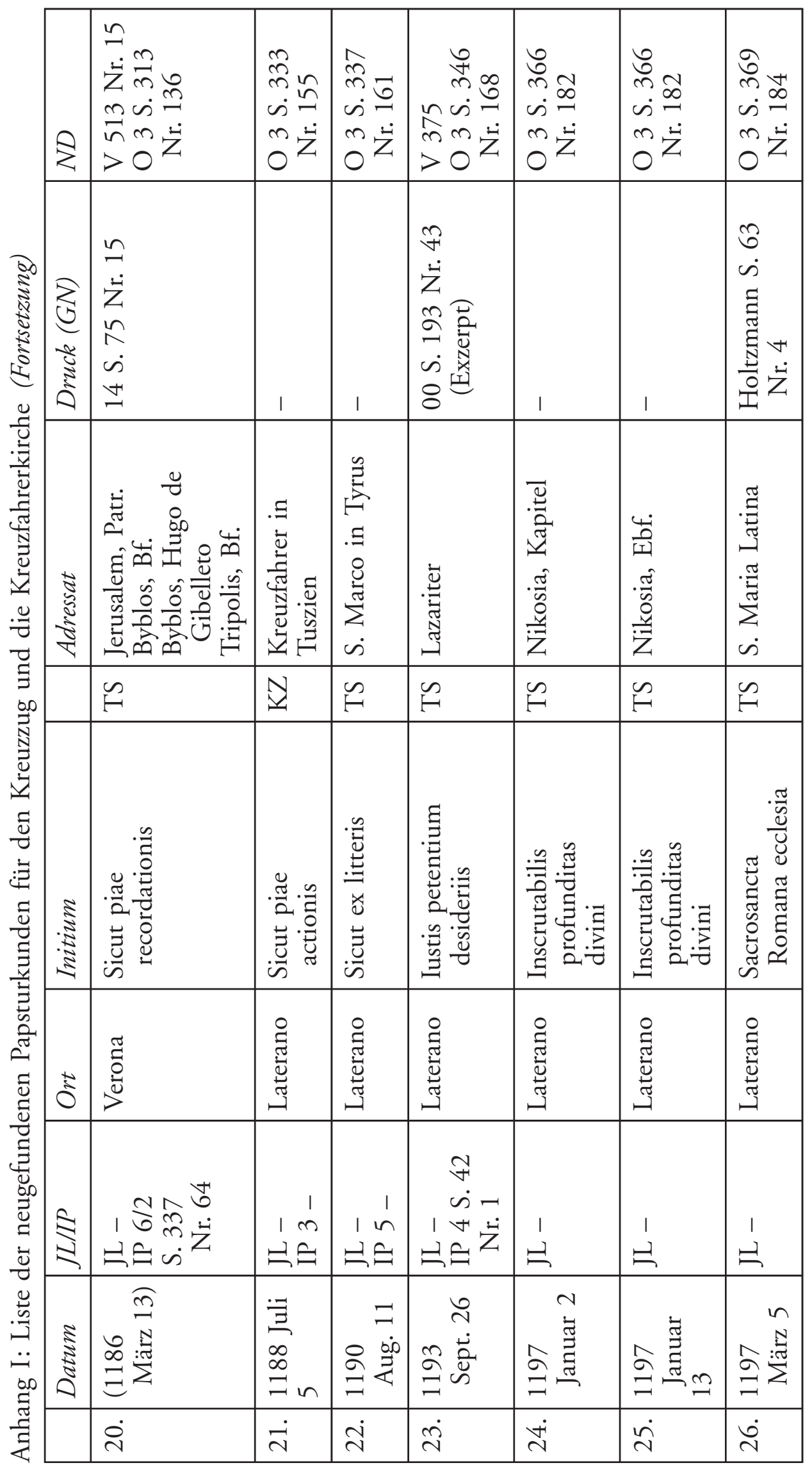




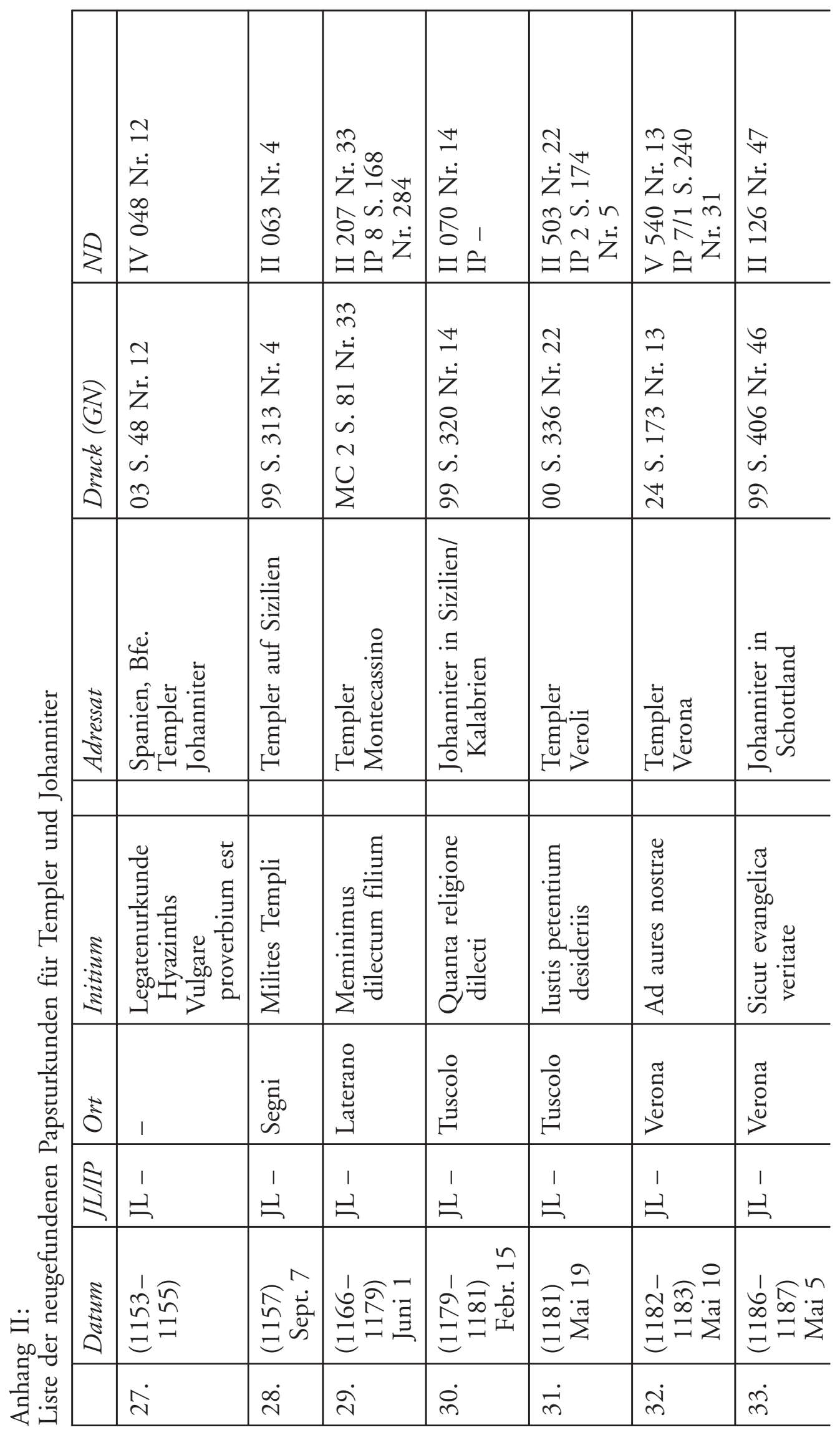




\begin{tabular}{|c|c|c|c|c|c|}
\hline & $\frac{z}{z}$ & 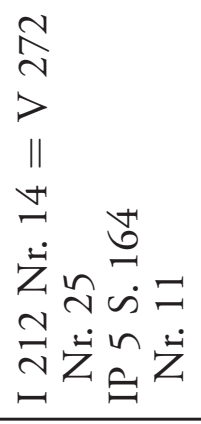 & 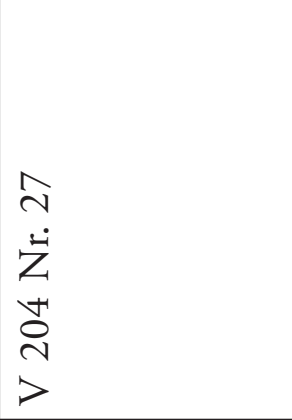 & 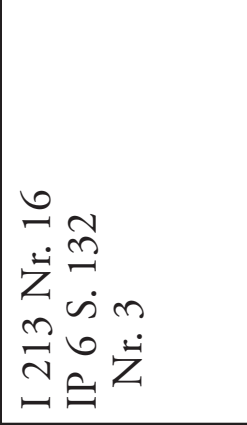 & 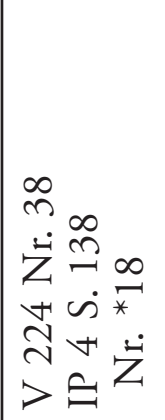 \\
\hline & 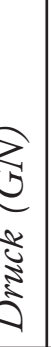 & 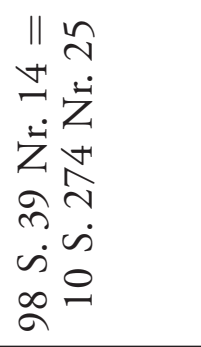 & 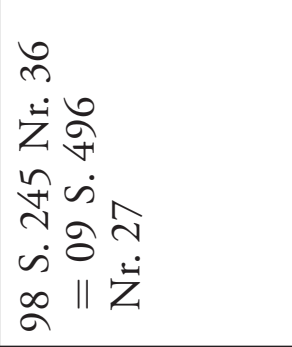 & $\begin{array}{l}0 \\
\stackrel{1}{1} \\
\dot{z} \\
0 \\
+ \\
\dot{n} \\
\infty \\
\infty\end{array}$ & $\begin{array}{l}\infty \\
i \\
\dot{z} \\
0 \\
\sigma \\
\tilde{n} \\
\dot{w} \\
o \\
o\end{array}$ \\
\hline & 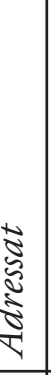 & 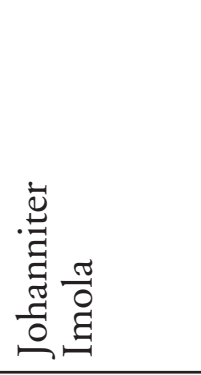 & 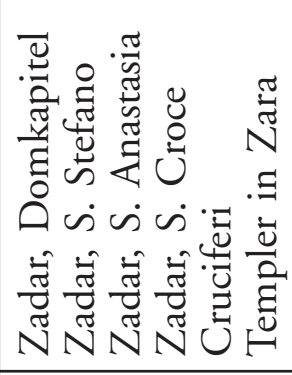 & 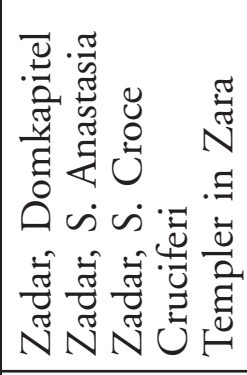 & 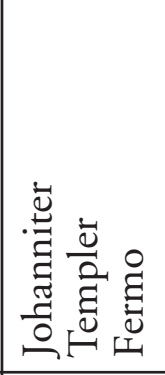 \\
\hline & & & & & \\
\hline & 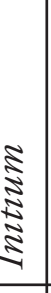 & 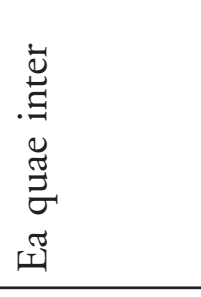 & 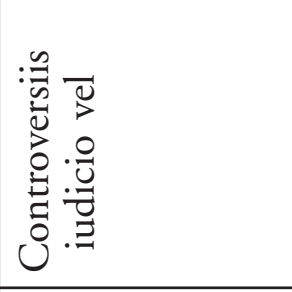 & 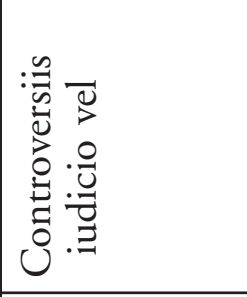 & 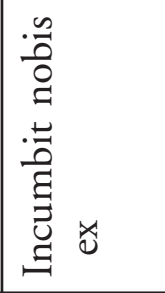 \\
\hline & है & 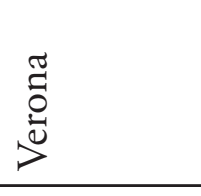 & 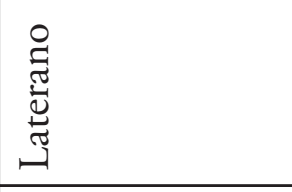 & 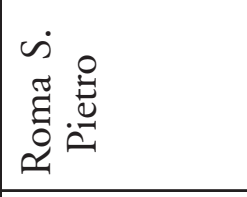 & 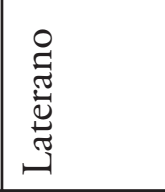 \\
\hline & 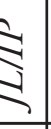 & $\stackrel{1}{\oplus}$ & $\stackrel{1}{\Perp}$ & $\stackrel{1}{=}$ & $\stackrel{1}{=}$ \\
\hline & $\begin{array}{l}\mathbf{n} \\
\mathbf{8} \\
0\end{array}$ & $\begin{array}{l}1 \\
\stackrel{1}{\mathbb{C}^{m}} \\
\stackrel{\infty}{\infty} \cdot \vec{\Xi} \\
\Xi \\
\Xi\end{array}$ & $\begin{array}{r}\stackrel{0}{1} \\
\infty \\
\infty \\
\Xi \\
=\end{array}$ & $\begin{aligned} & \vec{\lambda} \\
& \vec{\Xi} \vec{\Xi} \\
& \vec{\Xi} \\
&\end{aligned}$ & 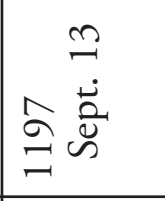 \\
\hline & & m & $\tilde{n}$ & $\dot{n}$ & $\hat{n}$ \\
\hline
\end{tabular}




\section{Resümee}


Bereitgestellt von | De Gruyter / TCS

Angemeldet | 217.89.40.26

Heruntergeladen am | 21.12.12 10:51 


\section{Ergebnisse und Perspektiven}

\section{Klaus Herbers und Jochen Johrendt}

Dem Diktum des habsburgischen Staatskanzlers Metternich auf dem Wiener Kongreß 1815, Italien sei nur ein geographischer Begriff, steht die These entgegen, daß trotz der fehlenden staatlichen Einheit bis ins 19. Jahrhundert Italien sich während des Mittelalters als ein eigenständiger Kulturraum geformt habe ${ }^{1}$. $\mathrm{Da}$ bei diesen Formierungsprozessen das Papsttum als wichtige Kontinuitätsund Innovationsinstanz maßgeblich beteiligt war, ergab sich die übergreifende Fragestellung, wie sehr und in welch unterschiedlichen Formen die Päpste in dieser Hinsicht wirkten. Die Vielfalt Italiens brachte es mit sich, hier ein „Europa en miniature“ zu sehen und zugleich die methodischen Fragestellungen der neueren vergleichenden Europaforschung kleinräumiger und damit auch tiefergehender zu erproben, wie die einleitenden übergreifenden Beiträge der ersten Sektion weiter entfalten ${ }^{2}$. Dabei war vorneweg davon auszugehen, daß sich Integrationsprozesse nicht im Sinne einer Entwicklungslogik verfolgen lassen, sondern zugleich von vielen Faktoren der Desintegration begleitet waren - Papstschismen sind hierfür nur das eklatanteste Beispiel. Wichtige Hilfe war dabei die weitgehend abgeschlossene, aber dennoch „unvollendete Italia pontificia" (Rudolf Hiestand), deren Leistungsfähigkeit auch durch die verschiedenen Interpretationsversuche erwiesen werden konnte. Daß Interpretation und Grundlagenforschung sogar enger zusammengehören als oft angenommen, zeigt sich daran, daß zugleich nach den spezifischen Formen der Ergänzung für die vorliegenden 10 Bände der Italia Pontificia gesucht wurde.

Daraus ergab sich die Gliederung der Kongreßbeiträge und des nun vorliegenden Bandes, dessen Ertrag wir in einigen Aspekten hervorheben und aus dem wir Fragen für die weitere Forschung ableiten können. Zunächst folgen wir dem Aufbau des Bandes, berücksichtigen dabei teilweise auch Diskussionsvoten der römischen Tagung, bevor wir an den Schluß einige synthetisierende Thesen stellen und weitere Perspektiven zu öffnen versuchen.

1 So schon beispielsweise Werner Goez: Geschichte Italiens in Mittelalter und Renaissance, Darmstadt ${ }^{3} 1988$, S. $1-12$, bes. S. 1 .

2 Siehe zu verschiedenen Forschungsansätzen den Einleitungsbeitrag von Klaus Herbers, oben, S. $17-36$. 
Die zweite Sektion mit der Frage nach den wechselnden politischen Kraftzentren Italiens kann teilweise mit der fünften Sektion verbunden werden, denn die Probleme, daß Papstprivilegien, Papstbeziehungen sich nur bedingt räumlich fassen lassen, galt nicht nur für die in Italien wirkenden unterschiedlichen politischen Herrschaften, zumal die Universalgewalten, sondern ebenso für die universal agierenden Orden. Gerade in diesen Bereichen war besonders von kulturellem Transfer auszugehen.

Der Beitrag von Matthias Maser behandelt die frühen Beziehungen Roms zu Byzanz und unterstreicht, ausgehend vom akakianischen Schisma, die Bedeutung des Konzils von Chalkedon 451 für die zahlreichen - teilweise sehr turbulenten - Kontakte im Verlauf des 6. Jahrhunderts. Als große Leitlinie der Auseinandersetzungen dieser Zeit ist der Streit um den römischen Primatsanspruch zu erkennen, wobei die Möglichkeiten der Päpste, diesen gegenüber dem Kaiser und den Patriarchen von Konstantinopel zur Geltung zu bringen, eng an die jeweiligen politischen Verhältnisse der „vielgestaltigen Italia“ gebunden waren. Gerade in der ersten Hälfte des 6. Jahrhunderts waren es die mangelnden Zugriffsmöglichkeiten des Imperiums auf Rom und seine Kirche, die den Päpsten der Zeit die Entwicklung und Behauptung eines primatialen Maximalprogramms erlaubten. Dabei darf die römische Opposition zu Konstantinopel jedoch nicht in auf spätere Entwicklungen vorgreifender Weise als eine gewollte Emanzipation aus dem Verband des christlichen Imperiums fehlgedeutet werden. Die Einheit der Reichskirche blieb während des gesamten Untersuchungszeitraums wichtiger Bezugs- und Orientierungsrahmen für das politische Handeln der Päpste, jedoch belasteten neben divergierenden ekklesiologischen Modellen unterschiedliche Vorstellungen des Weges zu einer kirchlichen Union sowie abweichende Konzepte der höchsten Autorität in der Kirche die römisch-byzantinischen Beziehungen der Zeit mehrfach auf das Schwerste. Inwieweit die Kontakte Transferprozesse implizierten, blieb zunächst offen, zumindest wurde keine definitive Antwort gewagt, ob man in Rom die subtilen theologischen Fragen überhaupt verstanden hätte.

Dezidiert zu Fragen des Transfers nimmt hingegen Guglielmo Cavallo Stellung, der am Beispiel von Neapel und Rom ein breites Panorama zum 9. und 10. Jahrhundert entfaltet und zeigen kann, wie durch Übersetzungen griechische Traditionen akzeptiert und anverwandelt wurden. In Rom betraf das griechische Traditionen in bestimmten Klöstern sowie Fragen des Kultes ${ }^{3}$. Die

3 Vgl. neben den wichtigen Beiträgen zur Neuzeit, z. B. von Wolfgang Schmale: Historische Komparatistik und Kulturtransfer. Europageschichtliche Perspektiven für die Landesgeschichte. Unter besonderer Berücksichtigung der sächsischen Landesgeschichte, Bochum 1998, vgl. zum Mittelalter Klaus Herbers: „Europäisierung“ und „Afrikani- 
wichtigste Figur im Zusammenhang mit der Thematik des Kongresses und nun vorliegenden Bandes war sicherlich der Übersetzer Anastasius Bibliothecarius. $\mathrm{Da}$ er auch als Verfasser oder zumindest als geistiger Kopf hinter einer Vielzahl von Papstschreiben des 9. Jahrhunderts steht, ließe sich ausgehend vom Beitrag Cavallos nach der Rolle solcher Personen in der päpstlichen Umgebung fragen. Inwieweit hingen die pointierten Positionen und Äußerungen eines Nikolaus I., Hadrians II. und Johannes VIII. von diesen Personen ab? Welche Möglichkeiten eröffneten sich wenn - wie von Anastasius geschehen -, Konzilsakten aus dem Griechischen übersetzt, und das hieß auch: interpretierend übersetzt wurden?

$\mathrm{Da}$ in der zweiten Sektion Beiträge zu anderen Kraftzentren außer Byzanz hätten stehen können und vielleicht müssen, wurde dadurch ausgeglichen, daß Langobarden, Karolinger, Ottonen, Normannen und weitere politische Konstellationen in den vier Studien der dritten Sektion wiederholt angesprochen wurden, die mit dem Titel „Rom und die Kirchen Italiens - zwischen Autonomie, Konkurrenz und Anpassung" überschrieben war. ${ }^{4}$ Jean-Marie Martin und Maria Pia Alberzoni konzentrieren sich dabei auf spezifische Zentren oder Regionen, Kirchenprovinzen: auf den süditalischen Raum und Mailand. Die Beschränkung auf ein fest umrissenes Gebiet - die Kirchenprovinz Mailand liegt dem Beitrag von Maria Pia Alberzoni zugrunde, der vor allem die Zeit ab 1135 behandelt. Ausgehend von Überlegungen Kehrs steht die Frage im Vor-

sierung" - Zum Problem zweier wissenschaftlicher Konzepte und zu Fragen kulturellen Transfers, in: España y el „Sacro Imperio“. Procesos de cambios, influencias y acciones recíprocas en la época de la "Europeización" (Siglos XI-XIII), hg. v. Julio Valdeón/Klaus Herbers/Karl Rudolf, Valladolid 2002, S. 11-31; jüngst die deutsch-italienische Publikation: Pellegrinaggio e Kulturtransfer nel Medioevo europeo. Atti del $1^{\circ}$ seminario di studio dei Dottorati di ricerca di ambito medievistico delle Università di Lecce e di Erlangen. Lecce 2-3 maggio 2003, hg. v. Hubert Houben/Benedetto Vetere (Università degli studi di Lecce. Dipartimento dei beni delle arti e della storia 2), Lecce 2006, darin: Hartmut Kuglen: Che cosa significa „Kulturtransfer“ nel Medioevo europeo?, S. 7-11, und die weiteren Beiträge dieses Bandes.

4 Der Vortrag von Antonio Carile konnte leider nicht in die Drucklegung einfließen. „Wenig Konkurrenz", so karikierte Antonio Carile auf der römischen Tagung seinen eigenen Vortragstitel und bot einen breiten Abriß zum Verhältnis von Rom und Ravenna seit dem 8. Jahrhundert. Er konnte sich dabei vielfach auf Aussagen des «Liber pontificalis» des Agnellus stützen, um die Dreiecksgeschichte Exarch - Erzbischof - Papst, später erweitert um langobardische und karolingische Herrscher, nachzuzeichnen. Macht die Form der Überlieferung, so ließe sich in der Rückschau fragen, einen Vergleich Roms mit anderen Kraftzentren, in den Fällen leichter, wenn wie im Falle Ravennas die Überlieferung ähnlich strukturiert ist? Auch für Neapel könnte dies gelten. Entscheidende Etappen sah Carile in den Kaiserpakten, insbesondere im Hludovicianum von 817 und der Constitutio Romana von 824. Die Bedeutung Ravennas für die Karolinger und deren Beziehungen zu den Päpsten wurde besonders bei der Nachfolge Ludwigs II. akut ebenso wie bei den Auseinandersetzungen zwischen Formosianern und Antiformosianern - auch hier drängt sich unmittelbar der vergleichende Blick zu den Streitschriftautoren in Neapel auf. 
dergrund, inwieweit päpstliche Durchdringung und Einflußnahme verfolgt werden können. Die Prozesse verdeutlicht sie mit Aspekten zu den Reisen, zu Kardinälen, Legaten sowie Subdiakonen. Vor allem durch die Subdiakone bzw. päpstlichen Kapläne wurden die Anbindungsversuche der Legaten ersetzt bzw. deren Tätigkeit reduziert und damit sogar eher eine alltägliche Kontrolle erreicht. Hinsichtlich der Motive hebt Alberzoni Fragen des Rechtes und der Bildung sowie der Karriere hervor. Inwieweit für das Institut der Subdiakone auch praktisch-kirchenrechtliche Aspekte zum Beispiel für eine notwendige littera dimissoria bestimmend wurden, bleibt noch zu klären. In Mittel- und Oberitalien scheint es sich bei Mailand vielleicht auch um einen Sonderfall zu handeln, da im Schisma von 1130 Anaklet II. nur hier und in Süditalien anerkannt wurde.

Jean-Marie Martin wendet sich dem Süden zu und charakterisiert weniger die Bedeutung dieses Schismas, sondern die komplizierten Strukturen zwischen griechischen, lateinischen und arabisch-muslimischen Ausrichtungen. Seine Thesen - an den Bänden der Italia Pontificia orientiert und differenzierend nach dem unterschiedlichen quantitativen Anteil an Papstkontakten - münden in Fragen, welche die zahlreichen neuen Bistümer, Erzbistümer und die Tendenzen zur Exemtion betrafen. Benevent war demnach der einzige größere päpstliche Erfolg bei dieser Neustrukturierung des kirchlichen Raumes.

In der Beurteilung der Errichtung des Erzbistums Benevent weicht Martin allerdings von den Interpretationen Wolfgang Huschners ab, der im Erzbistum Benevent des 10. Jahrhunderts auch eine Reaktion auf die Erhöhung des süditalischen Otranto sieht. Während Martin darüber hinaus die politischen Zielsetzungen des byzantinischen Herrschers anders einschätzt, vergleicht Huschner Benevent mit der Gründung Magdeburgs. Daraus leitet er vermutliche universale Konzeptionen ab, die auch mögliche Zielvorstellungen Johannes' XIII. betreffen. Die Errichtung auf einer Synode deute auf einen breiten kommunikativen und konsensualen Prozeß. Magdeburg - kaum als civitas zu bezeichnen - habe sodann für Ostmitteleuropa Vorbildfunktion gewonnen. Deshalb hätten sich lateinische und griechische Welt im 10. Jahrhundert erneut voneinander abgegrenzt, endgültige Entscheidungen seien in dieser Zeit noch nicht getroffen worden. Als eine der grundlegenden Fragen in diesem Zusammenhang erwies sich diejenige nach den Handlungsmöglichkeiten der Päpste: Wie aktiv dürfen wir uns die Päpste dieser Zeit - und in diesem Fall Johannes XIII. - überhaupt vorstellen, wo lagen die jeweiligen Interessen? Wie weit reichte der aktiv von Rom gestaltete Kommunikationsraum ${ }^{5}$ ?

5 Fragen ergeben sich nicht zuletzt aus der erstaunlichen Passivität der Päpste bei der Ausstellung von Urkunden, vgl. dazu Hans-Henning Kовтüм: Zur päpstlichen Urkundensprache im frühen Mittelalter. Die päpstlichen Privilegien 896-1046, Sigmaringen 1995 (Beiträge zur Geschichte und Quellenkunde des Mittelalters 17), zusam- 
Wie repräsentativ sind Räume, was ist vergleichbar, wie lassen sich Gebiete abgrenzen und auswählen? Diese Fragen stellen sich besonders im Zusammenhang mit dem Beitrag von Jochen Johrendt, der drei Regionen, Ligurien, Umbrien und Kalabrien, in der Zeit von 1046-1198 hinsichtlich der empfangenen Papsturkunden in quantitativer und in inhaltlicher Hinsicht bezüglich der Rechtsinhalte und des Formulars miteinander vergleicht. Die in methodischer Hinsicht Neuland betretende Studie kann die Unterschiedlichkeiten der Regionen plastisch vor Augen führen und so verdeutlichen, daß trotz der scheinbar in allen regionalen und inhaltlichen kirchlichen Bereichen einer von Rom vorangetriebenen Zentralisierung die Regionen nicht nur Eigenheiten bewahren konnten, sondern auch neue entwickelten. Wertvolle weitere Aufschlüsse bietet etwa die Beantwortung der Frage, wo der Empfängereinfluß bei den unterschiedlichen Formulierungen lag und wie Kanzleiformen in die Untersuchung einzubinden $\operatorname{sind}^{6}$. Wie aber ist bei der Interpretation die doppelte Brechung der Informationen durch Überlieferungsunterschiede und durch unterschiedlich intensive Bearbeitung der verschiedenen Italia Pontificia-Bände auszugleichen?

Vor dem Hintergrund dieser Fragen sind die Bemerkungen von Dieter Girgensohn erhellend, der die Genese des Kehrschen Unternehmens zu einem anderen Jubiläum in Bezug setzte, zu Christoph Kolumbus ( $\dagger$ 1506). Der fruchtbare Irrtum, der für Kolumbus zu neuen Welten führte, ohne daß er dies direkt merkte, führte bei Paul-Fridolin Kehr zu einem Papsturkundenwerk, dessen Ziel und Aussehen er erst auf dem Weg präzisierte und auch änderte. Die

menfassend S. 425-429 sowie Jochen Johrendt: Papsttum und Landeskirchen im Spiegel der päpstlichen Urkunden (896-1946), Hannover 2004 (MGH Studien und Texte 33), bes. S. 12-20. - Vgl. auch Thomas Wetzstein: Wie die urbs zum orbis wurde. Der Beitrag des Papsttums zur Entstehung neuer Kommunikationsräume im europäischen Hochmittelalter, in: Römisches Zentrum und kirchliche Peripherie. Das universale Papsttum als Bezugspunkt der Kirchen von den Reformpäpsten bis zu Innozenz III., hg.v. Jochen Johrendt/Harald MülLer, Berlin/New York 2008 (Neue AAG 2), S. 47-75.

6 Eine umfangreiche Geschichte der päpstlichen Kanzlei vom Beginn des Reformpapsttums bis zu Innozenz III. fehlt bis heute. Bereits 1935 formulierte Leo Santifaller als Ziel zukünftiger Forschung die „Untersuchung und Feststellung der Formulare, Formeln und Diktate in vorgregorianischer, gregorianischer und nachgregorianischer Zeit aus dem gesamten überlieferten Material“, Leo Santifaller: Die Verwendung des Liber Diurnus in den Privilegien der Päpste von den Anfängen bis zum Ende des 11. Jhs, in: MIÖG 49 (1935) S. 225-366 (Wiederabdr. in: Ders.: Liber Diurnus. Studien und Forschungen von Leo Santifaller, hg.v. Harald Zimmermann, Stuttgart 1976 [Päpste und Papsttum 10], S. 14-158, hier S. 18). Auch wenn Santifaller das genannte Forschungsdesiderat in Hinblick auf den «Liber Diurnus» aussprach, so gilt die Forderung nach einer Sichtung des Materials hinsichtlich einer Kanzleigeschichte nach wie vor. Santifaller hat dies selbst geplant, doch konnte er dieses Vorhaben nicht mehr abschließen, vgl. Liber Diurnus, S. Xf. 
großen Vorteile für die Forschung sind unbestritten, aber die fehlende Vollendung der Italia Pontificia macht der Verfasser an strukturellen Problemen fest, die er am ehesten in Anbindung des Werkes an Institutionen sah, am besten an ein „Institut für Papsturkundenforschung“.

Die vierte Sektion trägt dem teilweise inkongruenten Grundlagenwerk der Italia Pontificia dadurch Rechnung, daß in allen Beiträge mögliche Ergänzungen oder Richtigstellungen bisheriger Forschungsinstrumente thematisiert wurden. Vor allem ging es um die nichturkundliche Überlieferung bzw. die möglichen Nachträge für die Italia Pontificia. Den Reigen eröffnet Rudolf Schieffer mit seinem Beitrag über die päpstlichen Register vor 1198, den Abschriften des Registers Gregors I., Johannes' VIII., dem Originalregister Gregors VII. und dem Registerfragment Anaklets II. Diese zusammen bieten immerhin 1600 Jaffé-Nummern von insgesamt knapp 18.000, somit fast $9 \%$ der gesamten in diesem Werk verzeichneten brieflichen und urkundlichen Überlieferung. Zwischen den Registern und der Empfängerüberlieferung besteht so gut wie keine Überschneidung, was durch den unterschiedlichen Charakter der tradierten Stücke bedingt ist. Hinsichtlich der regionalen Verteilung der Empfänger von in den Registern enthaltenen Briefen ergibt sich ein zunehmender Verlust der zentralen Bedeutung Italiens. Die Register selbst bergen zwar kein Potential für Ergänzungen zur Italia Pontificia, doch spiegeln sie - und damit wird die zweite zentrale Fragestellung des Bandes nach Integration und Desintegration thematisiert - die Öffnung des Papsttums aus dem italienischen Horizont zum universalen Papat und den damit einhergehenden Bedeutungsverlust Italiens für die Päpste wider.

Lotte Kéry verdeutlicht in ihren Ausführungen zu den vorgratianischen Kanonessammlungen als Fundort päpstlicher Schreiben die Empfängergebundenheit der Dekretalen, die als Antworten auf Anfragen zu verstehen sind. In den Kanonessammlungen finden sich jedoch nicht nur Dekretalen, sondern ebenso Papstschreiben zu Verwaltungsangelegenheiten oder reine Freundschaftsbriefe. Sofern die Regesta pontificum Romanorum Kontakte zwischen den Gliedern der Christenheit und dem Papsttum abzubilden suchen, sind durch sie wichtige Informationen hinsichtlich des Gebens und Nehmens zwischen dem römischen Zentrum und den Gliedern zu erhalten. Die Durchsicht zumal der "kleineren und bisher noch weniger bekannten Sammlungen“ läßt Aufschlüsse nicht nur bei der Identifizierung der Adressaten erwarten, sondern auch Neufunde. Hinsichtlich des Arbeitsaufwandes würde eine systematische Durchsicht aller Kanonessammlungen als Arbeitsauftrag für die Nachtragsbände jedoch in keinem Verhältnis zum Ertrag stehen.

Giulia Barone behandelt in Ihrem Beitrag anhand des Materials im ersten Band der Italia Pontificia drei Bereiche, die sie in Zusammenhang mit der Hagiographie beleuchtet: liturgische Prozessionen, Reliquientranslationen bzw. Kirchweihen und Reformen von Klöstern. Dabei weist sie auf divergierende 
Datierungen in unterschiedlichen Quellengattungen hin. Zumal bei Reliquientranslationen ist - wie Beispiele der Karolingerzeit verdeutlichen - mit einer parallelen Ausstellung von Papstschutzprivilegien zu rechnen, doch handelt es sich dabei nur um eine Möglichkeit. Keineswegs könne von jeder Translation auch auf eine Urkunde geschlossen werden ${ }^{7}$. Größere Ergänzungsmöglichkeiten für die Italia Pontificia sieht Barone aus dem Bereich der Hagiographie nicht.

Dietrich Lohrmann verweist in seinem an französischem Material erarbeiteten Beitrag auf konkrete Möglichkeiten zu Nachträgen in Zusammenhang mit Nachrichten über Appellationen an den Heiligen Stuhl. Zwar seien Petitionen und Entwürfe, mit denen sich Streitparteien an Rom wandten, selten erhalten. Doch mit Paschalis II. beginnend führt Lohrmann vor, wie aus Berichten über Beschwerden an der Kurie Nachrichten zu Urkunden entnommen werden können. Eine nähere Beleuchtung der innerkurialen Prozesse der Delegationsgerichtsbarkeit könnte also durchaus Nachträge zur Italia Pontificia zutage fördern.

In diese Stoßrichtung zielen ebenso die Ausführungen von Werner Maleczek, der unterschiedliche Typen kardinalizischen Schriftgutes, Urkunden, Briefe, kurialinterne Schriftstücke, Testamente, Schreiben mehrer Kardinäle und ihre literarische Tätigkeit behandelt. Der im Vergleich zum Vortrag wesentlich erweiterte Beitrag erfaßt jegliche Form von literarischer Produktion durch die Kardinäle zwischen dem Beginn des Reformpapsttums und dem Pontifikat Innozenz' III. Zumal bei der Nachlese der kurialinternen Schriftstücke, den Schreiben der Kardinäle als Auditoren, sei von einer ,systematischen Nachlese zweifelsohne noch so mancher Fund" zu erwarten. Die Aktivitäten in diesem Bereich erweisen sich nicht zuletzt deswegen als wichtig, da die Kontakte zwischen Rom und den Gliedern der christianitas nicht nur eine Beziehung mit dem Papst bedeuten. Rom bzw. das römische Zentrum sind vielmehr ab der zweiten Hälfte des 11. Jahrhunderts als Papst und Kardinäle zu verstehen. Der Arbeitsaufwand der Nachlese für die ersten drei Italia Pontificia-Bände ist jedoch schwer abzuschätzen.

Sebastian Scholz demonstriert die eingeschränkte Leistungsfähigkeit der in Regestenform aufgenommenen Inschriften. Da sich die Regesten praktisch nur am dispositiven Rechtscharakter bzw. dem Faktischen - wie einer Weihe oder einem Neubau - orientierten, fallen entscheidende Aussagen, die der Quellengattung eigen sind, weg: In weitestem Sinne betrifft dies die Formulierung päpstlicher Ansprüche sowie die Selbstdarstellung der Päpste, Belege für eine korrekte Amtsführung und ähnliches. Für die konkrete Arbeit an der Italia Pontificia stellen die Inschriften jedoch auch bei einer Aufarbeitung in Rege-

7 Vgl. dazu Klaus Herbers: Rom im Frankenreich - Rombeziehungen durch Heilige in der Mitte des 9. Jahrhunderts, in: Mönchtum - Kirche - Herrschaft 750-1000. Festschrift für Josef Semmler, hg.v. Dieter R. BAuER u.a., Sigmaringen 1998, S. 133-169. 
stenform in gewohnter Weise inner- und außerhalb Roms ein noch nicht genügend beackertes Feld dar, was man als konkrete Arbeitsaufforderung auffassen kann - in Zusammenarbeit mit dem neuen italienischen Inschriftenwerk.

Tommaso di Carpegna Falconieri bietet in seinem Beitrag einen Überblick über die Quellenlage in Rom, mit dessen Hilfe das Verhältnis des Papsttums zum römischen Klerus zu beleuchten ist. Zumal der Verlust des Archivs der „Romana fraternitas" und des „Vicarius urbis“ erweisen sich als besonders schmerzhaft für die Beantwortung der mit dem Vortragstitel aufgeworfenen Fragen. Doch sei nicht nur ein Verschwinden ganzer Quellenbestände zu beklagen, sondern auch aus Sicht der heutigen Forschung das Fehlen einer zusammenfassenden Quellendokumentation, vergleichbar der Italia Pontificia, zumal die Aufarbeitung der Quellenbestände nach dem Zweiten Weltkrieg ins Stocken geraten sei.

Hubert Houben widmet sich der Überlieferung von Papsturkunden in den Aufzeichnungen Gelehrter zwischen dem 16. und 18. Jahrhundert an süditalienischen Beispielen, oftmals Überlieferungen aus dritter Hand. Zumal der eher freie Umgang mit Texten durch Lokalhistoriker dieser Epoche stellt die "Regestenschuster" hinsichtlich der Echtheitskritik vor schwierige Probleme. Die Bedeutung dieser sekundären oder oftmals tertiären Überlieferung verdeutlicht er am Beispiel von Venosa, der Deutschordensballei Apulien und Otranto. Er ermuntert nachdrücklich dazu, die neuzeitliche Überlieferung noch weiter nach erhaltenen Urkunden zu durchforsten.

Der umfangreiche Beitrag von Rudolf Hiestand beschäftigt sich mit den Nichtitalica innerhalb der italienischen Überlieferung. Diese waren von Kehr in seinen Vorarbeiten zum Regestenwerk, den „Reiseberichte zur Italia pontificia“ angezeigt bzw. bereits ediert worden. Es handelt sich um nicht weniger als ca. 200 Stücke, von denen 85 auf die Reform- und vor allem auf die Ritterorden entfallen, 66 Stücke aus den päpstlichen Registern des 13. bis 16. Jahrhunderts, von denen Kehr bereits 50 als Volltext druckte, und 72 Stücke aus unterschiedlichen Überlieferungszusammenhängen. Letztere sind in der Regel $\mathrm{Zu}$ fallsfunde, die ein erhellendes Licht auf die jeweilige Archivgeschichte werfen.

In Hinblick auf seine integrierende und desintegrierende Funktion innerhalb der Kirche trat mit der Entstehung der Orden ein weiteres Element neben das Papsttum, dem sich die fünfte Sektion annimmt. Mit der Ausbildung von Ordenszentralen, die wie im Falle der Cluniazenser, Zisterzienser oder Prä-

8 Vgl. etwa als ähnlich gelagerten, jedoch von seiner Bedeutung bereits im Umfang herausragenden Fall für die Polonia Pontificia die Aufzeichnungen des Jan Dugłosz: Jery Wyrozumski/Stanisław Szczur: Jan Dugłosz und die Polonia Pontificia, in: Hundert Jahre Papsturkundenforschung. Bilanz - Methoden - Perspektiven. Akten eines Kolloquiums zum hundertjährigen Bestehen der Regesta Pontificum Romanorum vom 9.-11. Oktober 1996 in Göttingen, hg.v. Rudolf Hiestand, Göttingen 2003 (AAG, phil.-hist. Kl., 3. Folge 261), S. 219-228. 
monstratenser nicht in Rom und nicht einmal in Italien lagen, waren zwar neue, die Gesamtkirche durchdringende und zugleich zentrierende Gefüge entstanden, die spätestens im innozentianischen und alexandrinischen Schisma die Leistungsfähigkeit ihrer integrierenden Fähigkeiten unter Beweis gestellt hatten. ${ }^{9}$ Doch welche Auswirkungen hatten diese „Nebenzentralen“ für das Verhältnis des Papsttums zu Italien? Nutzte das Papsttum diese oder traten sie in eine wie auch immer geartete Konkurrenz?

Am Beispiel der Eremiten kann Mario Sensi in seinem Beitrag aufzeigen, $\mathrm{da} ß$ es sich um eine seit dem ausgehenden 10. Jahrhundert ungebrochene Bewegung handelte, zumal in Umbrien. Spätestens am Ende des 11. Jahrhunderts entstanden aus den teilweise unabhängig voneinander gegründeten oder in Filiation entstandenen Einzelkonventen von Eremiten Kongregationen, wie der Verfasser ausgehend von den Beispielen Camaldoli, Fonte Avellana und Vallombrosa verdeutlicht. Parallel zu dieser organisatorischen Verdichtung zu einer Kongregation erfolgte die Unterstellung des neuen Gebildes unter das Papsttum, das die Gemeinschaften in seinen Schutz aufnahm. Doch neben diesen in Kongregationen zusammengefassten und auf das Papsttum ausgerichteten Eremitengemeinschaften, aus denen sich teilweise eigne Orden entwickelten, ist zumal für das Gebiet Umbriens daneben und in zeitlichem Horizont darüber hinaus ebenso ein „irreguläres Eremitentum“ festzustellen, oftmals an Michaelsheiligtümer gekoppelt, die sich in Grotten oder Höhlen fanden. Diese rein auf den lokalen Kontext ausgerichteten Gründungen konnten aufgrund ihrer fehlenden Vernetzung neben ihrer bisweilen nicht zu unterschätzenden Wirkmächtigkeit als Heiligtum keine integrierenden Wirkungen entfalten, weder aus eigenem Antrieb noch in Verbindung mit dem Papsttum.

Die enge Bindung der Zisterzienser an das Papsttum zumal während des innozentianischen Schismas betont Rinaldo Comba, der den Orden als in seiner Frühphase durch „unanimità e diversità " geprägt und rasch mit dem Papsttum verbunden beschreibt. Letzteres gelte sowohl für den Gesamtorden als auch für die einzelnen Zisterzen in Italien, deren Äbte bisweilen ihre Weihe durch den Papst erhalten mußten. Dass die Päpste den Orden als integrierendes Moment einzusetzen suchten, wird nicht zuletzt daran deutlich, daß Innozenz II. Bernhard von Clairvaux zur Unterstützung gegen Anaklet II. nach Italien gerufen hatte - wenn auch nicht als Klostergründer. Die anhand der päpstlichen Urkunden für die einzelnen Zisterzen ersichtlichen bisweilen sehr engen Kontakte zwischen den Päpsten und diesen Einzelklöstern offenbaren zudem die engen Wechselwirkungen nicht nur zwischen dem Orden insgesamt und dem Papst-

9 Vgl. Hubertus Seibert: Autorität und Funktion. Das Papsttum und die neuen religiösen Bewegungen in Mönch- und Kanonikertum, in: Das Papsttum in der Welt des 12. Jahrhunderts, hg. v. Ernst-Dieter Hehl/Ingrid Heike Ringel/Hubertus Seibert, Stuttgart 2002 (Mittelalterforschungen 6), S. 207-241. 
tum, sondern auch zwischen Rom und dem einzelnen Kloster vor Ort. Nicht zuletzt durch diese von seiten der Päpste bewirkte Außenformung des Ordens stellte sich für diesen in der zweiten Hälfte des 12. Jahrhunderts auch die Frage nach der eigenen Identität.

Kristjan Toomaspoeg widmet sich den Ritterorden, die vor allem seit der zweiten Hälfte des 12. Jahrhunderts auch in Süditalien, namentlich in den großen Aufbruchsorten ins Heilige Land agierten. Zunächst waren es die Hospitaliter, dann die stärker militärisch ausgerichteten Templer, die schon seit den Zeiten Innozenz' II. und Alexanders' III. päpstliche Förderung erhalten hatten, besonders an den Wegen und Orten, die Orient und Okzident verbanden. Unter Innozenz III. und Honorius III. dienten die Ritterorden auch päpstlichen Zielen auf der Apenninhalbinsel, wie der Verfasser an den Häusern des Deutschen Ordens in Sizilien illustriert. Fördermaßnahmen hingen aber zugleich mit der Unterstützung der Gemeinschaften im Orient zusammen. Der Beitrag behandelt weiterhin die Bedeutung in Süditalien während des 13. Jahrhunderts mit den verschiedensten Niederlassungen und bietet einen Ausblick auf die Zeit des avignonesischen Papsttums, in der auch die Aktivitäten der Ritterorden mit denjenigen im östlichen Mittelmeer (Türken) und im Baltikum zusammen gesehen werden müssen. Insgesamt bietet die Studie - weit über den zeitlichen Rahmen 1198 hinausgreifend - Beispiele dafür, wie lokale und universale Interessen auch in der Förderung durch die Päpste zusammengefaßt oder gegeneinander ausgespielt werden konnte.

Rudolf Hiestand sichtet in seinem Beitrag die vielfältigen und teilweise komplizierten Verknüpfungen der Italia Pontificia mit dem Kreuzzugsgeschehen und bietet damit auch Hilfen, wie die bisherigen Ergebnisse zu nutzen sind und welche Aufgaben bleiben. Sein hilfreicher Überblick zur Aufarbeitung der Kreuzzugsquellen, die teilweise parallel zu den Anfängen des Göttinger Papsturkundenwerkes verlief, kann manche Probleme wissenschaftsgeschichtlich erklären. Zur Diskussion stehen vier Fragebereiche: die eigentlichen Kreuzzüge, die Kreuzfahrerherrschaften und -kirchen, die Niederlassungen der italischen Seestädte im Osten sowie die Ritterorden. Die anschließende Durchforstung der Italia-Bände und die Hinweise auf Nachträge - meist in den „Vorarbeiten zum Oriens pontificius" $1-3$ publiziert - betreffen zunächst die Kreuzfahrerstaaten und -kirchen, was immerhin 16 neue gegenüber zuvor 63 bekannten Belege ergab. Anschließend werden die Teile der Italia hervorgehoben, die in den Narrationes oder Regesten den Bezug zu den Kirchen und Herrschaften im lateinischen Osten erkennen lassen (II). Für die Legaten ist noch mehr als bisher zu beachten, nach welchen verschiedenen, kurz besprochenen Kriterien im Laufe der Zeit Legationen Eingang ins Papsturkundenwerk fanden, um unnötige Sucharbeiten zu vermeiden (III). Die Nachlese für das eigentliche Kreuzzugsgeschehen ergab einige wichtige Ergänzungen; die zahlreichen Spuria erklären sich auch daraus, daß manche Städte den eigenen Anteil an den 
Kreuzzügen durch Urkunden lückenloser gestalten wollten (IV). Zwischen Diözesen und Ritterorden steht das Kapitel des Heiligen Grabes, weil immer wieder aufgrund mancher Patrozinien zu entscheiden ist, ob eine Kirche Dependance der Gemeinschaft oder unabhängig ist. Für die Ritterorden war die Nachlese vor allem in Valetta (Malta) und in Spanien ertragreich (V). Insgesamt differenziert diese ergänzende Durchsicht das Bild nicht unwesentlich, dies gilt für die Institutionen des lateinischen Ostens ebenso wie für die noch in die Italia Pontificia einzubringenden Nachträge. Damit wird erneut unterstrichen, wie wichtig es ist, bei der Archivsichtung grundsätzlich alle Überlieferungen zu erfassen (VI). In einem Anhang werden die in Italien gefundenen Papsturkunden zum Kreuzzug und den Kirchen im lateinischen Osten übersichtlich zusammengestellt.

II.

Im Anschluß an die Zusammenfassung der Ergebnisse ist nach den sich daraus ergebenden Perspektiven für die Fortführung des Regestenwerks und die weitere Forschung zu fragen. Zunächst zum Regestenwerk selbst: Wo lohnt die Nachlese? Was ist pragmatisch vertretbar? Was verspricht eine deutliche Veränderung und Präzisierung des bisherigen Bildes? Hinweise bzw. Arbeitsempfehlungen an das Regestenwerk ergeben sich aus den Beiträgen von Lotte Kéry, Dietrich Lohrmann, Werner Maleczek, Sebastian Scholz, Hubert Houben und Rudolf Hiestand. Allen Vorschlägen eigen ist jedoch, daß die Relation von Arbeitsaufwand und Ergebnis schwer abzuschätzen ist. Wies Rudolf Schieffer in der Diskussion der Tagung mehrfach auf die kaiserlich-königlichen Empfänger hin, so dürfte ein Band zu "Imperatores et reges", der bereits von Graf Finckenstein begonnen wurde, unstreitig sinnvoll $\operatorname{sein}^{10}$. Derartige Einstimmigkeit wird in der Fachwelt hingegen schon nicht mehr zu erwarten sein, wenn es um die Frage geht, ob die kanonistischen Sammlungen ortsbezogen oder generell für das Gesamtunternehmen für eine Nachlese durchforstet und die hieraus abzuleitenden Regesten präsentiert werden sollten ${ }^{11}$. Neben der zunehmend schwieriger werdenden Frage nach einer geeigneten Bearbeiterin oder einem geeigneten Bearbeiter der jeweiligen Materie ist auch hier nach dem Verhältnis von Aufwand und Ertrag zu fragen. Konkret sind zum Abschluß der Italia Pontificia drei Bände ins Auge genommen: neben dem bereits genannten Band „Imperatores et reges“ zum einen die „Decretalia generalia“ und schließ-

10 Erste Regestenentwürfe bis ins ausgehende 9. Jahrhundert liegen in Rohform vor.

11 Welche Erkenntnismöglichkeiten sich durch eine gezielte Verortung der Sammlungen, der Suche nach dem Ort, an dem sie zusammengestellt wurden, bringen kann, veranschaulicht Lotte Kéry: Dekretalenrecht zwischen Zentrale und Peripherie, in: JoHRENDT/MüLLER (wie Anm. 5) S. 19-45. 
lich noch ein Nachtragsband, mit dessen Bearbeitung seit vielen Jahren Raffaello Volpini begonnen hat, der jedoch weitere Funde präsentieren könnte ${ }^{12}$. Vorrangig in diesen Nachtragsband sind ebenfalls die durch die Tagung und den Band formulierten Hinweise auf mögliche Ergänzungen zu integrieren.

Doch werfen die ergänzenden Nachträge nicht zuletzt Fragen nach ihrer Systematisierung und ihrem Ort innerhalb des Regestenwerks auf: Wie steht es um Regesten für auswärtige Empfänger, die aber - wie der Beitrag Lohrmanns verdeutlicht - mehrere Zwischenschritte in Rom erkennen lassen, wie um erzählende, epigraphische Notizen und deren weiten Bedeutungsgehalt, wie um Kardinalsurkunden, die erst ab dem vierten Band der Italia Pontificia aufgenommen wurden, ganz zu schweigen von den delegierten Richtern. Soll die bestehende Orientierung der Regesten auf Rechtliches, auf Individuelles bei den Urkunden, Strukturelles bei den Registern und kanonistischer Überlieferung aufgebrochen werden, wie Bemerkungen zu Inschriften oder Übergabeverhandlungen nahelegen? Wie ist hinsichtlich der konrekten Regestierung (Nebenregesten) mit der italienischen Überlieferung der Nichtitalica in den anderen Pontificiae umzugehen?

Diese Fragen führen zielgenau auf den Charakter und die Aussagefähigkeit des Regestenwerks, das Kehr selbst als "Notbehelf“ bezeichnet hatte ${ }^{13}$. Die Leistungsfähigkeit dieses Hilfsmittels haben die unterschiedlichen Beiträge des Bandes demonstriert. Doch zugleich wurde deutlich, was die Regesta Pontificum Romanorum aufgrund ihrer inhaltlichen Ausrichtung nicht bieten können. Da die Regesten sich auf das rechtliche Substrat der Kontakte zwischen der Leitung der Kirche und der christianitas konzentrieren, kommt in ihnen gleichsam allein das in Schrift geronnene Ergebnis der Beziehungen zum Ausdruck, vorrangig rechtlicher Natur. Sie verzeichnen mit anderen Worten allein die konkrete Ausformung der Kontakte, nicht jedoch deren Motivationen. Viele andere Faktoren, welche die in der Italia Pontificia verzeichneten Beziehungen beeinflußten und gestalteten, bleiben unberücksichtigt, auch wenn sie in ihrer Bedeutung nicht zu unterschätzen sind: Fragen wie etwa nach der Bedeutung der Doppelapostolizität Roms, der konkreten Vorstellung von der Binde- und Lösegewalt der Päpste in den unterschiedlichen Regionen, deren Folgen für die Heilssuche des individuellen Gläubigen werden in ihnen nicht thematisiert und würden den Rahmen des Werkes sprengen.

12 Vgl. Klaus Herbers: 100 Jahre Italia pontificia (1906-2006) - Anregungen zur Abrundung, in: QFIAB 87 (2007) S. 374-379.

13 Vgl. dazu Rudolf Hiestand: 100 Jahre Papsturkundenwerk, in: Hundert Jahre Papsturkundenforschung. Bilanz - Methoden - Perspektiven. Akten eines Kolloquiums zum hundertjährigen Bestehen der Regesta Pontificum Romanorum vom 9.-11. Oktober 1996 in Göttingen, hg.v. Dems., Göttingen 2003 (AAG, phil.-hist. Kl., 3. Folge 261), S. $11-44$, hier S. 20. 
Doch bevor die Aufarbeitung dieser Aspekte für die Beziehungen zwischen Rom und der christianitas eingefordert wird, ist vielmehr auf das bisher zu weiten Teilen noch brachliegende Potential der Regesta Pontificum Romanorum am Beispiel Italiens hinzuweisen ${ }^{14}$. Für regionalbezogene Beispielstudien bieten die Regestenbände mit ihrem nach den Empfängern aufbereiteten Material eine ideale Ausgangsbasis. Schon die Anordnung erleichtert Fragen nach Integration und Desintegration, die fruchtbringend an die Ende des 19. Jahrhunderts konzipierte „urkundlichen Quellenkunde“"15 herangetragen werden können. Damit wird zugleich die ungebrochene Bedeutung von Grundlagenforschungen zumal im geisteswissenschaftlichen Bereich unterstrichen, die langfristig von den einmal bereitgestellten und aufbereiteten Materialien profitiert. Denn etliche Fragestellungen ergeben sich erst aus der Aufarbeitung des in der Italia Pontificia gebotenen Materials. Bevor nach der Motivation des Handelns gefragt werden kann, ist dieses zunächst schlicht zu erfassen. Bereits hinsichtlich dieser banal erscheinenden Aufgabe der weiteren Forschung kann der vorgelegte Band zentrale methodische Probleme aufzeigen, ohne zugleich allgemein gültige Lösungen anzubieten: die zeitliche und räumliche Abgrenzung der untersuchten Einheiten, die asymmetrische Überlieferung und Aufarbeitung sowie kontroverse Positionen zur aktiven Politik der Päpste und deren Kontrahenten, seien es Urkundenempfänger, politische Partner oder Gegner, erweisen sich als Kernprobleme der auf Regionen bezogenen Einzelstudien. Entscheidend ist für die Beiträge des Bandes stets, wie Zeitabschnitte und Regionen ausgewählt und abgegrenzt werden. Das wird auch für die weitere Forschung ein entscheidendes Kriterium für die Auswahl von geeigneten Untersuchungsregionen bleiben. Das Grundproblem und zugleich der Reiz Italiens besteht nicht nur in der Inhomogenität des Gesamtgebildes, sondern auch in derjenigen der einzelnen Regionen in Italien: Was bedeutet etwa aus herrschaftlicher Perspektive im 9. Jahrhundert ,Apulien' und was im 12. Jahrhundert? Was im vorliegenden Band an einigen ausgewählten Beispielen der Italia behandelt wird, gilt ebenso für andere Regionen, bei denen statische Entwick-

14 Diese Ausführungen gelten grundsätzlich auch für die anderen Teile des Regestenwerkes. Zur Zeit ist eine Nutzung in ähnlicher Weise jedoch in größerem Umfang allein für die Germania Pontificia möglich. Zumal nach dem Erscheinen des Bandes von Herman Jakobs GP 5/2 ist die Aufarbeitung der Kirchenprovinz Mainz abgeschlossen und bietet sich für vergleichende Studien geradezu an.

15 So der Ausdruck von Kehr in seiner Besprechung der Italia Pontificia Paul Fridolin Kenr: Selbstanzeige von Italia Pontificia I, in: Göttingische gelehrte Anzeigen 168 (1906) S. 593-610, S. 597 (Wiederabdr. in: Ders.: Ausgewählte Schriften, hg. v. Rudolf Hiestand, 2 Bde., Göttingen 2005 [AGG, phil.-hist. Kl., 3. Folge 250], hier Bd. 1 S. $18-35$, S. 20). 
lungen ohne allzu große Veränderungen der kirchlichen und politischen Rahmenstruktur die Ausnahme bleiben ${ }^{16}$.

Doch wie lassen sich diese Räume abgrenzen? Derartige jeweils am Einzelfall zu prüfenden Problemstellungen bestimmten die Diskussionen der Tagung und werden auch die weitere Forschung beschäftigen. Das gilt sowohl für das Ganze, denn das notgedrungen exemplarische Vorgehen in einer Vielzahl von Beiträgen, von Maria Pia Alberzoni, Jochen Johrendt, Jean-Marie Martin und anderen läßt sehr eindringlich deutlich werden, wie unterschiedlich Italien offensichtlich war $^{17}$. Und das gilt ebenso für kleinräumigere Einheiten, wobei sich stets die Frage anschloß und -schließt, wie typisch und wie singulär beispielsweise die Situation in Mailand - eigentlich ist.

Der vorliegende Band konzentriert sich bewußt auf die Italia und thematisiert dabei nicht explizit das Verhältnis von Italia und Orbis. Doch liegt gerade darin sein Potential für weitere Forschungen, wenn die an Italien in den einzelnen Beiträgen beispielhaft angewandten Fragestellungen auf die gesamte lateinische Christenheit und ihre unterschiedlichen Regionen übertragen werden. Dabei wären die jeweiligen Räume auch in ihrer Dynamik und ihren Formierungsprozessen zu berücksichtigen: die Mittel der päpstlichen Einflußnahmen oder die Wünsche der Petenten können hier sehr aufschlußreich sein. Dies mag sogar zu Überlegungen führen, ob in einzelnen Fällen die Distanz Roms sogar zu stärkeren Möglichkeiten der päpstlichen Einwirkungen führen konnte. Auch hier bietet der Band methodische Anregungen, da er an Beispielen verdeutlicht, daß neben der begründeten Auswahl einer Region, die untersucht werden soll, in einem weiteren Schritt sowohl bei der empfängerorientierten als auch bei der nicht empfängerorientierten Überlieferung eine Asymmetrie zu berücksichtigen ist ${ }^{18}$ : Neben den wechselhaften Schicksalen der Empfängerüberlieferungen muß der Blick zugleich stets der ausstellungsbedingten Überlieferung in Registern oder Kanonessammlungen gelten. In diesem Zusammenhang demonstrieren insbesondere die Ausführungen über die Collectio Britannica oder die päpstlichen Register vor 1198, daß durch den weiter gespannten Integrationsrahmen des Papsttums spätestens ab dem 12. Jahrhundert verstärkt andere Regionen als Italien in den Vordergrund traten. Dabei wirkt die Unterschiedlichkeit der Quellenarten befruchtend auf die Erkenntnismöglichkeiten - urkundliche

16 Das betrifft nicht nur Regionen am südlichen, westlichen und östlichen Rand der lateinischen Christenheit, sondern ebenso zentrale Landschaften wie etwa Oberitalien, Süd- und Westfrankreich.

17 Es bleibt fraglich, ob Ergänzungen und Präzisierung der Italia Pontificia hier künftig weiteren Halt geben können.

18 Vgl. dazu grundlegend Arnold Esch: Überlieferungs-Chance und Überlieferungs-Zufall als methodisches Problem des Historikers, in: HZ 240 (1985) S. 529-570 (ND in: DERs.: Zeitalter und Menschenalter. Der Historiker und die Erfahrung vergangener Gegenwart, München 1994, S. 39-69). 
Überlieferung, die Register, Inschriften oder historiographische Quellen besitzen jeweils ihren sehr eigenen Fokus und offenbaren damit stets neue Seiten des Papsttums.

Die Formulierung von Ernst-Dieter Hehl, daß die Kirche im 12. Jahrhundert "größer und dichter" wurde" ${ }^{19}$, ist in ihrer allgemein Aussage absolut zutreffend, doch wird die weitere Forschung genauer zu beachten haben, an welchen Stellen die Kontakte zu Rom intensiver, die Beziehungen zwischen dem Papsttum und den Einzelkirchen „dichter“ wurden und wo die Quellen eines Gebens und Nehmens zwischen dem Papsttum und der lateinischen Kirche zu verorten sind. Für Italien bedeutet diese grundlegende Entwicklung, daß die Beziehungen in Relation zu anderen Regionen „dünner“ wurden. Denn sowohl die Verteilung der Legatenurkunden als auch die Anzahl der im Register Gregors VII. registrierten Stücke für französische Empfänger belegen die neue Position Frankreichs im Prozeß des Gebens und Nehmens seit dem ausgehenden 11. Jahrhundert und deuten damit Konsequenzen auch für Italien an. Doch wird man auch in diesem Punkt hinterfragen müssen, in welchem Maße diese Einheiten durch das Papsttum und in welchem durch die Kirchen vor Ort geformt wurden. Zugleich verdeutlicht eine nicht statische, sondern sich an den wandelnden Beziehungen orientierte Perspektive, daß die noch näher zu bestimmende Funktion des Papsttums innerhalb der „Kirche“ zugleich davon bestimmt war, daß es Teil dieser „Kirche“ war. Die Beiträge des vorliegenden Bandes umfassen unterschiedliche Zeitabschnitte zwischen dem 6. und dem 12. Jahrhundert. Die Beziehungen zu Byzanz werden besonders für das 6. und 7. Jahrhundert, Fragen nach der Kenntnis des Griechischen in Italien sowie Prozesse der Kirchenorganisation auf das 9. und 10. Jahrhundert erörtert, weitere Beiträge widmen sich epocheübergreifenden Fragestellungen. Ein großer Teil befaßt sich jedoch mit dem 12. Jahrhundert. Eine Aufgabe des Bandes war es, die Leistungsfähigkeit der Italia Pontificia in ihrer thematischen und chronologischen Breite zu verdeutlichen. Doch dürfte eine gewisse Konzentration auf das 12. Jahrhundert nicht nur der steigenden Fülle des Quellenmaterials geschuldet sein. Gerade die Epoche von der Mitte des 11. Jahrhunderts bis zum Beginn des 13. Jahrhunderts, eine Phase der zunehmenden Ausrichtung der Kirchen auf Rom hin, bietet sich wie kaum eine andere Zeit der Kirchengeschichte an, um die integrativen und desintegrativen Einflußnahmen des Papsttums in Italien, aber auch im Orbis generell näher zu beleuchten ${ }^{20}$.

19 Ernst-Dieter Hehl: Das Papsttum in der Welt des 12. Jahrhunderts. Einleitende Bemerkungen zu Anforderungen und Leistungen, in: Das Papsttum in der Welt des 12. Jahrhunderts, hg.v. Ernst-Dieter Hehl/Ingrid Heike Ringel/Hubertus Seibert, Stuttgart 2002 (Mittelalter-Forschungen 6), S. 9-23, hier S. 9.

20 Daher berühren sich die Beiträge des Tagungsbandes mit einem weiteren Band, der seit April 2008 gedruckt vorliegt und ebenfalls mit dem Deutschen Historischen Institut in 
Die Verbindung von räumlichen Aspekten (Sektion III) und quellentypischen Überlieferungsformen (Sektion IV) wurde zwar mehrfach in den Diskussionen angesprochen, aber nur bedingt in die Vorträge und Beiträge einbezogen. Doch die neuere Forschung hat die Bedeutung eines in Regionen differenzierten Ansatzes, der im Kehrschen Unternehmen für die Erfassung und Aufbereitung der Quellen schon angelegt war, nun auch für die Interpretation verstärkt aufgegriffen und um Aspekte des Vergleichs erweitert ${ }^{21}$. Erst durch eine komparatistisch angelegte Analyse sind Spezifika der Überlieferung einer Region zu erkennen, die ansonsten innerhalb der Italia Pontificia in der Masse der gebotenen Regesten formlos verschwinden würden. Dem haben weitere Forschungen zum Papsttum und zur Kirche Rechnung zu tragen, was beispielsweise in dem internationalen DFG-Netzwerk „Zentrum und Peripherie? Das universale Papsttum und die Regionen Europas" erarbeitet wird ${ }^{22}$.

Gegebenenfalls werden weiterführende Forschungen sowohl zur Italia als auch zur Gesamtkirche stärker als bisher die Epochengrenze von 1198 bewußt $\mathrm{zu}$ überschreiten haben. Innerhalb des hier vorliegenden Bandes zur Italia Pontificia geht neben den Studien von Werner Maleczek und Dietrich Lohrmann lediglich der Beitrag von Kristjan Toomaspoeg deutlich über die Grenze von 1198 hinaus. Doch gerade angesichts einer problematischen Überlieferungslage - wie etwa in den Regionen Süditaliens - ist der Blick zuweilen auch über diese Epochengrenze zu richten. Das bedeutet zugleich, daß damit die fast ausschließlich durch Empfängerüberlieferung geprägte Zeitgrenze überschritten

Rom verbunden ist: Johrendt/Müller (wie Anm. 5). Der Band untersucht gezielt die Zentralisation der Kirche, deren konkreten Vollzug - eine Ausrichtung an Rom in den einzelnen Kirchen vor Ort - und die Instrumente, die dem Papsttum dazu zur Verfügung standen. Explizit zu Italien vgl. darin die Beiträge von Nicolangelo D’Acunto und Jochen Johrendt.

21 Zur komparatistischen Vorgehensweise vgl. Michael Borgolte: Perspektiven europäischer Mittelalterhistorie an der Schwelle zum 21. Jahrhundert, in: Das europäische Mittelalter im Spannungsbogen des Vergleichs. Zwanzig internationale Beiträge zu Praxis, Problemen und Perspektiven der historischen Komparatistik, hg.v. DEMs., Berlin 2001 (Europa im Mittelalter 1), S. 13-27, bes. S. 22-24. Zum historischen Vergleich, seinen Merkmalen und Grenzen vgl. allg. die Ausführungen von Hartmut KaELble: Der Historische Vergleich. Eine Einführung zum 19. und 20. Jahrhundert, Frankfurt/New York 1999; Heinz-Gerhard Haupt/Jürgen Kocka: Historischer Vergleich. Methoden, Aufgaben, Probleme. Eine Einleitung, in: Geschichte und Vergleich. Ansätze und Ergebnisse international vergleichender Geschichtsschreibung, hg. v. Dens., Frankfurt/New York 1996, S. 9-39.

22 Die Mitglieder dieses Netzwerks sind: Nicolangelo D'Acunto (Brescia), Stefan Burkhardt (Heidelberg), Ingo Fleisch (Bamberg), Klaus Herbers (Erlangen), Jochen Johrendt (München), Lotte Kéry (Bonn), Harald Müller (Aachen), Rainer Murauer (Rom), Jörg Peltzer (Heidelberg), Przemyslaw Nowak (Warszawa), Matthias Schrör (Düsseldorf), Ursula Vones-Liebenstein (Frankfurt a. M.), Thomas Wetzstein (Heidelberg) und Claudia Zey (Zürich). Zum Netzwerk informiert die Internetseite http://www.zentru mundperipherie.de/ (15.5.2009). 
wird. Vergleiche der dominierenden Überlieferungsform in einer bestimmten Region vor und nach 1198 könnten methodisch fruchtbare Ergebnisse zu unseren Erkenntnismöglichkeiten überhaupt zeitigen.

Ein weiteres, in besonderem Maße die Italia betreffendes Problem, wird durch den vorliegenden Band thematisiert: die Abwesenheit und Anwesenheit des Papstes in verschiedenen Teilen oder sogar außerhalb Italiens spielte für die Beziehungen der Päpste zu den Regionen sicher eine nicht unbedeutende Rolle, was sich in den Ergebnissen zu Mailand, zu Süditalien oder den entsandten Kardinälen widerspiegelt. Zugleich demonstrieren die Beiträge des Bandes, daß das Begriffspaar Nähe/Ferne nicht allein aus der rein geographischen Distanz zwischen den Päpsten und den Regionen zu sehen ist. Geographische Nähe ist keinesfalls automatisch mit Intensität gleichzusetzen ${ }^{23}$. Und auch bei dem Versuch einer näheren Bestimmung dieses Verhältnisses von Nah und Fern tritt erneut nicht nur der regionale Bezugsrahmen als entscheidend in den Vordergrund, sondern ebenso der zeitliche. In den über 1000 durch das Gesamtunternehmen des Göttinger Papsturkundenwerkes zu bearbeitenden Jahren standen den Päpsten nicht nur unterschiedliche Instrumente zur Verfügung, um Ferne in Nähe zu verwandeln, sondern auch die Intensität ihrer Nutzung war weder chronologisch noch in seiner geographischen Ausrichtung kontinuierlich. Nähe ist daher auch durch die in den untersuchten Phasen möglichen Mittel der Kommunikation bedingt und an diesen zu messen.

Der Wert der Italia Pontificia ist für den Papsturkundenforscher unbestritten. Auch der Kreis der Autoren dieses Bandes setzt sich vorrangig aus dieser zum Teil hoch spezialisierten Forschergemeinde zusammen. Neben Fragen nach der Verbesserung und Abrundung der Italia Pontificia werden aber bei der Frage nach der Formierung von Räumen und Gemeinschaften vielfältige allgemeine Fragen angesprochen, die nicht nur unter den Stichworten Integration und Desintegration zu fassen sind, sondern Überlieferung, Herrschaftsmittel, Arten des Zusammen- und Gegeneinanderwirkens von lokalen und zentralen Interessen, Kommunikation und weitere Aspekte betreffen. Damit sind allgemeine Fragen genannt, Brücken zu verwandten Disziplinen geschlagen. Italien war jedenfalls schon vor 1815 mehr als ein geographischer Begriff.

23 Vgl. dazu Jochen Johrendt/Harald MüLler: Zentrum und Peripherie. Prozesse des Austausches, der Durchdringung und der Zentralisierung der lateinischen Kirche im Hochmittelalter, in: Johrendt/Müller (wie Anm. 5) S. 1-16, hier S. 9. 
Bereitgestellt von | De Gruyter / TCS

Angemeldet | 217.89.40.26

Heruntergeladen am | 21.12.12 10:51 


\section{Orts- und Personenregister}

Die Abkürzungen folgen dem Abkürzungsverzeichnis im Lexikon des Mittelalters, Bd. 1 S. XVII-XXI mit Ausnahme von abg. = abgegangen, Fam.= Familie, KB = Kardinalbischof, $\mathrm{KD}=$ Kardinaldiakon, $\mathrm{KP}=$ Kardinalpriester, Kl. = Kloster, Stift, L. = Legat, O. = Ort, S. = Saint, Sankt, San, Sant', Santo, Santa, SS. = Sante, Santi, Santissima, Santissimo, Terr. = Region, Landschaft, Herrschaftsgebiet.

Italienische Ortsnamen wurden bis auf gängige deutsche Ortsbezeichnungen wie Rom, Florenz, Mailand, Venedig, Genua etc. beibehalten. Personen wurden soweit wie möglich unter ihrer deutschen Namensform eingeordnet, Gottesnamen wurden nicht aufgenommen. Sofern ein Name nur in einer Anmerkung erscheint, wurde dies eigens ausgewiesen.

Abaelard(us) 338

Abruzzen (Abruzzo), Terr. 109-111, 113, $115 \mathrm{f} ., 119 \mathrm{f} ., 125,130,573$, 606

Acacio, Heiliger 74

Acerenza, Ebm. 98, 100, 117, 122, 128, 265, 409

Acquafredda di Lenno, Kl. $\quad 528$ Anm. 52

Acquapendente, O. 624, 650, 655

- S. Sepolcro, Ki. 650

Acquatetta, O. 118

Acquaviva Colle di Croce, O. 605

- S. Angelo del Palazzo, Kl. 605, 613

Acqui, O. 149,166

- S. Margarita, Kommende 656

Acqui-Alexandria, Bm. 167 Anm. 137

Acri, O. 604-606, 613

Adalbert, Ebf. von Magdeburg (Adalbert von Trier) 90, $94 \mathrm{f}, 103$

Adalbert, Bf. von Metz 308

Adalbert, Bf. von Prag, Heiliger 80

Adalbert, Kg. von Italien 97

Adaldag, Ebf. von Hamburg-Bremen 90

Adelardo, KP von S. Marcello 146

Adhemar von Le Puy, L. $\quad 615,634$

Adria, O. 615

Adriano, siehe Hadrian

Aecae, O. 110 Anm. 9, 115

Aegidius von Toucy (Gilo von Toucey), KB von Tusculum 337
Afrika 22 f., 64

Agapit (Agapet) I., P. 41 Anm. 5, 50

Anm. 37, 57 f., 60, 282

Agapit II., P. 308, 444

Agatha, Heilige 376

Agimendus (Agimondo), Presbyter 80

Agira, O. 622-624, 628, 650

Agira, S. Philippi, Kl. 628

Agnes, Heilige 589

Agostino, siehe Augustinus

Agrigento, O. 122, 621 f., 628, 642, 665

Agropoli, O. 110 Anm. 9

Ägypten 45

Aicardo von Ivrea, Subdiakon 166, 172 Anm. 155, 173 Anm. 159, 174 Anm. 164

Aicardo von Burolo, Magister 164 Anm. 127

Akakios, Patriarch von Konstantinopel $45 \mathrm{f} ., 48,52$

Akkon, O. $\quad 335,617,622,624,629 \mathrm{f}$. , 652

Alba, O. 149

Albano, O. 146

Alberich (Alberico), Princeps von Rom 308

Alberich (Alberico) von Montecassino 565-567

Albert, KP von S. Sabina 356

Albert (Alberto) von Somma, Subdiakon 162 
Albert (Alberto), Ebf. von Tarent 122 Anm. 80, $411 \mathrm{f}$.

Albert, Bf. von Montecorvino 123

Albert, Templermeister der Lombardei 659

Albert von Morra, siehe Gregor VIII., P.

Alberto Amicone, Kanoniker, Subdiakon 164 Anm. 127, 168, 170 Anm. 151

Albi, Saint-Salvy, Ki. 442

Albinus, KD von S. Maria Nuova 31, 244,342

Alderich (Alderico) von Padua (Padova), Abt 161 Anm. 111

Aleramo, Mgf. von Monteferrato 525

Alesa, Bm. 111 Anm. 11

Alexander (Alessandro, Alexandre) II., P. $\quad 117,122,204$ Anm. 53, 207 Anm. 67, 264, 287, 289, 293-295, $413,445,560,563$

Alexander (Alessandro, Alexandre) III. (Rolando Bandinelli), P. 119, 123 Anm. 88, 136, 140, 142-143, 145, 146 Anm. 47, 147-149, 151-156, $161-163,173,192,196,197$

Anm. 33, 200 Anm. 40, 203, 204

Anm. 53, 206, 210, 223, 265, 320$322,338-340,352,354,360,364$, 415, 429, 431-433, 439-442, 447, 539 f., 541 Anm. 128, 543, 549 f., 553, 570 f., 599, 612, 620, 623-625, 628, 631, 642, 651, 655 Anm. 189, 656 Anm. 198, 657 Anm. 208, 660662,684

Alexander IV., P. 223, 229, 325, 435

Alexander (Alessandro) VI. (Rodrigo Borgia), P. 612

Alexander der Große, Kg. von Makedonien (Macedonia) 72

Alexandria, O. und Patriarchat 43, 46, 54, 77, 145 Anm. 42, 149 f., 163, 175 Anm. 165

Alexios I. Komnenos, byz. Ks. 665

Alexius, KP von S. Susanna 160 Anm. 108, 167 Anm. 138, 172 Anm. 158, $363 \mathrm{f}$.

Alfan II., Ebf. von Salerno 122

Alferius, Subdiakon $412 \mathrm{f}$.

Alfred der Große, Kg. von Wessex und Angelsachsen 289
Algisius von Pirovano, L. 156

Aligerno, Abt von S. Nilo 77

Alpen 70, 525

Alta Comba, siehe Hautecombe

Altavilla Silentina, S. Lorenzo, Ki. Anm. 72

Amadeus (Amedeo) III., Gf. von Moriana Savoia 533 Anm. 84

Amalfi, O. und Hzm. 21, 23, 96, 113, $115-117,119,269$ f., 630

Amiternum, O. 110 Anm. 6

Anacleto, siehe Anaklet

Anagni, O. 325, 369, 431, 449

Anaklet (Anacleto) II., P. 190 Anm. 20, 194, 337, 419 Anm. 15, 526, 527 Anm. 45, 534 f., 537, $598 \mathrm{f} ., 678,683$

Anastasio Bibliotecario, siehe Anastasius Bibliothecarius

Anastasios, byz. Ks. 50 Anm. 38

Anastasius I., P., Heiliger 301, 305, 306 Anm. 28, 307

Anastasius IV., P. 204 Anm. 53, 205 Anm. 59, 319, Anm. 19, 353, 536, 538, 540, 548

Anastasius Bibliothecarius (Anastasio Bibliotecario) $\quad 73-75,81,83,677$

Ancona, O. 142 Anm. 27, 629

Andreas von Viterbo, Notar und Richter 661

Andreas, Mönch von Gorze $308 \mathrm{f}$.

Andria, O. und Bm. 118

Angilberga, Kgn. und Ksn. 269 f.

Angiò, siehe Anjou

Angleterre, siehe England

Anglona, Terr. 128

Anna Porphyrogenneta, Schwester des Ks. Basileios II. 106

Annibaldi, röm. Fam. 371

Annifo, Terr. $\quad 571 \mathrm{f}$.

Anselm, Ebf. von Canterbury 358

Anselm IV., Ebf. von Mailand 634, 636, 645

Anselm V. von Pusterla, Ebf. von Mailand 528

Anselm II., Bf. von Lucca 285

Anselm von Laon, Magister 314

Anselm von St. Viktor, Kanoniker 321

Ansger, Bf. von Catania 122, 200 Anm. 43 
Anthimus I., Patriarch von Konstantinopel 58

Antiochia, O. $\quad 43,54,97,428,616$, 625, $629 \mathrm{f} .$, 632, 634, 639, $644 \mathrm{f}$.

Antivari, O. $\quad 420,421$ Anm. 21, 429 f., 443, 447

Antonius, Heiliger 77

Apenninen 560

Apt, Saint-Eusèbe, Kl. 442

Apulien (Puglia, Pouille), Terr. 96$100,109,115,117-119,122,123$ Anm. 88, 125, 403, 407-410, 412, 621, 637, 652, 662, 682, 687

Apulien-Kalabrien, Terr. 115

Aquileja, O. und Ebm. 26, 64, 94, 141, 216 Anm. 6, 244 Anm. 142, 271,427

Aragón, Terr. 242

Archivum Arcis, siehe Rom, Castel S. Angelo

Arditio (Ardizzo) Rivoltella, Kardinallegat $144,151,153,156,160,161$ Anm. 111

Arditio (Ardizzo), KD von S. Teodore 154,157

Arduin, Bf. von Piacenza 528

Arduin, Subdiakon 150, 175 Anm. 165

Arezzo, O. 366

Ariano Irpino, Bm. 615, 646

Ariprando Visconti, Bf. von Vercelli, L. $163,165,167$

Arnaud, Ebf. von Acerenza 122

Arnulf, Bf. von Lisieux $359 \mathrm{f}$.

Arnulf, Bf. von Martirano 646

Arnuf, Bf. von Mileto 198 Anm. 37

Arpi, O. 113

Ascoli Piceno, O. $\quad 587,600$

Ascoli Satriano, O. 99, 112

Assisi, O. $\quad 573,587,657$

Asti, O. $\quad 142,149,597,656 \mathrm{f}$.

Atanasio, siehe Athanasius

Atella, O. 110 Anm. 9

Athanasius II., Bf. von Neapel 24

Athanasius (Atanasio) I., Dux von Neapel 70

Athanasius (Atanasio) II., Dux von Neapel $70 \mathrm{f}$.

Athos, Terr. und Kl. 79

Atri, Bm. 119
Atto, Stifter von S. Stefano di Gallano 570

Aufidena, O. 110 Anm. 9

Augustinus (Agostino) von Canterbury, Heiliger 127, 577

Aulps, Kl. 432

Autun, Bm. 441

Aversa, O. 119, 296, 635

Avignon, O. 442, 609

Ayraldus, Bf. von Genua 635

Azo von S. Paolo fuori le mura 632

Azzo, KP von S. Anastasia 144, 178 f.

Bagnara, Terr. 572

Bagno, Berg 561 Anm. 20

Bailaradus, Ebf. von Oria-Brindisi (Brindisi-Oria) 123

Balduin I., Kg. von Jerusalem $\quad 615,635$

Balduin II., Kg. von Jerusalem 636

Balkan, Terr. 127

Bamberg, Bm. 353

Banzi, S. Maria, Kl. 265, 145 Anm. 42

Barcelona, O. 352, 561 Anm. 20, 642

Bardas Phokas, Dux von Antiochia 106

Bari, O. 114, 117-119, 121, 128, $597,639,645,657,662$

- S. Nicola, Ki. 630, $636 \mathrm{f}$.

Barletta, O. $\quad 118,407,600,619$ Anm. 19, 621 f., 651-653, 655657, $662 \mathrm{f}$.

- S. Samuel, Kl. 621

Barnwell, Kl. 439

Baronius, Caesarius 429

Basil, Heiliger 125

Basileios II, byz. Ks. 106

Basilikata (Lucanien), Terr. 96, 99, 109, 112, 118, 128, 242, 403, 408, 519, 599, 604, 652

Baudry von Gallipoli, Prälat 122 Anm. 80

Baybars, Sultan von Ägypten und Syrien 621

Beatrix, Äbt. von Quedlinburg 366 f.

Beatrix, Mgfn. von Tuszien 271

Beirut, O. 430, 446, 627, 637, 664, 666

Belcastro, Bm. 115, 118

Belisar, byz. Feldherr 58

Benedikt IV., P. $\quad 381,384$

Benedikt (Benoît) VIII., P. 113 
Benedikt (Benoît) IX., P. 113

Benedikt (Benedetto, Benoît) XII., P. 435

Benedikt XIV., P. 435

Benedikt (Benedetto) von Aniane 559

Benedikt (Benedetto) von Nursia, Abt und Heiliger $77,78,522,525,541$, $552,559,567,571,574,588$

Anm. 137

Benedikt, KP von S. Pudenziana, L. 352

Benevent, O. 27 f., 31, 35 f., 39, 91, 96, 98-100, 102-105, 107-109, 114, 116-119, 123 f., 130, 145, 320, 346, 597, 632, 678

Benno von S. Pietro di Cerreto, Stifter 530

Beno, KP 356

Benoît, siehe Benedikt

Berardus (Bérard), Bf. von Marses 123

Berardus (Berardo), Prior von Belliccione 552

Berardus (Berardo), Stifter von S. Stefano $\quad 570$

Berardus (Bérard) von Otranto, Prälat 122 Anm. 80

Bergamo, S. Vincenzo, Ki. 162

- Terr. 149, 153 Anm. 83, 164 Anm. 127, 166, 168

Berkeley, O. 277

Berlin, O. 4, 13, 236 f., 248 f., 417, 665

- Kaiser-Wilhelm-Institut für deutsche Geschichte 246

- Preußische Akademie der Wissenschaften 228

Bernard, siehe Bernhard

Bernardo Paganelli, siehe Eugen III., P.

Bernardus, siehe Bernhard

Berneredus, KB von Tusculum 360

Bernhard (Bernardus, Bernard) von Chiaravalle, siehe Bernhard von Clairvaux

Bernhard (Bernardus, Bernard), Prior, KP von $\mathrm{S}$. Clemente, $\mathrm{KB}$ von Porto 339, 352

Bernhard (Bernardus, Bernard), Bf. von Carinola 123

Bernhard (Bernardus, Bernard), Kleriker 412, 413
Bernhard (Bernardus, Bernard) von Clairvaux, Heiliger (Bernhard von Chiaravalle) $126,138,142,154$, $316,319,337,350,358,519,527$ Anm. 45, 528, 531, 534, 536 Anm. 101, 538, 552, 596, 598 f., 615,683

Berno von Baume, Abt von Cluny 559

Besançon, Ebm. 440

- Saint-Étienne, Ki. $441 \mathrm{f}$.

- Saint-Jean-l'Évangeliste, Ki. 441

Bethanien, S. Lazarus, Kl. 621

Bethlehem, O. 621, 630, 646

Bethmann, Ludwig, Gelehrter $226 \mathrm{f}$.

Betton-en-Maurienne, Kl. 432

Beverlery, O. 440

Biagio, Abt von Fiastra 552

Biccari, O. 111

Bicester, S. Edburga, Ki. 439

Biella, S. Stefano, Ki. 437

Bisaccia, O. 115

Bisanzio, siehe Byzanz

Bisignano, Bm. 100, 119

- S. Maria de Sambucino, Kl. 198 Anm. 37, 199 Anm. 38, 204

Anm. 53, 210, 211 Anm. 84

Bitetto, Bm. 115, 118

Bitonto, Bm. 115, 118

Blois, O. 433

Bock, Friedrich, Gelehrter 8 Anm. 22

Boemund, siehe Bohemund

Boethius 52 Anm. 46

Bohemund (Boemund) I., Fs. von Antiochia $412,428,616,630,634$, $639 \mathrm{f} ., 643,645$

Bohemund II., Fs. von Antiochia 428

Böhmen, Terr. 92, 101, 421, 441

Böhmer, Johann Friedrich, Gelehrter 231

Bojano, O. 112, 115

Boleslaw, Chrobry, Fs. 107

Bologna, O. 156, 163, 168, 172, 343, 416, 427, 602, 621, $637 \mathrm{f}$.

- S. Maria de Reno, Ki. 144, 416

Bonifaz (Bonifacio) VIII., P. 399 Anm. 38, 435, 440, 444, 456 Anm. b, 478 Anm. a, 588 Anm. 137, 605 f.

Bonifaz (Bonifacio) IX., P. 435, 437, 444

Bonifaz (Bonifacius), Diakon $412 \mathrm{f}$. 
Bonifaz (Bonifatius), Templermeister der Lombardei 659

Bonifaz (Bonifacio, Bonifatius), Missionar 95, 264, 304 Anm. 20

Bonifaz (Bonifacio), Gf. von Vasto 533

Bonnevaux, O. $\quad 442,524 \mathrm{f}$.

- S. Maria, Kl. 525 Anm. 37

Borgogna, siehe Burgund

Boris I., bulgarischer Fs. 89, 105

Bosco Marengo, O. 145 Anm. 42

Bosco, O. 525

Boso, KP von S. Anastasia, Kardinallegat 353,357

Boso von Lucca, KD von SS. Cosma e Damiano, päpstl. Kanzler und Kämmerer 339, 391

Bourges, O. 156

Bourg-lès-Valence, O. 445

Bova, Bm. 115, 120

Bovino, O. 99

Brackmann, Albert, Gelehrter $\quad$ 236, 247

Braga, O. $\quad 443,478$ Anm. a

Brancaleone, Senator von Rom

Brandi, Karl, Gelehrter $243 \mathrm{f}$.

325

Brescia, O. 142, 151, 163

- S. Giovanni Evangelista, Ki. 155, 156 Anm. 91

Breßlau, Harry 9 Anm. 28, 227 Anm. 57

Brettino, Kl. 577

Brindisi, O. und Bm. 99, 114, 117, 408, 428, 602, 651, 659

Brindisi-Oria, siehe Oria-Brindisi

Bruco, Stifter von S. Stefano di Gallano 570

Brun I., Ebf. von Köln 89, 104

Brun von Querfurt, Missionsbf. 106 Anm. 107

Bruno, Bf. von Segni $\quad 334,644$ Anm. 129

Bruno, Abt von Chiaravalle Milanese $530 \mathrm{f}$., 551

Bruno, Mönch 210 Anm. 80

Bucco, Hzg. von Nocera (Lupo) 571

Buglioni, Hzg. 648

Bulgarien 89, 91, 98

Burgos, Bm. $432 \mathrm{f}$.

Burgund (Borgogna), Terr. 141 f., 318, 524

Byblos, O. 625-628, 630
Byzanz (Bisanzio), siehe auch Konstantinopel 21, 23, 26, 29-31, 40$42,50,52-55,58,60,62,64,69$, $71,74-76,80-83,87-89,98 \mathrm{f}$, 109, 306, 645, $676 \mathrm{f.}, 689$

Cadalus von Parma, siehe Honorius II., P.

Caecilia (Cecilia), Heilige $\quad 303,375 \mathrm{f}$.

Caen, Saint-Étienne, Kl. 436, 442

Caffaro, Stadtchronist von Genua 630, 635,644

Cagliari, O. 266

Calabria, Calabre, siehe Kalabrien

Caledonia, Heilige 586

Cales, O. 115

Calixt (Callisto) II., P. $123,141,142$ Anm. 22, 194, 198 Anm. 37, 203, 204 Anm. 53, 207 f., 211, 337, 368, 429, 432, 441, 485 f., 489-492, 497-499, 501, 522, 524 f., 534, 540 f., 545, 635 f., 646, 649, 651, 661, 663 Anm. 243

Calixt (Callisto) III., P. 661

Caltanissetta, S. Spirito, Kl. 628

Calvi, Bm. 114

Camaldoli, Kl. 562

Cambridge, O. 437

Camerino, O. 531, 561 Anm. 19, 571, 574 f., 585

Campania, Campanie, siehe Kampanien

Campi, O. 566 Anm. 40

Campobasso, O. 112

Canigou, Berg 561 Anm. 20

Canosa di Puglia, Bm. 110 Anm. 9, $115,117,662$

Canterbury, Ebm. 416, 439

Capitanata, O. 117, 119, 128, 656

Capocci, röm. Fam. 160 Anm. 108

Capodacqua, O. 566 Anm. 40

Capodistria (Koper), Bm. 427

Capoue, siehe Capua

Capri, Insel 117

Capua (Capoue), Ebm. und Fsm. 28 f., 31, 96, 99 f., 102, 104 f., $107-$ 109, 114-116, 268-270, 655-657, 663

- Johanniter-Priorat $\quad 600,653,655 \mathrm{f}$, 659 
Carbone, O. 112, 126

Cariati, S. Pietro, Ki. 210, 211 Anm. 84

Carini, Bm. 111 Anm. 11

Carlisle, Bm. 440

Carlo, siehe Karl

Carmeianum, frühchristl. Bm. abg. Anm. 9, 115

Carpineto, S. Bartholomäus, Kl. $112 \mathrm{f}$.

Carrara, S. Andrea, Ki. 205 Anm. 59

Casale Monferrato (Casale Sant'Evasio), O. 141 Anm. 21, 142 Anm. 22

Casamari, O. $539-541,550 \mathrm{f}$.

- S. Giovanni e Paolo, Kl. 540

Casanova, O. 535

- S. Maria, Kl. 516 Anm. 4, 521 Anm. 23

Casauria, S. Clemente, Ki. und Kl. 114,125

Cascia, O. 587, 588 Anm. 137

Caspar, Erich, Gelehrter 237, 248, $266 \mathrm{f}$.

Cassano allo Jonio, Bm. 112, 199

Cassiano, O. 561

Castañeda, O. 439

Castellaneta, Bm. 118

Castello di Gallano, O. 570

Castro, Bm. 115, 127, 568, 586 Anm. 128

Catania (Catane), O. 112, 116, 120, $126,268,610,623 \mathrm{f}$.

Caudium, frühchristl. Bm. abg. 110 Anm. 9

Cava de Tirreni, O. 621

Cava, Kl. 114, 126, 407

Cayphas, O. 629

Cecilia, siehe Caecilia

Cefalù, Bm. 120, 126, 607, 610

Celestino, siehe Coelestin

Cencelle, O. 606

Cencius (Centius), Notar 531, $551 \mathrm{f}$.

Cencius (Centius), päpstl. Kämmerer, KP von SS. Giovanni e Paolo, siehe Honorius III., P.

Ceprano, O. 655

Cerenzia, Bm. 115

Cerreto, Kl. 154

- S. Pietro, Kl. 530, 535, 540, 544, 545,549

Chaise-Dieu, Kl. 430
Chalkedon, Bm. $\quad 44-46,48-50,59$, $61,66,104,676$

Chalon-sur-Saône, O. 159 Anm. 104

Chartres, Bm. 292 f., 323, 327, 426

- Saint-André, Kl. 146 Anm. 47

Chelles, Kl. 322

Chiara, siehe Clara

Chiaravalle della Colomba, Kl. 519, 528, 533 Anm. 87, 535, 541 f., 551 Anm. 172

Chiaravalle di Castagnola presso Ancona, Kl. $\quad 551$ Anm. 172

Chiaravalle di Fiastra (S. Maria Chiaravalle di Fiastra), Kl. $\quad 520,531 \mathrm{f}$, 535, 544, 551-553

Chiaravalle Milanese, Kl. 519 f., 528, $530-532,535,540,544,551,553$

Chienti, Fluss 531

Chieti, Bm. 120

Chiusa, S. Vittore, Kl. 575 f.

Christophorus, P. 381, 384

Cirella, Bm. 110 Anm. 9

Ciriaco, siehe Zyriakus

Cirillo, siehe Kyrill

Cisterna, Bm. 111

Cîteaux, Kl. $\quad$ 515, 518 f., 522, 525 Anm. 37, 526, 528 f., 535, 538, 540 f., 545, 547 f., 550, 551 Anm. 172, $552 \mathrm{f}$.

Città di Castello, Bm. 564, 575

Clairvaux, Kl. 340, 519 Anm. 14, 527 f., 532, 535 f., 538, 544, 548, 551,553

Clara (Chiara), Heilige 589

Classe, O. 94, 104

Clemens (Clemente) I., P. 74

Clemens (Clemente) (III.) (Paolo Scolari), P. $146,158,164$ Anm. 127, 187, 198, 200, 206, 223, 343, 365, 427, 429, 431, 439, $441 \mathrm{f} ., 619,634$ Anm. 89, 642 f., 645-647, 649, 654 Anm. 183, 666

Clemens (Clemente) III. (Wibert von Ravenna), P. 271, 356, 368, 420, 421 Anm. 21, 428 f., 447

Clemens (Clemente) IV., P. 347 Anm. 45, 370 f., 605

Clemens (Clemente) V., P. $\quad 603,606$, 662

Clemens VII., P. 626 
Clerkenwell, Kl. 446

Clermont, O. $\quad 445,615,633,637$ f., $644 \mathrm{f} ., 648 \mathrm{f}$.

Cluny, Kl. 126 Anm. 99, 141 Anm. 21, 307 f., 315 f., 336 f., 352, 368, 489, 492, 497, 499 f., 504, 559

Coelestin (Celestino) II., P. 532, 651

Coelestin (Celestino) III. (Hyazinth, KD von S. Maria in Cosmedin), P. 159 Anm. 102, 162, 164 Anm. 127, 165 f., 167 Anm. 138, 175

Anm. 165, 219, 236, 353, 367, 619, 624, 626, 629, 637, 641, 643

Anm. 127, 647, 651 f., 655, 657, 664

Colfornaro, O. 566 Anm. 40

Collalto, Berg 531

Collepardo, O. 568

Comer See, siehe Lario

Como, O. und Bm. 141, 148, 150, 153, 528 Anm. 52

Conflent, Gft. 561 Anm. 20

Constantinopoli, Constantinople, siehe Konstantinopel

Conversano, Gft. 113

Conza, O. und Bm. 100, 114, 117

Corato, frühchristl. Bm. abg. 118

Coronate, O. 528

Corrado von Rovellone 577

Cosenza, Bm. 100, 120, 657

Costanza, O. 153

Cozza-Luzi, Guiseppe, Leiter der Vatikanischen Bibliothek 410

Cremona, Bm. 142, 149, 153 Anm. 83, 163

Crescenzago, Kl. 154

Cresconius Africanus, Theologe 280, 283

Crivellucci, Amedeo 116 Anm. 42

Crotone, Bm. 115

Cubulteria, frühschristl. Bm. abg. 110 Anm. 9

Cucullo, O. 565

Cuozzo, Ericco 112

Cyprian, Bf. von Karthago 288

Cyrillo, siehe Kyrill

Dacien, Terr. 279

Daimbert, Bf. von Pisa, Patriarch von Jerusalem 288, 633, $644 \mathrm{f.,} 649$
Dalmatien, Terr. 420 f., 426-429, 443, 644

Damasus, P. $\quad 377,378,386$

Daniel Stylites (Daniele lo Stilita), Heiliger 583

Decentius von Gubbio 279

Desiderius, Abt von Montecassino 30

Desiderius (Desiderio), langob. Kg. $\quad 580$

Deusdedit, KP von S. Pietro in Vincoli 31, 264, 285, 287 f., 293, 335

Deusdedit, KP von S. Lorenzo in Damaso $\quad 357$

Deutschland 4, 6, 227, 228 Anm. 63, $233,235,248,250,271,333,339$, $346,349,352-355,367,369,424$, 433,642

Diego Gelmirez, Bf./Ebf. von Compostela 357

Dietwin, KB von S. Rufina 353

Dijon (Digione), O. 314, 518, 581

Dijon (Digione), Saint-Benigne, Kl. $\quad 581$

Dionysius (Dionisio), Abt 566

Dionysius (Dionigi), Heiliger 74

Dionysius Areopagita (Pseudo-Dionysius), Heiliger 74

Dionysius Exiguus, Kanonist, Geschichtsschreiber $280 \mathrm{f}$.

Dobrava, böhm. Prinzessin 92

Dominikus (Dominico), Abt von Sora (Dominikus von Foligno) 565568, 573, 586, 590

Domora, S. Michele (S. Eustachio) 585

Dondeo von Plazano, Adeliger 535

Drogo, Abt von Saint-Jean in Laon 337

Drogon von Tarent, Prälat 122 Anm. 80

Dublin, O. 439

- S. John's, Ki. 439

- S. Mary's, Ki. 439, 446

Dubrovnik, O. 429

Dunfermline, Lindores, Kl. 436, 439 f.

Eberhard I., Ebf. von Salzburg 362

Ebremar, Ebf. von Caesarea 636

Einhart (Eginardo), Geschichtsschreiber 304 
Ekkehard IV. von S. Gallen, Geschichtsschreiber 30 Anm. 56

Eleonore von Aquitanien, Kgn. von Frankreich und England 320

Ely, Bm. 439

England (Inghilterra, Angleterre) 33, $116,162,175,188,227,228$

Anm. 63, 233, 235, 271, 289, 318, 345 f., 349, 354 f., 360 f., 365, $438-$ 440, 442-444, 642, 649

Enrico, siehe Heinrich

Entremont, Ki. 432

Ephesus, O. 45

Ermanno, siehe Herrmann

Ernisius, Abt von St. Viktor

321

Étienne, siehe Stephan

Etrurien, Terr. 268, 271

Eudes, siehe Odo

Eugen (Eugenio, Eugène) III. (Bernardo Paganelli), P. 136 Anm. 2, 140, 142, 161 Anm. 111, 197 Anm. 33, 199 Anm. 38, 204 f., 207, 210-213, 318 f., 339, 366 f., 430-432, 439, $442 \mathrm{f} ., 532,534-536,538-542$, 544-548, 550 f., 554, 598 f., 619, 624, 625 Anm. 49, 637, 639, 642, 646, $650 \mathrm{f} ., 660$

Eusebius, Bf. von Caesarea 44

Eustach II., Gf. von Boulogne 615

Eutizius, Heiliger 566 Anm. 40

Évreux, Bm. 442

Ewald, Paul, Gelehrter 267, 291, 295, 419 Anm. 15

Fabriano, O. 586

Faleri, S. Maria, Kl. 541-543

Farabasiliana, O. 535

Farfa, Kl. 17, 272, 560 Anm. 18, 583

Farleigh, Kl. 440

Federico, siehe Friedrich

Felice, Feliciano, siehe Felix

Felicitas, Heilige 304

Felix III., P. 46-48, 49 Anm. 35

Felix (Felice, Feliciano) von Narco, Heiliger $566,569,579$

Ferdinand (Ferdinando) II., Kg. von Aragón (Ferdinand der Katholische, Ferdinando il Cattolico) 612

Fermo, Kommende $655 \mathrm{f}$.

Ferrara, O. 409, 457 Anm. h
Ficker, Julius, Gelehrter 408

Figarolo, S. Salvatoris, Ki. 437

Filippo, Ebf. von Lampugnano 165 , 167 f., 170, 171 Anm. 154, 173

Fiorentino, Bm. 115

Florenz (Firenze, Florence), O. 171, 562, 564, 575, 629, 634, 637

- S. Donato a Torri, Kl. 634

- S. Miniato, Ki. 564

Foggia, Bm. 119, 407, 656

Foligno, O. und Gft. 204 Anm. 53, 566, 569-571, 573 f., 584, 586, $590 \mathrm{f}$.

- S. Angelo de Gruttis, Kl. 584

Fondi, Bm. 110

Fonte Avellana, Kl. 197 Anm. 33, 204 Anm. 53, 333, 562, 683

Fontebuono, Hospital 562

Fontevivo, Kl. 528 Anm. 53, 541

Forcone, Bm. 120

Formiae, O. abg. 110 Anm. 9, 115

Formosus, P. $\quad 75,381-383,386$ Anm. 53

Fortunato, Giustino 408

Forum Popilii, O. abg. 110 Anm. 9, 115

Fossanova, S. Stefano, Kl. 367, 519, 536-539, 549

Frankreich (Francia, France) 6, 141 f., $160,175,188,227,233,235,248$, 254, 271, 287, 304, 314, 317, 326, 333 f., 339, 345 f., 348 f., 352, $354-$ 356, $359 \mathrm{f},, 370,419,424,426,430$, 432 f., 438, 442 f., 530, 548, 559, 609, 615, 634f., 637-640, 643, 645, 647, 649, 651, 666, 688 Anm. 16, 689

Franziskus von Assisi, Heiliger 572, 587, 589, 590

Frensdorff, Ferdinand 234 Anm. 93, 236 Anm. 101

Freudenberg, siehe Mons Gaudii

Friedrich (Federico) I. (Friedrich Barbarossa), dt. Kg. ., Ks. 32, 136, 143 f., 147-149, 151, 154, 156, 163, 173,369

Friedrich (Federico) II., dt. Kg., Ks. 122,124 f., 407 Anm. 9, 601-603, 612, 622 
Friedrich (Federico) von Sanseverino, KD von S. Teodoro 612

Frohse, S. Ciriaco, Kl. 306

Frosinone, O. 109

Fruttuaria, Kl. 559 Anm. 14

Fulgentius Ferrandus, Diakon der Kirche von Karthago 283

Gaeta (Gaète), Terr. 21, 96, 109 f., 270

Galdin von Sala, KB von Mailand 135, 136 Anm. 2, 145, 147-156, 161 f., 164,170

Gallano, S. Stefano, Kl. 569 f.

Gallien, Terr. 64, 279

Gallinaria, S. Maria und S. Martino, Kl. 196, 197 Anm. 33, 206

Gallipoli, O. 113 Anm. 18, 127, 129

Galterus (Gautier), Bf. von Laon 315, 317

Gandersheim, O. und Kl. 305 f., 444

Gap, Bm. 442

Gaufried, Abt von Fossanova 634

Gauthier Ophamil, Ebf. von Palermo 123

Gauthier von Palearia, Bf. von Troia 122

Gautier, siehe Galterus

Gelasius I., P. 50 Anm. 38, 51 Anm. 41, 264, 280 Anm. 31, 282, 285 f., 287 Anm. 64, 288

Gelasius II., P. 197 Anm. 33, 351, 368

Gênes, siehe Genua

Genga, O. $\quad 575$

Genova, siehe Genua

Gentile da Montefiore, L. 347

Genua (Ianuensis, Genova, Gênes), O. und $\mathrm{Bm} . \quad 31,158,187,190$ Anm. 20, 192, 197 Anm. 33, 200 f., 203, 206, 527, 621, 625, $630 \mathrm{f}$. , $635 \mathrm{f} ., 644-647,649,651,657$

- S. Fidis, Ki. 657

- S. Stefan, Kl. 187, 203 Anm. 52

Geoffroy Malaterra, Mönch von SaintEvroul, S. Trinità in Venosa, S. Eufemia, S. Trinità in Mileto 122

Georges, Patrizier von Tarent 127

Georgius Synkellos (Giorgio Sincello), Chronist 74

Gerald, KB von Ostia 348

Gerald, Bf. von Mileto 198 Anm. 37
Gerhard (Gerardo), KP von S. Croce, siehe Lucius II., P.

Gerhard, KD von S. Adriano 355

Gerhard, Ebf. von Ravenna 634

Gerhard (Gerardo), Bf. von Bologna 161 Anm. 111

Gerhard (Gerard), Bf. von Clermont 646

Gerhard (Gerardus) Pucella, Magister 354

Gerhard (Gherardo), Mönch 576

Gerhoch von Reichersberg, Propst 361

Gerland, Bf. von Agrigent 122

Gernrode, Kl. 306

Gero I., Mgf. von Sachsen 306

Gerusalemme, siehe Jerusalem

Gherardo, siehe Gerhard

Giacinto, siehe Hyazinth

Giacomo Guainerio, Hzg. von Spoleto 551

Giacomo Sicco 165 f.

Gilbert, Bf. von Poitiers 319

Gilbert Foliot, Bf. von London 354, 360

Gilbert von Sempringham, Heiliger und Ordensgründer 354

Gilo von Toucey, siehe Aegidius von Toucey

Giorgio Sincello, siehe Georgius Synkellos

Giovanni, siehe Johannes

Giovanni Damasceno, siehe Johannes Damaskenos

Giovanni Immonide, siehe Johannes Diaconus

Giovenale, siehe Juvenal

Giovinazzo, O. 112

- S. Giovanni Battista, Kl. Anm. 71

Girolamo, Theologe $\quad 560$

Gisors, O. 354

Giudice, Giuseppe del, Mitarbeiter des Staatsarchiv Neapels und Gelehrter 408

Glanfeuil, Saint-Maur-sur-Loire, Kl. 422 Anm. 27, 430, 433

Gnesen (Gniezno), Ebm. 105, $107 \mathrm{f}$.

Godino Brun, siehe Godinus

Godinus, Ebf. von Brindisi (Godino Brun) $\quad 411 \mathrm{f}$. 
Goizo, KP von S. Prassede 351

Goizone, KP von S. Cecilia 144

Goleto, O. 126

Gorze, Kl. 308

Goslar, O. 248

Gottfried, Abt von Vendôme 359

Gottfried von Bouillon, Hzg. von Niederlothringen $337,615,635,649$

Göttingen, O. 4, 9, 233, 237 Anm. 111, 248, 416, 420 Anm. 16, 428

- Akademie der Wissenschaften 12, 111, 215 f., 219 Anm. 18, 228 Anm. 63, $251 \mathrm{f}$.

- Königliche Gesellschaft der Wissenschaften $3 \mathrm{f} ., 6,10,217 \mathrm{f} ., 223$, 230, 234, 235 Anm. 99, 236, 246, 248 f., 331, 416 Anm. 3, 418

Gozvino, Abt von Cîteaux 538

Grado, O. 26, 141, 216 Anm. 6, 271, 427

Gran, Ebm. 107 f.

Gratian (Graziano), KP von SS. Cosma und Damiano 158

Gratian (Graziano), Kanonist 255, $275-277,285,289,297,317,341$, 545

Gravina, Bm. 98, 124, 128

Great Malvern, Kl.. 439

Gregor (Gregor der Große) I. (Gregorio Magno), P. 21, 26, 62, 64-66, 75 f., 105, 114, 221 Anm. 24, 263, 265, 267-272, 282-284, 286

Anm. 57, 300-303, 309, 390, 443, 578,680

Gregor (Gregorio) II., P. 373

Gregor (Gregorio) III., P. $\quad 70,373$

Gregor (Gregorio) IV., P. 81, 284

Gregor (Gregorio) VII. (Hildebrand, Il-

debrando), P. $\quad 30,121,159$

Anm. 104, 168, 193, 197, 198

Anm. 37, 203, 266, 272 f., 289,

295 f., 300, 301 Anm. 6, 308, 335, 342, 347, 360, 365 Anm. 120, 391, 429, 437, 446, 560, 689

Gregor (Gregorio) VIII., P. 168, 342, 347, 360, 365 Anm. 120, 441

Anm. 100, 446, 646, 649
Gregor (Gregorio) IX., P. 173

Anm. 161, 275 f., 347, 355, 370, 433, 441 Anm. 100, 443

Gregor X., P. 435

Gregor (Gregorio) XI., P. 609 f.

Gregor XII., P. 435

Gregor, KP von S. Grisogono 282, 336

Gregor de Crescentio, KP von S. Vitale 368

Gregor Asbestas, Ebf. von Syrakus 22

Gregor (Gregorio), Bf. von Tours, Geschichtsschreiber 302

Gregor (Gregorio), Abt von Casamari 541 Anm. 128

Grijó, O. 439

Grottaferrata, S. Nilo, Kl. 559 Anm. 14

Grottafucile, Einsiedelei 577

Grumentum, frühchristl. Bm. abg. Anm. 9

Guala Bicchieri, KP von S. Martino 346

Guala, Bf. von Bergamo 164 Anm. 127

Gualdo Tadino, O. 586

- S. Maria, Kl. 126

Gualterio, Ebf. von Palermo 200

Guarcino, O. 567 Anm. 46, 568

Guardialfiera, Bm. 115

Guarinus (Guarino), KB von Preneste 144

Guarinus (Guarino), Abt von Conflent 561 Anm. 20

Guarinus (Guarino), Abt von St. Viktor 363

Guarnerio, Hzg. von Spoleto, Mgf. von Ancona 531, 535

Gubbio, Bm. 197 Anm. 33, 204 Anm. 53, 561 Anm. 19, 562 f., 587

- S. Mariano, Ki. 563

- S. Secondo, Ki. 563

Guglielmo, siehe Wilhelm

Guibert von Nogent, Geschichtsschreiber $314 \mathrm{f}$.

Guido von Burgund (Borgogna), siehe Calixt II., P.

Guido von Crema, siehe Paschalis III., $P$.

Guido von Somma, KB von Ostia 144, 162

Guido, KB von Preneste 355 
Guido, Abt von Santo Stefano

187 Anm. 12

Guido von Lusignan, $\mathrm{Kg}$. von Jerusalem 629

Guigo, Prior der Grande Chartreuse 357

Guillaume, siehe Wilhelm

Gurdimer, comes 278

Gurias, Heiliger 70

Hadrian (Adriano) II., P. $\quad 73,83,285$, 677

Hadrian III., P. 25

Hadrian (Adriano, Hadrien) IV., P. 124, 145 Anm. 42, 151, 153, 339, $353,364,432,538,542,599,624$

Haimerich, KD von S. Maria Nuova, päpstl. Kanzler $316 \mathrm{f}$.

Halberstadt, Bm. 94 Anm. 44

Halinard, Bf. von Lüttich 580

Hamburg-Bremen, Ebm. 91, 106, 108

Hannover, O. 248

Hariulf, Abt von S. Peter in Oudenbourg $316 \mathrm{f}$.

Al-Hasan ben al Abbas, Emir von Syrakus 25

Haseloff, Arthur, Gelehrter 232

Hathui, Äbt. von Gernrode 306 Anm. 30

Hattin, O. in Galiläa 622, 646

Hautecombe (Alta Comba), Kl. 536 Anm. 101

Heiliges Land (Terra Santa) 79, 158, 446, 566 Anm. 40, 593, 597-600, 602-604, 608, 612f.

Heinrich von Marcy, Abt von Clairvaux, $\mathrm{KB}$ von Porto 339

Heinrich von Pisa, KP von SS. Nereo et Achilleo 348

Heinrich (Enrico) von Settala, Subdiakon 165, 167, 170 Anm. 151

Heinrich von Reims, Ebf. 363

Heinrich, Bf. von Autun 318

Heinrich Contarini von Castello, Bf. 634,648

Heinrich I., dt. Kg. 267

Heinrich (Enrico) II., dt. Kg., Ks. 322, 354,580

Heinrich IV., dt. Kg., Ks. 295, 361

Heinrich V., dt. Kg., Ks. 336, 356
Heinrich (Enrico, Henri) VI., dt. Kg., Ks. $122,158,166,357,601,637$

Heinrich VIII., Kg. von England 440

Helena, siehe Olga von Kiev

Henri, siehe Heinrich

Heraklius, Patriarch von Jerusalem

642

Herdonia, O. abg. 110 Anm. 115

Herrmann (Ermanno) von Salza, Hochmeister des Dt. Ordens 602

Hildebert von Lavardin, Bf. von Le Mans, Ebf. von Tours 359

Hildebrand (Ildebrando), siehe Gregor VII., P.

Hildebrand (Ildebrando) Crassus, KP von SS. XII Apostoli 144, 150, 152, 154

Hildegard von Bingen, Heilige 338

Hilduin (Ilduino) von Saint-Denis, Prälat, Magister 74

Hinkmar, Ebf. von Reims 285

Holtzmann, Walther, Gelehrter 9, 111, $113,131,217,241,249-252,255$, 275-277, 280 Anm. 30, 410, 412, 421, 438-440, 623, 639, 650

Honoratus, Abt von S. Salvatore am Monte Letenano bei Rieti 17, 35

Honorius II. (Cadalus von Parma), P. 204 Anm. 53, 208, 333, 353, 435 Anm. 76, 440

Honorius (Onorio) III. (Cencius), P. 31, 166, 173 Anm. 161, 244, 290, 343, 392, 409, 433, 435, 601-603, 612,684

Hormisdas (Ormisda), P. 41 Anm. 5, 49 Anm. 36, 50 Anm. 37, 52

Anm. 45, 53 Anm. 51, 54-56, 282

Hrotsvit (Roswitha) von Gandersheim, Dichterin 305

Hubald, KB von Ostia, siehe Lucius III., P.

Hubald, Ebf. von Pisa 634, 646

Hubert (Uberto) Crivelli, KP von S. Lorenzo in Damaso, Ebf. von Mailand, L. 146,156 f., 162 Anm. 114

Hubert (Uberto) von Pirovano, Subdiakon 167, 172 Anm. 155, 345

Hubert (Ubertus), Subdiakon $412 \mathrm{f}$.

Hubert (Uberto), Ebf. von Turin 533 Anm. 84 
Hubert, Abt von S. Eufemia 200 Anm. 43

Hugo (Ugo, Hugues), KB von Ostia 539

Hugo (Ugo), KP von S. Lorenzo in $\mathrm{Lu}-$ cina 144

Hugo (Ugo) von Bologna, $\mathrm{KD}$ von $\mathrm{S}$. Eustachio 145

Hugo Etherianus, KD von S. Angelo 340

Hugo Pierleone, KD von S. Angelo 354

Hugo (Ugo) von Settala, Subdiakon 170 Anm. 151

Hugo, Bf. von Grenoble, Hl. 314 Anm. 9, 644

Hugo (Ugo) von Racaneto, Bf. von Squillace 165

Hugo (Ugo) Tornielli, Bf. von Acqui 166

Hugo (Ugo), Kanoniker von Lodi, Theologe 162

Hugo von Saint Victor, Kanoniker, Theologe 338

Hugo, Gf. von Vermandois 615

Hugo von Champfleury, Kanzler von Frankreich $363 \mathrm{f}$.

Hugo (Hugues) von Otranto, Prälat 122 Anm. 80

Hugo Falcandus, Geschichtsschreiber 31

Humbert, KB von Silva Candida 332

Hyazinth, KD von S. Maria in Cosmedin, siehe Coelstin III., P.

Ianuensis, siehe Genua

Ibas von Edessa, Magister 59

Ignatios, Patriarch von Konstantinopel 22

Igor I., Fs. von Kiev 88

Ildebrando, siehe Hildebrand

Ilduino, siehe Hilduin

Imola, O. 656

Ingeborg von Dänemark, Kgn. von Frankreich 361

Inghilterra, siehe England

Innozenz (Innocentius, Innocenzo) I., P. 278 f., 280 Anm. 31, 301, 305, 306 Anm. 28, 307
Innozenz (Innocentius, Innocenzo, Innocent) II., P. $135,142,144$ Anm. 32, 154, 190 Anm. 20, 197 Anm. 33, 200, 203 Anm. 52, 204, 207-209, 211, 316 f., 353, 366, 369, 420 Anm. 15, 421, 433, 440, 443, 525 f., 527 Anm. 45, 529 f., 533 Anm. 84, 534-540, 545, 548, 550, 554, 563, 574, 598, 612, 621, 624, $649,655,683 \mathrm{f}$.

Innozenz (Innocentius, Innocenzo, Innocent) III. (Lothar von Segni), P. 3, 159, 163, 164 Anm. 127, 165, $167-$ 169, 170 Anm. 151, 171, 173, 175 Anm. 165, 176 Anm. 167, 181, 185, 188, 191 Anm. 20, 195 Anm. 29, 198, 212 Anm. 85, 218, 261, 308 Anm. 36, 311, 314, 323 f., 343-346, $349,355,357,365,369,389,391$, 396, 399, 400 Anm. 42, 435, 437 Anm. 83, 543, 650, 679 Anm. 6, 681, 684

Innozenz (Innocenzo) IV., P. $\quad 173,181$

Innozenz VII., P. 435

Innozenz (Innocenzo) VIII., P. 575, 612

Irland (Irlanda) 439, 444, 446

Isaak II. Angelos, byz. Ks. 642

Istrien, Terr. 268

Italia inferior 36,191

Italia media 36,191

Italia superior 36, 191

Italiae, Regnum $20 \mathrm{f}$.

Italien (Italia, Italie) 6, 8, 11, 18-22, $25-27,29-36,39$ f., 42 f., 50, 52 f., 56 f., $61-66,69$ f., 74-77, 80-82, $92-94,96-105,109-111,116 \mathrm{f}$, 126, 130, 136 Anm. 2, 138 Anm. 6, 139-143, 147 Anm. 54, 150-154, 157-159, 162 f., 174 f., 183, 188 f., 190 Anm. 20, 191, 194 f., 201

Anm. 46, 203, 212, 223, 226 f., 229, 237, 240 Anm. 128, 242, 248, 257, 267-269, 271 f., 279 f., 283, 285, 312, 327 Anm. 40, 333, 347, 349, 398 f. , 403, 411, 413, 417, 419-427, $430-434,516,519,521,534-536$, 544, 550, 553, 558-561, 578 f., 581, 586, 588, 589 Anm. 140, 590 f., 596, 598, 600, 602, 606-610, 612-617, 
$619-622,626-628,630,639-641$, 643, 647-650, 652-654, 657-660, 662 Anm. 237, 663-666, 675-678, 680, 683-685, 687-691

Ivo, Bf. von Chartres 285, 545

Ivrea, O. 164 Anm. 127, 166, 174

Anm. 164

Jaffé, Philipp, Gelehrter 4, 25, 183

Anm. 2, 223 f., 236, 261, 649

Jakob Belmusto 648

Jean, siehe Johannes

- Jerusalem (Gerusalemme), O 43, 421, 616, 623-625, 628-632, 635, 642, 645 f., 649 f., 652, 657

- Grabeskirche $650 \mathrm{f}$.

- (Gerusalemme), S. Johannes, Hospital 596, 600, 606, 608-610

- S. Maria auf dem Sionsberg, Kl. 621, 665

- (Gerusalemme), S. Maria Latina, Kl. 620 f., 623 f., 628, 650, 652, 660, 665

- S. Samuel auf dem Mons Gaudii (Freudenberg) 621

Johannes I., P. 52 Anm. 46, 55

Johannes II., P. 50 Anm. 37, 56 f., 282 Johannes IV., P. 26

Johannes (Giovanni, Jean) VIII., P $23 \mathrm{f} ., 26,73,81,83,114,263-265$, 267, 269-272, 286, 287 Anm. 64, 293, 295, 300, 391, 677, 680

Johannes IX., P. 381,384

Johannes XII., P. 92

Johannes (Giovanni, Jean) XIII., P. $\quad 93-96,444,678$

Johannes (Jean) XV., P. $100,106,117$, 444

Johannes (Giovanni) XVIII., P. 567

Johannes (Jean) XIX., P. 118, 444

Johannes XXII., P. 424 Anm. 35, 435

Johannes (Giovanni) KB von Albano, L. 365,146

Johannes, KB von Porto 644 Anm. 129

Johannes Anagninus, KB von Preneste 365

Johannes Marsicanus, KB von Tusculum 356

Johannes (Giovanni) Tornielli, Subdiakon 164 Anm. 127, 165 f., 168
Johannes (Giovanni) Buono da Furnovo, Kanoniker, Magister, Subdiakon 154, 162, 164 Anm. 127, 172 Anm. 155

Johannes, KP von S. Anastasia, L. 352 Johannes, KP von SS. Giovanni e Paolo, L. 623

Johannes von Toledo, KP von S. Lorenzo in Lucina 327

Johannes (Giovanni), KP von S. Stefano in Celiomonte 158

Johannes (Giovanni), KD von S. Maria in Porticu 149

Johannes II., Patriarch von Konstantinopel $51,53 \mathrm{f}$.

Johannes (Giovanni), Bf. von Florenz 575

Johannes (Giovanni), Bf. von Ivrea

173 Anm. 159

Johannes (Jean), Bf. von Montemarano 123

Johannes, Bf. von Narni, siehe Johannes XIII., P.

Johannes (Jean), Bf. von Trani und Siponto 31, 128

Johannes, Bf. von Trium Tabernarum 198 Anm. 37

Johannes (Giovanni) von Lodi, Bf. von Gubbio 563

Johannes (Jean) von Salisbury, Magister, Bf. von Chartres, L. 124, 313, 319, 360

Johannes (Giovanni) III., Abt von Montecassino (Mönch Liutius) 79

Johannes (Giovanni) Gualberto, Abt von S. Miniato in Florenz 564, 566

Johannes (Giovanni) Bono, Mönch von Brettino 577

Johannes (Giovanni) Gradenigo, Mönch 561 Anm. 20

Johannes (Jean) von Matera, Mönch, Heiliger 126

Johannes (Giovanni) Morosini, Mönch 561 Anm. 20

Johannes Moschus (Giovanni Moscus), Mönch und Hagiograph 79

Johannes (Jean) von Tufara, Mönch, Gründer von S. Maria del Gualdo 126 
Johannes (Jean) Sainsaulieu, Eremit 558

Johannes Damaskenos (Giovanni Damasceno), Kirchenvater 73

Johannes (Giovanni) von Capua, päpstl. Notar 604

Johannes (Giovanni) Grasso 162

Johannes Tsimiskes, oström. Ks. 91, 98 Johannes (Giovanni) III., Fs. von Neapel 70, 72

Johannes (Giovanni) Scotus 74

Johannes (Giovanni) Teutonicus, Magister 155 Anm. 89

Johannes (Giovanni), Schüler des Dominikus von Foligno 565-567

Johannes Diaconus (Giovanni Immonide), Autor 75, 302 f., 391 Anm. 12

Jordan, KP von S. Susanna 367

Jordan, Bf. von Savona 187 Anm. 12

Joscius, Ebf. von Tyrus 631

Joseph Abibos, Heiliger 70

Juliana, Adelige 278

Julius I., P. 378

Justin I., byz. Ks. 51-53

Justin II., byz. Ks. 63

Justinian I., byz. Ks. 45 Anm. 20, 50 Anm. 37, 51 f., 54-61, 63, 64

Anm. 107, 67

Juvenal (Giovenale), röm. Dichter 82

Kalabrien (Calabria, Calabre), Terr. 22, 76, 78, 97 f., 100, 109, 115 f., 118 f., $125,127-129,165,190-192$, 194 f., 198-201, 203, 204 Anm. 53, $211-213,242,250,269,411,516$, 519, 599, 605, 623, 646, 652, 662, 679

Kalbfuss, Hermann, Gelehrter 135

Kaltenbrunner, Ferdinand, Gelehrter 227 Anm. 57, 419, 421

Kampanien (Campania, Campanie), Terr. $69 \mathrm{f} ., 72,76,78,81,83,99,109 \mathrm{f}$, 114 f., 117 f., 216 Anm. 5, 242, 268, 270, 599

Karl II. der Kahle, westfrk. Kg., Ks. 269

Karl III., frk. Kg., Ks. 269

Karl V., Ks. 246

Karl (Carlo) I. von Anjou (Angiò), Kg. von Sizilien 370, 603
Karlmann, $\mathrm{Kg}$. von Ostfranken und Italien 269

Katalonien, Prinzipat 242

Kehr, Paul Fridolin, Gelehrter 3-15, 19 f., 26, 27 Anm. 40, 30 f., 35 f., 110 Anm. 5, 111-113, 130 f., 135, 136 Anm. 2, 137 f., 140 f., 147, 153, $161,174,176,181,183,188,215$ Anm. ${ }^{*}$ und 3, 216-224, 225 Anm. 46, 226-233, 234 Anm. 93, $235-243,245-251,254-257$, 261 f., 266-268, 272, 275 f., 299304, 308, 331 f., 371, 373 f., 387, 389 f., 395, 399 f., 415, 417-422, 426-429, 431 f., 434-436, 438, 440, 443-446, 563, 570, 574 Anm. 74, 590, 593, 594 Anm. 4, 595, 599, 614, 616-618, 620, 622 f., 625-627, 633 f., 640, 641 Anm. 117, 648 f., 657 Anm. 211, 659, 664-666, 677, 679, 682, 686, 687 Anm. 15

Kenilworth, S. Mary's, Kl. 440

Kerbogha, türk. Emir 630

Kiev, O. $\quad 87$ f., 90, 105, 107 f.

- Höhlenkloster 87

Kingswood, S. Mary's, Ki. 439

Klemens Wenzel Lothar von Metternich, Gf. und Fs. 675

Klewitz, Hans-Walter, Gelehrter 249

Klinkenborg, Melle, Gelehrter 111, 233

Köln, O. und Ebm. 163

Kolumbus, Christoph, Seefahrer 228, 679

Konrad I., ostfrk.-dt. Kg. 267

Konrad von Montferrat, Kg. von Jerusalem 629

Konrad von Wittelsbach, KB von S. Sabina, Ebf. von Mainz, L. $\quad 354,637$

Konrad I. von Querfurt, Bf. von Hildesheim und Kanzler Ks. Heinrichs IV. $636 \mathrm{f}$.

Konrad von Urach, KB von Porto 346

Konstantin Bodin, serb. Herrscher 428

Konstantin I., röm. Ks. 44, 383

Konstantin V., byz. Ks. 22

Konstantin VII. Porphyrogennetos, byz. Ks. $\quad 72$ 
Konstantinopel (Constantinopoli, Constantinople), O. und Patriarchat, siehe auch Byzanz $21 \mathrm{f} ., 29,40 \mathrm{f}$., 43, 45 f., 48, 49 Anm. 36, 51-56, 58-60, 64 Anm. 107, 65 f., 69, 71, 74, 87-91, 96-98, 100, 102, $106 \mathrm{f}$, $127,129,340,370,428,676$

- Akoimetenkloster 49 Anm. 36

Konstanze I., Kgn. von Sizilien, Ksn. $\quad 125$

Konstanze von Frankreich, Tochter Philipps I. von Frankreich 428

Koper, siehe Capodistria

Kopp, Georg, Bf. von Breslau 247

Korsika, Insel 31, 110

Kroatien 279, 352

Kyrill (Cirillo) von Jerusalem (PseudoKyrill), Kirchenvater und Theologe 70

Kyrill (Cirillo) von Scitopoli, Mönch und Hagiograph 74

Kyrill von Alexandrien, Patriarch von Alexandria 46 Anm. 21

La Chiusa, S. Michele, Kl. 533

La Ferté, Kl. 525, 528, 535, 551 Anm. 172

La Roé, Kl. 317

La Verna, Kl. 591

Laborans, KP von S. Maria in Trastevere $341 \mathrm{f}$.

Lacedonia, Bm.

115

Lambert (Lamberto), Gf. von Spoleto, Ks. von Italien 270

Lambert, Gf. 571

Lamis, S. Giovanni, Kl. 112

Lamis, S. Matteo, Kl. 112

Lampert von Hersfeld, Geschichtsschreiber 101

Landolf von S. Paolo, Chronist 142 Anm. 22

Landolina, S. Pietro, Kl. $570 \mathrm{f}$.

Landus, sacerdos $412 \mathrm{f}$.

Landward, Bf. von Minden 93 Anm. 42

Lanercost, Kl. 439

Lanfranco, Bf. von Parma 528 Anm. 53

Lanfranco, Bf. von Pavia 162

Langobardia, Terr. 96 f., 99
Lanterio von Lampugnano, Subdiakon 170 Anm. 151

Lanuinus von S. Maria de Turri 200 Anm. 43, 210 Anm. 80

Laodicea, O. 635

Laon, O. und Bm. 285, 314-315

Lario, See (Comer See) 528 Anm. 52

Latium (Lazio), Terr. 69 f., 76, 78, 81, 83, 271, 389, 537, 541, 606, 624, 634,650

Laurentius (Lorenzo), Ebf. von Amalfi, Mönch von Montecassino 78

Laurentius (Laurent) von Siponto, Heiliger 118 Anm. 52

Laurentius (Lorenzo), Heiliger 304

Lazio, siehe Latium

Le Puy, Hôpital Notre-Dame 442

Legnano, O. 156

Lehmann, Max, Gelehrter 218, 234 Anm. 93, 235 Anm. 94

Lentini, Bm. 111 Anm. 11

Leo I. (Leo der Große), P. $\quad 46,48,263$, 282, 286 Anm. 57

Leo (Leone) III., P. 304

Leo (Leone, Léon) IV., P. 17 f., 264, 285-289, 379-381

Leo V., P. $\quad 381,384$

Leo (Leone) IX., P. 30 Anm. 56, 141, 186, 196, 207, 333, $580 \mathrm{f}$.

Leo (Leone) XIII., P. 395

Leo (Léon), Ebf. von Ohrid 128

Leo (Leone), Archipresbyter $71 \mathrm{f}$.

Leo Marsicanus, Mönch von Montecassino 336

Leo (Leone) V., byz. Ks. 73

Leo, Friedrich, Gelehrter 234

Leone, Léon, siehe Leo

Lérins, Kl. 431, 447

Les Andelys, Insel 322

Lesina, Bm. 115

Lettere, Bm. 117

Leuca, Bm. 115, 118

Liberatus von Karthago, Historiograph 58 Anm. 79

Libutius, Mönch von S. Alban in Mainz, Missionsbf. 90

Ligurien (Liguria), Terr. 190-193, 195-204, 207, 209, $211 \mathrm{f} ., 215$

Anm. 3, 268, 519, 621, 679

Lilybée (Marsala), Bm. 111 Anm. 11 
Limassol, O. 621

Limoges, O. 146 Anm. 47

Limousin, Terr. 546

Lincoln, Bm. 440, 639

Lipari, O. und Terr. $27 \mathrm{f}$.

Lissabon, O. 439

Liudolf, Hzg. von Sachsen $305 \mathrm{f}$.

Liudprand (Liutprando), Bf. von Cremona, Geschichtsschreiber 75, 82, 95-99, 390

Liutius, Mönch, siehe Johannes von Montecassino

Liutprando, siehe Liudprand

Lodi, O. 148, 153 Anm. 83, 162, 165

- S. Ambrogio, Kl. 148, 156, 170

- S. Vincenzo, Kl. 148

Loewenfeld, Samuel, Gelehrter 224

Lombardei (Lombardia), Terr. 136 Anm. 2, 137, 139-142, 150

Anm. 67, 151-154, 156, 158, $161 \mathrm{f}$, 169, 170 Anm. 151, 176, 181, 215

Anm. 3, 216 Anm. 6, 347, 627, 653, $655,658 \mathrm{f}$

Lombardo von Piacenza, KP von S. Ciriaco, Ebf. von Benevent 145, 160

Longinus, Praefectus Praetorio von Ravenna 62

Lorenzo, siehe Laurentius

Lothar III., dt. Kg., Ks. 369

Lothar von Segni, siehe Innozenz III., P.

Louis, siehe Ludwig

Lucania, O. 78

Lucanien, siehe Basilikata

Lucca, Bm. 271, 336, 339, 577, 598, $629,645,655,659$

- S. Frediano, Kl. 575

Lucedio, Kl. 424, 519 f., 525, 535

Lucera, Ebm. 117

Lucius II., P. 208 f., 211, 338, 347, $351,353,542,598,630,650$

Lucius III., P. 32 f., 142, 146, 153

Anm. 84, 156 Anm. 91 und 92,

157 f., 162 Anm. 114, 163, 200, 206

Anm. 60, 210, 340, 424, 430-433, 439-441, 532, 543, 619 Anm. 19, 625, 627, $641 \mathrm{f.}, 646,652,661 \mathrm{f}$, 666
Ludwig (Ludovico) I., der Fromme, frk. Kg., Ks. 304

Ludwig II., Kg. von Italien, Ks. 270, 677 Anm. 4

Ludwig VII., Kg. von Frankreich 364, 615

Ludwig IX., Kg. von Frankreich, Heiliger 370,615

Lukas, Bf. von Isola Capo Rizzuto 123

Luni, Bm. 205 Anm. 58, 437

- S. Maria, Ki. 437

Lupo, siehe Bucco, Hzg. von Nocera

Lyon, Ebm. 432, 442

- St-Irénée, Kl. 432

Macchia, O. 584

Macedonia, siehe Makedonien

Magdeburg, Ebm. 91-96, 102-108, 184 Anm. 5, 367 Anm. 123, 678

- S. Mauritius, Kl. 92, 95, 103 Anm. 95

Maggiulli, Luigi $410 \mathrm{f}$.

Magnus von Reichersberg, Geschichtsschreiber 354

Maguelonne, O. 415

Mähren, Terr. 92, 101

Mailand (Mediolanum, Milano), O. und Ebm. 27, 64, 94, 120, $135 \mathrm{f}$., 139 f., 145, 146 Anm. 49, 147-151, 153, 154 Anm. 87, 155, 156 Anm. 91, 157 f., 163-170, 181, 190 Anm. 20, 268, 270 f., 283, 333, 335, 345, 351, 456 Anm. h, 527 f., 551, 627, 634, 636, 645, 659, 677 f., 688, 691

- S. Nazaro, Ki. 162

Mainard, KB von Silva Candida 361

Mainard (Mainardo), Mönch von Sitria $\quad 572-574$

Mainz, Ebm. 11, 87, 95, 104, 106, 433, 687 Anm. 14

- Sankt Alban, Kl. 90

Makedonien (Macedonia) 72, 279

Malaga, O. 439

Mallavalle, S. Guglielmo, Kl. 577

Malta 109, 433, 593, 613, 618, 623625, 639, 659-661, 664, 666, 685

Malvito, Bm. 100, 118

Manfred von Lavagna, KB von Preneste $145,151 \mathrm{f} ., 154,162$ 
Mantua (Mantova), O. 141,158

- S. Andrea, Ki. 437

Manturana, O. 308 Anm. 36

Manuel I., byz. Ks. 340

Marburg, O. 248

Marcellianum, frühchristl. Bm. abg. 110 Anm. 9

Marcellinus, Heiliger 304

Marengo 145 Anm. 42

Marescottus, Propst von S. Maria Gualtieri 164 Anm. 127, 166, 172 Anm. 155

Maria, Heilige 303, 306

Maria Egiziaca, Heilige 77

Marino, Sohn Johannes' (Giovanni, Jean) III., Fs. von Neapel 72, 561 Anm. 20

Marinus I., P. 25

Marken, Terr. $\quad 11,158,531$

Marmoutier, Kl. 442

Marsala, siehe Lilybée

Marseille, O. 265

- Saint-Victor, Kl. 442

Martin I., P. 74

Martin IV., P. 435

Martin V., P. 435 Anm. 76, 590

Martin, Bf. von Tours, Heiliger $379 \mathrm{f}$.

Martirano, Bm. 115, 615, 646

Massa Lubrense, Bm. 111, 115, 117

Massarelli, Angelo 428, 429

Massimo il Confessore, siehe Maximus Confessor

Matera, Bm. 98

Mathilde, Mgfn. von Tuszien 271

Matthäus, KB von Albano 353

Matthäus Paris, Geschichtsschreiber 370

Matutinus, Abt von Cerreto 535 Anm. 95

Maurienne, Kl. 445

Mauritius, KB von Porto 635 f., 645

Maximus Confessor (Massimo il Confessore) 74

Meaux, Bm. 322

Medicina, Terr. 602

Mediolanum, siehe Mailand

Medolago, O. 149 Anm. 63

Meinert, Hermann, Gelehrter 438

Meißen, O. 104

Melfi, O. 29-31, 119
Menas, Patriarch von Konstantinopel 58

Merseburg, O. und Bm 103 Anm. 93, 104

- Kl. 93

Messina, O. und Bm. 112, 126, 439 Anm. 15, 593 Anm. 2, 597, 600, 602, 610,621 f., 628 f., 642, 653, 655$657,659,662 \mathrm{f}$.

- S. Salvatore, Kl. 128

Methodios, Patriarch von Konstantinopel 22,74

Mezzogiorno, Terr. $\quad 109,519,600$ f., $605,609,612$

Michael III., byz. Ks. 75 f., 288

Michael VIII., byz. Ks. 370

Mieszko I., Fs. von Polen 92, $106 \mathrm{f}$.

Milano, siehe Mailand

Milazzo, Bm. 111 Anm. 11

Mileto, O. 118 f., 198 Anm. 37

- SS. Trinità, Kl. 198 Anm. 37, 204 Anm. 53, 210

Milhau, Kl. 442

Milo, KB von Preneste 337

Milone von Cardano, Ebf. von Mailand 149

Minervino, Bm. 115

Minori, Bm. 117

Minturnae, frühchristl. Bm. abg. 110 Anm. 9, 115

Miroslav, Gf. von Zachulmia 415417, 420, 430

Miseno, Bm. 76, 110 Anm. 9

Misenus, Bf. von Cumae 46 Anm. 24

Modena (Mutinensis), O. 144 Anm. 39, 152

- S. Giminiano, Ki. 144 Anm. 39, 154 Anm. 85

Modugno, O. 118

Molesme, O. 522

Molfetta, Bm. 115

Molise, Terr. 109, 112

Monaldo, Sohn Buccos von Nocera 571

Moncalieri, O. 656, 659

- S. Egidio, Kommende 656

Monferrat, Mgft. 525

Monkton Farleigh, O. 439

Monopoli, O. 119

Monreale, O. und Kl. 120, 126 
Monta Tancia, S. Michele, Kl. 583

Monte Acuto, S. Salvatore, Kl. 204 Anm. 53

Monte Amiata, S. Salvatore, Kl. 519

Monte di Collalto, S. Maria, Kl. 531

Monte Gargano 566 Anm. 40

- S. Michele, Kl. $\quad$ 561, 579, 581 f., 591

Monte Mirteto, S. Maria, Kl. 585

Monte Oliveto, Kl. 575

Monte Sant'Angelo, O. 112,119

Montesantangelo, Kl. $580 \mathrm{f}$.

Montecassino, Kl. 78, 112, 114, 122, 125 f., 128, 269-271, 334, 336, 407, 430, 433, 443, 565, 567, 586, $631 \mathrm{f}$, 654 Anm. 183, $656 \mathrm{f}$.

- S. Nilo, Kl. 77

Montecorvino, Bm. 115

Montefano, S. Benedetto, Kl. 577

Monteluco, Kl. 586, 589

Montemilone, O. 118

Montenero, O. 541

Montevergine, S. Maria, Kl. 126, 407

Montione, S. Savino, Kl. 437

Mont-Saint-Michel, Kl. 581

Monza, O. 161, 164 Anm. 127, 167

- S. Giovanni Battista, Kl. 148

Morciano di Leuca, O. 410

Morcone, Bm. 111, 115

Morimont (Morimondo), Kl. $519 \mathrm{f}$, 528, 535, 551 Anm. 172, 553

Morro Reatino (Scoglio di S. Michele), O. 584

Mortara, O. 142

Mottola, Bm. 118

Moyenmoutier, O. u. Kl.

332

Muro Leccese, O. 410

Mutinensis, siehe Modena

Myria, frühchristl. Bm. abg. 110 Anm. 9

Napoli, Naples siehe Neapel

Narbonne, O. 279

- Saint-Paul, Ki. 442

Nardò, O. 113

- S. Maria, Kl. 129

Narni, Bm. 204 Anm. 53, 208

Narses, Feldherr Justinians I. 61-63, 64 Anm. 107

Naumburg-Zeitz, Bm. 444
Navarra, Terr. 242, 663 Anm. 243, 664

Nazareth, O. und Ebm. 619 Anm. 19, 621, 630

Neapel (Napoli, Naples), O., Terr. und Ebm. 21, 24, 69-73, 76, 79 f., 82 f., 96, 109, 113 f., 116 f., 119 , $121,125,127,130,268-270,405$, 408, 566 Anm. 40, 648, 676, 677 Anm. 4

- S. Giovanni Maggiore, Ki. 71

Neapel-Amalfi 109

Nervi, Hospital und Ki. des Hl. Grabes in Jerusalem 651, 658

Nestor, Mönch des Höhlenklosters in Kiev 87

Nicäa, O. 74

Nicastro, Bm. 119

Nicola, Nicolas, siehe Nikolaus

Nikephoros Phokas, byz. Ks. 97-99

Nikolaus (Nicola) I., P. $\quad 73,75-76,83$, 105, 285, 287 f., 292, 677

Nikolaus (Nicola, Nicolas) II., P. 30, 121, 204 Anm. 53, 207, 403, 405, 560

Nikolaus IV., P. 435

Nikolaus V., P. $440 \mathrm{f}$.

Nikolaus, KB von Tusculum 355

Nikolaus (Nicola), Abt von Sassovivo 575

Nikolaus, Abt von SS. Trinità in Mileto 198 Anm. 37

Nikolaus, Prior des Hl. Grabes 658

Nikolaus (Nicolas), Sohn des Vizekanzlers Mathieu von Ajello 122

Nikosia, Kathedrale 619,621

Nilus, Heiliger 77, 79

Ninfa, S. Angelo, Kl. 585

Nocera Umbra, O. 570 f., 572 Anm. 64, 575

Nocera, Bm. 110 Anm. 8

- S. Cristoforo, Ki. 571

Nola, Bm. 100, 407

Nonantola, Kl. 443

Normandie, Terr. $\quad 318,322,442,615$

Norwich, O. 440

- Holy Trinity, Ki. 440

Nostitz-Rieneck, Robert von 243

Notre-Dame de Lyre, Kl. 442

Notre-Dame-du-Bourgmoyen, Kl. 
Novara, O. 142,145 Anm. 42, 148, 163, 164 Anm. 127, 165 f., 171 Anm. 154

- S. Gaudenzio, Ki. 166, 168

- S. Maria, Ki. 166-168, 175 Anm. 165

Noyon, O. 325 f., $328 \mathrm{f}$.

Nur ad Din, islam. Herrscher 322

Nusco, Bm. 115, 118

Obazine, O. 547

Oberto von Terzago, Archipresbyter von Monza 148, 161, 162 Anm. 114, 164,170

Oberto, Bf. von Novara 165

Obizo von Castello, Subdiakon und Kanoniker von Novara 164

Anm. 127, 165, 171 Anm. 154

Ochrid, Ebm. 91

Oda, Hzgn. von Sachsen 306

Odalrich, Bf. von Cremona 101 Anm. 84

Odo, KB von Tusculum, Abt von Ourscamp 321

Odo (Oddo) von Brescia, KD S. Nicola in Carcere Tulliano 144, 150-152, 154, 354

Odo (Eudes), Ebf. von Besançon (Odo von Rougemont) 371

Odo Rigaldi, Ebf. von Rouen 328 f.

Odo, Bf. von Beirut 627

Odo (Oddo), Abt von Cluny $307 \mathrm{f}$, 559

Odo (Oddo) Frangipane (Frangentispanem), röm. Adeliger $\quad 542$ Anm. 132

Odo, KB von Ostia, siehe Urban II., P.

Odo (Eudes) von Rougemont, siehe Odo, Ebf. von Besançon

Odoaker, Kg. in Italien 39, 43

Ofena, frühchristl. Bm. abg. 110 Anm. 6

Offredo, Bf. von Cremona 149 Anm. 63

Ogerio von Plazano, Adeliger 535

Oktavian (Ottaviano), KB von Ostia 166, 355, 366 Anm. 120

Oktavian (Ottaviano) degli Ubaldini, L. 347
Oldeberto Tornielli, Bf. von Novara 164 Anm. 127, 168

Olga, Fsn. von Kiev (Helena) 88-90

Onorio, siehe Honorius

Oppido, Bm. 115, 120

- S. Salvatore, Ki. 209

Orest, Patriarch von Jerusalem 80

Oria, O. $\quad 117,119 \mathrm{f}$.

Oria-Brindisi (Brindisi-Oria),

Terr. $\quad 119,123$

Oristano, O. und Ebm. 621

Ormisda, siehe Hormisdas

Orticoli, S. Maria, Ki. 204 Anm. 53

Ortona, frühchristl. Bm. abg. 110 Anm. 6

Osimo, O. 577

Osma, Bm. 433

Ostfränkisches Reich 91

Ostia, Bm. 144 Anm. 35, 162, 563

Ostuni, O. 119

Otger, Bf. von Speyer 93 Anm. 42

Otranto, O. und Ebm. 96-98, 100, 113 Anm. 18, 117 f., 127-129, 403, $410,412-414,597,657,678,682$

- Metropolitankirche 100

- S. Annunziata, Ki. $\quad 403,410,412$

Ottaviano, siehe Oktavian

Otto VI., Bf. von Bamberg 353

Otto I., dt. Kg., Ks. 89-99, 105, 267, 306

Otto II., dt. Kg., Ks. 96, 100, 106, 306 Anm. 30

Otto III., dt. Kg., Ks. $\quad 561,580$

Otto IV. (Otto von Braunschweig), dt. Kg., Ks. 163

Otto I. von Wittelsbach, Pfalzgf. 369

Otto Morena, Geschichtsschreiber 145 Anm. 41

Ottobonus Belmusto 648

Oudenbourg, O. 316, 325

Oxford, Bm. 338, 439

Padua (Padova), O. 158, 430, 594

- S. Marino, Kl. 430

Palaikastron, Bm. 127

Palermo, O. und Ebm. $\quad 112,114,122-$ $124,268,594,623,642,655,659$, 661, 664, 666

- SS. Trinità, Ki. $\quad 601,605$

Pamplona, Bm. 431, 642, 662 
Pandulf I. Eisenkopf, Fs. von Capua und Benevent 99, 102

Panzo, S. Angeli, Ki. 589

Paolo, siehe Paul

Paolo Scolari, siehe Clemens III., P.

Paris, O. $\quad 172,254,319,325,337 \mathrm{f}$, 340, 343-345, $363 \mathrm{f} ., 417,420$ Anm. 15, 625

- S. Vittore, Kl. 160 Anm. 108, 167 Anm. 138, 173 Anm. 158, 363

- Sainte-Geneviève, Kl. 363

Parma, Bm. 158, 163, 269, 528 Anm. 53, 541

Paschalis (Pasquale) I., P. 73, 303, $374-376$

Paschalis (Pascal, Pasquale) II., P. 119, 141, 197 Anm. 33, 198 Anm. 37, 200, 208 f., 210 Anm. 80, 211, 265, 304, 314 f., 317, 336 f., 348 f., 352 f., 356, 428, 430, 432, 523, 527 Anm. 45, 533 Anm. 84, 574, 597 f., 600, 624, $631 \mathrm{f} ., 635,639,645,649$, 657, 663 Anm. 243, 681

Paschalis (Pasquale) III., P. 144, 148, 151

Passau, O. 295

Paternò, O. 624, 628

Patir bei Rosanno, siehe Théotokos

Patria, frühchristl. Bm. abg. 110 Anm. 9

Patti, Bm. 120

Patti-Lipari, Bm. 126

Paul I., P. 113

Paul (Paolo) II., P. 435, 575

Paul III., P. 435, 437

Paul (Paolo) V., P. 576

Paulinus, Bf. von Fossombrone 62

Paulus, Apostel 306 Anm. 28, 373, 376-378

Pavia, Bm. 141 f., 146 Anm. 47, $149-$ 151, 153, 160 Anm. 108, 162, 270, 295, 432, 457 Anm. h, 528, 551 Anm. 172

- S. Maria Gualtieri, Kl. 164 Anm. 127

- S. Maria Teodote, Kl. 163

Pelagius I., P. $\quad 61-64,264,277$ f., 285-287

62, 64-66,
Penne, Bm. $\quad 120$

Pennino, Berg $571 \mathrm{f}$.

Perugia, O. 193 Anm. 25, 204 Anm. 53, 564, 575, 578 Anm. 94, 650

- S. Pietro, Kl. 192, 193 Anm. 25, 196,651

Pesto, O. und Bm. 100

Petrucci, Armando 581

Petrus, KB von Albano 352

Petrus (Pietro) von Collemedio, KB von Albano 325

Petrus (Pier) Damian (Petrus de Honestis), $\mathrm{KB}$ von Ostia, Heiliger 333, 358, 361, 558, 559 Anm. 14, 562-564, 569, 572

Petrus, KB von Porto, L. $\quad 368,636$, 646

Petrus von Pavia, KB von Tusculum, Archidiakon von Pavia, L. 145 f., 339, 348, 354, 360, 363, 367

Petrus (Pietro) Dianus, KP von S. Cecilia 146, 156-160, 166, 172 Anm. 155, 367

Petrus Iterius, KP von S. Grisogono 354

Petrus Pisanus, KP von S. Stefano 351

Petrus von Piacenza, KP von S. Cecilia, L. 197 Anm. 33, 365, 646, 651

Petrus Capuanus, KD von S. Giorgio in Velabro 344

Petrus (Pietro) von Mizo, KD von S. Eustachio 160 Anm. 108, 352

Petrus Mongos, Patriarch von Alexandria 46

Petrus, Bf. von Anagni 334

Petrus von Celle, Bf. von Chartres, Abt von Montier-la-Celle und SaintRémi 360

Petrus (Pietro), Bf. von Novara 166

Petrus Lombardus, Bf. von Paris 338, 344

Petrus, Bf. von Pistoia 288, 291

Petrus, Bf. von Squillace 198 Anm. 37

Petrus von Amiens (der Einsiedler), Kreuzzugsprediger 648

Petrus (Pietro) von Bussero, Diakon 149

Petrus Collivaccinus, päpstl. Subdiakon und Notar 346 
Petrus Venerabilis, Abt von Cluny 359 Poitiers, Bm. 438, $441 \mathrm{f}$.

Petrus (Pietro), Apostel und Heiliger 299, 301 Anm. 9, 304-306, 373, $376-378,635$

Petrus Diaconus, Mönch von Montecassino, Geschichtsschreiber 336

Petrus (Pietro) Orseolo, Doge von Venedig 561 Anm. 20

Petrus (Pietro) Latrus, röm. Adeliger 542 Anm. 132

Petrus von Blois, Theologe 361

Petrus de Honestis, siehe Petrus Damiani

Petrus Fantinus 656

Petrus Manducator, Magister 354

Petrus Pictaviensis, Sekretär des Petrus Venerabilis 359

Pflugk-Harttung, Julius von, Gelehrter 4, 224, 227, 405, 415, 416 Anm. 4, 419, 421, 623

Philipp II. August, Kg. von Frankreich 360, 615, 634 Anm. 89

Philipp von Lampugana, Ebf. von Mailand 198

Philipp von Schwaben, dt. Kg. 355

Photios, Patriarch von Konstantinopel 88

Polen (Polonia) 101, 108, 421, 441, 443

Policastro, Bm. 114

Polizzi, SS. Trinità, Ki. 607

Polonia, siehe Polen

Polyeuktos, Patriarch von Konstantinopel 98

Pontignano, O. 559

Pontigny, O. und Kl. 524, 541, 543, 551 Anm. 172

Pontius, Bf. von Roda und Barbastro 356

Pontius von Antiochia, L. $\quad 631,632$

Pontius Pilatus, röm. Präfekt 560 Anm. 16

Ponzone, O. und Mgft. $\quad 525$

Port'Albera, O. 162

Porto Torres, Ebm. 266

Porto, O. und Bm. 145 Anm. 42, 151, 278, 339, 354, 381, 439, 443, 635

Portovetere, O. 197 Anm. 33

Portugal 353

Potenza, O. 403, 431

- Hospital 431

Potenza Picena, O. $\quad 536$

- Montesanto, O. 536

Potthast, August, Gelehrter

399 157-160, 162 f., 166, 269, 368, 438 Anm. 84, 527 f., 533 Anm. 87, 643, 650, 665

- S. Antonino, Ki. 158

- S. Sepolcro, Ki. 650 f., 666

Piemont, Terr. 140, 141 Anm. 17, 268, 551, 656

Pier, siehe Petrus

Pietra del Demonio, S. Maria, Kl. 566

Pietro, siehe Petrus

Pio, siehe Pius

Piperno, S. Maria, Kl. 537 Anm. 104

Pisa, O. und Bm. 31, 158, 200, 271, 317, 533 Anm. 84, 535, 597 f., 600, 629, 644-647, 649, 653, 655, 657, 659

Pius II., P. $\quad$ 435, 437

Pius (Pio) XI. (Ratti, Achille), P. VI, 10, 13-15, 221, 222 Anm. 31

Pizzo, S. Vito, Kl. 129

Plazano, O. 535

Pogliola, O. 521 Anm. 23

Pouille, siehe Apulien

Prag, O. und Bm. 92, 106

Prato, O. $\quad 648 \mathrm{f}$.

- S. Stephano, Ki. 436

Preneste, Bm. 144 Anm. 37, 145 Anm. 43, 152

Prepositino von Cremona, Theologe 163

Prokop, Geschichtsschreiber 58 Anm. 79

Provence (Provenza), Terr. 597

Prutz, Hans, Gelehrter $\quad 618,623,640$, 659 f., 666

Pseudo-Dionysius Areopagita, siehe Dionysius Areopagita

Pseudo-Kallisthene (Pseudo-Callistene) 72

Pseudo-Kyrill (Cyrillo) 70

Puente la Reina, S. Crucifijo, Ki. 662

Puglia, siehe Apulien 
Pugliano, S. Maria, Ki. $\quad 73$

Pulsano, O. 126

Quedlinburg, O. und Kl. 91 Anm. 28, 101,367

- St. Wiperti, Ki. 367

Radulf Grosparmi, KB von Albano 370

Radulf von Domfront, Patriarch von Antiochia 632

Radulf Glaber (Rudolf il Glabro), Geschichtsschreiber 583

Rahewin, Geschichtsschreiber 151 Anm. 73, 369, 658

Raimund IV. von Toulouse, siehe Raimund von Saint-Gilles

Raimund von Nîmes, KD von S. Maria in Via Lata 341

Raimund von Saint-Gilles (Raimund IV.), Gf. von Toulouse 615

Rainald, Bf. von Paris 185

Rainer, KP von S. Clemente 352

Ramackers, Johannes, Gelehrter 422 Anm. 27, 438

Rambolla, Kard. und Historiker 10

Rangerius, Ebf. von Reggio Calabria 200, 644

Ranieri, Mönch von Sassoferrato 576

Raniero Parvo da Pavia, KP von SS. Giovanni e Paolo 146

Ranke, Leopold, Gelehrter 29

Rapallo, S. Gervasius, Ki. 197 Anm. 33

Rapolla, O. 119

Raterius, Bf. von Verona 82

Ratti, Achille, siehe Pius XI., P.

Ravello, O. und Bm. 119

Ravenna, Ebm. 26 f., 36, 62, 94, 120, 268 f., 271, 381, 420 Anm. 15, 64 Anm. 107, 562, 677 Anm. 4

- S. Apollinare in Classe, Kl. 561

Reggio Calabria, Ebm. 100, 116, 119 f., 127, 129, 200

Reggio-Emilia, O. 164 Anm 127, 655

- S. Stefano, Kommende 655

Reginaldus, Kleriker und Notar $412 \mathrm{f}$.

Regino, Abt von Prüm, Geschichtsschreiber 90

Reims, O. und Ebm. 142

Reno, S. Maria, Ki. 416
Ribaldo, KP von S. Anastasia 144

Richar, Abt von St. Mauritius 95

Richard, KB von Albano 349, 352, 356

Richard, Bf. von Andria 123

Richard I. Löwenherz, Kg. von England 629

Rieti, Bm. 565

- S. Angelo ad pontem fractum, Kl. $\quad 584$

- S. Salvatore Maggiore, Kl. 584

- S. Salvatore sub Monte Lentenano, Kl. $17 \mathrm{f}$.

- S. Salvatore di Scandriglia, Kl. 565, 566 Anm. 40, 567 Anm. 45

Rifreddo, Kl. 519

Rimini, S. Pietro e Paolo, Ki. 437

Rinaldo von Concorezzo, Ebf. von Ravenna 607

Rivalta Scrivia, Kl. $\quad 519$

Rivoltella, Terr. 145 Anm. 41

Robald (Robaldo) von Alba, Ebf. von Mailand 135, 170 Anm. 151, 528

Robert Pullus, KP von SS. Martino e Silvestro 337

Robert (Roberto) Diana, Templer 608

Robert von Corson, Magister, L. 345

Robert II., Hzg. von der Normandie 615

Robert Guiscard, Hzg. von Apulien und Kalabrien 30, 126, 271, 648

Robert II., Gf. von Flandern 615

Rodegarius, Presbyter $412 \mathrm{f}$.

Rodi, O. 606, 613

Rodolfo, siehe Rudolf

Rodrigo Borgia, siehe Alexander VI., P.

Roffrid (Roffredus), Ebf. von Benevent 410, 414

Roger, Ebf. von Reggio Calabria 200

Roger, Bf. von Cannes 123

Roger, Bf. von Syrakus 122

Roger von Molinis, Johannitermeister 642

Roger, Abt von SS. Trinità in Mileto 198 Anm. 37

Roger (Ruggero) II., Kg. von Sizilien 111, 124, 126, 191 Anm. 20, 194, 203, 265 Anm. 16, 598, 663

Roger Bursa, Hzg. von Apulien 412

Roger I., Großgf. von Sizilien und Gf. von Kalabrien 30, 111 
Roger Belmusto, Adeliger aus Genua 648

Roger von Howden, Geschichtsschreiber 322

Rolando Bandinelli, siehe Alexander III., P.

Rollandus von Antiochia, L. $\quad 631 \mathrm{f}$.

Rom, O. 9, 12, 14, 17, 19-21, 23 f., 26-29, 32 f., 36, 40, 42-44, 46, $48-64,66-70,73-76,79$ f., 82, 89, $91 \mathrm{f},, 94,96 \mathrm{f} ., 100,102 \mathrm{f} ., 107 \mathrm{f}$. , $110-113,116 \mathrm{f}, 119,123-125$, 127 f., 129 Anm. 116, 130, 135, 142 f., 154 Anm. 87, 161, 164 Anm. 127, 168-172, 183, 185,187193, 195 f., 198-200, 212, 215 Anm. 3, 220 Anm. 21, 226, 248 253, 269, $271 \mathrm{f} ., 299,302-309,312$, 315 f., 318, 324 Anm. 32, 325, 328, 332, 337 f., 364 f., 368-370, 373$379,381,385-387,389,390-399$, 401, 411, 417, 419 f., 422 Anm. 25, 428, 430, 432 f., 443, 537 Anm. 106, 538, 544, 566 Anm. 40, 567, 598, 600, 603, 608 f., 626, 632f., 636, 643 f., 651-653, 655, 658 f., 663, 665, 672, 676, 677 Anm. 4, 678 f., 681-684, 686-689

- Aventin, Berg 79, 633 Anm. 78, 658, 663

- Borgo Angelico 651

- Castel S. Angelo (Archivum Arcis) 395, 398, 399 Anm. 38

- Deutsches Historisches Institut (Rom, Preußisches Historisches Institut) 6, 227, 239, 248, 250, 689 Anm. 20

- Doria Pamphili, Palast 112

- Lateran, Palast 75

- S. Giovanni, Ki. $\quad 307,389$

- Ponte Mammolo 357

- Preußisches Historisches Institut, siehe Rom, Deutsches Historisches Institut

- S. Agnese e Costanza, Ki. 437

- S. Anastasia, Ki. 144 Anm. 32 und 33

- S. Andrea in Clivo Scauri, Kl. 75, 443

- S. Angelo, Ki. 164 Anm. 127, 167

- S. Antonino, Ki. 144 Anm. 32
- SS. Apostolorum in Eudoxia, siehe Rom, S. Pietro in Vincoli, Ki.

- S. Bartolomeo, Ki. 567 f.

- S. Basilio al Foro di Augusto, Ki. $\quad 599$

- SS. Bonifacio ed Alessio auf dem Aventin, Kl. 79 f., 559 Anm. 14

- S. Cecilia in Trastevere, Ki. 144 Anm. 34, 145 Anm. 43, 152, 158, 303 Anm. 17

- S. Ciriaco, Ki. 146 Anm. 46

- S. Clemente, Ki. 146

- SS. Cosma e Damiano in Mica Aurea, Kl. 399

- S. Crisogono, siehe Rom, S. Grisogono

- S. Egidio, Ki. 651

- S. Eustachio, Ki. 144 Anm. 39, 145 Anm. 44, 160 Anm. 108, 352

- S. Giorgio in Velabro, Ki. 145 Anm. 43, 146 Anm. 48, 152

- SS. Giovanni e Paolo, Ki 146 Anm. 48

- S. Grisogono, Ki. 146 Anm. 47, 336, 349 Anm. 53

- S. Lorenzo in Damaso, Ki. 144 Anm. 35, 146 Anm. 49, 157, 160 Anm. 108

- S. Lorenzo in Lucina, Ki. 144 Anm. 36, 272, 301, 304

- S. Marcello, Ki. 146 Anm. 50

- S. Marco, Ki. 81, 335, 340, 629

- S. Maria auf dem Aventin (S. Maria del Priorato), Ki. $\quad$ 599, 608, 655, 658

- S. Maria in Domnica, Ki. 603, 607

- S. Maria in Porticu, Ki. 144 Anm. 38

- S. Maria del Priorato, siehe Rom, S. Maria auf dem Aventin

- S. Maria in Trastevere, Ki. 144 Anm. 38

- S. Maria in Via Lata, Ki. 398

- S. Maria Maggiore, Ki. 164 Anm. 127, 301-303, 307, 390

- S. Nicola in Carcere Tulliano, Ki. 144 Anm. 39, 158

- S. Paolo fuori le mura, Ki. 265 Anm. 16, 301, 307, 308 Anm. 36, $309,390,626,632$ 
- S. Peter, Ki. $\quad 75,106,136,301$ f., 307, 390, 529, 536 f., 542, 544

- S. Pietro in Vincoli (SS. Apostolorum in Eudoxia), Ki. 145 Anm. 42, 151,335

- S. Sabina, Ki. 145 Anm. 45, 147, 302

- S. Sisto, Kl. 398

- S. Spirito in Saxia, Hospital 566 Anm. 40

- S. Susanna, Ki. 160 Anm. 108, 303, 304 Anm. 18

- S. Teodoro, Ki. 145 Anm. 41, 151, 153 f., 157, 635

- SS. Vincenzo e Anastasio delle Tre Fontane alle Acque Salvie, Kl. $\quad 538$, 539 Anm. 113, 540, 544 f., $550 \mathrm{f}$.

Romagna, Terr. $\quad 11,150$

Romanus II., byz. Ks. 72

Romanus, P. 381

Romuald (Romualdo) von Ravenna, Heiliger 558, 559 Anm. 14, 560$562,564,566,580,586,590$

Romuald (Romualdo) I., Fs. von Benevent 580

Romuald Guarna, Geschichtsschreiber 122

Rossano, O. 129

Rossiglione, O. 561 Anm. 20

Roswitha, siehe Hrotsvit

Rotland, Ebf. von Arles 26 Anm. 39

Rouen, O. 279, 442

Rudolf (Rodolfo) I., Prior von Camaldoli 562

Rudolf (Rodolfo) il Glabro, siehe Radulfus Glaber

Rudolf (Rodolfo), Sohn des Gf. Lambert 571

Rufinus, KP von S. Prassede 647

Ruppel, Aloys 11

Rustico, Abt von Vallombrosa 288

Rutigliano, SS. Pietro e Paolo, Ki. 121 Anm. 71

S. Andrew's, Bm. 439, 440

S. Angelo de Prefolio, Einsiedelei 585

S. Apollinare del Sambro, Kl. 573

Saint-Barbe-en-Auge, Kl. 318

S. Benedetto am Monte Favale, Kl. 577

S. Caloceri Hospitalariorum, Ki. 657
S. Capriagio dell'Aula, Kl.

$$
\text { Anm. } 33
$$

S. Domingo de Silos, Kl. 439

Saint-Donat d'Oulx, Kl. 442

$S$. Eligio di Noyon, siehe Noyon

Saint-Éloi (S. Eligio di Noyon), Kl. 325329

S. Eufemia in Kalabrien (Calabre, Calabria), Kl. 605

S. Eugenio in Ligurien (Liguria), Kl. 204 Anm. 55

S. Flaviano bei Giulianova, Kl. 431

S. Fruttuoso, Kl. 206 Anm. 60

S. Gallen, O. und Kl. 385

S. Germano, O. 656

S. Giacomo ab aqua, Kl. 566 Anm. 40

Saint-Gilles, Kl. 597

S. Giusto, Bm. abg. 115 Anm. 39

S. Iulianius, Ki. 187 Anm. 12

S. Marco Argentano, Bm. $118 \mathrm{f}$.

S. Maria de Fitero, Kl. 431

S. Maria de Refoyos, Kl. 433

S. Maria della Matina, Kl. 209

S. Maria de Turri, Kl. 200 Anm. 43, 204 Anm. 53

S. Maria di Chiaravalle di Fiastra, siehe Chiaravalle di Fiastra

S. Maria di Scurcola, O. 606

S. Maria im Tale Josaphat, Kl. 420, 437, 441, 620 f., 623, 628, 652, 665

S. Maria Maddalena de Monte Niblo, Leprosenhaus 626

S. Maria Mattina in Kalabrien, Kl. 198 Anm. 37

S. Martino al Cimino, Kl. 541-543

Saint-Maur-des-Fossés, Kl. $\quad$ 185, 430

Saint-Maurice-en-Valais, Kl. 533 Anm. 84

Saint Michel de Cuxà, Kl. 561

S. Nabore, Ki. 535 Anm. 95

S. Nicola de Casole, Kl. 129

Saint-Omer, O. 265

S. Paolo Belsito, O. $407 \mathrm{f}$.

S. Paterniano, Kommende 655

Saint-Pierre-de-Maillezais, Kl. 438, 441

S. Pietro in Avellana, Kl. 565, 567 Anm. 45, 586

S. Salvatore d'Orcla, Kl. 543 
S. Severina, Ebm. $\quad$ 100, 116, 118, 127, Schiaparelli, Luigi, Gelehrter $\quad$ 9, $111 \mathrm{f}$. , 129

S. Severino, O. 426, 585 Anm. 124, 587 Anm. 136

S. Severo in Classe, Kl. 93

S. Severo, O. 112

S. Silvestro, Ki. 535 Anm. 95

S. Silvestro (S. Spirito, Hospital), Kl. 566

S. Silvestro de Monte Suavi, Kl. 204 Anm. 53

S. Spirito, Hospital, siehe S. Silvestro

S. Stefano di Gallano, Kl. 570

Saint-Sulpice in Savoyen, Kl. 541

$\mathrm{S}$. Teodoro e S. Salvatore in Fasiolo, Ki. 635

S. Trinità, Ki. 538

Sabina, Terr. 566, 583

Sachsen (Sassonia), Terr. 305 f.

Saladin, Sultan 322, 642

Salento, Terr. $118,122,127,129$

Salerno, O., Fsm. und Ebm. 99 f., 102, $104 \mathrm{f} ., 107,109,114,116 \mathrm{f}$, $120,122,269 \mathrm{f}$.

Salisbury, Bm. 440

Salona, Bm. 65, 279

Salpi, Bm. 113, 123 Anm. 88

Salzburg, O., Ebm. 91, 105 f., 108, 244 Anm. 142, 441, 529

Sambuci, O. 542 Anm. 132

Samonas, Heiliger 70

Sangro, Fluß 565

Santiago de Compostela, O. und Bm./ Ebm. $\quad 566$

Sardica, siehe Sofia

Sardinien, Insel 31, 110, 519

Sarno, Bm. 114, 118

Sassoferrato, O. 575 f., 591

- S. Croce dei Conti, Ki. 575 f., 591

Sassonia, siehe Sachsen

Sassovivo, S. Croce, Kl. 570, 572, 575

- S. Trinità, Kl. 572

Satriano, Bm. 115

Saumur, Saint-Florent, Kl. 658

Savigny, O. und Kl. $\quad 547,551 \mathrm{f}$.

Savoia, siehe Savoyen

Savona, O. 327 Anm. 40, 203 Anm. 52

Savoyen (Savoia), Terr. 541

Scala, Bm. 117

Schaffhausen, O.265

233 f., 247, 593 Anm. 2, 594

Anm. 4, 618, 620, 623, 625 Anm. 49, 639, 655, 660

Schlechte, Horst, Gelehrter 249

Schmidt-Ott, Friedrich, Gelehrter 234

Schottland (Scozia) 160 Anm. 108, 439, 444, 662 Anm. 237

Schweiz 10

Sciacca, S. Maria Iummaris, Ki. 126 Anm. 99

Scoglio di S. Michele, siehe Morro Reatino

Scozia, siehe Schottland

Scozola, Kl. 168, 171 Anm. 154

Sebastian, Heiliger 304

Selz, Kl. 444

Sempringham, Kl. 440

Sens, Ebm. 323, 364, 442

Sentino, Terr. $\quad 575$

Senzias, Heiliger 579

Sepino, S. Cristina, Ki. 112

Seprio, Terr. 149

Sergius II., P. $\quad 305-307,380 \mathrm{f}$.

Sergius III., P. $\quad 381,383$ f., 386

Sergius IV., P. 647

Sergius, Ebf. von Damaskus 79

Sergius I., Hzg. von Neapel 70

Serra San Quirico, O. 577

Serradeconti, O. 576

Serrasanta, Berg 586

Sesto Calende, O. 168

Sestri, S. Andrea, Kl. 529, 535

Sevilla, O. 417, 629

Sicard (Sicardo) von Cremona, Subdiakon 163, 167, 168 Anm. 140, 172 Anm. 155

Sicilia, siehe Sizilien

Sickel, Theodor von, Gelehrter 11, 218, 222, 223 Anm. 36, 226, 228, 243, 267, 292

Siegfried, Sohn des Mgf. der sächs. Ostmark Gero I. 306

Siena, Bm. 334, 577, 598, 629, 655

Sila, Terr. 118

Silva Candida, Bm. $\quad 387,415,443$

Silverius, P. $\quad 58 \mathrm{f}$.

Silvester I., P., Heiliger 379 f., 383

Silvestro Guzzolini, Heiliger 577

Simplicius, P. 282 
Sinai, Terr. und Berg 79, 385

Siponto, Bm. 31, 99, 113, 118 f., $122 \mathrm{f} ., 128,580,613$

- S. Leonardo, Kl. 407, 604, 613

Siria, siehe Syrien

Siricius, P. 279, 280 Anm. 31

Sisto, siehe Sixtus

Sitria 561 Anm. 19, 572

Sixtus (Sisto) IV., P. $\quad 612,661$

Sizilien (Sicilia), Insel, Terr. 21 f., 24 f., $31,59,80,109-111,114-116,120$, 122, 124 f., 126 Anm. 99, 127-130, 133, 268 f., 355, 407, 411, 417, 419 Anm. 15, 421, 593, 598 f., 601-605, 607 f., 611 f., 620 f., 623 f., 628, $642,652,655$ f., 660, 662, 665, 684

Skandinavien $90 \mathrm{f},, 349,441,443$

Soffred, KD von S. Maria in Via Lata 646, 158

Sofia (Sardica), O. 104

Soissons, O. und Bm. 316, 326

- Saint-Médard, Kl. 316, 325

Soldanus, Gründer eines Hospitals in Asti 656

Sora, O. 110, 142 Anm. 27, 565, 567

Sorrent, O. und Ebm. 116 f., 119, 268

Sossius, Heiliger 76

Spanien 64, 227, 228 Anm. 63, 233, 235, 279, $348 \mathrm{f}$, 357, 417, 433, 435, 443, 629, 641, 650, 663, 685

Sperandia di Cingoli, Heiliger 587

Spes, Heilige 566 Anm. 40

Spinelli, Fam. aus Neapel 648

Split, O. 352, 429, 443

Spoleto, Bm. 39, 99, 109, 208, 551, $571,574,579,583,586,590$

- S. Concordio, Ki. 579

Squillace, Bm. 119, 165

Staffarda, Kl. 519 f., 532 f., 535, 544

Stefan Grube, Deutschordensmeister 611

Stefan (Stefano), Sohn des Sergius' I., Hzg. von Neapel 70

Stefanus (Gencius), röm. Adeliger 542 Anm. 132

Stephan II., P. 284

Stephan (Étienne) V., P. 24-26, 127, 264, 286, 287 Anm. 64, 383 Anm. 40

Stephan VI., P. 381-383

Stephan IX., P. 207, 563
Stephan Langton, KP von S. Grisogono, Ebf. in Canterbury 344

Stephan (Stefano), Bf. von Tournai, Abt von Saint-Euverte in Orléans und Sainte-Geneviève in Paris 157 Anm. 94, 363

Stephan, Abt von Notre-Dame di Bonnevaux 525 Anm. 37

Stephan (Stefano) von Obazine, Heiliger 546, 547

Stephan I., Kg. von Ungarn 102

Stephan, Gf. von Blois 615

Strongoli, Bm. 115, 118

Subasio, Berg 587

Suger, Abt von Saint-Denis 362

Sutri, Bm. 184 f., 187, 443

Svjatoslav Igorevic, Fs. von Kiev 88, 90-92, 106

Sybille von Anjou, Kgn. von Jerusalem 629

Symeon, Zar von Bulgarien 89

Symeon Metaphrastes, Hagiograph 71

Symmachus, P. 43, 282

Syrakus, Bm. 61, 112, 114, 116, 122, 127, 268

Syrien (Siria) 97, 430, 578, 629 f., $632,635-637,649 \mathrm{f}$.

Taillebourg, O. 442

Talloires, Kl. 432

Tarent (Taranto), Bm. 99, 112, 115, 117-119, 127-129, 597, 657

- S. Pietro Imperiale, Kl. 128

Tarragona, Ebm. 279, 443

Taureana, frühchristl. Bm. abg. 110 Anm. 9

Taverna, Bm. 119, 204 Anm. 53

Tavoliere, Terr. 115

Tedaldo, Bf. von Piacenza 162

Telese, S. Salvatore, Kl. 631

Tempsa, frühchristl. Bm. abg. 110 Anm. 9

Teramo, Bm. 120

Termini Imerese, Bm. 111 Anm. 11

Terracina, Bm. 536, 537 Anm. 104

Terrasson, Ki. $\quad 442$

Thabor, Kl. 621, 624, 660

Thame, S. Mary's, Ki. 440

Theobald, KB von Ostia, Abt von Cluny 365 
Theobald I., Ebf. von Canterbury

Theodahat, Kg. der Ostgoten 58 Anm. 78

Theoderich der Große, Kg. der Ostgoten $50,52,55$

Theodor II., P. 381

Theodor, Bf. von Mopsuestia, Theologe 59

Theodor, röm. Adeliger 542 Anm. 132

Theodora I., oström. Ksn. 58

Theodoret, Bf. von Kyrrhos 59

Theodoros Studites, Abt von Sakkudion, Theologe 79

Theophanu, Ksn. 106

Theophanus Homologetes, Geschichtsschreiber 74

Théotokos von Patir bei Rosanno, Kl. 129

Thérouanne, Bm. 315, 442

Thessalonike, O. 642

Thietmar, Bf. von Merseburg, Geschichtsschreiber 91 Anm. 28, 101 Anm. 84, 306

Thomas, KP von S. Vitale, L. 367

Thomas Becket, Ebf. von Canterbury, Heiliger $\quad 322,354,360,362,366$ Anm. 120

Thomas, Mönch von Evesham 324

Thurii, frühchristl. Bm. abg. 110 Anm. 9

Tiberius, byz. Ks. 66

Tiburtius, Heiliger 376

Tiglieto, O. 525, 535

- S. Maria e S. Croce, Kl. 526

Tindari, Kl. 111 Anm. 11

Tivoli, O. 166, 586

Todi, O. und Bm. 196, 626

- S. Leucio, Kl. 196

Toledo, Ebm. 131 Anm. 119, 432 f., 438, 443, 446, 478 Anm. a

Topino, Fluss 566

Tornielli, Fam. in Novara 167 Anm. 137

Tortona, O. 142 Anm. 22, 145 Anm. 42, 149, 163, 164 Anm. 127, 657

- S. Croce, Ki. 657

Tortosa, Bm. 444, 621

Toskana, Terr. 20, 215 Anm. 3, 341, 643 f., 647, 652
360 Toulouse, O., Ebm. und Gft. 279, 339

Tournai, O. 316, 363

Tours, O. und Ebm. $\quad 364,442 \mathrm{f}$.

- Saint-Martin, Kl. 443

Trani, Bm. 99, 114-115, 117-119, 128

Transmundus, päpstl. Notar, Vizekanzler 360

Tremiti, Insel 656

Trevico, Bm. 115

Treviso, Bm. 427

Tricarico, Bm. 98

Trient, Bm. 216 Anm. 6, 244

Trier, Ebm. 104

Triocala, Bm. 111 Anm. 11

Tripolis, O. und Gft. $\quad 615,621,625$, 629

Tripozzo, O. und Hzm. 572 Anm. 64, 575

Trisulti, S. Bartolomeo, Kl. 565 Anm. 36

Troia, Bm. 112, 119, 122, 131

Tropea, O. 115

Turin, Ebm. 149, 166, 424, 432, 533, 619

Tursi, Bm. 98, 128

Tuscania, Bm. 146 Anm. 52

- S. Giusto, Kl. 541-543

Tusculum (Tuscia), Bm. und Gft. 146 Anm. 47, 541, 543

Tyrus, O. und Ebm. 444, 621

Ubaldus (Ubaldo), Bf. von Gubbio, Heiliger 563

Ubaldus (Ubaldo), Abt von Grotta 552

Uberto, Ubertus, siehe Hubert

Udo, Bf. von Hildesheim 356

Ugento, Bm. 115, 118, 122

Ugo, siehe Hugo

Ugolino, siehe Gregor IX., P.

Uhlirz, Karl, Gelehrter 243

Ulger, Bf. von Angers 317

Umbria, siehe Umbrien

Umbriatico, Bm. 115

Umbrien (Umbria), Terr. 190-193, 196-201, 203, 204 Anm. 53, 207, 211 f., 215 Anm. 3, 268, 331, 519, $563,569,575,579-581,586,591$, $626,679,683$ 
Ungarn (Ungheria) 92, $101 \mathrm{f} ., 105$, 108, 152, 347, 354 f., 368, 421, 441, 443

Uppello, Gft. $\quad$ 573, 574

Urban II. (Odo von Ostia), P. 210 Anm. 80, 136, 141, 263-267, 270, 286, 290-296, 312 f., 334 f., 356, 365, 368, 410 f., 422 Anm. 27, 428, 430, 432, 443, 522, 524 Anm. 31, 560, 564, 615, 636, 644 f., 666

Urban III., P. 142 f., 146, 157, 163, 206 Anm. 59, 365 Anm. 120, 425, 625, 657, 661, 662 Anm. 237

Urban IV., P. 435

Urban VI., P. 435

Urso, Ebf. von Bari 412

Uzès, O. und Bm. 431

- Saint-Thierry, Ki. 431

Val di Castro, Einsiedelei 561 Anm. 19

Val di Noce, S. Croce, Kl. 587

Valence, O. und Bm. 442

Valenia, Bm. 444, 621

Valetta, siehe Valletta

Valle di Vaccagna, Terr.

Vallelucio, S. Michael, Kl. 79

Valletta (Valetta), O. 624, 641, 659, $662-664,685$

Vallombrosa, Kl. 415, 564, 578 Anm. 93, 637 f., 641, 643, 650, 683

Valnerina, Terr. 566 Anm. 40

Valtopina, O. $\quad 570 \mathrm{f}$.

Valvisciolo, Kl. $\quad 520$

Varazze, O. 621, 665

Varese, S. Maria del Monte, Ki. 149

Vasto, frühchristl. Bm. abg. 110 Anm. 6

Vendôme, Kl. $317 \mathrm{f}$.

Venedig (Venezia, Venetien, Veneto), O., Bm. und Terr. 27, 141 Anm. 17, 142, 150, 153, 154 Anm. 85, 163, 203, 223, 227 Anm. 57, 242, 268, 271, 417-419, 426, 561 Anm. 20, 600, 619, 629, 635 f. , 644, 646-649, 653, 655, 659

- S. Maria della Carità, Ki. $\quad 635,646$

- S. Niccolò al Lido, Ki. 629

Venosa, Bm. 403, 405, 407, 412 f., 682

- S. Trinità, Kl. $\quad 403,605$ f., 613
Ventimiglia, Bm. 437, 206 Anm. 60

Vercelli (Verceil), O. und Bm. 141 f., 149, 156, 167, 283

- S. Maria, Ki. 142

Verghereto, S. Michele, Kl. 561 Anm. 20, 565 Anm. 36

Veroli, O. 541 Anm. 128

Verona, Bm. 32 f., 82, 142, 146 Anm. 50, 157 f., 266, 431, 634 Anm. 89, 642, 654 Anm. 183, 656

- S. Vitalis, Kommende 656

Vettabbia, O. 535

Vézelay, O. 318 f., 387, 441

Vibo Valentia, frühchristl. Bm. abg. 110 Anm. 9, 118

Vico del Gargano, O. 112

Vico Equense, Bm. 111, 115, 117

Vico, Terr. 568

Vienne, Ebm. und Gft. 279, 442, 524

Vieste, O. 112, 119

Vigilius, P. 58 Anm. 80, 59-61, 64, 67,282

Viktor (Vittore) II., P. 159 Anm. 104

Viktor (Vittore) IV., P. 152, 623, 658, 663

Viktor, Bf. von Tunnuna 58 Anm. 79

Villeneuve-lès-Avignon, O. $431 \mathrm{f}$.

Vitalba, O. 118

Vitalis, Bf. von Cumae 46 Anm. 24

Viterbo, Bm. 146 Anm. 52

Vittore, siehe Viktor

Vivianus, KP von S. Stefano in Celiomonte 342,354

Vladimir I., Großfs. von Kiev 87, 106

Volturara, Bm. 115

Volturino, S. Angelo, Einsiedelei 584

- S. Vincenzo, Kl. 114, 125, 189 Anm. 18

Vulturnum, röm. O. abg. 115

Walter, KB von Albano, Kardinallegat 355,359

Walter, Ebf. von Rouen 322 f., 327, 328

Warmund von Picquigny, Patriarch von Jerusalem 636

Watten, Kl. 442

Wattenbach, Wilhelm, Gelehrter 223

Weißenburg (Wissembourg), Kl. $94 \mathrm{f}$.

Wendland, Wilhelm 237 
Wenzel von Böhmen, Heiliger 304 Anm. 20

West Smithfield, S. Bartholomew's, Hospital 440

Wibald, Abt von Stablo, L. 362

Wibert von Ravenna, siehe Clemens III., P.

Widukind, Mönch von Corvey, Geschichtsschreiber 101 Anm. 84

Wiederhold, Wilhelm, Gelehrter 233, 247, 331, 432, 438, $637 \mathrm{f}$.

Wien, O. 223, 408, 417

Wilhelm von Marengo, KP von S. Pietro in Vincoli, L. 145, 146 Anm. 47, 151 f., 154, 167 Anm. 138, 176 Anm. 170, 354, $363 \mathrm{f}$.

Wilhelm (Guglielmo) von S. Pietro in Vincoli, Kard. 154

Wilhelm, Ebf. von Mainz 89, 93

Wilhelm, Ebf. von Otranto 412

Wilhelm II., Ebf. von Tyrus 631, 633

Wilhelm, Bf. von Orange 644

Wilhelm (Guglielmo) Balbo, Archipresbyter von Mailand 164 Anm. 127, 168, 171 Anm. 154

Wilhelm, Abt von Aebelholt 360

Wilhelm (Guillaume) von Vercelli (Verceil), Eremit, Heiliger 126
Wilhelm (Guillaume) I., Kg. von Sizilien $30,31,124,130$

Wilhelm (Guillaume) II., Kg. von Sizilien 30, 125, 642

Wilhelm (Guglielmo) von S. Stefano 606

Winchester, Bm. 319

Winkelmann, Eduard, Gelehrter 227 Anm. 57

Wissant, Hospital 436, 442

Wissembourg, siehe Weißenburg

Witigis, ostgot. Kg. 58

Worcester, Bm. $439 \mathrm{f}$.

York, Bm. 319, 439 f.

Zacharias, P. $\quad 95,443$

Zagreb, O. in Kroatien 429

Zara, O. 426 f., 429 f., 443, 654

Anm. 183

- S. Grisogono, Ki. 427

Zaragoza, Bm. 431

- S. Maria la Mayor (del Pilar), Kl. 431

Zeitz, Bm. 103 Anm. 93, 104

Zenon, byz. Ks. $\quad 45,47 \mathrm{f}$.

Zypern 97, 617, 619, 621, 637

Zyriakus (Ciriaco), Heiliger 306 